\title{
Overheidstoezicht op afstand : verzelfstandiging van toezichthoudende taken naar zelfstandige bestuursorganen verkend
}

Citation for published version (APA):

van Nus, A. (1995). Overheidstoezicht op afstand : verzelfstandiging van toezichthoudende taken naar zelfstandige bestuursorganen verkend. [Doctoral Thesis, Maastricht University]. Maklu etc.

https://doi.org/10.26481/dis.19950908an

Document status and date:

Published: 01/01/1995

DOI:

10.26481/dis.19950908an

Document Version:

Publisher's PDF, also known as Version of record

Please check the document version of this publication:

- A submitted manuscript is the version of the article upon submission and before peer-review. There can be important differences between the submitted version and the official published version of record.

People interested in the research are advised to contact the author for the final version of the publication, or visit the DOI to the publisher's website.

- The final author version and the galley proof are versions of the publication after peer review.

- The final published version features the final layout of the paper including the volume, issue and page numbers.

Link to publication

\footnotetext{
General rights rights.

- You may freely distribute the URL identifying the publication in the public portal. please follow below link for the End User Agreement:

www.umlib.nl/taverne-license

Take down policy

If you believe that this document breaches copyright please contact us at:

repository@maastrichtuniversity.nl

providing details and we will investigate your claim.
}

Copyright and moral rights for the publications made accessible in the public portal are retained by the authors and/or other copyright owners and it is a condition of accessing publications that users recognise and abide by the legal requirements associated with these

- Users may download and print one copy of any publication from the public portal for the purpose of private study or research.

- You may not further distribute the material or use it for any profit-making activity or commercial gain

If the publication is distributed under the terms of Article $25 \mathrm{fa}$ of the Dutch Copyright Act, indicated by the "Taverne" license above, 
Overheidstoezicht op afstand 
De Stichting voor Recht en Openbaar Bestuur (ReOB), deel uitmakend van de Nederlandse organisatie voor Wetenschappelijk Onderzoek (NWO), heeft financieel bij gedragen aan de totstandkoming van dit proefschrift.

Nettie Litjens, secretaresse bij de vakgroep publiekrecht van de faculteit der rechtsgeleerdheid aan de rijksuniversiteit van Limburg, heeft technisch zorg gedragen voor het camera-ready maken van dit proefschrift.

Van dit proefschrift verschijnt een handelseditie in de Ius Commune Reeks onder ISBN nummer 90-6215-495-6 


\section{Overheidstoezicht op afstand}

Verzelfstandiging van toezichthoudende taken naar zelfstandige bestuursorganen verkend

\section{PROEFSCHRIFT}

ter verkrijging van de graad van doctor aan de Rijksuniversiteit Limburg te Maastricht, op gezag van de Rector Magnificus, Prof mr M.J. Cohen, volgens het besluit van het College van Dekanen, in het openbaar te verdedigen op vrijdag 8 september 1995 om 14.00 uur

door

Johanna Gesina Levina van Nus 
Promotor: $\quad$ Prof mr F.A.M. Stroink

Beoordelingscommissie: Prof mr A.Q.C. Tak (voorzitter)

Prof mr J.B.J.M. ten Berge (Universiteit Utrecht)

Prof mr C.A. Schwarz

Prof dr B.E.F.M. de Witte 




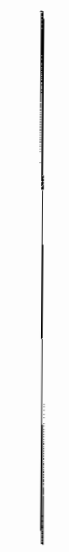

\section{Voorwoord}

"Over het water

spoelt de eerste zin ontwereld

op de vertekening van lippen aan." 1

Ontwereld is het voorwoord.

Het nawoord golft er over heen.

Driftig domineert een dankwoord dan ook dit voorwoord.

Slechts in de schaduw

- zo ergens tussen schijnsels van slimheid en zotheid kon dit boek tot stand komen:

Leerzaam was het licht.

Dank zij daarom

met name

mijn promotor Frits Stroink, de voorzitter van de beoordelingscommissie Twan Tak, de andere leden van de beoordelingscommissie Gio ten Berge, Kid Schwarz en Bruno de Witte en de initiatiefnemer inzake boekuitgave Michael Faure.

Aan Kid, die mij tijdens de sollicitatieprocedure verhelderend vroeg of ik van "Mercedessen en mooie jongens" hield (kennelijk in de veronderstelling dat bij een positieve beantwoording daarvan het heil elders gezocht moest worden), moet ik nu - na drieëneenhalf jaar - nageven dat de faculteit mij inderdaad geen dure auto's heeft opgeleverd. Overigens kan ik hem gerust stellen in de zin dat de faculteit gelukkig nog wel dat andlere in huis heeft. En dat is maar goed ook. Want wat had ik moeten beginnen zonder die mooie jongens, als voornoemd? 


\section{Inhoudsoverzicht}

Voorwoord ............................ VII

Inhoudsoverzicht $\ldots \ldots \ldots \ldots \ldots \ldots \ldots \ldots \ldots \ldots \ldots \ldots$

Inhoudsopgave $\ldots \ldots \ldots \ldots \ldots \ldots \ldots \ldots \ldots \ldots \ldots \ldots \ldots$

Afkortingenregister $\ldots \ldots \ldots \ldots \ldots \ldots \ldots \ldots \ldots \ldots \ldots \ldots \ldots$

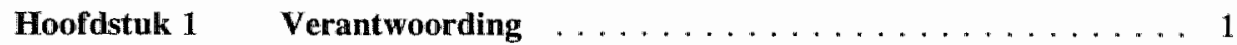

Geraadpleegde literatuur bij hoofdstuk $1 \ldots \ldots \ldots \ldots \ldots$

Hoofdstuk 2 Rechtsstatelijkheid . . . . . . . . . . . . . . . . . 19

Geraadpleegde literatuur bij hoofdstuk $2 \ldots \ldots \ldots \ldots \ldots \ldots$

Hoofdstuk 3 De verantwoordelijkheid veranderd . . . . . . . . . 35

Geraadpleegde literatuur bij hoofdstuk $3 \ldots \ldots \ldots \ldots$. . . . . . . . . . 90

Hoofdstuk 4 Legaliteitsbeginsel . . . . . . . . . . . . . . 103

Geraadpleegde literatuur bij hoofdstuk $4 \ldots \ldots \ldots \ldots \ldots \ldots$. . . . . . . . . . . . .

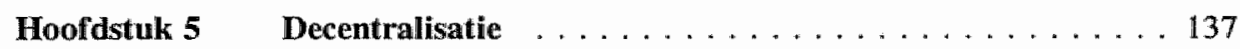

Geraadpleegde literatuur bij hoofdstuk $5 \ldots \ldots \ldots \ldots \ldots . \ldots \ldots$

Hoofdstuk 6 Verzelfstandiging van overheidsdiensten ......... 163

Geraadpleegde literatuur bij hoofdstuk $6 \ldots \ldots \ldots \ldots \ldots \ldots \ldots$

Hoofdstuk 7 Publiekrechtelijke bevoegdheid . . . . . . . . . . 227

Geraadpleegde literatuur bij hoofdstuk $7 \ldots \ldots \ldots \ldots \ldots \ldots \ldots$

Hoofdstuk 8 Op weg naar (overheids)kerntaken en -departementen . . 237

Geraadpleegde literatuur bij hoofdstuk $8 \ldots \ldots \ldots$. . . . . . . . . . 249

Hoofdstuk 9 Uitvoering van overheidsbeleid $\ldots \ldots \ldots \ldots$

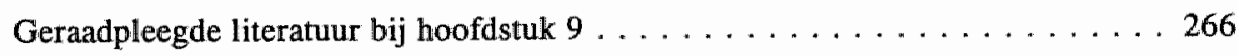

Hoofdstuk 10 Rechtshandhavingsbeleid in Nederland . . . . . . . . 275

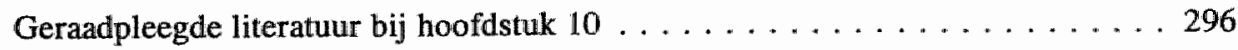


Hoofdstuk 11 Toezicht op naleving van het recht . . . . . . . . . 301

Geraadpleegde literatuur bij hoofdstuk $11 \ldots \ldots \ldots \ldots \ldots \ldots \ldots$

Hoofdstuk 12 Toepassing wan sancties . . . . . . . . . . . . . 343

Geraadpleegde literatuur bij hoofdstuk $12 \ldots \ldots \ldots \ldots \ldots \ldots$

Hoofdstuk 13 Communautaire rechtshandhaving . . . . . . . . . 367

Geraadpleegde literatuur bij hoofdstuk $13 \ldots \ldots \ldots \ldots . \ldots \ldots . \ldots \ldots$

Hoofdstuk 14 Commissariaat voor de Media . . . . . . . . . . . . . . . 397

Geraadpleegde literatuur bij hoofdstuk $14 \ldots \ldots \ldots \ldots \ldots \ldots$

Hoofdstuk 15 Nederlandse Filmkeuring . . . . . . . . . . . . . . 461

Geraadpleegde literatuur bij hoofdstuk $15 \ldots \ldots$. . . . . . . . . . . . 469

Hoofdstuk 16 Registratiekamer . . . . . . . . . . . . . . . . 471

Geraadpleegde literatuur bij hoofdstuk $16 \ldots \ldots \ldots \ldots \ldots \ldots$. . . . . . . 496

Hoofdstuk 17 Kwaliteitscontrole-instellingen ............... 501

Geraadpleegde literatuur bij hoofdstuk $17 \ldots \ldots \ldots \ldots \ldots$. . . . . . . . . . 556

Hoofdstuk 18 Stichting Verzekeringskamer ............... 557

Geraadpleegde literatuur bij hoofdstuk $18 \ldots \ldots$. . . . . . . . . . . . . 603

Hoofdstuk 19 Stichting Toezicht Effectenverkeer . . . . . . . . . . . . . 607

Geraadpleegde literatuur bij hoofdstuk 19 . . . . . . . . . . . . . . . . . . 669

Hoofdstuk 20 Toezichthoudende zelfstandige bestuursorganen:

conclusies en bevindingen . . . . . . . . . . . 673

Geraadpleegde literatuur bij hoofdstuk $20 \ldots \ldots \ldots \ldots \ldots$. . . . . . . . . . . . . . . . . . . . . . . . .

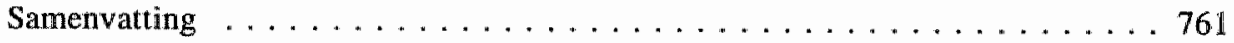

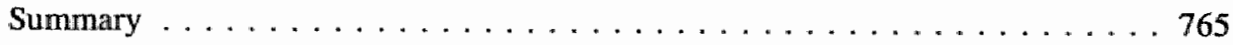

Jurisprudentieregister . . . . . . . . . . . . . . . . . . . . . . . . . . . 769

Trefwoordenregister . . . . . . . . . . . . . . . . . . . . . . 779

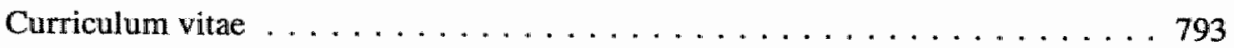




\section{Inhoudsopgave}

Voorwoord . . . . . . . . . . . . . . . . . VII

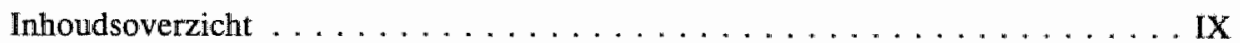

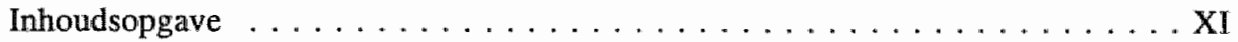

Afkortingenregister $\ldots \ldots \ldots \ldots \ldots \ldots \ldots \ldots \ldots \ldots \ldots \ldots \ldots \ldots \ldots$

\section{Hoofdstuk 1 Verantwoording}

$1.1 \quad$ Inleiding $\ldots \ldots \ldots \ldots \ldots \ldots \ldots \ldots \ldots$

1.2 Omvang verschijnsel zelfstandige bestuursorganen $\ldots \ldots \ldots 4$

1.3.1 Onderzoeksobject $\ldots \ldots \ldots \ldots \ldots \ldots \ldots \ldots \ldots$

1.3.2 Onderzoekssubject $\ldots \ldots \ldots \ldots \ldots \ldots \ldots \ldots \ldots$

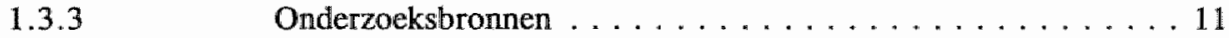

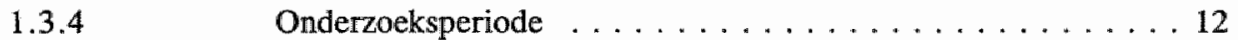

1.3.5 Onderzoeksterminologie $\ldots \ldots \ldots \ldots \ldots \ldots \ldots \ldots \ldots$

Geraadpleegde literatuur bij hoofdstuk $1 \ldots \ldots \ldots \ldots \ldots$

Deel I Inleiding bestuurlijk organisatierecht $\ldots \ldots \ldots \ldots \ldots 17$

\section{Hoofdstuk 2 Rechtsstatelijkheid}

$2.0 \quad$ Rechtsstaat . . . . . . . . . . . . . . . 19

2.1 Transformatie rechtsstaatsgedachte $\ldots \ldots \ldots \ldots \ldots 20$

2.1.1 Materiële rechtsstaatsgedachte $\ldots \ldots \ldots \ldots \ldots \ldots 21$

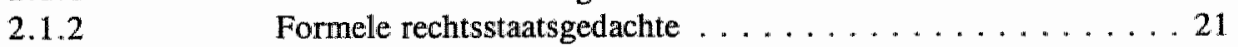

2.1.3 Fusie materiële en formele rechtsstaatgedachte . . . . . 22

2.2 Institutionele eisen van staatsinrichting en -handelen $\ldots \ldots .22$

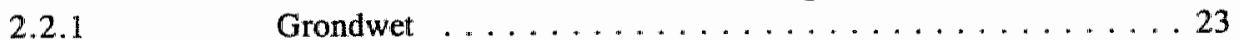

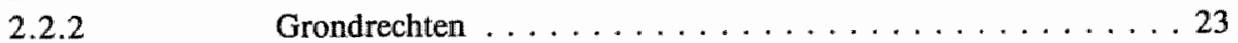

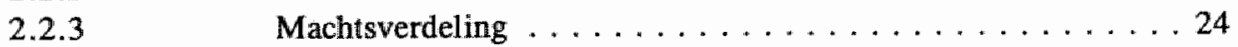

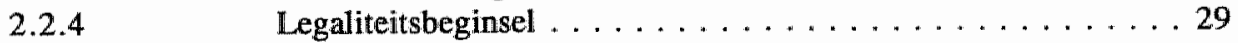

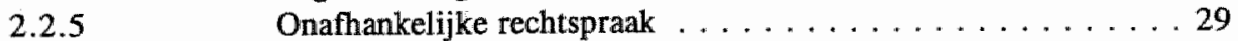

Geraadpleegde literatuur bij hoofdstuk $2 \ldots \ldots \ldots \ldots \ldots \ldots \ldots \ldots$ 


\section{Hoofdstuk 3 De verantwoordelijkheid veranderd}

3.0

3.1

3.2

3.2 .1

3.2 .2

3.2 .3

3.2 .4

3.3.1

3.3.2

3.3. 3

3.3.4

3.3.4. 1

3.3.4.2

3.3 .5

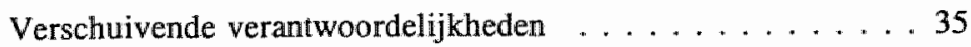

Functie politieke controle . . . . . . . . . . . . . 38 Ministeriële verantwoordelijkheid door een staatsrechtelijke bril 39 Informatieve fase . . . . . . . . . . . . . . 43 Ambtenaarlijke aanspreekbaarheid ....................... 47 Opzeggen van vertrouwen $\ldots \ldots \ldots \ldots \ldots$............. 51

De regel van ministeriële verantwoordelijkheid en de vertrouwensregel $\ldots \ldots \ldots \ldots \ldots \ldots \ldots$

Politieke controle in praktijk .............. 58

Ministeriële verantwoordelijkheid een sprookje? . . . . . . . 59

Aanpassen aan actualiteit? .................63

Zelfstandige bestuursorganen als surrogaat? . . . . . . . . 64 Beperkte ministeriële verantwoordelijkheid bij zelfstandige bestuursorganen: feit of formaliteit? . . . . . . . . . 73

De minister en het openbaar ministerie . . . . . . . . 78 Andere argumenten voor instelling van zelfstandige bestuursorganen .............. 86 Handhaven oorspronkelijke omvang ministeriële

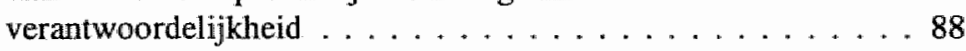
Geraadpleegde literatuur bij hoofdstuk $3 \ldots \ldots$. . . . . . . . . . . . 90

\section{Hoofdstuk $4 \quad$ Legaliteitsbeginsel}

4.0

Wettelijke gronds]ag . . . . . . . . . . . . . 103

4.1

4.1.1

4.1 .2

Brokkelig legaliteitsbeginsel ... . . . . . . . . . 1.04

Verminderde omvang legaliteitsbeginsel . . . . . . . . 104

Ruim legaliteitsbeginsel . . . . . . . . . . . . . . . 105

4.2

4.3

Instellingsgrondslag zelfstandige bestuursorganen . . . . . 106

4.4

Helder patroon toedeling publiekrechtelijke bevoegdheden . . 108

Titels van bevoegdheidsuitoefening ... . . . . . . . . . 109

4.4 .1

Attributie aan zelfstandige bestuursorganen . . . . . . . 109

4.4 .2

4.4 .3

Delegatie aan zelfstandige bestuursorganen ........ 110

Attributie en delegatie naar nieuw recht $\ldots \ldots \ldots \ldots \ldots 111$

4.5

Toetsingskader zelfstandige bestursorganen . . . . . . 116

4.5 .1

Aanwijzingen voor de rijksdienst inzake

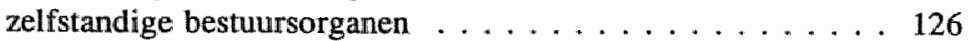

Geraadpleegde literatuur bij hoofdstuk $4 \ldots \ldots \ldots \ldots$. . . . . . . . . . . . .

\section{Hoofdstuk 5 Decentralisatie}


Openbaar lichaam . . . . . . . . . . . . . . 142

\section{Hoofdstuk 6 Verzelfstandiging van overheidsdiensten}

6.0

6.1

6.2

6.2 .1

6.2 .2

6.3

6.3 .1

6.3 .2

6.3 .3

6.3 .4

6.4

6.4 .1

6.4 .2

6.4 .3

6.4 .4

6.4 .5

6.5

Verzelfstandigen bij de rijksoverheid als aandachtspunt . . . 163

Reorganisatie rijksdienst . . . . . . . . . . . . . . . 163

Privatisering . . . . . . . . . . . . . . . . 164

Doeleinden privatisering . . . . . . . . . . . . . 165

Privatiseringsvarianten . . . . . . . . . . . . 166

Interne taakverzelfstandiging . . . . . . . . . . . . . . . . 179

Overheidsbedrijven . . . . . . . . . . . . . . . . . . . . 179

Zelfbeheer . . . . . . . . . . . . . . . . . . . 180

Agentschappen . . . . . . . . . . . . . . . 182

Deconcentratie . . . . . . . . . . . . . . . . . . . 187

Externe verzelfstandiging . . . . . . . . . . . 188

Grondwettelijke functionele decentralisatie . . . . . . . . 190

Buitengrondwettelijke functionele decentralisatie . . . . . . 190

Zelfstandige bestuursinstellingen . . . . . . . . . . . . . 192

Zelfstandige bestuurslichamen . . . . . . . . . . . . . . 192

Zelfstandige bestuursorganen . . . . . . . . . . . . . 193

a. Aard van de bevoegheden . . . . . . . . . . . . 196

b. Organisatievorm . . . . . . . . . . . . . . . . . . 197

c. Privaatrechtelijke functionele decentralisatie . . . . . . 198

d. Rechtsstatelijke eisen . . . . . . . . . . . . . . . 200

e. (De)centrale overheid . . . . . . . . . . . . . . . . . 204

f. Begripsomschrijving . . . . . . . . . . . . . 205

Overige organisatievorming . . . . . . . . . . . 206

a. Vervlechting publiekrechtelijke en privatrechtelijke organisaties . . . . . . . . . . . . . . . 207

b. Functioneel gedecentraliseerde bestuurszorg . . . . . 208

c. Verstatelijking versus vermaatschappelijking . . . . . 209

Privaatrechtelijke functionele decentralisatie . . . . . . . 210

Verstatelijkte particuliere sector . . . . . . . . 2 210

Particulier initiatief . . . . . . . . . . . . . 212

Ten slotte . . . . . . . . . . . . . . . 213 
Geraadpleegde literatuur bij hoofdstuk 6

\section{Hoofdstuk 7 Publiekrechtelijke bevoegdheid}

Toedeling overheidstaak op grond van een publiekrechtelijke bevoegdheid

Hoofdstuk 8 Op weg naar (overheids)kerntaken en -departementen

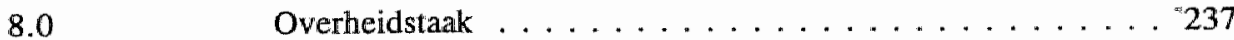

$8.1 \quad$ Overheidstaak in politiek debat . . . . . . . . . 238

8.2 Roep om principiële herbezinning op overheidstaken . . . 244

8.2.1 Rechtshandhaving als elementaire overheidstaak . . . . . 245

Geraadpleegde literatuur bij hoofdstuk $8 \ldots \ldots$. . . . . . . . . . . 249

\section{Hoofdstuk 9 Uitvoering van overheidsbeleid}

$9.0 \quad$ Uitvoering van overheidsbeleid $\ldots \ldots \ldots \ldots \ldots$

9.1 Zbo's als inzet in de strijd om machtsevenwicht . . . . . . 254

9.2 Beleidsvorming en beleidsuitwoering verstrengeld . . . . 256

$9.3 \quad$ Overheidstaken in overzicht . . . . . . . . . . . . 261

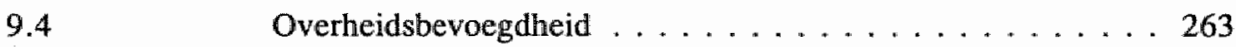

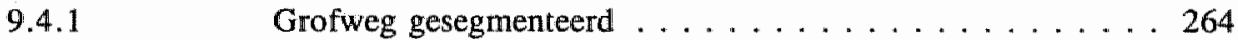

9.4.2 Concreter categoriseren . . . . . . . . . . . . . 264

Geraadpleegde literatuur bij hoofdstuk $9 \ldots \ldots \ldots \ldots$

Deel II Samenvatting, bevindingen en conclusies

functioneel bestuur . . . . . . . . . . . . . . 269

Deel III Inleiding rechtshandhaving door toezichthoudende

zelfstandige bestuwrsorganen . . . . . . . . . 273

Hoofdstuk 10 Rechtshandhavingsbeleid in Nederland

10.0 Rechtshandhaving in de belangstelling $\ldots \ldots \ldots 275$

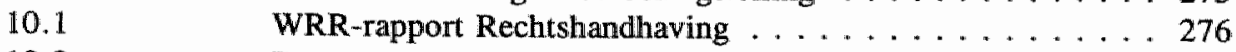

10.2 Rapport commissie-Deetman . . . . . . . . . . 277

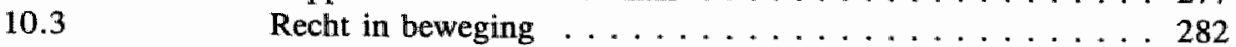

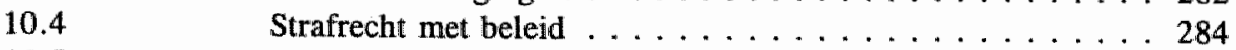

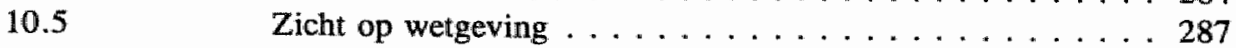

$10.6 \quad$ Met vaste hand . . . . . . . . . . . . . . . . 294

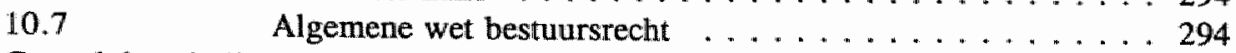

Geraadpleegde literatuur bij hoofdstuk $10 \ldots \ldots \ldots \ldots \ldots$ 


\section{Hoofdstuk 11 Toezicht op naleving van het recht}

$11.0 \quad$ Het begrip handhaving $\ldots \ldots \ldots \ldots \ldots \ldots \ldots$

$11.1 \quad$ Handhaving: toezichtsuitoefening . . . . . . . . 301

11.1.1 Toezichtsbevoegdheden in het

$11.1 .2 \quad$ Overdaad schaadt $\ldots \ldots \ldots \ldots \ldots \ldots \ldots \ldots \ldots$

11.1.3 Toezicht op naleving (van wet- en regelgeving) . . . . . 309

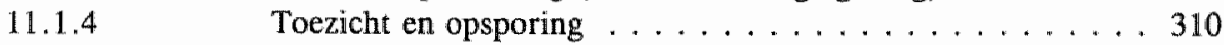

11.1.5 Toezichthouders . . . . . . . . . . . . . 318

11.1.6 Particulieren als toezichthouders . . . . . . . . . 325

11.1.7 Zelfstandige bestuursorganen als toezichthouders . . . . . 330

11.1.8 De derde tranche Awb zonder winst naar de eindstreep . . . 333

Geraadpleegde literatuur bij hoofdstuk $11 \ldots \ldots \ldots \ldots \ldots \ldots$

\section{Hoofdstuk 12 Toepassing van sancties}

$12.0 \quad$ Handhaving: sanctietoepassing . . . . . . . . 343

$12.1 \quad$ Strafrechtelijke handhaving $\ldots \ldots \ldots \ldots \ldots \ldots \ldots \ldots$

$12.2 \quad$ Bestuurlijke handhaving . . . . . . . . . . 347

$12.3 \quad$ Privaatrechtelijke handhaving $\ldots \ldots \ldots \ldots \ldots \ldots 4$

$12.4 \quad$ Tuchtrechtelijke handhaving $\ldots \ldots \ldots \ldots \ldots \ldots \ldots$

$12.5 \quad$ Art. 6 EVRM $\ldots \ldots \ldots \ldots \ldots \ldots \ldots \ldots$

Geraadpleegde literatuur bij hoofdstuk $12 \ldots \ldots \ldots \ldots \ldots \ldots$

\section{Hoofdstuk 13 Communautaire rechtshandhaving}

13.0 Communautaire rechtshandhaving $\ldots \ldots \ldots \ldots \ldots 76 \ldots \ldots$

$13.1 \quad$ Gemeenschapstrouw . . . . . . . . . . . 370

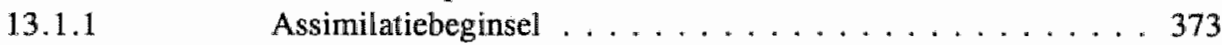

13.1.2 Evenredigheidsbeginsel $\ldots \ldots \ldots \ldots \ldots \ldots \ldots \ldots$

13.1.3 Effectiviteitsbeginsel . . . . . . . . . . . 376

13.1.4 Afschrikwekkendheidsbeginsel . . . . . . . . . 377

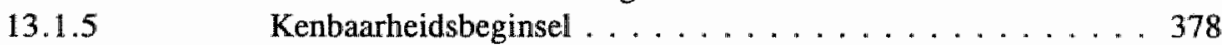

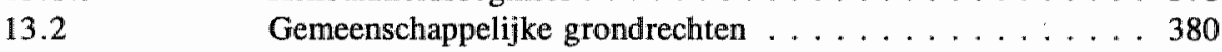

$13.3 \quad$ Versterking Europees handhavingskader $\ldots \ldots \ldots \ldots 381$

$13.4 \quad$ Euro-toezichthouders . . . . . . . . . . . . . . . . . 389

Geraadpleegde literatuur bij hoofdstuk $13 \ldots \ldots \ldots \ldots . \ldots \ldots 2$

\section{Hoofdstuk 14 Commissariaat voor de Media}

14.0 Communicatievrijheid t.a.v. radio- en televisieuitzendingen . 397

$14.1 \quad$ Overheid op afstand en deregulering . . . . . . . . 398

14.2 Taakstelling Commissariaat voor de Media . . . . . . . 399

14.2.1 Toezichtsbevoegdheden Commissariaat voor de Media . . . 403 
Overheid verder op afstand . . . . . . . . . . . . . 404

Taken Commissariaat voor de Media niet uitgebreid . . . . . 406

Samenwerking en informatie-uitwisseling met Europese en

\section{Hoofdstuk $15 \quad$ Nederlandse Filmkeuring}

Geraadpleegde literatuur bij hoofdstuk $15 \ldots \ldots \ldots$. . . . . . . 469

\section{Hoofdstuk 16 Registratiekamer}


Repressief toezicht . . . . . . . . . . . . . . . 476

Hoofdstuk 17 Kwaliteitscontrole-instellingen:

SKAL, KCB, COKZ, NVK, ISC, NAKG

Vrij handelsverkeer van landbouwprodukten en zaai- en plantgoed . . . . . . . . . . . . . . 501 Extra kwaliteits(certificerings)eisen . . . . . . . . 502 502 Privaatrechtelijke kwaliteitscontrole-instellingen . . . . 508 Toezichtsbevoegdheden kwaliteitscontrole-instellingen Stichting Keuring Alternatief voortgebrachte Landbouwprodukten . . . . . . . . . . . . . . . . . 508 Europees streven naar harmonisatie regelgeving en gelijkwaardige controle-instellingen . . . . . . . . . . . 509 Taakstelling stichting Keur Alternatief voortgebrachte Landbouwprodukten . . . . . . . . . . . . . . . . . . 509 Nalevingsplicht gecontroleerden . . . . . . . . . . . 510 Toezichtsbevoegdheden stichting Keur Alternatief voortgebrachte Landbouwprodukten . . . . . . . . . . . 510 Meld- en betaalplichten onder toezicht gestelden ...... 511 Rijkstoezicht en (financiële) verslaglegging . . . . . . . 511 Maatregelen bij niet-naleving: merkverwijdering of merkgebruiksverbod ............... 512 Tucht- en sanctierecht op grond van publiek- en privaatrechtelijke normen $\ldots \ldots \ldots \ldots \ldots \ldots \ldots \ldots . \ldots . \ldots 512$ Certificering . . . . . . . . . . . . . . . 514 Certificaatverlenings- en controleprocedure ... . . . . 515 Rechtsbescherming en klachtbehandeling . . . . . . . 516 Cijfermatige gegevens stichting Keur Alternatief voortgebrachte Landbouwprodukten . . . . . . . . . . . . . 517 Kwaliteits-Controle-Bureau groenten en fruitprodukten ... 519 Taakstelling Kwaliteits-Controle-Bureau groenten en fruitprodukten . . . . . . . . . . . . 520 
17.3 .2

17.3.2.1

17.3.3

17.3.3.1

17.3.4

17.3 .5

17.3 .6

17.4

17.4 .1

17.4 .2

17.4 .3

17.4.3.1

17.4.3.2

17.4 .4

17.4 .5

17.4.5.1

17.4 .6

17.4 .7

17.5

17.5.1

17.5 .2

17.5 .3

17.5 .4

17.5.4.1

17.5.5

17.6

17.6.1

17.6 .2

17.6 .3

17.6 .4

17.7

17.7.1

17.7.3

17.7 .3 .1

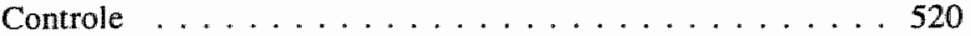

Certificering . . . . . . . . . . . . . . . . 520

Keuring . . . . . . . . . . . . . . . . . . . 522

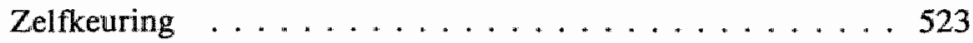

Monitor-en normtoezicht ............... 523

Streng toezicht . . . . . . . . . . . . . . . . . 524

Cijfermatige gegevens werkzaamheden Kwaliteits-

Controle-Bureau groenten en fruitprodukten . . . . . . . 524

Stichting Centraal Orgaan voor Kwaliteitsaangelegenheden

in de Zuivel . . . . . . . . . . . . . . . . . 526

Toezicht zuigelingenvoeding . . . . . . . . . 527

Toezicht boterprodukten . . . . . . . . . . . . 528

Toezicht kaasprodukten . . . . . . . . . . . . . . 528

Rechten en plichten onder toezicht gestelden . . . . . . . 529

Rechten en plichten Centraal Orgaan Kaas- en Zuivelcontrole 531

Toezicht poedervormige melkprodukten ... . . . . 531

Kostenverhaal ...................... 532

Toezichtsbevoegdheden Centraal Orgaan Kaas- en

Zuivelcontrole . . . . . . . . . . . . . . . . . 532

Rijkstoezicht . . . . . . . . . . . . . . . . 533

Cijfermatige gegevens werkzaamheden zuivelcontrole . . . . 533

Stichting Nederlandse Vleeswaren Kontrole . . . . . . . . 534

Taakstelling stichting Nederlandse Vleeswaren Kontrole ... 535

Rechten en plichten onder toezicht gestelden ....... 535

Toezichtsbevoegdheden stichting Nederlandse

Vleeswaren Kontrole . . . . . . . . . . . . . . . . 536

Toezicht op merkechtheid en betrouwbaarheid

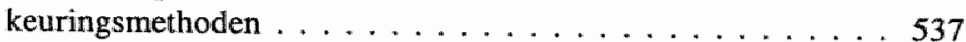

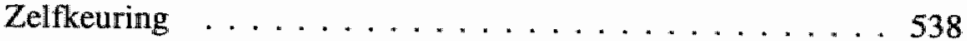

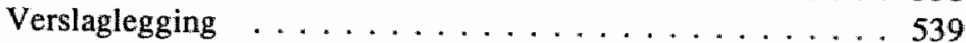

Stichting Internationale Scharrelvlees Controlle . . . . . . 540

Taakstelling stichting Internationale Scharrelvlees Controle . 540

Rechten en plichten onder toezicht gestelden ........ 541

Toezichtsbevoegdheden stichting Internationale

Scharrelvlees Controle . . . . . . . . . . . . . . . . . . 544

Cijfermatige gegevens stichting Internationale

Scharrelvlees Controle . . . . . . . . . . . . . . . . 545

Stichting Nederlandse Algemene

Keuringsdienst Groente- en bloemzaden . . . . . . . . . 546

Taakstelling stichting Nederlandse Algemene Keuringsdienst

Groente- en bloemzaden . . . . . . . . . . . . . . . 546

Aansluitplicht in het kader van de Europese eenwording . . 547

Toezichtsbevoegdheden stichting Nederlandse Algemene

Keuringsdienst Groente- en bloemzaden ... . . . . . . . . 547

Toezicht ten aanzien van aangeslotenen . . . . . . . . 547 
Toezicht ten aanzien van niet-aangeslotenen . . . . . . . 548

17.7 .4

Kostenverhaal ........................ . . 549

17.7.5

Zelfkeuring ........................... 549

17.7 .6

Aansprakelijk- en verantwoordelijkheden . . . . . . . . . 550

17.7 .7

Tuchtrecht ... . . . . . . . . . . . . . . . . 550

17.8

Nederlands Controlebureau Levensmiddelen . . . . . . . . 551

17.8 .1

17.8 .2

Nutricia-kwestie . . . . . . . . . . . . . . . . . . . 552

Voedingskwaliteitstoezicht verantwoordelijkheid van

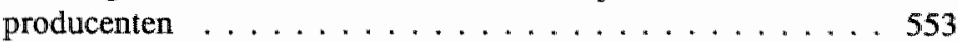

Ten slotte . . . . . . . . . . . . . . . . . . . . . . . 554

Geraadpleegde literatuur bij hoofdstuk $17 \ldots \ldots \ldots \ldots \ldots$

\section{Hoofdstuk 18 Stichting Verzekeringskamer}

18.0

18.1

18.2

18.3

18.3 .1

18.3 .2

18.3 .3

18.3 .4

18.3 .5

18.3 .6

18.3.7

18.4

18.5

18.6

18.6 .1

18.6 .1 .1

18.7

18.8

18.9

18.9 .1

18.9 .2

18.9 .3
Vrijheid van uitoefening van het verzekeringsbedrijf $\ldots 557$

Toezichthouder verzekeringsmarkt verzelfstandigd . . . . . 557

Taakstelling stichting Verzekeringskamer . . . . . . . 560

Normatief toezicht ... . . . . . . . . . . . . 561

Vergunningverlening, -wijziging, en -intrekking . . . . . 5 562

Voorschriften of verbod tot acquisitie van

assurantie-overeenkomsten .............. 563

Beperking of verbod voor verzekeraar on vrij te beschikken

over zijn waarden . . . . . . . . . . . . . . 563

Beperking of verbod bij niet-nakoming solvabiliteitsmarge

tenzij goedgekeurd saneringsplan aanwezig is ......... 563

Verklaring van geen bezwaar . . . . . . . . . . . . . . . 564

Toestemming voor overdracht van rechten en plichten uit verzekeringsovereenkomst en voor omzetting rechtvorm van verzekeringsbedrijf . . . . . . . . . . . . . . . . 564

Overige goedkeuringseisen ............... 565

Toezichtsbevoegdheden stichting Verzekeringskamer ... . 565

Aanwijzingsrecht als omstreden sanctiemogelijkheid . . . . 568

Noodregeling als uiterste sanctiemogelijkheid . . . . . . . . 569

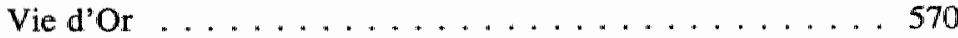

Vie d'Or ter lering van stichting Verzekeringskamer .... 574

Rechtsbescherming en klachtbehandeling . . . . . . . . 548

Kostenverhaall en (financiële) verslaglegging . . . . . . 587

Beperking van de vrijheid tot uitoefening van het

verzekeringsbedrijf in het licht van harmonisatic van

nationale regelgeving ter zake . . . . . . . . . . 588

Samenwerking en informatie-uitwisseling met Europese

(en niet-Europese) staten . . . . . . . . . . . . . . 593

Protocol . . . . . . . . . . . . . . . . . . . . . . 598

Mededingingsrecht en zelfregulering ............ 599

Ten slotte . . . . . . . . . . . . . . . . . . 601 


\section{Hoofdstuk 19 Stichting Toezicht Effectenverkeer}

19.0

19.1

19.1.1

19.2

19.2.1

19.3

19.4

19.5

19.6

19.6 .1

19.7

19.8

19.9

19.10

19.11

19.11 .1

19.11 .2

19.12

19.12.1

19.12 .2

19.12.2.1

19.12.2.2

$19.12 .2 .2 \mathrm{a}$

$19.12 .2 .2 \mathrm{~b}$

$19.12 .2 .2 \mathrm{c}$
Vrijheid van effectenverkeer . . . . . . . . . . . . . 607

Taakstelling Stichting Toezicht Effectenverkeer . . . . . . . 607

Toezicht op naleving van effectenwet- en regelgeving . . . . 611

Overheidstoexicht als aanvulling op zelfregullering ..... . 612

Disfunctioneren controlebureaus . . . . . . . . . . . . 614

Stichting Toezicht Effectenverkeer als gesubdelegeerde

wetgever ....................... . . 619

Vergunningverlening, -wijziging en -intrekking ..... 620

Toezichtsbevoegdheden Stichting Toezicht Effectenverkeer . . 623

Misbruik van voorwetenschap . . . . . . . . . . . . 626

Het strafproces inzake de HCS-kwestie . . . . . . . . . . 630

Meldingsplichten zeggenschap in vennootschappen . . . . 636

Prospectusplicht ..................... 639

Rechtsbescherming en klachtbehandeling ......... 640

Kostenverhaal en (financiële) verslaglegging . . . . . . . 644

Beperking van de vrijheid van effectenverkeer in het licht

van harmonisatie van nationale regelgeving ter zake . . . . 644

Samenwerking en informatie-uitwisseling met Europese

(en niet-Europese) staten . . . . . . . . . . . . . . 650

Mededingingsrecht en deregulering . . . . . . . . . . . 650

Toezicht op effectenverkeer naar nieuw recht: Wte 1995 . . 651

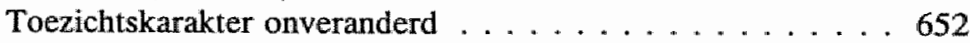

Gedelegeerd toezicht .................. 653

Ministeriële bevoegdheden .............. 653

Bevoegdheden Stichting Toezicht Effectenverkeer . . . . . . 655

Toezichtsbevoegdheden Stichting Toezicht Effectenverkeer . . 661

Samenwerking en informatie-uitwisseling binnen- en

buitenlandse toezichthouders ............. 663

Rechtsbescherming . . . . . . . . . . . . . . . 665

Ten slotte . . . . . . . . . . . . . . . . . . 666

Geraadpleegde literatuur bij hoofdstuk $19 \ldots \ldots$. . . . . . . . . . . 669

Hoofdstuk 20 Toezichthoudende zelfstandige bestuursorganen: samenvatting, bevindingen en conclusies

20.0

Toenemend aantal toexichthoudende zelfstandige

bestuursorganen

20.1

20.1 .1 minister als modetrend ................ 674
Op zoek naar de verantwoording voor de vermagering van de

$\mathrm{Na}$ de, voor verzelfstandiging vereiste, verkleedpartij

niet totaal ontbloot 
Drang tot definiëren kerntaken overheid als voordeel van verzelfstandiging

Vóór verzelfstandiging klinkt het "kruis of munt":

kosteloos of niet

De draaitol van het, mogelijk door verzelfstandiging onstane,

'dollar'-denken . . . . . . . . . . . . . . . . . . . . 680

Concurrentievervalsing door overheidssteun aan

verzelfstandigde entiteiten . . . . . . . . . . . . . 680

20.2

20.2 .1

20.2 .2

20.2 .2 .1

Mededingingsrecht

Mededinging in geding door bevoegdheidsuitoefening van een toezichthoudend zbo . . . . . . . . . . . . . . . . . . 690

Hoe meer marktwerking, hoe meer burgerlijk recht . . . . . 692

Verhaal van toezichtskosten: burgerlijk recht meer soelaas

dan bestuursrecht?

Verzelfstandiging toezichtstaken veroorzaakt door

Hiaten handhaving(sorganisatie) bezien van uit het

20.3 .2

20.3.2.1

20.4

20.4 .1

20.4 .2

20.4 .3

20.4 .4

20.4.4.1

20.4 .4 . $1 \mathrm{a}$

$20.4 .4 .1 \mathrm{~b}$

$20.4 .4 .1 \mathrm{c}$

20.4.4.1d

20.4 .4 .2

20.5

20.5.1

20.5 .2

20.5 .3

20.5 .4

20.5 .4 .1

20.5 .5

20.5 .6

20.5 .7

20.6

20.6 .1 holistisch perspectief . . . . . . . . . . . . . 698

Verzelfstandiging rechtshandhaving .......... 700

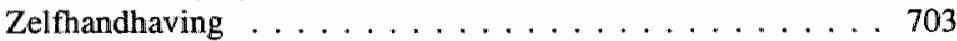

Treden van toezicht . . . . . . . . . . . . . . . . . . . 709

Inspecties ingedeeld volgens Algemene Rekenkamer . . . . . 709

Toezichthoudende zelfstandige bestuursorganen op een rij . 710

In het kader van aan zbo's op- of overgedragen toezichtstaken

uit te offenen bevoegdheden .............. 714

Legitimatie van uitoefening overheidstoezicht door

zelfstandige bestuursorganen . . . . . . . . . . 720

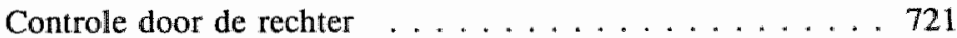

Bestuursrechtspraak . . . . . . . . . . . . . . . 721

Civiele rechtspraak . . . . . . . . . . . . . . . 725

Tuchtrechtspraak ... . . . . . . . . . . . 726

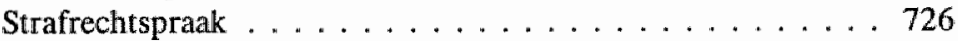

Controle door de minister . . . . . . . . . . . . . . 728

Toezichthoudende verzelfstandigde entiteiten . . . . . . 730

Toezicht als overheidszorg . . . . . . . . . . 730

De toezichthoudende verzelfstandigde entiteit gekarakteriseerd 730

Functies van toezicht . . . . . . . . . . . . . . 732

Verdeling van verantwoordelijkheden met

manipulatie van machten . . . . . . . . . . . 736

Rechtsstatelijkheid rigoreuzer in regressie . . . . . . . 738

Stelsels ten grondslag liggend aan toezicht . . . . . . . . 738

Toezicht verplicht tot geheimhouding . . . . . . . . . . 740

Toezicht, zonder zelfregulering, met mededingingsbeperking 742

Aanbevelingen . . . . . . . . . . . . . . . . 743

Aanbevelingen m.b.t. rechtsorde en rechtsstaat $\ldots \ldots \ldots 743$ 
20.6 .2

Aanbevelingen m.b.t. rechtshandhaving en rechtsbescherming 745

20.6 .3

Aanbevelingen m.b.t. grond- en gemeenschapsrechten .... 748

20.6 .4

Aanbevelingen m.b.t. zelf- en deregulering

Samenvatting

Summary

Jurisprudentieregister

Trefwoordenregister . . . . . . . . . . . . . . . . . 779

Curriculum vitae 


\section{Afkortingenregister}

\begin{tabular}{|c|c|c|c|}
\hline $\begin{array}{l}\text { AA } \\
\text { ganw. }\end{array}$ & $\begin{array}{l}\text { Ars Aequi } \\
\text { aanwijzing }\end{array}$ & Avro & $\begin{array}{l}\text { Algemene Vereniging Radio } \\
\text { Omroep }\end{array}$ \\
\hline \multirow[t]{2}{*}{$\mathrm{AB}$} & Administratiefrechtelijke & awy & algemeen verbindend voorschrift \\
\hline & Beslissingen & a.w. & aangehaald werk \\
\hline Abar & $\begin{array}{l}\text { Algemene bepalingen van } \\
\text { administratief recht }\end{array}$ & Awb & Algemene wet bestuursrecht \\
\hline \multirow[t]{2}{*}{$a b b b$} & algemene beginselen van & $B \& M$ & Beleid en Maatschappij \\
\hline & behoorlijk bestuur & $\mathrm{BB}(\mathrm{M})$ & Binnenlands Bestuur \\
\hline \multirow[t]{2}{*}{ ABRS } & Afdeling Bestuursrechtspraak & & (Management) \\
\hline & Raad van State & BLWn & Beleidswetenschappen \\
\hline adv.gen. & t-generaal & $\mathrm{BK}$ & Bestuurskunde \\
\hline \multirow[t]{2}{*}{ AGRS } & Afdeling Geschillen van bestuur & $\mathrm{BWn}$ & Bestuurswetenschappen \\
\hline & van de Raad wan State & Bf & Besluit op de filmvertoningen \\
\hline AID & Algemene Inspectie Dienst & $\mathrm{BON}$ & Besturen Op Nixeau \\
\hline \multirow[t]{2}{*}{ AMI } & Informatierecht, tijdschrift voor & bw & besloten vennootschap \\
\hline & $\begin{array}{l}\text { Auteurs-, Media- en Informatie- } \\
\text { recht }\end{array}$ & $\begin{array}{l}\text { BW } \\
\text { b.w. }\end{array}$ & $\begin{array}{l}\text { Burgerlijk Wetboek } \\
\text { bij voorbeeld }\end{array}$ \\
\hline AMR & $\begin{array}{l}\text { Auteursrecht, tijdschrift voor } \\
\text { Auteurs- en Mediarecht }\end{array}$ & $\mathbf{B}(\mathrm{i}) \mathbf{Z}(\mathrm{a})$ & Binnenlandse Zaken \\
\hline amvb & algemene maatregell van bestuur & $\mathrm{CBB}$ & College wan Beroep voor het \\
\hline $\mathrm{AP}$ & Acta Politica & & Bedriffslewen \\
\hline APB & Algemeen Politie Blad & $\mathrm{CDA}$ & Christen-Democratisch Appèl \\
\hline APK & Algemene Periodieke Keuring & cie. & commissie \\
\hline $\mathrm{Ar}$ & Algemeen reglement & CJV & Calvinistisclse Juristen Vereniging \\
\hline $\mathrm{AR}$ & h Recht & $\mathrm{CM}$ & Civis Mu \\
\hline ARAR & Algemeen Rijks Ambtenaren & COZ & Centraal Orgaan Zuivelcontrole \\
\hline \multirow[t]{2}{*}{ Arbo } & $\begin{array}{l}\text { Reglement } \\
\text { (wet) Administratieve rechtspraak }\end{array}$ & COKZ & $\begin{array}{l}\text { Centraal Orgaan voor Kwaliteits- } \\
\text { aangelegenheden in de Zuivel }\end{array}$ \\
\hline & bedrijfsorganisatie & $\mathrm{Cl}$ & Computerrecht \\
\hline Arob & $\begin{array}{l}\text { (wet) Administratieve rechtspraak } \\
\text { overheidsbeschikkingen }\end{array}$ & $\begin{array}{l}\text { c.q. } \\
\mathrm{Cr}\end{array}$ & $\begin{array}{l}\text { casu quo } \\
\text { Controlereglement }\end{array}$ \\
\hline ARRS & $\begin{array}{l}\text { Afdeling Rechtspraak van de } \\
\text { Raad van State }\end{array}$ & CRM & $\begin{array}{l}\text { Cultuur, Recreatie en } \\
\text { Maatschappelijk werk. }\end{array}$ \\
\hline rt. & $\begin{array}{l}\text { artikel } \\
\text { artikelen }\end{array}$ & $\begin{array}{l}\text { CRvB } \\
\text { C.s. }\end{array}$ & $\begin{array}{l}\text { Centrale Raad van Beroep } \\
\text { cum suis }\end{array}$ \\
\hline
\end{tabular}




\begin{tabular}{|c|c|}
\hline $\mathrm{CTB}$ & $\begin{array}{l}\text { Commissie (College) Toelating } \\
\text { Bestrijdingsmiddelen }\end{array}$ \\
\hline CTW & Commissie Toetsing Wetgeving \\
\hline CvdM & Commissariaat voor de Media \\
\hline $\mathrm{Cw}$ & Comptabiliteitswet \\
\hline D. 66 & Democraten ' 66 \\
\hline d.d. & de dato \\
\hline $\begin{array}{l}\text { DD } \\
\text { dir.-gen. }\end{array}$ & $\begin{array}{l}\text { Delikt en Delinkwent } \\
\text { directoraat-generaal }\end{array}$ \\
\hline $\mathrm{ECD}$ & Economische Controle Dienst \\
\hline EEG & $\begin{array}{l}\text { Europese Economische } \\
\text { Gemeenschap }\end{array}$ \\
\hline $\mathrm{EG}$ & Europese Gemeenschappen \\
\hline EHRM & $\begin{array}{l}\text { Europees Hof voor de Rechten } \\
\text { van de Mens }\end{array}$ \\
\hline $\mathrm{ESB}$ & $\begin{array}{l}\text { Economische en statistische } \\
\text { berichten }\end{array}$ \\
\hline evt. & eventueel \\
\hline EVRM & $\begin{array}{l}\text { Europees Verdrag tot bescher- } \\
\text { ming van de Rechten van de Mens } \\
\text { en de fundamentele vrijheden }\end{array}$ \\
\hline EK & Eerste Kamer \\
\hline EUR & Erasmus Universiteit Rotterdam \\
\hline $\mathrm{EZ}$ & Econonische Zaken \\
\hline
\end{tabular}

Fieccom financieel-economische commissie

$\begin{array}{ll}\text { GBA } & \text { Gemeentelijke basisadministratie } \\ \text { Gem.w. } & \text { Gemeentewet } \\ \text { gewijz. } & \text { gewijzigd } \\ \text { GPV } & \text { Gereformeerd Politiek Verbond } \\ \text { Gst. } & \text { De Gemeentestem } \\ \text { Gw } & \text { Grondwet }\end{array}$

$\begin{array}{ll}\begin{array}{ll}\text { Hand. } \\ \text { h.i. }\end{array} & \begin{array}{l}\text { Handelingen } \\ \text { huns insziens }\end{array} \\ \text { HR } & \text { Hoge Raad } \\ \text { H.J } & \text { Hof van Justitie } \\ \text { I\&R } & \text { Informatica en recht } \\ \text { i.c. } & \text { in casu } \\ \text { i.d. } & \text { idem dito } \\ \text { IER } & \text { Intellectuele Eigendom \& } \\ & \text { Reclamerecht } \\ \text { i.h.b. } & \text { in het bijzonder } \\ \text { i.h.k. } & \text { in het kader }\end{array}$

100 Instituut voor Onderzoek van Overheidsuitgaven

i.o. . in opdracht van

i.t.t. in tegenstelling tot

IVBPR Internationaal Verdrag inzake Burgerrechten en Politieke rechten

IvI Instituut voor Informatierecht

JB Jurispradentie Bestuursrecht

jo. juncto

Jur. Jurisprudentie van het Hof varn Justitie der Europese Gemeenschappen

JV Justitiële Verkenningen

K\&R Kabel en Reintjes

KB Koninklijk Besluit

KCB Kwaliteits Controle Bureau groenten en fruit

KG Kort Geding

$\mathrm{Kr} \quad$ Keuringsreglement

KRO Katholieke Radio Omroep

KUB Katholieke Universiteit Brabant

KUN Katholieke Universiteit Nijmegen

KvK Kamer van Koophandel en Fabrieken

laatst. laatstelijk

Lkb Landbouwkwalliteitsbesluit

Lkbg Landbouwkwaliteitsbeschikking

Lkw Landbouwkwaliteitswet

LNV Landbouw, Natuur \& Visserij

LR Liberaal Réveil

$\mathrm{Mb} \quad$ Mediabesluit

MC Management Centrum

min. minister(ie)

MF Mediaforum

m.nt. met noot

mon. monografie

MR Nederlands tijdschrift woor Milieu en Recht

m.v. ministeriêlle verantwoordelijkheid

mva memorie van antwoord

mvt memorie van toelichting

Mw Mediawet 


\begin{tabular}{|c|c|c|c|}
\hline NAKG & $\begin{array}{l}\text { Nederlandse Algemene Keurings- } \\
\text { dienst voor Groente- en }\end{array}$ & pbo & $\begin{array}{l}\text { publiekrechtelijke bedrijfs- } \\
\text { organisatie }\end{array}$ \\
\hline & blloemzaden & $\mathrm{PD}$ & Publiek Domein \\
\hline $\mathrm{NAKS} / \mathrm{B}$ & Nederlandse Algemene Keurings- & p.g. & procureur(s)-generaal \\
\hline & dienst voor Siergewassen/ & pgo & paragouvernementele organisatie \\
\hline & Boomkwekerijprodukten & $\mathrm{pp}$ & pagina's \\
\hline n.b. & nota bene & pres. & president \\
\hline NCRV & $\begin{array}{l}\text { Nederlandse Christelijke Radio } \\
\text { Vereniging }\end{array}$ & PS & $\begin{array}{l}\text { Periodiek voor Sociale verzeke- } \\
\text { ringen, sociale voorzieningen en }\end{array}$ \\
\hline NFK & Nederlandse Film Keuring & & arbeidsrecht \\
\hline $\mathrm{Ng}$ & Nederlandse gemeenten & Psw & Pensioen- en spaarfondsenwet \\
\hline NJ & Nederlandse Jurisprudentie & PTT & Posterijen, Telegrafie en \\
\hline NJB & Nederlands Juristen Blad. & & Tellefonie \\
\hline $\mathrm{NJCM}$ & Nederlands Juristen Comitee voor & publ. & publikatie \\
\hline & de Mensenrechten & Publ. & Publications of the Court \\
\hline NJV & Nederlandse Juristen Vereniging & PVdA & Partij van de Arbeid \\
\hline NO & Nationale Ombudsman & & \\
\hline NOS & Nederlandse Omroep Stichting & R\&K & Recht en Kritiek \\
\hline Nozema & Nederlandse Omroep-Zender- & rapp. & rapport(age) \\
\hline & Maatschappij & rb. & rechtbank \\
\hline $\operatorname{nr}(s)$ & nummer(s) & $\mathrm{Rbb}$ & Raad voor het binnenlands bestuur \\
\hline NRC & Nederlandsche Rotterdamse & red. & redactie \\
\hline & Courant (Handelsblad) & Rhvv & Reglement huisvesting, verzor- \\
\hline $\mathrm{NSC}$ & Nederlands Congres Centrum & & ging en woeding scharrelvarkens \\
\hline NTB & $\begin{array}{l}\text { Nederlands Tijdschrift woor } \\
\text { Bestuursrecht }\end{array}$ & RPF & $\begin{array}{l}\text { Reformatorische Politieke } \\
\text { Federatie }\end{array}$ \\
\hline nv & naamloze vennootschap & Rkmb & Reglement keuring en merk- \\
\hline NV & de Naamlooze Vennootschap & & uitreiking baconprodukten \\
\hline NVE & $\begin{array}{l}\text { Nederlandse Vereniging voor } \\
\text { Europees recht }\end{array}$ & $\mathrm{Rkmv}$ & $\begin{array}{l}\text { Reglement keuring en merk- } \\
\text { uitreiking vleeswaren }\end{array}$ \\
\hline NVIR & Nederlandse Vereniging voor & $\mathrm{RL}$ & Rijksuniversiteit Limburg \\
\hline & Informatica en Recht & $\mathrm{RM}$ & RegelMaat \\
\hline NVK & Nederlandse Vleeswaren Kontrole & RM Themis & is Rechtsgeleerd Magazijn Themis \\
\hline $\mathbb{N V} \vee \mathbb{R}$ & Nederlandse Vereniging voor & r.o. & rechtsoverweging \\
\hline & Rechtspraak & RO & $\begin{array}{l}\text { (wet op de) Rechterlijke } \\
\text { Organisatie }\end{array}$ \\
\hline $\mathrm{OB}$ & Openbaar Bestuur & Rv. & (wetbock van burgelijke) Recht- \\
\hline $\mathrm{OCV}$ & Openbare Commissie Vergadering & & vordering \\
\hline$O C W$ & Onderwijs, Cultuur en Weten- & RvO & Reglement van Orde \\
\hline & schappen & RvT/B & Raad van Toezicht/Bestuur \\
\hline $\mathrm{OM}$ & Openbaar Ministerie & RUG & Rijksuniversiteit Groningen \\
\hline OMn & Overheidsmanagement & RUL & Rijjksuniwersiteit Leiden \\
\hline ou & Openbare Uitgaven & RUU & Rijksuniversiteit Utrecht \\
\hline OUH & Open Universiteit Heerlen & RvdW & Rechtspraak van de Week \\
\hline ovj & officier van justitie & RvSt & Raad van State \\
\hline & & $\mathrm{RW}$ & Rechtskundig Weekblad \\
\hline p. & pagina & & \\
\hline P\&R & Privacy en Registratie & S\&U & Editie Schuurmans en Jordens \\
\hline par. & paragraaf & $S \& V$ & Stichting en Vereniging \\
\hline
\end{tabular}




$\begin{array}{ll}\text { SER } & \text { Sociaal-Economische Raad } \\ \text { SEW } & \text { Sociaal-economische wetgeving } \\ \text { SGP } & \text { Staatkundig Gereformeerde Partij } \\ \text { SMA } & \text { Sociaal Maandblad Arbeid } \\ \text { SMO } & \begin{array}{l}\text { Stichting Maatschappij en Onder- } \\ \text { neming }\end{array} \\ \text { So } & \text { Sanctieregeling omroep } \\ \text { SOG } & \text { Stichting Onderzoek Gemeenten } \\ \text { SR } & \text { Nederlands tijdschrift voor } \\ & \text { Sociaal Recht } \\ \text { Stbl. } & \text { Staatsblad } \\ \text { Stcrt. } & \text { Staatscourant } \\ \text { STE } & \text { Stichting Toezicht Effecten- } \\ & \text { verkeer } \\ \text { STER } & \text { Stichting Ether Reclame } \\ \text { suppl. } & \text { supplement } \\ & \\ \text { t.a.p. } & \text { ter aangehaalde plaatse } \\ \text { TAR } & \text { Tijdschrift voor Ambtenarenrecht } \\ \text { tB/S } & \text { Ten Berge/Stroink (losbladige } \\ & \text { Administratieve Rechtspraak } \\ & \text { Overheids Beschikkingen) } \\ \text { TK } & \text { Tweede Kamer } \\ \text { Trbl. } & \text { Tractatenblad } \\ \text { TROS } & \text { Televisie Radio Omroep Stichting } \\ \text { TvBP } & \text { Tijdschrift voor Bestuursweten- } \\ & \text { schappen en Publiekrecht } \\ \text { TvC } & \text { Tijdschrift voor Consumenten- } \\ & \text { recht } \\ \text { TvO } & \text { Tijdschrift woor Openbaar bestuur } \\ \text { TwP } & \text { Tijdschrift voor de Politie } \\ \text { TVVS } & \text { Tijdschrift Voor Vennootschappen } \\ & \text { en Stichtingen } \\ & \\ & \end{array}$

UCV Uitgebreide Commissie

$\begin{array}{ll} & \text { Vergadering } \\ \text { uitg. } & \text { uitgave } \\ \text { UT } & \text { Universiteit Twente } \\ \text { UvA } & \text { Universiteit van Amsterdam } \\ \text { V\&W } & \text { Verkeer en Waterstat }\end{array}$

$\begin{array}{ll}\text { VA } & \text { het Verzekeringsarchief } \\ \text { VAR } & \begin{array}{l}\text { Vereniging voor Administratief } \\ \text { recht }\end{array} \\ \text { VARA } & \begin{array}{l}\text { Vereniging van Arbeiders Radio } \\ \text { Amateurs }\end{array} \\ \text { Vgl. } & \begin{array}{l}\text { vergelijk } \\ \text { VMC }\end{array} \\ & \begin{array}{l}\text { Vereniging voor Media- en } \\ \text { Communicatierecht }\end{array}\end{array}$

VNG Vereniging voor Nederlandse Gemeenten

Vo Verordening van de Europese

Gemeenschappen

vol. volume

VoO Veronica Omroep Organisatie

VPRO Vrijzinnig Protestantse Radio Omroep

VR Verkeersrecht, juridisch maandblad betreffende het wegverkeer

VROM ministerie van Volkshuisvesting, Ruimtelijke Ordening en Milieu

vs. versus

VU Vrije Universiteit Amsterdam

v.v. vice versa

VV voorlopig verslag

VvB Vereniging voor Bestuurskunde

$\mathrm{VvBr} \quad$ Vereniging voor Bouwrecht

VVD Volkspartij voor Vrijheid en Democratie

VvM Verdrag van Maastricht

VVSR Vereniging voor de Vergelijkende Studie van het Recht

VWS Volksgezondheid, Welzijn en Sport

Vww Vereniging voor wetgeving en wetgevingsbeleid

VZ AGRS Voorzitter van de Afdeling Geschillen van bestuur van de Raad van State

VZ ARRS Voorzitter van de Afdeling Rechtspraak van de Raad van State

Wabm Wet algemene bepalingen milieuhygiëne

Wap Wet autovervoer personen

WB Waterschapsbelangen

WED Wet op de Economische Delicten

WEM Wet Economische Mededinging

Wf Wet op de filmvertoningen

WFR Weekblad voor Fiscaal Recht

Wgr Wet gemeenschappelijke regelingen

Wgw Wet gevaarlijke werktuigen

Wifd Wet identificatievaststelling bij financiële dienstwerlening

Wmot Wet melding ongebruikelijke transacties 
Wmz Wet melding zeggenschap in ter beurze genoteerde vennootschap-

pen

Wno Wet nationale ombudsman

Wob Wet openbaarheid van bestuur

WPNR Weekblad voor Privaatrecht, Notariaat en Registratie

Wpr Wet persoonsregistraties

Wpolr Wet politieregisters

WRR Wetenschappelijke Raad voor het Regeringsbeleid

Wsc Wet op het specifiek cultuurbehouid

Wte Wet toezicht effectenverkeer

Wty Wet toezicht verzekeringsbedrijf

WVC Welzijn, Volksgezondheid en Cultuur

WvK Wetboek van Koophandel

WvSr Wetboek van Strafrecht

WvS $\quad$ Wetboek van Strafvordering

zbo zelfstandige bestuursorgaan

zbo's zelfstandige bestuursorganen

z.i. zijns insziens

Zpw Zaaizaad-en plantgoedwet 


\section{Verantwoording}

\section{$\S 1.1$ Inleiding}

Volgens politiek Den Haag "mogen binnen de overheidsorganisatie duizend bloemen bloeien, zo lang ze zich maar efficiènt naar de zon richten en niet te veel water behoeven". 1

Niet alleen in Den Haag wordt geregeerd. Ook democratisch verkozen openbare lichamen als waterschappen, gemeenten, provincies en binnenkort ook regio's oefenen overheidsmacht uit.

Minder bekend zijn de organen en rechtspersonen die, hoewel in beperkte mate democratisch gelegitimeerd, met oog op een bepaalde taak 'overheidsonderdeel' zijn. Even als territoriaal bestuur zetelt dit functioneel bestuur her en der in Nederland. Functionele organen of rechtspersonen zijn min of meer autonome autoriteiten, bevoegd tot het uitoefenen van de aan hen - als zelfstandige entiteiten (wel te verstaan: zelfstandige bestuursorganen) belast met een bepaalde opgedragen overheidstaak - overgedragen of toegekende bevoegdheden.

Functionele decentralisatie heeft een hoge vlucht genomen: "Behalve aan territoriale decentralisatie is er de laatste jaren veel gebeurd aan functionele decentralisatie om burgers en organisaties meer ruimte te geven voor eigen verantwoordelijkheid. " 2

Aan de vooravond van prinsjesdag 1994, waarop presentatie van het regeerakkoord voor het kakelverse kabinet-Kok plaatsvindt, gaat een waarschuwing uil tegen het reële risico, dat het kernbegrip in de regeringsverklaring "eigen verantwoordelijkheid van de burgers" geen sleutel zonder deuren mag worden. De waarschuwing is vervat in een interessant pleidooi. ${ }^{3}$ Dit pleidooi houdt in dat de politiek haar traditionele sturingspretenties moet laten varen om vervolgens het lef te hebben overheidssturing in belangrijke mate over te

1. O. van de Vijver, Verzelfstandigen; Priwatiseren is domweg geen politiek thema meter, in: BBM, nr.7, 1 now. 1991, p.11.

2. Troonrede, in: NRC, 21 sept. 1993, p.28.

3. M. Bovens, W. Derksen, W. Witteveen, P. Kalma en F. Becker, Den Haag heeft steeds minder te vertelLen, in: NRC, 19 sept. 1994, p.7 
laten aan mondige, goed opgeleide en initiatiefrijke burgers, die kennelijk het middelpunt van de democratie kunnen vormen.

Bedoeld pleidooi is een teken aan de wand bij het, in een stroomversnelling geraakte, verzelfstandigingsbeleid. Vandaar een samenvatting van dit betoog.

Het Deetman-debat, waarin delibererend denken centraal staat, kenmerkt zich helaas vooral door een technocratische benadering. In plaats van legitimiteit en rechtwaardigheid, vormen effectiviteit en efficiency het hart van holistisch heersende overheden die als hetzij beleidsbepalers hetzij beleidsuitvoerders hun taken, onderling consistent, moeten uitvoeren. Daardoor wordt de democratische rechtsstaat in wezen aangetast. 'Erosie van gelegitimeerde overheidsmacht' onstaat op drie manieren. Ten eerste, de invloed van lobbyisten, pressiegroepen, overlegpartners, beleidsnetwerken en dergelijke is immens. Ten tweede, een scala aan complexe organisaties van publieke en private aard nemen, al dan niet bewust, de formele en feitelijke macht van de rijksoverheid, aan wier dobber in de Haagse vijver al lang niet meer alle touwtjes vast zitten, over. Verzelfstandiging en privatisering maken van Nederland een "republiek van rechtspersonen". Ten derde, politiek Den Haag verliest veel macht aan het, zonder blikken of blozen bijtende, Brussel die in haar Europese eigenaardigheid geen sterke traditie kent waar het politieke controle betreft. Het "democratisch vacuüm" dat op alle drie terreinen drukt, kan niet meer alleen door de politiek zelf worden ingevuld. Het primaat van de politiek vervaagt zo tot "hersenschim".

Daarom vereist het weg cijferen van het democratisch tekort 'verbreding van het democratiedenken' als volgt. Ten eerste, aan te bevelen zijn nieuwe vormen van publieke verantwoording als: uitbreiding van formele zeggenschapsrechten (o.a. invloed werknemers in aandeelhoudersvergaderingen of raden van commissarissen); garanties voor openbaarheid (o.a. via verplichte verslaglegging van bedrijven en instellingen); en ruimte voor discussie en kritiek in particuliere en overheidsorganisaties (o.a. beroepscodes, klokkeluidersbescherming, vertrouwenspersonen, fora). Ten tweede, om ambtelijk falen en beleidswillekeur zo veel mogelijk in de kiem te smoren en tegen te gaan is het inbouwen wenselijk van garanties als: uitbreiding van individuele rechtsbescherming van burgers (o.a. via zgn. citizen's charter); verfijning van beginselen van behoorlijk bestuur (o.a. motiveringsplicht overheidsbesluiten); stelselmatige evaluatie van overheidsbeleid (o.a. met medewerking van - eventueel door het lot aan te wijzen - burgers); en rechterlijke toetsing van nieuwe wetgeving aan de Grondwet. Ten derde, het is aan te raden om de directe betrokkenheid van burgers bij het beleid te vergroten via beïnvloedingsmogelijkheden als: het volksinitiatief; informele raadpleging van burgers (o.a. via enquêtes en tweeweginformatiesystemen); ad hoc-maatschappelijke debatten (o.a. via nationale televisiediebatten, stadsgesprekken en kwaliteitspanells); maatschappelijke enquêtes (o. $a_{n}$, , op verzoek van groepen burgers te verrichten, onderzoek van onafhankelijke deskundigen 
naar omstreden investeringen); en de betrokkenheid van bewoners bij de verbetering van de leefbaarheid in de steden. ${ }^{4}$

Het voorgaande vraagt om een "Copernicaanse Omwenteling" in het denken over de verhouding tussen politiek, overheid en samenleving. De distantie, die de politiek zich moet leren aanmeten, leidt niet tot passiviteit. In haar nieuwe rol coördineert zij de inbreng van burgers en smeedt zij het geheel van concurrerende opinies en botsende belangen om tot een politieke consensus. Kortom, van de overheid wordt minder sturing, maar meer visie verwacht.

Aldus een, verlossing predikend, verhaal voor een falende, pretentieuze overheid.

De problemen, waarop het pleidooi woor verandering is gebaseerd, zijn inderdaad herkenbaar. In het bijzonder bij het functioneel decentraliseren van taken en bevoegdheden naar, in principe niet hiërarchisch aan ministers ondergeschikte, zelfstandige bestuursorganen kijkt het probleem van gebrek aan democratische legitimatie al snel om de hoek. Zelfstandige bestuursorganen, die op afstand van de politiek staan, ontberen per definitie volledige parlementaire politieke controle. Overigens moet daar niet al te zwaar aan worden getild.

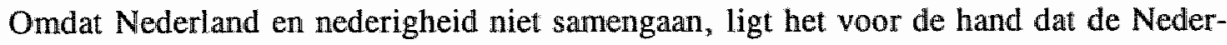
landse overheid, voornemens overige overheden elders met een staaltje van kennis inzake de overheidsorganisatie te veroveren, al vrij vroeg overgaat tot instelling van zelfstandige bestuursorganen. Als een van de eerste Europese landen plant Nederland, de natie die bezig is voorgoed te vervreemden van het haar opgeplakte etiket wan behoudendheid, Amerikaans gedachtengoed (inzake verzelfstandiging ${ }^{5}$ ) over in eigenaardige Hollandse bodem. Eerst als de bloemen van het zaad bloeien, wordt duidelijk dat het kruid ook stekels heeft. Pas dan worden oplossingen bedacht en gevonden. Van Scandinavië, waar zelfstandige uitvoeringsorganen al iets langer een vertrouwd verschijnsel zijn, kan Nederland gelukkig het goede af kijken. Kortom, Neêrlands trots teert op tijd. De tijd leert wel een oplossing voor (potentiële) problemen als het gebrek aan democratische legitimatic bij zelfstandige bestuurorganen. Met andere woorden, het griezelige gegeven van het ontbreken van legitimiteit (waarwoor tegenwoordig waardige alternatieven worden aangedragen) mag niet bepalend zijn om de weg naar zelfstandige bestuursorganen af te sluiten. Te alarmerend aandacht daarvoor verduistert de lichtpunten van zelfstandige bestuursorganen.

4. Natuarlijk koant de Algemene wet bestuursrecht al enigszins tegemoet aan de problemen als adangegeven in bovenstaand betoog. Bij voorbeeld, hoewell de abbb nog alitijd niet woldoende verfijnd zijn legt de Awb wel expliciet een motiveringsplicht t.a.v. bestuiten van bestursorganen wast (zie afdeling $3.7 \mathrm{Awb}$ ). En ook de betrokkenheid van bewoners voorgenomen bestuiten wordt onder meer gewarborgd door de in de afdelingen 3.4 en $3.5 \mathrm{Awb}$ neer gelegde (uitgebreide) voorbereidingsprocedure warin al dan niet deskundige belanghebbenden in staat worden gesteld om te worden gehoord en ook owerigens hun bezwaren tegen besluitvoornemens kenbaar kunnen maken.

5. In de Verenigde Staten van Amerika wordt al langer geèxperimenteerd met o.a. "regulatory bodies". In Nederland wordt graag gebuik gemaakt wan de daar opgedane ervaringen betreffendle verzelfstandiging van overheidstaken. 


\section{$\$ 1.2$ Omvang verschijnsel zelfstandige bestuursorganen}

Een eerste uitvoerige inventarisatie ${ }^{6}$ zet in 1983 zelfstandige bestuursorganen rigoreus op een rij. Hierbij worden twee groepen overheidsorganen onderscheiden. Ten eerste zijn

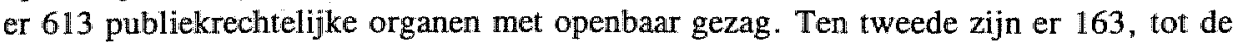
overheid te rekenen, rechtspersonen. Magische getallen dus.

De getallen nopen tot reductie, als een andere inslag wordt gekozen. Een financiële rapportage ${ }^{7}$ ter zake spiegelt in 1991 dan ook andere cijfers voor. De opstellers er van zien daarvoor de nodige aanleiding. ${ }^{8}$

In de eerste plaats overlappen beide groepen overheidsorganen elkaar.

Sommige organen van functioneel bestuur vallen onder zowel groep a (publiekrechtelijke organen met openbaar gezag) als groep b (tot de overheid te rekenen rechtspersonen). Denk aan de stichting Bedrijfsfonds voor de pers. ${ }^{9}$

Bovendien zijn alle zelfstandige bestuursorganen apârt geteld. Dat is op zich niet onjuist. Immers, functioneel gedecentraliseerde organen kunnen territoriaal vertakt zijin. In feitelijke uitvoering van hun werkzaamheden verschillen zelfstandige bestuursorganen mogelijk. Maar hun taken- en bevoegdhedenpakket moet in principe hetzelfde inhouden. Veel functioneel gedecentraliseerde organen vallen namelijk onder een of andere categorie van organen. Bij voorbeeld reclasseringsstichtingen ${ }^{10}$, kamers van koophandel en fabrieken, besturen van bedrijfswerenigingen, stichtingen inzake keuring van zaden en gewassen, erkende stamboekverenigingen voor paarden, bureaus inzake kwaliteitscontrole zuivel-en vleeswaren, commissies voor samenstelling van (gewassen)rassenlijsten, commissies voor gebiedsaanwijzing, grondkamers, bureaus van consultatie en raden van rechtsbijstand. " $\mathrm{Na}$ eliminatie van de dubbeltellingen omvat bedoelde inventarisatie 239 categorieën van organen en rechtspersonen.

6. H.F. Munneke, J.B.J.M. ten Berge, F.A.M. Stroink, P. Haighton en P. den Hoed, Organen en rechtspersonen rondom de centrale overheid, WRR-serie voorstudies en achtergronden $V 35$, delen $U / 11,1983$.

7. Ministerie van financiër, centrale accountantsdienst, projectgroep functionele decentralisatie, Wrifheid in gebondenkeid; Een rapportage overfunctioneel gedecentraliseerde insteltingen rondom de rijksoverheid, in het bijzonder over opzer en werking wan toezicht en controle buj deze instellingen, respectievelijk deel I en deel II, 's Grav., nov. 1991.

8. Ministerie van financiën, CAD, projectgroep functionele decentralisatie, ta.p. (deell), pp.1/34.

9. Voorgesteld is dit fonds te verwangen door het Bedrijfsfonds voor de Informatieproduktie. Mediaraad, Advies inzake herstructurering beleid informatievoorziening . Deel II De informatieproduktie. "s-Gravenhage, 27 jan. 1994, p. 23.

10. Zie over gewijzigde opzell daarvan (De 19 autonome, aan de arrondissementen gekoppelde, reclasseringsstichtingen worden vervangen door één landelijke organisatie met verschillende units in het land. De units worden op managementniveau weer gerelateerd aan de ressorten van de hoven van justitie en op uitvoeringsniveau aan de arrondissementen. De eigen verantwoordelijkheid vam de reclassering krijgt scherper accent, omdat de beleidsmatige sturing van de minister meer op afstand komt) Besituit houdende nieuwe regels inzake de reclassering van $15 \mathrm{dec} .1994$, Stbl 1994, 875. Deze Reclasseringsregeling 1995, die minder gedetailleerde taakstelling omwat, werkt sinds 1 jan. 1995.

11. Zie over nieuwe opzet daarvan, t.w. wijf (hofressort)raden voor rechtsbijstand, ellk gekoppeld aan een bureau rechtsbijstandvoorziening, TK 1992-1993/1993-1994, 22609, nrs. 1-24, gewijz. TK 1993-1994. 23464 , nr.9 e.v., respectievelijjk Wet op de rechtsbijstand, Stbl. 1993, 775 en uitwoering sbesluiten Stbl. $1994,31-33$. 
In de tweede plaats is, van uit financieel oogpunt, niet elk zelfstandig bestuursorgaan even important. ${ }^{12}$ 'Slechts' 62 (groepen van) organen van functioneel bestuur hebben een budgettair belang van betekenis. Dat wil zeggen, zij vertegenwoordigen meer dan éen miljoen gulden. Deze organen samen zijn, voor de uitgavenkant van de rijksbegroting, jaarlijks goed woor 40,1 miljard gulden.

Een andere actualisering van zelfstandige bestuursorganen gaat in 1992 uit van 165 zelfstandige bestuursorganen. ${ }^{3}$ Geclassificeerd naar type produkt is hun aantal: 12 belast met uitvoering van inkomensoverdrachten; 40 belast met economische steunverlening, marktordening en toezicht; 21 belast met vergunningverlening en toelating; 20 belast met kwaliteitscontrole en keuringen; 23 belast met onderzoek en onderwijs; en 49 belast met voorlichting, advies en overige dienstverlening. ${ }^{14}$ Bij elkaar doen zij voor bijna 12,1 miljard gulden aanslag op de publieke middelen.

En de meest recente, indringende inventarisatie van zelfstandige bestuursorganen is levert in elk geval 189 zelfstandige bestuursorganen, of clusters daarvan, op. Deze, zowel publieke als private, zelfstandige bestuursorganen, die in $1992 / 1993$ bijna 38 miljard gulden rijksbegrotingsgeld (d.i. 18 procent van de totale uitgaven van het rijk) opslorpen, hebben tot taak: houden van toezicht ( $12 \%$ ); geven van bindende kwaliteitsibeoordelingen (16\%); verlenen van vergunningen (4\%); opstellen van bindende regelgeving (5\%); registreren $(5 \%)$; memen van overige bindende beslissingen $(10 \%)$; verstrekken van uitkeringen, subsidies $(31 \%)$; innen van heffingen $(3 \%)$; adviseren, stimuleren, opleiden, beheren (14\%); en onderzoeken $(4 \%)$. ${ }^{16}$

Hoe verschillend deze categoriserende cijfers ook zijn, duidelijk is dat zelfstandige bestuursorganen, qua kwantiteit, nieuw onderzoek rechtvaardigen.

\subsubsection{ONDERZOEKSOBJECT}

Het onderliggende onderzoek - hoewel een term als studie voorkeur heeft - staat in het teken van toezicht door zelfstandige besturursorganen.

12. Wel is het zo dat toezichthoudende zbo ${ }^{\circ}$, die financieel gezien weing interessant kunmen zijn, niet zijn te veronachtzamen in het licht van hun bevoegdheden, waarvande witoefening ingripend ten op zichte wan burgers en maatschappij kan zijn.

13. E. Bonescharsiker en H. de Groot, Instrumenten bij sturen op afstand, 100-reeks ur. 36, 's-Grav., 1992 , p.32.

14. Bij deze laatste categorie is de vraag te stellen of wel spmake is van besturursorganen. Voor zover zbo ${ }^{\circ} \mathrm{s}$ enkel en alleen adviseren of voorlichten is in elk geval geen sprake van uitoefening van openbaar gezag.

15. Algemene Rekenkamer, Zelfstandige bestuursorganen en ministeriele werantwoordelikheid, TK 1994 1995,24130 wr.3, pp.9-10. Daarmee wordt dam ook weer een concreet cijfer van zeker 550 afzonderlijke zbo"s benaderd.

16. Algemene Rekenkamer, Zbo's en ministeriële neranmoordelijheid, TK 1994-1995, 24130, nr.3, pp. 12. 13. 
Vernuftig genoeg valt dit, overigens bij de vakgroep publiekrecht (van de faculteit der rechtsgeleerdheid aan de rijksuniversiteit Limburg te Maastricht) uitgevoerde en door de stichting Recht en Openbaar Bestuur gefinancierde, onderzoek binnen het, van de vakgroep privaatrecht uitgaande, meer omvattende onderzoeksproject "toezicht óp complexe juridische organisaties".

Binnen dat overkoepelende onderzoeksproject doet een studie naar het toezicht door zelfstandige bestuursorganen aan als een vreemde eend in de bijt. Het karakter van deze studie is inderdaad van ander kaliber.

Weliswaar kan zij zeer zeker het onderwerp 'toezicht op complexe juridische organisaties (als zelfstandige bestuursorganen)' raken. Maar dit soort toezicht, dat toch vooral is te realiseren via uitoefening van goedkeurings-, stem-, schorsings- of vernietigingsrechten, krijgt in deze studie bewust geen bespreking.

Ter illustratie het volgende. Binnen sommige sectoren, als de sociale zekerheid, houdt het ene zelfstandig bestuursorgaan toezicht op een of meer andere zelfstandige bestuursorganen die weer toe moeten zien op uitvoering of naleving van wet- en regelgeving. Hierbij is sprake van fundamenteel verschillend toezicht: a. intern toezicht, d.w.z. het toezicht op het functioneren van min of meer departementsonafhankelijke overheidsorganen (indirect toezicht); en b. extern toezicht, d.w.z. het toezicht op het naleven van wetten en regeis (direct toezicht).

Eerst genoemd toezicht is voomamelijk organisatierechtelijk van aard. Met oog op de afwezigheid van volledige ministeriële politieke verantwoordelijkheid voor het handelen en nalaten van zelfstandige bestuursorganen, is het - met oog op een democratische legitimatie van bestuurlijk gedrag - belangrijk dat enige onpartijdigheid of onafhankelijkheid wordt gewaarborgd via het, bij het (op andere zbo's) toezichthoudende zelfstandig bestuursorgaan, inbouwen van essentiële elementen van rechtspersonenrecht: kent het orgaan een raad van bestuur of een onafhankelijke raad van toezicht. Dit toezicht, als bedoeld onder a, heeft te maken met mogelijke ministeriële interventiemechanismen. Formeel kan dit interne toezicht binnen een studie naar het 'toezicht door zelfstandige bestuursorganen" vallen. Materieel hoort dit toezicht er echter niet thuis.

Deze studie ziet dus op het, door zelfstandige bestuursorganen, toezicht houden op de naleving van het bij of krachtens de wet gestelde. Voor een goed begrip, toezicht op naleving van wet- en regelgeving is principieel niet gelijk aan het toezicht op de uitvoering van wet- en regelgeving. Beide kunnen wel samenvallen, maar de toezichtsterreinen zijn in essentie te scheiden taakgebieden.

Juist de rechtshandhavende taakopdracht, met de daaraan gekoppelde (dwang)bevoegd heden, wan zelfstandige bestuursorganen is interessant.

In deze studie is de centrale vraag of externe verzelfstandiging van overheidstoezicht naar publieke of private, min of meer zelfstandige, rechtsvormen meerwaarde heeft in het licht wan het, door een groeiende grensoverschrijdende gerichtheid ontstane, adagium 'Minder overheid, meer markt en minder regelgeving'. Deze vragg over de relevantie van toezichthoudende zbo's en in welke vorm en in welke mate die betekenis zich voordoet, wordt beantwoord van uit: 

a. rechtsordelijk en -statelijk perspectief;
b. rechtshandhavings- en rechtsbeschermingsperspectief;
c. grond- en gemeenschapsrechtelijk perspectief;
d. zelf- en dereguleringsperspectief;
e. harmonisatie- en liberaliseringsperspectief;
f. monopolievorming- en mededingingsperspectief;
g. verzelfstandigings- en privatiseringsperspectief.

De studie kent een driedelige opbouw. Haar hoofdcomponenten bestaan uit inleidingen en afsluitingen inzake respectievelijk bestuurlijk organisatierecht, functioneel bestuur en rechtshandhaving door toezichthoudende zelfstandige bestuursorganen.

Wat betreft het, in hoofdstuk 2 tot en met 5 vervatte ${ }^{17}$, eerste deel bestuurlijk organisatierecht:

Van uit de machtenscheiding, als uitvloeisel van de rechtsstaatgedachte, worden de ministeriële verantwoordelijkheid en de legaliteitseis beschreven.

Omdat zelfstandige bestuursorganen niet in hiërarchische relatie tot de minister staan, is belangstelling voor deze beperking van politieke ministeriële verantwoordelijkheid logisch. Aandachtspunten zijn: theorievorming rond objectieve en subjectieve politieke verantwoordelijkheid als ook reikwijdte en fasen van het het verantwoordingsproces, de nuttige functie van een (fictieve) ministeriële verantwoordelijkheid, de mogelijkheid en wenselijkheid van een zelfstandige politieke aanspreekbaarheid en/of verantwoordelijkheid voor ambtenaren.

Tegen de achtergrond van het legaliteitsbeginsel staat beknopte bespreking van wetmatigheid van bestuur en attributie/delegatie van publiekrechtelijke bevoegdheden aan zelfstandige bestuursorganen voorop. Vervolgens verdienen de algemene delegatiebepalingen in de derde tranche Awb bespreking. Omdat deze bepalingen samen, als algemene regeling ook voor zelfstandige bestuursorganen, niet voldoen, is het van regeringswege gegeven loetsingskader voor zelfstandige bestuursorganen elementair. Zij oogst waardering en kritiek. Bezien wordt in welke mate de mogelijkheid, tot omzetting er van in een kaderwet voor zelfstandige bestuursorganen, bestaat. Ten slotte zijn decentralisatie in het algemeen, daarnaast territoriale en functionele decentralisatie in het bijzonder, beschreven. Plaatsbepaling van zelfstandige bestuursorganen binnen het openbaar bestuur, perspectief van het toekomstig bestuur en integratie (via regiovorming) van functionele en territoriale bestuursorganen komen zo aan de orde.

Wat betreft het, in hoofdstuk 6 tot en met 9 vervatte ${ }^{18}$, tweede deel functioneel bestuur: Dit deel handelt over de verzelfstandiging van overheidstaken in het licht van de reorgam nisatie van de rijksdienst. Privatisering(svarianten) als mede interne en externe verzelfstandiging komen aan bod. Naast onder meer zelfbeheer en agentschapsvorming, krijgt functioneel bestuur in zijn verschijningsvormen uitvoerig bespreking. Daarbij zijn bij

17. Waarbij de hoofdstukken 3 (i.h.b. paragraaf 3.3.3) en 4 centrale waarde en algeme re gelding hebben voor de studie.

18. Warbij de hoofdstukken 6 en 7 centrale warde en algemene gelding hebben voor de studie. 
voorbeeld relevante aspecten: de organisatievorm, rechtsstatelijke eisen, de innige relatie tussen publieke en private sector en zijn plaats ten opzichte van maatschappelijke decentralisatie, als ook de aard van de bevoegdheidsuitoefening. Laatst genoemd element, te weten de bevoegdheid, is een centraal gegeven in de studie. Vandaar apart aandacht voor toezichtsbevoegdheden als publiekrechtelijke bevoegdheden. Dit van wege de onlosmakelijke relatie mssen taak en bevoegdheid. De toezichthoudende taakuitoefening door zelfstandige bestuursorganen wordt bezien tegen de achtergrond van de (principiële) herbezinning van overheidstaken, de hierbij spelende problematische scheiding van overheidsbeleidsuitwoerende en -vormende taken, als mede de andersoortige taakuitoefening door zelfstandige bestuursorganen.

Wat betreft het, in hoofdstuk 10 tot en met 20 vervatte ${ }^{19}$, derde deel rechtshandhaving door toezichthoudende zelfstandige bestuursorganen:

Tegen de achtergrond van ministeriële beleidsplannen - inzake onder meer bestrijding van het handhavingstekort, verbetering van de wetgeving(sprocedure), reorganisatie van de justitiële instellingen en vernieuwing van het handhavingsinstrumentarium - als mede de derde tranche Algemene wet bestuursrecht wordt de rechtvaardiging van toedeling van toezichtsbevoegdheden aan zbo's bezien. Ook hun functie als handhavers in repressieve zin, dat wil zeggen als sanctietoepassers, krijgt beschouwing.

De Awb ruimt voor handhaving in de zin van toezichtsuitoefening, plaats in. In overvloedige mate voorziet de Awb in toezichtsbevoegdheden. Algemene maatstaf voor vitoefening van deze bevoegdheden is het vage redelijkheidscriterium. Vandaar bestaat de noodzaak het optreden van toezichthouders aan de algemene beginselen van behoorlijk bestuur te toetsen. Uit het oogpunt van rechtsbescherming is de onduidelijke grens tussen toezicht en opsporing onwenselijk. Bovendien overheerst de twijfel over de, in gevolge de Awb mogelijk in het kader van de rechtshandhaving handelende, particuliere toezichthouder.

De handhaving in de betekenis van sanctionering blijft natuurlijk niet onberoerd. Verschillende soorten handhaving worden, alan de hand van hun toepassing door verschillende zbo's, belicht.

Omdat het nationalle handhavingsrecht sterk wordt beïnvloed door communautair recht inzake controle, opsporing en sanctionering, trekken ook gemeenschapsrechtelijke handhavingsaspecten de aandacht. Op de lidstaten rust de plicht de uitvoering van EG-recht te realiseren. Hierbij moeten zij algemene beginselen van gemeenschapstrouw nakomen, te weten de principes van assimilatie, evenredigheid, effectiviteit, afschrikwekkendheid en kenbaarheid. In dit licht worden belangrijke grondrechten bezien. In het verlengde hiervan ligt de beschrijving van de wijze waarop bepaalde zelfstandige bestuursorganen toezien op respectering en handhaving van verschillende fundamentele vrijheden, die vooral voort vloeien uit het EVRM.

Voorts worden de bevoegdheden in het kader van handhaving, die de Europese Commissie zich al meer toeëigent, besproken. Ten slotte komt de doorkruising, van de werkzaamheden van de Euro-controleurs met die van nationale toezichthouders, aan bod.

19. Waarbij de hoofdstukken $11,13,14$ (vanaf paragraaf 14.11), 16 (paragraaf 16.6 en ten dele paragrat: 16.6.1), 17 (paragraaf $17.1 \mathrm{t} / \mathrm{m} 17.1 .1$ ) en 20 centrale waarde en algemente gelling hebben woor de studie. 
De laatste hoofdstukken van deel drie (d.w.z. hoofdstuk 14 tot en met hoofdstuk 19, met aansluitend een uitvoerig hoofdstuk 20 waarin bevindingen, conclusies en aanbevelingen zijn neergelegd) bevatten uiteenzettingen van taken, bevoegdheden en verantwoordelijkheden van toonaangevende toezichthoudende zel fstandige bestuursorganen. Beoogd wordt een overzichtskader te geven van het nut en het onnut van toezichthoudende zelfstandige bestuursorganen. Uitgangspunt hierbij zijn de zelfstandige bestuursorganen die toezicht houden op wet- en regelgeving, als hoofdstuksgewijs behandeld aan de hand van in elk geval: a. taakstelling in het licht van door zelfstandige bestuursorganen, mogelijk onder beperkingen, te beschermen vrijheden en grondrechten; b. toezichtsbevoegdheden, gerelateerd aan eventuele andere bevoegdheden van zelfstandige bestuursorganen (rechten toezichthoudende zelfstandige bestuursorganen); $c$. rechten en plichten van onder toezicht gestelden; $d$. rechtsbescherming, klachtbehandeling en rijkstoezicht door de minister; $e$. kostenverhaal en, al dan niet financiële, verslaglegging (plichten van toezichthoudende zelfstandige bestuursorganen); f. samenwerking en informatie-uitwisseling met gelijksoortige toezichthouders binnen Nederland als mede buiten Nederland dat wil zeggen in of buiten Europa; en g. relatie tussen nationale autoriteiten en communautaire controleinstellingen, gegeven de harmonisatie van wet- en regelgeving in EG-lidstaten.

Aandacht, bij het geven van bedoeld overzicht, verdienen aspecten als: de grondslag, het motief, de noodzaak, de aard, de reikwijdte en de indringendheid van het overheidstoezicht door zelfstandige besturursorganen; toezichthoudende zelfstandige bestuursorganen en 'machtenscheiding'; toezichthoudende zelfstandige bestuursorganen in het licht van het onderscheid beleidsbepaling-beleidsuitvoering (reorganisatie rijksdienst); de kennelijke tegenstrijdigheid om, mogelijk op privaatrechtelijke leest geschoeide, zelfstandige bestuursorganen te belasten met handhavingstaken; verzelfstandiging alls voorbode van privatisering; overheidstoezicht en marktwerking in het licht van mededingingsrecht; overheidstoezicht en zelfregulering of convenanten; de doelstelling van deregulering versus de realiteit van reregulering; de vergeten verhouding tussen de NederlandseEuropese-internationale gemeenschap; en de problemen met het toezicht op naleving van wet- en regelgeving.

\subsubsection{ONDERZOEKSSUBJECT}

Met toezicht als object, kan de toezichthouder subject zijn.

Toezichthoudende zelfstandige bestuursorganen bewegen zich op diverse, uiteen 'lopende vakgebieden. Om enig inzicht te krijgen van het toezicht, dat immers wet- en regelnaleving beoogt, is kennis van betrokken wet- en regelgeving nodig.

Onvermijdelijk is dan ook de descriptie van delen dynamische wet-en regelgevingscomplexen. Bezwaarlijke beschrijvingen worden voorzien van verlichtende voorbeelden en sauverend cijfermateriaal. Problematisch, aan het in kaart brengen van een relevant rechtsgebied, is de bepaling van de grens er van. Aan het streven, dat zich richt op het bouwen van een - weliswaar niet dicht gemetselde - muur die de coördinatiepunten van toezicht steun biedt, wordt zo veel mogelijk tegemoet gekomen. Volledigheid van elk, omvangrijk, onderdeel is dus geen doelstelling. Het bieden van een heldere indruk van de drukke domeinen van toezichthoudende zelfstandige bestuursorganen volstaat. 
In de poging een beeld te geven van een bepaald wet- en regelgevingscomplex wordt het specifieke, bijzondere recht afgezet tegen algemene delen van het recht. Hierbij richt de aandacht zich onontkoombaar op zowel nationale als Europese dimensies van het recht. Afhankelijk van onder meer bestaande jurisprudentie, toepasselijke (on)geschreven rechtsbeginselen en geldende waarden/normen verwijzend naar algemeen erkende gemeenschappelijke belangen, krijgt het recht meer concrete invulling. Alleen in het totale wet-en regelgevingskader, dat regulerend (bestuursrechtelijk, civielrechtelijk, strafrechtelijk of tuchtrechtelijk) en, al dan niet gecombineerd, zelfregulerend van aard is, is de essentie van toezichthoudende zelfstandige bestuursorganen te begrijpen. Elk hoofdstuk biedt zo een eigen verhaal en is afzonderlijk te lezen. Wel is elk hoofdstuk een passend stuk in de puzzel die het proefschrift vormt.

In de, voor een dergelijke juridische jacht gespannen, boog liggen de pijlen die zich richten op analyse van positief recht en reflectie op komend recht.

De werksferen van de toezichthoudende zelfstandige bestuursorganen bepalen ten dele de, in deze studie te maken, kardinale keuze van te bespreken zelfstandige bestuursorganen.

Persoonlijke voorkeur gaat uit naar het juridisch terrein van media-, film-, data- en telecommunicatierecht. Daartoe vormt een genoten journalistieke opleiding een eerste aanzet. In de werv(el)ende wereld van media-, film-, data- en telecommunicatie zoeken en veroveren zelfstandige bestuursorganen zich als heersende handhavers een profane positie. Hetzij als vergunningverlenende en regulerende entiteit met ruimte voor zelfregulering binnen overheidstoezicht. Hetzij als rechtsverdelende en marktordenende entiteit met, na een slotakkoord uit tonen van overheidstoezicht, privatisering in het vizier.

Rellevante rechtsgebieden, woor een studie naar toezilchthoudende zelfstandige bestuursorganen, liggen ook op de pleinen van het effectenbedrijf en het assurantiebedrijf. Beide gebieden vallen onder nauwlettend oog van belangrijke zelfstandige bestuursorganen. Het toezicht op deze financiële markten is vergelijkbaar.

Daarnaast bieden de private zelfstandige bestuursorganen, die - ter kwaliteitscontrole hun messen scherp over sierteelt- en landbouwakkers laten gaan, een intrigerend inzicht in het gebruik van toezichthoudende organen van functioneel bestuur in de levensmiddelensector. Dit gebied is een toonbeeld van vroegtijdig en noodzakelijk rekening houden met Europese en internationale implicaties van rechtshandhaving voor nationale wet- en regelgeving ter zake.

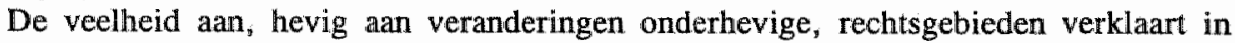
belangrijke mate de 'belastende' omvang van de dissertatie.

De verschillende zelfstandige bestuursorganen, die bedoelde bedrijfsculturen nauwlettend in de gaten houden, zijn met betrekking tot hun toezichtstaak afwijkend in aard. Terwijl het ene orgaan vooral keurend bezig is, leidt optreden van het andere orgaan hoofdzakelijk tot controle en opsporing. Of, geeft de ene toezichthouder middels voorlichtende activiteiten blijk van zijn overheidstaak, dan kan een andere toezichthouder zich juist sterker doen gelden door strenge toepassing van sanctiemiddelen. Deze verschillen in verzelfstandigd overheidstoezicht verklaren tevens de keuze van de te bespreken zelfstandige bestuursorganen. 
Naast argumenten als eigen interesse voor bepaalde zbo's, afbakening met een nauw verwant onderzoek naar toezicht op zbo's en inhoud/vorm van zbo-toezicht, geeft nog een ander argument aanleiding tot voornoemde voorkeur.

De selectie van voor de dissertatie relevante zelfstandige bestuursorganen laat zich namelijk ook bepalen door actualiteitswaarde. De evaluatie van (al wat langer) bestaande zelfstandige bestuursorganen is in belangrijke mate gaande of wordt snel gerealiseerd. De ministeries, al dan niet in samenwerking met organisatieadviesbureaus of rekenkundige instituten, nemen hier veelal het voortouw. Vandaar blijven de zelfstandige bestuurs. organen van oudere datum, die vaak ook al zijn meegenomen bij de in paragraaf 1.2 vermelde inventarisatie- en evaluatieonderzoeken, in beginsel buiten beschouwing. De meeste toezichthoudende zelfstandige bestuursorganen, als hier behandeld, zijn zo nieuwelingen van redelijk recente datum. Zij hebben hoogstens hun eerste bestaanslustrum kunnen vieren, of ze zijn daar nog niet eens aan toe. Daamaast is sprake van 'oude rotten' in het vak die door het verzelfstandigingselixer zo danig innoverend werken, dat zij weliswaar niet echt nieuwelingen zijn maar wel dermate jong en fris ogen dat zij "als ware het nieuwelingen" zijn. Coconworming van een te werzelfstandigen organisatie gaat vaak gepaard met verpopping van haar omgeving. Een maal de gedaanteverwisseling voorbij, blijkt meestal niet alleen de betreffende organisatie te zijn gewijzigd, maar blijkt ook haar wet- en regelgevingsweb te zijn veranderd. Zowel nieuwe (of, nota bene, nog op te richten) zelfstandige bestuursorganen als nieuwe wet-en regelgevingscomplexen hebben in deze studie aantoonbaar aandacht.

Ander aspect van actualiteit, is het feit dat bepaalde zelfstandige bestuursorganen, speciaal wat betreft hun toezichtstaken, de laatste tijd sterk in de belangstelling staan. Die belangstelling, die voort vloeit uit de alom herleefde aandacht voor rechtshandhaving, is dan voornamelijk negatief van aard. Kortom, hier is het juist het omstreden optreden van toezichthoudende zelfstandige bestursorganen, dat een studie naar uitoefening van hun toezichtsbevoegdheden rechtvaardigt.

\subsubsection{ONDERZOEKSBRONNEN}

Om op de hoogte te blijven van voor deze studie relevante juridische en feitelijke ontwikkelingen is het noodzaak het oog te kijk te zetten en het oor te luister te leggen.

Als leesbron voor deze studie geldt gebruikelijk juridisch documentatiemateriaal. Denk aan Nederlands recht (algemene wet- en regelgeving, met belangrijke nadruk op bijzondere wet- en regelgeving) en Europees recht van generale en meer nog van specifieke aard (verdragen, richtlijnen, verordeningen). Hierbij zijn Staatsblad/Staatscourant en Tractatenblad indicatief. Voor de concrete toepassing van het recht bieden min of meer deskundige hand-en leerboeken hulp, daarnaast bewijst jurisprudentie haar dienst. Wel is het zo dat, van wege het jonge karakter van de juridische deelterreinen waarop deze studie betrekking heeft, compendia karig aanwezig zijn en jurisprudentie schaars is.

Van niet geringe waarde zijn dan ook de informatieve/analytische (achtergrond)artikelen, in de tegenwoordig voor bijna elk vakgebied aanwezige wetenschappelijke periodieken. Daarin wordt eigenlijk elke willekeurige ontwikkeling - heet van de naald - beschreven. Een andere schrijvende pers, wier proeve van schrijwen dagelijks wia kiosk te koop ligt, heeft er nooit van gehouden genegeerd te worden. Zeker nu in toenemende mate titula- 
tuur en deskundigheid in huis worden gehaald, is een landelijk dagblad als NRC Handelsblad inderdaad serieus te nemen. In het kader van deze studie dient zij, weliswaar als minder officiële documentatiebron, bij uitstek om met kennis en kunde recente ontwikkelingen aan te geven, te illustreren of van commentaar te voorzien.

Ten slotte is de, regelmatig of incidenteel gevoerde, schriftelijke en mondelinge communicatie met personen, die beroeps- of beleidsmatig bekend zijn met (toezichthoudende) zelfstandige bestuursorganen, voor deze studie onmisbaar. De door hen afgestane jaarverslagen en -rekeningen, statuten of akten van oprichting, informatie- en voorlichtingsbrochures , al dan niet getalsmatige toezichtsactiviteitenoverzichten, handhavingsdraaiboeken en -richtlijnen, sanctieregelingen, periodieke verslagen van (bestuurs)vergaderingen of symposia, beleidsnota's, evaluatierapporten en overige relevante publikaties bewijzen nut. ${ }^{20}$

\subsubsection{ONDERZOEKSPERIODE}

Uit de aard der zaak is de studie onvolledig.

Niet alleen omdat elk - in deze studie, helaas onmogelijk diep uit te spitten, vervat deelterrein op zich een boek waard is. Maar ook omdat de NWO-geldstroom in beginsel niet langer dan vier jaar de werktank vol laat lopen, is het onderzoek beperkt in de tijd. Start de studie op 1 september 1991, zij vindt medio maart 1995 afsluiting. Met voor de studie relevante ontwikkelingen, die zich in de periode van medio maart 1995 tot eind juni 1995 voordoen, is nog wel in beperkte mate rekening gehouden.

Overigens sluit deze studie zo veel mogelijk aan bij de meest recente ontwikkelingen op elk, aan het onderzoek rakend, rechtsgebied. Als vermeld, betreft deze studie rechtsgebieden die voortdurend veranderen. Dat bemoeilijkt het beschrijven er van. De werkmethode in deze studie is dan ook onvermijdelijk als volgt. Van uit de bestaande situatie worden de ontwikkelingen, waar mogelijk, in chronologische volgorde aan gegeven. Zo krijgt, bij voorbeeld, eerst het voorontwerp derde tranche Awb en vervolgens het later verschenen wetsvoorstel derde tranche Awb, bespreking. Ook is te denken aan de Mediawet, de Wet toezicht effectenverkeer of de Wet toezicht verzekeringsbedrijf, waarvan in eerste instantie de eerdere versies en in tweede instantie de recentere en meer definitieve versies, worden behandeld. Deze werkwijze heeft als voordeel, dat commentaren en kritieken op wet- en regelgeving in eerste fase worden mee genomen bij de bespreking van wet- en regelgeving in tweede, of latere, fase.

20. Deze illustratie wan documentatiemateriaal, van de zijde van degenen die beroepsmatig en wakkundig voor of met toezichthoudende zbo's werken "toont aan dat het dissertatieonderzoek onvermijdelijk ann de oppervlakte blijft. Voor een echt empirisch en indringend onderzoek is het niet voldoende te vertrouwen op uitspraken en mededelingen van (directies van) toezichthoudende zbo's, die zelf - bij toezichtsuitoefening - immers vaak worden geconfronteerd met verhullend taalgebuik en mooipraterij. M.a.w. zij die het "klappen van de zweep" kennen, hanteren hem misschien ook zelf. 


\subsubsection{ONDERZOEKSTERMINOLOGIE}

Het kennelijk goede gebruik om, bij het uitleggen van de in deze studie gebruikte terminologie, te refereren aan de 'Dikke van Dale' wordt in deze studie niet overgenomen. De definitiedrift, die menig jurist aan de dag pleegt te leggen, doet nog al eens een dood spoor in slaan. Innovatieve interpretaties zijn daarmee niet per se geïndiceerd. Bovendien maakt het tot in het vervelende toe formuleren van termen en begrippen arglistige advocaten brodeloos. Daarom kenmerkt deze studie zich niet door het mateloos, feitelijk interpreteren van, in juridische kringen, gebezigde woorden waarover een redelijk niveau van overeenstemming bestaat.

Wat woordkeuze zelf betreft is deze studie wellicht ook afwijkend. Weliswaar opgegroeid met en, nota bene, onderwezen in de regels van het "Groene boekje" valt het zwaar trouw te blijven aan de voorkeursspelling. Het feit, dat sommigen met deze spelling 'akkoord' gaan, impliceert niet dat afvalligen hiermee "accoord' moeten gaan. Beide spellingen volstaan. $\mathrm{Zij}$ het dat de ene spellingswijze wordt voorgeschreven en de andere spellingsmethode slechts wordt gedoogd. Een dergelijk gedoogbeleid duidt er op dat er veel overspeligen zijn, dat de voorkeursspelling niet algemeen wordt aanvaard of dat het onverschillig is dat de voorkeursspelling wordt nageleefd. Laatst genoemde optie lijkt aannemelijk. De voorkeursspelling overtuigt namelijk niet. Haar idioom irriteert. Over de weinig fraaie voorstellen betreffende nieuwe spellingsmethoden voor de Nederlandse taal is het helemaal beter het doek te laten liggen. Natuurlijk laat deze eigenzinnigheid onverlet, dat een ieder mag proberen te bewijzen dat de in deze studie gehanteerde, subjectieve schrijfwijze apert onredelijker is dan de officieel voorgeschreven spelling.

Enige opheldering over de betekenis van woordgebruik is wel geboden.

De term overheid betekent in deze studie: zowel rijksoverheid in ruime zin (inclusief verzelfstandigde entiteiten)/rijksoverheid in enge zin (exclusief verzelfstandigde diensten) ${ }^{21}$ als de lagere overheden (provinciaal/territoriaal). Een ene keer duidt het begrip beide aan. Een andere keer doelt het, als op te maken uit het zinswerband, slechts op eén er van.

De term overheid op afstand betekent in deze studie: ten eerste, het beleidsuitvoerende zelfstandig bestuursorgaan staat op afstand van het betrokken, voor beleidsuitwoering op hoofdlijnen verantwoordelijke, beleidsbepalende departement of, ten tweede, het op zelfregulering toezichthoudende zelfstandig bestuursorgaan staat op afstand van het belanghebbende bedrijfsleven dat onder meer belast is met certificering.

De term overheidsorganisatie betekent in deze studie: ten eerste, het complex van de gehele overheid in samengestelde compositie wan entiteiten van verschillende aard of, ten tweede, een bepaald - meestal privaatrechtelijk - zelfstandig bestuursorgaan.

21. Commissic-Wiegel, Naar kermdepartementen, klezen woor een hoogwaardige en flexibele rijksdienst, TK $1992-1993,21427$, nr. 51, p.27. 
De term verzel fstandigde entiteit betekent in deze studie: een, in verband met het zoveel mogelijk scheiden van het beleidsbepalende kerndepartement en de beleidsuitvoerende eenheid, financieel/politiek autonome autoriteit van publiekrechtelijke of privaatrechtelijke aard. Op zich beschouwd kan de term zien op zowel intern als extern verzelfstandigde eenheden ${ }^{22}$ In deze studie wordt er een zelfstandig bestuursorgaan mee bedoeld. Weliswaar oefenen de in deze studie centraal staande organen, gegeven hun toezichtsbevoegdheden, per definitie openbaar gezag uit en zijn zij daarom, ongeacht hun vorm, een bestuursorgaan in de zin van de Awb. Maar meer in het algemeen gesproken is het begrip zellfstandig bestuursorgaan niet altijd toereikend, omdat zelfstandige bestuursorganen meer dan eens een privaatrechtelijke vorm hebben en daarom niet zonder meer als bestuursorgaan zijn aan te merken. Wat betreft die gevallen blijft dan ook persoonlijke voorkeur uitgaan naar het begrip verzelfstandigde entiteit. Daarmee worden dan extern verzelfstandigde privaal- of publiekrechtelijke rechtspersonen bedoeld, tenzij anders aangegeven. Overigens wordt nog wel de term zelfstandig bestuursorgaan gebezigd. Voorop gesteld, de term is herkenbaar. Daarnaast geldt dat het gebruik van bedoeld begrip in het kader van deze studie geen kwaad kan omdlat het niet vreemd is om juist toezichthouders, die met oog op hun publiekrechtelijke handhavingstaken behoorlijk ingrijpende gezagsbevoegdheden uitoefenen, van het predikaat orgaan te voorzien. Regeringsstukken spreken hier consequent van 'toezichthoudende autoriteiten'.

De term handhaving betekent in deze studie: zowel het houden van toezicht als het toepassen van sancties. Wel staat, in deze studie waarin toezichthoudende verzelfstandigde entiteiten een hoofdrol spelen, de toezichtsfunctie van handhaving centraal.

De term toezicht betekent in deze studie: de uitoefening van ten behoeve van rechtshandhaving (in relatief lichte vorm) op- of overgedragen openbaar gezagstaken, met grondslag in publiekrechtelijke bevoegdheden, door een bestuursorgaan ten einde de naleving van het, door de overheid al dan niet na overleg met het bedrijfsleven ${ }^{23}$, bij of krachtens wet gestelde te bewerkstelligen. Hierbij verdient aantekening dat, ten einde toezicht in een compleet kader te plaatsen, in deze studie niet alleen de hoofdtaak (van het toezicht houden in eigenlijke zin) aandacht krijgt, maar ook de, daaraan soms noodzakelijk vooraf gaande, taken (als vergunningverlening, certificaatafgifte en dergelijke) en de, daarmee naww verband houdende, neventaken (als advisering, evaluatie en dergelijke) in de be-

22. Bij interne verzelfstandiging (agentschap) valt de verzelfstandigde entiteit nog altijd binnen de hiërarchie van de verantwoordelijke minister. Interne verzelfstandiging beoogt vooral een doelnatiger beheer bij de werzelfstandigde entiteit. Bij externe verzelfstandiging ( $z b o)$ valt de verzelfstandigde entiteit voortaan buiten de politieke verantwoordelijkheid van de betrokken bewindspersoon omdat de hiërarchiale band tussen hen wordt doorgesneden. Kortom, een extem verzelfstandigde entiteit staat op afstand wan het departement, dat slechts de hoofdlijnen wan het op afstand uit te voeren belleid bepalt.

23. In sectoren met wettelijk geconditioneerde zelfregulering en -handhaving is het toezicht vooral sturingstoezicht. Hoewel omschrijvingen van toezicht spaarzaam zijn, wordt dergelijk toezicht in art, 30 van het Voorstel tot wijziging wan de Wet op de geneesmiddelenwoorziening en de Gezondheidswer (reclame, registratie, bewaking, toejicht/handhaving inzake geneesmiddelen). TK 1994-1995, 23959, nrs 1 1-2, p.3, gedefinieerd als "de controle op de toepassing en de uitleg van wettelijke voorschriften betreffende reclame voor geneesmiddelen, als mede de beoondeling van reclame, preventief of repressief". 
spreking worden meegenomen. Met andere woorden, in deze studie staat toezicht in ruíme zin centraal.

De afkortingen t.a.p. en a.w. staan in deze studie voor: respectievelijk ter aangehaalde plaatse (in deze studie wordt met deze aanduiding - soms voorzien van jaartal - gerefe-reerd aan een eerder vermelde publikatie in een tijdschrift of ander periodiek) en aangehaald werk (in deze studie wordt daarmee een publikatie in de vorm van een boek of met het karakter van een boekwerk bedoeld). ${ }^{{ }^{4}}$

24. Hieronder worden, van wege hun soms onbedoeld grote omvang, tevens begrepen de rapporten van, al dam niet externe, kamercommissies. 


\section{Geraadpleegde literatuur}

Algemene Rekenkamer

Verslag over 1994, deel 3; Zelfstandige bestuursorganen en ministeriele verantwoordelijkheid. TK $1994-1995,24130$, nr.3.

Boneschansker, E. \& Groot, H. de

Instrumenten bij sturen op afstand, IOO-reeks nr.36, 's-Gravenhage, 1992.

Boven, M., Derksen, W., Witteveen, W., Kalma, P. \& Becker, F.

Den Haag heeft steeds minder te vertellen, in: NRC. 19 sept. 1994, p.7.

Ministerie van financiën

Wrijheid in gebondenheid; Een rapportage over functioneel gedecentraliseerde instellingen rondom de rijksoverheid, in het bijzonder over opzet en werking van toezicht en controle bij deze instellingen, publ. centrale accountantsdienst projectgroep functionele decentral isatie, deel I/II, s-Gravenhage, november 1991.

Munneke, H.F., Berge, J.B.J.M. ten, Stroink, F.A.M., Haighton, P. \& Hoed, P. den organen en rechtspersonen rondom de centrale overheid, WRR-serie voorstudies en achtergronden V35, delen I/III, 's-Gravenhage, 1983. 
Deel I

\section{Inleiding bestuurlijk organisatierecht}

"Het rijk mag sjoemelen, foezelen en de zaak belazeren, zonder dat enig minister daar de. konsekwenties uit hoeft te trekken." 1

Honend wordt herhaaldelijk de hoge pet, die elk op heeft van de hoogsten in rangorde in politiek Den Haag, afgezet. De Staat ziet zich vervelend in verlegenheid gebracht. En zoekt desparaat om antwoord op het cynisme. Commotie alom.

Niet voor de eerste keer dus, dat de ministeriële verantwoordelijkheid aan $\mathrm{kritiek}$ blootstaat. Haar turbulente gedrag doet, van oudsher, velen in de pen klimmen. Reeds van, onder anderen, de door Batavus Droogstoppel zo genaamde Sjaalman is een "Verhandeling over ministeriële verantwoordelijkheid" ${ }^{\text {"l }}$ bekend. ${ }^{2}$

Immers, het schermen met verantwoordelijkheid is prima. Maar die moet dan wel worden waar gemaakt. En met de ontwikkeling van de oorspronkelijke rechtsstaat naar de democratische moderne rechtsstaat (paragraaf 2 tot en met paragraaf 2.1.3) is het soms, schots en scheef, schuiven met politieke verantwoordelijkheid geweest. In de tegenwoordige complexe sociale rechtsstaat staat de minister er niet meer alleen voor "Veel ambtenaren als mede maatschappelijke organisaties bieden een helpende hand bij het, in principe, uitwoeren van beleid. De praktijk laat zien, dat daaraan niet enkel uitwoeringsfacetten kleven. Er is meer aan de hand. Vandaar is het een niet ongebruikelijk verschijnsel, dat ministeriële verantwoordelijkheid wordt afgewenteld op een of andere persoon dan wel instelling. Verantwoordelijkheden worden pij|nlijk uit de weg gegaan. Alle "demoraliserende werking" er van ten gevolg. ${ }^{3}$

Problemen genoeg met de ministeriële verantwoordelijkheid. Daarom eist zij alle aandacht op. De discussie over de status van de ministerièle verantwoordelijkheid, de wense-

1. J. Opland in visfraudekwestie-cartoon, herplaatst bij Then jaar Lubbers, in: De Vollkskrant; Het verwolg. 31 okt. 1992, p.2.

2. Multatuli, Max Hawelaar of de koffieveilingen der Nederlandse Handelsmaatschappij, van uit vijfde druk, Ede, 1979, p.35.

3. E.M. Michiels won Kessenich, Christelijk erfgoed is inspiratiebron burger, in: NRC Handelsblad, 3 nowember 1992 , p.8. 
lijkheid van functioneel gedecentraliseerde zelfstandige bestuursorganen en de relatie ambtenaren/parlement, krijgt met de instelling van onder meer de externe commissieScheltema in belangrijke mate stimulans.

In het hierna volgende worden respectievelijk ministeriële verantwoordelijkheid en functionele decentralisatic belicht van uit de institutionele eisen van een rechtsstaat. Zie paragraaf 2.2 tot en met paragraaf 2.2.5. Wat betreft de ministeriële verantwoordelijkheid wordt uiteen gezet wat haar bedoeling is (paragraaf 3.1). Vervolgens staat in de belangstelling de vraag hoe ver de verantwoordelijkheid zich uitstrekt (paragraaf 3.2), als ook hoe het proces van verantwoordelijk stellen zich voltrekt (paragraaf 2.3.2.1 tot en met paragraaf 3.2.3). Dat geijkte paden, in feite, niet altijd zijn te volgen, blijkt uit paragraaf 2.3.3 tot en met paragraaf 3.3.1. Daarom is een kritisch kijken naar de huidige omvang van de ministeriële verantwoordelijkheid een overweging waard (paragraaf 3.3.2). En is een beperking van de ministeriële verantwoordelijkheid (paragraaf 3.3.3) door middel van het instellen van zelfstandige bestuursorganen (paragraaf 3.3 .4 en paragraaf 3.3.5) mogelijk een aardig alternatief. Overigens ziet niet iedereen daarin heil (paragraaf 3.3 .6$)$.

Omdat functionele decentralisatie, van uit andere motieven dan voornoemd, wellicht wel wenselijk is, verduidelijkt paragraaf 4 dit als uitvloeisel van de legaliteitseis. Mede in het kader van de Awb krijgen attributie en delegatie aandacht (paragraaf 4.4 tot en met paragraaf 4.4.3). Tegen het licht van attributie of delegatie naar vormen van functioneell bestuur wordt het nut van een toetsingskader voor zelfstandige bestuursorganen als mede algemene aanwijzingen of een kaderwet voor de inrichting en het functioneren van zelfstandige bestuursorganen bezien (paragraaf 4.5 tot en met paragraaf 4.5.1). Daarnaast is het onderscheid territoriale/functionele decentralisatie belangwekkend (paragraaf 5 tot en met paragraaf 5.5). Met oog op de huidige disharmonisatie van gebieden, waarop deze decentrallisatievormen betrekking hebben, is bespreking van de kabinetsplannen inzake regiovorming zinvol (paragraaf 4.4). 
Hoofdstuk 2

\section{Rechtsstatelijkheid}

\section{$\S 2.0$ Rechtsstaat}

Alle machtsuitoefening coor de overheid is onderworpen aan het recht. Ook het handelen van zelfstandige bestuursorganen is gebonden aan wet - en regelgeving. Even als zijn onderdanen is een staat zelf aan het recht geketend. Kennelijk is recht niet alleen middel tot, maar ook maatstaf voor openbaar gezagsoptreden. ' $\mathrm{Zo}$ snijdt het recht tweezijdig. Het recht is "zowel instrument van als ook waarborg tegen de overheid". 2

Deze gedachte ligt hoofdzakelijk ten grondslag aan de rechtsstaatsidee. ${ }^{3}$ Rechtsstatelijkheid kenmerkt zich nog anders. "Van uit de moderne rechtsstaat geredeneerd, is het namelijk onjuist het legaliteitsaspect van rechtsstatelijk overheidsoptreden enkel in negatief afwerend zin op te vatten. Zeker niet te verwaarlozen is het positieve, materièle facet aan de rechtsstaatsidee: sociale rechtvaardigheid. Hiermee staat een staat garant voor in het bijzonder de verwerkelijking van sociale grondrechten. Tevens kleurt hij klassieke grondrechten fraaier in middels voorwaardenscheppend beleid ter zake.

Naast rechtsgebondenlieid en sociale rechtvaardigheid verlangt rechtsstatelijkheid rechtszekerheid. Dat wil zeggen de juridische bindingen van de burger moeten voldoende duidelijk, stabiel en uit het oogpunt van handhaving betrouwbaar zijn. Aandachtsgebieden daarbij zijn de aard en het niveau van de normstelling van overheidswege, het handha-

1. H.J. wan Eikema Hommes, Hoofdijnen wan de geschiedenis der rechfsfilosofie, Deventer, 1972. pp. $118-119$.

2. E. Helder, Ombudsman en administratieve rechtsbescherming; De Nationale Ombudsman, gemeentelije klachreninstanties, alsmede enkele buitenlandse ombudswoorgieningen, in relatie rot rechtsbescherming tegen de overheid: een juridische en empirische studie, diss. Uniwersiteit Twente. Enschede, 1989, p.30.

3. Vooral Duitse relewante literatuur. O.a. H. Schambeck, Vom Simwandel des Rechtssaates, Berlin, 1970 ; R. van Mohl, Das Staatsrecht des Königreiches Wirttemberg. 1829, Dïe Geschichie und Lirercutar der Stactswissenschaften, dl. 1,1855 .

4. E.M.H. Hirsch Ballin, Regelen ap afstand als wereciste van een sociale rechtsstaat, uit: M.A.P. Bovens, W. Derksen en W.J. Witteveen (red.), Rechtsstaat en sturing, Zwolle, 1987, pp, 91-104, in: Rechtsstaat en beleid; Een keuze uit het werk van wr. E.M.H. Firsch Ballin, Zwolle, 1991, pp.383-395. 
vingssysteem en de rechtsbescherming. Op alle terreinen zorgt de overbelasting van de overheid voor problemen. Dit te zwaar beladen zijn van het politieke systeem maakt duidelijk dat aan rechtsstatelijkheid nog een belangrijk facet kleeft. Spreiding van verantwoordelijkheid is noodzakelijk. Dat betekent een zoektocht naar de juiste verhouding tussen de centrale overheid en de verschillende decentrale overheden, het particuliere kader van georganiseerde belangen, het maatschappelijk middenveld en individuele rechtsgenoten.

Dit kwartet eigenschappen karakteriseert de nieuwe rechtsstaat. Van een streng karakter is echter geen sprake. In plaats van grenzen ${ }^{5}$, die rechtsstatelijkheid aan overheidsingrijpen stelt, verdient het voorkeur te spreken van eisen die rechtsstatelijkheid aan (in)directe overheidssturing stelt. Soms is zekere overheidsinterventie vereist. Overheidssturing wordt namelijk niet slechts gelimiteerd. Daar waar een beleidsvoerende overheid dan negatief wordt gelimiteerd, kan zij alleen kritisch met formeel-negatieve factoren van rechtsstatelijkheid worden geconfronteerd. Dat betreft de "wijze waarop overheidssturing plaatswindt en de hieraan verwante dichotomie van verantwoordelijkheden", met ander woorden de verantwoordelijkheden van simpelweg de politieke staat en de maatschappelijk markt. ${ }^{6}$ Overigens is de terminologie van grenzen, in de zin van beperkingen, misleidend. Het suggereert, ten onrechte, dat sturend overheidsbeleid rechtvaardiging zoekt buiten de rechtsstaatsgedachte om. "Orndat overheidssturing zelf haar rechtvaardiging dient te vinden in de vereisten van de rechtsstaat als sociale rechtsstaat, is het juister sturing te zien als wijze van real isering van de rechtsstatelijkheid met de antinomieën die daartoe nu eenmaal behoren." 7 Om die sturing kwalitatief optimaal te doen beantwoorden aan de rechtsstatelijke eisen zijn verschillende uitgangspunten van uitvoering van overheidsbeleid geformuleerd. Zij betreffen de keuze van de wijze van sturing, de wijze van institutionalisering, de mogelijkheid van subsidie en de controleerbaarheid van taakvervulling.

\section{$\S 2.1$ Transformatie rechtsstaatsgedachte}

Voornoemde rechtsstatelijke eisen zijn al eisen, die aan een rechtsstaat met democratische inslag ${ }^{8}$ zijn te stellen. Die rechtsstaat heeft zich langzaam aan ontwikkeld. De rechtsstaat is langs vier lijnen van geleidelijkheid geëvolueerd. Te weten: a. de oorspronkelijke rechtsstaat of nachtwakersstaat; $b$. de klassieke rechtsstaat; $c$. de formele rechtsstaat; en

5. C.J.M. Schuyt, Sturing en het recht, in: M.A.P. Bovens en W.J. Witteveen (red.), Het schip van stact; Beschowwingen over recht, staat en sturing, Zwolle, 1985, pp.113-124.

6. E.M.H. Hirsch Ballin, t.a.p., pp.388-389.

7. E.M.H. Hirsch Ballin, t.a.p., p.388.

8. C.W. van der Pot, bewerk. A.M. Donner, m.m.v. L. Prakke, J.L. de Reede en G.J.M. Wissen, Handboek van het Nederlandse stactsrecht, twaalfde druk, Zwolle, 1989, pp. 158-167, i.h.b. pp.160-167, noemt "de nige, bewegende krachten, die zich in toenemende mate beroepen op de idee van de democmatie, de krachten die de rechtsstaat trachten te fatsoeneren." De zwakte van de rechtsstaatsidee is dat zij "eent regulerende norm biedt, maar geen motorische $\mathrm{kracht"}$ ". 
d. de sociale rechtsstaat allias relationele rechtsstaat ook wel geïntroduceerd als verzorgingsstaat ${ }^{9} .10$

Ruw weg zijn een materieel en een formeel rechtsstaatsconcept te onderscheiden. Feitelijk zijn die opvattingen uitgemond in de bestaande situatie van de geformaliseerde materiële rechtsstaat.

\subsubsection{MATERIËLE RECHTSSTAATSGEDACHTE}

In een rechtsstaat, in materiële zin, windt een staat doel en zin in het onveranderlijke recht. Rechtsorde en -handhaving alsmede bescherming van leven, vrijheid en eigendom. van burgers geschiedt middels wet- en regelgeving. Daartoe is tegelijkertijd de taak van de overheid beperkt. Deze verwezenlijking van het recht overheerst het oorspronkelijke rechtsstaatsdenken. Latere invloeden zetten de discussie over de rechtsstaat op de koers van de klassieke rechtsstaatsgedachte. Aldus wordt het recht van doel tot instrument van de staat. De klassieke rechtsstaat behelst een scheiding van de functies wetgeving, rechtspraak en uitvoering.

Een staat kent zo organisatorische beperkingen. Hiernaast wordt overheidshandelen procedureel en inhoudelijk begrensd. Kenmerkend is dat een overheid alles mag doen waartoe de wet haar verplicht en bevoegd verklaard. Daarbij is de wetgever niet gebonden aan inhoudelijke beperkingen. Althans, in principe niet. Betreft het inbreuk op grondrechten door de overheid, dan mag dit alleen plaatswinden op grond van een algemene rechtsnorm die uitdrukking vindt in een wet. Deze wet is tot stand gekomen in een daarvoor voorgeschreven procedure. Bovendien moet zo'n ingreep in overeenstemming zijn met de constitutie, waarin de vrijheid van burgers is gewaarborgd. De grondrechten vormen het juridisch instrumentarium waarmee burgers worden behoed tegen veranderlijke wetgeving en, individueel toegespitste, frequent aan wijzigingen onderhevige uitvoering.

Het materiële aspect voert dus de boventoon. Helemaal met in het achterhoofd de gedachte, dat de executieve en de rechtsprekende taak slechts worden uitgeoefend voor zover de wetgever daartoe, via algemene regels, uitdrukkelijk machtigt.

\subsubsection{FORMELE RECHTSSTAATSGEDACHTE}

In tegenstelling tot de materiële rechtsstaatsopvatting is, in de formele rechtsstaatsidee, binding van een overheid aan het recht niet allereerst inhoudelijk maar vooral procedureel. Een, in praktijk toch denkbare, procedurerechtsstat ontbeert een grondrechtencatalogus in zijn constitutie. Zo ${ }^{3} \mathrm{n}$ overheid is wel aan de wet, en daardoor aan een parlemen-

9. P. Thoenes, De elite in de verzorgingsstaat, diss. RUL, 1962; Volgens J.Th.J. v.d. Berg, Verantwoordelijkheid in een polycentrische samenteving, in: M.A.P. Bovens, C. J.M. Schuyt, W.J. Witteveen en Th.H.M. de Beer, Verantwoordelijkheid: retariek of reatiteit? Z Zwolle, 1989 . p. 191 , garandeert het begrip niets, geeft het miswerstanden en klinkt het truttig.

10. Zie over de verschuiving in de betekenis van de rechtsstatsopyattingen en, overigens, zijn ontwerp en analyse van twee rechtsstaatstypes. P.M. Langbroek, Machenscheiding en decentralisatie ${ }_{*}$ Een onderzoek naar de rechtswerhouding tussen centrale en decenrale owerheidsorganen in Nederland, dissertatie Universiteit Twente, Enschede, 1988, pp.39-62/104-108. 
taire meerderheid gebonden. Maar die wetten zijn niet inhoudelijk beperkt door het algemeenheidsvereiste. En de parlementaire meerderheid kan zowel goedaardig als kwaadwillend zijn. Van deze tweede optie geeft de Nazi-periode schrijnend blijk.

\subsubsection{FUSIE MATERIËLE EN FORMELE RECHTSSTAATSGEDACHTE}

Desparaat na de Tweede Wereldoorlog zoekt menigeen heil in het combineren van elementen uit de materiële en formele rechtsstaatsgedachte. Het is een poging de negatieve vrijheid van de klassieke rechtsstaat, die de menselijke waardigheid betreft, te verbinden met de positieve vrijheid er van en nieuwe waarden als gerechtigheid, vorm gegeven in de sociale grondrechten. Met een perfecte harmonie tussen rechtszekerheid en gerechtigheid voor ogen. Verabsolutering van een van beide aanspraken is uit den boze. Kortom, de moderne democratische rechtsstaat gaat uit van de volkomen verhouding tussen klassieke en sociale grondrechten enerzijds en procedurele aspecten anderzijds. Bij het realiseren van die combinatie ontstaat een basale spanning tussen de burgerlijke behoefte an rechtszekerheid en het overheidshandelen ten behoeve van gerechtigheid. In dit spanningsveld spelen rechter en executieve, via hun concretisering van globale regelgeving in het licht van de algemene beginselen van behoorlijk bestuur, een toonaangevende rol als veldmaarschalk.

\section{\$ 2.2 Institutionele eisen van staatsinrichting en -handelen}

Met de toenemende integratie van de verschillende versies en tradities betreffende de vraag naar de intrinsieke kwaliteit van de regels en hun resultaat, met andere woorden respectievelijk de mate waarin zij (maatschappelijke) zekerheid bieden en de wijze van totstandkoming van rechtsregels, worden mankementen van de rechtsstaat manifest. Moeilijkheden rijzen onder andere met falend beleid en wie, in hoe verre, daarvoor verantwoordelijk is. Bovendien blijkt dat bij voorbeeld: de administratie zich niet altijd aan wettelijke voorschriften houdt; bezuinigings- en ombuigingsbeleid voor problemen zorgt; sprake is van een afnemende gehoorzaamheid aan wet- en regelgeving; en in praktijk niet alle rechtsregels (even) rechtmatig zijn. "

Een optimale regeling van de relatie tussen overheidsorganen onderling en de verhouding van staat tot burgers komt, tot op heden, niet of nauwelijks goed uit de verf. Dat is niet zo vreemd. Opvattingen omtrent rechtsstatelijkheid zijn meestal ideaalbeelden. $\mathrm{Zij}$ zijn normatief van aard. Ongeacht hoe praktische uitwerking van de verschillende denkkaders plaats vindt, is in elk geval een basis voor rechtsstatelijkheid aanwezig. De inrichting als ook het handelen van de Nederlandse democratische rechtsstaat voldoet aan vijf institutionele eisen $^{12}$ : a. aanwezigheid van een constitutie; a. garantie van grondrechten voor de

11. J.Th.J. van den Berg, t.a.p., pp.184-185.

12. C.W, van der Pot, bewerkt door A.M. Donner, a.w. p.159; Vg\|. H.D. van Wijk, bewerkt door W. Konijnenbelt en R. M. van Male, Hoofdstukken wan her administratief recht, negende druk, Utrecht, 1994, pp. 40-49; Deels overeenkomend met C.A.J.M. Kortmann, Constitutioneel recht, Deventer, 1990, 199. 3335; Als mede M. Scheltema, De rechtsstaat, in: J.W.M. Engels e.a., De rechtsstaat herdacht, Zwolle, 
burger; c. machtsverdeling; d. legaliteitsbeginsel; en e. onafhankelijke rechtspraak . Deze elementen en hun samenhang variëren.

\subsubsection{GRONDWET}

Een raamwerk van rechtsregels voor de rechtsworming en thandhaving van de staat, anders gezegd een staatsregeling, kan niet zonder de dynamiek van een daadwerkelijk gevestigde overheidsorganisatie. ${ }^{13}$ Hiermee wint de constitutie aan aanpassingsvermogen en blijft zij actueel. Bij dit alles moet niet uit het oog worden verloren dat een constitutie voornamelijk vaste voorschriften bevat. Dit stelsel van voorschriften is tweeledig. Splitsing is aan te brengen tussen de geschreven grondwet en de ongeschreven constitutionele regels. Tot laatst genoemde 'levende' staatsregels, dat wil zeggen "rechtsregells die de gezagsfunctie organiseren en er de werkingssfeer van afpalen" ${ }^{14}$, is de, nog te bespreken, vertrouwensregel te rekenen.

\subsubsection{GRONDRECHTEN}

Rechtsstatelijkheid garandeert tweesoortige grondrechten. Primair zijn er fundamentele vrijheidsrechten. Op de bescherming daarvan ziet de rechter nauwlettend toe. Naast deze klassieke grondrechten zijn er, secundair, sociale grondrechten. In plaats van staatsonthouding, wordt hiervoor juist een actief overheids(voorwaardenscheppend)beleid verwacht. Sociale grondrechten zijn fraai gedefinieerd als "grondplichten" 15 of "algemeen aanvaarde opdrachten aan de staat". " Uit al datgene, wat in de Nederlandse grondwet wordt geëtaleerd, volgt aan wie, en waarvoor, het staatsbestuur verantwoording heeft af te leggen. Een constitutioneel bestel legt namelijk wast: "a. dat aan de staat opdrachten kunnen worden gesteld en welke dat in elk geval zijn, maar ook; b. dat hij dat zal hebben te doen met behulp van een forum waar het afleggen van verantwoording wordt gereguleerd; en $c$. dit in een polycentrische matschappij die al eigen en soms hoog ontwikkelde centra van zowell opdracht als verantwoording kent". "Klassieke en sociale grondrechten veronderstellen elkaar. ${ }^{18}$

Beide vinden gedeeltelijk hun oorsprong in international recht. Daarom is, in art. 94 Grondwet, terecht bepaalld dat Nederlandse formele wetsbepalingen door de Nederlandse

12. $\rightarrow$

1989, p. 15; M.C. Burkens, H.R.B.M. Kummeling en B.P. Vermeulem, Beginselen wan de democratische

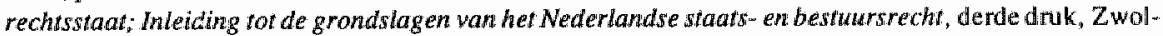
le/Utrecht, 1994, pp.37-38; A.M. Bos, Demokratie en rechtsstaat, derde druk, Nijmegen, 1993, p.60.

13. Idee (constitutie als respectievelijk regeling en organisatie) ontleend aath C.W. van der Pot, bewerk. A.M. Donner, a.w., pp.168-181.

14. T. Koopmans, bewerkt door J E. Goldschmidt, A. W. Heringa en R. E. de Winter, Compendium van het staatsirecht, vijfde druk, Deventer, 1986 , p. 10 .

15. A.M. Donner, Over het doel van de staat, in: Tussen het echte en het gemaakte; Uit de geschriftert wam professor mr A.M. Donner, Zwolle, 1986, pp.433-438.

16. J.Th.J. van den Berg, t.a.p., p.188.

17. J.Th.J. van den Berg, ta.p., p.189.

18. E.M.H. Hirsch Ballin, t.a.p., pp.94-95. 
rechter buiten toepassing kunnen worden gelaten wegens strijd met een ieder verbindende bepalingen van verdragen en van besluiten van volkenrechtelijke organisaties. Rechterlijke toetsing ter zake is een hoofrol toebedeeld. In het Nederlandse rechtssysteem is echter geen speciale constitutionele rechter aangesteld. Brandende vraag blijft waarom de onschendbaarheid van wetten nog wel geldt wat betreft de Nederlandse Grondwet. Art. 120 Grondwet, met de bepaling dat de rechter niet in de beoordeling treedt van de grondwettigheid van wetten en verdragen, houdt de gemoederen steeds meer bezig. ${ }^{19}$ Dat het kabinet tot op heden geen definitief standpunt ${ }^{20}$, over de vraag of de rechter een formele wet mag toetsen aan de Grondwet, heeft kunnen innemen, stelt teleur.

\subsubsection{MACHTSVERDELING}

Het beginsel van machtenscheiding valt te herleiden tot de theorievorming van Plato en Aristoteles omtrent de Griekse polis. Sindsdien is de interpretatie van het begrip velerlei. De algemene notie van machtenscheiding betreft de afbakening van wetgever, bestuur en rechter. Praktisch gezien, blijkt dit een gesimplificeerde voorstelling van zaken. Opvattingen over bedoeld functioneel separatisme moeten altijd in historisch verband en tegen geografische achtergrond worden geplaatst. Tegenwoordig wordt een bepaalde leer van machtenscheiding te pas en te onpas, ongeacht periode en plaats, toepasselijk verklaard.

19. Over constitutioneel toetsingsrecht: brief van de minister-president d.d. 18 febr. 1991, 21427, nr.5; TK $1992-1993,21427, \pi r .27$. Het voorstel voor een rechterlijk toetsingsrecht is als concept bij een viertal deskundigen, de Hoge Raad, de Raad van State en vervolgens de Tweede Kamer aangeboden; Het advies van de externe deskundigen, te weten M.C. Burkens, C. Flinterman, A.M. Goudsmit, I. van der Hoeven en C.A.J.M. Kortmann, is inmiddels via een arob-procedure openbaar gewozden. Zie NJCM-bulletin, Op weg nat een constitutionele toetsing, nr.3, 1992, p.233 e.v, M.B.W. Biesheuvel, in: NJB, 1992, p.726; M.C. Burkens, H.R.B.M. Kummeling en B.P. Vermeulen, a.w. ,pp.141-148; A.F.M. Brenninkmeijer, Het primaat var de politiek bestaat niet meer; Over polineke rechtspraak, rechrerlijk activisme en de leginmatie van rechterlijke oordeelsvorming. in: Ars Aequi themanummer Rechter en politiek, m. 11, november 1992 , pp. 687-688/692; P.B. Cliteur, Argumenten voor en tegen constitutionele toetsing. in: NJB, nr.38, 1989, p.7; P.B. Cliteur, Grondwet ligt op sterven doar toetsingsverbod, in: NRC, 15 febr. 1993, p.7; A.H.M. Dölle en J.W.M. Engels, Constitutionele rechtspraak, Groningen, 1989; A.H.M. Dölle, Constitutionele toetsing, in: P.B. Cliteur en M.R. Rutgers, De trias onder spanning, Groningen, 1990, pp.89-100; J.W.M. Engels, Constitutionele toetsing en machtenscheiding, in: P.B. Cliteur en M.R. Rutgers, a.w. , pp.101-108; E.M.H. Hirsch Ballin en M. L.P. wan Houten, Toetsing wan wetgeving:" shitsuk van de democratische rechtssstaat, in: Namens, 5 september 1989, pp.19-26; T. Koopmans, Vergelijkend publiekrecht, Dewenter, 1986, p.42 e.v.; T. Koopmans, bewerkt door Th.L. Bellekom, A.W. Heringa en R. E. de Winter. Compendium van het staatsrecht, zesde druk, Deventer. 1992, pp. 256-261, zie ook zevende druk, Deventer, 1994, pp.253-267; C.A.J.M. Kortmann, Constitutioneel recht, Deventer, 1990, pp.131-132; P.M. Langbroek, a.w. pp.55/99-103; B.M.J. van der Meulen, Rechserlikk toetsing van wetgeving in Europees perspectief, in: Bestuursrecht na 1992, preadviezen voor de conferentie d.d. 20 april 1989 t.g.v. het 50-jarig bestaan van de VAR, Alphen a/d Rijn, 1989, pp.5574 ; preadviezen L. Prakke, T. Koopmans en J.M. Barendrecht, Toetsing; Dient de wetgever de mogelijkheid te bieden, dat de rechter de formele wertoetst aan de Grondwet en ongeschreven rechtsbeginselen. en za ja, hoe dient deze mogelykheid dan te worden uitgewerkt?, hand. NJV, Zwolle, 1992-I; F. A. M. Stroink, De plaats vam de rechter in het staatsbestel, inaugurele rede, Zwolle, 1990; F.A.M. Stroink, Rechterljke organisatie en rechtspraak in beweging. Zwolle, 1993. pp.15-29; M.F.J.M. de Werd, De

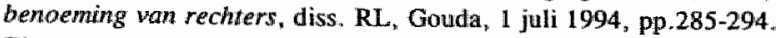

20. Zie weergave persbericht justitie, 29 april 1994, in: Advocatenblad, nr.10, 13 mei 1994, p.440. 
Dat noopt tot relativisme. Want "het recht mag nooit worden geisoleerd uit de culturele en ethische context waarin het heeft te functioneren. ${ }^{21}$

Een paar doctrines ${ }^{22}$ ter zake zijn noemenswaardig. In meest zuivere vorm maakt de trias politica ${ }^{23}$ een exclusieve driedeling. Wetgeving, uitvoering en rechtspraak existeren autonoom in personele afzondering. Evident is het horizontale karakter van deze machtenscheiding. De spreiding van bevoegdheden vindt slechts plaats binnen het centrale overheidsniveau. ${ }^{24}$

Deze driestroom ontbreekt het niet aan varianten. Bekende correcties ${ }^{25}$ zijn, ten eerste, de onderscheiding naar ieders typische wilsverrichting, te weten de executieve, de delibererende en de electorale (kies)macht; En ten tweede de functionele onderverdeling van regelstellen, regeltoepassen en rechtspreken. Laatst genoemde taken zijn onlosmakelijk verbonden met en aangevuld door drie daaraan vooraf gaande, eventueel er mee strijdige, activiteiten, namelijk het tot uiting brengen van belangen, het bundelen van belangen en het politiek communiceren.

21. D.J. Elzinga, De wacarde van een relatief rechtsbegrip, oratie, Groningen, 1988, p.3.

22. D.W.P. Ruiter, Ontworpen verticaal machtsevenwich, in: D.W.P. Ruiter, Verticaal machtsevernich in het bimenlands bestur, Raad voor binnenlands bestuur, "s-Gravenhage, 1982, p.62 e.v.: Tevens P.M. Langbroek, a.w., pp. 29-39.

23. Enige bronvermelding is in W.J. Witteveen, Zeer vrij nat Montesquieu, in: P, B. Cliteur en M.R. Rutgers, a.w., pp. 29-35, aangetroffen: Voorlopers van de triasleer, die eigenlijk geen leer is ormdat nauwelijks sprake is van een zelfstandig en systematisch betoog (M.R. Rutgers en P. B. Cliteur, Inleiding, in: P.B. Cliteur en M.R. Rutgers, a.w., p. 10), zijn: J. Locke, On civil Governement, 1690 (NB auteur voegt rechterlijke en uitvoerende functie nog samen); en A. Nedham, The excellence of a free state, 1566 , uatwoerig behandeld door W.B. Gwym, The separation of powers, 's.Gravenhage, 1965. Beroemder is Ch.L. de Montesquieu, De l'Esprit des lois, Paris, 1979. Toch is hij niet de vader van de triasleer". Zie - a. F. . wan der Burg, De triasleer revisited, in: $T$. Hoogenboon en L.J.A. Damen (red.), In de sfeer van administratief recht, Utrecht, 1994, pp. 33-48, i.h.b. p.35. Bovendien is Montesquieu niet strikt in de leet. Op gegeven moment brengt hij namel jk ewenwichtsmechanismen tussen de absolute machten aan. Hierop wijst M.J.C. Vile, Constitutionatism and the separation of powers, Oxford, 1967. Witteveen ageert er trouwens tegen, dat zo weinigen echt kennis nemen van het oeuvre wan Montesquieu. Zix ook C.M. Zoethont in zujn Boekbespreking van C.P. Cliteur en M.R. Rutgers, t.a.p., in: Civis Mundi, nr.1. 1990, p.30. Tevens F.A.M. Stroink, De ploats wan de rechter in het staatsbestel, Zwolle, 1900, p. 12. Treurig gevolg hierwan is dat weinig tot geen relaties tussen staftsrechtsleer en geschiedenis zijn gelegd. Witteveen wil deze impasse doorbreken. Hij sutueert Montesquïeu in zijn tijd. Zijn verhandeling eindigt dan ook met een verfrissende lezing van de trias: Montesquieu geeft slechus een wetgevingsleer! Die houdt in dat wetten moeten passen bij de drijwende krachten wan een bepaalde samemleving en een bepaald staatsty pe. Dat is de kardinale kwestie "Hamvraag is dus niet of wetgeving aansiluit bij andere wetgeving Zo bezien, wekt de vermeende inconsequentie in het werk van Montesquiet geen verbazing meer. De rechter is kenmelijk niet echt een louter passieve functie gegeven. Bestuur, em wooral wetgever en rechter mogen dan wel zijn gescheiden. Zekere samenwerking blijft vereist.

24. In tegemstelling tot verticale machtenscheiding, waarbij sprake is van bevoegdheidstoekenning aan overheidsorganen buiten het centrale niveau. Zie M.C. Burkens, H.R.B.M. Kummeling en B.P. Vermeulen, a.w., pp. 85/218.

25. Raadpleeg miteenzetting van S.W. Couwenberg, De trias voorbij? Een aliernatieve visite op machtenscheiding en machtsevenwicht, in: P.B. Cliteur en M. IR. Rutgers, a.w., pp. 112-114, verhandelend over respectievelijk M. Hauriou, Précîs de Droit Constitutionnel, 1929 en G.A. Almond en G.Bringham Powell, Comparative politics, Boston, 1972. 
De tweede versie duidt op een conceptueel kritiekpunt van de trias politica. De trias stoelt op de term macht. Dat is het kernbegrip. Helaas is dat een hoogst ongrijpbaar begrip. Macht kan betekenis hebben als functie, institutie, orgaan, bevoegdheid of vermogen. In juridische optie ligt macht als bevoegdheid het meest voor de hand. Feitelijke machtsconstellatie en formele bevoegdheidsverdeling moeten, zo veel mogelijk, congruent zijn. Hoe is verantwoordelijkheid te scheppen als er geen eens een bevoegdheid tot handelen bestaat? ${ }^{26}$

In verschillende andere disciplines wordt de tegenwoordige discussie over de mogelijkheid van een moderne machts(balans)leer beheerst door een ruimere opvatting. Macht blijkt dan vooral vermogen. ${ }^{27}$ Dat is het sturend vermogen van een individu, van een groep of van een organisatie om het handelen van anderen te beïnvloeden. Afgezien van de onheuse plaats die het zo genaamd ambtelijk apparaat als afzonderlijke, autonome actor ${ }^{28}$, en soms zelfs als vierde macht ${ }^{29}$ op eist, staan allerhande politieke partijen met hun fractiespecialisten, belangen- en pressiegroepen, groot- en interstedelijke/provinciale organen, adviesdiensten en media in de rij om als nieuwe machten te worden erkend. ${ }^{30}$

De kritiek klopt dus. Er zijn meer functies dan die van de trias politica. En er zijn meer organen en dergelijke dan waarin zij voorziet. Dit nieuw besef laat de gemoederen niet onberoerd. Terecht komt in tegenwoordige theorieën de democratische rechtsstaat als "cyclisch proces" naar voren. ${ }^{31}$ Daarmee verdwijnt het machtsbegrip achter de horizon. Ter aanduiding van de organen wordt de lans gebroken voor het procesbegrip. Een ideaaltypisch onderscheid tussen politiek, administratief en rechterlijk (besluitwormings)proces benadrukt het dynamische karakter van de moderne rechtsstaat.

De valse viool voldoet dus niet meer. Het is hoog tijd het instrument te stemmen. Enkele nieuwe tonen en het spel is gezuiverd. Verknochtheid aan de trias-machten vraagt verloochening van de werkelijkheid. Want de waarheid wil anders.

26. H.G. Lubberdink, De betekenis wan de ministerielte verantwoordelijkheid voor het openbaar bestuur. dissertatie Rijksuniversiteit Groningen, Deventer, 1982, p.13.

27. M.R. Rutgers en P. B. Cliteur, Inleiding, in: P.B. Cliteur enM.R. Rutgers, a.w., p.13.

28. U. Rosenthal, De trias en het openbaar bestuar: bij de tijd?, in: P.B. Cliteur en M.R. Rutgers, a.w., p. 80 .

29. R. Crince le Roy, De vierde macht, de ambtelijke bureaucratie als machtsfactor in de staat, diss, derde druk, Baarn, 1976; Vgl. A.B. Ringeling, Beleidsvrijheid van ambtenaren, Alphen a/d Rijn, 1978; J., van Putten (red.), Haagse machten. 's-Gravenhage, 1980; J. Raadschelder, De vierde macht, het ambtelijk apparaar in Nederland, stichting burgerschapskunde, serie basisboeken, Leiden, 1992; Gaston L. Sporre. Ambtelike inwloed (werkend; De verhouding tussen politiek bestuur en ambtelijke organisatie nader beschouwd, "s-Graw., 1988; Anders C. W. wan der Pot, bewerk A.M. Donner, a.w., pp.478-483; En M.C. Burkens, tijdens symposium Ambtenaar, dienaar van de minister? d.d. 28 aug. 1986, stafafdeling constitutionele zaken en wetgevingsaangelegenheden van het ministerie van BiZa, "s-Grav., jan. 1987 , p. 19, heeft moeite met de term wierde macht. Anbtelijke macht is, z.i., een "schuilhoekenmacht". Hij spreekt lilever over de "macht van het systeem". D.w.z. de "macht die een gevolg is van inertie ofwel het ingeslepen gedragspatroon wan elke grote arganisatie".

30. Zie uitgebreid S.W. Couwenberg. t.a.p., p.109.132.

31. B. Hessel, Nederlandse economisch publiehrecht; De bestursrechrelijke aspecten, Zwolle, 1992, pp.1013. 
Zinvoller is zo het denken in (machts)verhoudingen. Duidelijker de vraag wie welke bevoegdheden heeft. Op die wijze kunnen ook territoriale en functionele decentralisatie van publiekrechtelijke bevoegdheden een voornamere positie verwerven. Immers, de oude trias gaat uit van ển overheidscentrum. $\mathrm{Zij}$ negeert medeoverheden, die juist de inrichting van het binnenlands bestuur in hoge mate bepalen. ${ }^{32}$

Beter in de Nederlandse constitutionele staat past dan ook de radicalere doctrine van checks and balances. Dit evenwichtsprincipe houdt het volgende in. De ene overheid kan, met een haar daartoe verschafte bevoegdheid, in beperkte mate interfereren in de bevoegdheidsuitoefening van de andere overheid. Op centraal, maar ook op decentraal niveau. Naast horizontale is dus wooral verticale machtsverdeling mogelijk. Competenties, tot formele wetgeving, regering en rechtspraak, genieten geen exclusiviteit.

Zo is wetgeving athankelijk van zowel parlement als executieve gezamenlijk. Zo is de wet een bestuursinstrument geworden. Tegenwoordig kan het bestwur wet- en regelgeving tot op grote hoogte zelf invullen en construeren. Kortom, de uitvoerende macht blijkt steeds meer wetgevende macht. En omgekeerd wordt legislatieve al meer executieve. ${ }^{33}$ Bovendien is de invloed van de rechter op de wetgever niet meer uit te vlakken. Natuurlijk is een "politieke rechtspraak", in de zin dat de rechter niet onafhankelijk is en functioneert als verlengstuk van de politiek ${ }^{34}$, verderfelijk. Ergo: voor excessieve taakvervulling ter zake door de rechter is geen plaats in de Nederlandse rechtsorde. Maar wel mag sprake zijn van een actieve, sturende ${ }^{35}$ rechter, die de "juridisch effectieve veiligstelling van de belangen van het individu rechtsvormend in aan hem voorgelegde geschillen nastreeft". ${ }^{36}$ Daarbij geldt het primaat van het recht als uitgangspunt. ${ }^{37}$ Want de

32. Vardaar het pleidooi voor een decentrale trias. U. Rosenthal, t.a.p., pp.85-86.

33. L.A. Geelhoed, E.M.H. Hirsch Ballin, J.M. Polak, U. Rosenthal, I. Th.M. Snellen en I.C. van der Vhess, Wergewing in beweging, uitgave Centrum voor wetgevingsw raggstuken Katholieke Unversiteit Tilburg. Zwolle, M. N. E.M.H. Hirsch Ballin, De gekoppelde staat, pp.61-74; Zich op wetgeving, TK 1990-199!" 22008, nrs.1.2; W.F. de Gay Fortman (red.). Problemen van mergewing, Deventer, 1982, nu. M. Scheltema, Bestuwrsech: is het bestuw wetgever in eigen zaak?, pp. 131-144; J.M. Polatk en M. Scheltema, Dient verandering le worden gebracht in de wijze van woorbereiding en totstandkowing van wetgevimg respectievelijk het proces wan wetgeving, preadviezen $\mathbb{N J V}$, deel $1, \mathrm{j} \mathrm{rg} .109,1976$.

34. A.F.M. Breminkmeijer, t.a.p., p.682.

35. W.J. Witteween, Evenwicht wan machten, oratie KUB d.d. 15 febr. 1991, Zwolle, 1991, p.88.

36. A.F.M. Breminkmeijer, t.a.p. p.41: Vgl. A.F.M. Brenninkmeijer, Democrafische rechtspraak en ondemocratische wetgeving, in: MJB, nr.39, nov. 1993, pp.1387-1395; A.F.M. Brenninkmeijer, De rechterlike mach in de steigers, in: Beleid \& Matschappij, nr. 1-2, 1994, pp.48-56; Ook over 'wetgeverplaatsvervanger" M.C. Burkens, H,R.B.M. Kummeling en B.P. Vermeulen, : W., p1. 137-141; E.J. Dommering, Welgevingsonrecht en wetsprekende rechters, in: RM, febr. 1989, pp.2-9;, $\mathrm{T}$. Koopmarns e.a., Compendiw man het staatsrech, zevende dnk, Deventer, 1994, pp.265-266; M.G. Rood e.a.. Rechters en poltiek; nationale en intermationale beschouwingen. Zwolle, 1993; A. Grotenhuis, Wetgevende rechrers, in: NRC, 15 dec. 1993 , p.18; M.F.J.M. de Werd, a.w , pp.284-285/300-305; W.I. Witteveen, Van wetstoepassing naar belangenafineging? De rechier als democranisch politiek orgaan, in: A. A. Franken en E.P.M. Joosen, Wederkerige rechtsbetrekkingen, verslag themadag JUVAT Tilburg 30 okt. 1992, Lelystad, 1993, pp 3-22; Maar over de arresten (t.w. HR 30 sept. 1994 en RwdW 1994, 185188), waarin de Hoge Radid niet als wetgever-plaatsvervanger handelt, maar zich - sterker nog - zelfs 
rechter is wel een onafhankelijke, maar geen autonome actor. Naar aanleiding van kamervragen, interpellaties en wetsontwerpen is de (on)aanvaardbaarheid van rechterlijke uitspraken, veelal gedaan in kort geding waardoor rechterlijk activisme een "overvalkarakter" krijgt ${ }^{38}$, nog wel steeds onderwerp van parlementaire discussie. ${ }^{39}$ De rechtsvormende taak van de rechter past in een door checks and balances gekenmerkte machtsverdeling.

Rechter, wetgever en bestuurder controleren elkaar. De antwoorden op de vragen wellke machtsverdeling er precies is en wie wie controleert, zijn afhankelijk van de concrete maatschappelijke en politieke situatie. ${ }^{40} \mathrm{Nu}$, in de Nederlandse samenleving, wetgever en bestuurder herhaaldelijk het zelfde huis delen ${ }^{4 !}$, bestaat de noodzaak van een aangescherpte controle ter zake door de rechter. Omdat de controle tussen eerst genoemden verzwakt, moet de rechterlijke waakzaamheid worden vergroot. Aldus is de extra controle door de rechter op legislatieve en executieve terecht. ${ }^{42}$

Het systeem van checks and balances ${ }^{43}$ is van, extra evenwicht beogende, aanvullende controles niet vies. In dit verband wordt nadrukkelijk gewezen op de ministeriële verantwoordelijkheid ter democratisering van bestuur.

Dat machtsverdeling ook nu nog een niet te veronachtzamen factor is, blijkt uit argumentem die ter verdediging van haar bestaansrecht worden aangevoerd. ${ }^{44}$ Machtsverdeling is noodzakelijk uit oogpunt van efficiency en het algemeen belang. Zij staat garant voor

36. $\rightarrow$

uitdrukkelijk in de plaats stelt van de wetgever, kritisch en zeker niet enthousiast J.M. van Dunné, Wie. sterk is mag dom zijn, De aitspraken van de HR, andermaal als wetgever-plaatsvervanger, inzake grootschalige whilieuverwuling in het verleden, door Shell, Philips-Duphar en Fasson, in: NJB, nt.39, 4 now. 1994, pp.1329-1338.

37. Zile over de samenwerking tussen rechter en wetgever, die in het teken stat van hun gemeenschappelijk belang t.w. Het belang van goede rechtsnomen, B.W.N. de Waard, Samenmerkende machen, oratie KUB, 2 nov. 1994, Zwolle, 1994.

38. M.F.I.M. de Werd, a.w., pp.301-304/310-311. Volgens auteur blijken "controversiële vraagstukken steeds vaker wan spoedeisend belang (of worden als zodanig gepresenteerd), en op dat punt kan de - zoals dat tegenwoordig heet - "stroperige" wetgewing niet concurreren met een (alleensprekende) rechter, die, desnoods in pyjama, vonnis kan wijzen" (p.311).

39. C.A. Groenendijk, Parlementaine reacties ap rechrerlike witspraken: democratische contrale op aamunallende regelgevers, in. G.J.M. Corstens (red.), Met hoofd en hart, Zwolle, 1991, pp.67-85 (incl. literauurfijst betreff. reliatie wetgever-rechter).

40. W.J. Witteveen, a.w., pp.63-100; Hij spreekt wan "een nieuwe episode in het vervolgverhaal van de trias politica" (p.67); M.F.J.M. de Wend, a.w., p.310, verwijt Witteveen terectht onderschatting van de democratische legitimatie, mar ziet wel de reële noodzalk in van de door Witteveen beoogde koerswijziging t.a.v. de trias-opvatting.

41. H.D. Tjeenk Willink, in: NRC Handelsblad, 1 juli 1992.

42. A.F.M. Brenninkmeijer (1992), t.a.p. " p.683; F.A.M. Stroink, De plaats wan de rechter in het staatsbestel, it.w., p.12/25. Hij acht "een activistische houding van de rechter nodig om het evenwicht tussen democratie en rechtsstaat te herstellen".

43. Frappant vertaald als "teugels en tegenwichten" door E.C.M. Jurgens, Over Montesquieu, aan wie ten onrechie de leer der Trias Politica wordt toegeschrewen, in: RegelMaat, nr.6, 1994, pp.245-246.

44. H.J. Aquina, Kijk op beleid; Inleiding in de beleidswetenschappen, Assen/Maastricht, 1993, pp. 142-144. 
onpartijdige wets- of beleidsuitvoering. Zij dwingt bestuurders tot het afleggen van verantwoording. En ten slotte is een stelsel van checks and balances zonder machtenscheiding onmogelijk.

Resumerend omvat machtsverdeling in hedendaagse staatsrechtelijke betekenis het volgende. "Bepaalde hoofdorganen in het staatsbestel, te weten Staten-Generaal, regering en rechterlijke macht, zijn belast met bepaalde taken, die zij deels zelfstandig en deels in samenwerking met elkaar uitoefenen, waarbij sprake is van onderlinge afhankelijkheid en onderlinge controle." 45

\subsubsection{LEGALITEITSBEGINSEL}

Belangrijke bijdrage aan democratische legitimatie van overheidsgezag is de binding aan, uiteindelijk, algemene wetgeving in formele zin. Anders gezegd, er bestaat geen bevoegdheid zonder grondslag in wet of grondwet. ${ }^{46}$. De legaliteitseis geldt voor het gehele overheidsoptreden. ${ }^{47}$

Herleidbaarheid tot een formele wet garandeert niet per se rechtsgeldigheid. Rechtsgeldigheid doelt onder meer op het volgende. Een wettelijk voorschrift moet correct tot stand komen. Het voorschrift moet op de juiste manier bekend worden gemaakt. En het moet verenigbaar zijn met hogere regelgeving, inclusief algemene beginselen van behoorlijk bestuur.

Bij gelede normstelling in geval van attributie of delegatie van bevoegdheden, betekent herleidbaarheid weliswaar voor de rechter soms een speurtocht. Mogelijk heeft hij de opgave om in de decentralisatieketen uiteindelijk een formeel-wettelijk grondslag te vinden. Het zoeken naar een de burgers algemeen bindend besluit, kan lastig zijn. Ondanks de moeilijkheden voor een rechter die de regel van herleidbaarheid met zich mee kan brengen, staat herleidbaarheid als zo danig niet in de weg aan het legaliteitsbeginsel. ${ }^{48}$ Nadere uiteenzetting, over de specifieke problemen van de gedecentraliseerde eenheidsstaat en de legaliteitseis, volgt in hoofstuk 4.

\subsubsection{ONAFHANKELIJKE RECHTSPRAAK}

Deze institutionele eis vloeit voort uit de vorige. Voor civiel-, administratief-, straf-en tuchtrechtelijke geschillen tussen burgers onderling als ook bij onenigheden tussen overheid en burgers, moeten rechters zijn. Dat wil zeggen, van regeringswege benoemde ${ }^{49}$, geschillenbeslechters die onafhankelijk en onpartijdig zijn.

45. M.C. Burkens, H.R.B.M. Kummeling en B.P. Vermeulen, a.w., p. 85.

46. P. Nicilai, B.K. Olivier, L.J.A. Damen en H. Troostwijk, Bestuursrech, derde herziene druk, Amster dam, 1992, p.47.

47. P. de Haan, Th.G. Drupsteen en R. Fernhout, Bestuurspecht in de sociale rechisstaat, instrument en waarborg, deel 1, ontmikkeling, organisatie en instrumentarium, Deventer, 1987, pp.24.28.

48. Vergelijk M.C. Burkens, H.R.B.M. Kummeling en B.P. Vermeuten, a.w. pp.60-61.

49. Over de benoeming van rechters uitvoerig M.F.J.M. de Werd, a.w. 


\section{Geraadpleegde literatuur}

Aquina, H.J.

Kijk op beleid; Inleiding in de beleidswetenschappen. Assen/Maastricht, 1993.

Berg, J.Th.J. van den

Verantwoordelijkheid in een polycentrische samenleving, in: Bovens, M.A.P., Schuyt, C.J.M., Witteveen, W.J. \& Beer, Th.H.M. de (red.), Verantwoordelijkheid: retoriek of realiteit?, Zwolle, 1989, p. 191 .

Bos, A.M.

Demokratie en rechtsstaat, derde druk, Nijmegen, 1993.

Brenninkmeijer, A.F.M.

- Het primaat wan de politiek bestaat niet meer; Over politieke rechtspraak, rechterlijk activisme en de legitimatie van rechterlijke oordeelsworming, in: AA, themanummer Rechter en politiek, nr.11, november 1992, pp.680-697;

- Democratische rechtspraak en ondewocratische wetgeving, in: NJB, nr. 39. 4 november 1993, pp.1387-1395;

- De rechteriijke macht in de steigers, in: Beleid \& Maatschappij, nr.1-2, 1994, pp.48-56.

Burg, F.H. van der

De triasleer revisited, in: Hoogenboom, T. \& Damen, L.J.A. (red.), In de sfeer van administratief recht; Opstellen aangeboden aan Willem Konijnenbelt, Utrecht, 1994, pp.33-48.

Burkens, M.C., Kummeling, H.R.B.M. \& Vermeulen, B.P.

Beginselen van de democratische rechtsstaat; Inleiding tot de grondslagen van het Nederlandse staats- en bestuursrecht, derde druk, Zwolle/Utrecht, 1994.

Cliteur, P.B.

- Argumenten voor en tegen constitutionele toetsing, in: NJB, nr.38, 1989, p.7 e.v.;

- Gronalwet ligt op sterwen door toetsingsverbod, in: NRC, 15 febr. 1993, p.7.

Couwenberg, S.W.

De trias voorbij?" Een alternatieve visie op machtenscheiding en machtsevenwicht, in: Cliteur, P.B. \& Rutgers, M.R., De trias onder spanning, Groningen, 1990, pp. 109-132.

Crince Ie Roy, $\mathbb{R}$.

De vierde macht, de ambtelijke bureaucratie als machtsfactor in de staat, dissertatie derde druk, Baarn, 1976.

Dölle, A.H.M.

Constitutionele toetsing, in: Cliteur, P.B. \& Rutgers, M.R., De trias onder spanning, Groningen, 1990, pp.89-100.

Dölle, A.H.M. \& Engels, J.W.M.

Constitutionele rechtspraak, Groningen, 1989.

Dommering. E.J.

Wetgevingsonrecht en wetsprekende rechters, in: RM, februari 1989, pp.2-9.

Donner, A.M.

Over het doel van de staat, in: Tussen het echte en het gemaakte; Uit de geschriften vam professor mr A.M. Donner, Zwolle, 1986, pp.433-438.

Dunné, J.M. van

Wie sterk is mag dom zijn. De uitspraken van de Hoge Raad, andermaal als wetgever-plaatsvervanger, inzake grootschalige milieuvervuiling in het verleden, door Shell. Philips-Duphar en Fasson, in: NJB, nr. 39, 4 november 1994, pp.1329-1338.

Elzinga, D.J.

De waarde van een relatief rechtsbegrip, oratie, Groningen, 1988;

Engels, J.W.M. 
Constitutionele toetsing en machtenscheiding, in: Cliteur, P.B. \& Rutgers, M.R., De trias onder spanning, Groningen, 1990, pp.101-108.

Gaay Fortman, W.F. (red.)

Problemen van wetgeving, Deventer, 1982.

Gaston L. Sporre

Ambtelijke invloed (v)erkend; De verhouding tussen politiek bestuur en ambtelijke organisatie nader beschouwd, 's-Gravenhage, 1988.

Geelhoed, L.A., Hirsch Ballin, E.M.H., Polak, J.M., Rosenthal, U., Snellen, I.Th.M. \& Vlies, I.C. v.d.

Wetgeving in beweging, verslag landelijke bestuurskundedag d.d. 21 maart 1991, uitgave Centrum voor wetgevingsvraagstukken Katholieke Universiteit Tilburg, Zwolle, 1991.

Groenendijk, C.A.

Parlementaire reacties op rechterlijke uitspraken: democratische controle op aanvullende regelgevers, in: Corstens, G.J.M., Met hoofd en hart; Opstellen aangeboden aan professor mr.J.C.M. Leijten t.g.v. zijn afscheid als hoogleraar aan de KUN, Zwolle, 1991, pp.67-85.

Grotenhuis, A.

Wetgevende rechters, in: NRC, 15 december 1993, p.18.

Haan, P. de, Drupsteen, Th. G. \& Fernhout, R.

Bestuursrechtin de sociale rechtsstaat: instrumenten waarborg; Deel 1 , ontwikkeling ${ }_{x}$ organisatie en instumentarium, derde herziene druk, Deventer, 1987.

Helder, E.

Ombudsman en administratieve rechisbescherming; De Nationale ombudsman, gemeentelijke klachteninstanties, alsmede enkele buitenlandse ombudsmanvoorzieningen, in relatie tot rechtsbe w scherming tegen de overheid: een juridische en empirische studie, dissertatie UT, Enschede, 1989.

Hessel, B.

Nederlands-economisch publiekrecht; De bestuursrechtelijke aspecten, Zwolle, 1992.

Hirsch Ballin, E.M.H.

- Regelen op afstand als vereiste van een sociale rechtsstaat, in: Bovens, M.A.P., Derksen, W. \& Witteveen, W.J.(red.), Rechtsstaat en sturing, Zwolle, 1987, pp.91-104, in: Rechtsstaat en beleid; Een keuze sut het werk van mr E.M.H. Hirsch Ballin, Zwolle, 1991, pp.383-395;

- De gekoppelde staat, in: Geelhoed, L.A., Hirsch Ballin, E.M.H., Polak, J.M., Rosenthal, U., Snellen, I.Th.M. \& Vlies, I.C. van der, Wetgeving in beweging, Zwolle, 1991, pp.61-75.

Hirsch Ballin, E.M.H. \& Houten, M.L.P. van

Toetsing van wetgeving: sluitsiuk wan de democratische rechtsstaat, in: Namens (themanummer), 5 september 1989, pp.19-26.

Iurgens, E.C.M.

Over Montesquieu, aan wie ten onrechte de leer der Trias Politica wordt toegeschreven, in: RegelMaat, nr.6, 1994, pp.245-246.

Koopmans, T., m.m.v. Goldschmidt, J.E., Heringa, A.W. \& Winter, R.E. de Compendium van het staatsrecht, vijfde druk, 1986.

Koopmans, T., m.m.v. Biellekom, Th.L., Heringa, A.W. \& Winter, R.E. de

- Compendium van het staatsrecht, zesde druk, Deventer, 1992;

- Compendium van het staatsrecht, zewende druk, Deventer, 1994.

Kortmam, C.A.J.M.

Constitutioneel recht, Deventer, 1990.

Langbroek, P.M.

Machtenscheiding en decentralisatie; Een onderzoek naar de rechtsverhouding tussen centrale en decentrale overheidsorganen in Nederland, dissertatie UT, Enschede, 1988. 
Lubberdink, H.G.

De betekenis van de ministeriele verantwoordelijkheid voor het openbaar bestuur, diss. RUG, Deventer, 1982.

Meulen, B.M.J. van der

Rechterlike toetsing van wetgeving in Europeesperspectief, in: Bestuurstechtna 1992, preadwiezen voor de conferentie d.d. 20 april 1989 ter gelegenheid van het 50-jarig bestaan van de VAR. Alphen aan den Rijn, 1989, pp.55-74.

Nicolaï, P., Olivier, B.K., Damen, L.J.A. \& Troostwijk, H.

Bestuursrecht, derde herziene druk, Amsterdam, 1992.

NJCM-bulletin

Op weg naar een constitutionele toetsing, nr. 3,1992, p.233 e.v.

Polak, J.M. \& Scheltema, M.

Dient verandering te worden gebracht in de wize van voorbereiding en totstandkoming van wetgeving respectievelijk het proces van wetgeving, preadviezen NJV, deel 1, jrg.109, 1976.

Pot, C.W. van der \& Donner, A.M., m.m.v. Prakke, L., Reede, J.L. de \& Wissen, G.J.M. van Handboek wan het Nederlandse staatsrecht, twaalfde druk, Zwolle, 1989.

Prakke, L., Koopmans, T. \& Barendrecht, J.M.

Toetsing. Dient de wetgever de mogelijkheid te bieden, dat de rechter de formele wet toetst aan de Grondwet en ongeschreven rechtsbeginselen, en zo ja, hoe dient deze mogelijkheid dan te worden uitgewerkt?, hand. NJV, Zwolle, jirg.122, 1992-I.

Raadschellders, J.

De wierde macht, het ambtelijk apparaat in Nederland, stichting burgerschapskunde, serie basisboeken, Leiden, 1992.

Rood, M.G. (red.)

Rechters en politiek: nationale en internationale beschouwingen, Zwolle, 1993.

Rosenthal, U.

De trias en het openbaar bestuur; bij de tijd?, in: Cliteur, P.B. \& Rutgers, M.R., De trias onder spanning, Groningen, 1990, p.77-88.

Ruiter, D.W.P.

Ontworpen verticaal machtsevenwicht, in: Ruiter, D.W.P., Verticaal machtsevenwicht in het binnenlands bestuur, reeks bestuur in beweging, raad voor het binnenlands bestuur, "s-Gravenhage, 1982, p.62 e.w. .

Rutgers, M.R. \& Cliteur, P.B.

Inleiding, in: Cliteur, P.B. \& Rutgers, M.R., De trias onder spanning, Groningen, 1990, p.927.

Scheltema, $M$.

De rechtsstaat, in: Engels, J.W.M. (e.a.), De rechtsstaat herdacht, Zwolle, 1989 , p. 15 e.v.

Schuyt, C.J.M.

Situring en het recht, in: Bovens, M.A.P., Witteveen, W.J. (red.), Het schip van staat; Beschouwingen over recht, staat en sturing, Zwolle, 1985, pp.113-124.

Stroink, F.A.M.

$\sim$ De plaats van de rechter in het staatsbestel, inaugurele rede, Zwolle, 1990;

$\sim$ Rechterlijke organisatie en rechtspraak in beweging, Zwolle, 1993, pp.14-29.

Werd, M.F.J.M. de

De benoeming van rechters, dissertatie Rijksuniversiteit Limburg, 1 juli 1994, Gouda.

Witteveen, W.J.

- Zeer vrij naar Montesquieu, in: Cliteur, P.B. \& Rutgers, M.R., De trias onder spanning,

Groningen, 1.990, pp.29-53;

$\sim$ Evenwicht wan machten, Zwolle, 1991; 
Hoofdstak 2

- Van wetstoepassing naar belangenafweging? De rechter als democratisch politiek orgaan, in: Franken, A.A. \& Joosen, E.P.M., Wederkerige rechtsbetrekkingen: belangenafweging door de rechter, verslag themadag JUVAT Tilburg d.d. 30 oktober 1992, Lelystad, 1993, pp.3-22.

Wijk, H.D. van, bewerkt door Konijnenbelt, W. \& Male, R.M. van Hoofdstukken vam administratief recht, negende druk, Utrecht, 1994.

Zoethout, C.M.

Boekbespreking, in: CV, nr.1, 1990, pp.30-31. 
Hoofdstuk 3

\section{De verantwoordelijkheid veranderd}

\section{$\S$ 3.0 Verschuivende verantwoordelijkheden}

In de gedateerde triasgedachte is het web van verantwoordelijkheden minder ondoorzichtig dan nu. Simpel weg is het de rechter, die regellnaleving in het oog houdt. In het huidige staatsbestel zijn, niet te verwaarlozen, verschuivingen in onderlinge machtsrelaties te constateren. In de eerste plaats betekent regeren ook het vaststellen van regels. Een gedeelde competentie dus, die trouwens niet alleen nadeel brengt. En, in de tweede plaats, mag bestuur niet worden vereenzelvigd met uitvoering. Vooral dit secundaire signaal is interessant.

Ter preventie van een oppermachtig bestuur zijn aanvullende checks and balances nodig. Die gaan langs twee hoofdlijnen. Uit de aard der zaak is, ten eerste, (semi-)rechterlijke controle ' op overheidshandelen onontbeerlijk. Een preponderante positie van de executieve vindt mogelijk beteugeling in de handen van een goed geëquipeerde rechter, die volwaardig toegankelijk is. ${ }^{2}$ De rechtshandhaafbaarheid en -zekerheid ${ }^{3}$ krijgen in deze studie nog aandacht.

Ten tweede krijgt effectieve controle gestalte in de politieke ministeriële verantwoordelijkheid. Die gedraagt zich grillig.

Immers, in de complexe Nederlandse bestuurlijke organisatie van vandaag zijn de beslissende touwtjes niet meer in handen van een persoon. Het proces van toe- en verdeling van taken, bevoegdheden en verantwoordelijkheden is onomkeerbaar. Generaal wordt

1. Ministeriele verantwoordelijkheid als middel wan rechtsbegcherming beschowwen is oneigenlijk. F.A.M. Stroink, Het leerstuk der deconcentratie, dissertatie Rijksuniversiteit Utrecht, "s-Gravenhage, 1978, p. 1.41.

2. A.F.M. Brenninkmeijer, De toegang tor de rechter, Zwolle, 1987.

3. Gelet op verandering van wet- en regelgeving, in de vorm van kader", machtigings-en planningswetgewing, moeten compensatiemechanismen hum nut bewijzen. Te denken is an abbb, beleidsregels, uitbreiding en aanyulling administratieve rechts- en ombudsgangen. Ook het "handhavingslek", vooral manifest in de ecomomisch-functionele sectorem, vraagt om invulling. Zie overwegingen $\$$.J. Oostenbrink, De actuele betekenis wan de trias politica, in: P.B. Cliteur en M. R. Rutgers, ta. .p. "pp.55-65; S.W. Couwenberg, t.a.p., p. 124-125. 
gedecentraliseerd. Naar private maatschappelijke organisaties. Naar lokale en provinciale overheden. En naar functionele(-regionale) bestuursorganen. De overheveling van werkballast van de rijksoverheid in enge zin naar, specifiek toezichthoudende, zelfstandige bestuursorganen krijgt in onderhavig onderzoek de volle aandacht. Functionele decentralisatie naar zelfstandige bestuursorganen wordt juist woorgesteld ter ontlasting van de departementstop. "Kernachtig te kenmerken zijn deze, in principe beleidsuitvoerende, zelfstandige bestuursorganen als overheidsorganen die niet in hiërarchische relatie tot een minister staan.

In zijn relatie tot zelfstandige bestuursorganen, hoewel die niet door hiërarchie is bepaald, staan de minister meestal marginale beïnvloedingsmechanismen ter beschikking. Belangrijke reden daarvoor is dat zelfstandige bestuursorganen zich, naast uitvoering, toch vaak met beleidsbepaling inlaten. ${ }^{5}$ Hoe ver de formele afstand tussen minister en zelfstandige bestuursorganen wordt aangetast door het feitelijk verkeer tussen beiden is een apart aandachtsgebied. ${ }^{6}$

Al met al is, in het algemene bestuurlijke kader, het ontbreken van politieke verantwoordelijkheid evident. Een oplossing wordt gezocht in het doorschuiven van stukjes verantwoordelijkheid naar zelfstandige eenheden. Of die oplossing adequaat is?

In elk geval gelden, bij het zoeken naar een optimale verantwoordelijkheidsverdeling, drie maatstaven: democratie, kwaliteit en economie. ${ }^{7}$ Het eerste criterium is ver uit dominant.

Denk hierbij aan de betekenis van de ministeriële verantwoordelijkheid voor het realiseren van de democratische greep van het parlement op het bestuur. In dit licht is de fundamentele betekenis van ministeriële verantwoordelijkheid, dat "de totale bestuurlijke organisatie in de hand wordt gehouden en wordt zorggedragen voor een adequate behartiging van het algemeen belang". "Bij een falend ministerieel verantwoordingsproces schreeuwt de vraag naar democratische legitimatie van overheidsoptreden om alternatieve antwoorden. In plaats van de, gebrekkig werkende, ministeriële verantwoordelijkheid wordt ruimte gemaakt voor, gedeeltelijk aanvullende, beleidscontrole: participatie van burgers, benoeming van een raad van toezicht of een raad van bestuur, openheid van structuur, openbaarheid, ombuds- en klachtinstanties, algemene rekenkamercontrole en rechtszekerheid. ${ }^{9}$ Ook, anders dan de klassieke weg wan ministeriële politieke verant-

4. In het bijzonder pleidooi van M. Scheltema, Zelfstandige bestuursarganen, oratie, Groningen, $1974 ;$ M. Schelitema, Raden en commissies als zelfstandige bestuursorganen, in: Adviseren aan de owerheid", WRRstudie V5, 1977, pp.334-338.

5. Zie over het onbruikbare onderscheid beleidsvorming en -uitvoering paragraaf 3.4.3.

6. J.L. Boxum, Zelfstandige bestuursorganen op maat, in: Bestuur, nr.4, 1990, pp.101-111; J.M. M. Polman, Zelfstandige bestuursorgaan: actueel fenomeen in polatiek en bestuar, in: Bestumr nr.9, 1988, pp.202-206.

7. J.Th.J van dern Berg, t.a.p., p. 191.

8. A.M. Donner, Veranwoording. redactionele kawttekeningen, in: Rechtsgeleerd Magazijn Themis, 1987 , pp. $365-366$.

9. Vgl. criteria woor democratie van de WRR, De organisatie voor het openbaar bestuur, 's-Grav., 1975. p.114; Raadpleeg voor aanvulling hierop paragraaf 3.5; Zie ook uitwoerig H.G. Lubberdink, a.w., pp. 125142. 
woordelijkheid, zijn vervangende of complementaire verantwoordingspatronen te construeren via ver ontwikkelde, juridisch afdwingbare, vormen van kwaliteitsborging. Daarbij spelen "principia van intercollegiale toetsing, self-assessment, peer-review, creatie van performance of certificering " een bepalende rol. ${ }^{10}$ Aldus ontstaan moderne democratielagen. "I

Als gezegd is de, in eerste instantie als aanwullend bedoelde, rechterlijke controle een equivalent van politieke controle. ${ }^{12}$ De relevantie van rechtsbescherming is duidelijk. De in de Verenigde Staten opgedane praktijk met regelgevende zelfstandige bestuursorganen leert het volgende. "Op de eerste plaats verschaft de rechterlijke controle democratische legitimatie, in het geval dat de alles dekkende politieke controle wegvalt." "13 Rechtsbescherming op zich is trouwens niet strijdig met het beginsel van ministeriële verantwoordelijkheid. ${ }^{14}$

Benadrukt wordt, dat het belangrijk is beide vormen van verantwoordelijkheid te onderscheiden. Juridische en politieke verantwoordelijkheid verschillen namelijk qua sfeer, fora en criteria of inhoudelijke gronden. $\mathrm{Zij}$ verhouden zich weliswaar als broers en zussen. Maar niet als leden van een identieke tweeling. ${ }^{\text {is }}$

Dat tegenwoordig toch meer de nadruk moet gaan liggen op hun verwantschap doet een plausibel pleidooi ${ }^{16}$ voor publieke verantwoordelijkheid voor rechtspraak vermoeden. Beide verantwoordelijkheden krijgen in het openbaar gestalte. Zowel politieke gezagsdragers als rechters moeten stelselmatig werken en een zorgvuldigheidsnorm bewaken die voor burgers enigszins voorspelbaar en betrouwbaar is. En, of iemand nu belast is met publieke of politieke verantwoordelijkheid, het zegt weinig over de mate van sturing die kan of behoort te worden uitgeoefend. Bedoeld betoog plaatst de publieke verantwoordelijkheid voor rechtspraak, dat is "van al degenen die met rechtspraak te maken hebben het vertrouwen wekken (en dus het rechterlijk gezag ondersteunen) in een gehandhaafd kwaliteitsniveau van de diensten van gerechtsorganisaties door in het openbaar inzichtelijk te maken hoe deze organisaties en rechters hun werk doen" - binnen de meer

10. R.J. in "t Veld in zijn (syllabus) bijlage voor thet congres Verzelfstandigen bij de rijksowerheid, voortgang of woorwitgang, georganiseerd door het NSC en stiching MC, ie 's-Gravenhage, d.d. 30 now. 1993, pp. 1 6. i.h.b. p.5.

11. P.H.A. Frissen in zijn woordracht voor het congres Verzelfstandigen toij de rijksoverheid, woortgang of wooruitgang, georganiseerd door het NSC en stichting MC, te "s-Crawentage, d.d. 30 now. 1993.

12. H.G. Lubberdink, a.w., p.15; H.R. van Gunsteren, Zbo's en het wraggstak wan politieke en bestumalijhe verantwoordelijheid, in: Studiemiddag Zbo"s, d.d. 12 novenaber 1985 , WRR-serie woorstudies en achtergrondem V54, 's-Grav., 1986, p.38.

13. H.J. de Ru, Algemene disciastie, in: Studievniddag zelfstandige bestwursorganen, tu. p., p. 52 .

14. H.G. Lubbendink, a.w., p.141; Anders A. Mulder, Zelfstandige bestuarsdiensten in Nederland, Zwolle. 1980, p. 75 .

15. M.A.P. Bovens, De velwormigheid van verantwoordelijhtheid, in. M.A.P. Bovens, C.I.M. Schuyt, W. J. Witteveen en Th, H.M de Beer, a.w, pp.17-41. Overigens wat Bovens verantwoordelijkheid op in de zin wan (passieve) aansprakelijkheid. Dus niet als oorzak, vermogen, tak of, de door hem bedachte actieve worm, deugd.

16. Zie interessant P.M. Langbroek, De publiek verantwoordelikheid voor rechtspraak, in: Trema, nr.11, 1994, pp.405-413. 
omvattende politieke ministeriële verantwoordelijkheid. ${ }^{17}$ De aandacht voor deze publieke verantwoordlelijkheid ontstaat door het toegenomen maatschappelijk gewicht van de (bestuurs)rechtspraak. Steeds vaker wordt de mening van een rechter gevraagdover gedragingen van bestuursorganen of regelgevers. Aandacht voor een doelmatige recht spraak op een redelijk kwalitatief niveau kan conflicten tussen de politieke ministeriêle verantwoordelijkheid voor het beheer van gerechten en de eigen verantwoordelijkheid van rechters voor de produktie en inhoud van hun uitspraken voorkomen.

Allereerst de betekenis of essentie wan de algemene politieke verantwoordelijkheid. Voor alle duidelijkheid het volgende. Slechts de politieke ministeriële verantwoordelijkheid is uitgangspunt. Zij vloeit voort uit art. 42 Grondwet.

Hiernaast bestaan andersoortige verantwoordelijkheden van bewindspersonen. Te weten, ten eerste, de civielrechtelijke verantwoordelijkheid ex art. 1, boek 2 Burgerlijk Wetboek, theoretisch in connectie te brengen met art. 36 Wet op de ministeriële verantwoordelijkheid. Ten tweede bestaat de, aan contraseign gekoppelde, strafrechtelijke verantwoordelijkheid in gevolge art. 18 Wet op de ministeriële verantwoordelijkheid juncto art. 119 Grondwet juncto art. 47 Grondwet junctis artt. $355,356,363$ WvSr en art. 483 WvSv. ${ }^{18}$ Deze verantwoordelijkheid is tot nog toe een dode letter. ${ }^{19}$ Ten derde is de comptabele of financiële verantwoordelijkheid ex art. 105, derde lid, Grondwet bekend. ${ }^{20}$ Deze verantwoordelijkheden blijven buiten beschouwing.

\section{$\S 3.1$ Functie politieke controle}

"Niemand kan een bevoegdheid vitoefenen zonder verantwoording schuldig te zijn of zonder dat op die uitoefening controle bestaat. "21 Kennelijk is de politieke ministeriële verantwoordelijkheid meer dan important. $\mathrm{Zij}$ is noodzaak. Haar functies verschaffen haar dit 'bijna onmisbaar' etiket. Parlementaire controle dient het volgende. ${ }^{22}$ Ten eerste heeft zij cognitieve betekenis. Dat wil zeggen controle levert resultaten voor toekomstig beleid. Door voortdurende beleidsterugkoppeling wordt zij zelfreferentieel.

17. P.M. Langbroek, De publieke verantwoordelijkheid voor rechtspraak, ìn: Trema, nr. 11, 1994, pp.405413 , i.h.b. p.408.

18. Specifiek S.N. Vlaar, De strafrechtelijke ministeriële weranwwoordelijkheid, Enkele aspecten envan, in het bijzowder met betrekking tot de laatste grondwetherziening, in: TwO, nr. 14, 1985, pp.287-293.

19. A.D. Belinfante en J.L. de Reede, Beginselen van het Nederlands staatsrecht, twalfifle druk, Alphen aan den Rija, 1994, pp.87-88; M.C. Burkens, H. R.B.M. Kummeling en B.P. Vermeulen, a.w., p.187; C. W. van der Pot en A.M. Donner ${ }_{x}$ a.w. , p.394; D.J Elzinga, De strafrechrelike ministeriele verantwoordelijkheid, in: D.J. Elzinga (red.), De minusteriele werantwoordely'k heid in Nederland, Zwolle, 1994, pp.65-78. betoogt weliswair dat, het "feit dat de procedure (wan de strafrechtelijke ministeriële werantwoordelijkheid - JGLvN) nog nooit is toegepast, niet de argumentatie kan dragen om de regeling af te schaffen ${ }^{\text {th }}$.

20. C.A.J.M. Kortmann, a.W., p.298; Hitrover ook H.G. Warmelink, De geldelike ministeriele verantwoordelijkheid, in: D.J. Elzinga (red.), Ministerïle verantwoordelijkheüd in Nederland, Zwolle, 1994 , pp. 79-90.

21. A.D. Belinfante en J.L. de Reede, a.w., p.24. Het geciteerde uitgangspunt laat de vormgeving wan controle open.

22. W. Beck, Parlementaire controle: ritued of besturingsinstrumert?; Een anolyse van verhoudingem. wisselwerkingex en mechamismen in her politieke proces, Assen/Maastricht, $1987, \mathrm{pp}, 15-19$. 
Evaluatieve controle betekent meer relevante informatie, meer rationaliteit bij het opzetten van beleids(uit)voering en meer ervaring/kennis via falsificatie. Ten tweede is voor noemd voordeel nauw verweven met de, inmiddels van waarde gebleken, legitimatiefunctie. Voor alle bestuursgedragingen, voort vloeiende uit de bevoegdheden die een minister namens zijn ambt heeft, is hij gehouden verantwoording af te leggen aan een democratisch samengesteld orgaan, met andere woorden de volksvertegenwoordiging. In dit verband is gesproken van de "gehoudendheid van de minister om van datgene wat voor zijn rekening komt aan het parlement verantwoording af te leggen.". Hierbij zijn verantwoorden (dat is het inlichten, toelichten en antwoorden) en rekening (in de zin dat de minister zelf verklaart òf dat het parlement de minister aanzegt een of ander voor zijn rekening te nemen) onderscheiden. ${ }^{23}$ Hierop luidt de terechte kritiek dat het terminologisch juister is "om voor verantwoorden antwoorden te lezen en voor rekening verantwoording" ${ }^{24}$ of rekenschap ${ }^{25}$. En ten derde dient controle de continuatie en stabilisatie van het politiek bestel. Anders uitgedrukt, zij bezit een sociaal-integratieve waarde. In havar huidige betekenis vormt de ministeriële verantwoordelijkheid "de staatsrechtelijke basis voor de verwezenlijking van het beginsel van democratische controle op het gehele openbare bestuur - regering en bureaucratie beide". ${ }^{26}$

\section{§ 3.2 Ministeriële verantwoordelijkheid door een staatsrechtelijke bril}

Volgens art. 42, tweede lid, Grondwet wordt de regering gevormd door Koning en ministers. De Koning is onschendbaar. De ministers zijn verantwoordelijk voor overheidshandelen of -nalaten. Die verantwoordelijkheidsrelatie tussen ministers en parlement is viervoudig. ${ }^{27}$ Aansprakelijkheid bestaat voor: a. het optreden van de Kroon en de

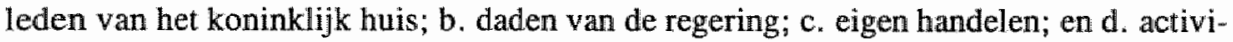
teiten van aan de minister ondergeschikte ambtenaren.

Middels de eis van het ministerieel contra-seign voor koninklijke besluiten krijgt de ministeriele verantwoordelijkheid voor het optreden van de Kroon gestalte. Overigens geldt die eis niet voor alle activiteiten wan de Kroon. Verantwoordelijkheid voor het handelen van andere leden van de Kroon, anders gezegd het koninklijk huis, dan het

23. H.G. Lubberdink, a.w., P.13; H.Th.J.F. wan Maarseveen, Ministerïle verantwoordelijkheid en OM na 1976, in: NJB, 1977, p. 209.

24. F.A.M. Stroink, a.w., p.138; L.J.A. Damen, Ongeregeld en ondoorzichtig bestuur, diss. RUG. Deventer, 1987, p. 598 .

25. Th.C. de Grat, Ambtenaar, minister en volksvertegenwoordiging, in: B.F. de Jong , C.A.J.M. Kortmann en H.R.B.M. Kummeling (red.), Nijmeegs staatsrech; Bundel opstelien aungeboden aan mr H.J.M. Beekman, Nijmegen, 1987, p.37.

26. Commissie-Scheltema, Steekhoudend ministerschap; Betekenis en taepassing van de ministeriêle verantwoordelijkheid, TK 1992-1993, 21427, nr.31, p.7.

27. Cie-Scheltema, a.w., pp.9-12: Vgl. D.J. Elzinga, Politieke verantwordelijkheid, Over verval en voorsitgang in de politieke democratie, in: M.A.P. Bovens, C.J.M. Schuijt, W.J. Witteveen en Th.H.M. de Beer (red.), a.w., p.70; D.J. Elzinga, De staat wan het rechi; Opstellen over staatsrecht en politiek, Zwolle, 1990 , p.81; D.J. Elzinga, De politieke ministeriële verantwoordelikkheid, in: D.J. Elzinga (red.), De ministeriêle verantwoordelijkheid in Nederkand, Zwolle, 1994, pp.31-49. 
staatshoofd bestaat slechts voor zover dit het openbaar belang ${ }^{28}$ aangaat. ${ }^{29}$ Deze leden van het koninklijk huis zijn weliswaar niet onschendbaar. Maar als hun gedragingen het openbaar belang raken, kan sprake zijn van een "afgeleide ministeriële verantwoordelijkheid". ${ }^{30}$

De verantwoordelijkheid voor daden van de regering vindt haar basis in art. 45 Grondwet junctis artt. 4, 5 en 11 Reglement van orde voor de raad van de ministers. Deze gezamenlijke verantwoordelijkheid geldt ook voor de ministerraad in Europees verband. ${ }^{3 / 4}$

28. J.P. Rehwinkel, Ministeriële verantwoordelikheid voor het Koninklijk Huis, in: D.J. Elzingat (red.). Ministeriele weranwoordelykheid in Nederland, Zwolle, 1994, pp.91-101, geefi terecht aan dat het eigen domein wan het statshoofd moeilijk is af te grenzen van dat openbaar belang. Owerigens verwacht anteur niet alleen van de minister-president, maar ook van het complete kabinet (alle ministers zijn aanspreekbaar!) actieve betrokkenheid bij het kominklijk opireden.

29. Frappant voorbeeld is het volgende. Medio januari 1995 raaki de Nederlandse kroonprins Willem-Ale Xamder, op weg naar een wintersportbestemming in het buitenlamd, met een door hem zelf besturde auta betrokken bij een aanrijding op een snelweg. Enige jaren woor dit ongeluk makt hij, ook als bestuurder'. brokken met een auto. Desgev raagd antwoondr minister-president Kak dat de ministeriele verantwoordelijkheid voor dit lid wan het koninklijk huis niet zo ver reikt, dat het kabinet de kroonprins voortaan wil zien in dienstauto met chauffeur. Kennelijk heeft de prins hier een eigen vrijheid en eigen verantwoordielijkheid. Nu het hier een wel zeer bijzonder lid van het koninklijk huis betreft, is het de vraag of hier niet een te grote vrijheid wordt gegeven. K. van der Malen, Premier Kok royaat voor de kroonprins, in: $\mathrm{NRC}_{w}$ 23 jan. 1995, p.2; Met in het achterhoofd nog de consternatie over de opmerking van de kroonprins over de 5-mei-viering als mede over de (mogelijke) partnerkeuze wan de prins meent I Sewandono, Toenemende ministeriele verantwoordelijkheid voor de Prins wan Oranje, in: NJB, nr.12, 24 maart 1995, pp.457459, dat "maarmate de opvolging van het huidige staatshoofd naderbij komt, de ministeriële verantwoordelijkheid voor de gedragingen van de Prins van Oranje toeneemt. Zo langzamerhand moet zij zelfs reeds. nu als nagenoeg volledig worden aangemerkt". Volgens auteu $r$ kan "in ieder geval de minister-president" worden aangesproken voor gedragingen wan kroonprins Willem-Alexander omdat hij nu een maal een prins is met "een zeer reële troonswerwachting".

30. C.A.J.M. Kortmann en P.P.T Bovend'eert, Inleiding constihutioneel recht "Deventer, 1993, p.35; Strenger is de regering die beperking van m. v. -voor andere leden van het koninklijk huis dan de Kroonuitsluit, TK 1993-1994, 21427, nr.60.

31. R.K. Visser, Ministeriele werantwoordelikhetd ma Maastricht, in: NRC, 21 okt. 1994, nr. 37, pp. 12711273, betoogt dat een minister die in Bnussel ondenwerpen bespreekt waarvoor geen parlementaire controle op Europees niweau bestaat, in zijn nationaal pallement verantwoording voor zijn optreden schuldig is. Dit zou er toe moeten leiden dat de gezamenlijke ninisters uit een lidstaat wooraf, dus voor het optreden van de minister die aan de Europese beraadsilagingen ter zake deelneemt, tot afspraken komen. Overigens brengt, volgens Visser, mationale parlementaire controlle yoor Europese aangelegenheden (als alternatief voor de vrij wel afwezige aandacht en controle van uit het Europees Parlement) weinig heil. De controle is, $x . i_{\text {, }}$ onvolledig en komt bijna nooit neer op het afleggen van verantwoording in staatsrechtelijke zin; Ook H.G. Hoogers en N.Y. Del Grosso, De ministeriële verantwoordelijkheid wor het buitentands beleid, in: D.J. Elzinga (red.), Ministeriële verantwoordelijkheid in Nederland. Zwolle, 1994, pp. 187-209, i. h.b. p. 202, concluderen cornect tot ministeriéle verantwoordelijkheid, in het Nederlandse staatsrechtelijke stelsel, voor het door Nederland gevoerde en te woeren communautaire beleid (dit impliceert, gelet op art. 5 EG-verdrag, dat de minister aanspreekbaar is voor gedragingen van zbo's voor zover ze communautaire regelgev"ng uitwoeren; een maal deze verantwoordelijkheid verondersteld, is duidelijk dat de minister op genoemd gebied invloed op het zbo moet kunnen hebben). Wel geven ziji aan dat activering van de ministeriële verantwoondelijkheid aanmerkelijk verbetert door het bestaan

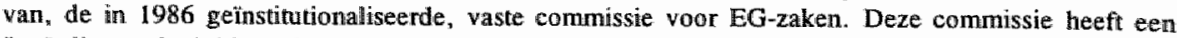
"coördinenende, initiërende en stimulerende rol ten aanzien van de controle op het communautaire beleird en de commumautaire dimensie voor het Nederlandse regeringsbeleid" (p.207). 
Het parlementair stelsel raakt, in toenemende mate, geconfronteerd met deze collectieve ministeriële verantwoordelijkheid. ${ }^{32}$ De collectieve verantwoordelijkheid manifesteert zich wooral in de jaarlijkse algemene, politieke beschouwingen na de troonrede, het optreden van de minister-president ${ }^{33}$ en de kabinetskwestie ${ }^{34} .{ }^{35}$ In het bijzonder de, met het oog op een effectieve rijksdienst, bepleitte transparantie van de overheidsorganisatie wordt bereikt door "de collegiale verantwoordelijkheid dienstbaar te doen zijn aan de functie van de ministerraad, inhoudende de beraadslaging en besluitvorming over het algemene regeringsbeleid. Anders gezegd, de individuele verantwoordelijkheid behoort een functie te zijn van de collectieve verantwoordelijkheid, die zich manifesteert in het orgaan van de ministerraad" ${ }^{36} .{ }^{37}$

Verantwoordelijkheid voor eigen ministerieel gedrag omvat zowel persoonlijke als functionele aspecten. Deze verantwoordelijkheid laat het parlement de mogelijkheid, zowel over reeds gedane zaken als over toekomstige besluiten, zekere zeggenschap te hebben. Die opvatting staat haaks op de oude continentale Franse visie op controle. Daarin regeert de regering. En het parlement controleert (achteraf).

Eerst genoemde gedachte beheerst de ruimere Angelsaksische opvatting. Controle omvat dam "beheersen, (be)sturen of toezicht uitoefenen, weellal aangeduid als meeregeren. Hiermee worden het parlement invloed en sturingsmogelijkheden ten opzichte van de regering toegekend in alle fasen van het beleidsproces"'. ${ }^{3 *}$ Daaronder zijn dus zowel controle vooraf als controle achteraf begrepen. Hiervoor zijn termen als respectievelijk prospectieve en retrospectieve parlementaire controle gebruikelijk. ${ }^{39}$

32. L.J.A. Damen, a.x", pp $585-589$

33. Wat betreft de, tijdens het RSV-debat prominent/crucial geworden, rol $v$ d minister-president en twijfels rondon solidaire orgaanweramtwoordelijkheid $v$.d. minusterrad J.P. Reliwinkel, Begrip minisrerielle verantwoordelijhleid nog steeds niet helder, in: Namens, nr.9, 1990, pp. 24-29; J.P. Rellwinkell, De ministerpresident en de commissie-Deetman, in: J.P. Rehwinkel, P. P.T. Bovend'eert en R.J. Hoekstra. De posifie wan de misister president, publikatie Staatsrechtkring nr.8. Zwolle, 1994, pp.1-21; A.H.M. Dölle en J. W. M. Engels, De affaire-Brinkman; Symptoom wan de ringende ster van het ambo wan ministerpresiden, in: TvO, nr. 19, 1984, pp. $411-416$.

34. Zie J.J. Vis, De mwisteriele veranwoordelijkheid en kabinetsformatie, in: D.J. Elzingat (red.), Ministeriete verantwoordelijkheid in Nederland, Zwolle, 1994, pp.177-185.

35. P.P.T. Bowend'eent, Regeerakkoorden en regeringsprogramma 's, "s-Gravenhage, 1988, pp.125-134.

36. Stelling 4 van R.J. Hoekstra in zijn (syllabus) bijdrage aan het congres Verzelfstandigen buj de overheid, voorgang of vooruitgang, georganiseerd door het $\mathrm{NSC}$ en stichtirg $\mathrm{MC}$, te 's-Cravenhage, d.d. 30 nov. 1993 .

37. I.W.M. Engels, De collectieve mixusterielle werantwoordelikheid, in: D.J. Elzinga (red.), Ministeriele verantwoordelijkheid in Nederland, Zwolle, 1994, pp.51-63, i.h.b. p.62, onderstreept juist dat de individuele politieke ministeriele verantwoordelijkheid dominant is ten opzicht van dis collectieve politieke ministeriële verantwoordelijkheid.

38. G.H. Hagelstein, De parlementaire commissies, reeks Nederlands parlementsrecht, monografie 6, diss. RUG, 1991, p.7.

39. M. E. Tuurenhout, Parlementaire conrole er ambtelijke verantwoordelijkheid, diss. RUL, 1992, Amhem, pp: $28-29$. 
De toenemende behoefte aan debatten van de volksvertegenwoordiging van te voren, met andere woorden controle vooraf heeft twee hoofdoorzaken. ${ }^{40}$

Ten eerste valt dit te wijten aan de voortdurend blijkende ineffectiviteit van de politieke ministeriële controle achteraf. Immers, wantrouwen is moeilijk aan te wijzen voor indivi duele besluiten. Meestal betreft het meer de algemene oriëntatie van het handelen en nalaten van bewindspersonen, of wel het soort beleid. Bovendien is verwezenlijking van de vertrouwensregel niet simpel. De verminderde bruikbaarheid van dit wapen hangt samen met een aantal factoren. ${ }^{41}$ Eerste oorzaak is de angst, van partijen die een meerderheidspositie in de Tweede Kamer innemen, voor zetelverlies. Tweede reden is de dubbele positie van politieke leiders. Politieke leiders zitten steeds meer in het kabinet: Derde probleem is de onmogelijkheid campagne te voeren met een heen gestuurde minister. Vierde aspect is de toename van regeerakkoorden. Eigen beleid door regeringsfracties ondervindt belemmering. En oppositie doet nawwelijks meer mee. Kortom, de binding tussen kabinet en volkswertegenwoordiging is sterk. Vandaar staat vermijding van politieke vall voorop. Geknipoogd wordt naar het electoraat. Conclusie is: "Deze afhankelijkheid van het parlement tegenover het kabinet leidt ertoe, dat ook de effectiviteit van de parlementaire controle in sterke mate door het kabinet wordt beînvloed." 42 De leus luidt: liever regeren dan controleren.

Ten tweede is de "verschuiving in de aard van belangrijke beleidsbeslissingen" 43 van invloed. Regeringsbesluiten hebben, in verhouding tot formele wetgeving, een belangrijke positie veroverd. Eerlijkheid gebiedt hier een kanttekening. Niet zo zeer de aard van beleidsbeslissingen is veranderd. Veeleer is het patroon van besluitnemers verschoven. Het is illusoir te denken, dat alleen nog de wetgever alle wettelijke regels vaststelt. Tegenwoordig zijn Nederlandse legislatieve en executieve soms sterk geliëerd. De trias politica blijkt gedateerd. In haar hedendaagse interpretatie klinkt een duo-politica door. In dit eigentijdse "diademodel" is sprake van concurrente besluitvorming tussen het democratisch bestuur, d.w.z. regering en parlement, en de rechter. ${ }^{44}$ Kortom, er is "niet zo zeer meer sprake van een trias, maar van een duas". 45

Kortom, voor het bijtijds beïnloeden en bijstellen van beleid, wat toch het uiteindelijke doel van controle moet zijn, biedt controle vooraf de meeste garantie.

En, ten slotte, verantwoordelijkheid voor het ambtelijk doen en laten wordt begrensd door formele bevoegdheden die de minister heeft. Controle op aan de minister onder-

40. M. Scheltema en H.G. Lubberdink, Ministeriêle verantwoordelijkheid ex parlementaire comtrole, in: Parlementaire controle en democratie in de verzorgingsstaat, serie staats- en bestuursrecht, Staatsrechtcongres, Utrecht, 1980, pp.2-5.

41. H. Engels, Verirowwensbeginsel of genegenheidsbeginsel, im: PD, nr.2, 1988, pp.38-45, i. . b. p. p. 42 .
42. H. Engels, t.a.p., p.43.

43. M. Scheltema en H.G. Lubiberdink, t.a.p., p.4.

44. A.F.M. Brenninkmeijer, De plaats van de rechter in onze constitutionele rechtsorde, in: De rechter als dictator, Lochem, 1987, pp.60-61; N.S.J. Koeman, Over beleid en controle; Op zoek naar een opvolger wan de triasleer, in: NTB, nr. 3,1989, p. 73 e.v. Kaeman geeft 9 criteria alan de hand waarvan volkswer-
tegemwoordiging en rechter de beleidsmaker controleren.

45. F A M Stroink De plaats van de rechter in her stoleren. p. 72 . 
geschikte ambtenaren leidt vooral tot controle achteraf. Een niet, in de eerste plats, door hiërarchie gekenmerkte relatie tussen minister en ambtenaren komt ook voor. In dat geval is het zinvol beleidsbepalende en -uitwoerende, niet sterk beleidsbepalende, concrete beslissingen te onderscheiden. Controle vooraf is dan duidelijk een mogelijkheid. Maar alleen controle op beleid zelf. Preventieve toetsing van beleidsuitwoering is onjuist. Dit standpunt is slechts serieus te noemen, als de "hoofdlijnen van beleid duidelijk en doorzichtig zijn en dat voldoende informatie over die uitvoering wordt verstrekt". ${ }^{46}$

Het verantwoordelijkheidsmechanisme verfijnt. Verantwoordingsprocessen kennen drie componenten ${ }^{47}$ : a. informatieverstrekking; b. debatfase; en c. sanctionering.

\subsubsection{INFORMATIEVE FASE}

Verantwoording afleggen kan niet zonder inlichtingenfase.

Ex art. 68 Grondwet geven de ministers aan het parlement alle verlangde inlichtingen. Het verstrekken daarvan mag niet strijdig zijn met het belang van de staat. Evidente staatsbelangen zijn: veiligheid van de staat en zijn bondgenoten; belangen van de buitenlandse politiek: (minder duidelijk) persoonlijke levenssfeer of zo genaamde natuurlijke belemmeringen; en, achter elkaar, de eenheid van de Kroon, de betrekkingen van Nederland met andere landen en de economische en financiële belangen van de staat ex art. 4 WOB. ${ }^{48}$ Het beroep op deze verschoningsgronden verdient uitdrukkelijk motivering. Naast deze grondwettelijke beperking aan het inlichtingenrecht, zijn andere, ten aanzien van behandeling van wetsvoorstellen vermoedelijk belangrijkere, begrenzingen aan het inlichtingenrecht te stellen: inlichtingen hoeven niet direct, of onmiddellijk, te worden verstrekt (tijdelijk of voorlopig weigeren is mogelijk); inlichtingen waarover het niet beschikken of niet redelijkerwijs kunnen beschikken over inlichtingen en ook het eventueel verschaffen van inlichtingen waarvoor onevenredige inspanning van betrokkene wordt vereist, kunnen gerechtvaardigde belemmeringen opleveren (feitelijke onmogelijkheid tot inlichtingenverstrekking); het verstrekken van inlichtingen kan door het reglement wan orde van de Tweede Kamer aan banden worden gelegd (regulering van informatiever-

46. L.J.A. Damen, a.w., pp.580-582.

47. D.J. Elzinga (1989), t.a.p., p.70; D.J. Elänga (1990), a, , p.81, D.J. Elzinga en H. O. Warmelink, Het Nederlandse parlemevtaire stelsel. A cahiers stats-en bestuurstecht, deel 3, Nijmegen "1993, p $3.44-45$.

48. L.J.A. Damen, a.w., pp.619-626; L.J.A. Damen, Individueel inlichingenrecht van kamerleden. een veitigg bezit?, in NJB, 1987, p.935; L.J.A. Damen, Het individwele inlichtingenrecht van kamerleden. nog geen veilig bezit: Recente parliprudentie ower her inlichingenrecht, in: A. W. Heringa c.a., Verhaten over de grondwet. 's-Gravenhage, 1993, pp 72-78; Art: 68 Gw moet voor witzonderimgusgevallen worden gereserveerd. Aldus R.C. Hessing an P.J. Langenberg, Politik -awbtelihke betrekkingen in ren nieuw perspectief?, in: B\&M, 1983, nr.11, pp.306-313, i.h.b. p.313; Over oordeel rectiter ter zake A.A.L. Beers, Grondwettelijk inlichtingenreckt afidwingbaar bij Arob-rechter?, in. Hirsch Ballin-bundel, Rechr doen can wetgewing, Zwolle, 1992, pp.377-389, en Art.68 en art. 69, in: P. W.C. Akkermans en A.K. Koekkouk, De Grondwet, tweede druk, Zwolle, pp.654-666. Kritiek darop van C. Waaldijlk, Moriveringuplichten

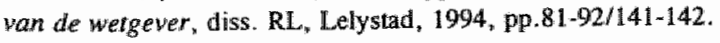


strekking); en naleving van art. $68 \mathrm{Gw}$ is verre van eenvoudig af te dwingen (politieke beïnvloeding van informatieverstrekking). ${ }^{49}$

Ongevraagd verschaffen de ministers informatie die nodig is ter controle van hun handelen. In het RSV-debat komt naar voren dat deze informatie pur feitelijk van aard moet zijn. ${ }^{50}$ Dit standpunt lijkt niet logisch. Ook opinies en waardeoordelen kunnen politiek relevant zijn. Bovendien is het scheiden van feit en mening moeilijk.

De normale wijze om de ministeriële verantwoordelijkheid te activeren, is het stellen wan vragen. Ministeriëlle verantwoordelijkheid veronderstelt een ministeriële antwoordplicht: De onderscheiding, voor wat betreft het handelen van niet aan de minister ondergeschikte zelfstandige besturen, tussen "de plicht vragen te beantwoorden, welke het hele functioneren van een zelfstandig bestuursorgaan kan omvatten, en de ministeriële verantwoordelijkheid die zich slechts uitstrekt tot zover als de bevoegdheden van de minister reiken", boet daarmee aan zin en waarde in. ${ }^{51}$ Immers, "de omvang van de ministeriële antwoordplicht wordt even zeer door de omvang van de bevoegdheden van de minister bepaald als de ministeriële verantwoordelijkheid in ruime zin". ${ }^{52}$ Bovendien is een "scherpe scheiding tussen de inlichtingenplicht, als een neutrale activiteit, en de verantwoordingsplicht wel denkbaar. Maar in de parlementaire praktijk is zij moeilijk hanteerbaar." 53

Naast deze reguliere verschijningsvorm neemt de inlichtingenplicht andere vormen aan. Mede dank zij de gunstige doorwerking van de openbaarheidsregels hebben het interpellatierecht ex art. 120 RvO Tweede Kamer, het vragenrecht ex art. 121 Reglement van

49. Zie C. Waaldijk, Moriveringsplichten van de wetgever, diss. RL, Lelystad, 1994, pp.81-92. Auteur ziet de inlichtingenplicht niet enkel in het licht wan de min histeriële verantwoordelijkheid. Uit de wetgeving seis wan "gemeen overleg", waardoor het parlement de wetgevende taak adequaat kan uitoefenen, vloeit woort dat de wetgever ook informatie nodig heeft aangaande zaken "waarvoor nog geen minister verantwoondelijk is" (p.82). Juist daar waar de ministeriële verantwoordellijkheid voor zelfstandige besturursorganen te wensen over laat, is dus toch - ju het kader wan wetgeving en beleidsbepaling - een beroep te doen op de inllichtingenplïcht.

50. Handelingen TK 1984-1985, pp.3883-3890.

51. Rbb, Adnies over functionele decentralisatie, 's-Grav., sept 1988, p.4; preadvies J.B. J.M. ten Berge en F.A.M. Stroink, Functionele decentratisatie uit de schaduw" Een globale verkenning van aard, omwang. verschijningswormen en bestuurlijke aspecten vam zbo 's en anderefinctionele orgamisatie-eenheden binnen Aet openbaar bestuur, 's-Graw, juni 1988, p.62.

52. H.G. Lubberdink, Kronieken bestuurlijke organisatie, in: NTB, nr.3, 1989, p.83.

53. L.I.A. Damen, a.w. " p.612; Vgl. P.J. Langenberg, Ambtelijke aanspreekbaarheid; Aanvulling op de tanende ministeriele verantwoondelijkheid, in: Bestuur, nr.3, 1988, p. 66 . 
orde van de Tweede Kamer ${ }^{54}$ en het parlementair onderzoeks-, begrotings- ${ }^{\text {ss }}$ en enquêterecht ${ }^{56}$ zich ontwikkeld. ${ }^{57}$

In verband met de vraag of bepaall beleid succesvol is, is het referendum weer actueel. Het referendum verschaft niet direct inhoudelijke inlichtingen over beleidsvoering $M a a r$ de uïtkomst van een referendum kan zijn, dat burgers geen consent geven aan bepaald beleid. Dit is mogelijk een indicatie voor mislukt beleid. Omgekeerd zijn referenda mogelijk zinvol in het stadium voorafgaand aan wet- en regelgeving. Aansluitiend bij de ontwikkeling, "die het parlement tot toezichthouder van de regering heeft gemaakt", dienen referenda daar, waar zij de aan wetgeving vooraf gaande "elementaire vragen naar noodzaak, acceptatie en vitvoerbaarheid accentueren" , mogelijk de creatie van een nieuw evenwicht tussen taken en bevoegdheden van regering en Staten-Generaal. ${ }^{58}$

Aldus verdient misschien zelfs het referendum stimulans. De deur, richting referendum, is door de CDA-fractie op een kier gezet. In het kader van de studie naar staats- en bestuursrechtelijke vernieuwingen, krijgt de commissie $\propto$ De Koning een extra taakopdracht ter zake. ${ }^{59}$ Een meerderheid van de commissie besluit, uiteindelijk, tot invoering van een centraal (en mogelijk decentraal) correctief wetgevingsreferendum. ${ }^{60}$ De mogelijkheid van een correctief bindend referendum, op zowel landelijk als lokaal niveau, is volgens de commissie niet in strijd met het beginsel van de representatieve democratie. De commissie-Koning acht bedoeld teferendum juist "daarop een nuttige aanvulling in

54. Over interpellatie- en individueel vragenrecht $G$. Visscher, Ministeriële veramioordelihheid en parlementair inlichtingennech, in: D.J. Elzinga (red.), Ministeriële werannwoordelikheid in. Nederiland. Z wolle, 1994, pp. $237-256$.

55. Uitvoerig H.G. Warmelink, Parlement en begroting, serie Nederlands parlementsrecht nt.9, diss. RUG, Groningen, 1993; Ook E... Janse de Jonge, Fet budgerrechr, Deventer, 1993. Auteur bepleit aanscherping van het budgetrecht. De Tweede Kamer moet zich wapenen met een eigen begrotingsbureau, een algemene begrotingsmotie, en jaarlijkse hoorzittingen.

56. Het wettelijk régime van de patementaire enquête was átanvankelijk n.v.t. op mỉnisters. Deze uitzondering is echter in 1977 geschrapt. A.H.M. Döllw, Het recht var parlementaire enquête, serie Nederlands parlementsrecht, monografie 3, Groningen, 1985, pp.76-82; Ook G. H. Hagelstein, 6., p. 302; Zie voor aanpassing, in de zim van verruiming t.a. . het besprokene in de ministerrad Initiatiefvoorstel tot wiziging van de Wet op de parlementaire enquête, Hand. TK, 19816, 11 sept. 1990, pp.5099-51 10, Als aangenomen in TK 1992-1993, 22400, nr.9; Het enquetemiddel wint aan gezag. Aldus de overgrote meerderheid van de Tweede Kamerleden. Dit blijkt uit een, in 1990 naar opvattingen leden van de Eerste/Tweede Kamer verricht, onderzoek. Hierover K. van der Malen, Kamerleden grumen van chaos, in.: NRC, 1 dec. 1992, p. 3.

57. In owerzicht H.M. Franssen (red.), Het parlement in akiie; Bewegdheden wan de Staten-Generaal, Assen/Maastricht, 1986 ; Zie ook J.A. van Schagen, De Tweede Kamer der Staten-Generaal; Een staatsrechtelijke studie over haar organisatie en werkwhize, diss. RUU, Zwolle/Utrecht, 1994, pp. 197-295.

58. D.J. Elzinga en H.G. Warmelink, a.w...p.31.

59. P. Nieuwenhuijsen, Hoera woor het referendum! Marar niet als 't radplegend is, dat is cen lapmiddet. voor het correctief referendum is weel te zeggen, in: $\mathrm{BB}, 23$ okt. 1992, pp.28-31; Ook Referendum alsmog toegevoegd aan taken commissie-Deetman; CDA gedoogt nu wel nodere studie, in: BB, 23 okt. 1992, p. 12 .

60. Landelijk referendum, in: BE, ars. 31 -32, 13 aug. 1993, p. 3, NJB, 14 okt. 1993, nr. 36, p. 1290; Commissie-De Koning, Het bestel bijgesteld, TKK 1993-1994, 21427, nr.64, en Het correctief refierendwm, TK 1993-1994, 21427, nr.65; Bijval van PvdA, VVD en D"66 in hun Regeerakkoord 1994, TK 1993-1994. 23715, nr. 11, p. 24 . 
die zin dat een correctiemiddel kan worden ingezet wanneer door de werking wan het representatief stelsel een kloof tussen kiezers en gekozenen wordt gesignaleerd". ${ }^{61}$

In het verleden is slechts plaats geacht voor een beperkte, aanvullende rol voor het referendum. ${ }^{62}$ Weliswaar spreekt een staatscommissie zich uit voor een correctief referendum. ${ }^{63}$ Serieuze belangstelling voor het referendum dateert pas uit een jong verleden. De meningen variëren. De een acht het referendum een favoriet meerzijdig communicatiemiddel. ${ }^{64}$ Mogelijk leveren, overigens volgens huidig staatsrecht nog niet toegestane, facultatief beslissende referenda, waartoe kiesgerechtigden het initiatief kunnen nemen, veel profijt op. ${ }^{65}$ Gesuggereerd wordt zelfs dat het correctief referendum een plaats verdient en, wettelijk gezien, mag verdienen in de Nederlandse samenleving. Volgens anderen kan een referendum slechts een perspectief, in het bijzonder als besluitvormingsmechanisme in een direct-democratische procedure, zijn.. ${ }^{67}$ En sommigen zien referenda helemaal niet zitten. Duidelijker, dan het "fel gekant tegen" zijn, kan het niet klinken. ${ }^{68}$ Of, wat te denken van het referendum als "een speeltuin voor demagogen" ${ }^{169}$ In het algemeen bestaat bij de helft van de landelijke politici een gematigd enthousiasme ter zake. 70 "Een adviserend referendum heeft de steun van 50 procent van de Tweede Kamerleden en 54 procent van de Eerste Kamerleden. Beide kamers wijzen een volksraadpleging, waarbij de kiezer bindende uitspraken doet, bijna unaniem af." 71

Vlak voor de Tweede Kamerverkiezingen 1994 heeft D'66 het rapport van de commissieKoning aangevuld door indiening van een referendumplan, waarin een grondwets- en wetsherziening is opgenomen tot invoering van bindende referenda. Ten behoeve van het,

61. Cormissie-De Koning, Het bestel bijgesteld, TK 1992-1993/1993-1994, 21427, nirs 36-37/64, zie ook Het correctief referendum, TK 1993-1994, 21427, nr.65; Commissie-De Koning wil mogelijkheid van correctief referendum, in: NRC, 7 okt. 1993, p.3.

62. P.C. Githuis, Het referendum; Een rechtswergelifkende studie, dissertatie Rijksuniversiteit Leiden, Alphen a/d Rijn, 1981.

63. Handelingen TK 1988-1989, p.5656; Later Handelingen TK 1990-1991, pp.3609/3666.

64. J.A.G.M. van Dijk, Referendum, onderzoek, stadsgesprek en bestwurlijke wernieuwing, in: BWn, nr.5, 1.992, pp. 384-401.

65. P.C. Gilhuis, Ower de hwidige mogelijkheden van het houden van referenda in het Koninkrijk der Nederlamden, in: H.Ph.J.A.M. Mennekens e.a., Beshursechr aan de horizon, Zwolle, 1994, pp.21-34.

66. Ph. van Praag sr. (red.), Een stem verder; Het referendum in de lokale politiek, A dam, 1993. Enkelle auteurs hiervan, t.w. H. wan der Brink en I.C. wan der Vlies, betogen dat introductie van bindende referenda geen grondwetswijziging behoeft. Anders D.J. Elzinga, Hoe moet de grondwet etgenlijk worden geänterpreteend?, in: BB, nr.51-52, 24 dec. 1993, pp. $41-42$.

67. W.E. Saris, P. Neijens en J.J.M. Slot, Het eerste Amsterdamse referendum in perspectief, Amsterdan, 1992.

68. VVD'er Wiebenga n.a.v. brief cie.-Deetman, TK 1991-1992, 21427, mr.26, UCV-25 d.d. 19 nov. 1992, Pp. $1817-1818$.

69. SGP*er Van den Berg tijdens UCV -25 d. d. 19 november 1992, p.1819.

70. J.J.A. Thomassen, M.P.C.M. van Schendelen en M.L. Zielonka-Goei (red.), De geachte afgevaardigde; Hoe kamerleden denken over her Nederlands parlement, Muiderberg. 1992, pp.266-269.

71. KK. van der Malen, Kamerleden grawen wan chaos, in: NRC, 1 dec. 1992, p.3. 
in dat plan voorgestane, tijdelijk gebruik van experimentele adviserende (burger- of bestuurs)referenda, is een voorontwerp van wet opgesteld. "7

In praktijk ontstaat een beeld van "partementair onderzoek dat door kamerleden zelf of rechtstreeks onder hun verantwoordelijkheid wordt gedaan, onderzoek dat door (een commissie uit) de Tweede Kamer wordt uitbesteed, en ten slotte onderzoek dat op verzoek van de "Tweede Kamer wordit verricht door derden". ${ }^{73}$

\subsubsection{AMBTENAARLUKE AANSPREEKBAARHEID}

Tegenwoordig is de inlichtingenplicht aan discussic onderhevig. Antwoordplicht, akkoord. Maar op wiens schouders rust deze plicht tot informatieverstrekking? In eerste instantie op de voor het betrokken beleid aansprakelijke bewindspersoon. En in de tweede plaats wijzen vingers steeds vaker naar ambtenaren, die de minister bijstand verlenen. Via bij voorbeeld (quasi-)enquêtes van parlementaire commissies en verhoren van subcommissies worden ambtenaren rechtstreeks in de politieke strijd betrokken.

Twee situaties, waarin ambtenaren inlichtingen verschaffen, zijn te onderscheiden.

Ten eerste zijn er ambtenaren die werken onder werantwoordelijkheid van bepaalde ministers. Ten tweede bestaan er overheidsdienaars die niet ondergeschikt zijn aan enig minister. Hun contacten met het parlement verschillen. ${ }^{74}$

Wat betreft de, binnen 's ministers hiërarchie vallende, ambtelijke personen geldt het volgende. De minister beslist of en, zo ja, welke ambtenaar door de Eerste/Tweede Kamer mag worden gehoord. Hij is verantwoordelijk voor uitlatingen van de ambtenaar. De minister blijft de uiteindelijke verdediger van het beleid. De ambtenaar verstrekt alleen feitelijke informatie. Overigens kan de bewindspersoon aanwijzingen geven aangaande het spreken van de hem ondergeschikte. Slechts de minister, en niet het parlement, kan de ambtenaar verschijnings- en/of antwoordplicht opleggen.

Voor ambtenaren, in dienst van zelfstandige bestuursorganen, gelden bovenstaande regels niet. Formeel is geen enkele minister ten volle verantwoordelijk voor deze ambienaren. Wel moet de minister de bevoegdheid hebben informatie van zelfstandige bestuursorganen in te winnen. ${ }^{75}$ Zo geeft bij voorbeeld art. 31 (van het voorstel van) Wet tot verzelfstandiging van de Rijksdienst van het Kadaster en de Openbare Registers ${ }^{76}$ aan, dat

72. Daarover in positieve zin D.J. Elzinga, Experimemten met referenda vereisen grote zorgulligheid, in: BB3, nr.21-22, 3 juni 1994, p.37, die wan oprdeel is dat het voorontwerp "tot wet moet worden verheven".

73. P.A. Koppen, Beleid wan rijkambtenaren moet controleerbaar worden, in: Namens, ne. 11/12, 1990, pp.31-39, i.h.b. p.33; Hierover ook uitwaerig C. W. van der Pot en A. M. Donner, t.a.p., pp.570-581.

74. Cie-Scheltema, a.w., pp. 18-21: Het regeringsstandpunt (TK 1992-1993, 21427, nr.60) onderschrijft de conclusies van de cie-Schelliema. Het kabunet benadrukt well dat zij slechts de uirwisseling valn feítelijke informatie wil bevorderen.

75. Instemming van G.J. Schutte, Kerndepartementen en m.v., in: OD, ir.4. 1994, pp.2-4.

76. Organisatiewetswoarstel Kadaster, TK 1992-1993, 23007, nrs. 1-2, pp.8-9, zie ook uite ind lijke Organisatiewer Kadaster, Stbl. $1994,125$. 
het bestuur en de raad van toezicht aan de betrokken minister, met het oog op uitoefening van zijn bevoegdheden krachtens die wet of krachtens andere wetten, desgevraagd alle inlichtingen verstrekken, mogelijk in de worm van een periodieke rapportage. ${ }^{77} \mathrm{De}$ minister kan de hem aangereikte gegevens en informatic laten onderzoeken door een accountant, die toegang heeft tot lokaliteiten van als mede boeken en bescheiden van de Dienst van het Kadaster en de Openbare Registers kan inzien.

Serieus te overwegen is dat regering en parlement de bestaande mogelijkheden, van rechtstreekse contacten met uitwoerend personeel van zelfstandige bestuursorganen, op intensivering bezien.

Een zelfstandige ambtenaarlijke aanspreekbaarheid ${ }^{78}$ is omstreden. ${ }^{79}$ De voordelen er van liggen in het volgende. Ambtenaarlijke aanspreekbaarheid beoogt de ministeriële verantwoordelijkheid te versterken. Zij dient de positie van het parlement, die vollediger en sneller wordt geïnformeerd, te verbeteren. En zij moet het primaat van de politiek kracht bijzetten. ${ }^{80}$ "Belangrijke reden voor ministers om het verstrekken van (gedetail-

77. Vergelijk, woor rad van toezicht bij $\mathbb{I B G}$, art. 15 Woorstel wet verzelfstandiging en organisatie van het publiekrechtelijk zbo Informatie Beheer Groep, TK 1992-1993, 23073, nrs. 1-3, p.7, zie zelfde antikel in uiteindelijke Wet verzelfstandiging informatiseringsbank, Stbl. 1993, 714. Omgekeerd heeft de rvc, conform art. 17 IBG-wet, inzage in alle bij de minister berustende stukken, voor zover dat voor een goede vervulling van taken noodzakelijk is; Gelijke verplichting bestant voor de directie van het publiekrechtelijk zbo Dienst wegverkeer ex art. $3 \mathrm{u}$ Wetswoorstel wijziging Wegenverkeerswet 1992 houdende regeling van de verzelfstandiging voor de Rijksdienst woor het Wegverkeer, TK 1992-1993, 22961, ars. 1-2, p.6.

78. Hiervan te onderscheiden zijn pleidooien voor ambtenaarlijke verantwoordelijkheid. H.Th.J.F. van Marseveen, Reidons der nief-verantwoordelijken, in: NJB, nt.45/46, 26 dec. 1987, p.1516; M.H. Klijnsma, Politieke verantwoordelijkheid voor ambtenaren noodzakelijkheid, in: Idee "66, nr.6, 1987, pp.7-11. Daarin is de positie van ambtenaren afhankelijk van de politieke levensduur v.d. minister. Met als bezwaarlijke gevolgen dat $0 . a$. de samenstelling van de ambtemarenkolos wordt geteint in de kleur $w . d$. minister, als ook dlat bewindspersoon en ambtenaar zich achter elkaar verschuilen. P.J. Langenberg (1988), t.a.p.,p.65. Dit argument ook bij M.C. Burkens, H.R. B.M. Kummeling, B.P. Vermeulen, a.w", p.197.

79. Voorstanders zijn Th.C. de Graaf, t.a.p., pp.44-45; J, van der Bij, Coreferaat, in: H. de Groot en C.G.M. van Oosteren, De toekomst Nam de publieke sector, "s-Gravenhage, 1994, pp. 223-234, i.h.b. p. 228; R. Crince le Roy a.w., pp.132-133; P.J. Langenberg (1988), 4.a.p., pp.61-67; R.C. Hessing en P.J. Langenberg, t.a.p., p.312; H.Th.J.F. van Maarseveen, Ambtenaar, dienaar van de minister? t.a.p." p.11; M.E. Tuurenhout, a.w. pp.205-209; J. van Schendelen, in: CDActueel, 28 mei 1988. Hij is voorstander v.e. zelfstand ige verantwoordingsplicht voor hogere ambtenaren. Die zou gaan functione ren, analoog aan de ministerraad, als cen collegial politiek concept. Dit getuigt van naïviteit, aldus W.J. Deetman, De ministeriële werantwoordelijheid: de afsrand ussen norm en fictie, in: W.C.M. van Lieshout (red.), Bestuar en meesterschap: Opstellen over samenleving, staat ent sturing, 's-Grawenliage, 1988, pp. 101-113, i.lh.b. p.110. Deetman is tegenstander van een zelfstandige werantwoordingsplicht. Ook nodige scepsis bij J.A. de Brijn en $\mathbb{N}$. Lammers, Een juridische benadering van de departementen, in: J.L.M. Hakwoort en J.M. de Heer, Wetenschapover departementen; Theoretische confrontaties, departementale sturdies, "s-Grav., 1989, p.58; G.H. Hagelstein, a.w., p.302 e.w.; M.C. Burkens, H.R.B.M. Kummeling en B.P. Vermeulen, a.w., pp.195-197; J.A.B. Janus, Ambtelijke bijstand, informatie en verantwoording, in: Gegeven de Grondwet, CZW, Deventer, 1988, pp. 105-115; Over relatie ambtelijke bijstand en m.v. M.M. den Boer, Ambtelijke bijstand bij het opstellen van amendementen en initiatiefwetspoorstellen, in: RM, nr.3, 1993, pp.93-98; J.G.C. Wiebenga, Ambtenaar, dienaar wan de minister?. t.a.p., p.44; H. Engels, Vertrouwensbeginsel of genegenheidsbeginsel, in: PD, nr.2, 1988, p.43.

80. P.l. Langenberg (1988), t.a.p., p.65; Th.C. de Graaf, t.a.p., p.44. 
leerde) feitelijke informatie aan ambtenaren over te laten is, dat het de minister in contacten met het parlement in staat stelt zich te concentreren op de gedachtenwisseling met het parlement over hoofdlijnen van beleid." 81 Andere argumenten worden geopperd. $\$ 2$ Aanspreekbaarheid van ambtenaren is vanzelfsprekend, omdat het ambtelijk kader als bestuur in de contemporaine rechtsstaat merendeels zelf eigen regels vaststelt. Overigens werkt een zelfstandige ambtenaarlijke antwoordplicht preventief. Want voortdurend wordt hernieuwd inzicht verkregen in de wijze van totstandkoming van beleid. En ten slotte heeft het horen van ambtenaren door het parjement een "zuiverende werking " op de ministeriële verantwoordelijkheid. ${ }^{83}$ Politieke aanspreekbaarheid van ambtenaren, dat will zeggen een "zelfstandige verplichting van ambtenaren ten opzichte van een onderzoekscommissie uit de Tweede Kamer tot het geven van inlichtingen en het affeggen van rekenschap inzake hun rol als ambtenaar in het door die commissie te onderzoeken beleidsproces" ${ }^{84}$, heeft een reinigende functie. Ambtenaren stemmen hun handelen af op de ministeriële beleidslijnen. Dit dwingt de bewindspersoon er toe duidelijk beleid vast te stellen. Via het horen kan een ambtenaar er blijk van geven dat hij, voor een of ander, uitdrukkelijk ministeriële instructie heeft gehad. Ontkenning er van door de bewindspersoon is zinlloos. Evenmin kan hij zich zo afzijdig bouden van bepaalde belangrijke feiten. En uiteindelijk kunnen ambtenaren mededelingen doen, waartoe de minister niet in staat is omdat hij van bepaalde gebeurtenissen eenvoudig weg niet op de hoogte is.

Maar ambtenaarlijke aanspreekbaarheid is natuurlijk niet zonder problemen. Moeilijkheden rijzen in verband met de vaak onduidelijke afbakening tussen de verantwoordelijkheid van de minister en zijn ambtenaren. Een "dergelijke constructie maakt de minister tegenover zijn staf alleen nog maar zwakker" ${ }^{85}$ Bovendien is het nog maar de vraag of ambtenaren, bij absentie van de politiek verantwoordelijke minister, meer vertellen dan in diens presentie. ${ }^{86}$ Daarnaast kunnen meer verschillende verantwoordelijkheden leiden tot departementale coördinatieproblemen, meer bevoegdheidsconflicten of sterkere fragmentatie van de overheidlsorganisatie. ${ }^{87}$ Via een zelfstandige aanspreekbaarheid kunnen ambtenaren een verantwoordelijke minister in het vaarwater zitten daar waar de bewindspersoon bij voorbeeld: weigert inlichtingen te verschalfen met een beroep op het belang van de staat; of verlangde informatie (waaronder informatie met een beleidsmatig karakter) op zijn wijze, in afwachting van de juiste tijd en plaats, wil geven, m.a.w. inlichtin-

81. Commissie-Scheltema, a.w., p. 20 .

82. P.J. Langenberg (1988), t.a.p.,p.66.

83. M.E. Tuurenhout, a.w., pp.4-6/118-121/141-142/167/196.

84. M.E. Tuurenhout, a.w., p.205; Deze zelfstandige politieke aanspreekbaarheid van ambtenaren is dus in beginsel besloten van aard (p.204). De verantwoording splicht strekt zich, wolgens auteur, unit over zowel informatie in enge zin, $d . W . z$. "technische ünformatie en informatie met een meer politiek karakter" als informatie in ruime $z$ in, d.i. "informatie bettreffende de rechtwaardiging en motivering door ambtenaren van hun gedrag" (p.200).

85. H. Engels, Vertrouwensbeginsel of genegenheidsbeginsel, in: PD, nr.2, $1988,0.43$.

86. I.C. van der Vlies; Recensie, in: NIB, nr.32, 17 september 1992, pp.1053-1054.

87. J.A. de Bruijn en N. Lammers, t.a.p., p.58. 
genverschaffing voorlopig wil uitstellen. Misschien meest lastig is de rechtspositionele kant wan de ambtelijke aanspreekbaarheid. En een eventuele parlementaire sanctie ter zake ${ }^{89}$ remt waarschijnlijk de informatieuitwisseling. Ten slotte rijst de vraag naai juridische inpasbaarheid ${ }^{90}$ van ambtenaarlijke verantwoordelijkheid. Dat vereist aanpassing van het Reglement wan orde van de Tweede Kamer ${ }^{91}$ of de Aanwijzingen voor de rijksdienst/Aanwijzingen inzake contacten tussen ambtenaren en kamercommissies en tussen karnercommissies en regeringsadviescolleges. ${ }^{92}$ Zo danig dat een verschijningsplicht woor, niet aan een minister ondergeschikte, ambtenaren wordt voorgeschreven. De eerste mogelijkheid is strijdig met art. 109 Grondwet juncto art. 125 Ambtenarenwet geacht. De tweede optie, aanpassing van voornoemde aanwijzingen, klinkt beter. ${ }^{93}$

Al met al verdient de gedachte van ambtenaarlijke aanspreekbaarheid nog nader studie. Voor nu oogt zij, aan de ene kant, niet echt aantrekkelijk. Vooral vervelend is het akelig achterliggende bezwaar: afschuiven van verantwoordelijkheid. ${ }^{4}$ Op zich is dat niet per se onnuttig. Maar, indien gecombineerd met bestuurlijke traagheid, heeft dit aspect nog al negatieve kanten. Daardoor vermindert, bij voorbeeld, de prikkel om ministeriële controle over toekomstig beleid te waarborgen.

Van andere zijde kunnen volle ministeriële verantwoordelijkheid en ambtelijke aanspreekbaarheid prima een huwelijk aangaan. Uit gaande van de presumptie, dat het draagvlak van aanspreekbaarheid wordt verbreed naar de basis, omlijnen, al dan niet belastende, verklaringen van ambtenaren de ministeriële verantwoordelijkheid juist scherper. Daarmee komt de verantwoordelijkheid exacter in beeld. ${ }^{95}$

88. Aldus H.G. Warmelink, Ministeriële verantwoordelijkheid poor anbtelijk handelen, in: D.J. Elzinga (red.), Ministeriële veranwoordelijkheid in Nederland, Zwolle, 1994, pp.103-115, i.h. ib. pp. 110-112. Auteur onderkent ook de mogelijkheid dat de minister bewust geen of onjuiste informatie geeft. In dat geval ziet auteur meer, dan een zelfstandige aanspreekbaarheid wan ambteniaren, heil in een parlementaire enquête. Met referentie aan het spiegelbeeld er van (de ambtenaar verdrait feiten en treft daardoor. bewust of niet bewust, de minister) wijst auteur er op dat een zelfstandige ambtenaarijkke aanspreekbaarheid waarschijnlijk vooral 'onwerkbate verhoudingen' oplevert.

89. Tuurenhout stelt, dat de sanctiebevoegdheid in handen van de minister blijft. Het parlement kan de müister slechts adviseren strafmaatregelen te nemen of achterwege te laten. Anders dreigt, ten eerste, gevaar voor een politiek spelletje. Ten tweedle is de minister de "lhoogste superieur van de ambtenaren". M.E. Tuurenhout, a.w., pp.200/202.

90. Zie conclusie M.E. Tuurenhout, a.w., pp. 203-205.

91. Het RvO treedt d d. 17 mei 1994 gewijzigd in werking. Zie Nieuw Reglentent wan Orde, TK 1993-1994, 22590.

92. TK 1979-180, 15858, nr.3.

93. I.C. van der Vlies, t.a.p., p.1053; P.J. Langenberg (1988), t.a.p., p.67; Th.C. de Graaf, t.a.p., p.45.

94. Sprake kan zijn van gecamoufleerde verantwoordelijkheid. De actor legt niet zelf volle verantwoording af. Hij verwijst naar anderen, die aanspreekbaar zijn omdat zij (mede) beleid bepalen. Zie voor filosofische theorievorming $\mathrm{R}$. de Winter en W. Witteveen, De will wan de wetgever en het afschuiven wan verantwoordelijkheden, in: NJB, nr.26,27 juni 1981, pp.669-678.

95. H.R. van Gunsteren, Ministeriele verantwoordelijkheid in diskrediet, in: P.B. Cliteur en M.R. Rutgers, a. W. p. 73 . 


\subsubsection{OPZEGGEN VAN VERTROUWEN}

Na de inlichtingenfase breekt de periode van debatteren aan. Daarin bepaalt, meer dan woorheen, het parlement, weliswaar nog in samenwerking met de ministers, de politieke agenda ter zake.

Het laatste tijdsbestek wordt, zo nodig, opgevuld met sanctionering. Ten eerste zijn er verschillende staatsrechtelijke sancties. Hiervan is het opzeggen van vertrouwen in een bepaald bewindspersoon een belangrijke sanctie. Overigens is vertrouwensverlies niet in alle gevallen gerelateerd aan de ministerielle politieke verantwoordelijkheid. "De vertrouwensnorm is een politiek criterium met een buitengewoon groot subjectief karakter." 96 Het medio 1993 abrupt aftreden van staatssecretaris ${ }^{97}$ Ter Veld leert, dat ook discommunicatie met de bevriende fractie reden kan zijn om aan de vertrouwensregel toepassing te geven. De vertrouwensregel is negatief geformuleerd. ${ }^{98}$ Dat wil zeggen: pas bij wantrouwen volgt aftreden van een bepaald bewind(spersoon). Vertrouwen wordt dus aanwezig geacht tot het moment dat anders blijkt. Vertrouwen houdt zo soms ook gedogen in. ${ }^{99}$ Een motie van wantrouwen is ongebruikelijk. Kortom, het nemen van initiatief is nodig om de vertrouwensregel in werking te stellen. Daaraan zijn geen formele vereisten verbonden.

Ten tweede kunnen politieke strafmaatregelen toepasselijk zijn. Zij zijn ter vervanging van of als aanvulling op de staatsrechtelijke sancties. Voorbeelden zijn het verbod van terugkeer in een komend kabinet, het uitblijven van promotie van een staatssecretaris tot minister in een nieuw kabinet en het (in)direct vertrouwensverlies van de bevriende fractie. ${ }^{100}$

\subsubsection{DE REGEL VAN MINISTERIELLE VERANTWOORDELIJKHEID EN DE VERTROUWENSREGEL}

Voor alle duidelijkheid een herhaling. De regel van de ministeriéle verantwoordelijkheid en de vertrouwensregel zijn twee verschillende spelregels van het parlementaire stelsel. Door hun eigen taakstelling onderscheiden zij zich wan elkaar. Zij kunnen afzonderlijk

96. D.J. Elzinga, Belangrijk: heldere politieke veranwoordelikheid, in: $\mathbb{B B}, \mathrm{nr} .24,18$ juni 1993 , p.31.

97. Zie over staatsrechtelijke en politieke positie van staatssectetarissen J.J. Wis, De ministeriele veronvwoordelijkheid en de staatssecretaris, in. D.J. Elzinga (red.), De minisiteriele verantwoordelijkheid in Nedertand, Zwolle, 1994, pp.129-147.

98. M.C. Burkens, H.R.B.M. Kummeling en B.P. Vermeulen, a.w., pp.183-186, i.h.b. p.184.

99. De Tweede Kamer kan, bij voorbeeld, anwezigheid van een tewindspersoon gedogen in wemband met de homogenteitsregel. Die makt het mogelijk. "dat een evenituel politiek wantrouwen jegens een bewind spersoon zal worden opgevat als wantrouwen jegens het kabinet". Ter afwering van de dre iging van een kabinetscrisis, beschermt het kabinet dan een minister. L. Besselink, Kronieken Nederland; Ministeriêle verantwoordelijkheid, in: TvBP, nr.4, 1988, p.198.

100. Mogelijk ook als (tweede) vertrouwensregel. M. C. Burkens, H.R.B. M. Kummeling en B.P. Vermeulen, a.w., p.185. 
betekenis hebben. ${ }^{101}$ Dit aspect is wel eens veronachtzaamd in de discussie over de reikwijdte van de ministeriële verantwoordelijkhelid.

Die reikwijdte wordt, volgens de literatuur, gekenmerkt door onlogisch opportunisme. Al naar gelang valt, de ene keer, de keuze op objectieve politieke ministeriële werantwoordelijkheid. Dat is van rechtswege aan bewindslieden toegerekende verantwoordelijkheid. En in een andere situatie is behoefte alan subjectieve verantwoordelijkheid. Die omvat alleen cloor persoonlijk handelen ontstane verantwoordelijkheid. ${ }^{102}$

Er bestaan dus twee opties. Er bestaat een zo genaamde al om vattende interpretatie van de ministeriële verantwoordelijkheid. Ter illustratie daarvoor wordt veelal aangehaald de enquête bouwsubsidies betreffende staatssecretaris Brokx. En tegenover die formele verantwoordelijkheidsgedachte staat de beperktere materiële opvatting. ${ }^{103}$ Die zou zich gemanifesteerd hebben tijdens, bij voorbeeld ${ }$ de RSV-enquête aangaande minister Van Aardenne, de visquoteringskwestie betreffende minister Braks, de studiefinancieringszaak met minister Deetman als doelwit en de paspoortaffaire waardoor de staatssecretarissen Van Eekelen en Van der Linden zijn gedupeerd.

Volgens zeggen koerst de winnende knikker, in het politieke spel, steeds vaker aan op causaliteit. Zie de zaak-Walrus als getuige. Van een minister wordt niet zo zeer gevraagd wat hij weet. Belangrijker is wat hij behoort te weten. Hij hoeft niet aan alle ambtelijke fouten debet te zijn. Hierbij zorgt de minister er wel voor dat hij, aan de onder zijn supervisie gestelden, zijn beleidslijnen duidelijk maakt. Vervolgens controleert hij regelmatig of zijn ambtenaren beleidsmatig werken. Bovendien treft hij, bij beleidsafwijking door ambtenaren, geschikte maatregelen. ${ }^{104}$

101. Commissie-Scheltema, a.w.., pp.12-13; D.J. Wlzinga, De politieke ministeriële verantwoordelijkheid, in: D.J. Elzinga (red.), Ministeriële verantwoordelijkheid in Nederland, Zwolle, 1994, pp.31-49, i.h.b. p.47, verwerpt de stelligheid wan de commissie-Scheltema in haar constatering dat de politieke ministeriële verantwoordelijkheid altijd losgekoppeld kan worden vande vertrouwensregel. Volgens auteur miskent deze uitspraak het verband tussen parlementaire controle, veranwwoordelijkheid en wertrouwensregel. Bovendien suggereert zij dat loskoppeling normakl en gebruikelijk is. Auteur vindt de constatering van de commissie dan ook "te ver gaan": door loskoppeling onstaat hef "beeld van een parlement dat enerzijds druk doende is met verzelfstandiging, privatisering etc. en de daarmee gepaarde gaande beperking van de ninisteriële verantwoordelijkheid, maar anderzijds onder alle omstandigheden de minister voor het eventueel optreden van zbo's of zelfs geprivatiseerde diensten tot aftreden kan dwingen". Weliswaar acht auteur dit niet "onomstreden" maar zijns insziens ligt het "niet voor de hand" (i.v.m. het ontbrekken van volle politieke ministeriële verantwoondelijkheid voor het functioneren van zbo's) en is het wok "niet de reguliere situatie".

102. Dit onderscheid hanteert L. Besselink, t.a.p., p.199.

103. Terminologie is van o.a. L.J.A. Damen, a.w., pp.602-603; E. Helder, a.w., p.79; P.J. Langenberg (1985), t.a.p... p.159.

104. Tijdens BVD-debat, Handelingen EK, 1 dec. 1987, p.204 e.v., citeert minister-president R.F.R.M. Lubbers, als mede refereert Pvd.A-kamerlid Pronk in de wisquoteringszaak aan "Handelingen TK 19861987, p.4623, oud-premier J. den Uyl inzake de WOB-kwestie, Handelingen TK 1976-1977, pp. 30313032 . 
Deze drie aanwijzingen voor de beleidspraktijk krijgen de nodige aandacht. Hiervan geeft het, veel aangehaalde, debat aangaande de grondwetsherziening blijk. In citaat: "Daarnaast staat de vraag in hoe verre de minister het optreden van zijn ambtenaren kan worden aangerekend. Te dien aanzien meen ik, dat de minister slechts een verwijt mag worden gemaakt voor eigen daden of eigen nalatigheid. Dit laatste zal vrij ruim moeten worden opgevat. Ook indien een minister door het vele dat zijn aandacht vraagt, niet in de gelegenheid is alles hetgeen zijn ambtenaren doen nauwlettend te volgen, in het algemeen mag het parlement hem bij gebleken verkeerde handelingen of nalatigheden in beginsel zeker verwijten, dat hij de minister, te kort is geschoten in het houden of het organiseren van voldoende toezicht. [...] Moet een minister in dat geval het beleid van zijn ambtenaren voor zijn rekening nemen? Neen, is mijn mening. Hij moet daarover verantwoording afleggen en eventueel een verwijt van malatigheid incasseren, maar hij zal indien duidelijk een ambtelijke fout is gemaakt, dit zonder bezwaar moeten erkennen." 105

In het bijzonder dit debat is verkeerd geïnterpreteerd. Verwarrend is verwijtbaarheid (van de minister) alls criterium voor de omvang van de ministeriële verantwoordelijkheid aangenomen. Dat is helaas buiten het besef, dat de bewindspersoon verantwoordelijk is voor het handelen van al zijn ambtenaren. Anders gezegd, de omvang van van de ministeriële verantwoordelijkheid wordt bepaald door juridische criteria (zijn bevoegdheden).

Bij de toepassing van de vertrouwensregel gelden uitsluitend politieke maatstaven. Daarvan kan de factor verwijtbaarheid eventueel wél deel uitmaken. ${ }^{106}$ Immers, tussen daad en straf dient eerlijke evenredigheid te bestaan. Soms treft een minister slechts weinig blaam. In bepaalde gevallen is hij zelfs ontheven van schuld. Denk aan de problematiek van nu fungerende ministers voor tekortkomingen van ambtenaren onder hun woorgangers. ${ }^{107}$ Treft de nieuwe minister geen maatregelen, terwijl uit onderzoek of anderszins blijkt van falend beleid onder zijn voorganger, dan is hem dit kwalijk te nemen. ${ }^{108} \mathrm{De}$ relatie tussen "het (redelijkerwijs) kemnis hebben kunnen of moeten dragen van" en de (ex post) verantwoordingsplicht is dus relevant. ${ }^{10 \%}$

105. Regeringscommissaris w/d grondwetsherziening Simons ajdens Handelingen TKK 1986-1987, p.4662; Th.C. de Graaf, t.a. p., p.42, merkt op, dat de handelingen de oorspronkelijke vindplaats van dit citaat: niet aangewen. Hij zegt die evenmin te kunten traceren. Daarom het volgende. Bedoelde politicus put, voor bovenstaande bewering, uit eigen bron. Zie D. Simons, Ministeriale veranwwordelijkheid en. ministerielle werantwoording, 1979, in: LR-bundel, In weede lezing, p.82.

106. Commissie-Scheltema, a. $w_{n}$, pp. 12-15.

107. A.H.M. Dölle en D.J. Elzinga, Ministeriele weranmoondetijkheid woor niet-funcrioneel gedrag. in: D.J. Elzinga (red.), Ministeriele verantwordelikheid in Nederlantd, Zwolle, 1994, pp.117-128, stellen zeer uitgesproken dat de ministeriële werantwoordelijkheid niet "meereist" met de toevallige ambtsbekleder. De zittende bewinds persoon is verantwoordelijk: "De aanw aarding van zijn benoeming is de aanwaarding van de erfenis zonder de voorwaarde van boedelbeschrijving (p. 124).

108. Commissie-Scheltema, a. $w_{n}$, p: 16: Minder genuanceerd H.Th.J.F. van Maarseveen, Reidons der nietverantwoordelijken, in: NJB, nrs.45/46, 26 december 1987, p. 1516.

109. M. Schoonhovem, De individuele ministerięle verantwoordelijkheid, grenzeloos?, in: TvO " nr. 5,3 maart 1988, pp. $92-96$. 
Aan het criterium, of betrokken bewindspersonen persoonlijk fouten zijn te verwijten, wordt wooral in het debat inzake (de opheffing wan ${ }^{110}$ ) het Interregionaal Recherche Team Noord-Holland/Utrecht aandacht besteed. "De, door de commissie-Wierenga onderzochte ${ }^{112}$, IRT-kwestie ${ }^{113}$ betreft het "runnen' van een informant in een misdadige organisatie, die met medleweten van politie en justitie grote hoeveelheden hasj, en - om tot de top van het syndicaat door te dringen - noodzakelijkerwijs ook cocaïne importeert. Naast het inrichten van 'front stores', of wel door de politie gedreven dekmantelbedrijven, zijn riskante opsporingsmethoden gebruikt als het uitwoeren van 'kijkoperaties' (d.w.z. inbraken bij personen tegen wie bepaalde vermoedens bestaan "14) en het plaatsen van afluisterapparatuur. ${ }^{115}$

Middels de maatstaf van verwijtbaarheid lijken de politiek verantwoordelijke ministers van justitie en binnenlandse zaken, te weten Hirsch Ballin en Van Thijn, de dans te kunnen ontglippen. Ondanks hun formele politieke verantwoordelijkheid gaan zij aanvankelijk vrij uit. ${ }^{16}$ De direct aanwijsbare schuldigen in de IRT-kwestie, met name de Amsterdamse hoofdofficier van justitie, de procureur-generaal, de hoofdcommissaris van politie en een commissaris, krijgen maatregelen opgelegd in de vorm van functioneringsgesprekken. ${ }^{117}$

110. De oprichting van een Nationaal Rechercheteam wordt al door de IRT-oprichter bepleit. M. Haemun, "Amsterdam deed arrogante greep naar de macht" in: NRC, 6 april 1994, p. 11 ; Behoedzaam vindt $\mathbf{F}$. Kuitenbrowwer, Interregionale politheteans zweven ver boven de democratie, in: NRC, 30 sept. 1994, p.9. dat oprichting van zo' $\mathrm{n}$ organisatie eerst plaats kan vinden als de regieproblemen binnen de politie zijn opgelost en helderheid ower opsporingsmethoden bestat; G.J.N. Bruinsma, M.R. Daniel en G.J. Veldhuis, Enkele verwaarloosde organisatarische vraggstukken warn de IRT's, in: DD, nr. 10, 1994. p. $1056 \mathrm{ev.}$., vragen aandacht voor ondergesneeuwde of onderbelichte aspecten van IRT"s.

111. M. Kranenburg, Staalije wan politiek opportunisme; WRT past in rijtie visfraude, bouwfraude en paspoorlen, in: NRC, 31 maart 1994, p. 11 .

112. Rapport cie-Wierenga: commentar en nadere uinwerking. TK 1993-1994, 23593, nrs. 1-16, i. h.b. nrs.6\% 7 .

113. Zie chronologische beschrijving van. IRT-kwestie IRT 1989-1994, in: NRC, 8 april 1994, p.3.

114. Uiteindelijk keurt de Hoge Raad inkijkoperaties goed indien daarbij strenge eisen van zorgvuldigheid in acht worden genomen. De rechter moet onderzoeken of opsporingsambtenaren de betrokken plaats hebben betreden en, zo ja, o.g.v. welke bepaling betrokken ambtenaren daartoe bevoegdheid waren. Daarnaast gat hij na of verkregen bewijsmateriaal tot bewijs mag strekken. Van zijn onderzoek(sresultaten) legt hij verantwoording fif in zijn uitspraak. HR 31 mei 1994, nr.96871, in: NJB-rechtspraak, nr.25, 24 juni 1994, pp.314-325, ook in: DD, nr.8, 1994, pp.880 881

115. Hierover G.P.M.F. Mols, Th.A. de Roos en T. Spronken, Her echte IRT-debat; Grenzen van opsporingsmethoden, in: NJB, nr.24, 17 juni 1994, pp.797-804; Tevens interessant J.A.W. Lensing, De evolutie van de polntiebevogdheden in het raam van de bestrijding wan de ernstige. georganiseerde misdaad, in: DD, nr.10, 1994, pP.1007-1029; Ook lezenswaardig is de kritiek wan T. Blom en P.A.M. Mevis, Ziende blind? Een beschowwing over inkijkoperaries, in: DD, nr.1, 1995, pp.5-27. Auteurs betreuren de kennelijke afwezigheid bij optredende politiemensen, behandelende ovj's en de minister vanjustitie van een "ten behoeve van fundamentele waarden van de rechtsstaat moodzakelijke waakzame beroepshouding" : En J.J. Th.M. Pieters en C.J.P. M. Revis, Het wettelijk kader woor 'kijkoperaties", in: $\mathrm{NJB}_{x}$ nr. 11, 17 maart 1995, pp.401-407, achten een expliciete wettelijke regeling woor kijkoperaties niet nodig, nu er wettelijke kaders bestaan die de opsporingspraktijk al lang voldoende mogelijkheden bieden; Zle ter zake ook uitvoerig themanummer van DD, juli 1995.

116. Gezag aangetast, in: NRC, 8 april 1994, p.9.

117. Maatregelem tegen hoofdrolspelers $I R T_{*}$ Kamer aanvardt witleg mimisters, in: NRC, 8 april 1994, pp. 1/3. 
Bovendien besluit het kabinet, "als troostprijs voor de oppositie", tot het instellen van een parlementair onderzoek naar de (grenzen van en controle op) opsporingsmethoden die justitie en politie hanteren. ${ }^{18}$ Met oog daarop melden strafrechtsgeleerden in een preadvies ten behoeve van de commissie van de Tweede Kamer belast met onderzoek ter zake, dat inkijkoperaties en dergelijke acties van criminele inlichtingendiensten strijdig zijn met de Grondwet. ${ }^{119}$ Bovendien juichen zij een parlementaire enquête niet toe. Bij openbare verhoren bestaat het risico, dat juist misdaadorganisaties profiteren van de kennis over informatietactieken die naar buiten komt. De werkgroep vooronderzoek opsporingsmethoden van de Tweede Kamer, t.w. de commissie-Van Traa, die een wettelijke regeling van toepassing van en controle op politiële en justitiële opsporingsmethoden als mede een landelijk aansturende toetsingscommissie voor bijzondere opsporingsmethoden ${ }^{120}$ en een onderzoek naar de omvang van de zware georganiseerde criminaliteit wenselijk acht, beveelt toch een parlementaire enquête naar de opsporingsmethoden van politie en justitie aan (die het meest zinvol is als zij het karakter van een "wetgevingsenquête" draagt ${ }^{12 l}$ ). De commissie-Van Traa stelt zich een onderzoek voor, dat a. het beeld van ernst, aard en omvang van de zware georganiseerde criminaliteit, $b$. de feitelijke toepassing, de rechtmatigheid, het verantwoord zijn en de effectiviteit van opsporingsmethoden, en $\mathrm{c}$. de organisatie, het functioneren en de controle op de opsporing in kaart moet brengen, waardoor onderzoekers zich moeten richten op vormen/voorwaarden van wetgeving van de te gebruiken methoden in de proactieve fase, categorisering/ omvang van de zware georganiseerde criminaliteit, opsporingsmethoden in het algemeen, observatie, informanten en infiltratie, als mede informatieopslag en -uitwisseling. ${ }^{122}$ Deze enquête, die kennelijk nodig is om "zo helder mogelijk duidelijkheid te verschaffen over de vraag: wat kan, wat moet en wat niet moet in de strijd tegen de zware, georganiseerde criminaliteit", moet echter wel een vertrouwelijk karakter hebben. "23 Deze eis van beslotenheid wordt uitdrukkelijk gesteld van uit de Tweede Kamer. De kamerfracties

118. Terugtrekkende beweging in kabinet over schuld in affaire, in: NRC, 8 april 1994, p. 3, Zie angenomen motie Dijkstal. Kohnstamm en Brouwer, TK 1993-1994, 23593, nrs.1-16 en Handelingem TK 19931994, pp.4916-5002/5246-5280.

119. M. Haenen en T.J. Meeus, Inkijkoperaties 'in strijd met wet', in: NRC, 8 okt. 1994, p. 1.

120. Deze aanbeveling krijgt per januari 1995 witwerking middels oprichting van de Centrale Toe tsingscommissie voor bijzondere opsporimgsmethoden. Deze (regelmatig aan de p-g's en de minister vam justitie rapporterende) commissie toetst, $0 . \mathrm{g}$. $\%$. de infiltratierichtlijn, jurisprudentie en beginselen van behoorlijke opsporing, wooraf verschillende wonmen van infiltratie-acties, of deals met criminelen, door het openbaar ministerie. Toetsingscommissle voor bijzondere opsporingsmethoden, in: NIB, nT.45/46, 16 dec. 1994, p.1591. Zie ook Opsporingsmethoden, in: NJB, nr.1, 6 januari 1995, pp.34-35; " $\mathrm{gl}$. aansturing door landelijk OM-bureau van landelijk rechercheteam, TK 1994-1995, 22838, nr.9.

121. Aldus A van der Stoel, geciteerd door M. Haenen en T.J. Meeus, ' $/ k$ begrijp nu beter de boosheid van Nordhols; WD-kamerlid Van der Stoel over politie-enquete, in: NRC, 22 okt. 1994, p. 3.

122. Uitvoerig Commissie-Van Traa, Opsporing gezocht, TK 1994-1995, 23945, nrs.1-2.

123. Enquête gevraagd naar methoden wan opsporing politic; Kabinet wil beslotenheid bij enquëtte, in: NRC. 21 okt. 1994, pp. 1/3; Uitwoerig M. Haenen en T.J. Meeus, Onderzoek naar opsporingsmethoden van politie was met jongensboek, in: $\mathrm{NRC}^{2} 21$ okt. 1994, $\mathrm{p} 3$; Zie ook Regels voor politie-informatie aan lokaal bestuur gewenst, Werkgroep-Van Traa opsporingsmethodem, in: BB, nr.43, 28 okt. 1994, p.3. 
van in elk geval PvdA, D'66, GroenLinks, RPF/GPV ${ }^{124}$, SP en Unie $55+$ spreken zich uit voor een politie-enquête. ${ }^{125}$ In politieke kringen heerst nog wel onderlinge onenigheid over wie zo'n enquête moet voor zitten. ${ }^{126}$ Weerstand tegen een enquête bieden CDA (althans aanvankelijk) ${ }^{127}$, SGP en VVD, de VVD-fractie vindt het minder ver gaande parlementair onderzoek voldoende. ${ }^{128}$ Medio november 1994 is duidelijk dat er, door steun van een meerderheid van de Tweede Kamer, een enquête (niet één met het karakter van een 'spannend jongensboek', maar juist één van strikt zakelijke aard) komt, die volgens voorstel eind zomer 1995 voltooing vindt. ${ }^{129}$ En begin december 1994 valt het besluit dat M. van Traa de zevenkoppige enquêtecommissie gaat voorzitten. ${ }^{130}$ De enquêtecommissie presenteert medio februari 1995 haar plan van aanpak. ${ }^{131}$ Haar werkzaamheden worden al snel belemmerd door de weigering van het openbaar ministerie om informatie van zijn criminele inlichtingendiensten te verschaffen. ${ }^{132}$ Commissievoorzitter Van Traa verwacht echter, conform toezegging van de minister van justitie, "volledige medewerking" van het openbaar ministerie. ${ }^{133}$ Hoe volledig die medewerking moet zijn, moet weliswaar gemeten wordt naar de maatstaf van de Wet op de parlementaire enquêtes, en hangt daardoor af van thet belang van de Staat: Ter zake komt de enquêtecommissie met de ministers van respectievelijk justitie en binnenlandse zaken overeen dat slechts in "exceptionele gevallen" een beroep op het staatsbelang mogelijk is, en overigens dat een politieambtenaar of een officier van justitie die om informatie wordt gevraagd niet direct inlichtingen hoeft te verstrekken als hij vreest dat dit leidt tot herkenning van informanten of tot levensbedreigende situaties. Dergelijke informatie wordt mogelijk gecodeerd of geanonimiseerd onder overdracht er van aan bepaalde officieren van justitie, die als tussenpersonen bekijken welke informatie aan de enquêtecommissie kan worden toegespeeld. Hierbij is het trouwens de vraag of codering of anonimisering het betrokkenen niet erg gemakkelijk maakt zich af te scher-

124. Beide partijen steunen die gedachte van een enquête onder de voorwaarde dat een enquêtecommissie geen voorstellen inzake wetgeving doet. Stewn in Kamer voor enquête politiemethoden, in: NRC, 16 now.. 1994, p.5.

125. PudA, D'66 steunen enquête ower politie; 'Groot deel van enquête in beslotemheid', in: NRC, 26 okt. 1994, p.3.

126. Voorzitterschap enquête potitie werdeelt coalitie, in: $N$ RC, 27 okt. 1,994, p. 3; D '66: Kamerlid De Graaf voorzitter enquêtecommissie, in: NRC, 29 okt. 1994, p.2.

127. Unteindelijk stemt de CDA als nog in met het woorstel van een parlententaire enquête. Kamer akkoord mer politie-enquête, in.: NRC, 23 nov. 1994, p.2.

128. WD wil onderzoek werkwijze politie" in: NRC, 1 nov. 1994, p.1; Onzekerheid over komst enquête, in." $\mathbb{N R C}_{\star} 2$ nov. 1994, p.6; IRT: enquêtte kan de misdaad helpen, in: NRC, 15 nov. 1994, p.3.

129. Kamer besluit tot enquête naar politiemethoden. in: NRC, 17 nov. 1994, p.3, zie ook commentaar op p.9.

130. Van Traa leidt enquête door 7 kamerleden, in: NRC. 2 dec. 1994, p.7.

131. Brief parlementaire enquêtecommissie inzake opsporingsmethoden, TK 1994-1995, 24072, nr.1.

132. M. Haenen, Justitie wil Kamer beperkt informeren; OM vreest gevolgen van enquête, in: NRC, 18 febr. 1995, p.1. Het openbaar ministerie is hoogstems bereid tot een compromis in de zin dat via een vertrouwenspersoom (bij voorlkeur een rechter), door hem 'gezeefde', informatie wondt doorgegeven.

133. Commissie eist volledige medewerking. Top OM weigert informatie, in: NRC, 20 febr. 1995, p.3.

134. Afspraak over politie-enquête, in: NRC, 28 febr. 1995, p.1. 
men tegen precaire vragen. Zo zich dat voordoet wordt tekort gedaan aan het wezenlijke van een parlementaire enquête, namelijk dat deze door alle bonte ballonnen heen prikt.

Uiteindelijk krijgt de positie van beide betrokken ministers toch nog een flinke deuk door de motie, die aan geeft dat "ernstig tekort geschoten is in de samenwerking tussen de beide politieministers bij de afdoening van de IRT-affaire, waardoor na 7 april 1994 (datum van eerste IRT-debat) verdere schade is ontstaan". "Naar aanleiding van deze motie, die weliswaar met krappe kamermeerderheid wordt aangenomen, maakt de Tweede Kamer duidelijk "dat een nieuwe vormgeving en aansturing van de interregionale rechercheteams dienen te worden overgelaten aan een volgend kabinet". ${ }^{136}$ Uit deze evidente afkeuring trekt minister Hirsch Ballin zijn conclusie door - hoewel hij op dat moment reeds demissionair minister is ${ }^{137}$ - zijn ontslag in te dienen, ondat aanvaarding van de motie door een meerderheid in de Tweede Kamer een politiek feit is dat hij "niet terzijde kan en wil leggen". ${ }^{198}$ Hoewel hij vindt dat bedoelde motie "inhoudelijk geen blokkade opwerpt om ook op het gebied van de bestrijding van de georganiseerde criminaliteit de lopende zaken, dus alles wat in 's lands belang is, af te ronden" volgt minister Van Thijn later het voorbeeld van Hirsch Ballin, "gewoonweg omdat het sop de kool niet waard is om nog een discussie te voeren over de pro's en contra"s over het aanblijven van een demissionaire minister". 138

Het verdient nog een keer vermelding: ministeriële verantwoordelijkheid veronderstelt bevoegdheid en impliceert tegelijkertijd hiërarchie. ${ }^{140}$ Ministeriële beinvloedingsmechanismen zijn bij voorbeeld: bevoegdheden tot oplegging van disciplinaire straffen of benoeming, schorsing en ontslag van (waarnemende) bestuurders, rechten tot goedkeuring, schorsing of vernietiging van bepaalde besluiten, begroting, jaarrekening en jaarverslag; bepaling (wijze) opheffing van, in casu, zelfstandige bestuursorganen; mogelijkheden om aanwijzingen te geven.

Ten slotte, bij het adagium "zonder bevoegdheid geen verantwoordelijkheid" $\$ 4 i$ zijn wel kanttekeningen te plaatsen. "De minister is ook, ja juist verantwoordelijk, voor handelingen waarbij de bevoegdheidsgrenzen worden oversch reden. En bovendien verant-

135. D.d. 26 mei 1994 ingediend door VVD-kamerlid Dijkstal, D'66-kamer'lid Kohnstamm en GroenLinkskamerlid Rabbae. Zie Het aftreden van de minister yan justitie Hirsch Ballin, in: NJB, nr. 23, 10 juni 1994. pp.790-791.

136. Kamer veroordeelt rol politieministers; Geen bemoetenis meer met IRT, in: NRC, 26 mei 1994, PP. $1 / 3 / 11$.

137. Herover M. Kranenburg, Aftreden na verkiezingen is schemergebied in staasrecht, in: NRC. 26 me 1994, p. 1; C.A.J.M. Kortmann, Kroniek van het staatsrech, in: kroniekenbijlage N.1B, nr. 33, 23 sept. 1994, pp.46-49, i. h. b. p. 47, merkt nauwkeurig op dat formeel geen sprake is van demmissionair ministerschap. De betrokken bewindspersoon heeft namelijk eerder als statesecretaris, bij zijn plotselinge promotie tot minister, geen ontslag ingediend.

138. Zie zijn verklaring van aftreden weergegewen in: 'Het beleid waarwoor ik sta geeft de doorslag. NRC. 27 mei 1994, p. 3.

139. Zie zijn verklaring van aftreden in: $\mathrm{NRC}, 28$ mei $1994, \mathrm{p}, 3$.

140. I.A. de Bruin en $\mathbb{N}$. Lammers, t.a.p., pp.49-51.

141. H.G. Lubberdink, a.w.., p.185. 
woordelijk voor het niet bevorderen van een wetswijziging die hem wel (voldoende) bevoegdheden zou verlenen." 142

\section{$\S 3.3$ Politieke controle in praktijk}

Het praktisch functioneren van de ministeriële verantwoordelijkheid wijkt aanzienlijk af wan het theoretisch stramien van het verantwoordingsproces. De controle, op zich, is zacht maar zeker zoekgeraakt. Dat is geen novum. "Het zoeken naar controle kan in de publieke sfeer, waar een pluraliteit van mensen handelt, nooit geheel slagen. Gebrek aan controle is inherent aan handelen, dat wil zeggen iets nieuws beginnen, in een plurale samenleving." :4 Maar als een, speciaal daarvoor ingesteld, controlesysteem uitzonderlijk ineffectief is, stemt dit tot nadenken.

Sombere geluiden klinken reeds door in met name de RSV-rapportage en het OOWverslag.

Tijdens het RSV-debat wordt de teleurstelling verwerkt van het achterwege blijven van controle op beleidsuitvoering. In verband met dit falen van de democratie zijn suggesties gedaan met betrekking tot verlichting van het controlesysteem. Te weten: a. reductie van complexiteit van controle; $\mathrm{b}$. vermindering van controletaken; en $\mathrm{c}$. ondersteuning door derden. Omgekeerd zijn voorstellen gedaan ter vergroting (van de kwaliteit) van de controle. In het bijzonder: a. uitbouw controleapparaat; b. verbetering controlecapaciteit; en $\mathrm{c}$. verbetering van de besluitvorming en verfijning en verduidelijking van de grenzen van verantwoordelijkheid.

De commissie-Dolman reduceert controle tot een staatsrechtelijk minimum, namelijk de verhouding parlement-regering. Tekenend hiervoor is de herdefiniëring van controleversterking als verbetering van toezicht. Die terminologie verwijst niet naar een wijziging van machtsverhoudingen, maar fixeert de status quo. De commissie beschouwt controle als routinewerk. Voor een adequaat overheidstoezicht acht zij een beter geinformeerde Tweede Kamer, meer assistentie en stroomlijning en verstrakking van kameractiviteiten noodzakelijk. Kosten, werkwijze, procedures en deskundigheid van de kamer moeten worden geperfectioneerd ter vergemakkelijking van controle. ${ }^{144}$ Met het opstellen van het nieuwe Reglement van Orde ${ }^{145}$ wordt ten dele tegemoet gekomen aan deze wensen.

In navolging van het RSV-debat en het OOW-rapport van de commissie-Dolman, vraagt de commissie-Deetman zich daarom ook af "op welke wijze de kloof tussen de fictie van

142. Terecht L.J.A. Damen, a.w., p.60; Laatste argument ook bij J.L. Boxum, J. de Ridder en M. Scheltema, Zelfstandige bestuursorgaren in soortem; Verslag v.e. onderzoek naar de praktijk wan zbo "s, i.o.v. Biza, Deventer, 1989, p.241.

143. H.R. van Gunsteren, Wie in zijn graf ligt, maakt geen fouten meer; Een interwemieleer te ontwikkelem door ambtenaren, in: Beleid en Maatschappij, nr.6, 1984, p. 162.

144. Uitvoerig over beide rapportages W. Beck,a.w.,pp.27-128. Auteuracht, trouweris, de overgang tusser beide een proces van ontpolitisering wan een in wezen politiek vraagstuk.

145. Nieww Reglement van Orde, TK 1993-1994, 22590. 
de (collectieve en individuele) ministeriële verantwoordelijkheid en de werkelijkheid er van kan worden overbrugd c.q. verkleind. ${ }^{146}$

Frappant feit is het volgende. De commissie-Deetman kiest, naar eigen zeggen, voor de traditionele Franse ${ }^{147}$ betekenis van controle. Maar feitelijk hangt zij de Engelse versie aan. $\mathrm{Zij}$ onderschrijft controle namelijk als "toetsing van daden, woorden en beleidsvoornemens van de regering". ${ }^{148}$

De commissie-Deetman appelleert, ter versterking van de disfunctionerende individuele en collectieve ministeriële verantwoordelijkheid, aan a. interesse, ambitie en sectorale gerichtheid van betrokken bewindspersonen en $\mathrm{b}$. het $\mathrm{t}_{\text {, }}$ mede in het licht van internationale betrekkingen belangrijke, coördinatievermogen van de minister-president. ${ }^{149}$ Blijkt de ministeriële verantwoordelijkheid toch te groot, dan brengt functionele decentralisatie naar zelfstandige bestuursorganen mogelijk heil. ${ }^{\text {iso }}$

\subsection{MINISTERIËLE VERANTWOORDELUKHEID EEN SPROOKJE?}

"De ministerieele verantwoordelijkheid is een paradepaard, dat, alleen bij plechtige gelegenheden, voor den dag gehaald, opgetuigd en van gouvernementswege bereden wordt. Voor het dagelijks gebruik, is het edelle ros ongeschikt. Dat het, als dan, op stal gezet wordt, daarvoor zorgen de politieke partijen, die immers voor iedere "bagatel', een ministerie van hunne gading niet ter verantwoording kunnen roepen, op gevaar af, dat het heenga." $\| 51$

Instrumenten, als contractmanagement, zelfbeheer en niet als laatste redmiddel functionele decentralisatie, bevorderen mogelijk de verdichting van de kloof tussen de fictie van de ministeriële verantwoordelijkheid en de werkelijkheid. De commissie-Deetman laat geen gras groeien over het feit, dat de "oude ministeriële verantwoordelijkheid kreupel

146. Commissie-Deetman, Rapport van de bijzondere commissie vraagpunten, TK 1990-1991, 21427, mi. 3, p. 14. Zie voor daarbij hotend debat UCV 63-64, betreffende Stactkundige, bestuurlike on staotsrechtelijke vernieuwing d.d. 19 maart 1991 pp.3536-3628. Dat de commissie inderdaad oude koeien uit de stoot halt, wekt dus geen bevreemding. Welklinkt terecht het verwijt van J.L. de Reede, Kronieken Nederland; Staatkundige, bestuaritjke en staatsvechtelijke verniewwing in Nederland?, ir: TwBP. 1991, p.582, vgl. S.W. Couwenberg. Nieuwe hoop op staatkundige en bestumrijke vernieuwing in het fin de siècte, in: M.C. Burkens, S.W. Couwenberg. H. Franken en L.J. Brinkhorst, Staatsrechtelijke vermieuwingen; Commemiaren op het rapport van de commissite-Deemian, publikatie van de Staatsrechtkring. Zwolle, 1991, pp. 29-30, dat die koeien soms "reeds lang overleden" zijn. En voor zover zij nog wel vitaal zijm, stelt het teleur te moeten constateren, dat ze niet zijn voorzien van een meer uitgeplozen, passende statart of dat ze zijn verplalatst naar een andere, nieuwe wei.

147. Zie commissie-Dolman, Rapport anderzoek van de organisathe en werkwize der Kamer, TK 1985-1986. $19336, \mathrm{nr} \cdot 2, \mathrm{p} \cdot 4$.

148. Commissie-Deetman, Rappont wan de bijzondere commissue wraggpunten, TK 1990-1991, 21427, nr.3, pp.4/8; Zie ook H.G. Hagelstein, a., w., p.9; M. E. Tuurenhout, a. w., p.28, houdt nog aan optie wan de commissie vast.

149. Commissie-Deetman, a.w., pp.7/12; Uitwerking door commissie-Scheltema, a.w, pp. 26-35.

150. Commissie-Deetman, a.w., p. 11 .

151. J.A. Levy, Des ambrenaars grondwettelijke rechter, 's-Gravenhage; 1905, p.32, aangehaald door R.E. Winter, Nota bene: ministeriele verantwoordelijkheid, in: $\mathrm{PD}, 014.1988$, p. 142. 
is geworden door nieuwe omstandigheden". ${ }^{152}$ "Het is onmiskenbaar, dat de ministeriele verantwoordelijkheid, tenminste gedeeltelijk, een fictie is geworden, omdat een minister niet meer op alles goed kan toezien wat er op het ministerie in zijn naam gebeurt." 153

Fictie geeft vaak frictie. Dat is een bekend gegeven. Daarom is getracht die fictie meer in overeenstemming te brengen met de realiteit als volgt. ${ }^{154}$

Ten eerste is beperking van overheidstaken hulpmiddel.

Ten tweede is de ministeriële verantwoordelijkheid te verdunnen door anderen tevens of zelf, scherp omlijnde en goed te effectueren, verantwoordelijkheid te geven. ${ }^{155}$ De eis hierbij, om verantwoordelijkheden duidelijk af te bakenen, is niet uit de lucht gegrepen. Bij verzelfstandiging van overheidsdiensten loert een groot gevaar om de hoek. De beperking van ministeriële verantwoordelijkheid kan een verenging van de parlementaire controle met zich meebrengen. Ieders bevoegd- en verantwoordelijkheden moeten daarom volkomen ondubbelzinnig zijn. Bij instelling van een zelfstandig bestuursorgaan moet de wetgever heldere lijnen ter zake trekken. Alleen zo is de kans op een nieuwe "leemte" in de controle op het openbaar bestuur gering. ${ }^{156}$

Ten derde zijn technische maatregelen met betrekiking tot werkwijze en inrichting van het parlement te overwegen.

152. H.Th.J.F, van Marseveen, Opinie; Reidans derniet-verantwoordeliken, in: NJB, nr. $45 / 46,26$ december 1987, p. 1516.

153. Commissie-Deetman, a.w., p. 13; Overeenkomstig P.J. Langenberg (1988), t.a.p., p.63; P.J. Langenberg, Gebonden zelfbeheer: over de verhouding tussen regering. parlement en functionele organen, in: Th. C. de Graaf, D.A. van der Hoeven en P.J. Langenberg, Omtrent het parlement; Opstellen over parlement en democratisch bestwur. Utrecht/Antwerpen, 1985, p.158; Th.C. de Graaf, t.a.p., p.36; L.J.A. Damen, a.w., p.603; H.R. van Gunsteren, Ministerielte verantwoordelijkheid in diskrediet, in: P.B. Cliteur en M.R. Rutgers, a.w., p. 72; C.M. van den Hoff en R. de Groot, Decentralisatie." zelfstandige bestuursorganen, nr.2, dl.2, aan cie. hoofdstructuur rijksdienst, "s-Grav., 1981, p. I en hoofdstuk 8; met positievere, neutralere ondertoon, $t . w$. fictie als "conplicatie" U. Rosenthal, M.P.C.M. van Schendelen en G.H. Scholten, Mïnisters, ambtenaren en parlementariërs in Nederland, Groningen. 1977, p.274; U. Rosenthal, M.P.C.M. van Schendelen en A.B. Ringeling, Openbaar bestuur, Alphen a/d Rijn, vierde druk, 1987, pp.157-176/241.

154. G.H. Scholten, De toekomst van de parlementaire democratie (1977), in: LR, In tweede lezing, p.67; G.H. Scholten, De fictie van de verantwoordelijkheid als grondslag voor democratisch bestuw, in: A.P, nr.3, jrg.5, 1969-1970, pp.237-253.

155. Krachtige voorstanders er van zijn M. Scheltema en H.G. Lubberdink, t.a.p., p.14; M. Scheltema. Raden en commissies als zbo"s, t.a.p., pp.336-338/344; H.G. Lubberdink, a.W., pp.153-181; W.J. Deetman, t.a.p., pp.101-113, i.h.b. p.111-113.

156. Commissie-Scheltema, a.w., p.12/40/48-49; Het parlement stemt, middels aanvaarding van de motieJurgems (TK 1993-1994, 21247, nr.69), in met de bevindingen van de cie-Scheltema t.a.v. de inthound van de $\mathrm{m} . \mathrm{v}$. Zij benadrukt nog, dat beperking van de $\mathrm{m}_{\mathrm{in}} \mathrm{v}$. bij verzelfstandiging van overheidstaken geregeld moet zijn in verzelfstandigingswetten. 
Niet iedereen acht een fictie aanwezig. ${ }^{157}$ Immers, de ministeriële verantwoordelijkheid veronderstelt niet dat ministers alles weten. ${ }^{158} \mathrm{Zij}$ berust juist op "de staatsrechtelijke realiteit dat bewindslieden de gesprekspartners zijn van de kamers, aan de kamers alle gevraagde en relevante ongevraagde informatie moeten verschaffen en ook door de kamer op alles wat er onder hun verantwoordelijkheid gebeurt kumnen worden aangesproken. Voorts moeten zij tegenover de kamers hun beleid verdedigen." ${ }^{159}$ Analoog is het argument, dat fictieve ministeriële verantwoordelijkheid "over het hoofd ziet dat in het staatsrecht die daden (daden en nalaten van anderen, waaronder ambtenaren - JGLVN) waarlijk aan iemand toegerekend worden, zoals dit zeer vaak gebeurt in allerlei andere takken van het recht" ${ }^{\text {"160 }}$ Aldus "impliceert politieke verantwoordelijkheid volgens ons constitutionele stelsel geen persoonlijke, maar een primair functionele aansprakelijkheid". ${ }^{161}$ Ministeriële verantwoordelijkheid bestaat zo, als risicoaansprakelijkheid $^{162}$, op grond van het objectieve recht ongeacht gevoelen van de op het matje geroepen bewindspersoon. In dit kader bestaat wel de angst dat "juist het overvragen van een minister zorgt dat hij over steeds verdergaande bevoegdheden zal willen beschikken". 163

Zo ontstaat een "normatieve werkelijkheid". 154 In die werkelijkheid kan de "sluimerende functie van politieke verantwoordelijkheid terecht op elk moment in een scherp controlemiddel worden getransformeerd". Daardoor verbetert en vervolmaakt zich het politieke verantwoordingsproces. ${ }^{165}$ Verval en vooruitgang liggen dicht bij elkaar. De kracht van de ministeriële verantwoordelijkheid ligt dus in haar preventieve werking. ${ }^{166}$

Daarmee lijkt de fictie verdwenen. Fictie onstaat trouwens pas als dat lang genoeg wordt gepredikt. ${ }^{167}$

157. I. de Ridder, Ministeriale verantwoordelikheid en politiek-anbtelijke verhoudingen, in: D.J. Elzinga (red.), Minisferielle verantwordelikhed in Nederland, Zwolle, 1994, pp.279-291, kan deze fictie nier ditect beamen.

158. Commissie-Schehtema, a.w. "pp.5/17/36, wind de rếgel van de m. $y_{\text {a }}$ "levende staatkundige werkelijk"

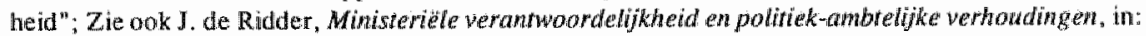
D.J. Elzinga (red.), Ministeriete veranfwoordelijheid in Nederland, Zwolle, 1994, pp. 279-291, i.h.b. P. 279 .

159. E.M.H. Hirsch Ballin tijdens UCV 63-64 d.d. 19 matart 1991, pp.3536-3628, geciteerd in: J.L. de Reede, t.a.p., p. 582 .

160. L. Besseink, t.a.p., p. 200

161. H. Engels, Verrouwensbeginsel of genegenheidsbeginsel, in: PD, nr. 2, 1988, p. 43 .

162. Zie M. Schoonhowen, t. p.,p.94. Auteur ziet overigens wel mogelijkheden voor mitigatie; Ook H.G. Warmelink, Ministeriêle veramwoordelikheid voor ambtelijk handelen, in: D.J. Elzingat (red.). Ministe-

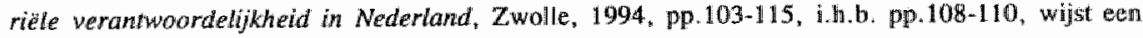
schuldaansprakelijklieid af.

163. J. wander Bij, Publiekrechtelijke verzelfsilandiging: agentschap wersis zbo, in: $13 \mathrm{Wn}, \mathrm{nr}, 2,1993,10.102$.

164. L. Besselink, t.a.p., pp. $200-201$.

165. D.J. Elzinga (1989), t.a.p.,pp.72-73/76, Recenter D.J. Elzinga (1990), a.w., pp. 83-84/87.

166. Zie A. M. Donner, Verantwoordelikheld: redactionelekantekeningen, in: RM Themis, 1987, pp.365366.

167. Vgl.F.A.M. Stroink, a.w., p.141. Auteur windt bet onjuist te spreken over fictic als een bepaalde notie in feite is verouderd. Zijns insziens moet dan niet worden stil gehouden bij een constatering, als fictieve of formele verantwoordelijkheid, maar dient het achterhaalde te worden bijgesteld. 
Het desondanks blijven werken met de fictie gebeurt toch. Nu valt ook wel te leven met een fictie. Soms vervult de fictie zelfs een nuttige functie. ${ }^{16}$ Namelijk, de fictie van ministeriële verantwoordelijkheid krijgt steeds meer erkenning. Daardoor lijkt het niet altijd zo rechtvaardig, dat een minister ter verantwoording wordt geroepen voor gebeurtenissen ver van politiek Den Haag. Wel komt zo mogelijk het feitelijk invloedsvacuüm aan het licht. Dat leidt onder meer tot een behoefte, hier en daar, aan participatie van burgers.

In beeldende taal betekent de nuttige functie van dit invloedsvacuüm het doorbranden van een stop. Die stop kan daar meestal weinig of niets aan doen. Maar het doorbranden is wel het signaal voor het feit, dat het systeem niet meer goed functioneert. ${ }^{169}$

Van een fictie is sprake "als iedereen het er over eens is dat de stelling 'de minister is verantwoordelijk" letterlijk genomen best onwaar kan zijn, maar men bereid is om het ongeloof onder voorwaarden op te schorten en dan te doen alsof de fictie waarheild is ". . ${ }^{170}$ Deze formule resulteert in een "zorgvuldig uitgevoerd toneelstukje". Het betekent een "oproep om verandering aan te brengen in de gang van zaken, om controle die verloren was weer te vestigen". ${ }^{171}$ Waar het op aankomt is het vinden van de voorwaarden waaronder men kan doen als of. In elk geval zijn er twee voorwaarden noodzakelijk voor zo'n ruime, fictieve ministeriële verantwoordelijkheid. ${ }^{172}$ Ten eerste moet de dramatische voorwaarde in vervulling gaan. Dat will zeggen het activeren van de ministeriële verantwoordelijkheid vindt zijn oorsprong in iets buitengewoons. Het verantwoordingsproces is dus een noodsprong. Ten tweede voldoet een nuttige en aanvaardbare fictieve verantwoordelijkheid aan de zo genaamde structurele conditie. Die houdt in, dat degenen die verantwoording vragen over voldoende en verschillende sancties beschikken.

Het, in een juridisch systeem, vrij wel onvermijdelijk werken met ficties, geeft natuurlijk wel aanleiding tot extra oplettendheid. ${ }^{173}$ Uitholling van effectiviteit van controle is mogelijk. Kortom, voorzichtigheid is geboden. Vooral als de fictie dubbel is. Met andere woorden, "de minister weet niet wat er op zijn departement gaande is en niemand zal hem dit verwijten bovendien", als hij maar zijn best heeft gedaan. ${ }^{174}$ Dáar wringt de schoen.

168. P.J. Langenberg, Gebonden zelfbeheer: over de verhouding regering, parlement en functionele organen, t.a.p. pp. 158-159.

169. G.H. Scholten, De fictie van verantwoordelijkheid als grondslag vaor democratisch bestuur, t. a.p., p. 250 e.N.

170. W.J. Witteveen, Opinie: De ministeriële verantwoordelijkheid, Visies op een nuttige functie, in: PD nr. 4,1988 , pp.127-132, i.h.b. p. 130 .

171. W.J. Witteveen, t.a.p., p.130; Gebaseerd op H.R. van Gunsteren (1986), t.a.p., p.37.

172. W.J. Witteveen, t.a.p., pp.130-131.

173. L.J.A. Damen, a.w., p.603.

174. Th.C. de Graaf, t.a.p., p.43. 


\subsubsection{AANPASSEN AAN ACTUALITEIT?}

Juridische doctrine en parlementaire praktijk lopen niet synchroon. Daarom liggen voorstellen op tafel om de politieke wil te juridificeren. Invoering van beperkte ministerièle verantwoordelijkheid wordt overwogen. Verbeten voorvechters ${ }^{175}$ er van achten een volledige ministeriële verantwoordelijkheid, die de rotsvaste relatie tussen aansprakelijkheid en beìnvloedingsbevoegdheden veronachtzaamt, overduidelijk onhanteerbaar en daarmee ontoelaatbaar." "Voor het optreden van organen waarop de minister geen invloed kan uitoefenen, en aan wite hij geen opdrachten en instructies kan geven, kan hij niet verantwoordelijk worden gesteld." 176 De minister wordt dus "slechts verantwoordelijk gesteld voor datgene waarop hij feitelijk invloed heeft kunnen uitoefenen". " 77

Het belang van de ministeriële verantwoordelijkheid ligt kennelijk in datgene "wat de minister zelf doet of kan overzien". ${ }^{178}$ In deze zienswijze wordt de minister slechts verantwoordelijk gehouden voor eigen doen en nalaten. Dat omwat vaststelling en, daarnaast, het doen uitvoeren van algemeen beleid. Dit vloeit voort uit de aard van het verantwoordelijkheidsbegrip. Hier wordt miskend dat, even als in andersoortige rechtssferen, de minister verantwoordelijk is voor andermans daden als of het zijn eigen daden zijn. Dit geldt onder de voorwaarde dat de minister beïnvloedingsbevoegdheden heeft ten aanzien van het doen en laten van die ander. Een minister is niet voor niets hoofd van zijn departement. Vreemd is dat aanhanger van bedoelde opinie hier "niet de bevoegdheden beslissend acht voor de omvang van de ministeriële verantwoordelijkheid". 179 De ministeriële verantwoordelijkheid vindt har grondslag in positief recht. Zij heeft dus een juridisch karakter.

Een waarschuwing tegen de beperkte draagkracht van de ministeriële verantwoordelijkheid wijst er op dat aldus "de functie van de ministeriele verantwoordelijkheid voor het

175. M. Scheltema er H.G. Lubberdink, t.a. p., pp. 10-14; M. Scheltema (1977), H.a.p., P. 335; H.G. Lubberdink, a.w., pp.143 148; A. Mulder, Zelfstomdige bestuuradiensten, prendviezen voor de VVSR van Belgüe en Nederland, Zwolle, 1980, p.71 e.V.; F.A.M. Stroink (1978), a.,W., pp. 140-142; D. Simons, t.a.p.., pp.81 $-83 ;$ Th.C. de Graaf, t.a.p., pp.37/41. Auteur vindt, in dogmatisch opzicht, een strakke interpretatie vam de m.w. wenselijk. D.w.z. "een nieuwe bezem makk better schoon dan een door vuil angetast exemplaar" "Toch wijst z.i. "de politicke realiteit in een andere richting en gebiedt wellicht om naar alternatievem te zoeken". Zie Th.C \&e Graaf en F.C.M.A. Michiells; Ower bowwen en wertronwen; stads. en bestuhrsrechtelijke opmerkingen bij het rappont wan de parlementaire enguêtecommissie bouwsicsidies, in: NJB, nr. 15, 16 april 1988, pp .493-500, i.h. b. p.499; M.E. Tunrenhout, t.a.p., p. 39; H. van Marseween, De reidans der niet-verantwoordeliken, ta.p.., p.1516, als medie Mer recht. minder minister, in: NJB, 16 april 1988 , nr. 15, pp.485-486.

176. M. Scheltema (1977), t.a.p., p.335.

177. M. Scheltema en H.G. Lubberdink, t.a.p., p.13; Overigens lijkt Lubberdink entgszinis in contradictie met zich zelf. In werk van latere datum, H.G. Lubberdink, t.a.p. p.12, merkt hij op dat "onder de mogelijkheid on te beirnwloeden niet moet worden verstaan de feitelijke mogetijlkheld om dat te doen, maar de juridische bevoegdheid daartoe". Dit moet dan warschijnlijk toch worden opgevat in de zin dat de ministeriele verantwoordelijkheid "nathurlijke grenzen" heeft (p.130).

178. F.A.M. Stroink, a.w., p.141.

179. H.G. Lubberdink, t.a.p., pp.11-12. 
in de greep houden van de gehele bestuurlijke organisatie wordt ondergraven en bovendien de parlementaire controlle wordt bemoeilijkt". " 80

\subsubsection{ZELFSTANDIGE BESTUURSORGANEN ALS SURROGAAT?}

Bewust is een zeker streven er op gericht een overdaad aan overheidstaken onder de ministeriële verantwoordelijkheid weg te schuiven. Dit krijgt vorm via functionele decentralisatie. Daarmee is de instelling van zelfstandige bestuursorganen verklaarbaar. ${ }^{181}$ "Tegenover hiërarchie en integratie langs een over all-ministeriële verantwoordelijkheid staat een nieuwe conceptie van hiërarchie. Het politiek primaat op centraal niveau (regering en parlement) stelt de randvoorwaarden en de intersectorale communicatie vast. Daarbinnen vindt integratie door zelfbeherende beleidsbepaling plaats, die reageert en anticipeert op de problemen van de bestuurspraktijk." 182

Kritiek op dit concept van zelfstandige bestuursorganen blijft, weliswaar, niet uit. Zo is er angst voor een gebrekkige samemhang in (algemeen) beleid. Daaraan inherent is de vrees, voor een onoverzichtelijk geheel van overheidsorganen, uitgesproken. ${ }^{183}$ Daarnaast lijkt het een misvatting te denken, dat door functionele decentralisatie de democratische controle groter wordt. Anders gezegd, je raakt "door te dlecentraliseren de beperkte controle niet kwijt, maar je verplaatst het naar de organisatie die de taken er bij krijgt" . 184

Weerstand bestaat ook tegen de eng-juridische interpretatie die voorstanders van zelfstandige bestuursorganen aanhangen. Dit heeft tot gevolg dat de "botsing tussen de feitelijke verantwoordelijkheid van de minister voor feitelijk ambtelijk handelen enerzijds en de

180. J.L. Boxum, Zelfstandige bestuursorganen en de greep van ministers op de bestuarlijke organisatie, in: J.W.M. Engels, C. Lambers, E. Niemeijer, M. Scheltema, K.F. Schuiling en R.L. Vuçsân, De rechusstaat herdacht, Zwolle, 1989, p $_{2} 257$; Ondanks zijn voorzichtigheid ziet auteur het op zich wel ats voordeel, dat voor de gedragingen wan zbo"s geer integrale politieke ministeriële verantwoordelijkheid nodig is. Voor een positieve bijdrage van zbo's aan een goede werking van de ministeriêle verantwoordelijkheid moet wolgens Boxum wel aan twee voorwatrden worden woldaan. Ten eerste, de wormgeving is primair afhankelijk van de kenmerken wan de taak van het zbo. Bij complexe takstelling is het moeilijk vooraf centrale beslispunten in het beleidsproces helder in wetgeving vast te leggen. Anders dan bij de duidelijke verantwoordelijkheidsverdeling bij cenwoudige taken, noodzaakt complexe taakstelling nog steeds tot ruime interventiemogelijkheden van de minister met overbelasting en onduidelijke: afbakening van verantwoordelijkheden als gevolg. Ten tweede, de betrokken minister mag zelf geen zitting nemen in het bestuur van thet betreffende zbo. Hoogstens stan bem bevoegdheden tot benoeming van bestuur e.d. ter beschikking. Aldus J.L. Boxum, Ministeriële verantwoordelijkheid en zelfstandige bestuursorganen, in: D.J. Elzinga (red .) Ministeriële veramwoordelijkheid in Nederland, Zwolle, 1994. pp. 257-277, i.h.b. pp. 274-275.

18. M. Scheltema en H.G. Lubberdink, t.a.p. ,pp.8-1 1 ; H.G. Lubberdink, t.a.p., pp. 153-181; J.L. Boxum, a.w., pp.255-181; J.L. Boxum, J. de Ridder en M. Scheltema, a.w. pp.65-76; F.A.M. Stroink, Leestafel; Boekbespreking, in: TwO, nr. 18, 21 oktober 1982, p.544-546; C.M. van den Hoff en R. de Gront, a. w..p. 2 .

182. P.J. Langenberg (1985), t.a.p., pp.147-179, i.h.b. p. 163.

183. J.M. Kan, Boekbespreking H.G. Lubberdink, in: NJB, nr.30, 10 sept. 1983, pp.998-999.

184. W.J. Witteveen, Opinie: ministeriële verantwoordelijkheid; visies op een nuttige functie, t.a.p., pp. 128129 
ministeriële verantwoordelijkheid als vertrouwensregel anderzijds" niet herkend wordt. Ergo: "De oplossing die zelfstandige bestuursorganen heten te bieden maken anderen feitelijk verantwoordelijk, zonder dat zij daarop door het parlement in voldoende mate kunnen worden aangesproken". ${ }^{185}$ Dit bezwaar kan even wel worden ondervangen door het ontwikkelen van alternatieve controlemechanismen.

Voorts is frappant te constateren dat aan het door velen als voornaamst geziene motief voor functionele decentralisatie, namelijk de noodzaak van beperking van de omvang van ministeriële verantwoordelijkheid, wordt voorbij gegaan. Functionele decentralisatie wordt namelijk gezien "als goede aanvulling op grondwettelijke bestuursorganen, in die gevallen waar de directe beïnvloedingsmogelijkheden van het politiek bestuur kunnen vervallen of verminderen". ${ }^{86}$ "Het "behoorlijk functioneren van de ministeriëlle verantwoordelijkheid wordt als het ware verondersteld" " 187

Toch wordt instelling van zelfstandige bestuursorganen, ter vermindering van de omvang van de ministeriële verantwoordelijkheid, bepleitbaar geacht.. ":s Zeker met in het achterhoofd de gedachte, dat ministeriële verantwoordelijkheid maar een van de middelen is, waarmee het parlement het doen en laten van het bestuur kan beïnvloeden.

Naast het uitoefenen van controle achteraf heeft de volksvertegenwoordiging medewetgeven als taak. Het volledig uitoefenen van beide taken is een illusie. De ene gaat altijd ten koste van de andere. Dat de taakstelling regelmatig wisselend is, hangt samen met fundamentele factoren. Namelijk, "het verzorgen van voldoende legitimatie en het instandhouden van het politieke vertrouwen, beïnloeden afzonderlijk en in onderlinge relatie in hoge mate de manier waarop het parlement zijn rijkgeschakeerde taakstelling invult".

Nota bene, een aantal auteurs vindt voornoemde traditionele gedachte van de "medezeggenschap "van de volksvertegenwoordiging in het parlementair stelsel, dat wil zeggen "een regeringsstelsel, dat beheerst word door een complex van regels, dat de verhouding tussen regering en volksvertegenwoordiging op tal van terreinen vorm geeft, steeds in verschillende gedaanten, maar met als gemeenschappelijk kenmerk de mogelijkheid voor het parlement om regeringsbesluiten in beslissende zin te kunnen beïnvloeden", nauwelijks nog bevredigend. ${ }^{190}$ Immers, ook bij de ene taak van medewetgeven ligt de parlementaire controle snel op de loer. En de andere taak, te weten controleren, reikt tegenwoordig verder dan eigenlijke (formele, financiële) controle zelf.

185. V.F. Thunnissen, Ministeriële veranwwordelikheid. een kwestie van vertrowwen, in: A. W. Heringa, R.E. de Winter en W.J. Witteveen, Staatkundig jaarboek 1983-1984, Zwolle, 1983, pp.49-59, i.h.b. pp. $54-55$.

186. Functioneel bestuur, waarom en hoe?, TK $1988-1989,21042$, nr.2, p.7.

187. H. G. Lubbendink, Kronieken bestuwrijke organisatie, in: NTB, nr.8, 1989, p.278.

188. Met name H.G. Lubberdink, a.w., pp.145-147.

189. D.J. Elzinga en H.G Warmelink, a.w., p.47.

190. D.J. Elzünga en H.G. Warmelink, a.w. pp.12/25. 
Vandaar is het volgende onderscheid misschien reëler.

Ten eerste is het parlement "juridisch verplich" tot bepaalde samenwerking met de regering. ${ }^{191}$ Denk aan het vaststellen van de begroting en de medewetgevende taak. Hierbij moet worden bedacht dat "financiële autorisatie tot inhoudelijke zeggenschap" is geworden. ${ }^{192}$ Kennelijk is de huidige betekenis van het begrotingsrecht het stadium van repressieve controle voorbij. Zij koerst regelrecht aan op, zo vroeg mogelijke, structurele beleidsbeïnvloeding. Vérdere versterking van de rol van het parlement ${ }^{193}$ ter zake wordt voorgestaan. Aan de jaarlijkse begroting van elk departement is mogelijk eer artikelsgewijze vastlegging van beleidsvoomemens toe te voegen. ${ }^{194}$ Daarmee valler deze beleidspunten uitdrukkelijk binnen de jurisdictie van de volksvertegenwoordiging Met andere woorden, om "te verzekeren dat de politieke hoofdlijnen de instemming var de Kamer hebben, kunnen deze tevoren in een nota aan de Kamer worden neer gelegd". ${ }^{195}$ Gelet op de huidige ongelijkheid tussen beide organen die wetgever heter (regering en volkswertegenwoordiging), is het pleidooi bekend de zgn. Meerenberg doctrine te verlaten en "de zelfstandige verordenende bevoegdheid van de regering wee te erkennen en andere middelen te bedenken om de regering bij de uitoefening van di bevoegdheid te controleren. Immers, de huidige zwakke positie van het parlement al medewetgever falsificeert in te sterke mate de werkhypothese (de fictie) dat alle wetge ving en delegatie van regelgeving door de volksvertegenwoordiging wordt gelegitj meerd." "196. Een dergelijk pleidooi voor delegalisering gaat vrij ver. Zij maakt in el geval duidelijk dat de medewetgevende positie van het parlement aan versterking toe is

Ten tweede kent de volkswertegenwoordiging een "vrijwillige samenwerking". Die betre "alle overige invloed op het regeringsbeleid, waarvoor ook wel de term meeregere wordt gebruikt". ${ }^{197}$ Bij beide soorten samenwerking is de politieke controle inval: hoek. Uit deze visie spreekt dus duidelijk de, in paragraaf 3.2 genoemde, behoefte ac controle nooraf.

Aan de eigenlijke, officiële, traditioneel toebedeelde regelstellende taak van het parleme mag in beginsel niet worden getornd. Dat dit slechts een principe is, laat de praktijk zies Inmers, de centralle overheid kan uiteindelijk niet alles tor in detail regelen. Dat is of

191. D.J. Elzinga en H.G. Warmelink, a.w., p.25.

192. D.J. Elzinga en H.G. Warmelink, a.w. . Pp.27-28.

193. Ook o.a. J.A. van Schagen, De Tweede Kamer der Staren-Generaal. Een staatsrechtelijke studie on haar orgamisatie en werkwijze, diss. RUU, Utrechi/Zwolle, 1994, waarschuwt tegen verzwakking w de positie: wan het parlement. Daarom beveeit auteur aan structureel aandacht te besteden woor de wet vingsi ${ }_{n}$ controlle- en begrotingstaken van de Tweede Kamer. Bovendien moet bij behandeling van spe fieke wetgewing meer belangstelling komen voor kader waarin de wetgeving thuis hoort.

194. Commissie-Wiegel, Naar kerndepartementen, kiezen woor een hoogwaardige en flexibele rijksdiek TK 1992-1993, 21427, nr.52, p.26; Ook E.J. Janse de Jonge, Het budgetrechi; Rechtsvergelijken studie naar de begrotingshandeling door het parlement in de VS, Engeland en Nederland, diss. KL Zwolle, 1993.

195. E.C.M. Jurgens, De mythe van Meerenberg; Over de betrekkelike legitimatie die witgaat van medew geving door de Staten-Generaal, in: NJB, nr.39. 4 now. 1993, pp.1381-1386, i.h.b. p.1382.

196. E.C.M. Jurgens, t.a.p., p.1386.

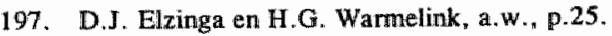


mogelijk. Maar bovenal onpraktisch. Vandaar is het geoorloofd dat op de werkvloer zelf nadere regelstelling plaats vindt. Hierop wordt summier ingegaan in paragraaf 3.3 .3 .

Wat de controlerende taak van het parlement ${ }^{198}$ aangaat, is het volgende essentieel. In praktijk is het parlement niet bij machte een stelselmatige controle op het totale bestuurlijk handelen uit te oefenen. Anders dan voor het toezicht op het algemene beleid, is het parlement niet de meest geschikte instantie voor het precies nagaan van beleid(suitvoering) in concreto afkomstig van het veelvormig overheidsbestuur. ${ }^{199}$

Weliswaar, tegenwoordig is niet meer de oude triasleer actueel. De doctrine van het duaal stelsel heeft de primaire plaats ingenomen. Dit betekent dat de rechter de volksvertegenwoordiging te hulp schiet. ${ }^{200}$ Beiden controleren gezamenlijk het bestuur. Beleidsvormende en -voorbereidende taken van de volksvertegenwoordiging worden losgekoppeld van haar controletaken. Deze tweesplitsing in bestuurs/beleidsmacht en controlerende macht heeft ondere andere de volgende consequenties. ${ }^{201}$ Volkswertegenwoordiging en rechter controleren samen het maken van beleid. Zij zijn elkaars bondgenoten zonder enige concurrentie. Art. $12 \mathrm{AB}$ verdient interpretatie in het licht van de wissellwerking tussen volkswertegenwoordiging en rechter. Regelgeving en uitvoeringshandelingen worden het zelfde beoordeeld, nu deze wat betreft controle niet fundamenteel verschillen. De rechter wordt zo min mogelijk door het bestuur benoemd. De volksvertegenwoordiging moet zich er steeds van vergewissen voldoende vrijheid te bezitten om het bestuur behoorlijk te kunnen controleren. Daartoe dient zij ook voldoende toegerust te zijn. Dat wil zeggen, zij mag geen beroep doen op beleidsambtenaren.

Maar ondanks de, op deze wijze, versterkte poot van het controlerende lichaam, schiet het toezicht op het bestuur nog vaak te kort. En dat terwijl de controlerende taak van het parlement toch nadruk, ten opzichte van haar medewetgevende taak dient te krijgen. Gesproken wordt wel van "een mogelijke substantiële versterking van de controlerende taak van de Tweede Kamer ${ }^{2021 "} .{ }^{203}$

198. Over de controlerende tagk van het parlement in hed hicht wan de oude trassleer, J.N. J. van den Broek. K. Groenveld en I. A. de Hoog (red.), Dewocratie scheiding der machen, geschrift Haya wan Somerenstichting en professor mr B.M. Telderstichting nr.64" 's-Gravenhage, 1987.

199. T. Koopmans, De rol van de wetgever, a. a. . p.232.

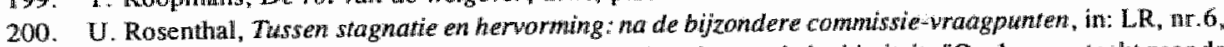
1992, pp. 202-208, i.h.b. p.204, vreest steeds verder afnemende legitimiteüt. "Op de speurtocht naar de legittmiteit komen we logischenwijze bij die rechterlijke macht kerecht. Het toegenomen beroep op de rechier levert even Iogisch vroeg of laat het zelfde soort problemen op als bij bestum en parlement: hooggestemde verwachtingen, overwaging, frustaties over de resul taten."

201. N.S.J. Koeman, Over beleid en controle; Op zoek naar de opwolger van de triasheer, in: NTB, nu. 3 , 1989, pp.77-78.

202. Over de moeizame positie van de Eërste Kamer, als controllerend en medewetgevend organ, $F$, de Vries, De politieke veranwoordelijkheid en hel functioneren wan de Eerste Kamer" in: D.J. Elxinga fred.). Ministeriele werantwoordelijkheid in Nederland, Zwolle, 1994, pp. 149-175.

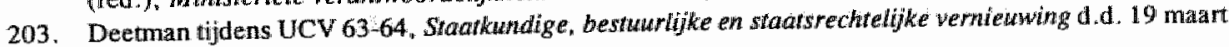
1991, p. 3587. 
Vandaar richt de aandacht zich op het gebrek aan controle en de verschillende, wellich gelukkiger, gedaanten van ministeriële verantwoordelijkheid.

Het gapende gat van parlementaire controle achteraf wordt mogelijk gevuld door deel name van belangstellende burgers ${ }^{204}$ in het bestuur.

Bovendien kan beperking van de ministeriële verantwoordelijkheid voordeel opleveren De minister en zijn staf zijn gedwongen hun beleid expliciet aan te geven. Dit met oo op heldere afbakening van bevoegdheden en verantwoordelijkheden van beleidsbepalend en beleidsuitvoerende eenheid. Beleidskeuzen en -methodieken moeten voortdurend e uitdrukkelijk worden geformuleerd. Kortom, een adequate aansturing van zelfstandig bestuursorganen door een betrokken departement is onontbeerlijk. "Slordige of amate ristische aansturing is immers levensgevaarlijk voor de effectiviteit op wat langere te mijn, en leidt bovendien geleidelijk tot beleidsresistente uitvoeringsorganen, die $z$ mergens meer iets van aantrekken, zoals de erosie in de sociale zekerheid heeft lat zien." 200

Voor zo'n professionele sturing zijn bepaalde controlevoorzieningen noodzakelijk. T verzekering van een goede koppeling tussen beleidsbepaling en -uitvoering is standa: disering er van nodig. De volgende, belangrijke instrumenten zijn goed te realis ren. ${ }^{206}$ Bovendien geven zij een aanzet tot het opstellen van een "kwaliteitshandves woor zelfstandige bestuursorganen ${ }^{207}$, waarvan invoering mogelijk leidt tot scheidi van beleid en uitvoering, koppeling van budget en prestatie, overheidskwaliteitsnormeri en duidelijke communicatie. ${ }^{20 s}$

Vooraf nog een woord over de essentie van goede, open communicatiekanalen in openbare sector. In de huidige maatschappij, waarin de overheid 'slechts" een rol spe tussen vele andere actoren in een complex netwerk, moet de overheid haar tradition taak als alles bepalende staat opgeven en inruilen voor de rol van primus inter pares zelfis pur participant. Hierbij blijft de overheid nog wel aangewezen om een rechtva dige, veilige en democratische maatschappij te waarborgen. In een dergelijk verandere overheidsklimaat bestaat meer ruimte voor zelfsturend vermogen van de maatschapl bij voorbeeld door deregulering en decentralisatie. "De rol van de overheid wordt eri

204. H.G. Lubberdink, a.w. pp. 172-174; Daaremtegen verkiest M. Scheltema (1977), L.a.p., pp. 344-: hier belanghebbende burgers; P. de Haan, G. Th. Drupsteen en R. Fermhout, m.m.v. C.S. Valkenb Bestuursyecht in de sociale rechrsstaat; Ontwikkeling. organisatie en instrumentarium, di.1. at herziene druk, Deventer, 1987, p.137, spreken zo van belangenorganisaties; F.A.M. Stroink (19 t.a.p., p.545, vraagt zich af of belangstellenden wel in voldoende mate aanwezig zijn. Daama.ast grens tussen beiden soms onduidelijk. En het gevaar bestaat dat een belangstellende als stroman geert:

205. R.J. in "id Veld, Normen, in: BB, nr.5, 4 febr. 1994, p.13.

206. Cie-Scheltema, t.a.p., pp.50-51; Cie-Wiegell, t.a.p., pp.22-23; A. wan Bram, Verniewwing va rijksdienst" 'a continuing story" in Nederland, in: BWn, nr.4, 1993, pp.225-233, watarschuwt te tegen een al te fraaie voorstelling van zaken. Hij vreest dat bedoelde bewaking smechamismen problt van bureaucratie, coördinatie en controle met zich meebrengen.

207. Commissie-Wiegel, a.w., p. 30.

208. D.P. Noordhoek, Van Nexf Steps naar verzelfstandiging, van Citizin's Charter naar Kmaliteitshan ren, in: Beleidsanalyse, nr. 3-4, 1993, pp. 15-20, i.h.b. p. 20 . 
van regisseur die niet zo zeer "zorgt voor", als wel "zorgt dat"." 209 "Zij schept het rechtsstatelijke en democratische kader van handelen. "Waar proces- en uitvoerende verantwoordelijkheden worden gedecentraliseerd en/of (intern of extern) verzelfstandigd, neemt uit rechtsstatelijk oogpunt het gewicht toe van autorisatie vooraf en verantwoording achteraf op hoofdlijnen. Dit vereist naast allereerst een heldere toedeling van verantwoordelijkheden, een duidelijke(r) articulatie van sturing en explicitering van sturingsparameters. Die stellen op hun beurt ook hoge eisen aan kwaliteit van de verantwoordings/sturingsinformatie die tussen betrokken partijen wordt uitgewisseld. [...] Uit vorenstaande vloeien vooralsnog als hoofdlijnen van het beleidskader voor de informatievoorziening in de openbare sector voort: 1 . zorgen voor een probleemloze uitwisseling van informatie binnen en met de overheid; 2 . zorgen voor stroomlijning en explicitering van de vraag naar sturingsinformatie, rekening houdend met de tendentie naar meer eigen verantwoordelijkheden voor overheidsmanagers, naar meer bevoegdheden voor lagere overheden en naar sterkere organisatorische scheiding van beleid en uitvoering (verzelfstandigingen) ${ }^{210} ; 3$. zorgen voor algemene toegankelijkheid van overheidsinformatie, rekening houdend met toenemende technische mogelijkheden en stijgende verwachtingen van burgers en bedrijven ten aanzien van serviceniveau." 211 Dit in ogenschouw nemend, zijn de sturingsinstrumenten en controlevoorzieningen te noemen.

Ten eerste is een informatieplicht op te leggen aan een uitvoerende dienst. Zie paragraaf 3.2.2. De zo genaamde uitvoeringstoets is een uitstekend middel om inlichtingen te verstrekken. Daarin kunnen, op grond van opgedane ervaring, ook nieuwe beleidsvoornemens worden verwerkt. Voorwaarde voor het optimaliseren van de beleidsterugkoppeling van uit de werksituatie naar het denkplatform ten departemente, is wel dat de beleidsbepalende eenheid over voldoende expertise beschikt om de uitvoeringstoets te kunnen beoordelen. ${ }^{212}$ Bovendien mag de beleidsbepalende instantie, en dit geldt omgekeerd evenredig ook voor de uitvoerende instantie, niet vooringenomen zijn en evenmin bij voorbaat de van uit het werkveld aangedragen suggesties weg wuiven. ${ }^{2 \Downarrow 3}$ De uitvoeringstoets is openbaar en wordt door de verantwoordelijke minister meegestuurd naar het parlement. Met oog op beleidsevaluatie is nog te overwegen, dat - on hiaten, omis-

209. Jaaroverzicht informatiewaorziening 1993, TK 1993-1994, 23861, n1:1-2, pp.6/9

210. Bij voorbeeld via de herkenbarheid van de oveneid vergrotende kwaliteitssystemen, citizens charters of informatiestatuten ('checklist" omvattende randwoorwarden voor verzelfstandiging). Met laatst genoe md informatiestatuut " wordt op hoofdingen een woor de doorzichtigheid en democratische controle belangrigke stroomlijning van functionele decentralisatie be reikt, terwij i verdere uibbouw en toespitsing in elk concreet gevall wan verzelfstandiging mogelijk blijft". Zie Jaaroverzicht informatewoorziening 1993. TK $1993-1994,23861$, nrs. 1-2, p.13, dat hier de algemene bepalingen opgenomen in Gemeenteen Provinciewell ten voorbeeld stelt.

211. Jaaroverzicht informatievoorziening 1993, TK 1993-1994, 23861, mrs. 1-2, pp.11-12, zie ook pp.12-15.

212. R.J. un 't Veld, De kerwakenbenadering bij de Rijksoverheid: anderwerp wan gesprek, in: C. Sips en P.H.J. Vrancken, De kermakenbenadering bij de Rijksoverheid, 100-rappon nt.59, "S. Gravenhage. april 1994, pp.7-15, i.h.b. p.12.

213. J.N. Breunese en J.W. van der Dussen, De scheiding wssen beleid an witwoering, in: Beleid sanallyse, n. 1/2, 1994, pp.6-11, i.h.b. p.8, wijzen hier op tegengestelde belangen tussen beleidsbepalers en uitwoenders, wardoor hun onderling vertrouwen kan ontbreken. Om politieke wil meer met vitvoerende kracht in overeenstemming te brengen achten auteurs uitvoeringstoetsen niet voldoende. Informele werkbezoeken en weel tussentijdse communicaitie gelden hier als aravullingen. 
sies en dergelijke in regelgeving te elimineren - beleidsuitwoerders de betrokken minister adviseren omtrent verbetering wan werkzaamheden ten behoeve van het betreffende beleid. Deze adviezen kunnen in een uitvoeringstoets worden verwerkt, maar ook op andere wijze aan een minister worden medegedeeld. Een voorstel luidt om "een mimister in de desbetreffende wet de bevoegdheid te geven om onder owerlegging van een advies van een uitvoeringsorgaan bij ministeriële beschikking met een $z g n$. voorhangprocedure aanpassingen te bewerkstelligen. Zo'n beschikking zou slechts twee jaar mogen gelden, daarna moet langs de formele koninklijke weg de regelgeving worden aangepast ${ }^{\prime 3} .214$ Ten tweede is te denken aan een jaarlijks uitvoeringscontract. Dit contract betreft een zo: concreet mogelijke specificatie van, door het uitvoerend orgaan, te leveren prestaties. Ook dit uitwoeringscontract moet, via de minister, aan de Tweede Kamer worden over legd. ${ }^{215}$ Dat versterkt de beleidsbepalende rol van het parlement ten aanzien van de beleidsvoorbereiding.

Ten derde moet een zelfstandig bestuursorgaan een jaarverslag opstellen. ${ }^{216}$ Daarii staan financiële en beleidsmatige gegevens. Zij vinden basis in het uitvoeringscontract. Ook is te denken aan het in een jaarverslag opnemen van een "schandaalparagraaf", me vermelding van het aantal klachten, welke klachten volgens een onathankelijke ombuds achtige figuur terecht zijn ingediend, en hoeveel aan tegemoetkomingen is betaald, 20 In praktijk blijkt bij de betrokken departementen behoefte te bestaan aan informatie ove het aantal klachten over zelfstandige bestuursorganen en de inhoud daarvan. ${ }^{218}$

Vooral wat betreft adequate informatieverschaffing op financieel gebied worden aanbevo len ${ }^{219}$ : expliciete formulering van subsidievoorwaarden, overlegging accountantsver klaring en regeling van afspraken via controleprotocollen. Speciaal met oog op adequal verslaglegging van het reilen en zeilen van een zelfstandig bestuursorgaan kan het handi zijn om accountant, controller en twee daartoe aangewezen, regelmatig te vervangen departementsambtenaren te verenigen in een apart audit-comité, welk comité aan d minister rapporteert. ${ }^{220} 221$ Vooral in de jaren 1985 tot en met 1992 heeft het bij d

214. Aldus J.N. Brewnese en J.W. van der Dussen, t.a.p., pp.8/10, die hierin meer heil zien dan in de in t Kamer woorgesane (naar helaas veel detaildiscussies in kamercommissies - wararin volgens auteurs on eens plaats zou moeten zijn voor de leiding wan een zbo i.p.v. de per definitie aan het woord kornem betrokken bewindspersoon opleverende, moeizame en tijdrovende) weg van opstelling wan forme wetten i.p.v. totstandkoming van allerlei amwb's.

215. Commissie-Wiegel, a.w., p.26.

216. E. Boneschansker en H. de Groot, Gutrumenten bij sturen op afstand, 100-publ. nr. 36, "s-Graw., 199 p. 22 .

217. C.W. wan der Dussen, Oude en niewwe overheidsmonopolies, in: OMn, nr. 12, 1994, p 318. Auteur pl er voor om aan clienten, van in het bijzonder monopolistische (privaatrechtelijke) zbo's, klachtrecht geven en ook recht op een financiële tegemoetkoming ter compensatie van zijn of haar ergenis on disfunctioneren van dergelijke zbo's.

218. Algemene Rekenkamer, Zbo's en ministeriële verantwoordelijkheid, TK 1994-1995, 24130, nr.3, p.1

219. Min. $v$. financië $n$, centrale accountantsdienst projectgroep functionele decentralisatie, Vrijheid in geb, denheid, a.w. p.2.

220. J.N. Breunese en J.W. van der Dussen, t.a.p., p.10.

221. In het kader van thun strevem naar accountability van overhedlen, juichen W.J. Kuijken en $B$. van $\mathbb{N}$ Overheid: Make yourselfaccountable!, in: De accountant, nr.4, dec. 1994, pp. 268-269, dergelijke aul commissies toe. Auteurs geven wel aan dat het hele proces van het meten van doelmatigheid, rechtm 
meeste destijds reeds gerealiseerde verzelfstandigingen ontbroken aan financiele berichtgeving. "De informatie die over verzelfstandigde diensten in begrotingen, jaarverslagen en dergelijke (aan het eind van bedoelde periode - JGLvN) beschikbaar is, is in het algemeen summier. Gegevens over de produktie of prestaties zijn van slechts weinig diensten beschikbaar." 222 Dat bij daarna tot stand gekomen verzelfstandigingen de situatie niet aannemelijk is veranderd, blijkt uit een rekenkameronderzoek, waarin onder meer aandacht bestaat woor het per 1 mei 1994 verzelfstandigde kadaster. Vermeld wordt dat "het verzamelen, uitwisselen en benutten van gegevens over het beleid en over de effecten van beleid als een zwak punt naar voren komt. Dit bemoeilijkt de bijstelling van beleid, als de noodzaak daartoe door het gebrek aan informatie al aan het licht komt" ${ }^{223}$. ${ }^{224}$ Vandaar is meer aandacht voor verplichte ${ }^{225}$ en volledige verslaglegging van financieel beheer en andere verantwoordingsinformatie niet overbodig.

Even wel, bij deze trits aandachtspunten, er toe leidend dat beleidsuitvoerders en beleids bepalers wederzijds informatie uitwisselen waardoor passend beleid kan worden geconstrueerd, moet een belangrijk aspect niet worden onderschat. Om de nodige koppeling tussen budget en prestatie te realiseren, is inderdaad informatie nodig. Waarschuwing geldt echter weer voor te veel informatie. In een sturen-op-afstand-situatie blijkt de kwantitatieve en kwalitatieve informatiebehoefte van de minister groot. Soms irritant groot. Uitvoeringsinstanties zijn formeel dan wel verlost van het juk van ministerieel toezicht. Maar materieel moeten zij het departement nog voorzien van veel gedetailleerde informatie over hun functioneren op afstand van het ministerie. Dat bewindspersonen niet altijd inzichtelijk maken, hoe zij die informatie aanwenden bij het verdelen van financiëlle middelen en bij de controle op de beleidsuitvoering, wordt als onaangenaam aspect van

221. $\rightarrow$

tigheid en effectiviteit (met daaraan gepaard het afleggen van verantwoording daarwoor) binnen bet openbaar bestuur nog 'in de kinderschoenen staat".

222. H. de Groot, H.M.M. Haring, B. Kuhry en E.A. van Noort, Kerngegevens openbalar bestuur: over produkten, personeel en kosten vam publieke diensiverlening, 100-rapport ur .51, " $\$$-Grawenhage, sept. 1993 , pp. 11/63-74, i.h.b. p. 73.

223. Decemberverslag van de Algemene Rekenkamer over 1994, TK 1994-1995, 24045, nrs. I-2, p.4.

224. Tevens negatieve toonzetting ter zake in andere bevindingen van de Algemene Rekenkamer, Zbo "s en ministeriële verantwoordelijkheid, TK 1994-1995, 24130, m.3, pp.26-30/36-44/54. De rekenkamer meldt dat ministers van meer dan de helft van de door hatar onderzochte zbo's tiet de jaarlijkse verantwoordingsinformatie ontvangen. Daardoor kan het ministericel toezicht niet goed worden uitgeoefend. Soms bestaat zelfs geen bewoegdheid woor de betrokken bewindspersoon inlichtingen van een zbo te vragen. Dit is bij 31 zbo's, waaronder de Nederlandse Filim Keuring, het geval.

225. De Algenvene Rekenkamer, Zbo's en ministerielle werantwoordelijkheid, TK 1994-1995, urr.3, p.54, beveelt terecht aan "de toezending van de minimaal noodzakelijke informatie door de organen van de ministeries te formaliseren door opname van de verplichting hiertoe in de desbetreffende regeling. Afhankelijk van factoren als het maatschappelijk belang vam de taak van het orgaan, de omvang van het financieel belang en het al dan niet bezitten van een monopoliepositie, zou het minimal vere iste verantwoording spakket met extra periodieke verantwoordingsinformatie kunnen worden uitgebreid. Het us van belang dat ministers zorgvuldig kennisnemen van de hun toegezonden informatie en maar aanleiding daarvan, indien nodig, actie ondernemen. Dit houdt ook in dat op de ministeries voorwaarden dienen te worden geschapen om de binnengekomen informatiestroom te beheren en te bewaken. De verant woordingen vain de commissies en de raden onder de zbo's (die deel uitmaken van de rekeningen wan de ministeries) zouden afzonderlijk in de departementale rekeningen tot witdrukking moeten komen." 
de, op een ingewikkelde overheidstaakuitvoering afgestemde, informatietechnologi ervaren. ${ }^{226}$

Ten vierde is de instelling van een raad van toezicht bij een zelfstandig bestuursorgaa zinvol. $\mathrm{Z}$ ij werkt zowel preventief als correctief. In het licht van checks and balances $k a$ de raad van toezicht tegenwicht bieden aan een mogelijk te sterk interveniërende, vol het optreden wan een zelfstandig bestuursorgaan op hoofdlijnen verantwoordelijke, minis ter.

Ten vijfde dient benoeming, van leidinggevend personeel van een uitvoerend orgaan, $b$ voorkeur voor een beperkte termijn (bij voorbeeld vijf jaar) te geschieden. ${ }^{227}$

Ten zesde zijn bij instellingswet interventiemechanismen te regelen. Hiertoe is een ve waarlozingsregeling geschikt. ${ }^{228}$ Kan een uitvoerend orgaan zijn taak niet aan, dan ingrijpen van hogerhand geoorloofd.

Zo, als omschreven aan de hand van zes aandachtspunten, geven - optimale werkende "interfaces" 229 aan het parlement de mogelijkheid om beleid in grote lijnen te toe sen. ${ }^{230}$ Detailbemoeienis doett namelijk een "mierparlement" ontstaan. ${ }^{23 !}$

Wel is er iets curieus met de terminologie besturen op hoofdlijnen. "Het klinkt plausibe maar de instincten van de volksvertegenwoordigers gaan voortdurend de andere kant ui Kijk naar de vele kamervragen die over details gaan. [...] Omdat politici willen lat merken dat ze er niet voor niets zitten, vindt op dat kleine terrein waarop nog veranderi gen mogelijk zijn, een soort hyperactiviteit plaats." 232 Wat betreft lagere overhed is een dergelijk cynisme te horen. Verkozen bestuurlijke vertegenwoordigers zitten ine

226. Over betekenis informatietechnologie voor verhouding beleidsuitwoerders en -bepalers uitvor V.J.J.M. Bekkers, Nieuwe wormen van sturing en informatisering. Delft, 1993.

227. Denk ook aan bepalingen voor vijfjaarlikse evaluatieverplichtingen, als weer gegeven in o.a. art. Voorstel wet verzelfstandiging en organisatie van het publiekrechtelijk zbo Informatie Beheer Gro TK 1992-1993, 23073, nrs. $1-3, p, 13$, zie Wet verzelfstandiging informatiseringsbank, Stbl. 1993, 7

228. Bij voorbeeld neergelegd in art. 20 Voorstel wet verzelfstandiging en organisatie van het publiekrecl lijk zbo Informatie Beheer Groep, TK 1992-1993, 23073, nrs. 1 3, p.7, idem dito Wet verzelfstandige Informatiseringsbank, Stbl. 1993, 714.

229. Commissie-Wiegel, a.w, p.22. I.c. betreffen interfaces de verticale bindingen tussen beleidsvorn en -uitwoerders. Vgi. R.I. Kuiper, Verzelfstandiging en informatievooriening, in: P.H.A. Frissen e Het managen van werandering door verzelfstandiging, Management Centrum, april 1993, 's-Graver ge, pp.87-104.

230. Volgems H. Wansink, Passende kleren; Kleine departementen zijn miet automatisch beter, in: Interm air, nr.34, 27 ang. 1993, pp.11-13, overigens nog niet voldoende. Z.i. betreffen de randvoorwaa.1 slechts de verhouding ussen beleidsmakers en -nitvoerders, m.a.w. de relatie ambtenaren-ambtena

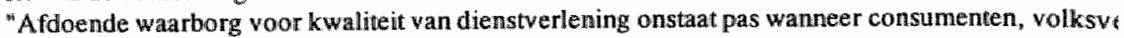
genw oordiging, rechter en markt direct worden ingeschakeld." "Tevens J. Breunesse, Ower her eind. port van de commissie-Wiegel, in: OB, nr.12, 1993, pp.8-13, i.h.b. p.11.

231. D.J. Eppink en H. Spiering, Kamerleden winden dat ze te veel op ambtenaren gaan lijken, in: NRC maart 1992, p.39. Uit een enquête onder de volksvertegenwoordigers blijkt driekwart van de Nederl se parlementariers varig "minder specialisme en meer grote lijnen" te wensem.

232. De nationale ombudsman noemt dat wel de "dynamiek van de pas op de plaats" tijdens interview P. Nieuwenhuijsen, De nationale ombsalsman, in: BBM, 29 januari 1993, pp.4-7, i.h.b. p.7. 
"spagaathouding", omdat besturen op hoofdlijnen "strijdig is met het specifieke karakter van overheidswerk" ${ }^{\text {"t }}{ }^{233}$

De roep om parlementaire controle op hoofdlijnen klinkt fraai, maar lijkt inderdaad een loze kreet. ${ }^{234}$ Ten eerste impliceren hoofdlijnen een (beleids)programma. De identificatie darvan is vaak problematisch. In de meeste gevallen blijki zij een ongrijpbaar samenstel van beleidsregelingen, -verklaringen, -fragmenten et cetera. Ten tweede wordt een helaas, in feite, vermeende rationaliteit van beleidsvoering verondersteld. En ten derde vindt controle langs algemene lijnen basis in een merkwaardige ambiguïteit. Er is een onvoorstelbaar grote hoeveelheid informatie nodig om beleid vast te stellen. Is het niet een vergissing te denken dat met een globale ministeriêle toetsing beleid valt te evalueren? Per definitie wreekt zich de behoefte aan duizendvoudig detaillisme. Ten slotte moet de aard van het politiek bedrijf niet worden onderschat. Daaraan inherent is de hang naar de waan van de dag. Kortom, korte termijnsuccessen spelen een grote rol. ${ }^{235}$

\subsubsection{BEPERKTE MINISTERIËLE VERANTWOORDELUKHEID BIJ ZELFSTANDIGE BESTUURSORGANEN: FEIT OF FORMALITEIT?}

Gieven zo een paar prognoses met betrekking tot een beleidscontrole op grote lijnen een lichtelijk pover beeld. In het algemeen is het de vraag of instelling van zelfstandige bestuursorganen werkelijk "(regering en) parlement tot een andere gedragslijn zal kunnen moveren". ${ }^{236}$ Het aandachtspunt, dat "in het feitelijk functioneren regering en parlement geen rekening houden met de bestaande formele bevoegdheidsverdeling tussen een minister en een zelfstandig bestuursorgaan, en dat de minister volledig verantwoordelijk wordt gehouden voor de (concrete) behartiging van de taak" ${ }^{237}$, is dus de moeite van bestuderen waard.

Inderdaad is met het maken van grote illusies, omtrent het verminderen van de ministeriële verantwoordelijkheid bij het instellen van zelfstandige bestuursorganen, enige voorzichtigheid geboden. Exemplarisch daarvoor is een concluderende uitspraak, die op De Nederlandsche Bank ${ }^{238}$ van toepassing is. "Wanneer een kamermeerderheid van mening is dat een bepaalde taak zelfstandig uitgeoefend dient te worden, ziet die zelfde

233. A. Dolle, in: Bimmenlands Bestuur Management, 29 januari 1993, p.13.

234. W. Beck, a.w., pp.13-14; Vgl. H.R. van Gunsteren (1986), t.a.p., p. 38.

235. E. Helder, a.w., p.82.

236. J.M. Kan, t.a.p., P.998.

237. J.L. Boxum, J. de Ridder en M. Scheltema, a.w., p.68; Meer gematigd J.L. Boxum, Zelfstondige bestuursorganem, organisatie op maat, in: Bestuur, nr.4, april 1990, pp. 101-111.

238. Deze bank is owerigens naast zelfstandig bestuursorgaan, "deels overheidsbedrijf en deels adviesorgaan terwijl ze tewens bevoegdheden heeft tot het geven wan algemeen verbindende woorschriften". H.J. de $\mathrm{Ru}_{3}$ Nacar een nieuw overheidsorganisatierecht; De betekenis wan de organisatie voor de rechtsontwikkeling. in: Rechtsworming in de sociale rechisstaat. Bundel opstellen aangeboden aan professor wr $P$. de Haant $_{\mathrm{n}}$ Deventer, 1989 , pp.65-77, i.h.b. p.73. 
kamermeerderheid niet in, dat het zelfstandig uitoefenen van die bevoegdheden conse quenties voor de invloed wan de minister dient te hebben. ${ }^{7239}$

Ander voorbeeld betreft een deel van het, overigens officieel gedeconcentreerde, staats toezicht op de volksgezondheid. Inspecteurs volksgezondheid vormen samen, toch dat gene wat sterk neigt naar, een zelfstandig bestuursorgaan. Dienstbevelen en aanwijzin gen ${ }^{240}$ bewijzen de knaag. en bemoeizucht van de minister. Daardoor komt de zo ge naamde onafhankelijke positie grof in het geding. ${ }^{24 i}$

Even eens is bij het Centraal Fonds voor de Volkshuisvesting de goed bedoelde gedeelte lijke ministeriële verantwoordelijkheid behoorlijk opgerekt. ${ }^{242}$

En ook bij het, recent opgerichte, Centraal Bestuur voor de Arbeidsvoorziening reikt $\mathrm{c}$ ministeriële hand ver. ${ }^{243}$

Een paar korte opmerkingen, betreffende het karakter van ministeriële aanwijzingen, zi hier gepast. Daarmee wordt misschien de inzichtelijkheid in de mate, waarin een $b$ stuursorgaan aan cen dergelijke aanwijzing is gebonden, verhoogd. Gesteld is dat i aanwijzingen geen beleidsregels zijn en evenmin "op basis van het voorontwerp den tranche Awb als algemeen verbindende voorschriften kunnen worden aangemerkt", grond van de volgende redenen. 244

Géén beleidsregels om drie redenen. Ten eerste, een aanwijzing betekent inbreuk op eigen verantwoordelijkheid van de delegataris. Ten tweede is het kenmerk van beleic regels dat onder omstandigheden afwijking er van is gerechtvaardigd. Deze inherer afwijkingsbevoegdheid is niet van toepassing op algemene aanwijzingen. Ten derc anders dan beleidsregels, gelden algemene aanwijzingen slechts interbestuuriijk.

Géén algemeen verbindende voorschriften. Ten eerste wordt in de Awb een algeme aanwijzing slechts afgeleid wit een verbod van bijzondere aanwijzingen. En ten tweet er is geen speciale bekendmakingsregeling toepasselijk.

Uiteindelijk is meer duidelijkheid omtrent het rechtskarakter van aanwijzingen vere Hiertoe is de uitdrukkelijk creatie van een wettelijke grondslag ter zake reeds voldoenc

239. H.G. Lubberdink, a.w., p.109.

240. Wat betreft het Centraal Orgaan Tarieven Gezondheidszorg is, conform de uitspraak wan her CBB 3 aug. 1984, AB 1986, 76, m.nt. B.C. Punt, beslist dat een aanwijzing er toe verplicht overeenkon richtijnen vast te stellen. Zo'n aanwijzing draagt het rechtskarakter van een besltit van algen strekking.

241. M.E.W.H. de Bock-Joosten, Hoe zelfstandig is her staatstoezicht op de valksgezondheid, in: NJB, ns 10 sept. 1988, pp. 1077-1082; Overigens bestaat tegenwoordig nog maar één ìnspectie voor de gez heidszorg, die de oude geneeskundige inspectie, de geneeskund ige inspectie voor de geestelijke voll zomdheid en de inspectie voor de geneesmiddelen vervangt. Zie besluit d.d. 7 nov. 1994, Stbl. 1 839.

242. C.M. van den Hoff, Ministeriële verantwaordelijkheid en politieke controle, in: Bestuur, nr.1, ja 1989, pp.8-10.

243. M.M.G. Hukkelhoven, De zelfstandigheid van de, Arbeidsvoorzieningenorganisatie, in: $\mathrm{BK}, \mathrm{nr} .1,1$ pp. 13-20.

244. C.P.J. Goorden, Kroniek: bestuarlijke organisatie, in: NTB, nr. 10, 1992, p.320; C.P.J. Goorden, beleidsregels bij mandaat en delegatie, in: NTB, nr.5, 1992, pp.163-168, i.h.b. pp.166-168. 
Conclusie uit het voorgaande luidt als volgt. De zelfstandigheid van zelfstandige bestuursorganen is vaak van hybridische aard. De onafhankelijkheid van het orgaan kan bedreigd worden door sterke beïnvloedingsmogelijkheden van de betrokken minister(s).

Overigens is het raadzaam zich te realiseren dat "de neiging om in te breken in de competentie van een zelfstandig bestuursorgaan vaak nog eerder te verwachten valt van ambtenaren ten departemente dan van politici. Departementsambtenaren die zich op het zelfde beleidsterrein bewegen, verkeren immers in een rechtstreekse concurrentieverhouding met het zelfstandig bestuursorgaan." ${ }^{245}$ Deze bureaucratische tendens om te centraliseren is wel getypeerd als een "schaarbeweging" om het betrokken zelfstandig bestuursorgaan heen, die de positie van het zelfstandig bestuursorgaan dreigt uit te hollen. ${ }^{246}$

De vaak problematische verbouding tussen de zelfstandig bestuursorgaan en minister, die in eerste instantie afhangt van hun onderlinge bevoegdheidswerdeling, is ter begripsverheldering te plaatsen in een traditioneel theoretisch kader. De discussie, omtrent ministeriële interventie in het handelen of nalaten van een min of meer autonoom overheidsorgaan, dateert niet van gisteren. Sinds de bekende kwesties Menten en Wibo van der Linde twisten juristen en politici over de aanvaardbaarheid van concrete aanwijzingen van minister of staatssecretaris. In het debat over de reikwijdte van departementale invloed op beleid(sgedragingen) van een op afstand van de minister geplaatst overheidsorgaan, waaraan specifieke taken met de daarvoor benodigde bevoegheden van hogerhand zijn toebedeeld, wordt onderscheiden naar bevoegdheidsgrondslag.

Ten eerste kan een bevoegdheidsgrondslag liggen in attributie of delegatie. Bij attributie gaat het om rechtstreekse bevoegdheidstoekenning. Bij delegatie wordt een bestaande bevoegdheid overgedragen. Bij de constructie van attributie (of delegatie) van zelfstandige bevoegdheden aan ambtenaren kan, merkwaardigerwijze, een hiërarchische band met de minister knellen. Immers, volgens sommigen zijn zowell algemene als bijzondere instructies mogelijk. ${ }^{247}$ Bedacht moet worden, dat de bewindspersoon niet in de plaats kan treden van het lagere ambt. Hij kạn niet zélf een nieuwe beslissing nemen. Hij kan slechts een bijzondere instructie geven met betrekking tot door het betrokken orgaan genomen besluiten die in concreto aanwijzing nodig hebben. Kortom, rechtstreekse bevelen zijn zo inderdaad aanvaardbaar als bij voorbeeld sprake is van verwaariozing van toegekende of overgedragen bevoegdheden.

Ten tweede worden sommige bevoegdheden, vooral uit praktisch oogpunt, uitgeoefend door een ander dan wie de bevoegdheid toekomt. Deze bevoegde blijft als enige bevoegd,

245. Het Commissariaat voor de Media, Gerard Heijne den Bak-symposium d.d. 2 ll april 1993, pp.1-6, i.h.b.

246. E.J. Dommering, Nieuwe Mediawet in zich zelf tegenstrijdig, in: Comedia, nr. 24 , sept. 1993 , Hilwetsum, p. 4 .

247. O.a. H.G. Lubberdink, a.w., p.44.e.v.; Commissie inzake algemene bepalingen van auministratief recht, Rapport ABAR, vijfde druk, Alphen aan den Rijn, 1984, p. 18; E. Helder "a w. pp 78-79; C.W. van der Pot, bewerkt door A.M. Donner, a w., pp.402-403; A.D. Belinfante en J.I. de Reede, a. w.., p.132; H.D. van Wijk, bewerkt door W. Konijnenbelt en R.M. van Male, a.w., pp. $132-133 / 140-141$, i.h.b. p.133. 
met andere woorden degene die de bevoegdheid feitelijk uitoefent is hiërarchisch onder geschikt aan zijn opdrachtgever. Er is sprake van deconcentratie. Anders dan bij attri butie of delegatie onstaat door dergelijke mandatering geen eigen bevoegdheid. De meest voorkomende opvarting is dat deconcentratie de directe bevelsmacht van de minister onverlet laat. In afwijkende zin is ten aanzien van gedeconcentreerde ambten wel $\mathrm{ge}$ meend, dat de minister geen concrete aanwijzingsbevoegdheid toekomt. Daarvoor zijn drie redenen aangedragen. Ten eerste vervaagt, anders, het onderscheid tussen attributie/delegatie en mandaat. Ten tweede verdient het voorkeur verantwoordelijkheid zo veel mogelijk daar te leggen waar zij ook feitelijk kan worden gerealiseerd. Ten derde hebben gedeconcentreerde bevoegdheden, in het algemeen, een gebonden a-politiel karakter. Hierbij is terecht nuance aangebracht wat betreft uitoefening van politiebe voegdheden van gedeconcentreerde ambten. ${ }^{2.48}$

In het bijzonder aangaande rechtstreekse bemoeienis van de staatsecretaris van financiei met de aan de belastinginspecteur toekomende bevoegdheden, heeft de discussie stof doe opwaaien.

Sommigen ${ }^{249}$ ontkennen individueel ingrijpen van wege het belang dat zij hechten aa het wetmatigheidsbeginsel en de algemene beginselen van behoorlijk bestuur, in hi bijzonder het gelijkheidsprincipe. Belangrijke reden voor een enge interpretatie van in hi bijzonder fiscale wetgeving is dat de wet, waarin bevoegdheden aan ambtenaren worde toegekend, een lex specialis is ten aanzien van de algemene regels van ambtelijke onde schikking. ${ }^{250}$

Sommigen schipperen nog. ${ }^{251}$ Een van de twijfelaars ${ }^{252}$ schept meer duidelijkheil Hij wil individueel ingrijpen naar huidig recht niet aan de minister ontzeggen. Maar de toekomst wenst hij deze bevoegdheid wettelijk uit te sluiten.

In het licht van voorgaande moet het samenspel tussen minister en zelfstandige bestuur organen worden bekeken. De relatie departementstop - zelfstandig bestuursorgaan imp ceert juist geen ondergeschiktheid. Voor zelfstandige bestuursorganen geldt niet vanze sprekend, dat zij rekening moeten houden met aanwijzingen van bovenaf. Zij worden zekere zin onafhankelijk geacht. Daarbij is het het proberen waard de ministeriële vera woordelijkheid tot reële proporties te reduceren. Toch wenst de minister zijn greep $\mathbf{n}$ totaal te verliezen.

248. F.A.M. Stroink, a.w.,pp. 147-157; F.A.M. Stroink, Staatssecretaris, Kaning en belastinginspectie NJB, nr.32, 1 sept. 1985, pp.1029-1031.

249. O.a. J. Wortel, Verwolgen in belastingzaken, fiscale monografieën nr.56, Deventer ${ }_{n} 1991$, pp.295-:

250. P. de Haan en H.J. de Ru, De ministeriële verontwoordelijkheid en de bevoegdheid van de (adjiw inspecteur, adviezen aan federatie $v$. verenigingen van (adjunct-)inspecteurs van 's Rijksbelastin: Herveld/Delft/Amsterdam, 1985, pp.31-36.

251. O,a. J.M. Polak, De rechtspositie wan de belastinginspecrie en de zbo 's, in: NJB, nr.43, 7 dee. $1^{\prime}$ pp. 1370-1371.

252. M. Scheltema, De bevoegdheid" wan de minister c.q. staarssecretaris van financiën om in te grijp: de aanslagregeling van individuele personen, uitgave op versoek van de directeur der belastingen, 1 bijl. TK 1985-1986, 19022, nrs.8-10. 
Vandaar houdt hij de bevoegdheid, met betrekking tot de hoofdlijnen van beleid, algemene aanwijzingen te geven. ${ }^{253}$ Als vermeld, is dit geven en (terug)nemen van ministeriele verantwoordelijkheid niet altijd gemakkelijk verteerbaar. Vooral niet in die gevallen waar, feitelijk, veel vingers van de bewindspersoon in de brei van het betrokken bestuursorgaan roeren. Gedoemd tot overkoken dus.

Daarom zijn de volgende resolute woorden niet raar. "In ieder geval zal de ministeriële beînvloeding niet zo ver mogen gaan dat de minister de bevoegdheid heeft ook aanwijzingen in individuele beslissingen te geven. Deze bevoegdheden zou het orgaan van een zelfstandig tot een feitelijk hiërarchisch ondergeschikt orgaan maken." 254255

Deze gedachtengang wordt voor bij voorbeeld het toezich thoudend zelfstandig bestuursorgaan Registratiekamer onderschreven. Erkend wordt dat "een zekere mogelijkheid voor de regering om het beleid van de Registratiekamer te beïnvloeden op zich zelf is gewenst, omdat dat beleid ook zijn weerslag kan hebben op allerlei onderdelen van het algemene regeringsbeleid"; Tegelijkertijd bestaat het besef, "dat de Registratiekamer bij haar optreden in afzonderlijke, concrete gevallen geen aanwijzingen van de regering zal behoeven te aanvaarden". ${ }^{256}$

Als het een privaatrechtelijk vorm gegeven zelfstandig bestuursorgaan betreft, in het bijzonder een vennootschap, vloeit uit het Burgerlijk Wetboek voort dat het geven van bijzondere instructies de zelfstandige leidinggevende positie van het bestuur van de vennootschap ongeoorloofd aantast. ${ }^{257}$ Is sprake van een publiekrechtelijk zelfstandig bestuursorgaan, dan moeten de situaties, waarin incidenteel instructiebevoegdheden van bijzondere aard mogen worden uitgeoefend, wel op zeer exacte wijze wettelijk worden omschreven. ${ }^{258}$

253. Bepaald voor bij voorbeeld Dienst wegverkeer in art. $3 \mathrm{c}$ Wetswoorstel wijziging Wegenverkeerswet 1992 houdende regeling voor de verzelfstandiging van de Rijksdienst voor het Wegverkeer, "TK 1992 . 1993, 22961, nrs. 1-2, p.3 en woor de Informatie Beheer Groep in art. 16 Wetsvoorstel verzelfstandiging en organisatie IBG. "TK 1992-1993, 23073, nrs.1-3, p.7, zie uiteindelijke Wet verzelfstandiging infor. matiseringsbank, Stbl. 1993,714; zie ook art. 36, derde lid, Mediawet.

254. Functioneel bestuwr; hoe en maarom?, TK 1990-1991, 21042, nr.4, 1.27.

255. Even wel wordt, wat betreft het toezichthoudend zbo Stichting Toezicht Effecterverkeer de in art. 25. viende lid, Wte neergelegde "(wettelijke) arwijking" (van de heersende lewer betreffende de rechtsfighur delegatie als verwoord in art. 1 A.1.2.4 Awb-JGLvNy "verklaarbaar (en velaatbaar)" geacht, "nu het hier gat om een delegatie 'sui generis'". Zie D.R. Doorenbos, Financieel strafrecht, diss. KUN, Van der Heijden-monografieẻn deel 40, Deventer, 1992, p 240.

256. Memorie van toelichting Wet persioansregistraties, TK 1981-1982, 17207, nr.3, pp.20-21.

257. C.A. Schreuder, Publiektrechtelijke taken, private rechispersonem, Dewenter, 1994, p.393.

258. Art. 14, eerste lid, Wet tarieven gezondheidszorg ( $\$$ tbl. 1991, 584/585) voorziet in het volgende voorbeeld: "De minister van WVC en de minister van economische zaken te zamen kunnen aan het $z$ bo Centraal orgaan tarieven gezondheidszorg aanwijzingen geven m.b.t. die inhoud wan richtlijnen. Tot de inhoud van een aanwijzing kan tevens behoren dat in een richtlijn ter uitvoering van de aanwijzing dient te worden opgenomen dat het Central orgaan ter vervanging wan een reeds goedgekeurd of vastgesteld tarief ambtshalve een ander tarief dient wast te stellen. Alvorens een aamwijzing wordt gegeven, wordt het Centraal orgaan gehoord, tenzij de wereiste spoed zich naar thet oordeel wan genoemde ministers daartegen werzet." Art. 16 conditioneert de aanwijzing als volgt: "Indien de aanwijzing 0.g.v. art. 14 wordt woorbereid, wordt de zakelijke inhoud wan het woorgenomen besiuit schriftelijk medegedeeld aan dhe beide Kamers der Staten-Generaal. Het besluit wordt niet eerder uitgevoerd dan madat 10 dagem zijn 
De stelling, dat concrete aanwijzingen in beginsel worden uitgesloten bij functioneel bestuur, is uitstekend als uitgangspunt. Dat de praktijk echter, meer dan eens, aandit principe zijn praal ontneemt, komt niet geheel onverwacht. Als besturen op afstand misloopt, moet de minister optreden. Desnoods tot in detail.

In eerste instantie hoort hij zijn sturing tot hoofdlijnen te beperken. Maar juist met het oog op de verstrengeling van beleidsbepaling en -uitvoering is dit soms moeilijk. Mis schien moet het dan ook wel anders, en is een accurate aanpak wenselijk. Rigoureus is de confrontatie met het feit, dat veel wetten, bedoeld voor zelfregulerende instanties, onduidelijk van tekst zijn of legitimatie ontberen omdat duidelijke rechtsovertuiging er over ontbreekt. Het daardoor ontstane, niet tegen te houden, proces van regelgeving verdient bewaking van bovenaf.

Zo betekent, bij voorbeeld in arbeids-en sociale zekerheidswetgeving, beleidsuitvoering vaak rechtsworming op principiele punten. Veelal laat de eigenlijke wetgever het hie afweten. Daarom is het zinvol juridische eisen aan besluitworming door basiseenhede te stellen. Aldus is sprake van behoorlijke regelgeving door beleidsuitvoerders als, in ell geval, aan de volgende voorwaarden is voldaan. Te weten: evenwichtig overleg me betrokkenen; organisatie van betrokkenen in verband met de te behartigen belanget afstemming van te behartigen belangen en procedurele waarborgen; en integratie va beleidsvoorbereiding en -uitwoering. ${ }^{259}$

Overigens is het vaststellen van en werken langs hoofdlijnen los van de details "alls h. voetballen met een lekke bal". ${ }^{260}$

\subsubsection{De minister en het openbaar ministerie}

Vooral in geval van toezichthoudende overheidsorganen is het treden in finesses $n$. geheel ondenkbaar. Juist toezichthoudende bestuursorganen, met controleurs en opsp ringsambtenaren, mogen soms een straffe hand van de minister niet ontberen. Interessia voorbeeld is het openbaar ministerie belast met de rechtshandhaving in het algemeen. tegenstelling tot zelfstandige bestuursorganen is het openbaar ministerie een gedeconce treerd ambt. Omdat niet iedereen daarmee kan of wil instemmen is het debat, over aanwijzingsbevoegdheid van de minister van justitie ten opzichte van het openbaar min

258. $\rightarrow$

verstreken na die mededeling." In december 1992 maakt staatssecretaris van volksgezondheid Sim bij voorbeeld gebruik van de zanwijzingsbevoegdheid. Simons geeft het COTG de aanwijzing tarieven woor medisch specialisten met circa 15 procent te verlagen. Het COTG reageert daarop met tariefverlaging van de ziekeafondstarieven met 11 procent, de particuliere tarieven met 12 procent de periode van 1 april 1993 tot 1 april 1994. De tarieven van psychiaters dalen in het tijdsbestek juni 1995 geleidelijk aan met 40 procent. Zie Tarieven omlaag van specialisten, LSV protesteert NRC, 16 febr. 1993, p.2.

259. I.C. van der Vlies, Gedeeltelijke regelgeving, in: OB, nr. 10, 1992, pp.6-11.

260. H.R. wan Gunsteren (1986), t.a.p., p.35. Auteur vat de ministeriële verantwoordelijkheid, name op als "reservecircuit". De minister staat, weliswaar alls uitoefemaar van controle tussen anderen, pri op metaniveau. Zijn verantwoordelijkheid kan een heel gebeuren betreffen. 
terie, aandacht waard in het licht van theorievorming over de omvang van politieke ministeriële verantwoordelijkheid voor uitoefening van handhavingsbevoegdheden.

Toezicht op nalleving van wet- en regelgeving vereist de grootsre zorgvuldigheid. Implicatie bij uitoefening van politiebevoegdheden is dat de minister, anders dan gebruikelijk, zowel algemene als bijzondere bevelsmacht heeft. Maar dit geldt slechts voor de bevoegdheden, waarover hij zelf beschikt.

Deze volle ministeriële verantwoordelijkheid betreft alleen, hoewel een omvangrijke hoeveelheid, dat deel van de werkzaamheden van het openbaar ministerie, wat overwegend bestuurlijk is te noemen. ${ }^{261}$ De bestuurlijke taken van het openbaar ministerie zijn flink toegenomen.

Gewaarschuwd wordt tegen de ontwikkeling van het openbaar ministerie naar een beleidsorganisatie. Bij de, zich onder meer in het driehoeksoverleg manifesterende ${ }^{262}$, bestuurlijke pretentie van het openbaar ministerie zijn de volgende kanttekeningen te plaatsen: a. "het vertrouwen van burgers in rechtshandhaving kan worden ondermijnd indien bestuur en openbaar ministerie worden beschouwd als twee handen op een buik en zichzelf ook als ledematen van het zelfde lichaam gedragen"; $b$. "de beleidsmatige en bestuurlijke ambities van het openbaar ministerie zetten de klassieke strafvorderlijke taken onder druk en daarmee het hart van het openbaar ministerie zelf"; c. "het bestuur heeft baat bij een heldere en scherpe verantwoordelijkheidsverdeling" [...] "het is belangrijk voor het bestuur om de eigen beleidslijn niet te doen verwarten met justitiêle wensen" : $d$. "de juridisch-technische vaardigheden van het openbaar ministerie zijn nog geen waarborg voor bestuurlijke talenten en gevoeligheid". ${ }^{263}$ Van uit deze visie doet het openbaar ministerie er verstandig aan, zich zelf te waarderen op eigen karakter, kwaliteit

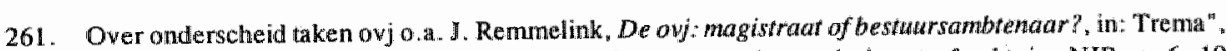
nr.6. 1991, pp.167-178; A.F.M. Brenminkmeijer, De magistraat in het strafrecht, in: NJB, nr.6, 10 febr. 1995, p.211, is opmerkelijk stellig tioor de "ovj per definitie nimmer magistratat" te achten. Volgers auteur moet de ovj, als ambtenaar, dan owk uit de rechterlijke machu worden gezet; E.J Daalder, Het openbaar mimisterie: magistraat of bestuursambienaar, in: Trema" "nr. 3/4, 1991, p.88. Vgl. ple idooi voor terugkeer van OM naar magistratelijke taken door T.M. Schalken, Openbaar ministenie moet weer terugkeren naar zijn oertaken, in: NRC, 31 okt. 1994, p.7; Ook minister wan justitie W. Sorgdrager benadrukt de magistratelijke taakstelling. C.M.Th. Lindo, Het perspectief wan mimister" W". Sorgdrager, in: NJB , ar.1,6 jan. 1995, pp.1-6, i.h.b. p.5.

262. H.J. Albert, De ongelikzijdige driehoek; Onderlinge betrekkingen tussen lokaal begtwur, diss. RUL, Arnhem, 1994 , betoogt dat het bestururlijk handelen wan het OM bitter tegen valt. In het driehoeksoverleg kont de politie vaak als 'overwinner" uit de bus, ondat het OM weinig totgeen bestuurlijke capaciteiten in huis heeft en zij bang is haar onafhankelijke magistratelijke positie te verliezen. Auteur acht het noodzaak dat het $O M$ haar verioren positie herovert. Hiertoe moet zij, bestuurlijk gezien, wel steviger in de schoenen gaan staan.

263. J.I. van Aartsen, Openbaar ministerie doet teveel aan beleid, te weinig an kerntaak, in: NRC, 7 juni 1994, p.11. 
en professie, met welke meerwaarde het openbaar ministerie een welkome aanvul ling ${ }^{264}$ op het openbaar bestuur kan zijn.

Wat betreft de strafrechtelijke afdoening in individuele gevallen moeten minister en in zijn voetspoor de Tweede Kamer zich van elke dwingende bemoeienis onthouden. Deze richtlijn wordt in praktijk nageleefd. Althans volgens beweringen van ministeriële zijde. Daarin wordt geappelleerd aan de uiteindelijke slotverantwoordelijkheid van de minister, die soms sterk merkbaar voor het publiek wordt geactiveerd. Bij voorbeeld in de zaken Heijn, Van der Valk of Oude Pekela. Weliswaar is het duidelijk dat in bepaalde gevallen individuele interventie plaats vindt. Maar dit gebeurt dan alleen in bepaalde stadia van opsporingsonderzoeken. Dat is immers terug te leiden tot de politieke ministeriële verantwoordelijkheid. Hierbij "verwarre men dus niet de verantwoordelijkheid van de minister voor opsporing, met de afstand die hem betaamt als het om een concreti strafzaak gaat". 265

Toch blijkt in realiteit de politiek maar moeilijk handen af te willen houden van ander mans professie. Minister Hirsch Ballin concludeert dat "de minister in individuele zaket aanwijzingen aan een lid van het openbaar ministerie kan geven". ${ }^{267}$ Tot grote ergeni van de vijf procureurs-generaal van het openbaar ministerie is, bovendien, het volgend vereist. Officieren van justitie moeten de minister ook "raadplegen over de inhoud va het requisitoir" als een strafzaak betekenis heeft voor het algemene opsporings- en ve volgingsbeleid. Te denken is aan euthanasiegevallen. Dit ministerieel optreden draagt w: een terughoudend karakter. ${ }^{268}$ Deze voorzichtigheid is als volgt verklaarbaar. De $\mathrm{m}$ nister is weliswaar integraal en ten volle verantwoordelijk voor een geloofwaardige stra rechtshandhaving. Maar het parlement houdt hem vooral verantwoordelijk voor zij meta-sturing. Anders gezegd, de minister heeft tot taak een "gestructureerd regiona netwerk, waarbinnen het openbaar ministerie een spilfunctie bekleedt" ${ }^{\text {" }}$, te creëren. ${ }^{2}$ Anders dan voor deze ketensturing, laat de minister het openbaar ministerie enige ruim in haar regionaal-bestuurlijke rol. De verbijzondering van het algemene beleid op mes

264. Wolgens A.C. 't Hart, Penale bestukrskande: het rapport-Downer, in: DD, nr.7, 1994, pp.643-6.' accepteert die cie-Donner, die stelt dat OM-optreden verweven is met bestuurijk optreden en daar onderling wanwullend moeten werken, te gemakkelijk die werbondenheid. $Z$.i. moet het OM die wen venheid en bestuurlijke pretentie juist ter discussie stellen.

265. H. de Doelder, De ministeriële veranmoordelijkheid voor her openbaar ministerie, in: Trema", 19 pp. 374-377.

266. F. Korthals Alttes, De minister is politiek verantwoordelijk voor het OM, in: NRC, 9 december 19 p. 8; In oppositie tegen M. Haenen, Debat over OM en minister is nog niet beëindigd, in: NRC, 28 n 1992, p.6.

267. Memorie wan toelichting bij begroting justitie 1993, TK 1991-1992; Ook Minister sichept duidelijkt in relatie met $O M$, in: Justitiekrant, sept. 1992; P.J. Blauw, Justitiebegroting, in: AA katern strafre: nr. $11 / 12,1992$, pp.2085-2090.

268. Jusritiebegrating 1992 , TK 1992-1993, 22800 V1, nr.2, p.8.

269. E.M.H. Hirsch Ballin, Ministeriele verantwoordelijkheid, verzelfstandiging en sturing; Een beschoun over ministeriële verantwoordelijkheid en de strafrechtelijke handhaving van de rechtsorde, in: P.F Frissen e.a., Het managen van verandering door verzelfstandiging, publ. Management Centrum Gravenhage, april 1993, pp.45-72, i.h.b. pp.60/68. 
niveau betreft de "verwerkelijking van de rechtsstaatsidee die om specifieke afwegingen van het openbaar ministerie" vraagt. ${ }^{270}$ Daaraan ontleent het openbaar ministerie een relatief zelfstandige handelingsvrijheid.

Overigens verwacht de minister weinig confrontatie met het openbaar ministerie ter zake. Dit komt omdat hij het onderscheid politiek en juridisch beleid niet aanhoudt.

Dit onderscheid wordt juist wel gehanteerd door het openbaar ministerie. ${ }^{271}$ Het verschil, dat de procureurs-generaal zien, is verklaarbaar als volgt. ${ }^{272}$ De minister legt rekenschap af tegenover het parlement. ${ }^{273}$ Daarentegen heeft het openbaar ministerie een verantwoordingsplicht tegenover zowel minister als rechter. Hier blijkt dus, ten eerste, van verschillende fora. Naast dit verschil in "doelgerichtheid" is de "intensiviteit" van beiden fundamenteel anders. De tweede afwijking betreft daarom het volgende. Ondanks beider theoretische gezamenlijke verantwoordelijkheid voor rechtshandhaving, dat wil zeggen effectieve normhandhaving alsmede handhaving van een behoorlijk niveau van proceswoering, spreekt de praktijk voor zich. In de reguliere taakuitoefening van het openbaar ministerie staat uiteindelijk toch processuele afdoening van strafzaken centraal. 's Ministers bemoeienis daarmee is feitelijk marginaal. Slechts in algemene, abstracte zin houdt de bewindspersoon zich beleidsmatig bezig met rechtshandhaving.

De minister negeert, als gezegd, het onderscheid. Zo komt hij tot zijn oordeel "dat de belangen en verantwoordelijkheden van de minister en het openbaar ministerie wel (steeds en per definitie) parallel lopen". ${ }^{274}$ Volgens de vertegenwoordigers van het openbaar ministerie, te weten de sectie van het openbaar ministerie van de Nederlandse vereniging voor rechtspraak, is het ministeriële standpunt iets te scheutig. Vandaar de wenselijkheid van nuancering ter zake.

Daarom heeft een informeel onderhoud tussen minister en procureurs-generaal een, volgens laatst genoemden, redelijker resultaat. ${ }^{275}$ De minister van justitie mag "alleen bij zeer zwaarwegende redenen en in geval van kennelijke beoordelingsfouten" officieren van justitie dienstbevelen geven. Overigens mag hij zich, in beginsel, slechts achteraf met individuele zaken bemoeien. Een en ander beschouwd is een "wordt vervolgd" van de discussie onvermijdelijk. ${ }^{276}$

270. E.M.H. Hirsch Ballin (1993), ta.p.,p.61.

271. Vgl. A.C. "Hart, Openbaar Ministerie en rechtshandhaving. Arnhem, 1994, p. 307 e.v.

272. Procureurs general in hun Brief aan de minister van justinie d.d. 21 april 1992.

273. Arrondissementsrechtbank Amsterdam 28 nov. 1991, KG 1992, 5 .

274. Justitiebegmoting, TK 1991-1992; Tevens. Minister verantwoordelik voor OM, beknopt weergegeven begroting justitie 1993, in: Staatscourant, 16 september 1992, nr.179, p. 14; In dit verband wordi gesproken van een 'petitio principin'. Zie Commentaar: OM en minister, in: NRC. 8 december 1992 , p.9.

275. Van wege beslotenheid van dit overteg, d.d. 28 oktober 1992 , is roep om het "zwart-op-wit openbaar" maken van de belangrijke uitkomst erwan begrijpelijk. Zie brief NVWR, A.H. van Dellden; Verslag var dit owerleg is op 3 dec. 1992 door de minister naar de Tweede Kamer gestuurd. Weergave van dit verslag is te vinden in De relatie tussen de minister van justihe en het openbaar ministerie: overleg tussen minister en pracureurs-generaal, in: Trema", nr.3, 1993, pp-125-126.

276. M. Haenen, Debat aver relatie OM en minister is nog niet beeindigd, in: NRC, 28 november 1992, $\mathrm{p} .6$; Tevems Hirsch Ballin grijpt miet in bi strafiaken, in: NRC, 27 nowember $1992, \mathrm{pp} .118$. 
Het debat over het domein van de minister is kennelijk nog niet ten einde. Immers, onduidelijk blijven de antwoorden op de volgende vragen. "In welke mate behoort de minister zich de op hem uitgeoefende druk aan te trekken? En hoe vertaalt hij die in zijn verhouding tot het openbaar ministerie, bijvoorbeeld door de wijze waarop hij zich in de interne besluitvorming mengt (vooraf of achteraf) dan wel het beleid inhoudelijk toetst (volledig of marginaal)? ${ }^{177}$ De definiëringsdrift, betreffende territoria van minister en openbaar ministerie, draait om een dilemma. Namelijk, "de minister zal, gelet op de inhoudelijkheid van de zaak en de maatschappelijke context, een afweging moeten maken ten aanzien van de hachelijke vraag of hij (hier) zijn politieke verantwoordelijkheid zal activeren ten koste van de bandbreedte van onafhankelijkheid waarover het openbaar ministerie beschikt. Als zijn verantwoordelijkheid werkelijk predominant is - dat wil zeggen dat het in strijd met de politieke redelijkheid, de juridische integriteit en de maat schappelijke urgentie zou zijn om bemoeienis achterwege te laten - dan zal het openbaar ministerie wanneer puntje bij paaltje uiteindelijk toch moeten wijken." ${ }^{278}$ In dit ver band is het volgende pleidooi plausibel. ${ }^{279}$ De gedachte is voortaan, in gevallen var predominante gevallen van ministeriële verantwoordelijkheid gewoon toepassing $\sharp$ geven aan art. 5 RO. Art. 5 RO moet in de schijnwerpers komen te staan. Want "doo" de onzichtbare context waarbinnen art. $5 \mathrm{RO}$ feitelijk werkzaam is zonder dat er formee een beroep op wordt gedaan, onttrekt de bemoeienis van de minister zich aan elke vort van parlementaire controle". "Dit zelfde geldt natuurlijk woor de mystieke besprekingei in de PG-vergadering." ${ }^{280}$ Die volledige vrijblijvendheid is uit den boze.

Het nemen van art. 5 RO als ütgangspunt voor de ministeriële verantwoordelijkheid 1 í in de lijn van de gedachte aan een getrapte verantwoordelijkheid ter zake. Volgens $d$ opvatting van een beperkte ministeriële verantwoordelijkheid draagt de bewindspersion geen politieke verantwoordelijkheid voor al datgene wat het openbaar ministerie doet 1 nalaat, maar slechts voor zover de minister gebruik maakt van zijn bevelsbevoegdhedx ex art. 5 RO. Aldus is hij niet verantwoordelijk voor de bevoegdheden tot opsporing a vervolging. Wél voor zijn bevoegdheden tot beinvloeding daarvan, in gevolge art. RO. ${ }^{281}$

277. T.M. Schalken (1992), t.a.p., p.815; T.M. Schalken, Het toboe wan art, 5 RO; Over de bestwurlijke magistratelike niveaus in de rechsbescherming ussen minister wan justitie en $O M$, in: Trema", nu" 1991, pp. 179-194, i.h.b. p.184.

278. T.M. Schalken (1991), t.a.p.,p.184; Herhaald in T.M. Schalken (1992), t.a.p., p.815. Dit inaplice dus de afstand tussen OM en departement. Anders H.G. Lubberdink, a.w., pp. 62 70. Haj propag juist hierarchische onderschikking als elk ander gedeconcentreerd ambt; Vgl. S.A.M. Stolwijk. minister van Justitie, het OM en art. 5 RO, in: Magistraat met beletd: de Ow' en zijn omgeving; Ops len aangeboden aan mr $C$. van Steenderest bij zijn afscheid als hoofdofficier van justitie te Amster. op 25 september 1992, Amuent, pp.33-42, i.h.b. p. 39.

279. T.M. Schalken (1991), t.a.p., p.190.

280. T.M. Schalken (1991), t.a.p., p.190; E. Jurgens, Vrees voor politieke inbreng in de rechrspleg. NRC, 15 dec, 1992, p.8.

281. F. Korthals Altes ${ }_{\text {n }}$ De verhouding tussen minister van justitie en het OM; Inleiding najaarsvergade van de sectie $O M$ wan de NVWR d.d. 15 aktober 1988 , in: Trema", 1988, pp.367-373; Dit is conf het voorstel van de procureurs-generaal bij de gerechtshoven, als is terug te winden in hun brief ar 
Leeft echter het besef, dat "de mate van ministeriele verantwoordelijklieid niet per se samen valt met de mate ministeriële bemoeienis", anders gezegd "een volle ministeriële verantwoordelijkheid kan gepaard gaan met een uiterst terughoudende bemoeienis" en ongekeerd, dan ligt de keuze voor een indirecte ministerielle verantwoordelijkheid voor het openbaar ministerie niet het meest voor de hand. ${ }^{282}$

Al met al blijfi de exacte verhouding tussen minister van justitie en openbaar ministerie duister. Wel blijft het juiste staatsrechtelijke uitgangspunt: volledige ministeriële verantwoordelijkheid voor het doen en laten van het openbaar ministerie. ${ }^{283}$

De geldigheid van dit principe staat buiten kijf. Uiteindelijk is het openbaar ministerie een gedeconcentreerde rijksdienst. ${ }^{284}$ Wel is, gelet de op de rechterlijke functie toegesneden taakstelling van het OM sprake van een bijzondere vorm van deconcentratie. ${ }^{285}$ Met andere woorden: "Op zich zelf is er geen enkele aanleiding de politieke ministeriêle verantwoordelijkheid voor het $O M$ te relativeren. Wel kan het echter wijs beleid zijn om miet al te sterk te interveniëren in de werkwijze van het $O M$ (betreffende vooral de afhandeling van individuele strafzaken - JGLvN). " 286 Vreemd genoeg neemt minister Hirsch Ballin, wat betreft zijn politieke ministeriele verantwoordelijkheid voor de IRT-affaire,

281. $\rightarrow$

minister van justitie d.d. 21 april 1992; Zie Trema"', nr.4, 1992, p.291 e.v:; Dit schrijven wordt als paasbrief bekend door T.M. Schalken, Eenn niewwe cultuar binnen het OM?; De paasbrief wan de prockreurs-general over de eigen verantwoordelijkheid wan het openbarar mimisterie, in: NJB, mr.26, 25 juni 1992. pp.813-819; H. de Doelder, Van paasbrief tot herfstweer, in: DD, 1992, p.911 e.v.; L.C.M. Meijers, in: Trema", 1992, p.306; W.B.M. Tomesen, De paasbrief: de minister neemt positie in in: Trema", nr.9, 1992, pp.407-409; Volgens de minister van justitie, die erkent dat zij als minister wan justitie politiek verantwoordelijk is voor het algemeen beleid van het $O M$, speelt art. 5 RO slechts een rol in "individuele zaken waarin de kamer de minister alleen achteraf kan bevragen over de gang van zaken", geciteerd door C.M.Th. Lindo, Het perspectief van minister W. Sorgdrager, in: NJB, nr.1, 6 jan. 1995, pp.1-6, i.h.b. p.5.

282. D.J. Elzinga, Een volle ministeriele verantwoordelijheid woor het Openbatar Ministerie, maar geen ongebreidelde sturing wan het $O M$, in: NJB, mr.16, 22 april 1994 , pp.529-537, i.h.b. p.534; Auteur werduidelijkt zijn standpunt (Naschrift, in: NJB, nr.22, 3 juni 1994, p.751) n.a.v. commentaren van respectievelijk C.A.J.M. Kortmann, Consistentie?, in: NJE, nr.22, 3 juni 1994, p. 750 en H. Munneke, Wetmatigheid van bestuur belangrijker dan toetsing politiek, in: NJB, nr. 22, 3 juni 1994, pp .750-751; Terecht laat auteur zich niet uit het veld slaan. Zie het interessante betoog van D.J. Elzinga en J. Koopmans, Mintsiteriële verantwoordelijkheid en openbaar ministerie, in: D.J. Elzinga (red.), Ministerielle perantwoordelijkheid in Nederland, Zwolle, 1994, pp. 211-235; En ook E. Jurgens, De Staten-Generaal en thet $O M$, in: H. de Doelder e.a., Taak en functioneren van het OM, SI-EUR-reeks deel 4, 1994, Arnhem, pp.267-274.

283. H.G. Lubberdink, a.w., pp.62-70; S.A.M. Stolwijk, De minister van justitie, het om en art. 5 RO, in: Magistraat met beleid: de ovj en zijn omgewing; Opstellen aangeboden aan $m r C$. wan Steenderen bij zijw afscheid als ovj re A'dam d.d. 25 sept. 1992, pp.33-42, i.h.b. p.39; J. Wortell, a.w., p. 300; G.P.M.F. Mols, Th.A. de Roos en T. Spronken, t.a.p., p.803.

284. Alert merkt O.J.D.M.L. Jansen, Bestuurstecht en strafprocesrecht: doorwerken of afgrenzen?, in: T. Hoogenboom en L.J.A. Damen, In de sfeer van administratief recht, Utrecht, 1994, pp. 257-283, i. h. b. p. 159, op dat het OM meestal als orgaan wordt gezien, terwijl z.i. "niet het OM, maar de p-g's bij de gerechtshoven, de ovj's de verkeersschouten alls bestuursorganen moeten worden beschouwd".

285. D.J. Elzinga (1994), t.a.p., p.535.

286. Aldus D.J. Elzinga volgens F. Kuitenbrouwer, Relatie ministers met politie en OM onduidelijk geregeld, in: NRC, 8 aprii 1994, p. 3. 
een sterk utilitaire houding aan. De minister, die eerder zo graag duidelijk heeft gemaakt het $O M$ in zijn greep te willen houden ${ }^{287}$, doet al het mogelijke om zijn verantwoor: delijkheid ter zake uit te sluiten. Daartoe luidt zijn laffe betoog opeens, dat het openbaar ministerie "geen buitendienst van zijn departement" is. ${ }^{288}$

De toepassing van bovenstaand beginsel is nog problematisch. Onder omstandigheden kan een "te pregnante invulling van de volle politieke verantwoordelijkheid ongewenste effecten krijgen". ${ }^{289}$ In praktijk blijkt namelijk, dat de Tweede Kamer de minister van justitie te pas en te onpas ter verantwoording roept. Hierbij wordt het vragen van rekenschap van afhandeling van individuele strafzaken niet gemeden. Daarmee wordt nu net het verkeerde pad betreden. Hier heeft het openbaar ministerie een eigen, noodzakelijke ruimte. Kennelijk is de gebiedsafbakening nog niet voor iedereen voldoende duidelijk. Vandaar is het zaak dat betrokkenen snel aanvang maken met een helder handelingskader ter zake.

Daartoe geeft de commissie-Donner een serieus startsein. In haar rapportage inzake hei functioneren van het openbaar ministerie ${ }^{290}$ concludeert zij tot aanpassing van het open. baar ministerie. ${ }^{291}$ Uit kwaliteits-, rendements- en effectiviteitsoverwegingen moet hes openbaar ministerie reorganisatie ondergaan. De veranderingen, waarvoor jaarlijks circ: tachtig miljoen gulden extra op moet worden gehoest, betreffen vooral: structurele sa: menwerking tussen de arrondissementen, verbetering van de gezagsverhouding tussen he openbaar ministerie en de politie, en versterking van de politieke ministeriële verantwoor delijkheid.

De individuele parketten moeten elkaars expertise meer benutten. Het parketpersoneel waarvan volgens voorstel ook niet-juristen deel uit dienen te maken ${ }^{292}$, moet voortaa bij het openbaar ministerie worden aangesteld.

Om de relatie met de politie te verstevigen luidt de aanbeveling te komen tot instellin, van een landelijke operationele politie-eenheid. ${ }^{293}$ Zo'n eenheid mag zich alleen bezi houden met concrete strafrechtelijke onderzoeken, die bovendien "scherp omschreven zijn. Bovendien is het "niet wenselijk dat er een grote, zwaar opgetuigde dienst worc ingericht maar een klein team van wisselende samenstelling dat wordt gevoed van uit d

287. O.a. TK 1992-1993, 22800 VI, nr.1.

288. Verziekte werhoudingen in Amsterdam, in: NRC, 8 april 1994, p.3.

289. D.J. Elzinga, Hirsch Ballin neemt wel erg veel werannwoordelijkheid, in: BB, nrs.29-30, 30 julit 199 p.31.

290. Commissie-Donner, Het functioneren wan het OM binnen de rechtshandhaving, "s-Gravenhage, 8 ju 1994.

291. Reorganisatie, in praktische en theoretische zin, uitwoerig belicht door H. de Doelder, F.M.G.E. Foq en R.A.F. Gerding (red.), Taak en functioneren van het OM, Arnhem, 1994.

292. Ower wooral het op grote schaal miei-juristen de rechtszal binnen halen, en daarnaast het uit de rech zaal weren wan een normatieve discussie over de (ony)toelaatbaarheid van proactieve opsporingsmeth den, terecht kritisch D. R. Doorenbos en M. Wladimiroff, Het (dis)functioneren van het Openba Ministerie; De rigorewze no nonsense-benadering commissie-Domer, in: Advocatenblad, nr, 20,280 ! 1994, pp.83-87.

293. Dit bevestigen PvdA, VVD en D'66 in hun Regeerakkoord 1994, TK 1993-1994, 23715, nr. 11, p.2 Conform TK 1994-1995, 22838, nr.9, stuurt een landelijk OM-bureau het landelijk rechercheteam ax. 
regio's door detachering". ${ }^{294}$ De politie zelf staat kritisch tegenover dit voorstel. Bestrijding van georganiseerde misdaad op verschillende niveaus "creèert wanorde en leidt tot onderlinge competitie". ${ }^{295}$

En met zorg voor de verstoorde verhouding tussen departement en openbaar ministerie spreekt de commissie-Donner zich uit voor vervanging van het bestaande leidinggevende college van de vijf gelijkwaardige, ieder voor hun ressort verantwoordelijke procureursgeneraal door een mieuw te vormen raad van bestuur van het openbaar ministerie. Daarin hebben drie of vier ${ }^{296}$ - niet noodzakelijk uit het openbaar ministerie of strafrecht afkomstige - leden, en een direct aanspreekbare, managementvaardige voorzitter met beslissendle $\operatorname{stem}^{297}$, zitting. Deze raad werkt, zowel intern als extern, mogelijk conflictoplossend. Naar de procureurs-generaal toe heeft de raad een strakke regie in handen. En naar de regering toe krijgt het openbaar ministerie een "gezicht met een duidelijk aanspreekpunt" . ${ }^{298}$ De minister van justitie moet "systematischer" dan in het verleden de kwaliteit van het openbaar ministerie in de gaten houden. Wat betreft de mate van ingrijpendheid van dit toezicht, blijft het de bedoeling dat de minister zich op de achtergrond houdt. Het openbaar ministerie blijft "organisatorisch en juridisch op afstand van de minister van justitie" staan. De "strafrechtelijke handhaving mag niet het exclusieve instrument worden van de heersende politieke meerderheid". ${ }^{299}$ Van regeringszijde luidt de reactie, dat de rol van de minister wel eens te beperkt kan worden. Een leidinggevend college bij het openbaar ministerie, dat in de ogen van de commissie-Donner in zekere mate zelfstandig functioneert, mag juist door die zelfstandigheid de "greep van de minister op het openbaar ministerie niet verzwakken". ${ }^{300}$ Van uit de wantrouwen wekkende gedachte, dat het college een beetje zelfstandig mag zijn, is het noodzaak dit college rechtstreeks onder het ministerie te doen vallen. ${ }^{301}$ Een maal de juiste kandidaat voor procureur-generaal te 's-Gravenhage gevonden kijkt de, per september 1994 aantredende, minister van justitie Sorgdrager de kunst af van de commissie-Donner. De bewindsvrouw draagt de kandidaat voor als voorzitter van het nieuwe, per 1 januari 1995 ingestelde ${ }^{302}$, leidinggevende college van het openbaar ministerie. ${ }^{303}$ Met dit feit voor ogen, dringt de Tweede Kamer er op aan, de formele positie van deze voorzitter (als

294. Commissie-Donner, a.w.

295. Politie tegen landelik rechercheteam, in: NRC. 9 juni 1994, p.3.

296. De $\mathrm{p}-\mathrm{g}$ 's willen met elkaar, dus viff in getal, zo'n raad van bestuur vormen. Aldus W. Sorgdrager, aangehaald door $\mathbb{R}$. Schoof, 'IK wil niet overal de schuld van krijgen', in: MRC, 14 juli 1994, p. 2.

297. Anders dan de commissie-Donner willen de p-g ${ }^{*}$ s uit eigen kring een voorzitter aan wijzen. Zie W" Sorgdrager, IRT-debas, AP, 30 april 1994, nr.9. Een onderlinge machtsstrijd is daarbij, gegeven eerdere confrontaties over zeggenschap, niet uitgesloten. Zie M. Haenen en $\mathbb{R}$. Schoof, Donner wil openbaar ministerie een gezich' geven, in: NRC, 8 juni 1994, p.3.

298. Commissie-Donner, a.

299. Commilssie-Donner, a.w.

300. D'66-kamerlid Wolffensperger, gecitend in: 'Paarse' fracties positief over rapport Donner, in: NRC, 8 juni 1994, p.3.

301. Zo meent VVD-kamerlid Korthals. Zie 'Paarse' fracties positief over rapport Donner, in: NRC, 8 jun: 1994, p.3.

302. Hierover o.m. Reorganisarie $O M$, in: NJB, nr..1, 6 januari 1995, pp.33-34.

303. R. Schoof en K. Versteegh. Voorstel Sorgdrager aan kabinet: BVD-chef leider OM, in: NRC, 1 nov. 1994 , p.1. 
mede de positie van de minister van justitie tegenover het openbaar ministerie) wettelijk vast te leggen. Daartoe is - in de ogen van de PvdA - een wijziging van de Wet op de rechterlijke organisatie nodig, of is - in de optie van D'66 - een speciale wet noodzake. lijk. ${ }^{304}$

Uiteindelijk maakt de minister van justitie, in reactie op het rapport van de commissieDonner, de hoofdlijnen van de reorganisatie van het openbaar ministerie bekend ${ }^{10}$ De minister acht, met de commissie-Donner, een reorganisatie van het openbaar ministerie, zowel qua structunur als cultuur, noodzakelijk. Hierbij acht de minister het essentieel. dat het openbaar ministerie zijn kerntaak ex art. 4 Wet RO - welke wet volgens voornemen van de minister wijziging ondergaat - de rechtsorde strafrechtelijk te handhaven met beleid uitvoert. Inherent daaraan is volgens de minister dat de beleidsvoerende rol van het openbaar ministerie wordt "beheerst en begrensd" door zijn magistratelijke rol. 306 De minister, die zich zelf politiek verantwoordelijk acht voor het openbaar ministerie ${ }^{307}$, concludeert to het volgende 'streefbeleid' t.a.v. het openbaar ministerie. ${ }^{308}$ Het openbaar ministerie, dat als geheel dient te functioneren, krijgt een "herkenbaar, collegiaal, landelijk bestuur met een interne en externe strategische functie, een lijnfunctie en een beheersfunctie" ${ }^{309}$. Onverlet de centrale leiding ligt bij het parket, aangevoerd door integrale managers, het zwaartepunt. Differentiatie in de organisatie dient de nodige flexibiliteit. De ressortelijke structuur wordt gehandhaafd, zij kan de kwaliteitsbewaking ten goede komen. En de schaalgrootte van de parketten wordt geoptimaliseerd.

In het wervolg van deze studie worden toezichthoudende zelfstandige bestuursorganen, mede in het licht van hun relatie tot de minister, nader besproken.

\subsubsection{Andere argumenten voor instelling van zelfstandige bestuursorganen}

Uit het woorgaande blijkt het volgende. "Vergroting van verantwoordelijklieid van zelfstandige bestuursorganen betekent niet eo ipso een inkrimping van de ministeriële verantwoordelijkheid". 310

304. PudA: positie leider openbaar ministerie duidelijk vastleggen, in: $\mathrm{NRC}_{2} 2$ nov. 1994, p.1.

305. Brief van de minister van justitie inzake de reorganisatie wan het openbaar ministerie, TK 1994-1995 $24034, \mathrm{nr} .1$.

306. Reorganisatie wan het openbaar ministerie, TK 1994-1995, 24034, nr.1, p.3.

307. Weliswaar met "bewuste distantie t.a. $\mathrm{k}$. individuele zaaksbehandeling door het openbaar ministeris Reorganisatie openbaar ministerie, TK 1994-1995, 24034, nr.1, p.3.

308. T.M. Schalken en G.J. Lind, Het Openbaar Ministerie moet niet meer, maar minder gaan sturen, it NJB, nr. 12, 24 maart 1995, pp.455-456, zien in alleen financiële versterking en uiterlijke reorganisati als door de minister in navolging van de commissie-Donner woorgestaan, niet veel heil. Alateurs stells dat "alleen een fundamentele oriëntatie op de eigen kerntaak van het $O M$ " oplossing kan bieden.

309. D.w.z. een college van $\mathrm{p}-\mathrm{g}$ 's, dat regelmatig overlegt met de minister van wege de politieke ministerie verantwoordelijkheid voor het openbaar ministerie. Reorganisatie van het openbarar ministerie, I $1994-1995,24034$, nr.1, p.3.

310. H.R. van Gunsteren (1986), t.a.p., p.35. 
Hoewel beperking van de ministeriële verantwoordelijkheid in praktijk soms nog tegenvalt, staan voorstanders van vorming van zelfstandige bestuursorganen toch niet met lege handen. Andere argumenten pro zelfstandige bestuursorganen zijn er wel degelijk. ${ }^{311}$ Onder andere: $a$. ontlasting of ontheffing van de departementstop alias gezagsspreiding; b. transparanter bestuur; c. democratisering via inspraak en participatie van, al dan niet (maatschappelijk) georganiseerde burgers, met als gevolg cliëntgerichtheid, gelijke behandeling en beluitvorming toegesneden op omgeving; d. bevorderen expertise door inbreng van deskundigen; e. korte termijnplanning; $f$. onttrekking aan bepaalde regels van de rijksdienst; en $g$. publiekrechtelijk bestuur ten aanzien van een afgezondierd publiek vermogen.

Daar tegenover, en soms inherent aan, staan potentiële nadelen. Bij voorbeeld: a. gevaar voor particularisme; b. verstoring van taakbehartiging door territoriaal gedecentraliseerde organen, als mede coördinatieproblemen door verzwakking van de samenhang tussen een onoverzichtelijk aantal organen behorend tot het openbaar bestuur; c. relatief gebrek aan interne flexibiliteit, doelmatigheid en rechtsstatelijkheid; $d$. angst voor onbrekende rechtsbescherming en andersoortige controle; e. tegenvallende feitelijke toegankelijkheid voor individuele burger; en $\mathrm{f}$. gevaar dat minister zelfstandige bestuursorganen helemaal links laat liggen.

Ondanks de praktische problemen, betreffende hiërarchaal houvast, klampen fervente voorstanders van zelfstandige bestuursorganen zich toch vast aan de hypothese, dat

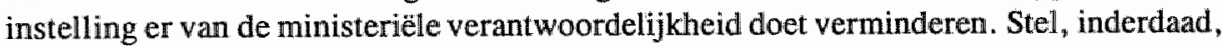
dat de minister niet ingrijpend individueel interveniëert en "en voorbij een zekere grens slechts verantwoordelijk moet worden gehouden voor de algemene functioneringscondities en voorschiriften van de met overheidstaken belaste zelfstandige bestuursorganen" ${ }^{\text {" }}{ }^{3 / 2}$ Dan moeten specifieke andere of nieuwe controlemechanismen worden ontworpen. Beperking sec van de ministeriële verantwoordelijkheid ligt tegen het ongeoorloofde aan. Beter is het het verlies c.q. de vermindering van politieke controle te compenseren door andere wegen van democratische controle. ${ }^{313}$ Deze noodzakelijke compen satie bieden bij voorbeeld "controle door een onafhankelijk orgaan (onder anderen de rechter) op de beslissingen van het bestuursorgaan, als mede goede regelingen met betrekking tot openbaatheid en verslaglegging" ${ }^{3 / 4}$ De in dit verband gesuggereerde rol

311. H.R. van Gunsteren (1986), t.a.P., p.35; J.B.J.M.ten Berge en F.A.M. Stroink, A.w. p.35; Functio neel beswur, waarom en hoe?, a.w., pp.18-21; F.A.M. Stroink, Zelfstimalige bestuursorganer, een intrigerend verschinsel, in: Bestuur, 1982, p.10: W. Derksen, De noodzaak van een functionele benade-

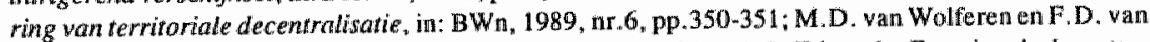
Hebjningen, Privatisering en $z b o^{\prime} s$, in: $L R_{,}, 1987$, nr.3, pp. 76-77; A. R. Edwards, Functionele decentralisatie en bestumrlijke organisatie, VNG-studies nr.2. "s-Grav., 1982, pp:28-31; J.L. Boxum, J. de Ridder en M. Scheltema, a., "pp. 51 -75, I.T. van den Berg. Waterschap en functionele decentralisatie. diss. RUU, Alphen a/d Rijn, 1982, p.72; D.J. Elxinga (1989), t.a.p., pp.76-77 resp. (1990), a.w., p.88. Hij stelt verfrissend, dat "de relatie die voondurendl wordt gelegd met de beperking van de volle ministeriele verantwoordelijkheid de discussie over de introductie van zbo's zodanig bellast, dat her constructieve ellement reeds "lang uit de gedachtenwisseling is verd wenen".

312. C.M. wan den Hoff en R. de Groot, a.w., p.2.

313. H.G. Lubberdink, a.w., pp.147-148.

314. Functionel bestuur: warom en hoe, TK 1990-1991, 21042, nr.4, p.15. 
van de ombudsman is aan twijfel onderhevig. Vervanging van politieke controle, door die van de nationale ombudsman, is kennelijk vooral door pragmatische gronden ingegeven. Bovendien is substitutie een vreemde eend in de bijt. Immers, beide controles zijn twee totaal verschillende vormen. Ook ombudswerk definiëren als aanvullende controle doet tekort. Hoogstens is aanvaardbaar, dat naar aanleiding van bevindingen van de ombudsman initiatief wordt ontplooid om de ministeriële verantwoordelijkheid te active ren. ${ }^{315}$

\subsubsection{HANDHAVEN OORSPRONKELIJKE OMVANG MINISTERIËLE VERANTWOORDELIKKHEII}

Met de politieke olie wordt, kennelijk, voortdurend gemorst op plekken waar dat slordij staat. De ministeriële verantwoondelijkheid wordt opgerekt waar dat nu juist niet d bedoeling is. Blijkt dan toch dat de rechtsidee van zelfstandige bestuursorganen "eent rationeel bepaalde constructie is, die te weinig rekening houdt met de politiek-emotionet overwegingen". 316

Vandaar gaan nog steeds stemmen op om de omvang van de ministeriële verantwoord lijkheid te handhaven. ${ }^{3 i}$ Waar het hierbij om gaat wordt duidelijk uit de volgens vergelijking. De verantwoordelijkheid van een minister is in feite gelijk aan die van et voetbaltrainer en een generaal. "Als het resultaat tegenvalt, dan gaat hij of zij de laan uj hoe onberispelijk hun inspanning en kundigheid ook geweest mogen zijn." 318 In zucht naar stabilisatie van de status quo ligt de nadruk op de ideologische, preventie werking van de ministeriële verantwoordelijkheid. De, niet te ontkennen, kracht van politieke controle ligt in haar latente normatieve invloedssfeer. Formele gezagsstructur hebben een belangrijke oriënterende en corrigerendle functie. Dit performatieve aspi nuanceert terecht de bekende correlatie verantwoordelijkheid-gezag. ${ }^{3 / 9}$

Verantwoordelijkheid reikt verder dan daadwerkelijke beheersingsmacht.. Klaarblijkel is er een conceptie van ministeriële verantwoordelijkheid die iemand ter verantwoordj

315. Aldus uitvoerig E. Helder, a.w., pp.82 85.

316. P.P.J van Buuren, Zelfstandige bestuursorganen, in: NJB, nr. 55,1980, p. 590.

317. A.D. Belinfante en J.L. de Reede, a.w., pp.83-104/129; F. Bolkestein, Problemen bij regeren, in: in "t Veld en W.I.M. Kickert (red.), Voorbij de grenzen aan sturing, "s-Gravenhage, 1989, pp. 15 i.h.b. p.22; M.C. Burkens, Ambtenaar, dienaar van de minister?, t.a.p., pp.9/19-20; D.J. Elaz (1989), t.a.p., pp.76-77 en (1990), a.w., p.88; A.M. Donner, ta.p., p.367; D.J. Elzinga, Verantw delijkheid te vack werward met verwijtbaarheid, in; BB, nov. 1987 ; E. Helder, a.w., p.82; R.J. H stra, stelling 3, syllabus congres Verzelfstandigen bij de rijksoverheid, te 's-Grav., d.d. 30 mow. 1 C.A.J.M. Kortmann, a.w., p.35; C.A.J.M. Kortmanm en P.P.T Bovend 'eert, a.w., p. 52; M. Schoo wen, t.a.p., p.94; K.F. Schuiling, Stants-en bestuursrechtelijke kroniek, in: BWn, nr.5, 1992, p. Vgl. H. Engels, t.a.p., p.43. Echter kritiek, op diens tweespaltigheid, door W.J. Witteveen, $t$. pp.128-129. Witteveen, die overigens zelf een rume opvatting van de m. $v$. aanhangt, prijst Engel zijn af wijzing van de verwijtbaarheidsconstructic. Maar auteur verwijt Engels" propageren varu (fur nele) decentralisatie. Daarmee schuift Engels meteen in de richting van een beperkte opvatting w ministeriële verantwoordelijkheid.

318. C.W. van der Pot, bewerkt door A.M. Donmer, a.w., p.399.

319. L.J.A. Damen, a.w., p.601; Zie paragraaf 3.1. 
roept juist daar waar controle ontbreekt of dreigt weg te vloeien. ${ }^{320}$ "Verantwoordelijk houden is dan een oproep tot leren, tot het vestigen van controle over uit de hand gelopen gebeurtenissen." 32t

Met in het spiegelbeeld de reflectie van datgene wat is gebeurd, maar vooral in het vizier van de toekomst, vindt het afleggen van verantwoording voor een forum plaats. Meer dan de aangesproken persoon, zijn innerlijk en zijn mogelijke verwijtbaarheid, staan de daad en de daarbij horende gebeurtenissen centraal. In het politieke verantwoordingsproces ligi de nadruk op futuristisch handelen. De hoop leeft dat het handelen, dat is het dragen van verantwoordelijkheid en de daar uit te trekken consequenties, herhaling krijgt.

Trouwens, dat dragen wan verantwoordelijkheid is niet een last waaronder slechts een rug lijdt. Indien overeen gekomen, zijn verschillende entiteiten verantwoordelijk. Er kan sprake zijn van overdracht van verantwoordelijkheid. Dat betekent het veranderen van relaties tussen mensen. Delegatie of attributie van bevoegdheden creeert neven- of subverantwoordelijkheid. Daaraan liggen, in principe, geen onaanvaardbare afschuivingstaktieken ten grondslag. ${ }^{322} \mathrm{Er}$ is geen vrijbrief om door te geven. Iedereen is, weliswaar op eigen wijze, onverminderd verantwoordelijk...

Nog maals, deze gedachtengang vindt alleen ingang, onder de volgende voorwaarde. Namelijk dat de ministeriële verantwoordelijkheid als, niet dagelijks te gebruiken, "reservoir ${ }^{s t}$ fungeert. ${ }^{323}$ Immers, in het midden van alle andere controlemechanismen neemt de ministeriële verantwoordelijkheid een aparte plaats in. Uitzonderlijk is dat de minister voor een heel gebeuren zondebok kan zijn. Als alles mis gaat, moet de bel over kunnen gaan bij een ministeriële, potentièle post.

320. H.R. van Gunsteren (1986), t.a.p., pp.34-37; H. R. van Gunsteren, Denken over politieke verantwoorde lijkheid, aratie Rijksuniwersiteit Leiden d.d. 25 okt. 1974, serie sociagl-politieke verkennimgen, Alphen a/d Rijn, p.19.

321. H.R. wan Gunsteren, Ministeriële verantwoordelijkheid in diskrediet, in: P. B. Cliteur en M. R. Rutgers, a. $w_{*}$ p. 72 .

322. Hierover uitvoerig. $R$. de Winter en W. Witteveen, t.a.p., pp.675-678.

323. H.R. van Gunsteren (1974), t.a.p., p.14; H.R. van Gunsteren (1986), t.a.,p., pp.38/46-47. 


\section{Geraadpleegde literatuur}

Aartsen, J.J.

Openbaar ministerie daet teveel aan beleid, te weinig aan kerntaak (samenvatting van zijn leaing tijdens het symposium 'Taak en functioneren OM', 7 juni 1994, Rotterdam) in: NRC, 7 juni 1994, p.11.

Albert, H.J.

De ongelijkzjdige driehoek: Onderlinge betrekkingen tussen lokaal bestuur, dissertatie RUL, Arnhem, 1994.

Baauw, P.J.

- Justitiebegroting, in: AA katern strafrecht, nr.11/12, 1992, pp.2085-2090;

-Justitiebegroting 1994, in: AA katern strafrecht 49, pp.2307-2311.

Beck, W.

Parlementaire controle: ritueel of besturingsinstrument?: Een analyse van verhoudingen, wissel. werkingen en mechanismen in het politieke proces, Assen/Maastricht, 1987.

Belinfante, A.D. \& Reede, J.L. de

Beginselen van het Nederlands staatsrecht, twaalfde druk, Alphen aan den Rijn, 1994.

Beers, A.A.L.

- Grondwettelijk inlichtingenrecht van kamerleden afdwingbaar bij Arob-rechter?, in: Hirsch Ballin-bundel, Recht doen door wetgewing, Zwolle, 1990, pp.377-389;

$\sim$ Art. 68 en art. 69, in: Akkernins, P.W.C. \& Koekkoek, A.K. (red.), De grondwet, tweede druk, Zwolle, 1992, pp.654-666.

Berg, J.Th.J. van den

Verantwoordelijkheid in een polycentrische samenleving, in: Bovens, M.A.P., Schuyt, C.J.M. Witteveen, W.J. \& Beer, Th.H.M. de (red.), Verantwoordelijkheid: retoriek of realiteit? Zwolle, 1989, p.191.

Berge, J.B.J.M. ten \& Stroink, F.A.M.

Functionele decentralisatie uit de schaduw; Een globale verkenning wan aard, omvang, verschit ningsvormen en bestwurlijke aspecten van zelfstanaige bestuursorganen en andere functionei organisatie-eenheden binnen het openbaar bestuar, "s-Gravenhage, juni 1988.

Besselink, L.

Kronieken Nederland; Ministeriële verantwoordelijheid, in: TVBP, respectievelijk nr.4, 198 : pp.189-201 en nr.3, 1989, pp. 107-110.

Blom, T. Mevis, P.A.M.

Ziende blind? Een beschouwing over inkijkoperaties, in: DD, tor. 1, 1995, pp.5-27.

Bock-Joosten, M.E.W.H. de

Hoe zelfstandig is het staatstoezicht op de volksgezondheid, in: NTB, nr.30, 10 september 198 pp. 1077-1082.

Boer, M.M. den

Ambtelijke bijstand bij het opstellen van amendementen en initiatiefvoorstellen, in: RM, $\mathrm{nr}$. 1993, pp.93-98.

Bolkestein, $F$.

Problemen bij regeren, in: Veld, R.J. in 't \& Kickert, W.J.M. (red.), Voorbij de grenzen a sturing, "s-Gravenhage, 1989, pp.15-34.

Boneschansker, E. \& Groot, H. de

Instrumenten bij sturen op afstand, IOO-reeks nr. 36, "s-Gravenhage, 1992.

Bovend"eert, P.P.T.

Regeerakkoorden en regeringsprogramma"s, "s-Gravenhage, 1988, pp.125-135.

Bovens, M.A.P. 
De veelwormigheid van verantwoordelijkheid, in: Bovens, M.A.P., Schuyt, C.J.M., Witteveen, W.J. \& Beer, Th.H.M. de, Verantwoordelijkheid: retoriek en realiteit; Verantwoording in publiek recht, politiek en maatschappij, Zwolle, 1989, pp.17-41.

Boxum, J.L.

- Zelfstandige bestuursorganen en de greep wan minisfers op de bestumplijke organisatie, in: Engels, J.W.M., Lambers, C., Niemeijer, E., Scheltema, M., Schuiling, K.F., Vis, B.C. \& Vuçsán, De rechtsstaat herdacht, Zwolle, 1989, pp.255-267;

- Zelfstandige bestuursorganen op maat, in: Bestuur, nr.4, 1990, pp. 101-111:

- Ministeriële verantwoordelijkheid en zelfstandige bestuursorganen, in: D.J. Elxinga (red.), De ministerielle verantwoordelijkheid in Nederland, Zwolle, 1994, pp.257-278.

Boxum, I.L., Ridder, J. de \& Scheltema, M.

Zelfstandige bestuursorganen in soorten, Verslag van een onderzoek naar de praktijk van zelfstandige bestuursorganen, i.o. W. ministerie van BZ, publikatie vakgroep bestuursrecht en -kunde. Groningen, Deventer, 1989.

Braam, A. wan

Vernieuwing van de rijksdienst: 'a contimuing story' in Nederland, in: Bestuurswetenschappen, $\mathrm{nr} .4,1993, \mathrm{pp} .225-233$.

Brenninkmeijer, A.F.M.

De magistraat in het strafrecht, in: NJB, 10 februari 1995, p.211.

Breunesse, $J$.

Over het eindrapport wan de commissie-Wiegel, in: OB, nr.12, 1993, pp.8-13.

Breunese, J.N. \& Dussen, J.W, van der

De scheiding tussen beleid en uitvoering, in: Beleidsanalyse, nr.1/2, 1994, pp.6-11.

Broek, J.N.J. van den, Groenveld, K. \& Hoog, J.A. de

Democratie, scheiding der machten, geschrift Haya van Somerenstichting en professor mr B.M.

Telderstichting nr.64, 's-Gravenhage, 1987.

Bruijn, J A. de \& Lammers, $N$.

Een juridische benadering van de departementen, in: Hakvoort, J.L.M. \& Heer, J.M. (red.), Wetenschap over departementen;" Theoretische confrontaties, reeks departementale studies, 'sGravenhage, 1989, pp.42-61.

Buwren, P.P.J. van Zelfstandige bestuursorganen, in: NJB, nr.55, 1980, pp.590-591.

Burkens, M.C.. Kummeling, H.R.B.M. \& Vermeulen, B.P.

Beginselen van de democratische rechtsstaat; Inleiding tot de grondslagen van het Nederiands staats-en bestuursrecht, derde druk, Zwolle/Utrecht, 1994.

Bij, J, van der

Coreferaat, in: Groot, H. de \& Oosteren, C.G.M. van, De toekomst van de publieke sector, IOO-jubileurnuitgave, verslag van IOO-congres d.d. 17 maart 1994, 's-Graventhage, pp .223-234.

Commissariaat voor de Media

Uittreksel verslag Gerard Heyne den Bak-symposium; Het CudM als zbo, 21 april 1993, Hilversum, pp. $1-7$.

Commissie-Deetman (bijzondere commissie vraagpunten)

Staatkundige, bestuurlijke en sraatsrechtelijke vernieuwing, TK 1991-1992, 21427, nr.3 (nrs.1101).

Commissie-Dolman

Rapport anderzoek van de organisatie en werkwijze der Kamer, TK 1985-1986, 19336, mrs. 1 -2.

Commissie-Duk (commissie inzake Algemene Bepalingen van Administratief recht)

Rapport Abar, vijfde druk, Aiphen aan den Rijn, 1984.

Commissie-(de) Koning 
Het bestel bijgesteld, TK 1993-1994, 21427, nrs.36-37/64, zie ook Fiet correciief referendwm, TK 1993-1994, 21427, nr.65.

Commissie-Scheltema (eerste externe commissie van de bijzondere commissie vraagpunten) Steekhoudend ministerschap; Betekenis en toepassing wan de ministeriële verantwoordelijkheid, TK 1992-1993, 21427, nrs.40-41.

Commissie-Van Traa (werkgroep vooronderzoek opsporingsmethoden) Opsporing gezocht, TK 1994-1995, 23945, nrs.1-2.

Commissie-Wiegel (vierde externe commissie van de bijzondere commissie vraagpunten) Naarkerndepartementen, kiezen voor een hoogwaardige en flexibele rijksdienst, TK 1992-1993, $21427, \mathrm{nr} .52$.

Couwenberg, S.W.

Nieuwe hoop op staatkundige en bestuurlijke vernieuwing in het fin de siècle, in: Burkens, M.C., Couwenberg, S.W., Franken, H. \& Brinkhorst, L.J., Staatsrechtelijke vernieuwingen; Commentaren op het rapport van de commissie-Deetman, publikatie van de Staatsrechtkring, Zwolle, 1991 , pp. $21-40$.

Daalder, E.J.

Het OM: magistraat of bestuursambtenaar?, in: Trema", nr.3/4, 1991, p.88 e.v.

Damen, L.J.A.

- Ongeregeld en ondoorzichtig bestuur, diss. RUG, Deventer, 1987;

- Individueel inlichtingentecht van kamerleden: een veilig bezit?, in: $N \mathrm{BB}, 1987, \mathrm{pp} .935-937$;

- Het individweel inlichtingenrechtvan kamerleden: nog geen veilig bezit; Recente parliprudentit over het inlichtingenrecht, in: Heringa, A.W., Litjens, C.H.A. \& Winter, R.E. de, Verhater over de Grondwet; T.g.v. het tienjarig jubileum van de Grondwet, 's-Gravenhage, pp.72-78.

Deetman, W.J.

De ministerielle verantwoordelijkheid: de afstand tussen norm en fictie, in: Lieshout, W.C.M (red.), Bestour en meesterschap; Opstellen over samenleving, staat en sturing, 's-Gravenhage 1988, pp. 101-113.

Derksen, w.

De noodzaak wan een functionele benadering van territoriale decentralisatie, in: Bestuursweter schappen, nr.6, 1989 , pp. 347-358.

Doelder, H. de

- De ministeriele verantwoordelijkheid voor het OM, in: Trema ", 1988, pp.374-377;

$\sim$ Van paasbrief tot herfstweer, in: DD, 1992, p.911 e.v.

Doelder, H. de, Foqué, R.M.G.E. \& Gerding, R.A.F.

Taak en functioneren wan het openbaar ministerie, SI-EUR-reeks deel 4, Arnhem, 1994.

Dölle, A.H.M.

Het recht van parlementaire enquête, Nederlands parlementsrecht, monografieën nr.3, Gronỉ gen, 1985, pp.76-85.

Dölle, A.H.M. \& Engels, J.W.M.

- De affaire-Brinkmant: symptoom van de rijzende ster van het ambt wan minister-president, i TvO, nr. 19, 1984, pp.411-419;

- Ministeriële verantwoordelijkheid voor niet-functioneel gedrag, in: D.J. Elzinga (red.), I ministeriële verantwoordelikheid in Nederland, Zwolle, 1994, pp.117-128.

Donner, A.M.

Verantwoording, redactionele kanttekeningen, in: RM Themis, 1987, pp.365-366.

Doorenbos, D.R. \& Wladimiroff, W.

Het (dis)functioneren van het Openbaar Ministerie; De rigoreuze no nonsense-benadering w de commissie-Donner, in: Adwocatenblad, nr.20, 28 oktober 1994, pp.84-87.

Dussen, C.W. van der 
Oude en nieuwe overheidsmonopolies, in: Overheidsmanagement, nr.12, 1994, p.318.

Dijk, J.A.G.M. van

Referendum, onderzoek en stadsgesprek en bestuurlijke vernieuwing van machten, in: Bestuurswetenschappen, ar.5, 1992, pp.384-401.

Edwards, A.R.

Functiomele decentralisatie en bestuurlijke organisatie, VNG-studies nt. 2, 's-Gravenhage, 1982.

Elzinga, D.J.

- Veramtwoordelijkheid te vaak verward met verwijtbaarheid, in: BB, november 1987;

- De waardle wan een relatief rechtsbegrip, oratie, Groningen, 1988;

- Politieke verantwoordelijkheid: Over verval en vooruitgang in de politieke democratie, in:

Bovens, M.A.P., Schuyt, C.J.M., Witteveen, W.J.\& Beer, Th.H.M. de, Verantwoordelijkheid: retoriek of realiteit; Verantwoording in publiek recht, politiek en maatschappij, $\mathbb{Z}$ wolle, 1989. pp.63-79;

$\sim$ De staat van het recht: opstellen over staatsrecht en politiek, Zwolle, 1990, pp.75 115;

- Commissie-Scheltema; Belangrijk: heldere politieke verantwoordelijkheid, in: BB, nr.24, 18 juni 1993, p.31:

- Hirsch Ballin neemt wel erg veel verantwoordelijkheid, in: BB, nr.29/30, 30 juli 1993, p.31;

$\sim$ Hoe moet de grondwet eigenlijk worden geimterpreteerd?, in: BB, nr.51/52, 24 december 1993, pp.41-42;

- Een volle ministeriële verantwoordelijkheid voor het Openbaar Ministerie, maar geen ongebreidelde sruring van het $O M$, in: NJB, nr. 16, 22 april 1994, pp.529-537;

$\sim$ Naschrift, in: NJB, nr.22, 3 juni 1994, p.751;

- Experimenten met referenda vereisen grote zorgwuldigheid, in: BB, nr.21/22, 3 juni 1994. p. 37;

- De politieke ministeriële verantwoordelijkheid, in; D.J. Elzinga (red.), De ministeriële verantwoordelijkheid in Nederland, Zwolle, 1994, pp.31-49;

- De strafrechtelijke ministerielle verantwoordelijkheid, in: D.J. Elzinga (red.), De ministeriële verantwoordelijkheid in Nederland, Zwolle, 1994, pp.65-78.

Elzinga, D.J. (red.)

Minsteriële veramtwoordelijkheid in Nederland. Zwolle, 1994.

Elzinga, D.J. \& Koopman, J.

Ministerięle verantwoardelijkheid en Openbaar Ministerie, in: D.J. Elzinga (red.), De ministeriele verantwoordelijkheid in Nederland, Zwolle, 1994, pp.211-236.

Elzinga, D.J. \& Warmelink, H.G.

Het Nederlandse parlementaire stelsel, AA cahiers stats- en bestuursrecht, deel 3, Nijmegen. 1993.

Engells, $H$.

- Vertrouwensbeginsel of genegenheidsbeginsel, in: PD, nr.2, 1988, pp.38-45;

- De collectieve ministeriële verantwoordelikheid, in: D.J. Elzinga (red.), De ministerielle verantwoordelijkheid in Nederland, Zwolle, 1994, pp.51-64.

Eppink, D.J. \& Spiering, $H$.

Kamerleden vinden dat ze te veel op ambtenaren gaan lijken, in: NRC, 14 maart 1992, p.39.

Faber, S. \& Ruller, S. van

Vrijwel voortdurend in ontwikkeling; Het $O M$, de commissie-Donner en de geschledenis, in: DD. nr.9, 1994, pp.894-905.

Ficq, C.R.L.R.M.

De officier van justitie, magistraat (of bestuursambtenaar), in: Trema", nr.6, 1991, pp. 159-166.

Franssen "H.M. (red.)

Het parlement in aktie; Bevoegdheden van de Staten-Generaal, Assen/Maastricht, 1986. 
Gilhuis, P.C.

- Het referendum; Een rechtsvergelijkende studie, diss, RUL, Alphen a/d Rijn, 1981;

- Over de huidige mogelijkheden van het houden van referenda in het Koninkrijk der Nederlanden, in: Hennekens, H.Ph.J.A.M., e.a., Bestuursrechtaan de horizon; Opstellen over materieel bestuursrecht t.g.v. de tachtigste verjaardag van professor mr S.F.L. baron van Wijnbergen. Zwolle, 1994, pp.21-34.

Goorden, C.P.J.

$\sim$ Awb: beleidsregels bij mandaat en delegatie, in: NTB, nr. 5,1992, pp. 163-168;

$\sim$ Kroniek: bestuurlijke organisatie, in: NTB, nr.10, 1992, pp.318-321;

- Bestuurlijke organisatie, in: C.P.J. Goorden (red.), Kroniek bestuursrecht1987-1992, Zwolle, 1993, pp.1-13.

Graaf, Th.C. de

Ambtenacar, minister en volksvertegenwoordiging, in: Jong, B.F. de, Kortmann, C.A.J.M. \& Kummeling, H.R.B.M. (red.), Nijmeegs staatsrecht; Bundel opstellen aangeboden aan mr H.J.M. Beekman, Nijmegen, 1987, pp.35-46.

Graaf, Th.C. de \& Michiels, F.C.M.A.

Over bouwen en vertrouwen; Staats-en bestuursrechtelijke opmerkingen bij het rapport wan de parlementaire enquêtecommissie bouwsubsidies, in: NJB, nr.15, 16 april 1988, pp.493-500.

Groot, H. de, Haring, H.M.M., Kuhry, B. \& Noort, E.A. van

Kerngegevens openbaar bestuur; Over produkten, personeel en kosten wan publieke diensfwerleming, IOO-rapport nr.51, 's-Gravenhage, september 1993, pp.63-74.

Gunsteren, H.R. van

-Denken over politieke verantwoordelijheid, oratie RUL d.d. 25 aktober 1974, serie sociaalpolitieke verkenningen, Alphen aan den Rijn;

- Wie in zijn graf ligt, maakt geen fouten meer; Een interventieleer te ontwikkelen door ambienaren, in: B \& M, nr.6, 1984, pp.159-163;

-Zbo's en het vraagstuk van politieke en bestuurlike verantwoordelikhetd, in: WRR, Studiemiddag zelfstandige bestuursorganen, d.d. 12 november 1985, serie voorstudies en achtergronden V54, "s-Gravenhage, 1986 , pp.34-40;

- Ministeriele verantwoordelijkheid in diskrediet, in: Cliteur, P.B. \& Rutgers, M.R., De trias onder spanning, Groningen, 1990, pp.67-75.

Haan, P. de, Drupsteen, Th.G. \& Fernhout, R.

Bestuursrechtin de sociale rechtsstaat: instrumenten waarborg; Deel 1 , ontwikkeling, organisa tie en instumentarium, derde herziene druk, Deventer, 1987.

Haan, P. de \& Ru, H.J. de

De ministeriele werantwoordelikheid en de bevoegdheid van de (adjunct-)inspecteur, adwiezen aan de federatie van verenigingen van (adjunct-)inspecteurs van 's Rijksbelastingen. Her. veld/Amsterdam, 1985.

Haenen, $M$.

'Amsterdam deed arrogante greep naar de macht', Oprichter over IRT-debacle, in: NRC, 6 apri 1994, p.ll.

Haenen, M. \& Meeus, T.J.

- Inkijkoperaties 'in strijd met met', in: NRC, 8 oktober 1994, p.1;

- Onderzoek naar opsporingsmethoden van politie was net jongensboek, in: NRC, 21 oktobe 1994, p.3;

- 'Ik begrijp nu beter de boosheid van Nordholt; VWD-kamerlid Van der Stoel over polinit enquềre, in: NRC, 22 aktober 1994, p.3.

Haenen, M. \& Schoof, R.

Donner wil openbaar ministerie een gezicht geven, in: NRC, 8 juni 1994, p.3. 


\section{Hagelstein, G.H.}

De parlementaire commissies, reeks Nederlands parlementsrecht, monografieèn nr.6, dissertatie RUG, Groningen, 1991.

Hakwoort, J.L.M. \& Heer, J.M. de Wetenschap over departementen: theoretische confrontaties, reeks departementale studies, "\$Gravenhage, 1989.

Hart, A.C. 't

Penale bestuurskunde: het rapport-Donner, in: DD, nr.7, 1994, pp.643-650.

Helder, E.

Ombudsman en administratieve rechtsbescherming, De Nationale ombudsman, gemeentelijke klachreninstanties, alsmede enkele buitenlandse ombudsmanvoorzieningen, in relatie tot rechtsbescherming tegen de overheid: een juridische en empirische studie, dissertatie UT, Enschede, 1989.

Hessing, R.C. \& Langenberg, P.J.

Politiek-ambtelijke betrekkingen in een nieww perspectief?, in: B \& M, nr.11, 1983, pp.306-313. Hirsch Ballin, E.M.H.

Ministeriële verantwoordelijkheid, verzelfstandiging en sturing; Een beschouwing over ministeriële veramiwoordelijkheid en de strafrechtelijke handhaving van de rechtsorde, in: Frissen, P.H.A. e.a., Het managen wan verandering door verzelfstandiging, Management Centrum, "sGravenhage, april 1993, pp.45-72.

Hoff, C.M. van den Ministeriële verantwoordelijkheiden politieke controle, in: Bestuur, mr.1, januari 1989, pp.8-10.

Hoff, C.M. van den \& Groot, R. de Decentralisatie: zelfstandige bestuursorganen, Essay over het verschijnsel van zelfstandige bestuursorganen, hun mogelijke bijdrage aan de ontlasting van de politieke en ambtelijke top en de consequenties met betrekking tot de omvang van de ministeriële verantwoordelijkheid, achtergrondstudie nr.2, deel 2, uitgebracht aan de commissie hoofdstructuur rijksdienst, 's-Gravenhage, 1981 .

Hoogers, H.G. \& Del Grosso, N.Y.

De ministeriële verantwoordelijkheid voor het buitenlands beleid, in: D.J. Elzinga (red.), De ministeriële verantwoordelijkheid in Nederland, Zwolle, 1994, pp. 187-210.

Hoogteijling, $\mathrm{J} . \mathrm{H}$. (red.)

Besturen op afstand, 10O-reeks nr.34, "s-Gravenhage, december 1991.

Hukkelhoven, M.M.G.

De zelfstandigheid van de Arbeidsvoorzieningsorganisatie, in: Bestuurskunde, nr. 1, 1994, pp.1320.

Janse de Jonge, E.J.

Het budgetrecht, Deventer, 1993.

Jansen, O.J.D.M.L.

Bestuursrecht en strafprocesrecht: doorwerken of afgrenzen?, in: T. Hoogenboom en L.J.A. Damen, In de sfeer van administratief recht, Utrecht, 1994, pp.257-283.

Janus, J.A.B.

Ambtelijke bijstand, informatie en verantwoording, in: Gegeven de Grondwet, CZW-bundel, Deventer, 1988, pp.105-115.

Jong, P. de, Korsten, A.F.A., Modderkolk, A.J. \& Pröpper, I.M.A.M. (red.)

Verantwoordelijkheiden verantwoording in het openbaar bestuur, Geschriften van de Vereniging woor Bestuurskunde nr.18, "s-Gravenhage, 1995.

Jurgens, E.C.M.

- Vrees voor politieke inbreng in de rechtspleging, in: NRC, 15 december 1992, p.8; 
- De mythe van Meerenberg; Over de betrekkelijke legitimatie die uitgaat van medewetgeving door de Staten-Generaal, in: NJB, nr.39, 4 november 1993, pp.1381-1386.

Kalberg, F.A.J.Th.

Staatsrechtelike aspecten van de paspoortaffaire, in: Two, nr.20, 17 november 1988, pp 431433.

Kan, J.M.

$\sim$ Ministeriële verantwoordelijkheid in gevallen wan decentralisatie en deconcentratie, in: $\mathrm{NJB}_{\mathrm{B}}$ nrs.22/23, juni 1963 , pp. 457-464/485-491;

$\sim$ Boekbespreking dissertatie H.G. Lubberdink, in: NJB, nr.30, jrg. 58,10 september 1983 , pp.997-999.

Kelk, C.

Openbatar Ministerie en rechtshandhaving; Een nieww werk van A.C. 't Hart, in: NJB, nr. 10 , 11 maart 1994, pp.333-336.

Koeman, N.S.J.

Over beleid en controle; Op zoek naar een opvolger wan de triasleer, in: NTB, nr.3, 1989. pp.73-79.

Koppen, P.A.

Beleid van rijksambtenarenmoet controleerbaarworden, in: Namens, nr.11/12, 1990, pp.31-39

Korthals Altes, $F$.

$\sim$ De verhouding tussen minister wan justitie en het openbaar ministerie; Inleiding najaarsverga dering van de sectie openbaar ministerie van de NVvR d.d. 15 oktober 1988, in: Trema", 1988 pp.367-373;

$\sim$ De minister is politiek veranmoordelijk woor het $O M$, in. NRC, 9 december 1992, p.8.

Kortmann, C.A.J.M.

- Constitutioneel recht, Dewenter, 1990;

- Consistentie?, in: NJB, nr.22, 3 juni 1994, p.750;

- Kroniek wan het staatsrecht, in: De staat van het recht, kronieken 1 augustus 1993 - 1 augu tus 1994 als bijlage van NJB, nr.33, 23 september 1994, pp.46-49.

Kortmann, C.A.J.M. \& Bovend"eert, P.P.T.

Inleiding constitutioneel recht, Deventer, 1993.

Kranenburg, $M$.

Staaltje van politiek opportunisme; $I R T$ past in rijtje visfraude, bouwfraude en paspoorten, i NRC, 31 maart 1994, p.11;

- Aftreden na verkiezingen is schemergebied in staatsrecht, in: NRC, 26 mei 1994, p.1.

Kuiper, R.J.

Verzelfstandiging en informatievoorziening, in: Frissen, P.H.A. e.a., Het managen vam veranu ring door verzelfstandiging, Management Centrum, april 1993. pp.87-104.

Kuitenbrouwer, $\mathrm{F}$.

- Ethiek van het rechercheteam is abacadabra, in: NRC, 6 april 1994, p.13;

- Relatie ministers met politie en OM onduidelijk geregeld, in: NRC, 8 april 1994, p. 3;

-Interregionale politieteams zweven ver boven de democratie, in: $\mathrm{NRC}, 30$ september 19 ! p.9.

Kuijken, W.J. \& Nes, B. van Overheid: Make yourself accountable!, in: De Accountant, nr.4, december 1994, pp.268-2

Lagas, P.C..

Over het gezicht van verantwoordelijkheid; Politieke legitimiteit in het geding, in: BB, nr. 17, april 1994, pp.28-29.

Langenberg, P.J. 
$\sim$ Gebonden zelfbeheer: over de verhouding tussen regering, parlement en functionele organen. in: Graaf, Th.C. de. Hoeven, D.A. van der \& Langenberg, P.J., Omtrent het parlement; Opstetlen over parlement en democratisch bestuur, Utrecht/Antwerpen, 1985, pp.116-147;

- Ambtelijke aanspreekbaarheid", Aanvulling op de tanende ministeriële aanspreekbaarheid, in: Bestuur, nr.3, 1988, pp.61-67.

Langbroek, P.M.

De publieke verantwoordelijkheid voor rechtspraak, in: Trema, nr.11, 1994, pp.405-413.

Lensink, J.A.W.

De evolutie van de politiebevoegdheden in het raam van de bestrijding van de ernstige, georganiseerde misdaad, in: DD, nr.10, 1994, pp.1007-1029.

Lindo, C.M.Th.

Interview; Het perspectief van minister W. Sorgdrager, in: NJB, nr. I, 6 januari 1995, pp.1-6.

Lubberdink, H.G.

- De betekenis van de ministeriële verantwoordelijkheid voor het openbaar bestuur, dissertatie

RUG, Deventer, 1982;

- Kronieken bestuurlijke organisatie, in: NTB, 1987 tot en met 1992.

Maarseveen, H.Th.J.F. van

- Ministerièle verantwoordelijkheid en OM na 1976, in: NJB, 1977, p.209-211;

- Reidans der niet-verantwoordelijken, in: NJB, nr.45/46, 26 december 1987, p.1516;

- Meer recht, minder minister, in: NJB, nr.15, 16 april 1988, pp.485-486.

Malen, K. van der

Kamerleden gruwen van chaos, in: NRC, 1 december 1992, p. 3.

Meij, J.M. de

Inleiding tot het staatsrecht en het bestuursrecht, derde druk, Groningen, 1990.

Ministerie van financiën

Vrijheld in gebondenheid; Een rapportage over functioneel gedecentraliseerde instellingen rondom de rijksoverheid, in het bijzonder over opzet en werking van toezicht en controle bij deze instellingen, publikatie centrale accountantsdienst projectgroep functionele decentrallisatie, deel I/II, 's-Gravenhage, november 1991.

Mols, G.P.M.F., Roos, Th.A. de \& Spronken, T.

Het echte IRT-debar; Grenzen wan opsporingsmethoden, in: NJB, nr.24, 17 juni 1994, pp.797804.

Mulder, A.

Zelfstandige bestuursdiensten in Nederland, preadvies voor VVSR van België en Nederlland, Zwolle, 1980.

Munneke, $\mathbb{H}$.

Wetmatigheid van bestuur belangrijker dan toetsing politiek, in: NJB, nr.22, 3 juni 1994. pp. 750-751.

Nieuwenhuis, w.

Lubbers breekt reis Indonesië af voor IRT-kamerdebat, in: NRC, 6 april 1994, p.2.

Nieuwenhuijsen, $P$.

Nationale ombudsman: "een altruilsme moet kenmerk blijwen woor de overheid", in: BBM, 29 januari 1993, pp.4-7.

Noordhoek, D.P. Van Next Steps naar verzelfstandiging, van Citizin's Charter naar Kwaliteitshandwesten; Britse voorbeelden voor Nederlandse verhoudingen, in: Beleidsanalyse, nr.3-4, 1993, pp.15-20.

Oostenbrink, J.J.

De actuele betekenis van de trias politica, in: Cliteur, P.B. \& Rutgers, M.R, De trias onder spanning. Groningen, 1990 pp.55-65. 
Pieters, J.J.Th.M. \& Revis, C.J.P.M.

Het wettelijk kader voor 'kijkoperaties', in: NJB, nr.11, 17 maart 1995, pp.401-407.

Polak, J.M.

De rechtspositie wan de belastinginspectie en de zbo's, in: NJB, nr.43, 7 december 1985; pp. 1370-1371.

Polman, J.M.M.

Zelfstandige bestuursorganen: aciue el fenomeen in politiek en bestuur, in: Bestuur, nr.9, 1988 , pp.202-206.

Pol, C.W. van der \& Donner, A.M., m.m.v. Prakke, L., Reede, J.L. de \& Wissen, G.J.M. wan Handboek wan het Nederlandse staatsrecht, twaalfde druk, Zwolle, 1989.

Praag, Ph. van jir. (red.)

Een stem verder: Het referendum in de lokale politiek, Amsterdam, 1993.

Raad voor het binnenlands bestuur

Advies over functionele decentralisatie, "s-Gravenhage, september 1988.

Reede, J.L. de

Kronieken Nederland; Staatkundige, bestuurlijke en staatsrechtelijkevernieuwing in Nederland? in: TVBP, $1991, \mathrm{pp} .581-586$.

Rehwinkel, J.P.

- Begrip ministeriële verantwoordelijkheid nog steeds niet helder, in: Namens, nr.9, 1990, pp.24-29;

De minister-president en de commissie-Deetman, in: Rehwinkel, J.P., Bowend'eert, P.P.T. \& Hoekstra, R.J., De positie van de minister-president, publikatie Staatsrechtkring nr.8, Zwolle, 1994, pp.1-21;

- Ministeriële verantwoordelijkheid voor het Koninklijk Huis, in: D.J. Elzinga (red.), De ministeriële verantwoordelijkheid in Nederland, Zwolle, 1994, pp.91-102.

Remmelink, J.

De ovj: magistraat of bestuursambtenaar?, in: Trema", nr.6, 1991, pp.167-178.

Ridder, J, de

Ministeriële verantwoordelijkheid en politiek-ambtelijke verhoudingen, in: D.J. Elzinga (red.), De ministeriële verantwoordelijkheid in Nederland, Zwolle, 1994, pp.279-292.

Rosenthal, U.

Tussen stagnatie en hervorming: na de bijzondere commissie-vraagpunten, in: LR, nr.6, 1992, pp. 202-208.

Rosenthal, U., Schendelen, M.P.C.M. van \& Ringeling, A.B.

Openbaar bestuur, Alphen aan den Rijn, vierde druk, 1987.

Ru, H.J. de

Algemene discussie, in: WRR, Studiemiddag zelfstandigebestuursorganen, V54, "s-Gravenhage, 1986 , pp.52-56.

Saris, W.E., Neijens, P. \& Slot, J.J.M.

Het eerste Amsterdamse referendum in perspectief, Amsterdam, 1992.

Schagen, J.A. van

De Theede Kamer der Staten-Generaal; Een staatsrechtelijke studie over haar organisatie en werkwijze "dissertatie RUU, Utrecht/Zwolle, 1994.

Schalken, T.M.

- Het taboe van art. 5 RO; Over de bestuurlijke en magistratelijke niveaus in de rechtsbescherming tussen minister wan justitie en OM, in: Trema", nr.6, 1991, p.179-194;

- Een nieuwe cultur binmen het OM?; De paasbrief van de procurewrs-generaalover de eigen verantwoordelijkheid van het openbaar ministerie, in: NJB, nr.26, 25 juni 1992, pp.813-819; - Openbaar ministerie moet weer terugkeren maar zijn oertaken, in: $\mathrm{NRC}_{n} 31$ okt. 1994, p.7; 
$\sim$ Controle op politie, in: DD, nr.10, 1994, pp.993-997.

Schalken, T.M. \& Lind, G.I.

Het openbaar mimisterie moet niet meer, maar minder gaan sturen, in: NJB, nr.12, 24 maart 1995, pp. 455-456.

Scheltema, $M$.

- Zelfstandige bestuursorganen, oratie, Groningen, 21 mei 1974;

$\sim$ Raden en commissies als zelfstandige bestuursorganen, in: Wetenschappelijke raad voor het regeringsbeleid, Adviseren aan de overheid, serie studies en achtergronden V5, 1977, pp.331363;

- De bevoegdheid van de minister c.q. staatssecretaris van financiën om in te gripen in de aanslagregeling van individuele personen, rapport uitgegeven op verzoek van de directeurgeneraal der belastingen, 1985, als bijlage van TK 1985-1986, 19022, nrs.8-10;

- Slotbeschowwing tijdens Studiedag zelfstandige bestuursorganen d.d. 12 november 1985 , WRR-serie voorstudies en achtergronden V54, 1986, pp.60-61;

- Ministeriele verantwoordelijkheid en contractmanagement, in: Lieshout, W.C.M. van (red.), Opstellen over samenleving, staat en sturing, 's-Gravenhage, 1988, pp.93-99.

Scheltema, M. \& Lubberdink, H.G.

Ministeriële verantwoordelijkheid en parlementaire controle, in: AA, Parlementaire controle en democratie in de verzorgingsstaat, staatsrechtcongres, Utrecht, 1980, pp.1-18.

Scholten, G.H.

- De fictie van de verantwoordelijkheid als grondslag woor democratisch bestuur, in: Acta Politica, nr.3,jirg.5, 1969-1970, pp.237-253;

$\sim$ De toekomst van de parlementaire democratie (1977), in: LR, In tweede lezing, 1988, pp.6471 .

Schoof, $\mathbb{R}$.

$\sim$ 'Tk wil niet overal de schuld van krijgen': Procureur-generaalvan Den Haag W. Sorgdrager, in: NRC, 14 juli 1994, p.2;

Politie is waak de meerdere van het OM; Promovendus Albert over de zwakke stee in het drichoeksoverleg, in: NRC, 12 oktober 1994, p.3.

Schoot, R. \& Versteegh, $\mathbf{K}$.

- Sorgdrager tegen beleid voorganger; Geen kroongetuigen en 'imkijken', en "De politie moet geen wapenwedloop beginnen met de misdaad", in: NRC, 29 oktober 1994, pp. 1/3;

- Voorstel Sorgdrageraan kabinet: BVD-chefleider openbaar ministerie, in: NRC, 1 november 1994 , p.1.

Schoonhoven, $M$.

De individuele ministerielte verantwoordelijkheid, grenzeloos?, in: TvO, nr.5, 3 maart 1988 , pp.92-96.

Schuiling, K.F.

Staats- en bestuursrechtelijke kroniek, in: Bestuurswetenschappen, respectievelijk nr.4, 1992 , pp. 365-368 en nr.5, 1992, p.452-455.

Schutte, G.J.

Kerndepartementen en ministeriële verannwoordelijkheid, in: Openbaar Bestuur, nr.4, 1994, pp. $2-4$.

Sewandono, 1 .

Toenemende ministeriële verantwoordelijkheid voor de Prins van Oranje, in: NJB, nr.12, 24 maart 1995 , pp. $457-459$.

Simons, D.

Ministeriele verantwoordelijkheid en ministeriele verantwoording (1979), in: $\mathbf{L R}$, in tweede lezing, 1988, pp.81-83. 
Sorgdrager, W.

IRT-debat, in: AP, 30 aprill 1994, nr.9.

Staatscommissie

Relatie kiezers en beleidsvorming over referendum en volksinitiatief, "s-Gravenhage, 1985.

Stafafdeling constitutionele zaken van het ministerie van binnenlandse zaken

Ambtenaar, dienaar wan de minister?, verslaglegging symposium d.d. 28 augustus 1986, 'sGrav., januari 1987.

Stolwijk, S.A.M.

De minister van justitie, het $O M$ en art. 5 RO, in: Magistraat met beleid: de officier van justitie en zijn omgeving; Opstellen aangeboden aan $\mathrm{mr} C$, van Steenderen bij zijn afscheid als hoofdofficier van justitie te Amsterdam op 25 september 1992, Arnhem, 1992, p.33 e.v.

Stroink, F.A.M.

- Het leerstuk der deconcentratie, dissertatie RUU, "s-Gravenhage, 1978;

- Zelfstandige bestuwrsorganen, een intrigerend verschijnsel, in: Bestuur, 1982, pp.8-11;

- Leestafel: boekbespreking dissertatie Lubberdink, in: TvO, nr. 18, 21 oktober 1982, pp.544546 ;

- Staatssecretaris, Koning en belastinginspectie, in: NJB, nr.32, 1 september 1985, pp.10291031.

Thomassen, J.J.A., Schendelen, M.P.C.M. \& Zielonka-Goei, M.L.. (red.)

De geachte afgewaardigde; Hoe kamerleden denken over het Nederlandse parlement, Muiderberg, 1993.

Thunnissen, V.F.

Ministeriele verantwoordelijkheid: een kwestie van vertrouwen, in: Heringa, A.W., Winter, R.E. de \& Witteveen, W.J., Staatkundig jaarboek 1983-1984, Zwolle, 1983, pp.49-59.

Tomesen, W.B.M.

De paasbrief: de minister neemt positie in, in: Trema", nr.9, jrg.15, pp.407-409.

Tuurenhout, $\mathbf{M} . \mathbb{E}$.

Parlementaire controle en ambtelijke verantwoordelijkheid, dissertatie RUL, Arnhem, 1992.

Tweede Kamer

- Rapport onderzaek van de organisatie en werkwijze der Kamer, TK 1985-1986, 19336, nr.2;

Functioneel bestuur: waarom en hoe?, TK 1988-1989, 21042, nr.2, TK 1990-1991, 21042. nrs. 4-10;

- Landelijk OM-bureau en landelijk rechercheteam, TK 1994-1995, 22838, nr.9;

- Regeerakkoord 1994: kewzes voor de toekomst, TK 1993-1994, 23715, nr.11;

- Jacaroverzicht Informatievoorziening 1993, TK 1993-1994, 23861, nrs, 1-2;

- Vaststelling begroting uitgaven en ontvangsten ministerie van justitie, TK 1994-1995, 23900

VI, nrs. 1-2;

Opsporing gezocht, TK 1994-1995, 23945, nurs.112;

- Reorganisatie wan het openbaar ministerie, TK 1994-1995, 24034, nr.1;

- Decemberverslag van de Algemene Rekenkamer over 199.4, TK 1994-1995, 24045, nrs.1-2.

- Parlementaire enquête opsporingsmethoden, TK $1994-1995,24072$, nr.1 e.v.;

- Verslag wan de Algemene Rekenkamer over 1994, deel 3; Zelfstandige besiuursorganen en ministeriele verantwoordelijkheid, "TK 1994-1995, 24130 , nr.3.

Veld, R.J. in 't

- Normen, in: Binnenlands Bestuur, nr.5, 4 februari 1994, p.13;

$\sim$ De kerntakenbenadiering bij de Rijksoverheid: onderwerp van gesprek, in: Sip, C. \& Vrancken, P.H.J., De kerntakenbenadering bij de Rijksoverheid, 's-Gravenhage, aprill 1994, pp.7-15. Vermeulen, $F$.

IRT-debat knakt carrieres Van Thijn en Hirsch Ballin, in: NRC, 26 mei 1994, p.3. 
Vis, $J . J$.

- De ministeriële verantwoordelijkheid en de staatssecretaris, in: D.J. Elzinga (red.), De mimisteriele verantwoordelijkheid in Nederland, Zwolle, 1994, pp.129-148;

- Ministeriële verantwoordelijkheid en kabinetsformatie, in: D.J. Elzinga (red.), De ministeriële verantwoordelijkheid in Nederland, Zwolle, 1994, pp.177-186.

Visscher, G.

Ministeriële verantwoordelikheid en parlementair inlichtingenrecht, in: D.J. Elzinga (red.), De ministeriële verantwoordelijkheid in Nederland, Zwolle, 1994, pp.237-256.

Visser, R.K.

Ministeriele verantwoordelijkheid na Maastricht, in: NJB, nr.37, 21 oktober 1994, pp.1271 1273.

Vlaar, S.N.

De strafrechtelijke ministeriele verantwoordelijkheid; Enkele aspecten ervan, in het bijzonder $m . b_{. t}$. de latste grondwetsherziening, in: TvO, nr.14, 1985, pp.287-293.

Vlies, I.C. van der

- Recensie Tuurenhout, in: NJB, nr.32, 17 september 1992, pp.1053-1054;

$\sim$ Gedeeltelijke regelgeving, in: $\mathrm{OB}, \mathrm{nr} .10,1992, \mathrm{pp}, 6-11$.

Vries, $\mathbf{F}_{\text {. de }}$

De politieke verantwoordelijkheid en het functioneren wan de Eerste Kamer, in: D.J. Elxinga (red.), De ministeriële verantwoordelikheid in Nederland, Zwolle, 1994, pp.149-176.

Waaldijk, C.

Motiveringsplichten wan de wetgever, dissertatie RL, Lelystad, 1994.

Wansink, $\mathrm{H}$.

Passende kleren; Kleine departementen zijn niet automatisch beter, in: Intermediair, nr.34, 27 augustus 1993, pp.11-13.

Warmelink, H.G.

-De geldelijke ministeriële verantwoordelijkheid, in: D.J. Eizinga (red.), De ministeriële verantwoordelijkheid in Nederland, Zwolle, 1994, pp.79-90;

- Ministeriële verantwoordelijkheid woar ambtelijk handelen, in: D.J. Elzinga (red.), De ministerielle verantwoordelikheid in Nederland, Zwolle, 1994, pp.103-116.

Wetenschappelijke raad voor het regeringsbeleid

De organisatie voor het openbaar bestuur, 's-Gravenhage, 1975.

Winter, R.E.

Nota bene: ministeriële verantwoordelijkheid, in: PB, nr.4, 1988, p.142.

Winter, R.E. \& Witteveen, W.J.

De wil v.d. wetgever en het afschuiven van verantwoordelijkheden, in: NJB, nr. 26, 27 juni 1981 , pp. 669-678.

Witteveen, W.J.

Opunie: de ministeriële verantwoordelijkheid; Visies op een nuttige functie, in: $\mathrm{PD}, \mathrm{nr} .4,198$. pp. 127-132.

Wolferen, M.D. van \& Heijningen, F.D.

Privatisering en zelfstandige bestuursorganen, in: LR, nr.3, 1987, pp.73-78.

Wortel, J.

Vervolgen in belastingzaken, diss. KUN, fiscale monografieën nr.56, Deventer, 1991, pp.295303.

Wijk, H.D. van, bewerkt door Konijnenbelt, W. \& Male, R.M.. van

Hoofdstukken van administratief recht, negende druk, Utrecht, 1994. 
Hoofdstuk 4

\section{Legaliteitsbeginsel}

\section{\$ 4.0 Wettelijke grondslag}

Zelfstandige bestuursorganen oefenen hun taken niet onder volledige ministeriële verantwoordelijkheid uit. Deze organen zijn niet hiërarchisch ondergeschikt aan de minister. Daarom is het de meest volkomen situatie als de instelling van deze overheidsorganen met publiekrechtelijke bevoegdheden aan de legaliteitseis voldoet. Sterker nog, wat betreft het overheidsoptreden is toepasselijkheid van het rechtsstatelijke legaliteitsbeginsel wenselijk.

Van oudsher geldt het legaliteitsbeginsel als het beginsel van wetmatigheid van bestuur. ${ }^{1}$ De overheid tast 'des onderdaans' vrijheid, goed of have niet aan dan door of op grond van een of andere wet. Het belang hiervan blijkt uit het doel van de wet. Die beoogt drieërlei. ${ }^{2}$ Ten eerste heeft zij een legitimerende functie. Ten tweede beschermt zij grondrechten door de nodige beperking van bevoegdheden van het uitvoerend bestuur. En ten derde dient de wet rechtszekerheid en -gelijkheid. ${ }^{3}$ Dit nut van de wet weerspiegelt zich in elementen van wetmatigheid van bestuur.

Anders dan in de oude rechtsstaatgedachte, waar scheiding van machten nog leidraad is, omvat wetmatigheid zowel formele als materiele begripsaspecten. De kern van wetmatigheid van bestuur bestaat ook uit drie factoren. ${ }^{4}$ Ten eerste mag bestuurlijk handelen niet strijdig met de wet zijn. Met in het vizier de beperkende en beschermende functie van de wet is deze norm gecreëerd. De norm is een negatieve formule. Een tweede factor, die duidelijk op de legitimerende en beschermende functie van de wet accent legt, is het formeel-positieve aspect. Anders gezegd, uitoefening van bepaalde bevoegdheden door het bestuur is slechts geoorloofd voor zover ze bij of krachtens de wet zijn verleend. En

1. F.W. ter Spill en A.Q.C. Tak, Onwermatg bestuur, preadvies VAR, geschriften VAR LXXXVI, Alphet a/d $\mathbb{R i j u}, 1981$.

2. N. Verheij, De lijn: Alleen de wet heerscht aver ons; Over wetmatigheid van bestutu, in: PD, nu, 5, 1989, pp. 188-197, i.h.b. pp.190-192.

3. Vgl. H.J. Simon, a.w.. pp.128-130. Auteur benadrukt het democratisch vereiste van de grondslag in een formele wet. Vooral als normatief (kwaliteits)beginsel voor behoorlijk wetgevend handelen.

4. N. Verheij. tha.p., pp.192-196. 
ten derde moeten, conform de materieel-positieve factor, publiekrechtelijke bevoegdheden wolgens algemene regels worden gehanteerd. Daarmee zijn rechtsgelijkheid en -zekerheid gewaarborgd.

\section{$\$ 4.1$ Brokkelig legaliteitsbeginsel}

Waarheidsgetrouw is helaas de constatering, dat "het legaliteitsbeginsel in Nederland niet geheel is gerealiseerd". ${ }^{5}$ In feite zijn de scheuren van her formele wetmatigheidsideaal steeds sterker te signaleren. Het bewijs van gebrek aan formeel-wettelijke grondslagen met betrekking tot steunverlening aan noodlijdende bedrijven is evident. ${ }^{6}$

\subsubsection{VERMINDERDE OMVANG LEGALITEITSBEGINSEL}

Daarom hangt, uilt praktische overwegingen, de ene doctrine een beperkt motto aan. Steeds meer stemmen gaan op voor het minder onverkort handhaven van het legaliteitsbeginsel. Immers, het feit dat de wetgever niet meer alles zelf kan regelen, de sterke binding tussen regeringsfracties en kabinet met andere woorden het monisme, het groeiende ambtenarenapparaat, de mogelijke spectaculaire contra-legemwerking van algemene beginselen van behoorlijk bestuur en de opkomst van pseudo-wetgeving/beleidsregels zijn tekenen aan de wand. Vooral de wonderbaarlijke werking van zowel ongeschreven als geschreven algemene rechtsbeginselen van behoorlijk bestuur relativeert het legaliteitsbeginsel sterk. ?

Het, schijnbaar onvermijdelijk, toenemende buitenwettelijk bestuur is een indicatie voor twijfel aan de omvang van de legaliteitseis. Met de wetmatigheid van bestuur wordt het minder nauw genomen dan voorheen. Voor dit minder stringent hanteren van de legaliteitseis wordt de volgende verklaring aangedragen. ${ }^{8}$ In historisch besef vindt niet alle uitbreiding van bestuur basis in een formeel-wettelijke grondslag. Overheidstaakuitoefening geniet namelijk een 'democratische legitimatie'. Die is veelvormig. De formeelwettelijke legitimatie is slechts een van haar verschijningsvormen. Voortdurend is het zoeken naar 'positieve indicaties' voor overheidsoptreden. Bestuurlijk handelen kan bij voorbeeld toelaatbaar zijn als de financiering er van is af te leiden wit een büjzondere begrotingspost. Of overheidsgedrag krijgt erkenning als zij zonder protest wordt geaccepteerd. Uit feitelijke taakstelling is dan veelal een publiekrechtelijke bevoegdheid af te leiden.

5. I.C. van der Vlies, Het wetsbegrip en beginselen van behoorlijke regelgeving, diss. UvA, "s-Grav., 1984, p.56; Vgl. A.D. Belinfante en J.L. de Reede, Beginselen van het Nederlands stactsrecht, twaalfde druk, Alphen a/d Rijn, 1994, pp.22-24.

6. L.J.A. Damen, Ongeregeld en ondoorzichtig bestuur, dissentatie RUG, Deventer, 1987.

7. H.D. Stout, De betekenmissen van de wet; Theoretische beschouwingen over het principe van wetmatigheid wan bestuur, serie rechtsstat en sturing nr.21, Zwolle "1994, p.164.

8. A.Q.C. Tak, tijdens mondeling referaat over het wetsvoorstel-Algemene Wet Bestuurstecht, op studiemiddag van aio-netwerk Staats- en bestuursrecht d.d. 27 november 1992 te Maastricht. 
In de moderne rechtsstaat verandert de legaliteitseis kennelijk. "Overheidsoptreden dat geen gestalte krijgt in ge- en verboden voor de burgers, maar in 'sturen' door middel van financiële steun (subsidie) zou, omdat het niet direct ingrijpt in rechten en vrijheden van burgers maar juist (financiële) aanspraken van burgers jegens de overheid vestigt, geen uitdrukkelijke machtiging van de wetgever behoeven." 9

Hierbij blijkt helaas de afbakening problematisch. Namelijk, veel beschikkingen of besluiten van de overheid zijn zowel belastend als begunstigend. Denk aan een voorwaardelijke subsidie of vergunning. Bovendien klinkt een bepaald overheidsbesluit voor de een positiever, of anders negatiever, dan voor de ander. De subjectieve beleving er van is verschillend. Dit gegeven heeft tevens te maken met een ander onderscheid. Te weten, van oudsher geldt de stelling dat in elk geval alle algemeen verbindende voorschriften wettelijke grondslag moeten hebben. Tegenwoordig komen sommige individuele, eenzijjig genomen bestuurlijke beschikkingen harder aan dan algemene regelingen. Zeker wat betreft toezichthoudende zelfstandige bestuursorganen is de mate van maatschappelijk ingrijpen soms niet gering.

Vandaar is, in het algemeen, het criterium aanwezig, dat "ingrijpende besluiten slechts bij wet" worden genomen. ${ }^{10}$ Naarmate de ingreep zwaarder is, dient de voorkeur uit te gaan naar een regeling in een formele wet. "Aan deze regel kleeft uiteraard de onduidelijkheid van het begrip ingrijpend. ${ }^{12}$ Natuurlijk is van ingrijpendheid sprake daar, waar overheidsorganen bepaalde activiteiten verbieden en strafbaar stellen zonder vergunning. Vergunningenstelsels, veelal gehanteerd door toezichthoudende zelfstandige bestuursorganen, horen dus in het algemeen met beide benen op wettelijke bodem te staan. Dit vloeit voort uit de essentie van art. 89 Grondwet. Voor de rest verdient het aspect ingrijpendheid voortdurend concretisering.

\subsubsection{RUIM LEGALITEITSBEGINSEL}

Deze interpretatiemoeilijkheid wordt vermeden aan die kant van de arena, waar de wederpartij zetelt. Daar is een rigoreus ruim legaliteitsbeginsel richtsnoer. Het principe, aan dit front, is een "programmatisch uitgangspunt". ${ }^{13}$ Dat wil zeggen "het streven dient er meer dan ooit op gericht te zijn het owerheidsbeleid en daarmee het bestuur over de

9. P. Nicolaï, B.K. Olivier, L.J.A. Damen e日 H. Troostwijk (red.), Bestuurshecht, derde herziene druk, Amsterdam, 1992, p.48; Gebaseerd op aanpassing legaliteitse is in de zin dat een wet in formele betekenis nodig is voor de zgn. "Leistungsverwaltung" voor zover deze tevens "Eing riffsverwaltung" is. Zie H.D. Yan Wijk, bewerkt door W. Konijnenbelt en R.M. van Male, a.w., pp.41-45; Gelet op opkomst presterende owerheid wijst B. Hessel, a.W., p.21, op "sluimerende nornstelling" bij delegatiewetgeving.

10. I.C. van der Vlies, Handboek wetgewing, tweede herziene dnuk. Zwolle, 1991 , pp. 87-88; Vgl. Methadonbriefarrest, HR 27 jumi 1986, NJ 1987, 898, m.nt. M.S. (zelfs als op te leggen verpliclytingen niet door strafsancties worden gehandhatd).

11. B. Hessel, a.w. , p.17; Dit ongeschreven beginsel is gebaseend op het Filuorideringsarrest, HR 22 jumi 1973, NJ 1973, 386.

12. N. Verheij, De lijw: Denken in het ideaal, Over wetmatigheid van bestuur $I$, in: PD, nr.6/7, 1989, pp. $237-242$, i.h.b. p. 241 .

13. P. de Haan, Th. Drupsteen en R. Fernhout, a.w. (dl.I), pp.227-235, i.h.b. p.229. 
gehele linie een wettelijke grondslag te geven". Daartoe geven de volgende factoren aanleiding. Te weten, de behoefte aan doelmatigheid en eenheid van bestuur, de democratisering wan het bestuur en het bevoegdheidsmotief. Kortom, het juridisch verkeer is veiliger en ordelijker als het gehele overheidsoptreden op de wielen der wet voort rolt. ${ }^{14}$ Een fraaie, en tegelijkertijd onmogelijke, constructie die via kaderwetten gedeeltelijk gestalte krijgt.

Daarbij verschuift de aandacht naar gelegitimeerde toekenning of overdracht vam publiekrechtelijke bevoegdheden. Omdat bij zelfstandige bestuursorganen de democratische legitimatie moeilijkheden op kan leveren, is een formeel-wettelijke basis voor overheidsinterventie geen onredelijke gedachte.

\section{$\S 4.2$ instellingsgrondslag zelfstandige bestuursorganen}

Eenvoudig weg is het idee geopperd, dat het legaliteitsbeginsel niet van toepassing hoeft te zijn op de oprichting van belissende overheidsinstanties. Reden: het overheidshandelen is het meest fundamenteel. En daarvoor geldt toch al de legaliteitseis. ${ }^{\text {is }}$

Toch wordt terecht gesteld, dat "voorschriften waarbij nieuwe bestuursorganen in het leven worden geroepen zo veel mogelijk in de wet worden opgenomen". "Zo zijn goede argumenten ${ }^{17}$ te bedenken voor een formeel-wettelijke basis van zelfstandige bestuursorganen. Tot op heden worden de meeste zelfstandige bestuursorganen, in tegenstelling tot de traditionele vormen van functioneel bestuur ex art. 133 juncto art. 134 Grondwet, niet beschouwd als openbare lichamen en zijn zij dus buitengrondwettelijk. ${ }^{18}$ De stelling dat, analoog aan andere overheidsorganen, een formele legitimatie bij zelfstandige bestuursorganen is vereist, berust op de volgende gronden.

Allereerst is het ontbreken van een hiërarchische lijn van minister naar zelfstandig bestuursorgaan niet te verwaarlozen. Juist bij instelling van een zelfstandig bestuursorgaan is de steun van het parlement onontbeerlijk. De Staten-Generaal moeten de mogelijkheid hebben, al dan niet, akkoord te gaan met een bepaalde vermindering van politieke ministeriële controle. Ten tweede eist art. 79 Grondwet reeds voor vaste colleges met slechts adviserende bevoegdheden inzake wetgeving en bestuur oprichting bij of krachtens de

14. Inzake subsidies o.g.v. formele wetgeving Orde in de regelgeving, 1985, pp.25-26/66, eindrapport van de commissie wetgevingsvraagstuklken "s-Gravenhage, 1985, Vgl. TK 1987-1988, 20527, mrs.1-3, wetsontwerp Kaderwet werstrekking Financiele middelen EZ, als wet gepubliceend in Stbl. 1991, 767; E.M.H. Hirsch Baltin en J.H. van Kreveld, Rechtsstorelijke subsidieverhoudingen, preadviezen $V A \mathbb{R}$, 1988; L.J.A. Damen, a.w. pp.8/269 e.v./295-296. M. Scheltema in zijn adviles aan de parlementaire enquétecommissie bouwsubsidies, 19623, nr, 30, pp.475-476; Lonkend narar de Awb, waar subsidieverlening slechts o.g.v. wettelijk woorschrift is toegestaan ex art. 4.2.1.3, eerste lid. Awb jo. art. 4.2.2.1 Awb, verkondigen M.C. Burkens, H.R.B.M. Kummeling en B.P. Vermeulen, $a_{n} w .$, pp.69-71, terecht een zelfde mening.

15. I.C. van der Vlies, t.a. p., p.45.

16. C. Borman, Aawwijzingen voor de regelgewing, Zwolle, 1993, p.64 (aanwijzing 24, eerste lid, sub c).

17. Functioneel bestuw, waarom en hoe?, TK 1990-1991, 21042, nr.4, p. 21; H.G. Lubberdink, a.w., pp. 164-166; I.B.J.M. ten Berge en F.A.M. Stroink, Functionele decentralisatie uit de schaduw "preadvies Rbb, juni 1988, "s-Grav., pp.57-58.

18. J.L. Boxum, J. de Ridder en M. Scheltema, a.w., p.16. 
wet. Het derde lid van het artikel bepaalt dat andere taken alleen bij of krachtens de wet mogen worden opgedragen aan die adviesorganen. Dan geldt dir zeker ook voor de oprichting van zelfstandige bestuursorganen die méér doen dan adviseren. ${ }^{19}$ Vooral als die zelfstandige bestuursorganen eenzijdig en ingrijpend kunnen beschikkken in het kader van thun toebedeelde toezichthoudende taken. Er is voldoende gepleit voor een officiele regeling voor zelfstandige bestuursorganen, gelijk waardig aan art. 79 Grondwet. ${ }^{20}$ Daarmee is overigens geen succes behaald. ${ }^{21}$ Ten derde is het tot 19 december 1991 (Stbl. 752) lange tijd gewoonte geweest, in gevolge art. 40 Comptabiliteitswet 1976, voor (mede)oprichting van privaatrechtelijke rechtspersonen een machtiging bij of krachtens de wet te eisen. In het verlengde hiervan geldt dit "a fortiori voor publiekrechtelijke zelfstandige bestuursorganen die publiekrechtelijke bevoegdheden uitoefenen". ${ }^{22}$ Hoewel dit artikel nu vervallen is, is de strekking er van duidelijk.

Kortom, de in art. 134 Grondwet neergelegde rechtsstatelijke en democratische waarborgen dienen tevens rechtskracht te hebben voor vormgeving en instelling van zelfstandige bestuursorganen.

In praktijk blijkt dat "ongeveer $85 \%$ van de categorieën zelfstandige bestuursorganen een onmiddellijk aanwijsbare wettelijke instellingsgrondslag heeft. In de overige gevallen kunnen bevoegdheden berusten op een van de wet afgeleide algemene maatregel van bestuur of ministerieel besluit, of op een artikel uit de rijksbegroting ${ }^{\text {" }} .{ }^{23}$

Eind maart 1995 merkt de Algemene Rekenkamer weinig enthousiast op dat de publieke taken van 1 publiekrechtelijk zelfstandig bestuursorgaan (van de 89 publiekrechtelijke zbo's die zij heeft onderzocht) niet op een wet steunen, van 8 privaatrechtelijke zelfstandige bestuursorganen (van de 73 privaatrechtelijke zbo's die zij heeft onderzocht) uitsluitend berusten op een ministeriële regeling en van 8 (van laatst vermeld aantal) enkel op statuten berusten. ${ }^{24}$

19. H. G. Lubberdink, a.w., pp. 164-166, is, mede omdat art. 89 Grond wet ter zake niet toereikend is, groot voorstander van een aparte grondwettelijke bepaling woor oprichting van $z$ bo's. Echter, z.i is zo 'n nievwe regeling geclausulleerd als volgt. Instelling van zbo's geschiedt bij wet. Dus niet krachtens wet.

20. M. Scheltema, Zeffstandige bestuursorganen, a.w. (oratie), p. 12; H.G. Lubberdink, a.w., pp. 165-166; J.M. Polak, Opinie: Een wettelijke basis wopr zelfstandige bestuursorganen, in: NJB, 5 april 1980, ar. 14, p.298; Verslag vergadering van de VVSR van België en Nederland, met bespreking G. Craenen en A. Mulder, a.W., in: N.JB, 1980, p. 112.

21. Hieraan is waarschijnlijk debethet destijds gevordetde stadium van de grondwetsherziening. Zie wetsontwerp art. $79 \mathrm{Gw}$. TK 16040 , R1141. Aldus J.M. Polak, t.a.p., p. 298. Tegelijkertijd met die erkenning wenst auteur, dat bij behandeling vam het wetsontwerp beoogd aspect van zbo's ter sprake komt; L. I.A. Damen, a.w. p.508, koestert evenmin de hoop dat "de terechi voorgestane uitbreid ing wan het legaliteitsbeginsel snel in de Grondwet zal worden neergelegd". M.b.t. de instelling van zbo"s ziet auteur, à la Polak, bij gebrek aan beter een taak voor de ministerraad of het parlement.

22. L.J.A. Damen, a.w., p.508.

23. Verslag van de Studiemiddag zelfstandige besfuursorgamen, d.d. 12 nov. 1985, WRR-voorstudies V54, 1986. P.66.

24. Algemene Rekenkamer, Zbo"s en ministeriele werantwoardeljkheid, TK 1994-1995, 24130, nr . 3, pp. 1920. In eén op de tien gevallen bestaat dus geen formeel-wettelijke grondslag voor publieke takuitoefening (p.53). 


\section{\& 4.3 Helder patroon toedeling publiekrechtelijke bevoegdheden}

Juridische status, positie, maar vooral publiekrechtelijke bevoegdheden van zelfstandige bestuursorganen moeten dus, bij voorkeur, wettelijke regeling vinden. Direct of indirect. Bovendien bepaalt aanwijzing voor de regelgeving 17: "1. Bij de toekenning van bestuursbevoegdheden wordt de uitoefening daarvan zo veel mogelijk genormeerd; 2 . Met het oog hierop worden discretionaire bevoegdheden en bevoegdheden met vage toepassingscriteria niet toegekend, tenzij daarvoor goede gronden zijn." 25

Bovenstaande geldt zeker in geval van bevoegdheidsuitoefening ter naleving van bepaalde bijzondere wet-en regelgeving. Analoog aan het algemene art. 89 Grondwet, dat een expliciete wettelijke basis vergt voor door straffen te handhaven beperkingen, dient het handelen van toezichthoudende, dat wil zeggen controlerende, opsporende en sanctionerende, zelfstandige bestuursorganen binding te hebben met de wet. De aanwijzingen voor de regelgeving bevestigen dit. Aanwijzing voor de regelgeving 24 , eerste lid, sub a, e en f schrijft voor: "Zo veel mogelijk worden in de wet opgenomen: voorschriften die de grondslag vormen van een stelsel van vergunningen of een stelsel waarbij anderszins de toelaatbaarheid van handelen afhankelijk wordt gesteld van verlof van de overheid, respectievelijk woorschriften inzake sancties van administratiefrechtelijke of civielrechtelijke aard, respectievelijk voorschriften waarbij toezichts- en opsporingsbevoegdheden worden toegekend". ${ }^{26}$

Tegenwoordig worden ook wel andere wijzen, dan attributie of delegatie, waarmee mogelijk openbaar gezag wordt verkregen gepropageerd. Art. 32a, eerste lid, Wet op de studiefinanciering bepaalt bij voorbeeld dat de minister met een rechtspersoon (OVstudentenkaart bv) kan overeen komen dat deze de toekenning van de reisvoorziening en de beëindiging daarvan zal uitvoeren. En art. $9 \mathrm{~g}$ Wegenverkeerswet houdt in dat bij of krachtens amvb te stellen regelen een erkenning kan worden verleend, waardoor een natuurlijke of een rechtspersoon (APK-keuringstation of houder daarvan) gerechtigd wordt keuringen te verrichten. Van de ene zijde wordt dan beweerd, dat door respectievelijk die overeenkomst en die erkenning eenzijdig publiekrechtelijke rechtshandelingen kunnen worden verricht, ${ }^{27}$ Tegenstanders vinden dat nu juist een bewering uit boze tong. Slechts attributie en delegatie kunnen tot het bekleden met openbaar gezag leiden. ${ }^{28}$ Wat betreft toezichthoudende zelfstandige bestuursorganen heeft de laatste opvatting voorkeur.

Het patroon van toedeling van publiekrechtelijke bevoegdheden aan zel fstandige bestuursorganen moet inzichtelijk zijn. In realiteit valt dit nog wel eens tegen. Bepaalde bestaande bevoegdhedenconstructies zijn niet geheel ongecompliceerd. Vandaar is aandacht voor

25. C. Borman, a.w., p.58.

26. C. Bormani, a.w. , p.64."

27. S. E. Zijlstra, Het Aanwizingsbesluit bestwursorgaan Wob en Who, in: NTB, nr.5, 1994, pp. 132-133.

28. Met name C.P.J. Goorden, Het aanwijingsbestwit bestuursorganen Wob en Who, in: NTB, nr. 3, 1994, p. 65; Herhaald in Repliek op en reactie, in: NTB, nr.5, 1994, p.134. 
detitel, waaronder zelfstandige bestuursorganen publiekrechtelijke bevoegdheden uitoefenen, gerechtvaardigd.

\section{$\$ 4.4$ Titels van bevoegdheidsuitoefening}

Zekere mate van consistentie in democratische legitimatie van overheidsoptreden door zelfstandige bestuursorganen is gewaarborgd door de aanwezigheid van rechtsgeldig verkregen titels van bevoegdheidsuitoefening. In die grondslagen is zo veel mogelijk inhoudelijk genormeerd. Vooral de wijze waarop en de condities waaronder bepaalde bevoegdheden moeten worden gebruikt. Soms lukt dit niet goed. In dat geval bieden politieke en rechterlijke controle op bevoegdheidsuitoefening ${ }^{29}$ mogelijk uitkomst. Hierbij wordt herhaald dat de ministeriële verantwoordelijkheid bij zelfstandige bestuursorganen in principe afwezig is. Maar er zijn wel beperkte ministeriële beïnvloedingsmechanismen. Deze hebben de vorm van algemene aanwijzingen, goedkeuring of vernietiging van beschikkingen van zelfstandige bestuursorganen, of bepaling van de samenstelling van een (bestuur van) zelfstandige bestuursorganen door benoeming en ontslag.

\subsubsection{ATTRIBUTIE AAN ZELFSTANDIGE BESTUURSORGANEN}

Conform het wetmatigheidsbeginsel ${ }^{30}$ berust publiekrechtelijke bevoegdheidsuitoefening door zelfstandige bestuursorganen merendeels op attributie. Attribueren betreft het creeren van een nieuwe rechtsgeldige bevoegdheid. Bij attributie "schept een daartoe bevoegde originaire of gedelegeerde wetgever een bestuursbevoegdheid en kent deze toe aan een bestaande of daartoe in het leven geroepen bestuursorgaan". ${ }^{31}$

29. F.A.M. Stroink en J.G. Steenbeek, Inleiding in het staats-en bestuursrecht, wierde herz. druk, Alphen a/d Rijn, 1993, p.49. Zij hanteren hier de term rechtmatigheid van bestuur. Dit principie is verwant aan dat van wetrnatigheid van bestuur.

30. Het wetmatugheidsprincipe staat niet in de Grondwet. Toch accepteert de HR (en ook de ARRS, 13 dec., 1990, Gst. 6917) haar als leidraad voor het bestuur. In liet Jamin- of polkacheltjesarrest (HR 25 januari 1926 , NJ 1926, p.246) spreekt de rechter $\mathrm{nl}$. als volgt. Een discretionaire beschikking sbevoegdheid mag niet zonder , (al dan niet directe - JGLvN) formeel-wettelijke grondslag worden overgedragen (nota bene: F.A.M. Stroink en J.G. Steenbeek, a.w., p.49, benadrukken deze term, die h.i. wijst op attributie; Vgl. kritiek op MVT bij voorontwerp-Awb, waarin onnadenkend nog sprake is van delegatie, door F" A.M. Stroink, Regeling delegatie in derde tranche. Awb ondoondacht, in: syllabus bij themadag derde tranche Awb d.d. 16 maart 1992, pp. 1-6; later gepubliceerd in: NJB, nr.15, 9 april 1992, pp.478-479) aan een. i.c. gedeconcentreerd, overheid sarmbt. A-contrario tolereent de HR trouwens wel toekenning van een sterk gebonden uitwoeringsbevoegdhetd , die een wettelijke basis mist. Dit geldt tevens voor eem sterk gebonden regelingsbevoegdheid. Zie Bromfietsvalhelmarrest.(HR 11 januari 1977 , NJ 1977, 467). Maar overdracht van cen ongeclausuleende regelingsbevoegdheid $k a n$, terechi, weer niet büten cen formeel-wettelijk fundament. Hiervoor staat het Vuurwerkarrest (HR 26 november 1957, NJ 1958-53) garant; Over interpretatieprobltematiek van uitvoeringsbegrip F.A.M. Stroink en J G. Steenbeek, a.w., pp.40-46; F. A.M. Stroink, Beginsel van wermatigheid van bestuur en het begrip witvoering: ARRS contra HR? "in: TvO, mr.8, 21 april 1983, pp.204-206; F.A.M. Stroink, a.w., pp.110-118.

31. H. van der Sluijs, Distributie van bewaegdheden; De ral van de wetgever bij het toedelen van bestuursbevoegdheden op het niveau van de centrale overheid, in: $\mathbf{B W n}, \mathrm{nr} .5,1988$, pp. 302-321, i. h. b. p. 305; Over attributie (en delegatie/mandaat) M.C. Burkens, H.R.B.M. Kummeling en B.P. Vermeulen, a.w., pp.51 
Dergelijke bevoegdheidstoedeling aan zelfstandige bestuursorganen is geoorloofd. De ministeriële verantwoordelijkheid geldt onverkort. Slechts haar bestuurstechtelijke inhoud verandert. Ten opzichte van de niet hiërarchische ondergeschikte zelfstandige bestuursorganen mag de minister doorgaans alleen algemene aanwijzingen geven. Logischerwijze betreft de uitoefening van openbaar gezag door zelfstandige bestuursorganen daarom enkel "bevoegdheidsuitoefening die geen voortdurende politiek-beleidsmatige afweging nodig maakt". ${ }^{32}$

Attributie aan zelfstandige bestuursorganen is kortom aanvaardbaar in geval van een vooraf wrij wel vast gelegde bevoegdheid. Aldus is de uitoefening van de betrokken bevoegdheid globaal gebonden aan een, in een durzame materiële normstelling neergelegd, beleid. Ook hier laat zich het principe herkennen. De minister trekt de hoofdlijnen. En, in zijn kielzog, trekken zelfstandige bestuursorganen de kleine, scherpe strepen. Daarmee bestaat de bestuurlijke discretie van zelfstandige bestuursorganen niet zo zeer in beleidsvrijheid. Maar eerder in feitelijke waarderings- of beoordelingsvrijheid.

\subsubsection{DELEGATIE AAN ZELFSTANDIGE BESTUURSORGANEN}

Een andere manier, waardoor zelfstandige bestursorganen legitiem een publiekrechtelijke bevoegdheid op eigen naam en verantwoordelijkheid uitoefenen, is dellegatie. Delegatie verschuift bevoegdheden. De delegans draagt zijn (geattribueerde) bevoegdheid over aan de delegataris. Dit uit handen geven van een bevoegdheid is alleen acceptabel, indien en voor zover wettelijk is toegestaan. Voor deze delegatie, even als bij attributie, in beginsel overwegend gebonden bevoegdheden op nominatie. Ook hier is sprake van, in officiële regelingen gegoten, beleidsbepaling vooraf. Geen ad hoc beleid dus.

Wat betreft publiekrechtelijke taakverrichting door zelfstandige bestuurorganen met een private rechtsvorm luidt een aannemelijk advies als volgt. ${ }^{33}$ Niet zo zeer met oog op intrekking van attributie- of delegatiebesluit, maar juist met oog op de mogelijkheid tot taakuitbreiding is het verschil tussen taaktoedeling en taakoverdracht essentieel. Anders dan bij attributie ${ }^{34}$, is het voor het uiteindelijk taakbehartigende privaatrechtelijke zelfstandig bestuursorgaan mogelijk de naar hem overgehevelde wettelijke hoofdtaken aan te vullen met neventaken. Voorwaarde daarbij is dat deze bijkomende taken niet strijdig

31. $\rightarrow$

53/56-60/71-72; Commissie-Duk, Rappont Abar, wjide geheel herz. druk, Alphen a/d Rijn, 1984, pp. 1050; A.M. Donner, a.w., p.161 e.v.; P.W.A. Gerritzen-Rode en 1.C. van der Vlies, Beginselen vaw bewtuursrecht, tweede duk. Alphen a/d Rijn, 1994, pp.61-68; C.P.J. Goorden, Rechtsbevaegdheid in heir bestuursrecht: Een rechtsvergelijkende studie naar het bevoegdhedenwraagstuk in het bestulersrecht, diss. KUE, Zwolle, 1990, pp. 82-96, "J.L.M. Hakwoorten J.M. de Heer, a.w., pp. 50-52; C.A.J.M. Kortmann, a.w., pp.21-25; T. Koopmans, Compendium wan het stautsrecht, t.a.p., pp. 20-23; H.G. Lubberdink, a.w., p.43 e.v.; P. Nicolai, B.K. Olivier, L.J.A. Damen en H. Troostwijk a.w., pp.47-87; C.J.N. Versteden, Inleiding algemeen bestuursrech, vierde druk. Alphen aan den Rijn/'s-Gravenhage, 1993, pp.33-34; H.D. van Wijk, bewerkt door W. Konijnenbelt en R.M. van Male, a.w., pp. 131-148.

32. H. van der Sluijs, t.a.p., pp.313319.

33. C.A. Schreuder, Publiekrechelijke taken, private rechtspersonen, diss. RUG, Deventer, 1994, p.231.

34. Uitgezonderd situaties waarin een attributiewet ruimte laat voor andere takbehartiging of een formelle wet vendere taken opdraggt. 
zijn met de gedelegeerde taken. Delegatie verdient daarom voorkeur bij publieke taakverrichting door vennootschappen. Bij stichtingen is dit niet urgent, omdat via statuten het werkterrein kan worden beperkt tot enkel de publiekrechtelijke taak.

\subsubsection{ATTRIBUTIE EN DELEGATIE NAAR NIEUW RECHT}

De derde tranche Algemene wet bestuursrecht handelt onder meer over delegatie. Aanwankelijk benoemen de opstellers het overdragen van bevoegdheden als delegatieverlening. Dat doet kunstmatig aan. Door samentrekking van twee woorden, die allebei activiteiten impliceren, ontstaat iets als "het geven van de mogelijkheid om een bevoegdheid over te dragen"; Terwijl art. 1A.1.2.1 Awb ${ }^{35}$ zich niet tot de wetgever, maar tot de delegans richt. ${ }^{36}$ Het uiteindelijk schrappen van de term "verlening' getuigt dan ook van correct inzicht. ${ }^{37}$ Bovendien wordt het verleningsbegrip in art. 1A.1.2.2 en art. 1A.1.2.3 Awb gewijzigd in de neutrale terminologie 'geschieden'.

Art. 1A.1.2.1 voorontwerp Awb omschrijft delegatie nog als "het overdragen door een bestuursorgaan van zijn bevoegdheid tot het nemen van besluiten aan een ander die deze onder eigen verantwoordelijkheid uitoefent". ${ }^{38}$ Deze definitie is niet geheel onproblematisch. ${ }^{39}$ Moeite geeft, ten eerste, de beperking tot overdracht van besluüibevoegdheid door het oorspronkelijk bevoegde orgaan zélf. De praktijk laat namelijk anders zien. Vandaar het pleidooi voor een Awb-regeling die zowel auto- als allodelegatie omvat. Ten tweede is het enthousiasme over de bijzin in de definitie ver te zoeken. Het taalgebruik van die bijzin is onduidelijk (wat is verantwoordelijkheid?), normatief en eigenlijk zijn de woorden overbodig. Bovendien geeft een goede definitie alleen de aard van het betrokken verschijnsel weer en niet de rechtsgevolgen er van.

Bedoeld betoog voor een meer adequate Awb-regeling ter zake wordt opgepakt. Mede naar aanleiding van het advies van de Raad van State ${ }^{40}$ wordt een dergelijke regeling in het wetswoorstel derde tranche Awb neergelegd. Het toegevoegde art. 1A.1.2.8 Awb verklaart afdeling 10.1.2 Awb, met uitzondering van art. 1A.1.2.4 Awb, terecht toepasselijk op de overdracht door een bestuursorgaan van een bevoegdheid van een ander bestuursorgaan tot het nemen van besluiten aan een derde. Het tweede lid maakt het mogelijk dat, indien bij wettelijk voorschrift of overdrachtsbesluit bepaald, het bestuurs-

35. Nu de bepalingen inzake delegatie en mandaat nog geen wettelijke statws hebben (waar zij kennelijk nog miet rijp woor zijn volgens o.a. H.Ph.J.A.M. Hennekens, Mandaat en delegatie voor verbetering wabaar, in: De Gemeentestem, nr. 7011, 16 jumi 1995, pp.321-326), is in het hierna volgende sprake wan het wetsvoorstel $A w b$, tenzij anders vermeld.

36. R.L. Vugsän, Katern bestuwrsrecht, in." Ars Aequil kwartaalbijlage, nr.44, pp.2035-2039, i. h.b. p.2038.

37. Wetsvoorstel derde tranche Awb. TK 1993-1994, 23700, nr.2, p.23.

38. Commissie-Sicheltema, Voorontwerp derde tranche von de Algemene wet bestuwrstecht, aangeboden aan de ministers van justitie en binneniandse zaken d.d. 5 december 1991, "s-Gravenhage, p. 3.

39. W. Konijnenbelt, Attributie, delegatie en mandact in de Awb, in: W. Konijnenbelt (red.), De derde tranche. Commentaar op het vaorontwerp woor de derde tranche van de Awb, vakgroep bestuursrecht Universiteit van Amsterdlam, Alphen aan den Rijn, 1992, pp.6-22, i.h.b. pp.11-12. Auteur steit een allematief onnwerp van de Awb-titel inzake delegatie voor.

40. Adwies Raad van State, 17 dec. 1993, W03.93.0142. Nader rappon voorstel derde tranche Awb, TK 1993-1994, 23700, A. 
orgaan wiens bevoegdheid het betreft beleidsregels over de uitoefening er van kan geven. En in gevolge het derde lid moet de delegataris, als het oorspronkelijk bevoegde bestuurs. orgaan er om verzoekt, informatie verschaffen over uitoefening van de bevoegdheid.

Aan delegatie stelt de Awb een aantal voorwaarden.

$\mathrm{Zij}$ wordt niet verleend aan ondergeschikten. Zie art. 1A.1.2.2 Awb. Deze eis doet geen recht aan de talloze gedeconcentreerde ambten. ${ }^{41}$ Daarentegen levert de regel wat betreft zelfstandige bestuursorganen geen problemen op.

De toelichting bij het wetsvoorstel Awb vermeldt dat de Rbb-kritiek, waarin wordt gewezen op de inconsistentie met de regeling van attributie, serieus wordt genomen. Het verbod van delegatie aan ondergeschikten blijft echter omstreden. Mede omdat in praktijk vaak delegatie plaats vindt zonder dat dit afbreuk doet aan een ondergeschiktheidsverhouding, is het geen logische gedachte "attributie aan ondergeschikten wel toe te staan, maar delegatie aan ondergeschikten niet". ${ }^{42}$

Overigens geeft de Awb-wetgever te kennen dat, omdat een "innerlijk tegenstrijdige regeling van verantwoordelijkheid, die het gevolg is van delegatie aan ondergeschikten, onwenselijk is" ${ }^{43}$, Provinciewet en Gemeentewet worden aangepast.

De verlening van delegatie moet, in gevolge art. 1A.1.2.3 Awb, berusten op een wettelijk voorschrift dat in de mogelijkheid van delegatie voorziet ${ }^{44}{ }^{45}$ Krachtens de memorie van toelichting moet de wetgever in materiële zin met bevoegdheidsoverdracht instemmen. ${ }^{46}$ De commissie-Scheltema acht, ter zake, geen formeel-wettelijk grondslag nodig. Om haar opvatting kracht bij te zetten hanteert zij, kennelijk onvoorzichtig ${ }^{47}$, uitspraken van het Hoge Raad.

Het voorgestelde art. 1A.1.2.4 Awb ontstaat uit onvrede met het (delegatie)instructieartikel uit het voorontwerp.

41. F.A.M. Stroink, Regeling delegatie in derde tranche voorontwerp Awb ondoordacht, t.a.p. , p.479; Vgl.. Rbb. Advies aan de ministers Hirsch Ballin en Dales over her voarontwerp van de derde tranche Awb. "s-Grav., mei 1992, p.10.

42. G.R.J. de Groot, B.M.J. van der Meulen en A.A. van Rassum, Subsidies, beleidsregels, bestuarsorganen, in: $\mathrm{NJB}, \mathrm{nr} .35,7$ okt. 1994 , pp. 1193-1200, i.h.b. p.1198.

43. Mut wersvoorstel derde tranche Awb. TK 1993-1994, 23700, nr.3, p.178.

44. De multi-interpretabele term "voorzien" is onwoldoende scherp volgens I.C. van der Vlies, Delegatie, mandaat en de rechtsstaat, in: T. Hoogenboom en L.J.A. Damen, In de sfeer van administratief recht, Utrecht, 1994, pp.409-427, i.h.b. p.424.

45. In het licht van het legaliteitsbeginsel pleit P. van Bunren, Awb-notities (13), in: NJB, nr. 14, 7 april 1995, p.532, er voor de woordem "bij wettelijk voorschrift' te wervangen door "bij of krachtens de wet".

46. Mvtwoorontwerp derde tranche Awb, a.w., p. 39; De Mvtwetswoorstel derde tranche Awb, TK 1993-1994, 23700, nr.3, haalt 0.a.. CRvB, 16 aprill 1992, TAR 1992, 122, aan.

47. F.A.M. Stroink (1992), t.a.p., p.478-479. 
In gevolge art. 1A.1.2.4, eerste lid, voorontwerp Awb stelt namelijk nog de delegans, na bevoegdheidsoverdracht, niet meer in bijzondere zin instrueren. Het tweede lid van dat artikel voorziet in inlichtingenverschaffing over bevoegdheidsuitoefening door de delegataris. Dit gebeurt echter onder de karige clausule "op diens verzoek (van degene die de bevoegdheid heeft afgestoten - JGLvN)" Yolgens de toelichting is de "inlichtingenplicht noodzakelijk zowel ten behoeve van algemene aanwijzingsbevoegdheid als ten behoeve van de bevoegdheid delegatie te beëindigen". Ook is de bepaling belangrijk omdat zo "beter kan worden voldaan aan de inlichtingenplicht die het heeft jegens een algemeen vertegenwoordigend lichaam. Zo is het gewenst dat bij voorbeeld het parlement inlichtingen van de minister kan krijgen over de gedelegeerde taakuitoefening, ook al is de minister daarvoor zelf niet meer verantwoordelijk." 49 Inderdaad is het belang van de inlichtingenplicht voor algemene belangenvertegenwoordigers evident. Maar juist door dat algemeen belang valt niet te stellen, dat eerst wordt gevraagd om informatie. De relevantie er van eist eigenlijk automatische, regelmatige, volledige en het algemeen belang betreffende, inlichtingenverschaffing.

Het wetsvoorstel derde tranche Awb verandert art. 1A.1.2.4 Awb belangrijk. De toelichting gaat nog wel uit van de algemene veronderstelling dat "de delegans geen bijzondere instructies aan de delegataris mag geven". ${ }^{50}$ Maar art. 1A.1.2.4, eerste lid, Awb stelt toch expliciet en uitdrukkelijk, dat de delegans "uitsluitend beleidsregels" ten aanzien van uitoefening van de overgedragen bevoegdheid mag geven. ${ }^{51}$ Beleidsregels zijn - ex art. $1: 3$, vierde lid, Awb wetsvoorstel derde tranche Awb - regels, niet inhoudende al gemeen verbindende voorschriften, omtrent de afweging van belangen, de vaststelling van feiten of de uitleg van wettelijke voorschriften. ${ }^{52}$ De toelichting wijst er op dat daaronder ook clausulering van delegatie (bij voorbeeld delegatie van besluiten tot een maximumbedrag) valt. ${ }^{5}$

Door de daaraan verbonden problemen keert, mede op aanbeveling van de Raad van State $^{54}$, het tweede lid van het aanvankelijk ontworpen art. 1A.1.2.5 Awb niet meer terug in afdeling 10.1.2 wetsvoorstel derde tranche Awb. Voor alle duidelijkheid is vermelding van dit niet van kritiek gespaard gebleven artikel uit het voorontwerp zinvol.

48. O.g.v. literatuur en jurisprudentie meent de Rbb (1992), a.w. p.23, terecht dat bij delegatie van beschikkingsbevoegdhe id aan ondergeschikte ambtenaren bijzondere aamwijzingen mogelijk moten blijwen; Ook I.C. van der Vlies, Delegatie mandaat en de rechtsstaar, t.a.p, p.426; Tevens G. R.J. de Groot, B.M.J. van der Meulen en A.A. van Rossum, Subsidies, beleidsregels, bestuwrsorganen, in: NJB, nr. 35,7 okt. 1994, pp.1193-1200, i.h.b. p. 1198.

49. Mut voorontwerp derde tranche Awb, a.w., p.40.

50. Mvt wetswoorstel derde tranche Awb. TK 1993-1994, 23700, nr.3, p. 179 .

51. Wetswoorstel derde tranche Awb. TK 1993-1994, 23700, ar.2, p.23.

52. Over de Awb-regeling inzake beleidsregels o.a. Sectie bestuarsrecht RL, Beleidsregels. gebruiksaanwijzing van bestuursbewogdheid, in: RegelMaat, nr.2, 1993, pp.54-60, met literatuurvermelding, zie ook G.R.T. de Groot, B.M.J. van der Meulen en A.A. van Rossum, Subsidies, beleidsregels, bestuursorgamen, in: NJB, nr.35, 7 okt. 1994, pp.1193-1200.

53. Mut wetswoorstiel derde tranche Awb, TK 1993-1994, 23700, nr.3, p. 180.

54. Adwies Raad wan Srate. TK 1993-1994, 23700A, p.12. 
Art. 1A.1.2.5, eerste lid, woorontwerp Awb zet buiten twijfel, dat degene die een bevoegdheid delegeert deze niet meer zelf kan uitoefenen. Tenzij het, in gevolge het tweede lid, een bevoegdheid, om algemeen verbindende voorschriften vast te stellen, betreft, 55 Dan geldt, volgens argumentatie van de commissie-Scheltema, namelijk "het beginsel dat wanneer de hogere regel voorziet in een materie warin tot dan toe op grond van delegatie een lagere regel in voorzag, deze laatste van rechtswege ophoudt te gelden". ${ }^{56}$ Dit beginsel is een vreemde eend in de bijt. Onder meer met de stelling dat even goed onverbindendverklaring kan volgen, is het beginsel weg geredeneerd. ${ }^{57}$ Bovendien betekent het tweede lid feitelijk, dat in voorkomende gevallen "twee organen tegelijkertijd zeggenschap over hetzelfde onderwerp kunnen hebben". ${ }^{58}$ Deze laatste opvatting is overigens geen gemeengoed. De moeilijkheid met de mening is, dat zij zowel een heus als een onheus karakter draagt. "Het is waar dat beide organen de bevoegdheid kunnen uitoefenen. Zij kunnen dat echter niet tegelijkertijd. " 59 Weliswaar, in feite hoeft het probleem niet meer dan academisch te zijn. Soms is er inderdaad een moment, dat de Kroon de regeling van het betrokken onderwerp aan zich wil trekken. Dit geschiedt dan meestal bij algemene maatregel van bestuur. Daarbij is de intrekking van het delegatiebeshuit gebruikelijk. Maar de kans bestaat, dat zelfs dat wordt verzuimd. Dan nog zal de ministeriële regeling van rechtswege ophouden te bestaan. Het maken van een andere regeling is de minister niet meer toegestaan.

Ter vermijding van die ongelukkige situatie kan de delegans beter duidelijk reageren. Volgens art. 1A.1.2.6 Awb kan beëindiging van dellegatieverlening te allen tijde. Intrekking en vervanging van (genomen) beschikkingen bieden dan een oplossing. ${ }^{\infty}$ Overigens stelt de toelichting op art. 1 A.1.2.6 Awb, dat intrekking van delegatie moet geschieden bij besluit en moet voldoen aan de algemene beginselen van behoorlijk bestuur. ${ }^{6 !}$

Ten slotte eist art. 1A.1.2.7 Awb vermelding ${ }^{62}$ van het delegatiebesluit en vindplaats daarvan in een besluit, genomen op grond van een overgedragen bevoegdheid. Het dele-

55. T.a.v. deze uitzondering merkt F.H. wan der Burg, Awb- mandaat en delegatie, in: NTB, nr.8, 1992 . pp. 268/274-275, op, dat die niet verder reiku dan de Awb. Zij geldt dus niet voor de formele wetgever. Zie art. 1:1 Awb (Stbl. 4 juni 1992, 315). Zo ziet auteur een dubbelle delegatieterminologie. Ten eerste is "het in de derde tranche aanvaarde delegatiebegrip in Triepelse zin warbij competentieverles intuerent is". Ten tweede bestat de "traditionele conserverende delegatie door de formele wetgever, waarbij nu juist competentiebehoud inherent is aan delegatie". Daarom stelt Van der Burg woor te spreken van overdracht van bestuursbevoegdheid. Daamaast is de term delegatie te reserveren voor delegatie van regelgevende bevoegdheid.

56. Mwt vooronnuerp derde tranche Awb, a.w. , p. 40 .

57. F.A.M. Stroink (1992), t.a.p., p.479; Idem dito F.A.M. Stroink, Rechterijke organisatie en rechtspraak in beweging, Zwolle, 1993, pp.29-35, Echter anders R.L. Vuçsán, t.a.p., p.2038.

58. F.A.M. Stroink (1992), t.a.p.., p.479.

59. R.L. Vuçsán, t.a.p., p.2038.

60. F.A.M. Stroink (1992), t.a.p., p.479.

61. Mw wetswoorstel derde tranche Awb. TK 1993-1994, 23700, nr.3, p.181.

62. Het verdient, conform amwijzing voor de regelgeving 86 , voorkeur de vermelding op nemen in de toelichting. 
gatiebesluit wordt toegelicht als een algemeen verbindend voorschrift. ${ }^{63} \mathrm{Dat}$ doet het nodige stof op waaien. Eerder is namelijk te denken aan delegatiebesluiten als interne publikaties. Immers, "delegatiebesluiten werken niet naar buiten, maar zijn gericht tot overheidsorganen". "Bovendien is bedoelde benaming onjuist, omdat een algemeen verbindend voorschrift "niet een beslissing ad hoc inhoudt, maar een regel is die toepassing vindt in alle gevallen die beantwoorden aan een in abstracte termen gegeven omschrijving" . ${ }^{5}$ Dit kenmerk draagt een delegatiebesluit nu net niet. In dit verband wordt. het volgende gesteld. Hoogstens kan sprake zijn van een "besluii van algemene strekking, niet zijnde een algemeen verbindend. voorschrift" in geval dat het delegatiebesluit een "reeks gevallen beslaat, hetgeen niet steeds het geval zal zijn". Slechts "waar de bevoegdheid tot vaststelling van algemeen verbindende voorschriften in een (materiële) wet gedelegeerd wordt, is sprake van een algemeen verbindend voorschrift omdat het delegatiebesluit zelf deel uitmaakt van de desbetreffende wet" ." ${ }^{66}$ Als ander bezwaar wordt geopperd, dat het delegatiebesluit doorgaans een figuur sui generis is. ${ }^{67}$ Alleen al daarom is de betiteling in de Awb oneigenlijk.

Bij alle kritiek op de summiere delegatietitel, bestaat soms ergernis over het geheel ontbreken van een attributieregeling in de derde tranche Awb. ${ }^{68}$ De leemte inzake attributie wordt met de IRT-kwestie vers in het geheugen nog sterker gevoeld. Immers, is de intrigerende IRT-affaire niet het zo veelste bewijs dat nog altijd niet duidelijk is hoe ver een ambtenaar, die krachtens attributie met een bepaalde publiekrechtelijke bevoegdheid. wordt belast, is gebonden aan instructies en bevelen van de politiek verantwoordelijke minister. ${ }^{69}$ Juist met oog op de mistige ministeriële politieke verantwoordelijkheid voor het optreden van zelfstandige bestuursorganen misstaat een adequate attributieregeling, met aandacht voor bijzondere of algemene aanwijzingen van hogerhand, niet.

Bedoelde, hier en daar bekend gemaakte, behoefte aan regeling van attributie geldt niet voor attributie door de formele wetgever. Die valt immers buiten het kader van de Awb.

63. Mut woorontwerp derde tranche Awb, a.w., 0.41

64. F.A.M. Stroink (1992), t.a.p., p.479.

65. F.H. van der Burg, c.a.p., p.273.

66. H.Ph.J.A.M. Hennekens, Delegatie en mandaat in het licht van het voorontwerp Awb (I), in: Gst. . m. 6955,1992, p. 609.

67. W. Konijneribelt, t.a.p., p.20.

68. F.A.M. Stroink (1992), t.a.p., p.478; Het zwijgen in de mwt ter zake wordt, met oog op het in praktijk soms onduidelijke onderscheid tussen attributie en delegatie, ook betreurd door R.L. Vuçstán, t.a.p.. p. 2038; Tevens teleurstelling bij de rbb (1992), ta.p., pp.7-8. De Rbb ervaart het gemis atan regeling ter zake voonal bij attributie "aan ambtenaren" en attributie "aam privaatrechtelijke rechtspersonen". Bespreking rbb-advies door C.H. van Marle en A.J.H. Smallenbroek, Binnenlandse kroniek, Voorontwierp derde rianche Awb vergt madere witwerking, in: BWn, nr.5, 1992, pp.461-462; 1.C. van der Vlies, Delegatie, mandaat en de rechisstaat, in: T. Hoogenboom en L. I.A. Damen (red.), In de sfeer van administratief recht, Utrecht, 1994, pp.409-427, i.h. b. p.416, vindt het niet in de Awb opnemen van een attributieregeling om redenen terecht.

69. G.R.J. de Groot, B.M.J. van der Meulen en A.A. van Rossum, Subsidies, beleidssegels, bestuursorganen: Het wetswoorstel derde tranche van de Awb, in: NJB, nr.35, 7 akt. 1994, p.1193-1200, i.h.b. p.1199. 
Daarom gaat de wens tot regeling alleen attributie door lagere wetgevers aan. ${ }^{70}$ Is echter een eng legaliteitsbeginsel uitgangspunt, dan luidt de mening dat lagere bestuursorganen geen attributiebevoegdheid hebben. Van uit die visie is een voorstel bekend om te bepalen dat bestuursorganen, als bedoeld in de Awb, niet kunnen attribueren. ${ }^{71}$

Wat betreft gemeentelijke en provinciale verordenende autoriteiten staan trouwens in het bijzonder de herziene Gemeentewet en Provinciewet, voor mogelijke (functionele) decentralisatie naar ambtenaren of commissies, model.

Al met al levert, wat betreft functionele decentralisatie van overheidstaken en -bevoegdheden naar zelfstandige bestuursorganen, de delegatie- en mandaatregeling in de derde tranche Awb weinig op. Vragen omtrent zellstandigheid, mate van verantwoordelijkheid en reikwijdte van aanwijzingen blijven open.

Een deel van de zelfstandige bestuursorganen valt al buiten het schot van de overkoepelende Awb. Want bevoegdheidstoekenning, anders gezegd attributie, aan zelfstandige bestuursorganen geschiedt ook wel door de formele wetgever.

De nieuwe regeling schiet tevens te kort wat betreft delegatie/attributie van publiekrechtelijke bevoegdheden aan zelfstandige bestuursorganen. Juist met oog op de fundamenteel andere inhoud van de politieke ministeriële verantwoordelijkheid voor het reilen en zeilen van zelfstandige bestuursorganen, is een adequate, optimalle regeling ter zake verdienstelijk.

Vandaar moeten, bij gebrek aan beter, voor als nog de verschillende instellingswetten baat brengen.

\section{$\S 4.5$ Toetsingskader zelfstandige bestuursorganen}

Ter versterking van de democratische legitimatie van zelfstandige bestuursorganen is een aparte lleidraad, inzake "eisen met betrekking tot inrichting en functioneren bij attributie dan wel delegatie van bevoegdheden aan ambtelijke organen, voor zover niet vallend onder de grondwettelijk verankerde decentrale lichamen" ${ }^{72}$ wenselijk.

Verschillende suggesties ${ }^{73}$ zijn gedaan te komen tot zo"n algemeen toetsingskader betreffende organen van functioneel bestuur, in het bijzonder zelfstandige bestuursorganen.

70. J.C. Oudshoorn, Delegatie en mandaat in de derde tranche, in: BWn, nr.3, 1992, pp.271-275, i.h., b. p.272. Oudshoom betwijfelt of er wel sprake is van "een gemiste kans" . Aan materièle wetgeving mogen, zijns insziens, "uit oogpunt van uniformiteit best regels worden gesteld" "Maar auteur "houdt het er voorlopig op dat het achterwege laten van negelgeving ter zake niet voorkomt uit onachtzasmhe id" Oorzaak erwan ligt juist in "het (willen) respecteren" wan de autonomie wan lagere wetgevers met betrekking tot regelgeving en bestuur aangaande de eigen huishouding.

71. I.C. van der Vlies, Delegatie, marialat en de rechtsstaat, in: T. Hoogenboom en L. J.A. Damen (red.), In de sfeer van administratief recht, Utrecht, 1994, pp.409-427, i.h.b. pp.417-418.

72. H.F. Munneke, Aanwijzingen voor de rijksdierst met betrekking tot de instelling van zelfstandige bestuursorganen, in: NJB, nr.8, 22 febr. 1986, pp.255-256, i.h.b. p.256.

73. Funcrioneel bestuar; waarom en hoe?, TK 1988-1989,21042. par. 5; Studiemiddag zelfstandige besturorsorganen d.d. 12 november 1985, a.w., par. 4; J.B.J.M. ten Berge en F.A.M. Stroink, Functionele decentralisatie wir de schaduw, a.w., pp.65-67. 
Inmiddells is sprake van concretisering van een aantal aandachtspunten. ${ }^{74}$ Deze randvoorwaarden vormen een 'checklist' ten behoeve van departementen bij de instelling en inrichting van nieuwe functionele bestuursorganen. Aan de hand hiervan is ook evaluatie van reeds bestaande zelfstandige bestuursorganen mogelijk. Daartoe is de commissie-Oele ingesteld. 75

De commissie-Oele is een subcommissie van de adviescommissie rijksdienst. ${ }^{76}$ Deze, medio september 1992 ingestelde, commissie-Oele heeft "tot taak te adviseren over aspecten van doelmatigheid en aspecten van juridische en bestuurlijke aard". 7

Tem eerste omvat het werk van de commissie, in het algemeen, alle externe verzelfstandigingen.

Ten tweede houdt de commissie zich, in het bijzonder, bezig met zelfstandige bestuursorganen. Hieraan wordt de volgende inhoud gegeven. Inventarisatie van de reikwijdte of omvang van het verschijnsel zelfstandig bestuursorgaan vindt plaats. ${ }^{78}$ Daarvoor dient de staatsalmanak ${ }^{79}$ als uitgangspunt. In de almanak is tegenwoordig een openbaar register van zelfstandige bestuursorganen opgenomen. ${ }^{80}$

Helaas is dit register, bedoeld is het register van 1992/1993, nog incompleet. Ter illustratie een paar voorbeelden.

Niet opgenomen in de staatsalmanak zijn onder meer de volgende nieuwe of vernieuwde zelfstandige bestuursorganen: Bureaus rechtsbijstandvoorzieningen gelieerd aan Stichtingen rechtsbijstand samenwerkend met Raden voor rechtsbijstand (TK 1992-1993, 22609, Stbl. 1993, 775); Centraal bureau gecombineerd met een Centrale commissie voor de statistiek (TK 1993-1994, 23576); Centraal orgaan opvang asielzoekers (TK 1993-1994, 23540); College voor de toelating van bestrijdingsmiddelen (TK 1993-1994, 23156, Stbl. 1994, 51, beschikking J9220315, Stcrt. 1992, 252); Controlebureau voor pluimvee, eieren en eiprodukten (vervangt sinds 12 april 1993 stichting scharreleierencontrole); Dienst wegverkeer (TK 1992-1993, 22961); Fonds voor de podiumkunsten (1993); Informatie beheer groep (TK 1992-1993/1993-1994, 23073); Mondriaan stichting (1993); Nederlands literair produktie- en vertalingenfonds (1991); Nederlandse omroep stichting (TK 1993-1994, 23257); Rijksdienst voor het kadaster en openbare registers (TK 1992-1993/1993-1994, 23007/22347); Stichting centraal orgaan kwaliteitsaangelegenheden in de zuivel; Stichting dienstverlening emigratie Nederland (per 1 jan. 1994); Stichting fonds voor bijzondere journalistieke produkten (1990); Stichting internationale

74. Functioneel bestuur; warom en hoe?, TK 1990-1991, 21042, nr.4, pp.31-35.

75. A.T.L.M. van den Ven, Privatisering en functionele decentralisatie, in: OMn, nr.3, 1993, pp.56-61.

76. Functionele decentralisarie, TK 1991-1992, 21042 , nr.13, p.2.

77. Zie de aanbeweling voor de commissie in Functioneel bestuur: waarom en hoe?, TK 1990-1991, 21042 , nr. 4, p. 5 .

78. Functionele decentralisatie, TK 1991-1992, 21042, nr.12, p.2; A.J.H. Smallenbroek en T.J.M. Spit, Bünnenlandse kroniek; De organisatie var de rijksdienst, in: BWn, n. 7, 1992, p.637.

79. Stactsalmanak voor het Koninkrijk der Nederlanden, "s-Gravenhage, respectievellijk 1992 en 19913 , pp.Z1Z110.

80. Dit is conform de aanbeveling ter zake in Functioneel bestuur: waarom en hoe?. TK 1990-1991, 21042, p. 6 . 
scharrelvleescontrole; Stichting keur alternatief voortgebrachte landbouwprodukten (1) jan. 1992); Commissie vergunningverlening beroepsvervoer; Stichting Nederlandse vleeswaren kontrole (medio 1991 activiteiten stichting baconcontrole overgenomen); Stichting Verzekeringskamer; Stimuleringsfonds Nederlandse culturele omroepprodukten (1988); Stimuleringsfonds voor architektuur (1993).

Evenmin vermeldt de almanak de volgende overheidsorganen die wel een zbo-status genieten: bij voorbeeld het Landelijk selectie- en opleidingsinstituut politie (Stbl. 1992, 320).

Wegens opheffing of het niet bezitten van de zbo-status niet, of misschien niet, in een komende staatsalmanak te registreren zijn onder andere de volgende organen: Bestuur Algemeen burgerlijk pensioenfonds (privatisering per 1 januari 1995 in gevolge TK 1993 1994, 23442); Commissie ex art. 14 Sera- en vaccinbesluit (opgeheven); Nederlandse filmkeuring (met opheffing bedreigd, er bestaan plannen om te komen tot een systeem van wettelijk geconditioneerde zelfregulering in gevolge TK 1992-1993, 23001); Dienst omroep bijdragen (onderdeel KPN nv); Octrooiraad (krijgt andere vorm); Pensioenbestuur van het spoorwegfonds (per 1 jan. 1994 verzelfstandigd); Raad wan Beheer Stichting administratie Indonesische Pensioenen (binnenkort genoodzaakt tot opheffing); Raad voor de casinospelen (ernstig bedreigd met opheffing, met College van toezicht op de kansspelen als substituut in gevolge TK 1992-1993, 21277, TK 1992-1993/1993-1994, 23605); Raad voor de kinderbescherming (mandaatvorm deconcentratie; de aan de raden gerelateerde Instellingen voor de voogdij of gezinswoogdij komen zo langzaam aan wel steeds. sterker in aanmerking voor een zbo-status, in het kader van taakherziening van de Raden voor de Kinderbescherming nemen de voogdij-instellingen in elk geval de RvdK-taak t.W. het opleggen wan de maatregel tot voorlopige voogdij over ${ }^{81}$ ).

In een staatsalmanak voor een van de volgende jaren moet rekening worden gehouden met mogelijk op te richten zelfstandige bestuursorganen als: Commissariaat voor de etherfrequenties; Commissariaat voor de elektronische informatievoorziening (in plaats van het Commissariaat voor de media resp. de Hoofddirectie telecommunicatie en post van het ministerie van verkeer en waterstaat); Raad voor de ongevallen; Raad voor de zorgverzekering (in plaats van de Ziekenfondsraad); Stichting Bedrijfsfonds voor de telecommunicatie (in plaats van de Stichting bedrijfsfonds voor de pers); Zbo belast met toezicht op kartelafspraken en machtsconcentraties.

Ten slotte, de volgende zelfstandige bestuursorganen voorziet de staatsalmanak van een onjuiste adressering: College voor de toelating van bestrijdingsmiddelen; Controlebureau voor pluimvee, eieren en eiprodukten; Nederlandse orde van accountantsadministratieconsulenten; Stichting centraal orgaan kaas- en zuivelcontrole; Bestuur van de bedrijfsvereniging voor tabakverwerkende industrie; Inspectie jeugdhulpverlening regio NoordWest; Kamer van koophandel en fabrieken te respectievelijk Harderwijk en Rotterdam Beneden-Maas; Pensioenbestuur van het spoorwegfonds; Registro Italiano Navale; Stichting toezicht effectenverkeer; IJkwezen bv regio Zwolle.

81. Wetsvoorstel tot wijziging $B$ W en enige andere wetten in.m. de herziening van de voorlopige maatregel wan kinderbescherming. TK 1993-1994, 23808, nrs 1-3; Zie ook scheiding beleid en uitwoering doorgevoerd in organisatie RvdK conform woorstellen commissie-Wiegel neergelegd in TK 1994-1995, 21980, ners $1-30$. 
Inmiddels is de zbo-lijst gelukkig de kinderschoenen ontgroeit. In de recentere uitgave er van wordt terecht in de meeste lacunes voorzien en worden de nodige correcties aangebracht. In zijn huidige staat is het register ${ }^{22}$ vrij volwaardig. ${ }^{83}$.

Naast boven genoemde inventarisatie in de breedte, doet de commissie-Oele een proefonderzoek naar specifiek drie soorten zelfstandige bestuursorganen. Deze research heeft een meer inhoudelijk, diepgaand karakter. Centraal staan het Commissariaat voor de Media, de Kamers van Koophandel en fabrieken en de Nederlandse Organisatie voor Toegepast Natuurwetenschappelijk Onderzoek.

De evaluatie van bestáande zelfstandige bestuursorganen lijkt dus een feit. ${ }^{84}$ Helaas verloopt het onderzoek niet volgens wens. Verschillende departementen en zelfstandige bestuursorganen verlenen geen medewerking, hebben volgens zeggen geen tijd of achten zich zelf verantwoordelijk voor evaluatie. ${ }^{85}$

Overigens blijkt in praktijk dat er van evaluatie door zelfstandige bestuursorganen zelf bitter weinig terecht komt. ${ }^{86}$ Weliswaar ontbreekt het de meeste instellingsregelingen van zelfstandige bestuursorganen an nadrukkelijke bepalingen (inzake regelmatige evaluatie van taakvervulling). ${ }^{87}$ Maar dat, op zich, is geen valabel excuus. Terwijl in wet- en regelgeving geen voorzieningen worden getroffen, kunnen zelfstandige bestuursorganen zich in praktijk manieren aanleren om 'accountable" te worden. ${ }^{88} 89$

82. Stactsalmanak voor het Koninkrijk der Nederlanden, 's-Gravenhage, 1994/1995, pp.Z1-Z29.

83. Dit neemt niet weg clat, wergeleken met de imventarisatielijst in het Aanwijzingsbesluit Wob/Wno, zekere zelfstandige bestutu rsorgamen nog steeds ontbreken in de opsomming van de Staatsalmanak. Zie Algemene Rekenkamer, $Z 6$ o "s en ministeriële verantwoordelijkteid, TK 1994-1995, 24130, nr.3, p. 60, die aandringt op een compleet "openbaar register" van zbo"s (p.53). Volgens het kabinet zit het verschil tussen beide in het feit, dat de Staatsalmanak slechts informatieve waarde heeft en het Aanwij|zingsbesluit rechtsgevolg beoogt. Wel stelt zij dat de zbomgegewens, die de AR zelf via onderzoek in huis heeft gehald, worden meegenomen in een rapport-met een nadere standpuntbepaling inzake zbo's- dat in de earste helft van 1996 aan de Tweede Kamer wondt titgebracht (p.58).

84. De evaluatie is conform de motie-Van den Berg, TK 1990-1991, 21042, nr.9; Conform TK 1991-1992. $21042, n r .12, p .2$, richt de evaluatie zich ten eerste op het in beeld brengen van feitelijkhed an m.b.t. het functioneren vam zbo"s, ten weede op het beoordelen van deze feitelijkheden in het licht wan de toetsingspunten die de regering in haar standpunt inzake functioneel bestuur heeft verwoord en ten derde op het ontwikkelen van een handraiking voor een beter functioneren van bestaande zbo"s; Zie eerder TK 1990 1991, 21042, nr.6, war minister van bimenlandse zaken I.C. Dales stelt evaluatie en toetsing van reeds bestaande organen van functioneell bestuur bij voorkeur "consequent ter hand te nemen telkens: wanneer wijziging van wetgeving m. b.t. een zbo aan de orde komt en overigens in die gevallen, waarin de StatenGenerala , de eerst betrokken minister of thet orgaan zelf daartoe de wemselijkheid aangeeft" .

85. Commissie-Oelle, Voortgangsrapportage aver her project evaluatie zbo's, inteme publ., binnenlandse zaken, 15 febr. 1993.

86. Gemeenten en zelfstandige bestuursorganen zwak in evaluatie, in: BBM, 29 jan. 1993, p.22; F. L. Leeuw, Produktie en effectiviteit van overheidsbeleid, Institutionele analyse en effectmeting, oratie $\mathbb{R U U}$, "sGrawenhage, 16 oktober 1992 , p.43.

87. G.M. Kuiper, J.J. van Vliet, M. Klijnstra, J.L. Boxum, J. de Ridder en M. Scheltema, Functioneel bestuur getoetst, Groningen, 1991, p.43. Dit onderzoelk omvat 27 zelfstandige bestumrsorganen.

88. Daarvan blijkt ewenmin. F.L. Leeww, Mogelijkheden en beperkingen wan sturen-op-aftand, in: H. de Groot en C. G.M. van Oosteren, De toekomst van de publieke sector, 100 -jubileumuitgave, "s-Gravenhage, 1994 , pp. $185-198$, i.h.b. p. 188 . 
Hoewel terecht, geschiedt het luiden van de noodklok vrij vroeg. Waarschijnlijk zal de tijd het (beter) leren. Zelfstandige bestuursorganen moeten léren omgaan met de toetsingspunten van regeringswege.

Niettemin is het alarm, aangaande het gebrek aan evalwatieonderzoek (door derden) naar het functioneren van zelfstandige bestuursorganen, wel serieus te nemen. De klacht luidt als volgt. Zonder voldoende inzicht vindt de vraag, of een complexer geworden institutionele context ook (doelmatig en maatschappelijk) effectiever beleid oplevert, geen oplossing. De twijfels rondom functioneel bestuur blijven. De volgende vragen liggen open. ${ }^{9}$ Ten eerste, brengen functioneel gedecentraliseerde organen de burgers wel dichter bij het bestuur? Ten tweede, is het wel waar dat de beleidsmaker met zijn neus op de afnemers van diensten/produkten zit, zodat hij belleid effectief kan corrigeren? Ten derde, verheldert het werken met zelfstandige bestuursorganen het inzicht op de kijk op beleidseffectiviteit? Ten vierde, leidt bestuur mer de nadruk op de overlegfunctie niet tot vertraging van besluitworming en verschuiving van verantwoordelijkheden? De antwoorden daarop zoekt de vraagsteller in empirisch effectiviteitsonderzoek naar functioneel bestuur.

Voor het instellen wan zo"n eerste evaluatieonderzoek wordt kennelijk tijd en geld gevonden. De algemene rekenkamer zet, in nauwe samenwerking met de commissie-Oele, het van uit het ministerie van binnenlandse zaken begonnen evaluatieonderzoek naar ongeveer 250 zelfstandige bestuursorganen voort. ${ }^{91}$ Hierbij baseert de Algemene Rekenkamer zich op de vragenlijst ${ }^{32}$, die de commissie-Oele, op grond van het van regeringswege gegeven toetsingskader voor organen van functioneel bestuur, heeft opgesteld. Aan invoering van het besturingsconcept, van zelfstandige bestuursorganen die op hoofdlijnen worden aangestuurd door kerndepartementen, zijn volgens de rekenkamer risico"s verbonden die onderzoek rechtvaardigen waaronder: het gevaar voor een zeer krachtige positie van, hun eigen beleid bepalende, zelfstandige bestuursorganen van wege de moeilijke scheiding tussen beleiösbepaling en -uitvoering; het risico van een "ivorentoren-effect" op kerndepartementen omdat zij geen goed zicht hebben op de beleidsuitvoering; en de kans op niet-economisch handelen, onder afwenteling van kostenstijgingen op premie- en heffingsplichtigen, van zelfstandige bestuursorganen wegens het ontbreken

89. Naast de hier bedoelde kwantitatieve (en kwalitatieve) zbo-evaluatie, zijn ook andere evaluaties denkbaar. Bij voorbeeld een wetenschappelijk ondersteunde evaluatie van de wet- en regelgeving waarmee een zbo moet werken. Denk aan de Wet persoonsregistraties of de Mediawet. J.M. Polak, De wetgeving varn het Departement van Justitie, in: NIB, nr. 1, 6 jan. 1995, pp.7-15, i. k.b. p. 10, die terecht wijst op de evaluatieverplichting "als politiek drukmiddel", pleit woor het aanleggen van criteria on juist wêl of niet over te gaan tot evaluatie. Daarbij moet de sóónt ewaluatie expliciet worden aangegeven.

90. F.L. Leeuw, a.w., pp. 31-43.

91. Functionele decentralisatie, TK 1993-1994, 21042, nr.14, p.2.

92. Zie bijlage bij de Voortgangsrapportage van de comamissie-Oele. 
van de tucht van de markt. ${ }^{93}$ De uitkomst van het onderzoek publiceert de Algemene Rekenkamer eind maart 1995.

Bij bekendmaking van de resultaten van dit door haar in 1993 en 1994 rijksbreed uitgevoerde onderzoek naar de wijze waarop de ministerielle verantwoordelijkheid is geregeld en naar de wijze waarop ministers in de praktijk aan deze verantwoordelijkheid invulling geven, toont de Algemene Rekenkamer zich cynisch ten aanzien van zel fstandige bestuursorganen. Na de door haar bij $162^{95}$ (clusters van) zelfstandige bestuursorganen uitgevoerde evaluatie, die zij aan de hand van een belangrijk deel van de door de regering opgestelde toetsingspunten voor functioneel bestuur uitvoert ${ }^{96}$, spreekt zij mistroostig van "wildgroei" wat betreft de inrichting en vormgeving van zelfstandige bestuursorganen. ${ }^{97}$ Ten einde te komen tot de door de Algemene Rekenkamer gewenste "eenheid in verscheidenheid" luidt haar aanbeveling de regelgeving van zelfstandige bestuursorganen zo danig aan te passen dat duidelijkheid ontstaat over taken, bevoegdheden, bekostigingswijze en samenstelling er van. Overigens adviseert de Algemene Rekenkamer de ministers om: "meer helderheid te scheppen t.a.v. de vraag welke organen gerekend moeten worden tot de zbo's; in de regelingen de door de rekenkamer noodzakelijk geachte bevoegdheden voor toezicht van de ministers/toezichthouders op te nemen; scherper toe te zien op het verkrijgen van informatie die de organen krachtens de regeling aan het ministerie dienen te zenden; voorwaarden te scheppen om de binnenkomende verantwoordingsinformatie te beheren en te bewaken; zorgvuldig kennis te nemen van de door de zbo's toegezonden verantwoordingsinformatie en naar aanleiding daarvan, indien nodig, actie te ondernemen; en zelfstandige bestuursorganen regelmatig the evalueren ${ }^{98}$ op hun functioneren, taakuitoefening en effectiviteit". ${ }^{99}$

93. H.E. Koning, Controlerem is vooruatzien, De risico-analyses van de Algemene Rekenkamer, in: Overheidsmanagement, nr.5, 1994, pp.126-129; Voorzitter Koning van Algemene Rekenkamer: 'Vervlechting publieke en private sector werkt corruptie in de hand' , in: BB, nr.35, 2 sept. 1994, p.9. Herhatd door. zbo-onderzoeksleider, F.L. Leenw (1994), t.a.p. , pp.189-191.

94. Algemene Rekenkamer, Zelfstandige beshursarganen en ministerietle verantwoordelijkheid, TKK 1994. 1995,24130, nr. 3 .

95. De Algemene Rekenkamer, Zbo"s en ministeriële werantwoordelikheid, TK 1994-1995, 24130, nr.3, pp. 9-10, komt -aan de hand van haar op de Awb geinspireerde omschrijving-tot 189 (clusters van' zbo's. Daarwan onderzoekt zij 162 (d.w.z. 545 zbo"s, t.w. 139 afzonderlijke zbo"s en 23 clusters omwattende 406 aparte zbo's). De rest blijft bu iten beschow wing van wege een 'papieren bestaan', de geringe omvang wan de openbaar gezagstaak of instelling na de peildatum van bet onderzoek: Het valt de president van de Algemene Rekenkamer H. E. Kaning op, dat het "bij die zbo's een warwinkel is. Het zit tegen chaos. aan, ze zijn volkomen onhelder georganiseend. We hebben wit die onoverzichtelijke kluwen uiteindelijk 189 clusters van soorten zbo's kunnen halen. Er zit geen lijn in." Aldus geciteerd door T.J. Meeus, Kaning: privatiseringen zijn warwinkel, tegen chaos aan, in: NRC, 30 maart 1995, p.21.

96. De Algemene Rekenkamer, Zbo's en ministeriële verantwaordelijkheid, TK 1994-1995, 24130, nr.3. p. 23 , constateent dat slechts "gemiddeld per orgaan iets meer dan de helft van de toetsingspunten is geregeld", Geen enkel zbo voldoet volledig aan de matstaven yoor exteme werzelfstandiging naar $z b 0^{\circ} \mathrm{s}_{\mathrm{n}}$

97. Algemene Rekenkamer, Zbo"s en ministeriële verantwoordelijkheid, TK 1994-1995, 24130, nr.3, Pp. $4 / 24 / 53$.

98. De Algemene Rekenkamer, Z60 "s en ministeriële verantwoordelikheid, TK 1994-1995, 24130, nr 3 , pp. 4/40, brengt verongelijkt naar voren dat slechts $30 \%$ van de bestudeerde zbo's beschikt over toereilkende evaluatieonderzoeksrapportages. De AR hanteen voor haar evaluatieonderzoek de volgende criteria: 
Het kabinet reageert op het rapport van de Algemene Rekenkamer door te beloven met frisse moed aan de (ten dele eerder zonder succes aangevangen) evaluatie van bestaande zelfstandige bestuursorganen te beginnen. Bij beoordeling van bestaande zelfstandige bestuursorganen wordt vooral gelet of zij a. nog reden van bestaan hebben en b. efficiënt en effectief zijn georganiseerd. ${ }^{100}$

Bij evaluatie van zelfstandige bestuursorganen, dient het volgende in aanmerking te worden genomen. Waardering van zelfstandige bestuursorganen geschiedt aan de hand van de volgende toetsingspunten ten aanzien van de keuze voor functionele decentralisatie en de keuze voor vormgeving van zelfstandige bestuursorganen.

Met betrekking tot de overweging over te gaan tot functionele decentralisatie bestaan vier criteria. Ten eerste de motivering. Is de optie ingegeven door de hoop op een doelmatiger bestuur? Of is er behoefte aan ervaren bestuurders, deskundigen en maatschappelijke belangenbehartigers bij bepaalde taakuitvoering? De motiveringsplicht betreft in elke geval argumenten met betrekking tot het verlies aan volledige politieke controlle, de inen aanpassing in het algemeen, territoriaal bestuur, en natuurlijk de kosten en baten van functionele decentralisatie. Ten tweede verdient de voorkeur voor het type zelfstandig bestuursorgaan toelichting. Ten derde is aandacht nodig voor de oprichtingsgrondslag. Oprichting gebeurt bij of krachtens wet. Vandaar is een instellingswet altijd aanwezig. Daarin staan speciale regells betreffende delegatie en attributie. In feite komen in instellingswetten de hierna volgende toetsingspunten aan de orde. En ten vierde is bekendmaking van de achterliggende gedachte bij de beslissing voor hetzij een publiekrechtelijke hetzij een privaatrechtelijke organisatievorm belangrijk.

Met betrekking tot de vormgeving van zelfstandige bestuursorganen zijn zes maatstaven te noemen. Ten eerste moeten taken- en bevoegdhedentoedeling ondubbelzinnig duidelijk zijn. Ten tweede zijn de samenstelling, met daaraan inherent de wijze van benoeming, als mede de inrichting van het zelfstandig bestuursorgaan toetsingspunten. Ten derde is een regeling van toezicht en controle op de uitoefening van openbaar gezag door zelfstandige bestuursorganen nodig. Delegatie- of attributieterminologie moet uitermate transparant zijn. In verband met adequate gedeeltelijke politiek-bestuurlijke doelmatigheidsen rechtmatigheidscontrole zijn publikatie van beleidsregels van zelfstandige bestuurs-

98. $\rightarrow$

het onderzoek mag niet marginaal zijn; het onderzoek betreft expliciet de takuitvoering van het zbo binnen het beleidsterrein waarop het zbo werkzaam is; het onderzoek is een ex post evaluatie; het onderzoek heeft een doel- of probleemstelling; het onderzoek baseert zich op empirische gegevens; en het onderzoek besteedt aandacht aan uitvoeringswijze, doelbereiking, effectiviteit of neveneffecten.

99. Algemene Rekenkamer, Zbo's en ministeriële verantwoordelijkheid, TK 1994-1995, 24130, mr.3, p.5. In een later stadium wil de rekenkamer in een vervolgonderzoek dan bekijken wat er met deze raadgevingen is gedlaan.

100. Kabinet verscherpt toezicht op verzelfsrandigde dienstem, in: NRC, 3 mei 1995, p.19. 
organen, openbaarheid en verslaglegging van vergaderingen en regelmatige evaluatie ${ }^{101}$ door regering en parlement noodzaak. Ten vierde regelt de instellingswet het beheer. Bekostiging, personeel en informatievoorzieningen zijn daarbij essentiële factoren. Ten vijfde is openbaarheid van bestuur in beginsel regel. En ten slotte dienen mogellijkheden van rechtsbescherming duidelijk te zijn. Overigens moet, in principe, de weg naar een klachteninstantie openstaan.

Wat betreft laatst genoemde aspecten gaat het de goede kant uit.

De ontwikkeling van openbaarheid van bestuur laat het volgende zien. "Het zonder meer van toepassing verklaren van de Wet openbaarheid van bestuur op deze veelheid van zelfstandige bestuursorganen, met hun grote verscheidenheid van taken, acht het kabinet niet verantwoord. Daarom is er in navolging van de oude Wob voor gekozen om de overheidsorganen waarvan het evident is dat deze onder de Wob moeten vallen, in de wet te noemen en voor het overige de mogelijkheid te scheppen organen bij algemene maatregel van bestuur aan te wijzen." ${ }^{102}$ Een ministeriële toezegging ter zake ${ }^{103}$ wordt gestand gedaan. ${ }^{104}$ Als gevolg daarvan gaat de vernieuwde Wob van 31 oktober 1991 houdende regelen betreffende de openbaarheid van bestuur ${ }^{105}$ vergezeld van een verzamel-amvb aangaande zelfstandige bestuursorganen. ${ }^{106}$ In beginsel vallen zelfstandige bestuursorganen op rijksniveau, daartoe als overheidsorganen in de zin van art. $1 \mathrm{~A}$ Wob angewezen, dus onder de wet. Hiervan zijn niet uitgesloten zelfstandige bestuursorganen met een privaatrechtelijke status. ${ }^{107}$ In concreto vindt aanwijzing plaats voor het Commissariaat voor de Media en het Centraal bestuur als mede de Regionale besturen van de arbeidsw voorzieningenorganisatie. ${ }^{108}$ Provinciale en gemeentelijke zelfstandige bestuursorgamen vallen vanzelfsprekend onder de werking van de Wob. De nieuwe regeling geeft dus een positief geluid. Toch is sprake van gematigd optimisme. ${ }^{109}$ Menigeen ziet, bij voorkeur, alle zelfstandige bestuursorganen geconfronteerd met regels inzake openbaarheid. "Een algemeen of categoriaal omschreven wettelijk orgaanbegrip" is dan noodzakelijk

101. Zie voor modelevaluatiebepalling C. Bomam, Aanwijzingen woor de regelgeving, Zwolle, 1993, pp. 135136 (atnwijzing 164 ), althans wat betreft evalatie van regelgeving: "Indien her wenselijk is te bepalen dat een wet eenmalig of periodiek wordt geèvaheerd, of over de uitvoering daarvan verslag wordt gedaan, word het wolgende model als uitgangspunt genomem: Onze minister [...] zendt binnen ... (in de rede: vijf - JGLVW) jaar ma de inwerkingtreding van deze wet, (en vervolgens telkems na ... jaar), aan de Staten-Generaal een verslag over de doeltreffendheid en de effecten van deze wet in de praktijk. (of madtere omlijning wan aspecten of onderdelen vian de wet). ", Overigens spreekt minister Dales ta. $v$. met name tijdelijke of voorlopige zbo's woorkear uit voor een horizonbepaling, d. w.z. een bepaling die er toe strekt dat de werkzaamheid vam een zbo wettelijk aan een eindtermijn wordt gebonden. Hand. "TK. 82,22 mei 1991, pp.82-4580/4581.

102. Minister Van Dijk tijdens kamendebat d.d. 16 febr. 1989, hand. TK 1988-1989, p.50-5015; Tevens: Th.J.M. Lindner, Actuele wetgeving Wob, in: NTB, nr. 3,1988, p. 102.

103. Minister C.I. Dalles, 29 oktober 1991, handelingen EK 1990-1991, p.4-44.

104. Conform de motie-Kohnstamm/Van den Berg, TK 19859" nir.20.

105. Stbl. 1991, 703, pp.1-8.

106. Th.J.M. Lindner, Actuele wergeving Wob, in: NTB, mr.1.1992, p.31.

107. EK 1990-1991, 19859, nr.21A, p.1 juncto nr.21B, p.1.

108. Stbl. 19911, 357.

109. H. G. Lubberdink, Openbaarheid en zelfstandige bestuursorganen, in; Besum, nu. 2 , 1985, pp.26-27. 
"omdat en voor zover zelfstandige bestuursorganen met openbaar gezag zijn bekleed of anderzins een publiekrechtelijke taak vervullen". ${ }^{110}$ Uiteindelijk worden per 1 november 1993 weliswaar niet alle, maar wel de meeste zelfstandige bestuursorganen aan de zelfde regels van openbaarheid gebonden als ministeries, provincies of gemeenten. ${ }^{\text {III }}$

Recente ontwikkelingen inzake het klachtrecht bij de nationale ombudsman geven ook een fraai licht. Maar het licht komt pas na de duisternis. In het debat over de wijziging van de Wet nationale ombudsman is de minister namelijk nog van mening dat slechts "per geval" competentieuitbreiding kan platsvinden. ${ }^{112}$ "Gelet op de complexiteit en onbepaaldheid van het losse-eindenbegrip zelfstandige bestuursorganen en het diffuse en zeer gevarieerde karakter van die instellingen" blijft het motto "liever maatwerk dan confectie". ${ }^{113}$ Wel is er de ministeriële belofte om te zijner tijd een verzamel-amvb op te stellen. Een motie dringt aan tot het zo spoedig mogelijk voorbereiden daarvan. ${ }^{114}$ Met de motieaanvaarding lijken de extra bevoegdheden van de nationale ombudsman in zuicht.. Helaas wordt uitbreiding uit bezuinigingsoverwegingen (3,8 miljoen gulden aan investeringskosten) afgeblazen. ${ }^{115}$ Een domper op de feestvreugde van het tienjarig jubileum van de nationale ombudsman. De ombudsman zelf vindt zijn onafhankelijke positie ten aanzien van uitvoerende zelfstandige bestuursorganen "van vitaal belang". 116 Gelukkig ziet de regering uiteindelijk in dat de macht van de nationale ombudsman ook voor zelfstandige bestuursorganen (en waterschappen) norm moet zijn. Het voorstel is zo snel mogelijk "een limitatieve amvb te realiseren". "117 Voor akkoord wordt getekend. "18 Uiteindelijk schijnt het groene licht, per 1 november $1993^{119}$, vol op voor uitbreiding van de bevoegdheid van de nationale ombudsman ten aanzien van zelfstandige bestuursorganen ${ }^{120}$ " $1211_{22}$ Naar verwachting leidt de competentie-uitbreiding jaarlijks tot

110. A.L.L. Beers, Gewijzigd voorstel nieuwe Wob aangenomen in de Tweede Kamer, in: NTB, nr.1, 1991, pp. 1-9.

111. Uitbreiding van regets op openbaarheid, in: NRC, 24 juli 1993, p.2; Zelfstandige bestuursorganten, WOB en WNO, in: NJB, 5 aug. 1993, nr.28, pp.1037-1038; Ontwerp-amvb aan te wijzen zbo's, TK 1992-1993, 22731, nr.3, pp. 2-8; Bestuit tot aanwijzing van bestuursorganen als bedoeld in de Wob/ Who, 16 okt. 1993, Stbl. 1993, 535, pp.1-15, ook Stbl. 1994, 468; Hierover J.P. de Jong, Aanwijzing van bestuursorganen o.g. w. de Wab en de Wno, in: NTB, nr.10, 1993, pp.329-330.

112. Wijziging Wno, TK 1985-1986, 19426, nrs.1-3/8.

113. Th.J.M. Lindner, Actuele wetgeving, in: NTB, nr.4, 1989, p.132.

114. Motie Kohnstamm/Van den Berg. TK 1988-1989, 19426, nr.17.

115. Vaststelling van de begroting van de uitgaven en de ontvangsten wan de Hoge Colleges van Staat en het Kabinet der Koningin woor het jaar 1991, TK 1990-1991, 21800II, nr.11, p.1.

116. L. Schaap en M. van Twist, Het kritisch geweten van de overheid jubileent; Tien jaar ombudsman, in: BBM, nr.1, 21 febr. 1992, pp.45-47.

117. C.I. Dales in notitie aan de Tweede Kamer d.d. 24 augustus 1992.

118. A.J.H. Smallenbroek en T.J.M. Spit, Binnenlandse kroniek; Competentieuitbreiding van nationale ombudsman, in: BWn, nr. 5, 1992, p.463; Ministerraad geeft nationale ombudsman meer bevoegdheden, in: NRC, 15 juli 1992, p.2.

119. KB 16 okt. 1993, Stbl. 1993, 535, zie ook Stbl. 1994, 468.

120. Het Wno-begrip "administratief orgaan" is vervangen door de Awb-term 'bestuursorgaan". Zie Wno, gewijz. 4 juni 1992, Stbl. 1992, 623. 
zo'n 800 klachten inzake zelfstandige bestuursorganen. De helft er van zal de uitvoering(sorganen) van sociale zekerheidswetgeving betreffen. Invoering van dit klachtrecht kost circa één miljoen gulden. Deze kosten, die zijn gemoeid met de uitbreiding van de competentie van de nationale ombudsman tot zelfstandige bestuursorganen, worden op deze organen verhaald. ${ }^{123}$

Wat betreft toepasselijkheid van zowel de Wob als de Wno wordt het Aanwijzingsbesluit bestuursorganen Wob/Wno dus de plaats bij uitstek geacht om zelfstandige bestuursorganen onderdak te bieden. Helaas is de bescherming er van niet optimaal.

Het besluit omvat slechts een limitatieve opsomming van 151 zelfstandige bestuursorganen die onder de werkingssfeer van respectievelijk de Wob en de Wno vallen. Dit leidt tot de twee volgende negatieve consequenties. ${ }^{124}$ Ten eerste, de aansluiting tussen de Awb en de Wob/Wno ontbreekt. Onder de Awb vallen álle personen en colleges met openbaar gezag bekleed. En onder de Wob/Wno vallen alleen de aangewezen organen. Deze divergentie moet zijn opgelost voordat de Wob in de Awb (vierde tranche) wordt geïncorporeerd. Ten tweede, er onstaat een ongerechtvaardigd onderscheid in verschillende zelfstandige bestuursorganen. Op grond van welke criteria zijn sommige zelfstandige bestuursorganen wel of niet aangewezen? Bovendien is de vraag te stellen of er niet meer dan circa 150 zelfstandige bestuursorganen zijn, gegeven het bekende WRR/RUUrapport uit 1983 . En, moet het aanwijzingsbesluit niet elk jaar worden geactualiseerd? Een categoriale aanwijzing ter zake schept mogelijk meer helderheid.

Hoewel dit niet-akkoord-gaan-met het opgestelde aanwijzingsbesluit op zich wordt ondersteund, bestaat terecht 'kritiek op kritiek'. ${ }^{125}$ Het aanhalen van het WRR/RUU-onderzoek blijkt niet correct. Die studie omvat niet slechts zelfstandige bestuursorganen, maar ook een belangrijk aantal stichtingen en vennootschappen waarop de overheid een overheersende invloed heeft. De gezochte criteria voor aanwijzing zijn te vinden in het, overigens zeer onheldere ${ }^{126}$, begrippenpaar: zêl fstandige organen, zijnde bestúúrsorganen in de zin van art. 1:1 Awb. Onder meer de daarbij te voorziene interpretatieproblemen doen de twijfel aan de voorkeur voor een categoriale aanwijzing van zelfstandige bestuursorganen rijzen. Zo'n aanwijzing is praktisch gezien moeilijk haalbaar binnen het huidige systeem van respectievelijk Wob en Wno. Art. la Wob verklaart de Wob van toepassing op alle (Awb-)bestuursorganen, met uitzondering van zbo's op rijksniveau. Voor het categoriaal aanwijzen van zelfstandige bestuursorganen is wijziging nodig van

121. Notitie betreffende competentie-uitbreiding wan de Nationale ombudsman, TK 1991-1992, 22731, 24 aug. 1992, nrs. 1-3; Vgl. J.M. Polak, F.D. van Heijningen, J.G.C. Wiebenga en M. Oosting, Rondom de nationale ombudsman; Tien jaar ervaring mes hel institum, uitgave professor mr B.M. Telderstichting nr. 78, "s-Gratvenhage. 1993, pp.13-16/42-45/69-70.

122. Overigens wordt tegenwoordig ook het belang ingezien van de ombudsfunctie voor verzelfstandigde entiteiten op lokaal niveau, voorheen gemeentelijke diensten. 'Na privatisering ombudsumctie handhaven" "in: BB, nr. 50,16 dec. 1994, p.4.

123. Uitbreiding competentie ombudsman wordt doorberekend, in: $\mathrm{BB}, \mathrm{nr} .45,12$ nov, $1993, \mathrm{p} .3$.

124. C.P.J. Goorden, Het aanwijzingsbesluit bestuursorganen Wob en Wno, in: NTB, nr. 3, 1994, pP. 61-67.

125. S.E. Zijlstra, Het Aanwijzingsbesluit bestuursorgaan Wob en Who, in: NTB, nr. 5, 1994, pp. $132-133$.

126. Darom ziet C.P.J. Goorden in zijn Repliek op een reactie, in: NTB, nr.5, 1994, pp. 133-134, woor de wetgever toch een taak om een goede zbo-omschrijving en -regeling op te stellen. 
dat artikel, inhoudende dat voortaan âlle bestuursorganen onder de Wob vallen. Bij de Wno levert zo'n verandering moeilijkheden op, omdat dan de principiële vraag van competentie-uitbreiding naar lagere overheden om antwoord vraagt. Mede gegeven het feit, dat het systeem van zbo-aanwijzing bij amvb ook na de - al dan niet door slechte aansluiting met de Awb bemoeilijkte - integratie van de Wob in de Awb hinderlijk is, luidt de conclusie dat inderdaad een categoriale aanwijzing voorkeur verdient, "maar dan via de koninklijke weg, namelijk wijziging van het stelsel van Wob en Wno". ${ }^{127}$

Dat het aanwijzingsbesluit, bij publikatie in aanvankelijke vorm, reeds gedateerd blijkt, wordt duidelijk door het noemen van een paar willekeurige voorbeelden. Over de exacte status van de aangewezen Raden voor de kinderbescherming (B4) bestaat voor als nog geen helderheid. ${ }^{128}$ Feitelijk zijn ze niet meer als zelfstandige bestuursorganen aan te merken. Bij onder meer de raad voor de kinderbescherming in Maastricht bestond tot 1991 nog een college, waarvan de leden - op grond wan te verwachten ontwikkelingen (afschaffing colleges) - ${ }^{129}$ ontslag uit hun lidmaatschap hebben gevraagd. Sinds de koninklijke aanvaarding hiervan functioneert de raad als een, gedeconcentreerde, welddienst van het ministerie van justitie. ${ }^{130}$ Wat betreft de Verzekeringskamer (E3) is het belangrijk te beseffen, dat deze sinds 1 september 1992 de vorm van een stichting heeft. ${ }^{3}$ Intussen heeft het aanwijzingsbesluit, even als het zbo-register, verandering ondergaan.

Uitwerking van bovenstaand toetsingskader moet, bij de afzonderlijke departementen, natuurlijk eenduidig toepassing vinden. Helaas ontbreekt het daaraan nog wel eens. Ook van regeringswege zelf is het streven naar uniformiteit in de vormgeving van verzelfstandiging beperkt benadrukt. Toch is een algemeen beleidsconcept ter zake essentieel. Ten eerste hebben controlerende instanties, alls het parlement en de algemene rekenkamer, groot belang bij een algemeen doorzichtig patroon van inrichting van zelfstandige bestuursorganen. Ten tweede zijn de evenwichtigheid van belangenafweging en de samenwerking binnen zelfstandige bestuursorganen elementair. De wijze van inrichting van een organisatie als geheel beïnvloedt (de mate van belangenbehartiging in) besluitvorming. Rijksdiensten, die strijdige belangen vertegenwoordigen, moeten daarom bij voorkeur op de zelfde wijze invulling geven aan alle aandachtspunten. ${ }^{132}$

\subsubsection{AANWIZINGEN VOOR DE RIJKSDIENST INZAKE ZELFSTANDIGE BESTUURSORGANEN}

Voornoemde toetsingspunten voor zelfstandige bestunrsorganen worden meer nader gedetailleerd in allerlei instellingswetten van zelfstandige bestuursorganen. De toetsings-

127. S.E. Zijlstrai, t.a.p.,p.133.

128. Vereniging wan secretarissen van de RvdK in antwoord bij brief d.d. 12 juli 1993, Arnhem/Utrecht.

129. Uitvoerig Rechizetten. TK 1990-1991, 21818, nrs.1-2, i.h.b. pp.38-39.

130. RvdK Mastricht, in antwoord bij brief d.d. 13 mei 1993, Maastricht.

131. Wet werzelfstandiging Verzekeringskamer, Stbl. 1992, 372.

132. I. de Ridder en M. Scheltema, Verzelfstandiging vanuit bestuurlik-juridisch gezichtspunt; Dejuridische dimensie wan zelfstandige bestursorganen, in: W.J.M. Kickert, N.P. Mol en A. Sorber, Verzelfstand:ging wan overkeidstiensten, geschriften van de vereniging voor bestuurskunde nr. 16, "s-Gravenhage, 1993, pp. $63-75$, i.h. b. pp. $72-73$ 
punten dragen geen vrijblijvend karakter. Daarom moeten zij in elk geval geformuleerd worden als aanwijzingen voor de rijksdienst. ${ }^{133}$ Voor deze transformatie in aanwijzingen voor de regelgeving inzake zelfstandige bestuursorganen bestaan de nodige redenen.

Ten eerste, dergelijke receptuur voor de rijksdienst dient de eenheid van beleid. Analoog aan de toelichting op de aanwijzingen voor externe adviesorganen geldt voor zelfstandige bestuursorganen het volgende. Aanwijzingen voor de rijksdienst "beogen nieuwe willgroei te voorkomen en de totstandkoming te bevorderen van een doorzichtig en efficiënt stelsel van" zelfstandige bestuursorganen. ${ }^{134}$ Zelfstandige bestuursorganen hebben tot op heden een uitermate uiteen lopend karakter qua omvang, vorm, taken en bevoegdheden. Harmonisatie van, in de toekomst mogelijk te realiseren, zelfstandige bestuursorganen is geen overbodig streven.

Aanwijzingen voor de rijksdienst bieden een tweede voordeel. In principe horen de departementen tot hun bereik. In praktijk komen ze daarnaast onder de aandacht van zowel de Raad van State als de Eerste en Tweede Kamer. ${ }^{135}$

Ten derde genieten aanwijzingen een formelere status dan aandachts- of toetsingspunten. $\mathrm{Zij}$ benaderen de formele en strakke redactie van officiële wetgeving. Hoewel aanwijzingen voor de rijksdienst weer wel elastischer dan wetten zijn. Deze flexibiliteit is gunstig met oog op de diversiteit in zelfstandige bestuursorganen. ${ }^{136}$ Deze meerwaarde verschaft aanwijzingen dus een tussenpositie. Overigens betekent dit niet dat aanwijzingen afdwingbaar zijn. Met andere woorden, zij "hebben geen zelfstandige bindende kracht". ${ }^{137}$

Zo bewijst zich het nut van aanwijzingen voor wetgeving inzake zelfstandige bestuursorganen. De wil is aanwezig. Maar kan het opstellen van dergelijke modelbepalingen wel? De recente instelling van het Centraa]. Bestuur voor de Arbeidsvoorziening toont de mogelijkheid er toe inderdaad aan. ${ }^{138} \mathrm{Bij}$ oprichting van dit bestuur vindt opstelling plaats van regels inzake voldoende taakspecificatie, inpassing in het algemeen bestuur, omvang van de ministeriële verantwoordel lijkheid, kenbaarheid en verantwoordingsplicht. Die regels kunnen uitstekend de vorm van aanwijzingen aannemen. ${ }^{139}$

133. Motie-De Cloe, TK 1990-1991, nr.10; J.M. Polak, Opinie: Toetsingspunten of aanwijingen woor de insteling en inrichting van organen van functioneel bestuur?, in: NJB, nr.37, 25 okt. 1990, p. 1453; I.M. Polak, Aanwijzingen voor de wergeving inzake zelfstandige bestumsorganen, in: $\mathrm{BWn}$, oktober 1989, pp. $440-444$.

134. Aanwizingen voor externe adviesorganen, d.d. 11 maart 1987, in: Stent. 6 aprill 1987, nr.67

135. J.M. Polak, Aanwijzingen voor wetgeving inzake zelfstandige bestuursorganen, in: BWn, akt. 1989, p. 441 .

136. J.M. Polak (1986), t.a.p., p.441.

137. Minister-president Lubbers in zujn Vaststelling wan de Aanwijingen vaor de regelgewing, d.d. 18 now. 1992, nu. 92M008337, än: Stcrt. 26 now. 1992, 230, p.13.

138. Mustellingswet van de Arbeidswoorzieningsorganisatie, TK 1989-1990, 20569; als mede de van minister De Koning afkomstige Nota naar aanleiding wan het eindverslag wan het wetswoorstel, 1 juni 1989 , nr. 14.

139. J.M. Polak (1989), t.a.p., pp.442-444. 
De aandacht voor het nut van de aanwijzingen bij het proces van wetgeving blijkt ook uit vooral de adviezen van de Raad van State wat betreft zelfstandige bestuursorganen rakende wetgeving. Bij voorbeeld de vervanging van de Wet toezicht verzekeringsbedrijf door de Wet toezicht verzekeringsbedrijf 1993 (TK 23199), de wijziging van de Bestrijdingsmiddelenwet 1962 in verband met de implementatie van de richtlijn gewasbeschermingsmiddelen (TK 23177) en de wijzigingen van de bepaling van de Mediawet in verband met het versterken van de organisatie van de landelijke publieke omroep en het bieden van langdurige zekerheid aan omroepverenigingen (TK 23257). Deze en andere adviezen van de Raad van State laten zien, "dat bepaalde aanwijzingen - o.a. de nummers $61,82,86,89,164,219,304$ - telkens terugkeren en reeds daarom voor catalogisering in aanmerking komen. Wil de met de aanwijzingen beoogde eenheid en onderlinge vergelijkbaarheid goed van de grond komen dan is een systematische verzameling, naar analo-

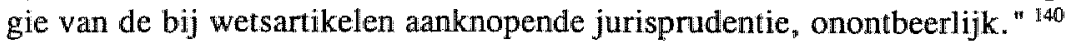

Bij dit alles hoort toch een kanttekening. Uiteraard gelden aanwijzingen voor de wet- en regelgeving alleen woor regelingen die onder ministeriële verantwoordelijkheid tot stand komen. Zelfstandige bestuursorganen zijn dus in feite niet gebonden aan de aanwijzingen. Want de directe gezagsrelatie tussen hen en ministers of staatssecretarissen ontbreekt.

Toch hebben "gezien de belangrijke rol die aanwijzingen kunnen spelen bij het bevorderen van de kwalliteit van regelgeving, de opstellers andere participanten in het proces van regelgeving aanbevolen rekening te houden met de aanwijzingen" 141 . ${ }^{142}$ In dit verband wordt overigens terecht betreurd dat "alléén even in de toelichting" bij aanwijzing 16 (aanwijzing 16 stelt: taken en bevoegdheden worden op decentraal niveau gelegd, tenzij het onderwerp van zorg niet op doelmatige en doeltreffende wijze door decentralle organen kan worden behartigd - JGLvN) het verschil tussen territoriale en functionele decentralisatie wordt vermeld en de politieke zwaartepunten inzake de te decentraliseren taken en bevoegdheden worden opgevoerd; Hierbij is het "jammer dat de richtlijnen uit de nota functionele decentralisatie niet zijn verwerkt, terwijl evenmin naar deze nota wordt verwezen" 143 . 144

"Daarnaast zijn er op bepaalde punten gerichte afspraken met het presidium van de Tweede Kamer gemaakt over de werking van de aanwijzingen. Ook zijn de aanwijzingen reeds in de conceptfase doorgesproken (gelet op wetgevingsprojecten - JGLvN). Tussen

140. J.M. Polak, De Aanwijzingen voor de regelgeving, in: NJB, nr.39, 4 nov. 1993, pp.1396 1399, i. th. b. p.1399; Zie uitwoerig over de relevantie van de aanwijzingen in het algemeen J.M. Polak, De Awb en de Aanwijingen voor de regelgeving, monografieën Awb deel B-9, Deventer, 1995.

141. Bedoeld zijn de aanwijzingen woor de regelgeving, in werking getreden per 1 januari 1993. Zie toelichting vier van de minister-president op de Vaststelling van de Aanwijzingen voor de regelgeving, in: Stcrt. 26 nov. 1992,230, p.13.

142. C. Waaldijk, Motiveringsplichten wan de wetgever, diss, RL, Lelystad, 1994, p.221, acht het logisch dall zbo"s "niet zomaar - en in ieder geval miet ongemotiveerd - afwijken van de adviezen van de alanwijzingengevert ${ }^{\text {th }}$.

143. I.C. wan der Vlies, De lagere overheid aangewezen, in: RegelMaat, nr.1, 1993, pp.8-9.

144. C. Waaldijk, Motiveringsplichten van de wetgever, diss. RL, Lely stad, 1994, p. 217, benadrukt de, door hem correct uit de toelichting bij aanwijzing 16 afgeleide, plicht om decentralisatie naar organen van functioneel bestuur, i.p.v. organen van algemeen bestuur, nadrukkelijk te motiveren. 
de rijksoverheid en decentrale overheden zal ten slotte overleg worden gevoerd over een wederzijdse aanpak op het gebied van de kwaliteit van regelgeving." 145

Van wege het, uiteindelijk, niet echt verplichtende karakter van aanwijzingen voor de rijksdienst is een klare conclusie te trekken. Er is maar een goede wijze om de gewenste uniformiteit in de warwinkel van zelfstandige bestuursorganen te bewerkstelligen. Dat is een "wettelijke regeling waarin de hoofdregels over de inrichting van een zelfstandig bestuursorgaan en over de voorzieningen voor controle zijn neergelegd". "146 Voordat een dergelijk normenstelsel tot stand komt, is het niet wijs nieuwe zelfstandige bestuursorganen in te stellen. ${ }^{147}$ Het' wachten is dus op zo' $n$, volgens de minister van binnenlandse zaken toegezegde ${ }^{148}$, kaderwet. Mogelijk alternatief voor een kaderwet is een algemene zbo-regeling in hoofstuk $1 \mathrm{~A}$ van de Awb. ${ }^{149}$ Eind 1994 valt uit de begroting van het ministerie van binnenlandse zaken op te maken, dat de ambtenaren daar ten departemente werken aan een algemene wet op zelfstandige bestuursorganen. ${ }^{150}$

Voordat een dergelijke wet mogelijk tot stand komt, zet het kabinet, dat een procedure in werking stelt ten einde een artikel inzake zelfstandige bestuursorganen op te nemen in de Grondwet, zijn zinnen voorlopig op aanwijzingen voor zelfstandige bestuursorganen. ${ }^{151}$ Die aanwijzingen krijgen volgens plan via een spoedprocedure, nog voor de zomer van 1995, directe werking. Dit betekent dat de regels, vervat in de aanwijzingen, effectief zijn voordat de Raad van State er advies over uitbrengt.

Overigens intrigeert de inhoud van de aanwijzingen. Essentialia zijn de volgende. Slechts bij wijze van (uitdrukkelijke gemotiveerde) exceptie op de hoofdregel van publiekrechtelijke vormgeving wordt een op te richten zelfstandig bestuursorgaan een privaatrechtelijke - voor burgers herkenbare! - gedaante aangemeten. En de ministers krijgen meer mogelijkheden orm zelfstandige besturursorganen te sturen. Denk aan een algemeen inlichtingenrecht voor bewindspersonen (in elk geval moet hen jaarverslag en jaarrekening worden overlegd), een regelstellende bevoegdheid van ministers en een ontslag- en benoemingsbevoegdheid van ministers. Vooral het informatierecht is broodnodig, maar bij het bezien van het pakket mogelijk in te voeren maatregelen, valt direct op dat van

145. Ph. Eijlander en W. Voermans, Nieuwe aanwijzingen voor de regelgeving, in: NJB, 4 febr. 1993, nr.5, pp. $171-172$.

146. Cie-Scheltema, a.w. , D.52; Vgl. G. J Schutte, Kerndepartementen en ministeriale verantwoordelikheid, in: OB, nr.4, 1994, pp.2-4; P.J. Langenberg, Gebonden zelfbeheer, in: P. J. Langenberg e.a., Omtrent het parlemen, Utrecht/Antwerpen, 1985, pp.169-174.

147. G.M. Kersten, Oppassen met zbo"s, in: OMn, nr.7/8, 1994, p. 194.

148. TK 1993 1994, 21427, mr.73, p.1; In het verzelfstandigingsdebat medio juni 1995 dringt de Tweede Kamer aan op waststelling van de toegezegde kaderwet, Kamer: wet nodig voor overheidsorganen, in: NRC, 15 junil 1995, p. 3

149. P. de Haan, Het bestuursrecht en de scheiding tussen beleid en uitwoering, in: T. Hoogenboom en L.J.A. Damen (red.), In de sfeer van administratief recht, Utrecht, 1994, pp.121-150, i.h.b. p.150.

150. Zie Veranderingen bij het rijk, in: OMn, nr.11, 1994, p.292; Bevestiging bij A.J.H. Smallenbroek en T.J.M. Spit, Binnenlandse kroniek, in: BWn, nr.6, 1994, pp.509-512, i.h.b. p.511.

151. Kabinet verscherpt toezicht op verzelfstandigde diensten, in: NRC, 3 meil 1995, p.19; Het officiëlle kabinetsstandpunt wordt verwoord als reactie op het rapport van de Algemene Rekenkamer in TK. 19941995,24130 , nr.5. 
hogerhand hard wordt ingehakt op de zelfstandigheid van functioneel gedecentraliseerde bestuursorganen. Gegeven de vele fiasco's die zich de afgelopen jaren hebben voorgedaan bij zelfstandige bestuursorganen is dat begrijpelijk. Hierbij is het alleen zwaar te accepteren dat politiek Den Haag, grof gesteld, eerst nu nadenkt over het concept functioneel bestuur en de inkadering daarvan. Zo van: laat zo veel zelfstandige bestaansorganen maar spelen in het zand, tot dat ze er min of meer een modderboel van maken. Dat proeft als mosterd na de maaltijd. 


\section{Geraadpleegde literatuur}

Beers, A.L.L.

Gewijzigd voorstel nieuwe Wob aangenomen in de Tweede Kamer, in: NTB, nr.1. 1991, pp.1-9.

Belinfante, A.D. \& Reede, J.L. de

Beginselen van het Nederlands staatsrecht, twaalfde druk, Alphen aan den Rijn, 1994.

Berge, J.B.J.M. ten

Nationale ombudsman op bestelling, in: NTB, nr.2, 1994, pp.39-40.

Berge, J.B.J.M.ten \& Strounk, F.A.M.

Functionele decentralisatie ait de schaduw; Een globale verkenning van aard, omvang, verschijningsvormen en bestuurlijke aspecten van zelfstandige bestuursorganen en andere functionele organisatie-eenheden binnen het openbaar bestuur, "s-Gravenhage, juni 1988.

Borman, C.

Aanwijzingen voor de regelgeving en andere voor de regelgeving relevante aanwijzingen, $Z$ wolle, 1993.

Boxum, J.L., Ridder, J. de \& Scheltema, M.

Zelfstandige bestuursorganen in soorten; Verslag van een onderzoek naar de praktijk van zelfstandige bestuursorganen, i.o.v. ministerie van $B Z$, publikatie vakgroep bestuursrecht en -kunde Groningen, Deventer, 1989.

Burg, F.H. van der

Awb: mandaat en delegatie, in: NTB, nr.8, 1992, pp.268-275.

Burkens, M.C., Kummeling, H.R.B.M. \& Vermeulen, B.P.

Beginselen wan de democratische rechtsstaat; Inleiding tot de grondslagen van het Nederlands staats-en bestuursrecht, derde druk, Zwolle/Utrecht, 1994.

Buturen, P. van

Awb-notities (13); Delegatie en het legaliteitsbeginsel, in: NJB, nr.14, 7 april 1995, p.532.

Commissie-Duk (commissie inzake Algemene Bepalingen wan Administratief recht)

Rapport Abar, vijfde druk, Alphen aan den Rijn, 1984.

Commissie-Oele

Voortgangsrapportage over het project evaluatie zelfstandige bestursorganen, ministerie $\mathrm{BZ}$, 15 februari 1993.

Commissie-Scheltema (commissie wetgeving algemene regels van bestuursrecht)

Voorontwerp derde tranche van de Algemene wet bestuurstecht, aangeboden aan de ministers van justitie en binnenlandse zaken d.d. 5 december 1991 " "s-Gravenhage.

Daalder, E.J.

Klagen bij de Nationale ombudsman; Een (nog) onvoldoende door de advocatuur ontgonnen terrein, in: Advocatenblad, nr.7, 1 april 1994, pp.268-273.

Damen, L.J.A.

Ongeregeld en ondaorzichtig bestuu, dissertatie RUG, Deventer, 1987.

Donner, A.M.

Nederlands bestuursrecht; Algemeen deel, wijfde herziene druk, Alphen a/d Rijn, 1987.

Dijk, G.W. (red.)

Staatsalmanak woor het Koninkrijk der Nederlanden, ministerie van BZ, "s-Gravenhage, respectievelijk juni 1992 en juni 1993.

Eijlander, Ph. \& Voermans, W.

Nieuwe aanwijzingen voor de regelgeving, in: $\mathrm{NJB}_{\text {, }} \mathrm{nr} .5$, 4 februari 1993, pp.169-174.

Gerritzen-Rode, P.W.A. \& Vlies, I.C. van der

Beginselen van bestuursrecht, tweede druk, Alphen aan den Rijn, 1994.

Groot, G.R.J. de, Meulen, B.M.J. van der \& Rossum, A.A. van 
Subsidies, beleidsregels, bestuursarganen; Het wetsvoorstelderde tranche wan de Algemene wet bestuursrecht, in: NJB, nr.35, 7 oktober 1994, pp.1193-1200.

Goorden, C.P.J.

- Rechtsbevoegdheid in het bestuursrecht; Een rechtsvergelijkende studie naar het bevoegdhedenvraagstuk in het bestuarsrecht, dissertatie KUB, Zwolle, 1990;

- Kroniek bestuurlijke organisatie, in: NTB, nr.2, 1994, pp.40-51;

- Het aanwijzingsbesluit bestuursorganen Wab en Wno, in: NTB, nr.3, 1994, pp.61-67;

- Repliek op een reactie, in: NTB, nr. 5, 1994, pp.133-134;

- Kroniek bestuurlijke organisatie, in: NTB, nr.2, 1995, pp.39-47.

Haan, P. de

Het bestuussrecht en de scheiding tussen beleid en witvoering, in: Hoogenboom, T. \& Damen; L.J.A. (red.), In de sfeer van administratiefrecht; Opstellen aangeboden aan Willem Konijnenbelt, Utrecht, 1994, pp.121-150.

Haan, P. de, Drupsteen, Th.G. \& Fernhout, R.

Bestuursrecht in de sociale rechtsstaat: instrumenten waarborg; Deel 1, ontwikkeling, organisatie en instumentarium, derde herziene druk, Deventer, 1987.

Hennekens, H.Ph.J.A.M.

- Delegatie en mandaat in het licht van het voorontwerp voor de $A w b$, in: De Gemeentestem, respectievelijk nr.6955, 1992, pp.609-616 en nr.6956, 1992, pp.641-647;

- Mandaat en delegatie voor verbetering vatbaar, in: De Gemeentestem, nr.7011, 16 juni 1995. pp.321-326.

Hessel, B.

Nederlands-economisch publiekrecht; De bestuursrechtelijke aspecten, Zwolle, 1992.

Jong, J.P.

Aanwijzing van bestuursorganeno.g.v. de Wob en de Who, in: NTB, nr.10, 1993, pp.329-330.

Jurgens, E.C.M.

De mythe van Meerenberg; Over de betrekkelijke legitimatie die uitgaat van medewetgeving door de Staten-Generaal, in: NJB, nr.39, 4 november 1993, pp.1381-1386.

Kersten, G.M.

Oppassen met zelfstandige bestuursorganen, in: Overheidsmanagement, nr.7/8, 1994, p.194.

Koning, H.E.

Controleren is vooraitzien: De risico-analyses van de Algemene Rekenkamer, in: Overheidsmanagement, nr.5, 1994, pp.126-129.

Konijnenbelt, W. (red.)

De derde tranche; Commentaar op het voorontwerp voor de derde tranche van de Awb, vakgroep bestuursrecht UvA, Alphen a/d Rijn, 1992.

Koopmans, T'., m.m.v. Bellekom, Th.L., Heringa, A.W. \& Winter, R.E. de Compendium van het staatsrecht, zesde druk, 1992.

Kortmann, C.A.J.M.

- Constitutioneel recht, Deventer, 1990;

- Delegatie, beleidsregels en decentralisatie, in: De Gemeentestem, nr.7006, mei 1995, p.165.

Kuiper, G.M., Vliet, J.J. wan, Klijnstra, M., Boxum, J.L., Ridder, J. de \& Scheltema, M.

Functioneel bestuur getoetst, Groningen, 1991.

Leeuw, F.L. de

- Produktiviteit en effectiviteit van overheidsbeleid: institutionele analyse en effectmeting, oratie Utrecht, "s-Gravenhage, 16 oktober 1992;

- Mogelijkheden en beperkingen bij sturen-op-afstand, in: Groot, H. de \& Oosteren, C.G.M. van, De toekomst van de publieke sector ${ }_{n}$ bijdragen aan het jubileumsymposium van het IOO d.d. 17 maart 1994, 's-Gravenhage, 1994, pp.185-198. 
Lindner, Th.J.M.

Actuele wetgeving, in: NTB, respectievelijk nr.3, 1988, p.102, nr.4, 1989, p.132, en nr.1. 1992 , p. 31.

Lubberdink, H.G.

- Het begrip centrale overheid in wet-Arob in verband met de regeling facultatieve bezwaarschriftprocedure, in: TvO, nr.2, 1980, pp.33-37;

- De betekenis van de ministeriële verantwoordelijkheid voor het openbaar bestuur, dissertatie RUG, Deventer, 1982;

- Openbaarheid en zelfstandige bestuursorganen, in: Bestuur, nr.2, 1985, pp.26-27.

Lubbers, R.F.R.M.

Vaststelling van de Aanwijzingen voor de regelgeving, d.d. 18 november 1992, nr.92M008337, in: Staatscourant, 26 november 1992, nr.230, p.13.

Marle, C.H. van \& Smallenbroek, A.J.H.

Binnenlandsekroniek: Voorontwerpderde tranche Awb vergt nade re uitwerking, in: Bestuurswetenschappen nr.5, 1992, pp.461-462.

Meelus, T. $\mathbf{J}$.

Koning: priwatiseringen zijn warwinkel, tegen chaos aan, in: NRC, 30 maart 1995, p.21.

Munneke, H.F.

Aanwijzingen voor de rijksdienst met betrekking tot de instelling van zelfstandige bestuursorganen, in: NJB, nr.8, 22 februari 1986, pp.255-256.

Nicolaï, P., Olivier, B.K., Damen, L.J.A. \& Troostwiijk, H.

Bestuursrecht, derde herziene druk, Amsterdam, 1992.

Oudshoorn, J. C.

Delegatie en mandaat in de derde tranche in: Bestuurswetenschappen, nr .3, 1992, pp.271-275.

Polak, J.M.

- Opinie: een wettelijke basis voor zelfstandige bestuursorganen, in: NJB, $\mathrm{nr} .14,5$ april 1980 , p.298;

- Aanwijzingen voor de wetgeving inzake zelfstandige bestuursorganen, in: Bestuurswetenschappen, oktober 1989, pp.440-444;

- Opinie: toetsingspunten of aanwijzingen voor de instelling en invichting van organen van functioneel besturur?, in: NJB, nr.37, 25 oktober 1990, p.1453;

$\sim$ De Aanwijzingen woor de regelgeving, in: NJB, nr.39, 4 november 1993, pp.1396-1399;

$\sim$ De wergeving van het Departement van Justitie, in: NJB, nr.1, 6 januari 1995, pp.7-15;

- De Algemene wet bestuursrechten de Aanwijingen voor de regelgeving, monografieën Awb deel B-9, Deventer, 1995.

Polak, J.M., Heijningen, F.D. van, Wiebenga, J.G.C. \& Oosting, M.

Rondom de nationale ombudsman; Tien jaar ervaring met het instituut, uitgave professor $\mathrm{mr}$ B.M. Telderstichting, geschrift 78, 's-Gravenhage, 1993.

Pot, C.W. van der \& Donner, A.M. m.m.v. Prakke, L., Reede, J.L. de \& Wissen, G.J.M. van Handboek van het Nederlandse staatsrecht, twaalfde druk, Zwolle, 1989.

Raad voor het binnenlands bestuur - Advies over functionele decentralisatie, "s-Gravenhage, september 1988;

- Advies aan de ministers Hirsch Ballin en Dales over het voorontwerp van de derde tranche Awb, mei 1992, "s-Gravenhage.

Ridder, J. de \& Scheltema, M.

Verzelfstandiging vanuit bestuurlijk-juridisch gezichtspunt; Dejuridische dimensie van zelfstandige bestuursorganen, in: Kickert, W.J.M., Mol, N.P. \& Sorber, A., Verzelfstandiging van overheidsdiensten, congrespublikatie 1992, geschriften van de VvB, nr.16, "s-Gravenhage, 1993, pp.63-75. 
Schaap, L. \& Twist, M. van

Het kritisch geweten van de overheid jubileert; Tien jaar ombudsman, in: BBM, nr.1,21 februsri 1992 , pp. $45-47$.

Scheltema, M.

Zelfstandige bestuursorganen, oratie, Groningen, 21 mei 1974.

Schreuder, C.A.

Publiekrechtelijke taken, private rechtspersonen; Verzelfstandiging en privatisering in de worng van vernootschappen en stichtingen, dissertatie RUG, serie bestuursrecht theorie en prakijix nr.16, Deventer, 1994.

Schutte, G.J.

Kerndepartementen en ministeriële verantwoordelijkheid, in: Openbaar Bestuur, nr.4, 1994, pp.2-4.

Simon, H.J.

Publiekrecht of privaatrecht?, diss. UvA, Zwolle, 1993.

Sluijs, H. van der

Distributie van bestuursbevoegdheden; De rol van de wetgever bij het toedelen van bestuursbevoegdheden op het niveau van de centrale overheid, in: Bestuurswetenschappen, nr.5, 1988 , pp. 302-321.

Smallenbroek, A.J.H. \& Spit, T.J.M.

Binnenlandse kroniek, in: Bestuurswetenschappen, respectievelijk nr.5, 1992, p.463 e.v., nr.7, 1992, p.637 e.v. en nr.6, 1994, pp.509-512.

Staatsblad

Besluit wan 16 oktober 1993, houdende aanwijzing van bestuursorganen als bedoeld in de Wob en de Who, Stbl. 1993, 535, pp.1-15.

Stout, H.D.

De betekenis van de wet; Theoretische beschouwingen over het principe van wetmatigheid wan bestwur, serie rechtsstaat en sturing nr.21, Zwolle, 1994.

Stroink, F.A.M.

- Het leerstuk der deconcentratie, diss. RUU, 's-Gravenhage, 1978;

$\sim$ Beginsel van wetmatigheid van bestuur en het begrip uitvoering: ARRS contra HR? in: TwO, nr. 8, 21 aprill 1983, pp.204-206;

- Regeling in de derde tranche Awb ondoordacht, in: NJB, nr.15, 9 april 1992, pp.478-479:

$\sim$ Rechterlijke organisatie en rechtspraak in beweging, Zwolle, 1993, pp.29-35.

Stroink, F.A.M. en Steenbeek, J.G.

Inleiding in het staats - en bestuursrecht, vierde herziene druk, Alphen aan den Rijn, 1993.

Tweede Kamer

- Functioneel bestuur: waarom en hoe?, TK 1988-1989, 21042, nr.2, TK 1990-1991, 21042 , nrs.4-10, Functionele decentralisatie, TK 1991-1992/1993-1994/1994-1995, 21042, nrs.13/ $14 / 15$;

- Instellingswet Arbeidsvoorzieningsorganisatie, TK 1989-1990, 20569;

- Wet nationale ombudsman, TK 1988-1989, 19426, nr.17, en TK 1990-1991, 21800II, nr.11, gewijz. 4 juni 1992, Stbl. 1992,623;

- Wet openbaarheid van bestuur, Handelingen TK 1988-1989, p.50*5015, als mede TK 1989 1990, 19859, nr.20, en Handelingen EK 1990-1991, p.4*44, tevens EK 1990-1991, 19859 nrs.21A-21B, ook Stbl. 1991, nr.357;

- Memorie van toelichting woorontwerp derde tranche Awb. TK 1988-1989, 21.221, nr.3;

- Vaststelling van de begroting van de uitgaven en de ontvangsten van de Hoge colleges van Staat en het Kabinet der Koningin voor het jaar 1991, TK 1990-1991, 21800II, nr.11; 
- Noritie betreffende competentie-uitbreiding wan de Nationale ambudsman, TK 1991-1992. 22731, nrs.1-2, resp. TK 1992-1993, 22731, nr.3;

- Wetswoorstel tot aanvulling Awb (derde tranche Awb), TK 1993-1994, 23700, nrs.1-3;

- Verslag van de Algemene Rekenkamer over 1994, deel 3; Zelfstandige bestuursorganen en ministeriële verantwoordeijikheid, TK 1994-1995, 24130, nr.3.

Ven, A.T.L.M. van de

Privatisering en functionele decentralisatie, in: Overheidsmanagement., nr. 3, 1993, pp.56-61.

Verheij, $N$.

- De lijn: alleen de wet heerschtover ons; Over wetmatigheid van bestuur I, in: PD, nr.5, 1989, pp.188-197;

- De lijn. deuken in het ideaal; Over wetmatigheid van bestuur II, in: PD, nr.6/7, 1989, pp. $237-242$.

Versteden, C.J.N.

Inleiding algemeen bestuursrecht, vierde ingrijpend herziene druk, 1993, Alphen aan den Rijn/"s-Gravenhage, pp.28-37.

Vhies, I.C. wan der

— Het wetsbegrip en beginselen van behoorlijke regelgeving, diss. UvA, "s-Grav., 1984;

- Handboek wetgeving, tweede herziene druk, Zwolle, 1991 :

$\sim$ De lagere overheid aangewezen, in: RM, nr.1, 1993, pp.8-9;

- Delegatie, mandaat en de rechtsstaat, in: Hoogenboom, T. \& Damen, L.J.A. (red.), In de sfeer van administratief recht; Opstellen aangeboden aan Willem Konijnenbelt, Utrecht, 1994 , pp. 410-427.

Vuçsä̀n, R.L.

Katern bestuursrecht, in: AA, nr.44, pp.2035-2039.

Waaldijk, C.

Motiveringsplichten wan de wetgever, dissertatie RL, Lelystad, 1994.

Wijk, H.D. van, bewerkt door Konijnenbelt, W. \& Male, R.M. van

Hoofdstukken van administratief recht, negende druk, Utrecht, 1994.

Zijlstra, S.E.

Het Aanwijzingsbesluit bestuursorgaan Wob en Who, in: NTB, nr.5, 1994, pp.132-133. 
Hoofdstuk 5

\section{Decentralisatie}

\section{$\$ 5.0$ Plaatsbepaling van functioneel bestuur binnen het algemeen bestuur als toetssteen}

Bij het instellen van een zelfstandig bestuursorgaan mag een belangrijke beslissingsfactor niet worden onderschat. Dit blijkt al uit voornoemd toetsingskader. Namelijk, inpassing van functioneel bestuur in het algemeen bestuur verdient uitdrukkelijk overweging al vorens bewerkstelliging van een zelfstandig bestuursorgaan feit is. Anders geformuleerd, functionele decentralisatie is prima, mits zij op haar plaats is binnen het reguliere openbaar bestuur.

Bij de politieke keuze om te decentraliseren spelen vier vragen. ' $T$ Ten eerste: is de betrokken taak een overheidstaak? Bij bevestiging hiervan is de tweede vraag, of de taak in wisselwerking met de samenleving uitvoering moet krijgen. In bepaalde gevallen blijkt dan toch onverdeeld de mening, dat de betreffende taak in eigen beheer vervuld moet worden. Derde punt van overweging is zo doende, of de minister zelf de taak aan zich trekt. Concluderen de politici, dat de taak in kwestie niet langer onder de (volledige) verantwoordelijkheid van een bepaalde bewindspersoon valt. Dan rest de slotvraag aangaande decentralisatie. Geschiedt zij territoriaal of functioneel?

De laatste, vierde keuze is in feite geen keuze. Immers, in eerste instantie is algemeen bestuur aangewezen. Slechts als aard van de betrokken taakbehartiging of reikwijdte van taakuitvoering daartoe aanleiding geven, is territoriale decentralisatie onwenselijk. Ergo, uitgangspunt is als volgt. Bestaat de noodzaak tot decentralisatie, dan geldt: territoriale decentralisatie, tenzij...

1. Funcrioneel bestuur, warom en hoe? "TK 1990-1991, 21042, nr.4, p.14. 
Het zo genaamd primaat van de grondwettelijke hoofdstructuur in organen van algemeen bestuur, is kennelijk onomstotelijk. ${ }^{2}$ Dit betekent, dat functionele decentralisatie "niet meer dan een - adequate - aanvulling kan zijn op de in de Grondwet neergelegde hoofistructuur". ${ }^{3}$ Functionele decentralisatie mag "niet leiden tot niet te woorkomen belemmeringen van organen van algemeen bestuur". "Kortom, functionele decentralisatie is slechts een "next-best oplossing"'. ${ }^{5}$ Op dit dogma is tweeërlei kritiek mogelijk.

Voorstanders van territoriale decentralisatie vinden de leer te ver gaan. In de mogelijkheid van aanvullende functionele decentralisatie schuilt het gevaar van een sluipende, ongewenste opmars van organen van functioneel bestuur. Bedoeld uitgangspunt zou "slechts een beschrijving en een waardering van de bestaande situatie zijn. Daarmee is niet gezegd, dat de hoofdstructuur verder moet worden aangevuld met functioneel bestuur". 6

Voorstanders van functionele decentralisatie vinden de leer juist niet ver genoeg gaan. De praktijk licht dan ook schromelijk de hand met het kabinetsstandpunt. "Verscheidene ministeries blijken in de Decentralisatie Impuls en in de Grote Efficiency Operatie toch een voorkeur te hebben voor functionele decentralisatie boven territoriale decentralisatie." "Bewindspersonen houden taken, qua beheer, budget en sturing op hoofdlijnen, kennelijk toch graag in eigen hand.

Ten gunste van functionele decentralisatie speelt mogelijk de relativiteit van de "constitutionele superioriteit" van territoriale decentralisatie een rol. Eerste reële kanttekening is, dat er "wellicht andere, en betere afstemmingsmechanismen, in plaats van slechts de publiekrechtelijke afstemmingsmechanismen tussen functioneel en algemeen bestuur denkbaar zijn". Ten tweede luidt terecht de vraag of bij algemeen bestuur inderdaad "sprake is van een integrale belangenafweging en effectieve democratische controle". Hier spreken het wanbeleid en de corruptie van het Maastrichtse gemeentebestuur anno 1993 boekdelen.

Voor een goed inzicht in een en ander is het, ten eerste, essentieel te weten wanneer sprake is van decentralisatie. En, ten tweede, in welke gedaanten doet zij zich voor?

2. Tot uitdrukking gebracht, met instemming van in elk geval de grote politieke partijen PvdA, CDA, VVD en D'66, tijdens parlementaire behandeling ter zake. Zie overzichtelijk O.E.J. Webster, Funcriosteel bestuur: waarom en hoe?, in: WB, nr.19, 1991, pp.710-712; Ook commissie-Deetman, a.w., p.8.

3. Functioneel bestuur; waarom en hoe?, TK 1990-1991, 21042, nr.4, p.16; Rbb (1988), a.w., p. 3; gebaseerd op J.B.J.M. ten Berge en F.A.M. Stroink, a.w.; Motie-De Cloe, TK 1990-1991, 21012, nr. 10.

4. Functioneel bestuur; waaram en hae?. TK 1990-1991, 21042, nr.4, p.17.

5. Commissie-Franssen, Over decentralisatie is nog nooit een vers geschreven. TK 1992-1993, 21427, nrs. $42-43$, p. 53 .

6. W. Derksen, De noodzaak wan een functionele benadering van territoriale decentralisatie, in: BWn, nr.6, 1989 , pp.347-358, i.h.b. p. 354.

7. Commissie-Franssen, Over decentralisatie is nog nooit een vers geschreven, TK 1992-1993, 21427, nrs. $42-43$, p. 28 .

8. G.H. Hagelstein, De verhouding tussen algemeen en functioneel bestuur: naar bestuur op maat, in: Funcrioneel bestuur, publikatie van de staatsrechtkring, nr.4, Zwolle, 1993 , pp.1-35, i.h.b p.15. 
Recentelijk is, in het kader van de onwenselijke paradox van de verkokering ${ }^{9}$ van het Nederlands bestuur, uitdrukkelijk aandacht gevraagd voor de noodzaak van een 'overallvisie’ inzake decentralisatiebeleid. ${ }^{10}$ Ter begripsbepaling het volgende.

\section{$\$ 5.1$ Decentralisatie}

Aan decentralisatie, onverschillig of deze territoriale, functionele, maatschappelijke, financiële " ${ }^{1}$ gecombineerde decentralisatie betreft, ligt een fraaie filosofie ten grondslag. Entiteit $X$ geeft, iets uit handen, aan entiteit $Y$. Bij voorbeeld omdat entiteit $X$ al te veel hooi op de vork heeft. Of, simpel weg, entiteit $Y$ sneller, deskundiger en efficienter met het overdraagbare object kan omspringen. In vertrouwen dat entiteit $\mathrm{Y}$ ze iets beter hanteert dan entiteit X zelf, schenkt entiteit X (aan) entiteit $Y$ bevoegdheden van bestuur, beheer en/of beleid. Daarmee raakt entiteit $X$ een stukje autonomie kwijt ten gunste van entiteit $Y$. De decentrallisatie is geslaagd, als optimalisatie plaatsvindt van democratie, competentie, effectiviteit en kostenbesparing. ${ }^{12}$

Bedoelde beteugeling van centrisme van overheidsmacht is moeilijk te beschrijven. Het in woorden vatten van decentralisatie blijkt, voor velen, een lastige opgave. ${ }^{13}$

Decentralisatie is een algemeen aanvaard, leidend ${ }^{14}$ beginsel voor de organisatie voor openbaar bestuur. Hiermee gaat decentrallisatie, feitelijk gezien, sterk in de richting van een zelfstandig beginsel. Dat wil zeggen een autonoom principe voor staatsinrichting naast beide beginselen van rechtsstatelijkheid en democratie. ${ }^{15}$ Erkenning als zelfstandig staatsrechtelijk beginsel betekent, dat decentralisatie niet enkel uit doelmatigheidsoverweging plaats vindt. Bij toepassing van het decentralisatieprincipe moet met verschillende argumenten rekening worden gehouden. Hierbij komt vooral het rechtsbeschermingsaspect om de hoek kijken. Deze invalshoek wijkt af van het traditionele gedachtenpatroon. Van oudsher wordt decentralisatie belicht van uit de institutionele rechtsstatelijke eis spreiding van macht/gezag.

9. D.J. Elzinga en G. H. Hageistein, Een parlenentaire impuls woor het decentralisatiebeleid; Een onderzoek

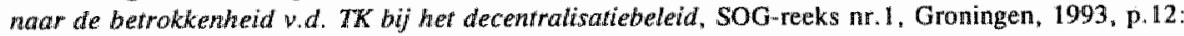
wan regering en parlement wordt eigenljk gevraagd zich als een soort baron von Munchhausen aan do eigen haren uit het moeras te trekken"

10. D.J. Elzinga en G.H. Hagelstein, a.w., pp.12-13.

11. Commissie-Firanssen, Over decentralisatie is nog nooit een vers geschreven. Tk 1992-1993, 21427, nrs $42-43, p .9$.

12. Dit zijn maatstaven voor de keuze woor een van, en tevens tussen, de decentralisatiewarianten. Aldus. I.Th.J. van den Berg, "Old stares never dhe, they just fade away" in: BWn, nir.6, 1989, pp.368-369.

13. Zie uitw oerig over het decentralisatiebegrip P.M. Langbroek, a.w., pp. 143\%170. Anteur erkent de moellijkheidsgraad van definitiebepaling ter zake. In dit opzicht wit hij een verwijt aan het adres van andere schrijvers. Op p. 145 stelt hij: "Ook in de Nederlandse literatuur worden de begrippen centralisatie en decentralisatie natwelijks geproblematiseerd."

114. $13 W$, Rapport onderzoek naar de bestuurlike organisatie, deel 1, Rijswijk, 1972, p.65; CommissieFranssen, t.a.p., p. 38 .

15. J.T. van den Berg. Waterschap en functionele decentralisatie, serie hand-en leerboeken der bestuurswetenschappen, nr.27, dissertatie Rijkstuniversiteit Utrecht, Alphen aan den Rijn, 1982, p.24. 
De gedecentralliseerde eenheidsstaat, als Nederlands staatsbestel, vindt haar oorsprong eigenlijk in de verschillende maatschappelijke en levensbeschouwelijke opvattingen hier te lande. Door de historie heen is dus de situatie ontstaan, dat verschillende entiteiten binnen een organisatie openbaar gezag uitoefenen. Voor menigeen is de waarde van het verdelen van macht, dat wil zeggen taken, bevoegdheden en verantwoordelijkheden, zeer groot. Soms is zelfs "het recht op decentralisatie" geclaimd. ${ }^{16}$

De decentralisatiedoctrine is, op grond van de Franse administratiefrechtelijke literatuur, tot op zekere hoogte ontwikkeld. Bekend is de creatie van het onderscheid tussen decen tralisatie in ruime zin en decentralisatie in enge zin. Decentralisatie, ruim opgevat, omvat dan decentralisatie in enge zin en deconcentratie.

Decentralisatie in enge zin wordt aangemerkt als "bevoegdheidsoverdracht aan onafhankelijke personen". " 77 Daaraan worden dan de volgende kenmerken verbonden. ${ }^{18}$ Ten. eerste is sprake van overdracht van beslissingsbevoegdheid. Ten tweede heeft degene aan wie is overgedragen een beperktere taak-en werkomvang dan de ander. Ten derde bestaat voor degene die overdraagt, na overdracht, geen mogelijkheid tot het geven van (concrete) aanwijzingen. Ten vierde kan hij evenmin zijn beslissing, voor die van de ander, in de plaats stellen. Ten vijfde mag hij, volgens eigen voorstel, niet degene vervangen aan wie overdracht heeft plaats gevonden. En inherent daaraan kan laatst genoemde niet, door degene die de bevoegdheid heeft overgedragen, van de troon worden verstoten. Althans niet zonder reden. Denkbaar is namelijk wel intrekking van delegatie of attributie (dan wel wijziging van voorwaarden daarvan) indien blijkt van verwaarlozing van gedecentraliseerdle taakuitvoering.

Om enige invulling te geven aan het enge begrip decentralisatie, is afbakening met deconcentratie elementair. Stelligheid spreekt uit de volgende opvatting: "Het onderscheidende kenmerk lijkt mij te zijn, of de bevoegdheid wordt uitgeoefend door de formele wetgever, de Kroon, minister of ambten die in een hiërarchische relatie staan tot de Kroon of minister. In deze gevallen is er sprake van bevoegdheidsuitoefening door de centrale overheid. Alle overige bevoegdheidsuitoefening is derhalve gedecentraliseerde bevoegdheidsuitoefening." 19 De term hiërarchisch duidt, in dit verband, slechts op ondergeschiktheidswerhoudingen van departementsambtenaar tot minister. Daarmee is tegelijkertijd de beperking van deze optie evident. Deconcentratie leent zich niet voor uitoefening op provinciaal of gemeentelijk niveau. ${ }^{20}$ Dit vloeit voort uit de aard van de bevoegdheden. ${ }^{21}$ Ten eerste zijn het min of meer gebonden witvoeringsbevoegdheden.

16. J.T. van den Berg, a.w., p.28. Overigems beveelt auteur hierwoor een "algemene beginselbepaling ün de Grondwet" niet aan (p.27). De Grondwet moet slechts de contouren wan een gedecentraliseerd stelsell aangeven.

17. J. Bulthuis, Samenwerking van gemeenten, Utrecht, 1957, p.9.

18. J. Bulthuis, a.w., pp.13-14.

19. F.A.M. Stroink (1978), A.W., p.21.

20. Anders J.T. van den Berg, a.w., p.33.

21. F.A.M. Stroink (1978), a.w., pp.184-185. 
Ten tweede staat gelijkheid in uitvoering voorop. Aldus opgevat heeft deconcentratie een beperkt karakter. ${ }^{22}$

Ten gevolge hiervan is de reikwijdte van het decentralisatiebegrip groot. "Reeds het doorsnijden van de hiërarchische verhouding tussen minister en betrokken orgaan is voldoende om van decentralisatie te spreken." ${ }^{23}$ Het moeras is bijna helemaal ondoorwaadlbaar als voor de vraag, of sprake is van decentralisatie, "niet beslissend is het aanwezig zijn van vertegenwoordigende ambten (gemeenteraad of provinciale staten) of civiellrechtelijke rechtspersoonlijkheid" ${ }^{24}$

Dit laatste aspect heeft in diverse definitiebepalingen van decentralisatie een prominente plaats. Juist het privaatrechtelijk of publiekrechtelijk zelfstandig karakter van een rechtsentiteit is mogelijk een wezenlijk onderscheidend criterium in de theorievorming rond decentralisatie en deconcentratie.

Dat wordt duidelijk aan de hand van ongeveer gelijk onderscheid als voornoemd. Opnieuw is de tweedeling decentralisatie in ruime zin en decentralisatie in enge zin aan de orde. Daaraan is alleen anders invulling gegeven. Decentralisatie in ruime zin doelt hier op de geledingswijze van een overheidsorganisatie. ${ }^{25}$ Zo zijn alternatieven: unitarisme en federalisme, concentratie en deconcentratie, als ook centralisatie en decentralisatie in enge zin.

Deconcentratie beoogt administratieve functies te laten vervullen door a. op een niveau ruimtelijk verspreide relatief zelfstandige eenheden of $b$. een ambtelijke organisatie met een zekere zelfstandigheid ten opzichte van de politieke leiding op dat niveau. ${ }^{26}$

Decentralisatie in enge betekenis betreft de relatie tussen hogere en lagere bestuurslagen. Haar definitie luidt: "Het erkennen of toekennen door hoger gerangschikte openbare lichamen aan lager gerangschikte openbare lichamen van bevoegdheden om in een zekere onafhankelijkkeid en op grond van een eigen belangenafweging besluiten van regeling en bestuur te nemen, als mede de daaruit voort vloeiende bevoegdhedenstructuur. " 27 In

22. Deze vernawwing acht miet iedereen anwezig. P.M. Langbroek, a.w. p. 148, windt de opinie van Stroink zelfs "ruimer dan de meestal woor deconcentratie kenmerkend geachte bevelsbevoegdheid in de relatie. tussen een hoger en een lager bestútirsorgaan, ongeacht of het lagere bestuursorgaan door de wetgever of door het bestuur in het leven is geroepen". Zijns insziens leidt de mening wan Stroink tot de "merkwaardige consequentie dat delegatie van wetgevingsbevoegdheid of van bestuursbevoegdheid aan lagere openbare lichamen tevens gezien worden als een vorm wam deconcentratie".

23. J.T. wan den Berg, De henwardering van de functionele decentralisatie; Een omstreden fenomeen in de schijmwerper, in: Bestuur, nr.3, 1989, p.88. In zijn kritiek op $\mathrm{B} /$ /Str., t.a.p., verwijt Van den Berg auteurs bun, z.i., formeel-organusatierechtelijke benadering (i.p. . een staatsrechtelijke beschowwing) wan het decentrallisatiebegrip. Die benadering betekent geenzins dat de afstand tussen bestuur en bestuurden vermindert. Terwijl dat toch de centrale notie van thet decentralisatiebegrip is.

24. F.A.M. Stroink (1978), a.w., p.22.

25. D.W.P. Ruiter, Centralisatic en decentralisatie, in: A. Hoogerwerf (red.), Overheidsbeleid, dende druk. Alphen a/d Rijn, 1985, p.404.

26. D.W.P. Ruiter, t.a.p., p.407.

27 . D.W.P. Ruiter, t.a.p., p.405. 
een hierop gebaseerde omschrijwing van decentralisatie ontbreekt het laatste zinsdeel: "Het overlaten of toekennen wan publiekrechtelijke bevoegdheden door hoger gerangschikte openbare lichamen aan lager gerangschikte lichamen." 28 Voor de lacune bestaath een goede reden. Decentralisatie is geen statisch gegeven. Zij kenmerkt zich juist door dynamiek. Decentralisatie is namelijk meer een proces/activiteit dan een toestand/situatie. ${ }^{29}$ Als proces (het veranderen in de verdeling van taken) wordt zij via decentralisatiebeleid nagestreefd. ${ }^{30}$

Beide beschrijvingen hebben een belangrijke bodem. Alles wat openbaar lichaam heet, valt onder het dak van decentralisatie. ${ }^{3 \|}$ Hier voelen zelfstandige bestuursorganen dus geen vaste grond onder de voeten. Hun positie, als gedecentraliseerde organen, lijkt wankel. Wellicht is het beter zelfstandige bestuursorganen in te delen onder de noemer deconcentratie? ${ }^{32}$ Een aardige optie. Maar zij is moeilijk aanvaardbaar. Ten eerste blijft, in elk geval, het ontbreken van een hiërarchische band tussen minister en zelfstandig bestuursorgatan toch een duidelijk signaal om niet te spreken wan deconcentratie. Ten tweede zaait de, niet trouwe, terminologie van openbaar lichaam twijfel.

\subsubsection{OPENBAAR LICHAAM}

Art. 134 Grondwet luidt: 1 . Bij of krachtens de wet kunnen openbare lichamen voor beroep en bedrijf en andere openbare lichamen worden ingesteld en opgeheven; 2 . De wet regelt de taken en inrichting van deze openbare lichamen, de samenstelling en bevoegdheid van hun besturen, als mede de openbaarheid van hun vergaderingen. $B \mathrm{j} j$ of krachtens de wet kan aan hun besturen verordenende bevoegdheid worden veleend; 3. De wet regelt het toezicht op deze besturen. Vernietiging van besluiten van deze besturen kan alleen geschieden wegens strijd met het recht of het allgemeen belang. Dit artikel ligt ten. grondslag aan bij voorbeeld produkt- en (hoofd)bedrijfsschappen als ook de openbare lichamen voor het beroepsleven. Op deze organisatievormen drukt duidelijk het stempel functionele decentralisatie. Wel te verstaan grondwettelijke functionele decentralisatie.: Maar hoe zit het nu met de, buiten de grondwet om, ingestelde zelfstandige bestuursorganen?

28. J.T. van den Berg, Waterschap en functionele decentralisatie, t.a.p., p.38; Vgl. A. Mulder en G. Craenen, a.w., pp.55-56.

29. B. de Goede, Waterschap als functioneel bestuur, in: De Gemeentestem, 1981, p.373.

30. Commissie-Franssen, a.w., p.9/39.

31. Uitgezonderd binnenprovinciale of -gemeentelijke decentralisatie. Zie J.T. van den Berg, a.w., p.39.

32. Dat prefereert J.T. van den Berg, a.w., p.39. Zijn andere argument is, dat zbo's "uitvoerende organen van het rijk zijn, die dan ook tot de centrale overheid dienen te worden gerekend, al kunnen zij dan met een meerdere of mindere mate van zelfstandigheid bekleed zijn" (p.34). Ergo: wat betreft zbo's acht Van den Berg het, z.i., wezenskenmerk van decentralisatie, t.w. verkleining afstand bestuur-bestuurden, niet aanwezig (p.39); Vgl. B. de Goede, bewerk. H. van den Brink, Beeld van het Nederlands bestuursrecht, "s-Gravenhage, vijfde druk, 1986, p.41, die - naar een z.i. moodzakelijk negatieve omschrijving - zbo"s, die weliswar worden gekenmerkt door zelfstand igheid, toe voegt aan de "incoherente stoet" gedeconcentreerde organen. 
Het is reeds verduidelijkt, niet iedereen acht zelfstandige bestuursorganen het predikaat van organen van functioneel bestuur waardig. Functionele decentralisatie zou slechts openbare lichamen van functioneel bestuur betreffen. Of deze opvatting, dat wil zeggen de visie van decentralisatie gekoppeld aan een verbands- of gemeenschapsgedachte, nog. opgeld doet, is belangrijk te weten. Daartoe is inhoudsanalyse van het begrip openbaar lichaam onvermijdelijk.

De grondwet zelf is debet aan de onduidelijkheid die met betrekking tot de term openbaar lichaam heerst. Geen afdoende begripsverklaring is voorhanden. Ten eerste is het, door sommigen aangenomen ${ }^{33}$, bezit van een regelgevende bevoegdheid niet doorslaggevend voor de status van openbaar lichaam. ${ }^{34}$ Deze bevoegdheid, ex art. 134, tweede lid, Grondwet, is slechts facultatief. Ten tweede is de aanwezigheid van ingezetenen, te weten burgers, ingelanden of bedrijfsgenoten, geen adequaat criterium. Van overheidswege is wat betreft art. 134 Grondwet het volgende uitgemakkt. "Dit artikel houdt niet in dat 'andere openbare lichamen' als daar bedoeld 'ingezetenen' hebben. De Arbeidsvoorzieningsorganisatie is een (zelfstandig) openbaar lichaam (ex art. 2, eerste lid, Arbeidsvoorzieningswet - JGLvN) dat geen 'ingezetenen" heeft." 35

Ten derde is indirecte interpretatie van het begrip openbaar lichaam misschien wel te verkrijgen door de plaats welke voomoemd artikel in de geschreven Grondwet inneemt. De artt. 134-136 Grondwet, handelend over openbare lichamen, vallen onder het zevende hoofidstuk van de Grondwet. Dit hoofdstuk betreft "provincies, gemeenten, waterschappen en andere openbare lichamen". Eerste gedachte die opkomt, is dus de gemeenschapsgedachte. In tweede instantie vat dan wel direct de vraag vlam, waarom art. 134 Grondwet dan als, waarschijnlijk ruim bedoelde, réstbepaling is gedefinieerd. Is hier juist niet sprake van een uitzonderingscategorie? Bedoeld voor een verzameling organisatievormen, die maar moeilijk bij de horens is te vatten? Inderdaad lijkt de term van openbaar lichaan niet anders te zijn dan een "containerbegrip met daarin al die organisatievormen die zijn ingesteld en ingericht op grond wan het publiekrecht en die beschikken over privaatrechtelijke rechtspersoonlijkheid" ex art. 1, eerste lid tot en met derde lid, juncto art. 4, boek 2 BW. ${ }^{36}$

Toch vinden sommigen zelfstandige bestuursorganen geen (organen van) openbare lichamen. ${ }^{37}$ Standvastig houden $z i j$, in de discussie decentralisatie/deconcentratie, vast aan het in hun optie doorslaggevende kenmerk van openbare lichamen, te weten de gemeenschapsgedachte. ${ }^{38}$ In deze opinie verschillen zelfstandige bestuursorganen van openbare

33. P. de Haan. Th. G. Drupsteen en R. Fernhout, a.w. (dl. 1), p.117.

34. H.D. van Wijk, bewerkt door W. Konijnenbelt en R.M. wan Male, a.w., pp.97-98; C.P.J. Goorden, a.w., p. 27.

35. Nader rapport van het, op 27 mei 1988 ingediende, voorstel van de Wet houdende de instelling wan de Arbeidswoorzieningsorganisatie ren regelen op het gebied van de arbeidswoorziening of Arbeidsvoorzieningswet, TK $1987-1988,20569$.

36. J.B. J.M. ten Berge en F.A.M. Stroink, a., w., p. 23.

37. G.A.C.M. Ballegooij e.a., Rechtsbescherming in het Amb-tijdperk, Deventer, 1992, p.17.

38. Bij woorbeeld J.M. de Meij, Inleiding to het staatsrecht en het bestuursirech, derde druk, Groningen, 1990, p. 194. 
lichamen "doordat zij weliswaar een zekere publiekrechtelijke en soms ook privaatrechtelijke zelfstandigheid bezitten, maar niet zijn een territoriale of functionele gemeenschap van personen vatbaar voor democratisering". ${ }^{39}$ Met andere woorden, openbare lichamen zijn "eenheden met eigen bevolking en (mede) aan die bevolking ontleend gezag". ${ }^{40}$ De gemeenschapseis stelt dus de voorwaarde van een zeker verband. In het belang van die achterban, dat wil zeggen "een vaste, territoriaal, functioneel of krachtens andere gegevens bepaalde groep", is het openbaar lichaam (mede) werkzaam. ${ }^{4 \mathrm{l}}$

Maar dit criterium heldert niet echt de vaagheid van de terminologie openbaar lichaam op. Het zo genaamde kernelement gemeenschap is namelijk zelf ook niet zuiver glashelder. Bij decentralisatie zal het "altijd gaan om een mate van autonomie en het in grotere of kleinere mate aanwezig zijn van een "verband" ". ${ }^{42}$

Theoretisch gaat dit kenmerk van openbaar lichaam dus ook voor sommige zelfstandige bestuursorganen op. Immers, "een orgaan dat een publieke taakomschrijving met zich draagt, veronderstelt een groep van personen met bepaalde rechten en plichten die op een of andere wijze met dit orgaan is verbonden". " Daarmee wordt het onderscheidende karakter van het element gemeenschap van tafel geveegd.

Ook in praktisch opzicht boet de voorwaarde van een of ander verband aan waarde in. Namelijk, in praktijk is het aanmerken als gemeenschap vaak gekunsteld. De gemeenschap van gedecentraliseerde organen is meestal een 'gemeenschapsfictie'. Dit houdt het volgende in. Het overgrote deel van functionele decentralisatie geschiedt niet van onderop, maar juist van bovenaf. ${ }^{44}$ De totaliteit van bestuurseenheden en overheidsorganen die écht door de gemeenschap wordt bestuurd, dat wil zeggen via verkiezingen of benoeming van representatieve organisaties wordt samengesteld volgens de gemeenschapszin, is niet groot.

Kortom, het weinig scherpe criterium van de gemeenschapsgedachte als mede de beperkte feitelijke toepassing er van maken dat (functionele) decentralisatie niet alleen gereserveerd mag blijven voor openbare lichamen.

39. P. de Haan, Th.G. Drupsteen en R. Fernhout, Bestuursrecht in de sociale rechrsstaat, a.w. (dil.1), pp.134-135; Deze zienswijze is helaas overgenomen bij behandeling van de Mediawet. Het CvdM wordi namelijk wel beschouwd als zelfstandig bestuursorgaan, maar niet als vorm van functionele decentralisatie. Zie TK 19136, Mva I, p.19. Het CvdM is openbaar lichaan ex art. 134 Gw confonm Voarlopig. verslag, TK 19136, nr. 7,20 nov. 1985, p.47.

40. A.M. Donner, Nederlands bestuursrecht, algemeen deel, vijfde herziene druk, Alphen aan den Rijn. 1987 , p. 165 .

41. J.T. van den Berg, a.w., P.35; J.T, van den Berg (1989), t.a.p., p.88; A.R. Edwards (1982), a.w., p.11.

42. P.J. Langenberg (1985), t.a.p., p.152; J.B.J.M. ten Berge en F.A.M. Stroink, a.w., p.22, spreken wan een "glijidende schaal".

43. P.J. Langenberg (1985), t.a.p., p. 152.

44. J.B.J.M. then Berge en F.A.M. Stroink, a w., pp.10/22. 
Aldus is functionele decentralisatie tweeëriei. ${ }^{45}$ Ten eerste statat zij voor grondwettelijke functionele decentralisatie naar waterschappen en openbare lichamen. Openbare lichamen betreffen dan "publiekrechtelijke organisatievormen, waarbij sprake is van rechtspersoonlijkheid en voor leden van de gemeenschap (belanghebbenden) de mogelijkheid bestaat invloed uit te oefenen op de samenstelling van het bestuur van het lichaam en waarbij ten slotte de wetgever bij de instelling nadrukkelijk uitvoering aan art. 134 van de Grondwet heeft willen geven". ${ }^{46}$ Ten tweede omvat zij buitengrondwettelijke functionele decentralisatie in de vorm van zelfstandige bestuursorganen.

Een en ander is ook anders geformuleerd als functionele decentralisatie in enge en in ruime zin. In beperkte betekenis is sprake van decentralisatie, van bevoegdheden inclusief regelende bevoegdheden, naar openbare lichamen met volledige verantwoordelijkheid voor taakuitoefening. In brede opvatting vindt decentralisatie plaats van uitvoeringsbevoegdheden, betreffende meestall een enkele regeling, aan zelfstandige bestuursorganen met afgeleide verantwoordelijkheid. ${ }^{47}$

Ten slotte, belangrijkste basis voor de betekenisomschrijving van decentralisatie moet de verkregen zelfstandigheid zijn. Zo omvat decentralisatie, in het algemeen, het overdragen of toekennen van publiekrechtelijke bevoegdheden door hoger gerangschikte organen aan lager gerangschikte organen.

\section{$\$ 5.2$ Territoriale decentralisatie}

Het begrip territoriale decentralisatie is hier slechts relevant ter afbakening van de term functionelle decentralisatie. Van oudsher heeft territoriale decentralisatie alies te maken met toekenning en overdracht van publiekrechtelijke bevoegdheden aan en naar provincies, gemeenten en ten dele waterschappen.

Inmiddels is de wens bekend om, in plaats van de vertrouwde provinciale organen van algemeen bestuur, circa 25 gewesten of regio's in het leven te roepen. ${ }^{48}$ De regio's mogen de grondwettelijke plaats van de provincies niet innemen. ${ }^{49}$ Dat deze optie wei-

45. Onder anderen J.B. I.M. ten Berge en F.A.M. Stroink, a.w., p.21; J.L. Boxum, J. de Ridder en M. Scheltema, a.w., p. I5; M.C. Burkens, H.R.B.M. Kummeling en B.P. Vermeulen, a.w., pp.208-210/223; Vergelijk onderscheid zbo's-functionele openbare lichamen bij P. de Haan, Het bestursrecht en de scheiding tussen beleid en uirwoering, in: T. Hoogenboom en L.J.A. Damen (red.), In de sfeer van administratief recht, Utrecht, 1994, pp.122-150.

46. Functioneel bestuur; waarom en hoe? "TK 1990-1991, 21042, nr.4, p. 8; Overigens merken J. L. Boxum, J. de Ridder en M. Scheltema, a.w., p. 16, terecht op dat deze kenmerken van openbare lichamen "geen juridische criteria opleveren om openbare lichamen te onderscheiden van zelfstandige bestuursorganen". Ook $z b 0^{\circ}$ s kumnen verordenend optreden, rechtspersoonlijkheid bezitten en invloed ondergaan van representatieve belangenorganisaties.

47. A.R. Edwards, a.w. p.14.

48. Bij woorbeeld Dales als Thorbecke, in: NRC. 26 jan. 1993, p.9.

49. Aldus, in senaat aangenomen, motie. Kaderwet mag positie prowincie niet aantasten, in: $\mathrm{BB}, 22$ april 1994, p.3. 
nig kans van slagen heeft, volgt uit het standpunt van het kabinet. Het kabinet ziet een ander alternatief voor de toekomstige structuur van het Nederlandse staatsbestel. Voorlopig luidt de wens regioworming te beperken rondom de zeven grootstedelijke gebieden. ${ }^{50}$ Instelling hiervan is alles behalve budgettair-neutraal. Meerkosten voor elk van de zeven regio's bedragen minimaal 25 miljoen gulden, afgezien van de incidentele invoeringskosten. ${ }^{51}$ Hoe het plaatje er exact uit gaat zien, blijft een zaak van de politiek. De algemene richtlijnen voor de parlementaire discussie worden al wel gegeven. ${ }^{92}$ Daarin blijft een sterk regionaal bestuur het uitgangspunt. De groei naar regio's gaat gefaseerd. In eerste instantie moeten gemeenten intensiever gaan samenwerken. De regio in spe is in dat stadium in feite versterkt verlengd lokaal bestuur (regionaal openbaar lichaam). De problematische afbakening tussen huishouding van dit regionaal openbaar lichaam en gemeentebesturen wordt onderkend. ${ }^{53}$ Anders dan de aanvankelijk voorziene kroonbenoeming van de voorzitter daarvan, prefereert een ruime meerderheid van de Tweede Kamer deze aanwijzingsbevoegdheid in handen te leggen van het algemeen bestuur van het regionaal openbaar lichaam. ${ }^{{ }^{4}}$ De oorspronkelijke gedachte om dit regionaal bestuur ${ }^{55}$, in de eindfase, te verzelfstandigen in een regionale gebiedsautoriteit wordt bij amendement van de hand gewezen. ${ }^{56}$ Bij het mogelijk realiseren van bovenlokale bestuursvormen, in welke gedaante dan ook, wordt coördinatie van het decentralisatieproces belangrijk. Daartoe wordt een "politieke regiegroep" aanbevolen.. ${ }^{57}$ Om op de tegenwoordige ideeën daaromtrent ${ }^{58}$ in deze studie in te gaan, voert te ver. Slechts aangestipt wordt, dat het huidige geografische bestuursbestel hevig in beroering is dan wel gaat komen in de toekomst. Verandert zo de vormgeving van territoriaal bestuur, haar fundamenten blijwen overeind.

De wortels van territoriale decentralisatie liggen niet in haar taakspecificatie, maar in haar gebiedsaanduiding. Er is sprake van geografische gerichtheid. Territoriale verbanden kunnen zich binnen hun hele territorium bezighouden met alles wat hen is toegestaan. Zo oefenen zij, in autonomie of in medebewind, zowel algemene als bijzondere bestuurs-

50. Sienat regen herindeling provincies in 25 regio's, in: NRC, 3 febr. 1993 , p. 2; Kabinet legt zlch niet wast op regiovorming in hele land in: BB, nr.6, 12 febr. 1993, pp.1-2.

51. Zeven BoN-regio's minstens 175 milioen gulden, in: BB, nr.49, 10 dec. 1993, p.3.

52. Kadenwet bestuur in verandering. TK 1992-1993, 23048, nrs. 1-3, Stbl. 21 april 1994, 396; Bestwur ap niveau H-III, TK 1992-1993, 21062, nrs.3-7.

53. C.B.M. van Haaren-Dresens, Kroniek; Decentralisatie 1993, in: RegelMaat, nr.2, 1994, pp.77-86, i.h.b. p.82.

54. Kamer schrapt gebiedsautoriteit en kroonbenoeming uit Kadenwet, in: BB, nr. 50, 17 dec. 1993, p.7.

55. In het bijzonder over dit regionaal openbaar lichaam H.Ph.J.A.M. Hennekens, De Kadenuet bes.tutar un herandering: Een nieuw(e) ROL op het bestuurstoneel, in: De Gemeentestem, 4 nov, 1994, 6997, pp. 521530.

56. Kamer schrapt gebiedsautoriteit en Kroonbentoming wit Kadenwet, in: BB, nr. 50, 17 dec. 1993, p.7; O0k E. Figee, Kamer stemt in met "afgestankte" Kadenwet, in: NG-magazine, 24/31 dec. 1993, pp. 15-16.

57. Commissie-Franssen, a.w., pp.55-57, in mavolging van D.J. Elzinga en G.H. Hagelstein, a.w., pp.5/30 3.

58. Interessante publikatie vam D.J. Elzinga, J.P. Balkenende, A. Traag, Bestuur in verandering, Zwolle, Staatrechtkring, 1993. 
taken uit. ${ }^{59}$ Anders gezegd hebben gebiedscorporaties een "niet tot belangen beperkte regelende en besturende taak, slechts beperkt door de grenzen van het eigen gebied (ook ower eigen ingezerenen heeft men buiten die grens geen zeggenschap) en de grenzen die het hoger gezag heeft gesteld, hetzij om het zelf hetzij om het door anderen te laten regelen en besturen". ${ }^{60}$ Bovendien treden zij natuurlijk "niet in zaken die geen openbaar karakter (particuliere bellangen) hebben". ${ }^{61}$ Hun taak is, kort gezegd, algemeen ${ }^{62}$ of, anders gezegd, integraal ${ }^{63}$.

Overigens lijkt de keuze voor de term integraal niet gelukkig. Bij nader inzien is het juister algemeen bestuur van integraal bestuur te onderscheiden. Algemeen bestuur duidt dan "op een rechtstoestand: het gaat om publiekrechtelijke organen die een in beginsel onbepaalde of algemene taak uitoefenen op een bepaald territoir"; Integraal bestuur wordt gereserveerd voor het institutionele kader, en ziet vooral "op de bestuurlijke processen die nodig zijn om een algemeen bestuur besluiten te laten nemen en wel zo danig dat op evenwichtige wijze relevante belangen tegen elkaar zijn afgewogen". ${ }^{64}$

\section{$\$ 5.3$ Functionele decentralisatie}

Nu functionele decentralisatie ${ }^{65}$ veelal als tegenhanger van territoriale decentralisatie wordt gezien, bestaat alle reden om bij functionele decentralisatie te denken aan overdracht of toekenning van typische taken "aan bestuursorganen werkzaam op een bijzonder terrein". ${ }^{66}$ Als een taak een zo danig specifiek karakter heeft dat afzonderlijke taakbehartiging mogelijk en geboden is, is functionele decentralisatie mogelijk een behoorlijk bestuursmodel.

Aan het feit dat organen van functioneel bestuur een taak uitoefenen, die de overheid als overheidstaak beschouwt, zijn kostencondities verbonden. Functionele decentralisatie betekent meestal een financiêle relatie tussen de op hoofdlijnen sturende overheid en het betrokken uitvoerend orgaan. Hierbij kan, bij voorbeeld, het ontbreken van de 'tucht van

59. A.D. Belinfante en S.L. de Reede, a.w. "13. 133.

60. C.W. van der Pot en A.M. Donner, a.w., pp.614-619, i.h.b. p.614.

61. F.P.C.L. Tonnaer, Schets van het Nederlandse rechtsstelsel; Een systenatische inleiding, Utrecht, 1990 , p.125.

62. M.C. Burkens, H.R.B.M. Kummeling en B.P. Vermeulen, a.w., pp.2018-210/223, i.h.b. p.209.

63. A.R. Edwards, a.w.,p.11.

64. G.H. Hagelstein (1993), t.a.p., p.15.

65. Naast respectievelijk territoriale en functionele decentralisatie onderscheidt G. M. do Schipper , Studieboek algemeen bestuursecht, Middelburg. 1982, p. 32, ambtelijke decentralisatie. Deze figuur doelt op ambtelijke organen, die een obafhankelijke positie genieten zonder gezagswerhouding. Auteur noemt voorbeelden wan de Octrooiraad en de (oude) Verzekeringskamer. Afgezien van het feit dat de uitdrukking weinig fraal is, omdat zij de begrippen ambx en orgaan achter elkaar zet, is zij te weinig onderseheidend en bovendien te eng voor thet hiema volgende, waarin ook niet-ambtelijke, d.w.z. privaatrechtelijke orgamisaties, onderwerp van studie zijn. Vandaar de voorkenr voor de term functionele decentralisatie.

66. Functioneel bestuur; warom en hoe?, TK $19901991,21042, \mathrm{nr} .4, \mathrm{p} .7$. 
de markt' zand in de ogen strooien. Het gebrek aan marktwerking veroorzaakt weinig structurele stimulansen tot kostenbeheersing. ${ }^{67}$

Middels uitgifte van vergunningen (o.a. vergunning om bedrijf te vestigen door Kamers: van Koophandel en Fabrieken, vergunning om assurantiebedrijf uit te oefenen door stichting Verzekeringskamer, aanbod van afzetgarantie of verplicht gebruik van bepaalde voorzieningen als APK-keuring door Dienst voor het wegverkeer, premiebetaling voor uitkering sociale verzekeringen door bedrijfsverenigingen ${ }^{68}$ ) meet de overheid zich mogelijk een gelegitimeerde monopoliepositie aan. ${ }^{69}$ Daarin schuilt een reëel gevaar. Natuurlijk wordt de kans op excessen, waar mogelijk, gereduceerd door het in instellingsen organisatiewetten van organen van functioneel bestuur opnemen van bepalingen, waarin ministeriële goedkeuring wordt vereist voor tariefstelling voor dienstverlening door het verzelfstandigd orgaan. Mogelijk misbruik van (monopolie)positie wordt tegen gegaan in bij voorbeeld art. 31, tweede lid, jo. art. 3q Wijziging Wegenverkeerswet 1992 houdende regeling van de verzelfstandiging van de Rijksdienst voor het Wegverkeer " en in art. 108 Verzelfstandigingswet van de Rijksdienst van het Kadaster en de Openbare Registers $^{71}$.

Toch dreigt vooral bij controle-, inspectie- of keuringstaken en bij basisvoorzieningstaken het gevaar van "autarkische monopolies". Immers, taakoverdracht naar functionele bestuursorganen kan wel vergezeld gaan van concurrentiecreatie. Maar vaak is het resultaat het volgende. Of er is slechts sprake van quasi-concurrentie. Of de periode

67. E. Gerritsen, Flexibilsering van beheersregels als alibi voor slecht (politiek) management, in: $\mathrm{OB}$, nr. 12 , 1994, pp.2-5, i.h.b. p.4.

68. Daarom stelt de WRR voor financièle prikkels in het steisel van sociale verzekeringen in te bouwen. Volgens bedoeling wan de WRR dienen bedrijwen, die relatief veel schade hebben veroorzaakt, hogere premies te betalen. Op deze wijze zijn zij eerder bereid arbeidsomstandigheden te verbeteren en inactiewe werknemers wederom in het arbeidsproces op te nemen. Tijdens de presentatie wan dit WRR-p $\|_{a n,}$ Belamg en beleid: naar en weranwoorde uiwoering wan werknemerswerzekeringen, 's-Gravenhage, 7 juni 1994. merkt een van de samenstellers er van, t.w. WRR-lid D.J. Wolfson, op, dat de bedrijfsverenigingen kunnen blijven bestaan, "naar dan well in een open, transparant en concurrerend bestel, dat bet belang van de cliënt central stelt ${ }^{\star}$. Zie WRR bepleit einde van monopolie bedrijfsvereniging, in: NRC, 7 juni 1994, p.15, zie ook interview F. van Empel met D.J. Wolfson op p.18. Vgll. W.J.P.M. Fase, Socialle zekerheid: privaat of publiek?, verslag forundiscussie d.d. 24 maart 1994 alan de RUG, Deventer, 1994; Consequentie wan het meer marktgericht werken van bedrijfswerenigingen is dat bedrijfsvereningen, willen zij goede kwalitatieve diensten blijven leveren en opgewassen zijn tegen private verzekeraars, de concentratieslag aangam en fuseren. Bekend is de fusie van de BVG met de Detam. Aldus interim-directeur wan de BVG Venema, aangehaald in: Bedrijfserenigingen op de private markt, in: NJB, nr.36, 14 okt. 1994. p. 1256. Door de BVG-reorganisatie staan 700 van de 3000 werknemers op strat, aldus Kwart personeel BVG overbodig na reorganisatie; Bedriffsereniging saneert, in: NRC, 18 okt. 1994, p.19, zie ook Fussie kost 660 banen bij bedrifsverenigingen, in: NRC, 7 febr. 1995, p.18.

69. Kritisch over gevaren van de marktanalogie H.M. van de Kar, Kosten en baten wan functionele decenrayisatie, in: J.H. Hoogteijling (red.), Besturen op afstand, IOO-uitgave nr. 34, "s-Gravenhage, dec. 1991, pp. $33-41$, i.h.b. p. 34 .

70. Zie voorstel Wet organisatie Dienst wegverkeer, TK 1992-1993, 22961, nrs.1-2, pp.4/6.

71. Zie Organisatiewetsvoorstel Kadaster. TK 1992-1993, 23007, nr, 3, pp.10-12, wgl uiteindelijke wet, Sibl. 1994, 125 . 
tussen momenten van concurrentiecreatie duurt lang. ${ }^{72}$ Een (voor concurrentie vatbare) taak moet bij woorkeur worden geprivatiseerd. Tenzij sprake is van een tijdelijke overgangsmaatregel of, anders, als het een bijzonder geval van natuurlijk monopolie betreft.

Toekenning van een dergelijke taak aan een orgaan van functioneel bestuur brengt namelijk soms mee, dat dure 'checks and balances' worden aangebracht tussen rijksoverheid en uitvoerend orgaan. Deze kostbare informatie- en signaleringssystemen moeten dan de roll van clièntele en concurrentie overnemen.

Ook als geen sprake is van een uitgesproken monopoliepositie, dient een op afstand van de rijksoverheid gezette uitvoerende entiteit, zo lang niet de tucht van de markt werkt, speciale checks te creëren. Een verzelfstandigde entiteit, die drijft op een collectieve kurk, moet onder de "tucht van het budget" (met onder meer geldende begrotingsnormering en -allocatie, doelmatigheids- en rechtmatigheidseisen als mede controle- en verantwoordingsvoorwaarden) vallen; Het door een verzelfstandigde entiteit verkrijgen en beheren van, door de burgers opgebrachte, geldelijke middelen dient dan aan "extra strenge eisen" te worden onderworpen, als: prestatiegerichte sturing, efficiencywinst/kwaliteitsverhoging, adequate (verantwoordings)mechanismen via kengetallen en verplichte beleidsevaluaties. ${ }^{73}$

Ondanks alle aangebrachte specifieke checks ter waarborging van democratische legitimatie, is een democratisch controlesysteem van een orgaan van functioneel bestuur, anders dan bij territoriale decentralisatie, niet altijd eenvoudig te realiseren.

In tegenstelling tot territoriale decentralisatie kenmerkt functionele decentralisatie zich in het algemeen door een gesloten huishouding. ${ }^{74}$

De grens tussen algemeen en functioneel bestuur is vloeiend. Dit volgt al uit drie cumulatieve vereisten voor functionele decentrallisatie. Te weten: "a. een opdracht om de taak te vervullen; $b$. regels en normen, waaraan de taakbehartiging is gebonden; en $c$. de onmogelijkheid om de taak af te stemmen en af te wegen ten opzichte van andere overheidstaken". ${ }^{75}$ Laatst genoemde conditie is beslissend voor functionele decentrallisatie. Aan de andere eisen voldoet ook territoriale decentralisatie.

72. R.J. in "it Veld, in zijn bijdrage aan congres Nederlands Studie Centrum \& stichting Mamagement Centrum, Verzelfstandigen bij de rijksowerheid, voortgang of voorwitgang', 30 nov. 1993, 's-Grawenhage, p.4; R.J. in "t Veld, De kermakenbenadering bij de Rijksowerheid: ondenwerp van gesprek, in: C. Sips en P.H. J. Vrancken, De kerntakenbenadering bij de Rijksoverheid, lOO-rapport nr. 59, "s-Graventhage, april 1994, pp.7-15, i.h.li. p.13.

73. R.II.M. Kuipers, Verzelfstandiging bij de rijksoverheid, in: H. de Groot en C.G.M. van Dosteren, De toekamst van de publieke sector, IOO-jubileumuitgave, 's-Gravenhage, 1994, pp.171-183, i.h.b. pp.179180.

74. H.M. van den Kar, Kosten en baten van functionele decentralisatie, t.a.p. „ p.33.

75. A.R. Edwards, t.a.p., p.15. 
Geen aanleiding is er om elk territoriaal aspect aan functionele decentralisatie te ontzeggen. ${ }^{76}$ Ook doelcorporaties ${ }^{77}$ kennen vaak een indeling van het oppervlak birnen $\mathrm{Ne}$ derland. Uitstekende voorbeelden zijn de Kamer van Koophandel en fabrieken en de Raden voor de Kinderbescherming. Ook taakbegrenzing per regio komt voor bij functionele decentralisatie naar zelfstandige bestuursorganen. Dit is duidelijk aan de hand van de blokvorming binnen het nog vrij verse Centraal Bestuur voor de Arbeidsvoorzieningenorganisatie, als onderverdeeld in Regionale Besturen voor de Arbeidsvoorzieningenorganisatie. Even zo spreekt de groepering in de, onder toeziend oog van de College van Toezicht Sociale verzekeringen staande, bedrijfsverenigingen boekdelen. En de nieuwe, af te wachten, ontwikkelingen in de gezondheidszorg, te weten een nieuw op te richten Raad voor de Zorgwerzekering met regionale bestuurssectoren ${ }^{78}$, duidt op geografische grootheden binnen functionele decentralisatie. Overigens gaan de situatie met betrekking tot het Kadaster en de voorgenomen situatie van de Onderwijsinspectie in die zelfde richting.

Ondoordacht is de onderwaardering van deze regionale rubricering binnen functionele decentralisatie. In praktijk blijkt bij voorbeeld dat de regionale indeling van onder meer de arbeidswoorzieningenorganisatie of de Kamers van Koophandel en fabrieken ${ }^{79}$ niet correspondeert met, er mee samenhangende, (regionale) indelingen van uit het algemeen bestuur. "Eigen regionale constructies, die niet goed aansluiten bij de gebiedsindeling van het binnenlands bestuur zijn zeer geliefd bij functionele bestuursvormen." ${ }^{80}$ Van uit het oogpunt van efficiency, effectiviteit en legitimiteit is, ook in dit opzicht, afstemming van functionele decentralisatie op territoriale decentralisatie wenselijk. Het is zelfs noodzaak dat het functioneel bestuur zich ter zake richt op de territoriale bestuurlijke indeling. ${ }^{81}$ In het, van regeringswege gegeven, toetsingskader verdient deze onderlinge coherentie meer, dan nu het geval is, nadruk. ${ }^{82}$ Hierbij mag bovendien de, tot op heden achterge-

76. J.T. van den Berg, t.a.p., p,42; Zie ook A.R. Edwards, t.a.p. p.16.

77. C.W. van der Pot en A.M. Donner, t.a.p., p.614, rekenen tot doelcorporaties "alleen de lichamen die regelings- en bestuursbevoegdheid bezitten. Wanneer geen bevoegdheid tot het witvaardigen van algemeen verbindende voorschriften is toegekend, als bij voorbeeld bij de kamers wan koophandel en universiteiten, dan blijven zulke instellingen, ook al zou men wan functionele decentrallisatie kunnen spreken, buiten beschouwing."

78. TK 1987-1988, 19945, nrs.27-28, pp.26-27/45-46; Rbb, Effectiviteit van overheidstoezicht op kwaliteit wan gezondheidszorg; Advies over de ontwerp-Kwaliteitswet zorginstellingen en de ontwerpwijagingGezondheidswer, juni 1992, "s-Gravenhage.

79. Kamers van Koophandel, in: OMn, nr.10,1993, p.259; Overigens is verbetering, d.w.Z. afstemming wan functionele gebiedsindeling op bestuurlijke regio-indeling, beloofd in: Toekomst KvK, TK 1993-1994, 23400 XIII 23.

80. Commissie-Framssen, Over decentralisatie is mog nooit een vers geschreven, TK 1992-1993, 21427, nrs. $42-43$, p. 28.

81. O.E.J. Webster, Functioneel bestuur, warrom en hoe?, in: WB, nr.19, 1991, pp.710-712; CommissieDeetman, a.w., p.8.

82. J.L. Boxum en L.J.A. Damen, Nog steeds hetzelfie liedje of now samething completeiy different?: De witvoeringsorganisatie v. d. soc, werzek. en de nota Functioneel bestuwr, waarom en hoe?, "in: Funcrioneed bestuar, a.w., pp.53-76, i.h.b. p.61. 
bleven, overeenstemming tussen Nederlandse regio's en de regionale gebieden in Europees kader geen ondergeschoven kind blijven. ${ }^{83}$

Inniddels is voor onderlinge afstemming wel meer aandacht. ${ }^{84}$ Het streven richt zich allereerst op definiëring van de $\mathrm{Wgr}^{85}{ }^{85}$ en $\mathrm{BON}-{ }^{86}$ gebieden. ${ }^{87}$

Dan moet worden bezien welke functionele regio's zich lenen voor harmonisatie ${ }^{88}$. Het "opruimen van de bestuurlijke lappendeken van gemeenschappelijke regelingen en functionele regio's is één van de centrale beleidsdoelstellingen van het kabinet op het gebied van de vernieuwing van de bestuurlijke organisatie" ${ }^{89}$ Voorlopig heerst helaas voorzichtigheid. ${ }^{90}$ Omdat politie, justitie, arbeidswoorziening en alle gedeconcentreerde ambten voor als nog buiten het integratiekader vallen, wordt verwijtend gesproken van "schraalhans keukenmeester". ${ }^{91}$ In een notitie, waarin een samenhangende visie over de vernieuwing van de bestuurlijke en financiële organisatie van het binnenlandse bestuur wordt gegeven, staat wel de aangekondiging zo snel mogelijk te komen tot een hanteerbaar werkprogramma betreffende harmonisatie van functionele gebiedsindeling. ${ }^{92}$

Daarna volgt als sluitstuk het overdragen van bestuurlijke verantwoordelijkheden van functionele naar territoriale autoriteiten. ${ }^{93}$ Door zo'n reïntegratie van belangen is namelijk "territoriale decentralisatie denkbaar op terreinen waar eerder voor functionele decentralisatie was gekozen, omdat een geschikt bestuurlijk kader ontbrak". ${ }^{24}$

Aldus wordt "integratie van de veelheid functionele bestuurseenheden op de schaal van het middenbestuur en van gedeconcentreerde rijksdiensten in het algemeen organiek

83. A.G.J.M. Rombouts, Nederlandse regio's geen synoniem voor regio's in Europa, in: NTB, nr. 2, 1993, p.99. Discussie bestuurlijke vemienwing moet beter aanshiten op Europa, in: BB, nrs.31-32, 13. aug. 1993 , p. 30; Vier scenario's bij G.H. Hagelstein (1993), t.a.p. p. 26.

84. BZ Plan wan aampak harmonisatie van de vele functionele rijksregio"s, in: BB, nr. 3, 22 jan. 1993, p.3.

85. Het definitieve regeringsstand punt brengt de Wgr-gebieden "stechts" terug van 59 naar 39 en sluit werdere daling (tot $31 \mathrm{Wgr}$-gebieden) niet uit. Zo gaat de BON gedachte van 20 a 30 reg io's te niet. Zie Provincie Uhecht blift bedreigd, Flevoland kan verder, in: BB, nr.43,29 okt. 1993, pp. 1-2; Nader kabinetsstandpunt over de $W_{\mathrm{g}}$ r-indeling in relatie tot de functionele gebiedsindelingen, TK 1993-1994, 21062, nr.27, nrs. 1-2, pp.1-12, i.h.b. pp.11-12; Op 21 april 1994 is er dan de Wetswijziging Wgr i. w.m. aampassing en witbreiding wan bepalingen inz. werplichte samenwerking. Stbl. 1994, 399-400.

86. De afbakening wan de BON-gebieden wil de regering bij woorkeur zêlf tregelen in de Kaderwet. Zie Kamer will heft in handen bij indeling BON-gebieden, in: BB, nr. 42,22 okt. 1993, p. 3.

87. O.g. . unaniem aangenomen motie De Cloe/Wan der Heijden. TK 1991-1992, 21062, nr.11.

88. Utrecht andervind hier problemen. Regiovoorstel BiZa slecht woor Utrecht, in: BB, 10 sept. 1993, p. 11 .

89. Nader kabinetsstandpunt over de Wgr-indeling in relatie tot de functionele gebiedsindelingen, a. W., p. 12 .

90. Functionele regio's mondjesmaat bij Wgr-indeling, in: BB, 1 april 1994, pp.1/4-5.

91. De Cloe betreurt 'mager resultaat' afstemming functionele regio's, in: BB, nr. 18, 6 mei 1994, p. 13.

92. Op weg naar provincies-nieuwe stijl. TK 1993-1994, 23697, nr.1.

93. Zie het tweede spoor van de brief van het ministerie van binnenlandse zaken waarbij de beleidsnotitie Vermieuwing bestumilike organisatie wordt aangeboden, TK 1992-1993, 21062, nr. 12.

94. Commissie-Franssen, a.w., pp.43/45; De commissie wenst "maximale uitvoering "van de motie-De Cloe c.s. $(\mathrm{pp} .43 / 46)$. 
bestuur van de (samenwerkende) gemeenten en provincies" als hoofdpunt van beleid aanbevolen. ${ }^{95}$

Uiteindelijk blijkt bij het aantreden, medio september 1994, van de paarse coalitie PvdA, VVD en D'66 onder leiding van premier Kok, dat de nieuw verantwoordelijke staatssecretaris van binnenlandse zaken de Wgr-lijn verlaat. Niet de, door schaalvergroting en bevoegdhedenuitbreiding te versterken, Wgr-samenwerkingsgebieden, maarde provincies (en gemeenten) worden de coördinatiepunten voor de bestuurlijke reorganisatie. Deze beleidswijziging vindt vooral basis in de angst dat, door het uitgroeien van de Wgrsamenwerkingsgebieden tot provincies-nieuwe-stijl, een nieuwe vierde bestuursllaag onstaat. ${ }^{96}$ De Tweede Kamer reageert niet negatief op bedoelde beleidsaanpassing. ${ }^{97}$ Hierbij neemt zij waarschijnlijk het gevaar voor lief, dat het bewandelen van de nieuw ingeslagen weg niet mogelijk is zonder een "ijzersterke centrale regie met uitsluiting van tal van ontwikkelingsmogelijkheden", die door onvermijdelijk opgelegde "verderfelijke blauwdrukken" de bottom-up-benadering doet wervagen. ${ }^{98}$ Sterker nog, de staatssecretaris stimuleert zelfs, na een periode "van initiatief van onderaf', een sterkere sturing door de rijksoverheid. ${ }^{99}$

\section{$\$ 5.4$ Toenemende toenadering functionele en territoriale decentralisatie}

Het is "zaak dat de gemeentebesturen en provinciebesturen de ontwikkeling inzake functionele decentralisatie met grote aandacht blijven volgen. Angst voor concurrentie moet daarbij niet hun voornaamste drijfveer zijn, maar wel democratische legitimatie, integraal bestuur en openbaarheid. " 100

Immers, de praktijk levert het bewijs van, hoewel buiten de grondwet om ontstane, zelfstandige bestuursorganen. Daarvan zijn veel organen zo belangrijk, dat ze niet meer weg te denken zijn uit het maatschappelijk leven. Anders geformuleerd, de tegenwoordige bestururscultuur moet leren leven met organen van functioneel bestuur.

95. Raad voot binnenlands bestum, Advies over BON; Vernienwing bestuurlikke organisatie, 's-Gravenhage, april 1993, p.32; Meer uitdrukkelijk Rbb, Functioneel bestuur in organieke kaders; 's-Gravenhage. januari 1995 .

96. Aldus verklaart A. van de Wondervoort op de IPO-jaarwergadening 1994. Zie Kabinet trekt prowinciale kaart voor regioworming, in: BB, nr.40, 7 okt. 1994, pp. 1-2 en Geen ruimte vaor vierde bestwurilagg'. in: NRC, 6 okt. 1994, p. 3 .

97. Komer positief oner toespraak bestuurlijke organisatie: Van de Vondervoort wel om briefter verdwideth. king gevraagd in: BB, nr.41, 14 okt. 1994, p.11.

98. Aldus krachtige kritiek wan D.J. Elzinga, Van de Vondervoort kiest voor riskante koers; Reorgawisarie bimenlands bestuur, in: BB, nT.42, 21 okt. 1994, p.31. Elzinga rijdt twee andere routen (resp. prowim. ciaal-regional bestum en gedifferentieerd provinciaal bestuur). Zie E.J. Elzinga, The allernatiewe concepten aantrekkelijkste lijn, in: $\mathbf{B B}, \mathrm{nr} .44,4$ nov. 1994, p.31.

99. Sterkere regie van bovenaf bij bestuw rijke organisatie: "kleinere en grotere provincie" mogelijk", in: $\mathrm{BB}$, nr. 44, 4 nov. 1994, p.13.

100. T. Renes, Kroniek Rbb: advies over functionele decentralisatie, in: TvO, nr. 3, 2 febr. 1989, p.56. 
Ontkennen van buitengrondwettelijke functionele decentralisatie is praten tegen beter weten in. Niet tegenwerken, maar samenwerken - als van oudsher gebruikelijk in de landinrichting ${ }^{10 t}$ - is de juiste veroveringsformule. Van de zijde van algemeen bestuur is het beter "zich te bezinnen op wegen waarlangs in samenspel met functionele organen de eigen verantwoordelijkheid kan worden waargemaakt. Wat opvalt is, dat tussen functionele organen en lagere overheden vrij well nooit directe op een wet gebaseerde lijinen bestaan. Nadere bezinning is nodig op het tot stand brengen van juridische relaties tussen functionele organen en lagere overheden", bij voorbeeld toezichtsrelaties. ${ }^{102}$

Deze kameraadschappelijke bejegening is anders dan de vijandige houding naar functionele bestuursorganen toe. Uit een aanvallende attitude spreekt de wens functionele decentralisatie niet alleen ondergeschikt aan territoriale decentralisatie te doen zijn, maar zelfs helemaal te elimineren. In die benadering krijgt territoriale decentralisatie een ereplaats. Via territoriale decentralisatie kunnen even goed, ja zelfs beter, de voordelen van functionele decentralisatie, worden gerealiseerd. ${ }^{103}$ Dat kan via "aanpassing van de bestuurlijke schaal aan de maatschappelijke schaal: dat is in wezen een functionele benadering wan territoriale decentralisatie". ${ }^{104}$

In de verwachting dat de zo genaamde terug tredende overheid in de jaren negentig niet meer modieus is, luidt de boodschap: meer "differentiatie in het territoriaal bestuur". ${ }^{105}$ Dit gebeurt "van onderop". Ergo, differentiatie, waar nodig, bezien van uit de situatie ter plekke. Daarmee zijn de onzin en overbodigheid van algemene normering ter zake uit politiek Den Haag gegeven. Deze theorie is wellicht een troef voor de toekomst. $\mathrm{Zij}$ mag, als negatief klinkende optie, niet direct ter zijde worden geschoven. Soms zijn met name gemeentelijke instanties voortreffelijk in staat bezigheden op functionele terreinen te verrichten.

Tegelijkertijd is er wel de wetenschap, dat bepaalde nu existerende functionele bestuursorganen van een dergelijk krachtig kaliber zijn, dat zij hun bestaan dagelijks bewijzen ondanks het officiele ontbreken van een democratische legitimatie in de zin van politieke verantwoordelijkheid.

101. Sinds medio maant 1993 in de vorm wan cen Gemeenschappelijke Uitwoeringsdienst, die de gebiedsgewijze ingedeelde landinrichtingscommissies ondersteunen. Het, ten dele op een doeluitkering van het Rijk berustende, nieuwe Groenfonds beheert de financiën. P. de Haan (1994), t. a.p., p. 130, spreekt van een "mixtum van territoriale en functionele decentralisatie, waarin wel de invloed van de provincies gezamenlijk belangrijk is vergroot".

102. J.B.J.M. ten Berge, Bezinning op de jurudische positie van de gemeente en de gevolgen woor het decentralisatiebeleid, in: Best.w., nr.1, 1988, pp.18-29, i.h.b. p.28; 1.d. kringloopgedachte bij J.A.M. Hendrikx, Wedloop of kringloop tussen territoriale en functionele decentralisatie, in: Bestuur, nr. 11 , 1988, pp. $324-330$, i.h.b. p. 329 .

103. A.R. Edwards, a.w., p.36.

104. W. Derksen (1989), t.a.p., p.354.

105. W. Derksen, t.a.p., p.356; T. Renes, Tjd woor apinie: functioneel bestuur, in: TvO, nr. 22,15 dec. 1989, p.467; Gecodificeerd in art. 110 van de nieuwe Gemeentewet. 


\section{Geraadpleegde literatuur}

Ballegooij, G.A.C.M. ,Bruil, D.W., Kleijn, G.P. \& Schilder, A.E. Rechtsbescherming in het AWB-tijdperk; Herziene rechtsbescherming tegen het bestuur en hei uniforme bestuursprocesrecht, Deventer 1992.

Belinfante, A.D. \& Reede, J.L. de Beginselen van het Nederlands staatsrecht, twaalfde druk, Alphen aan den Rijn, 1994.

Berg, J.T.

- Waterschap en functionele decentralisatie, dissertatie RUU, Alphen aan den Rijn, 1982;

- De herwaardering van de functionele decentralisatie; Een omstreden fenomeen in de schijithwerper, in: Bestuur, nr.3, maart 1989, pp.86-91.

Berg, J.Th.J. van den

'Old statey never die, they just fade away', in: Bestuurswetenschappen, nr.6, 1989, pp.367-371.

Berge, J.B.J.M. ten

Bezinning op de juridische positie van de gemeente en de gevolgen voor het decentralisatiebeleid, in: Bestuurswetenschappen, nr. 1, 1988, pp.18-29.

Berge, J.B.J.M. ten \& Stroink, F.A.M.

Functionele decentralisatie ait de schaduw; Een globale verkenning van aard, omvang, verschijningswormen en bestuurlijke aspecten van zelfstandige bestuursorganen en andere functionele organisatie-eenheden binnen het openbaar bestuur, 's-Gravenhage, juni 1988.

Boxum, J.L. \& Damen, L.J.A.

Nog steeds het zelfde liedje of now something completely different?; De uitvoeringsarganisaties van de sociale werzekeringen en de nota Functioneel bestuur, waarom en hoe?, publikatie Staatsrechtkring, nr.4, Zwolle, 1993, pp.53-76.

Boxum, J.L., Ridder, J. de \& Scheltema, M.

Zelfstandige bestuursorganen in soorten; Verslag wan een onderzoek naar de praktijk van zelf-

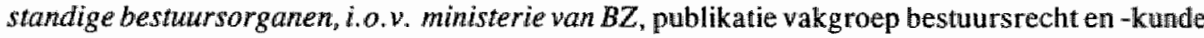
Groningen, Deventer, 1989.

Burkens, M.C., Kummeling, H.R.B.M. \& Vermeulen, B.P.

Beginselen van de democratische rechtsstaat; Inleiding tot de grondslagen van het Nederlands staats-en bestuarsrecht, derde druk, Zwolle/Utrecht, 1994.

Commissie-Franssen (bijzondere commissie wraagpunten decentralisatie)

Over decentralisatie is nog nooit een vers geschreven, TK 1992-1993, 21427, nrs.42-43.

Derksen, W.

De noodzaak van een functionele benadering van territoriale decentralisatie, in: Bestuurswetenschappen, nr.6, 1989, pp.347-358.

Donner, A.M.

Nederlands bestuursrecht; Algemeen deel, vijfde herziene druk, Alphen a/d Rijn, 1987.

Edwards, A.R.

Functionele decentralisatie en bestuurlijkeorganisatie. VNG-studies m. 2, "s-Gravenhage, 1982.

Elzinga, D.J.

- Van de Vondervoort kiest voor riskante koers; Reorganisatie binnenlands bestuur, in: $\mathrm{BB}_{\text {" }}$ nr.42, 21 oktober 1994, p.31;

$\sim$ Twee alternatieve concepten aantrekkelijkste lijn, in: BB, nr.44, 4 november 1994, p.31.

Elzinga, D.J. \& Hagelstein, G.H., m.m.v. Baan, E.A., Koopman, J. \& Schoenmaker, A. Een parlementaire impuls woor het decentralisatiebeleid; Een onderzoek naar de betrokkenheid van de Tweede Kamer bij het decentralisatiebeleid, SOG-reeks nr.1, Groningen, 1993, pp.1-37. Gerritsen, E. 
Flexibilisering van beheersregels als alibi voor slecht (politiek) management, in: Openbaar Bestuur, nr.12, 1994, pp.2-5.

Goede, B. de

Waterschap als functioneel bestuur, in: De Gemeentestem, 1981, p.373.

Goede, $\mathbf{B}$, de, bewerkt door Brink, $\mathrm{H}$. van den

Beeld wan het Nederlands bestuturstecht, vijfde druk, 's-Gravenhage, 1986.

Goorden, C.P.J.

- Rechtsbevoegdheid in het bestursrecht; Een rechtsvergelijkende studie naar het bevoegdhedenvraagstuk in het bestaursrecht, dissertatie KUB, Zwolle, 1990;

- Kroniek bestuurlijke organisatie, in: NTB, nr.2, 1994, pp.40-51.

Haan, $_{,}$P. de

Het bestuursrechten de scheiding tussen beleid en uitvoering, in: Hoogenboom. T. \& Damen, L.J.A. (red.), In de sfeer van administratief recht; Opstellen aangeboden aan Willem Konijnenbelt, Utrecht, 1994, pp.121-150.

Haan, P. de, Drupsteen, Th.G. \& Fernhout, R.

Bestuursrechtin de sociale rechtsstaat: instrumenten waarborg. Deel 1, ontwikkeling, organisawie en instumentarium, derde herziene druk, Deventer, 1987.

Haaren-Dresens, C.B.M. van

Kroniek; Decentralisatie 1993, in: RegelMaat, nr.2, 1994, pp.77-86.

Hagelstein, G.H.

De werhouding tussen algemeen en functioneel bestur; naar bestuur op maat, in: Functioneel bestuur, publikatie van de staatsrechtkring, nr.4, Zwolle, 1993, pp.1-35.

Hendrikx, J.A.M.

Wedloop of kringloop tussen territoriale en functionele decentralisatie, in: Bestuur, nr. 11,1988 , pp. 324-330.

Hennekens, H.Ph.J.A.M.

De Kaderwet bestuur in verandering; Een nieuw (e) ROL op het bestuurstoneel, in: De Gemeentestem, 4 november 1994, nr.6997, pp.521-530.

Kortmann, C..A.J.M.

Kroniek van het staatsrecht, in: De staat wan het recht, kronieken 1 augustus 1993 - 1 augustus 1994 als bijlage van NJB, nr.33, 23 sept. 1994, pp.46-49.

Kuipers, R.I.M.

Verzelfstandiging bij de Rijksoverheid, in: Groot, H. de \& Oosteren, C.G.M. van, De toekomst van de publieke sector, bijdragen aan het jubileumsymposium van het IOO d.d. 17 maart 1994 , 's-Grawenhage, 1994, pp.171-183.

Langbroek, P.M.

Machtenscheiding en decentralisatie; Een onderzoek naar de rechtsverhouding tussen centrale en decentrale overheidsorganen in Nederland, dissertatie UT, Enschede, 1988.

Langenberg, P.J.

Gebonden zelfbeheer: over de verhouding tussen regering, parlement en functionele organen, in: Graaf, Th.C. de, Hoeven, D.A. van der \& Langenberg, P.J., Omtrent het parlement; Opstellen over parlement en democratisch bestuur, Utrecht/Antwerpen, 1985, pp.116-147.

Mulder, A.

Zelfstandige bestuursdiensten in Nederland, preadvies voor VVSR wan België en Nederland, Zwolle, 1980.

Pot, C.W. van der \& Donner, A.M., m.m.v. Prakke, L., Reede, J.L. de \& Wissen, G.J.M. van Handboek van het Nederlandse staatsrecht, twaalfde druk, Zwolle, 1989.

Raad voor het binnenlands bestuur - Advies over functionele decentralisatie, "s-Gravenhage, september 1988. 
- Advies over BON; Vernieuwing bestuurlijke organisatie, 's-Gravenhage, april 1993;

- Functioneel bestuur in organieke kaders, "s-Gravenhage, januari 1995.

Renes, $\mathrm{T}$.

$\sim$ Kroniek Rbb: advies over functionele decentralisatie, in: TvO, nr. 3,2 februari 1989, pp.55 56 ;

$\sim$ Tijd voor opinie: functioneel bestuur, in: TrO, nr. 22,15 december 1989, p.467.

Rombouts, A.G.J.M.

Nederlandse regio's geen synoniem voor regio's in Europa, in: NTB, nr.31-32, 13 augustus $\llbracket 993$, p. 99 .

Ruiter, D.W.P.

Centralisatie en decentralisatie, in: Hoogerwerf, A., Overheidsbeleid, derde druk, Alphen aan den Rijn, 1985 , p.404 e.v.

Schipper, G.M. de

Studieboek algemeen bestuursrecht, Middelburg, 1982.

Stroink, F.A.M.

Het leerstuk der deconcentratie, dissertatie RUU, 's-Gravenhage, 1978.

Tonnaer, F.P.C.L.

Schets van het Nederlandse rechtsstelsel, Een systematische inleiding, Utrecht, 1990.

Tweede Kamer

- Functioneel bestuur: waarom en hoe?, respectievelijk TK 1988-1989, 21042, nr.2, en TK 1990-1991, 21042, nrs.4-10;

- Vernieuwing bestuurlijke organisatie, TK 1992-1993, 21062, nrs.3/7/11/12, en ook Nader kabinetsstandpunt over de Wgr-indeling in relatie tot de functionele gebiedsindelingen, TK 1993 1994, 21062, ir. 27;

$\sim$ Kaderwet bestuur in verandering, TK 1992-1993, 23048, nrs.1-3;

- Toekomst Kamers wan Koophandel en fabrieken. TK 1993-1994, 23400, XIII 23;

- Op weg naar provincies-nieuwe stijl, TK 1993-1994, 23697, nr.1.

Veld, R.J. in 't Veld,

De kerntakenbenadering bij de Rijksoverheid: onderwerp van gesprek, in: Sips, C. \& Vrancken, P.H.J., De kerntakenbenadering bij de Rijksoverheid, IOO-rapport nr.59, 's-Gravenhage, april 1994 , pp. 7-15.

Webster, O.E.J.

Functioneel bestuur, waarom en hoe?, in: WB, nr. 19, 1991, pp.710-712.

Wijk, H.D. van, bewerkt door Konijnenbelt, W. \& Male, R.M. wan

Hoofdstukken wan administratief recht, negende druk, Utrecht, 1994. 


\section{Samenvatting, bevindingen en conclusies}

\section{bestuurlijk organisatierecht}

Ten aanzien van de rechtsstatelijke eis van machtsverdeling:

De ministeriële verantwoordelijkheid is een democratisch controlemiddel binnen het stelsel van checks and balances. De feitelijke werking er van laat te wensen over. Aan de opgesmukte boom van de Nederlandse overheidsorganisatie, met haar vele takken van diensten, hangt meer dan eens een besmeurd blad. Een prachtige boom met enkel frisse loten wordt het nooit. Van wege zijn complexe takenpakket is de minister niet bij machte alle smetten op te merken, laat staan te verwijderen. Kortom, klaarblijkelijk voldoet de politieke controle niet.

De politieke verantwoordelijkheid is een fictieve ministeriële verantwoordelijkheid. Toch stemt die fictie niet tot wanhoop. In tegendeel. Hoe vaak ook (in haar functioneren) fictief, belangrijk is vooral de geldingskracht van de regel van ministeriële verantwoordelijkheid in uitzonderlijke situaties. Een paar lelijke blaadjes mag een boom wel hebben. Maar wanneer afwijkende antasting, als rotting tot op de wortel, dreigt, is interventie noodzaak. De kracht van de volledige ministeriële verantwoordelijkheid ligt dus in wezen in haar normatieve, potentiële werking. Het verantwoordingsproces dient een voorbeeldfunctie. Het is vooral ter lering wat betreft de toekomst. Activering van de ministeriële verantwoordelijkheid is te allen tijde mogelijk. In principe moeten regering en parlement zich altijd en overal kunnen bemoeien met de uitoefening van overheidstaken middels openbaar gezag. Zelfs als zij daartoe geen bevoegdheid hebben.

In dit verband zijn zelfstandige bestuursorganen problematisch. Toezichthoudende zelfstandige bestuursorganen oefenen publiekrechtelijke bevoegdheden uit. Zelfstandige bestuursorganen staan niet in hiërarchische positie tot bepaalde ministers. Zij ontberen deze democratische legitimatie juist uit oogpunt van het verminderen van de omvang van đe ministeriële verantwoordelijkheid in het algemeen. De minister kan wel, zij het slechts in algemene zin, aanwijzingen geven. Ook heeft hij beïnvloedingsinstrumenten, bij voorbeeld vernietigings- of goedkeuringsrecht van besluiten en benoemings- of ontslagrecht van personeel van zelfstandige bestuursorganen. Overigens geeft hij slechts de hoofdlijnen van het, door zelfstandige bestuursorganen uit te voeren, beleid. 
Dat is een klinkende theorie. Maar, praktisch gezien, slaat de meter toch erg ver uilt bij geconstateerd disfunctioneren van zelfstandige bestuursorganen. Het ter verantwoonding roepen geschiedt in de regel bijna uitsluitend via de details. Minister en zelfstandig bestuursorgaan zullen beiden, naar redelijke verhouding, verantwoordelijk moeten zijn. Bowendien, als het parlement vindt dat een zelfstandig bestuursorgaan niet adequaat met de haar gegeven publiekrechtelijke bevoegdheden omgaat, lijkt het van de dolle dat een minister daarop niet kan worden aangesproken omdat hij geen bevoegdheid ter zake heeft (hij zal in elk geval aanspreekbaar zijn indien hij niet tijdig ingrijpt bij taakverwaarlozing door een betrokken zelfstandig bestuursorgaan en ook als hij geen gebruik maakt van de hem ter beschikking staande mogelijkheid de bevoegdhedendelegatie of -attributie, of voorwaarden daarvan, geldend voor een in gebreke blijvend zelfstandig bestuursorgaan. in te frekken of te wijzigen).

Blijkt een minister, met beroep op zijn beperkte politieke verantwoordelijkheid, in staat om onder elke aansprakelijkheid uit te komen, dan biedt mogelijk rechtsbescherming. legitimatie. Hiervan is het nadeel, dat rechtsbescherming pas achteraf en incidenteel kan worden ingeroepen.

Echte ontlasting van de minister kunnen zelfstandige bestuursorganen alleen betekenen in de optimale situatie, dat hun taken, bevoegdheden en controlemogelijkheden (waaronder rechtsbescherming) exact regeling hebben. Te veel zelfstandige bestuursorganen zijn nog omfloerst in dit opzicht. Wellicht biedt de toekomst positief perspectief.

Met beperking van de ministeriële verantwoordelijkheid, door het instellen van sommige zelfstandige bestuursorganen, moeten voor als nog niet te grote verwachtingen worden gewekt. Resultaten in de praktijk zijn soms strijdig met deze gedachte achter zelfstandige bestuursorganen. De formele afstand tussen minister en zelfstandige bestuursorganen bestaat. Maar in feitelijke situaties is de ingrijpende hand van de minister soms sterk voelbaar. Alle idee ten spijt. Overigens rest genoeg reden voor het instellen van zelfsitandige bestuursorganen.

Blijft de vraag of zo veel uitoefening van openbaar gezag, als storende stoelpoot onder 's ministers zetel, moet worden weg gezaagd. Met andere woorden is de vorm, waarin zelfstandige bestuursorganen nu zijn gegoten, wel zo ideaal als bedoeld? Vooral wat betreft, de in het maatschappelijk leven soms zeer ingrijpende, toezichthoudende zelfstandige bestuursorganen is dit een brandende kwestie.

In dit onderzoeksproject, naar de uitoefening van toezichthoudende overheidstaken door zelfstandige bestuursorganen, wordt nog uitgegaan van het theoretische uitgangspunt van afwezigheid van ondergeschiktheid aan enig minister. Anders gezegd, een gedeeltelijke ministerièle verantwoordelijkheid is uitgangspunt.

\section{Ten aanzien van de rechtsstatelijke eis van legaliteit:}

Vooral van wege het ontbreken van een hiërarchische lijn van zelfstandig bestuursorgaan naar minister, is het, tegenwoordig ten onrechte soms sterk in omvang afgenomen, beginsel van wetmatigheid van bestuur bij zelfstandige bestuursorganen dominant. $O p$ en inrichting van een zelfstandig bestuursorgaan geschieden, bij voorkeur, bij of krach- 
tens wet. In elk geval moet de taakuitoefening berusten op een formeel-wettelijke basis. Tenzij het slechts een puur uitvoerende en gebonden bevoegdheid betreft, moeten aan toezichthoudende zelfstandige bestuursorganen over te dragen of toe te kennen publiekrechtelijke bevoegdheden uiteindelijk formeel-wettelijke grondslag hebben.

Uit democratisch oogpunt zijn, wat betreft zelfstandige bestuursorganen, attributie en delegatie de aangewezen rechtsgeldige titels van bevoegdheidsuitoefening. De regeling wan delegatie naar nieuw recht, dat wil zeggen de derde tranche Algemene wet bestuursrecht., is mager. Bovendien ontbreekt een fundamentele herbezinning op het verschil in terminologie van delegatie/attributie.

Voor zelfstandige bestuursorganen betekent dit in feite altijj terug vallen op de verschillende instellingswetten indien aanwezig. Die moeten voldoen aan het, van regeringswege opgestelde, toetsingskader voor zelfstandige bestuursorganen. De toetsingspunten vormen een leidraad inzake eisen met betrekking tot inrichting en functioneren bij attributie dan well delegatie van bevoegdheden aan ambtelijke organen voor zover niet vallend onder de grondwettelijk verankerde decentrale lichamen.

Het verdient prioriteit deze maatstaven officieel vast te leggen. Daartoe zijn zij, uit oogpunt van de rechtseenheid, bij voorkeur om te zetten in een raamwet of anders in aanwijzingen voor de rijksdienst inzake zelfstandige bestuursorganen (waarbij weliswaar aanwijzingen, boven een wettelijk kader, het voordeel van flexibiliteit hebben).

Zeer belangrijke toetssteen is de inpassing van het functioneel besturur in het algemeen bestuur. De eis van generalistisch, belangenafwegend, integraal bestuur vergt afstemming van algemeen en functioneel bestuur. 'Oorzaak daarvan is het primaat van de in de Grondwet neergelegde hoofdstructuur. Daaronder valt de decentralisatie naar geografisch bepaalde organen.

In tegenstelling tot deconcentratie is decentralisatie, algemeen genomen, in beginsel vrij van ministerièle hiërarchie.

Bij territoriale decentralisatie gaat het om de uitoefening van een algemene taak binnen het totale oppervlak van een bepaald gebied. $\mathrm{Zij}$ is territorium gericht.

$\mathrm{Bij}$ zowel grondwettelijke functionele decentralisatie naar openbare lichamen als buitengrondwettelijke functionele decentralisatie naar zelfstandige bestuursorganen staat specifieke taakvervulling centraal. $\mathrm{Zij}$ is doelgericht. In werkelijkheid vertoont functionele decentralisatie veelal territoriale trekken.

In de toekomst is meer aandacht nodig voor het weinig synchroon lopen van, mogelijk samenhangende, territoriale en functionele regiovorming. Daarbij is ook onderlinge afstemming tussen functionele regionale besturen gewenst. Hiernaast blijkt ook uit de, van wege gedeconcentreerde ambten gegeven indeling, dat mauwelijks sprake is van een eenduidig regiobegrip.

1. G.H. Hagellstein (1993), t.a.p.,p. 18 . 
Samenvatting, bevindingen en conclusies Deel I

Ten slotte, indien het tot de mogelijkheden behoort, de doelmatigheid dient en kostenbesparend werkt, lijkt een functionele benadering van territoriale overheidsorganen niet zo negatief als het lijkt. 


\title{
Inleiding functioneel bestuur
}

\begin{abstract}
"Binnen de overheidsorganisatie mogen duizend bloemen bloeien, zo lang ze zich maar efficiënt naar de zon richten en niet te veel water behoeven." I
\end{abstract}

In het voorgaande is de term zelfstandig bestuursorgaan veel gebezigd. Het begrip geniet geen grote bekendheid. Daarom is het vaak gissen naar de betekenis er van. In dit hoofdstuk wordt het verschijnsel zelfstandig bestuursorgaan omschreven.

Voor een goed begrip moet eerst het grote verband, waarbinnen het zelfstandig bestuursorgaan een plaats heeft, duidelijk zijn. Gedoeld wordt op het politieke raam van verzelfstandiging van overheidstaken. In paragraaf 6 tot en met paragraaf 6.5 treden privatiserings- en verzelfstandigingsbeleid in het voetlicht. Verschillende soorten overheidsbestuur, waaronder vormen van functioneel bestuur, worden tegen elkaar afgezet. De inrichting van de bestuurlijke organisatie krijgt beschouwing van uit een onomstotelijk gegeven. Namelijk dat de Nederlandse overheid een massale hoeveelheid modaliteiten van bestuur kent. Met veelkleurige consequenties. In de problematische wirwar moeten lijnen, als volgt, worden aangehouden. Welk soort taakuitoefening betreft het? Worden dlaartoe publiekrechtelijke bevoegdheden overgedragen of toebedeeld? In welke vorm wordt het betrokken bestuur gegoten? Wie is voor wat verantwoordelijk en hoe ver? Welk rechtsregime is toepasselijk? Waar komen de financiële middelen vandaan? Aan de hand van dergelijke vragen wordt de overheidsorganisatievorming globaal getypeerd.

Wat betreft in het bijzonder het zelfstandig bestuursorgaan geeft paragraaf 7 tot en met paragraaf 7.1 aandacht aan de bevoegdheidsverlening in het kader van een toegewezen overheidstaak. Hoofdstuk 8 handelt over de (soorten) overheidstaken, die een zelfstandig bestuursorgaan kunnen toekomen. In dit kader blijft de politieke discussie over kerntaken niet onvermeld (paragraaf 8.1). Natuurlijk passen daarbij de nodige opmerkingen betreffende de voorstellen inzake kerndepartementen. Volgens plannen van ministeriële

1. Opgemerkt tijdens Haags politiek debat inzake privatisering- en verzelfstandigingsbeleid, weer gegeven door $O$. van de Vijver, Verzelfstandigen; Primatiseren is domweg geen politiek thema meer, in: BBM, nr.7, 1 nov. 1991 , p. 1 . 
commissies die zich bezig houden met staatkundige en bestuurlijke vernieuwing, bepalen die kerndepartementen het beleid en worden concrete beleidsstappen ondernomen door zelfstandige uitvoeringsorganisaties. Een kwaliteitshandvest kan een goede koppeling tussen beleidsbepalers en -beleidsuitvoerders werzekeren. Maar het risico is niet denkbeeldig, dat beleidsvorming en -uitvoering moeilijk zijn te scheiden (paragraaf 9 tot en met paragraaf 9.2). Tot slot, paragraaf 9.4 geeft een indruk van de aard van de bevoegdheden, waarmee zelfstandige bestuursorganen mogelijk worden uitgerust.

Bij het praten over verandering van de rijksdienst geldt een belangrijke waarschuwing. Verschillende discussies zijn "tegelijkertijd aan de gang die deels in elkaars verlengde liggen, maar deels ook van elkaar onderscheiden kunnen worden en zelfs onderlinge spanningen opleveren". " Bedoeld is, ten eerste de discussie over de omvang en aard wan de overheidstaak als geheel. Ten tweede bestaat de discussie over verzelfstandiging en de andere organisatorische scheiding van beleid en uitvoering. En ten derde wordit gediscussieerd over sturingsconcepten. Het concept van kerndepartementen zit ingeklemd tussen deze drie discussies. Het is zinvol de discussies meer transparant te krijgen.

2. R.J. in 't Veld, De kerntakentenadering bij de Rijksoverheid: onderwerp van gesprek, in: C. Sips en P.H.J. Vrancken, De kerntakenbenadering bij de Rijksoverheid, IOO-rapport nr.59, 's-Gravenhage, april 1994, pp.7-15, i.h.b. pp.8-9. 
Hoofdstuk 6

\section{Verzelfstandiging van overheidsdiensten}

\section{$\$ 6.0$ Verzelfstandigen bij de rijksoverheid als aandachtspunt}

De aandacht bij de rijksoverheid voor verzelfstandiging van departementstaken heeft veel verschijningsvormen aangenomen de afgelopen vijftien jaar. Begin jaren tachtig geeft thet kabinet voorkeur aan privatisering. Medio jaren tachtig krijgen zelfbeheer en contractmanagement belangrijke accenten. Eind jaren tachtig trekt de discussie over functionele decentralisatie, met name naar zelfstandige bestuursorganen, de belangstelling van de regering. En het pleidooi voor agentschappen kenmerkt de vroege jaren negentig. Kortom, beleid in beweging. Begripsbepaling is geboden. Daarom een beschrijving van een "landschap in de mist". '

\section{\$ 6.1 Reorganisatie rijksdienst}

Na de onstuimige groei van haar taken, bevoegdheden en verantwoordelijkheden in de decennia na de Tweede Wereldoorlog wordt de Nederlandse overheid zich pas laat bewust van de gebreken die aan haar organisatie kleven. De inrichting van het openbaar bestuur kan beter. Dit politiek besef dringt serieus door na publikatie van de rapportages van de commissie hoofdstructuur rijksdienst (commissie-Vonhoff) ${ }^{2}$ begin tachtiger jaren. De commissie acht de tijd rijp voor een structurele bestuurlijke verandering in het functioneren van de centrale overheid. Als hoofdprobleem van de rijksdienst ziet de commissie-Vonhoff: hoe kan de overheid, als open systeem, instrumenten ontwikkelen om de maatschappelijke ontwikkelingen te volgen en op die ontwikkelingen anticiperen door sommige activiteiten prioriteit te gaan geven en andere te staken. Oplossing daarvan zoekt de commissie, als eerste, in andere organisatieprincipes dan het klassieke hiërarchisch ambtelijke lijn- en stafmodel.

1. Bimenstebuiten, in: NRC, 7 jan. 1995 , p. 11 .

2. Commissie hoofdstnuctuur rijksdienst (commissie-Vonhoff), met name rapporten Zou Thorbecke nu Hevreden zijn, "s-Gravenhage, 1979, Elk kent de loan die derwaan gaat. 's-Grave rhage, 1980, Eindadvies, "S-Gravenhage, 1981 . 
De voorstellen van de commissie-Vonhoff missen praktische uitwerking. De Vonhoffrapporten vormen wel de grondslag voor het project reorganisatie rijksdienst. Dit project maakt onderdeel uit van zes pragmatische operaties, die het kabinet-Lubbers I in gang zet. Met als doel het aantal overheidsactiviteiten, -maatregelen, -werknemers, en -uitgaven te verminderen ten einde het restant beter te kunnen beheersen tegen mimder kosten. De 'grote operaties' betreffen: reorganisatie van de rijksdienst, heroverwegingen van de overheidsuitgaven, de min twee procent operatie (tijdens de tweede regeringsperiode van kabinet-Lubbers omgezet in het project afslanking van het ambtenarenapparaat), deregulering van overheidsmaatregelen ten aanzien van de particuliere sector, decentralisatie van rijkstaken naar lagere overheden, en privatisering van overheidstaken. ${ }^{3}$

\section{$\S 6.2$ Privatisering}

Het privatiseringsbeleid staat hoog in rangorde op de politieke agenda van de regering. Van meet af aan heeft het privatiseringsstreven zo danig gewicht dat hierover in regeerakkoorden afspraken worden gemaakt. Het eerste kabinet-Lubbers maakt privatisering tot een hoofdpunt van beleid. ${ }^{4}$ Het daarop volgende kabinet zet deze ontwikkeling voort en intensiveert de uitvoering van privatiseringsprojecten. In het regeerakkoord komt privatisering naar voren als een wezenlijk onderdeel van het kabinetsbeleid. "De privatisering van overheidsdiensten zal krachtdadig worden aangepakt. Richtsnoer hierbij zal zijn dat alle diensten, welke niet noodzakelijk door de overheid behoeven te worden uitgevoerd, in beginsel door privatisering in aanmerking komen. Tevens worden hieronder begrepen die operaties, die ten doel hebben, met het oog op een duidelijke scheiding van beleid en uitvoering, een zo doelmatig mogelijke bedrijfsvoering bij dienstverlening te waarborgen. De procedures zullen voldoende inbreng van niet-ambtelijke zijde garanderen." 5 Ook tijdens de derde regeringsperiode van het kabinet-Lubbers geldt de leidraad "dat de rijksdienst belangrijke beleidsfuncties vervult en dat de uitvoering daarvan wordt overgedragen aan zelfstandige bestuursorganen, dan wel opgedragen aan andere overheden of te verzel fstandigen diensten" ${ }^{6}{ }^{6}$ Het beleidskader blijft dus hetzelfde. Wel doet zich een zekere accentverschuiving voor ten aanzien van de politieke keuze voor en de invulling van privatiseringsvarianten.

3. TK 1984-1985, 18315, mr.3,; Uitgebreid E. Buddenbaum, Doetmatigheid van beheer in de rijks diensi, Deventer/"s-Grav., 1986; C.A. de Kam en J. de Haan (red.), Terugtredende overheid: realineit of reig. riek?. Schoonhoven, 1991 ; F.K.M. van Nispen en D.P. Noondhoek. De grote operaries: De averheid onder het mes of snijden in eigen wlees, Deventer, 1986.

4. Regeerakkoord, Stcrt. 1982, 203.

5. Regeerakkoord, Stcrt. 1986, 131.

6. Regeerakkoord Lubbers III: kabinetscrisis en formatie 1989, TK 1989-1990, $21132, \mathrm{nr}^{8} 8$, p.48.

7. Brief van de minister van financiën aan de voorzitter van de Tweede Kamer d.d. 26 nov, 1990, TK 1990. 1991,21362, nr.3, p. 1; Met verwijzing naar de Notitie over verzelfstandiging en privatisering, TK, 1989 $1990,21632, \mathrm{nr}_{1} 1$, p.3. 


\subsection{DOELEINDEN PRIVATISERING}

De oorspronkelijke motieven achter het privatiseringsbeleid bij de rijksoverheid zijn tot op heden gehandhaafd. Deze doelstellingen luiden als volgt: "het bereiken van een betere bestuurlijke beheersing, een versterking van de marktsector en de realisering van budgettaire besparingen" ". 8

Het eerste oogmerk betreft het verzelfstandigen, uitbesteden en "afstoten van niet-essentièle overheidstaken". "Beoogde gevolgen daarvan zijn "afslanking en stroornlijning van het overheidsapparaat". ${ }^{10}$ De tweede overweging, dat bepaalde particuliere ondernemingen of branches meer kansen krijgen voor ontwikkeling en innovatie, is gebaseerd op het algemene regeringsbeleid gericht op onder meer terugdringing van overheidstekorten en beperking van collectieve lasten. En de derde wens is ingegeven door de politieke stellingnames van effectiviteit en efficiëntie. Daarbij gaat het om een "betere afstemming van de voorzieningen in de collectieve sector op de behoeften". "Bovendien kan, in het kader van eigenlijke privatisering, sprake zijn van lagere produktiekosten en toepassing van het profijtbeginsel ${ }^{12}$ dan wel het prestatiebeginsel ${ }^{13}$.

Deze uitgangspunten zijn, zonder koerswijziging, terug te vinden in recent beleid. Wel blijkt uit ervaring dat een andere beklemtoning van doelstellingen nodig is. Het bestuurlijk-economisch motief krijgt prioriteit. Het bezuinigingselement blijft belangrijk, maar doet zich in onverwachte vorm voor. Budgettair woordeel doet zich namelijk pas op termijn voor van wege aanloopkosten en fasering van privatisering. ${ }^{14}$ Vandaar een herformulering van doelstellingen: "vergroting van doelmatigheid, zodat - meestal na een aanloopfase - budgettaire besparingen kunnen optreden; bestuurlijke stroomlijning, waardoor de kwaliteit van het bestuur kan worden verbeterd". 15

Deze motieven zijn overwegingen om tot verzelfstandiging over te gaan. Daardoor krijgen zij tevens betekenis als criteria waaraan privatiseringsvarianten moeten worden getoetst.

8. Brief van de minster wan financièn aan de voorzitter van de Tweede Kamer d.d. 25 mel 1983, TK 1982 $1983,17938, \mathrm{nr} .1, p_{1}$; Brief vain de minister wan verkeer en waterstaat aan de voonzitter wan de Tweede Kamer d.d. 9 aug. 1983, 17938, nr.2, p.1.., Uiteindelijk neergelegd in Evaluatienota privatisering. TK $1987-1988,17938$, nr. 42 , pp. $3 / 19$.

9. Minister Ruding in antwoond op vraag van D'66-kamerlid Engwirda, vaste commissies voor financiên en voor ambtenarenzaken, UCV 73 betreffende Evaluatienota privatisering, 5 sept. 1988, pp. 17/25.

10. TK 1982-11983, 17938, nr.1, p.2.

11. TK $1982-1983,17938$, ne. 1, p.2.

12. R.H. Kunneke , Op armlengte van de overheid; Een theoretisch en empirisch onderzoek naar de effecten van verzelfstandiging op de efficiëntie van openbare mutsbedrijwen, diss. UT, Enschede, $199 \mathrm{~d}, \mathrm{p.3} ; \mathrm{Vgl}$. economische benadering van organisatorische veranderingen binnen het openbaar bestuur door R.W. Kunneke, Verzelfstandiging bezien wamuit de 'property rights'-theorie, in: N.P. Mol en H.A.A. Verbon, Imstitutionele economie en openbaar bestuur; Perspectieven op de verzelfstandiging wan overheidsdiensten, 'si-Gravenhage, 1993, pp.31-50.

13. H.J. de Ru (red.), Privatisering in de praktijk; juridische aspecten. Zwolle, 1987, p.5.

14. Minister Ruding in antwoond op wragg CDA-kamerlid Van Iersel, UCV 73, 5 sept. 1988, p.2

15. TK 1989-1990, 21632 , nr. 1, p.2 


\subsubsection{PRIVATISERINGSVARIANTEN}

Verschillend gebruik van termen, in afwijkende kringen en tijden, kan aanleiding geven tot begripsverwarring. Voorheen het financieel-economisch geladen begrip privatisering vooraan in het politiek debat. $\mathrm{Nu}$ is de optiek van bewindslieden verschoven naar verzelfstandiging als paraplubegrip. Daarmee worden het juridische en het management-organisatorische referentiekader geactualiseerd. ${ }^{16}$ Beide begrippen verhouden zich tot elkatr als volgt.

Privatisering is een verzamelterm voor een groot scala aan activiteiten, gericht op vermindering van overheidsbemoeienis .. Kort gezegd betekent privatisering "het meer inschakelen door de overheid van het particulier initiatief ${ }^{n} .{ }^{17}$ Privatisering, als hier bedoeld, betreft alleen privatisering van het aanbod. Dat is "het terugtreden van de overheid als aanbieder van goederen en diensten". ${ }^{18}$ Dit komt tot uitdrukking bij de aanvang van de grote privatiseringsoperatie. In regeringsstukken wordt de volgende begripsomschrijving gehanteerd. "Privatisering houdt in, dat overheidsvoorzieningen worden afgestoten naar de particuliere sector, dan wel werkzaamheden aan particuliere bedrijven worden uitbesteed, terwijl onder bepaalde voorwaarden ook de zo genaamde verzelfstandiging binnen de overheidssector mogelijkheden biedt om doelmatiger handelen te verwezenlijken." "Conform het beleid in het kader van de heroverwegingen collectiewe uitgaven, betreft een en ander "al die vormen van verzelfstandiging, waarbij door de overheid verrichte taken hetzij onder een minder directe vorm van overheidsinvloed worden gesteld, hetzij geheel aan die overheidsinvloed worden onttrokken". ${ }^{20}$ Bezwaarlijk aan deze definitie is, dat hiermee het verschil tussen privatisering en verzelfstandiging nog niet duidelijk is. ${ }^{21} \mathrm{Bij}$ de definitie worden wël drie concrete hoofdwormen onderscheiden. Te weten: afstoten, uitbesteden en verzelfstandigen. ${ }^{22}$

$\mathrm{Bij}$ afstoten wan rijkstaken is het de bedoeling dat de particuliere sector zowel de omvang van de overheidsvoorziening als de produktie en financiering er van gaat bepalen. Het marktmechanisme treedt in de plaats van de budgetwerking. Daardoor verdwijnt de bepaalde voorziening mogelijk. Differentiatie is aan te brengen tussen actief afstoten en

16. W.J.M. Kickert, Verzelfstandiging bï de rijksoverheid, in: BWn, nr.6, 1991, pp,406-419; W J.M. Kickent, N.P. Mol en A. Sorber, Verzelfstandiging van overheidsdiensten, in: BK, nr.1. 1992, pp.8 21.

17. P.B. Boorsma, Privatisering, in: OU, nr.16, 1989, p.284.

18. P.B. Boorsma en N.P. Mol, Priwatisering, in: SMO-informatief, nr.4, 1983, Schevenimgen, p.23.

19. TK 1983-1984, 17938, nr. 1, p.1.

20. TK 1983-1984, 17938, nr. 1, p.2; Heroverweging collectieve uitgaven, deelrapp. nr. 3, TK 1980-1981, 16625, nr.8, p.20; Vgl. Handboek privatisering, rapp. van de commissie bundeling ervaringen bij privatisering, "s-Gravenhage, 1990, p.17.

21. P.B. Boorsma en N.P. Mol, t.a.p., pp.23-24; Frappant feit is dat J.A. Bijker, Personele aspectem acam privatiserimg, sociale monografieen 1, "s-Grawenhage, 1993, p. 15, Boorsma zelf betrapt op een dergelijke fout. In een door Bijker aangehaald citaat rekent Boorsma "verzelfstandiging door creatie van een over. heidsbedrijf mede tot privatisering. Anders dan uit zijn definitie blijkt, is voor zo'n creatie inschakeling van het panticulier wezen niet noodzakelijk.

22. Deze wormen doen zich voor op zowel centraal als decentraal niveau. Omdat zbo"s onderzoeksonderwerp zijn, is echter in beginsel rijksniweau uitgangspunt. 
passief overlaten. ${ }^{23}$ In de laatste siuatie trekt de rijksoverheid zich geheel terug. De garantie, dat door middel van wet- en regelgeving (inzake bij voorbeeld subsidies) voor het continueren van de afgestoten staatstaak wordt zorg gedragen, ontbreekt zelfs.

Het feit dat de centrale overheid besluit dat zij voor een bepaalde taak voortaan niet meer zorg hoeft te dragen, betekent - anders dan de theorie doet vermoeden - in praktijk niet. altijd dat overheidsbemoeienis geheel afwezig is. Soms is nog sprake van verkapte overheidsinvloed, al dan niet van tijdelijke aard. "Het blijft fascinerend hoe in privatiseringsland vrolijk wordt vastgesteld dat bepaalde aangelegenheden 'geen overheidstaak' meer zijn, onder handhaving van vergunningstelsels, toezicht en wat heb je niet meer aan overheidsbemoeienis. Het zich werkelijk terug trekken kost blijkbaar grote moeite, als ook de welig tierende convenantencultuur aantoont." 24 Weliswaar kan deze gematigde overheidsinvloed bedoeld zijn om de overgang van overheidscultuur naar bedrijfscultuur voorspoedig te laten verlopen. Hier dient de privatisering van het Algemeen Burgerlijk Pensioenfonds als voorbeeld. Om de overgang per 1 januarï 1996 van publiekrechtelijk fonds naar privaatrechtelijke stichting optimaal te laten verlopen wordt door de rijksoverheid een inleidend convenant met de betrokken ambtenarenvakorganisaties gesloten. ${ }^{25}$

Uitbesteding betekent het, in contractuele relatie (waak onder financiële voorwaarden) met de rijksoverheid, uitwoeren van departementstaken door particuliere organisaties. In deze situatie blijft de overheid verantwoordelijk voor de planning en doorgaans ook de financiering van de voorziening. $\mathrm{Zij}$ bepaalt zo nog steeds de omvang van de overheidsvoorziening. Slechts de produktie wordt, al dan niet gedeeltelijk uit handen gegeven. Daarover hebben betrokken ministers dus geen zeggenschap meer. Tenzij bij overeenkomst anders wordt bepaald. Want ministers zijn (alleen) aanspreekbaar op het afsluiten van het uitbestedingscontract. Dit impliceert, overigens, dat zij toezien op naleving van het contract.

De derde variant is een meer diffuus privatiseringstype. Bij verzelfstandiging is sprake van indirecte overheidsinvloed. Sprake is van besturen ${ }^{26}$ op afstand. Er wordt een bepaalde "afstand" gecreëerd tussen overheid en verzelfstandigde organisatie.

De terminologie overheid op afstand blijft onwennig. Het rijk en de verzelfstandigde eenheid horen beide tot de overheidsorganisatie. ${ }^{27}$ Daarmee zijn zij, weliswaar te onderscheiden, maar minder te scheiden, delen van het openbaar bestuur. In welke vorm

23. W.J.M. Kickert(1991), t.a.p., pp.408-409, onderscheidt mindergeforceerd: privatiseren (oorspronkelijk) err wolledig afstoten.

24. S.E. Zijlstra , Ammotatie, bij voorzitter ARRS 18 mei 1993, S03.93.1111, AB 1994, 333.

25. E. Lutjens, 'Point of no retum' bereikt bij de complexe privatisering van ABP, in: NRC, 13 mei 1994 , P. 13.

26. H.A.P.M. Pont spreekt van de z. i. meer omwattende wariant "bestieren op afstand" (d.i. besturen inclusileff management). Evaluatie, in: I..H. Hoogteijling , Bestaren op afstand, IOO nr.34, 's-Graw., dec. 1991 , Pp. $91-98$.

27. Bevestigd wat betreft o.m. het CvdM. TK 1986-1987, 19136, nr.27a, p.4; H.M. Linthorst, De Mediawel. in: A.A, nr .6. juni 1988, pp.379-390, i.h.b. p.384; I.P. Balkenende, a. w., p.164; J.H.J. van den Heuwell, Mediabeleid in de interventiestaat, in: E.M.H. Hirsch Ballin e.a., Massamedia d staatsrech, 1989 , Zwwalle, p.82. 
ook, het is en blijft overheidsbestuur. Hier wordt het spreken van een rijksoverheid in enge betekenis (d.w.z. exclusief verzelfstandigde diensten) en rijksoverheid in ruime zin (d.w.z. inclusief verzelfstandigde diensten) duidelijk. ${ }^{28}$ "Verzelfstandigde lichamen of lichamen van functionele decentralisatie blijven binnen de overheidssfeer. Het vervangen. van rijksambtenaren door een even groot aantal ambtenaren in zelfstandige bestuursorganen is dan ook geen vermindering, maar alleen een verschuiving van personeel. " 29 30

Te constateren is slechts een, min of meer beperkte, beteugeling. "De overheidsbemoeienis met alle functies (van de gehele bedrijfskolom voor een bepaald overheidsprodukt JGLVN) blijft wel gehandhaafd, maar wordt op 'arms length" gebracht." 31 De betrokken takuitvoering wordt niet alleen in juridisch-organisatorisch opzicht van het departement afgesplitst. Deze wordt ook niet meer langer onder (volledige) ministeriële verantwoordelijkheid verricht.

Voor politici blijft het helaas moeilijk om afstand te houden. Het adagium 'overheid op afstand' is bij voorbeeld expliciet neergelegd voor het functioneren van het Commissariaat voor de Media. ${ }^{32}$ De wijze, waarop het beginsel in praktijk wordt gehanteerd, is veel betekenend. Ondanks de voorgestane depolitisering wordt van de ene ministeriële zijde onverbloemd gedreigd met overheidsingrijpen tegen toenemend geweld op de televisie, en van de andere departementale kant opgeroepen om tijdens de verkiezingscampagne wan 1994 af te zien van het kopen van reclamespots op de commerciële zendlers. ${ }^{33}$ Hoewel het slechts kleine voorbeelden zijn, is het duidelijk dat ze grote gevolgen kunnen hebben. In de kern tasten ze mogelijk de verantwoordelijkheid van de verzelfstandigde toezichthoudende entiteit aan.

Het publiekrechtelijk karakter van de betrokken overheidstaak blijft na verzelfstandiging gehandhaafd. Anders dan bij de eerder genoemde privatiseringsvormen, gaat het niet om terugtred ${ }^{34}$ van de centrale overheid. Terugtred van de overheid betreft a. vermindering van overheidszorg of b. versterking van de marktwerking. Bij verzelfstandiging is van geen van beide sprake. Terugtred verschilt van, de woor verzelfstandiging nodige, decentralisatie. Bij decentralisatie verandert in principe niets aan de omvang of intensiteit van overheidsinterventie. Wel tendeert decentralisatie naar laatst genoemde vorm van terug. treden. Immers, ook taakuitoefening door gedecentraliseerde organen kan tot betere

28. Commissie-Wiegel, Naar kerndepariementen, kiezen voor een hoogwadardige en flexibele rijkstienst, TK $1992 \% 1993,21427$, ar. 51, p.27.

29. SGP-kamerlid Van der Vlies tijdens debat Grote efficiency operatiedafstanking rijksowerheid. TK 77, 7 mei 1991, p.4353.

30. "Door verzelfstandigingen (in de periode 1985-1992 - JGLwN) is de personeelsterkte van de rijksdierust in de afgelopen jaren met nüm zes procent gedaald. [...] De nog te realiseren plannen voor verzelfstand jgingen leiden tot een verdere reductie wan de personeelssterkte van de rijksdienst mett nog eens ruim dertien pracent." Aldus H. de Groote.a. , Kerngegevens openbaar bestuwr, IOO-rapport nr. 51 , "s-Gravienhage, sept. 1993, pp.63-74, i.h.b. p.73.

31. Rapport van de werkgroep juridische aspecten van privatisering, ministerie van funanciën, 1985, p.2.

32. Medianora, TK 1982-1983, 18035, nr.1, pp.8-10.

33. Zie Politieke reclame, in: NRC, 1 febr. 1994, p.8.

34. F. Fleurke en P.J. de Vries, Terugtred wan de overheid uit de wolkshuisvesting, in: F. Fleurke, H. van de Graaf en J.P. Verhoogt (red.), Minder staat, meer samenleving; Beschouvingen over de terugrredende verzorgingsstaat, serie over politiek, bestuur en communicatie. Amsterdam, 1990, pp.49-50. 
resultaten uit oogpunt van efficiëntie en effectiviteit leiden. ${ }^{35} \mathrm{Zo}$ is decentralisatie mogelijk als publieke variant van versterking van de marktwerking te beschouwen. Hierbij moet wel goed in de gaten worden gehouden, dat verzel fstandiging (naar met name zelfstandige bestuursorganen of agentschappen) geen effectieve winstprikkel in zich draagt. ${ }^{36}$ Wel wordt in sommige sectoren (bij voorbeeld openbaar vervoer), die rijp zijn voor verzelfstandiging, bij dit verzelfstandigingsstreven "quasi-concurrentie" of andersoortige "concurrentiecreatie" ingebouwd. ${ }^{37}$ Is echter het bereiken van optimale winst het belangrijkste doel, dan is concurrentie gerichte privatisering geboden.

Voorop bij verzelfstandiging staat de probleemstelling van een optimale inrichting en organisatie van het openbaar bestuur. Van wege de fundamenteel verschillende bestuurlijke en staatsrechtelijke invalshoeken van privatiserings- en verzelfstandigingsbeleid, is het pleidooi voor hun ontkoppeling terecht. Voor verzelfstandiging is een breder beleidskader wenselijk. De term privatisering dient bij woorkeur te worden gereserveerd voor situaties, "waarbij het uitdrukkelijk gaat om beëindigen van overheidstaken en het afstoten daarvan naar de marktsector" ${ }^{38}$

Recente regeringsstukken geven blijk van dit onderscheid. ${ }^{39}$ Privatisering en verzelfstandiging zijn twee op zich zelf staande grootheden. Daarom wordt het begrip privatisering in enge zin opgevat. Voortaan omvat de term alleen volledige afstoting of uitbesteding, "met dien verstande dat daartoe ook gerekend wordt creatie van een volledig op de marktcondities werkend bedrijf waarvan de eigendomstitels echter (voor als nog) bij de overheid berusten en stichtingen die volgens het beginsel van kostendekking werken en die geen specifieke bescherming - bij voorbeeld in de vorm van gedwongen winkelnering - genieten". Daarnaast wordt verzelfstandiging gehanteerd als apart verzamel-

35. Zile echter de terechte wijfel van het organisatie-adviesbureau W.L. de Galan-groep te Bussum, dat in 199.4 in samenwerking met de vakgroep bedrijfskunde van de Landbouwuniversiteit te Wageningen een rapport ower de prestatieverbetering van twintig verzelfstand igde eenheden verricht. Halfslachtige privatiseringen of tyybride tussenvormen van werzelfstandiging zijn. door het in stand houden van funanciele of beleidsmatge banden wan uit de rijksoverheid, (als "politiek veilige" vormem) witeindelijk efficiëntie- en efficiency belemmerend. Hierover Hoe meer wijheid, des te effectiever de verzelfstandiging; Voormalige rijksdiensten onderzocht, in: BB, nr. $31 / 32,12$ aug. 1994, p. 3 .

36. D J. Kraan, Verzelfstandiging bezien wanait de bureakcratietheorie II: normkostenfinanciering, in: N.P. Moll en H.A.A. Verbon, a.w., pp.107-125. O.g.v. het bilateral monopolie-model stelit auteur o.a. invoering van nomkostenfinanciering als voorwaarde voor verzelfstandiging.

37. R.J. in 't Veld in zijn (syllabus)bijdrage aan het congres Verzelfstandigen buj de rijksoverheld, woorfgang of wooruitgang. georganiseerd door het NSC en stichting MC, te 's-Gravenhage, 30 nov. 1993, pp.1-6, i. h.b. p.4."R.J. in "t Veld, De kerntakenbenadering bij de Rijksowerheid: onderwerp wan gesprek, in: C. Sips en P.H.J. Vrancken, De kerntakenbenadering bij de rijksoverheid, IOO-rapport nr.59, 's-Gravenhage, apmil 1994, pp.7-15, i.h.b. p.13.

38. H.J.L. vander Linde, Verzelfstandiging van departementstaken; Privatisering van het openbaar bestuur? in: Bestunr, nr 9, okt. 1989, p.276; Vgl. A.R. Edwards, Privatisering: een publieke keuze, VNG-studies nr.4, 's-Gravenhage, 1983, p.15.

39. Deze tweedeling is "een stap in de goede richting". Aldus H.J. de Ru, De lange weg naar privatisering in Nederland, in: TVVS, nr.5, 1992, pp.111-116, i.h.b. p.112

40. "TK 1989-1990, 21632, nr.1, P.3. 
begrip. Daartoe zijn veel organisatievormen te rekenen. Belangrijk indelingscriterium is de mate van ministeriële verantwoordelijkheid voor de verzelfstandigde taak of activiteit. Kritiek ter zake is ontstaan ${ }^{41}$, omdat de regering nog een tweede definitie ${ }^{42}$ hanteent. Weliswaar sluit die omschrijving aan bij boven genoemde definitie. Maar het grootste deel van die omschrijwing is weg gelaten. Slechts de privatiseringsvorm afstoten komt in beeld. Criterium daarbij is of de betreffende taak al dan niet een bestuurstaak is. Zo wordt de uitbestedingsvariant stilletjes uit het oog verloren. Vermelding verdient dat deze kritiek uitgaat van de veronderstelling, dat een uit te besteden taak haar karakter als bestuurstaak behoudt. ${ }^{43}$ De overheid blijft verantwoordelijk voor produktiefinanciering en -planning.

In elk geval leiden de regeringsstandpunten tot de volgende conclusie. Als privatiseringsvariant heeft verzelfstandiging geen betekenis meer. ${ }^{44}$ Het is omgekeerd. Privatisering is tegenwoordig een verzelfstandigingsvariant.

De duidelijkheid eist begripsbepaling. Onder privatisering zijn de volgende verschijnselen te brengen. 45

Ten eerste, het aan de particuliere sector overdragen van tot dan toe door staatsbedrijven en provinciale of gemeentelijke takken van dienst of nutsbedrijven werrichte bedrijfsmatige activiteiten, betreffende - voor de burger essentiële - goederen. Het algemeen belang vereist, dat die essentielle goederen worden geproduceerd. Dit hoeft niet door de overheid zelf, als monopolist, te geschieden. Wél is het haar taak te garanderen, dat die goederen kwantitatief en kwalitatief voldoende worden geproduceerd. Hiertoe staan de overheid de gebruikelijke staats- en bestuursrechtelijke sturing- en toezichtsinstrumenten ter beschikking: regelgeving, vergunning- en subsidiestelsels, meldings- en herinvesteringsplichten als mede controle-, opsporings- en sanctiebevoegdheden.

Vaak is privatisering een proces. De meeste reorganisaties, waarvan de omwenteling bij de vroegere PTT een duidelijk voorbeeld is, lopen "van de bureaucraat via de paradijsvogel (organisatie die wel alle middelenvrijheden kent, maar niet marktconform hoeft te handelen) naar de ondernemer". ${ }^{46}$

In dit verband is de term 'privatiseringsmalaise' bekend. In datgene wat in Nederland privatiseringsbeleid heet, wordt dan niet meer dan een voorbereiding tot verzelfstandiging

41. C.A. Schreuder, Privarisering, functionele decentr. en de wennootschap als hun probleemkind, in: NTB, nr.8, $1991, \mathrm{p} .226$.

42. Functioneel bestuur: warom en hoe? TK 1990-1991, 21042, nr.4, p.9.

43. Dit ondersteunt H.G. Lubberdink, Kronieken bestuurlijke organisatie, in: NTB, nr.10, 1990, p.323. Datrom dient, $z . i_{\text {, }}$ uitbesteding van een bestuurstak, strikt genomen, niet als privatisering te worden aangeduid."

44. Desondanks ziet J.A. Bijker, a.w., p.25, verzelfstandiging (uitgezondlerd interne verzellfstandiging) als privatiseringsworm.

45. Vergelijk -ten dele- de eendere publikatie van F.A.M. Stroink en J.G.L. van Nus, Besturursrechtelijke consequenties van privatisering, in: S\&V, nr.3, mei/juni 1994, pp.61-65.

46. J.W.L.H. Croonen en P.G. Janssen, Verzelfstandiging van organisaties; Ofwel het balanceren tussen "paradijwogel" en 'bolser', in; OMn, nr.1, 1994, pp.16-19, i.ll..b. p.17. 
gezien. Dat betekent een privatisering 'langs de weg der geleidelijkheid', die niet direct staatsinkomsten uit verkoop op levert. De tegenvallende resultaten van het privatiseringsbeleid heeft de regering dus eigenlijk aan zich zelf te wijten. In de meeste gevallen van privatisering, te weten publiekrechtelijke beheersvorm (type staatsbedrijf) als voorbereiding tot daadwerkelijke verzelfstandiging, omzetting in een privaatrechtelijke rechtspersoon en volledige privatisering, niet voltooid. Reeds het tweede stadium geeft problemen. Ook de introductie van agentschappen maakt duidelijk dat echte privatisering voor als nog illusoir is. ${ }^{47}$

Om privatisering meer leven in te blazen luidt het betoog om een Dienst privatisering (dienst Financiën-Binnenlandse zaken Privatisering) op te richten. ${ }^{48}$ Tot nu toe toont de overheid zich, in haar privatiseringsbeleid, wel zeer schuchter. Wil zij geloofwaardig overkomen en zich een aandeel op de Europese markt verwerven, dan is daadkracht geboden onder het motto: echt privatiseren of niet.

Inderdaad wordt de weg naar privatisering soms erg lang gerekt. De centrale overheid hanteert dan allerlei kunstgrepen om (nog) oneigenlijke privatisering te legitimeren. Is een maal besloten om op den duur te komen tot gelijke markvoorwaarden, met andere woorden ligt privatisering in het verschiet, dan kan bij voorbeeld functioneel bestuur een zinvolle rol spelen.

Denk aan het, in een privaatrechtelijke onderneming omgezette ${ }^{49}$, staatsbedrijf der Posterijen, Telegrafie en Telefonie. De Staat is daarvan aanvankelijk $100 \%$ aandeelhouder. Per juni 1994 begint de rijksoverheid met de verkoop van aandelen. ${ }^{50}$ De daarmee gepaard gaande Amsterdamse effectenbeursgang van de vernieuwde $\mathbb{P T T}^{51}$ is omstreden. ${ }^{52}$ De kritiek spitst zich op toe zowel de bij de concessiehouder mogelijk toe te passen sancties (bestuursdwang, last onder dwangsom, en administratieve boete) als het 'bijzondere aandeel' dat de Nederlandse staat in KPN nv heeft. ${ }^{53}$ Dat garandeert, op voor de vennootschapswereld unieke wijze, overheids(bedrijfs)bemoeienis. Middels het activeren van de noodmaatregel op het bijzonder aandeel, waardoor de bescherming het karakter krijgt wan een "ingenieuze tweetrapsraket" 54 , heeft de Staat - na verkoop van de gewone aandelen - het recht om, nota bene tegen de zin van de KPN nv-directie in en mogelijk op kosten van KPN nv, met preferente aandelen weer een meerderheid te

47. H.J.de Ru (1987), a.w., pp.111-116.

48. P. Felix, Schandolige venwaarlozing moet snel worder ingehaald, in: NRC, 11 mei 1994, p.21; Meer algemeen Felix en co., De prakrik van het privariseren. Amsterdam, oktober 1994.

49. Machrigingsiwet PTT Nederland $n$, Stbl. 26 okt. 1988, 521 .

50. In juni 1994 stoot de Stat een eerste tranche KPN-alandelen af. H. Wammes, Kleurloos imstifuat PTT werd marktrijp, in: NRC, 30 maart 1994, p.19; Eind maart wordt bekend dat de Stat eind 1995 of witerlijk begin 1996 een tweede tranche aandelen in KPN verkoopt. Staat verkoopt tweede KPN-aandelen, in: NRC, 24 maart 1995, p.1. Een derde en een vierde tranche volgen waarschijnlijk daarna.

51. Als geregeld in Wet bewrsang KPN, Stbl. 1994, 159.

52. P. Wessels, 'Beurs kan driedubbele bewcherming KPN niet ioestaan", in: NRC, 15 april 1994, p.11.

53. Hierover terecht kritisch o.a. C.A. Schreuder, Publiekrechtelijke taken, private rechtsvormen, Deventer, 1994, pp.288-301.

54. M. Tamminga, KPN krijgt het beste van twee werelden, in: NRC, 17 mei 1994, p.13. 
behalen als het algemeen belang daartoe noopt ${ }^{55}$. Bovendien valt betrokken beursgang onder de terreur van tweeslachtigheid: "Als toezichthouder op de financiële markten heeft: de minister al aangekondigd met wetgeving te komen wanneer beursfondsen hun bescher mingsconstructies onvoldoende afbreken. Anderzijds wil de overheid als aandeelhouder van KPN en regelgever in de telecommunicatie dat het nutsbedrijf optimaal beschermd naar de beurs gaat" ${ }^{56}$

Kennelijk wil de Staat met KPN nv punten scoren op het gebied van bedrijfseconomisch verantwoord handelen. Bedoelde Koninklijke PTT Nederland nv (met als twee mooiste dochters respectievelijk PTT Telecom bv en PTT Post bv) onderscheidt zich echter van reguliere ondernemingen. Immers, aan de nv is van rijkswege een exclusieve concessie verleend voor het (tegen redelijke vergoeding op grond van een tariefbeheersingsstelsel en onder overige gelijke voorwaarden en voldoende kwaliteit) aanleggen, beheren en exploiteren van basisvoorzieningen ${ }^{57}$ in het post- en telecommunicatieverkeer. ${ }^{58}$ Daarmee wordt de nv een gunst, maar ook een verplichting om de hals gehangen. Op uitvoering van die concessietaak ziet het regelgevend orgaan Hoofd Directie Telecommunicatie en Post van het ministerie van verkeer en waterstaat (overigens aanvankelijk nog onvoldoende) toe, waardoor een merkwaardige dubbelrol van de rijksoverheid als (in eerste instantie: enig) aandeelhouder onderscheidenlijk regelgever/toezichthouder ontstaat. ${ }^{59}$ Van wege deze fallende controle, de voortdurende dreiging van kruissubsidiëring (dat wil zeggen dat de concessionaris de diensten, die hij in een concurrerende markt aanbiedt, subsidieert uit de opbrengsten van de nutsdienst) ${ }^{60}$ en van uit het perspectief op een markt waarin niet langer de PTT als enig concessiehouder heerst, maar een aantal vergunninghouders de gebruikers bedient, luidt het voorstel om een toezichthoudend zbo ter regulering van de - als horizontaal aangestuurd te beschouwen - telecommunicatiemarkt op te richten: t.w. de rechtspersoon sui generis Commissariaat voor de Elektronische Informatievoorziening ${ }^{61}$, te splitsen in een Dienstenkamer en een Infrastructuur- en

55. Kritisch daarover L. Timmermans, Prospectus $K P N_{\text {a }}$ in: TVVS, nr.6, 1994, pp.161-162.

56. M. Tamminga en P. Wessels, Staat heeft bij beursgang KPN twee petten op, in: NRC, 27 april 1994 , p.15; Ook P. Wessels, Bescherming KPN smet op blazoen Staat en beurs, un: NRC, 14 mei 1994, p. 14.

57. Als aangegeven in het Beshut opgedragen Telecommunicatiediensten. Stbl. 1988, 551, gewij|z., Stbl. 1994 , 21.

58. Hiermaast bestaat de verplichting een ieder tegen vaste tarieven huurlijnen aan te bieden (art. 4 Wet telecommunicatie voorziening) en machtigingen te verlenen aan telecommunicatie-inrichtingen wan bijzondere aard of geringe omvang (hfdst. III Wtv).

59. Terecht kritisch W. Hulsink en G.J. Kemme, Van publiek monopolie naar gereguleerde markt? Bestwurs. kundige en institutionele aspecten wan de openbare elektronische informatievoorziening. in: $\mathrm{BWn}$, nr. 5 , 1992, pp.414-445; Idem dito J.M.E. Freije en A.T. Ottow, Telecommunicatie: van monopolie naar wije markr?, in: NJB, nr.22, 3 juni 1994, pp.745-749, i.h.b. p.748.

60. Over "cross-subsidisation by regulatory monopolies ${ }^{\circ}$ M.C.E.J. Bronckers, Cross-swbsidisation in EEC competition law, in: J.H.V. Stuyck en A.J. Vossestein, State entrepreneurship, national monopolies amd european community law. Deventer/Boston, 1993, pp.103-112, vgl. in de zelfde uitgave de opvattingen over kruissubsidièring in relatie tot privatisering $T$. $\mathbb{R}$. Ottervanger, Transparancy in the relations between member states and public undertakings: state aids, pp 73-85.

61. E.J. Dommering en N.A.N.M. van Eijk, Agenda voor de publieke discussie over telecommunicanie, bericht aan het parlement, Nota, 18 nov. 1993, pp. 1-23, i.h.b. p.20; Herhaald door E.J. Dommering, Onze wergever en de innovatie: omroep-en relecommunicatie na de kabinetsformatie, in: MF, nr. 5,1994 , pp.50-53/64. 
transportkamer waarmee respectievelijk het Commissariaat voor de Media en de HDTP vervangen kunnen worden ${ }^{62}$. Voor oprichting van zo'n deskundige, opmerkzame, flexibele en non-commerciële marktregulator spreekt een kamermeerderheid zich, n.a.v. daartoe ingediende moties ${ }^{63}$, uit. ${ }^{64}$

Wat betreft het voor de veilingmarkt met schaduwprijzen rijpe frequentiebeheer, ten dele in handen van de PTT, lijkt bovendien oprichting van een zbo, te weten de rechtspersoon sui generis Commissariaat voor de Frequenties, als waakhond "tegen misbruik gedurende de geleidelijke overgang naar marktgeoriënteerde methodieken" inderdaad wenselijk. ${ }^{65}$ De betrokken bewindspersoon betracht even wel terughoudendheid en voelt slechts voorkeur voor een "enigszins verzelfstandigde" dienst als een agentschap. ${ }^{66}$

62. I.C. Arnbak e.a., Yerbinding en Ontvlechting in de Communicatie; Een studie naar toekomstig overheidsbeleid voor de openbare elektronische informatievoorziening, Amsterdam, 1990, p.127-129.

63. Debat Tweede Kamer inzake Hoofdlinennotitie, UCV 37, 21 maart 1994, pp.37-42, TK 1993-1994, 21693, nr. 13; Na de UCV aanvaardt de kamer de motie-Van cer Hoeven c.s. (TK 1993-1994, 21.693, nr. 18), waarin wordt aanbevolen de instelling van een zbo te owerwegen en in dat kader de Wet op de telecommunicatievoorzieningen te herzien. Bij de behandeling van de begroting wan het ministerie wan verkeer en waterstaat wordt het kamerstandpunt nog eens uitgediept via de motie-Van Zuijlen (TK 1993 1994, 23900 XII, nr.12) waarin wordt verzocht om oprichting van een zbo voor de overgangsperiode naar volledige concurrentie"; Over het belang van zo'n marktregulator G.y. Kemme, The Electronic Powarway, in: M1F, na.7/8, 1994, pp.81-85, i.h.b. p.85.

64. Ondat de minister van verkeer en waterstaat, t.w. A. Jorritsma-Lebbink, het niet verantwoord acht om in een geforceerd tempo bedoeld zbo tot stand te brengen (gegeven: a. het risico van overdracht van ver gaande beslissingsbevoegdheden aan het zbo, en het daardoor onttrekken wan min of meer discretionaire besturende macht aan de ministeriële verantwoordelijkheid, wegens het ontbreken vam wetgeving; en b. het gevaar van vertraging van het liberaliseringswetgevingsproces), stelt zijeen alternatieve aanpak voor. Instelling wan een zbo wordt meegenomen in de definitiewe herziening van de Wet op de telecommunicathe voorzieningen, waardoor ruimte is voor zorgvuldige voorbereiding vain het beoogde zbo. In de periode voordat realisatie van het zbo feit is, wordt alwast naar de verzelfstandiging toegewerke in de zin dat binnen de HDTP alle toezichtstaken worden ondergebracht bij een afzonderlijke directie Toezicht Netwerken en Diensten. Met deze directie wordt in aprill 1995 een start gemaakt. Zie brief mimister van verkeer en waterstatat aan de voorzitter van de Tweede Kamer der Staten-Generaal inzake de motie-Van Zujlen, d.d. 6 maart 1995, 's-Gravenhage, p.3. De TND heeft tot missie: "a. de grenzen van exclusieve en speciale rechten te handhaven met het oog op het doel wastvoor zij zijn verleend: $b$. goede dienstverlening tegen redelijke voorwaarden aan burgers en bedrijven te bevorderen; en c. een redelijke verhouding te handhaven tussen de kansen en belangen wan nieuwkomers op de markt en die van dominante aanbieders". Hierbij zijn haar hoofduaken: "1. het uitoefenen wan toezicht op de handhaving van exclusieve en speciale rechten; 2 , het verlenen wan wergunningen en machtigingen voor telecommunicatie-infrastructuren en -diensten; 3 . het toezien op de naleving van de voor de concessionaris en vergunninghouders geldende regelgeving en vergunningvoorwaarden; 4 . het bemiddelen en zo nodig beslechten van geschillen tussen marktpartijen; en 5 . het wan uit de eisen van de toezichts-en uitwoeringspraktijk leveren van een bijdrage aan de ontwikkeling van beleid en regelgeving". Aldus Voorlopige beschrijuing van de organisatie van de projectirectie toezicht netwerken en diensten; In thet overleg eind meil 1995 met de vaste kamercommissie voor verkeer en waterstaat maakt de minister kenbaar niet in staat te zijn om wón 1997 een onafhankelijk toezichthouder op de telecommunicatiemarkt in leven te roepen. Zie Telecom-bewaker nog ver weg, in: NRC, 24 mei 1995, p.23.

65. Raad voor verkeer en waterstaat, Uitwerking frequemtiebeleid, 5 maart 1993, 's-Gravenhage, p.15; NOZEMA, Van beheer naar beleid, Toewizing en gebruik van etherfrequenties in Nederland, april 1993 . Zoetermeer, pp 15-16; Mediarad, Advies inzakefrequentiebeleid, "s-Gravenhage, 3 april 1992, pp.22/29.

66. Stert. 22 juni $1994,116$. 
Ook bestaan sterke argumenten voor het pleidooi te komen tot instelling van een zellstandig bestuursorgaan in het algemeen "belast met het toezicht op kartelafspraken en machtsconcentraties", omdat de Nederlandse overheid in toenemende mate wordt geconfronteerd met Europese en internationale krachtige concurrentie. ${ }^{67}$

Kennelijk bestaat er een tendens om, ter begeleiding van privatiseringsprocessen ${ }_{\text {inaf- }}$ hankelijke regelgevende en toezichthoudende bestuursorganen op nationaal niveau in te stellen. Bij processen van privatisering van de vraagkant, via versterking van de marktwerking en vermindering van kostprijssubsidies, worden 'zachte" oneigenlijke privatiseringen mogelijk gecombineerd met instelling van nationale onafhankelijke toezichthouders. ${ }^{68}$ Dergelijke toezichthouders hebben inderdaad bestaansrecht. In een wereld waar regelgeving, in het streven naar een vrije markt, meer en meer van uit een Europese en een internationale gemeenschap wordt geredigeerd ${ }^{69}$, blijft de noodzaak om een zekere consumentenbescherming ${ }^{70}$ op plaatselijk, regionaal of landelijk niveau te bieden. Van uit het perspectief op een vrije markt waarin niet alleen het belang van aanbieders maar ook die van afnemers wordt benadrukt is het volgende verhelderende betoog terecht: "In many sectors, such as post, telecommunications, media and energy, internationalisation of the markets concerned results in deregulation at national level and reregulation $^{71}$ at Community level. The general trend [...] seems tot provide for more market and less 'social securisation', possibly followed by more internalisation. These trends involve of necessity more competition at the supply side of these markets and, hence, enforcement of the competition rules. Many of these supply side driven competition issues, especially those relating to internationalisation and competitive structure of these markets ('level playing field'), generally create involvement at Community level. On the other hand these very same sectors also generate a multitude of regional, or even local, competition issues: e.g. at local distribution or users level, and, specifically at the demand side, protection of the position of the (private) consumer. These issues may reach to a certain extent beyond the grasp of Community Law, but need to be addressed in order to make and keep these markets competitive and deregulated at both sides of these

67. W. Hulsink en G.J. Kemme, t.a.p., p.440.

68. A.T.L.M. van de Ven, Verzelfsrandiging en bestuurlijke decentralisatie, in: S\&V, nr.3, mei/jumi 1994. pp. $61-65$, i.h.b. p. 63 .

69. Ter ondersteuning van het proces Europese regelgewing tot op zekere hoogte the harmoniseren, luidt het voorstel te komen tot instelling van onafhankelijke, toezichthoudende instanties die communantaine regelgeving centraal worm geven en coôndineren. Denk aan de ideeën rondom oprichting van een Europese centrale bank. D. Heremans, Economics aspects of the second banking directive and of the proposal for a directive on investment services in the securities field, in: J. Stuyck. Financial and monetary integration in the European Economic Conmumily, Deventer/Boston, 1993, pp.37-55, i.h.b. p.53.

70. Zie overigens art. $3 \mathrm{~s} \mathrm{jo.} \mathrm{art.} 129 \mathrm{~A}$ EG-verdrag waarin de versterking van (een hoog niveau van) consullmentenbescherming als doelstelling van gemeenschapsrecht centraal staat.

71. W. Kleinwächter, Broadcasting and Telecommumications in Transition: The Wind of Change in Eastem Europe, in: W.F. Altes e.a.. Information law towards the 21st century, Dewenter/Boston, 1992, pp. 105 116, verhaalt echter wan weerstand tegen reregulering (i.c. in de sfeer van telecommunicatierecht). Private ondernemers zien al weinig in regulering, laat staan in reregulering. In plaats daarvan roepen zij om zelfregulering. 
markets. This means that the role of national competition authorities, which so far has been rather limited in the Netherlands, may (have to) gain considerable importance." 72

Ten tweede, tevens tot privatisering te rekenen zijn allerlei feitelijke activiteiten die op contractbasis uit handen worden gegeven. Denk aan het schoon houden van kantoren of het onderhouden van plantsoenen. De bestuursrechtelijke consequentie er van is vermindering van overheidspersoneel (hetzij werknemers met een ambtenaarlijke aanstelling hetzij werknemers op arbeidscontract). Afstoting van bedoelde taken is goed mogelijk. Immers, de overheid kan beperkt blijven tot de uitoefening van publieke bevoegdheden, waarmee de overheid zich als eigenlijke overheid, dat is als gezagsorganisatie, manifesteert.

Deze vorm van privatiseren is niet zo onschuldig als het beeld doet vermoeden. Bij het door de particuliere sector laten uitvoeren van, wan oudsher aan de overheid opgedragen, dienstverrichting als vuil ophalen, schoon maken of verzorgen van kantinewerkzaamheden, eist de rechter bescherming van rechten van werknemers. Dit blijkt uit de geruchtmakende zaak waarin drie straatvegers uit Eastbourne een heldenrol toekomt. Het trio wordt, samen met 30 collega's, in 1990 op staande voet ontslagen door hun nieuwe werkgewer UK Waste Control, aan wie de betrokken gemeente, die van de centrale overheid moet bezuinigen, de taak van vuil ophalen heeft overgedragen, omdat het particuliere bedrijf UK Waste Control dat goedkoper dan de gemeentereiniging kan doen. Voor de personen die wel mogen blijven werken voor de private onderneming worden eenzijdig nieuwe arbeidsvoorwaarden ingevoerd: loonswerlaging, vakantiekorting en het schrappen van ziekte-uitkeringen. De begin juni 1994 gedane uitspraak van de Europese rechter ${ }^{73}$ getuigt er van dat deze zich het lot van de straatvegers aan trekt. Het oordeel bevestigt het recht van alle werknemers, al dan niet vakbondslid, om tijdig geraadpleegd te worden wanneer sprake is van massaal ontslag of van overname door een andere bedrijfswoerder. Gevolgtrekking uit dit arrest van het Europese Hof is, dat "bedrijven waaraan (binnen de onderneming van de uitbesteder uitgevoerde) werkzaamheden worden uitbesteed - of ze dit nu leuk vinden of niet - van rechtswege werkgever worden van de aan de activiteiten verbonden werknemers van de uitbesteder of van de branchegenoot die voordien met de werkzaamheden was belast.". ${ }^{74}$ Het behoud van rechiten moet worden

72. I.G.F. Cath , D.F. Edens, Hil. Hulsman en K. Sevinga, Competition law implications of deregulation and priwatisation in the Netherlands, in: SEW, nr.5, meil 1994, pp.353-385, i.h.b. pp.384-385.

73. Commissie us. Verenigd Koninkrijk wan Groot-Brittamië en Noord-Ierland, HvJ EG (C-382/92 en C$383 / 92), 8$ juni 1994, NJ 1995, 194 en 195

74. A.M. Lutmer-Kat, Wanneer is sprake vam overgang van onderneming?, in: TVVS, nr.8, 1994, Pp.197201 , i.h.b. p.201. Auteur, die een aan het HWJ EG tegenowergestelde opwatting verkond igt (d.w.z.: hoewel minder bij uitbesteding, maar wel büj afstoting van activiteiten die niet tot de kemactiviteitem van een ondierneming behoren - wia verkoop, verhuur of verpachting wan bedrijfsonderdelen of door verzelfstandigingsoperaties - is $z . i$. sprake van overgang van onderneming), meent dat bedioeld arrest van 8 juni 1994 en andere relevante uitspraken over de EG-richtijn 77/187 (Publ. EG 1977, L 61) inzake overgang van ondernemingen "een bedreiging vormen woor privatiseringsoperaties, als verzelfstandiging van pablieke diensten of uitbesteding aan derden van overheidsactiviteiten ${ }^{\mathrm{m}}{ }^{\prime}, P$. Vlas, Owergang wan ondermemüngen, in: TVVS, nr. 1, 1995, pp. 12-13, bespreekt het, vermelde richtlijn vervangende, woorstell inzake livet behoud van rechten en plichten van ondernemingen (Publ. EG 1994, C 274, 1 okt. 1994, p. 10). Zie 
gewaarborgd, ongeacht het aantal werknemers, dus ook als slechts één werknemer door overdracht wordt getroffen. ${ }^{75}$

Al met al is te constateren dat het paradepaard 'privatisering' van het eerste kabinet Lubbers, de wagen niet meer trekt op de weg van kabinet-Lubbers III. Privatisering staat op de zijbaan. Haar prominente positie moet zij af staan aan het wonderkind met de naam "verzelfstandiging".

Slechts in de marge is sprake van privatisering: onderbrenging van activiteiten in aparte $n v$ "s, waarbij de rijksoverheidl enig aandeelhouder is, en verkoop van grote staatsdeelnemingen op de beurs als Postbank, DSM of KPN nv.

Juist de paternalistische positie van de Staat bij de medio 1994 begonnen verkoop van de aandelen van KPN nv doet terecht weer enige aandacht voor het privatiseringsbeleid ontstaan.

Omdat met de voorkeur voor verzelfstandigingsoperaties het opzetten van een helder privatiseringsprogramma wordt verwaarlloosd, dreigt - daar waar nog wordt geprivatiseerd - privatisering door beschermingsconstructies (tot behoud van een sterke positie van de overheid in het te privatiseren bedrijf) te mislukken. "De overheid kampt met de gerechtvaardigde vraag 'What if?' en dan bedenkt zij steeds nieuwe ingewikkelde constructies met als gevolg dat het pak wel in de kast wordt verhangen, maar het de kast uiteindelijk niet uitkomt. " ${ }^{76}$ De Staatsdrukkerij- en uitgeverij, in huidige vorm, geldt bij uitstek als triest voorbeeld. ${ }^{n}$ Ook KPN nv is een omstreden voorbeeld van privatisering. De daarbij gegeven beschermingsconstructies leveren commotie op. En de aanwending van het overgrote deel van de opbrengst uit de eerste aandelenverkoop stemt ook niet iedereen tot tevredenheid. Veel geld verdwijnt, als bijdrage aan het financieringstekort, in de beurs van de minister van financiën.

74. $\rightarrow$

specifiek over deze problematiek J.A. Bijker, Personeelsaspecten na priwatisering, " 5 Gravenhage, 1992 en A.T.J.M. Jacobs, Een Europees-sociaalrechtelijk aspect van priwatisering, in: juridisch en fiscaal vijdschrift Priwatisering, nr.2, 1994, pp.4-7, in aanmerking nemende dat de artt. 7A:1639aa-dd BW niet van toepassing zijn op ambtenaren, zie M.J. van der Vliet, Overgang wan eem onderneming., De artikelem $1639 a d-d d B W$, actualia ondernemingsrecht ar.7. Amhem, 1994.

75. Schwidt ws. Spar- und Leihkasse der fribheren Amter Bordesholm, Küel und Cronshagen, HwJ EG (C. 392/92) 14 april 1994, Jur. 1994, p. [-1311, NJ 1995, 149. I.c. wordt schoonmaakster Schmidt in dienst wan de Sparkasse, wegens verbouwing van het filiaal te Wacken welke vestiging zij schoon houdt, door Sparkasse ontslagen omdat Sparkasse de schoonmaakwerkzaamtheden voortaan opdraagt aan de furma Spiegelblank die de meeste overige Sparkasse-filialen reeds reinigt. Spiegelblank wil Schmidt wel aanne-men, maar dan tegen andere condities. Het hof bepaalit nu dat in het concrete gewal, waarin die aard van de werkzaamheden na overdracht niet verandert (het identiteitscriterium wan o, a. het arrest stichting Redmond, NJ 1992, 476), ongeacht het feit dat de schoonmaakwerkzaambeid slechts een nevenactiviteit wan de overdragencle Sparkasse is, en ook nu het niet een gehele ondernening maar enkel een filial van de Sparkasse betreft, voor de bescherming wan werknemers bij wijziging van onderneming moett worten zorg gedragen.

76. S.R. Schuit (advocaat Loeff Claeys Verbeke), geciteerd door W. van Enk, Jurist: overheid moet bedriyf terug kummen nemen, in: NRC, 2 juni 1994, p. 19.

77. Sdu is onder meer beschreven in congresbundel Loeff Claeys Verbeke, Nederland privatiseert, 's-Grawen-" hage, 1994. 
Met andere woorden, will privatisering geloofwaardig zijn, dan moet zij voldoen aan de nodige eisen. Die eisen zijn bij voorkeur neer te leggen in een privatiseringswet. In een privatiseringswet moeten essemtialia worden geregeld als: a. het recht van de overheid om geprivatiseerde bedrijven in moeilijkheden terug te kopen (vergelijkbaar met het recht van De Nederlandsche Bank of de stichting Verzekeringskamer om bij in nood geraakte banken of verzekeraars in te grijpen om te voorkomen dat een kettingreactie wordt veroorzaakt); b. de plicht van de overheid om voorafgaand aan privatisering een nuttige bestemming aan financiële opbrengsten te geven, bij voorbeeld investeringen; $\mathrm{c}$. het recht van het bedrijf op een inwerkingsperiode van vijf jaar, waarin marktaanpassing kan plaatsvinden en een fiscale afdeling kan worden opgezet; en d. de plicht van de overheid om - hoewel tegenstrijdig aan het mededingingsrecht - een 'bruidschat' aan het te privatiseren bedrijf mee te geven, denk aan de mogelijkheid van jaarlijkse opvoering van aardgasbaten bij DSM of monopolistische tariefstelling bij KPN nv. ${ }^{78}$

In een toekomstig privatiseringsbeleid speelt vooral de vraag hoe "het evenwicht moet worden gehandhaafd tussen voldoende marktwerking en mededinging enerzijds en regulerende normatieve randwoorwaarden woor publieke belangen anderzijds" . ${ }^{9}$

Als gezegd is privatisering een verzelfstandigingsvariant. Tegenwoordig legt het kabinet nadruk op verzelfstandiging. Dat het veld van verzelf'standiging, in het verlengde van de armoedige akker van privatisering, nog flink ontginning verdient, is duidelijk.

Verzelfstandiging kent het zelfdie probleem als privatisering. Gaat zij de ene keer niet ver genoeg, de andere keer reikt zij veel te ver. De banden met de rijksoverheid kunnen klemmen, maar Staat's strengen zitten soms zichtbaar te los. Vooral door het afstoten of het verzelfstandigen van overheidsdiensten met monopolies op de commerciële markt, creëert de Staat meer dan eens "monster van een monopolie". ${ }^{80}$ De in paragraaf 6.2.1 vermelde doelstellingen, die het gedachtengoed van privatisering en verzelfstandiging doordrenken, zijn fraaie ideologische uitgangspunten. Maar, pragmatisch gezien, stellen zij nauwelijks iets voor. Praktijkvoorbeelden van privatiseren en verzelfstandigen wijzen op het omgekeerde van efficiëntie en efficiency. Aan de casus van de geprivatiseerde Dienst informatievoorziening en de Rijksluchtvaartschool, het afgestoten Staatsvissershavenbedrijf, het verzelfstandigde Loodswezen ${ }^{31}$ als mede de op afstand van de overheid gezette Luchtverkeersbeveiliging ${ }^{82} \mathrm{en}$, als nu al te voorzien, ook de verzelfstandiging van de Rijksdienst voor het wegverkeer, kleven haken en ogen als de volgende. Bij de overheid en het bedrijfsleven ontstaan hoge kosten door de confrontatie met, vooral

78. $S_{n}$ R. Schuit, gecitteend door W, van Enk, t.a.p., p.19.

79. L. Geellhoed, geciteerd in Nederland kan nog veel privatiseren, in: NRC. 3 jumi 1994 , p. 11.

80. T.J. Meeus, Neelie Kroes liet een dure erfenis na, in: NRC, 30 sept. 1994, p.13.

81. Biy het onderzoek van het Algemene Rekenkamer naar de verzelfstandiging naar de Loodsdienst (TK 1988-1989, 212 10, nrs 1-2) worden, in het algemeen voor toekomstige privatiseringen en verzelfstandigingen, aanbevelingen gedaan inzake o.a. we coördinatie van het werzelfstandigingsproces, het opstellen van een draaibock, de tjdsplanning, de informatie aan de Staten-Generaal, en het niet in het veranderingsproces mee nemen van niet met reorganisatic samenhangende knelpunten.

82. Conform Wer Lchtwerkeer, Stbl. 1992, 368; Zie ook Luchtverkeersbeveiliging, TK 1993-1994, 23915, nis. 1-2. 
verzelfstandigde, overheidsdiensten die commerciële bedrijfs- of beheersvoering kunstmatig combineren met een monopolie op de markt. ${ }^{83}$ Onder opvoering van tarieven en inkomens van respectievelijk werkzaamheden en werknemers, worden kosten van wettelijke overheidstaken afgewend op overheid en bedrijfslewen. ${ }^{84}$ Deze problemen, waarover de Tweede Kamer het "principieel debat" moet (her)openen ${ }^{85}$, kunnen zich zeker voordoen bij het verzelfstandigen van toezichthoudende overheidstaken, die zich per definitie in hoge mate monopoloïde manifesteren. Bij een inderdaad wenselijke kamerdiscussie moet natuurlijk niet door het eenzijdig benadrukken van negatieve verzelfstandigingservaringen 'het kind met badwater worden weggegooid'. Het is juist zinvol, op grond van (positieve) ervaringen van reeds verzelfstandigde organisaties, te leren boe a. het 'afscheidsproces' van respectievelijk politiek verantwoordelijken en departementen en b. het 'heroriënteringsproces' van te verzelfstandigen organisaties, via het scheppen van de juiste condities en een neutrale regie, zo optimaal mogelijk kan verlopen. ${ }^{86}$

In het vervolg voert verzelfstandiging dus de boventoon. Verzelfstandiging is tweeledig. In geval dat diensten, die niet tot de departementale kern behoren, op een of andere wijze op grotere afstand van het bestuurscentrum worden geplaatst, is namelijk een tweedeling mogelijk in interne en externe verzelfstandiging.

In afwijking van, dit van regeringswege gehanteerde, onderscheid zijn andere verzelfstandigingsprofielen denkbaar. Te weten verzelfstandiging als sequentietype (beleidsuitvoering) en interdepentiemodel (volledige beleidscyclus). ${ }^{87}$ Deze theoretische constructie

83. Bij de, enkel beheersmatige aspecten rakende, verzelfstandiging wan de Verzekeringskamer merkt de minister van financiën al op, dat "zekere kostenstijging" voor het onder toezicht staande bedrijfsleven ontstaat. "TK 1988-1989, 21235, nr. 1, p.2.

84. Dat het met artbeidswoorwaarden uit de thand kan lopen, toont bij voorbeeld de verzelfstandiging wan de luchtwerkeersleiding en -beveiliging aan. De luchtverkeersleiders, die na verzelfstandiging nog de sians wan ambtenaar hebben, ondergaan na verzelfstandiging een flinke inkomensstijging t.o. $v$. rijksambtenaren in vergelijkbare positie. Tegelijkertijd neemt het geldelijk tekort toe bij de luchtverkeersbeveilligingsorganisatie (reden watrom kostenverhaal op anderen nodig is). De verzelfstandigingsoperatie verloopt dus. niet efficient, terwijl doe lmatigheid - waarvoor de minister wan verkeer en waterstaat in casu ten onrechte geen wettelijk controlemiddel heeft- toch de belangrijkste drijfveer van verzelfstandiging is. Aldus resultaat van onderzoek ter zake door Algemene Rekenkamer, als vermeld in: Rekenkamer laakt verzelfstandiging luchtverkeersteiding, in: $\mathrm{NRC}_{n} 28$ sept. 1994, p.1; Ook meer in het algemeen geldt dat het arbettsen personeelswoorwaardenbeleid van zbo's te kort schiet. Ontevreden spreekt de Algemene Rekenkamer, Zelfstandige bestuursorganen en ministeriële verannwoordelijhteid. TK 1994-1995, 24130, nr. 3, pp.45-52, bij woorbeeld van een loorstijging (t.o.w. de loonstijging bij de rijksoverheid) van het Loodswezen wan 77 procent en bij de Nederlandse Algemene Keuringsidienst voor zaaizaad en pootgoed van Landbouwgewassen van 30 procent.

85. Lid van de Algemene Rekenkamer M. B. Engwirda, als geciteerd door T.J. Meeus, Lid Rekenkamer bepleit nieuwe debat ower privatiseringen, in: NRC, 30 sept. 1994, p.1.

86. E. Keet en J. de Kotring, Goede ervaringen wan pioniers nuttig bij verdere privatisering; Professionele aonpak gewenst, in: $\mathbb{B B}$, nr.45, 11 nov. 1994, pp.28-29.

87. P.H.A. Frissen (red.), Verzelfstandiging in het openbaar bestuur; Een bestuurskundige verkenning van zelfstandige verbindingen en informatisering, 's-Gravenhage, 1992, pp. 37-41: P.H.A. Frissen, Verzelfstandiging in het opembaar bestuur; Verbindingen, management en politiek, im: P.H.A. Frissen e. a., Het managen van verandering door verzelfstandiging, 's-Gravenhage, 1993, pp.13-44. 
van bestuurskundige beleidsconstellaties is toepasselijk op reeds verzelfstandigde entiteiten of nog te verzelfstandigen overheidsorganen. De mate, waarin beide verzelfstandigingsvormen worden gerealiseerd, verschilt per orgaan. Bovendien is zij afhankelijk van een aantal variabelen. Zo kent het sequentietype een hiërarchische doelbepaling en een grote mate van stabiliteit (mede omdat sprake is van voltooid beleid). Het interdepentiemodel is polyarchisch in doel, heeft te maken met controversieel (nog te vormen) beleid, is daardoor labiel en kent overigens geen reflectieve, hiërarchische en cognitieve structurur.

Een dergelijke bestuurskundige theorie bewijst, weliswaar, haar praktisch nut. Voor een juridisch betoog is zij minder geschikt. Vandaar vindt het hierna volgende basis in het onderscheid tussen interne en externe verzelfstandiging.

\section{$\$ 6.3$ Interne taakverzelfstandiging}

Interne verzel fstandiging betekent verzelfstandiging binnen de departementale organisatie. Er vindt differentiatie van beheersregels binnen overheidsinstanties plaats. De minister blijft politiek verantwoordelijk voor de taakbehartiging. Dit gegeven heeft, trouwens, consequenties voor de bewoegdheden van de minister naar binnen toe. Namelijk in die zin dat van formele zelfstandigheid van de intern verzelfstandigde organisatie-onderdelen geen sprake kan zijn. Daarom lijkt het, in dergelijke gevallen, wat ongelukkig te spreken van verzelfstandiging. ${ }^{88}$ Verschillende vormen van interne taakverzelfstandiging zijn denkbaar.

\subsubsection{OVERHEIDSBEDRIJVEN}

Exemplarisch zijn de overheidsbedrijven. Overheidsbedrijven kunnen op verschillende niveaus bestaan. Van oudsher bekend zijn de, inmiddels ter ziele gegane, staatsbedrijven (ex art. 88 Comptabiliteitswet 1976 in relatie tot de Bedrijuenwet 1928 ${ }^{85}$ ). Daarnaast zijn er provinciale en gemeentelijke takken van dienst in gevolge art. 202 Provinciewet, voorheen art. 133 Provinciewet (oud), en art. 198 Gemeentewet, voorheen art. 252 jo. art. 265 Gemeentewet (oud). ${ }^{90}$ Deze onderdelen van de overheidsorganisatie worden gekenmerkt door administratieve zelfstandigheid. Dit betekent dat een commercieel gerichte bedrijfsvoering mogelijk is. Daardoor is een juister inzicht in de reële baten en lasten te verkrijgen. Hierop aangepast is de aparte begroting die een overheidsbedrijf wordt toegekend. Kapitaal en andere voorzieningen krijgt het bedrijf van het rijk dan wel de provincie of de gemeente. Positieve en negatieve exploitatiesaldi worden verrekend

88. H.G. Lubberdink, a.w. p. 323 .

89. De wijziging van de Comptabiliteitswet en de intrekking van de Bedrujwenwet maken een eindle aan de mogelijkheid tot het oprichten van statsibedrijven.

90. Terminologische verwarring dreigt. Provinciale/gementelijke bedrijven betreffen meestal nv"s waarvan de betrokken lagere overheid alle aandelen bezit, d.w.Z. overheidsdeelnemingen. N.A.A. Baakman (red.) en J.G.A. van Mierlo, Owerheid en onderneming, OUH, 1992, p.31; Op rijksniveau zijn $100 \%$ overheidsnw's een weg naar privatisering. O. m. Rijks computer centrum nv, waarvan het overheidsrneerderheidsbelang eind 1995 wordt afgestoten, zie Stcrt. 14 maart 1994. 
via de algemene middelen. Er is dus geen recht op eigen vermogen, en evenmin is er een zelfstandig recht op toegang tot de kapitaalmarkt. Er bestaat volledige politieke verantwoordelijkheid. De controle beoogt overeenstemming van de bedrijfsbegroting met de rijksbegroting. Met andere woorden, de bedrijfsvoering doet gekunsteld aan. De onafhankelijkheid van het overheidsbedrijf is beperkt. In juridisch opzicht heeft het overheidsbedrijf zelfs geen zelfstandigheid. Het beheer is van overheidswege. En de overheidsonderneming bezit geen rechtspersoonlijkheid. Uiteindelijk is het gebrek aan juridische zelfstandigheid en rendement als schrijnend ervaren. Vandaar dat, in elk geval, de staatsbedrijven voor privatisering rijp zijn gebleken. Zo zijn de PTT ${ }^{91}{ }_{\text {, }}$ 's-Rijksmunt ${ }^{92}$, het Staatsvissershavenbedrijf en de Staatsuitgeverij ${ }^{93}$, in hun hoedanigheid als staatsbedrijf, verleden tijd.

\subsubsection{ZELFBEHEER}

Bekende situatie, van mandaat van grotere beslissingsbevoegdheden aan een onderdeel van de overheidsorganisatie zonder dat daarbij een afzonderlijke wettelijk gegarandeerde juridische status wordt toegekend, is zelfbeheer ${ }^{94}$. Een voorbeeld van zelfbeheer is de, per begin 1994 van start gegane, Inspectie Jeugdhulpverlening en Jeugdbescherming . De conceptie van zelfbeheer begint na het uitbrengen van een ambtelijk rapport betreffende bedrijfsvoering door de overheid. Deze analyse signaleert essentiële knelpunten. Zo wordt het produktieproces op departementen niet beheerst van uit een centrum. Daarnaast is de produktiebesturing van de onderneming niet gericht op het produkt, maar op de input en het proces van produktie. De calculatie van de kostprijzen geschiedt vaak verkeerd. Bovendien vindt in hoge mate deling van verantwoordelijkheid plaats. Bestuurlijke hiërarchie belemmert een doelmatige bedrijfsvoering. En ook ontbreekt meer dan eens een gemeenschappelijk doel. Al met al is sprake van een geringe flexibiliteit. ${ }^{97}$ In feite: het budgetmechanisme traditioneel onder kritiek. De aandacht voor zel fbeheer blijkt dus een voomamelijk organisatorisch-financiële/economische ondertoon te hebben.

91. TK 1987-1988, 20730, nrs.1-6 (per 1 jan. 1989 oprichting Koninklijke PTT Nederland nv), resp. Splitsing PTT Telecom, TK 1991-1992/1992-1993, 21693, nrs.1-10. Zie ook Machtigingswet PTT Nederland nw, Stbil. 1988,521 .

92. Uit Privatisering 's Rijks Munt, TK 1993-1994, 23413, blijkt van de optichting wan De Nederlandse Munt nv per 1 januari 1994. Feitelijk passeert de akte van oprichting pas op 1 juli 1994 de notaris.

93. Wetswowrtel tot oprichting NV Staatsdrukkerij. en Uirgeverij. TK 1986-1987, 20041, nrs.1-6. Zie ook Machtigingswet nw Sdu, Stbl. 1988, 421.

94. Ook wel integraal management genoemd. H. Buurma, Zelfbeheer, in: J.H. Hoogteijling, Besturen op afstond, 100-reeks nr.34, dec. 1991, pp.43-48.

95. Bijlage 2, als toegevoegd aan De Inspectie Jeugdhulpwerlening en Jeugdbescherming "Toezicht op kwaliteit: hoofdlijnen en organisatie, Rijswijk, april 1993, p.26, meet de IJJ een onafhankelijke positie, zijnde zelfbeheer, an.

96. Commissie-Verbaan ${ }_{i n}$ Zelfbeheer $I_{w}$ rapport wan de interdepartementale herowerwegingswerkgroep verbetering van de bedrijfsvoering bij de overheid, he noverweging derde ronde deelrapport nr. 53 , "s-Gravenhage, 1983.

97. Zie ook ministerie van financiển, Kompas woor zelfbeheer, "s-Gravenhage, 1985. 
Daarin ligt het verschil met het, aan zelfbeheer nauw verwante, contractmanagement. ${ }^{98}$ Bij zelfbeheer krijgen weliswaar recht- ên doelmatigheidheid van bestedingen accent. Maar contractmanagement put nog dieper. $\mathrm{Zij}$ "omvat doorgaans meer dan alleen financiële of beheersregels". ${ }^{99}$ Vooral de ambtelijke werkwijze staat centraal. Een kloppende balans is prima. Maar bovenal is belangrijk te weten wat je aan elkaar hebt.. Wederzijdse verwachtingen moeten duidelijk zijn. Vandaar ontstaan, via contractmanagement, vooral wérkafspraken.

Zelfbeheer komt op het volgende neer. De politieke en ambtelijke top van een departement en de directie van het uitvoerende overheidsonderdeel maken een afspraak over de, in een bepaald tijdsbestek en onder bepaalde condities, door de betreffende dienst te verrichten werkzaamheden en daartegenover staande prestaties (met name financiële middelen). Correcte uitvoering wordt beloond met premies. Minder succesvolle uitvoering wordt gesanctioneerd.

De hoofdlijnen van zelfbeheer zijn omschreven als: "Het hoofd van een dienst wordt zelf budgethouder; De leiding van een departement sluit een overeenkomst met de budgethoudler met betrekking tot de produktieactiviteiten en het budget; De budgethouder heeft vrijheid in het besteden van het budget c.q. bevoegdheden over de inrichting van de eigen produktie; De budgethouder is gebonden aan het budget, jaarlijks legt hij verantwoording af over de verhouding input- en outputkosten; Blijkt de relatie input- en outputkosten gunstiger te zijn dan bij planning, dan kan de dienst het daaruit voort vloeiende voordeel gedeeltelijk naar eigen inzichten besteden." 100

Van uit juridische optiek is de term partijenafspraak, boven het begrip overeenkomst, te prefereren. Zelfbeheer betreft immers een vorm van interne verzelfstandiging. Juridisch gezien heeft zelfbeheer (of contractmanagement) geen invloed op de ministeriële verantwoordelijkheid. ${ }^{101}$ Woordgebruik, in de zin van overeenkomst, contract of convenant, verdoezelt het gegeven dat bij mandaatsverhoudingen feitelijk gezien slechts sprake kan zijn van een partij, in casu de centrale overheid.

Ervaringen melt zelfbeheer wijzen uit dat voor deze wijze van verstrekking van bepaalde autonomie geen bovenmatig enthousiasme bestaat. ${ }^{102}$ Althans, wat betreft de rijksdienst. Op het terrein van de lagere overheden vindt daadwerkelijk acceptatie plaats. ${ }^{103}$

98. Volgens H.J. ter Bogt, Contractmanagement, valkuil van sjablonen, in: Beleidsanalyse, nr.112, 1994. pp. 24-39, omvat contractmanagement, anders dan het enkel 'input' betreffende zelfbeheer, zowel produktieniddelen als daarmee te lleveren prestaties.

99. Commissie-Schelltema, a.w., p. 36.

100. E. Biesmeijer en E.C.W. Verbaan, Zelfbeheer I; De ambtenaar wordt manager, in: 0U, nr.5, 1984, P.231.

101. M. Scheltema, Ministeriëleverantwoordelijkheud en contractmanagement, in: W.C.M. Lieshout, Bestuur en meesterschap. Opstellen ower samenlewing, staat en sturing, 's-Gravenhage, 1988, pp.93-99; Com" missie-Scheltema, a.w., p.39.

102. Ministerievanfinanciën, Eündrapportinterdepartementalebegeleidingsgroepzelfbeheer, 's-Gravenhage, 1988.

103. J.A. van der Vaart, Spanningsvelden rondom contractmanagement in een provinciale organisatie in: TrO, nr.19, 1986, pp.398-401; H.J.M. ter Braak, Contractmanagement met vallen en opstoan, in: Tvo, nr. 19, 1986, pp.408412; A. Abrahamsen-Spijker en Th. wan der Krogt, Contractmanagement 
In praktijk wordt een aantal grote nadelen van zelfbeheer zichtbaar. De meest wezenlijke zijn de volgende. Beheersbevoegdheden zijn in te beperkte mate aan de lagere bestuurlijke niveaus overgedragen; Zelfbeheer is duur: de kosten van totstandkoming van een partijenafspraak zijn hoog in relatie tot het nut er van; Zelfbeheer leidt niet per se tot deregulering, eerder is sprake van het tegendeel; Exacte vaststelling van de verhouding voorgenomen werkzaamheden en beschikbaar te stellen gelden is moeilijk. ${ }^{104}$

\subsubsection{AGENTSCHAPPEN}

Toch wordt, in het verlengde van zelfbeheer, het agentschap ${ }^{105}$ geïntroduceerd. Denk aan de Immigratie- en Naturalisatiedienst ${ }^{106}$, het Duyvermam Computer Centrum ${ }^{107}$, Senter ${ }^{108}$, de Plantenziektekundige dienst ${ }^{109}$ en de Dienst informatievoorziening overheidspersoneel ${ }^{110}$. Eind maant 1994 worden het Koninklijk Nederlands Metereologisch Instituut ${ }^{1 / 1}$ en de Dienst justitiële inrichtingen ${ }^{1 / 2}$ aan dit rijtje toegevoegd. Ook de Centrale Financiën/instellingen van het ministerie van onderwijs en wetenschap-

103.

bij de gemeentelijke overheid: een brug te ver?, in: MO Tijdschrift voor Organisatiekunde en Sociaal beleid, sept./okt. 1989, pp.325-338; Evaluatie van provincie Gelderland door L.J.F. Dolmans en M.F. Dubbeldam, Contracimanagement. bestuwhijke verniewwing of ambtelijke rearganisatie?, in: Openbaar bestuur, nr.11, 1992, pp.11-17; Volgens P. Nieuwenhuijsen, Zelbeheer motiveert dan 'paraafjes haten', in: BBM, 29 jan. 1993, pp.8-13, leert o.a. de Groningse kredietbankaffaire dat zelfbeheer te weimig veiligheidlskleppen heeft; Evaluatie bij 76 Nederlandse gemeenten in de periode $1988-1992$ levert 5 varianten op. Daarover M. Wolters, Babylonische spraakverwarring rond containerbegrip "zelfbe" heer', in: BBM, 29 jan. 1993, pp.16-19; Over contractmanagement bij de gemeenten Groningen en Deventer $\mathbf{P}$. Leenders, Op afstand besturen, maar niet te ver, want dan herkent de burger je niet meer. in: $\mathrm{BB}, \mathrm{nr} .13,31 \mathrm{maart} 1995, \mathrm{pp} \cdot 16-19$.

104. $\mathrm{R}$. Zunderdorp en L. Smook, Zebbeheer: ontmanteling wan de bureaucratie, in: OU, nr.4, 1988, pp. 176-177; Vgl. W. F.J. Verhoeven, Valkuilen bij de inwaering wan contractmanagement, in: Zetfbelteer en contractmonagement, SBN-reeks m. 5, Groningen, 1986, p.24; Th. van der Krogt en A. Spijker. Contractmanagement, Enschede, 1989; H. Puts, Wie geloof er mu nog in contractmanagement?, in: OB, nr.9, 1993, pp.17-19.

105. Ministerie van financiën, heroverwegingsgmep beheersregels, Verder bowwen aan beheer, juli 1991 ; Ministerie van financiën, Miljoenennora, 1992, p.77; N.P. Mol, Doelmatig financieel beheer in de rijkstlienst, in: OU, febr. 1992, pp. 15-22; E.L. Leeuw, Agentschappen en de Nederlandse rijksdienst. in: $\mathrm{BK}, \mathrm{nr}, 1,1992$, pp.46-56:

106. Mnmigratie-em naturalisatiedienst als agentschap van justitie, TK 1992-1993, 23182; Hierower ook H.P.A. Nawijin in zijn (syllabus)bijdrage aan het congres Verzelfstandigen bij de rijksoverheid, woongang of vooruitgant, georganiseerd door het NSC en stichting MC, te 's-Gravenhage, 30 nov. 1993. pp. $1-11$.

107. Duyverman Computer Centrum als agentschap wan defensie. TK 1992-1993, 23181; Over deze, huns insziens redelijk succesvol verlopen, concurrentie gerichte verzelfstandiging $C$. Bakker en B, Bossen, Agentschap: de verzelfstandiging vant het Duyverman Computer Centrum, in: OB, nr.6, 1994, pp. 13-17.

108. Seruter als agentschap wan economische zaken, TK 1992-1993, 23183.

109. Plantenziektenkundige dienst als agentschap van L.N.\& V., TK 1992-1993, 23180.

110. Informatievoorziening overheidspersomeel per I jan. 1995 als agentschap Biza, TK 1993-1994,23708, nr. 1 .

111. TK 1993-1994, 23171, nr.2; TK 1993-1994, 23673, nrs.1-2.

112. TK 1993-1994, 23182, nr.3. 
pen ${ }^{113}$ staan op de nominatie om per 1 januari 1996 de status van agentschap te verkrijgen.

Agentschappen vinden formeel regeling in de vernieuwde Comptabiliteitswet ${ }^{114}$ "115 Daarin zijn opgenomen bepalingen betreffende de instellingsprocedure van agentschappen, de keuzemogelijkheid voor een baten-lastenstelsel en de relatie (qua begroting en rekening) tussen agentschap en betrokken minister(s).

Agentschapsvorming lijkt, gelet op de positieve praktische werking er van in andere landen waaronder het Verenigd Koninkrijk, een stap verder op weg naar een optimale comptabele infrastructuur van het rijk. Mogelijke invoering van agentschappen heeft alles te maken met verbetering van doelmatigheid van openbaar bestuur.

Daarbij is de opmerkelijke aandacht weer gericht op het beheersregime van de rijksdienst. Zowel in financieel als in personeel opzicht. De belangstelling richt zich vooral op het in zekere mate overboeken tussen op een volgende jaren. Meerjaarlijkse reserveringen moeten mogelijk zijn. Daarnaast op het laten vervallen van de begrotingstechnische scheidling tussen personele en materiële uitgaven. Dit met het oog op een integrale afweging van apparaatsuitgaven. Er is een budget woor apparaatsuitgaven. Er vindt enkel sturing plaats op apparaatsuitgaven, niet meer apart op het aantal formatieplaatsen. En er bestaat interesse voor stroomlijning van het begrotingsproces. Stroomlijning moet geschieden door het leggen van expliciete relaties tussen middelen en prestaties, budgetteringsafspraken, begrotingsreserves en doorlichting. Tijdens de begrotingsuitvoering zijn minder overlleg en onderhandelingen nodig, omdat de aandacht al is geconcentreerd op de voorbereiding en verantwoording. Terughoudendheid is voelbaar op twee punten, te weten a. verdere differentiatie in arbeidsvoorwaarden/beloning en $\mathrm{b}$. de bevoegdheid tot lenen op de kapitaalmarkt.

$\mathrm{Nu}$ gaat het bij deze agentschappen niet alleen om een versoepeling van regels en procedures. De kern van de zaak is dat "bij agentschappen substantiële bevoegdheden en verantwoordelijkheden voor de uitvoering van beleid worden overgedragen aan het management van een dienst, binnen de overkoepelende ministeriële verantwoordelijkheid". "16 De juiste balans tussen bevoegdheden en verantwoordelijkheden moeten praktijk en politiek nog aangeven. ${ }^{\$ 7}$ Ook hier dus herbezinning op de verdeling van overheidstaken en -bevoegdheden.

Bij agentschapsvorming gaat het dus allereerst om deconcentratie van financiële functies. Daaraan is, tegelijkertijd, sturing op afstand inherent. Kenmerkend voor het agentschaps-

113. TK 1993-1994, 23673, nr. 1

114. Weswoorstel wijziging Comprabiliteitswet i. v. m. o.a. introductie agentschappen, TK 1993-1994, 23796, nrs . 1-3.

1.15. Mstelling van agentschappen, TK 1992-1993, 23171, nr.1, pp.1-5.

116. Postma. secr.-gen. ministerie van financiën, Goede argumenten nodig voor externe verzelfstandiging owerheidsdiensten, rede congres VwB did. 26 maart 1992, Stcrt. 27 maart 1992, 62, pp.4/24; Oweir problemen met ministeriële verantwoordelijkheid bij zelfbeheer $\mathrm{R}$. Bekker, Zelfbeheer bij de averheid, 5im: Besturir, nr. 11, 1987, pp. 338-341.

117. Brief wan de minister van financiën aan de woorzitter Tweede Kamer d.d. 25 juni 1992, heroverwegingsgroep beheersregels, Vervolgmota beheer, TK 22300, nr. 39, 1992. 
model zijn zo: meer integraal management ${ }^{118}$, centrale sturing op hoofdlijnen, afspraken over produkten en budgettaire randwoorwaarden, systematische verantwoording achteraf en periodieke doorlichting. Resumerend, de agentschapsconstructie is een combinatie van onder andere mandaat en attributie dan wel delegatie van interne bevoegdheden. "19

Om zuiverheid in terminologie te bewaren gaat bij interne verzelfstandiging voorkeur uit naar de term deconcentratie ${ }^{120}$ in plaats van decentralisatie ${ }^{121}$ van bevoegdheden. Vooral aspecten van mandaat springen namelijk in het oog. ${ }^{122}$ Als een paal boven water blijft immers staan de ministeriële verantwoordelijkheid voor het functioneren van het orgaan, waaraan taken en bevoegdheden zijn doorgeschoven.

Kort gezegd is een agentschap in de kern "het spiegelbeeld van een zelfstandig bestuursorgaan". ${ }^{123}$ In het dilemma tussen beide valt de keuze soms op het agentschap als "bruikbaar alternatief voor het zo welig tierende zelfstandig bestuursorgaan". ${ }^{24} \mathrm{De}$ daartoe gebezigde argumenten luiden als volgt. Bij agentschappen is de administratieve rechtsbescherming beter geregeld. Bovendien is ruimte voor aanvullende controlemogelijkheden door middel van het, in de Aanwijzingen inzake contacten tussen contacten kamercommissies en ambtenaren en tussen kamercommissies en regeringsadviescolleges, opnemen van een zelfstandige hoorplicht. Daamaast speelt de nationale ombudsman bij agentschappen een essentiële rol. Bij dit alles is het wel noodzaak agentschappen niet alleen van adequate beheersregels te voorzien, maar vooral in organieke wetten geattribueerde bevoegdheden te geven. Anders dan bij de wanordelijke bevoegdheidsverdeling in

118. In dit verband doemt de figuur 'managerial controller' op volgens E. Gerritsen en H.D. Idema, Onnwikkelingen infinancieel management (I), Van 'boekhouden " wa financial cantrol natar manage rial cowtrol. in: OMn, mr.3, 1995, pp.67-73 en Ontwikkelingen in financieel management (II); Uitdagingen en valkwillen voar de managerial controller, in: OMn, nr.4, 1995, pp.99-105.

119. P. den Hoed, De samenstelling van de overheid, in: B\&M, nr. 3, 1992, p.119.

120. F. A.M. Stroink en J.G.L. van Nus, Bestuursrechrelijke consequenties van privatisering, in: S\&W, n, 3 , mei/juni 1994, pp.66-71.

121. A.T.L.M. van de Ven, Verzelfotandiging en bestuurlike organisatie, in: S\&V, nr.3, mei/juni 1994, pp.61-65, i.h.b. p.61.

122. C.A.J.M. Kortmann, Kroniek van het sraatsrecht, in: kroniekenbijlage NJB, nr. 33, 23 sept. 1994. pp. $46-49$, i.h.b. p. 47 , stelt de retorische vraag of al de constmacties van zelfbeheer, contractmanagement en agentschappen "geen thodievze vervanging van al wat een degelijk jurist mandaat noemt" zijn.

123. J. van der $\mathrm{Bij}$, Publiekrechtelike verzelfstandiging : agentschap versus zbo, in: BWn, nr. 2, 1993, pP.97107; Met de zelfde strekking J. van der Bij, Coferaat, in: H. de Groot en C.G.M. van Oosteren, De toekomst wan de publieke sector, 100-witgave t.g.w. jubileumbijeenkomst d.d. 17 maart 1994, "s-Giravenhage, 1994, pp. 223-234.

124. J. van der Bij, t.a.p. "p.107. Tegen Van der Bij" "s "van uit de typische financiële sfeer" gedane "krampm achtige poging" om aggentschappen als alternatief voor zbo's te zien, voert $\mathrm{P}$. de Haan, Het bestuursrech: en de scheiding wssen beleid en uitvoering, in: T. Hoogenboom en L.J.A. Damen (red. I, In de sfeer van administratief recht, Utrecht, 1994, pp.121-150, i.h.b. p.147, alert ais belangrijkste bezwaar aan, dhat Van der Bij wan een agentschap meer wil maken "dan een enkele beheersconstructie". Als bij organieke wet (beleidsmatige!) bevoegdheden aan 'agentschappen-nieuwe-stijl", waarbij doellmatigheid vam beheer wondt gewaarborgd door sturing op input, worden geatribueerd, waandoor de grenzen wain ministeriële verantwoordelijkheid zichtbaar zijn, is niet meer sprake van interne maar van exteme verzelfstandiging. Voorkomen moet worden dat, vanuit de toren van het Babel van besturen-op-afstand. nóg meer spraakverwarring verzelfstandigings-en privatiseringsland in stroomt. 
de verschillende instellingswetten van zelfstandige bestuursorganen, dient "de regeling die het agentschap uitvoert tevens de bevoegdheidsgrondslag te bevatten en de uitoefening van de geattribueerde bevoegdheid te normeren". 125

Bowengenoemde argumenten contra zelfstandige bestuursorganen zijn, trouwens, niet alle even steekhoudend. De kaart, betreffende het klachtrecht bij de nationale ombudsman, is niet meer geldig. Als eerder vermeld, is de competentie van de nationale ombudsman medio $\| 993$ uitgebreid tot de meeste zelfstandige bestuursorganen. Bovendien is de winst wan agentschappen, aangaande een zelfstandige hoorplicht, mogelijk tevens troef voor zelfstandige bestuursorganen. En wat betreft administratieve rechtsbescherming spelen agentschappen en zelfstandige bestuursorganen gewoon gelijk spel.

Met deze argumenten is de preferentie voor interne verzelfstandiging of externe verzelfstandiging (bij voorbeeld commissie-Wiegel) dus niet goed te onderbouwen. Naar de vraag welke vorm van verzelfstandigen voorkeur verdient, verricht de commissie-Sint onderzoek. ${ }^{126}$ Hierbij put zij uit de praktijkproblemen bij Staatsbosbeheer, de Immigratie- en naturalisatiedienst, de Rijksdienst voor het wegverkeer en de Sociale Verzekeringsbank. In afwijking van het algemene ambtelijke standpunt ten aanzien van externe decentralisatie, dat min of meer bevestiging vindt in het regeerakkoord van de coalitie PvdA, VVD en D'66 voor de periode 1994-1998 ${ }^{127}$, staat deze commissie-Sint gereserveerd tegenover functionele decentralisatie naar zelfstandige bestuursorganen, welke decentralisatie slechts mogelijk is uit onafhankelijkheids-, participatie- en onpartijdigheidsmotieven. ${ }^{128}$ Weliswaar spreekt de commissie niet expliciet haar afkeur van externe verzelfstandiging uit. Maar door verzelfstandiging aan te merken als "modetrend" en aan externe verzelfstandiging het predikaat "panacee voor alle kwalen" te ontnemen, laat

125. J. wan der Bij, t.a.p., p.106

126. Dit meldt $\mathrm{P}$. Nieuwenhuijsen, Twijfels over verzelfstandiging steken de kop al weer op, in: BBM, 29 apwil 1994, , pp. 22-23, als mede Commissie zet rem op externe verzelfstandiging rijkstaken, in: BB, nr. 3132, 12 aug. 1994, pp.2-3.

127. Zie Keuzes voor de roekomst, regeerakkoord coalitie PvdA, VVD en D'66, TK 1993-1994, 23715. nir 11, pp.4/24-25. Daarin is, met referentie aan het $o$. m. het rapport van de cie-Wiegel, vernieuwing van de overheid leidraad: "Meer kwaliteit en dienstgerichtheid, als mede concentratie op kerntaken zijn sleutelbeg rippen. De taakverdeling binnen de overheid en de dienstverlening aan de burger kunnen door verder gaande decentralisatie worden verbeterd"; Helaas ontbreekt het bij de kabinetsformatie, waar juist concreet knopen kunnen worden doorgehakt, al aan daadkracht ter zake. "Een gemiste kans" volgens De ambrelijke dienst, in: NRC. 29 aug. 1994, p.7.

128. Voordat officiële publikatie van het rapport van de cie-Sint fe it is, opperen M.J.W. van Twist en R.J. in "I Veld, Een kerndepartement' is lets anders dan 'wat er na vergelfstandiging overbliff", in: $\mathrm{OB}, \mathrm{nr} .8$, 1994, pp.14-19, i.h.b. pp.15-16, bezwaar tegen het naar hun mening te "analytisch-rationeel (bijna wetenschappelijk!) verhaal" van de commissie-Sint; De auteurs vinden het rapport te veel structuralistisch en te weinig cultureel van aard, R.J. in "t Veld en M.J.W. van Twist, Eer onwolledig betoog over verzelfsrandiging; Het rapport van de commissie-Sint nader beschouwd, in: juridisch en fiscaal tijdschrift Priwatisering, nr.3, 1995, pp.3-5. 
de commissie-Sint haar voorkeur duidelijk door schemeren. ${ }^{129}$ Ver uit favoriet in haar ogen zijn kennelijk agentschappen met een aangepast en vrijer comptabel regime. Als sturings- en beheersregels van interne verzelfstandigde eenheden worden aangepast, zijn zij kennelijk een volwaardig alternatief voor het besturen op hoofdlijnen via exteme verzelfstandiging. Met het voorhanden zijn van op flexibilisering van beheersregels gerichte agentschapsvorming, meent de commissie dat een van de vier zelfstandige overwegingen om te komen tot instelling van zelfstandige bestuursorganen, $t$. w. verbetering en rationalisering van de rijksdienst, geen bestaansrecht meer kan en mag hebben. ${ }^{130}$ Al met al lijkt de voorkeur van de commissie-Sint voorbij te gaan aan de uiteindelijke doelstelling van decentralisatie. Immers, meer dan interne verzelfstandiging, die leidt tot een "octopusorganisatie", draagt externe verzelfstandiging bij aan taakontlasting en -werdeling ${ }^{131}$ bij de rijksoverheid. ${ }^{132}$

Wel is het verstandig te realiseren dat externe verzelfstandiging naar zelfstandige bestuursorganen niet altijd de ultieme oplossing is. Omdat externe verzel fstandiging vrij wer gaat, kan soms worden volstaan met mindere middelen. Het toekennen of overdragen van publiekrechtelijke bevoegdheden naar zelfstandige bestuursorganen is bij voorbeell niet nodig, als een bepaalde instantie slechts op, uit kostenaspect en organisatorische overweging beter hanteerbare, beheersmatige bodem moet worden gezet. Voor een dergelijk beheersregime, waarin het huis inwendig wordt opgebouwd (met warmhoudende werkeisen, kleurige kostencondities en vriendelijke verantwoordingsvoorwaarden), blijft agentschapsworming aangewezen. Voorheen is dit te veel onderkend. Waarschijnlijk van wege het "onbekend maakt onbemind". Verzelfstandiging naar zelfstandige bestuursorganen wordt al vroeg aangegrepen, terwijl interne verzelfstandiging in een hoek blijft liggen. Weliswaar bestaat mandaat vam bevoegdheden maar eerst, als mandaat modernisering ondergaat en wordt aangevuld waardoor omtovering tot agentschap kan plaats vinden, is sprake van volwaardige erkenning van deze vernieuwde verzelfstandingsvorm. Tijdens de vroegere verwaarlozing van interne verzelfstandiging, bloeit externe verzelf-

129. Commissie-Sint, Verantwoord verzelfstandigen, witgave $\mathrm{BIZa},{ }^{3}$-Gravenhage, jant. 1995; Terecht weinhig enthousiast stelt M. Sicheltema, Verontwoord verzelfstandigen! Opmerkingen over het rapport vande commissie-Sint, in: juridisch en fiscaal tijdschrift Privatisering, nr. 3, 1995, pp.1-3, dat het rappori dle indruk geeft van een "bestuursinterne discussie".

130. Functionele decentralisanie, TK 1994-1995, 21042, nr. 15, pp.2-3 (aanbewelingsbrief ninisters binnenlandse zaken en financiẽn). Bovendien beveelt de commissie aan het politiek primaat en de ministeriele sturingsmechanismen te preciseren en and te vullen, als mede de voorbere idingsprocedure $m$. $b$.t. exterme en interne verzelfstandigingen te integreren in een ambtelijk begeleidingsteam verzelfstandig ingen. Dit is de korte en klare concllusie uit de alanbevelingsbrief. H.J. de Ru, Verzelfstandiging vs privarisering" Commentaar op het rapport van de commissie-Sint, in: juridisch en fiscaal tijdschrift Privatisering, nr. 3 , 1995 , pp. 5-7, vindt de brief terecht helderder dan het rapport van de commissie-Sint, maar constateent dat betrokken bewindspersonen de commissie meer in de mond leggen dan zij zelf zegt, namelijk "dat er bij privatisering aandacht moet zijn voor woldoende marktwerking ${ }^{\text {"t }}$.

131. Beter dan agentschappen zijn $z b{ }^{*}$ 's in stat de overheid een sterkere structuur te geven. Voor een goed begrip: in beginsel geen enkele verzelfstandiging, maar alleen het afstoten van owerheidstaken vermindert de omvang van de owerheid.

132. C.P.A.G. Crasborn, Verzelfstandiging wan departementsonderdelen: een oplossing $\ldots$ woor welk probleem?, in: OB, nr.9, 1994, pp.15-17, i.h.b. p.16. 
standiging ongekend. Duidelijk zijn de doornen en distels van deze verbloeming. Te lang en te vaak worden zelfstandige bestuursorganen, soms nota bene zonder legitiem doel om de ministeriële verantwoordelijkheid te beperken, de sinistere sleutels geacht om te komen tot een beter functionerende rijksdienst. ${ }^{133}$ Ook daar waar interne verzelfstandiging zuiverder zou zijn geweest. Dit verleden leert om helder, en vooral verantwoord, te kiezen tussen agentschappen als interne verzelfstandigingsworm en zelfstandige bestuurorganen als externe verzelfstandigingsvorm. Daarbij is het essenticel niet weer in de fout te vervallen om, evenmin als het tomeloos toekennen van de status van zelfstandig bestuursorgaan, ongenuanceerd agentschappen op te richten.

Naast het - ter begripsbepaling - tegen elkaar uitspelen van agentschappen tegen zelfstandige bestuursorganen, is de poging bekend de term agentschap helder te krijgen door deze af te zetten tegenover deconcentratie. In die beschouwing zijn agentschappen combinaties van zelfbeheer en deconcentratie. De "beleidsmatige en soms fysieke of geografische verzelfstandiging van agentschappen onderscheidt ze van zelfbeherende eenheden". En de "ruime zelfbeherende autonomie ${ }^{134 "}$ onderscheidt agentschappen van gedeconcentreerde rijksdiensten. ${ }^{135}$

\subsubsection{DECONCENTRATIE}

Via deconcentratie is interne verzelfstandiging ook mogelijk. In tegenstelling tot decentralisatie vindt spreiding van overheidstaken naar en toedeling van rijksbevoegdheden aan gedeconcentreerde ambten uitsluitend plaats binnen een overheidsdienst. Bij deconcentratie wordt een, vooral territoriaal samengestelde, rijksdienst van binnen uit opgedeeld. Deze spreiding van gezag is buitengrondwettelijk. Wat betreft de lagere overheden vindt wel regelgeving ter zake plaats, te weten art. 168 Gemeentewet, voorheen art. 211 Giemeentewet (oud), en art. 166 Provinciewet, voorheen art. 104 Provinciewet (oud). Bedoelde verzelfstandigingsvorm is ontstaan van uit organisatorische overwegingen. In de meeste gevallen van deconcentratie moet een groot aantal beslissingen worden genomen. Daarvoor is, bovendien, een specifieke deskundigheid vereist. Denk aan de Belastingdienst, de Arbeidsinspectie en de Keuringsdienst van Waren. Het gaat dus om attributie of delegatie van publiekrechtelijke bevoegdheden aan ambtenaren uit opportuniteitsredenen van kwantiteit en kwalliteit. Ruimtelijke of categorale toedeling van overheidstaken en -bevoegdheden aan bekwame ambtenaren, die deze in eigen naam uitoefenen,

133. R.U.M. Kuipers, Verzelfstandiging bij de rijksowerheid, in: H. de Groot en C.G.M. van Oosteren, De toekomst van de publieke sector, 100 -jubileumuitgave, "s-Gravenhage, 1994, pp.171-183, 1.h. b. p. 175. Auteur acht -bij publiekrechtelijke bevoegdheden- externe verzelfstandiging naar zbo "s slêchts in drie gewallen (t.w.: a. bij cen veelheid van uitvoeringsbeslissingen; b. bij politiek onafhankelijke beslissingen; en $c$. bij wellbewust op voet van gelljkwaardigheid handelen wan de overheid met anderen, via o.a. bi- of tripartiet overleg) "denkbaar", hoewel nog "niet geboden" (pp.176-178).

134. P. Vermeulen, Overheidsmanagement en bestuursvernieuwing: autonomie à la carte, de agencies, in: TVBP, juli 1994, pp.443-453, beschrijft de (Belgische) agentschapsvorm in het licht van die autonomie of vrijheid.

135. P.H.A. Frissen, a.w., p.8. 
is soms een fraaie oplossing. Wel te verstaan, zelfstandige ${ }^{136}$ taakuitoefening is niet in hoofdzaak kenmerkend voor deconcentratie. Wezenlijk onderscheidend vermogen, ten aanzien van decentralisatie, is de ondergeschiktheid aan de politieke top van het betrokken departement. ${ }^{137}$ De hieruit voortvloeiende consequentie is algemeen aanvaard. Het: gedeconcentreerde ambt heeft zich te richten naar algemene richtlijnen van de algemene leiding. Omstreden blijft de kwestie of het de minister daarnaast is geoorloofd bijzondere aanwijzingen te geven. ${ }^{138}$ De politiek is ruim denkend. Maar in de literatuur is, mede mett het oog op het gelijkheidsbeginsel, een zeker verzet tegen concrete ministeriële aanwijzingen in individuele gevallen te constateren.

\section{§ 6.4 Externe verzelfstandiging}

Het verschil tussen interne en externe verzelfstandiging volgt al uit de benaming zelf. Externe verzelfstandiging van een overheidstaak houdt in het bij of krachtens de wet opdragen van deze taak aan "een juridisch verzelfstandigde eenheid buiten de rijksoverheid". "139 Deze organisatie geniet een eigen juridische positie.

Zij betreft mogelijk een publiekrechtelijke of privaatrechtelijke rechtspersoon. De eis, dat externe verzelfstandiging naar organen van functioneel bestuur altîjd gepaard moet gaan met toekenning van rechtspersoonlijkheid aan de verzelfstandigde entiteiten ${ }^{140}$, komt echter te stellig over. Met name sommige (besturen van) zelfstandige bestuursorganen bezitten nu een maal geen eigen rechtspersoonlijkheid. Wel zijn zelfstandige bestuursorganen organen van de, ex art. 8:72, zevende lid, Awb vermogensrechtelijk aansprakelijke, rechtspersoon Staat. Daarom overtuigt de mening, dat in het bijzonder zelfstandige bestuursorganen "geen organen van een openbaar lichaam en derhalve ook meestal geen organen van een rechtspersoon" ${ }^{4 \|}$ zijn (hoewel moet worden vermeld dat dit slechts in het kader van art. 1:1, eerste lid, Awb - waar de voor het bestuursorgaan geldende eis van rechtspersoonlijkheid krachtens publiekrecht is neergelegd - wordt opgemerkt),

136. Eengedeconcentreerd ambtkent geen formeel-juridische zelfstand igheid. F.A.M. Stroink, Inventarisarie deconcentratie, Zwolle, 1977.

137. F.A.M. Stroink, Het leerstuk der deconcentratie, diss. RUU, 's-Grav., 1978, pp.21/58-63; Vgl. H.J.P. van Muijden en C.M. Geers, Rijksheren in de regio, Rbb-advies gedeconcentreerde rijksdiensten, bestuur in beweging, "s-Grav., 1984, p.7.

138. Zie paragraaf 3.3.4.

139. Notitie ower verzelfstandiging en privatisering, TK 1989-1990, 21632, mr.1, p.3. In gevolge de notitie omvat externe verzelfstandiging ook functionele decentralisatie naar zbo's. Juister is het te spreken wan een aparte categorie. Immers, zbo's staan op afstand van de rijksoverheid, maar formeel horen zij nog wel tot dit openbaar bestuur. Vgl. Handboek privatisering.

140. A. van der Ven, Privatisering bij de rijksoverheid, in: A. Berg, R. Depre, A. Korsten, P. Lansbergen, A. Ringeling en G. Stienlet (red.), Handboek beleidsvoering voor de overheid, M 4200, Alphen a/d Rijn, suppl. okt. 1990, pp. 1-29 i..h.b. p.9; Vgl. H.J. Hamer en A.T.L.M.. van der Ven, Verzelfstandiging narionaal en internarionaal, in: W.J.M. Kickert, N.P. Mol en A. Sorber, Verzelfstandiging want overheidsdiensten, publ. VwB. mr.16, 1993, 's-Graw., pp.163-176, i.h.b. pp.163/170.

141. G.A.C.M. van Ballegooij, D.W. Buil, G.P. Kleijn en A.E. Schilder, Rechtsbescherming in het Awbtijdperk; Herziene rechtsbescherming tegen het bestwur en het uniforme bestuursprocesrecht, Dewenter. 1992 , p. 17. 
slechts ten dele. Zij is onvolledig, omdat zij de Staat als rechtspersoon van zelfstandige bestuursorganen zonder eigen rechtspersoonlijkheid veronachtzaamt.

Sommigen prefereren ter zake het gebruik van de publiekrechtelijke rechtspersoon (ex art. 1, tweede lid, boek 2 BW) als organisatievorm, indien de overheid langs die weg tot sturing en beleid wenst te komen. De inrichting van zo'n rechtspersoon sui generis kan namelijk goed worden afgesteld op de te vervullen (overheids)taak. ${ }^{1 / 2}$ Omdat specifiek een zelfstandig bestuursorgaan, in de vorm van een rechtspersoon sui generis (ex art. 134, tweede lid, Grondwet juncto art. 1, tweede lid, boek 2 BW) ${ }^{143}$ "nog al wat witte vlekken" vertoont, achten anderen het "goed mogelijk om bij de - wettelijke - invulling van deze rechtsvorm gebruik te maken van de regelgeving voor de privaatrechtelijke rechtsvorm". 144

Externe verzell fstandiging wordt herhaaldelijk gedefiniëerd in de zin van "een verandering in de uitvoering van overheidstaken of in de taken zelf door attributie of delegatie van bevoegdheden aan een nieuw op te richten of bestaande organisatie, die een zekere zelfstandige juridische status heeft of verkrijgt en eigendom van een openbaar lichaam is, met als doelstelling deze in daden en optreden in sterke mate economisch onafhankelijk te maken van andere overheidsinstellingen". ${ }^{145}$ Hierbij passen drie opmerkingen. Ten eerste heeft de omschrijving een economische inslag. Die nadruk is voor het verdere betoog te eenzijdig. Ten tweede verdient vermelding dat niet alle in de definitie gebruikte begrippen voldoende duidelijk zijn. Onduidelijk blijft wat exact wordt verstaan onder uitvoeren. En de term overheidsinstellingen draagt een beperktheid in zich. En ten derde is in de definitie sprake van openbaar lichaam. Daartoe kan een zelfstandig bestuursorgaan niet altijd worden gerekend. Opnieuw een vraagteken achter de aanduiding externe verzelfstandiging voor functionele decentralisatie naar zelfstandige bestuursorganen.

Buiten de overheid plaats vindende openbare gezagsuitoefening, die ook door haar zelf kan worden verzorgd, met andere woorden overheidsvervangende taakverzelfstandiging ${ }^{146}$, kent een diversiteit aan verschijningswormen. Verschillende soorten bestuur

142. Büj voorbeeld J.A.F. Peters, Privatisering bezien wanuit een ander juridisch perspectief, in: TvO, nr.9, 28 april 1989 , pp. 175-179, i.h.b. p.175.

143. Bepaald niet enthousiast over de rechispersoon sui generis is C.A. Schreuder, Publiekrechtelije taken, private rechispersonen, Deventer, 1994, pp.226-227. Immers, bij wettelijke oprichting van een rechtspersoon sui generis wijken de, van overeenkomstige toepassing zijnde, bepalingen van boek 2 BW, als de inrichting van die rechtspersoon regeling vindt in een bijzondere wet: "Een dergelijke organisatie levert een buitengewoon anduidelijke en daardoor onwenselijke constructie op, omdat deze rechtspersoon weliswaar de naam van een in boek 2 BW geregelde rechtspersoon draagt (bij woorbeeld vennootschap -DNB nw - of stichting , maar haar structuur en inuchting in het publiekrecht kunnen zijn aangepast."

144. A.T.L.M. van der Ven, Privatisering en functionele decentralisatie, in: OMn, nr.3, 1993, pp.56-61. i.h.b. p. 61 .

145. R.W. Künneke, a. ., P. 13; Gebaseerd op H.J. de Ru (1987), a.w., p.12.

146. H.A. Brast, Owerheidswerwangendetaakverzelfstandiging als innowerendkader woor decentralisatietherie, in: $\mathrm{BW}, \mathrm{n}, 6,1989, \mathrm{p} .420$. 
op maat, aangaande afzonderlijke collectieve en collectief-categoriale/private ${ }^{147}$ behoeften, zijn herkenbaar. Te onderscheiden zijn grondwettelijke en buitengrondwettelijke vormen van functioneel bestuur.

\subsubsection{GRONDWETTELUKE FUNCTIONELE DECENTRALISATIE}

Van oudsher zijn de waterschappen de meest bekende vormen van doelmatig gespreidd. overheidsbestuur. Dit zijn functionele organisaties en ook regionaal-bestuurlijke eenheden. Een mengvorm van functionele en territoriale taken- en bevoegdhedenoverdracht dus. Deze overheidsinstanties vinden hun grondslag in art. 133 van de Grondwet.

Art. 134 Grondwet biedt de andere basis voor grondwettelijke functionele decentralisatie. Deze constitutionele norm betreft de openbare lichamen wan beroep en bedrijf, de overige openbare lichamen en enkele orden. Exemplarisch zijn bepaalde produkt- en bedrijfsschappen (waaronder het Hoofdbedrijfsschap Ambachten), de Nederlandse Loodsencorporatie, de Nederlandse Orde van Advocaten, de Orde Nederlands Instituut van Registeraccountants, de Nederlandse Orde van Accountants-Administratieconsulenten en volgens voorstel ook de Koninklijke Notariële Broederschap. ${ }^{148} \mathrm{Zij}$ bezitten in beginsell rechtspersoonlijkheid op grond van art. 1, eerste lid, boek 2 Burgerlijk Wetboek. Daarnaast beschikken ze vaak over verordenende publiekrechtelijke bevoegdheden. En een ander gemeenschappelijk kenmerk kan zijn invloedsuitoefening, door leden van de betrokken doellgemeenschap, op het bestuur van het openbaar lichaam.

\subsubsection{BUITENGRONDWETTELIJKE FUNCTIONELE DECENTRALISATIE}

Onder deze eenheden van functioneel bestuur wordt in het algemeen verstaan "het totaal aan buitengrondwettelijke organen, lichamen en instellingen die weliswaar als overheid en binnen de overheid functioneren, maar die op grond van op een specifiek terrein gelegen bevoegdheden (publiekrechtelijk of privaatrechtelijk, dan wel bevoegdheden tor feitelijk handelen) ontleend aan publiekrechtelijke voorschriften, over enige zelfstandigheid beschikken". ${ }^{149}$ Kort weg wordt deze complexe groep, als deel van parastatale

147. Uitgebreid A.J.G.M.Bekke en H.J Aquina, Publieketaakverwulling en private organisatievormen vamuit een bestuurskutudig perspectief, Rbb-preadvies III Privaatrechtelijke organisatieworming in het brandputat, "s-Gravenhage, maart 1991, pp.9-17.

148. TK 1993-1994, 23706, nr. 3; Over consequenties overgang van particuliere vereniging naar publiekrech. telijke beroepsorganisatie I.C. van der Vlies, De KNB als publiekrechrelijke beroepsorganisatie, in: NJB, nr. 20, 19 mei 1995, pp. 768-770.

149. J.B.J.M. ten Berge, A. van der Jagt en J.J.H. Pop, Tokkomstrewds en binnenlands besthur, essaybundel i.o.w. Rbb, bestuur in beweging nr.15, 's-Grav., 1989, p.274; I.d. J.B.J.M. ten Berge en F.A.M. Stroink, Functionele decentralisatie wit de schaduw, preadvies i.o. W. Rbb, "s Grav., juni 1988, p.23, in: Rbb-advies Functionele decentralisatie, "s-Graw., sept. 1988; Nuanceverschil driedeling organem., lichamen en instellingen in Funct. bestuur, TK 1990-1991, 21042, nr.4, p.8. 
of paragouvernementele instituties ${ }^{150}$, wel onder de noemer zelfstandige bestuursorganen ${ }^{158}$ gebracht. Daarmee worden allerlei organen, commissies, raden, colleges, kamers; instituten, instellingen en dergelijke bedoeld.

Gecreëerd is de driedeling tussen organen, lichamen en instellingen. Hoewel niet tot ieders genoegen ${ }^{152}$, wordt er tot op heden nog trouw aan gezworen. Terecht. Want ten eerste zijn aan een organisatie, die uitsluitend feitelijk handelt, toch andere eisen te stellen dan aan een organisatie die direct kan ingrijpen in burgerlijke rechten en plichten. En ten tweede is voor het verrichten van privaatrechtelijke rechtshandelingen rechtspersoonlijkheid vereist. Dat is een eigenschap die niet elk zelfstandig bestuursorgaan, in enge zin, heeft. ${ }^{153}$ In het algemeen is rechtspersoonlijkheid geen vereiste eigenschap van een administratief orgaan. ${ }^{15.4}$

De afbakening, die is gemaakt tussen organen, lichamen en instellingen, kent wel een probleem. $\mathrm{Zij}$ is een vloeiende. De grenzen zijn niet altijd scherp te trekken. Oorzaak daarvan is het verschil in, door overheidsinstanties uit te oefenen, bevoegdheden. ${ }^{155}$ Bestuurlijke organisaties hebben veelal de bevoegdheid tot het nemen van eenzijdig bindende besluiten. Steeds vaker vindt uitoefening van een overheidstaak ook plaats middels bevoegdheden tot privaatrechtelijk rechtshandelen, feitelijk handelen en overig. handellen met rechtsgevolg voor andere overheidsinstanties welk handelen geen juridische consequenties voor burgers inhoudt. ${ }^{156}$ Ter taakuitoefening worden soms verschillende soorten bevoegdheden aangewend. Voor zover een bepaalde overheidsinstantie is uitgerust met een publiekrechtelijke bevoegdheid, is deze (mede) als zelfstandig bestuursorgaan aan te merken. Het indelingscriterium doet, in bepaalde gevallen, de positie van een orgaan van een zelfstandig bestuurslichaam/-instelling met de status van een zelfstandig bestuursorgaan versmelten. Het criterium is dus ontoereikend. Toch kan zij verhelderend werken. De maatstaf is zinvol gelet op de aard van de in deze studie centraal staande overheidstaken en -bevoegdheden. Toezicht houden veronderstelt meestal in het maatschappelijk leven ingrijpende bevoegdheden gericht op het te weeg brengen van publiekrechtelijke rechtsgevolgen voor burgers.

150. Sociologisch bezien vormen zbo's een subcategorie van de paragouvernementelle organisaties. Deze instanties zijn overheidsachtig door hun tak en funetie. Strikt genomen staan zij buiten de kem van de overheid. Ze kennen geen rechtstreekse controle door een representatief gekozen bestuur en vinden hun bestaan buiten Grond-, Provincie-, Gemeente-en Waterschapswet om. Ze behoren wel tot het openbaar bestunr, omdat zij op andere wijze democratisch zijn gelegitimeerd. H.J. Aquina, Herovemweging paragouvernementele organisaties; Veranderingen in legitimiteit en gebruik van PGO"s in Nederland, in: Beleidswetenschappen, nr.1, 1987, pp.21-37; Vgl. N.A.A. Baakman, a.w., pp.13-15.

151. Term wordt geacht gel̈ntroduceend te zijn door M. Scheltema, Zelfstandige bestuursorganen, inaugurelie rede, Groningen, 21 mei 1974, maar het zbo-begrip is al eerder gebezigd.

152. I.L. Boxum, J. de Ridder en M. Scheltema, a.w., pp.7/11.

153. F.A.M. Stroink, Boekbespreking 'Zelfstandige bestuwrsorganen in soorten", in: Beleidswetenschappen, nr. 3, 1992, p.27․

154. Mut wetswoorstel Awb, TK 1988-1989, 21221 , nr.3, p.33.

155. Z.ie kritüek J.L. Boxum, J. de Ridder en M. Scheltema, a.w., p.11.

156. Uitgebreid J.B.J.M. ten Berge, Decentraliseren met commissies; Binnengemeentelike organisatiestructurur op basis van art. 61 Gemeentewet, "s-Gravenhage, 1978, p.111 e.v. 


\subsubsection{ZELFSTANDIGE BESTUURSINSTELLINGEN}

Sommige departementsdiensten, bij voorbeeld het Rijksinstituut voor Oorlogsdocumentatie, hebben een takenpakket dat vooral feitelijke werkzaamheden omvat. Het accent bij opdrachtuitvoering ligt vooral op professionele deskundigheid. Aard en inhoud van het bestuurlijk handelen impliceren een mate van zelfstandigheid. Te weten op het terrein van juridische bevoegdheden, maar juist ook aangaande personele en materiële middelen ${ }^{157}$. Qua functie en opbouw doen zelfstandige bestuursinstellingen sterk denken aan gewone departementsafdelingen. Het extraordinaire is het bestuur dat, in de regel, tussen instelling en minister wordt geplaatst. Bij koninklijk besluit kan de betrokken minister in meer of mindere mate zijn terugtred, ten gunste van dat bestuur, vast leggen. De (besturen van deze) zelfstandige instituten zijn ware vormen van functioneel bestuur, onder de conditie dat de meerderheid van het bestuur bestaat uit niet hiërarchisch ondergeschikte personen en dat dit orgaan over een eigen bevoegdheidsruimte beschikt. In deze situatie, waarin een instelling de aanwezigheid van een relatief gezien eigenmachtig bestuur kent, is het instellingsbestuur zonder formeel bezwaar tot de categorie zelfstandige bestuursorganen te rekenen. Overigens is hiervan sprake in sporadische en uitzonderlijke gevallen. Op het niveau van de lagere overheden wordt dit functioneel bestuur vertegenwoordigd door instellingen met besturen in de vorm van commissies, als bedoeld in art. 82 e.v. Gemeentewet, voorheen art. 61 e.v. Gemeentewet (oud), en art. 80 e.v. Provinciewet, voorheen art. 64 e.v. Provinciewet (oud).

\subsubsection{ZELFSTANDIGE BESTUURSLICHAMEN}

Zelfstandige bestuurslichamen vertegenwoordigen een aanzienlijk deel van functioneel gedecentraliseerde overheidsorganisaties. Het zijn rechtspersonen naar privaatrecht die bij of krachtens de wet zijn ingesteld. Kortom: rechtspersonen sui generis. Voorbeelden zijn rijksuniversiteiten, het Fonds voor de Luchtverontreiniging, de Centrale Raad voor de Volksgezondheid, de Sociale Verzekeringsbank, het Schadefonds Geweldsmisdrijven en sociale zekerheidsfondsen. Deze veelal regulerende, verordenende, controlerende of beleidsvoorbereidende instanties zijn gebaseerd op art. 1, eerste lid, boek 2 Burgerlijk Wetboek. Rechtspersonen sui generis genieten in principe administratieve en juridische autonomie. De exacte verhouding tot de hogere overheid, het precieze taken- en bevoegdhedenpakket en de concrete verantwoordelijkheden zijn in specifieke wet- en regelgeving geregeld. De eigensoortige rechtspersonen zijn, ten behoeve van hun overheidstaakuitoefening, soms (mede) uitgerust met publiekrechtelijke bevoegdheden. Deze bevoegdheden worden toegekend aan de organen, dat wil zeggen besturen, van de zelfstandige bestuurslichamen. In hoe verre de besturen van de lichamen gelijkenis vertonen met zelfstandige bestuursorganen, hangt af van de betrokken instellingsbesluiten waarin de bevoegdhedentoedeling van hogerhand is geregeld. Daarbij staan, als gezegd, de publiekrechtelijke bevoegdheden centraal.

157. Kenmerkend voor overheidsinstellingen volgens P. de Haan, Th. G. Drupsteen en R. Fernhout, met medewerking van C.S. Valkenburg, a.w. (d1.1), pp. 159-160; Zie ook A.M. Donner, a.w., pp. 158-160. 
Op het niveau van de lagere overheden zijn, in het kader van medebewindswetgeving, (rechtsbevoegde besturen van) zelfstandige bestuurslichamen te ontwaren, die dus zonder onoverkomelijk probleem tevens als zelfstandige bestuursorganen zijn te bestempelen. Tot dit soort functionele decentralisatie bieden Provincie- en Gemeentewet zelf geen mogelijkheid. Maar de Wet gemeenschappelijke regelingen in aanmerking nemend, is oprichting van dergelijke lichamen, bimnen of tussen provinciale en gemeentelijke bestuurslagen, niet uitgesloten.

Kort weg is bovenstaande te herhalen als volgt. De besturen van instellingen ${ }^{158}$ en lichamen zijn (zelfstandige) bestuursorganen, indien en voor zover zij publiekrechtelijke bevoegdheden bezitten.

\subsubsection{ZELFSTANDIGE BESTUURSORGANEN}

De, uit het verleden stammende, rechtsopvatting ten aanzien van het orgaanbegrip is dat daarmee, in elk geval, wordt bedoeld iedere persoon en elk college met enig openbaar gezag bekleed. Dat betreft dus alle ambten waaraan een of meer overheidstaken zijn opgedragen en die daartoe de wereiste publiekrechtelijke bevoegdheden krijgen toebedeeld.

Deze traditionele invulling van het orgaanbegrip is min of meer gecodificeerd in ant. 1:1, eerste lid, Algemene wet bestuursrecht. Mede met oog op de toename van verzelfstandiging binnen het openbaar bestuur, is de in de Awb voorgestane uitbreiding van het orgaanbegrip begrijpelijk. Ex art. 1:1, eerste lid, Awb wordt namelijk onder bestuursorgaan verstaan: a. een orgaan van een rechtspersoon die krachtens publiekrecht is ingesteld of $b$. een ander persoon of college, met enig ${ }^{159}$ openbaar gezag bekleed. Het van oudsher gehanteerde criterium van openbaar gezag blijft wel overeind, zij het niet meer als dominant criterium.

158. In hoe verre zelfstandige bestut rsinstellimgen en $z b^{+}{ }^{\dagger}$ s met een geschilbeslechtend karakter onder de: Awb vallen, is niet geheel duidelijk. I.B.J.M., ten Berge. Functioneel bestuur in de Awb. onscherp en niet ver genoeg, in: NTB, nr.4, 1991, pp.121-122; Ook C.P.J. Goorden, De Onderwijswand: rechter entof bestwursorgaan? in: NTB, ar.6, 1991, pp.169-177.

159. In navolging van Steenbeek merkt C.A. Schreuder, Publiekrechtelijke taken, private rechspersomen, Deventer, 1994, pp. 141-142, terecht op dat het begrip 'enig' geen toegevoegde waarde heeft als, in het kader van inschakelling van priwate rechtspersonen voor publiekrechtellike taakvervulling, het 'voor zover ${ }^{n}$-criterium wordi gehanteerd. Zue paragraaf 6.4.4. De woor zover-maatstaf hanteert de rechter bij voorbeeld in de zaak X ws. Bestuur Stichting Katholiek Utrechts Voortgezet Onderwijs, president rechtbank Utrecht, 31 maart 1994, AB 1995, 111, ook in: JB 1994, 101: voor zover het bestur van de stichting geen publiekrechtelijke bevoegdheid uitoefemt (i.c. ontslagverlening) vervult, is geen sprake van een bestuursorgaan; M. Bense en S. Zijlstra, Het begrip bestuwrsorgaan, in: NTB, nr.9, 1994, pp. $253-270$, i.h.b. p.265, stemmen in met het 'voor zover"-criterium, zo lang dat maar geen "strategisch" criterium wordt. Hierbij tonen zij er zich voorstanders van dat private organisaties, zijnde organen als bedoeld in art. $1: 1$, eerste lid, sub $b$, Awb "niet alleen onder de werking vallen in die gevallen warin zij openbaar gezag uitoefenen, maar ook voor zover zij anderszins een bestuurstaak vervullen" (p.270). 
Daarnaast worden andere criteria voor het orgaanbegrip geïntroduceerd. Te weten, ten eerste, rechtspersoonlijkheid krachtens publiekrecht. Ten tweede, overwegende overheidsinvloed op het beheer van privaatrechtelijke rechtspersonen (bij voorbeeld Stichting centraal bureau rijvaardigheidsbewijzen en de Stichtingen (bureaus) voor rechtshulp) ${ }^{160}$ of het criterium van het vallen onder de openbare dienst ${ }^{161}$. Terecht is de wens uitgesproken nog meer aanvullende criteria, om rechtssubjecten onder het bereik van de overheid en daarmee onder de reikwijdte van algemene wetgeving te doen vallen, te ontwikkelen. ${ }^{162}$

Meer nauwkeurigheid lost mogelijk afbakeningsproblemen op. Want sommigen voorzien problemen met de Awb-terminologie. Zij wensen nuancering van het begrip bestuursw orgaan. Zij onderscheiden vier categorieën, die onder art. 1:1, eerste lid, Awb kunnen vallen. ${ }^{163}$ Ten eerste, "organen van publiekrechtelijke rechtspersonen, die met openbaar gezag zijn bekleed". Bij voorbeeld publiekrechtelijk georganiseerde zelfstandige bestuursorganen, aangenomen dat zij organen van een rechtspersoon zijn. Ten tweede, "niet met openbaar gezag beklede organen van een rechtspersoon die krachtens publiekrecht is ingesteld, en tevens andere wel met openbaar gezag beklede organen kent" ${ }^{\text {". Bij }}$ voorbeeld het Centraal Bureau voor de Statistiek ${ }^{164}$. Ten derde, "niet met openbaar gezag beklede organen van een rechtspersoon die krachtens publiekrecht is ingesteld en die geen organen heeft die wel met openbaar gezag zijn bekleed". Bij voorbeeld het Jachtfonds en de Organisatie voor de binnenvisserij. En ten vierde, "met openbaar gezag beklede (organen van) privaatrechtelijike rechtspersonen". Bij voorbeeld de stichting Ontwikkelings- en saneringsfonds voor de Landbouw, maar ook Twijnstra Gudde en de NMB (ING). Moeillijkheden zijn te verwachten bij "onderdelen van publiekrechtelijke rechtspersonen die niet met openbaar gezag zijn bekleed. Wanneer is een dergelijk onderdeel orgaan van de rechtspersoon? Daamaast rijzen mogelijk problemen met bepaalde privaatrechtelijke rechtspersonen. Uit hun bevoegdheden moet men afleiden dat zij bekleed zijn met openbaar gezag, hetgeen niet altijd even eenwoudig is. " 165 De praktijk zal het leren.

Ook van andere zijde wordt gewezen op het feit, dat de Awb niet alle gaten dicht. Met referentie aan de, uiterlijk privaatrechtelijke, naamloze vennootschap De Nederlandsche Bank die door bijzondere voorschriften zo veel afwijkt van datgene wat zij lijkt, dat zij

160. Mvt wetswoorstel Awb, TK 1988-1989, 21221, ir.3, p.28.

161. N. Verheij, Naar een wetboek wan beswwrswecht, in: A.W. Heringa en N. Verheij (red.), Publiekrechtelijke bewegingen, Deventer, 1990, pp.83-102, i.h.b. pp.93-94.

162. J.B.I.M. ten Berge, Boekbeschowwing C.P.J. Goorden, in: RM Themis, nr.6, juni 1993, pp. 282-285, i.h.b. 0.284 .

163. G.M. Kuiper en J.L. Boxum, flet begrip bestuursorgaan in de Awb, in: J.L. Boxum, L.J.A. Damen, C. Lambers, J. de Ridder, B.C. Vis, Aantrekkelijke gedachten; Beschouwingen over de Awb, Deventer, 1993, pp. $275-289$, i.h.b. pp. $280-283$.

164. Het Centraal bureau en de Centrale commissies voor de statistiek worden trouwens intern verzelfstandigd. Zie voorstel Wet op het Centraal bureaw en de Centrale commissie voor de statistiek, TK 1993 . 1994,23576, nrs. $1-3$.

165. G.M. Kuiper en J.L. Boxum, t.a.p., pp.283-284. 
- wat betreft haar toezichthoudende taak - valt onder art. $1: 1$, eerste lid, sub a, $A w^{166}{ }^{166}$ wordt de verzelfstandigingsproblematiek op de Awb-tafel gegooid. "De verschillende privatiseringsoperaties hebben een toename laten zien van hybridische vormen. Of en en in hoe verre dergelijke operaties als bestuursorgaan moeten worden beschouwd en wanneer er - in de tweede categorie - sprake is van de unitoefening van openbaar gezag is lang niet altijd duidelijk. Evenmin geeft de Awb een indicatie voor het antwoord op de vraag of met deze mengvormen geen voorzichtigheid moet worden betracht. " 167

Wel is het meest juist het begrip zelfstandig bestuursorgaan tegen het licht van de Awb te zien. Of het nu gedecentraliseerdle of gedeconcentreerde ${ }^{168}$ organen betreft, de Awb is er op van toepassing. En, zowel publiekrechtelijk als privaatrechtelijk vorm gegeven organen vallen onder de Awb. Daarnaast behoren daartoe zowel organen mét als zonder openbaar gezag. ${ }^{169}$ Toegegeven, in een studie naar zelfstandige bestuursorganen die zijn belast met toezicht op naleving van wet- en regelgeving zijn in feite de organen met openbaar gezag relevant.

De kern van zelfstandige bestuursorganen is hierin gelegen, dat de hiërarchische band met attribuans of delegans is verbroken. Dat wil zeggen: publiekrechtelijke bevoegdheden worden geattribueerd dan wel gedelegeerd aan ambtenaren die niet ondergeschikt zijn aan een bepaalde minister. ${ }^{170} \mathrm{Bij}$ deze bevoegdheidstoekenning of -overdracht kan de ambtelijke top van het betrokken departement zich even wel het recht voorbehouden tot het geven van algemene aanwijzingen.

Een willekeurige greep uit het boordevolle bestand van zelfstandige bestuursorganen levert een gevarieerd gezelschap op. Bij voorbeeld het Commissariaat voor de Media, de Registratiekamer, het College van Toezicht Sociale Verzekeringen (dat sinds 1 januari 1995 de Toezichtkamer van de Sociale Verzekeringstaad vervangt) ${ }^{171}$, het Centraal Bestuur voor de Arbeidsvoorziening, het Centraal Orgaan Tarieven Gezondheidszorg, de Commissie tot beheer van het schadefonds geweldsmisdrijven, de Huurcommissies, de Stichting bureau architektenregister, de Kamers van Koophandel en Fabrieken, de stichting Nederlands Instituut voor Vliegtuigontwikkeling en Ruimtevaart, de erkende stamboekverenigingen voor paarden, het Instituut voor Toetsontwikkeling (CITO), de Nederlandse Organisatie voor Wetenschappelijk Onderzoek , de Koninklijke Bibliotheek,

166. O.a. N. Verheij, Het system van de Awb. Ars Aequi cahiers staats- en bestuursrecht, nr. 4, Nijmegen, 1993. p.15.

167. D.A. Lubach, De Awb en het grensgebied wan priwart en publiekrecht, in: NTB-special, jan. 1994, pp. $39-40$, i.h.b. p. 40; Vgl. M. Bense en S. Zijlstra, Het begrip bestuursorgaan, in: NTB, nr.9, 1994 , pp. 253-270, i.h.b. pp. 261-262.

168. Bij voorbeeld de directeur van de Veterinaire Dienst wan het ministerie van LNV blijkt bestuursorgalam. Zie ARRS 26 aug. 1993, AB-kort 1994, 49.

169. In Functione bestuur: wotarom en hoe?, TK 1990-1991, 21042, nr.4, p.8, vallen onder zbo"s o. a. ook "publiekrechtelijk vormgegeven organen die uitsluitend bevoegd zijn tot privaatrechtelijke handelingen en/off feitelijke handelingen maar niet met openbaar gezag zijn bekleed". Dit "vanwege hun mogelijk grote invloed op de feitelijke positie van derden".

170. Vgl. F.A.M. Stroink, Het leerstuk der deconcentratie, dissertatie RUU, "s-Gravenhage, pp. $21-22$. Auteur thanteert de term hiërarchie eveneens voor verhoudingen op departementsambtenaarlijke basis.

171. Zie o. a. Wetswoorstel Invoering Organisatiewet sociale verzekeringen, TK 1993-1994, 23775, trrs. 1-3. 
de Raad woor Studie- en Beroepskeuze, het Centraal Bureau voor de Grafische Bedrijven in Nederland, de OV-studentenkaart BV, het College ter beoordeling van Geneesmiddelen, het Centraal bureau voor de Grafische Bedrijven in Nederland, de Stichting Nederlands Instituut voor Lifttechniek, de Stichting Fonds voor de Letteren, Stichting fonds voor beeldende kunsten, bouwkunst en vormgeving ${ }^{172}$, de stichting Fonds voor de Scheppende Toonkunst, het Nederlands Fons voor de Film, de Mondriaan Stichting met het Fonds buitenlandse presentaties en het Bijzondere aankoopfonds in haar beheer ${ }^{173}$, de Stichting Fonds woor bijzondere journalistieke produkties, het Nederlands Literair Produktie- en vertalingenfonds, het Stimuleringsfonds voor Architectuur en het Fonds voor de Podiumkunsten. ${ }^{174}$

\section{a. Aard van de bevoegdheden}

Zelfstandige bestuursorganen ontlenen hun zelfstandigheid aan specifieke publiekrechtelijke regelingen. Organisatie-eenheden met publiekrechtelijke bevoegdheden, uit te oefenen in het algemeen belang, vertegenwoordigen overheidsgezag. Zodra daarvan sprake is, zijn juridische consequenties verbonden aan de normen die van toepassing zijn op hun bestuurlijk handelen. Normen ten aanzien van het handelen zijn afhankelijk van de betrokken taakbehartiging en de daaraan gerelateerde bevoegdheidsuitoefening. Toezichthouders handelen binnen een publiekrechtelijk kader. Uitgangspunt is dat inspecterende, controlerende en sanctionerende zelfstandige bestuursorganen als in deze studie bedoeld, die in het algemeen belang ${ }^{175}$ publiekrechtelijke bevoegdheden kunnen uitoefenen, openbaar gezag genieten. Dat is de centrale notie.

Toezichthoudende diensten (waaronder diensten die vergunningen verstrekken) hebben publiekrechtelijke bevoegdheden. ${ }^{176}$ Dat is het kernpunt. In een werkdefinitie voor dit

172. Over implicaties van dit fonds als zbo (o.a. beleidsvrijheid), in thet licht van de verstrengeling overheid en particulier initiatief, J. van der Bij, De geswbsidieerde muze en het maatschappelijk middenveld: Het Fonds woor beeldende kunsten, wormgeving en bouwkunst, in: M.C.P. van Eijk (red. ), Gesloten of open overlegstelsel, "s-Gravenhage, 1994, p.147 e.v.

173. M. Vermeijden, Nieuwe fondsen ter ondersteuning van moderne kunst, in: NRC, 15 juni 1994, p. 7; Zie ower oprichting van verschillende fondsen als rechtspersonen ex art. 9 e.w. Wet op het specifieke cultuurbeteid, Stbl. 1993, 193.

174. Over laatst genoemde fondsen, opgericht in de periode 1990-1993, ministerie WVC, dir.-gen. culturele zaken, Cultureel beleid in Nederland; Nationaal rapport, Europees programma voor de evaluatie van nationaal cultuurbeleid, 1993.

175. Deze toevoeging is noodzakelijk volgens R.L. Vuçsán, Katern bestuursrecht, in: AA, juni 1994, pp.2429-2433, i.h. b. p.2431. Auteur ziet daarin namelijk het onderscheidend element voor de overheid als openbaar gezagsorgaan met de willekeurige burger die z.i. ook publiekrechtelijke bevoegdheden heeft. Vuçsín beschouwt bij voorbeeld een aanvraagg van een burger om een bouwvergunning als een publiekrechtelijke bevoegdheid, ondat daardoor de plicht voor het betrokken bestuursorgaan ontstaat om binmen een bepaalde termijn op de aanvraag te beslissen.

176. Notitie verzelfstandiging en privatisering. TK 1989-1990, 21332, nr. 1, p.3; Dit standpunt vindt bevestiging bij de president van de rechtbank te Ansterdam inzake Vereniging Bureau voor Muziekauteursrecht vs. regeringscommissaris belast met toezicht op Buma, 29 aug. 1994, nr.94/527/V, Jurisprudentie Bestuursrecht, 27 jan. 1995, nr. 1. pp.11-15. De regeringscommissaris, formeel-wettelijk belast met het toezicht op Buma, is bestuursorgaan. Zijn, in het kader van toezicht genomen, besluit tot het instellen van een accountantsonderzoek wordt aangemerkt als een besluit in de zin van art. 1:3 Awb. Het besluit 
onderzoek zal dus niet zo zeer de bestuurstaak, die een toezichthoudend zelfstandig bestuursorgaan in het kader van uitoefening van openbaar gezag is toebedeeld, uitgangspunt zijn. Het getuigt van meer realiteitszin het rechtskarakter van de specifieke handelingen, die een toezichthoudend zelfstandig bestuursorgaan verricht ter regeling van dat bestuur, te benadrukken. Vandaar is in beginsel de beperking tot een soort bevoegdheid, namelijk de publiekrechtelijke bevoegdheid, aangebracht.

\section{b. Organisarievorm}

Uitoefening van openbaar gezag impliceert, anders dan voor het handelen van uit de organisatie, geen juridische gevolgen voor de normen met betrekking tot de structuur van de organisatie. Publieke taakvervulling dient in beginsel te geschieden door publiekrechtelijke organisaties. Maar zij kan ook -mits voorzien van de nodige waarborgen, betreffende vooral democratische als mede financiële controle, openbaarheid en rechtsbescherming- prima plaats vinden door (besturen van) privaatrechtelijke rechtspersonen. ${ }^{i 77}$ De mogelijkheid om via hetzij attributie of delegatie van bevoegdheden van openbaar gezag aan publiekrechtelijke organen, hetzij oprichting of deelneming in een privaatrechtelijke rechtspersoon indien de behartiging van een openbaar belang dat vereist, een zelfde doel te bereiken, duidt op een "organisatierechtelijke twee-wegenleer". ${ }^{178}$

Zelfstandige bestuursorganen kunnen dus een publiekrechtelijke of privaatrechtelijke rechtsvorm hebben. ${ }^{179}$ Afhankelijk van de bij de functionele decentralisatie gehanteerde doelstellingen en de aan een zelfstandig bestursorgaan op te dragen taken en toe

176. $\rightarrow$

is namelijk gericht op rechtsgevolg, omdat het werplichtingen schept t.w. het toelaten van accountants en het medewerken aan een onderzoek.

177. Overtigens geeft C.A. Schreuder, Publiekrechtelijke taken, privatrechtelijke rechtspersonen, Deventer, 1994, pp 406-417/425-426 ter beoordeling daarwan correcte criteria: "a. Indien de overheid zich zo danige beinv loedingsmogelijkheden wenst voor te behouden dat de aand van de priwaa trechtelijke organisatie wordi gedenatweerd, dient niet voor takverrichting door cen privaatrechtelijke organisatie te worden gekozen; b. Bij taakopdracht aan vennootschappen moet men zich er rekenschap wan geven dat de opgedragen tak zich dient te verdragen met een streven naar winst" $c$. Een vennootschap dient geen taken opged ragen te krijgen die spanning veroorzaken tussen een adequate publiekrechtelijke takakuitvoering en het belang wan de vennootschap; $d$. Voor de siruatie dat een voor de aitwoering van een bepaa lide publiekrechtelijke takk opgerichte privaatrechtelijke organisatie naast deze publiekrechtelijke taak andere taken op zich neemt, dient (in de statuten) de werhouding tussen deze taken zo danig te zijn geregeld, dat de publiekrechtelijke taak de hoofdlak van de organisatie is en blijft; e. De publiekrechtelijke takak (en de daamit voort vloeiende werkzaamheden) dienen nauwkeurig te kunnen worden omschreven; en f. De a ro van de aan een priwaatrechtelijke organisatie op te dragen publiekrechtelijke taak dient zich te verdragen met een normering waarin het eigen belaing van de organisatie is verdisconteerd".

178. S.E. Zijlstra, Annotatie inz. standplaatsvergunning Pinkpopburo, Vz ARRS 18 mei 1.993, S03.93.1111, AB 1994, 333.

179. I.B.J.M. ten Berge en F.A.M. Stroink, a.w., pp.15-16/21; J.B.J.M. ten Berge, Taalverwarring romd functionele decentralisatie, in: BWn, nr.6, 1989, p.340; J.A. de Bruijn en N. Lammers, t.a.p., p.54; G.P.J. Goorden, Bestuurlijke organisatie, in: G.P.J. Goorden e.a.. Kroniek wan het bestuwrsecht 19871992, 1993, Zwolle, pp.1-13, i.h.b. p.8; H.G. Lubberdink, Kronieken Bestuarlijke organisatie, in: NTB, ne.4, 1990, pp.123-124; F.A.M. Stroink, Boekbespreking, t.a.p. p. 271; TK 1990-1991, 21042 , nr.4, pp. 8-9; H. van der Sluijs, t.a.p. , p.305; A.T.L.M. van de Ven, Verzelfstandiging en bestumrlijke decentralisatie, in: S\&V, nr.3, mei/juni 1994, pp.61-65, i.h.b. p.63; Algemene Rekenkamer, Zbo "s en ministeriële verantwoordelijkheid, TK 1994-1995, 24130, nr.3, pp.7-8. 
te kennen bevoegdheden moet in het concrete geval een keuze, qua vormgeving, worden gemaakt.

Kortom, de juridische vorm van een organisatie is van secundair belang. De splitsing tussen publiek- en privaatrecht, in de zin van verschil tussen publiekrechtelijke organisaties (waarvan de instelling en inrichting berust op een formele wet) en privaatrechtelijke organisaties (verenigingen, stichtingen, vennootschappen en andere rechtspersonen bedoeld in boek $2 \mathrm{BW}$ ), is slechts een aanvullend onderscheid. ${ }^{180}$ In eerste instantie is de vraag naar de aard wan de bevoegdheden aan de orde.

De, van uit de tegenovergestelde optie, namelijk dat de organisatievorm (in het licht van de aard van de taakbehartiging) rechtens relevant en bepalend is ${ }^{181}$, uitgesproken voorkeur ${ }^{182}$ voor het laten uitvoeren van bestuurstaken door publiekrechtelijke organisaties is, gelet op het rechtszekerheidsbeginsel, niet onbegrijpelijk. De verdediging "het begrip zelfstandig bestuursorgaan te reserveren voor publiekrechtelijk georganiseerde organim saties" ${ }^{183}$ wekt weinig bevreemding. Toch is de stelling te stringent. Reeds voorstanders van het principe erkennen, hoewel mondjesmaat, uitzonderingen op de regel. $\mathrm{Zij}$ achten het "denkbaar dat voor commerciële activiteiten, waarbij (eventueel tijdelijk) overwegende overheidsinvloed wenselijk wordt geacht in verband met een monopolieachtige situatie, de overheids-bv of overheids-nv de aangewezen organisatie-vorm is". ${ }^{184}$ Inderdaad past hier nuance.

\section{c. Privaatrechtelijke functionele decentralisatie}

Privaatrechtelijke rechtswormen met, al dan niet gedeeltelijke, overheidsinvloed ${ }^{1: 85}$ zijn overheidsorganisaties ongeacht hun bevoegdheden. Ter bepaling van de mate van overheidsinvloed worden de volgende criteria gehanteerd. Ten eerste, ten minste respectievelijk de helft van de bestuursleden (wat betreft stichting en gewone vennootschap) en de helft van de leden van de raad van commissarissen (in geval van structuurvennootschap) zijn door organen van de overheid benoemd. Ten tweede, de overheid bezit vijftig procent van de aandelen (wat betreft de gewone vennootschap). Ten derde, in hoe ver bestaat overheidsinvloed op het personeelsbeleid van de betreffende organisatie. Ten vierde, is de besluitvorming van de organisatie in hoge mate afhankelijk van goedkeuring van

180. J.B.J.M. ten Berge en F.A.M. Stroink, a.w., p.13; Recenter J.B.J.M. ten Berge (1989), t.a.p., pp.336339.

181. J.L. Boxum, J. de Ridder, M. Scheltema, a.w., p.9; Protest van F.A.M. Stroink (1992), Recensie, t.a.p., pp.270-271.

182. TK 1990-1991, 21042, nr.4, pp.25/29-30; Vgl. J.C.E. Ackermans-Wijn, Contracten met de overheid, diss. KUN, Deventer, 1989, p.23; Hoewel minder nadrukkelijk voorkeur woor publiekrechtelijke rechtsvorm, wel evidente bezwaren tegen private rechtsvormen bij G.M. de Schipper, Studieboek algemeen bestuwrsrecint. Middelburg, 1982, pp.49/89.

183. J.L. Boxum, J. de Ridder en M. Scheltema, a.w., p.7.

184. Commissie-Scheltema, a.w., p.42.

185. H.F. Munneke, J.B.J.M. ten Berge, F.A.M. Stroink, P. Haighton en P. den Hoed, a.w., pp. $21-22$. 
hogerhand. Beide laatst genoemde maatstaven zijn, uit de CRvB-jurisprudentie, gedistilleerde, criteria. ${ }^{186}$

Problematisch is of dergelijke privaatrechtelijke organisaties functioneel gedecentraliseerde organisaties zijn te noemen. De neiging bestaat inderdaad om functionele decentralisatie uitsluitend te hanteren voor publiekrechtelijke organisatiestructuren. Bij voorkeur, en strikt genomen, is de term functionele decentralisatie niet toepasselijk op privaatrechtelijke organisaties. Bepaalde privaatrechtelijke rechtspersonen en vooral vennootschappen zijn genoodzaakt marktconform op te treden en zijn qua cultuur, werkwijze en juridische ophanging ver verwijderd van het openbaar bestuur. Terwijl onder meer dat laatste, te weten het behoren tot het openbaar bestuur, kenmerkend is voor functionele decentrallisatie. ${ }^{187}$ Daarbij gaat het om een verschuiving van verantwoordelijkheden tussen overheden.

Wanneer nu het criterium van openbaar gezag centraal wordt gesteld, blijkt het toch mogelijk in termen van functionele decentralisatie te spreken. Sleutelwoord is dan privaatrechtelijke functionele decentrallisatie. ${ }^{188}$

Het scharen van een privaatrechtelijke organisatie, bekleed met openbaar gezag, onder functionele decentralisatie klinkt niet voor iedereen even fraai. In elk geval zij, die de juridische vorm van de organisatie en niet zo zeer de alard van de uit te oefenen bevoegdheden voorop stellen, hebben moeite met privaatrechtelijke functionele decentralisatie. ${ }^{189}$

186. Ower dit afmeten van overwegende invloed, die de overheid zowel feitelijk als rachtens op vennootschappen, stichtingen e.d. uitoefent, A.H. van Zutplnen, Het begrip openbare dienst in de Ambtenarenwet 1929; Een verkenning op de grens wan het bestuurstecht, in: NTB, nr.4, 1988, p. 125, Tevens A.H. van Zutphen, De rechtspositie wan de rijksambtenaar; Aanstelling en ontslog. 1991, 's-Graventhage. pp. 87-99; Ook L.F.M. Verhey, Horizontale werking van grondrechtem, in bijonder van het recht op privacy, Zwolle/Utrecht, 1992, pp.100-101; C.A. Schreuder, Publiekrechrelijke taken, privare rechtspersonen, serie bestuursrecht theorie en praktijk nr. 16, Deventer, 1994, p.42, constateert correct dat het CRvBi de teugels strakker aan trekt. De feitellike overheidsinvloed krijgt minder nadruk. Doorslaggevend is de formele overheidsinvloed. Ook al is de invloed, van de overheid op de privaatrechtelijke rechtspersoon, groter dan de formele juridische structuur doet vermoeden, dan nog rekent het CR. B de private rechtsvonn niet tot de openbare dienst. Sclureuder ondersteunt hat mening met jurisprudentie: CRwB 25 juni 1991. AB 1992, 12 en CRwB 13 mei 1993, AB 1993, 482.

187. TK 1990-199॥, 21042, mr.4, p.7.

188. I.B.J.M. ten Berge en F. A.M. Stroink, a.w., p.21; Als mede J.B.J.M. ten Berge (1989), t.a.p., p.339.

189. Over overlapping privatisering - functionele decentralisatie C.A. Schreuder (1991), t.a.p.,pp.226-230. Een geprivatiseerde instantie -door auteur opgevat als een privaatrechtelijke organisatie die "i.p.w. een pabliekrechtelijke organisatie (gekomen), een overheidstak behartigt - is, indien met openbaar gezag bekleed, een vorm van functionele decentralisatie; C. A. Schreuder, Verzelfstandiging wan het likwezem, in: W.J.M. Kicken, N.P. Mol en A. Sorber, t.a.p., Pp.153-162, i.h.b. p.153; G.M. Kuiper, J.J. van Vliet, J.L. Boxum, J. de Ridder en M. Scheltema, Verzelfstandiging: publiek of privaar; Organisatiewormen voor beschikkingyerlening door Informatiseringsbank, Deventer, 1992; Ook G. M. Kuiper, Her verlenen van beschikkingen: door uitbesteding of een zelfstandig bestuursorgaan? ${ }_{\text {in: }} \mathrm{BK}$, ni.. 1. (themanummer), 1.992; Vgl. M. Scheltema, brief aan staatssecretaris van viom betreffende Verzelfstandiging van het Kadaster d.d. 16 okt. 1990, pp.2-3/5-6; W.S.P. Fortuyn, Op weg naar een geatomatiseerde samenleving?. in: Namens, nr.5, 1991, p.11. 
Maar ook als het karakter van taken en bevoegdheden primair uitgangspunt is, heeft privaatrechtellijke functionele decentralisatic een lelijke toonzetting. Uitoefening van openbaar gezag door een privaatrechtelijke organisatie impliceert dat de vitvoering van een staatstaak binnen een publiekrechtelijk kader plaats vindt. Het publiekrecht is per definitie van toepassing op het handelen van uit de organisatie. De vraag rijst of het mogelijk is of (besturen van) privaatrechtelijke organisaties "zonder meer zijn te behandelen als zelfstandige bestuursorganen met een publiekrechtelijk karakter". 190

Het feit dat het gaat om een overheidstaak is reden voor eventuele publiekrechtelijke inkleuring van de norm ten aarzien van het handelen. Dat hierbij een privaatrechtelijke organisatie is betrokken, doet daar niet aan af. ${ }^{191}$

Slechts het simpele gegeven dat een privaatrechtelijke organisatiestructuur bij publiekrechtelijke taakbehartiging wordt ingeschakeld, maakt dat dit wel juridische consequenties voor het handelen van een organisatie heeft. ${ }^{192}$ Hiervan getuigen natuurlijk ook art. 3:1 Awb juncto art. 3:13/14 BW. Uit rechtsstatelijk oogpunt is een en ander op te merken.

\section{d. Rechtsstatelijke eisen}

Binnen de opbouw van het Nederlands recht zijn aan een publiekrechtelijke organisatie, en niet aan een rechtspersoon met privaatrechtelijk karakter, bepaalde waarborgen met oog op de uitvoering van een overheidstaak bekend. ${ }^{193}$ Deze waarborgen betreffen zwaar wegende garanties bedoeld om uitvoering van overheidstaken, op afstand, zo goed mogelijk te doen verlopen.

Zo is er, ten eerste, de regel dat de wetgever de grondslag legt voor taakuitvoering en deze zo goed mogelijk normeert. Weliswaar zal hieraan ook voor privaatrechtelijke zelfstandige bestuursorganen in de toekomst steeds strakker de hand worden gehouden. Ten tweede is te denken aan een behoorlijke regeling van politieke verantwoordelijkheid voor de takuitwoering. Ten derde vinden parlementaire controle en rechtmatig- en doelmatigheidstoezicht door de algemene rekenkamer op het functioneren van een betrokken organisatie regeling. Ook wat dit punt betreft treedt een kentering ten voordele van privaat rechtelijke rechtspersonen op. Juist met aandacht woor functionele decentralisatic,

190. TK 1990-199n, 21042, nr.4, p.9.

191. Zie bij woorbeeld J.A.F. Peters, Privatisering bezien vamuit een ander juridisch perspectief II, in: TwO, nr. 9, 28 aprill 1989, pp.175-179, i.h.b. p.179.

192. C.A. Schreuder, Publiekrechtelijkeraken, private rechtspersonen, diss. RUG, Deventer, 1994, pp. 109. 178 , bespreekt uitvoerig het toepasselijk recht bij publiekrechtelijke taakverrichting - volgens auteur ook publiekrechtelijke takikvervulling zonderuitoefening van openbaar gezag - door private rechtspersonen. Denk aan i. h. b. a. rechtsstatelijke, beginselen als legaliteits-, autonomie-en democratiebeginsel en b. algemene beginselen van behoorlijk (onde memings) bestuur. Auteur benadn kt wel de nodige nuancering bij invulling van 0. a. de abbb op private rechtspersonen, gegeven de eigen aand en kenmerken wan private rechtsvormen; Dissertatie besproken door H.J. Simon, in: NJB, nr.16, 21 april 1995, pp. $600-603$.

193. A.C. Schreuder, Publiekrechtelijke raken, private rechspersonen, diss. RUG. Deventer, 1994, pp.65107 , geeft het historisch perspectief waarbinnen, gelet op die waarborgen bij publiekrechtelijke rechtsvormen, toedel ing van owerheidstaken aan privaatrechtelijke rechtswormen met argusogen wordt bekeken of met open handen wordt ontvangen. 
in het bijzonder zelfstandige bestuursorganen, wijst de Algemene Rekenkamer in het jaarverslag over 1993 op de toepasselijkheid van art. 59, eerste lid, sub d, Comptabiliteitswet op privaatrechtelijke rechtspersonen, die een bij of krachtens de wet geregelde publieke taak uitoefenen en daartoe geheel of gedeeltelijk worden bekostigd uit bij of krachtens de wet ingestelde heffingen. ${ }^{194}$ En ten vierde stelt het publiekrecht elementaire voorzieningen veilig, te weten in regelingen van rechtsbescherming, klachteninstanties en openbaarheid. Het reeds vermelde aanwijzingsbesluit inzake organen die vallen onder de Wno en de Wob biedt hier voor privatrechtelijke organen ten dele oplossing. $\mathrm{Er}$ is nog een andere belangrijke overweging om bij privaatrechtelijke zelfstandige bestuursorganen voorzichtigheid te betrachten. Deze organisatie heeft de uiterlijke verschijningsvorm van een gewone privaatrechtelijke instantie. Hierdoor kan, voor de burger, overheidsbestuur minder herkenbaar zijn.

Het personeels- en arbeidswoorwaardenbeleid kan ook invloed hebben op de keuze voor een privaatrechtelijke of publiekrechtelijke status van een zelfstandig bestuursorgaan. In geval van publiekrechtelijk vorm gegeven zelfstandige bestuursorganen wordt, weliswaar op beperkte schaal, de rechtspositie van personeel bij amvb geregeld. Vooral bij zelfstandige bestuursorganen op het terrein van onderwijs en wetenschappen voelt de minister zich primair verantwoorde $l i j k$. Overigens zijn bij het merendeel van publiekrechtelijk vorm gegeven zelfstandige bestuursorganen de besturen daarvan de eerst geroepenen. De instellingsregeling draagt vaak aan het bestuur van een zelfstandig bestuursorgaan op de rechtspositie van het personeel te regelen. Mogelijk heeft de betrokken minister nog enige invloed ter zake. Dat staat dan in de instellingswet vermeld. Soms behoeven de rechtspositiebesluiten, die door het bestuur zijn vastgesteld, nog goedkeuring van de minister. Het is ook mogelijk, dat de instellingswet ter zake niets bepaald. Dan is de ministeriële macht eventueel indirect. Bij voorbeeld als de minister bevoegdheden heeft ten aanzien van de begroting van een zelfstandig bestuursorgaan of ten aanzien van de door een zelfstandig bestuursorgaan te hanteren tarieven. Ten aanzien van privaatrechtelijk vorm gegeven zelfstandige bestuursorganen bestaat geen verantwoordelijkheid ter zake van enig minister. Regeling van rechtspositie en regeling van arbeidsvoorwaarden van personeel staan vrij. ${ }^{195} \mathrm{k} 96$ Wel verdient het aanbeveling om personeelsbeleid van privatrechtelijk vorm gegeven zelfstandige bestuursorganen af te stemmen op, specifiek voor zelfstandige bestuursorganen opgestelde, modelreglementen ${ }^{197}$ ter zake. ${ }^{198}$

194. Verslag wan de Algemene Rekenkamer over 1993, TK 1993-1994, 23670, nrs.1-2, pp.10-11.

195. Zie voor een en ander Vaststelling begrating uig./ontw. min. BiZa (1993), TK 1992 1993, 22800 VII, nr. 43, pP. 1-3.

196. Paragraaf 6.2.2. maakt duidelijk dat arbeids-en personeelswoorwaardenregelingen bij verzelfstandigingen soms iets te vrij zijn. Zie Algemene Rekenkamer, Zbo's en ministerièle werantwoordelijkheid, TK 1994-1995, 24130, nr.3, pp.45-52.

197. Ministerie van binnenlandse zaken directoraat-generaal management en personeelsbeleid, Model wan algemeen rechispositiereglement, bezoldigingsbesluit, wachtgelawithering en witkeringsregeling voor een zbo, "s-Gravenhage, 18 febr. 1992.

198. P.L. de Vos, De ambtenaar in Nederland; Sectoralisatie, afslanking en normalisatie, in: TwBP, 1995. pp.794-799, wrangt zich aff of het opsitellen van alternatieve reglementen ed. de, door onder meer externe verzelfstandiging naar zbo's, ontstane verslechtering van de rechtspositie van anabtenaren kan opheffen of tegenhouden. 
$\mathrm{Nu}$ is het wel zo dat het privaatrecht als zo danig relatief gezien ruimte laat om op privaatrecht gebaseerde organisaties via nadere vormgeving met publiekrechtelijke waarborgen te omgeven. Duidelijk is dat civiel recht daarbij wel beperkingen kent. ${ }^{199}$ Van wege deze restricties wil niet iedereen openbaar gezag aan nv's en bv's toekennen. ${ }^{200}$ Maar niet elke rechter heeft daar oren naar. Het argument, dat het aan een nv opdragen van publiek(rechtelijk)e taken, als de controle op de naleving van de wet en de opsporing van overtredingen daarvan, ontoelaatbaar is omdat die nv - gelet op structuur en apparaat van een $\mathrm{nv}$ - een winstoogmerk heeft, wordt in geding weerlegd. ${ }^{201}$

De volgende conclusie is gerechtvaardigd. De constructie, dat (besturen van) privaatrechtelijke organisaties zijn belast met de uitvoering van bepaalde overheidstaken, is denkbaar. Als overigens in feite betrekkelijk schaarse ${ }^{202}$ uitzondering, op het principe dat de Nederlandse overheid zelf zorg draagt voor bestuurlijke activiteiten, is zij verdedigbaar.

Integratie van het privaatrecht in het publiekrecht kan zelfs ten dienste komen van het openbaar bestuur. Bij een dergelijk pleidooi, voor het gebruik van privaatrechtelijke organisatievormen door de overheid, gelden twee condities. Het gebruik wan privaatrechtelijke rechtspersonen is zinloos als "men de verhouding overheidslichamen-rechtspersonen vrij wel geheel identiek wil maken aan die tussen een respectievelijk hiërarchisch hoger en lager overheidsorgaan. Evenmin is het gebruik van privaatrechtelijke organisaties aangewezen wanneer publiekrechtelijke bevoegdheidsuitoefening een wezenlijk bestanddeel van de activiteiten vormt. " ${ }^{203}$ Inschakeling van privaatrechtelijke organisatievormen brengt voordelen van slagvaardigheid, financiële verslaglegging, risicobeperking, fiscale aard ${ }^{204}$, medezeggenschap en vooral behoorlijke belangenbehartiging. Immers, de door de wet en statuten verleende bewoegdheden zijn bepalend voor het

199. Wat betreft vennootschappen, over de verhoudingen algemeen belang en eigen belang van een private rechtsworm, de zelfstandige inwulling wan abbb en de moeilijkheden met - zo een administratieve rechter als competent is (verklaard) - gerechtelijke oordeelsvorming daarbij: C.A. Schreuder (1991), t.a.p.,

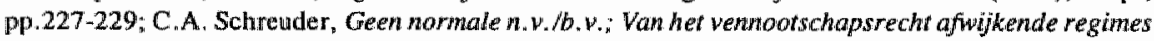
woor de overheids-n.v. 's en-b.v. 's, in: TVVS, nr.8, 1993, pp.189-194; C. A. Schreuder, Publiekrechtielijk taken, priwate rechtspersonen, diss. RUG, Deventer, 1994, pp.48-63; V.A.M. wander Burg, De verzelfstandiging van rijksmuseale diensten in de vorm van een stichting, in: $\$$ \&V, 1993, pp.6-9, i.h.b. p.7, V.A.M. w/d Burg, Juridische aspecten wan privatisering, in: TwO, nr.3, 1987, pp.50-52.

200. C.A. Schreuder, Toepassing wan de Awb op besturursorganen met een eigen belang, in: J. L. Boxum en L.J.A. Damen, Aantrekkelijke gedachten; Beschouwingen over de Awb, Deventer, 1993, pp.291-305.

201. Woarborg Platina, Gowd en Zilver nv, Hof 's-Gravenhage, 17 maart 1992, NJ 1993, 213. Het hof ziet niet in dat het wettelijk aanwijzen en met keuringstaken belasten van de waarborginstelling "in strijd zou zijn met emige geschreven of ongeschreven regel van staats- of administratief recht dan wel enig algemeen beginsel van behoorijk bestnur".

202. J.B.J.M. ten Berge en H.J. de Ru, Overheid en priwaatrechtelijke organisatieworming, Rbb-preadvies I Privaatrechtelijke organisatieworming in het brandpunt, "s-Gravenhage, maart 1991, p.14.

203. T.J. van der Ploeg, H.J. de Ru en C.A. Schwarz, Bedrïfsmatige structuren bij de overheid, in: BW $\mathrm{n}$, maart 1983, nr.3, pp.175-194, i.h.b. p.192.

204. Hierover 0.a. E. Magnin, Projectfinanciering voor de overheid de fiscale voordelen, in: juridisch en fiscaal tijjdschrift Privatisering, nr.1, 25 jan. 1995, pp.1-4; Belangrijk is het te realiseren dat, bij de overgang wan publieke instelling naar privaat bedrijf, ook minder voordelige fiscale aspecten (heffing van omzet- en vennootschapsbelasting) kumen spelen. 
privaatrechtelijik bestuursorgaan. Het algemeen belang kan nog een doorslaggevende rol spelen in geval van subsidie- en vergunningverlening door de overheid ${ }$ bij enig aandeelhouderschap van de overheid, of bij taak-en doelomschrijving in de statuten van een private rechtsvorm dan wel in de instellings-en organisatiewet van een privaatrechtelijk zelfstandig bestuursorgaan. Maar ook dan wordt tegen een ongeoorloofde monopoliepositie gewaakt door mogelijkheden van rechterlijk beroep als mede door de beginselen van redelijkheid, billijkheid en de goede trouw. Kortom, "bij het hanteren van privaatrechtelijke rechtspersoonsvormen door overheidslichamen zal de politiek een veer laten met betrekking tot het toezicht op en het beïnvloeden van het functioneren van de organisatie. Voor de publiekrechtelijke mogelijkheden komen privaatrechtelijke en ondernemingsrechtelijke middellen in de plaats als vernietiging van besluiten, jaarrekening- en enquêteprocedures etc. De burgerlijke rechter spreekt niet recht op basis van het door het overheidslichaam aangevoerde algemeen belang, maar op grond van privaatrechtelijke regels, waarbij hij, indien het op afweging van belangen aankomt, niet zonder meer het algemeen belang het zwaarst behoeft te laten wegen." $205 \mathrm{Het}$, door de overheid te dienen, algemeen belang is slechts deelbelang te midden van andere deelbelangen die (mede) bepalend zijn voor het zelfstandig belang van privaatrechtelijke rechtspersonen als stichting of vennootschap. 206207

Een privaatrechtelijk vorm gegeven zelfstandig bestuursorgaan heeft bestaansrecht, mits zijn statuten voldoen aan de noodzakelijke rechtsstatelijke randvoorwaarden van legaliteit, rechtsbescherming en democratische controle. ${ }^{208}$ Daartoe bieden de toetsingspunten ten aanzien van de vormgeving van zelfstandige bestuursorganen ${ }^{209}$ een bruikbare basis. Besluit de Staat tot oprichting van of neemt de Staat, met risicodragend vermogen, betekenisvol deel aan een privaatrechtelijke organisatie, dan verdient deze keuze ${ }^{210}$ uildrukkelijk motivering. ${ }^{211}$

205. T.J. van der Ploeg, H.J. de Ru en C.A. Schwarz, t.a.p., p.193.

206. Het bellang van de rechtspersoon als integratief belang bij privalutrechtelijk vorm gegeven $z$ bo' $s$ is te $z i e n$ bij onder meer: de Stichting Verzekeringskamer, conform art. 7, derde lid, Statuten Vk (De Brauw, Blackstone en Westbroek 1.S.m. De Bandt, Van Hecke en Lagat, 5 aug. 1992) richt de raad van toezicht zich naar thet belang van de stichting; Stichting Toezicht Effectenverkeer , conform art. 4 , weede lid, Statuten STE (Lubbers en Dijk, jaa. 1992) dient het bestuur, werkend zonder last of ruggespraak. uitsluitend het doel wan de stichting; vgll. het weliswaar publiekrechtelijk zbo dat op vennootschappelijksrecht is geinspureerd $t$. w. de Rjjksdienst voor het Kadaster en de Openbare Registers, conform art. 12, tweede lid, jo, art. 9 Voorstel Organisatiewet Kadaster (TK 1992-1993, 23007, nrs. 1 2, p.4), zie ook uiteindelijke Organisatiewet Kadaster, Stbl. 1994, 125, richt de raad van toezicht zich natir her belang van de dienst, daaronder begrepen het belang vam behoorlijke takkervulling van de bij of krachtens de wet aan de dienst opgedragen taken.

207. Vgl. Commissie Bundeling Ervaring bij privatisering, Handboek privatisering, "s-Gravenhage, 1990, p.118.

208. Zie ook J.B.J.M. ten Berge en H.J. de Ru, t.a.p., pp.32-45.

209. TK 1990-1991, 21042, ni.4, pp.33-35; Vgl. randwoorwaarden J.B.J.M. ten Berge en F.A.M. Stroink, a.w., pp. 57-64.

210. J.B.J.M. ten Berge en H.J. de Ru. t.a.p., p.2.

211. J.B.J.M. ten Berge en H.J. de Ru, t.a.p., p.44; Zie ook TKK 1990-1991, 21042, mr.4, p.32. 
Overigens wordt die keuze, tussen publiekrechtelijke of privaatrechtelijke organisatiewormen voor de behartiging van (quasi-) )ollectieve taken die de politiek belangrijk vindt, beïnvloed door verschillende factoren. ${ }^{212}$ Ten eerste, bestaan er belangrijke particuliere organisaties die al op het betrokken terrein opereren. Ten tweede, in welke mate wil de politiek greep houden op de taakuitvoering. Ten derde ligt de vraag voorhanden, of jegens burgers of particuliere organisaties gezag wordt uitgeoefend. Ten vierde rijzen vragen van doelmatigheid inzake flexibiliteit ten opzichte van de markt, rechtspositie van het personeel en dergelijke. Ten vijfde moet rekening worden gehouden met politieke megatrends waaronder het streven naar een wenselijke omvang van de echte overheid.

Bovenstaande beschouwd ${ }_{y}$ is het voorstel tot verruiming van het orgaanbegrip in art. $1: 1$, eerste lid, Awb een vermelding waard. De uitbreiding betreft de volgende toevoeging: "In deze wet wordt onder bestuursorgaan mede verstaan het orgaan van een bij of krachtens de wet opgerichte rechtspersoon (rechtspersoon sui generis, $t B$ en $d R$ ) en van het bestuur van een tot de openbare dienst te rekenen stichting of vereniging. " 213

\section{e. (De)centrale overheid}

Andere afbakening, die uit de praktische situatie voortvloeit, is die tussen centrale en decentrale overheid. Doorgaans behoren toezichthoudende zelfstandige bestuursorganen tot de centrale overheid.

De onderzochte zelfstandige bestuursorganen zijn veelal van wege rijksoverheid ingesteld of zijn (middels bij voorbeeld benoeming van bestuursleden, linanciering of toezicht) verbonden met een onderdeel van de centrale overheid.

Bovendien blijkt uit jurisprudentie, aangaande het administratief orgaan-begrip in de Wet administratieve rechtspraak overheidsbeschikkingen, dat onder administratief orgaan van de centrale overheid moet worden verstaan een orgaan dat niet is een orgaan van provincie, gemeente, waterschap of publickrechtelijke bedrijfsorganisatie. Het bestuur van de stichting Centraal Orgaan Ziekenhuistarieven ${ }^{214}$, het bestuur van de stichting Ontwikkelings- en saneringsfonds voor de Landbouw ${ }^{215}$ " De Nederlandsche Bank ${ }^{216}$ en de

212. J.B.J.M. ten Berge en H.J. de Ru, t.a.p., p.2.

213. J.B.J.M. ten Berge en H.J. de Ru, t.a.p. pp.42-43; Vgl. soortgelijke oprekking neikwijdte van art. 3.1.1, derde lid, voorstel-Awb (nu: art, 3:1 Awb) door J.B.J.M. ten Berge, P.C. Githuis, E.M.H. Hirsch Ballin, R.M. van Male en F.A.M. Stroink (red.), VUGA-bundel; Lasbladig commentaar op de Awb. 's-Gravenhage, 30 mart 1990, pp.10/22-24; Voor een zelfde bestuursorgaanbegrip opteren $\mathrm{P}$. Nicolai, B.K. Olivier en L.J.A. Damen, Bestuarsrecht, derde herziene druk, 1992, Amsterdam, pp.2429: In navolging van Ten Berge pleiten M. Bense en S. Zijlstra, Het begrip bestuursorgaan, in: NTB, nr.9, 1994, pp.253-270, i.h.b. p.267 terecht voor "een interpretatie van art. 1:1, eerste lid, sub a, Awb in die zin dat ook privaatrechtelijke rechtspersonen warvoor geldt dat de owerheid een overwegende invloed op het beheer heeft, moeten worden beschouwd als orgaan van de rechtspersoon waartoe laatst genoemde overheid behoort". Auteurs kunnen unt de voeten met een dergelijke ruime uitleg van art. $1: \mathbb{l}_{\text {, }}$ eerste lid, sub a, Awb, maar prefereren wetswijziging ter zake (p.270); Instemming wan J.B.J.M. ten Berge, Schakelbepaling in privatiseringswergewing, in: NTB, nr.1, 1995, p.9.

214. ARRS 3, april 1979, AB 1979, 368, m.nt. FHvdB.

215. ARRS 19 september 1977. tB/S I, 3; ARRS 13 juni 1978, tB/S I, 8. 
Nederlandse organisatie voor Zuiver Wetenschappelijk Onderzoek ${ }^{217}$ zijn de eerste zelfstandige bestuursorganen die als administratieve organen zijn aangemerkt. Daarna volgen bij voorbeeld het bestuur van de stichting Fonds voor de Beeldende kunsten, vormgeving en bouwkunst ${ }^{218}$, het Centraal Fonds voor de Huisvesting 219 , de Centrale Landinrichtingscommissie ${ }^{220}$ en de Raad voor de Casinospelen ${ }^{221}$.

Ook via andersoortige rechtspraak, te weten inzake de restfunctie van de burgerlijke rechter wat betreft schadevergoeding naar aanleiding van een onrechtmatige overheidsdaad, is bekend dat de rechter bij voorbeeld bedrijfsverenigingen als overheidslichamen kenmerkt. ${ }^{222}$

Consequentie van een en ander is dat alle zelfstandige bestuursorganen tot de centrale overheid zijn te rekenen. ${ }^{223}$

Functionele decentralisatie op provinciaal en gemeentelijk niveau komt ook wel voor. ${ }^{224}$ Die valt buiten het perspectief van deze studie.

\section{f. Begripsomschrijving}

Van het begrip zelfstandig bestuursorgaan worden verschillende omschrijvingen gegeven. ${ }^{225}$ In algemene en bijzondere zin. Een ruime (werk)definitie brengt de veelzijdigheid van het fenomeen zelfstandig bestuursorgaan in beeld.

Principieel mogelijk is de omschrijving van een toezichthoudend zelfstandig bestuursor-

216. ARRS 15 januari 1981, AB 1982, 39, tB/S, V, 848; Hienuit concludeert De Ru echter dat De Nederlandsche Bank niet volledig administratief orgaan is. Dit tot ongenoegen van R.W.L. Loeb, B.K. Olivier en $\mathrm{H}$. Troostwijk, De wet Arob toegepast, vierde druk, serie staats-en bestuursrecht, nr.4, Nijmegen, 1990, p.9; Toch houdt De Ru, Zelfstandige bestuursarganen in Europa, in: Functioneel bestutur, publikatie statstechtkring, ar. 4, Zwolle, 1993, pp.37-51, i.ll.b. p.40, voet bij stuk van wege de diversiteit in handelen van de bank. Terecht wordt het 'voor zover' criteriura gehanteerd.

217. ARRS 29 september 1983, AB 1984, 349, m.nt. ICvdVlies.

218. Vz ARRS 16 januari 1991, AB 1991, 662, m.nt. ICvdVlies.

219. VZ ARRS 2 oktober 1990. AB 1991, 531 , m.nt. J. wan der Bij en J. Spanninga.

220. ARRS 21 juni 1990, in: Gemeentestem, nr.6920, 1991, p 247-248.

221. VI ARRS 9 april $1992, \mathrm{AB} 1992,534$.

222. Bedripfsuereniging Banken ws. Boulogne, HR 12 juni 1992, AB 1992, 559, m.n. W.A. Sinninghe Damstê, NJ 1993, 113; Aangehaald door o, a. F.A.M. Stroink, Rechterlijke organisatie en rechtspraak in beweging, Zwolle, 1993, pp. 158\% 158, en ook H.J.A. Jansen, Kantonrechtermiet gebonden aan arrexten HR?, in: NJB, nr.15, 15 april 1994, pp.513-514.

223. J.B.J.M. ten Berge en F.A.M. Stroink, Algemene administratieve wetgeving en zelfsrandige bestaursorgamen, in: TwO, mr. 15, 1983, pp 391-396; L.J.A. Damen, Ongeregeld en ondoorzichtig bestuwr, diss. RUG, Deventer, 1987, p.519; C.P.J. Goorden a.w., p.177; Anders H.G. Lubberdink, Het begrip centrale overheid in wet-Arab in werband met de regeling facultatieve bezwaarschriftenprocedure. in: TvO, nr. 2, $1980, \mathrm{pp} .33 \mathrm{37}$. Auteur hangt cen functionele wetsinterpretatie aan. Zo rekent hij alleen hierarchisch ondergeschikte ambten tot de centrale overheid.

224. J.B.J.M. ten Berge, Decentraliseren mer commissies; Binnengenteentelijke organisatiestructuren o.b.v. art. 61 Gem.w. "s-Gravenhage, 1978; J.C. Bekius, Functionele decentralisatic bij provincie en geneenre, in: BWn, nr.6, 1989, pp.414-418; Anders J.L. Boxum, J. de Ridder en M. Scheltema, a.w., p.8; P. de Haan, Th.G. Drupsteen en R. Fernhout, a.w., p.135.

225. M.n. G.A.C.M. van Ballegooij e.a., a.w., p.17; J.L. Boxum, J. de Ridder en M. Sicheltema, a.w., pp.7/16; M.C. Burkens, H.R.B.M. Kummeling en B.P. Vemeulen (1994), a.w., p.209; L.J.A. Damen, a.w., p.487; A.M. Donner, a.w., p.156; A.R. Edwards (1982), a.w., p.12; P.W.A. Gerritzen- 
gaan als een publiekrechtelijk of privaatrechtelijk vorm gegeven orgaan belast met de zelfstandige uitoefening van openbaar gezag, op grond van delegatie of attributie van een publiekrechtelijke bevoegdheid, waarvoor geen directe politieke verantwoordelijkheid bestaat.

In het engere kader van een studie naar toezichthoudende zelfstandige bestuursorganen zijn bepaalde kenmerken uit een dergelijke begripsbepaling minder relevant of eenvoudig weg niet toepasselijk. Zo zal niet altijd sprake zijn van een privaatrechtelijke organisatie. En meestal maakt de toezichthoudende verzelfstandigde entiteit onderdeel uit van de centralle overheid. Provinciale en gemeentelijke decentralisatie ${ }^{226}$ blijven buiten beschouwing.

Ten slotte, in verband met de herkenbaarheid blijft de term zelfstandig bestuursorgaan gehandhaafd. Het begrip is een soms vreemd etiket dat willekeurig wordt geplakt op raden, commissies, instellingen, fondsen en allerlei andere instituties. Om de term toch te hanteren zijn er, in elk geval, twee doorslaggevende redenen. Ten eerste is de terminologie populair. Zij wordt van algemene bekendheid verondersteld. Ten tweede wordt nog maals gewezen op een vrij gebruikelijke eigenschap van toezichthoudende zelfstandige bestuursorganen. Dat is het dragen van openbaar gezag. Met andere woorden, de ambtsuitoefening is in hoofdzaak kenmerkend. En ten derde spreekt de Awb van (bestuurs)orgaan. Dit gelet op de bewoordingen van art. 107, tweede lid, Grondwet. ${ }^{227}$ Vandaar de voorkeur voor het orgaanbegrip.

\section{$\S 6.5$ Overige organisatievorming}

In praktijk blijkt dus dat, ten einde de doelstellingen van openbaar bestuur te optimaliseren, voor de uitoefening van publiekrechtelijke bevoegdheden ook privaatrechtelijke organisaties worden ingeschakeld. Hoedanigheden van overheid en private sector wisselen elkaar zo soms in hoog tempo af. Daardoor dreigt verwarring. Het handelingsveld tussen staat en burger behoeft nadere onderscheiding.

Rode en I.C. van der Vlies, Beginsielen van bestuursrecht, AIphen a/d Rijn, 1994, pp.58-59; P. de Hatin, Th. G. Drupsteen en R. Fernhout, m.m.v. C.S. Valkenburg, a.w. (delen len 2), pp.138/160 en pp.35-36; C.M. van den Hoff en R. de Groot, a.w., p.4; Th. Holtenman (red.), Algemene begrippen stansrecht, tweede geheel herz. druk, Zwolle, 1989, pp, 218-219; Th. Holterman, Constamten in het publiekrectht: met het oog op besturen, Zwolle, 1995, pp.15/137-141; H.G. Lubberdink, a.w., p.154; W. Konjjnenbelt, Résumé; Hoofdlijnen van administratief recht in het licht wan de Awb, vierde druk, Utrecht, 1994, pp.31-32; R.IJ.M. Kuipers (1994), t.a.p., pp.171-183, i.h.b. p.172; J.M. de Meij (1990), a.w., p.84; A. Mulder (1980), a.w., p.4; P. Nicolai, B.K. Olivier en L.J.A. Damen (red.), a.w., p.59; M. Scheltema (1974), a.w., p. 10; H. van der Sluijs, t.a.p., p.305; J. de Wries en A.F.A. Konsten, Verzelfstandiging." panacee of placebo? Een introductie, in: BK, nr. 1 , 1992, P.6; H.D. van Wijk, bewerkt door W. Konijnenbelt en R.M. van Male (1994), a.W., pp.103-105.

226. Let wel, prowinciale of lokale besturen mogen geen openbaar gezag toekenmen aan privaatrechtelijke organisaties.

227. Mvt wetswoorstel Awb, TK 1988-1989, 21221, nr.3, p.27. 


\section{a. Vervlechting publiekrechtelijke en privaatrechtelijke organisaties}

De verduistering van de juridische betrekkingen tussen overheid en privaatrechtelijke organisaties is vooral veroorzaakt door de toegenomen overheidsrol. Sinds de hoogtijdagen van fundamentele maatschappijopvattingen, omtrent de klassiek-liberale rechtsstaat, de leer van souvereiniteit in eigen kring en het subsidiariteitsbeginsel ${ }^{228}$, geeft het concept van de verzorgingsstaat de impuls tot actiever overheidshandelen. Met als gevolg een toenemende vervlechting van staat en samenleving. ${ }^{229}$

De privaatrechtelijke organisatievorming vervult een dubbele functie voor de overheid. Ten eerste hebben private instanties, met name koepelorganisaties, betekenis als pressiegroepen in de beleidsvoorbereidende fase. Daarnaast is er een ander, voor deze studie belangrijk, aspect aan private organisaties. Ten tweede zijn privaatrechtelijke organisaties namelijk in hoge mate betrokken bij de uitvoering van overheidsbeleid. Hierin is het beeld van sociale democratie zichtbaar.

Particuliere organisaties kunnen bijdragen aan democratisering van openbaar bestuur, mits zij een representatief karakter en een intern democratische structuur hebben. Verzorgers van deelbelangen dragen dan medeverantwoordelijkheid voor het algemeen belang. Anders gezegd: particulier corporatisme. Dat is "een bestuursworm, die berust op een juridisch min of meer genormeerd samenspel van overheid en georganiseerd particulier initiatief, waarin de overheid binnen een op verschillende wijze ingevuld beleidskader de behartiging van een bepaalde taak van publiek belang geheel of gedeeltelijk toevertrouwd aan privaatrechtelijke maatschappelijke organen die de verzorging daarvan spontaan op zich genomen hebben of daartoe bereid zijn". ${ }^{230}$ Particulier corporatisme krijgt vorm via bepaalde bestuursinstrumenten, die meestal het karakter van beschikkingen dragen. De belangrijkste zijn concessie, vergunning of machtiging, statusverlening en subsidiëring.

Het particulier corporatisme bestaat naast publiekrechtelijk corporatisme. Publiekrechtelijke corporatisme is sinds 1922 grondwettelijk verankerd. Toch lijkt particulier corporatisme meer bestaanswaarde te hebben. Gelet op het succes van privaatrechtelijk corpo-

228. Zie voor laatst genoemde begrippen uitgebreid wetenschappelijk instituut voor het CDA, Publieke gerechtigheid, Houten, 1990, hoofdsukken III, IV en V: Verantoord boutwen; Program wan aktie 1989-1993. CDA: Ook A. Klink, Christen-democratie en owerheid, Leiden, 1991.

229. Vergelijk met name. A. Hoogerwerf, De verhouding tussen particulier initiatief, overheid en ondermeming. in: J.G.A. van Mierlo (red.), Particulier initiatief in de klem," Gemangeld fussen politiek en bedrijsleven?, Lochem, 1989, p.55.

230. S.W. Couwenberg, Besturen op afstand; Particulier corporatisme als bestuursworm, in: I.G.A. van Mierlo en L. G. Gerrichhauzen (red.), Het particulier initiatief in de Nederlands e verzorgingsmaatschappij: Een bestwurskundige benadering, Lochem, 1988, p. 2; Recenter J.G.A. wan Mierlo (1989), a.w., p. 13; Vgl. J.G.A. van Mierlo, Institutionele varièteit in de publieke sector: een polycentrische benadering, in: N.P. Mol en H.A.A. Verbon, t.a.P., pp.15-27. Van uit een institutionele benadtering ziet auteur de organisatie wan het openbaar bestuuir als een complex besturursbestel, warin publieke en private organisaties woortdurend met ellkaar in wisselwerking zijn; Negatief oordeel over corporatistische zbo's P. Rosenmüller, Democratie, corporatisme en Brussel als communicerende vaten, in: Namens. nr. 5,1991 , pp. 12-16. 
ratisme, past zij door haar flexibiliteit en sterke maatschappelijke binding kennelijk beter in de Nederlandse bestuursorganisatie dan publiekrechtelijk corporatisme.

Privaatrechtelijk en publickrechtelijk corporatisme samen vormen het maatschappelijke corporatisme. ${ }^{231}$ In tegenstelling tot het door totalitaire regimes geprezen staatscorporatisme, waarbij in geen enkel opzicht aan representativiteitseisen wordt voldaan, is in het maatschappelijk corporatisme geen sprake van overheidsdominantie. De maatschappelijke organisaties beïnvloeden juist, soms zelfs in hoge mate, het overheidsingrijpen. Aldus kan maatschappelijk corporatisme een aangename aanvulling op algemene democratie betekenen.

Van uit ideologische hoek is, overigens, geconstateerd dat het huidige neo-corporatisme in praktijk nauwelijks voet aan de grond krijgt. Afgezien van het uitvoeringsterrein hebben maatschappelijke organisaties, wat betreft het gebied van wet- en regelgeving, weinig tot geen invloed. ${ }^{232}$

\section{b. Functioneel gedecentraliseerde bestuurszorg}

Het is vooral de sterke groei van het particulier corporatisme die verandering van maatschappelijk corporatisme richting gemengde bestuursvorm bewerkstelligt. Dat is een "bestuurszorg door gemengde organen (door overheid en particuliere geînteresseerden gezamenlijk samengesteld en beheerd), hetzij op privaatrechtelijke, hetzij op publiekrechtelijke basis". ${ }^{233}$ Geleidelijk aan ontwikkelt het particulier corporatisme zich steeds meer in de lijn van de, van oudsher van uit sociaal-democratische kring voorgestane, functionele decentralisatie.

Hiermee is niet iedereen gelukkig. Tegenstanders willen deze, huns insziens, reductie van bestuursworm terug dringen. Zij pleiten voor herstel van autonomie van het (verstatelijkt) particulier initiatief. Dat vereist minimaal: a. terug dringen van ver gaande financiële afhankelijkheid van de overheid door opvoering van vrijwillige bijdragen van de eigen achterban, van regeringswege te stimuleren door adequate belastingverlaging en staatssubsidie gerelateerd aan wat eigen clièntele zelf opbrengt; b. ontwikkeling van een nieuw besef van eigen identiteit en verantwoordelijkheid bij het particulier initiatief; c. versterking van eigen vitaliteit, legitimiteit en weerbaarheid van het particulier initiatief door effectieve democratische structuren; en d. een overheid die besturen op afstand niet alleen met de mond belijdt. ${ }^{234}$

231. S.W. Couwenberg (1988), t.a.p., p.20.

232. J.P. Balkenende, Overheidsregelgeving en maatschappelijke organisaties, Alphen a/d Rijn, $1992,0.45$; Vreend genoeg is Balkenende"s vage inwulling en summiere behandeling wan, de door hem zo gepropageerde, 'zelfregulering ontoereikend. Het ontbreken van een expliciet normatief kader doet tekort aan. zijn studie. C.J. van Montfort, Recensie, in: Beleid en Maatschappij, nr.5, 1992, pp.286-288, resp. Th. Holterman, Boekbeschouwing, in: NTB, nr.4, 1993, pp.165-167. Vgl. P. VerLoren van Themaat, Recensie, in: SEW, nr.3, 1994, pp.208\%213.

233. S.W. Couwenberg (1988), t.a.p., p. 21.

234. S.W. Couwenberg, Nieuwe hoop op staatkundige en bestwurlijke vernieuwing, in: M.C. Burkens (red.), Stautsrechtelijke vernieuwingent commentaren op het rapport van de comunissie-Deetman, publikatie van de Staatsrechtkring. Zwolle, 1991, p.30; Zie ook M.E. Beck, Ruimte voor bestuur, bestuar voor de ruimute, 1986, pp.46-50. 
In het verlengde van die ontwikkeling (naar functionele decentralisatie), is gepleit voor een doortrekken er van naar een functioneel gedeconcentreerde bestuurszorg. ${ }^{235} \mathrm{Im}$ mers, ervaring leert dat meer sprake is van behartiging van, weliswaar min of meer onwezenlijke, overheidstaken dan van particuliere werkzaamheid. ${ }^{236}$

\section{c. Verstatelijking versus vermaatschappelijking}

Uitvoering van overheidstaken enkel beschouwd als reductie van het handelen van een privaatrechtelijke organisatie lijkt niet reëel. Het proces van verstatelijking van de maatschappij, het in toenemende mate afhankelijk worden van de overheid, gaat gepaard met dat van vermaatschappelijking van de overheid. Dat is het terug vallen van de overheid op volwaardige private organisaties. Daarmee weet zij zich verzekerd van instemming met en aanvaarding van haar beleid. ${ }^{237}$

Bij voorbeeld, de financiêle band waarmee een private organisatie aan de overheid is gebonden kan tegelijkertijd het gouden koord van verzelfstandiging betekenen. Juist het binnen nauwer aangehaalde en preciezer opgestelde randvoorwaarden uitkeren van schaarse overheidsselden garandeert veelal belangrijke maatschappelijke invloed. Strakke subsidieregels worden niet alleen uitgevaardigd om een bepaalde mate van overheidssturing te bereiken. Tevens is via strenge financielle criteria democratisering af te dwingen. Een corporatistische benadering, met technocratische accenten, geeft dus tweeërlei garantie.

De verhouding publieke-private sector draagt de kenmerken van distantie en toenadering. Beide sluiten elkaar niet per se uit. Zij vullen elkaar juist aan. Anders gezegd, zij zijn complementair. ${ }^{238}$

Problematisch blijft wel de grensafbakening bij het "maken van afspraken tussen elites van overheid en maatschappelijke organisaties, waarbij de overheid bepaalde gunsten of rechten aan deze organisaties verleent - in de vorm van regelgeving en (subsidie)beleid of publieke erkenning van deze organisaties als representatieve organisaties - in ruil voor de medewerking aan de realisatie van overheidsdoelen en het waarborgen van een draagvlak voor deze doelen binmen de betreffende organisatie". ${ }^{239}$ De scheidslijn tussen verantwoordelijkheden van overheid en private partners kan sterk vervagen.

235. J.H. Kreveld, Beleidsregets in het recht, Deventer, 1983, deel 1, 2e stuk, p.93 e.v. Nota bene, onder dit gedeconcentreende bestuursstelsel van zuiver anbtelijke aard verstaat auteur, a la Conwenberg, zelfstandige bestuursorganen. In deze stud ie is het terminologisch juister de term zelfstandig bestuursorgaan te reserveren voor gedecentraliseerd functioneel bestuur.

236. S.W. Couwenberg, Het particuliere stelsel dissertatie Rijksuniversiteit Leiden, 1953, p.108; S.W. Couwenberg, Her particulieve stelsel; De behartiging wan publieke belangen doar particuliere lichamen. in: $A_{A} \mathrm{nr}_{n} 12,1985$, p.671.

237. A.C. Zijderveld, Machi en onmacht van staat en burgers, in: R.J. in 't Veld en W.J.M. Kickert (red.), Voorbij de grenzen aan sturing; Enige visies op de weranderende rol van de staat in de samenlewing, "s" Gravenhage, 1989, pp.47-61.

238. J.G.A. van Mierlo, Inleiding tot de thematiek. particulier initiatief in de klem tussen politiek en bedrifslewen, in: J.G.A. van Mierlo (red.), a.w., pp.24-25.

239. J.P. Balkenende, a.w., p.44. 
Vooral bij het, aan een privaatrechtelijk vorm gegeven zelfstandig bestuursorgaan, toekennen van een publiekrechtelijke bewoegdheid om eenzijdig en dwingend op te treden ${ }^{240}$ moet zorgvuldig worden omgegaan met het creëren van dergelijke van overheidswege gelegitimeerde monopolieposities. De juridische aspecten ervan, in de sfeer van openbaarheid, representativiteit, interne democratie, verantwoording, derdenbelangen, rechtsbescherming en klachtrecht, blijven niet zelden onderbelicht. Van uit deze juridische optiek is enige notie van privaatrechtelijke organisatievorming onmisbaar.

De bedrading van overheid en particulier initiatief is tegenwoordig innig verstrengeld. $\mathrm{Er}$ is behoefte aan inzicht in de rechtsstructuren van intermediaire organisaties. Dat sprake is van verschillende entiteiten, met afzonderlijke consequenties, staat onbetwistbaar vast. Het transparant maken daarvan wergt vaak vergeefse moeite. Alleen in concreto is het onderscheid in privaatrechtelijke organisatievorming te ontwaren. Vandaar wordt hier volstaan met het aangeven van de hoofdlijnen waarlangs, van uit de overheid gezien, privaatrechtelijke organisatievorming plaats vindt. De ideaaltypen zijn aan te duiden. Daarom een drietal situatieschetsen.

\subsubsection{PRIVAATRECHTELUIKE FUNCTIONELE DECENTRALISATIE}

Privaatrechtelijke functionele decentralisatie is al in paragraaf 6.4.5 besproken. Daarom krijgt het begrip slechts zijdelings aandacht. Het betreft professionele, privaatrechtelijk vorm gegeven entiteiten die onderdeel uitmaken van de overheidsorganisatie. Samengevat omvat het begrip "het onderbrengen van een deel van de uitvoering van een taak, waarvoor de overheid zich verantwoordelijk acht, bij een privaatrechtelijke organisatie die overigens wel in meer of mindere mate onder directe institutionele invloed en controle van het betreffende overheidsorgaan of -lichaam blijft staan". ${ }^{241}$ Op dit gebied kan dus sprake zijn wan privaatrechtelijk vorm gegeven zelfstandige bestuursorganen met publiekrechtelijke bevoegdheden. ${ }^{242}$

\subsubsection{VERSTATELIYKTE PARTICULIERE SECTOR}

Het maatschappelijk middenveld wordt gekarakteriseerd als de diversiteit privaatrechtelijke organisaties die overheidstaken, op afstand, in eigen beheer en onder eigen verantwoordelijkheid uitvoert. Daarbij stuurt de overheid via vergunningenstelsels, subsidievoorschriften of algemeen verbindendverklaringen van afspraken tussen maatschappelijke

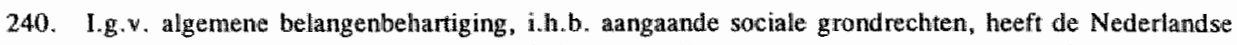
overheid een speciale verantwoordelijkheid. Zo verdient van overheidswege afgekondigde algemeen verbindend verklaringen van priwate afspraken -mogelijk met inachtneming van bepaalde toetsingspunten- voorkeur boven verlening van publiekrechtelijke verordeningsbevoegdheden aan particuliere organisaties. J.P. Balkenende, a., w, p.52.

241. J.B.J.M. ten Berge en H.J. de Ru, t.a.p.p. p.3.

242. Van wit bestuurskundige hoek, in het kader van owerheidsregelgeving, ook wel aangemerkt als zo genaamde maatschappelijke organisaties. Dat zijn privaatrechtelijke, niet-gouwernementele, zich op het publieke domein bewegende organisacies die regulerende actiwiteiten verrichten dan well daartoe in staat zijn of wensen te worden gesteld. I.P. Ballikenende, a.w., p.18. 
organisaties. Het is onomstreden een kwestie van privaatrechtelijke organisatievorming en overheidsfacilitering van maatschappelijke zorgtaken.

Elementair voor deze sociaal-grondrechtelijk georiënteerde particuliere organisaties ${ }^{243}$ is het ingeschakeld zijn bij publieke taakvervulling. Dat wil zeggen "het vervullen van taken in het algemeen belang, voor de continuiteit waarvan een overheid in een bepaald tijdsgewricht en op een bepaalde plaats in belangrijke mate een verantwoordelijkheid op zich heeft genomen". ${ }^{244}$ Taakvervulling dus die zich afspeelt op publiek domein. Daaronder vallen "zaken die het individuele en engere groepsbelang overstijgen, en die van overwegend belang zijn voor de samenleving in haar geheel of delen ervan". ${ }^{245}$ Ter witvoering van bedoelde taken hoeft niet per se overdracht van publiekrechtelijke bevoegdheden plaats te vinden.

Wat zijn nu de gemeenschappelijke factoren die het maatschappelijk middenveld to een geheel van verstatelijkte particuliere organisaties ${ }^{246}$ maken? Ten eerste gaat het om privaatrechtelijk vorm gegeven organisaties met respectievelijk een bestuur en cen raad van commissarissen waarvan de leden niet in meerderheid door een overheidsorgaan worden benoemd. Ten tweede zijn deze organisaties werkzaam op gebieden waarop de overheid van oudsher actief is. Tot deze terreinen behoren de basisvoorzieningen van de sociale rechtsstalat, waarvoor de overheid een expliciete grondwettelijke basis heeft gelegd. Door dit wettelijk stramien is publieke controle op de taakbehartiging beter te effectueren. Ten derde worden bedoelde organisaties grotendeels bekostigd uit de staatskas. Of anders, valt hun deelname aan de markt onder een of andere mate van garantie van de overheid. Ten slotte gaat het om organisaties die vrij wel alle losgeraakt zijn van hun oorspronkelijke achterban. ${ }^{247}$

Taaktoedeling, en eventueel daaraan gekoppelde bevoegdhedenoverdracht, aan georganiseerde particuliere belangenbehartigers mag geen functionele decentralisatie heten. ${ }^{24 \mathrm{k}}$ Wel bekend is de, benaming pseudo-functionele decentralisatie. ${ }^{249}$ Reden hiervoor is simpel weg, dat publieke taakvervulling door het verstatelijkte maatschappelijk middenveld witvoering yan overheidsbeleid betreft. Minder halfslachtig is het om het predikaat

243. Ditzijn privaatrechtelijke, niet-gouvernementele organisaties, wier oogmerk niet is gericht op regulerende activiteiten, maar die zich wel op het publieke domein begeven, daartoe in overwegende mate - voorall financieel- in staat gesteld door de owerheid. J.P. Balkenende, t.a.p., p.17.

244. J.B.J.M. ten Berge en H.J. de Ru, t.a.p., p.17.

245. A.M.J. Kreukels en J.B.D. Simonis (red.), Publiek domein; De veranderende balans tussen staat en samenlewing, Meppel, Amsterdam, 1988, p.10.

246. J.P. Balkenende, a.w., p.18, prefereent deze term terecht, boven de in het Rbb-advies Openbaar besturen door en met privantrechtelijke organisaties, ("s-Gravenhage, 1991) genoemde classificatie verstatelijkte particuliere sector.

247. J.B.J.M. ten Berge en H.J. de Ru, t.a.p., p. 18.

248. Overigems lijdt deze stelling uitzondering, als sprake is wan teen organisatie die zich bevindt op de grens tussen privaatrechtelijke functionele decentralisatie en de verstatelijkte particulie re sector. Eerst genoemde moet dan wel zwaar wegend zijn.

249. J.B.J.M. ten Berge, Taalverwarring rond functionele decentrolisatie, in: BWn, nr.6, 1989, p. 342 . 
functionele decentrallisatie in casu terminologisch uit te sluiten. ${ }^{250}$ Daartoe worden ook: wel meer principiële redenen aangedragen. Aanhangers van gespreide verantwoordelijkheid vinden het geen goede zaak om de eigenstandige rol van organisaties in het maatschappelijk middenveld, in hun optie méér dan alleen belleüdsuitvoerders, onder te brengen bij (pseudo-)functionele decentralisatie. In die optie komt functionele decentralisatie, in het geheel, geen grote rol toe. In het appèl aan de zorgzame en verantwoordelijke samenleving kan functionele decentralisatie slechts een tussenfase zijn 'op weg naar' gespreide verantwoordelijkheid. ${ }^{25}$ Overigens spelen, bij het streven naar versterking van het maatschappelijk middenveld, niet enkel politieke argumenten. ${ }^{252}$ Veel gehoord zijn namelijk, minder beleidsmatige, maar meer inhoudelijke bezwaren tegen functionele decentralisatie naar georganiseerde particuliere organisaties. ${ }^{253} \mathrm{Zo}$ wordt, bij voorbeeld daar waar territoriale decentralisatie in het gedrang komt, functionele decentralisatie naar het maatschappelijk middenveld onjuist geacht. ${ }^{254}$

Al met al bestaat, op dit punt, geen consensus. Vandaar het terechte pleidooi ${ }^{255}$ voor een duidelijke markering van de plats, die matschappelijke organisaties innemen in de Grondwet. In de eerste plaats wat betreft hun advies- en overlegrechten. In de tweede plaats wat betreft hun deelnemingsmogelijkheden aan zelfstandige bestuursorganen en zelfregulering. Duidelijke definïering in de Grondwet van wat moeilijker te situeren zelfstandige eenheden doet het meest recht aan het legaliteitsbeginsel. Overigens is het kabinet druk doende dergelijke plaatsbepaling te realiseren. Zie paragraaf 4.5.1.

\subsubsection{PARTICULIER INITIATIEF}

Het particulier initiatief neemt activiteiten voor haar rekening waarvoor de overheid zich, als zo danig, niet verantwoordelijk voelt. Weliswaar kan de overheid incidenteel (financiële) steun verlenen. ${ }^{256} \mathrm{Zij}$ ziet zich niet genoodzaakt de instandhouding van de betrokken belangenorganisaties, sportverenigingen, kunststichtingen en dergelijke te garanderen. Controle van overheidswege op het reilen en zeilen van deze instanties is minimaal.

250. J.B.J.M. ten Berge en F.A.M. Stroink, a.w., pp.19-21.

251. Aldus zijn politieke pijlen afgewuurd door J.P. Balkenende en A. Klink, Gespreide werantwoordelijkheid in plaats van finctionele decentralisatie, in: BWn, nr.6, 1989, p.362; C.J. Klop en J.P. Balkenende. Christen-democratie en de gemeente, in: BWn, okt. 1987, pp.477-487.

252. W.J.M. Kickert, Meer dan terugtred alleen, in: R.J. in "I Veld en W.J.M. Kickert, a..w., pp.77-84.

253. E.C.M. Jurgens, Functionele decentralisatie gewenst, maar sluit overdracht naar maatschappelijk middenweld, de georganiseerde belongenbehartiging, wit, in: BB, 10 dec. 1988, p.31; W.S.P. Fortuyn, t.ia.p., p.11.

254. Zie waarschuwende vingers van J.A. van Douwen en A.J.H. Smallenbroek, Het maatschappelijk middenweld heefi scheidsrechters nodig, in: $\mathrm{BW}, \mathrm{n}, 6,1989, \mathrm{pp} .436439$.

255. P. de Haan, Herstructurering van de adviesraden; Een vrijbrief voor technocratie en corporatisme, in: NJB, nr.21, 27 mei 1993, pp.778-783, i.h.b. p.783.

256. Van wege de onzekerheid van overheidsfinanciering acht T.J. van der Ploeg. Recht in het maatschappelijk middenveld; Een priwartrechtelijke blik op de verhouding overheid - particuliere organisaties, preadvies CIV 8 mei 1991, Zwolle, 1991, p.31, privaatrechtelijke regeling (i.p.v. bestuursrechtelijke, van politieke besluitvorming afhankelijke, oplossing) inz. controle op het functioneren van particuliere organisaties meest geschikt. Daartoe biedt boek $2 \mathrm{BW}$ voldoende varianten. 
Dat is verklaarbaar. De echte particuliere organisaties, veelal van temporele aard, voorzien niet in een basisvoorziening. Het betreft, kortom, geen publieke taakvervulling. ${ }^{257}$ Daarom bepaalt niet zozeer de staat, maar de samenleving zelf welke organisaties het handhaven waard zijn. Zo valt dit particulier initiatief in principe buiten het kader van deze studie.

Weliswaar gaat een stem op om de stelling, dat particuliere organisaties geen publieke taak vervullen, te ontkrachten. ${ }^{258}$ Kritiekpunt vormt dan de formele invalshoek van de stelling. Het alternatief is, logischerwijze, een materieelrechtelijke benadering van overheidsorganisatievorming. Aldus krijgt het begrip publieke taakvervulling naast een presterend, tevens een controlerend karakter. Anders gezegd, publieke taakvervulling ziet op zowel zelfstandige ontplooiing door de overheid (presterend) als begeleiding van anderen door de overheid (controlerend). In deze gedachtengang is handelen van uit particulier initiatief als controlerende publieke taakvervulling aan te merken. Natuurlijk kan zo"n materieelrechtelijke aanpak bijdragen aan het visualiseren van de grens tussen publieken privaatrecht. Maar dat onderwerp is een heel ander boek waard. Bovendien geldt voor onderhavig onderzoeksonderwerp, dat het echte particulier initiatief te verwaarlozen valt . Indien dat in de particuliere sfeer geschiedt, is functioneel gedecentraliseerd toezicht houden (als publieke taakuitoefening) eerder te vinden bij privaatrechrelijke organisatievormen als bedoeld in paragraaf 6.5.5.1 en paragraaf 6.5.5.2.

\section{Ten slotte}

Het totale terrein van functionele decentralisatie, middels publiekrechtelijke en privaatrechtelijke organisatievorming, is complex... Bovendien is het aan verandering onderhevig. In het algemeen is een streven waarneembaar naar organisatievormen, die steeds verder van het centrum van politiek-bestuurlijke machten zijn verwijderd. Naast deze dominante centrifugale tendens ${ }^{259}$ worden, omgekeerd, verambtelijkingsprocessen gestart. Ergo: aan de ene kant wordt een ambtelijke dienst in een zelfstandig bestursorgaan omgezet. Bij voorbeeld een privaatrechtelijk vorm gegeven zelfstandig bestuursorgaan verandert in een verstatelijkt deel van het maatschappelijk middenveld of verwordt misschien wel tot echt particulier initiatief. En, in mindere mate, is aan de andere zijde een mutatie van een puur privaatrechtelijke organisatie naar een dienst, geïntegreerd in de overheidssector, mogelijk.

Dit alles gaat gepaard met fundamentele verschuivingen van rechtsregimes. Alleen daarom al is de hiervoor uiteen gezette organisatietypologie nuttig. Het is niet doenlijk alle typen en soorten tot in detail te beschrijven. Eenvoudig weg omdat er te veel mengvormen bestaan en in dlagelijks nog ontstaan. In het kader van dit onderzoek is ook niet naar volledigheid gestreefd.

Met de organisatietypering, die op zich weinig opheldert over patronen van bevoegdheden en verantwoordelijkheden, is slechts eén doel beoogt. Dat is de verschaffing van

257. Zie ook J.B.J.M. ten Berge en H.J. de Ru, t.a.p., p.3.

258. J.A.F. Peters, Piercing the veil: Over het gebruik van privaarrechtelijke rechtspersonen door de averhetd, in: WPNR, nr.6074, 1992, pp.978-984, ith tb. p.979.

259. J.B.J.M. ten Berge (1989), t.a.P., pp.344-345. 
één inzicht. Namelijk dat er zo veel modaliteiten van organisatievorming beschikbaar zijn met afzonderlijke, meervoudige consequenties. ${ }^{260}$

260. Wat betreft de werking van grondrechten merkt L.F.M. Verhey, a.w., p.101, op dat sprake is van "een glijdende schaal wararbinnen de 'echte' overheid, het maatschappelijk middenveld en het particulier

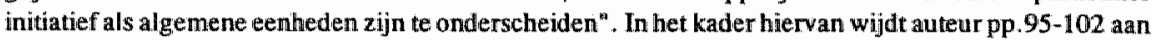
de problematische afbakening overheid en niet-owerheid. 


\section{Geraadpleegde literatuur}

\section{Ackermans-Wijn, J.C.E.}

Contracten met de overheid; Een onderzoek naar de contractsvrijheid van publiekrechtelijke rechtspersonenen het toepasselijke materiele recht, serie bestuursrecht - theorie en praktijk nr.7. dissertatie KUN, Deventer, 1989.

Aquina, H.J.

Heroverweging paragouvernementele organisaties; Veranderingen in legitimiteit en gebruik van PGO's in Nederland, in: Beleidswetenschappen, nr.1, 1987, pp.21-37.

Arnbak, J.C. e.a.

Verbinding en Ontvlechting in de Communicatie; Een studie naur toekomstig overheidsbeleid voor de openbare elektronische informatievoorziening, Amsterdam, 1990.

Baakman, N.A.A. (red.) \& Mierlo, J.G.A. van

Overheid en onderneming: Een inleiding, Heerlen, 1992.

Balkenende, I.P.

Overheidsregelgeving en maatschappelijke organisatie, Alphen a/d Rijn, 1992;

-Zelfregulering vereist juridische cultuuromslag, in: OB, nr.8, augustus 1992, pp.3-9.

Balkenende, J.P. \& Klink, A.

Gespreide veranwoordelijkheid in plaats van functionele decentralisatie, in: Bestuurswetenschappen, mr.6, 1989, pp.359-365.

Ballegooij, G.A.C.M., Bruil, D.W., Kleijn, G.P. \& Schilder, A.E.

Rechtsbescherming in het AWB-tijdperk; Herziene rechrsbescherming tegen het bestuur en het uniforme bestuursprocesrecht, Deventer, 1992.

Bekius, J.C.

Functionele decentralisatie bij provincie en gemeente, in: Bestuurswetenschappen, nr.6, 1989 , pp.414-418.

Bekke, A.J.G.M. \& Aquina, H.J.

Publieke taakvervulling en private organisatievormen vanuit een bestuurskundig perspectief, in: Rbb, Privaatrechtelijke organisatievorming in het brandpunt, advies III, 's-Gravenhage, maart 1991, pp. 1-31.

Bense, M. \& Zijlstra, $S$.

Het begrip bestuursargaan; Betekenis en strekking wan artikel 1:1, eerste lid, Awb, in: NTB. nr.9, 1994, pp. $253-270$.

Berge, J.A.J.M. ten

- Taalverwarring rond functionele decentralisatie. in: Bestuurswetenschappen, nr.6, 1989, pp.335-346;

- Boekbeschouwing C.P.J. Goorden, in: RM Themis, nr.6, juni 1993, pp.282-285;

$\sim$ Schakelbepaling in privatiseringswetgeving, in: NTB, nr.1, 1995, p.9.

Berge, J.B.J.M. ten, Boorsma, P.B., Ringeling, A.B. \& Gokkel, H.R.W. (red.)

Verklarend woordenboek Openbaar bestuur, Alphen a/d Rijn, 1992.

Berge, J.B.J.M. ten, Gilhuis, P.C., Hirsch Ballin, E.M.H. \& Stroink, F.A.M. (red.)

VUGA-bundel: losbladig commentaar op de Awb, "s-Gravenhage, $1990 \mathrm{e} . \mathrm{v}$.

Berge, J.B.J.M. ten, Jagt, A. van der \& Pop, J.J.H. (red.)

Toekomstrends en binnenlands bestuur, essaybundel i.o.v. rbb, bestuur in beweging nr.15, "s-Gravenhage, 1989.

Berge, J.B.J.M. ten \& Ru, H.J. de

Overheid en privaatrechtelijke organisatievorming, in: Rbb, Privaatrechtelijke organisatievorming in het brandpunt, advies I, "s-Gravenhage, maart 1991, pp.1-48.

Berge, J.B.J.M. ten \& Stroink, F.A.M. 
- Algemene administratieve wetgeving en zelfstandige bestuursarganen, in: TvO, nr.15, 1983. pp.391-396;

- Functionele decentralisatie wit de schadww: Een globale verkenting van aard, omvang, verschijningsvormen en bestuurlijke aspecten van zelfstandige bestuursarganen en andere functionele organisatie-eenheden binnen het openbaar bestuur, "s-Gravenhage, juni 1988.

Biesmeijer, E. \& Verbaan, E.C.W.

Zelfbeheer I; De ambtenaar wordt manager, in: OU, nr.5, 1984, p.231-234.

Bogt, H.J. ter

Contractmanagement: de valkail wan sjablonen, in: Beleidsanalyse, nr.1/2, 1994, pp.24-40.

Boneschansker, E. \& Groot, H. de

Instrumenten bij sturen op afstand, 10O-reeks nr.36, 's-Gravenhage, 1992.

Bioorsma, P.B.

- Privatisering van overheidstaken, in: NV, nr.3, 1982, p.49 e.v.;

$\sim$ Privatisering, in: OU, nr.16, 1989, p.284 e.v.

Bioorsma, P.B. \& Mol, N.P.

Privatisering, in: SMO-informatief, nr.4, 1983, Scheveningen.

Boxum, J.L., Ridder, J. de \& Scheltema, M.

- Zelfistandige bestuursorganen in soorten; Verslag van een onderzoek naar de praktijk van zelfstandige bestuursorganen, i.o.1. ministerie van $B Z$, publikatie vakgroep bestuursrecht en kunde Groningen, Deventer, 1989;

Functioneel bestuur: verslag studiebijeenkomst, in: NJB, nr .22, 30 mei 1991, pp.902-903.

Burg, V.A.M.

- Juridische aspecten van privatisering, in: TvO, nr.3, 1987, pp.50-52;

$\sim$ De verzelfstandiging van rijksmuseale diensten in de vorm vart een stichting, in: S\&W, november/decenber 1993, pp.6-9.

Buuren, P. van

Awb-notities (23): Stichtingen als bestuursorganen, in: NJB, nr.25, 23 juni 1995, pp.935-936.

Buurma $\mathrm{H}$.

Zelfbeheer, in: J.H. Hoogteijling. Besturen op afstand, IOO-reeks nr.34, december 1991, pp. $43-48$.

Brasz, H.A.

Overheidsvervangende taakverzelfstandiging als innoverend kader voor decentralisatietheorie, in: Bestuurswetenschappen, nr.6, 1989, pp.419-431.

Bronckers, M.C.E.J.

Cross-subsidisation in EEC competition law, in: Stuyck, J.H.V. \& Vossestein. A.J., State entrepreneurship, national monopolies and european community law; Competition and free movement in the energy, postal and telecommunications markets in the EEC, European monographs nr.6, Deventer/Boston, 1993, pp.103-112.

Bruijn, J.A. de \& Lammers, N.

Een juridische benadering van de departementen, in: Hakwoort, J.L.M. \& Heer, J.M. (red.), Wetenschap over departementen; Theoretische confrontaties, reeks departementale studies, 'sGravenhage, 1989, pp.42-61.

Burg, V.A.M. van der

- Juridische aspecten van privatisering, in: TvO, nr.3, 1987, pp.50-52;

- De verzelfstandiging van rijksmuseale diensten in de vorm wan een stichting, in: $S \& V$, november/december 1993, pp.6-9.

Bij, J. van der

Publiekrechtelijke verzelfstandiging: agentschap versus zelfstandig bestuursorgaan, in: Bestuurswetenschappen, nr.2, 1993, pp.97-107; 
- De gesubsidieerde muze en het maatschappelijk middenveld: Het Fonds voor beeldende kunsten, vormgeving en bouwkunsten, in: Eijk, M.C.P. (red.), Gesloten of open owerlegstelsel, t.g. $v$. congres over gesloten en open overlegstelsels d.d. 5 november 1993 gehouden aan de VU te Amsterdan, 's-Gravenhage, 1994, p.147 e.v.;

- Coreferaat, in: Groot, H. de \& Oosteren, C.G.M. van, De toekomst wan de publieke sector, bijdragen aan het jubileumsymposium van het 100 d.d. 17 maart 1994, "s-Gravenhage, 1994, pp.223-234.

Bij, J. van der \& Meij, J.P. van der

- Verzelfstandigen of privatiseren; Concurrentie, produkt en beleidswrijheid zijn bepalend $(I)$, in: Overheidsmanagement, nr. 3, 1995, pp.74-76;

$\sim$ Verzelfstandigen of privatiseren; Concurrentie, produkt en beleidswijheid zijn bepalend $(I I)$, in: Overheidsmanagement, nr.4, 1995, pp.106-110.

Bijker, J.A.

Personele aspecten van privatisering, sociale monografieën nr. 1, "s-Gravenhage, 1992, pp.1-56.

Cath, I.G.F., Edens, D.F., Hulsman, H. \& Sevinga, K.

Competition law implications of deregulation and privatisation in the Netherlands, in: SEW, nr.5, mei 1994, pp.353-385.

Christelijk Democratisch Appèl

Publieke gerechtigheid; Een christen-democratische visie op de rol van de overheid in de samenleving, Houten, 1990, zie ook Verantwoord bouwen; Program van aktie 1989-1993, Houten, 1989, en Herstelde verantwoordelijkheid: discussienota over de taken van de overheid, Houten, september 1991.

Commissie bundeling ervaringen bij privatisering

Handboek privatisering, "s-Gravenhage, 1990.

Commissie-Scheltema (eerste externe commissie van de bijzondere commissie vraagpunten)

Steekhoudend ministerschap; Betekenis en toepassing van de ministeriële verantwoordelijkheid, TK 1992-1993, 21427, mrs.40-41.

Commissie-Verbaan (cie. interdepartementale heroverweging ter verbetering bedrijfsvoering bij de overheid)

Zelfbeheer 1 , derde ronde deelrapport nr.53, 's-Gravenhage, 1983, en ook Eindrapport zelfbeheer, 's-Gravenhage., 1988.

Commissie-Vonhoff (commissie hoofdstructuur rijksdienst)

Zou Thorbecke nu tevreden zijn, 's-Gravenhage, 1979, tevens Elk kent de laan die derwaarts gaat, "s-Gravenhage, 1980, en Eindadvies, 's-Gravenhage, 1981.

Couwenberg, S.W.

- Het particuliere stelsel; De behartiging van publieke belangen door particuliere lichamen, in: AA, nr. 12, 1985, pp.668-677;

- Besturen op afstand; Particulier corporatisme ats bestuursvorm, in: Mierlo, J.G.A. \& Gerrichhauzen (red.);

- Het particulier initiatief in de Nederlandse verzorgingsmaatschappij; Een bestuurskundige benadering, Lochem, 1988, pp.20-50;

- Nieuwe hoop op staatkundige en bestuurlijke vernieuwing in het fin de siècle, in: Burkens, M.C., Couwenberg, S.W., Franken, H. \& Brinkhorst, L.J., Staatsrechtelijke vernieuwingen; Commentaren op het rapport van de commissie-Deetman, publikatie van de Staatsrechtkring, Zwolle, 1991, pp.21-40.

Crasborn, C.P.A.G.

Verzelfstandiging van departementsonderdelen: een oplossing... voor welk probleem?, in: Openbaar bestuur, nr.9, 1994, pp.15-17.

Croonen, J.W.L.H. \& Janssen, P.G. 
Verzelfstandiging van organisaties; Ofwel het balanceren tussen 'paradijsvogel' en 'bokser', in: Overheidsmanagement, nr.1, 1994, pp.16-19.

Damen, L.J.A.

Ongeregeld en ondoorzichtig bestuur, dissertatie RUG, Deventer, 1987.

Dommering, E.J.

Onze wetgever en de innovatie: amroep-en telecommunicatie na de kabinetsformatie, in: Mediaforum, nr.5, 1994, pp.50-53/64.

Dommering, E.J. \& Eijk, N.A.N.M. van

Agenda voor de publieke discussie over telecammunicatie, bericht aan het parlement, Nota, 18 november 1993, pp.1-23.

Donner, A.M.

Nederlands bestuursrecht; Algemeen deel, vijfde herziene druk, Alphen a/d Rijn, 1987.

Douwen, J.A. van \& Smallenbroek, A.J.H.

Het maatschappelijk middenveld heeft scheidsrechters nodig, in: Bestuurswetenschappen, nr.6, 1989, pp.432-439.

Edwards, A.R.

$\sim$ Functionele decentralisatie en bestuurlijke organisatie, VNG-studies nr.2, 's-Gravenhage, 1982;

- Privatisering: een publieke keuze, VNG-studies nr.4, "s-Gravenhage, 1983.

Enk, W. van

Jurist: overheid moet bedriff terug kunnen nemen: Nieuwe wet voor privatiseringen moet nutsfunctie veilig stellen, in: $\mathrm{NRC}, 2$ juni 1994, p.19.

Felix, $P$.

Schandalige verwaarlozing moet snel worden ingehaald, in: NRC, 11 mei 1994, p.21.

Felix en co.

De praktijk van het privatiseren, Amsterdam, oktober 1994.

Fleurke, F. \& Vries, P.J.

Terugtred van de overheid uit de volkshwisvesting, in: Fleurke, F., Graaf, H. van de \& Verhoogt, J.P., Minder staat, meer samenleving; Beschouwingen over de terugtredende verzorgingsstaat, serie over politiek, bestuur en communicatie, Amsterdam, 1990, pp.47-71.

Fortuyn, W.S.P

Op weg naar een geatomatiseerde samenleving?, in: Namens, nr.5, 1991, p.11.

Freije, J.M.E. \& Ottow, A.T.

Telecommunicatie: van monopolie naar vrije markt?, in: NJB, nr.22, 3 juni 1994, pp.745-749.

Frissen, P.H.A. (red.)

Verzelfstandiging in het openbaar bestuur; Een bestuurskundige verkenning van verzelfstandiging, verbindingen en informatisering, 's-Gravenhage, 1992.

Frissen, P.H.A., Hirsch Ballin, E.M.H., Hoekstra, R., Visser, R., Kuiper, R. \& Boer, R. de Het managen van verandering door verzelfstandiging, uitgave Managementcentrum, "s-Gravenhage, april 1993.

Gerritsen, E. \& Idema, H.C.

Ontwikkelingen in financieel management (I); Van 'boekhouden' via financial control naar managerial control, in: Owerheidsmanagement, nr.3, 1995, pp.67-73;

- Ontwikkelingen in financieel management (II); Uitdagingen en valkuilen voor de managerial controller, in: Overheidsmanagement, nr.4, 1995, pp.99-105.

Gerritzen-Rode, P.W.A. \& Vlies, I.C. van der

Beginselen van bestuursrecht, tweede druk, AJphen aan den Rijn, 1994.

Goorden, C.P.J. 
- Rechtsbevoegdheid in het bestuursrecht; Een rechtsvergelijkende studie nat het bevoegdhedenvraagstuk in het bestuursrecht, diss. KUB, Zwolle, 1990;

$\sim$ Kroniek: bestuurlijke organisatie, in: NTB, nr.10, 1992, pp.318-321;

$\sim$ Bestuarlijke organisatie, in: C.P.J. Goorden (red.), Kromiek bestuursrecht1987-1992, Zwolde, 1993, pp.1-13;

- Kroniek bestuurlijke organisatie, in: NTB, nr.2, 1994, pp.40-51;

- Kroniek bestuurlijke organisatie, in: NTB, nr.8, 1994, pp.229-241;

- Kromiek bestuurlijke organisatie, in: NTB, nr.2, 1995, pp.39-47.

Groot, H., Haring, H.M.M., Kuhry, B., \& Noort, E.A. van

Kerngegevens openbaar bestuwr; Over produkten, personeelen kosten wan publieke dienstverlening, IOO-rapport nr.51, 's-Gravenhage, september 1993, pp.63-74.

Haan, P. de

- Herstructurering van de adviesraden; Een vrijbrief voor technocratie en corporatisme, in: NIB, nr.21, 27 mei 1993, pp.778-783;

- Het bestuursrechten de scheiding tussen beleid en uitvoering, in: Hoogenboom, T. \& Damen,

L.J.A., In de sfeer van administratief recht; Opstellen aangeboden aan Willem Konijnenbelt, Utrecht, 1994, pp.121-150.

Haan, P. de, Drupsteen, Th.G. \& Fernhout, R.

Bestuursrechtin de sociale rechtsstaat. instrumenten waarborg, Deel 1, ontwikkeling, organisatie en instumentarium, derde herziene druk, Deventer, 1987.

Hamer, H.J. \& Ven, A.T.L.M. van den

Verzelfstandiging nationaal en internationaal, in: Kickert, W.J.M., Mol, N.P. en Sorber, A., Verzelfstandiging van overheidsdiensten, geschriften woor bestuurskunde, nr.16, 's-Gravenhage, 1993, pp.163-176.

Hoed, P. den

De samenstelling wan de overheid, in: $\mathrm{B} \& \mathrm{M}_{1}, \mathrm{nr} .3,1992$.

Hotf, C.M. van den \& Groot, R. de

Decentralisatie: zelfstandige bestuursorganen; Essay over het verschijnsel van zelfstandige bestuursorganen, hun mogelijke bijdrage aan de ontlasting wan de politieke en ambtelijke top en de consequenties met betrekking tot de omvang van de ministeriële verantwoordelijkheid, achtergrondstudie nr.2, deel 2, uitgebracht aan de commissie hoofdstructuur rijksdienst, "s-Gravenhage, 1981.

Holterman, Th. (red.)

$\sim$ Algemene begrippen staatsrecht, tweede geheel herziene druk, Zwolle, 1989;

-Boekbeschouwing Balkenende, in: NTB, nr.4, 1993, pp.165-167.

Hoogerwerf, A.

De verhouding tussen particulier initiatief, overheid en onderneming, in: J.G.A. van Mierlo (red.), Particulier initiatief in de klem; Gemangeld tussen politiek en bedrijfsleven?, Lochem, 1989.

Hoogteijling, J.H.

Besturen op afstand, IOO-reeks nr.34, "s-Gravenhage, december 1991.

Hulsink, W. \& Kemme, G.J.

Van publiek monopolie naar gereguleerde markt? Bestuurskundige en institutionele aspecten van de openbare elektronische informatievoorziening, in: Bestururswetenschappen, nr.5, 1992, pp.414-445.

Jippes, $\mathbf{H}$.

Europees flof wijst Britse regering terecht over rechten werknemers, in: NRC, 9 juni 1994, p. 18.

Jong, J.P. de

Interne verzelfstandiging en agentschappen, in: NTB, nr.8, 1994, pp.247-248. 
Jurgens, E.C.M.

Functionele decentralisatie gewenst, maar sluit overdracht naar maatschappelijk middenveld, de georganiseerde belangenbehartiging, uit, in: $\mathrm{BB}, 10$ december $1988, \mathrm{pp} .30-31$.

Kam, C.A. de \& Haan, J. de (red.)

Terugtredende overheid: realiteit of retoriek?, Schoonhoven, 1991.

Keet, E. \& Koning, J. de

Goede ervaringen van pioniers nuttig bij verdere privatisering; Professionele aanpak gewenst, in: BB, nr. 45, 11 november 1994, pp.28-29.

Kemme, G.J.

The Electronic Powerway, in: Mediaforum, nr.7/8, 1994, pp.81-85.

Kemperink, G.N.H. (red.)

Publieke taak, private markt; De gevolgen van privatisering voor de publieke taakstelling, Dewenter, 1995.

Kickert, W.J.M.

- Meer dan terugtred alleem, in: Veld, R.J. in 't \& Kickert, W.J.M. (red.), Voorbij de grenzen aan sturing: Enige visies op de veranderende rol van de staat in de samenleving. 's-Gravenhage, 1989, pp.77-84;

- Verzelfstandiging bij de overheid, in: Bestuurswetenschappen, nr.6, 1991, pp.406-419.

Kickert, W.J.M., Mol, N.P. \& Sorber, A.

Verzelfstandiging wan overheidsdiensten, in: Bestuurskunde, nr.1, 1992, pp.8-21.

Klinik, A.

Christen-democratie en overheid, Leiden, 1991.

Klop, C.J. \& Balkenende, J.P.

Christen-democratie en de gemeente, in: Bestuurswetenschappen, oktober 1987, pp.477-487.

Konijnenbelt, W.

Résumế; Hoofdlijnen van admimistratief recht in het licht van de Algemene wet bestuursrecht, vierde druk, Utrecht, 1994.

Kortmann, C.A.J.M.

Kroniek van het staatsrecht, in: De staat van het recht, kronieken 1 augustus $1993-1$ augustus 1994 als bijlage van NJB, nr.33, 23 sept. 1994, pp.46-49.

Kraan, D.J.

Verzelfstandiging bezien vanuit de bureaucratie II: normkostenfinanciering, in: Mol, N.P. \& Verbon, H.A.A., Institutionele economie en openbaar bestutu; Perspectieven op de verzelfstandiging wan overheidsdiensten, 's-Gravenhage, 1993.

Kuiper, G.M.

Het verlenen van beschikkingen: door uitbesteding of een zelfstandig bestuursorgaan?, in: Bestuurskunde, nr. 1, 1992, pp.33-42;

Kuiper, G.M. \& Boxum, J.L.

Het begrip bestuursorgaan in de Algemene wet bestursrecht, in: Boxum, J.L., Damen, L.J.A., Lambers, C., Ridder, J. de \& Vis, B.C. (red.), Aantrekkelijke gedachten; Beschouwingen over de $A w b$, deel 3, Deventer, 1993, pp.275-289.

Kuiper, G.M., Vliet, J.J. van, Boxum, J.L., Ridder, J. de \& Scheltema, M.

Verzelfstandiging: publiek of privaat; Organisatievormen woor beschikkingverlening door Informatiseringsbank, Deventer, 1992.

Kuiper, G.M., Vliet, J.J. van, Klijnstra, M., Boxum, J.L., Ridder, J. de \& Scheltema, M. Functioneel bestuur getoetst, Groningen, 1991.

Kuiper, R.J. Verzelfstandiging en informatievoorziening, in: Frissen, P.H.A. e.a., Het managen van verandering door verzelfstandiging, Management Centrum, april 1993, pp.87-104. 
Kuipers, R.II.M.

Verzelfstandiging bij de Rijksoverheid, in: Groot, H. de \& Oosteren, C.G.M. van, De toekomst van de publieke sector, bijdragen aan het jubileumsymposium van het IOO d.d. 17 maart 1994, 's-Gravenhage, 1994, pp.171-183.

Künneke, R.H.

- Op armlengte van de overheid; Een theoretisch en empirisch onderzaek naar de effecten van yerzelfstandiging op de efficiëntie van openbare nutsbedrijven, dissertatie UT, Enschede, 1991; - Verzelfstandiging bezien wanuit de 'property rights'-theorie, in: Mol, N.P. \& Verbon, H.A.A., Institutionele economie en openbaar bestur, Perspectieven op de verzelfstandiging van overheidsdiensten, "s-Grawenhage, 1993, pp.31-50.

Leenders, $\mathrm{P}$.

Op afstand besturen, maar niet te ver, want dan herkent de burger je niet meer; Gemeentepolitiek op zoek naar scherper profiel, in: BB, nr.13, 31 maart 1995, pp.16-19.

Leeuw, E.L.

Agentschappen en Nederlandse rijksdienst; Ervaringen en kritische vragen, in: Bestuurskunde, nr. 1, 1992, pp.45-56.

Leeuw, F.L. de

- Produktiviteit en effectiviteit van overheidsbeleid: institutionele analyse en effectmeting, oratie Utrecht, 's-Gravenhage, 16 oktober 1992;

- Mogelijkheden en beperkingen bij sturen-op-afstand, in: Groot, H. de \& Oosteren, C.G.M. wan, De toekomst van de publieke sector, bijdragen an het jubileumsymposium van het IOO d.d. 17 maart 1994, 's-Gravenhage, 1994, pp.185-198.

Linde, H.J.L. van der

Verzelfstandiging van departementstaken; Privatisering van het openbaar bestuur?, in: Bestuur, nr.9, oktober 1989 , pp.275-278.

Loeb, R.W.L., Olivier, B.K. \& Troostwijk

De wet Arob toegepast, vierde druk, serie staats- en bestuursrecht nr.4, Nijmegen, 1990.

Loeff Claeys Verbeke (red.)

Nederland privatiseert, "s-Gravenhage, 1994.

Lubach, D.A.

De: Awb en het grensgebied wan publiek-en privaatrecht, in: NTB-special, januari 1994 , pp. $39-40$.

Lubberdink, H.G.

- Het begrip centrale overheid in wet-Arab in verband met de regeling facaltatieve bezwar schriftprocedure, in: TvO, nr.2, 1980, pp.33-37;

- De betekenis van de ministeriële verantwoordelijkheid woor het openbaar bestuur, diss. RUG, Deventer, 1982;

- Kronieken bestuurlijke organisatie, in: NTB, 1987 tot en mett 1992.

Luttmer-Kat, A.M.

Wanneer is sprake van overgang van onderneming?, in: TVVS, nr.8, 1994, pp.197-201.

Mediaraad

Advies inzake frequentiebeleid, 's-Gravenhage, 3 april 1992.

Meij, J.M. de

Inleiding tot het staatsrecht en het bestuursrecht, derde druk, Groningen, 1990.

Meeus, T.J.

Lid Rekenkamer bepleit nieuw debat over privatiseringen, en Neelie Kroes liet een aure erfenis achter, in: NRC, 30 september 1994, pp.1/13.

Mierlo, J.G.A. van (red.)

Particulier initiatief in de klem; Gemangeld tussen politiek en bedrijfsleven?, Lochem, 1989. 
Ministerie van binnenlandse zaken

Model van algemeen rechtspositiereglement, bezoldigingsbesluit, wachtgelduitkering en witkeringsregeling voor een zelfstandig bestuursorgaan, "smavenhage, 18 februari 1992.

Ministerie van financiën

- Rapport van de werkgroep juridische aspecten wan privatisering, 's-Gravenhage, 1985 ;

Kompas voor zelfbeheer, 's-Grav., 1985, en Eindrapport zelfbeheer, 's-Gravenhage, 1989;

- Verder bouwen aan beheer, juli 1991;

$\sim$ Miljoenennota, 's-Gravenhage, 1992.

Mol, N.P.

Doelmatig financieel beheer in de rijksdienst, in: OU, februari 1992, pp.15-22.

Mol, N.P. \& Verbon, H.A.A. (red.)

Institutionele economie en openbaar bestuur, Perspectieven op de verzelfstandiging van overheidsdiensten, 's-Gravenhage, 1993.

Montfort, C.J. van

Recensie Balkenende, in: Beleid en Maatschappij, nr.5, 1992, pp.286-288.

Mulder, A.

Zelfstandige bestuursdiensten in Nederland, preadvies voor VVSR van België en Nederland, Zwolle, 1980.

Munneke, H.F., Berge, J.B.J.M. ten, Stroink, F.A.M., Haighton, P. \& Hoed, P. den Organen en rechtspersonen rondom de centrale overheid, WRR-serie voorstudies en achtergronden V35, delen V/II, 's-Gravenhage, 1983.

Muijden, H.J.P. van \& Geers, C.M.

Rijksheren in de regio, Rbb-advies inzake gedeconcentreerde rijksdienstem, reeks bestuur in beweging, 's-Gravenhage, 1984.

Nicolai, P., Olivier, B.K., Damen, L.J.A. \& 'Troostwijk, H. Bestuursrecht, derde herziene druk, Amsterdam, 1992.

Nieuwenhuijsen, $P$.

- Twijfels over verzelfstandiging steken nu de kop al weer op, in: BBM, 29 april 1994, pp.22-23;

$\sim$ Commissie zet rem op externe verzelfstandiging rijkstaken, in: BB, nr.31/32, 12 augustus 1994, p. 3;

- Hoe meer vrijheid, des te effectiever de verzelfstandiging; Voormalige rijksdiensten onderzocht, in: BB, nr.31/32, 12 augustus 1994, p.3.

Nispen, F.K.M. van \& Noordhoek, D.P.

De grote operaties; De overheid onder het mes of snijden in eigen wlees, Deventer, 1986.

Nozema

Van beheer naar beleid; Toewijzing en gebruik van etherfrequenties in Nederland, april 1993, Zoetermeer.

Ottervanger, T.R.

Transparancy in the relations between member states and public undertakings: state aids, in: Stuyck, J.H.V. \& Vossestein, A.J., State entrepreneurship, national monopolies and european community law; Competition and free movement in the energy, postal and telecommunications markets in the EEC, European monographs nr.6, Deventer/Boston, 1993, pp.73-85.

Peters, J.A.F.

- Privatisering bezien wanuit een ander juridisch perspectief, in: TwO, $\mathrm{nr} .9,28$ april 1989 , pp.175-179;

- Piercing the private veil; Over het gebruik van privaatrechtelijke rechtspersonen door de overheid door de overheid, in: WPNR, nr.6074, pp.978-984.

Ploeg, T.J. van der 
- Recht in het maatschappelijk middenveld; Een privaatrechtelijke blik op de verhouding overheid-particuliere organisaties, preadvies CJV, Zwolle, mei 1991;

- Privantrechtelijke bedenkingen tegen de overheidsstichting, in: TVVS, nr.6, 1995.

Ploeg, T.J. van der, Ru, H.J. de \& Schwarz, C.A.

Bedrijfsmatige structuren bij de overheid, in: Bestuurswetenschappen, nr.3, maart 1983, pp. 175-192.

Pluim, H. van der

De postbode gaat voor zichzelf beginnen, in: Intermediair, nr.22, 3 juni 1994, pp.24-29.

Postma, $\mathbb{R}$.

Goede argumenten nodig voor externe verzelfstandigingoverheidsdiensten, rede congres Vereniging woor bestuurskunde d.d. 26 malart 1992, in: Staatscourant, nr.62, 27 maart 1992, pp.4/24.

Raad voor het bimenlands bestuur

Advies over functionele decentralisatie, 's-Gravenhage, september 1988.

Raad voor verkeer en waterstaat

Vitwerking frequentiebeleid, 5 maart 1993 , 's-Gravenhage.

Rösenmuller , $\mathbf{P}$.

Democratie, corporatisme en Brussel als communicerende vaten, in: Namens, nr.5, 1991, pp.12-16.

Ru, H.J. de

$\sim$ Staat, markt en recht; De gevolgen van privatisering woor het publiekrecht, preadvies CJV, 27 mei 1987 ;

- Privatisering in de praktijk: juridische aspecten, Zwolle, 1987;

- De lange weg naar privatisering in Nederland, in: TVVS, nr.5, 1992, pp.111-116;

- Zelfstandige bestuursorganen in Europa, in: Functioneel bestuur, publikatie staatsrechtkring nr.4, Zwolle, 1993, pp.37-51;

- Verzelfstandiging us privatisering: Commentaar op het rapport van de commissie-Sint, in: Tijdschrift Privatisering, nr. 3, 1995, pp.5-7.

Scheltema, M.

- Zelfstandige bestuursorganen, oratie, Groningen, 21 mei 1974;

- Ministeriële verantwoordelijkheid en contractmanagement, in: Lieshout, W.C.M. van (red.), Opstellen over samenleving, staat en sturing, 's-Gravenhage, 1988, pp.93-99;

- Verzelfstandiging van het Kadaster, brief aan minister VROM d.d. 16 oktober 1990, pp.1-8;

- Verantwoord verzelfstandigen! Opmerkingen over het rapport van de commissie-Sint, in: Tijdschrift Privatisering, nr.3, 1995, pp.1-3.

Schipper, G.M. de

Studieboek algemeen bestuursrecht, Middelburg. 1982.

Schreuder, C.A.

- Privatisering, functionele decentralisatie en de vennootschap als hwn probleenkind, in: NTB, nr. 8, 1991, pp.223-231;

- Verzelfstandiging van het IJkwezen, in: Kickert, W.J.M., Mol, N.P. \& Sorber, A., Verzelfstandiging van overheidsdiensten, 's-Gravenhage, pp. 153-162;

- Toepassing van de Awb op bestuursorganen met een eigen belang, in: Boxum, J.L. \& Damen.

L.J.A., Aantrekkelijke gedachten; Beschouwingen over de Awb, Deventer, 1993, pp.291-305;

$\sim$ Geen normale n.w. Bb.v.; Van het vennootschapsrecht afwijkende regimtes voor de overheids-

n.v. 's en -b.w. 's, in: S\&V, nr.8, 1993, pp.189-194;

$\sim$ Publiekrechtelijke taken, private rechtspersonen; Verzelfstandiging en privatisering in de vorm van vennootschappen en stichtingen, dissertatie RUG, serie bestuursrecht theorie en prakijk nr. 16, Deventer, 1994.

Simon, H.J. 
Bespreking boek "publiekrechtelijke taken, private rechtspersonen, in: NJB, nr.16, 21 april 1995, pp.600-603.

Sluijs, H. van der

Distributie wan bestuursbevoegdheden; De rol van de wetgever bij het toedelen wan bestuursbevoegdheden op het niveau van de centrate overheid, in: Bestuurswetenschappen, nr.5, 1988 , pp. 302-321.

Stroink, F.A.M.

- Inventarisatie deconcentratie, Zwolle, 1977;

- Het teerstuk der deconcentratie, dissertatie RUU, "s-Gravenhage, 1978;

- Boekbespreking 'Zelfstandige bestuursorganen in soorten' "in: Beleidsw., nr.3, 1992, pp. 270-271.

Stroink, F.A.M. \& Nus, J.G.L. van

Bestuursrechtelijke consequenties van privatisering, in: S\&V, nr.3, mei/juni 1994, pp.66-71.

Stuyck, J. (red.)

Financial and monetary integration in the European Economic Community; Legal, institutional and economic aspects, Deventer/Boston, 1993.

Tamminga, $\mathrm{M}$.

KPN krijgt het beste van iwee werelden; Voormalig staatsbedriff profiteert van bescherming en expansierwimte, in: NRC, 17 mei 1.994 , p.13.

Tamminga, $M$ \& Wessels, $P$.

Staat heeft bij beursgang KPN twee petten op, in: NRC, 27 april 1994, p.15.

Timmermans, $\mathbb{L}$.

Prospectus KPN, in: TVVS, nr.6, 1994, pp.161-162.

Tweede Kamer

Heroverweging collectieve uitgaven, deelrapport nr.3, TK 1980-1981, 16625, nr.8;

$\sim$ Evaluatienota privatisering, TK $1987-1988,17938$, nrs. $1-2 / 42$ en UCV 73 d.d. 5 september 1988, pp. 1-40;

- Grote operaties, TK 1984-1985, 18135, nr.3;

- Functioneel bestuur: waarom en hoe?, TK 1988-1989, 21042, nr.2, zie ook TK 1990-1991, 21042, nrs.4-10, en Funciionele decentralisatie, TK 1993-1994/1994-1995, 21042, nrs.10/ 14/15;

- Regeerakkoord, TK 1989-1990, 21132, nr.3/8;

- Memorie van toelichting Awb, TK 1988-1989, 21221, nr.3;

- Notitie over verzelfstandiging en privatisering. TK 1989-1990, 21632, nrs. 1-3;

- Vaststelling van de begroting van de uitgaven en de ontvangsten van de Hoge colleges van Staat en het Kabinet der Koningin voor het jaar 1991. TK 1990-1991, 21800I, nr.11;

- Agentschappen, TK 1992-1993, 23180-23183, en TK 1993-1994, 23171/23673, als mede TK. 1993-1994, 23708:

- Verslag wan de Algemene Rekenkamer over 1993, TK 1993-1994, 23670, nrs. 1-2;

- Regeerakkoord 1994, TK 1993-1994, 23715, nr.11;

- Wetsvoorstellnvoering Organisatiewet Sociale Verzekeringen, TK 1993-1994, 23775, nrs. 1-3;

- Wetswoorstel tot wijziging van enkele artikelen van de Comptabiliteitswet verband houdende met onder andere de introductie van agentschappen, de integratie van de begrotingsartikelen 'personeel' en 'materieel' en een nadere aanpassing van de financiële verantwoording sprocedure (zesde wijziging van de Comptabiliteitswet), TK 1993-1994, 23796, nrs.1-3;

- Versiag van de Algemene Rekenkamer over 1994, deel 3; Zelfstandige bestuursorganen en ministeriële verantwoordelijkheid. TK 1994-1995, 24130 , nr.3.

Veld, R.J. in "t 
De kerntakenbenadering bij de Rijksoverheid: onderwerp van gesprek, in: Sips, C. \& Vrancken, P.H.J., De kerntakenbenadiering bij de Rijksoverheid, IOO-rapport nr.59, "s-Gravenhage, april 1994, pp.7-15.

Veld, R.J. in "t \& Twist, M.J.W. wan

Een onvolledig betoog over verzelfstandiging; Het rapport wan de commissie-Sint nader beschouwd, Tijdschrift Privatisering, nr.3, 1995, pp.3-5.

Ven, A.T.L.M. van de

- Privatisering bij de rijksoverheid, in: Berg, A., Depre, R., Korsten, A., Lansbergen, P., Ringeling, A. \& Stienlet, G. (red.), Handboek beleidswoering voor de overheid, M4200, Alphen aan den Rijn, supplement oktober 1990, pp.1-29;

- Privatisering en functionele decentralisatie, in: Overh.man., nr.3, 1993, pp.56-61;

- Verzelfstandiging en bestuurlijke decentralisatie, in: Si\&, nr.3, mei/juni 1994, pp.61-65.

Verhey, L.F.M.

Horizontale werking van grondrechten, i.h.b. van het recht op privacy, Zwolle/Utrecht, 1992, pp.95-101.

Verheij, $N$.

$\sim$ Naar een wetboek wan bestuursrecht, in: Heringa, A.W. \& Verheij, N. (red.), Publiekrechtelijke bewegingen, Deventer, 1990, pp.83-102;

- Het systeem van de Awb, Ars Aequi cahiers staats- en bestuursrecht nr.4, Nijmegen, 1993.

Vermeijden, $M$.

Nieuwe fondsen ter ondersteuning van moderne kunst, in: NRC, 15 juni 1994, p.7.

Vos, P.L. de

De ambtenaar in Nederland: Sectoralisatie, afstanking en normalisatie, in: TVBP, 1994, pp.794-799.

Vries, J. de \& Korsten, A.F.A.

Verzelfstandiging: panacee of placebo? Een introductie, in: Best.k., nr.1, 1992, pp.4-7.

Vuçsán, R.L.

Katern bestuursrecht, in: AA, juni 1994, pp. 2430-2433.

Wammes, $\mathrm{H}$.

- Kleurloos institucut PTT werd marktrijp, in: NRC, 30 maart 1994, p.19;

PTT Post loopt harder, zoekt markten op en boekt winst, in: NRC, 1 april 1994, p.13.

Wessels, $\mathbb{P}$.

- 'Beurs kan driedubbele bescherming KPN niet toestaan', in: NRC, 15 april 1994, p.11;

- Bescherming KNP smet op blazoen Staat en beurs, in: NRC, 14 mei 1994, p.14.

Wolters, M.

Babylonische spraakwerwarring rond containerbegrip 'zelfbeheer', in: BBM, 29 januari 1993, pp.16-19.

Wijk, H.D. van, bewerkt door Konijnenbelt, W. \& Male, R.M. van

Hoofdstukken van administratief recht, negende druk, Utrecht, 1994.

Zutphen, A.H. van

- Het begrip openbare dienst in de Ambtenarenwet 1929; Een verkenning op de grens van bestuursrecht, in: NTB, nr.4, 1988, pp.122-127;

- De rechtspositie van de Rijksambtenaar; Aanstelling en ontslag, 's-Gravenhage, 1991, pp. $87-99$. 
Hoofdstuk 7

\section{Publiekrechtelijke bevoegdheid}

\section{$\$ 7.0$ Toedeling overheidstaak op grond van een publiekrechtelijke bevoegdheid}

Bij het "vervullen van taken in het algemeen belang, voor de continuitteit waarvan de overheid in een bepaald tijdsgewricht en op een bepaalde plaats in belangrijke mate de

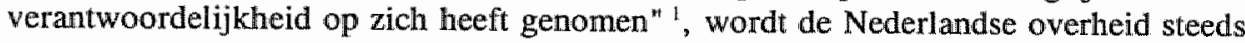
voor twee elementaire vragen geplaatst. Ten eerste, wat staat haar te doen. Met andere woorden, welke taken heeft zij te verrichten. En ten tweede, welke bevoegdheden staan daartoe open. Anders gezegd, van welke instrumenten kan zij zich bedienen. Eerst genoemde vraag blijft voorlopig onbeantwoord. Hier slechts van belang is dat zelfstandige bestuursorganen in principe overheidstaken behartigen. Voor de behandeling van de concrete inhoud er van wordt verwezen naar paragraaf 8 tot en met paragraaf 8.2.1, als mede paragraaf 9.3. De secundair gestelde vraag krijgt nu volle aandacht.

Een bellangrijk uitgangspunt in de vooraf gaande paragrafen is dit. Te weten, niet de juridische status, maar het bezit van een publiekrechtelijke bevoegdheid is bepalend voor de kwalificatie van de juridische bevoegdheid van een rechtssubject, in casu een zelfstandig bestuursorgaan. De mate waarin een zelfstandig bestuursorgaan rechtsbevoegdheid heeft, is afhankelijk van de omvang van de toegekende bevoegdheid.

Terecht wordt gesproken van een tóegekende bevoegdheid. Dat is juist. Het is incorrect aan het uitoefenen wan een overheidstaak automatisch een publiekrechtelijke bevoegdheid te ontlenen.

In het verleden is deze mening aangehangen met oog op de rechtsbescherming. De rechtsbescherming tegen optreden van de Nederlandse overheid staat, afgezien van aanvullende rechtsbescherming bij onder meer het vragen van schadevergoeding, voornamelijk los van de juridische protectie door de burgerlijke rechter. De begrenzing tussen beide gebieden vindt vooral grond in de, door de Awb overbodig zijnde, Wet Arob. Een beschikking wan een administratief orgaan is appellabel. Expliciet sluit de Wet Arob 
rechtshandelingen naar burgerlijk recht hiervan uit. Bij twijfel verifiëert de administratieve rechter of de bevoegdheid tot het nemen van eenzijdig bindende besluiten is te herleiden tot een publiekrechtelijke grondslag. Toch kunnen problemen rijzen. Hoe te komen tot oordeelsvorming als het bestuurlijk optreden niet berust op een uitdrukkelijk geformuleerde publiekrechtelijke bevoegdheid?

Aanvankelijk wordt de volgende oplossing voorgestaan. Ondanks de absentie van een publiekrechtelijke titel, is het in beroep gaan tegen een bepaald overheidsbesluit gerechtvaardigd in geval van uitoefening van een publieke taak. ${ }^{2}$ Volgens een fervent voorstander van deze gedachte moet tot publieke taak worden gerekend "alles wat in het algemeen belang is, waarbij algemeen belang naar zijn inhoud afhankelijk is van tijd, van plaats en van het oordeel van hen die met het vaststellen van de inhoud er van zijn belast". ${ }^{3}$ Van uit deze begripsbepaling wordt het volgende gesteld. "De omstandigheid dat een handeling deel uitmaakt van een publieke taakvervulling heeft gevolgen voor de inhoud van het recht waardoor die handeling wordt geregeerd. " 4 Kortom, het gaat niet om het gezag dat de een niet en de ander wel uitstraalt. Het gaat om de strekking van de handeling zelf. Onverschillig of het een publieke of private instantie is, die handelt.

Deze benadering van het vraagstuk biedt, in juridisch opzicht, weinig garantie. Het publieke taak-criterium, als enige basis om bepaalde besluiten een beschikkingskarakter te verschaffen, is ontoereikend. ${ }^{5}$ In dit verband is verschil gemaakt tussen de begrippen publieke taak en publiekrechtelijke taak. "Publieke taken heeft de overheid altijd; een publiekrechtelijke taak heeft zij waar uit een rechtsvoorschrift een taak voort vloeit die niet aan ieder krachtens het gemene recht kan toekomen." 6 En publiekrechtelijke taak, waarvoor logischerwijs een uitvoeringsplicht geldt, kan expliciet berusten op een wettelijke grondslag, maar kan ook via (al dan niet voorwaardelijke) financiële bindingen met of institutionele beïnvloedingsbevoegdheden van de overheid ontstaan. ${ }^{7}$ Een publieke taak, die door zowel publieke als particuliere sector kan worden uitgeoefend, leidt nooit tot een publiekrechtelijke bevoegdheid. Een publiekrechtelijke (beheers)taak ${ }^{8}$ impliceert mogelijk wél een publiekrechtelijke bevoegdheid. ${ }^{9}$

2. Bij woorbeeld ARRS 24 mei 1984, AB 1985, 197 en Vz ARRS 19 maart 1981, AB 1982, 411 m. H. HJdR.

3. J van der Hoeven, De magische lijm; Verkenningen op de grens van publiek- en privacriecht, in: H.C.F. Schoondijk, Honderd jaar rechisleven; De NJV 1870-1970, Zwolle, 1970, pp.217-218.

4. J. wan der Hoeven, a.w., p. 201.

5. C.P.J. Goorden, a.w., p.66 e.v.; G.P.J. Goorden, Kronieken, in: NTB, nr.3. 1992, pp.96-99; Owerigens constateert F.J. van Ommeren, Kronieken: bestuwrshandelingen, in: NTB, nr.5, 1995, pp. 125-136, i. h. b. p.127, met referentie aan de uitspraken van respectievelijk ARRS 29 sept. 1993, AB 1995, 144 en president rechtbank 's-Gravenhage 18 mei 1994, AB' 1995, 112 dat het publieke-taak-criterium kemnelijk nog niet he lemaal uit de gratie is.

6. P. Nicolaï, B.K. Olivier, L.J.A. Damen en H. Troosiwijk, a.w., p.249.

7. C.A. Schreuder, Publiekrechtelijke taken, private rechtspersonen, diss, RUG, Deventer, 1994 , P.43.

8. Volgens J.P. Balkenende, a.w., p.131, veronderstelt een "publiekrechtelijke taak' een "regelgevende rol van de overheid"

9. Hierbij halen P. Nicolaí, B.K. Olivier, L.J.A. Damen en H. Troostwijk, a.w., p.250, AR 14 juni 1984 , BR 1985, 19 aan. 
Bij toetsing van overheidsoptreden gaat de rechter er uiteindelijk toe over zo veel mogelijk aansluiting te zoeken bij een publiekrechtelijke grondslag. Rechtspraak geeft weer dat een overheidstaak moet zijn te herleiden tot een, eventueel algemeen geformuleerde, (grond)wettelijke publiekrechtelijke grondslag. ${ }^{10}$ Jurisprudentie, betreffende zelfstandige bestuursorganen in het bijzonder, laat een zelfde beeld zien. Hierbij is te denken aan het bestuur van de stichting Fonds voor Beeldende Kunsten, vormgeving en bouwkunst ", het Centraal Fonds voor de Huisvesting. ${ }^{12}$ en het bestuur van de stichting Nederlandse organisatie voor Wetenschappelijk Onderzoek ${ }^{13}$.

Gepoogd is het inzicht in de 'herleidingsregel' te verhelderen. Daartoe worden de begrippen publiekrechtelijke grondslag en publiekrechtelijke titel onderscheiden. De aanwezigheid van een geschreven publiekrechtelijke grondslag is wel een noodzakelijke, maar geen voldoende voorwaarde om van een publiekrechtelijke titel te kunnen spreken. Hiervoor moet ook worden gelet op de plaats, waar de bestreden rechtshandeling haar onstaansworm vindt. ${ }^{14}$

Ergo: een publieke taak houdt geen beschikkingsbevoegheid in. Dit blijkt al uit de op het Zeyense nachtbraker-arrest ${ }^{15}$ geleverde kritiek. ${ }^{16}$ Een betrokken besluit kan pas een beschikkingskarakter hebben als het afkomstig is van een administratief orgaan (naar Awb: bestuursorgaan). ${ }^{17}$ Bovendien is het criterium algemene/publieke bestuurstaak sec onbruikbaar door de vaagheid van de terminologie. ${ }^{18}$ Tegenwoordig gaan echter ook andere stemmen op. Zo moet het "voldoende zijn dat een besluit administratiefrechtelijk van aard is en dus herleidbaar tot een (grond)wettelijke taak. Het is niet noodzakelijk dat ieder besluit dat een bestuursorgaan neemt is gebaseerd op een wettelijke grondslag." En duidelijker dan de volgende kan een stelling niet luiden: "Uit een publieke taak kan beschikkingsbevoegdheid worden afgeleid." ${ }^{20}$ Vóốr deze stelling pleit ook een paar rechterlijke uitspraken. ${ }^{21}$ Toch klinkt terecht tegenspraak. "Dat een publieke taak vaak zowel publiek-als privaatrechtelijk kan worden behartigd, bewijst al de onhoudbaarheid van de zienswijze waarin de aard van de taak het karakter van de hande-

10. Bij woorbeeld $V_{Z}$ ARRS 21 augustus 1986, AB 1988, 193.

11. V2 AFRS 16 januari 1991, AB 1991, $662 \mathrm{~m}$.nt. I.C. van der Vlies

12. Vz ARRS 2 oktober 1990, AB 1991, 531, m.nt. J. van der Bij en J. Spanninga.

13. ARRS 29 september 1983 , AB 1984,349, m.nt. I.C. Wan der Vlies.

14. H.J. Simon in annotatie bij Vz ARRS 12 oktober 1987 , AB 1988, 448.

15. HR 24 aktober 1961, NJ 1962, 86.

16. O.a. W. Konijnenbelt in annotatie inzake ontruiming Lucky Luijk, HR 21 jan. 1983, in: Gemeentestem. rit. $67.48, \mathrm{p} .86$

17. F.C.M.A. Michiels, De Arob-beschikking, dissertatie KUN, p.65.

18. F.C.M.A. Michiels, a.w., pp.182-183.

19. J.A. Zewenbergen, Rechtsbescherming in de landinrichting en de Awb, in: $\mathbb{R}$, , nr.4, april 1993, p.171.

20. Als twaede stelling bij H.J. Simon. Publiekrecht of privaatrecht, diss. UvA, Zwolle, 1993; Vgl. nog anders H.J. Simon, De Arob-rechter en de rechtshandeling naar burgerlijk recht, in: RM Themis, 1989, p.469-489.

21. VZ ARRS 23 april 1992, AB 1993, 101; VZ ARRS 17 januari 1991. 
ling ter uitvoering daarvan zou kunnen bepalen." 22 Bij deze opvatting wordt hier aangesloten. Juist bij zelfstandige bestuursorganen, met hun afwijkende patronen van democratische legitimatie, is een duidelijke bevoegdheidsverdeling tussen ministers en betrokken organen van wezenlijk belang. Hoewel zelfstandige bestuursorganen in principe hun eigen boontjes mogen doppen, blijven de ministers meestal wel op hoofdlijnen van beleid(svorming) aanspreekbaar. In het algemeen bestaat politieke verantwoordelijkheid, trouwens, alleen voor uitoefening van een bepaalde bevoegdheid. ${ }^{23}$ Uit het voorgaande blijkt de essentie van een heldere, vaststaande bevoegdheidsverdeling. Het creëren van bevoegdheden uit, aan (toezichthoudende) zelfstandige bestuursorganen opgedragen, taken is niet geoorloofd. Kortom, een publiekrechtelijke grondslag is expliciet noodzakelijk. Hierbij geldt dat het voldoende is dat publieke taakvervulling indirect op een grondwettelijke of wettelijke bevoegdheidstoedeling is terug te voeren. ${ }^{24}$

Met andere woorden, overheidstaken kunnen niet zonder juridische erkenning in de vorm van bevoegdheden. Daarmee wordt aan het legalliteitsbeginsel recht gedaan. Aanvaarding van publieke taak als enige maatstaf, om een rechtssubject tot administratief orgaan -- of: bestuursorgaan naar Awb - te verklaren, is immers inbreuk op de wetmatigheid van bestuur. ${ }^{25}$ Elementaire eigenschap van een (toezichthoudend) overheidsambt is namelijk het bekleed zijn met openbaar gezag. Anders geformuleerd, er moet een bevoegdheid zijn tot publiekrechtelijk rechtshandelen. ${ }^{26}$

Dit wordt nog eens duidelijk gesteld in de Algemene wet bestuursrecht (aangaande art. $1: 1$, eerste lid, sub b): "Het uit art. 1 van de Wet Arob overgenomen definitie-element 'met enig openbaar gezag bekleed' betekent dat het moet gaan om een orgaan met een publiekrechtelijke bevoegdheid tot het bepalen van de rechtspositie (de rechten en/of verplichtingen) van andere rechtssubjecten." ${ }^{27}$ De aanmerking, dat bij het gebruik van beide omschrijvingen als synoniemen, wakkaamheid is geboden verdient aandacht. Verdedigbaar is dat "het hebben van een bevoegdheid tot beschikken een bekleed-zijn met openbaar gezag impliceert"; Maar niet zonder meer is aannemelijk "dat ieder bekleed zijn

22. F.C.M.A. Michiels, Kronieken: de beschikking en andere bestuwrshandelingen, in: NTB, nr.4, 1993 , 10. $\$ 60$.

23. H.J. de Ru, Staat, markt en recht; Gevolgen privatisering voor het publiekrecht, preadvies CIV, 27 meil 1987, Zwolle, p. 11 .

24. Mwt woorstel Awb, TK 1988-1989, 21221, nt.3, p.28; Vgl. A.W.M. Bijloos en Th.M.M. Lindner, De Awb eerste tranche, studiepockets staats-en bestuursrecht, wierde dnu, Zwolle, 1994, pp.28-29.

25. Zie annotatie C.J.A. Crasborn bij ARRS 18 september 1980, AB 1981, 148, in: J.B.J.M. ten Berge, B.W.N. de Waard en R.J.G.M. Widdershowen, in: $A R O B$-bundel, losbladig, rubriek V, Alphen a/d Rijn, p.759 (parkeerplaats Rotterdan).

26. Kritiek van J.B.J.M. ten Berge en F.A.M. Stroink bij ARRS 19 sept. 1977, tB/S, I, p.6 e.v., en ARRS 13 juni 1978, tB/S, 1, p.26 e.v. inz. bestuur Stichting Ontwikkelings- en Saneringsfonds voor de Landbouw. Nota bene, betreffend stichtingsbestuur wordt als administratief orgaan (wet Arob) aangemerkt slechts $0 . g . v$. een pseudo! - wettelijke verplichting. Het wetmatigheidsbeginsel staat zo wankel. Overigens lijkt de opmerking van J.C.E. Ackermans-Wijn, a.W. p.31, dat de rechtspersoon en niet het bestuur als administratief orgaan moet worden aangemerkt niet acceptabel. Het gatat hier juist om de extern werkende, beschikking sbevoegdlheden van het bestuur, ten gunste waarvan de minister in zekere mate is teruggetreden. Zie vitgebreid paragraaf $6.4 .5 \mathrm{a}$ tot en met paragraaf $6.4 .5 \mathrm{f}$

27. Mut wetsvoorstel Awb, TK 1.988 1989, 21221, ur. 3, p.27. 
met openbaar gezag beschikkingsbevoegdheid impliceert. Dit hangt af van de bevoegdheden die in concreto aan het administratief orgaan zijn toegekend. " 28

\section{\$ 7.1 Publiekrechtelijke bevoegdheid}

Evident is dat het begrip publiekrechtelijke bevoegdheid een centrale waarde heeft in het staats- en administratief recht. Daarom moet worden voorkomen dat het begrip een zwevend begrip wordt. Wat is een publiekrechtelijke bevoegdheid?

Alleen de begripsaanduiding verschilt al. Soms wordt gesproken van een overheidsbevoegdheid. ${ }^{29}$ Een andere keer is sprake van een bestuursbevoegdheid. ${ }^{30}$ En weer een volgende keer is de term bestuursrechtelijke bewoegdheid het sleutelbegrip. ${ }^{31}$

Ook over de positieve inhoud van een publiekrechtelijke bevoegdheid valt te twisten. Slechts wat betreft de negatieve begrenzingen luidt het antwoord vrij wel eenduidig. Een publiekrechtelijke bevoegdheid is "een bevoegdheid positief recht vast te stellen en te handhaven". ${ }^{32}$ In juridische zin is zij omschreven als "een wettelijk toegekend vermogen om rechtsgevolgen te kunnen bewerkstelligen". ${ }^{33}$ Hiermee zijn bedoeld rechtsgevolgen als uitvloeisel van eenzijdig bindende besluiten, bij voorbeeld algemeen verbindend verklaringen, overheidsbesluiten of rechterlijke vonnissen.

In het algemeen wordt de eenzijdig bindende kracht, van bestuurlijke regelgeving, als wezenskenmerk onderschreven. Hierbij valt in eerste instantie te denken aan externe, naar buiten werkende, bevoegdheden. Tegelijkertijd is het goed te beseffen, dat de invloed van interne bevoegdheden, uit te oefenen binnen (of tussen onderdelen van) de gehele overheidsorganisatie, op de burger niet mag worden onderschat. ${ }^{34}$ Incorrecties in interne bevoegdheden kunnen resulteren in foutief gebruik van externe bevoegdheden. Belangrijke interne bevoegdheden zijn bij voorbeeld goedkeurings- en vernietigingsbevoegdheden en instructies met betrekking tot externe bevoegdheidsuitoefening. Een niet onbelangrijk gegeven, want een zelfstandig bestuursorgaan is een orgaan waaraan zowel externe als interne bevoegdheden zijn geattribueerd of gedelegeerd. Een zelfstandig bestuursorgaan is immers een "orgaan dat naar buiten toe zelfstandig beschikkingen mag treffen en over zijn eigen budget en personeel mag beschikken". ${ }^{35}$

28. J.G. Steenbeek, bewerk. F.A.M. Stroink, Wer Arob, wierde druk, 's-Graw. 1988, p.55; Vgl. C.P.J. Goorden, a.w., p.306.

29. F.A.M. Stroink en J.G. Steenbeek, Inteiding staats-en bestutarspecht, vierde herz. druk. Alphen a/d Rijn, 1993, p.30.

30. C.P.J. Goorden, a.w., p.54. Auteur geeft hier aan de term publiekrechtelijke bevoegdlheid een beperkte invulling. namelijk als bestuursbevoegdheid. Ruim opgevat betekent publiekrechtelijke bevoegdheid de trias wetgeving, rechtspraak en bestuur.

31. P.Nicolaï, B.K.. Olivier, L.J.A. Damen en H. Troostwijk (red.), a.\%, , P.4.

32. F.A.M. Stroink en J.G. Steenbeek, a. w, p.30.

33. F.A.M. Stroink en J.G. Steenbeek, a.w., p.30; Vgl. Mvt bij wetsvoorstel art. 1:1 Awb, a.w., p.27.

34. F.A.M. Stroink en J.G. Steenbeek, a.w., p.31.

35. P. den Hoed, De samenstelling want de overheid, in: B\&M, nr. 3, 1992, p.119. 
Relativering van het eenzijdig bindende karakter van publiekrechtelijke bevoegdheidsuitoefening ${ }^{36}$ is, tot op zekere hoogte, wel begrijpelijk. In het bijzonder bij besluiten door zelfstandige bestuursorganen van het zo genaamde participatietype ${ }^{37}$ komt het voor dat besluitworming pas plaats vindt na aanvraag door en/of overleg met betrokkenen. ${ }^{38}$ Bepalingen van overheidswege gaan zo niet altijd buiten de wil van derden orn. Toch is het raadzaam om in het kader van deze studie, waarin de focus is gericht op toezichthoudende bevoegdheden, de grote intrinsieke waarde van eenzijdigheid niet te vergeten. Niet uit het oog dient te worden verloren dat uiteindelijk de overheid altijd haar stempel zwaar kan drukken. ${ }^{39}$

Het met publiekrechtelijke bewoegdheid bekleed zijn kent nog andere kenmerken. ${ }^{*}$ Een eenzijdige besluitmacht vindt ondersteuning in feitelijke afdwingbaarheid van wet- en regelgeving. Dit kan door middel van onder meer bestuursdwang en dwangsom. Juist bij toezichtsbevoegdheden, dat wil zeggen die bevoegdheden waarvan de uitoefening er toe strekt te controleren of wordt voldaan aan de vigerende wettelijke regels, is handhaving elementair. Ook van dit kenmerk is gesteld dat het niet absoluut is. ${ }^{41}$

De werking van vooral de algemene beginselen van behoorlijk bestuur moet er voor zorgen, dat bestuursorganen, die een grote mate van beoordelingsvrijheid hebben, consistent moeten handelen. Dit houdt in dat sprake is van beleidsvoering, waaraan de burgers zekere aanspraken kunnen ontlenen. Hoe ver dit geldt voor toezichthoudende ambtelijke diensten wordt nog nader beschouwd.

Hierover is, in het algemeen, in elk geval wel het volgende op te merken. De rechtens aan het gebruik van een publiekrechtelijke bevoegdheid te stellen eisen van behoorlijk bestuur verschillen naar gelang de aard van de vrijheid die het bevoegde orgaan wordt gelaten. Ten eerste heeft een bestuursorgaan beoordelingsvrijheid "voor zover het aan het orgaan zelf is overgelaten om, met uitsluiting van anderen, te beoordelen, of de wettelijke voorwaarden voor het gebruik van een bevoegdheid in concreto zijn vervuld" ${ }^{42}$ Beoordelingsvrijheid is ruimer dan beoordelingsruimte. Dit onderscheid is van belang gelet op de mate van, terughoudendheid in, rechterlijke toetsing. ${ }^{43} 44$ Ten tweede heeft een

36. C.P.J. Goorden, a.w., p.61.

37. J.L. Boxum, J. de Ridder en M. Scheltema, a.w., pp.42/230-231.

38. De zelfde zienswijze wordi voorgestaan in Memorie van toelichting bij het voorstel Awb, TK 1988-1989, $21221, \mathrm{nr} .3, \mathrm{p} .12$.

39. Ook F.A.M. Stroink "Boekbeschowwing C.P.J. Goorden t. at.p., p.296. A.Q.C. Tak, Overheiden burgerlijk wetboek: Naar een invwllende rechtsleer, in: R\&K, nr.2, 1993, pp.174-190, i.h.b. p.182; H.J. Simon, a.w., pp.202-207.

40. H. wan Marseveen in zijn Commentaar, betreffende art, 1 Wet Arob, op J.B.J.M. ten Berge em F.A.M. Stroink, De wet Arob, losbladige uitgave, Alphem aan den Rijn, p.7.

41. C.P.J. Goorden, a.w., p.62.

42. W. Duk, Inleiding tor het bestuursrecht, leerboek OUH, tweede druk, Alphen aan den Rijin, 1988, pp. 3235; W. Duk, Beoordelingsurigheid en beleidswrijheid, in: RM Themis, 1988, p.156 e.v.

43. P. Nicolai, B.K. Olivier, L.J.A. Damen en H. Troostwijk (red.), a.w., pp.138-142.

44. G.H.L. Weesing, Beoardelingswrihteid en beleidswrijheid, in: T. Hoogenboom en L.J.A. Damen (red.). In de sfeer wan administratief recht, Utrecht, 1994, pp.429-442, wijst -met oog op rechtsbeschermingop het belang van het duidelijk door de wetgever aangeven, of een bestuursorgaan beoordelings- of 
orgaan beleidsvrijheid "voor zover het niet wettelijk verplicht is zijn bevoegdheid uit te oefenen in gevallen waarin het gebruik er van wel wettelijk is toegestaan". "45 Het is moeilijk beide elementen helder uit elkaar te houden, en verdergaand luidt de vraag zelfs of het onderscheid wel zinvol is. ${ }^{46}$

Eigenaardig, aan het vitoefenen van een publiekrechtelijke bevoegdheid, is ook dat zij plaats vindt op grond van een door het recht gereglementeerde macht.

Kort gezegd komt het er op neer dat het begrip publiekrechtelijke bevoegdheid driedielig. is op te splitsen. ${ }^{47}$ Ten eerste is het element invloed aanwezig. In de tweede plaats is er de component rechtsconformiteit. Dit betekent dat uitoefening van een bepaalde bevoegdheid aan bepaalde juridische maatstaven moet voldoen. Ten derde is de rechtsgrond relevant. Dat onderdeel betreft de juridische grondslag voor het publiekrechtelijk optreden van een ambt.

Laatst genoemd element is ook sterk vertegenwoordigd in een andere heldere juridische analyse van de term publiekrechtelijke bevoegdheid. ${ }^{48}$ Ter begripsbepaling wordt dan uitgegaan van de rechtens relevante grondslag van overheidsoptreden. Zo doende is een ruime opvatting van publiekrechtelijke bevoegdheidsuitoefening mogelijk. Een publiekrechtellike bevoegdheid omvat meer dan alleen het bevoegd zijn tot het verrichten van publiekrechtelijke rechtshandelingen. Als een ambt publiekrechtelijk bevoegd is, is hem toegestaan te beschikken en overigens juridisch te handelen conform het publiek recht. Daarbij is feitelijk en privaatrechtelijk handelen niet uitgesloten. Dit wordt duidelijk aan de hand van vier stadia van publiekrechtelijke bevoegdheidsuitoefening. Te weten de bevoegdheidstoekenning middels attributie dan wel delegatie. Het tweede, te onderscheiden, element betreft de te verlenen bevoegdheid zelf. In de derde plaats is er de bevoegdheidsuitoefening. Dit houdt in het woorbereiden en het nemen van bepaalde beslissingen.

44. $\rightarrow$

beleidsvrijheid toekomt; En, van uit respect voor zowel bestuur als rechter zoekt A. Klap, Vage nornten in het besturrsrechi, diss. RUU, Zwolle, 1994, i.h.b. pp. 54-65, het -wat betreft rechtsbescherning in een geintegreerde a.anpak (d.w.z. soms marginale, soms integrale rechterlijke toetsing).

45. W. Duk, t.a.p; Ook S. Zwemstra, Bescherming van witingsrechten door adminisirafieve rechters, diss. KUB, Zwolle, 1992, pp.71-86. Hij werkt met nim beoordelingsvrijheid-begrip. Dat omvat zowel (subj./obj.) beoordelings- als belleidsvijheid.

46. A.Q.C. Tak, De niewwe Van Wijk/Konijnenbel, in: NTB, nr.6, 1994, pp.165-177, i.h.b. p.169 vindt het, ap Duk geinspireerde, onderscheid "volstrekt overbodig, immers, er zijn geen relevante rechtsverschillen aan verbonden". Ook wijst Tak scherp op de, in de nieuwe Van Wijk/Konijnenbelt (zie H.D. van Wijk. bewerkt door W. Konijnenbelt en R. M. van Male, Hoofdstukken van administratief recht, negende druk, Utrecht, 1994, pp.163-174) aangetroffen, terminologie "naar het oordeel" die op toekenning van beleidsnimte (dat is dus gén beoordelingsvrijheid of -nimte, en evenmin beleidswrijheid!) ziet, welke systematiek in de vW/K bundel madelig doorwerkt bij de bespreking van beleidsregels.

47. H. van Maarseween ,Bevoegdheid, in: "Th. Holterman (red.), Algemene begrippen wan stautsrecht, tweede geheel herziente druk, Zwolle, 1989, pp.60-65. Bezie in dit licht zijn definitue van bevoegdheid als "een. op het recht gebaseerde en door het recht genomeerde mogelijklueid om op het doen an laten van de mensen en andere rechtssubjecten invloed uit te oefenen".

48. F.A.M. Stroink (1978), a.w., pp.21-22. 
En de vierde fase in het proces gaat de rechtsgevolgen van de bevoegdheidsuitoefening aan. Dat is het geheel van rechten en/of plichten dat op een (of meer) burger(s) of ambt (en) rust. De twee eerst genoemde stadia zijn in elk geval van publiekrechtelijke aard. Deze vlieger gaat niet altijd op voor de beide laatste fasen.

Een en ander samengevat is een publiekrechtelijke bevoegdheid het "juridisch vermogen van een ambt" dat zowel rechten als plichten omwat. ${ }^{49}$ Een publiekrechtelijke bevoegdheid geeft dus de contouren aan waarbinnen een betrokken bestuursorgaan zich kan, mag en moet bewegen. $\mathrm{Zij}$ bepaalt wat een overheidsactor wel of niet mag bij de uitvoering van bepaalde taken en ten opzichte van wie zijn handelen wel of juist niet is geoorloofd. Voor justitiabelen betekent de eis van een (herleidbare) publiekrechtelijke grondslag voor uitoefening van een overheidstaak, dat het bestuurlijk gedrag kenbaar, voorzienbaar en democratisch controleerbaar is.

Een overheidstaak betreft alleen datgene wat tot stand moet worden gebracht. Binnen een en het zelfde taakgebied kunnen verschillende bevoegdheden worden uitgeoefend. Dit gebeurt door een toenemend aantal, onderling op bepaalde wijze aan elkaar gerelateerde, verschillende bestuurseenheden. Zo ligt soms een specifieke taak of een bijzonder complex van taken op uiteen liggende, al dan niet gezamenlijke, schouders. Vooral functionele dimensies doen beleidskolommen door bestuurslagen heen ontstaan. Bepaalde zellfstandige bestuursorganen hebben territoriale trekken of coëxisteren met geografisch bepaalde besturen. En in algemeen bestuur kan functioneel beleid doorklinken. Het is een machtenspel over en weer.

Nadrukkelijk wordt herhaald: toekenning of overheveling van bepaalde bevoegdheden is onontbeerlijk voor het op optimale wijze realiseren van bepaalde overheidsdoeleinden. Bevaegdheden en taken zijn onverbrekelijk met elkaar verbonden. Van uit deze integratie en verwevenheid van taak en bevoegdheid is het mogelijk een overheid als een gezagsgemeenschap $^{\text {so }}$ te zien. Onverschillig rang en stand, d.w.z.: kwalificatie, is het de - door een bepaalde entiteit met oog op overheidstaakbehartiging verkregen - (component) publiekrechtelijke bevoegdheid die een willekeurige entiteit binnen de overheidsorganisatie plaatst.

Van wege deze centrale waarde is inhoudelijke omlijning van het begrip publiekrechtelijke bevoegdheid zinvol. Hierboven is zij reeds in het algemeen gekenschetst. Nadere concretisering krijgt de term in paragraaf 9.4. Omdat aan de vraag, of een bepaalde publiekrechtelijke bevoegdheid dient te worden toegekend of -gedeeld, altijd de vraag vooraf gaat of sprake is van een of andere overheidstaak, verdient laatst genoemde kwestie aandacht.

49. F.A.M. Stroink, a.w., p.20.Z.i. moet de bevoegdheid we. ambt worden onderscheiden v.e. vertegenwoondiger w.e. ambt.

50. P. de Hoed, t.a.p., p.125. 


\section{Geraadpleegde literatuur}

Ackermans-Wijn, J,C.E.

Contracten met de overheid: Een onderzoek naar de contractsvrijheid wan publiekrechtelijke rechtspersonenen het toepasselijke materiële recht, serie bestuursrecht - theorie en praktijk nr.7. dissertatie KUN, Deventer, 1989.

Berge, J.B.I.M. ten, Gilluits, P.C., Hirsch Ballin, E.M.H. \& Stroink, F.A.M. (red.)

VUGA-bundel: losbladig commentaar op de Awb, 's-Gravenhage, 1990 e.v.

Berge, J.B.J.M. ten. Waard, B.W.N. de \& Widdershoven, R.J.G.M. Arob-bundel, losbladig, Alphen aan den Rijn.

Boxum, J.L., Ridder, J. de \& Scheltema, M.

Zelfstandige bestwursorganen in soorten; Verslag van een onderzoek maar de praktijk van zelfstandige bestuursorganen, i.o.v. ministerie wan $B Z$, publikatie vakgroep bestuursrecht en -kunde Groningen, Deventer, 1989.

Bijloos, A.W.M. \& Lindner, Th.J.M.

De Awb eerste tranche, serie studiepockets staats- en bestuursrecht, tweede druk, Zwolle, 1992 , ook vierde druk, Zwolle, 1994.

Duk, W.

- Inleiding tot het bestuursrecht, leerboek OUH, tweede druk, Alphen a/d Rijn, 1988;

- Beoordelingswijheid en beleidsvrijheid in: RM Themis, 1988, pp.156-169.

Goorden, C.P.J.

- Rechtsbevoegdheid in het bestuursrecht; Een rechtsvergelikende studie naar het bevoegdhedenvraagstuk in het bestuursrecht, dissertatie KUB, Zwolle, 1990;

$\sim$ Kronieken, in: NTB, nr.3, 1992, pp.96-99.

Hoed, P. den

De samenstelling van de overheid, in: B\&M, nr.3, 1992.

Klap, A.

Vage normen in het bestuursrecht, dissertatie RUU, Zwolle/Utrecht, 1994, pp.54-65.

Maarseveen, H.Th.J.F. van

Bewoegdheid, in: Holterman, Th. (red.), Algemene begrippen van staatsrecht, tweede geheel herziene druk, Zwolle, 1989, pp.60-65.

Michiels, F.C.M.A.

$\sim$ De arob-beschikking, diss. KUN, "s-Gravenhage, 1987;

- Kronieken: De beschikking en andere bestuurshandelingen, in: NTB, nr.4, 1993, pp. 157-162.

Nicolaï, P., Olivier, B.K., Damen, L.J.A. \& Troostwijk, H.

Bestuursrecht, derde herziene druk, Amsterdam. 1992.

Ru, H.J. de

Staat, markt en recht; De gevolgen van privatisering voor het publiekrecht, preadwies CJV, 27 meil 1987.

Schreuder, C.A.

Publiekrechtelijke taken, private rechtspersonen; Verzelfstandiging en privatisering in de vorm van vennootschappen en stichtingen, dissertatie RUG, serie besturssrecht theorie en prakijk nr.16, Deventer, 1994.

Simon, H.J.

- De behartiging van het publieke belang door de overheid via de uitoefening van privaatrechnelijke bevoegdheden, in: Ommeren, F.J. van, Ru, H.J. de, Simon, H.J. \& Wessels, B., Overheid en burgerlijk recht, serie praktijkhandleidingen, Zwolle, 1992, pp.1-65;

- Publiekrecht of privaatrecht?, diss. UvA, Zwolle, 1993.

Steenbeek, J.G. \& Stroink, F.A.M. 
Wet Arob, vierde druk, 's-Gravenhage, 1988.

Stroink, F.A.M.

- Het leerstuk der deconcentratie, dissertatie RUU, "s-Gravenhage, 1978;

Boekbeschouwing C.P.J. Goorden, in: NTB, nr.9, 1990, pp.295-297.

Stroink, F.A.M. en Steenbeek, J.G.

Inleiding in her staats-en bestuursrecht, vierde herziene druk, Alphen aan den Rijn, 1993.

Tak, A.Q.C.

- Overheid en burgerlijk wetboek; Naar een invullende rechtsleer, in: R\&K, nr.2, 1993, pp. 174-190;

-De nieuwe Van Wijk/Konijnenbelt, in: NTB, nr.6, 1994, pp.165-177.

Terpstra, B.

Vernieuwing van rijksoverheid op drijfzand, in: Openbaar Bestuur, nr.8, 1993, pp.27-32.

Tweede Kamer

- Functioneel bestuur: waaromen hoe?, TK 19.88-1989, 21042, m. 2, en TK 1990-1991, 21042 , nrs. 4-10;

- Memorie van toelichting Awb, TK 1988-1989, 21221, nr.3.

Weesing, G.H.L.

Beoordelingsvrijheid en beleidswrijheid: gegeven of te laten vrijheden?, in: Hoogenboom, T. \& Damen, L.J.A. (red.), In de sfeer van administratief recht; Opstellen aangeboden aan willem Konijnenbelt, Utrecht, 1994, pp.429-442.

Wijk, H.D van, bewerkt door Konijnenbelt, W. \& Male, R.M. wan

Hoofdstukken van administratief recht, negende druk, Utrecht, 1994, pp.162-174.

Zevenbergen, J.A.

Rechtsbescherming in de landinrichting en de Awb, in: Agrarisch Recht, nr.4, april 1993. p. 170 e.v.

Zwemstra, $\mathbf{S}$.

Bescherming wan uitingsrechten door administratieve rechters, dissertatie $\mathrm{KUB}_{\text {, }} \mathrm{Z}$ wolle, 1992, pp.71-86. 
Hoofdstuk 8

\section{Op weg naar (overheids)kerntaken en -departementen}

\section{$\$ 8.0$ Overheidstaak}

Een beslissing om te decentraliseren wordt vooraf gegaan door de vraag of de toe te delen taak (nog) wel moet worden beschouwd als overheidstaak. 'Neutralle criteria aan de hand waarvan beantwoording mogelijk is, zijn echter niet voorhanden. Dit gebrek aan maatstaven voor de geheel eigen taak en verantwoordelijkheid van de overheid wordt als lacune ervaren. Helaas is de leemte moeilijk op te vullen. Immers, datgene wat als typische overheidstaak wordt gezien, is naar tijd, plaats en maatschappijopvatting verschillend.

Denk alleen al aan het algemeen belang dat per definitie wordt gediend door een taak als uit te voeren door publiekrechtelijke of privaatrechtelijke overheid. De inhoud van het algemeen belang, voor welk belang de overheid dus voortdurend zorg moet dragen, is tijd-en plaatsafhankelijk. Zij kan concreet zijn (bij voorbeeld - en hier volgen willekeurige voorbeelden van taken van zbo's - het door de Nederlandse Organisatie voor toegepast-natuurwetenschappelijk onderzoek er toe bijdragen dat op toepassing gericht technisch-en wetenschappelijk en ander op toepassing gericht onderzoek op doelmatige wijze dienstbaar wordt gemaakt aan het algemeen belang en de daarbinnen te onderscheiden deelbelangen, of de door het Centraal Fonds voor de Huisvesting te verstrekken financiële steun uit de opbrengsten van door toegelaten instellingen verkregen bijdragen waarvan de bepaling overeenkomstig het instellingsbesluit plaats heeft, aangezien die instellingen geacht worden niet over de noodzakelijk geachte reserves te beschikken, of het door het Bestuur van de Stichting Nationale Commissie Voorlichting en Bewustwording Ontwikkelingssamenwerking te real iseren informatieactiviteiten over internationale ontwikkelingssamenwerking en stimulering van ontwikkelingsprocessen in Derde Wereldlanden door subsidiëring van informatieprojecten van derden en via activiteiten met anderen, of de door het Centraal Orgaan Opvang Asielzoekers te verzorgen materiẻle en immaterië]e opvang van asielzoekers, of de door de Stichting Verzekeringskamer te bewerkstelligen regulering van een optimale organisatie- en verkeersstructuur van het verzekeringsbedrijf), maar ook meer algemeen (denk aan het - door middel van onder 
meer het verstrekken van financiële middelen of het geven van goede en tijdige voorlichting - bestrijden van armoede, het zorgen voor huisvesting, het realiseren van infrastructuur, het bevorderen van een beter milieu of het creëren van werkgelegenheid). Op de vraag wat het algemeen belang is, zijn -al naar gelang omgeving en omstandighedenverschillende oplossingen mogelijk. Een eensluidend antwoord is ver te zoeken.

Slechts één conditie ligt voor de hand: een taak in algemeen belang is elementair. $\mathrm{Zij}$ voorziet in wezenlijke behoeften en kan dus niet ontbreken. Met andere woorden, een overheidstaak, anders gezegd een publieke taak ${ }^{2}$, heeft niet slechts een dienstig karakter. Alleen additieve of toegevoegde waarde maakt een taak nog niet tot overheidstaak.

\subsection{Overheidstaak in politiek debat}

De oriëntatic op de zo genaamde harde kern van overheidstaken wordt mede bepaald door de rol die de Nederlandse staat krijgt toegemeten. Van uit economische welvaartstheorie wordt van overheidswege zorg gedragen voor het aan de individuele burger toekomen van (quasi-)collectieve goederen op grond van de volgende motieven: allocatie, herwerdeling en stabilisatie. ${ }^{3}$ In deze optie beoogt overheidsingrijpen beïnvloeding van a. verdeling van produktiefactoren over verschillende mogelijkheden tot gebruik van deze produktiefactoren wegens het falen van het prijsmechanisme, $b$. verdeling van inkomens en c. de omvang van de effectieve vraag via variatie van uitgaven en inkomsten. De stabilisatiefunctie, en in mindere mate, de allocatieve functie ingegeven door onder meer paternalistische argumenten, motieven van compensatie van tekort schietende marktwerking,ontwikkelingsmotieven, argumentenvanrisicoverevening, anti-monopolie-motieven en de gedachte externe effecten te verdisconteren, hebben aan betekenis verloren. ${ }^{4} \mathrm{De}$ kerntakendiscussie raakt dus vooral aan de functie publieke uitgaven en heffingen opnieuw te verdelen. Elementair blijkt de vraag waar de financiële verantwoordelijkheden van de Nederlandse overheid liggen. In dat licht kan van overheidswege een taak het stempel van overheidstaak krijgen. Overigens is het niet zo dat als een taak overheidstaak heet, uitvoering van deze taak per definitie voor (gehele) overheidsfinanciering in aanmerking komt.

Tegenwoordig valt de zorgwekkende conceptie van de in crisis geraakte verzorgingsstaat niet meer te ontkennen. Het vaart allemaal niet meer zo well. In tegenstelling tot de bedrijfswereld, die de tucht van de markt voelt, kent een overheid de dwang tot zelfregulering niet. Daarom moet zij op zoek naar haar, zakelijk gesproken, 'core business'.

2. Van een publiekreclutelijke taak is pas sprake indien de taak een publiekrechtelijke grondslag heeft.

3. (In navolging van R.A. Musgrave en P.B. Musgrave) H. de Groot, C. Sips en P.H.J. Vrancken, Kerntakendiscussie bij de rijksoverheid in het perspectief wan de welvartstheorie, in: C. Sips en P.H.J. Vrancken, Kerntakendiscussie bij de Rijksoverheid, IOO-reeks nr. 59, 's-Gravenhage, april 1994, pp.17-27, i.h.b. pp. 18-19; Eerder J A.A. Poppelaars en C. Sips, Economische effecten wan caltuur, IOO-reeks nr. 53, 'sGravenhage, oktober 1993, pp. 43-56, i.h.b. pp.43-45.

4. G.J.M. de Vries, Raakt de kerntakendiscussie wel de kern?, in: C. Sips en P.H.J. Vrancken, a.w., pp.7380 , i..h. H. pp. $74-75$ 
Hierbij moeten "kleine kernministeries op hoofdlijnen sturing geven aan verzelfstandigde en bedrijfsmatige uitvoeringsorganisaties". ${ }^{s}$

Aan deze, 500 à 1000 koppige, beleidsvormende kerndepartementen ${ }^{6}$ wordt een zgn. project-ministerschap-nieuwe-stijl ${ }^{7}$ gekoppeld. Dat wil zeggen: ministers dragen, over de grenzen van eigen portefeuilles heen, (mede)verantwoordelijkheid voor bepaalde projecten waarbij verschillende departementen zijn betrokken. ${ }^{8}$

Annex hieraan moet, via interdepartementale/verticale mobiliteit ${ }^{9}$ en gecoördineerd opleidingsbeleid, een kwalitatief sterk staande algemene bestuursdienst ${ }^{10}$ worden ontwikkeld. Het in leven roepen van een algemene bestuursdienst heeft alles te maken met het concept van "besturen op afstand'. "Een dergelijke dienst wordt bij voorkeur ge-

5. F. wan der Doelen, De burger is koning: Overheidsdiensten moeten in navolging van het bedrif toleven hun kwaliteitsbeleid moderniseren, in: Intermediair, nr.32, 7 aug. 1992, p.15.

6. Hierower M. J.W. van Twist en R.J. in " Veld, Overkermdepartementen; Een vergelijkend onderzoek naar departementale weranderingsprocessen inn Groot-Brittanië, Zw'eden, Noorwegen en Denewarken, "s-Grav., 1993; Ook M.J.W. wan Twist en R.J. in "I Veld, Kerndepartementen: een wenkend perspectief? en Kerndepartementen in vergelijkend perspectief, in: BK, nr.7, 1993, pp.353-366 en pp.341-352; W.J.M. Kickert, "Le cabinet muinistêriel "in Frankrijk; De kern van een departement, in: BWn, nr. 1, 1994, pp.623. In navolging van beide voomoemde auteurs stelt Kickert, met referentie aan de organisatie van de Franse rijksoverheid, dat "het bij kerndepartementen niet alleen gat om de onderscheiding tussen beleidsvoomereiding en -nitwoering, maar even zeer om het onderscheid tussen politiek en administratie [...], het gaat of on een strategische beleidskern of om een politiek secretariaat" (p.20); Vervolgens beschrijven M.J.M. wan Twist en $\mathbb{R}$.J. in "t Veld, Een kerndepartement is iets as ders dan "wat er na verzelfstandiging overbliff", in: OB, nr.8,1994, pp.14*19, de kerndepartement-ontwikkeling: van strategische belleidskern naar sturings- of bestuursdepartement naat politiek secretariaat.

7. J. Breunesse, Over the eindrapport van de commissie-Wiegel, in: OB, nr.12, 1993, pp.8-13, i.h.b. p. 12, acht dit project-ministerschap-nieuwe-stijl een "misklleun". Z.i. levert de combinatie projectminister minister problemen op. Breunesse staaft zijn mening aan die van de vroegere regeringscommissaris H.D. Tjeenk Willink; Ook rijzen vragen over hoe een projectministerschap zich verhoudt tot ministeriele verantwoordelijkheid of, anders, begrotingpost. P. Nieuwenhuijsen, Genoeg werk voor projectministers wet tanden, in: BBM, 29 april 1994 , pp. 11-13, tevens pp.3-9.

8. Owerigens, wat betreft decentralisatie, niet ambevolen door commissie-Framssen, a. , pp.56-57.

9. Volgens. M.H. Meijerink en C.M.M. Paardekoper, De onwikkeling naar kerndepartementen; Was zijn de keruaken?, in: $\mathrm{OMn}$, nr.10, 1993, pp.236-239, i.h.b. p.239, vraagt de cie-Wiegel nog te weinig aandacht woor een mobiel en multi-d isciplinair politiek staforgaan van bewindslieder.

10. Hierover Een Algemene Bestuursdienst in hel vizier, TK 1993-1994, 23468, nrs. 1-2, pp. 1-12, zie accordering van ministerraad als verwoord in Algemene Bestutursienst, TK 1994-1995, 23468, nrs. 3-4, pp. 1-23; De gedachte van een algemene bestuursdienst "met een verplichtend karakter" vindt instemming bij de PviA, VVD en D"66. Zie hun Regeerakkoord 1994. Keuzes voor de taekomst. TK 1993-1994, 23715. nr. 11, p.25; Uit de Brief van de minister wan binnenlandse zaken waarbü hij de nota 'Koers naar de Algemene Bestuursdienst' aanbied, TK 1994-1995, 23877, nr.2. brijkt dat vaart wondt gezet achter de opbouw van een algemene besturursienst, die via een 'bottom up'-werkwijze tot stand moet komen.

11. Een Algemene Bestuwrsdienst in het vizier, a.w., p.3; Vgl. Algemene Bestuarsdienst, TK 1994-1995, 23468, nr.4, pp.5/8. De sturing wan zbo"s geschiedt var uit het kemdepartement: "De managers en medewerkers van verzelfstandigde diensten hebben een grote mate van zelfstandighe id. Zij dragen verantwoordelijkheid voor het reilen en zeilen en voor de resultaten yan hun werkeenheid. Van te voren ligt vast met welk budget welke resultaten in de vorm van diensten en produkten minimalal behaald dienen te wordem. Voor de werkwijze betekent dit dat er veel meer output-en klantgericht gewerkt zal worden, en dat het management en de medewerkers beoordeeld (kunnen) worden op de door hen geleverde presta- 
vormd door "breed inzetbare beleidsfunctionarissen die hun ervaring op meerdere plekken in de rijksdienst opbouwen ". "22 Langzaam maar zeker wordt een 'bovendepartementaal Management Development-beleid' ontwikkeld. Daaronder wordt verstaan "alles wat aan planmatige activiteiten moet worden ondernomen om op korte en middellange termijn te kunnen beschikken over een gekwallificeerd (top)kader van de ministeries". ${ }^{13} \mathrm{Bij}$ dit management development-beleid is de aandacht gericht op: "a. intensivering van vacature-inwulling via Intertop; b. ontwikkeling van een gemeenschappelijk te hanteren begrippenkader; c. ontwikkeling van mogelijkheden voor mobiliteitsbevordering; en d. ervaringsuitwisseling" 14 i.5

Bij toepassing van deze management-development-regels op toezichthoudende bestuursorganen geldt een waarschuwing vooraf. Vooral het streven naar meer mobiliteit van (secretariaats)ambtenaren kan frictie opleveren. Het betrokken orgaan verliest mogelijk aan expertise en competentie, als blijkt dat de om de zo veel jaar vertrekkende en komende (secretariaats)ambtenaren verschillende oplossingen bieden in aan hen voorgelegde identieke zaken. ${ }^{16}$ Weg is de duidelijkheid van zaaksbehandeling. Weg de beleidslijn. Vooral voor een bestuursorgaan, belast met toezicht op de naleving van wet- en regelgeving, kan dit frustrerend werken. In verwarring geraakte onder toezicht gestelden oefenen mogelijk druk uit op de ketel en kunnen snel een vertrouwenscrisis ontketenen. Kortom, bij uitoefening van handhavingstaken is het essentieel dat tussen toezichthoudend orgaan en onder toezicht gestelden openheid en helderheid over taakuitoefening bestaat. Overigens speelt dit probleem minder als een departementsafhankelijke toezichthouder wordt om gezet in een in beginsel van de minister onafhankelijk zelfstandig bestuursorgaan.

Misschien kunnen de voordelen van het voorgestelde systeem in praktijk zo'n nadeel er van elimineren. In het nieuw voorgestane stelsel gaan rijksambtenaren, die bezig zijn met

11. $\rightarrow$

ties. "In rechtspositioneel opzicht vindt zekere sturing van zbo's mogelijk plaats via convenanten ter zake "rnet het oogmerk aansluiting bij de algemene bestuursdienst te bewerkstelligen".

12. G.J. van Dinter mamens statssecretarissen-generaall, Notitie over de organisatie en firichting wan de rijksoverheid, 's-Gravenhage, 24 maart 1993, TK 1992-1993, 21835, nr.15, p.3: Over dit rapport 0.a. I.N. Breunesse, Rapport SG: een toch niet bewredigende exercitie, in: $\mathrm{OMn}_{n} \mathrm{nr} .10,1993$, pp.240-246; Het kabinet ziet de noodzaak in van integratie wan de voorstellen van de commissie-Wiegel en die van de secretarissen-generaal, TK 1992-1993, 21427, nr.61; Over de verschillen tussen beide rapporten, A. varn Braam, t.a.p., pp.225-233.

13. Een Algemtene Bestuursdienst in het wizier, a.w., p.7.

14. Een Algemene Bestuursdienst in her vizier, a.w. . pp.8-9.

15. Dat er op het gebied van arbeidswoonwaanden- en personeelsbeleid overigens nog heel wat moet gebeuren voordat een flexibeler, slagvaardiger en beter bestuurbare rijksoverheid in de vorm van een algemene bestuursdienst wordt bereikt, leggen A. van Essen en G.C.C.M. Aarts, De kern van thet departement...., klaar woor het kerndepartement?; Een kritische beschouwing over personeelsmanagement bij de rijksoverheid, in: $\mathrm{OMn}_{n} \mathrm{nr} .11,1994$, pp.280-285, aan de hand van beschrijving van het Human Recourse Management uit.

16. A.S. Junge, Centrate persoonsregistratie in Denemarken, in: JV, nr.5, 1994, pp.65-83, i.h.b. p.73, constateert dit probleem bij het, aan de minister van justitie ondergeschikte, Registertoezicht-orgaan (Registertilsynet) in Denemarken. 
beleidsbepaling en die deel uit maken van het topmanagement van verzelfstandigde entiteiten, hun dienstverband niet meer aan met de diverse departementen, maar met bedoelde algemene bestuursdienst. ${ }^{17}$ Een centralle eenheid, politiek aangestuurd door de minister van binnenlandse zaken en ambtelijk door de vergadering van secretarissengeneraal, dient de ambtelijke bestuursdienst vorm te geven. ${ }^{18}$

Op zich bestaat waardering voor het, van uit de (onder)scheiding van beleidsvorming en -uitvoering geleverde, betoog over de wenselijkheid van kerndepartementen. Kennelijk minder succes oogst het pleidooi als het wordt afgezet tegen de praktijk. Het huidige beeld van ontwikkeling bij departementen, d.w.z. het her en der uit proberen van verschillende privatiserings- en verzelfstandigingsfiguren, komt voorlopig niet over een met schone gedachten van de commissie-Wiegel. Daarom luidt een voorstel te komen tot procesordening. M.a.w. "de algemene gedachtengangen (van o.a. de commissie-Wiegel - JGLvN) moeten snel worden omgevormd tot toetsingscriteria om tezijnertijd uit de grote verscheidenheid van experimentele ontwikkeling te komen tot selectieve keuzen". ${ }^{19}$ Het is dus wachten op een concrete vertaling van de politieke plannen.

Volgens politieke plannen moet tweederde deel van de huidige rijksdienst op afstand (van de directe parlementaire controle) worden geplaatst. Niet alleen zijn ambtelijk verzet tegen en vertraging van een scheiding tussen "beleidsuitvoerende schapen en beleidsvormende bokken" te verwachten. ${ }^{20}$ Maar ook is de vrees reëel dat beleidsvorming- en uitwoering moeilijk zijn te separeren. ${ }^{21}$ Zie paragraaf 9.2 .

Overigens is het in dit verband aardig te beseffen, dat niet slechts sprake is van het op afstand zetten van beleidsuitwoering. Bekend is namelijk de bewering "dat het op afstand" plaatsen wan beleidsvorming vaak meer gedifferentieerde mogelijkheden biedt dan het op afstand plaatsen van beleidsuitwoering". ${ }^{22}$ Aardig schoolvoorbeeld is natuurlijk het Centraal Bestuur voor de Arbeidswoorziening. Daar is zelfs sprake van verzelfstandiging van de totale beleidscyclus. Anders dan de ambtenaren, die zich de laatste jaren kenmerken door professionaliteit, kwaliteit en zelfstandigheid, zijn de Haagse politici nog huiverig voor het verzelfstandigen van beleidsbepalende taken. Ten onrechte, volgens fielle voorstanders van die gedlachte. Immers: "Als de uitvoering van beleid door private partijen kan worden gedaan, waarom dan niet de ontwikkeling van beleid? Ik zie geen enkele legitimatie voor het feit dat dit alléén een zaak van politiek en bureaucratie moet zijn. En moeilijk te organiseren is het niet. Je vraagt per beleidsgebied vijf universiteiten

17. Algemene bestuursdienst. TK 1994-1995, 23468, nr.4, p.22, verduidelijkt dat het hier gatat om "zowel het management als alle ambtenaren die in hoofdgroep $V$ en VI (schaal 15 en hoger - JGLWN) ziju aangesteld in algemene dienst van het rijk".

18. Uitwoerig over kerndepartementen commissie-Wiegel, a.w., pp.4-6/25i-37.

19. R.J. in 't Veld, De kernakenbenadering bij de Rijksoverheid: onderwerp wan gesprek, yn: C. Sips en P.H.J. Vrancken, De kermakenbenadering bij de Rüjksoverheid, 100-rapport nr.59, 's Gravenhage, april 1994, pp. 7-15, i.h.b. p. 10.

20. D.J. Elzinga, Een witweg uit de bureawcratie, in: BB, nr.26, 2 juli 1993, p.27.

21. B. Terpstra, Vernieuwing van rijksoverheid op drijfand, in: OB, nr.8, 1993, pp.27-32, i.h.b. p.30.

22. Zie door het Management Centrum, onder redactie van P. Frissen, E.M.H. Hirsch Ballin, R.J. Hoekstra, R.K. Visser, R.J. Kuiper en R. de Boer, uitgegeven bundel Hel managen van verandering door verzelf standiging, "s-Grav, , 1993, p. 155. 
of andere deskundige priwate partijen om met elkaar te concurreren voor het beste beleid. De overheid wordt dan een facilitair bedrijf voor beleidsdiscussies. " 23

Alle fraaie voorstellen ten spijt, is het nog steeds onduidelijk wat onder beleidsvorming en -uitvoering wordt verstaan. Met andere woorden, definiëring van kerntaken wan de overheid blijft kennelijk uit. Hierbij gaat het a priori om afspraken, om politieke keuzen. ${ }^{24}$ Het wekt waarschijnlijk weinig verwondering, dat de kerntakendiscussie op politiek niveau nog steeds niet is uitgekristalliseerd. Praktisch gezien is dit teleurstellend. De herijking van overheidstaken blijft veelal een papieren aangelegenheid. De beleidsintenties, tot concrete afbakening van essentiële en niet-essentiële overheidstaken, van de eerste kabinetten-Lubbers bezitten tot op heden onvoldoende daadkracht. Uit recentere regeringsperioden blijkt de aandacht voor de terugtred van de Nederlandse overheid nog steeds. Helaas blijft de daaraan inherente herbezinning op eigenlijke ${ }^{25}$ staatstaken valse schijn. ${ }^{26}$ De kaars, van afweging van owerheidstaken, wordt weliswaar licht aangewakkerd door de zo genaamde kerntakendiscussie ${ }^{27}$, die overigens niet alleen op rijksniveau plaats vindt ${ }^{28}$. Maar daarmee vat de pit nog niet genoeg vlam om helder uit te stralen.

Het parlementair debat over echte overheidstaken vindt een uitgangspunt in het bijzondere vraagstuk "betreffende de kwaliteit van de overheid als geheel, de omvang van de totale overheidsorganisatie en de wijze waarop de overheid haar taken dient te vervullen". ${ }^{29}$ Deze vraagstelling raakt de democratische legitimatie van overheidsoptreden. Tevens, en niet pas als laatste redmiddel ${ }^{30}$, legt $z i j$ zo de relatie naar zelfstandige bestuursorganen.

Uit de discussie blijkt "een breed gesteund streven de taken van de overheid en de taakvervulling door de overheid kritisch te bezien". ${ }^{31}$ Dat dit streven een moeilijk streven is, is reeds duidelijk bij de aanvang van de kerntakendiscussie: "De herijking van verant-

23. Aldus expliciet P. Frissen "geciteerd door T.I. Meeus, "Waarom zou je de ontwikkeling van beleid niet priwatiseren?", in: NRC, 30 nowember 1994, p.21.

20. J.A.M. Hendrikx ${ }_{n}$ Wed-ofkringloop tussenterritoriale en finctionele decentralisatie, in: Bestuur, nr. I. dec. 1989, p.325.

25. RPF-kamerlid Leenling, Grote efficiency operatie, 11 febr. 1992, TK 50" p. 3240, prefereert het spreken in termen wan eigenlijke of wezenlijke overheidstaken boven de bewoording kemtaken.

26. J.P. Balkenende, Zelfregulering vereist furidische culturomslog, in: $\mathrm{OB}, \mathrm{nr} .8$, aug. 1992, p.4.

27. Commissie-Deetman, Rapport wan de Bijzondere Commissie Vraagpunten. TK 1990 1991, 21427, nr.3, pp.8-9/12-14; Zie voot daarbij horend debat UCV 63-64, betreffende Shaatkundige, bestwurlike en staatsrechelujke vernieuwing, d.d. 19 mart 1991, pp.3536-3628; Ook aan de orde in CDA-rapport, Herktelde werantwoordelijkheid" discussienota over de taken wan de overheid, Houten, sept, 1991 ; Overigens overzicht politieke standpunten in: ESB, nr.3828, 2 okt. 1991.

28. M.b.t. gemeenten V.J.J.M. Bekkers en A.F.A. Korsten, Gemeentebestuar in het landelijk perspecrief, in: BWn, nr.6, 1993, pp.449-475/pp.481-484; L. Geut en D. Kooistra, Kerntakendiscussie, in: OMn, nr.4, 1994, pp.92-96; I.h.b. over Lochem B. Visser, Kerntakendiscussie. kart en krachig, in: $\mathrm{OB}, \mathrm{nr} .3$, 1994, pp. 10-13; M.b.t, prowincies F, de Zeevw, Over her nut wan prowincies, in: $\mathrm{OB}, \mathrm{nr} .11,1993, \mathrm{pp} .6$ 10.

29. TK 1990-1991, 21427, nr.3, p.8.

30. TK 1990-1991, 21427, nr. 3, p.14.

31. TK 1990-1991, 21427, mr.3, p.9. 
woordelijkheid tussen centrale overheid en andere overheden en met de samenleving, het maatschappelijk middenveld (...) is lastig (...) onder meer doordat de bestaande taakverdelling tussen de overheid en de samenleving en tussen de overheid en andere overheden gestold is in instituties, in wetgeving en in bureaucratische instituties, en in vaak verstikkend vlechtwerk van rechtsbetrekkingen en, niet alleen tussen de overheid en de burgers, maar ook binnen de overheid, tussen bestuurslagen en bestuursorganen. Het is nu taak, dit te herijken, en dat is het richtsnoer voor het verdere werk aan staatkundige vernieuwing. " 32 Inderdaad is het streven tot herijking van overheidstaken moeilijk te verwezenlijken. Zo constateert de bijzondere commissie vraagpunten zelf al dat het spreken wan primaire overheidstaken wetenschappelijke schijn wekt. In praktijk is de term multiinterpretabel. Tot op heden is een inhoudelijke discussie zorgvuldig vermeden. Dat, in casu bij de commissie bijzondere vraagpunten, opnieuw de oriëntatie op overheidstaken ontbreekt is betreurenswaardig. De democratie verliest haar dynamiek en uiteindelijk haar primaat als zij, in plaats van een principieel debat, slechts een gedachtenwisseling met managers over de meest effectieve korte-termijnprobleemoplossingen aangaat. ${ }^{33}$ Uiteenzettingen over de omvang van de overheidstaak zijn kennelijk slechts geschikt voor publikatie in politieke partijprogramma's.

Nog maals, de voortgang van het kerntakendiscours verloopt traag. Het fundamentele debat ter zake is kennelijk moeilijk naar politiek niveau te tillen. ${ }^{34}$ Niet dat daartoe geen pogingen worden gedaan:

Serieuze pogingen, t.w. kerntakenanalyses, staan in het teken van de grote efficiency operatie. Deze operatie voorziet in een kritische doorlichting van het ambtenarenapparaat, zowel in kwantitatief als kwalitatief opzicht. Haar doelstelling is tweeërlei. Ten eerste beoogt zij "'afweging van nut en noodzaak van bestaande rijksoverheidstaken". Ten tweede wil zij "verbetering van doelmatigheid van uitvoering van overheidstaken" realiseren. ${ }^{35}$ De grote efficiency operatie is de uitvoering van een van de vele reorganisatieplannen inzake het Nederlandse staatsbestel. Hiermee is tegelijkertijd het hoofdprobleem gegeven. De samenhang tussen alle afzonderlijke operaties is ver te zoeken. Overdrachtelijk gesproken: "Soms doet de rijksoverheid dlenken aan een brandend huis met twee vuurhaardlen. [...] De ene reddingsoperatie doet de andere te niet. [...] Sommigen willen vooral hun eigen pand uitbreiden, anderen zien liever iets nieuws verrijzen." 36 Dit betreft dus de algemene coherentieproblematiek. Hiernaast geldt dat de resultaten van de grote efficiency operatie, op zich, tegenwallen. Hieraan zijn vooral de gebrekkigheid en

32. Minister Hirsch Ballin tijdens UCV 63 d.d. 19 maart 1991, p.3602.

33. S. W. Couwenberg, Nieuwe hoop op sraatkundige en besturlijke vernieuwing., in: M.C. Burkens (red.), Staatsrechitelijke wernieuwingen: commentaren op het rappont van de commissie-Deetman, Staatsrechtkring, Zwolle, 1991, p.45.

34. O. van den Vijver, Then jaar rearganisatie rijksdienst, in: BEM, nr.7/8, 27 nov. 1992, p.8.

35. Grote Efficiency Operatie, TK 1992-1993, 21835, nr, 16, p.4.

36. D"66-kamerlid Scheltema-de Nie tijdens debat GEO, 11 februari 1992, TK 50, p.3235. 
de ondoelmatigheid van de sturing door de politiek debet. ${ }^{37}$ Daarom wordt well geplleit voor een "parlementaire" efficiency operatie. ${ }^{38}$

Ten einde tot een verdere kwaliteitsverbetering van de rijksdienst te komen, is het kritisch bezien (op hoofdlijnen) van de taken per departement noodzakelijk. Van de zijde wan de secretarissen-generaal is het belang van de politieke discussie over afweging van rijksoverheidstaken benadrukt. ${ }^{39}$ Daaraan refereren de secretarissen-generaal opnieuw tijdens de formatie van het kabinet 1994-1998. Naar hun zeggen dient het aantal departementen in bedoelde kabinetsperiode nog ongewijzigd te blijven. In hun optie is een "kleinere overheid alleen mogelijk wanneer de politiek aangeeft welke taken niet meer hoeven te worden uitgevoerd" 40

De, (weliswaar traag) tot stand gekomen, kerntakenanalyses ${ }^{41}$ bevredigen echter nog steeds niet. Globaal omvatten kerntakenanalyses het volgende. ${ }^{42} \mathrm{Ze}$ schetsen de ontwikkelingen bij ministeries. Ze brengen relevante omgevingsfactoren, bij voorbeeld internationale ontwikkelingen, in beeld. Ze inventariseren interdepartementale raakvlakken en stimuleren zo het "bij-elkaar-over-de-schutting-kijken". Ze bepleiten een organisatorische scheiding tussen beleidsbepaling en -uitvoering. En ze gooien takenballast over boord. Kerntakendiscussies verzanden veelal, omdat de bureaucratie de neiging heeft in abstracties te vluchten. ${ }^{43}$

\section{$\$ 8.2$ Roep om principiële herbezinning overheidstaken}

In het bijzonder van uit confessionele zijde is de kritiek, op thet ontbreken van oplossingsrichtingen op het vraagstuk, groot. Als bezwaarlijk ervaren wordt een bezinning op de grenzen van de overheidstaak die is verengd tot een discussie over alleen maar de hoeveelheid taken. Wenselijk is een principiële bezinning op de aard en de grenzen van de overheidstaak. Die zal dan de erkenning moeten inhouden dat de Nederlandse overheid een publieke taak heeft met eigenaardige begrensde bevoegdheden. In de optie van klein rechts wordt deze publieke taak, van uit de zo geheten cultuuropdracht bezien in hoofdzaak gekenmerkt door handhaving van de rechtsorde. ${ }^{45}$ De rechtsorde wordt dan

37. J. de Haan, Moeizaam snijden in eigen wlees, in: Staatscourant, 23 sept. 1991, p.5; W. T. Gelder, (Be) sruren op kerntaken, noodsprong of noodzakelijk?, in: Beeld van besturen, 's-Gravenhage, 1992, pp.33-51" O. van den Vijuer, ta.p., pp.6-13.

38. T. Rodrigues, De E in de GEO is de ezel in het openbaar bestuur, in: BBM, nr.7/8, 27 nov. 1992, p.39.

39. Grote efficiency operafie, TK 1991-1992, 21835 , nr.9, p.2.

40. College van secretarissen-generaal in vertrouwelijk advies aan informateurs kabinet 1994-1998; Daarover C. Banning. Ambtelijke top: handhaaf aantal departementen, in: NRC, 3 juni 1994, p. 3.

41. Grote efficiency operatie. TK 1991-1992, 21835, nr.7; Vgl. TK 1992-1993, 21835, nr.16, pp,4-12.

42. Commissie-Franssen, Over decentralisatie is nog nooit een vers geschreven, TK 1992-1993, 21427 , nrs. $42-43$, p. 19.

43. W. Derksen, Kerntakendiscussie raakt verstrikt in bureaucratische regelzucht, in: BB, 26 febr. 1993 . pp.14-15.

44. Wat betreft GPV: P. Dijkstra e.a., Een zelfstandige overheid in een sterke samenleving, Groen van Prinsterer-reeks, nr.68, Barneweld, 1991, pp.55-57; Boekbespreking door J.W. Luger, Overheid en samenleving, in: $\mathrm{BB}, 24$ januari 1992, p.33; K. Veling, De dienst van de overheid, Groen van Prinstererreeks, nr.55, Bameveld, 1987; Wat betreft respectievelijk RPF-en GPV-denken, UCV 63-64 d.d.. 19 maart 1991, pp.3536-3548. 
gevormd en bepaald door zowel overheid als maatschappij, denk aan vooral wetgever, rechter, publieke en private rechtspersonen.

Dit klinkt ook door in de, wat wijdere kring aangehangen, christen-democratische visie op de rol van de overheid in de samenleving. Daarin wordt de identiteit van de overheid gekleurd door zo genaamde publieke gerechtigheid. ${ }^{46}$ Dit publieke gerechtigheidsbeginsell krijgt in onderlinge samenhang met gespreide (maatschappelijke) verantwoordelijk heid, solidariteit en rechtsgemeenschap contouren. $\mathrm{Zij}$ is van drievoudige aard. $\mathrm{Zij}$ draagt een waarborg-, aanspraak- en normerend karakter. In dit kader spelen maatschappelijke verbanden een hoofdrol. Gelet op de ideële oorsprongen en pluriformiteit van de verschillende sociale levenskringen wordt verzorging van bepaalde overheidstaken door deze particuliere organisaties aanbevolen. Van uit de, uit deze hoek afkomstige, traditionele scepsis ten aanzien van functionele decentralisatie naar overheidsorganen wordt deze decentralisatie slechts een tweederangs positie toebedeeld. Veeleer is het de verantwoordelijkheid van de overheid dat zij de weg voor dit maatschappelijk initiatief effent en die, waar nodig, normeert. Even wel kan deze normerende taak mogelijk worden gedecentraliseerd naar, bij voorkeur, zelfstandige bestuursorganen. ${ }^{47}$

Overigens is de ontwikkeling van een principiële visie op overheidstaken afgewezen. Een dergelijke benadering is te theoretisch. Bovendien leidt die aanpak tot vertraging. De minister van binnenlandse zaken ziet meer heil in een structurele, concrete werkwijze. ${ }^{48}$

\subsubsection{RECHTSHANDHAVING ALS ELEMENTAIRE OVERHEIDSTAAK}

Het normerend en rechtshandhavend optreden van de overheid betreft het geven van spelregels voor het vrije spel van maatschappelijke krachten. Hierbij passen zelfregulering, branchegewijs overleg, tripartisering et cetera. Deze elementaire taak wordt in rechtspolitieke kring onder de noemer kerntaak van de overheid geschaard. Zij betekent dan het scheppen van gunstige condities voor de eigenstandigheid en vergroting van beleidsvrijheid van maatschappelijke verbanden, het garanderen van financiële en sociale bodems in het bestaan en het handhaven van internationale veiligheid en van de rechtsorde. Aansluitend op dit primaat van de politiek moeten burgers en particuliere organisaties met hun respectieve verantwoordelijkheden worden geconfronteerd. Het creëren van voorwaarden voor een optimale sociaal-maatschappelijke infrastructuur, via onder andere beleid inzake milieu, subsidies, sociale voorzieningen, werkloosheids, onderwijs, gezond-

45. Ook Van der Hoeven, De magische lijn. Verkenningen op de grens wan publiek-en privaratrech, in: H.C. IF. Schoordijk (red.), Honderd jaar rechtslewen, NJV-bundel, Zwolle, 1970, p.218, redeneert bij publieke taakwervulling van uit de rechtsorde. Het gaat dan om "de vervulling van de krachtens die rechtsorde opgedragen taak ter behartiging van ên of meer aspecten van het algemeen belang."

46. CDA, Publieke gerechrigheid. een christen-democratische visie op de rol v.d. overheild in de samenleving . Houten, 1990.

47. P.A.J.M. Steenkamp in discussie met H. Dooyeweend, Een rooms-katholieke visie ap de protestantschristelijke devkbeelden inzake bedrijfsorgamisaties en de recente discussie ower de overheidstaak. AntiRevolutionaire Statkunde, 1952 , p.65 e.v. en p.47 e.v. in: J.P. Balkenende en A. Klink, t.a.p., p.361.

48. Minister Dales, Grote efficiency operatie, 11 febr. 1992, TK 50, p.3258. 
heidszorg, rechtshulpvoorzieningen, wegeninfrastructuur en volkshuisvesting, is vervolgens de eis.

Doel van overheidsoptreden is, conform een interessante optie die instemming verdient, "maximilisatie van het maatschappelijk nut. Dat wil zeggen de realisering van de individuele autonomie van de burger (grondrechten, vrijheden, positieve vrijheid) en de bescherming en waarborgen van de toegankelijkheid van het bonum commune (waaronder met name de toegang van alle burgers tot het publieke domein in ruime zin, met name ook ons natuurlijke leefmilieu". "49 Deze regel krijgt door de dynamiek der tijd verschilllend invulling. In grote trekken komt het op het volgende neer. In het meta-privaatrecht heeft de overheid een drieledige taak. ${ }^{50}$ Ten eerste, "de eenzijdige vaststelling door de overheid van een op zich zelf uit het meta-privaatrecht voort vloeiende rechtsbetrekking tussen de leden van de gemeenschap onderling". Ten tweede, "het beheer door de overheid over de collectieve, op het meta-privaatrecht terug te voeren, goederen van de samenleving". Ten derde, "de verzorging door de overheid van structureel bepaalde aspecten van het proces van nutsmaximalisatie (o.a. de verschaffing van een structuur voor de rechtshandhaving)". In het meta-publiekrecht heeft de overheid de volgende kerntaak: "respectering en realisering van autonomie (overigens niet ten koste van derdenbelangen) van de rechtssubjecten in de relatie tussen overheid en rechtssubjecten". si Hierbij ziet a. het meta-privaatrecht op de, door wederkerige erkenning van de autonomie van de ander gekenmerkte, individuele autonomie als dragend beginsel van het nutsmaximalisatieproces en b. het meta-publiekrecht op de positie van de overheid als organisatie belast met het bewaken, repareren en initiëren van nutsmaximaliserende processen. ${ }^{52}$

Al met al vindt dit staiatsoptreden een oorsprong in de Grondwet. Daaruit blijkt dat bij voorbeeld de politiefunctie, de rechtspraakfunctie en de verzorgingsfuncties ${ }^{53}$ typische overheidsfuncties zijn, waaraan overigens op verschillende manieren vorm kan worden gegeven. ${ }^{54}$ Grof te onderscheiden zijn: a. primaire staatstaken die rechtstreeks zijn gerelateerd aan de overheidsorganisatiestructuur en de instandhouding er van; en b.

49. H.J. Simon, De beharriging wan het publieke belang door de overheid via de uitoefening wan privaatrechvelijke bevoegdheden, in: F.J. van Ommeren, H.J. de Ru, H.J. Simon en B. Wessels, Overherd en burgerlijk rechr, Zwolle, 1992, pp.5-6.

50. H.J. Simon, Publiekrecht of privgatrecht?, diss. UvA, Zwolle, 1993, pp. 100-101. Besproken door I. van der Hoewen, in: RM Thenis, nr.4, 1995, pp.157-159.

51. H.J. Simon, a.w., p.111.

52. H.J. Simon, a.w., pp.85-86.

53. P. de Haan, Th.G. Drupsteen en R. Fernhout, a.w. (d1.1), pp.137/8-12, kennen een tweedeling in ordemingstaken (facetbeleid) en verzorgingsfuncties (sectorbeleid). De eerste soort betreft typische overheidstaken ten dienste van het algemeen belang. M.b.t. het tweede type is de overheid aanvullend. Verzorgingstaken kumen worden op gedragen aan zbo's. Via deze zbo's (in optie van auteurs: functionele openbare lichamen) kunnen maatschappelijke organisaties het openbaar bestuur beïnwloeden. Daarentegen is bij ordeningstaken geen sprake van deelname uit de samenleving aan het bestuur. Zie $\mathbb{P}_{\text {. de Haan, Het }}$ bestuursrecht en de scheiding tussen beleid en uitvoering, in: T. Hoogenboom en L.J.A. Damen (red.). In de sfeer van administratief recht, Utrecht, 1994, pp.121-150, i.h.b. p.146.

54. H.J. de Ru (red.). Privatisering in de prakijk; juridische aspecten, Zwolle, 1987, pp.22-23. 
secundaire overheidsdoeleinden die zich niet zo zeer via vaststaande constitutie maar zich middels veranderlijke politieke besluitvorming profileren als staatsbelangen. ${ }^{5 s}$ Duidelijk zal zijn, dat de Grondwet leidraad is voor de primaire staatstaken. Daarbij is zij inderdaad niet meer dan richting gevend. Naast deze indicatieve werking die van de Grondwet uitgaat, normeert de constitutie ook dwingend. Begrenzingen, aan het terug brengen van de rol van de overheid, bestaan in vier opzichten. ${ }^{56}$ Ten eerste is er de onomstotelijke opsomming van historisch bepaalde klassieke overheidsopdrachten. Denk in dit verband aan justitie, politie, defensie, waterstaat en dergelijke. Ten tweede zijn bepaalde overheidszorgplichten geformuleerd als sociale grondrechten. Die omvatten onder meer onderwijs, financiële bijstand, rechtshulp en woongelegenheid. Deze grondwettelijke bepalingen bezitten geen onmiddellijke werking. Ter taakuitoefening wordt de nodige vrijheid gelaten. Ten derde zijn er, wel direct werkende, klassieke grondrechten. Zij garanderen een menswaardig bestaan. En ten vierde beslaat de overheidsmacht het gehele staatsverband, maar is zij daartoe tegelijkertijd beperkt.

Primaire overheidstaken vallen binnen verantwoordelijkheid van de overheid. Privatisering daarvan verdient afkeuring. Zie paragraaf 11.1.6 over de schrijnende situatie van de geprivatiseerde parkeerhandhavingstaak. Onder strikte voorwaarden is wel verzelfstandiging van deze taken mogelijk. Bij verzelfstandiging van handhavingstaken naar specifiek zelfstandige bestuursorganen blijft immers plaats voor, weliswaar beperkt, ministerieel toezicht. Uitwoering van secundaire staatstaken is sneller vatbaar voor verzelfstandiging (of privatisering). De overheid houdt wel een oogje in het zeil door middel van regelgeving, subsidievoorwaarden, overeenkomsten en dergelijke. Voor de concrete juridische vastlegging van secundaire, en daarnaast ook primaire overheidstaken, zijn de wetten in formele zin waardevolle bronnen.

Uit een en ander blijkt opnieuw miet hoe concreet inhoud wordt gegeven aan datgene wat kerntaak van de overheid heet. Reëel beschouwd is het geven van een heldere en consistente visie ter zake ook een vrij wel ondoenlijke opgave. Een sluitende omschrijving verschilt namelijk al naar gelang de fundamentele waarden waarop zij moet worden gebaseerd en de waarborgen die voor de verwezenlijking van die waarden noodzakelijk worden geacht. Kerntaken wan de overheid zijn niet voor eens en altijd aan te geven. "De overheid bepaalt niet zelf haar kerntaken. Wat kerntaken zijn, is de uitkomst van het politieke proces. Dat politiek proces staat op zijn beurt weer onder invloed van maatschappelijke ontwikkelingen en zich wijzigende wensen uit de maatschappij. " 57 Het is "denkbaar noch uitvoerbaar te beginnen met een langdurige droogzwemoperatie voor het

55. H.J. de Ru, Staat, markt en rech; De gevolgen wan privatisering voor het publieknecht, preadvies voor vergadering wan de CJV d.d. 27 mei 1987, Zwolle, 1987, p.38; Vgl. de moreel-ideẻle oriëntatie van minister Hirsch Ballin, gericht op klassieke/sociale grondirechten, m. a.w. "de veilligheid en bescherming voor ieder mens". O. van den Vijwer, ta.p., p.12.

56. H.J. de Ru, t.a.p., pp. 40-41.

57. M. Sint, Kerntaken var de overheid, rede symposium DataVeem d.d. 11 maart 1992, Antstendam; Verslaggewing wan deze congresbijdrage "Terug naar core-business? Met permissie, dat is onzin", in: $\mathrm{BB}$, 20 maart 1992 , p.5. 
bepalen van kerntaken". ${ }^{58}$ Anders uitgedrukt: er bestaan geen echte overheidstaken. ${ }^{59}$ De relativiteit van het definiëren van kernoverheidstaken is evident.

Een blauwdruk van overheidstaken, voor altijd, is dus zinloos. Wel mogelijk is het orm de, in een bepaalde periode, door de overheid gelegde accenten in taakstelling te bepalen. "Een proces van regelmatige politieke bezinning op taken van de overheid" is geen onlogisch idee. ${ }^{60}$ Periodieke doorlichting van taken, beleidsterreinen, menskracht en middelen kan, bij voorbeeld, jaarlijks in het kader van de begrotingscyclus geschieden. De conclusie is duidelijk. Een bezinning op kerntaken kost veel tijd van wege haar enorme omvang. Bovendien is zij alleen mogelijk op relatieve, subjectieve, niet-wetenschappelijke criteria omdat zij politiek wordt bepaald. Vandaar luidt het voorstel de beschouwing geheel achterwege te laten. Deze gedachte stoelt op praktische overwegingen. De optie van herijking van overheidstaken wordt verlaten. Een meer pragmatische invalshoek komt er voor in de plaats. Namelijk dat er "organisatorische vormen moeten worden ontwikkeld die een snelle afstemming van de organisatie op beleid en taken van de overheid in concrete gevallen mogelijk maken". " Zo'n invalshoek opent duidelijk het perspectief naar zelfstandige bestuursorganen. Deze organen kunnen beter dan de rijksoverheid (in enge zin) kerntaken uitvoeren. Door hun flexibel vermogen zijn zij in staat, op gezette tijden, de juiste prioriteiten in taakstelling te leggen. Aldus betreft de vraag naar overheidstaken te definiëren "niet primair de onderwerpen waarmee de overheid zich bezig houdt, maar de intensiteit van die bemoeienis en de prioriteitstelling in het overheidsoptreden". ${ }^{62}$

58. Minister Dalles, Grote efficiency operatie, 11 febr. 1992 , TK 50, p.3254.

59. P.B. Boorsma, Echte overheidstaken, in: ESB, 11 januari 1989, p.31. Auteur ziet voor de overheid geen exclusieve functie om in alle matschappelijke behoeften te voorzien. Collectieve goederen -tit begrip is wolgens de econoom te prefereren boven de term overheidsgoederen-kunnen even goed door (groepen van) particulieren worden gedistribueerd. Levering skosten worden in dat geval opgebracht uit contributies, donaties en schenkingen.

60. D'66-kamerlid Scheltema-de Nie tijdens debat Grote efficiency operatie, 11 febr. 1992, TK 50, p.3236.

61. Commissie-Wiegel, a.w., pp.18/20.

62. Stelling $l$ van R.J. Hoekstra in zijn (syllabus)bijdrage aan het congres Verzelfstandigen bij de rijksoverheid, woortgang of wooruitgang, georganiseerd door het NSC en stichting MC, te 's-Gravenhage, d.d. 30 nov. 1993 . 


\section{Geraadpleegde literatuur}

Balkenende, J.P. Zelfregulering vereist juridische culturaromslag, in: $\mathrm{OB}, \mathrm{nr} .8$, augustus 1992, pp.3-9.

Banning, $\mathrm{C}$. Ambtelijke top: handhaaf aantal departementen, in: NRC, 3 juni 1994, p.3.

Bekkers, V.J.J.M. \& Korsten, A.F.A. Gemeentebestuur in landelijk perspectief, in: Bestuurswetenschappen, nr.6, 1993, pp.449-475. Boorsma, P.B. Echte overheidstaken, in: ESB, 11 januari 1989 , p.29 e.v.

Brewnese, $J$. - Over het eindrapport wan de commissie-Wiegel, in: OB, nr.12, 1993, pp.8-13;

- Rapport SG: een toch niet bevredigende exercitie, in: Overheidsmanagement, nr.10, 1993, pp. $240-246$.

Christelijk Democratisch Appèl

Publieke gerechtigheid; Een christen-democratische visie op de rol van de overheid in de samenleving, Houten, 1990, en Verantwoord bouwen; Program van aktie 1989-1993, Houten, 1989, als mede Hersitelde verantwoordelijkheid: discussienota over de taken van de overheid, Houten, september 1991 .

Commissie-Deetman (bijzondere commissie vraagpunten) Staatkundige, bestuurlijke en staatsrechtelijke vernieuwing. TK 1991-1992, 21427, nr.3.

Commissie-Franssen (bijzondere commissie vraagpunten decentralisatie) Over decentralisatie is nog nooit een vers geschreven, TK 1992-1993, 21427, nrs.42-43.

Commissie-Wiegel (vierde externe commissie van de bijzondere commissie vraagpunten) Naarkerndepartementen, kiezen voor een hoogwaardige en flexibele rijksdienst, TK 1992-1993, 21427, nr. 52 .

Couwenberg, S.W.

Nieuwe hoop op staatkundige en bestuurijke vernieuwing in het fin de siècle, in: Burkens, M.C., Couwenberg, S. W., Franken, H. \& Brinkhorst, L.J., Staatsrechtelijke vernieuwingen; Commentaren op het rapport van de commissie-Deetman, publikatie van de Staatsrechtkring, Zwolle. $1991, \mathrm{pp} .21-40$.

Derksen, W.

Kerntakendiscussie raakt verstrikt in bureaucratische regelzucht, in: BBM, 26 februari 1993, pp. 14-15.

Dinter, G.J. van

Notitie over de organisatie en inrichting van de rijksoverheid, 's-Gravenhage, 24 maart 1993 , TK 1992-1993, 21835, nr. 15.

Doelen, F. van der

De burger is koning; Overheidsdiensten moeten in navolging van het bedriffsleven hun kwalifeitsbeleid moderniseren, in: Intermediair, nr.32, 7 augustus $1992, \mathrm{p} .15$.

Dijkstra, P. e.a.

Een zelfstandige overheid in een sterke samenleving, Groen van Prinsterer-reeks ar.68, Barneveld, 1991.

Elzinga, D.J.

Een uitweg uit de bureaucratie, in: BB, nr.26, 2 juli 1993, p.27.

Essen, A. van \& Aarts, G.C.C.M.

De kern van het departement..., klaar voor het kerndepartement?; Een kritische beschouwing over het personeelsmanagement bij de rijksoverheid, in: Overheidsmanagement, nr.11, 1994, pp. 280-285. 
Frissen, P.H.A., Hirsch Ballin, E.M.H., Hoekstra, R., Visser, R., Kuiper, R. \& Boer, R. de Het managen van verandering door verzelfstandiging, witgave Managementcentrum, 's-Gravenhage, aprill 1993.

Gelder, W.T. van (Be)sturen op kerntaken, noodsprong of noodzakelijk?, in: Beeld van besturen; Bundel opstellen, april 1992, pp.33-51.

Geut, L. \& Kooistra, D.

Kerntakendiscussie, in: Overheidsmanagement, nr.4, 1994, pp.92-96.

Groot, H., Sips, C. \& Vrancken,

Kerntakendiscussie bij de Rijksoverheid in het perspectief wan de welvaartstheorie, in: Sips, C. \& Wrancken, P.H.J., De kerntakenbenadering bij de Rijksoverheid, IOO-reeks nr .59, "s-Gravenhage, april 1994, pp.17-27.

Haan, J. de

Moeizaam snijden in eigen vlees, in: Staatscourant, 23 september 1991, p.5.

Haan, P. de, Drupsteen, Th.G. \& Fernhout, R.

Bestuursrechtin de sociale rechtsstaat: instrument en waarborg; Deel 1, ontwikkeling, organisatie en instumentarium, derde herziene druk, Deventer, 1987.

Hendrikx, J.A.M.

Wedloop of kringloop tussen territoriale en functionele decentralisatie, in: Bestuur, ${ }_{n}, 11,1988$, pp. 324-330.

Junge, A.S.

Centrale persoonsregistratie in Dememarken, in: JV, nr.5, 1994, pp.65-83.

Kickert, W.J.M.

'Le cabinet ministériel' in Frankrijk; De kerr van een departement, in: Bestuurswetenschappen, nr.1, 1994, pp.6-23.

Meeus, T.J.

'Waarom zou je de ontwikkeling van beleid niet privatiseren?', interview met $P$. Frissen, in: NRC, 30 november 1994, p. 21.

Meijerink, M.H. \& Paardekoper, C.M.M.

De ontwikkeling naar kerndepartementen; Wat zijn de kerntaken?, in: Overheidsmanagement, nr. 10. 1993, pp.236-239.

Nederlands Studie Centrum i.s.m. stichting Management Centrum

Syllabus congresdag Verzelfstandigen bij de rijksoverheid, voortgang of vooruitgang , 's-Gravenhage, 30 november 1993.

Nieuwenhuijsen, $P$.

- Kerndepartementen: weg wit het Haagse moeras..., in: BBM, 29 april 1994, pp.3-9;

- Genoeg werk voor projectministers met tanden, in: BBM, 29 april 1994, pp.11-13;

- Verzelfstandiging bij Rijk compliceert bestuurvoor gemeenten, in: BBM, 29 april 1994, pp.2527.

Rw, H.J. de

- Staat, markt en recht; De gevolgen van privatisering voor het publiekrecht, preadvies CJV, 27 mei 1987 ;

- Privatisering in de praktijk: juridische aspecten, Zwolle, 1987.

Simon, H.J.

- De behartiging van het publieke belang door de overheid via de uitoefening wan privaatrechtelijke bevoegdheden, in: Ommeren, F.J. van, Ru, H.J. de, Simon, H.J.\& Wessels, B., Overheid en burgerlijk recht, serie praktijkhandleidingen, Zwolle, 1992, pp.1-65;

$\sim$ Publiekrecht of privaatrecht?, diss. UvA, Zwolle, 1993.

Sint $M$. 
Kerntaken van de overheid, toespraak symposium d.d. 11 maart 1992, Amsierdam. Terpstra, B.

Verniewwing wan rijksoverheid op drijfzand, in: Openbaar Bestuur, nr.8, 1993, pp.27-32.

Tweede Kamer

- Functioneel bestuur: waarom en hoe?, TK 1988-1989, 21042, nr.2, en TK 1990-1991, 21042, nrs. 4-10;

- Operatie grote efficiency, TK 1990-1991, 21835, nr.3, en TK 1991-1992, 21835, nrs.7/9, zie ook TK 1992-1993, 21835, mis. 15/16, als mede Handelingen TK 77 d.d. 7 mei 1991, pp.4352 4356, tevens Handelingen TK 50 d.d. 11 februari 1992, pp.3234-3258;

- Een algemene bestuurdienst in het vizier, TK 1993-1994, 23648, nrs.1-2, pp.1-12, en Algemene Bestuursdienst, TK 1994-1995, 23468, nrs.3-4;

- Regeerakkoord 1994: keuzes voor de toekomst, TK 1993-1994, 23715, nr.11;

$\sim$ Brief wan de minister wan binnenlandse zaken waarbij het de nota Koers naar de Algemene Bestuursdienst' aanbiedt, TK 1994-1995, 23877, nr.3.

Twist, M.J.W. van \& Veld, R.J. in "t.

- Over kerndepartementen; Een vergelijkend onderzoek naar departementale veranderingsprocessen in Groot-Brittanië, Zweden, Noorwegen en Denemarken, "s-Gravenhage 1993;

- Kerndepartementen: een wenkend perspectief, in: Bestuurskunde, nr.7, 1993, pp.353-366;

- Kerndepartementen in vergelijkend perspectief, in: Bestuurskunde, nr.7, 1993, pp.341-352;

- Een kerndepartement is iets anders dan 'wat er na verzelfstandiging overblijf', in: Openbaar Bestuur, nr.8, 1994, pp.14-19.

Veld, R.J. in 't

De kerntakenbenadering bij de Rijksoverheid: onderwerp van gesprek, in: Sips, C. \& Vrancken, P.H.J., De kerntakenbenadering bij de Rijksoverheid, IOO-rapport nr.59, "s-Gravenhage, april 1994, pp.7-15.

Vissen, $B$.

Kerntakendiscussie: kort en krachtig, in: $\mathrm{OB}, \mathrm{nr} .3,1994, \mathrm{pp} .10-13$.

Vries, G.J.M. de

Raakt de kerntakendiscussiede kern?, in: Sips, C. \& Vrancken, P.H.J., De kerntakenbenadering bij de Rijksoverheid, 10O-reeks nr.59, 's-Gravenhage, april 1994. pp.73-80.

Vijwer, O, van de

Tien jaar reorganisatie van de rijksdienst, in: $\mathrm{BBM}_{2}, \mathrm{nr} .7-8,27$ november 1992, pp.6-13.

Zeeuw, F. de

Over het nut van de provincies, in: $\mathrm{OB}, \mathrm{nr} .11,1993, \mathrm{pp} .6-10$. 
Hoofdstuk 9

\section{Uitvoering van overheidsbeleid}

\section{$\$ 9.0$ Uitwoering van overheidsbeleid}

Onverschillig welke opvatting - over wat overheidstaken zijn - wordt ingenomen, geldt de volgende basisregel. Normaliter worden zelfstandige bestuursorganen belast met uitvoerende taken.

Voor opdracht aan zelfstandige bestuursorganen komen in beginsel alleen in aanmerking "alle overheidstaken met een meer uitvoerend karakter, die het bestuur in de ruime betekenis van uitvoerende macht, meent ter hand te moeten nemen". 'Helaas is het begrip uitvoerende macht "een van de onduidelijkste begrippen uit het staatsrechtelijk arsenaal". ${ }^{2}$

Vandaar kenmerkt tweespaltigheid de discussie. Sommigen menen dat slechts "nagenoeg geheel gebonden uitvoerende taken" ${ }^{3}$ aan zelfstandige bestuursorganen mogen worden toebedeeld.

Anderen houden terecht een ruimere marge aan. In hun optie kunnen voor zelfstandige bestuursorganen taken weg zijn gelegd, die niet alleen uitvoering van, maar ook voorbereiding bij overheidsbeleid betreffen. ${ }^{4}$ In een voorstelling van zaken, waarbij de term uitvoering extensief wordt geïnterpreteerd, wordt voor zelfstandige bestuursorganen een gematigde beleidsruimte gecreëerd. ${ }^{5}$ Dit vooral gelet op mogelijke invloed van belanghebbenden. Bovendien kunnen zelfstandige bestuursorganen slechts werkelijk ontlasting van de politieke en ambtelijke top betekenen, als zij een takenpakket hebben dat in

1. M. Scheltema, Raden en commissies als zelfstandige bestuursorganen, t.a.p., p.353.

2. "T. Koopmans, Vergelijkend publiekrecht, Deventer, 1986, p.151.

3. Minister Rietkerk in Openingstoespraak op Studiedag Zelfstandige besturursorganen d.d. 12 nov. 1985. WRR-serie V54, 's-Gravenhage, 1986, p.10; J.P. Balkenende en A. Klink, Gespreide verantwoordelikkheid i.p. v. functionele decentralisatie, in: BWn, nr.6, 1989, pp.359-365, i.h.b. p. 362, S.W. Couwenberg (1988), t.a.p., p.48.

4. J.M. Polak en F.D. van Heijningen, Privatisering en zelfstandige bestuursorganen, in: LR, nr.2, 1988 , P. 68.

5. M. Scheltema tijdens Slotbeschowwing op Studiedag Zelfstandige bestuursorganen d.d. 12 november 1985 , t.a.p., p.60. 
hoofdzaak bestaat uit "routinematige handelingen waarbij dan wel sprake is van een geringe vrije beleidsruimte en de door het departement te nemen beslissingen gering in aantal en qua reikwijdte bescheiden zijn ${ }^{n} .{ }^{6}$ Krachtiger geformuleerd, zelfstandige bestuursorganen moeten worden belast met een "bepaald gedeelte van de beleidsworming op het terrein van een bepaalde overheidsactiviteit, waarop zij zich bewegen, omdat slechts op die wijze bereikt kan worden, dat regering en parlement zich concentreren op de grote lijnen van het overheidsbeleid". "Daarbij blijft de beleidsruime natuurlijk beperkt. Functionele decentralisatie naar zelfstandige besturursorganen is kennelijk "geen deugdelijk middel voor de uitvoering van taken die in hoge mate politiek zijn bepaald of waarvan de behartiging grote beleidsruimte vereist". "Bedoelde gelaagde beleidsvorming nu dient nauwkeurig te zijn omschreven in de instellingswet van een zelfstandig bestuursorgaan. ${ }^{10}$ Daarmee wordt ongewenste taakvermenging en -belemmering vermeden.

\section{\$ 9.1 Zbo's als inzet in de strijd om machtsevenwicht}

Het toekennen van min of meer uitvoerende taken aan zelfstandige bestuursorganen hangt samen met het, van oudsher aan de ministeriële verantwoordelijkheid gerelateerde, beginsel van machtsverdeling. Dat de machtenscheidingsleer van de trias politica is gedateerd, wordt in hoofdstuk twee besproken.

In de oude opvatting zijn wetgever, rechter en bestuurder in principe gescheiden entiteiten met afzonderlijke taakgebieden. De wetgevende machit stelt de (politieke) doeleinden vast. De uitvoerende macht hanteert de middelen tot het bereiken van die doelen. En de rechterlijke macht beslecht geschillen.

Terecht vinden nieuwe gedachten ingang. Weg met de verhalen over autonome machten. Het is hoog tijd voor relativering. Macht ligt namelijk op de weegschaal. Telkens is het zoeken naar de beste balans. Hierbij is het niet uitgesloten, dat lijnen van wetgeving, uitvoering en rechtspraak elkaar kruisen. De ene keer is het zinvol om, bij voorbeeld, beleidsworming en -uitwoering te scheiden. Een andere keer weer niet.

In het kader van checks and balances passen zelfstandige bestuursorganen uitstekend. Soms is het efficiënt als beleidsbepaling en -uitvoering niet in cen hand liggen.

6. C.M. van den Hoff en $\mathbb{R}$. de Groot, a.w., p.2 en ook boofdstuk 8

7. H.G. Lubberdink, a.W., p.163; P.J. Langenberg (1985), t.a.p., p. 172.

8. Ongekeend geldt dat het juist zinvol kan zijn om politiek gevoelige taken wél op afstand te laten uitvoeren of, anders, af te stoten.

9. P. Dijkstra e.a., Een zelfurandige owerhet in een sterke samenlevün , Groem wan Prinsterer-reeks nr.68. Barneweld, 1991, p.91; Ook J.B.J.M. ten Berge en F.A.M. Stroink, Functionele decentralisatie uit de schaduw, "s-Gravenhage, juni 1988, p.48; Functioneel bestuur, waarom en hoe? , TK 1990-1991, 21042, nr. 4, p. 18 ; P.J.J. wan Bunren, Zbo's, in: NJB, nr.55, 1980, pp.590-591, i.h.b. p.590; J. van Leerdam en J.W. van der Dussen, Zbo's: keuzecriteria en sturing swormen , in: Beleidsanalyse, nr. 1/2, 1994, pp. 12. 23, i.h.b. pp.13-15.

10. Funcrioneel bestuur, waarom en hoe?, TK 1990-1991, 21042, nr. 4, p.33. 
Denk aan afgifte van vergunningen, erkenningen en keuringsbewijzen door de Dienst Wegverkeer ${ }^{11}$. Of aan het respectievelijk verstrekken van studiefinanciering en tegemoetkomingen in studiekosten, de inning van lesgelden en de toekenning/uitbetaling van ontslaguitkeringen aan onderwijzend personeel door de Informatie Beheer Groep ${ }^{2}$. Of aan het houden en verstrekken van inlichtingen uit de openbare registers (m.b.t. registergoederen, schepen en luchtvaartuigen) door de Dienst van het Kadaster en Openbare Registers ${ }^{13}$. Of aan de (im)materiële verzorging van de centrale opvang en de plaatsing van asielzoekers, het witvoeren van de amvb inzake de toegekende rijksbijdragen in verband met de decentrale opvang, alls mede de verwerving en inrichting van nieuwe opvanglokaties en de sluiting van af te stoten lokaties door het Centraal orgaan opvang asielzoekers ${ }^{14}$. Of aan de dienstverlenende activiteiten op het gebied van werving, selectie, advisering en opleiding van politie door het Landelijk Selectie- en Opleidingsinstituut voor de Politie ${ }^{\text {is. }}$.

In all die gevallen bestaat beleidsuitwoering uit het toepassen van algemene regels op concrete situaties. In dergelijke gevallen is een logische knip tussen regelgever en uitwoerder vrij gemakkelijk te realiseren. Namelijk, "het beleid is sterk uitgekristalliseerd, de uitwoering gestabiliseerd en de relaties tussen beleid en uitvoering zijn in redelijke mate te disciplineren". ${ }^{16}$. Met een dergelijke duidelijke scheiding tussen beleidsworming en -uitvoering is het gelijkheidsbeginsel gedliend. Taken, waarbij individuele beslissingen met een routinematig karakter worden genomen, lenen zich bij uitstek voor "formalisering en standaardisering vooraf en (rechterlijke) toetsing op een juiste toepassing van de regels achteraf". ${ }^{17}$

11. Zie Wet verzelfstandiging Rijksdienst voor her wegverkeer, TK 1992-1993, 22961, nrs. 1-5, en Stbl. 1993, 200.

12. Zie Wetsvoorstel tor regeling v.d. bestuurlijke verhouding tussen de minister van onderwijs en de Informatie Beheer Groep, of Wet verzelfstandiging Informatiseringshank, TK 1992-1993, 23073, nrs. 1-6, en Stcrt. 1993, 61: Zie ook Wet verzelfstandiging Informatiseringsbank, Stbl. 1993, 714.

13. Zie Wer verzelffstandiging van de Dienst van het Kadaster en de Openbare Registers, respectievelijk TK 1991-1992, 22438, nr.1 en TK 1992-1993, 23007, nrs.1-3 e.v.; Als Organisatiewet Kadaster in Stbl. 1994, 125, Besluit rot wijziging van enige amvb's i v.m. Organisatiewet Kadaster, Stbl. 1994, 303.

14. Zie Voorstel instellingswet Centraal orgacn opwang asietzoekers, TK 1993-1994, 23540, nrs. 1-3 e.w.

15. Zie Instellingswet rechtspersoon LSOP, TK 1993-1994, 23446, nrs.1-3.

16. P.H.A. Frissen in (syllabus)bijdrage aan het congres Verzelfstandigen bij de rijksoverheid, voortgang of wooruitgang, georganiseerd door het NSC en stichting Management Centrum, te 's-Gravenhage, d.d. 30 nov. 1993.

17. J. van Leerdam en J.W. van der Dussen, Zho's: Keuzecriteria en sturingswormen, in: Beleidsanalyse, nr. 1/2, 1994, pp. 12-23, i.h.b. p. 19. Een dergelijke doorzichtigheid van beleid en uitvoering, of doel en midklel (m a w.w. taken zijn goed programmeerbaar) beinvloedt de keuze woor de zbo-constructie pasitief. Drie andere, op Hofstede en Ouchi gebaseerde, doorsllaggevende maatstawen voor instelling van zbo's zijn volgens auteurs: eenduidigheid van doelen (kleine ambiguilteit); meetbaarheid van resultaten (betrouwbare kwaliteitsbeoordeling); en herhaling van actitiviteiten (redelijke frequentie). 


\section{\$ 9.2 Beleidsvorming en beleidsuitvoering verstrengeld}

Het opdragen van uitwoerende taken aan zelfstandige bestuursorganen komt voort uit het onderscheid tussen beleidsvorming en beleidsuitvoering. ${ }^{18}$ Beleidsvorming is dan het proces van voorbereiding en creatie van beleid. Inhoudelijke doelstellingen en program$\mathrm{ma}^{x}$ s worden geformuleerd. Deze beleidsbepaling wordt herhaaldelijk bijgesteld na evaluatie en terugkoppeling er van. Beleidsuitvoering betekent: het uitvoeren van het beleid dat in het beleidsvormingsproces is vastgesteld. Kort gezegd doelt het ontwerpen van beleid en wet- en regelgeving op: "a. agendavorming; $b$. beleidsvoorbereiding; $c$. beleidsbepaling; en d. beleidsoperationalisering d.w.z. de vertaalslag van het vastgestelde beleid naar de uitvoering toe", en omvat het toepassen van ontworpen regels en belleid: " $e$. eigenlijke beleidsuitvoering; $f$. beleidsevaluatie; $g$. terugkoppeling, die in uiterste geval kan leiden tot: h. beleidsbeëindiging". ${ }^{19}$

De vorming en de uitvoering van beleid worden ook wel onderscheiden aan de hand van een bepaald beslissingsmoment of afwegingsprobleem. ${ }^{20} \mathrm{Bij}$ beleidsvorming valt dat beslissingsmoment, even als in een gewone consumptiehuishouding, op het moment dat de ene uitgaaf tegen de andere uitgaaf moet worden afgewogen. Hierbij moeten in de overheidssfeer, anders dan in een normale gezinshuishouding, tevens het nut van een extra uitgave en het offer van de daarvoor vereiste belastingheffing tegen elkaar worden afgezet. Bij beleidsuitvoering speelt het afwegingsprobleem daar waar het beleid wordt omgezet in produkten als geboden of verboden, uitkeringen of subsidies, vergunningen en collectieve goederen. Ambtsdragers dienen zich af te vragen hoe zij, bij de vervulling van hun taakopdracht, binnen de daarvoor openstaande begroting kunnen blijven. Deze tweedeling tussen beleidsvorming en beleidsuitvoering heeft duidelijk een doelmatige inslag.

De ratio van een organisatorische scheidling van beleidsvorming en -uitvoering hangt samen met het volgende. ${ }^{21} \mathrm{Zij}$ biedt transparantie van de rijksoverheid als organisatie. Zij levert een heldere verantwoordelijkheidsverdeling op. Zij accentueert de uitvoering en de hándhaving van beleid. En zij stimuleert bedrijfsmatig werken. Bij dit alles staat voor op dat scheiding van beleidsvorming en -uitvoering geen doel op zich zelf is, maar slechts een instrument is om vooruitgang van uitwoeringsorganisaties te bevorderen en

18. H.F. Munneke, J.B.J.M. ten Berge, F.A.M. Stroink, P. Haighton en P. den Hoed, a.w., p.13, M. Scheltema (1977), t.a.p. . p.338; De tweedeling berust op oude bestuurskundige inzichten. 1.t.t. heden, was de ambtelijke dienst vroeger een neutrale "lijdelijke beleidsuitwoender. J A.M. Maarse, De uitvoering wan overheidsbeleid, in: A. Hoogerwerf (red.), Overheidsbeleid, vierde druk. Alphen a/d Rijm, 1989.

19. J.N. Breunesse en J.W. van der Dussen, De scheiding tussen beleid en uitvoering, in: Beleidsanalyse, nr. 1/2, 1994, pp.6-11, i.h.b. p.6. Auteurs bespreken problematiek van scheiding beleid - uitwoering. Met terechte nadruk op aansturing en terugkoppeling zoeken zij de oplossing niet alleen in de structuur, matar vooral in de inhoud darvan.

20. W.J. v. Braband, Beleidsdoelmatigheid en marginale toetsingsregel, in: Beleidsanalyse, nr. 3/4, 1994 , pp.5-13, i.h.b. p.6.

21. G.J. Dinter in zijn (syllabus)bijdrage aan het congres Verzelfstandigen bij de rijksoverheid, voongang of woarsitgang, te 's-Gravenhage, d.d. 30 nov. 1993 , pp.1-11, i.h.b. pp.2-4. 
de kwaliteit van beleid te verhogen door een betere terugkoppeling van uitvoering naar beleid, met andere woorden verzelfstandigde organisaties mogen geen "los zwevende satellieten" ${ }^{\text {" worden. }}{ }^{22}$

Het voorstel, inzake de taakverdeling tussen regering en zelfstandige bestuursorganen, beleidsvorming en beleidsuitvoering stringent te scheiden ${ }^{23}$, is in praktijk niet altijd houdbaar.

Met de afsplitsing van beleidsuitvoering op zich is, als vermeld, niets mis. Het levert noemenswaardige voordelen. De omvang van het ambtelijk apparaat, waaraan de minister leiding geeft, neemt af. Het zicht op de uitvoerende werkzaamheden verbetert. Tegelijkertijd wordt een juiste wederkerige, directe communicatie tussen departementstop en zelfstandig bestuursorgaan bevorderd. Daarnaast wordt het informatiekanaal van uitvoerend orgaan naar burger verder open gesteld, omdat een zelfstandig bestuursorgaan extern verantwoordelijk voor takkuitoefening is. Tevens wordt de minister gedwongen zich langduriger en systematischer bezig te houden met het maken van beleid. Om zijn verantwoordelijkheid hiervoor waar te maken zal hij algemene regels, richtlijnen of aanwijzingen daaromtrent opstellen. En, zeker als zelfstandige bestuursorganen het uitvoerende werk verrichten, is het niet meer dan logisch dat deze regels aan de eis van openbaarheid voldoen.

De werkelijkheid ondergraaft echter de theorie. De empirische geldigheid van voomoemd onderscheid wordt betwijfeld. Weliswaar is de tweedeling, uit analytisch oogpunt, nuttig. In realiteit is strenge splitsing niet altijd hanteerbaar. ${ }^{24}$ "Niet zelden zal blijken dat een door een hoge bestuurlijke echelon als uitwoerend aangemerkte taak uit de optiek van het lagere echelon zowel beleidsvormende als uitvoerende aspecten heeft." ${ }^{25} \mathrm{De}$ inhoud van beleid kan bij voorbeeld pas in de uitwoeringsfase (nader) worden bepaald, omdat tot dan toe verborgen belangen manifest worden. Tevens kan zich beleidswijziging voordoen tijdens het uitvoerende werk. In dit verband is de term 'emancipatie van uitvoering' wel passend gevonden. ${ }^{26}$ Met andere woorden, beleidsuitvoering is "geen mechanische afwikkeling van in de fasen van beleidsontwikkeling en beleidsbepaling gevormd beleid ${ }^{1 *} .{ }^{27}$ Gewaarschuwd wordt ook tegen het uit elkaar groeien van beleid en uitvoering. Dat leidt namelijk op den duur "tot bloedarmoede en 'droogzwemmen' bij de beleids-

22. J.K.T. Postma, Verzelfstandiging: aanstwing en terugkoppeling essentieel, in: OB, nr.6, 1994, pp.2-5.

23. M. Scheltema (1977), t.a.p., p.339.

24. H.G. Lubberdink, a.w., pp. 161-162; Tevens A. Mulder (1980), a.w., p.68; Ook N.S.I. Koeman (1989), t.a.p., p.75.

25. C.M. van den Hoff, Ministeriële verammoordelijkheid en politieke controle, in:" Bestum, nr. 1, jan. 1989 , p.9. Auteur wijst op de nota van toelichting bij KB van 18 okt. 1988 nr.12. Daarin is, m.b.tt. de functie van secretaris-general, gesteld dat zijn beheersfunctie niet kan worden losgekoppeld van zijn bijdrage aan beleidsontwikkeling; A. Mulder, t.a.p., p.54.

26. E. Gerritsen en $R$. van Wuijtswinkel, Belastingdienst en verzelfstandiging, in: $O B$, nr. 1, 1993, pp.15-20, i.h.b. p. 19 .

27. P.H.A. Frissen (1993), t.a. p* p.20. 
makers". ${ }^{28}$ Ten sllotte spelen problemen daar waar het topmanagement van uitvoerende diensten tegelijkertijd beleidsadviserende diensten ten behoeve van de betrokken minister verricht.

Praktijkvoorbeelden bevestigen dit beeld. Verzelfstandiging omvat vaak meer dan beleidsuitvoering. Denk aan het toedelen van toezichthoudende of evaluerende taken aan zelfstandige bestuursorganen als de Registratiekamer en de stichting Verzekeringskamer. Of aan de uitoefening van allocatieve functies door bij voorbeeld het Commissariaat voor de Media en het Centraal Orgaan Tarieven Gezondheidszorg.

In dit verband is het goed aan paragraaf 8.1 te refereren. Gesproken is namelijk van verzelfstandiging van de gehele beleidscyclus. Daardoor is een 'meta-sturing', met andere woorden de in handen van betrokken (kern)departement liggende procesmatige , conditionerende en faciliterende verantwoordelijkheden, mogelijk. Bedoelde worm van verzelfstandiging "is adequaat in beleidsterreinen met een sterk (doelzoekend, horizontaal JGLvN) netwerk-karakter, waarbij de beleidsontwikkeling om inschakeling of medeverantwoordelijkheid van maatschappelijke actoren vraagt" ${ }^{\text {"29 }}$

Al met al blijft het oppassen. Als in paragraaf 9 al naar voren komt, moet uitdrukkelijk worden gewaakt tegen een toedeling van te ingewikkelde taken aan zelfstandige bestuursorganen. Hierbij zijn namelijk de volgende vraagtekens te zetten. ${ }^{30}$ Het gevaar bestaat dat een bepaald zelfstandig bestuursorgaan een eigen leven gaat leiden, zo dat het betrokken departement en wellicht ook andere ministeries zich van countervailing power, tegenover die van het zelfstandig bestuursorgaan, gaan voorzien. Vooral doemt hier het probleem op, dat verzelfstandigde entiteiten eigen belang boven algemeen belang stellen. In geval dat een zelfstandig bestuursorgaan de gedaante van een platform van complexe onderhandelingen aanneemt, is de kans groot dat bepaalde partijen, die menen onvoldoende aan bod te komen, andere wegen ter belangenbehartiging gaan bewandelen. Een zelfstandig bestuursorgaan belasten met belangrijke belangenafwegende taken kan trouwens op zich al dubieus zijn, orndat een zelfstandig bestuursorgaan zelf vaak een belangenorganisatie is. En als een zelfstandig bestuursorgaan tevens een interdepartementale overlegfunctie heeft, is het denkbaar dat herhaaldelijk op het betrokken departement moet worden terug gegrepen, waardoor regressie van zelfstandigheid optreedt. De problematiek van een versluierde verantwoordelijkheid ontstaat als departementale diensten secretariële, dan wel verder gaande, ondersteuning aan zelfstandige bestuursorganen verlenen waarmee zij hun materiële invloed mogelijk vergroten. In budgettair opzicht kunnen zich dergelijke moeilijkheden voordoen.

28. H. Wansink, Passende kleren; Kleine departementen zijn niet automatisch beter, in: Intermediair, nr. 34 , 27 aug. 1993, p.13.

29. P.H.A. Frissen in (syllabus)bijdrage aan het congres Verzelfstandigen bij de rijksoverheid, voortgang of vooruitgang, georganiseerd door het NSC en stichting Management Centrum, te 's-Gravenhage, d.d. 30 nov. 1993.

30. Zie C.M. van den Hoff en R. de Groot, a.w. 
Uit het voorgaande blijkt het volgende. Een formele scheiding tussen de minister als de centrale beleidsvormer en een zelfstandig bestuursorgaan alls uitvoerder doet gekunsteld aan. $\mathrm{Zij}$ leidt tot "verstarring in de onderlinge verhouding of tot een gebrek aan sturing door de minister". " Het aanhouden van dit officiële onderscheid is dus geforceerd. ${ }^{32}$ Met oog op de reorganisatie van de rijksdienst is het uitgangspunt, weliswaar, scheiding tussen beleid en uitvoering. Tegelijkertijd wordt erkend, dat consequente toepassing van dit "modebegrip" ${ }^{33}$ in veel gevallen zinloos is. "Het kabinet is wel van mening dat de mate en de wijze van het op afstand plaatsen van de uitvoering op ieder beleidsterrein afzonderlijk op zijn merites moet worden beoordeeld. Met name waar sprake is van noodzakelijkerwijze discretionaire bevoegdheden in de uitwoering." "${ }^{34}$

Elk geval is anders, telkens ligt de grens verschillend. In algemene zin is "hoogstens"t te "zeggen, dat de strategische beleidsbevoegdheden in ieder geval bij de verantwoordelijke minister blijven en de operationele alleen, in zoverre deze niet voor territoriale of functionele decentralisatie vatbaar zijn uit het oogpunt van democratisering. De instrumentatie staat dus bij scheiding tussen beleid en uitvoering niet los van legitimatie. Het zelfde geldt voor de juridificatie $[\ldots]$. " 3.5

Beste oplossing is na te gaan op welke gebieden en in welke mate de beleidsvorming onder de ministeriële verantwoordelijkheid dient te vallen. ${ }^{36}$ Daarop kan dan een sluitende taakverdeling tussen departementstop en zelfstandig bestuursorgaan worden gebaseerd. Zij krijgen allebei binnen de door het parlement getrokken grenzen een, al dan niet, beperkte beleidswormende taak met betrekking tot de overheidstaak waarvoor het zelfstandig bestuursorgaan is ingesteld. Zo ontstaat een doorzichtiger patroon van verantwoordelijkheden.

Regering en parlement stellen globale beleidskaders vast waarbinnen zelfstandige bestuursorganenzekere handel ingsvrijheid hebben. Doelstellingen, hoofdlijnen en randvoorwaarden moeten duidelijk worden vastgelegd, voor zover dat niet al wettelijk is gebeurd. Met het oog op het gestructureerd en systematisch bijstellen hiervan is betrouwbare verslaglegging door uitvoerenden, van het gebruik maken van gegeven beslissingsruimte,

31. J.L. Boxum, J. de Ridder en M. Scheltema, a.w., p.59.

32. Volgens wen autetur, die beweert dat een functioneel gedecentraliseerde taak niet alleen een opdracht ook beleidsatwtonomie in eigen kring onvat, hoeft dit echter aan een formele scheiding niet in de weg te staan. A. Mulder, a. $w$. , pp.54-55.

33. Aldus Lubbers. Zie Scheiding beleid en witwoering is modebegrip, in: OMm, nr.1, 1994, p.24.

34. Operatie grote efficiency. TK 1992-1993, 21835 , nr.15, p.2.

35. P. de Haan, Het bestutursrecht en de scheiding tussen beleid en witvoering, in: $T$. Hoogenboom en L.J.A. Damen, In de sfeer van administratief recht, Utrecht, 1994, pp. 12.1-150, i.h. b. p. 127. Auteur spireekt van "maatwerk" (p.146).

36. Dit betekent scheiding tussen zaken waarbij directe politieke sturing en verantwoording essentieel zijn en zaken waarbij dat niet het geval is. De noodzaak tot politieke sturing is een beter onderscheidend criteri um dan dat tussen beleid en uitvoering. Functioned bestuur, waarom en hoe?, TK 1990-1991, 21042. nr...4, p.15. 
nodig. ${ }^{37}$ Om externe controle en ministeriële sturing mogelijk te maken, moet een zelfstandig bestuursorgaan een boekje omtrent eigen handelen open doen. Juist met oog op het beschikbaar zijn van voldoende informatie over de uitvoering, handhaving en controle van beleid mag het beleidsbepalers niet ontbreken aan voldoende zicht hebben op de beleidspraktijk door gebrek aan informatie en voorlichting van uit het werkveld. ${ }^{38}$

Tegenover de op een zelfstandig bestuursorgaan te leggen verplichting ${ }^{39}$, alle informatie te verschaffen die nodig is om goed te kunnen beoordelen op welke wijze de verzelfstandigde entiteit de opgedragen taak uitvoert, is het betrokken zelfstandig bestuursorgaan mogelijk een bevoegdheid toe te kennen "gevraagd en ongevraagd te adviseren omtrent beleidsveranderingen met betrekking tot de taak die door de uitvoeringsorganisatie wordt uitgeoefend" "40 Door het op afstand zetten van beleid en uitvoering, wordt de dia$\operatorname{loog}{ }^{41}$ tussen departement en zelfstandig bestuursorgaan dus belangrijker.

De informatiecomponent wordt steeds belangrijker voor een heldere verdeling van verantwoordelijkheden. ${ }^{42}$ De overheid werkt zowel intern als extern bezien (namelijk afzonderlijk, maar ook als geheel van overheidsorganen waaronder zelfstandige bestuursorganen ${ }^{43}$ doelmatiger, doeltreffender en klantvriendelijker als zij is voorzien van een gedegen informatiesysteem. ${ }^{44}$ "Een optimaal informatievoorzieningsbeleid is nodig om communicatieprocessen en gegevensuitwisseling tussen centrale overheid en andere overheden helder te organiseren en uit te voeren. Ook kan de informatievoorziening een belangrijke rol spelen in de verwezenlijking van efficiency-doelstellingen." "45 Wel bepaalt de toelichting bij aanwijzing voor de regelgeving 161 , die terecht tot een informatie-

37. J.L. Boxum, Zelfstandige bestuursorganen en de greep wan ministers op de bestuurlijke organisatie, t.a.p. p.260. Auteur doet zijn stellingname steunen op de visie van N. Boerma en A.Th. vam Delden, Visies op verandering: de rijksdienst in beweging, ARD lezingencyclus, "s-Graw., 1986. Ook zij stann een objectivering van beleidsuitvoerders en -makers voor.

38. R.J. in 't Veld, De kernakenbenadering bij de Rijksoverheid: onderwerp van gesprek, in: $\mathbb{C}$. Sip en P.H.J. Vrancken, De kerntakenbenadering büjde Rijksoverheid, 1OO-rappont mo. 59, "s-Grawenhage, aprül 1994, pp.7-15, i.h.b. pp.11-12.

39. In praklijk slokt het volledig voldoen aan alle rapportageverpliclutingen trouwens (te) veel menskracht op: De Algemene Rekenkamer, Zbo's en ministeriële verantwoordelijkteid, TK 1994-1995, 24130, nr.3, pp. 36-44, constateert dan ook ernstige tekortkomingen van zbo' $\mathrm{s}$ wat betreft informatievoorzieningsplichten.

40. M.J.W. van "Twist en R.J. in "t Veld, Kerndepartementen: een wenkend perspectief?, t.a.p., p.361.

41. J.W. van der Dussen, Contractmanagement en zbo's, in: OMn, nr. 10, 1993, pp.247-250, i.h.b. p.250.

42. En dat is weer beter voor het agenderen/ontwerpen van nieuw beleid. Vertraagde, verouderde en gebrekkige informatie over feitelijke takkuitoefening door zbo's verhindert uiteindelijk het opstellen van gezond en verfrissend beleid.

43. M. Sint, Naar een openbaar digitaal wegennet, in: OMn, nr. 718, 1994, p. 181, wijst op het -voor informatiesy stemen, die voor $0 . a$, toezichtstaken onontbeerlijk züjn, bestaande- belang van "verstaambaarheid over de grenzen van de overheidsorganisatie heen". Met oog op een (wereld)wijd bereik, bepleit zij systeemstandaardisering (geen uniformiteit, maar verbindbaarheid).

44. Zie lezingenbundel t.b.w. symposium Verzelfstandiging en informatievoorziening bij de rijksoverheid, Nederlands Studie Centrum i.s.m. Cap Volmac, Rotterdam, 28 april 1994.

45. Ministerie van BiZa, Jaaroverzich Informatievoorziening 1992, TK 1992-1993, 23149, nrs. 1-2, pp. 1-62, i.h.b. p. 7 . 
paragraaf aanmaant ${ }^{46}$, met de nodige nuance: "Het is voor een goede takvervulling van de overheid van groot belang, dat het ten behoeve daarvan ingerichte of in te richten systeem van informatievoorziening niet alleen doelmatig en doeltreffend is, maar ook voldoet aan andere te stellen voorwaarden als onder meer van politiek-bestuurlijke, juridische en bestuurlijk-organisatorische aard." 47

Expliciet dient onder andere te worden aangegeven: a. welke keuzes zijn gemaakt bij transformatie van het beleid op papier naar de praktijk; $b$. hoe ver ieders politieke verantwoordelijkheid voor taakuitoefening strekt; en c. waar en wanneer wijziging van het algemene beleidskader nodig is. ${ }^{48}$ Hierbij dient ook uitdrukking te worden gegeven aan de benoeming van concrete overheidstaken, die zich in het bijzonder voor opdracht aan zelfstandige bestuursorganen lenen.

\section{$\$ 9.3$ Overheidstaken in overzicht}

Herhaaldelijk wordt aanbevolen een "typologie van taken en bijbehorende bevoegdheidsconstructies te ontwerpen ten einde op beredeneerde wijze de analytisch te onderscheiden stadia in de besluitvorming te kunnen vertalen in bestuurlijk-organisatorische termen, mede gericht op de bepaling van de grens tot waar de ministeriële verantwoordelijkheid onverkort moet worden gehandhaafd". "49 Hieraan is inmiddels, tot op zekere hoogte, gehoor gegeven.

Een aantal jaren geleden is een fraaie ordening van motieven, taken en structuren van (publiekrechtelijke) zelfstandige bestuursorganen gepresenteerd. ${ }^{50}$ Zelfstandige bestuursorganen zijn zo onder te verdelen in drie typen.

Tot het eerste type zijn te rekenen zelfstandige bestuursorganen met een oprichtingsmotief dat is gelegen in gezaghebbende deskundigheid. Deze gezaghebbende positie wordt eerst bereikt indien het ene belang dat de deskundigen behartigen niet verweven wordt met andere belangen. Onafhankelijkheid in de zin van afscherming van een belang is dus nevenoprichtingsmotief. Zo'n orgaan, samengesteld uit van regeringswege te benoemen deskundigen, kenmerkt zich qua taak door sterk technocratisme. Deze taak bestaat uit het geven wan een deskundig oordeel in een complexe feitelijke situatie. Die oordeelsvorming door specialisten vindt plaats binnen een tamelijk geïsoleerd beleidsmatig afwegingskader. Ministerieel ingrijpen kan slechts randvoorwaarden aangaan, het betreft nooit

46. Aanwijzing 1611 luid: "Indliem woor de uitvoering wan een regeling de beschikbaarheid van informatie van esserutiele betekenis is, wordt in een afzonderlijk deel van de toelichting bij die regeling ande informatievoorziening aandacht besteed."

47. C. Borman, Aamwijzingen voor de regelgeving, Zwolle, 1993, pp. 133-134.

48. 1.w.m. terugkoppeling van beleidspraktijk naar politiek wordt wel gepleit voor een Eentheid Aansturing Uitvoering sorganisatie. Die eenheid moet dienst doen als interface tussen kerndepartement en zelfstandig overheidsorgaan. M.J.W van Twist en R.J. in 't Veld, Kerndepartementen. een wenkend perspectief?, in: BK, ar. 7,1993, p. 365 .

49. Onder anderen C.M. Hoff en R. de Groot, a.w., p.2, vitgebreid in hoofdstuk 7 .

50. J.L. Boxum, J. de Ridder en M. Scheltema, a.w., pp.40-43/55-58/243-247; Zie ook J.L. Boxum, Zelfstandige bestuursorganen; organisatie op maat, in: Bestuur, nr.4, april 1990, pp.1011-103/111. 
individuele besilissingen. Een voorbeeld is de stichting Nederlands Instituut voor Vliegtuigontwikkeling en ruimtevaart.

Het tweede soort zellfstandige bestuursorganen heeft tot taak te komen tot een evenwichtige, objectieve afweging van belangen. Dit type, met normaliter een samenstelling van ervaren deskundlige bestuurders, staat borg voor onpartijdigheid en onafhankelijkheid. De talakuitoefening betreft meestal een massalle hoeveelheid individuele beschikkingen. Daartoe zijn gevallen te rekenen als het toekennen van studiebeurzen of sociale uitkeringen, het afgeven van verklaringen van geen bezwaar aan vennootschappen of van kentekenbewijzen, het verlenen van ontslagvergunningen of het toekennen van financiele bijdragen op het terrein van volkshuisvesting. Beleidsbeinvloeding via de minister kan alleen via algemene regelgeving. Voor individueel ingrijpen bestaat zijnerzijds geen bevoegdheid. Exemplarisch zijn het Commissariaat voor de Media en de Dienst wegverkeer.

Een derde belangrijk ideaaltype zelfstandig bestuursorgaan wordt ingesteld met een veel omvattend doel. Namelijk beleids-en besluitvorming op een bestuursterrein met veel en vaak tegenstrijdige belangen. In tegenstelling tot beide andere soorten zelfstandige bestuursorganen, zijn deze zelfstandige bestuursorganen merendeels relatief grote raden met representanten van verschillende maatschappelijke, beroeps-, bedrijfs- en overheidsbelangen in combinatie met een paar onafhankelijke deskundigen. Van wege de aanzienlijke invloed hiervan op het beleidsproces staan de betrokken minister diverse bevoegdheden, tot beleidsadstructie, ter beschikking. Daaronder zijn begrepen allgemene regelgeving en goedkeuring of vermietiging van daartoe aangewezen, door zelfstandige bestuursorganen genomen, besluiten. Zelfstandige bestuursorganen met een participatiekarakter zijn onder meer de Ziekenfondsraad, de College van Toezicht Sociale Verzekeringen, het Centraal Bestuur voor de Arbeidsvorziening en de Centrale Landinrichtingscommissie.

Deze soortindeling van zelfstandige bestuursorganen geeft onmiskenbaar het in hoofdzaak kenmerkende van het werk van die organen weer. De arbeid, aan zelfstandige bestuursorganen opgedragen, vereist in bijna alle gevallen deskundigen en specialisten op een bepaald gebied, behartigers van bijzondere belangen en professionele uitvoerders van feitelijke, technische of organisatorische werkzaamheden.

Bij nadere invulling van taken van zelfstandige bestuursorganen blijkt advieswerk geen hoofdtak van zelfstandige bestuursorganen te zijn. Zowel interne ambtelijke advisering door raden of commissies als externe beleidsadvisering door, bij of krachtens de wet ingestelde, vaste colleges inzake wetgeving en rijksbestuur ex art. 79 Grondwet passen niet in het pakket van primaire taken van zelfstandige bestuursorganen. ${ }^{51}$ Redengeving daarvan is dat adviesbevoegdheden, noodzakelijk om raadgevende taken uit te oefenen, geen echte dat wil zeggen overheidsbevoegdheden (of publiekrechtelijke bevoegdheden)

51. I.B.J.M. ten Berge en F.A.M. Stroink, a.w., p.18; Idem dito Functioneel bestwur; waarom en hoe?, TK 1990-1991, 21042, nr.4, p. 10; Tevens J.L. Boxum, J. de Ridder en M. Scheltema, a.w., pp.11-12. 
zijn. ${ }^{52}$ In de feitelijke uitoefening van hun functie hebben zelfstandige bestuursorganen wel eens ruimte voor advieswerk als nevenactiviteit.

Evenmin komt de, ook grondwettelijk verankerde, besluitvorming over voorbereiding aan wetgeving in aanmerking voor toedeling als hoofdtaak aan organen van functioneel bestuur. $\$ 3$

Ook toepassing van strafrecht, in algemene zin, zou aan zelfstandige bestuursorganen niet overdraagbaar zijn. ${ }^{54}$

En, tot slot, zijn organen met uitsluitende rechtsprekende taken, dat wil zeggen met bevoegdheden tot onafhankelijk rechtspreken, niet als zelfstandige bestuursorganen aan te merken. ${ }^{55}$ Geschillenbeslechting is een eigenlijke overheidstaak. Zij wordt niet toegelaten als functioneel te decentraliseren taak.

Na eliminatie van bepaalde overheidstaken resteren uiteindelijk de bestuurlijke taken. Een eigenlijke takeninventarisatie is te vereenvoudigen en te verduidelijken aan de hand van geintegreerde uiteenzetting van soorten publiekrechtelijke bevoegdheden, die ter taakbehartiging worden aangewend.

\section{\$9.4 Overheidsbevoegdheid}

Belangrijker nog dan de benoeming van, aan zelfstandige bestuursorganen aangezegde, taken, zijn de hun toebedeelde, met de taken samemhangende, bevoegdheden. In de hier gebruikte benaderingswijze staat de bevoegdheidstoekenning centraal. Een indeling in verschillende vormen van uitoefening van openbaar gezag kan verduidelijken hoe ver de machtspositie van zelfstandige organen overeenkomt met de mate van gegeven gezag. ${ }^{56}$

52. J.B.I.M. ten Berge (1989), taa.p., p.339; I.d. H.F. Munneke, J.B.J.M. ten Berge, F.A.M. Stroink* P. Haighton, a. w, p.23.

53. J.M. Polak en F.D. van Heijningen, 1.a.p., p.68; Vgl. R.J. Kuiper, Verzelfstandiging en informatievaorziening, in: P.H.A. Frissen e.a.. „Het managen van verandering door verzelfstandiging, a. w. pp. 89-103, i.h.b. p. 94.

54. J.M. Polak en F.D. van Heijningen, t.a.p., p.68. Zie in dit verband, over o. m. cle problematiek opsporing en toezicilit, hoofdstukken 11,17 en 20.

55. J.B.J.M. ten Berge (1989), t.a.P., p.339; J.B.J.M. ten Berge en F.A.M. Stroink, a.w.. p.39; H. wan der Sluijs, t.a.p., p. 305; Anders A. Mulder, a.w., p.62. Volgens auteur omvat het werk van een rechter, gelet op de hem veellal toegemeten wime discretionaire bevoegdheden en vage normen in wet- en regelgeving. onmiskenbaar beleidsuitwoering. Overigens poogt Mulder inzichtelijkheid, in de atard van destijds bestaande zelistandige bestuursorganen, te verschaffen. Daartoe ontwerpt hij een, inmid dels gedateerde, takenindeling. Hierin vindt ook de rechtspraak een plaats. Auteur onderscheidt: a. inkomensoverdrachten; $b$. overheidsbedrijvigheid; c. sanering en steunverlening; $d$. ordening van de landbouwmarkten; e. ordening wan het economisch verkeer; $\mathbb{f}$. waststelling van prijzen en tarieven; $\mathrm{g}$. kwaliteitscontrole; $\mathrm{h}$. toezicht op bedrijven en beroepen;" i. rechtspraak; en j. hoger onderwijs. A. Mulder, a.w „, pp.58-62.

56. Door de juridische relewantie, $v_{\text {.d. }}$ vragg of uitgeoefende macht genormeerd is tot gezag. wordt voorgesteld het. door M. Scheltema (1977, t.a.p., p.334) a.d. vijf toetspunten voor democratie toegevoegde, criterium machisspreiding te vervangen door dat van gezagsspreiding. H.F. Munneke, Particulieren met apenbaar gezag bekleed, in: Tro, nr. 3, 1981, p.61. 


\subsubsection{GROFWEG GESEGMENTEERD}

Globale gradaties van gezag zijn bekend. Twee schrijvers leren nauw verwante varianten van openbare gezagsuitoefening.

De een kent drie vormen gezagsbevoegdheden. ${ }^{57}$ Te weten, ten eerste, directe publiekrechtelijke bevoegdheden. Daardoor ontstaan meteen rechtsgevolgen. Ten tweede zijn er indirecte publickrechtelijke bevoegdheden. Hiermee kan juridische invloed op de totstandkoming van rechtsgevolgen worden uitgeoefend. En ten derde worden subsidiebevoegdheden, als zo danig, erkend. ${ }^{58}$

De ander ontleedt, eerder al, een analoge bedrading in het web van bevoegdheden waarmee uitoefening van openbaar gezag door gedeconcentreerde ambten plaats vindt. ${ }^{59}$ Onderscheiden worden, in de eerste plaats, politiebewoegdheden. Dat wil zeggen bevoegdheden uit te oefenen in het kader van overheidstoezicht op en overheidsdwang tot geldend recht. Deze bevoegdheden strekken dus tot handhaving van de status quo. Dergelijke, in principe strikt gereglementeerde, bevoegdheden zijn elementair wat betreft gedeconcentreerde ambten. Op de politiebevoegdheden van functioneel gedecentraliseerde organen wordt nog afzonderlijk ingegaan. In de tweede plaats worden bepaalde bevoegdheden ook hier onder de noemer indirecte bestuursbevoegdheden gebracht. Deze bevoegdheden hebben een formeel-wettelijke grondslag. Op zich zijn zij geen bevoegdheden tot publiekrechtelijk rechtshandelen. Maar het betreft well bevoegdheden, waarvan uitoefening gericht is op en kan leiden tot beïnvloeding van publiekrechtelijke rechtshandelingen ${ }^{60}$ van anderen. En in de derde plaats blijven de echte besturirsbevoegdheden over. $\mathrm{Zij}$ fungeren meestal als beschikkingsbevoegdheden.

\subsubsection{CONCRETER CATEGORISEREN}

In een, weliswaar niet meer van zo jonge datum zijnde, concretere classificatie van organen en rechtspersonen rondom de centrale overheid ${ }^{61}$ is een patroon van, in praktijk nog gangbare, soorten bevoegdheden van zelfstandige bestuursorganen bloot gelegd. Zo bestaat de dagelijkse gang van zaken bij die organen voornamelijk uit een, of meer, van het hierna volgende: a toetsing van privaatrechtelijke overeenkomsten; $b$. toekenning van zakelijke rechten naar privaatrecht; $c$. toekenning van schadevergoedingen; $d$. subsidiëring, garantieverlening, toevoeging en dergelijke; e. uitkering verrichten op basis wan

57. H.F. Munneke, t.a.p., p.62.

58. Door het apart categoriseren van subsidiebevoegdheden ontstaat overlapping. De indeling verliest zo aan onderscheidend vermogen, omdat de afzonderlijke categorieën door elkaar heen lopen.

59. F.A.M. Stroink, Het leerstuk der deconcentratie, 's-Gravenhage, 1978, pp.65-69.

60. Trouwens, boven het begrip rechtshandeling prefereert Stroink de term rechtsbeslissing.. Een rechtsbeslissing is aanwezig als zij rechtsgewolgen bewerkstelligt en justitiabelen (rechtstreeks) in hun belangen treft. De inhoud van een rechtsbeslissing is irrelevamt. $Z$ ij kan dus verschillen. Zowel een declaratoire alls een constirutieve beschikking kan in de kern van een rechtsbeslissing liggen. F.A.M. Stroink, a.w., pp.70/75.

61. H.F. Munneke, J.B.J.M. ten Berge, F.A.M. Stroink, P. Haighton en P. den Hoed, a.w, p.47; Ook F.A.M. Stroink, Zelfsrandige bestuursorganen: een intrigerend verschijhsel, in: Bestuur, 1982, p.9. 
sociale voorzieningen; f. vergunningverlening, ontheffing, toelating; g. registratie; $h$. toezicht; i. keuring, examinering; $j$. advisering; $k$. regelgeving; en $\mathbb{1}$. overige.

Functionele decentralisatie naar zelfstandige bestuursorganen betekent, alls gezegd, overdracht of toekenning van publiekrechtelijke bevoegdheden, met andere woorden bevoegdheden tot het te weeg brengen van rechtsgevolgen. Vandaar kunnen alleen adviserende bevoegdheden een bepaald overheidsorgaan nooit in de stand van zelfstandig bestuursorgaan verheffen. In feite is slechts sprake van decentralisatie als een zekere verschuiving van politiek-bestuurlijke macht plaats vindt. Daaraan is de uitoefening van regelgevende en bestuurlijke bevoegdheden inherent. "Met het toekennen van regelgevende bevoegdheden dient grote terughoudendheid te worden betracht." 62 Met deze terechte conclusie wordt voorlopig volstaan. Op deze regelgevende bevoegdheden wordt nog terug gekomen in thet kader van de behandeling van specifiek toezichthoudende bevoegdheden.

Hoewel in voormelde classificatie toezichthoudende bevoegdheden streng zijn afgescheiden van andersoortige publiekrechtelijke bevoegdheden, bestaat toezicht houden vaak uit werschillende componenten. Zo kunnen toezichtssystemen zich in hoofdzaak etaleren als vergunningstelsels. En soms bestaat toezicht houden uit pure registratie van personen of goederen. De bedoeling is het begrip toezicht houden aanschouwelijk te maken. Voor een nadere omschrijving van de term toezicht houden wordt verwezen naar het volgende hoofdstuk en verder.

In het kort is al op te merken, dat bij toezichthoudende bevoegdheden valt te denken aan bevoegdheden waarvan de uitoefening er toe strekt te controleren of wordt voldaan aan vigerende wettelijke regels.

62. Functioneel bestuur: waarom en hoe? "TK 1990-1991, 21042, nt.4, pp.25/33; Soms wordt zelfis voor een werbod geopteerd. H. van der Sluijs, t.a.p., p.305. 


\section{Geraadpleegde literatuur}

Balkenende, J.P. \& Klink, A.

Gespreide verantwoordelijkheid in plaats van functionele decentralisatie, in: Bestuurswetenschappen, nr.6, 1989, pp.359-365.

Berge, J.B.J.M. ten

Taalverwarringrond functionele decentralisatie, in: Bestuurswetenschappen, $\mathrm{nr} .6,1989$, pp.335346.

Berge, J.B.J.M. ten \& Stroink, F.A.M.

Functionele decentralisatie uit de schaduw; Een globale verkenning van aard, omvang, verschijningsvormen en bestuurlijke aspecten van zelfstandige bestuursorganen en andere functionele organisatie-eenheden binnen het openbaar bestuur, 's-Gravenhage, juni 1988.

Boxum, J.L.

- Zelfstandige bestutursorganen en de greep van ministers op de bestuurlijke organisatie, in: Engeis, J.W.M., Lambers, C., Niemeijer, E., Scheltema, M., Schuiling, K.F., Vis, B.C. \& Vuçsán, De rechtsstaat herdacht, Zwolle, 1989, pp.255-267;

Ｚlifstandige bestuursorganen op maat, in: Bestuur, nr.4, 1990, pp.101-111.

Boxum, J.L., Ridder, J. de \& Scheitema, M.

Zelfstandige bestuursorganen in soorten; Verslag van een onderzoek naar de praktijk van zelfstandige bestuursorganen, i.o.v. ministerie van $B Z$, publikatie vakgroep bestuursrecht en -kunde Groningen, Deventer, 1989.

Braband, W.J.van

Beleidsdoelmatigheid en de marginale toetsingsregel, in: Beleidsanalyse, nr.3/4, 1994, pp.5-13.

Breunese, J.N. \& Dussen, J.W. van der

De scheiding tussen beleid en uirvoering, in: Beleidsanalyse, nr.1/2, 1994, pp.6-11.

Buuren, P.J.J. van

Zelfstandige bestuursorganen, in: NJB, nr.55, 1980, pp.590-591.

Couwenberg, S.W.

Het particulier initiatief in de Nederlandse verzorgingsmaatschappij: Een bestuurskundige benadering, Lochem, 1988, pp.20-50.

Dussen, J.W. van der

Contractmanagement en zbo's, in: Overheidsmanagement, nr.10, 1993, pp.247-250.

Dijkstra, P. e.a.

Een zelfstandige overheid in een sterke samenieving, Groen van Prinsterer-reeks nr.68, Barneveld, 1991.

Frissen, P.H.A. (red.)

Verzelfstandiging in het openbaar bestuur; Een bestuurskundige verkenning van verzelfstandiging, verbindingen en informatisering, "s-Gravenhage, 1992.

Frissen, P.H.A., Hirsch Ballin, E.M.H., Hoekstra, R., Visser, R., Kuiper, R. \& Boer, R. de Het managen van verandering door verzelfstandiging, uitgave Managementcentrum, "s-Gravenhage, april 1993.

Gerritsen, E. \& Wuijtswinkel, R. van Belastingdienst en verzelfstandiging, in: $\mathrm{OB}, \mathrm{nr} .1,1993, \mathrm{pp} .15-20$.

Haan, P. de

Het bestuursrecht en de scheiding tussen beleid en uitvoering, in: Hoogenboom, T. \& Damen, L.J.A. (red.), In de sfeer van administratiefrecht; Opstellen aangeboden aan Willem Konijnenbelt, Utrecht, 1994, pp.121-150.

Hoff, C.M. van den

Ministeriële verantwoordelijkheid en politieke controle, in: Bestuur, nr.1, januari 1989, pp.8-10. 
Hoff, C.M. van den \& Groot, R. de

Decentralisatie: zelfstandige bestutrsorganen; Essay over het verschijnsel van zelfstandige bestuursorganen, hun mogelijke bijdrage aan de ontlasting van de politieke en ambtelijke top en de consequenties met betrekking tot de omwang van de ministeriële verantwoardelijkheid, achtergrondstudie nr.2, deel 2, uitgebracht aan de commissie hoofdstructuur rijksdienst, 's-Gravenhage, 1981 .

Koeman, N.S.J.

Over beleid en controle; Op zoek naar een opvolger van de triasleer, in: NTB, nr.3, 1989, Pp. $73-79$.

Kuiper, R.J.

Verzelfstandiging en imformatievoorziening, in: Frissen, P.H.A. e.a., Het managen van verandering door werzelfstandiging. Management Centrum, april 1993, pp.87-104.

Langenberg. P.J.

Gebonden zelfbeheer: over de verhouding tussen regering, parlement en functionele organen, in:

Graaf, 'Th.C. de "Hoeven, D.A. van der \& Langenberg, P.J., Omtrent het parlement; Opstellen over parlement en democratisch bestuur, Utrecht/Antwerpen, 1985, pp. 1.16-147.

Leerdam, J. van \& Dussen, J.W. van der

Zelfstandige bestuursorganen:keuzecriteriaen sturingsvormen, in: Bele idsanalyse, $\mathrm{nr} .1 / 2,1994$, pp. $12-23$.

Lubberdink, H.G.

De betekenis van de ministerielle verantwoordelijkheid voor het openbaar bestutur, dissertatie RUG, Deventer, 1982.

Lubbers, R.F.R.M.

Scheiding beleid en uitwaering is modebegrip, in: Overheidsmanagement, nur. 1,1994, p.24.

Mulder, A.

Zelfstandige bestuursdiensten in Nederland, preadvies voor VVSR van België en Nederland, Zwolle, 1980.

Munneke, H.F.

Particulieren met openbaar gezag bekleed, in: TvO, nr.3, 29 januari 1981, pp.58-62.

Munneke, H.F., Berge, J.B.I.M. ten, Stroink, F.A.M., Haighton, P. \& Hoed, P. den Organen en rechispersonen rondon de centrale overheid, WRR-serie voorstudies en achtergronden V35, delen $\mathrm{VII}$, 's-Gravenhage, 1983.

Nederlands Studie Centrum i.s.m. Cap Volmac

Verzelfstandiging en informatievoorziening bij de rijksoverheid "lezingenbundel symposium, Rotterdam, 28 april 1994

Polak, J.M. \& Heijningen, F.D. van

Privatisering en zelfstandige bestuursorganen, in: LR, nr.2, 1988, pp.67-70.

Postma, J.K.T.

Verzelfstandiging: aansturing en terugkoppeling essentieel, in: Openbaar Bestuur, nr.6, 1994, pp.2-5.

Ru, H.J. de

Openingstoespraak/Algemene discussie, in: WRR, Studiemiddag zelfstandige bestuursorganen, V54, 's-Gravenhage, 1986, pp. 10/52-56.

Scheltema, $M$.

- Raden en commissies als zelfstandige bestuursorganen, in: Wetenschappelijke raad voor het regeringsbeleid, Adviseren aan de overheid, serie studies en achtergronden V5, 1977 „pp.331363 ;

- Slotbeschouwing tijdens Studiedag zelfstandige bestuursorganen d.d. 12 november 1985 , WRR-serie voorstudies en achtergronden V54, 1986, pp.60-61. 
Sint, $M$.

Naar een openbaar digitaal wegennet, in: Overheidsmanagement, nr.7/8, 1994, p.181.

Sluijs, H. van der

Distributie van bestuursbevoegdheden; De rol van de wetgever bij het toedelen van bestuursbevoegdheden op het niveau van de centrale overheid, in: Bestuurswetenschappen, nr.5, 1988, pp.302-321.

Stroink, F.A.M.

$\sim$ Het leerstuk der deconcentratie, dissertatie RUU, "s-Gravenhage, 1978;

- Zelfstandige bestuursorganen, een intrigerend' verschijnsel, in: Bestuur, 1982, pp.8-111.

Tweede Kamer

- Functioneel bestuar: waaromen hoe?, TK 1988-1989, 21042, nr.2, en TK 1990-1991, 21042. nrs.4-10;

- Operatie grote efficiency. TK 1990-1991, 21835, nr.3, ook TK 1991-1992, 21835, nrs.7/9, en TK 1992-1993, 21835, nrs.15/16, als mede Handelingen TK 77 d.d. 7 mei 1991, pp.43524356, en Handelingen TK 50 d.d. 11 februari 1992, pp.3234-3258;

- Wet verzelfstandiging Rijksdienst voor het Wegverkeer, TK 1992-1993, 22961, nrs.1-5, en Stbl. 1993, 200;

- Verzelfstandiging wan de Dienst van het Kadaster en de Openbare Registers, TK 1991-1992, 22438, nr.1, en TK 1992-1993, 23007, nrs.1-3;

- Wetsvoorstel verzelfstandiging Informatiseringsbank ofwel wetsvoorstel tot regeling wan de bestuurlike verhouding tussen de minister van onderwijs en de Informatie Beheer Groep. TK 1992-1993, 23073, nrs.1-6, en Scrt. 1993, 61;

- Jaarowerzicht Informatievoorziening 1992, TK 1992-1993, 23149, nrs.1-2, pp.1-62;

- Instellingswet rechtspersoonLandelijk Selectie- en Opleidingsinstituut Politie, TK 1993-1994, 23446, nirs. 1-3;

- Wetsvoorstel houdende regels betreffende instelling van het zbo Centraal Orgaan Opvang Asielzoekers, belast met de (im)materiële opvang van asielzoekers, TK 1993-1994, 23540, nrs. 13;

- Verslag van de Algemene Rekenkamer over 1994, deel 3; Zelfstandige besiuursorganen en ministeriêle verantwoordelijkheid, TK 1994-1995, 24130, nr.3.

Twist, M.J.W. van \& Veld, R.J. in 't

- Kerndepartementen: een wenkend perspectief?, in: Bestuurskunde, nr.7, 1993, pp.353-366;

- Een kerndepartement is iets anders dan 'wat er na verzelfstandiging overblijft', in: Openbaar Bestuur, nr.8, 1994, pp.14-19.

Veld, R.J. in "t

De kerntakenbenadering bij de Rijksoverheid: onderwerp van gesprek, in: Sip, C. \& Vrancken. P.H.J., De kerntakenbenadering bij de Rijksoverheid, IOO-reeks nr.59, 's-Gravenhage, aprill 1994, pp. 7 15.

Wansink, H.

Passende kleren; Kleine departementen zijn niet automatisch beter, in: Intermediair, nr. 34, 27 augustus 1993, pp.11-13. 


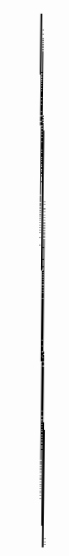

\section{Samenvatting, bevindingen en conclusies}

\section{functioneel bestuur}

Als uitvloeisel van het privatiseringsbeleid, in het kader van de reorganisatie van de rijksdienst, staat verzelfstandiging van overheidstaken boven aan op de verlanglijst van regering en parlement. Zowel interne verzelfstandiging (waaronder vooral agentschapsvorming en zelfbeheer) als externe verzelfstandiging (vaak voorbode - of anders: begeleider - van de, overigens wel wezenlijk te onderscheiden, taakafstoting middels privatisering) genieten vol op aandacht.

Onderhavig onderzoek werpt nader licht op de buitengrondwettelijke functionele decentralisatie. Dat wil zeggen decentralisatie naar (i.c. toezichthoudende) zelfstandige bestuursorganen, inclusief (besturen van) zelfstandige bestuursinstellingen en -lichamen indien en voor zover zij publiekrechtelijke bevoegdheden bezitten. Toezichthoudende zelfstandige bestuursorganen zijn ambten met openbaar gezag. Het bijzondere aan alle, hetzij publiekrechtelijke hetzij privaatrechtelijke, zelfstandige bestuursorganen is, dat zij niet hiërarchisch ondergeschikt aan enig minister zijn. Deze organen, die overigens onderdeel van de centrale overheid blijven wit maken, worden zo genaamd 'op afstand" van dat zelfde openbaar bestuur geplaatst.

Dat toekenning van publiekrechtelijke bevoegdheden, middels attributie of delegatie, niet alleen naar publiekrechtelijke, maar ook naar privaatrechtelijke organisatievormen kan plaats vinden, vindt oorzaak in de volgende centrale notie. Zelfstandige bestuursorganen, die op naleving van wet- en regelgeving toezien, oefenen openbaar gezag uit. Alles draait dus om de aard van de bevoegdheden. De rechtsvorm is zijdelings relevant. Natuurlijk moet een privaatrechtelijk zelfstandig bestuursorgaan, belast met de uitoefening van publiekrechtelijke bevoegdheden, wel aan de rechtsstatelijke eisen voldoen die volgens Nederlands recht ook aan publiekrechtelijke organisaties worden gesteld.

Van wege het gebrek aan democratische legitimatie, in de zin van politieke ministeriële verantwoordelijkheid, moet het legaliteitsbeginsel voor uitoefening van openbaar gezag door zelfstandige bestuursorganen juist sterke geldingskracht hebben. Het oude adagium 'geen publieke taakvervulling zonder publiekrechtelijke bevoegdheid" vormt, hoewel deze 
niet meer in het algemeen opgeld doet, juist wel extra rechtvaardiging van overheidsoptredten door zelfstandige bestuursorganen. Ook de rechtsbescherming is er mee gebaat.

Het met publiekrechtelijke bevoegdheid bekleed zijn impliceert het nemen van eenzijdige besluiten, overigens gereglementeerd door het recht, die feitelijk afdwingbaar zijn. Rechtseenheid en -conformiteit liggen aan de uitoefening van een publiekrechtelijke bevoegdheid ten grondslag. Kortom, een publiekrechtelijke bevoegdheid schept rechten en verplichtingen. Aldus is deze publiekrechtelijke bevoegdheid een rechtens relevante grondslag van overheidsoptreden.

De discussie over en de herbezinning op de harde kern van echte overheidstaken zijn in volle gang. Deze discussie staat in het teken van de grote efficiency-operatie. Dit project is vooral gericht op kwaliteitsverbetering van de rijksoverheid. Daarin past de gedachte van een enge rijksoverheid, d.w.z. kerndepartementen (gekoppeld aan een projectministerschap-nieuwe-stijl) en ruime rijksoverheid, d.w.z. inclusief zelfstandige uitvoerende diensten. In dit licht moet de toekomstige algemene bestuursdienst worden bezien. Interdepartementale of verticale mobiliteit en een gecoördineerd opleidingsbeleid moeten een sterke bestuursdienst creëren. Een, zowel politiek als ambtelijk aangestuurde, centrale eenheid geeft de bestuursdienst vorm.

Helaas levert de herijking van overheidstaken tot nu toe niet veel op. Het spel van politici, taken, bevoegdheden en verantwoordelijkheden af te schuiven, verloopt moeizaam. Kerntakenanalyses kenmerken zich door abstractheid, relativiteit en tijdelijkheid. Er bestaan geen objectieve wetenschappelijke criteria, aan de hand waarvan kan worden bepaald wat een overheidstaak is.

Daarnaast speelt de problematiek van de, in praktijk steeds minder te scheiden, tweedeling beleidsuitvoerende en -bepalende taken. De oorspronkelijke gedachte, dat aan functionele bestuursorganen slechts uitvoerende overheidstaken moeten toebedeeld, blijkt niet meer houdbaar. Bovendien is een strenge scheiding tussen beleidsbepaling en -uitwoering niet in alle gevallen nodig. In sommige situaties is niet het op afstand zetten van beleidsuitvoering, maar juist het op afstand zetten van de gehele beleidscyclus wenselijk. Consequentie daarvan is dat regering en parlement globale beleidskaders moeten vaststellen waarbinnen zelfstandige bestuursorganen een zekere handelings- en beleidsvrijheid hebben. Op informatieuitwisseling en interactie tussen ministers en zelfstandige bestuursorganen ligt een belangrijk accent. Met oog op evaluatie en, zo nodig, bijsturing van bevoegdheidsuitoefening door zelfstandige bestuursorganen, is dit niet vreemd. Wat betreft de noodzakelijke informatievoorziening zijn zelfstandigheid, (beleidsmatige/financiële) verantwoordelijkheid, aanspreekbaarheid en uitvoerbaarheid trefwoorden. Van wege het belang van wooral evaluatie van het functioneren van zelfstandige bestuursorgamen is het teleur stellend, zo niet schrijnend, dat het gros van de zelfstandige bestuursorganen in praktijk ver achter blijft met het, al dan niet verplicht, verschaffen van verschillende (feitelijke, inhoudelijke en financiële) rapportages.

Al met al vinden de kerntaken van de overheid, met andere woorden de intensiteit en de prioriteitstelling in overheidsoptreden, in het algemeen voeding in de Grondwet. In elk 
Deel III

\section{Inleiding rechtshandhaving door toezichthoudende zbo's}

\section{Vertrouwen is goed, controleren beter.}

Stalin's lijfspreuk geldt eigenlijk ook een beetje voor de Nederlandse democratische rechisstaat.

Zo houdt de Nederlandse overheid, in het algemeen belang, toezicht op de door haar uitgevaardigde regels. Soms kalm aan. Soms ingrijpend. De ene keer noodzakelijk, de andere keer minder nodig.

Hoe dit toezicht op naleving van wetten gestalte krijgt, is juist in het kader van deze studie relevant. De vraag is immers goed te stellen, of de handhavingstaak niet zó divers is dat voor de uitoefening er van, voor zover die geschiedt door een zelfstandig bestuursorgaan, kritische kanttekeningen geplaatst moeten worden bij de daartoe aangewende organisatievorm. '

In het handhavingsvraagstuk wordt aansluiting gezocht bij het volgende uitgangspunt. Bij het streven naar zo effectief mogelijke regels, moet er voor worden gezorgd dat regels naar hun doelstelling uitvoering vinden, een redelijke mate van acceptatie hebben en bóven all in behoorlijke mate handhaafbaar zijn. ${ }^{2}$

De aandacht yoor handhaafbaarheid van rechtsregels heeft de afgelopen jaren indrukwekkend impuls gekregen. Verschillende overheidsrapportages stellen het handhavingstekort aan de kaak (paragraaf 10.2 tot en met paragraaf 10.7). Hierbij wordt de rechtsstaat zelf aangewezen als belangrijke oorzaak van het handhavingsgebrek (paragraaf 10.1). Toevlucht wordt gezocht in alternatieve of aanvullende handhavingsinstrumenten (paragraaf 10.2). Ter verbetering van de rechtshandhaving wordt niet alleen vernieuwing van het handhavingsinstrumentarium, maar ook verjonging van de justitiële organisatie beoogd (paragraaf 10.3). En geleidelijk aan wordt duidelijk dat strafrecht niet altijd het eerst aangewezen handhavingssysteem is (paragraaf 10.4). De vraag, welk handhavingsstelsel meest effectief is, gaat vooraf aan een wetgevingsprocedure. Deze wetgevings-

1. K.F. Schwiting, Staats-en bestuursrechtelijke kroniek, in: BWn, nr.5, 1992, pp.425-456, i.h.b. p.455.

2. TK 1989-1990, 21502, nirs.1-2, p.39. 
procedure geniet steeds meer belangstelling. Naast haar nadruk op het proces van wetgeven, legt de Nederlandse overheid een klemtoon op de inhoud van wetgeving (paragraaf 10.5). Daartoe stelt zij kwaliteitseisen. Om de voorstellen niet het karakter te geven van het schermen met woorden, is een Inspectie voor de rechtshandhaving leven ingeblazen (paragraaf 10.6). Ook worden ministeriële commissies voor wetgevingsbeleid en rechtshandhaving ad interim ingesteld. De Algemene wet bestuursrecht voert de reservefunctie yan het strafrecht door (paragraaf 10.7).

De Awb ruimt voor handhaving als toezichtsuitoefening plaats in (paragraaf 11.1). In overvloedige mate wordt in toezichtsbevoegdheden voorzien (paragraaf 11.1 .1 tot en met paragraaf 11.1.3). Algemene maatstaf voor uitoefening van deze bevoegdheden is het vage redelijkheidscriterium. Vandaar bestaat de noodzaak het optreden van toezichthouders aan de algemene beginselen van behoorlijk bestuur te toetsen (paragraaf 11). Uit het oogpunt van rechtsbescherming is de onduidelijke grens tussen toezicht en opsporing onwenselijk (paragraaf 11.1.4). Bovendien overheerst de twijfel over de, in gevolge de Awb mogelijk in het kader van de rechtshandhaving handelende, particuliere toezichthouder (paragraaf 11.1.6 en paragraaf 11.1 .7 ).

Handhaving in de zin van sanctietoepassing blijft natuurlijk niet onberoerd (paragraaf 12). Verschillende soorten handhaving worden, aan de hand van hun toepassing door verschillende zelfstandige bestuursorganen, belicht (paragraaf 12.1 tot en met paragraaf 12.4).

Omdat het nationale handhavingsrecht sterk beinvloed wordt door communautair recht inzake controle, opsporing en sanctionering, trekken ook gemeenschapsrechtelijke handhavingsaspecten de aandacht (hoofdstuk 13).

Paragraaf 13.3 verhaalt over de bevoegdheden in het kader van handhaving, die de Europese Commissie zich al meer toeëigent. En in paragraaf 13.4 wordt er op gewezen, dat de werkzaamheden van de Euro-controleurs nog al eens kruisen met die van nationale toezichthouiders.

Op de lidstaten rust de plicht de uitvoering van EG-recht te realiseren (paragraaf 13.1). Hierbij moeten zij algemene beginselen van gemeenschapstrouw als principes van assimilatie, evenredigheid en effectiviteit nakomen (paragraaf 13.1.1 tot en met paragraaf 13.1.5). In dit licht worden belangrijke grondrechten bezien. Zo zien zekere zelfstandige bestuursorganen toe op respectering en handhaving van de communicatievrijheid ten aanzien van radio- en televisieuitzendingen (hoofdstuk 14)/filmvertoningen (hoofdstuk 15), de vrijheid van persoonsgegevensverkeer (hoofdstuk 16), het vrij handelsverkeer vam landbouwprodukten en zaai- en plantgoed (hoofdstuk 17), de vrijheid van uitoefening van het verzekeringsbedrijf (hoofdstuk 18) en de vrijheid van effectenverkeer (hoofdstuk 19). Deze zorgtaken van toezichthoudende zelfstandige bestuursorganen impliceren het bewaken van eerlijke mededinging en het wederzijds erkennen van de in verschillende lidstaten vigerende toezichtsregels en -stelsels. 
geval zijn de verzorgingsfuncties vatbaar voor functionele decentralisatie. De ordenende taken, die het algemeen belang raken, kunnen eventueel, begrensd via voorwaardenscheppend beleid, worden gedecentraliseerd. In beginsel niet in aanmerking voor overdracht naar zelfstandige bestuursorganen komen de volgende taken: zowel interne als externe beleidsadvisering, (in het algemeen) besluitvorming over voorbereiding van wetgeving, toepassing van strafrecht in algemene zin en geschillenbeslechting of rechtspraak.

Belangrijke motieven om functioneel te decentraliseren naar zelfstandige bestuursorganen zijn: gezaghebbende deskundigheid, evenwichtige, objectieve (of: onpartijdige en onafhankelijke) belangenafweging, als mede participatie van belanghebbende, deskundige burgers of representatieve belangenorganisaties.

In het hierna volgende staan, van alle taken die zelfstandige bestuursorganen uitoefenen, slechts de toezichthoudende, dat will zeggen controlerende, opsporende en sanctionerende, taken centraal. Toezichthoudende bevoegdheden worden in het algemeen omschreven als bevoegdheden waarvan de uitoefening er toe strekt te controleren of wordt voldaan aan vigerende wettelijke regels. 


\section{Rechtshandhavingsbeleid in Nederland}

\section{$\$ 10.0$ Rechtshandhaving ${ }^{1}$ in de belangstelling}

Stapels rapporten. Nieuwe, en nog nieuwere, nota's. En met de instelling van een speciale "oplossingsgerichte" 2 Inspectie voor de rechtshandhaving als mede de inschakeling van ministeriële commissie(s) ad hoc voor wetgevingsbeleid en rechtshandhaving bij complexe, prioritaire wetgevingsprojecten ${ }^{3}$, is het weer wachten op andere notities. Want over de handhavingsproblematiek is het laatste woord nog niet gezegd.

De problematiek rond naleving van rechtsregels spitst zich vooral toe op het handhavingstekort. Op zich is een zeker gebrek aan handhaving niet vreend. Ten eerste is volkomen handhaving feitelijk onmogelijk. Ten tweede is, gelet op het handhavingskarakter, honderd procent toezicht op naleving van het recht niet altijd wenselijk. De vrees bestaat zelfs dat een staat die honderd procent normnaleving nastreeft, en daarbij vooral strafrecht als handhavingsinstrument hanteert, al snel een politiestaat wordt. Daarom moet er voortdurend zorg zijn voor de "juiste balans tussen veiligheids- en vrijheidsbeleving van de burger". "

Handhavingssystemen zijn dus per definitie deficiënt.

De huidige (financiële) versterking van rechtshandhaving ${ }^{5}$ vloeit echter voort uit het besef dat het handhavingstekort onacceptabel is uitgedijd. Het fundament van de rechtsstaat is sterk aangevreten. Nog even en de rechtsstaat rest als ruïne.

1. Dedoeld is publieke rechtshandhaving. J.A.E. Vervaele, Handen en tanden wan het (gemeemschapsirecht, oratie RUU, 18 febr. 1994, Deventer, 1994, p.2, verkiest de term 'publieke' boven 'publiekrechtelijke" . Centraal staan z.i. "de spelregels voor de machtsuitoefening van overheid op samenleving en burgers, nuet net gebruik van het publicke recht."

2. Inspecteur-Generaal rechtshandhaving J.R.H. Kuyper tijdens interwiew met L. van Almelo, Wettent en regets moeten leven bij het publiek, in: BBM, nr.7/8, 27 nov. 1992, pp.26-28.

3. In gevolge het kabinetsstandpunt Voortwarend wetgeven, TK 1993-1994, 23426, mr.1, pp.10-11.

4. C.R. Niessen, Een aanvaardbaar niveau vam miet-handhaving, in: OB, nr.5, 1992, pp.18-23, i.h.b. p.18.

5. Begroting justitie 1993, Meer madruk op rechtshandhaving, in: Stcrt. 16 sept. 1992, 179, p. 12. 
Kortom, de gaten moeten gevwld. De overheid moet geen "slappe washandjes" 6 vitdelen, maar flink de handen uit de mouwen steken.

\section{\$10.1 WRR-rapport Rechtshandhaving}

De drang naar verbetering van uitvoerbaar- en handhaafbaarheid van wetten en regels doet zich, voor het eerst, sterk gelden in het rapport over rechtshandhaving. ${ }^{7}$ Hierin staat de rechtsstaatsgedachte centraal. Voorop staat: "de rechtsstaat impliceert de rechtsplicht tot rechtshandhaving". ${ }^{8}$

Frappant is dat de rechtsstaat zelf kennelijk debet is aan inefficiëntie van rechtsnalleving. ${ }^{9}$ Ten eerste is er de, bijna onvermijdelijke, latente spanning tussen het rechtsstatelijk mogen en moeten. Ten tweede werken deze strijdende elementen door in een andere spanning. Immers, het is moeilijk schipperen in het woelige water van, aan de ene kant, de waarborgen of resultaten van de rechtsstaat (anders gezegd, het mogen of het moeten van de rechtsstaat) $e_{n}$, aan de andere zijde, het beleidsinstrumentele optreden van de sociale rechtsstaat. Het evenwicht hiertussen laat zich zelden vinden.

Even gemakkelijk als voordeel ontstaat namelijk nadeel. Zo kunnen zelfstandige bestuursorganen, belast met de uitwoering van sociale zekerheidswetgeving, mediawetgeving of privacywetgeving, het maatschappelijk leven belangrijk belasten en beperken.

Op dergelijke beleidsterreinen treedt regeloverschrijding of -afwijking vooral op. Dat is soms zelfs onvermijdelijk. Veel moderne wetgeving zit namelijk vol met conflicterende regels en tegenstrijdige wetsdoeleinden. Dat is niet zo verwonderlijk als het lijkt. In het wetgevingsproces, waarin in toenemende mate sprake is van participatie van burgers en belangengroepen, moet vaak aan verschillende maatschappelijke belangen tegemoet worden gekomen. Soms zelfs in die mate, dat invoering van een bepaalde norm de ene partij tevreden stelt, terwijl in praktijk de andere partij wordt gesust doordat naleving van bedoelde norm bewust niet wordt afgedwongen.

Bovendien zijn de factoren, die klemmende rechtshandhaving in de hand werken, niet te verwaarlozen. ${ }^{10}$ Te weten, complexiteit, afnemende legaliteit en normativiteit van regelgeving; rechtsonzekerheid bevorderende instrumentele wetstocpassing waardoor soms zelfs de term medeplichtig bestuur actueel is; publieke en particuliere sfeervermenging; en afwenteling van het, achterop geraakte, bestuurlijke controlesysteem op het justitiële handhavingsstelsel.

Algemene aanbevelingen zijn daarom, onder meer, de volgende. "(Preventieve) bestuurlijke handhaving verdient een voorrangspositie. Strafrechtelijke handhaving krijgt

6. Lubbers: bestoande normen handhaven, in: NRC, 27 okt. 1992, p.7.

7. Wetenschappelijke raad voor het regeringsbeleid, Rechishondhowing, rapport aan de regering nr.35, 1988.

8. WRR, a.W., p. 20 ,

9. WRR, a.w., pp. 20-21.

10. WRR, a.W., p.147.

11. WRR, a.w., p.149. 
sllechts een reserveplaats. De voorkeur gaat uit naar lichtere en gemakkelijker hanteerbare sancties. Voor uitvoering van regelingen, met een sterk persoons- en omgevingsgerelateerd karakter, is (territoriale of functionele) decentralisatie, ten einde geîndividual iseerde uitvoering en adequate handhaving te realiseren, wenselijk. Bovendien is an te raden beleidsbepaling en -uitvoering organisatorisch te scheiden. En ook is meer zorg nodig voor consistente, eenvoudige, waardevolle en prospectieve regelgeving.

Bedoeld rapport luidt de noodklok in. Tegenwoordig is pijnlijk voelbaar, dat de alarmfase is ingetreden.

\section{$\S 10.2$ Rapport commissie-Deetman}

De commissie-Deetman begrijpt de boodschap. In het kader van staatkundige, bestuurlijke en staatsrechtelijke vernieuwingen lanceert zij met realiteitszin het vraagpunt van handhaafbaarheid van wetgeving. ${ }^{12}$ Verontrust klinkt de roep om systematische wetsevaluatie op het gebied van handhaafbaarheid, uitvoerbaarheid en consistentie van wetgeving. Wenselijk lijkt een vernieuwend denken in alternatieve of aanvullende handhavingsinstrumenten. Zo vindt de commissie-Deetman bestuurlijke boeten, bestuursrechtelijke dwangsommen, positieve sancties en uitbreiding van civielrechtelijke aansprakelijkheid het overwegen waard. Daarnaast stimuleert de commissie-Deetman in het bijzonder het sluiten van convenanten.

Inmiddels is het convenant een populair juridisch beleidsinstrument. ${ }^{13} \mathrm{Bij}$ categorisering van soorten convenanten wordt in de "convenantologie" zelfs een aparte plaats ingeruimd voor het gebruik van convenanten door zelfstandige bestuursorganen met een publieke functie. ${ }^{14}$ Kijkend naar de markten van onder meer arbeidsvoorziening (Centraal Bestuur voor de arbeidsvoorziening) ${ }^{15}$, monetaire middelen (De Nederlandsche Bank nv) juncto assurantievoorziening (stichting Verzekeringskamer), geneesmiddelen (Centraal orgaan tarieven gezondheidszorg), onderwijs (verschillende universiteiten en

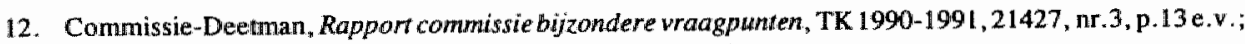
Zie als vraagpunt 40 in TK 1992-1993, 21427, ar. 27, p.8.

13. Over de toenemende aandacht en het toenemende belang van convenanten o.a. NJB-special, nr. 14, 8 april 1993; Zie ook A.J. Hoekema en H.D. Stout (red.), Onderhandelend bestuw, NJB-boekenreeks nr. 16. Zwolle, 1994; Tevens S.E. Zijlstra, Convenanten, preadvies voor de VVRS, Zwolle, 1994.

14. P.F. van der Heijden en I.C. wan der Vlies, De staat wan het convenant, in: NJB-special, nr. 14, 8 april 1993, p. 476.

15. Overeenkomst Staat en Arbeidswoorzieningsorganisatie inzake de uitvoering van Europese Sructuur Fondsen (EG-verordening 2052/88), Stcrt. 1991, 192. Het Centraal Bestuur woor de Arbeidswoorziening:sorganisatie draagt dan weer regelgevende bevoegdheden over aan de Regionale Besturen voor de Arbeidsvoorziening. 
hogescholen) ${ }^{16}$ of volkshuisvesting (Centraal fonds voor de volkshuisvesting/commissie woor de gebiedsaanwijzing), is zo'n afzonderlijke positie inderdaad gerechtvaardigd. Ter zake is wel voorzichtigheid geboden. Op terreinen, waar zelfstandige bestuursorganen opereren, kunnen convenanten zeker zinvol zijn. Verschillende goede redenen bestaan om convenanten te sluiten. Bij voorbeeld, het betrekken van belanghebbenden bij het bestuur, het voorbereiden/anticiperen op wetgeving, of het afwijken van bestaande regelgeving. Naar functie zijn trouwens de volgende soorten convenanten te onderscheiden: $a$. wetgeving wervangende convenanten; $b$. aanvullende convenanten; $c$. overbruggende convenanten; en $\mathrm{d}$. vooruit lopende convenanten. ${ }^{17}$

Helaas zijn er ook nadelen aan verbonden. Problemen rijzen bij voorbeeld als volgt. Een convenant is voor vertegenwoordigende instanties slecht of niet controleerbaar of beinvloedbaar. Omdat niet altijd alle bellanghebbenden tot een convenant toe treden, ligt zwakke handhaving voor de hand. Met oog op nadeel voor derden is te denken aan het gegeven dat publiekrechtelijke wet- en regelgeving niet opzij mag worden gezet door het gebruik van convenanten. Dit vloeit onder meer voort uit art. $3: 14$ BW (juncto art. 3:1, tweede lid, Awb), waarin wordt bepaald dat een iemand krachtens het burgerlijk recht toekomende bevoegdheid niet mag worden uitgeoefend in strijd met (on)geschreven regels van publiek recht. Daar waar een vergunningverlenend, toezichthoudend bestuursorgaan, ter behartiging van openbare belangen, gerechtigd is gebruik te maken van privaatrecht -in plaats van een bestaande publiekrechtelijke weg-en hierbij met vergunningaanvragers convenanten, betreffende vergunningvoorschriften e.d., sluit, is wat betreft in elk geval het millieurecht ${ }^{18}{ }^{19}$ uitgemaakt dat toezeggingen van de vergunningverlener aan de aanvrager in convenanten of anderszins niet passen in het systeem van milieuvergunningverleningsysteem ${ }^{20}$. Goed voorstelbaar is dat de administratieve

16. Overigens zijn zbo"s in de onderwijssector, door autonomie en democratisering van besluitvorming. "steeds meer het karakter gaan dragen wan openbare lichamen met eigen regelende en witvoerende bewoogdheden" volgens $P$. de Haan, Het bestuursrecht en de scheiding tussen beleid en uirwoering, in: $T$. Hoogenboom en L.J A. Damen (red.), In de sfeer won administratief recht, Utrecht, 1994, pp.121-150, i.h.b. p. 135 .

17. Wat betreft controle- en handhawingsmogelijkheden van convenanten splitsen M. Pleijte en B. van Geleu ken, Het milieuconvenant" Govede voormemens, slechte resultaten, in: JV, nr.9, 1994, pp,83-94, i.h.b. pp. 84-86, deze vierdeling op in twee categorieèn: het convenant als zelfstandig handhaafbaar beleidsinstrument (het, vergumning vervangende, wetgevingscomvenant) en het onzelfstandige convenant dat zelf geen voorwerp van handhaving is (het aanvullende, overbnggende en anticiperende convenant). Overigens achten auteurs convenanten als regelgevende instnmenten niet preferabel. Succesvoller, dan wetgeving in of na een convenant, is in hun ogen aanvullende wetgeving naast een convenamt.

18. Volgens Th.G. Dnupsteen, Kroniek milieurecht, in: kronieken 1 aug. 1993 - 1 aug. 1994 als bijlage bij NJB, nr. 33, 23 sept. 1994, pp.66-70, ontstaat door gebnik van allerlei constmcties (waaronder convenanten), die wel bepaalde rechtsgevolgen hebben maar waarvan niet duidelijk is wat die precies inhouden, een "schaduwrecht" naast thet officiële recht.

19. In het milieurecht neemt het conwenant een hoge vlucht. Zie Bedrijfsleven kent nu 100 milieuconvewanten. in: NRC. 21 nov. 1994, p. 10.

20. Hydro Agri, AGRS 1 sept. 1992, G05.90.1712, aangehaald door L.F. Wiggers-Rust, Owerheidsbestuur per contract en het primaat van het publiek recht, in: H.Ph.J.A.M. Hennekens e.a., Bestwursrecht aan de hovizon, Zwolle, 1994, pp.123-134, i.h.b. p. 129. Ter vergroting van de inroepbaarheid van conwenanten bepleit zij] individualisering van convenantdoelen; Bedoeld arrest, uiteindelijk gepubliceend in $A . B$ 
rechter, uit oogpunt van behoorlijke rechtsbescherming van derden, ook buiten het milieurecht het publiek recht voorrang geeft boven convenanten, die dat relevant recht ter zijde stellen dan wel waardevolle wetten ${ }^{21}$ weg schuiven. ${ }^{22}$

Op andere wijze negatief is het effect van samenwerking tussen bestuur en samenleving op basis van een convenant, als de overheid nog slechts in een 'koortje-op-de-achtergrond' mag mee zingen.

20. $\rightarrow$

1993, $400 \mathrm{~m}$. nt. Th. G. Drupsteen, bevestigt de uitsprak inzake Kemira van de voorzitter van de AGRS d.d. 26 sept. 1991, AB 1992, 283, m.nt. A.F.M. Brenninkmeijer. Zie NTB, nr.4, pp.362-364; Zie ook bespreking van de bewoegdhedenovereenkomst tussem Hydro Agri en de minister van verker en waterstaat H.D. Stout, Sprookjes bestáan! Het bestwursrecht als modeme Assepoenter, in: B.M., nr.6. 1994, pp. $322-333$.

21. Bij voorbeeld $\mathrm{VZ}$ ARRS I febr. 1994, AB 1994, 282, waarin een uitvoeringsbesluit wan een convenant schorsing ondergaat, omdat dat convenant (i.c. over wegbeheer) mogelijk strjjig is met de wet.

22. Hierbij ligt in herinneting de unperking van de zgn. tweewegenleer (verschillende leren besproken door H.D. van Wijk, bewerkt door W. Konijnenbelt en R.M. van Male, Hoofdstukken wan administratief recht, negende druk, Utrecht, 1994, pp.461-492). Zie Staat ws. Windmill, HR 26 jan. 1990, NJ 1991, 393; Becommentarieend door A.Q.C. Tak, Terugtocht van twee wegen, in: NTB, 1989, pp. 279-314; Recenter expliceert A.Q.C. Tak, Overheid en Burgerlijk Wetboek; Naar een invullende rechrsleer, in: R\&K, nr.2, 1993, pp.174-190, dat hij de tweewegenleer "exit" acht; Ook interessant zijn de commentaren van W.G. Huijgen, Art. 6:162 BW en de doorkrüsing wan het publiekrecht, in: WPNR, 19-26 dec. 1992, nr.6074, pp.964-969 en H.J. Simon, De averwinning van het privaatrecht?, in: NJB, nr.31, 9 sept. 1994, pp. 10761078; Vgl. de invalling van de Windmill-criteria in Staat ws, Magnus, HR 23 okt. 1993, AB 1994, 1; Hierover Th.G. Drupsteen, Staat/Magnus; nog eesmaal twee-wegen, in: A.A, nr. 3, 1994, pp. 158-165; Overigens interessant over osmose van publieke nornen in privaatrecht Staat/Kabayel c.s., HR 18 febr. 1994, RvdW 1994, 58 (art. 162 BW ter bescherming van publiek belang), met in gelijke zin Van Schaik vs. Nieuwveen $\mathrm{HR} 7$ okt. 1994, AB 1995, 47 (als aangehaald door D. A. Lubach, Bestuwr en privaatrecht $t_{\text {in: }}$ iTB, nr.6, 1995, pp.163-165), en De negende van ama, HR 20 mei 1994, RvdW 1994, 113 (art. 3:4 Awb komt via redelijkheid en billijkheid ex art. $3: 12 \mathrm{BW}$ civiel recht binnen); Zie, inzake art. 3:44 BW em art. 3:3 Awb. Hormkamp ws. gemeente Alkemade. Arrondissementsrechtbank 's-Gravenhage, 4 mei 1994, AB 1994, 366. Daarin constateert de rechter geen gebruik van priwatrechtelijke bevaegdheid die publiekrechtelijke regeling doorkruist; Tevens Gemeente Terschelling ws. Delhez, Hof Leeuwarden, 10 aug. 1994, NJ 1995, 202, waarin een vergelijkbare conclusie wordt getrokken, namelijk dat i.c. geen doorknising van de publiekrechtelijke regelingen van de Wro en de Woningwer plaats windt toor een avereenkomst tussen particulier en gemeente, waarbij eerst genoemde zich verplicht een bestaande woning af te breken indien hij op dat perceel een nieuwe wroning mag bouwen en hem daartoe een bouwvergunning wordt afgegeven; Zie ook A. w. minister van verkeer en waterstaat, No 22 dec. 1994, AB 1995, 154. I.c. wordt m. b.t. het door de minister vastgestelde trace voor de rijksweg A50 (dive tem dele door en langs de gemeente Son en Breugel komt te liggen) een voorontwerp-bestemmingsplan voor het tracé en omliggende wegen ter inzage gelegd, gelijktijdig met een concept voor een russen de gemeente Son en Breugel en het rijk te shiten convenant aangaande de hoofduitgangspunten en de verdere voorbereiding. van de aanleg wan de omlegging Son van de A50. Hoewel wijzigingen in numtelijke ordeningsprocedures moeten plaats vinden via de daarvoor door de wetgever vastgestelde procedures (i.c. dus via het bestemmingsplan), vormt her comvenant i.c. "geen doorkruising van de mogelijkheden van inspraak, bezwatr en beroep in het kader van de bestemmingsplamprocedure". Het concept is samen met het voorontwerp. dus in een vroeg stadium, ter inzage gelegd. Er is voldoende tijd en ruimte voor bezwalamaking en aanpassing van het convenant voor zover de oniwikkelingen in het bestemmingsplanprocedure daantoe aanleiding geven. Het convenant is slechts een intentieverklaring $\mathbf{m}$. b.t. een bepaalde inspanning en treedit niet in de plaats van een planologische procedure. Het convenant loopt niet woonit op in het kader van de procedure mog te nemen beslissingen. 
Dit wreekt zich vooral bij het uit beheer geven van handhavingstaken. In een pleidooi overheidscontrole "niet als paardemiddel, maar alls gezond dieet" te gebruiken luidt het oordeel hard, maar helder: "Veel controletaken worden via het sierlijke gebaar van het 'convenant' cadeau gedaan aan de clubs van potentiële boosdoeners. [...] Sierlijk tegenover de ontvangende belangengroepen, niet tegenover het parlement: dat laat zich door de wildgroei aan convenanten buiten spel zetten. ${ }^{\text {2. } 23}$

Illustratief daarvoor is de convenantvorming in de kansspelsector. ${ }^{24}$ Tegenwoordig controleren de gokexploitanten 'zich zelf' op grond van, door hen met lokale overheden gesloten, convenanten.

In 1993 worden twee gemeentelijke speelautomatencontroleurs, op grond van een convenant van de gemeente Breda met de Vereniging van Automatenhandelaren, voor 19 uur per week aangesteld om onder andere toe te zien of het aantal toegestane ${ }^{25}$ piekautomaten ${ }^{26}$ in de droge horeca (cafés) en natte horeca (snackbars) niet wordt overschreden. Niet alleen in Breda, maar ook elders, in bij voorbeeld Deventer ${ }^{27}$ en "s-Gravenhage $^{28}$, worden in navolging dergelijke convenanten opgemaakt en ondertekend. In 1992 gat drie procent van de Nederlandse gemeenten, ten einde meer differentiatie in het vergunningbeleid aan te brengen, er toe over om een speelautomatenconvenant met betrokkenen te sluiten. In 1993 gaat al negen procent van de gemeenten overstag. ${ }^{29}$ Het departement van economische zaken ziet het percentage graag groeien. "Het maken van afspraken in plaats van het uitoefenen van dwang past goed in een moderne bestuurlijke benadering, waarbij de overheid als partij in het maatschappelijk proces onderhandelt met andere partijen. " ${ }^{30} \mathrm{Om}$ onwenselijke onderlinge verschillen te voorkomen stelt de mi-

23. H. Vuijsje, Terug noar de controle-staat, in: NRC, 30 aprill 1994, p. 29.

24. Nu de Wet op de karsspelen de gemeenteraad de bevoegdheid geeft om bepalingen vast te stellen m. $\mathrm{b}$.t. de door de burgemeester aan een vergunning te verbinden voorschriften en beperkingen (aantal en soont speelautomaten) acht E.Ch. Lisser, Alternatieven voor wetgewing op decentraal niveau, in: RegelMaat, nr. 1,1995, pp. 19-31, i.h.b. p.28, wen convenant inzake aanwezigheid van speelautomaten in thorecabedrijven een alternatief woor regelgeving, maar weer niet voor een avw.

25. Per 1 jan. 1995 zija piekautomaten verboden. Gokautomaten voortaan taboe woor jongeren in: NRC, 9 dec. 1993, p. 2; Ook Kamer wil strenger optredten tegen verslaafden gokkast, in: NRC, 10 sept. 1993, p.5* Andriessen stelt aanscherping Speelautomatenbeshuit voor; Minister contra Random Rumners, in: BB, 20 nov. 1992, p.16.

26. Dat zijn automaten die bij 100 uur spelen slechts een à twee keer fors uitbetalen. Hierdoor werken ze zeer werslavend.

27. Over evaluatie oudste convenant ter zake C.J.D. Waal, Her Deventer speelautomatenconvenant, in: NJB, nr. 14, 8 april 1993, p.549; Inmiddels kent Deventer een hemieuwd, aangescherpt raamconvenant, dat met elke indiwiduele horeca-ondernemer wordt gesloten. Zie Cafebazen zwakke schakel in keten gokbestrijding, in: BB, nr. 3, 22 jan. 1993, p.17; Het conwenant heeft kennelijk een gwnstige werking. Via een eerste evaluatie wan een onderzoeks - en statistiekafdeling van de gemeente Deventer worclt een lichte daling van problematische gokkers geconstateerd. Zie Gokconvenont in Deventer lijkt effectief, in: BB, m. 5,3 febr. 1995, p. 22 .

28. Haags conwenant over gokken niet geheel nageleefd; Exploitanten én gokkers ontevreden, in: BB, nr. 1 , 7 jan. 1994, p. 10.

29. Ruim helft gemeenten voert anti-gokbeleid, in: $\mathrm{Ng}, 17$ dec. 1993, p.6.

30. EZ-topambtenaar M. de Vos, geciteerd in Taboe op riskante gokautomaten en meer controle op wildgroei: EZ bereidt wijziging Wet op Kamsspelen voor, in: BB, 30 oktober 1992, p.7. 
nister van economische zaken een landelijk model voor een speelautomaten-convenant te introduceren. ${ }^{31}$ Dit voomemen heeft instemming van de Raad voor de Casinospelen (dit toezichthoudend zbo heeft het College van toezicht op de kansspelen als vervanger) en de speelautomatenexploitanten die zich hebben verenigd in de Vereniging Automatenhandel Nederland. ${ }^{32}$

In de reeds bestaande convenanten verplichten ondernemers zich, even als in Breda, tot toezicht op leeftijd van spelers, speelduur, aantal speelautomaten, het opstellen van een 'zwarte lijst' en het opplakken van waarschuwingsstickers. ${ }^{33}$ Daarnaast kunnen convenantpartners afspraken maken omtrent te heffen lokale kansspelbelasting en besteding daarvan (ten gunste van een intensieve aanpak van de gokproblematiek ${ }^{34}$ als ook adequate controle op naleving van het betrokken convenant). ${ }^{35}$

Het project in Breda onderscheidt zich van de overige projecten door de aanstelling van personen die zijn belast met het toezicht op de naleving van de verplichtingen uit convenant. De Bredase controleurs behoren tot de reservepolitie. Ex art. 4, tweede lid (laatste gedeelte), junctis art. 5 , vierde lid, art. 6, tweede lid, en art. 7 Politiewet kunnen burgemeesters, op gemeenschappelijke voordracht van de ministers van binnenlandse zaken en justitie overeenkomstig door hen te stellen regelen, vrijwilligers voor de reservegemeentepolitie aannemen. Bedoelde Bredase vrijwilligers zijn niet opsporingsbevoegd. Zij surveilleren bij de individuele exploitanten van gokkasten. Concluderen ze, dat een bepaalde ondernemer zich niet houdt aan datgene wat in het convenant is bepaald, dan waarschuwen zij betrokkene. $\mathrm{Zij}$ wijzen hem bij voorbeeld op mogelijke vergunningintrekking. Hun bevindingen rapporteren zij aan de burgemeester. $\mathrm{Bij}$ herhaalde overtreding van de voorschriften kan proces-verbaal worden opgemaakt.

Inmiddels is duidelijk, dat ook de Tweede Kamer instelling van 'gokwachters' en de mogelijkheid om in het kader van een convenant afspraken te maken over frequente controle aantrekkelijke gedachten vindt. ${ }^{36} \mathrm{Om}$ naleving van het door haar afgekondigde, in 1997 te realiseren, verbod op gokautomaten in de "droge' horeca te bewerkstelligen will het parlement gokwachters aanstellen. Deze gokwachters moeten worden betaald uit een verhoging van, aan kansspelexploitanten opgelegde, leges. ${ }^{37}$

31. Gokautomaten woortaan taboe voor jongeren, in: NRC, 9 dec. 1993, p.2; De notitie Kansspelbeleid, TK 1993-1994, 21277, nr.28, p.20. Bovendien wordt, op pp. 12-13 van de notitie, melding gemaakt van een door de KUB opgesteld Model woor het evalweren van convenanten als instrument van lokaal kansspelbeLeid, Tilburg, 1993.

32. Automatenbranche wil duidelijhheid, in: BB, nr. $51-52,24$ dec. 1993, p.28.

33. B.I. Straatsma, Convenant speelautomaten leunt te sterk op goede wil van exploitanten, in: BB, nr. 37 . 17 sept. 1993, p.29, twijfelt aan het nut wan de convenanten.

34. Het beheersbaar maken wan gokverslaving en het inzichtelijk maken van gokcontrole zijn essentiele voorwarden voor verkrijging van het keurmerk, dat de Kema verstrekt aan gokhallen waarwan de bedrijfswoering in ordie is. Over deze 'unieke' vorm van certificering H. Moll, Kema-keurmerk vaor 'nette' gokhallen, in: NRC, 2 mei 1995, p. 11.

35. Mogelijke invoering van een (hogene) landelijke heffing ter zake ondermijntt de convenantvoordelen. Zie 'Landelijke heffing op gokautomaren doorkruist gemeentelijk beleid', in: BB, n. 36, 10 sept. 1993, p. 15.

36. Kansspelbeleid, TK 1993-1994, 21277, nr.28, p.22; Positiewe waardering van conwenanten is ook te vinden bij de commissie-Nijpels, Op de kast gejaagd, maart 1995, hïerover Aantal gokkasten moet drastisch worden verlaagd, in: NRC, 31 maart 1995, p.7.

37. Verbod gokkasten wordt uitgebreid tot "droge horeca', in: NRC, 25 febr. 1994, p. 3. 
Natuurlijk blijft het een bedenkelijke ontwikkeling, dat bedoelde speelautomatencontroleurs de, in hoofdstuk 1.1 te bespreken, ruime bevoegdheden van afdeling $5.1 \mathrm{Awb}$ in handen kunnen krijgen.

Van wege de evidente moeilijkheden die kunnen ontstaan door het sluiten van convenanten dringt het kabinet aan om aanwijzingen voor het gebruik van convenanten op te stellen ${ }^{38}$ en, daarnaast, om te onderzoeken of een, in het kader van de Awb op te stellen, wettelijke regeling voor bestuurlijke overeenkomsten zinvol is. ${ }^{39}$ Daartoe wordt vooral nagegaan of beschikkingsvervangende overeenkomsten in het milieurecht mogelijk zijn en of convenanten algemeen verbindend zijn te verklaren.

\section{\& 10.3 Recht in beweging}

In het kamerstuk Recht in beweging blijft het rechtsstatelijk aspect van handhaving belicht. De kwantiteits- en kwaliteitsproblemen met betrekking tot het overheidstoezicht op regelnaleving doen verwijzen naar algemeen menselijke waarden. "Een verbeterde rechtshandhaving houdt in een consequente herinnering aan de rechten en plichten die uit onze rechtsorde voortvloeien. Dit is echter maar half werk, als niet tegelijkertijd een zorgvuldiger omvang met het recht als zo danig uitgang mist. In een democratische em sociale rechtsstaat gaat het om rechtwaardige verhoudingen in een samenleving (...) Wij hechten waarde aan de vrijheid en de pluriformiteit van onze samenleving; godsdienstig, levensbeschouwelijk, cultureel, economisch en politiek. Overheidsbeleid, regelgeving en rechtshandhaving moeten die vrijheid beschermen, niet verstikken." 40

De nota is een algemeen justitieel beleidsplan. Daarom zijn slechts pijlers, waarop wetsuitvoering mag steunen, uitgezet.

De justitiële organisatie moet aan de verjongingskuur. Een moderne mantel ligt klaar om haar oude jas te vervangen. Bovendien moet het ministerie wan justitie de departementale kerntaken (her)formuleren ${ }^{41}$ en er vervolgens krachtig uitvoering aan geven. Dit beraad op kerntaken van het ministerie van justitie richt zich bewust op scheiding tussen beleidsbepaling en beleidsuitvoering. De plannen voor de reorganisatie, die volgens voorstel vanaf 1995 feitelijk gestalte krijgt, geven ruimte aan het op afstand zetten van uitvoerende diensten. Deze 'sterk autonome operationele eenheden" staan weer onder coördinatie van een bestuursraad (vertegenwoordigend de algemene top van justitie, waar onder de secretaris-generaal en de directeuren-generaal) vallen. Om beleidsuitvoering en beleidsbepaling op elkaar af te stemmen, moet er een besturingseenheid, als 'politieagent op een

38. De Jusritiebegroting 1995, TK 1994-1995, $23900 \mathrm{VI}$, nr. 2, p.4, meldt dat concept-aanwijzingen voor het gebruik van convenanten zijn opgesteld en dat zij ter advisering naar de Raad van State zijn gegaan.

39. Kabinetssrandpunt bestuarlijke overeenkomsten. TK 1993-1994, 23400 VII, nr.35, pp. 1-7. De reedis, 0.g.v. aanbevelingen van de CTW, ge formuleerde aanwijzingen voor hel gebruik van convenanten liggen ter advisering bij de Raad van State.

40. Recht in beweging; Een beleidsplan woor justitie in de komende jaren, TK 1990-1991, $21829, \mathrm{nr} .11, \mathrm{p} .18$.

41. Zie ook P.J. Baauw, Justitiebegroting 1994, in: AA-katern 49, now./dec. 1993, pp.2307-2311, i.h.b. p. 2307 . 
kruispunt', komen. Het klinkt als een klok. Maar het is nog de vraag, of de reorganisatie inderdaad de vertraging uit de wijzers haalt, zodat het uurwerk voortaan de juiste tijd aan kan geven. De twijfel overheerst kennelijk: ten eerste, justitie geeft niet aan hoe het kerndepartement 'het geheel' bestuurt; ten tweede, wat betreft de bestuursraad ontbreekt het aan duidelijkheid over taken, bevoegdheden en verantwoordelijkheden; en ten derde, de besturingseenheid ontwikkelt zich mogelijk als 'bureaucratisch monstrum', waar ambtenaren snel problemen op af wentelen. ${ }^{42}$ Van wege de onzekerheid, waardoor de uitvoering van beleid voorlopig niet veilig is te stellen, vragen de kamerfracties PvdA, VVD en D'66 de minister van justitie om meer duidelijkheid ter zake. ${ }^{43}$ Van uit de Tweede Kamer klinken zorgelijke geluiden over de verandering van het ministerie van justitie en overige reorganisaties bij de rijksoverheid. Met spijt wordt geconstateerd, dat bij dergelijke reorganisaties het feit zich "wreekt dat er geen algemene richtlijnen" voor verzelfstandigings- of privatiseringsoperaties zijn. ${ }^{44}$ Met oog op de omstreden reorganisatie bij justitie onderkent de staatssecretaris van het betrokken departement weliswaar de gevaren van verzelfstandiging (vooral de externe vorm er van, denk aan per 1 juli 1994 'op afstand' van het ministerie van justitie gezette Centraal Orgaan opvang Asielzoekers), maar steunt hij vervolgens de voortgang van de veranderingsoperatie: verzelfstandiging, die wel een "verstandige fasering" moet kennen, met eenduidige afspraken en strak toezicht kan doelmatigheidsbevorderend werken en "meer maatwerk" opleveren. ${ }^{45}$

Overigens is thet, volgens bedoelde beleidsnota, de bedoeling de samenleving tijdig bij rechtshandhaving te betrekken. Bedoeld wordt justitiabeien te wijzen op eigen verantwoordelijkheden op het terrein van de totstandkoming, toepassing en handhaving van rechtsregels. Justitie streeft naar samenwerking tussen overheid en maatschappij. De bijdrage van burgers manifesteert zich mogelijk in bij voorbeeld een preventieve aanpak van (kleine) criminaliteit.

In de samenwerking tussen samenleving en staat mag de overheid zich echter niet aan haar eigen zorgplichten onttrekken. Met de oprichting eind april 1994 van een 'kliklijn', waarmee burgers medeburgers die ze verdenken van uitkeringsfraude kunnen aangeven, geeft de overheid helaas een slecht voorbeeld. Van uit haar eigen falende fraudecontrolestelsel, brengt de overheid op ongeoorloofde wijze burgers op boze gedachten. Terecht wordt het negatieve karakter van zo'n kliklijn onderkend. ${ }^{46}$

Op Europees niveau wordt voor zo'n kliklijn echter weer niet terug gedeinsd. De Europese Commissie stelt eind 1994 een gratis telefoonlijn open, waarop iedere burger 'in eigen taal en op basis van volledige vertrouwelijkheid', mogelijk tegen beloning, infor-

42. Addus de kritiek van de adviesbureaus Twijnstra Guddle en Berenschot, weer gegeven door $\mathbb{R}$. Schoof, Reorganisatie justitie "niet veramwoord": taak van top justitie 'onduidelijk", in: NRC, 12 okt. 1994. pp. 1 -3.

43. Kamer eist opheldering ower reorganisatie van justitie in: NRC, 13 okt. 1994, p.3.

44. D'66-kamerlid Scheltema, geciteerd in: Kamer eist opheldering over reorganisatie van justitie, in: $\mathrm{N} R \mathrm{RC}$, 13 okt. 1994, p.3.

45. R. Schoof en K. Versteegh, Reorganisatie van Justitie moet "op volle krachr' doorgaan, in: NRC, 14 okt. 1994, p. 2 .

46. "Kliklin' sociale fraude Apeldoorn opgeheven, in: NRC, 9 mei 1.994, p.7. 
matie kan geven over vermoedelijke fraudegevallen, weliswaar, met gelden van de Europese Unie. Met deze maatregel wil de Europese Commissie haar opsporende roll inzake fraude, op misbruik waarvan in eerste instantie nationale staten zelf toezien, vergroten. Naast het openstellen van een kliklijn, is het (voorlopig nog) de wens van de Europese Commissie om een 'zwarte lijst' aan te leggen waarop zware overtreders van subsidiemaatregelen worden genoteerd, zodat zij voortaan worden uitgesloten van financiële steun. ${ }^{47}$ Meest drastische maatregel lijkt nog de, door de christen-democratische fractie van het Europees Parlement ex art. $138 \mathrm{c}$ Verdrag van Maastricht geïnitieerde, instelling van een tijdelijke enquêtecommissie die een diepgaandl onderzoek moet verrichten naar misbruik van Europese fondsen. ${ }^{48}$

\section{$\S 10.4$ Strafrecht met beleid}

Nadere uitwerking van de doelstellingen, inzake justitiële werkzaamheden, geeft het eerste beleidsplan van het openbaar ministerie. ${ }^{49}$ Voort bordurend op de WRR-gedachte, dat rechtshandhaving inherent aan de rechtsstaat is, luidt het beleidsmotto: "Rechtshandhaving impliceert ook rechtsbescherming." 50

Die rechtsbescherming bepaalt tegelijkertijd de keuze voor een handhavingsmiddel. Uitgangspunt is aan het handhavingsinstrument, dat het meeste rendement heeft, prioriteit te geven. Zo kent strafrechtelijke interventie wel kwaliteitseisen van rechtsgehalte, zekerheid, snelheid als mede aard en zwaarte van sancties. Vraag hierbij blijft wiens bescherming zij dient: dat van (potentiële) dader, slachtoffer of gezagsgetrouwe burger. Strafrecht is niet altijd het eerst aangewezen.

Van uit het driestappenbeleid moet het openbaar ministerie de voor- en nadelen van verschillende handhavingsregimes en sanctiesystemen verplicht en systematisch afwegen. Dit driestappenbeleid omvat de volgende discussiepunten. ${ }^{51}$ Ten eerste, is strafrechtelijke handhaving noodzakelijk, met andere woorden, is de norm niet anders afdwingbaar. Ten tweede, in welke mate en met hoeveel capaciteit moet handhaving plaats vinden. Ten derde, welke uitwerking wordt aan de vooraf gaande keuze gegeven: volledige of voorwaardelijke handhaving, dat wil zeggen onder meer vereenvoudiging van afdoening, verkorting van strafvorderingsprocedures of strafrechtelijk ingrijpen op lager niveau afhankelijk van andere overheidssectoren, maatschappelijke organisaties en dergelijke. Met de taak de geloofwaardigheid van rechtshandhaving te versterken, heeft het openbaar ministerie een signalerende en sturende, dus preventieve, rol.

47. B. Donker, Brussel stelt "kiktijn" in voor fraude EU-geld: 06-lijn voor Eura-burger, in: NRC, 12 now. 1994, p.18.

48. EVP wril enquête 'Europese fraude', in: NRC, 9 febr. 1995, p. 20.

49. Strafrecht met beleid; Beleidsplan van het openbaar mimisterie voor de jaren 1990-1995, TK 1990-1991, 21833, nrs. $1-2$.

50. Strafrecht met beleid, a.w., p.4.

51. Straffecht met beleid, a.w., p.9. 
Zorgvuldige sturing geschiedt op, ten eerste, arrondissementelijk niveau. Dit wordt aanschouwelijk in het politieoverleg, in het overleg met de bijzondere opsporingsdiensten en in het driehoeksoverleg. Tijdens de gesprekronden komen vooral omvang en methode van opsporing of controle aan bod. Richting wordt gegeven op, ten tweede, ressortelijk en landelijk niveau. In samenspraak met landelijke opsporingsdiensten en allerlei andere organen, die een beroep doen op handhavingscapaciteit, worden de prijskaartjes van het openbaar ministerie vastgesteld. Aldus is de (in dit geval op economische gronden te nemen) beslissing, of strafrechtelijke handhaving wel is geboden, in het geding.

Vooral wat betreft de (strafrechtelijke) handhaving van beleidsinstrumentele regelgeving zijn deze wederzijdse relaties essentieel. Om de samenwerkingsverbanden, waarbij onderlinge gegevensuitwisseling tussen de verschillende handhavingsdiensten onmisbaar is ${ }^{52}$, optimaal te laten functioneren moet het openbaar ministerie specialistische kennis in huis hallen. ${ }^{53}$ Het steken van de nodige energie in deze functionele relaties draagt er toe bij, "dat de juiste prioriteiten worden gesteld, de relevante zaken worden aangebracht en bovendien in een mate dat de rechterlijke organisatie haar binnen redelijke termijn kan verwerken". 54

Van strafrechtelijke bemoeienis is sprake als inspecteurs, controleurs of toezichthoudende instanties (als zelfstandige bestuursorganen) opsporingsbevoegd zijn. Daardoor vallen zij onder het gezag van een officier van justitie (art. 142 juncto art. 148 WvSv). ${ }^{5 s}$ Overigens "moeten uitsluitend die bijzondere opsporingsambtenaren opsporingsbevoegdheid hebben die daarvan een noodzakelijk en daadwerkelijk gebruik maken". ${ }^{56}$

Hoewel uitoefening van tóezicht dus niet onder het gezag van het openbaar ministerie staat, is wel gemeend dat "art. 4 RO voldoende aanknopingspunten biedt voor een productieve rol van het openbaar ministerie". ${ }^{57}$ Juist wat betreft preventief controlebeleid van een toezichthoudend orgaan (waarvoor tegenwoordig, gelet op efficiency - en afslankingsoperaties, de toezichthouders zelf al minder interesse kunnen tonen) is "sturing door het openbaar ministerie nodig en tegelijkertijd gellegitimeerd". ${ }^{58}$ Bij deze overigens, wat betreft bepaalde toezichthoudende zelfstandige bestuursorganen, niet van alle zin ontdane gedachte zijn wel vraagtekens te zetten. Wordt het openbaar ministerie niet een te grote macht toebedeeld? Vóór het in handen van het openbaar ministerie leggen van verantwoordelijkheid voor controlerend onderzoek pleit, dat bedoelde instantie daarmee "de verantwoordelijkheid verkrijgt woor alle onderzoekshandelingen die uiteindelijk strafvorderlijk relevante gevolgen kunnen hebben, waardoor het openbaar ministerie ook meer feitelijke greep zal krijgen op de als gedogen en administratieve afdoening verkapte

52. Hienover Y. Buruma, De strafrechtelijke handhawing wan bestuurswerten, Arnhem, 1993, pp.172-182.

53. Strafrecht met beleid, a.w., p.20.

54. J.R.H. Kuyper, Rechtshandhaving en het openbaarministerie; Enkele beschowwingen over de verthouding van het OM tot de wetgevende departementen, in: Magistraat met beleid: de ovj en zijn omgeving. Opstellen aangeboden aan mi $\mathrm{C} C$. van Steenderen bij afscheid als hoofdofficier van justitie te Amsterdam op 25 sept. 1992, Arnhem, 1992, pp.53-63, i.h.b. p.54.

55. Over die coördinatie van het OM, Y. Buruma, a.w., pp.159-172.

56. Strafrecht met beleid, a.w., p.21.

57. J.R.H. Kuyper, t.a.p., p.62.

58. J.R.H. Kuyper, t.a.P., p.62. 
sepots"; Er tégen aan te voeren is het nadeel, dat het "OM in dat geval ook verantwoording moet dragen voor controles die louter in het verlengde van het bestuurlijke werk liggen". ${ }^{59}$ Wordt desondanks gekozen voor een positieve benadering van de eerste vraag, dan doemt een tweede vraag op: is het idee wel uitvoerbaar, gegeven de nú al zorg barende overbelasting van het openbaar ministerie? Om nog maar te zwijgen van de toekomst. Denk alleen al aan de, door het openbaar ministerie bij de Politiewet 1993 verkregen, competentieuitbreiding. De efficientie en realisatie van het, door verkrijging van de bevoegdheid om over het beheer van de politie mee te beslissen, toegenomen sturingsterrein van het openbaar ministerie wordt met gemengde gevoelens afgewacht. ${ }^{60}$

Het ontbreekt het openbaar ministerie nog aan helder zicht op specifiek recherchewerk. Vandaar enige maatregelen ter zake. Uitbreiding van bijzondere opsporingsdiensten is alleen mogelijk na overleg met het openbaar ministerie. Bovendien zal het openbaar ministerie een hedendaags handhavings- en sanctiebeleid moeten uitstippelen met medewerking van (technisch/wet- en regel)deskundige ambtenaren belast met toezicht en/of opsporing. En ook zijn specifieke beleidsterreinen als aandachtsvelden van het openbaar ministerie aangewezen. Milieu, verkeer en fraude hebben brede belangstelling van het openbaar ministerie.

Het uit bedoeld beleidsplan sprekend optimisme, over de vervanging van strafrecht door bestuursrecht als handhavingsmiddel, is niet vrij van kritiek. ${ }^{61}$ Ten eerste: is bestuursrecht wel een handhavingsstelsel? Ten tweede: is de organisatie van dit zo genaamd bestuursrechtelijk handhavingssysteem niet vol gebreken? Belangrijker dan deze vragen, waarvan de eerste een bevestigend antwoord kan krijgen en de tweede in een positief licht kan worden gezien bij de gedachte aan de waarborgen van het immers ook op bestuursrechtelijke handhaving toepasselijke art. 6 EVRM, is het volgende.

Boven al luidt de vraag namelijk, "of het groter maken van het aandeel van de bestuursrechtelijke afdoening van laakbaar geachte feiten de macht van het bestuur niet te zeer vergroot". ${ }^{62}$ Dat met het buiten spel zetten van het strafrecht als handhavingsmiddel ook het OM overboord gaat, is overigens niet voor iedereen een overwegend bezwaar. Want "het $O M$ is geen rechtshandhaver op elk terrein (slechts op die terreinen waartoe de wet het orgaan expliciet een opdracht heeft gegeven of bevoegd heeft verklaard) [...] en kan derhalve niet worden gezien als de grote coördinator van de bestrijding van al het onrecht". ${ }^{63}$ Wel rijzen reële twijfels omtrent aantasting van het machtsevenwicht op nationaal en, sterker nog, op Europees niveau. Eerder dan het ontbreken van controle

59. Y. Buruma, a.w., p.168.

60. T.M. Schallken, Het OM in het nieuwe politiebestel, in: DD, nr.4, 1994, pp.335-339.

61. J.R.H. Kuyper, t.a.p., pp.58-63.

62. H. de Doelder, Handhaving van economische regelgeving; Is door de bestwurlyke handhaving hetprimaat was de strafrechtelijke handhaving doorbroken of geldt het strafrecht als ultimum remedium?, in: J.A.E. Verwaele, Bestuursrechrelijke toepassing en handhaving van gemeenschapsrecht in Nederland, Deventer, 1993, pp.137-147, i.th.b. p.141.

63. H. de Doelder, t.a.p., p.143. 
door het openbaar ministerie, is het verlies aan deugdelijke parlementaire controle mogelijk maatstaf.

\section{$\$ 10.5$ Zicht op wetgeving}

De tendens zet zich voort. Ondanks de kritiek. Opnieuw breekt een rapport rigoreus met de routine van rechtshandhaving via strafrecht. ${ }^{64}$ Het zonder meer strafrechtelijk sanctioneren is zinloos. De Nederlandse overheid stelt tot mu toe wel fraaie regels. Maar zij moet zich voortaan beter bezinnen op de betekenis er van voor de samenleving. Verfrissing van de oude uitvoerings- en handhavingscontext is noodzakelijk. Daar waar de calculerende burger het strafrecht ondermijnt. Of juist daar waar het commune handhavingsrecht te véel nadeel brengt. Weg dus met de horizon van heilloosheid.

Welk handhavingsmiddel scoort het meeste effect? Het antwoord hierop begint bij analyse van wetgeving. Proces en kwaliteit van wetgeving zijn coherent. Tijdige en stelselmatige betrokkenheid van uitvoerders bij regelgeving is even belangrijk als goede systematiek en techniek van wetgeving. Een overheid kan "in haar wetgevende taak alleen dan maar de vereiste kwaliteit leveren, wanneer zij ook zicht heeft en houdt op de samenleving"t. ${ }^{\text {t.5 }}$ Het is tijd voor herstel van het evenwicht tussen de verantwoordelijkheden van overheid en maatschappij. ${ }^{66}$ Anders gezegd, de verhouding tussen gemeenschappelijke regelingen en eigen verantwoordelijkheid is aan herijking toe. ${ }^{67}$ Hierbij past, zo mogelijk, wettelijk gestructureerde en geconditioneerde ${ }^{68}$ zelfregulering. ${ }^{69}$ Aanwijzing voor de regelgeving 8 schrijft het volgende voor. "Bij het bepalen van de keuze voor een mogelijkheid tot overheidsinterventie om een doelstelling te bereiken wordt zo veel mogelijk aangesloten bij het zelfregulerend vermogen in de betrokken sector of sectoren." 70 Handhaving van een kaderwet, nader vorm gegeven op het niveau dat zich daartoe het beste leent, is waarschijnlijk meest effectief. Binnen dit concept passen zelfreguleerders, convenantsluiters en zelfstandige bestuursorganen. "

64. Zicht op wetgeving; Beleidsplan van het ministerie wan justitie woor de verdere ontwikkeling en uitvoering van her algemeen wetgevingsbeleid, gericht op werbetering wan de rechtsstatelijke/bestuurlijke kwaliteit vam het overheidsbeleid, TK 1990-1991, 22008, wrs. 1-2.

65. 2icht op wetgeving. a.w., p.11.

66. Zicht op wetgeving, a.w., p.26.

67. Keuzes woor de toekomst (regeerakkoord 1994), TK 1993-1994, 23715, nr.11, p.3.

68. Door "sturingsbelang" (stellen van randvoorwaanden) en "waarborgbelang "van het rijk blijft bij zelfregulering de relatie overheid - burger. J.A.F. Peters, Zelfregulering zonder owerheid?, in: OB, nr.2, 1994, pp. 20-24.

69. Zicht op wetgeving, a.w., p.67; Over zelfregulering M. van Drie:, Zelfregulering; Hoog opspelen of thuisblijuew, diss. RUU, Deventer, 1989; Ook, zij het radicaler, N.J.H. Huls en H.D. Stout (red.), Reflecties op reflexief rech, Zwolle, 1992; Ph. Ejilander (red.), Overheid ${ }_{\text {en }}$ zelfregulering, Zwolle, 1993.

70. C. Borman, Aanwijzingen voor de regelgewing en andere voor de regelgeving relevante aanwijzingen, Zwolle, 1993, p.49.

71. E.M.H. Hirsch Ballin, De gekoppelde staat, in: L.A. Geelhoed, E.M.H. Hirsch Ballin, J.M. Polak, U. Rosenthal, 1.Th.M. Snellen, en 1.C. van der Vlies (red.), Wetgewing in beweging, a.w., pp.61-75, i.h.b. pp. $72-74$ 
Wel geldt een ware waarschuwing. Het streven naar deregulering krijgt snel een averechtse uitwerking. Bestuur op afstand werkt ongewenst vaak detaillisme en bureaucratische regelstelling in de hand. Misschien nog wel vaker dan in klassieke wetgeving gebruikelijk is. Door verruiming van delegatiemogelijkheden ontstaat een van-de-regenin-de-drup-effect. ${ }^{7}$ Ter illustratie dient de door de vice-president van de Raad van State, uit het jaarverslag van die raad over 1993, getrokken conclusie: "Deregulering is geen levend verschijnsel meer. [...] Van soberheid bij het maken van wetten is in Nederland geen sprake meer." ${ }^{73}$ De 'oogst van het kabinet Lubbers-Kok', in belangrijke mate beinvloed door implementatie van Europese regelgeving, is dat in 1993865 wetsvoorstellen voor advies aan de Raad van State zijn voorgelegd. ${ }^{74}$ Daarvan zijn er 818 afgehandeld. Ter wergelijking: in 1992 betreffen het 667 wetsvoorstellen. Hiervan zijn er 664 in behandeling genomen. Duidelijk voorbeeld van teleur stellende deregullering is de eind februari 1994 voorgestelde Mediawet. Uit oogpunt van deregulering wordt dit wetsvoorstel terecht een "horreur" genoemd. ${ }^{75}$

In het algemeen zijn de volgende redenen voor overbodig omvangrijke wetgevingscomplexen aan te dragen: "a. het vaststellen van nieuwe regels naast of als aanvulling op bestaande, zonder nauwkeurig na te gaan of die bestaande regels niet wat anders zouden kunnen worden toegepast, al dan niet na enige wijziging [...]; b. het maken van vele uitzonderingen op een hoofdregel, vaak ten behoeve van maatschappelijke groepen die de weg in Den Haag kennen [...]; en c. een sterke (ambtelijke) neiging tot detaillisme, perfectionisme en "dichttimmeren' ". ${ }^{76}$ Met betrekking tot het gestelde onder a. geldt tegenwoordig de eis van noodzakelijkheid. Aanwijzing voor de regelgeving 6 , eerste lid, stelt: "Tot het tot stand brengen van nieuwe regelingen wordt alleen besloten, indien de noodzaak daarvan is komen vast te staan." 77

Het probleem van een onverhoopte toename van regels en de daarbij komende handhavingsmoeilijkheden plushandhavingskostenstijging alsmedeonverschilligheid vanburgers tegenover het rechtssysteem keren ook terug bij gesubdelegeerde wetgevers in de sfeer

72. W.G.J.M. van de Camp, Voortvarend wetgeven door de praktijk beschouwd, in: RegelMaat, nr.4 1994 , pp.168-174, i.h.b. p.172.

73. Raad wan State stelt record toename vant wetten in 1993 vast, in: NRC, 13 april 1994, p.2; Ook Deregulering is geen beleid'sdoelstelling meer, in: NJB, nr.16, 22 april 1994, pp.553-554; De Toetsingscommissie voor wetgeving komt tot het zelfde oordeel, als de Raad van State, in haar Jaarverslag 1993/1994, TK 23400 VI, nr.49. De commissie-Kortmann constateert: a te weinig deregulering; b. gebrek aan continuiteit in wet- en regelgeving, waardoor hoge uitvoeringslasten ontstaan en het rechtszekerheidsbeginsel vermindert in waarde; $c$. de bereidheid om te volstaan met eenvoudige regels is ver te zoeken; en $d$. de aandacht voor feitelijke uitwoerbaarheid en handhaafbaarheid van regels is nog nihil; Aanslutitend stelt C.A.J.M. Kortmann, Kroniek van het staatsrecht, in: kroniekenbijlage NJB, mr.33, 23 sept. 1994, pp. 4649 , i.h.b. pp. $48-49$, dat ontregeling "uit' is. Z.i. is het dereguleringsstreven "een zachte dood" gestorven.

74. Raad wan State, Jaarverslag 1993, april 1994, p.?

75. E. Jurgens, Mediawet 1994: te weinig, te laat, in: MF, nr.4, 1994, p.37.

76. C.A.J.M. Kortmann, Ontregeling, in: NJB, nr.39, 4 nov. 1993, pp.1375-1380, i.h.b. p.1377.

77. C. Borman, a.w., Zwolle, 1993, p.47. 
van functionele decentralisatie. Denk aan de ingewikkelde, technische ${ }^{78}$, bijna in het overdrevene geregelde, snel verouderende respectievelijke landbouw- en zaaizaad- als mede plantgoed-, flora- en fauna-, kansspel-, wegenverkeers- ${ }^{79}$, effectenverkeers-, telecommunicatie- of persoonsregistratiewetgeving, waarmee de burger veelal onbekend is en ook nog eens op kosten wordt gejaagd ${ }^{80}$. Overigens bepaalt aanwijzing voor de regelgeving 13 tegenwoordig: "Bij de keuze voor een bepaalde regeling wordt gestreefd naar zo beperkt mogelijke lasten voor burgers, bedrijven en instellingen, voor zover niet uitdrukkelijk het opleggen van lasten wordt beoogd." ${ }^{81}$ Zo maakt het kabinet-Kok in zijn regeerakkoord duidelijk dat regelgeving en in het bijzonder aan regelgeving verbonden administratieve lastendruk moeten worden verminderd tot het minimaal noodzakelijke. ${ }^{82}$ Neemt het kabinet dit streven serieus, dan doet het kabinet er verstandig aan verlaging van administratieve 'taakstellend' op te leggen. Daaraan te koppelen is dan een toetsing door het ministerie van economische zaken van wetsontwerpen op interne en externe kosten van regelgeving. ${ }^{83}$

Om het inzicht in de kosten en baten van deregulering beter zichtbaar te maken, luidt een pleidooi een Rekenkamer voor de deregulering op te richten. ${ }^{84}$ Annex daaraan wordt aandacht gevraagd voor het ontwikkelen van een, binnen korte termijin te realiseren, wervend en helder hervormingsbeleid ten aanzien van uit de hand gelopen deregulering; "a. Regels worden afgeschaft wanneer ze niet nodig zijn om een marktfeilen te corrigeren of om een niet-economisch algemeen bellang na te streven; $b$. Regels worden aangepast of afgeschaft als de voordelen niet opwegen tegen de kosten; en c. Indien mogelijk worden op zich zelf wenselijke regels vervangen door een alternatief met minder marktverstorende werking en lagere kosten." ${ }^{85}$ Om dit beleid gestalte te gewen wordt adequate actie verwacht van een mogelijk aan te stellen regeringscommissaris voor deregulering, die wordt ondersteund door onafhankelijke deskundigen. Besluiten ter vermindering. van regeldruk moeten goedgekeurd worden door een, daartoe speciaal in het leven te roepen, ministeriële commissic voor deregulering. Het kabinet-Kok, dat zich in september 1994 met pracht en praal presenteert, lijkt te luisteren. Waarachtig weerklinkt de wens van PvdA, VVD en D'66 om, onder leiding van een ministeriële commissie, te komen tot een project voor wetgevingskwaliteit, marktwerking en deregulering ten einde

78. Hoewel $86 \%$ (wan 101 Eerste en Tweede Kamerleden) het niet accepteert, dat een wet zo geschreven is dat alleen deskwndigen die wet kunnen tezen, gaat het $76 \%$ weer te ver om te stellen dat leesbararheid bowen technische correctheid moet gaan. Zie 'Een ieder wordt geacht de wet te kennen', in: NJB, nr. $45 / 46,16$ dec. 1993 , pp. 1637-1638, i.h.b. p. 1637.

79. Volgens M. Otte, Her stelsel van gedragsregels in het wegverkeer, Arnhem, 1993, vereist het vertrouwen missen verkeersdeelnemers inderdaad gedetailleerde regelgeving.

80. Denk aan de kosten voor het vast stellen wan privacy reglementen in de (semi-) publieke sector en voor thet aanmelden van persoonsregistraties door het bedrijfsleven. Betalen yoor melden bij Registratiekamer, in: OMn, nr. 7/8, 1993, p. 200.

81. C. Borman, a.w., p.56; Aanwijzing 14 betreft trowwens een soortgelijke bepaling voor de overheid.

82. Keuzes woor de toekomst, TK 1993-1994, 23715, nr.11, p.3.

83. I. van der Bij, Kosten wan regelgeving, in: RegelMaat, nr.6, 1994, pp.227-233, i.h.b. p. 233.

84. K. Koedijk, Pleidooi voor Dereguleringskamer, in: NRC, 24 maart 1994, p. 19.

85. C.G. Koedijk en J.J.M. Kremers, Niewwe regering moet afrekenen met Nederlandse regelziekte, in: NRC, 6 mei 1994, p.9. 
de beoogde versterking van de economische dynamiek kracht bij te zetten. ${ }^{86}$ Eind december 1994 maakt een, wan uit het ministerie wan economische zaken en het ministerie van justitie uitgaand, plan van aanpak ${ }^{87}$ melding van inschakeling van zo'n ministeriële commissie. Deze commissie gaat na of bestaande regels nog wel goed zijn te handhaven of dat er misschien andere, betere manieren zijn om de doelstelling van beleid te realiseren. ${ }^{88}$ De commissie werkt vooral van uit het uitgangspunt dat verantwoordelijkheden (publiek/ privaat) moeten worden verdeeld. De ministeriële commissie, die zelf periodiek onderwerpen vaststelt en deze voorlegt aan de ministerraad, waarna de verantwoordelijke ministers de uitwerking ter hand nemen, kent een voorportaal: een, uit vaste of betrokken ministers, kabinetsleden met een 'standing invitation' en mogelijk interne of externe deskundigen samengestelde, ambtelijke commissie met voorbereidende en regisserende functie. ${ }^{89}$ Het pragmatische werk van de commissie moet de motto"s van het plan van aanpak, te weten 'betere regelgeving, dynamischer economie en slagvaardiger bestuur', zichtbaar maken.

De wetgever is reeds aangemaand tot voorzichtigheid met bepaalde delegatie. ${ }^{90}$ Duidelijk in dit verband is de boodschap van aanwijzing voor de regelgeving 7: "Alvorens tot: het treffen van een regeling wordt besloten, worden de volgende stappen gezet: [...] d. indien overheidsinterventie noodzakelijk is, wordt onderzocht of de gekozen doelstellingen kunnen worden bereikt door aanpassing of beter gebruik van bestaande instrumenten dan wel, indien dit niet mogelijk blijkt, welke andere mogelijkheden daartoe bestaan. " 9 De wetgever dient zich "rekenschap van te geven of er niet al wetgeving bestaat die het betrokken geval beter kan regelen dan weer een nieuwe specifieke wet". ${ }^{92}$ In het verlengde hiervan luidt het betoog dat de wetgever aansluiting moet zoeken bij open normen in algemene wetgeving, die door de jurisprudentie verder concrete invulling kunnen krij-

86. Kentex woor de toekomst (regeerakkoord 1994), TK 1993-1994, 23715, nr.11, p.23; Vgl. Begroting conomische zaken., TK 1993-1994, 23900 XIII, mr. 7, p.7.

87. Met üt dit plan (Brief van de ministers wan ecomomische zaken en justitie over het project Marktwerking. deregulering en wetgevingskwaliteit ter versterking van de economische dynamiek. TK 1994-1995, 24036, n..1) sprekende voornemen voor 1995 is, dat in de eerste plaats wordt bekeken of een aantal concrete fercenen -als monopolievorming in taxivervoer en advocatuur-voor liberalisering in aanmerking komt en in cen concurrentièle context kan wonden geplatst. In de tweede plaats is het streven om eind 1995 te rapporteren over vier wetgevingsthema"s: a. de kwaliteit en vereenvoudiging van EG-regelgeving hierover rapporteert ook de CTW-commissie-Koopman en hiemaar doet tevens een onafhamkelijke Europese groep t.w. de Molitor groep studie. J.M. Bonnes, Europese berichten, in: RegelMaat, nr. 6 , 1994, pp. 247-250, i.h.lb. p.249, acht het zinwol dat de nationale en de Europese werkgroep " elkaar aamullen en in ieder geval geen dubbel werk verrichten" ${ }^{*}$; b. de beperking wan plan- en informatieverplichtingen; $c$. de particuliere betalingen voor collectieve voorzieningen; end. certificering alls alternatief voor overheidsregulering. Zie ook commentaar op het plan Marktwerking, deregulering en wetgevingakwaliteit, in: NJB, nr.1, 6 januari 1995, pp.35-36.

88. Over ditplan 'Marknwerking "deregulering en wetgevingskwaliteit', in: NRC, 20 dec. 1994, pp. 1/17. De knip met het mes moet leiden tot het weg memen van concurrentiebeperking en monopolievorming.

89. Marktwerking, deregulering en wetgevingskwatiteit ${ }_{*}$ TK 1994-1995, 24036, nr.1, pp.4-5.

90. C.A.J.M. Kortmann, t.a.p., p.1378.

91. C. Borman, a.w., p.46 (aanwijzing 46).

92. C.M.Th. Lindo, Prikkelend priwatrecht als alternatief voor wetgeving; Het systeem De Ru, in: NJB. nr.39, 4 now. 1993, pp.1406-1410. 
gen. ${ }^{93}$ In dit kader zijn de mogelijkheden die civiel recht biedt, in het bijzonder art. 6:162 BW, het meest aangewezen. De betamelijkheidsnorm is kennelijk aantrekkelijk uit oogpunt van herkenbaarheid, flexibiliteit, rechtszekerheid, legitimiteit en subsidiariteit . Niet iedereen deelt de voorkeur voor open normstelling. Vage normen bieden een geringe rechtvaardigheid van de regel, een geringe mogelijkheid de rechterlijke activiteit te controleren, een geringe rechtsgelijkheid en er gaat een geringe voorspelbare kracht van uit. 2

Bij een reelle overtuiging van de noodzaak van deregulering, is het in bepaalde gevallen onvermijdelijk om de consequentie te trekken dat verschijnselen als zelfregulering ${ }^{95}$ en convenanten uit de mode moeten raken. ${ }^{96}$ De vraag is te stellen of die lijn ook niet voor zelfstandige bestuursorganen ${ }^{97}$, die toezien op de nalleving van wet- en regelgeving, moet worden getrokken. Kenbaar is de wens, om de meeste toezichthoudende instanties af te schaffen. In die optie kan kennelijk met name het zelfstandig bestuursorgaan Registratiekamer worden opgeheven. In plaats van de disproportionele belasting van collectieve en particuliere sector, die uit de Wpr voort vloeit, is een door de burger zelf te onderhouden ${ }^{98}$ "piep-systeem, ondersteund door actief rechterlijk onderzoek" op privaatrechtrechtelijke basis ${ }^{59}$, het alternatief. ${ }^{100}$ Deze rigoreuze stellingname wordt niet door iedereen onderschreven. Afschaffing van de Registratiekamer, op grond wan het feit dat die kamer alleen bezig zou zijn met het 'registreren van registraties', berust op een oneigenlijke motivering: van de 35 personen, die begin 1994 bij de Registratiekamer

93. H.J. de Ru, Stimulerende wetgewing of stimulerend recht, preadvies Vww, Alphen ald Rijn, 20 maart 1993, pp. 94-114.

94. In de ogen van H.D. Stout, Het labyrint wan de wetgeving en de alternatieve strategieën wan De Ru en. Simring op maat, in: RegelMaat, nr.3, 1994, pp.97-102 -zich baserend op J.M. Barendrecht, Recht als model woor rechwardigheid; Beschouwing en ower wage en scherpe normen wer binding aan het recht en over rechtsworming. diss. KUB, Deventer, 1992-kan De Ru's stelling "dat open normen de rechtvaardigheid en rechtszekerheid dienen niet zonder meer worden geponeerd" (p.101). Volgens haar mist Die $\mathbb{R u}^{\text {"s }}$ betoog "normatieve onderbowwing en theoretische reflectie" (p.101).

95. I.v.m. tegenvallende deregulering verricht de toetsingscommissie voor wetgevingsprojecten onderzoek naar het ontwikkelen $v$.e. toetsing skader voor toepassing van wettelijk gestructureerde zelfregulering. TK 1993 1994, 23400 VI, nr.5.

96. C. A.J.M. Kortmann, t.a.p.,p.1378; Vgl. minder uitgesproken, maar hoewel wetgevingsalternatieven een kans gevend-met de nod Hge scepsis t.a.v. zelfregulering, convenamten, beleidsregels, richtlijnen, gedragscodes en rechtspraak, J.M. Polak, De wetgeving van het Depantement wan Justite, in: NJB, nir. 1, 6 jan. 1995, pp.7-15, i.h.b. pp.8-9; Daarentegen ziet H.J. de Ru juist wel plats voor zelfregulering. Hij verwijst naar het, door de voedselbranche zelf gehandhafde, certificeringsstelsel., waardoor Warenwetinspecteurs slechts langs de zijlijn staan.

97. Dat doet resoluut C.A.J.M. Kormann, Dewrange wruckien van een megalomane overheid, lezing Inter Provinciaal Overleg d.d. 23 juni 1994, weer gegeven in: NJB, nir.27, 15 jull 1994, pp.933-934.

98. In praktijk geschiedt het toezicht van de Registratiekamer toch al "vooral naar aanleiding van klachten". Zie B. Crouwers in antwoord namens de Registratiekamer, bij brief, d.d. 7 julli 1993, p.2.

99. R.E. van Esch en J.M.A. Berkwens, Het BWals Wor in: CR, nr. 3, 1994, pp.93-101. Autetrs berwisten het bestaansrecht wan de Registratiekamer niet. Zij tonen wel aan dat privaatrecht het publiekrecht ter zake kan verwangen.

100. C.M.Th. Lindo, t.a.p., p.1409. 
werkzaam zijn, houden zich slechts twee personen bezig met het verwerken van aanmeldingen van persoonsregistraties. ${ }^{101}$

In het kader van de onbedoelde (handhavings- en uitvoerings)belastingen die voort vloeien uit bedoelde dereguleringsparadox is het nuttig het oog te laten glijden over kwaliteitseisen van wetgeving.

Naast het proces van wetgeving is namelijk de intrinsieke waarde van wetgeving een actiepunt van overheidsbeleid. In verband daarmee zijn de, door de stafafdeling algemeen wetgevingsbeleid ${ }^{102}$ te ontwikkelen, uit te werken en te verwezenlijken, volgende $k$ waliteitseisen van wetgeving geformuleerd. Te weten: a. rechtmatigheid en verwerkelijking van rechtsbeginselen; $b$. doeltreffendheid en doelmatigheid; $c$. subsidiariteit en evenredigheid; $d$. uitvoerbaarheid en handhaafbaarheid ${ }^{103}$; e. onderlinge afstemming; en $f$. eenvoud, duidelijkheid en toegankelijkheid. ${ }^{104}$ Deze voorwaarden hebben nu ook de status van modelbepalingen. ${ }^{105}$

In het bijzonder wat betreft handhaafbaarheid van wet-en regelgeving bestaat een aanwijzing. Deze luidt: "1. Tot het treffen van een regeling wordt niet besloten dan nadat is nagegaan of in voldoende mate handhaving te realiseren valt; 2 . Hierbij wordt onderzoch of handhaving het beste langs administratiefrechtelijke, civielrechtelijke of strafrechtelijke weg dan well op andere wijze (bij voorbeeld via tuchtrecht, zie toelichting bij aanwijzing JGLvN) kan plaatsvinden." 106 " De toelichting vermeldt criteria ter beoordeling van handhaafbaarheid. Regels moeten minimale ruimte laten voor interpretatieverschillen en uitzonderingsgevallen. Zij zijn gericht op zichtbare of objectief constateerbare feiten. En ze moeten werkbaar zijn voor zowel gebruiker als adressant. ${ }^{107}$

Helaas werpen de kwaliteitseisen nog geen vruchten af. Dit blijkt uit een door de Algemene Rekenkamer tussen 1991 en 1993 verricht onderzoek naar de totstandkoming van 36 wetswoorstellen. ${ }^{108}$ De rekenkamer wijt het feit, dat de kwaliteit van wetten (nog

101. P. Ippel, Reacrie, in: NJB, nr.3, 21 jan. 1994, pp.100-101. Auteur waardeert De Ru's opvatting "slordig mag niet" (en de rechter die daarop let, als de burger 'piept") als "fictie", maar z.i. klopt De Ru's toepassing "niet met de preek".

102. Ph. Eijlander, Wetgeving in de jaren negentig. Van deregulering naar algemeen wetgewingsbeleid, in: De wet stellen, Zwolle, 1993, pp.155-172, wijst op het belang van de instelling van deze afdelling in het najaar van 1989.

103. Uitvoerbaarheid en handhaafbaarheid vormen de "roded raad. "bij wetgevingsprojecten. Justitiebegrating 1995, TK 1994-1995, $23900 \mathrm{VI}$, nr.2, p.5.

104. Zicht op wetgeving a. w; Hierover Pth. Eijlander, Wetgeving in de jaren negentig, in: RegelMaat, nr.2, 1990, pp.26-32.

105. C. Borman, a.w., pp.182-184 (aanwijzing 254); D.W.P. Ruiter, Eisen van goede regelgeving, in: RegelMaat, nr. 1, 1993, pp.4-7.

106. C. Borman, a.w., pp.52-53 (aanwijzing 11).

107. C. Borman, a.w., p.52.

108. Algemene Rekenkamer, Wetgeving: organisatie, proces en produk, TK 1993-1994, 23710, nrs.1-2, zie ook vragenlijst TK 1994 1995, 23710, nrs.3-4, waarin het kabinet positief oondeelt over een "corps van breed inzetbare wetgevingsjuristen " (p.5); Zie over parlementaire behändeling(sduur) van wetswoorstellen G. Visscher, Parlementaire invloed op wetgeving, diss. RUL, april 1994. 
steeds) te wensen over laat, aan de volgende factoren: wetgevingsjuristen ontbreekt het aan voldoende kennis; de departementsleiding is te weinig betrokken bij het wetgevingsproces; er bestaat onduidelijkheid in afbakening van verantwoordelijkheden; en structurele voorzieningen voor evaluatie van regelgeving worden gemist. ${ }^{109}$ De rekenkamer beveelt aan deze lacunes op te vullen. Bovendien is het volgens haar zinvol gebruik te maken van tijdsbesparende managementinstrumenten, omvattende een beleidsplan met prioriteitstelling, werkprogramma betreffende hoofdzaken, prestatiegegevens over werkuitwoering, operationele doelstellingen, kwaliteits- en kwantiteitsanalyse na vijf jaar als mede tijdsverantwoording ten behoeve van de personele inzet voor het ontwerpen van wetgeving. ${ }^{110}$ Tevens wil de rekenkamer toetsingsmethoden en -bevindingen (van wetsvoorstellen) controleerbaar maken door systematische vastlegging daarvan. "'1 Met respect voor het, op zich nuttige, onderzoek van de Algemene Rekenkamer is het oordeel dat haar researchwerkzaamheden te veel aan de oppervlakte blijwen drijven. Diepgaand onderzoek naar de werkelijke merites van elk afzonderlijk wetsvoorstel biedt waarschijnlijk, meer dan de kale kwantificerende onderzoeksmethode van de Algemene Rekenkamer, nader inzicht in de factoren welke de duur van de totstandkoming van wetsvoorstellen beheersen." 12

Bij het toepassen van bedoelde kwaliteitseisen is het zeker zinvol om aandacht te besteden aan een nog te veel verwaarloosd aspect. Bij elk ontwerp of voorstel van wet- en regelgeving is het, omdat Nederland geen eiland is te midden van andere Europese eillanden, noodzakelijk om voorgenomen regels te toetsen aan buitenlandse regels. De, soms onvermijdelijke, afstemming op Europese en internationale wet- en regelgeving biedt mogelijk voordelen. Bovendien kan Nederland haar relatief sterke economische positie verliezen, als zij bij het opstellen van nieuw beleid, geen of onvoldoende rekening houdt met financiële bedrijfsbelangen door, voor de export naar Nederland belangrijke, wet- en regelgeving in het buitenland te veronachtzamen. Daarom introduceert het medio 1994 aantredende kabinet-KoK, dat concurrentie hoog in het vaandel heeft staan, een buitenlandtoets. ${ }^{113}$ Een dergelijke toets, die helaas het gevaar heeft vertragend op het ontstaan van wet-en regelgeving te werken, gaat na of voornemens tot wet-en regelgeving de concurrentiepositie wan Nederlandse bedrijven kunnen schaden. ${ }^{114}$

109. Wetgeving: arganisarie, proces en produkt, TK 1993-1994, 23710, nrs 1-2, pp.5-6/12-14; Hierover Rekenkamer kritisch over kwaliteit wetten. Tekort aan deskundigen, in: NRC, 11 mei 1994, p. 3; Depar tementale woorbereiding van wetswoorstellen werloopt volgens Rekenkamer te traag, in: NJB, ni. 21,27 mei 1994, p.727.

110. Wetgeving: organisatie, proces en produkt, TK 1993-1994, 23710, nrs. 1-2, pp.5/16-20; Hierover ook, bij het AR-onderzoek betrokken, I.M.M. van den Bos, R.M.G. Hub, R. Noé en C. Pietjouw, Her managen wan wetgevingrafdelingen, in: RegelMaat, nr.4, 1994, pp. 163-168.

111. Wetgewing: arganisatie, proces en produkt, TK 1993-1994, 23710, nrs. 1-2, p.6.

112. Lin de Vries. Enige kantrekeningen bij het rapport van de Algemene Rekenkamer over de wergeving, in: NJB, nr.32, 16 september 1994, pp.1098-1100.

113. Naast het bellang wan een buitenland toets wordt gehecht aan een bedrijfseffectentoets. Zie Marknwerking. deregulering en wetgevingskwaliteit, TK 1994-1995, 24036, nr. 1 , p.5.

11.4. Wijers: wetten mogen concurrentie niet aantasten, in: NRC, 21 sept. 1994, p.17. 


\section{\$10.6 Met vaste hand}

Ten slotte richt ook de voorlopig laatste kabinetsnota, inzake verbetering van de kwaliteit van rechtshandhaving, zich op integrale aanpak van wetgeving, uitvoering en handhaving. ${ }^{115}$ Wetsevaluatie en toetsing van rechtshandhaving in praktijk dienen hand in hand te gaan.

Van het met woorden schermen is geen sprake. Initiëring van de Inspectie voor de rechtshandhaving is inmiddels een feit. Deze inspectie heeft "een onderzoek- en adviesfunctie ten einde oplossingsgerichte bijdragen te leveren an het verminderen van het handhavingstekort met betrekking tot belangrijke onderdelen van, vooral de beleidsinstrumentele wet- en regelgeving". ${ }^{116}$ Hierbij rekent de inspectie vooral de gebieden van de sociale zekerheid, gezondheidszorg, verkeer/vervoer (studie naar wettelijk puntenstelsel) ${ }^{117}$, milieu, bestuurlijke sancties ter handhaving (studie van het Europees visserijsanctiebeleid) ${ }^{118}$ en (gedeeltelijke) decriminalisering van de warenwetgeving tot haar werkterrein. Met betrekking tot het milieuwet- en regelgeving meldt de inspectie eind 1994 dat zij een uitvoerbaarheids- en handhaafbaarheidstoets heeft ontwikkeld ${ }^{119}$ als mede meetinstrumenten en indicatoren voor de naleving van de Bestrijdingsmiddelenwet, de In- en uitvoerwet en de Wet individuele huursubsidie heeft verzameld. Helaas is de algemene constatering van de inspectie nog steeds dat "op de meeste beleidsterreinen voldoende inzicht in de mate van naleving van beleid en regelgeving ontbreekt ${ }^{\prime \prime}{ }^{120}$ Bij haar werk kan de inspectie de medewerking van instanties, die verantwoordelijkheid dragen voor rechtshandhaving, niet ontberen. Dat zal duidelijk zijn.

\section{$\S 10.7$ Algemene wet bestuursrecht}

De opstellers van afdeling 5.1 derde tranche Algemene wet bestuursrecht houden in het wetsvoorstel ${ }^{121}$, even als in het voorontwerp, terecht vast aan de bij herhaling ${ }^{122}$ vermelde reservefunctie van het strafrecht. Die omvat het volgende. "Voor minder

115. Met vaste hand: Verbetering wan de kwaliteit van de rechrshandhaving, TK 1990-1991, 22045, nrs: 1-2.

116. P.J. Baauw, Kroniek strafrecht, in: AA, nr.12, 1992, p.2088.

117. P.J. Baauw, t,a.p, , p.2308.

118. P.J. Bianw, t.a.p., p. 2308

119. Deze toets is ook buiten wermeld rechtsgebied toepasselijk. De toets "vergemakkelijkt het ex ante en ex post doorlichten van beleid en regelgewing op uitvoerbaarheid $c_{\text {. }} q$. handhaafbaarheid, het biedt tevens een leidraad die, mits consequent toegepast, het verloop van het beleidsproces van het begin tot het einde, zo danig rationaliseert dat de kansen op een doelmatig en doeltreffend eindresultaat wonden vergroot". De toets moet als leidraad "op onafhankelijke en objectieve wijze geschieden en alle poten tiële partners in het beleidsproces (als uitvoerings-em handhavingsorganisaties) dienen wanaf de aanvang bij de beleidsontwikkeling te worden betrokken". Justitiebegroting 1995, TK 1994-1995, 23900 VI, nr.2, p. 13; Zie ook nadere beschouwing van de toets door J.R.H. Kuyper, Het OM en de handhaving van regelingen, in: 11. de Doelder e.a., Taak en functioneren wan het OM, Armhem, 1994, pp.255-266.

120. Justitieblegroting 1995, TK 1994-1995, 23900 V1, nr.2, p.13; Hierover P.J. Baauw, Justitiebegroting 1995, in: AA katern strafrecht ar. 53, nr.12, 1994, pp.2524-2528, i.h.b. p.2525.

121. Mvt wetsvoorstel derde tranche Awb, TK 1993-1994, 23700, nr.3, p.136.

122. Zie cok weer Strafwordering in balans, TK 1993-1994, 23672, nr.1, p. 19. 
ernstige inbreuken op de rechtsorde komen zo veel mogelijk andere wijzen voor handhaving in aanmerking, bij voorbeeld van bestuursrechtelijke aard.." 123

Tot instelling van de, medio oktober 1994 geïstalleerde, commissie heroverweging instrumentarium rechtshandhaving, t.w. de commissie-Korthals Altes ${ }^{124}$, wordt besloten door de grote druk op de strafrechtelijke rechtshandhaving en de teleurstellende toepassing van vrijheidsstraffen. De taak van de commissie, die vóór 1 juli 1995 rapporteert, bestaat hierin dat zij "meer systematisch in kaart moet brengen welke ideëen er zo al op het terrein van alternatieve vormen van rechtshandhaving zijn ontwikkeld". 125 De commissievoorzitter begint zijn opdracht van uit de daarbij passende gedachte: "De handhaving van de rechtsorde is waar het de zwaardere vormen van criminaliteit betreft, alleen gediend met straffen die ook als zo danig worden ervaren. Inventiviteit is geboden. $Z_{i j}$ die de regels van onze rechtsstaat overtreden, plegen daarbij ook zeer inventief te zijn." 126

123. Cie. wetgeving algemene negels bestuursrecht, $M v t$ vooronwerp Awb derde tranche " 5 dec. 1991, "sGrav., p. 134.

124. Zie woor personalia Alternatieve rechtshandhaving, in: NJB, nr.39, 4 nov. 1994, pp. 1361-1362.

125. Aldus minister van justitie W. Sorgdrager bij het adantreden van de commissie, geciteerd in Allernatieven voor strafrechtelijke handhaving warden onderzocht, in: NJB, nr.38, 28 okt. 1994, p. 1323.

126. Aldus F. Korthals Altes, geciteerd in Altematieven voor strafrechrelijke handhaving warden onderzocht, in: NJB, nr. 38,28 okt. 1994, p.1323. 


\section{Geraadpleegde literatuur}

Addink, G.H. \& Sluis, M.J.

De Awb op scherp; Kanttekeningen bif het hoofdstuk handhaving, in: NTB, nr.2, 1992, pp. 33-45.

Almelo, L. van

Wetten en regels moeten leven bij het publiek, in: BBM, nr.7/8, 27 november 1992, pp.26-28.

Baauw, P.J.

- Justitiebegroting 1993, in: AA katern strafrecht, nr.11/12, 1992, pp.2085-2090;

- Justitiebegroting 1994, in: AA katern strafrecht 49, november/december 1993, pp. 2307-2311.

- Justitiebegroting 1995, in: AA katern strafrecht 53, nr.11/12, 1994, pp.2524-2528.

Borman, C.

Aanwijzingen woor de regelgeving en andere voor de regelgeving relevante aanwijzingen, Zwolle, 1993.

Bos, J.M.M. van den, Hub, R.M.G., Noé, R. \& Pietjouw, C.

Het managen van wetgevingsafdelingen, in: RegelMaat, nr.4, 1994, pp. 163-168.

Buruma, $Y$.

De strafrechtelijke handhawing wan bestuurswetten, dissertatie RUL, Arnhem, 1993.

Bij, J. van der

Kosten wan regelgeving, in: RegelMaat, $n$ r.6, 1994, pp.227-233.

Commissie-Deetman (bijzondere commissie vraagpunten)

Staatkundige, bestuurlijke en staarsrechtelijke vernieuwing, TK 1991-1992, 21427, nr.3.

Commissie-Scheltema (commissie wetgeving algemene regels van bestuursrecht)

Voorontwerp derde tranche van de Algemene wet bestuursrecht, angeboden aan de ministers van justitie en binnenlandse zaken d.d. 5 december 1991, "s-Gravenhage.

Doelder, H. de

Handhaving van economische regelgeving; Is door de bestuurlijke handhaving het primaat van de strafrechtelijke handhaving doorbroken of geldt het strafrecht als ultimum remedium?, in: J.A.E. Vervaele, Bestuursrechtelijke toepassing en handhaving van gemeenschapsrecht in Nederland, Europese monografieën nr.41, Deventer, 1993, pp.137-148.

Driel, M. wan

Zelfregulering; Hoog opspelen of thuisblijven, dissertatie RUU, Deventer, 1989.

Drupsteen, Th.G.

Kroniek van het milieurecht, in: De staat wan het recht, kronieken 1 aug. $1993-1$ aug. 1994 als bijlage van NJB, nr.33, 23 september $\llbracket 994$, pp.66-70.

Esch, R.E. van \& Berkvens, J.M.A.

Het $B W$ als Wpr, in: Computerrecht, nr.3, 1994, pp.93 101.

Eijlander, Ph.

Wetgeving in de jaren negentig; Van deregulering naar algemeen wetgevingsbeleid, in: $\mathrm{RM}$, nr.2, 1990, pp.26-32, alls opgenomen in: De wet stellen; Beschouwingen over onderwerpen van wetgeving, dissertatie KUB, Zwolle, 1993, pp.155-172.

Eijlander, Ph., Gilhuis, P.C. \& Peters, J.A.F. Overheid en zelfregulering; Alibi voor vrijblijvendheid of prikkel tot aktie?, Schoordijk instituut, centrum voor wetgevingsvraagstukken, Zwolle, 1993.

Haan, P. de

Het bestuursrecht en de scheiding tussen beleid en uitvoering, in: Hoogenboom, T. \& Damen, L.J.A. (red.), In de sfeer van administratiefrecht; Opstellen aangeboden aan Willem Konijnenbelt, Utrecht, 1994, pp.121-150.

Heijden, P.F. van der \& Vlies, I.C. van der 
De staat wan het convenant, in: NJB-special, nr.14, 8 april 1993, pp.475-478.

Hirsch Ballin, E.M.H.

De gekoppelde staat, in: Geelhoed, L.A., Hirsch Ballin, E.M.H., Polak, J.M., Rosenthal, U., Snellen, I.Th.M. \& Vlies, I.C. van der, Wetgeving in beweging, Zwolle, 1991, pp.61-75.

Hoekema, A.J. \& Stout, H.D. (red.)

Onderhandelend bestuur, NJB-boekenreeks nr.16, Zwolle, 1994.

Huls, N.J.H. \& Stout, H.D. (red.)

Reflecties op reflexief recht, Zwolle, 1992.

Ippel, $\mathrm{P}$.

Slondig mag niet (reactie interview H.J. de Ru), in: NJB, nr.3, 21 januari 1994, pp. 100-101. Jurgens, $\mathrm{E}$.

Mediawet 1994: te weinig, te laat, in: Mediaforum, nr.4, 1994, p.37.

Koedijk, $\mathrm{K}$.

Pleidooi voor dereguleringskamer, in: NRC, 24 maart 1994, p. 19.

Koedijk, C.G. \& Kremers, J.J.M.

Nieuwe regering moet afrekenen met de Nederlandse regelziekte, in: NRC, 6 mei 1994, p.9.

Koeman, N.S.J.

Handhawing, in: Konijnenbelt, W. (red.), Commentaar op het voorontwerp voor de derde tranche van de Awb, Alphen a/d Rijn, 1992, pp.103-110.

Kortmann, C.A.J.M.

- Ontregeling, in: NJB, nr.39, 4 november 1993, pp.1375-1380;

- Kroniek van het staatsrecht, in: De staat van het recht, kronieken 1 augustus 1993 - 1 augustus 1994 als bijlage van NJB, nr.33, 23 september 1994, pp.46-49.

Kuyper, J.R.H.

- Rechtshandhaving en het Openbaar Ministerie, Enige beschouwingen over de verhouding van het $O M$ tot de wetgevende vakdepartementen, in: Magistraat met beleid: de ovj en zijn omgeving;

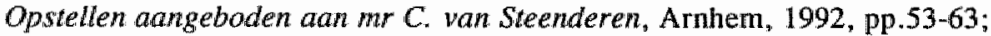

- Het Openbaar Ministerie en de handhaving van regelingen, in: Doelder, $\mathrm{H}$. de, Foqué, R.M.G.E. \& Gerding, R.A.F. (red.), Taak en functioneren van het $O M$, SI-EUR-reeks deel 4, Arnhem, 1994, pp.255-266.

Lindo, C.M.Th.

Prikkelend privatrecht als alternatief voor wetgeving; Het systeem De Ru, in: NJB, nr 39,4 november 1993, pp. 1406-1410.

Lisser, E.Ch.

Alternatieven voor wetgeving op decentraal niveau, in: RegelMaat, nr.1, 1995, pp.19-31.

Lubach, D.A.

Kronieken: bestuur en privaatrecht, in: NTB, nir.6, 1995, pp.162-165.

Niessen, C.R.

Een aanwaardbaar niveau van niet-handhaving, in: $\mathrm{OB}, \mathrm{nr} .5,1992, \mathrm{pp} .18-23$.

Ommeren, F. \& Ru, H.J. de

Convenanten tussen overheid en maatschappelikke organisaties, Den Haag, 1993.

Peeters, $\mathbb{B}$.

Convenanten, in het bijzonder milieuconvenanten, uitgave Vereniging voor de Vergelijkende studie van het Recht van België en Nederland, Zwolle, 1994.

Peters, J.A.F

Zelfregulering zonder overheid?, in: $\mathrm{OB}_{3} \mathrm{nr} .2,1994, \mathrm{pp} .20-24$.

Pleite, M. \& Geleuken, B. van

Het milieuconvenant; Goede voornemens, slechte resultaten, in: JV, nr.9, 1994, pp.83-94.

Polak, J.M. 
De wetgeving van het Departement van Justitie, in: NJB, nr.1, 6 januari 1995, pp.7-15.

Raad van State

Jaarverslag 1993, april 1994.

Raad voor het binnenlands bestuur

Advies aan de ministers Hirsch Ballin en Dales over het voorontwerp wan de derde tranche A wh, mei 1992, "s-Gravenhage.

Rogier, L.J.J.

Strafsancties, administratieve sancties en het una via-beginsel, Arnhem, 1992.

$\mathrm{Ru}_{\text {, H.J. }}$ de

Stimulerende wetgeving of stimulerend recht?, preadvies algemene jaarvergadering Vww d.d. 20 maart 1993, in: Kolhoop, I., Stimulerende wetgeving, Alphen a/d Rijn, 1993, pp.95-114.

Ruiter, D.W.P.

Eisen van goede regelgeving, in: RegelMaat, nr. 1, 1993 "pp.4-7.

Schalken, T.M.

Het OM in het nieuwe politiebestel, in: DD, nr. 4, 1994, pp.335-339.

Schoof, R.

Rapportadviesbureaus: reorganisatie justitie "niet verantwoord", Taak van top justitie 'onduidelijk", in: NRC, 12 oktober 1994, pp. 1-2.

Schoof, R. \& Versteegh, K.

Reorganisatie van Justitie moet 'op volle kracht' doorgaan, in: NRC, 14 oktober 1994, p.2.

Schuiling, K.F.

Staats-en bestuursrechtelijke kroniek, in: Bestuurswetenschappen, respectievelijk nr.4, 1992 , pp.365-368, en nr.5, 1992, p.452-455.

Stout, H.D.

$\sim$ Het labyrint van de wetgeving en de alternatieve strategieën van De Ru en Sturing op maat, in: RegelMaat, nr.3, 1994, pp.97-102;

Sprookjes bestáan! Het bestuursrecht als moderne Assepoester, in: Beleid \& Maatschappij, nr.6, 1994, pp.322-333.

Straatsma, B.J.

Convenant speelautomaten leunt te sterk op goede wil van exploitanten, in: BB, nr.37, 17 september 1993, p.29.

Tweede Kamer

- Kansspelbeleid, TK 1993-1994, 21277, nrs.1-28;

- TK 1989-1990, 21502, nrs.1-2;

$\sim$ Recht in beweging: Een beleidsplan woor justitie in de komende jaren, TK 1990-1991, 21829. ars. 1-2;

- Strafrecht met beleid; Beleidsplan van het OM voor de jaren 1990-1995, TK 1990-1991, 21833, nars 1-2;

$\sim$ Zicht op wetgeving; Beleidsplan vam het ministerie van justitie voor de verdere ontwikkeling en uitvoering van het algemene wetgevingsbeleid, gericht op de verbetering van de rechtsstatelijke en bestuurlijke kwaliteit wan het overheidsbeleid, TK 1990-1991, 22008, nrs.1-2;

$\sim$ Met vaste hand; Verbetering van de kwaliteit van de rechtshandhaving, TK 1990-1991, 22045, nrs. 1-2;

- Wetgeving: organisatie , proces en produktie, TK 1993-1994/1994-1995, 23710, nrs. 1-2/3-4; $\sim$ Jaarverslag/begroting Toetsingscammissie voor wetgevingsprojecten. TK 1993-1994, 23400 VI, nirs. 5/49;

$\sim$ Kabinetsstandpunt bestuurlike overeenkomsten, TK 1993-1994, 23400 VII, nr.35;

- Voortvarend wetgeven, TK 1993-1994, 23426, nr.1;

Wetsvoorstel Awb, TK 1993-1994, 23700, nrs.1-3; 
- Regeerakkoord 1994: keuzes voor de toekomst, TK 1993-1994, 23715, nr.11;

- Justitiebegroting 1995, TK 1994-1995, 23900 VI, nrs. 1-2;

- Brief van de ministers van economische zaken en justitie over het project Markwwerking. deregulering en wetgevingskwaliteit ter versterking van de economische dynamiek, TK 19941995,24036 , mr. 1 .

Vervaele, J.A.E.

Handen en tanden wan het (gemeenschaps)recht, oratie RUU, 18 februari 1994, Deventer, 1994. Verwaele, J.A.E. \& Widdershoven, R.J.G.M.

Bestuurlijke handhaving van visserijregelgeving; Een studie naar de relatie tussen EEG-recht en nationale handhaving. Utrecht, 1991.

Vries, L. de

Enige kanttekeningen bij het rapport van de Algemene Rekenkamer over de wetgeving, in: NJB. ni . 32, 16 september 1994, pp.1098-1100.

Vuijisje, $\mathrm{H}$.

Terug naar de controle-staat, in: NRC, 30 april 1994, p. 29 .

Waal, C.J.D.

Het Deventer speelautomatenconvenant, in: NJB, nr.14, 8 april 1993, p.549.

Wetenschappelijke raad voor het regeringsbeleid

Rechtshandhaving, rapport nr.35, "s-Gravenhage, 1988.

Wiggers-Rust, L.F.

Owerheidsbestuur per contract en het primaat van het publiek recht, in: H.Ph.J.A.M. Hennekens, Bestuursrechtaan de horizon; Opstellen over materieel bestuursrecht t.g. ${ }^{2}$. de tachtigste verjaardag van professor mr S.F.L. baron van Wijhbergen, Zwolle, 1994, pp.123-134.

Wijk, H.D. van, bewerkt door Konijnenbelt, W. \& Male, R.M. van

Hoofdsiuken van administratief recht, negende druk, Utrecht, 1995.

Zijlstra, S.E.

Convenanten, uitgave Vereniging voor de vergelijkende studie van het Recht van België en Nederland, Zwolle, 1994. 


\section{Toezicht op naleving van het recht}

\section{\$ 11.0 Het begrip handhaving}

Zelfstandige bestuursorganen met een handhavingstaak dragen zorg voor naleving van wet- en regelgeving. Deze zorg is tweeërlei. Te weten: a. uitoefening van toezicht (paragraaf 11.1 e.v.) en b. toepassing van een sanctie (paragraaf 12 e.v.). ${ }^{\prime}$

\section{$\$ 11.1$ Handhaving: toezichtsuitoefening ${ }^{23}$}

Deze vorm van handhaven ${ }^{4}$ betreft het er op toezien dat de burger, de hem opgelegde, rechtsregels betracht. Hiertoe staan toezichthouders speciale rechten of bevoegdheden ter beschikking. Die bevoegdheden, ter uitoefening van toezichthoudende taken, verschillen nog al. $\mathrm{Zij}$ vinden meestal regeling in bijzondere wetten ${ }^{5}$, voorzien van - subsidiair strafrechtelijk sanctioneerbare - "bestuursafhankelijke" ${ }^{6}$ handhavingsvoorschriften. Zo-

1. W. Duk, Inleiding tot het bestuursrecht, tweede druk, Alphen a/d Rijn, 1988, p.73; W. Duk, Handhaving wan bestuarsrecht; Capitula selecta, in: NTB, nr.4, 1988, pp.105-110, i.h.b. p. 105.

2. Sommigen preferen de term preventieve handhaving. Zie NMP+, TK 1989-1990,21137, nurs.20 21; P. Verfaille, Handleiding handhaving miliewrecht, tweede herz. dnuk, Lochem, 1992, pp. 19-20; S. Pront-Van Brommel, Controle op de nalewing van administratiewe wetgeving, in: W. Konijnenbelt (red.), Commentaar derde tranche Awb, a.w. . pp.115 116.

3. De paragrafien 11. tot en met 11.7 worden ten dele ontleend aan een eerdere publikatie van A. Derks, A. van Nus en H. Simon, Het toezicht op burgers in de Awb, in: NJB, nr. 43, 2 dec. 1993, pp.1544-1553.

4. J.A.E. Vierwaele, Handen en tanden wan het (gemeenschaps) recht, oratie RUU, 18 febr. 1994, Dewenter, 1994, pp.13-14, merkt terecht op, dat de geringe aandacht voor deze handhavingsworm, i.h.b. waar het: procesrechtelijke aspecten van uitoefening van toezichthoudende bevoegdheden door bijzondere opsporingsdiensten betreft, schril contrasteeri met de grote belangsteling in de discussie ower handhavingsrecht woor sanctionering.

5. Uitvoerig G.P.A. Aler, De politiebewoegdheid bij opsporing en controle; Enige aspecten van de regeling wan de dwangmiddelen in het Wetboek wan strafuordering en in de bijzondere wetten, Zwolle, 1982; Recenter Y. Bunma, De strafrechrelijke handhaving van bestuwrswetten, diss. RUL, Amhem, 1993, i.h.b. pp.208-256. Biesproken door J. Vervaele, in: R\&K, nr.4, 1994, pp.392-397.

6. Y. Buruma, a.W., pp.100-101/110-16. Auteur spreekt wan bestuursafhankelijke strafbaarstelling als de "strafbaarheid betrekking heeft op inbreuken op geïndividualiseerde administratieve plichten jegens uitvoerende (vergunning- of ontheffingverlenende) en handhavende bestuunders". 
wel redactie als omvang van de, in die bijzondere regellgeving neergelegde, toezichthoudende bevoegdheden zijn ver van eenduidig.

Vandaar beoogt de Algemene wet bestuursrecht harmonisatie ter zake. " Bevoegdheden, die her en der herhaaldelijk worden toegekend, zijn standaandbevoegdheden in afdeling 5.1 Awb inzake toezicht. ${ }^{8}$ Deze bevoegdheden zijn, volgens het Awb-wetgever, in het algemeen noodzakelijk woor toezicht houden. "Kortom, de Awb bevat een "weerspiegeling van het gebruikelijke pakket van bevoegdheden dat men in tal van bijzondere wetten aantreft". "Wel blijft de mogelijkheid, bij wettelijk voorschrift of bij besluit "van een bestuursorgaan, de aan toezichthouders toekomende bevoegdheden te beperken (art. 5.1.4 Awb). Immers, niet elke bevoegdheid is altijd even hard nodig. Omgekeerd bestaat soms behoefte aan aanvullende andere, specifieke bevoegdheden. Daarin mag de bijzondere wetgever dan terecht zelf voorzien.. ${ }^{12}$ Helaas stelt de Awb-wetgever aan dergelijke bijzondere toezichtsbevoegdheden geen inhoudelijke of procedurele eisen van algemene aard. ${ }^{13}$

Art. 5.1.2 Awb voorziet in een legitimatieplicht voor toezichthouders. Tenzij beroep mogelijk is op een of andere geheimhoudingsplicht, moet elke burger medewerken aan taakuitoefening door toezichthouders (art. 5.1.10 Awb ${ }^{14}$ ). Voor zover uit een geheim-

7. Cie-Scheitema, Mwt woorontwerp Awb derde tranche, a.w., p.130; Vgl. C. Borman, a.w., pp.115-119 (anw. 135).

8. De bepalingen inzake toezucht hebben nog geen wettelijke status. Vandaar wordt in het hierma volgende uitgegaan van het wetsvoorstel vart afdeling $5.1 \mathrm{Awb}$, tenzij anders vermeld.

9. Het theer nuance zoekende standpunt van O.J.D.M.L. Jansen, Muerventie. VAR-vergadering inzake bestuurlijke handhaving d.d. 12 mei 1995, pp.1-6, i.h.b. pp.3-4, intrigeert. Auteur wenst precisering wan harmonisatie. In zijn optie vormen de bevoegdheden om inllichtingen of inzage te vorderen, en in mindere nate de bewogdheid tot plaatsbetreding, de kern wan handhavingstoezicht. Auteur prefereert boven het "zwart-witharmonisatiesysteem" van de $A$ wb-wetgever een tussenvariant, neerkomend op toekenning van de drie vermelde essentielle toezichtsbevoegdheden in de $\mathrm{Awb}$, met de mogelijkheid dat in bijzondere wetgeving overige benodigde bevoegdheden worden toegekend; In dit kader moet met $\mathrm{Y}$. Buruma, Het OM en de büzondere opsporing, in: H. de Doelder e.a., Taak en functioneren van het OM, Arnhem, 1994, pp. 181-205, i.h.b. p. 185, worden opgemerkt dat juist voor door technische deskundigheid gekenmerkte toezichthouders bevoegdheden tot monsterneming en goederenonderzoek belangrijk en niet uitzonderlijk zijn. Volgens Buruma zijn de, in tweede fase aan te wenden, bevoegdheden tot het vorderen van inlichtingen en inzage een moodzakellik kwaad als (medewerkings)overleg van toezichthouders met onder toezicht gestelden faalt. Of de bevoegdheid tot monsterneming/goederenonderzoek inderdaad zo"n buitengewone bevoegdheid is als Jansen meent, valt dan ook te betwijfelen.

10. Mw woorontwerp Awb. a.,., p.130.

11. Vorm woorschrift/besluit staat open. Datarom eisen G.H. Addink en M.J. Sluijs, De Awb op scherp, in: NTB, nr.2, 1992, pp.33-45, i.h.b. p.38, publikatie daarvan in Stcrt./Stbl.

12. Mw voorontwerp Awb, a.w., pp. 133/137.

13. G.H. Addink en M.J. Sluijs, Het vijde hoofdstuk Awb, in: NJB, nr.35, 7 okt. 1994, pp.1201 1208, illi.b. p. 1202, missen o. m. "de eis dat er een wettelijke grondslag moet zijn en een pendant van de in art. 5.1 .3 neergelegde redelijkheidsnorm".

14. Geopperd wordt om aan art. 5.1.10 Awb een bepaling toe te voegen met betrekking tot de cautieplicht (gekoppeld aan het zwijgrecht). In het bijzonder bij het opleggen wan bestuwrlijke boeten (minder dan 500 gulden), waarbij toezichthouders wel inlichtingen kunnen vragen ex art. 5.1.6 Awb maar niet hoeven te 
houdingsplicht geen belemmering voort vloeit ${ }^{1 s}$, kunnen toezichthouders medewerking vorderen van onder toezicht gestelden. Hierbij geldt wel de redelijkheidseis.

Overigens is het redelijkheidscriterium algemene maatstaf ex art. 5.1.3 Awb. De tekst van de bepaling luidt: "Een toezichthouder maakt van zijn bevoegdheden slechts gebruik voor zover dat voor de vervulling van zijn taak redelijkerwijs nodig is."

Ten eerste wordt daarmee wederom een vage norm in het recht gecreeerd. En opnieuw een lastige taak op het volle bord van de wetgever-plaatsvervanger gedeponeerd. Beter is het als de wetgever zelf objectieve maatstaven geeft. ${ }^{16}$ Dan wordt het voor de rechter al een stuk minder moeilijk.

Ten tweede gaat het hier, volgens de Awb-wetgever, om een aanscherping van de algemene norm neergelegd in art. 3:4, tweede lid, Awb. ${ }^{\| 7}$ Te denken is in het bijzonder aan de beginselen wan noodzakellijkheid en subsidiariteit.

Natuurlijk is het niet zo dat het redelijkheidscriterium ook de enige maatstaf is waaraan het optreden van toezichthouders kan worden getoetst. Voor zover een toezichtshandeling (materieel) is te rangschikken als beschikking, zijn daarop de bepalingen uit de hoofdstukken 2, 3 en titel 4.1 van de Awb van toepassing. Voor zover de uitoefening van controle alleen feitelijk handelen betreft is, naast hoofdstuk 2 , art. 3:1, tweede lid, Awb van belang. ${ }^{18}$

14. $\rightarrow$

horen, is het gegewen de gevaarlijke verstrengeling wan bestuursrechtelijk en strafrechtelijk sanctietraject volgens A.J.C. de Moor-Van Vugt, Van een haringkoninkrijk en een bananenrepubliek, in: NTB, mr.5. 1995, pp.113-123, i.h.b. p. 117 , verstandig de bevoegde ambtenaar te verplichten om bij het vragen van inlichtingen de cautie aan betrokkene te geven.

15. Wat betreft de geheimhoudingsplicht is het arrest van de Hoge Raad d.d. 18 okt. 1994, nr.95.052, in: DD, nr.2, 1995, pp.176-177, het vermelden waard. Daarin oordeelt de HR dat "de opvatting dat het looninspecteurs vó́r 1 januari 1989 o.g.v. art. 58 OSV (oud) in het geheel niet vrijstond informatie te verschaffen aatu de FIOD onjuist is ${ }_{\text {, }}$ nu de op een looninspecteur rustende geheimhoudingsplicht tem noch conform art. 58 OSV (oud) noch conform enig ander in Nederland geldend allgemeen rechtsbeginsel gebood zich te onthouden van het doen van mededelingen $m$. b.t. vermoedelijk gepleegde bij de belastingwet strafbaar gestelde feiten".

16. Ook G.H. Addink en M.J. Sluijs, t.a.p., p.38.

17. Mw voorontwerp Awb, a.w., p.137. Herower G.H. Addink en M.J. Sluijs, t.a.p., p.38.

1.8. Overigens merkt de president van de rechtbank te Amsterdam, inzake vereniging Bureau voor Muziekauteursrecht vs. regeningscommissaris belast met toezicht ex art. 30a, vijfde lid, Auteurswet 1913, 29 aug. 1995 , nr. $94 / 5275 / \mathrm{V}, J \mathrm{~B}, \mathrm{nr} .1,27$ jair. 1995, pp.11-14, op dat de formeel-wettelijk toezichthoudende regeringscommissaris als, bestuursorgaan, in het kader wan zijn toezichtstaak, besluiten neemt, als i.c. het instellen van een accountantsonderzoek, die het karakter hebben van besluiten in de zin van art. $1: 3 \mathrm{Awb}$. $\mathrm{Er}$ is namelijk sprake van een rechtsgevolg, waardoor verplichtingen worden gecreëerd, in het voorliggende geval het toellaten van accountants en het medewerken aan onderzoek. Annotator F.A.M. Stroink is het terecht eens met deze uitspraak. Wel geeft hij aan dat ook een andere benadering mogelijk is (p.14): "De constructie is dan dat er aan de kant van de toezichthouder sprake is van puur feitelijk handelen en dat de verplichtingen van de burger rechtstreeks voort vloeien uit de wet. "; In een reactie op vermelde uitspraak uit D. Visser, Help, de toezichthouder houdt toezicht!, in: NJB, nr.9, 3 maart 1995, pp.314315 , zijn ongenoegen over het beklag van de nota bene monopoloüde Buma/Stemra tegen toezichtsuitoefening door de regeringscommissaris (welk toezicht zich trouwens op de mogelijke financielle betrokkenheid van Buma tegenower Radio Noordzee Nationaal bv richt). Auteur acht de bezwaarmaking en het voorlopige voorzieningverzoek van Buma, die stelt reeds cen eigen accountantsonderzoek te hebben gedaan, 
Dat ambtenaren (en niet-ambtenaren), die belast zijn met toezicht op naleving van weten regelgeving, bij uitoefening van hun bevoegdheden de beginselen van behoorlijk bestuur in acht moeten nemen, vindt bevestiging bij de Hoge Raad. Volgens de HR vindt een toezichtsbevoegdheid "haar begrenzing in algemene beginselen van behoorlijk bestuur". " Gelet op de ruim geredigeerde bevoegdheden van afdeling $5.1 \mathrm{Awb}$ en het vage redelijkheidscriterium zal deze regel waarschijnlijk nog het nodige nut bewijzen. Anders gezegd, onder het ruime regime van de Awb komt het aan "op toepassing van aan de abbb te ontlenen eisen". ${ }^{20}$

\subsubsection{TOEZICHTSBEVOEGDHEDEN IN DE ALGEMENE WET BESTUURSRECHT}

De Awb geeft de volgende toezichtsbevoegdheden. ${ }^{21}$

In art. 5.1.5 Awb is de bevoegdheid tot het betreden van niet-openbare plaatsen vervat. ${ }^{22}$ Het zich toegang verschaffen geschiedt mogelijk met behulp van de sterke arm. ${ }^{23}$ Bovendien kan degene, die binnen treedt, door hem aangewezen personen mee-

18. $\rightarrow$

"hilurisch" en eigenlijk nog "veel gekker" "Naast vermelde uitspraak waarin het verzoek om een voorlopige voorziening ten einde accountantsonderzoek te woorkomen door de rechter van de hand wordt gewezen. (KG 1995, 19) wijst auteur nog op de $19 \mathrm{okt}$. 1994 gedane uitspraak door de president van de $\mathrm{A}^{\mathrm{i}}$ damse rechtbank, inzake Buma vs. de minister wan justitie, aangaande Buma's verzoek om schorsing van de openbararmaking van het betreffende accountantsonderzoek, welk verzoek ook wordt afgewezen (KG 1995, 54); Volgens de verbolgen Buma/Siemra-medewerker H.J.W. Eijkelenboom, Dirkdoenerij, in: NIB, nr.24, 16 juni 1995, pp.904-905, met maschrift van D.J.G. Visser, betreft deze uitspraak echter niet her accountantsonderzoek maar gaat het om de Wob-w raag of justitie genoodzaakt is de continue rapportages wan de RC met bijbehorende informatiestromen openbaar te maken.

19. HR 4 noy. 1992, BNB 1993, 90, m.mt. Simons. 1.c. opem buitendienstambtenaar $v$ d. notorrijtuigenbelasting eigenmachtig (zonder coestemming en buiten medeweten $v$. d, auto-eigenaar) een kofferdeksel v.e. auto, als hij ziet dat een gasvuldop aanwezig is terwijl de auto niet 'op gas" staat geregistreerd. Hier is sprake wan schending van het zorguuldigheidsbeginsel. Dit beginsel impliceert een plicht voor de toezichthouder, die een bepaalde toezichtshandeling wil werrichten, om de betrokken onder toezicht gestelde daarvan tijdig op de hoogte te stellen.

20. P. Nicolal, Kroniek; Abbb, in:" NTB, nr.7, 1993, pp.259-265, i.h.b. p. 261; Ook Y. Buruma, a.w., pp. 208-255.

21. Onder nneer deze nieuwe toedeling vam toezichtsbevoegdheden duidt er op dat de Awb niet meer alleen het regleten van in bijzondere wetgeving toegekende bevoegdheden beoogt. De Awb streeft zich zelf woorbij. Naast de oude aandacht woor formele facetten, omvat de aspiratie van de Awb-wetgever nu ook meer materiële aspecten. Aldus krijgt de Awb meer "het karakter van een algemeen wetboek van bestuursrecht" ${ }^{\prime \prime}$ concluderen G.H. Addink en M.J. Sluijs, Het wiffe hoofdstuk van de Awb: handhaving in materieel perspectief, in: NJB, nr.35, 7 okt. 1994, pp.1201-1208, i.h.b. p.1203.

22. De Awb-wetgever sluit hier aan bij de per 1 oktober 1994 geldende Algemene wet op het binnentreden van 22 juli 1994 (Stbl. 1994, 572-574, zie ook inwerkingtnedingsbesluit d.d. 2 sept. 1994, Stbl. 1994, 683 ).

23. Opmerkelijk is dat in het voorstel $W$ te (1995) een zelfde bevoegdheid is neergelegd voor de STE. Door deze introductie van de bevoegdheid met behulp van de sterke arm toegang te hebben tot financièle instellingen (welke bevoegdheid, toen deze nog ontbrak, de STE nota bene nooit echt als belemmerend heeft ervaren), wordlt wrang genoeg niet zo zeer de STE zelf, maar vooral justitie ontlast. De ECD hoeft voortaan niet eerst te verbaliseren voor weigering van informatie door fimanciële instellingen. De STE kan voortaan, met ECD of politie, direct binmentreden en stukken inzien. 


\title{
brengen. Ook kan de toezichthouder die bevoegd is binnen treden benodigde apparatuur meenemen.
}

\author{
Art. 5.1.6 Awb geeft de bevoegdheid naar, niet publiekelijk toegankelijke, informatie te \\ vragen en inlichtingen zo nodig te vorderen. ${ }^{24}$. 25
}

In gevolge art. 5.1.7 Awb zijn toezichthouders bevoegd inzage ${ }^{26}$ te vorderen van zake-

lijke gegevens en bescheiden ${ }^{27}{ }^{28}$

24. Zinwot is het aan art. $5.1,6$ een ternijn te verbinden. Het Commissariaat voor de Media ervaart het ontbrelken van termijnstelling aan inlichtingenverstrekking als belemmerend. Zie CvdM, Evaluatie 1988 1992; Overheid en ontoep in Europees perspectief, Hilversum, 1993, p.17; In gevolge art. 21, vierde lid, Wte mag o. a de STE wel een termijn aan inlichtingenwerstrekking stellen.

25. Ook als geen wettelijke bevoegdheid tot het inwinnen van lichtimgen bestaat, kan informatie worden opgevraagd. Dit lat de casus Inlichtingenbevoegdheid Sociale Verzekeringsbank, FNV vs. SVB, NO 2 sept. 1994, AB 1994,595, zien. De Sociale Verzekeringsbank, ter gegevensverificatie genoodzaakt tot controle, heeft een wettelijke bevoegdheid tot het inwinnen wan inlichtingen over haar cliènten bij derden. Ook voor zover de SVB daartoe niet wettelijk bevoegd is, kan zij well informatie opvragen als zij toestem ming aan betrokken cliënt vraagt. In het, met oog daarop door de SVB gebruikte, machtigingsformulier worden derden niet met name aargeduid. Op het hiertegen geleverde bezwaar wan client antwoordt de SVB het volgende: het is niet altijd op voorhand aan te wijzen aan welke derde informatie wordt gev raiagd; het is niet altijd wemselijk aan client noede te delen wan welke derde gegevens worden gev raagd; de SVB wil niet dat cliènt met een derde contact opneemt voordat de SVB dat doet; met én niet gespecificeerde machtigingskaart word" voorkomen dat telkens (voor elke apart omschreven derde) nieuwe toestemming van cliënt nodig is. Deze overwegingen van de SVB verdienen respect gegevem het "belang wan de SVB bij een efficiênte en effectieve controle'. Gegeven dit controlebelang respecteert de Nationale Ombudsman een verzamelmachtiging, omdat haar bereik is gespecificeerd terwijl zij categorieèn van informanten (o.a. werkgever, scholen, banken, scholen, verhuurders) betreft die voor een goede wetsuitvoering zonder meer van direct belang kunnem zijn. Voor verder gaand onderzoek dat volgens de SVB slechts bij uitzondering geschiedt, kan de SVB nog een aparte machtiging vragen. De allgemene regel is dus: wanneer de SVB de medewerking van de betrokkene verlangt bij het inwinnen van informatie, dan moet de reikwijdte wan dat werzoek en dus van de verlangde medewerking, voldoende dujdelijk zijn.

26. De vraag rijst naar de mogelijkheid van inzage van financiële gegevens van anderen dan onder toezicht gestelden. Vroeger was het voor het Commissariaat voor die Media onmogelijk on de door exierne producenten gemaakte televisieprogramma"s (die doot een omroepvereniging werden uit gezonden) te traceren, ondat het CvdM geen inzage van boeken wan derden had. CvdM, a.w., p 28; Oplossing biedi het Voorstel tor wijziging Mediawet i.v. m. sponsoring, TKK 1993-1994/1994-1995, 23257, nr.6, p.49, zie ook nr. 199.

27. De Awb houdt hier, anders dan het WvSw inzake computercriminaliteit t.w. arti. 125i-125n WwSv, onvoldoende rekening met het onderzoeken van geautomatiseerde gegevens. Analoog tan de per 14 juli 1994 gewijzigde fiscalle administratieve verplichtingen (zie Awr) is het, in het bellang van toezichtsuil toefening, zinvol de formule 'gegewens, boeken en bescheiden" te voorzien van de toevoeging "en (andere) informatiedragers'. In het verlengde hiervan is dan te stellen, dat $-\mathrm{m}$.b.t. tot de tegenover het inzage recht van een toezichthouder staande plicht van een onder toezicht gestelde om al het in te ziene gedurende in het algemeen tien jaar te bewaren- betrokken onder toexicht gestelde niet alle originele informatie hoeft op te slaan. Hij kan volstaan met het bewaren wan informatiedragers als floppy disks of microfiches. Conditie daarbij is wel dat, voor zover een toezichthouder (of een extern deskundige die hem adviseert) er niet in slaagt om gegevens te ontcijferen of te verifièren ${ }_{\text {, }}$ op betrokken onder toezicht gestelde de plicht rust de informatie op de gegevensdrager inzichtelijk te maken. Overigeris is het interessant dat het geĭntro. duceerde art. 54 Awr inzake bedoelde bewaarplicht (ex art. 52 Awr) een wettelijk wermoeden inhoudt dat een onder toezicht gestelde niet aan die plicht woldoet als hij, op verzoek van de tbezichthouder, niet zijn administratie ter beschikking stelt. Deze omkering van bewijslast geldt niet als betrokken onder toezicht gestelde aannemelijk maakt dat de afwezigheid of onvolledigheid van de administratie een gevolg is van 
Een en ander mogen zij bovendien kopiëren. Daartoe kunnen zij, tegen schriftelijk bewijs, spullen voor korte tijid meenemen. ${ }^{29}$

Art. 5.1.8 Awb verleent toezichthouders de bevoegdheid zaken te onderwerpen aain onderzoek, opneming en monsterneming als mede het hiertoe openen van verpakkingen en zo nodig meenemen van zaken. Voor zover mogelijk worden monsters terug gegeven. Art. 5.1.9 Awb regelt de bevoegdheid vervoermiddelen en/of lading te onderzoeken. Indien nodig is vordering tot respectievelijk stilhouding en overbrenging van voer- of vaartuigen naar een andere plaats en inzage wan met oog op toezichthoudende taken wettelijk voorgeschreven bescheiden mogelijk.

Deze bepalingen winden integraal opneming als modelbepalingen in de Aanwijzingen voor de regelgeving ${ }^{30}$, onder voorbehoud van mogelijke wetswijziging. Deze bepalingen staan ook all als artt. 91-101 in de nieuwe Flora- en faunawet ${ }^{31}$, vergelijk tevens art. 18.5 van de niet onbelangrijke Wet Milieubeheer. ${ }^{32}$

De Awb kent alleen bevoegdheden. In afwijkende opvatting worden naast bevoegdheden réchten ter zake onderscheiden. Frappant is het volgende onderscheid. ${ }^{33}$ In het kader

27. $\rightarrow$

overmacht. Dit impliceert dat een onder toezicht gestelde, naar redelijkheid, maatregelen treft ten einde te bevorderen dat de admimistratie in goede staat blijft bewaard. Deze verlegging van de bewijslast naar onder toezicht gestelden achten E. Bas en P.C.J. Oerlemans, Wetswijziging fiscale administratieve verplichtingen, in: S\&V, nr.1, 1995, pp.7-11, terecht niet onrechtvalardig.

28. Met oog op de (voorbereiding van de) vendediging van een onder toezicht gestelde is het aan te bevelen on een toezichthouder die zakelijke bescheiden en boeken heeft ingezien, na elk boekenonderzoek te verplichten om uit zich zelf versiag te doen wan de, met oog op de individuele rechtsbescherming wan betrokkene belangrijkste, bevindingen en resultaten wan zo" onderzoek. Bij de belastingdienst is dit bij worbeld goed gebruik. Indicatief is de uitsprak inzake Actieve informatieplicht belastingsdienst. Nationate ombudsman, nr.94/313,24 mei 1994, AB 1994, 438: "De belastingdienst dient de belasting. phebige de informatie over een ingesteld boekenonderzoek te verstrekken , die relevant is woor de belashingphthige i.v.m. de besluitworming door de belastingdienst over de desbetreffende aangifte. De nat een boekewonderzok door de belastingdienstuitgebrachte (uitzondterings) rapportage (d. w.z. dat het controleraport uhtututend informatie als eventuele correcties, af spraken en mededelingen bevat en geen gegevens dite belngengplichtige al kent - MGLvN) werstrekt een belastingplichtige de gegevens, die hij nodig heeft on zija positie in zijn relatie met de fiscus te kunnen bepalen. En, een gecontroleerde belastingpilichtige mag feiten en omstandigheden, die redelijkerwijs door de bellastingdienst binnen de reikwijdte van het onderzoek hadden kunnen worden opgemerkt, als geaccepteend beschouwen, indien daarover in een controlemapport geem op- of aanmerkingen worden gemaakt."

29. Evenals thet un de Wet telecommunicatievoorzieningen ovememen van de eis van schriftelijk bewijs woor het -tet vemenigvuldiging-tijdelijk meenemen van gegevens en bescheiden (Mvt woorontwerp derde tranche $A w b$, a. W.. P. 139), is het, wan uit het oogpunt van optimaal toezicht, het overwegen waard de bevoegdheid, van toezichthoudende ambtenaren aan wie de handhaving van verplichtingen van het bij of krahtens de Wtw bepaalde is opgedragen, om afgifte te vorderen van ongeldige bescheiden over te nemen in de Awb.

30. C. Bomman, a., pp.117-118 (aanwijzing 133 tot en met aanwijzing 135).

31. Regels ter bescherning van in het wild levende plante- en diersoortem, TK 1992-1993, 23147, nr.3, pp 1-21/85, later als wet in Stbl. 1993,586.

32. Wet wan 13 juni 1979, Stbl. 1979, 422, gewijz. 2 juni 1992, Stbl. $1992_{\mathrm{m}} 415$.

33. W. Duk, Inleiding tot het besuursrecht, a.w., pp.71-72. 
van toezichthouden bestaan réchten op betreding van niet-openbare plaatsen zonder toestemming van de eigenaar, inzage, voertuig- en bagagedoorzoeking (eventueel fouillering personen) en monsterneming. ${ }^{34}$ Daamaast hebben rechtshandhavers bevóegdheden tot respectievelijk het geven van bepaalde bevelen (bij voorbeeld stopbevel voor voertuigen of opdracht tot inlichtingenverschaffing) en het verlenen van een vereiste machtiging of toestemming (bij binnentreding huis tegen de wil van de bewoner). Verklaring hiervoor is, dat het begrip recht slechts aanduidt "de vrijheid om bepaalde feitelijke handelingen te verrichten of na te laten" ${ }^{35} .{ }^{36}$

Toch is de voorkeur voor het bevoegdheidsbegrip, dat duidt op "het door of krachtens de wet gerechtigd zijn tot het uitvoeren wan bepaalde handelingen ${ }^{n} \mathfrak{n}$, niet vreemd. In praktisch opzicht is zij een waardig complement op het taalgebruik in de WED. De mogelijkheden tot monsterneming (art. 21 WED), verpakkingopening (art. 22 WED), inbeslagneming (art. $18 \mathrm{WED}$ ) en vergezelling van personen bij woningbinnentreding (art. 20 WED) beschouwt de WED als bevoegdheden van de, conform art. 17 WED aangewezen, opsporingsambtenaar van economische delicten. Ook in het kader van het streven naar gelijknamige begrippen is de gebruikte terminologie niet onlogisch. Bovendien sluit het bevoegdheidsbegrip aan op de eerder, in hoofdstukken 7 en 8 , gebruikte terminologie. Daar worden taak en bevoegdheid als separate grootheden beschouwd. Gesteld is, dat uitoefening van een overheidstaak een publiekrechtelijke bevoegdheid vereist. Uit praktisch oogpunt is aansluiting bij het bevoegdheidsbegrip de beste optie. Hieraan staan principiële argumenten niet in de weg. Publiekrechtelijke bevoegdheden betreffen namelijk bevoegdheden positief recht vast te stellen en te handhaven. Toezichthouders met publiekrechtelijke bevoegdheden kunnen dus rechten afdwingen. Zij kunnen rechtsgevolgen tot stand brengen. "Het vermogen om rechtsgevolgen tot stand te brengen impliceert het recht daartoe. Men zou dan ook een bewoegdheid gelijk kunnen stellen met een recht." 38

\section{1 .2 OVERDAAD SCHAADT}

Al met al krijgen toezichthouders, met de Awb, een surplus aan bevoegdheden in de schoot geworpen. Gevraagd of ongevraagd. Voor bepaalde terreinen van toezicht té veel en té ingrijpend. Het belang van controle wint. Het is nog maar de vraag of zij zo'n grote prijs verdient.

34. Analoge nechten binnentreding/monsterneming bij P. Nicolaï, B.K. Olivier, L.J.A. Damen en H. Troostwijk $k_{*}$ a.w. , p. 349

35. W. Duk, a.w. p.7.

36. In het licht van deze keuzevrijheid kan F.A.M. Stroink, Annotatie Buma, JB, 27 jan. 1995, mr.11, pp.1415. het door Duk gemaakte onderscheid slechts voligen wat betreft het binnentreden van een woning tegen de wil van de bewoner: "Voor de toezichthouder is dan sprake van een recht gebaseerd op door een ander utitgeoefende bevoegdheid."

37. Y. Buruma, a.w., p.193.

38. F.A.M. Stroink en J.G. Steenbeek, Inleiding in staats-en bestuursrecht, viende herz. druk, Alphen a/d Rijn, 1993, p.30. 
Contradictoir aan het strewen toezichtsbevoegdheden zo uitvoerig mogelijk te regelen, is het volgende. De Awb regelt wel onderzoeking, opneming en monstememing van zaken. Maar voor de daarmee corresponderende risico- en schadevergoedingsregelingen moeten de bijzondere wetten weer uit de kast worden gehaald. ${ }^{39}$ Overigens is een algemene schadevergoedingsregeling wenselijk. Zo'n regeling kan worden gecompleteerd met bepalingen inzake contra-monsterneming en onvoorwaardelijke teruggave van zaken. Dit strekt, mocht het tot een procedure komen, tot verdediging van betrokkene. ${ }^{40}$ Ondanks aandringen blijft de Awb-wetgever daar anders over denken. De Awb-wetgever bepaalt in het bijzonder wat betreft het recht op verdediging is met betrekking tot monsterneming wel: "De zorgvuldigheid eist dat, woor zover zulks mogelijk is, ook genomen monsters worden teruggegeven, zonder dat de rechthebbende daarom uitdrukkelijk behoeft te vragen [...] Om onnodige bestuurslasten te voorkomen, kan het aanbeveling verdienen om tevoren aan de rechthebbende te vragen of hij prijs stelt op teruggave." 41 Maar het recht op contra-monsterneming is helaas nog steeds niet gewaarborgd. ${ }^{42}$ Ook zoekt de Awb-wetgever niet naar relevante antwoorden op de volgende vragen die zij nalaat te stellen: impliceert de uit de abbb af te leiden zorgvuldigheid dat een toezichthouder, die monsters wil nemen, daarvan mededeling moet doen aan betrokken onder toezicht gestelde; dient de toezichthouder zelf de feitelijke monsterneming uit te voeren of kan hij die taak ook door anderen laten vervullen; wie draagt zorg voor de afwerking van monsterneming (d.w.z. veilig vervoer van monsters, koeling van monsters, verzegeling en bewaking van monsters, preparatie en analyse van monsters) en welke regels moeten daarbij in acht worden genomen.

Uitvoerige regeling van toezichtsbevoegdheden heeft nog een ander nadeel. $\mathrm{Zij}$ kan beperking betekenen om in vergunningvoorschriften bepalingen inzake toezicht op te nemen. ${ }^{43}$ Jonge jurisprudentie leert namelijk als volgt. ${ }^{44}$ Soms beschikken toezichthouders op grond van een betrokken wet al over controlebevoegdheden. In dat geval is regeling er van in vergunningvoorschriften niet toegestaan.

Bij lezing van afdeling 5.1 Awb ontstaat snel de indruk, dat een overvloed aan toezichtsbevoegdheden altijd en overal mag worden gebruikt. Dat is natuurlijk onjuist.

Ten eerste is een algemene beperking wenselijk. Bepaald niet overbodig is de volgende, op rechtspraak gebaseerde ${ }^{45}$, bepaling: "Wanneer een zaak eenmaal onder de rechter

39. Rbb (1992), a.w., p.28. De raad pleit ervoor art. 5.1.8. Awb mét schaderegeling op te nemen Of, anders, helemaal miet.

40. Y. Bunuma (1991), t.a.p., p. 324; I.h.b. over contra-expertise Y. Bunma, a.w., pp.228-237.

41. Mvt wetswoorstel derde tranche Awb, TK 1993-1994, 23700, nr. 3, p.145.

42. Ook 0.a. de PwdA-fractie, Inbreng verslag dende tranche Awb, febr. 1995, "s-Gravenhage, pp.6-7, i.d. TK 1994-1995, 23700, nr.4, p.29, betreurt dit. Daamaast vraagt de fractie zich af waarom niet wordt vereist, dat een onder toezicht gestelde zo spoedig mogelijk na het bekend worden van onderzoeksresultaten daarvan op de hoogte wordt gesteld, zo dat betrokkene zo hij wil contra-expertise kan laten verrichten. Ten slotte is het de PrdA-fractie onduidelijk wie aansprakelijk is voor schade in geval van monstermeming.

43. Rbb (1992), a.w., p.29; G.H. Addink en M.J. Sluijs, t.a.p., p.39.

44. O.a. ARGS 29 maart 1991, AB-kort 1991, 449.

45. HR 10 februari 1988, AB 1988, 547; Zie ook S. Pront-Van Bommel, t.a.p., p. 123. 
is, is het gebruik van toezichtsbevoegdheden niet langer toegestaan. " 46 Deze regel, dat beroep schorsende werking heeft, lijdt eventueel wel uitzondering voor toezichtshandelingen die onmiddellijke tenuitwoerlegging eisen.

Ten tweede ligt al snel een voorstel op tafel om de Awb-toezichtsbevoegdheden ats facultatieve bevoegdheden te formuleren. Dat wil zeggen, "een toezichthouder heeft niet alle bevoegdheden "tenzij", maar hij heeft slechts die bevoegdheden die de wettelijke regeling of het bestuursorgaan hem geven." 47 Uit rijkelijk veel koren kunnen regelgevers of bestuursorganen ${ }^{48}$ dan zelf de beste granen pakken.

Ten derde rijst in het verllengde daarvan de gedachte om enkel essentiële toezichtsbevoegdheden, als de bevoegdheid tot het vorderen van inlichtingen of inzage en de binnentredingsbevoegdheid, in de Awb te regelen. ${ }^{49}$

\subsubsection{TOEZICHT OP NALEVING (VAN WET- EN REGELGEVING)}

Met de term toezicht heeft het voorontwerp Awb verschillende situaties op het oog. In titel 10.2 voorontwerp Awb derde tranche staat toezicht voor het toezicht op bestuursorganen, welk toezicht onderwerpen als goedkeuring, vernietiging en schorsing omvat. ${ }^{50}$ En in afdeling 5.1 Awb wordt nog een keer gestuit op het toezichtsbegrip. Dit toezicht doelt op inspectie of controle. Daarom luidt de titel van afdeling 5.1 Awb uiteindelijk terecht 'toezicht op de naleving' (van het bepaalde bij of krachtens enig wettelijk voorschrift $\left.{ }^{51}\right) .{ }^{52}$ Deze aanduiding is gebruikelijk in gevolge de aanwijzingen voor de regelgeving. 53

46. Rbb, a.w., p.28; Stelling 4 G.H. Addink tijdens VAR-studiemiddag derde tranche Awb d.d. 25 sept. 1992 te Utrecht.

47. Rbb (1992), a., w., p. 28; Cie-Scheltema ziet echter het gevaar, dat bijzondere wetgevers bij hun keuze "niet steeds dezelfde afwegingen maken". Zie $M$ vt voorontwerp Awb, a.w., p. 132 .

48. N. Verheij, Naor een wetboek van bestuursrech, in: A. W. Heringa en N. Verheij (red.), Publiekrechtelijke beweginger, Deventer, 1990, p.94, heeft al de nodige huiver t.a.v. toedeling wan toezichts-en sanctiebewoegdheden in de Awb "aan bestuursorganen in het algemeen".

49. O.J.D.M.L. Jansen, Interventie, VAR-vergadering inxake hestuurlijke handhaving d.d. 12 mei 1995. pp.1-6, i.h.b. pp. $3-4$.

50. Het regeringsstandpunt, dat dit toezicht in beginsel terughoudend kan zigin, verdient geen lof in de ogen van werschillende fracties. Zie Verslag aawwling voorstel derde tranche Awb. TK 1994m 1995, 23700, nr.4, pp.44-46. Van uit de wraag of een terughoudende benadlering wel toereikend is tbij niet volledig democratisch gelegitimeerde zbo"s, luidt het verwijt dat zich hier het gebrek aan algemene beschouwingen over het woorkomen van de toezichtsifigaur in ons rechtsstelsel wreekt.

51. Met B.M.J, van der Meulem, Handhaving, un: E.C.H.J. van der Linden en A.Q.C. Tak (red.), Eienzijidig en wederkerig?, Deventer, 1995, pp.223-247, i.h.b. p.239, kam worden opgemerkt dat dit toezicht enkel gepositiveerd recht aangaat. Vooxtat toezicht op naleving van ongeschreven normen, beginselen en zorgplichten (welke laatste vooral voort vloeien uit de Awbmotie van de wederkerige rechtsbetrekking) mogelijk is, moeten deze dus eerst op schrift worden gesteld.

52. Rbb (1992), a.w., p.24; P.M. Langbroek e.a., t.a.p., p.475; C.P.J. Goorden (1993), t.a.p., p.59.

53. C. Borman, a.w., p.115 (aanwijzing 132, eerste lid); Anders Y. Buruma, a.w., p.132, die de term "controle" prefereent. 
De toezichtsregeling in de Awb betreft alleen het toezicht op de náleving van wettelike voorschriften. Daarvan onderscheiden word het toezicht op de uitvoering ${ }^{54}$ van wettelijke voorschriften, middels onder meer het bij werknemers inwinnen van inhichtinget door de, ex art. 98 Werkloosheidswet met het toezicht op wetsuitvoering belast zijnde, bedrijfsverenigingen. ${ }^{55}$ Darop is afdeling 5.1 Awb niet van toepassing.

Natuurlijk is het houden van toezicht slechts een van de handhavingsinstrumenter om regels af te dwingen. Voor naleving van wet-en regelgeving bestaan ook andere manieren. Te weten: publieksvoorlichting; beloning voor inspanning regels na te komen financiële zekerheidsstelling (bankgarantie, waarborgsom) voor risicovolle activiteiten; uitbreiding aansprakelijkheid van degene die zich conform voorschriften moet gedragen; of verzekeringsverplichting.

\subsubsection{TOEZICHT EN OPSPORING}

In de vorige paragraaf is het begrip toezicht, als gebruikt in afdeling $5.1 \mathrm{Awb}$, afgebakend tot het toezicht op naleving van wet-en regelgeving. Maar er is nog een andere grensaanduiding nodig. Namelijk, hoe ver gaat toezicht eigenlijk? Herhaaldelijk is er terecht op gewezen, dat bij het ontbreken van een duidelijke omschrijving van de reikwijdte van toezichtsbevoegdheden "het gevaar amnezig is dat bevoegdheden worden "opgerekt" ${ }^{* 57}$

Qua toepassingsgebied kent de Awb grenzen. Krachtens art. 1:6, aanhef en sub a, Awb is de Awb niet van toepassing op de opsporing en vervolging van strafbare feiten, en evenmin op de tenuitwoerlegging van strafrechtelijke beslissingen ${ }^{58}$. In de Awb wordt

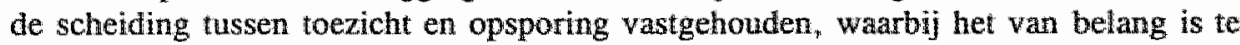
beseffen dat toezicht, in tegenstelling to opsporing, staat voor een "besturlijke acti-

54. De PvdA-fractie, Inbreng verslag derde tranche Awb, febr. 1995, "s-Gravenhage, p.9 id. TK 19941995, $23700, \mathrm{nr} .4, \mathrm{p} .27$, vindt het onderscheid tussen handhawingstoexicht, witvoeringstoezicht en comptabiliteitstoezicht onvoldoende omlijnd.

55. Memorie van toelichting wetsvoorstel derde tranche Awb, TK 1993-1994, 23700, nr 3, p. 140; Overigens vindt O.J.D.M.L. Jansen, Interventie, tijdens VAR-wergadering inzake bestuurlijke handhaving d.d. 12 mei 1995, pp.1-6, i.h.b. p.3, de ex ant. 25 Ww op onder toezicht gestelden rusten informatieplicht tegenover bedrijfsverenigingen, anders dan de cie-Scheltema, niet voort vloeien uit witwoeringstoezicht, maar uit handhavingstoezicht.

56. Positieve sanctionering volgens W. Duk, Inleiding tor het bestuurstech, a.w., p.72.

57. O.a. C.J. Kleijs-Wijmobel, Kronieken: Handhaving bestuursrecht, in: NTB, nr.4, 1994, pp.94-103. Auteur wijst op AGRS, 5 febr. 1992, Gst. $1993,6974,11$, waar een inlichtingenplicht kennelijk een (huisbezoek!)medewerkingsplicht omvat. I.c. weigert een ww-gerechtigde een controleur vande betrokken bedrijfsvereniging zijn huis binnen te laten.

58. Op de tenutwwoerlegging van wrijheidsonthemende maatregelen $0 . g . v$, de Vreemdelingenwet is " ex art. $1: 6$. aanhef onder sub $b$, Awb, de Awb niet van toepassing. Bedoelde bepaling stuit echter niet uit dat bij de V reemdelingenkamer kan worden opgekomen tegen de wijze van tenuitvoerlegging van de bewaring. De Vreemdelingemwet kent immers een eigen beroepsregeling op grond waarvan de rechtbank uitdrakkelijk bevoegd is zich mede over de tenuitvoerlegging van maatregelen tot vrijheid sbeperking en vrijheidsontneming uit te spreken. Inzake Oujda vs. staatssecretaris van justitie aldus Arrondissementsrechtbank "s Gravenhage 11 mei 1994, AB 1994, 598. 
viteit $^{\text {"59 }}$ met een preventief karakter ${ }^{60}$. ${ }^{61}$ Toch is de afbakening van toezicht met opsporing niet zo gemakkelijk als het lijkt. De grens tussen toezicht en opsporing blijft onduidelijk. ${ }^{62}$

Toezicht staat in het teken van het werkelijk gebeurde aan het licht brengen door het bestuur op een bijzonder terrein. Opsporing dient waarheidsvinding en bewijsverzameling in het kader van strafvordering. $\mathrm{Zij}$ is gericht op het voorbereiden van een strafproces. Het begrip opsporing wordt niet door art. $1 \mathrm{WvSv}$ begrensd. ${ }^{63}$ De aard van het optreden bepaalt de noodzaak van een wettelijke voorziening voor opsporing. ${ }^{64}$

Op grond van het bekende Heggeveldse stroperarrest ${ }^{65}$ krijgt het 'belang van de opsporing' ${ }^{66}$, als gebezigd in art. 23 WED, ruime interpretatie. ${ }^{67}$ Opsporing omvat mede toezicht. Met andere woorden, een ter opsporing gegeven bevoegdheid mag worden aangewend voor controlehandelingen. ${ }^{6}$ In dat geval geldt de eis van een concrete verdenking van een strafbaar feit niet. En, ambtenaren die zijn aangewezen voor de uitoefening van controlebevoegdheden, die tevens opsporingsbevoegdheid bezitten, mogen deze controlebevoegdheden blijven gebruiken tijdens opsporingsonderzoek. Ook de ambtenaar

59. O.J.D.M.L. Jansen, Toezicht en opsporing en de Awb, in: DD, nr.6, 1994, pp.534-552, i.h.b. p.546, p. 10, constateert een merkwaardige tegenstrijdigheid met de toelichting op art. $1: 1 \mathrm{Awb}$, waarin dat artikel van toepassing wordt geacht "op elk bestuurshandelen m.u.v, het besruurshandelen dat o.g.v. art. $1: 6 \mathrm{Awb}$ is uitgezonderd".

60. Mw wetswoorstel derde tranche Awb, TK 1993-1994, 23700, nr. 3, p.135.

61. P.J.J. wan Butren, Toezicht en opsporing, in: NJB, nr.23,9 juni 1995, pp.867-877, meent dat voor de tweedeling in art. 1:6 Awb bepalend moet zijn "met welke intentie een aan de toezichthoudende-en/of opsporingsambtenaar toekomende bevoegdheid wordt gehanteerd".

62. C.P.J. Goorden (1993), t.a.p., pp.60-61; K.F. Schuiling, t.a. p., pp.365-368; S. Pront-Van Bommel, t.a.P., pp.111-124; N.S.J. Koeman (1992), t.a.p., pp. 103-1 10; G.H. Addink en M.J. Sluijs, t.a.p., p.39;

E. Rood, Owerzicht EEG-en Nederlands levensmiddelenbeleid en recht, Apeldoorn/Amhem, 1993, pp. 110 -119. i.h.b. pp. $112 / 118$.

63. G. Knigge, Van opsporing en strafvordering, in: DD, ar.3, 1990, pp. 195-213.

64. P.A.M. Mevis, Van apsporing. strafwordering en legaliteit, in: DD. nr. 10, 1990. pp.937-945.

65. HR 30 oktober 1984, NI 1985, 275; Vgl, HR 9 januari 1987, NJ 1987, 928.

66. HR 9 maart 1993, nr.93581E, NJBirechtspraak nr.110, 20 mei 1993, p.259, ook in: NJ 1993, 633, tevens in: M\&R 1994, 2 en in: SEW, nr.2, febr. 1995, pp. 32-134, (vgl. respectievelijk Hof "s-Gravenhage d.d. 22 nov. 1991 en rechtbank A dam d.d 27 dec. 1991 m.n. H.C. Mooman, in: M\&R 1993/3, pp. $177-179$ en pp. $179-186$ ).

67. Y. Buruma, Onderzoek in milieuzaken, in: M.G. Faure e.a., Zorgen wan heden, Arnhem, 1991, pp.305. 336; Y. Bunuma, a.w., pp.192-208; P.J.J. van Buuren, Toezicht en opsporing, in: J.P. Balkema en C. Fijnaut, De politiele handhaving wan strafwergewing, Lochem, 1986, pp.66-75; A.M. Franssen., Toezicht es opsporing , het ondwidelike woortraject bij de publieke rechtshandhawing, in: DD, nr.2, 1993, pp.99112 ; H. Lefewre, Toezicht en bestuursrechtelike handhaving in de Awb (derde tranche), in: RegelMaat, mr.5, 1994, pp. 208-212; H.C. Moorman, Toezichthoudende bevoegdheid van opsporingsambtenaren in gevolge de WED, in: M\&R, nr.11, dec. 1988, pp.414-423; A. Mulder, Controlebevoegdheden ter opsporing, in: SEW, nr.9, okt. 1985, pp.564-566; A. Mulder en M.J.A. Engels, De positie wan de bijzondere opsporingsdiensten, in: Recht op scherp, Zwolle, 1984, pp.137-154; M.A. Wisselink, Cantrole en opsporing: de cirkel gesloten?, in: Fiscaal, nr.10, 1992; Vgl. G.P.A. Alet, a.w. pp.36/91, D.R. Doorenbos, Financiel strafrecht, diss. KUN, Deventer, 1992, pp.22-27, als mede A.E.H. Huygen, Controle en opsporing, in: M. Wladimiroff, Facetten van economisch strafrecht, Arnhem, 1990, pp.45-68.

68. Hof "s-Grav. 22 nov, 1991 en rechbank A dam 27 dec. 1991 , m.nt. H.C. Mooman, in: M\&R, nr.3, 1993, pp.177-186; HR 27 okt. 1987, DD 88082 
die een (controle)bevoegdheid tot het daartoe bestemde doel gebruikt en die, middels uitoefening hiervan, vervolgens bereikt dat hij een hem toekomende andere (opsporings) bevoegdheid kan aanwenden, maakt niet per se misbruik van bevoegdheid. ${ }^{69}$

Voor een goed begrip van bovenstaande is het volgende besef onmisbaar. Het opsporingsbegrip is tweëerlei. Het reguliere opsporingsbegrip is neergelegd in het algemene Wetboek van strafvordering. De Awb-wetgever hanteert dit algemene, enge opsporingsbegrip. Het andere opsporingsbegrip vindt oorsprong in de bijzondere Wet op de economische delicten. Juist de eerder genoemde extensieve interpretatie daarvan, waarvan recente rechtspraak nog blijk geeft, levert problemen op. De WED-bevoegdheden zijn kennelijk tweeslachtig van aard. Zij zijn aan te wenden in het kader van zowel opsporing als toezicht. Ze kunnen worden toegepast voordat sprake is van een redelijke vermoeden van schuld aan een strafbaar feit ex art. $27 \mathrm{WvSv}$, maar moeten altijd het belang van opsporing dienen. De normale toezichtsbevoegdheden, die dus een opsporingsbelang kunnen ontberen, zijn geregeld in de afzonderlijke wetten die in de WED zijn aangewezen. Belangen- en bevoegdhedenverstrengelingen kunnen niet uitblijven. Onder verwijzing naar mogelijke doorkruising van het optreden van een ex art. 17 WED aangewezen ambtenaar met het handelen van een toezichthouder die in gevolge een bijzondere WEDwet is aangesteld, de twee-pettenproblematiek die speelt als iemand zowel de opsporingsbevoegdheden ex artt. 19-23 WED als de controlebevoegdheden van een bijzondere WED-wet heeft, als mede de onwenselijke situatie dat WED-bevoegdheden (indien zij toezichthouden impliceren) mede onder Awb-normering kunnen vallen, luidt het betoog clat de wetgever de rechter moet corrigeren; "Aan titel III van de WED is een artikel toe te voegen dat duidelijk maakt dat onder opsporing in de WED het onderzoek n.a.v. een redelijk vermoeden wordt verstaan". ${ }^{70}$

Voor het zo ver is, blijft de 'stille samenleving' van opsporing en toezicht parten spelen. Het voor als nog geldende ruime rechterlijke uitgangspunt, gebaseerd op de WED, is dat tijdens de opsporingsfase controlebevoegdheden mogen worden uitgeoefend ${ }^{71} .{ }^{72}$ Dit uitgangspunt veroorzaakt gemakkelijk problemen van rechtsbescherming.

Als opsporing toezicht impliceert, kan de bewijsgaring vergemakkelijkt worden. Volgens de Hoge Raad kent het recht echter "niet een onvoorwaardelijk recht of beginsel volgens hetwelk een verdachte op generlei wijze kan worden verplicht tot het verlenen van mede-

69. Bekend is thet Geweerarrest, HR 2 dec. 1935, NJ 1936, 250. Deze "voortgezette toepassing" kent als variant 'vervangende toepassing " : de ene opsporingsdienst wendt haar controlebevoegdheid aan t.b.v. een andere opsporingsdienst die nietover die controlebevoegdheid beschikt. Hierover A. B. Hoogenboom, Het Politiecomplex, Arrhem, 1994, pp.393-395.

70. O.J.D.M.L. Jansen, Toezicht, opsporing en de Awb, in: DD, nr.6, juni 1994, pp.534-552, i.h.b. p.545; Bijval van G.H. Addink en M.J. Sluijs, Het wijfle hoofdsuk vam de Awb: handhaving in materieel perspectief, in: NJB, nr.35, 7 okt. 1994, pp.1201-1208, i.h.b. p.1202.

71. O.J.D.M.L. Jansen, t:a.p. . p.535, noemt dit "parallelle controle"; Idem dito O.J.D.M.L. Jarnsen, Bestuursrecht en strafprocesrecht: doonwerken of afgrenzen?, in: T. Hoogenboom en L.J.A. Damen, In de sfeer van administratief recht, Utrecht, 1994, pp.257-283, i.h.b. p.275. 
werking aan het verkrijgen van voor hem mogelijk bezwarend bewijsmaterial ". "Wel moeten "daarbij de aan de verdachte als zodanig toekomende waarborgen in acht worden genomen". ${ }^{74}$ Met oog op het legaliteitsbeginsel en mogelijke onduidelijkheden in de normering van onderzoeksbevoegdheden, is een "strikt restrictieve interpretatie" van de HR-overwegingen nodig. ${ }^{75}$ Bij de waarborgen, waarop de rechter doelt, is te denken aan art. 14 IVBPR, art. 6 EVRM, art. 8 EVRM en art. 29 WvSv. ${ }^{76}$ Hier speelt de vraag welke rechtswaarborgen, in welke mate, aan verdachten en, vooral niet te vergeten, niet-verdachten toekomen. Gelet op tijdens de opsporingsfase toe te passen toezichtsbevoegdheden wordt hier logischerwijs aandacht voor de niet-verdachte opgeëist. Terecht is inmiddels gesteld dat "bij niet-strafvorderlijk handelen strafprocesrechtelijke normen kunnen doorwerken". ${ }^{77}$ Art. 1:6, aanhef en sub a, Awb vormt geen belemmering voor toepassing van ongeschreven beginselen van behoorlijk bestuur.

In dit verband is vooral de Straatsburgse jurisprudentie ${ }^{78}$ toonaangevend. Daarin wor-

72. Wat betreft in elk gewal het milieurecht is over het feit dat toezicht zo een "carte blanche omvat om alle strafrechtelijke waarborgen te omzeilen" terecht zeer verbolgen $\mathrm{E}$. Alders, De handhaving van het bestuursrecht via toezicht en de gemiste kans van de derde tranche Awb, in: NTB, nr.2, 1995, pp.25-29. Auteur beveelt, als aanvulling op de Awb, onder meer het volgende aan: "De WED dient te worden gescreend op die wetten die daar -gezien de bedoeling van de WED-niet in thuis horen. In ieder geval zoudlen er binnen het bereik van de WED geen wetsartikelen mogen voorkomen waarop ook al bestuurlijke sancties zijn gesteld. De mogelijkheid dat in het strafrecht bewijsmateriaall wordt verzameld zonder een redelijk wermoeden van schuld staat op gespannen woet met de rechtsbescherming. Deze vorm van verzamelen wan bewijsmateriaal dient beperkt te worden tot die wetten waar zodanige vếrgaande opsporingsbevoegdheid absoluut niet kan worden gemist." En in zijn artikel ower inspectieverslaglegging merikt

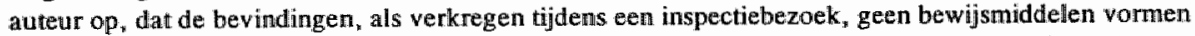
t.b.v. strafrechtelijke verwolging. Owerigens keurt auteur correct bestaande beleidsaansporingen inzake milieutóezicht m.b.t. inspectierapporten af. Het, inderdaad kromme, feit dat het openbaar ministerie het vooral toejuicht dat in, aan onder toezicht gestelden toegezonden, controlerapporten wordt vermeld dat aan de betrokken ovj een afschrift van het verslag is gestuurd, zit auteur niet lekker.

73. HR 5 jan. 1982, NJ 1982, 308, m.nt. Th. W. v. Veen (betreffende art. 33a WvW); Tevens HR 9 okt. 1984, NJ 1985, 176.

74. O.a. FIOD-controle, HR 26 april 1988, NJ 1989, 390, ook in: AA, p.772, m. nt. G. Knigge (inzake art. 49 AWR).

75. J. Wortel, Verwolgen in belastingzaken, fiscale monografieèn mr.56, Dewenter, 1991, pp.382-430, i.h. b. pp. $395-402$.

76. J.M. Reijntjes, Boef of burger? Over de relatie tussen toezicht en opsporing, oratie, Arnhem, 1989 . ppi.39-48.

77. Hierover O.J.D.M.L. Jansen, Bestuursrecht en strafprocesrecht: doorwerken of afgrenzen?, in: T. Hoogenboom en L.J.A. Damen (red.), In de sfeer van admimistratief recht; Opstellen aan W. Konijnenbet, Utrecht, 1994, pp.257-283; Bijval van H.J.B. Sackers, De Awb in straf(proces) rechtelijk perspectief. in: DD, nr.8, 1994, pp.802-813, i.h.b. p.807.

78. I.h.b. Funke vs. Frankrijk, EHRM 25 febr. 1993, NJ 1993, 485, m.nt. Knigge, ook in: NJCM-bulletin 1993, pp.584-592, m.nt. Myjer, tevens in: AA 1993, pp.672-680 en in: NJB, nr. 3, 20 jan. 1995, rechtspraakkatern nr.4, pp.B37-B38 (bijlage); De zelfdle overwegingen in respectievelijk Crëmieux us. Frankrijk, HWJ EG 25 febr. 1993, serie A, nr.256b, in: NJB, nr.4, 27 jan. 1995, rechtspraakkatern nr. 5, p. B49 (bijlage) en Miailhe vs. Frankrijk, HwJ EG 25 febr. 1993, in: NJB, nr.4, 27 jan. 1995, rechtspraakkatern nr.6. pp. B49-B50 (bijlage); Vgl. Medewerking aan (normaal periodiek) boekenonderzaek staat niet in de weg aan opleggen verhoging. Voor of tijdens onderzoek geen criminal charge, HR (belastingkamer) 23 nov. 1994, nr.29392, un: NJB, nr.4, 27 jan. 1995, rechtsprakkatern nr.5, pp.B57-B58 (bijlage), ook in: 
den eisen met betrekking tot de bescherming van het huisrecht als mede waarborgen rondom binnentreding/huiszoeking gesteld. Deze condities staan in het teken van het nemo tenetur-beginsel ${ }^{79}$. Dat is het strafrechtelijk beginsel, dat personen geen medewerking, waardoor zij zich zelf mogelijk in bewijsrechtelijk opzicht belasten, hoeven te verlenen. Dit beginsel kan, gegeven de vloeiende overgang tussen toezicht en opsporing ${ }^{80}$, al in de controlefase van waarde zijn. ${ }^{81}$ Op grond van vermelde jurisprudentie, met name de uitspraak inzake Funke/Frankrijk ${ }^{82}$, komt de Nederlandse rechter tot gelijke oordeelsvorming.

78. $\rightarrow$

NJ 1995, 239, m.nt. 't H.; Niemietz vr. Duitsland, EHRM 16 dec. 1992, series A nr.251b, tevens in: NJ 1993, 400, m.nt. EJD, in: NJCM-bulletin 1993, pp.320-329, m.nt. E. Myjer, ook in: NJB, 28, jant. 1994 , rechispraakkatern ni. 4 , pp.B45-B46 (bijlage).

79. Y. Buruma, a.w., pp.238-249, bespreekt dit principe in het kader van wat auteur noemt uitoefening wan 'onderzoeksbevoegdheden'; Zie ook Y. Buruma, Het OM en de bijzondere opsporing, in: H. de Doelder, R. Foqué en $\mathbb{R}$.A.F. Gerding (red.), Taak en functioneren van het OM, SI-EUR-reeks deel 4, Amhlim, 1994, pp. $181-205$.

80. Van uit het wloeiende onderscheid daartussen, S. Pront-Van Bommel, Onrechtmatig verkregen bemüjs, in: T. Hoogenboom en L.J.A. Damen (red.). In de sfeer wan administratief recht. Utrecht, 1994, pp. 345-363, ower de consequenties van strafrechtelijk onrechtmatig verkregen bewijs voor het bestuursrecht. Auteur wijst op het in de derde tranche Awb op grote schaal toekennen van controlebevoegdheden aan allerlei toezichthouders zonder dat de rechter veel mogelijkheden heeft de witoefening daarvan achteraf te toetsen; Ook R.J.G.M. Widdershowen, Handhawing van sociaaleconomisich recht in Nederland: terugblik en: perspectief, in: RM Themis, nr.5, 1995, pp.205-218, i.h.b. p.211, wijst op de bewijsproblematiek. Daarbij noemt auteur nog de uitspraak Saunders vs. United Kingdom. ECRM 10 mei 1994, nr.19187/191., waaruit blijkt dat het in een strafzaak gebniken van informatie, die een onder toezicht gestelde irl de toezichtsfase onder wettelijke dwang werstrekt, strijdig is met art. 6 EVRM; Vgl. Y. Buruma, De bijzondere politiediensten in het spanningswedd tussen nationale en unionaire ontwikkelingen, in: $\mathbb{D} D, n r .10$. 1994, pp. 1031-1055, i.h.b. p. 1040. Aureur constateert dat het onderscheid tussen toezicht en opsporing is "vertroebeld". Maar hij acht het onderscheid terecht niet zinloosi, gegeven de verschillende doelen wan toezicht en opsporing. Vooral wan uit de, op art. 5.1.3 Awb gebaseerde, discretionaire oordeelsvrijheid van handhavers, die "hooguit achteraf kan worden getoetst" "is de snelle sfeerovergang tussen toezicht en opsporing storend. Auteur hamert specifiek op thet herleven van het nemo tenetur-beginsel in het licht wan het in toememende mate koppelen van allerlei bestanden (p.1049).

81. Volgens F.C.M.A. Michiels, De boese in opmars?, oratie VU, Zwolle, 11 febr. 1994, pp.24 29, is het eethter niet de bedoeling het Funke-arrest, hoewel de uitspraak algemeen is geformuleerd, extensief wit te leggen: "Het merkwaardige gevolg zou namelijk zijn dat mogelijk belastende informatie niet zou howen te worden werstrekt ook al zou die informatie tegelijk ook nodig zijn voor een normale toepassing wan de wret" (p.25). Ruime uitleg leidt er volgens auteur toe dat het beginsel wan nemo tenetur prodere seipsum onverkort op toezichtsbev oegdheden toepasselijk is. Daardoor moet z. i. de gehele bestuursrechtenijke regelgeving voor controle "op de schop".

82. Hierover 0.2. N.J, Schutte, Funke en werder, de toekomst van art. 47 AWR, in: WFR, nr.6100, 21 april 1994, pp.620-626; Ook kritisch M.R. van der Waal, Boekenonderzoek: spreken is zilver, zwijgen is goud?, in: Bank- en effectenbedrijf, maart 1995, p.50. Auteur heeft moeite met de door de fiscale rechter getrokken grenzen, t.W.: a. er is sprake wan het stellen van (nadere) vragen - in het kader van fiscaal boekenonderzoek - c.b.v. de belastingheffing; en b. er is sprake vam het stellen wan vragen met oog op het opleggen van een boete. Anders dan geval a levert situatie b een criminal charge op en impliceert een zwijgrecht. Auteur acht de grenzen tassen beide niet scherp. Volgens auteur moet, door dit grijze gebied, een ondernemer "welhaast helderziende zijn om te weten of hij well of niet tot antwoorden verplicht is ofwel of hij al dan niet aan zijn eigen veroondeling meewerkt door te antwoorden". 
In een relevant arrest ${ }^{83}$ concludeert de Hoge Raad, dat de uit art. 41 Wegenverkeerswet voort vloeiende verplichting, van de eigenaar of houder van een motorrijtuig om, in het kader van de opsporing van een met dat voertuig begaan verkeersdelict, de identiteit mee te delen van de onbekend gebleven bestuurder van dat voertuig, op zich zelf niet overenigbaar is met art. 6 EVRM en art. 14 IVBPR. Wél is sprake van een niet te rechtvaardigen inbreuk op het in art. 6 EVRM en art. 14 IVBPR neergelegde 'fair trial'-beginsel, indien de eigenaar of houder ter zake reeds (ais pleger van het verkeersmisdrijf) is 'charged with a criminal offence" in de zin van verdragsbepalingen. Dan zou betrokkene immers onder dwang informatie verschaffen welke als bewijs van dat misdrijf tegen hem kan worden gebruikt.

Bedoelde eisen, die uit de rechtspraak naar voren komen, gaan vérder dan de voorwaarden als in afdeling 5..1 Awb vervat. In afdeling 5.1 Awb is de rechtsbescherming tegen optreden van toezichthouders verwaarloosd. Dat doet afbreuk aan de kwaliteit van de wetgeving. Aldus wordt de, in paragraaf 10.3 tot en met paragraaf 10.5 weer gegeven, wens van de regering om de rechtsstatelijkheid van rechtshandhaving te benadrukken, ondermijnd. In dit kader luidt het pleidoo ${ }^{84} \mathrm{om}$, in elk geval, de mogelijkheid van bezwaar en beroep tegen alle bij of krachtens afdeling $5.1 \mathrm{Awb}$, dan wel bijzondere wetgeving, voorziene toezichtsbesluiten en -handelingen (niet zijnde besluiten in de zin van de Awb), op te nemen, waarbij de beslissing op dat bezwaar of beroep ${ }^{85}$ gelijk is aan een besluit waartegen beroep bij de rechter mogelijk is. ${ }^{36}$ Bovendien is de kwaliteit van wetgeving inzake toezicht, wat betreft zowel kenbaarheid als voorzienbaarheid ${ }^{87}$, in het geding.

Deze kritiek op het feit, dat toedeling van veel toezichtsbevoegdheden - als in de Awb geschiedt - de mogelijkheid van inbreuk op grondrechten van burgers vergroot, laat de Awb-wetgever links liggen. Slechts in het licht van bepaalde bestuursrechtelijke sancties, in het bijzonder de indirecte dwangmiddelen bestuursdwang en dwangsom, waarvan het

83. HR 26 okt. 1993, nr.94871, in: NJB-rechtsprak, nr.2, 14 jan. 1994, pp. 16"17.

84. A. Derks, A. van Nus en H. Simon, Het toezicht op burgers in de Awb, t.a.p., p. 1552.

85. Hier volstaat ook de term klacht. Zie B. M.J. van der Meulen, Handhaving, in: E.C.H.J. van der Linden en A.Q.C. Tak (red.), Eenzijdig en wederkerig?, Deventer, 1995, pp.223-247, i.n.b. p.246. Volgens auteur kan deze rechtsbeschermingsmogelijkheid worden ingewlochten in, het in de vierde tranche van de Awb, op te nemen klachtrecht, dat daardoor aan wrijblijvendheid in de relatie met de klager verliest.

86. Ongeacht deze mogelijkheid is het zo dat tegen schriftelijke toezichtsbesluiten (en bij niet-schriftelijke besluiten, na gedaan verzoek om schriftelijke vastlegging er van achteraf aan welk verzoek niet wordt woldaan, tegen de weigering schriftelijk te besluiten) ex ant. 6:2 Awb bezwaar of beroep kan worden. atangetekend. Zie ook F.A.M. Stroink, Ammotatie Buma/Stemua, in: JB, ar. 1, 27 jan. 1995, pp.14-15.

87. Eisen als gesteld in Huvig en Krustin, EHRM 24 april 1990, NJ 1991, 523, m.nt. EJD, ook in: NJCMbulletin 1990, p.704, m.nt. E. Myjer en in: A.A 1991, pp.160-168, m.nt. A.H.J. Swart; Vgl Scholsen: vs. gemeente Wierden, HR 11 nov. 1994, rek.nr.8501, in: NJB, 2 dec. 1994, nr.43, rechitspramkkatern nr.241C, pp.576-577 (bijlage). Daarin oordeelt de $\mathrm{HR}$ het niet onjwist dat in weerwil van de woordern in art. 8, tweede lid, EVRM (in accordance with the law) onvermeld wordt gellaten op welke wetsbepaling of ongeschrewen rechtsregel de bevoegdheid tot het werzamelen van onderhavig bewijsmaterial (in casu wordt bewijs verkregen via waramemingen gedaan met een technisch hulpmiddel, in de vorm van filmopnamen) berust. Kennelijk gerechtvaardigd betreft het de opsporingsbevoegdheid ex art. 141 WvSw. De HR acht het opsporingsmiddel niet disproportioneel en niet onrechtmatig. 
punitiewe karakter volgens het wetsvoorstel Awb niet uitdrukkelijk vast staat, volgt een korte reactie op de kritiek. Kennelijk "nopen de artikelen 6 EVRM en 14 IVBPR bij de in hoofdstuk 5 geregelde sancties dan ook niet tot het opnemen van bijzondere wettelijke waarborgen". 88

Wel wordt, meer in het algemeen, terecht het volgende uitgangspunt voor een goede handhavingsregeling gegeven: "Recht moet worden gedaan aan rechtsstatelijke eisen van bescherming van de burgers tegen niet gerechtvaardigde of te zware inbreuken op vrijheden, aantasting van (vermogens)rechten of belangen van burgers, waaronder begrepen een bescherming van de persoonlijke levenssfeer." ${ }^{89}$ Helaas vertrouwt de Awb-wetgever nog te veel op de goedheid van de toezichthouders. Weliswaar in het besef van de vloeiende overgang tussen toezicht en opsporing stelt de Awb-wetgever eenvoudig dat dit gegeven niet leidt "tot grote problemen, mits de toezichthouders die tevens met de opsporing van strafbare feiten zijn belast zich tijdig realiseren dat zij in de opsporingsfase zijn gekomen (d.w.z. dat een concrete verdenking is gerezen) en dat zij dus bij voorbeeld de verdachte moeten wijzen op zijn recht om te zwijgen (art. 29 WvSv)". 90

In het bijzonder wat betreft schending van het privacyrecht is in de toelichting op art. 5.1.5 Awb een verduidelijking opgenomen. Met betrekking tot de toezichtsbevoegdheid plaatsen te betreden is bepaald dat dit niet "het doorzoeken van die plaatsen" omvat ${ }^{91} .{ }^{92}$ Zo nodig wordt in bijzondere wetgeving geregeld, dat kasten, laden, opbergkasten en inventaris mogen worden onderzocht.

De beide andere voorwaarden voor een adequate, in het teken van een wederkerige rechtsbetrekking tussen bestuur en burgers staande, toezichtsregeling, die er op gericht is het handhavingstekort terug te dringen, luiden: "Het toekennen van voldoende bevoegdheden. Aan de overheid toekomende handhavingsbevoegdheden moeten haar in staat stellen de burgers zo nodig te dwingen om de wettelijke voorschriften te respecteren en na te leven; en, de handhaving moet op efficiënte wijze kunnen geschieden. Deze eis ziet op het aspect dat de kosten van het hanteren van handhavingsbevoegdheden voor de overheid als een doelmatige besteding van overheidsmiddelen beschouwd moeten kunnen worden." 93

Gelet op mogelijke inbreuken op grondrechten van burgers is de rechtwaardiging van toedeling van bevoegdheden aan te wenden voor toezicht en opsporing belangrijk. In het kader van opsporing is toekenning van bevoegdheden geoorloofd door de anwezigheid

88. Mvt wetswoorstel derde tranche Awb, TK 1993-1994, 23700, ni.3, p. 132.

89. Mvt wetswoorstel derde tranche Awb, TK 1993-1994, 23700, nr.3, p.130.

90. Mvt wetswoorstel derde tranche Awb. TK 1993-1994, 23700, nr. 3, p. 136.

91. Mut wetswoorstel derde tranche Awb, TK 1993-1994, 23700, nr.3, p. 143.

92. Interessant ziet de PudA-fractie, Inbreng verslag derde tranche Awb, febr. 1995, pp.6/10, i.d.. TK 19941995, 23700, nr.4, pp. 20/28, thier mogelijk aanleiding om de bevoegdheid tot binmentreding te beperken tot: "a. gevallen waarin reden bestaat te vermoeden dat voor de betreffende wet relevante onderwerpen of persomen zich in de te betreden ruimte bevinden; of b. tot situaties waarin het doel van binnentreden bestalt in het aanwenden van bevoegdheden van art. 5.1.6 tot en met art. 5.1.9 Awb ${ }^{\text {m" }}$. Bovendien stelt zij zich de vraag of het wenselijk is in de Awb te bepalen dat de toezichthouder niet bevoegd is woningen the betreden, tenzij bij wet in formele zin anders wordt bepaald.

93. Mut wetswoorstel derde tranche Awb. TK 1993-1994, 23700, nr.3, p.130. 
van een redelijk schuldvermoeden. Maar bij toezicht gaat dat niet op. Ter rechtvaardiging. van toezichtsbevoegdheden worden wel de volgende uitgangspunten gegeven: "a. Van geval tot geval moet worden nagegaan of behoefte bestaat aan speciale toezichthoudende bevoegdheden en of niet met de algemeen geldende opsporingsbevoegdheden kan worden volstaan; $\mathrm{b}$. De toezichthoudende bevoegdheden moeten steeds zo beperkt als mogelijk is worden geformuleerd. Wanneer bij voorbeeld volstaan kan worden met de bevoegdheid tot het binnentreden van bedrijfsterreinen en -gebouwen, moet niet de bevoegdheid worden verleend alle plaatsen te betreden. In het bijzonder op het gebied van het binnentreden van woningen is de grootste terughoudendheid geboden; c. Ook in die gevallen waarin bepaalde toezichthoudende bevoegdheden op zichzelf gewenst zijn om de naleving van een bepaalde wet te kunnen verzekeren, dient het maatschappelijk belang dat met de betrokken wettelijke regeling wordt nageleefd te worden afgewogen tegen de ingreep in de privacy van de burgers die het gevolg zou zijn van uitoefening van toezichthoudende bevoegdheden." ${ }^{94}$

Zo is de noodzaak van toezichtsbevoegdheden af te meten aan de hand van de zwaarwegendheid van factoren als: het te beschermen belang; de aangiftebereidheid; de (on)mogelijkheid van handhaving door opsporing alleen; de mogelijkheid van effectief toezicht; de vaststelling van al-dan-niet naleving van wet- en regelgeving (bij voorbeeld controleren of iemand in het bezit is van een bepaalde vergunning of ontheffing daarvan, of het in een tijdige fase - d.w.z. voordat het tot overtreding komt, waardoor eerst opsporing mogelijk wordt - kunnen controleren of voldaan is aan vaak gecompliceerde technische/inhoudelijke voorschriften i.v.m. het ontbreken van directe waarneembaarheid of het ontbreken van een direct belanghebbende waardoor niet-naleving niet of nauwelijks opvalt). ${ }^{95}$ Aan deze factoren, om de wenselijkheid van toezichtsbevoegdheden aan te staven, wordt het onbreken van de mogelijkheid gebruik te maken van het klachtrecht toegevoegd. 96

Een belangrijke essentie van toezicht op naleving van voorschriften ligt in de preventieve werking die er van uitgaat: "Het toezicht kan tot resultaat hebben dat de wettelijke voorschriften zonder verdere sanctiemiddelen worden nageleefd. Het toezicht omvat een breed scala van activiteiten, vaak ook in voorlichtende en adviserende zin. Daardoor kan reeds in een vroeg stadium worden voorkomen dat een met de wet strijdige situatie ontstaat of kan door middel van aansporingen of waarschuwingen worden bewerkstelligd dat regels als nog worden nageleefd." 97

Dat het belang van toezicht, in relatie tot opsporing, niet te verwaarlozen is, geeft het volgende citaat scherp typerend aan. "Opsporing krijgt vaak - politieke - prioriteit, is namelijk 'spectaculair'. Maar toezicht is in feite $98 \%$ van het werk, aanwezig zijn en

94. Begroting justitie 1975, TK 1974-1975, 13100 VI, nr.20, p.4

95. G.P.A. Aler, De politiebevoegdheid bij opsporing en controle, diss. UVA, Zwolle, 1982, pp.109-133,

96. J. van Drongelen, De ontwikkeling yan de Arbeidsinspectie in een veranderende wetgeving, diss. RL, Scheveningen, 1990, pp.566-604, i.h.b. p.574.

97. Mut wetswoorsfel derde tranche Awb. TK 1993-1994, 23700, nr.3, p.128. 
overtuigen zijn dan kernbegrippen." 98 Kinderachtig doen over toezicht is dus beslist misplaatst.

\subsubsection{TOEZICHTHOUDERS}

Het diffuse onderscheid toezicht-opsporing raakt direct de persoon wan de toezichthouder. De toezichthouder is meervoudig. Ex art. 5.1.1 Awb is een toezichthouder "een persoon, bij of krachtens wettelijk woorschrift belast met het houden van toezicht op de naleving van het bepaalde bij of krachtens enig wettelijk voorschrift". 99

In wetgeving betreffende het optreden van diverse zelfstandige bestuursorganen komen de nodige bepalingen voor waarin toezichthouders, al dan niet tevens belast met opsporing van (economische) delicten, worden aangewezen. ${ }^{100}$

Slechts een paar voorbeelden:

Art. 94, eerste lid, voorstel Flora- en faunawet (d.i. de voor het Jachtfonds relevante wet) bepaalt: "Met het toezicht op de naleving van het bepaalde bij of krachtens deze wet zijn belast de bij besluit van onze minister (van LNV - JGLvN) aangewezen ambtenaren, als mede de ambtenaren der invoerrechten en accijnzen en de door onze minister van justitie 0.g.v. art. 17 WED met de opsporing van de bij of krachtens deze wet strafbaar gestelde feiten belaste ambtenaren."

Art. 5, eerste lid, Wet op de Filmvertoningen (d.i. de voor de Nederlandse Filmkeuring relevante wet) bepaalt: "Met het toezicht op de naleving van deze wet en de opsporing van feiten, strafbaar gesteld bij deze wet, zijn belast de bij art. 141 WvSv bedoelde personen."

Art. 134, eerste lid, Mediawet (d.i. de voor de rechtspersoon Commissariaat voor de Media relevante wet) bepaalt: "Met het toezicht op de naleving van het bepaalde bij of krachtens de hoofdstukken IV-VII, hoofdstuk VIII paragraaf 1, en hoofdstuk XI van deze wet is het commissariaat voor de media belast."

Art. 123, tweede lid, Mediawet (d.i. de voor de rechtspersoon Bedrijfsfonds voor de Pers relevante wet) bepaalt: "Naast de taken die het fonds heeft $0 . \mathrm{g} . \mathrm{v}$. andere wettelijke bepalingen, is het fonds belast met: a. het toezicht op de naleving van het bij of krachtens dit hoofdstuk bepaalde m.b.t. tot de pers."

Art. $27 \mathrm{v}$ Wet op de kansspelen (d.i. de voor de Raad voor de Casinospelen relevvante wet) bepaalt: "1. Op voordracht van de Raad voor de Casinospelen wijzen onze ministers (van justitie en economische zaken - JGLvN) ambtenaren aan, belast met de handhaving en de zorg voor de naleving van het bij of krachtens deze titel bepaalde. Zij zijn opsporingsambtenaar in de zin van art. 142 WvSv. [..]3. Met het toezicht op de naleving van het

98. Ministerie van verkeer en waterstuat, Citaten uit intenwiews met maatschappelijke sleutelfiguren in her kader van het project Naleving, augustus 1992 , p.14.

99. Vgl. C. Borman, a.w., p.116 (aanwijzing 133),

100. De wetgever lijkt zich niet te realiseren dat sprake kan zijn van een toezichthoudend zelfstandig bestiursorgaan, dat zelf niet als persoon is aaln te merken, en waabij elke bevoegdheid - om ambtelijke of niet-anbtelijke personen als toezichthouders, die de handhavingstaalk van het zbo uitoefenen, aan te wijzen - ontbreekt. 
bij of krachtens deze titel bepaalde zijn tevens belast de ambtenaren bij of krachtens art. 141 WwSv." 100

Art. 37, tweede lid, en art. 50, vierde lid, Wet persoonsregistraties (d.i. de voor de Registratiekamer relevante wet) bepalen: "De Registratiekamer ziet toe op de werking van persoonsregistraties overeenkomstig het bij en krachtens deze wet bepaalde en in het belang van de bescherming van de persoonlijke levenssfeer in het algemeen. ", en "Met de opsporing [...] zijn behalve de bij of krachtens art. 141 WvSv aangewezen ambtenaren belast de door onze minister daartoe aangewezen ambtenaren van het secretariaat van de Registratiekamer."

Art. 3b Wijziging van de Wegenverkeerswet 1992, houdende regeling van de verzelfstandiging van de Rijksdienst voor het wegverkeer (d.i. de voor de rechtspersoon Dienst wegverkeer relevante wet) bepaalt dat de Dienst wegverkeer is belast met het toezicht op de naleving die voortvloeien uit de verplichtingen verbonden aan de door haar verleende typegoedkeuringen, erkenningen, kentekenbewijzen, rijbewijzen, als mede met het opsporen van bij of krachtens die wet strafbaar gestelde feiten, woor zover de ambtenaren van de Dienst wegverkeer daarmee in gevolge art. 151 (159 sub c Wegenverkeerswet 1994) zi.jn belast.

Art. 31, eerste lid, Wet tarieven gezondheidszorg (d.i. de voor de rechtspersoon Centraal Orgaan Tarieven Gezondheidszorg relevante wet) bepaalt: "Onze minister wijst personen aan, belast met het toezicht op de naleving van het bij of krachtens deze wet bepaalde."

Voordat de gedachte aan zelfstandige bestuursorganen als toezichthouders boven drijft, zal in het algemeen bij toezichthouders toch eerst worden gedacht aan de reguliere politiefunctionarissen.

De wetgever meent zelfs, op grond van de rond art. 28 Politiewet (oud) gevormde jurisprudentie, dat uit de politietaak, voortaan voort vloeiend uit art. 2 Politiewet $1993^{102}$, een algemene toezichtstaak (m.b.t. de naleving van álle wettelijke voorschriften onder gebruikmaking van alle in de Awb genoemde toezichtsbewoegdheden ${ }^{103}$ ) is af te leiden. Begrenzing van taakuitoefening is gelegen in de hiërarchische ondergeschikheid van politieambtenaren en de conformiteit met hogere geldende rechtsregels. Toch voert deze opvatting te ver. ${ }^{104}$ De scheve verhouding van art. 2 Politiewet en afdeling 5.1 Awb verdient aanpassing.

101. Volgens het Besluit aanwijzing controleambtenaren d.d. 16 aug. 1989 zijn deze handhavers, van het bij of krachtens de Wet op de kansspelen bepaalde, de personen van de bv met beperkte aansprakellijkheid Jkwezen ( $v$. Dienst $v, h$. IJkwezen).

102. Inwoering nieuwe Politiewet, Stbl. 1994, 724/725.

103. B.M.J. wan der Meullen, Ordehandhaving: acroren, instrumenten en waarborgen, diss. VU, Deventer, 1993. pp.93-95.

104. O.a. H.Ph.J.A.M. Hennekens, het voorstel woor een nieuwe Politiewet: een bestuursrechtelike prothese woor de politie-organisatie I, in: Gst, nr.6944, 22 mei 1992, pp.281-288, i.h.b. pp.285-286; N. a.v. Rb. A'dam, 27 dec.. 199\, NJ 1993,69, tevens terechte kritiek wan O.J.D.M.L. Jansen, Toezicht, opsporing en de Awb, in: DD, תr.6, 1994, pp.534-552, ish.b. pp.548-551; Ook S. Pront-Van Bommel, Onrechmatig verkregen bewijs, in: T. Hoogenboom en L.J.A. Damen (tred.), In de sfeer van administratiefrecht, Utrecht, 1994 , pp.345-363, i.h. b. p.350. Volgens auteur is bij het opstellen van afdeling 5.1 Awb slechts gedacht aan bijzóndere toezichthoudende ambtenaren. 
Voorkomen moet worden dat alle willekeurige politieambtenaren de toezichthoudende Awb-bevoegdheden mogen uitoefenen. Tegelijkertijd moet duidelijk zijn, dat speciaal daartoe aangewezen politiefunctionarissen wel gerechtigd zijn toezicht te houden op naleving van bepaalde wet- en regelgeving.

Ten eerste zijn er zo'n $42.000^{105}$ algemene opsporingsambtenaren, opgesomd in art. 127 junctis art. $141 \mathrm{WvSv}$ en artt. $4 / 10$ Politiewet ${ }^{10 \%}$. Deze ambtenaren, niet zijnde bezoldigde ambtenaren in een lagere dan door de minister van justitie bepaalde rang of technische/administratieve personeelsleden, bezitten de bevoegdheid alle strafbare feiten op te sporen. Ex art. $146 \mathrm{WvSv}$ wordt die bevoegdheid mogelijk territoriaal beperkt. Overigens kan de brede bevoegdheid restrictief zijn. ${ }^{107}$ Doordat bepaalde bijzondere wetten daaraan zijn onttrokken. Daarnaast van wege de bij ambtelijke benoeming gemakte afpaling ervan tot zekere strafbare feiten. Of omdat zij slechts in gegeven gevallen bestaat.

Naar komend recht houdt de onbezoldigd ambtenaar ${ }^{108}$ op te existeren. Dit geldt, trouwens, zowel voor algemene als bijzondere opsporingsambtenaren.

De tweede categorie betreft het complex van bijzondere opsporingsambtenaren. Even als algemene opsporingsambtenaren kunnen bijzondere opsporingsambtenaren zowel ambtenaren als gewone personen zijn. ${ }^{109}$ Bijzondere opsporingsambtenaren zijn weliswaar niet per definitie, maar wel vaak tevens met toezicht belast. Omgekeerd geldt dat niet altijd. Bijzondere opsporingsambtenaren kunnen hun taak inzake specifieke wet- en regelgeving ontlenen aan het huidige art. 142 WvSv of een bijzondere wet. In samenhang met een verordening van een lager publiekrechtelijk orgaan of met een wet in formele zin, waarin slechts controleurs worden aangewezen, geldt dit ook voor particulieren. Particulieren, die gerechtigd zijn tot bijzondere opsporing, zijn bij voorbeeld in dienst bij Buma/Stemra. Daarnaast zijn bijzondere opsporingsambtenaren mogelijk bij beschikking door de minister, al dan niet in overleg met de betrokken vakminister, aangewezen krachtens art. 17, eerste lid, sub 2, WED of bijzondere wet. Vaak betreft de beperkte bevoegdheid een ruim gebied. Denk aan het werkterrein van de bijzondere opsporings-

105. C.J.C.F. Fijnaut (red.), Politiezorg in de jaren "90, politiestudies nr.5, Amhem/Amwerpen, 1991 , p. 144; Hervan zijn ongeveer 8000 onbezoldigd. Zie X. Buruma, E.M. de Koning-De Jong en J. van Wieringen, Bijzondere opsporingsdiensten, Amhem, 1990, p.18, als ook TK $1989-1990,21302$, wr. 2, p. 9 (sprake van respectiewelijk 8043 en 8679 ).

106. Wet 4 juli 1957, Stbl. 1957, 244, gewijz. 24 juni 1992, Stbl. 1992, 326, gewijz. Stbl. 1993, 725 ja. Stbl. $1994,145 / 265$.

107. Stapel en De Koning, Leerboek voor de politie, deel 6, 47ste druk, Lochem, supplement 132, 1991. p.26.

108. Aan de status van onbezoldigd ambtenaar zijn drie eisen verbonden: a. dringende noodzakelijkkeid; b. bekwaamheid; en c. betrouwbaarheid. Zie Circulaire ministerie van justitie, $16 \mathrm{sept}$ 1988, nr.882/588, zie ook Stcrt. 30 sept. 1988, 190, als opgenomen in Y. Bumma, E.M. de Koning-De Jong en J. van Wieringen, a.w., pp. 137-142.

109. Art. 127 WvSv: Onder opsporingsambtenaar worden werstaan alle personen met de opsporing van het strafbare feit belast. 
ambtenaren van AID (610 in loondienst + 550 onbetaalden), ECD (195) ${ }^{110}$, FIOD (360), RVV (900), Rijksverkeerinspectie (621), Vleeskeuringdiensten (1106), Loontechnische dienst (215), Staatsinspectie volksgezondheid (440), IJkwezen bv (130), Arbeidsinspectie (32), of Korps Controleurs Gevaarlijke Stoffen (40). ${ }^{111}$ De bijzondere opsporingsambtenaren samen worden aanvankelijk geschat op circa 46.000 in getal. "12 Een meer recente verhandeling over het fenomeen bijzondere opsporingsdiensten gaat uit van grof weg de dubbele omvang van 80.000 à 100.000 ambtenaren met bijzondere opsporingsbevoegdheid, de bijzondere opsporingsdiensten zijn circa 60 in getal. ${ }^{113}$

Bekende redenen om, op bijzondere wetten gebaseerde, opsporingstaken niet aan de reguliere politie, maar aan diverse diensten met opsporingsbevoegdheid van verschillende vakdepartementen toe te vertrouwen, zijn bij voorbeeld de volgende. Aan een dienst, die hoofdzakelijk toezicht houdt op wet- en regelnaleving, kan een bijzondere opsporingsbevoegdheid worden toegekend om dit toezicht aan te vullen. De opsporing dient dus het toezicht, zij is slechts ondersteunend. En, als een dienst deskundig personeel en adequate controlevoorzieningen in huis heeft, is het zinvol juist aan die dienst bijzondere opsporingsbevoegdheid toe te kennen. Het met bijzondere opsporing opzadelen van de reguliere politie vereist exorbitante investeringen in opleiding en apparatuur.

De regeling voor bijzondere opsporingsambtenaren ondergaat in de toekomst fundamentele wijziging. Naar komend recht kunnen gemeenten en andere publiekrechtelijke organen niet meer, via art. $142 \mathrm{WvSv}$, (voor bij verordening bepaalde strafbare feiten) zelfstandige bijzondere opsporingsambtenaren aanwijzen. Maar een wet is geen wet als niet in uitzondering is voorzien. Zo nodig, voorziet het openbaar ministerie in een categorale aanwijzing voor alle gemeenten en andere publiekrechtelijke organen. ${ }^{114}$ Middels zo'n interventie behouden deze organen de mogelijkheid in verordening apart opsporingspersoneel aan te stellen. Dit staat helaas haaks op de voorgenomen sanering van het bijzondere opsporingsambtenarenbos.

110. Aanvankelijk is het de bedoeling AID en ECD te laten fuseren. Zie o.a. NRC, 4 dec. 1993, p.3. De woorgenomen fusie is een woorbeeld wan organisatorische bundeling van witvoerende diensten, m. n. bijzondere opsporing sdiensten en inspecties, waarmee ontkokering en coördinatie $v_{\text {.d. }}$. rijksdienst wordt beoogd. G.J. van Dinter in (syllabus)bijdrage alan het congres Verzelfstandigen bij de rijksowerheid. t.a.p., p. 11 ; Zie over voorstellen tot fusie Samenwoeging ECD en AWD tot en controle-en opsporingsdienst, TK 1993-1994, 23457, 12. 1; Cie-Wiegel, a.w., p.31; Begin 1995 blijkt dat het, medio 1994 aangetreden, kabinet-Kok er anders over denkt. Dit kabinet beslist d.d. 3 febr. 1995, op grond van overwegingen van theoretische en praktische aard, dat de fusie miet doorgat. Wel benadnkt het kabinet hec belang de samenwerking tussen AID en ECD te intensiverem. Daardoor kan onder meer de overlapping van hun werkzaamheden worden weggenomen. ECD en ALD, TK 1994-1995, 23547, nr.2. Zie ook Fusies van rijksdienstem afgeblazen, in: NRC, 4 febr. 1995, p.19.

111. Zie voor overzicht, van wellicht ten dele gedateerde, formatiesterkte wan verschillende bijzondere opsporingsdiensten. P. wan Reenen, De bijzondere politie: een verwaarloosd onderdeel van het politiewraagstuk, in: BWn, nr. 5, 1986, pp.288-310, i.h.b. pp.296-297, C.J.C.F. Fijnaut, a.w, p.152.

112. Y. Buruma, E.M. de Koning-De Jong en J. van Wieringen, a.w., p. 20.

113. Duistere bijzondere opsporing bedenkelijk noor rechtsstaat; Studie Klinkers pleit voor aanslutring bij reguliere politie, in: $\mathrm{BB}, \mathrm{nr} .45,11$ nov. $1994, \mathrm{p} .4$.

114. Mva wetsonwerp nieuwe Politiewet, TK 1992-1993, 22562, p.43; Vgll. wet d.d. 9 dec. 1993 , Stbl. 1993,724 . 
Overigens verandert er niets aan aanwijzing van bijzondere opsporingsambtenaren krachtens formele, bijzondere wetgeving.

Het huidige stelsel van bijzondere opsporingsinstanties, waarin soms twee of drie bijzondere opsporingsdiensten -mogelijk naast de reguliere politie- op treden, wekt huiver op. Het is dermate buitensporig en gecompliceerd, dat de overweging mee wordt gegeven de bijzondere opsporing, a. waar het opsporingstaken betreft, onder te brengen bij de reguliere politie ${ }^{\text {is }}$ en $\mathrm{b}$. waar het toezichts- en controletaken betreft, over te hevelen naar regionale of lokale diensten. ${ }^{116}$ Immers, de rechtsstatelijkheid vraagt om een democratisch gecontroleerd en transparant opsporingsapparaat. De bijzondere opsporing wordt in het bijzonder complex, nu de overheid een flink verzelfstandigingsbeleid voorstaat. "Het voornemen om kerndepartementen in te stellen, met uitvoerende onderdelen 'op afstand' maakt de inzichtelijkheid en beheersbaarheid van de opsporingsdiensten er niet eenvoudiger op." 117

Ten derde is, met het nieuwe art. $142 \mathrm{WvSv}{ }^{118}$, introductie van buitengewone opsporingsambtenaren een feit. Dit zijn: a. personen aan wie door de minister van justitie onderscheidenlijk de procureur-generaal een akte van opsporingsbevoegdheid is verleend; of $\mathrm{b}$. meerderjarige personen, behorende tot de door de minister van justitie aangewezen categorieèn of eenheden ${ }^{119}$. ${ }^{120}$ Normaliter reikt de opsporingsbevoegdheid, ex art. 142, tweede lid, voorstel WvSv, niet verder dan bij amvb bepaald. Maar de akte of aanwijzing kán bepalen dat zij âlle strafbare feiten bestrijkt. Bij amvb worden nog nadere eisen gesteld aan extraordinaire ambtenaren. Denk aan voorwaarden van noodzakelijkheid, bekwaamheid en betrouwbaarheid. De met de inwerkingtreding van de Politiewet $1993^{121}$ tevens van kracht geworden nieuwe Ambtsinstructie voor politie en marechaussee geldt ten dele voor de buitengewone opsporingsambtenaar. Namelijk slechts in die gevallen waarin de minister van justitie (in het aanstellingsbesluit) bepaalt dat deze functionaris geweld mag toepassen of op veiligheid mag fouilleren. ${ }^{122}$

115. Aldus belangrijk BiZa-ambtenaar voor politiezaken. H. Borghouts, Topambrenaar politie tornt aan bijzondere opsporing, in: BB, nr.20, 19 mei 1995 , p.9.

116. Aldus L.E.M. Klinkers die ter zake om een politiek debat vraagt. Duistere bijzondere opsporing bedenkelijk voor rechisstaat"; Studie pleit woor aansluiting bij reguliere politie, in: $\mathrm{BB}, \mathrm{nr}, 45,11 \mathrm{nov}$. 1994. p. 4. Zie ook L. E. M. Klinkers, Milieu, nous maintiendrons?, in: RegelMaat, nr.5, 1994, pp.195. 200 , i...h.b. p. 199.

117. 'Duistere bijzondere opsporing bedenkelijk voor rechtsstaat'; Studie pleit voor aansluiting bij reguliere politie, in: BB, inr.45, 11 nov. 1994, p.4.

118. Wijziging Politiewet, TK 1991-1992, 22562, nrs. 1-3/11.

119. Uit Mut nieuwe Politiewet, TK 1992-1993, 22652, nr.14, p.31, is af te leiden dat voor priwaatrechtelijke zbo"s, die een publiekrechtelijke taak uitwoeren, normaal gesproken een categoriale aanwijzing geldt.

120. P. Muijen en D. Pijl. Nan onbezoldigd nat buirengewoon; Een reorganisatie zonder effect voor het aantal opsporingsambtenaren? , in: APB, nr.5, 6 mart 1993, pp.11-13. Auteurs vragen zich terecht af; of het onder $b$. gestelde de beoogde overzichtelijkheid van werkzame opsporingsambtenaren well ten goede komt.

121. In werking getreden op 1 april 1994 , Stbl. $1994,145$.

122. Ambtsinstructie politie, Koninklijke marechaussee en buitengewoon opsporingsambtenaar, Stb\|. 8/21 april 1994, 275; Tevens relevant is het Besiuit houdende regels inzake ter witwoering van art. 142, vierde 
Het blijft een moeilijk te verteren feit dat buitengewone opsporingsambtenaren inzetbaar zijn ten behoeve van een, niet onwaarschijnlijk: winstgerichte, verzelfstandigde entiteit met privaatrechtelijke rechtspersoonlijkheid.

Van een andere orde zijn, ten slotte, de particuliere toezichthouders. Zij zijn niet meer te veronachtzamen. Zo zijn er parkopzichters, stads- en dorpswachten ${ }^{123} 124125$, parkeerwachters, strandwachters ${ }^{126}$, flat-wachten/huismeesters, recherchebureaus (d.w.z. bureaus die op verzoek van derden informatie over personen vergaren) ${ }^{127}$ of beveiligingsorganisaties (te onderscheiden in particuliere beveiligingsbedrijven, particuliere allarmcentrales, particuliere waarde-en geldtransportbedrijven, bedrijfsbeveiligingsdiensten en een restcategorie) ${ }^{128} 129130.131$ Maar ook allerlei geprivatiseerde en

\section{$122 . \rightarrow$}

lid, WVSw betreffende de bekwaanheid en betrouwbaarheid, beëdiging en instructie van, als mede het toezicht op buitengewoon opsporingsambtenaren, het grondgebied werarvoor de opsporingsbevoegdheid geldt, de beëindiging van de opsporingsbevoegdhe id en enige andere ondenwerpen, 11 nov. 1994, Stbl. 1994, 825, geldend per 7 dec. 1994 met terugwerkende kracht tot 1 april 1994; Zie ook Uniforme regeling buirengewone opsporingsambrenaren, Stcrt. 25 april 1994, 79.

123. Niet te verwarren met de onbetaalde, opsporingsbevoegde politieassistent. Overigens is laatst genoemde naar nieuw recht de, ex art. $14 \llbracket$ WvSv als bezoldigd ambtenar opsporingsbevoegde, politiesurveillant. die geen vuurwapen mag dragen.

124. Uit een criminolog ische studie (RUL) blijkt, dat stadswachten, politiesurveillanten en openbaar werwoercontroleurs effectief en tot grote tevredenheid van de meeste burgers optreden. Zie NJB, nr.20, 20 mei 1994, p.701; Ook Stadswachten verhogen veiligheid op straat, in: BB, nr.2丩/22, 3 juni 1994, p.5.

125. PvdA, VVD en D'66 beloven, van uit de overheidskerntaak bescherming/veiligheid aan burgers te bieden, in hun Regeerakkoord, TK 1993-1994, 23715, nr.11, p.26, "aanzienlijke uitbreiding van het aantal surveillanten en stadswachten"; Justitiebegroting 1995. TK 1994-1995, 23900 VI, nr.2, p. 16, vindt het een versterking dat de Stichting stadswachten Nederland nu een landelijk bu reau heeft en meldt dat nieuwe vormen van functioneel toezicht worden gestimuleerd.

126. Zandvoort krijgt strandwachters, in: BB, nr. 21/22, 3 juni 1994, p. 17; Overigens valt het, politietaakprivatiserings-project van 'beachwatchers', betaald uit sponsoring en reclame, niet in goede aarde biji reddingsbrigade, plaatselijke EHBO en strandpachterswereniging. Zie $\mathbb{R}$. van den Boogaard, Het strand wan Zandvoort, in: NRC, 8 augustus 1994, p. 2 .

127. Deze bureaus zijn, in gevolge wijziging Wet op de weerkorpsen, sinds 1 dee. 1993 vergunningplichtig. Sindsdien hebben zij ook een meldingsplicht t.o.v. de politie. Bovendien moeten ze een gedragscode opstellen en zich aanmelden bij de Registratiekamer. Zie Detective wordl beschermd beroep, in: NRC, 10 aug. 1993, p. 3; Medio 1994 zijm er 270 verzoeken om vergunningverlening ingediend. Zie Justitie: 270 aanvragen voor detectivebureaus, in: NRC, 28 juni 1994, p.7.

128. In 1989 is hun omvang 14.957, TK 1990-1991, 21803 , nr.2, bijlage 1; Vgl. A.B. Hoogenboom, Bijzondere opsporingsdiensten en de politie, "s-Gravenhage, 1985; Recenter A.B. Hoogenboom, Het Politiecomplex; Over de samenwerking tussem politie, bijzondere opsporingsdiensten en particuliere recherche, politiestudies mr.15, Arnhem/Antwerpen, 1994.

129. Het is politieambtenaren (incl. overige opsporingsbevoegde personen, bij voorbeeld bij de spoorwegpolitie en De Nederlandsche Bank) niet toegestaan werkzaam te zijn voor recherche- of beveiligingsorganisaties. Uitgezonderd gevallen waarin een buitenstaander redelijkerwijs niet voor enig gevaar van taakvermenging hoeft te wrezen en ook geen overdracht van politie(-of opsporings)informatie is te verwachten. Wetsvoorstel particuliere beveiligingsorganisaties en recherchebureaus, TK 1993-1994. 23478, nrs. 1-3; T.J. Meeus, 'Bijkiussen politie is gevaarlijk", in: NRC, 17 dec. $1993_{\text {" }}$ p. 3 . 
werzelfstandigde organisaties (o.a. Dienst omroep bijdragen van de Koninklijke PTT Nederland nv ex art. 141 , eerste lid, juncto art. 112, tweede lid, Mediawet ${ }^{132}$ of bij woorbeeld priwaatrechtelijke landbouwkwaliteitscontrole-instellingen die via de regels uit: de Awb ook tegenover níet-aangeslotenen indringend toezicht mogen uitoefenen). Overigens moet met het verlenen van toezichthoudende bevoegdheden aan personen buiten het overheidsapparaat "terughoudend"-worden omgesprongen. ${ }^{133}$

Dit uitgangspunt verdient aandacht nu het aantal toezichthouders, in criminaliteitsgevoelige functionele sectoren, sinds halverwege de tachtiger jaren, stevig toeneemt. Het kabinet-Kok staat pal achter toezicht als preventief instrument om de samenleving bij te sturen. De komende jaren maakt dit kabinet zich dan ook breed voor een verruiming van toezichthouders met een slordige 20.000 menskrachten. In 1995 is 100 miljoen gulden beschikbaar voor 5000 toezichtsbanen. Daarvan gaat een derde deel naar stads- en dorpsgebieden van middelgrote of kleine omvang. De rest komt vrij voor de vier grote steden in Nederland. In de periode 1996 tot en met 1998 vindt verdeling van het resterende budget plaats. Hoewel de uitbreiding relatief goed is te meten, is de huidige sterkte van het toezichthouderskorps moeilijker te kwantificeren. Pas in 1994 beginnen zowel de Vereniging van Nederlandse Gemeenten als het ministerie van binnenlandse zaken met een inventarisatie van bestaande toezichthoudende personen (soms zijnde ambtenaren). Op het ministerie van binnenlandse zaken ligt een plan op tafel om een brancheorganisatie woor toezichthouders in de particuliere sfeer op te richten. ${ }^{134}$ Daarmee kunnen een ze-

130. Positief te waarderen is dat de particuliere beveiligingsbranche de samenwerking met de politie intensiweert. Deattoe sluit de Vereniging van Particuliere Beveiligingsorgamisaties, die verstandig afziet van aanspraken op wapengebruik of geweld sbevoegdheden, een convemant met de Raad van Hoofdcommissarissen. Politie en particuliere beveiliging halen barten stevig aan; Branche geeft ook nieuwe kwathteitsgarantes, in: BB, nr. 49.9 dec. 1994, p.5; Het overleg van in het bijzonder de eigen veiligheidsdienst van het grootwinkelconcern Vroom en Dreesman met de Raad wan Hoofdcommissarissen loopt echter stuk op het gebied van het door V\&D gewenste gebnuik wan handboeien. De Tweede Kamerleden De Graf en Scheltema-De $N$ ie (D'66) kondigen wijziging van de Wet particuliere beveiligingsorganisaties en recherchebureaus aan in de zin dat het gebruik van handboeien door particulienen in beginsel verboden wordt en slechts bij wege van exceptie mogelijk is. Gebruik handboeien bij V\&D voorlopig op losse schroeven, in: BB, nr.5, 3 febr. 1995, p.5; Meer algemeen P. Muijien, Zicht op de particuliere bevelligingsbranche, in: AP, nr.4, 18 febr. 1995.

131. Tegenwoordig bestain al gemeentelijke afdelingen toezicht. Zo vormen bij voorbeeld in Ede stadswachten, milieuwachten, parkeerwachten en jacht- en recreatietoezichthouders een geîntegreerde afdeling toezicht, die ressorteert onder een Dienst openbare werken. De afdeling onderhoudt een actieve relatie met niet-gemeentelijke toezichthouders, waaronderhuismeesters, flatwachten enparticulliere beveiliging. Toezichthouders Epe in één afdeling, in: BB, nr.12, 24 maart 1995, p.26.

132. Weliswaar met opsporingsbevoegdheid. Zie Besluit aanwilzing opsporingsfunctionarissen DOB, Stcrt. 1989, 149. Door inlijving bij KPN nw worden voomalige DOB-ambtenaren als huidige werknemers van KPN nw speciaal in het kader wan hun controletaak belast met opsporing, Stcrt. $\mathbb{1 9 8 9 , 3 8 .}$

133. Mn wetswoorstel derde tranche Awb. TK 1993-1994, 23700 , nr.3, p.139.

134. F. Vreeburg, Wat levert 't op; hogere veiligheid of lagere werkloosheid?; Toezichhouders, de nieume bromsnomen, in: BB, nr.49, 9 dec. 1994, pp.2-5 (bijlage publiek domein). 
kere eenvormigheid en een minimaal kwaliteitsniveau ${ }^{135}$ worden gegarandeerd. Ook acht het ministerie van binnenlandse zaken politiële aansturing en operationele regie van toezichthouders wenselijk. ${ }^{\circledR 36}$ Zo krijgt de, steeds meer voorgestane, gedachte van meer eenvormigheid en duidelijke regelgeving rond particuliere toezichthouders, vooral van wege de gewenste politieke en democratische controle, langzaam maar zeker gestalte. In dit licht is de nieuwjaarsboodschap voor 1995 van de minister van binnenlandse zaken interessant. Hij bepleit oprichting van een Inspectie voor de politie op rijksniveau. Deze inspectie vormt dan het 'sluitstuk' van het project Integrale Kwaliteitszorg Politie, waarin politiekorpsen verantwoordelijk zijn voor zelfcontrole en -evaluatie op basis van intercollegiale toetsing. ${ }^{137}$ De kwaliteitsverbetering van de veiligheidszorg vindt oorzaken in de toename van de georganiseerde criminaliteit, de stijging van de jeugdcriminaliteit en de vergroting van het aantal toezichthouders: "Bij de versterking van het toezicht komt het aan op een verstandige inzet van werkgelegenheidsgelden, op een beleid gefundeerd op een betrouwbare analyse van de behoefte, op bestuurlijk draagvlak voor afstemming en op de verbinding van doelen aan inzet van toezichthouders. Weinig vrijblijvendheid dus!" i38

\subsubsection{PARTICULIEREN ALS TOEZICHTHOUDERS ${ }^{139}$}

Tegenwoordig bestaat de tendens om uitvoering van overheidstaken te privatiseren. Dit leidt er toe dat steeds vaker privé-ondernemingen worden ingeschakeld bij publiekrechtelijke taakvervulling.

Allereerst rijst de vraag of de handhavingstaak, dat wil zeggen de taak om orde en veiligheid in een bepaalde staat te bewaken, niet een taak is die tot het overheidsmonopolie, om zo nodig dwang tegen burgers uit te oefenen, hoort.

Tijdens het debat in de Eerste Kamer, over de 'vrijwillig' te ondergane veiligheidscontroles op de luchthaven Schiphol, wordt deze vraag door de kamer in positieve zin beantwoord. Vervolgens beslist de regering in de zelfde zin. "40 In de nieuwe Luchtvaartwet ${ }^{141}$ behoudt de overheid de eindverantwoordelijkheid voor orde en veiligheid op Schiphol.

135. Voor het uitoefenen van een toezichtsfunctie is bij woorbeeld te denken aan eisen als: in aanmerking komende particulieren moeten minstens in het bezit zijn van een Ibo-diploma; en - i.g.v. toezich thouders "wit de banenpool" - hoeven personen niet minimal drie jaan maar voortaan slechts ến jaar werk. lloos te zijn.

136. F. Vreeburg, t.a.p., p.5.

137. Deze inspectie ziet dus, als bestuur op afstand, toe op zelfcontrole. 'Inspectie politie geen traditioneel toezich" ", in: BB, nr.8, 24 febr. 1995, p.13.

138. H. Dijkstal, Ook potitie ontkom niet aan inspectie; 'Niet een inspectie in sraditionele zint met snuffelaars die rapportciffers geven" (verkorte versie nieuwjaarstoespraak), in: NRC, 12 jan. 1995, p.7, zie ook: NIB, nr.3, 20 jan. 1995, p.111.

139. Hierover B.M.J, van der Meulen, Ordehandhaving, diss. VU, Deventer, 1993, hoofdistulk 5.

140. Handellingen EK, 13 nov. $1990_{\text {n }}$ p.68 e.v.

141. Nader gewijzigd woorstel Luchwaarnet, EK 1993-1994, 22570, nr.336 e.v.; De uiteindelijke tekst wan de Luchutwartwet is integraal opgenomen in Stbl. 1994,715. 
Een andere vraag is of de commissie-Scheltema zich wel voldoende rekenschap geeft van de mogelijke ondermijning van het algemeen belang ten gevolge van de verstrengeling van het algemeen belang met commerciële belangen. Bij uitoefening van toezicht op de naleving van wet- en regelgeving door een particuliere organisatie spelen twee belangen. Te weten, het eigen belang van de privé-onderneming en het belang van de overheidopdrachtgever. Eerst genoemd belang is louter van private aard. Het impliceert twee zaken: het streven naar het voortbestaan van de eigen onderneming en, in het verlengde daarvan, het streven naar winstmaximalisatie. Het belang van de opdrachtgever zal steeds Zijn vertaling vinden in het eigen belang van de onderneming. De vraag is of een dergelijke onderneming wel mag worden belast de handhaving van publieke belangen. Maar ook voor de overheid-opdrachtgever spelen mogelijk financiële belangen bij een juiste taakbehartiging. ${ }^{142}$ Belangenverstrengeling speelt zowel op het niveau van de individuele ambtenaar ${ }^{433}$ als op dat van het collectief vertegenwoordigend publiekrechtelijk orgaan. Niet ondenkbaar is dat degene, die controletaken uit besteedt, ten koste van betrokken rechtssubjecten, gretig een graantje meepikt.

Goed voorbeeld zijn de, op 20 september 1993 toegestane, experimenten met inschakeling van het particuliere bedrijf Parcon bv bij de handhaving van gemeentelijke parkeervoorschriften. ${ }^{144}$ De parkeerwachters hebben de status van onbezoldigd ${ }^{145}$ opsporingsambtenaar. In het geval van aanwijzing als onbezoldigd ambtenaar kan de minister van justitie, op grond van een bijzondere wet of via art. 4, tweede lid (eerste volzin), Politiewet, instructies geven of zelfs de 'commissie' van opsporingsambtenaar geheel intrekken. ${ }^{146}$

De firma Parcon by kent de volgende aandeelhouders. Randon beveiliging bv levert de parkeerwachters, die de status van onbezoldigd opsporingsambtenaar hebben. Honac bv voorziet de controleurs van draagbare computers. UPC bv verwerkt de bij inspectie verzamelde gegevens. De Bank Nederlandse Gemeenten nv betaalt het project, int boeten

142. Vgl. F. Kuitenbrowwer, Als particulieren gaan bekeuren spekken de gemeenten hun kas, in: NRC, 1 okt. 1993. p.9. Ook F. Kuitenbrouwer, Eenmanszack, in: BB, nr.42, 22 okt. 1993, p.13.

143. Denk aan de ambienaar van de gemeente Den Haag die, na verleende medewerking aan een raadisvoorstel voor priwatisering wan ruim 140 stedelijke parkeergarages, een baan aanvaardt bij de onderneming wataran tijdens onderhandelingen de meeste te verkopen parkeergarages worden beloofd. T.J. Meewus, Topambienaar mengt belangen bij privatisering " in: NRC, 7 okt. 1994, pp.1-2. Hoewel de Haagse B\&W stellen dat de overgang van de ambtenaar "zorgvuldig is verlopen" (Haags privatiseren verloopt 'zorgualdig', in: NRC, 11 okt. 1994, p.1) kleeft er toch een kwalijke geur aan. Zie uitwoerig over Haggs proces van privatisering wan parkeergarages ook T.J. Meeus, Privatisering in Den Haag - ongelukken in een zomptig proces, in: NRC, 15 dec. 1994, p. 15 .

144. Privé-firma wordt opsporingsbevoegd parkeenwacher, in: NRC, 25 sept. 1993, pp.1-2; $\$$. van Woensel, Particulier krijgt opsporingsbevoegtheid voor witwoering gemeentelijke parkeerbeleid, in: BB, nr.38. 24 sept. 1993, p.27.

145. Althans aanwankelijk, later krijgt dit aanpassing in de moderne vorm wan buitengewoon opsporingsambtenaar.

146. Vgl. art. 10, tweede lid, Politiewer getelateerd an de Rechtspositieregelüng onbezoldigde ambtenaren van het Korps Rijkspolitie (24 dec. 1957, Stbl. 1957, 557) wat betreft bij voorbeeld de werknemers wan het Nederlands Meetinstitunt nv (ii.h.b. de dochteronderneming Ukinstelling), die de nalleving wan de Ukwet en de Wet op de kansspelen controleren. O.g.v. de art. 29-29b Ukwet krijgen zij bij disfunctioneren met intrekking van de aanwijzing als onbezoldigd opsporingsambtenaar te maken. 
en verrekent gelden met de gemeenten. Het Centraal Justitieel Incasso Bureau is, voor de resterende $20 \%$, optioneel aandeelhouder. $\mathrm{Zij}$ moet afrekenen met wanbetalers. Wat betreft deze fiscalisering van het parkeerbeleid ${ }^{147}$ is lering te trekken uit een Haags proefproject. ${ }^{148}$ Dit project spreekt boekdelen, wat betreft het opgedane voordeel. Zo is onder meer afgesproken dat een burger, die een kwartier na aanzegging van overtreding van het parkeerverbod zijn achterstallige parkeergeld nog niet heeft betaald, het risico loopt van een onevenredig hoge naheffingsaanslag. Wielklem of takelwagen ${ }^{149}$ komen hem mogelijk duur te staan. Overigens laten de tarieven voor het aanbrengen/verwijderen van een wielklem en het weg slepen van auto"s ${ }^{150}$ grote verschillen zien. ${ }^{151}$ Met invoering van private ondernemingen zal dit beeld zeker niet anders worden. Van de aan de burger opgelegde kosten voor het aanbrengen ${ }^{152}$ van een wielklem, vangt de gemeente Den Haag circa een derde deel ${ }^{153}$ en de particuliere partner de rest. Tel uit de winst.

Ook de gemeente Boxtel gaat over tot privatisering van het parkeerbeheer, Parcon bv krijgt het parkeerbeheer in handen; Eerder draagt Venraij haar parkeerbeheer over aan een particulier bedrijf t.w. Ruijters Parking Beheer. ${ }^{154}$

Volgens de verantwoordelijke ministers gaan de experimenten in Boxtel en Venraij niet ver genoeg. Zij betreffen slechts uitbesteding. Ze voelen meer voor een particulier consortium van bedrijven (denk aan Parcon bv) dat ook de handhaving van de wet Mulder kan uitwoeren. Per 1 oktober 1994 stemmen de ministers van justitie en binnenlandse

147. Over deze fiscalisering 0.a. P. de Bruin, Ontwikkelingen m.b.t. parkeerbelastingen, in: Belastingblad, 1993. pp.575-579; W.G.A. Hazewindus, Administratieve sancties en wreemdelingenrecht, diss. UvA, Arnhem, 1994, pp.68-71.

148. R. Ronteltap, Para-overheid zet de auto Klem, in: ANWB-Kampioen, okt. 1993, pp.26-28.

149. In het Wetswaorstel wijziging (wegsleepregeling in de) Wegenwerkeerswetgeving, TK 1993-1994, 23941 , n:rs. 1-3, ruimt het strafrecht veld voor het Awb-bestwursrecht. Sanctieoplegging in de zin van de wet: Mulder, dan wel het opmaken van proces verbaal, is niet langer voonwaarde om over te gaan tot het verwijderen van een fout geparkeerd voertuig. Bovendien wordt rechthebbende voortaan geen mogelijkheid gegund tot mestitutie van de kosten van voertugwegsleping en -bewaring.

150. M.b.t. tot het weg slepen door de Dienst. parkeerbeheer te Amsteriam bepaalt de nationale ombudsman $\mathrm{M}$. Oosting als volgt. Het krachtig tegen gatan wan fout parkerren is begrijpelijk. Maar voor het toupassen wan een wegsleepregeling moet van meer dan alleen fout parkeren sprake zijn: geparkeerde auto"s moeten gevalir of hinder opleveren voor het overige verkeer. 'Parkeerbeheer te smel met wegslepen', in: $\mathrm{NRC}, 11$ aug. 1994, p.3, ook in: NJB, nr.30, 2 sept. 1994, p.1056; Deze mening deelt de Amsterdamse ombudsvrouw $\mathrm{N}$. Salomons, die spreekt van misbnilk van macht door de A'damse dienst parkeerbeheer. Amsterdam: Kritiek op optreden parkeerdienst, in: NRC, 11 okt. 1994, p.2; Burgemeester Patijn reageert rigoreus tegen de zin van de meerderheid in de $A^{\prime}$ damse gemeenteraad (Pvd.A, $D^{\prime} 66$ en Groen Links). Hij is voornemens de parkeerverordening te wijzigen conform het standpunt van de ombudspersonen. Patijn. soepel parkeerbeleid in binnenstad, in: NRC, 25 jan. 1995. p. 2.

151. Foutparkeerder betalit niet overal evenveel, in: BB, nr.41, 15 okt. 1993, p.22.

152. In reactie op de ervaringen bij Lockheed bv wil het Haagse OM verwijdering van wielklemmen strafrechtelijk, via art. 184 WvSr, aanpakken. Zie Doorzagen wielklem wordt bestraft, in: BB, nr.26, 2 jull 1993, p.4.

153. O.a. hell feit, dat gemeenten een deel van de parkeerboete mogen houden, veroorzakt een forse verhoging van lokale inkomsten. Zie Porkeeropbrengst gemeenten gestegen, im: NRC, 8 febr. 1994, p.2. VgI. Sichil waw betaald parkeren steeds dikker, in: NRC, 10 febr. 1994, p.27; Parkeren in drie jaar 70\% dururler, in: BB, 11 febr. 1994, nr.6, p.14.

154. Ook Boxtel priwatiseen parkeerbeheer, in: BB, nr. $17^{\prime \prime} 29$ april 1994, p.11. 
zaken dan ook in met nieuwe experimenten met het particuliere beveiligingsbedrijf Parcon bv. ${ }^{155}$ De experimenten, die tot uiterlijk $\mathbb{1}$ januari 1996 doorlopen, vinden uitwoerüg in de gemeenten Woerden, Venray, Boxtel en het Amsterdams stadsdeel Westerpark ${ }^{156}$. Wel stellen de verantwoordelijke bewindspersonen een aantal voorwaarden bij deze particuliere handhaving: burgemeesters, politie en openbaar ministerie moeten akkoord gaan; de procureur-generaal te Leeuwarden heeft houdt algemeen toezicht en de lokale politie houdt feitelijk dagelijks toezicht op de Parcon-medewerkers; er bestaat een klachtenprocedure ten aanzien van het uitvoerend optreden van de Parcon-eenheid; en de Parcon-functionarissen, die niet over wapens mogen beschikken ${ }^{157}$, krijgen gedurende de proefprojecten buitengewone opsporingsbevoegdheid omdat ${ }^{158} 159 \mathrm{zij}$ anders niet kunnen bekeuren. 160

De gretigheid waarmee privé-ondernemingen in de toekomst ook afhandeling van snel-

155. Justitiebegroting 1995, TK 1994-1995, $23900 \mathrm{VI}$, ar.2, p.20. Uitdrukkelijk merken de betrokken bewindspersonen op dat de beleidsbepaling overheidsaangelegenheidd blijft en dat slechts de uitwoering wondt geprivatiseerd.

156. Met de mogelijkheid dat nog maximaal vier andere bedrijwen zich, wöoór 1 jan. 1995, als gegadiggden aan melden.

157. Medio januari 1995 staken Rotterdamse parkeercontroleurs omdat zij hum wapenstok en hun handboeilen moetem indeveren. Ook een aantal Amsterdamse parkeerwachters thebben in juli 1994, op last van de Amsterdanse procureur-generaal, hun wapenstok moeten afgeven. Omdat de meeste medewerkers wan parkeertoezicht tegenwoordig beëdigd worden als buitengewoon opsporingsambtenaar, kan de $p$-g volgens het voor deze ambtenaren geldende besluit wanaf 1 april 1995 toestemming geven voor het gebruik van de wapenstok. Zie Deel parkeerbeheer krijgt wapenstok, in: NRC, 18 jan. 1995, p. 3.

158. Vooral het benoemen van werknemers van een vennootschap tot buitengewoon opsporingsambtenaar is C. A. Schreuder, Publiekrechrelijke raken, private rechtspersonen, Deventer, 1994, pp. 261-262, een doorm in het oog. Auteur betoogt terecht dat de bevoegdheid tot opsporing slecht verenigbaar is met de: commerciele gerichtheid wan takverrichting binnen een wennootschap. Daamaast steekt het feit dat de overheidswerantwoordelijkheid (van de minister wan justitie) voor opsporing staken dwars toopt door de ondememingszeggenschap over (opsporingsbevoegde) werknenuers in dienst wan de vennootschap.

159. Terecht onderkent de ministerraad d.d. 24 febr. 1995 de noodzak tot het indienen wan klachten over gedragingen van buitengewone opsporingsambtenaren, als parkeercontroleurs, in dienst van gemeenten en prowincies. Ondat het met de introductie van de nieuwe Politiewet en het nieuwe ant. $142 \mathrm{WwSw}$, anders dan woorheen, niet altijd zeker is of gedragingen wan genoemde personen aan die betrokken be. stuursorganen worden toegerekend, wordt op grond van eendoor staatssecretaris Kohnstamm ontworpen besluit (Besivit houdende aanwizing o.g. . de Who wan bestursorganen van gemeenten en provincie voor de gedragingen wan bwitengeworte opsporingsambtenaren, Stbl. 1995, 218) het zeke re voor het onzekere gesteld. Gemeenten en provincies worden als ter zake aanspreekbare bestuursorganen bedoeld in art. la, eerste lid, sub d, Wno aangewezen, nota bene met tengwerkende kracht tot en met 1 april 1994. Ombudsman bewoegd bij klachten over ale soorten opsporingsambtenaren, in: NJB, nr. 14,17 maart 1995, p.434; Wel moet de nationale ombudsman uitkijken of het in het concrete geval wel gaat om een opsporingshandeling wam een parkeercontroleur. Opsporingsharndelen betreft het als het gebnuik van dwangmiddelen aan de orde is. Gaat het slechts om wegslepen van auto"s, dan lijkt het eerder te gaan om bestuurlijk (toezichts)handelen van parkeerwachters, aldus Rubrieken: Nationale ombudsman, in: DD, nr.3, 1995, pp. 265-267; Zie over het belang wan het klachtrecht bij de gationale ombudsman, die een rechtsbescherming die de administratieve rechter anvult (denk aan art. 1:6 Awb, waarin word bepald dar opsporing van strafbare feiten buiten het toepassingsbereilk van de Awb vall) en cdaarnast zekere zelfstandige juridische protectie biedt, E. Helder en T. Rensen, Bescherming door de Natronale ombudsman in het kader van besluiten, in: NTB, ar.3, 1995, pp.53-60. 
heidsovertredingen, arrestantenvervoer, gevangenisbewaring, toezicht in de metro en andere onveilige plaatsen aan zich willen trekken, dwingt tot uitspraak over het karakter van de (parkeer)handhavingstaak ${ }^{161}$ en versterkt de twijfel over de particulier als toezichthouder ${ }^{162},{ }^{163}$

In het licht van takbehartiging door werknemers van private ondernemingen, valt nog te wijzen op een onzorgvuldigheid in art. 5.1.2 Awb. Conform dit artikel toont een toezichthouder zijn legitimatiebewijs desgevraagd. Het initiatief ligt dus bij de gecontroleerde. ${ }^{164}$ Volgens de commissie-Scheltema dient het telkens ongevraagd tonen van een legitimatiebewijs geen redelijk doel, gelet op de aard van de toezichthoudende werkzaamheden. ${ }^{165}$ Dit is dubieus. Juist (privé-)toezichthouders moeten als zodanig herkenbaar zijn. Ter vergelijking een voorbeeld. Met oog op, door de vervoerder aan te stellen, controleurs ${ }^{166}$ van vervoerbewijzen ex art. 80 Wet personenvervoer ${ }^{167}$ is niet voor niets het art. 3, tweede lid, Richtlijnen toezicht openbaar vervoer ${ }^{168}$ ingevoerd: "Wanneer de controlefunctionaris in burgerkleding optreedt legitimeert hij zich ongevraagd, tenzij bijzondere omstandigheden dit onmogelijk of ongewenst maken." Een dergelijke bepaling is geen overbodige, aan art. 5.1.2 Awb toe te voegen, regel met oog op met name particuliere toezichthouders. ${ }^{169}$

160. Bedrijf gaat in vier steden toezien op parkeerbeleid, in: NRC, 21 sept.. 1994, p.11; Ook Hamdhaving parkeerbeleid aan particulier bedrif witbesteed: proef in vier gemeenten, in: BB, nr.38, 23 sept. 1994 , pp. 12-13, Experiment handhawing parkeerbeleid door particulier bedrif, in: NJB, nr. 33, 23 sept. 1994, p. 1155; Tevens. Particulier bedrijf deelt parkeerboetes uit; Justitie: enige alternatief als handhaving fralt, in: $\mathrm{BB}, \mathrm{nr} .43,28$ okt. 1994, p.4.

161. Politiebonden tegen 'comnercialisering' parkeerbeleid, in: BB, nr.42, 22 okt, 1993, p.13.

162. Gemengde gewoelens in Tweede Kamer over private parkeercontrole, in: BB, nr.40, 8 okt. 1993, p. 12 .

163. Zie lezingenbundel t. b.w. symposium Politie wersus particulier intitatief: Een uitholling van politiele takerk en bevoegalheden? ,Vermande studiedagen, Diemen, 29 april 1994.

164. S. Pront-Van Bommel, t.a.p., p.121.

165. Mw voorontwerp Awb, a.w., p. 136.

166. M.b.t. tot aangewezen controleurs in dienst wan wervoersondernemingen komt, bij boeteoplegging, ook het verschil tussen toezicht en opsporing om de hoek kijken. Het opleggen van boete, inclusief daarme verbonden administratiekosten, door een opsporingsambienaar, maar zekerdoor een vervoersbewijscontrolleur, betreft geen transactieaanbod waardoor van strafvervolging kan worden afgezien. Daarover kan immers sllechts een ovj beslissen. Bovendien valt betaald boetegeld niet in de schatkist, maar komt. zij de vervoender ten goede. De HR oordeelt dan ook terecht dat boeteoplegging, en administratiekosteninning, aan een in casu hardnekkig zwartrijder niet van zuiver strafrecthtelijke aard is. De HR concludeert dat de door een zwartrijder an een werwoender verschuldigde boete (plus administratiekostem), indien die daadwerkelijk wordt betald, het recht om strafrechtelijke vervolging tegen de zwartrijder in te. zetten niet in de weg staat. Een vervoerder kan zijn vorderingsrecht ex art. 57 , eerste lid jo, vijfde lid, Besluit personenvervoer, bij de civiele rechter geldend maken. Aldus het, wel zeer vrij vertaalde en summier samengevatte, arrest Nv Gemengd Bedrijf Haagsche Tramweg Maatschappijws. Eysink Smeets, HR 15 okt. 1994, nr.15324, AB 1994, 632.

167. Wet van 12 mart 1987 , Stbl. $1987,175$.

168. D.d. 18 dec. 1987, Stcrt. 1987, 248.

169. Buiten beschouwing blijft nog het aspect van de (meestal minimaal gediplomeerde) toezichthouder in uniform, waardoor sterke gelijkenis met een opsporingsambtenaar ontstaat. Hier is vergelijking te trekken met de Dorpswacht te Badhoevedorp, Zwanenburg en Hoofedorp, als onderdeel van Hoogen- 
Gelet op de met de persoon van de toezichthouder verbonden legitimatieplicht is het te betreuren dat de wetgever niet expliciet aandacht besteedt aan delegatie van toezichtsbevoegdheden.

\subsubsection{ZELFSTANDIGE BESTUURSORGANEN ALS TOEZICHTHOUDERS}

Art. 5.1.1 Awb is tegen het licht van een algemene verantwoordingsplicht te houden. ${ }^{70}$ Degene, die de toezichthouder aanstelt, is aanspreekbaar op controledaden van betrokkene. Ook kan hij instructies, aangaande taakuitoefening „geven. Een regel, dat de toezichthouder tijdens uitoefening van zijn toezichtsbevoegdheden zich altijd in verbinding mag stellen met degene aan wie hij verantwoording schuldig is ${ }^{471}$, is gegeven deze verantwoordelijkheid acceptabel en zinvol.

Complicatie, inzake het afleggen van verantwoording, doet zich voor bij zelfstandige bestuursorganen. Specifiek toezichthoudende zelfstandige bestuursorganen zijn onder meer de stichting Verzekeringskamer, (ten dele) De Nederlandsche Bank nv, de Stichting toezicht effectenverkeer, de Toezichtkamer van de Sociale Verzekeringsraad (sinds 1 januari 1995 vervangen door het College van toezicht sociale verzekeringen), de (besturen van) bedrijfsverenigingen bij voorbeeld die voor Haven- en aanverwante bedrijven, Binnenscheepvaart en Visserij (toezichthoudend in de zin van wetsuitwoerend) , de Ziekenfondsraad, de Raad voor de Casinospelen (die overigens volgens daartoe gedane, algemeen aangenomen, motie an omvorming toe is ${ }^{172}$, welke gedachte uitvoering krijgt middels wijziging van de Wet op de kansspelen ${ }^{173}$ waarmee instelling van, een in de zin van art. $1: 1$, eerste lid, sub $b$, Awb bestuursorgaan te noemen ${ }^{174}$ maar kennelijk niet zijnde zelfstandig bestuursorgaan ${ }^{175}$, College van Toezicht op de Kansspelen ${ }^{175}$,

booms Bewakingsdienst, die begin augustus 1994 op lask wan het gerechtshof te Amsterdam de strepen van haar auto's noet verwijderen. Volgens het hof vertonen de voertuigen vam de particuliere bewakingsdienst te veel gelijkenis met politievoertuigen. Zie Politiestrepen ${ }_{n}$ in: NRC, 9 aug. 1994, p.3.

170. Veranwoordelijkheid vloeit in waarschijnlik de meeste gevallen al voort uit het ambtenarenrecht.

171. Vgl, resp. art 10 Instructie baconinspecteur, 1989 en artc. 2/9 Instructie weeswareminspecteur, 15 nov. 1989, NVK.

172. Motie Krajenbrink, TK 1989-1990, 21277, mr.7, vervolgens ministeriële accordering daarwan in TK 1990-1991, nrs.18-19, TK 1991-1992, nr.20, TK 1992-1993, 21277, nr.21.

173. Wyziging Wet op de kansspelen i.w.m. instellen College van toezicht op de kansspelen, TK 1993-1994. 23605 , nrs. 1-2.

174. Mwa wijziging Wet op de kansspelen. TK 1993-1994, 23605, nr.6, p.5.

175. Volgens TK 1993-1994, 23605, nr. 3, pp.1/3, bestaat voor een zbo i.c. "thans onvoldoende politiek en maatschappelijk draagviak". Wel wordt bij een evaluatie van de 'vervanger' van de RvdC, binnen 5 jaar, de "optie van een functioneel bestuursorgaan" betrokken (TK 1991-1992, 21277, nr.20, p.3); Dat het hier geen zbo betreft, is betwistbaar. Het college draagt de nodige kenmerken van een zbo, behalve dan dat het een primair raadgevende taakstelling heeft. Wrij wel geen enkel zbo heeft adviseren als hófdtaak. Wel als, met oog op de terugkoppeling van de beleidsuitvoerder naar de beleidsbepaler noodzakelijke, nevenactiviteit: De Algemene Rekenkamer, Zbo's en mimisteriële verantwoordelijkheid, TK 1994-1995, 24130, nr.3, p.73, merkt het college wel aan als zbo. 
te belasten met aan haar geattribueerde ${ }^{177}$ niet-bindende ${ }^{178}$ adviserende, aanwijzing gevende, coördinerende en toezichthoudende taken, feit is), het Commissariaat voor de Media, de Registratiekamer, de Dienst wegverkeer, en verschillende landbouwkwal iteitscontrole-instellingen als de Stichting keur alternatief voortgebrachte Landbouwprodukten. Gegeven de "duidelijke tendens tot verzelfstandiging van de toezichtstaak (los van de respectievelijke departementen) en tot rationalisatie" , is het in de toekomst niet uitgesloten dat een toenemend aantal zelfstandige bestuursorganen "bellangrijke ondlerzoekstaken zal uitoefenen in het kader van de bestuurlijke rechtshandhaving." " 79

Bij zelfstandige bestuursorganen kan zich frustratie van verantwoording voordoen. Zelfstandige bestuursorganen zijn niet hiërarchisch ondergeschikt aan betrokken minister(s). Dit gebrek aan democratische legitimatie moet worden gecompenseerd door externe controlemiddelen. Zo vallen de meeste zelfstandige bestuursorganen, sinds een paar jaar, onder de werking van de Wet nationale ombudsman alsmede de Wet openbaarheid van bestuur. ${ }^{180}$ Overigens kunnen participatie van deskundigen, onafhankelijke personen et cetera in besturen van zelfstandige bestuursorganen, controle op financieel beheer en bedrijfsvoering van zelfstandige bestuursorganen, en adequate (administratieve) rechtsbescherming tegen optreden van zelfstandige bestuursorganen uitkomst bieden.

De zelfstandige bestuursorganen kenmerkende onafhankelijkheid van de minister laat zich illustreren aan de hand van de, per begin 1994 als rechtspersoon sui generis gerealiseer-

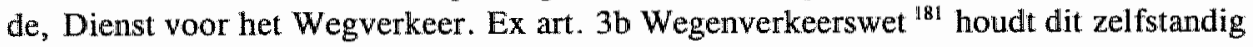
bestuursorgaan zich vooral bezig met typegoedkeuringen voor voertuigen, afgifte van kenteken- en rijbewijzen, en erkenningen van garages voor APK-keuringen. Daartoe beschikt zij over zowel opsporend als toezichthoudend personeel (in gevolge art. 3b juncto art. 151 Wegenverkeerswet, art. 159 sub c Wegenverkeerswet 1994 in relatie tot het Besluit houdende aanwijzing opsporingsambtenaren, Stbl. 1995, 247). Allen hebben de status van ambtenaar (art. 3o Wegenverkeerswet). "De ambtelijke status maakt ook voor de burger duidelijk dat het gaat om personen die een overheidstaak uitoefenen. Dit is te meer van belang, gezien de opsporingsbevoegdheden die door de Dienst wegverkeer zullen worden uitgeoefend." 182 "Wat betreft takuitoefening van de ambtenaren van de Dienst mag de minister van werkeer en waterstaat algemene aanwijzingen geven. Zie art.

176. Zie Kosto wil college voor kansspelen, in: Telegraaf, 22 sept. 1992, p.1; RvdC. Begeleidende brief inz. (18) openbare vergadering FwdC 1993, "s-Grav. , 14 mei 1993; Kansspelbeleid, TK 1992-1993, 21277. nrs. 18-21; Mvt wetrwoorstel inzake wijziging Wer op de kansspelen, TK 1993-1994, 23605, nr.3, pp.14.

177. Memarie wan antword wiziging Wet op de kamsspelen, TK 1993 1994, 23605, nr.6, p.4.

178. Memorie wan anwoord wijziging Wel op de Kansspelen, TK 1993-1994, 23605, nr.6, p.9.

179. I.A.E. Vervaele, Handen en tanden wan het (gemeenschaps)recht, oratie RUU, 18 febr. 1994, Deventer, 1994, pp. 21-22.

180. Notitie betreffende competentie-uitbreiding wan de Nationale ombudsman. TK 1991-1992, 22731, 24 aug. 1992, nrs. 1-2; Onfwerp-awwb aan te wijzen zbo "s, TK 1992-1993, 22731, nr.3, pp.2-8.

181. Wijziging wan de Wegenverkeerswet 1992 , houdende regeling van de verzelfstandiging van de Rijksdienst woor het weguerkeer, TK 1992-1993, 22961, nrs.1-2.

182. Mut wighiging Wegenverkeerswer, a.w., n. 3, p.6. 
$3 c$ Wegenverkeerswet. Betrokken bewindspersoon moet wel "terughoudendheid" 183 betrachten bij gebruik van bij voorbeeld zijn bevoegdheden tot tariefvaststelling, tot benoeming, schorsing of ontslag (van leden van de raad van toezicht), en tot het verzoeken (aan de directie van de Dienst) inlichtingen te verstrekken. Kortom, de Dienst voor het Wegwerkeer geniet veel beleidsvrijheid. De minister, die de Dienst voor het Wegverkeer bevoegdheden toekent, is slechts ten dele aanspreekbaar. Zijn verantwoordelijkheid is namelijk beperkt tot de bij instelling uitdrukkelijk aan de bewindspersoon toegekende bevoegdheden.

De toezichthouders van de Registratiekamer kunnen ook worden onderscheiden in controleurs en opsporingsambtenaren. Met de opsporing van de in art. 50, eerste tot en met derde lid, Wet Persoonsregistraties ${ }^{184}$ omschreven strafbare feiten zijn behalve de bij of krachtens art. 141 WvSv aangewezen ambtenaren belast de door Onze Minister daartoe aangewezen ambtenaren van het secretariaat van de Registratiekamer (art. 50 Wet Persoonsregistraties). ${ }^{185}$ Art. 46 handelt over degenen die met toezicht zijn belast. Het tweede lid stelt dat houders van persoonsregistraties alle inlichtingen verstrekken en alle overige medewerking verlenen aan de Registratiekamer, de ambtenaren van het secretariaat en andere, door de Kamer daartoe aangewezen personen. De mogelijkheid om (particuliere) derden voor controleactiviteiten in te schakelen bestaat. ${ }^{186}$ Ex art. 45, vierde lid, Wpr hebben bedoelde ambtenaren en andere personen uitdrukkelijke en bijzondere volmacht van de Registratiekamer nodig.

Al met al ontstaat de situatie dat een, niet onder de politieke ministeriële verantwoordelijkheid vallend, zelfstandig bestuursorgaan eigenhandig niet-ambtenaren als toezichthouders mag aanwijzen. Justitie ontbreekt het aan de mogelijkheid die personen, met oog op hun takkuitoefening, te instrueren. Deze derden bezitten in gevolge art. 45 , derde lid, Wpr al ver gaande bewoegdheden, maar met afdeling 5.1 Awb krijgen zij waarschijnlijk nog meer controlebevoegdheden in handen. De externe controle op het handelen van een zelfstandig bestuursorgaan, als alternatief voor de afwezige ministeriële verantwoordelijkheid, moet dan wel goed zijn geregeld. ${ }^{187}$

Ten slotte is, in het licht van voornoemde verantwoordingsplicht, te wijzen op een gebrek aan het voorontwerp. Gemist wordt een, op de toezichthouder neergelegde, verplichting om verslag wit te brevgen. Zo'n zaaksrapport moet minimaal voorzien in de vermelding van: a. naam en adres van de betrokkene; b. lokatie/plaats van uitvoering toezichtstaak en uitoefening van de toezichtsbevoegdheid; c. tijdstip en datum van de controle; d.

183. Zie MNt Wegenwerkeerswet, a.w., nr.3, p.6.

184. Wet Persoonsregistrafies, 28 dec. 1988. gewijz. 25 okt. 1988, Stbl. 1988, 480.

185. Gerealiseerd middels o.a. Aawwijzing opsporingsambtenaren WPR, in: APB, nr. 24, 7 dec. 1991 , p.29.

186. Ook A.H.I. Kulus, De Registratiekamer may be watching you!, in: CR, nr.3, 1990, pp. 123-126; Vgl. W.J.M. Voermans, Werk aan de winkel voor de Registratiekamer, in: CR, nr.2, 1989, pp.72-79.

187. Over verantwoordingsmechanismen bij zbo'so.a. cie-Scheltema, Steekhoudend ministerschap, TK 19921993,21427, nr.31, pp. 39-53; Vgl. cie-Wiegel, Naarkerndepartementen. TK 1992-1993, 21427, nr.52, pp. 29-36. 
indien monsterneming plaats vindt: wijze van monsterneming; aantal monsters van welk soort; methode van conserveren, preparen e.d. van genomen monsters; naam, functie of hoedanigheid en betrokkenheid van degene (of een, al dan niet externe, instantie) die het monster neemt en van degene die het monster verwerkt of bewaart; e. indien de toezichthouder handelingen verricht of aanwijzingen geeft: gegeven opmerkingen en geconstateerde bevindingen van de toezichthouder; en f. overige relevante feiten en omstandigheden. Het verslag geschiedt schriftelijk. Uitdrukkelijk opmerking verdient dat de verslagplicht niet alleen van belang is, als een overtreding is geconstateerd en vervolgens een sanctie wordt opgelegd. ${ }^{188}$ Juist het niet rapporteren aan de bevoegde autoriteiten van geconstateerde wet- of regelschending - waartoe toezichthouders geneigd zijn als zij bepaalde wetstegenstrijdige situaties of gedragingen tolereren en door de vingers zien of gedogen, welke voorstelling van zaken niet zo ondenkbaar is omdat afdeling 5.1 Awb toezichthouders in principe vrij laat om al dan niet aangifte te doen van door hen gesignaleerd onrecht - kan de rechtsbescherming van een justitiabele te kort doen. Hij kan zijn beklag over het, naar zijn mening onvolledige, optreden van een toezichthouder wel doen, maar hij kan daarbij niets overleggen. ${ }^{189}$

\subsubsection{DE DERDE TRANCHE AWB ZONDER WINST NAAR DE EINDSTREEP}

Uit het wetsvoorstel afdeling 5.1 derde tranche Awb inzake toezicht ${ }^{190}$ blijkt dat de wetgever het kennelijk nog (steeds) niet nodig vindt om in de Awb regelingen te treffen inzake bij voorbeeld een:

a. op de toezichthouder rustende plicht tot verslaglegging van toezichtsactiviteiten;

b. op de onder toezicht gestelde rustende plicht tot het administreren (met het recht van de toezichthouder om bindende ${ }^{191}$ aanwijzingen t.a.v. de administratie te geven) en melden van informatie, d.w.z. dat de onder toezicht gestelde op eigen initiatief bepaalde, bij of krachtens wet aangegeven, informatie bijeen vergaart, bij tijd en wijle actualiseert, enige tijd bewaart en aan de toezichthouder verschaft;

188. S. Pront-Van Bommel, t.al.p., p.121. Zij woelt hier sterk het gemis wan het motiveringsbeginsel m.b.t. toezichthoudem.

189. Het stelt dan ook teleur dat een landbouwkwaliteitscontrole-instelling als Skal onder toezicht gestelden conclusies van gedane inspectie toestuurt slechts in die gevallen waarin een sanctie is opgelegd of het zinvoll wordt geacht onn een bevinding schriftelijk te bekrachtigen. Een dergelijke, door redenen van efficiency en efficiëntie ingegeven, beleidslijn veronachtzaamt de verdediging srechten van onder toezicht gesteiden.

190. Besproken door bij voorbeeld C.P.J. Goorden, Handhaving onder het regime van de Awb (het wetsvoorstel derde (ranche), in: De Gemeentestem, nr.6998, 18 nov. 1994, pp.550-554.

191. In het algemeen wordt bindende kracht aan aanwijzingen van toezichthouders ontzegd. $Z$ ie bij voorbeeld Graasverbod Tsjernobyl, HR (strafkamer) 28 febr. 1989, NJ 1990. 28. Daarin bepaalt de rechter dat de medewerkingsplicht er wel toe dient dat toezichthouders hun taak onbelemmerd kunnen wervullen, maar niet zo ver strekt dat onder toezicht gestelden verplicht zijn aan alle aanwijzingen van toezichthouders gehoor te geven (i.c. betreft het de aanwijzing om, gegeven de radioactieve uitstraling door het ongeluk in de kerncentrale van Tsjernobyl, vee binnen te halen). Een dergellike ver gaande invloed kent de HR kennelijk eerder toe aan personen met opsporingsbewoegdheid. 
c. op de onder toezicht gestelde rustende plicht orn de toezichthouder in zijn toezicht, via een derdenbeding of via een algemeen verbindend voorschrift, toe te laten tot derden;

d. op de onder toezicht gestelde plicht om binnen een bepaalde termijn door de toezichthouder gevorderde inlichtingen aan laatst genoemde te verschaffen;

e. op de toezichthoudende entiteit rustende plicht een gemotiveerd (schriftelijk) toezichtsbeleid ${ }^{192}$ op te stellen en aan onder toezicht gestelden kenbaar te maken;

f. op toezichthouders rusttende plicht tot het uitwisselen van informatie en het verlenen van internationale wederzijdse administratieve bijstand ${ }^{193} .{ }^{194}$

192. F.C.M.A. Michiels, Hondhaving wan bestuursrecht, AA cahiers staats- en besturursrecht deell 6, Nijmegen, 1994, p.17, vindt volkomen terecht het voordeel van formulering van handhawingsbeleid dat "strategische keuzes kumnen worden gemaakt tegen de achterg rond van enerzijds de feitelijke mogelijkheden tot optreden (beschilkbaar personeel en materieel) en de ernst van onderscheiden categorieën voorkomende overtredingen. Bovendien zullen handhaving sbesluiten, die op basis van bekend gemaakt (redelijk) beleid worden genomen, walk "judgeproof $x^{\dagger i j n . " ~}$

193. Metoog op het grensoverschrijdend karakter vanovertredingen van (communautair) sociaal-economisch recht pleit ook R.J.G.M. Widdershoven, Handhaving van sociad-economisch rechr in Nederland: terugblik en perspectief, in: RM Themis, nr.5, 1995 , pp.205-218, i.h.b. pp.216-218, voor regelling van communautaire samenwerking met oog op wederzijdse informatievoorziening, loyale samenwerking en toellaatbaar (buitenlands) bewijs. Eerder annoteert auteur de, weliswat specifiek in het licht van de Wet op de internationale bijstandswerlening bij de heffing van belastingen gewezen, uitspraak van ARRS 15 okt. 1991, tB/S 1991, nr.136, waarin de rechter de werstrekking van inlichtingen aan atudere landen, welke verstrekking als een voor beroep vatbaar besluit in de zin van de Awb kan worden gangemerkt, vernietigt.

194. Om er voor te zorgen dat onder toezich gestelden niet ongestraft hun meld-, aantekening-, vergunningaanvraagplichten e.d. ontlopen, ligkt het logisch het "niet voldoen aan' strafbaar te stellen om in het nodige gewal een bestuurlijke boete te kunnen opleggen. Daarnaast blijwen andere sanctiemogelijkheden bestaan. Bij woorbeeld, als een onder toezicht gestelde bewust bepaalde gegevens of documentem niet opneemt in zijn bedrijfsadministratie kan dit valsheid in geschrifte opleveren ex art. 225 WwSW. Zül HR 8 nov. 1994, nr. 95.088, in: DD, nr. 2, 1995, p. 191. In dit verband is ook te denken aan de illustere handelswijze wan Enrique Gonzalez die, als kapitein van het (wegens binnentreding van de visgronden op de rand van de Canadese 200-milszone) door de Canadese marine geênterde schip Estai welke visserstreiller pas word teruggegeven na betaling van een borgsom van 500.00 Canadese dollars, twee logboeken er op na houdt, $t$ w. én voor de visserij-inspectie en én woor zijn Spaanse bazon. Vrijgeven treiler effent pad woor overleg Canada, in: NRC, 16 maart 1995, pp.1/20; Overigens is het zinvol toezichthouders te tramen wat betreft hun vermogen om de hen voorgelegde administratie van onder toezich gestelden te beoordelen. Daarbij behulpzaam is mogelijk een toetsijjst, die handreikingen geeft $\mathrm{m}$, b.t. toetsing op onvolledige informatie, tegenstrijdige inlichtingen of vergelijking van mieurwe met oude ad ministratieve opgaven; De casus Roermond Papier bv ws. Hoofdprodukt schap Akkerbouwprodukten, CBB 14 dec. 1994, in: NJB, nr. 13, 31 malart 1995, pp.172-173, leen trouwens dat ten onder toezicht gestelde geen beroep kan doen op vertrouwens- of rechtszekerheidsbeginsel (t.a.v. te rug vondlering wan verkregen restituthe $\alpha . g$. v. certificaat m. b.t. hoeveellheden werwerkt zetmeel) alls hij onvolledige en onjuiste informatie verschaft (welke incompleetheid/incomectheid "van meet af aan' door i.c. de controleurs van (le AID vastgesteld kon worden). Het CBB vindt intrekking van restitutietoekenming gerechtvaardigd omdat de "wereisten voor toekenning van restitutie niet worden bepaald door de verrichtingen wan de aangewezen controle-instanties, doch door de toepasselijke voorschriften. Van een ervaren -voor deelneming aan de onderhavige regeling erkende- marktdeelnemer (bedoeld wordt de onder toezicht gestelde - JGLvN) mag worden verlangd dat hij zich bij de invulling en indiening van de verwerkingsstaten terdege rekenschap geeft vande draagwijdte van die opgaven". Hierbij tekent de CBB 
Op ander gebied treedt de Awb-wetgever wel buiten haar oude oevers. Opvallend is de, op advies van de Raad van State aan het wetsvoorstel toegevoegde, inleidende paragraaf bij het wetsvoorstel derde tranche Awb. ${ }^{195}$ Daarin is, naar aanleiding van op het voorontwerp derde tranche Awb geuitte klachten over de onduidelijke verhouding tussen de verschillende soorten handhavingsinstrumenten ${ }^{196}$ en de afwezigheid van een regeling van samenloop van sancties of dubbele bestraffing ${ }^{197}$, terecht aandacht geschonken aan de (door overwegingen van proportionaliteit, subsidiariteit, doelmatigheid en doeltreffendheid bepaalde) relatie tussen verschillende bestuursrechtelijke, strafrechtelijke en privaatrechtelijke handhaving. Weliswaar wordt de samenloopproblematiek eerst bezien in het kader van de vierde tranche Awb waarin bepalingen aangaande de bestuurlijke boete worden opgenomen. Het wetsvoorstel derde tranche Awb treft al wel een regeling ter preventie van cumulatie tussen bestuursdwang en dwangsom. Overigens wordt in de inleiding verwezen naar relevante rechtspraak ${ }^{198}$, waarin het na elkaar opleggen van bestuursrechtelijke en strafrechtelijke sancties is toegestaan. ${ }^{199}$

Enigszins teleurstellend vermeldt de inleiding dat "in ieder geval in dit wetsvoorstel (zolang nog niet alle bestuursrechtelijke sancties zijn geregeld - JGLvN) geen 'kiesregels' omtrent sanctionering kunnen worden geformuleerd". ${ }^{200}$ De huidige sancties verschillen kennelijk zo zeer in aard, doel en strekking, dat formulering van algemene kiesregels niet eenvoudig is.

De Awb-regeling van toezicht in totaal overziend, kan de constatering niet anders zijn, dan dat de wederkerigheid die de Awb-wetgever beoogt in afdeling 5.1 wel zeer zwaar ten nadele van justitiabelen uit valt. Van uit het denken in een door de Awb-wetgever voor het bestuursrecht wenselijk wederkerigheidsprincipe klinkt dit onwaarschijnlijk. Maar na eerlijke overweging moet de Awb-wetgever wel toegeven, dat overheidsoptreden, ook al houdt het bestuur in grote mate rekening met rechten en belangen van burgers

194. $\rightarrow$

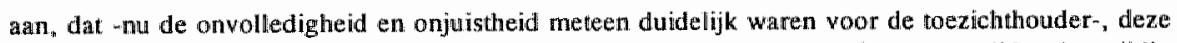
wezhichthouder, gelet op het zorgvuldigheidsbeginsel, "heder misverstand dient te vermijden door tijdig. matregelen te nemen".

195. Advies Raad wan State, nr. W03.93.0142, 17 dec. 1993, zie Nader rapport inzake het voorstel van wet derde tranche Awb, TK 1993-1994, 23700, A, p.54.

196. N. S.J. Koeman, Handhaving in de Awb, in: W. Konijnenbelt (red.), Comwentaar op het woorontwerp woor de derde tranche wan de Awb, Alphen aan den Rijm, 1992, pp.103-110, i.h.b. pp.105-106.

197. Rbb, Advies over voorontwerp derde tranche Awb. "s-Grav., mei 1992, p.19; G.H. Addink en M.J. Slujis, De Awb op scherp; Kantrekeningen bij hoofdstuk Handhaving, in: NTB, nr.2, 1992, pp.33-45. i.h.b. p. 34; K.F. Schuiling, Staats-en bestuursrechtelijke kroniek, in: Best. w. , nr.4, 1992, pp. 365-368. i.th.b. p.366; L.J.I. Rogler, Strafsancties, administratiewe sancties en het una wa beginsel, Arnhem, 1992; Samentloop sancties, in: N.JB, nr.41, 19 nov. 1992, pp.1321-\|402; C. J. Kleijs-Wijnnobel, SancHes, in: NTB, nr.8/9, 1993, pp.296-298; Y. Buruma, a.w.,pp.323-331, i.h.b. p. 330 .

198. HR 21 mei 1991. NJ 1991, 728, AB 1992, 15; HR 5 febr. 1991, NJ 1991, 402; AGRS, G04.90.1341/705, 15 mei 1992 .

199. De PvdA-fractie en de GPV-fractie vinden dat de mvt bij het wetsvoorstel meer aandacht moet besteden aan externe cumulatie van bestuursrecht met het privaatrecht (de mvt rept alleen van externe cumulatie van bestuxursrecht met strafrechty. TK 1994-1995, 23700, wr.4, pp.21-22. Mut wetsvoorstel derde tranche Awb, TK 1993-1994, 23700, nr.3 \# 129. 
en betrekt zij haar onderdanen bij bestuurlijke besluitworming, uiteindelijk altijd - als eerder vermeld in hoofdstuk 7 - eenzijdig is. Bij de toezichtsregeling in de Awb is het de vraag of die eenzijdigheid afdoende kan worden opgeheven door algemene beginselen van behoorlijk bestuur als zorgwuldige voorbereiding, evenredige belangenafweging of kenbare en deugdelijke motivering. ${ }^{201}$ Dat hangt telkens af van het concrete geval. Daarmee zijn zekerheden voor burger en overheid voortaan geen vaste zekerheden meer.

201. R.M. van Male, Onwoltooid reckit; Over rechtsbetreking, bestuursrecht en bestuursprocesrecht oratie EUR, 3 juni 1993, Zwolle, 1993, pp.18-23, stelt dat deze beginselen de eenzigdigheid van bestuurlijke besluitvorming mogelijk mitigeren. Auteur acht de - al dan niet wederkerige - bestuursrechtelijke nechtsbetrekking. d.w.z. "een door het recht genormeercle rechtsbetrekking tussen één of meer subjecten, dus naruurlijke en rechtspersonen ${ }^{\mathrm{fl}}$ (p.22), naar aand onvoltooid recht. De rechtsnormen, die partijen bij een dergelijke rechtsbetrekking in acht moeten nemen, zijn niet statisch. Een bestuursmechtelijke rechtsbetrekking komt, wolgens auteur, niet tot stand door wet, beschikking of overeenkomst (p.22); Over wederkerigheid in het bestuursrecht ook A.A. Franken en E.P.M. Joosten(red.), Wederkerige rechtsbetrekking em: belangenafweging door de rechter, versilag achtste themamiddag JUVAT $\mathrm{d}$.d. 30 o.kt. 1992, Lelystad, 1993, 


\section{Geraadpleegde literatuur}

Addink, G.H. \& Sluis, M.J.

- De Awb op scherp: Kantiekeningen bij het hoofdstuk handhawing, in: NTB, nr.2, 1992, pp.33-45;

- Het vijfde hoofdstuk van de Awb: handhaving in materieel perspectief, in: NJB, nr.35, 7 oktober 1994, pp.1201-1208.

Alders, $\mathbb{E}$.

De handhaving van het bestuursrechtvia toezicht en de gemiste kans wan de derde tranche Awb, in: NTB, nr.2, 1995, pp.25-29.

Aler, G.P.A.

De politiebevoegdheid bij opsporing en controle; Enige aspecten van de regeling van de dwangmiddelen in het Wetboek van straffordering en in de bijzondere wetten, Zwolle, 1982.

Biesheuvel, M.B.W.

Het Besluit horizontale prijsbinding; Nederlands mededingingsrecht in opmars, in: NJB, nr.23, 10 juni 1993, p.849.

Borman, $C$.

Aanwijzingen voor de regelgeving en andere voor de regelgeving relevante aanwijzingen, $\mathrm{Zwol}$ le, 1993.

Bos, E. \& Oerlemans, P.C.J.

Wetswijziging fiscale administratieve verplichtingen, in: Stichting en Vereniging, nr.1, 1995, pp.7-11.

Bruin, P. de

Ontwikkelingen m.b.t. parkeerbelastingen, in: Belastingblad, 1993, pp.575-579.

Buruma, $\mathrm{Y}$.

- Onderzoek in milieuzaken, in: M.G. Faure e.a. (red.), Zorgen van heden; Opstellen over het milieustrafrecht in theorie en praktijk, Arnhem, 1991, pp.305-336;

- De strafrechtelikke handhaving van bestuurswetten, dissertatie RUL, Arnhem, 1993;

$\sim$ De bijzondere politiediensten in het spanningsveld tussen nationale en unionaire ontwikkelingen, in: DD, ar. 10, 1994, pp.1031-1055;

— Het OM en de bijzondere opsporing, in: Doelder, H. de. Foqué, R.M.G.E. \& Gerding, R.A.F., Taak en functioneren vam het OM, SI-EUR-reeks deel 4. Arnhem, 1994, pp.181-205.

Buruma, Y., Koning-De Jong, E.M. de \& Wieringen, J. van

Bijzondere opsporingsdiensten; Inleiding in de sociaal economische fraudebestrijding, Arnhem, 1990.

Buuren, P.P.J. van

-Toezicht en opsporing, in: J.P. Balkema en C. Fijnaut, De politiële handhaving van strafwergeving, Lochem, 1986, pp.66-75;

$\sim$ Toezicht en opsporing, in: NJB, nr.23, 9 juni 1995, pp.867-868.

Commissariaat voor de Media

Evaluatie 1988-1993; Overheid en omroep in Europees perspectief, 1993.

Commissie-Scheitema (commissie wetgeving algemene regels van bestuursrecht)

Voorontwerp derde tranche van de Algemene wet bestuurstecht, aangeboden aan de ministers van justitie en binnenlandse zaken d.d. 5 december 1991, 's-Gravenhage.

Commissie-Scheltena (eerste externe commissie van de bijzondere commissie vraagpunten)

Steekhoudend ministerschap; Betekenis en toepassing van de ministeriële verantwoordelijkheid, TK 1992-1993, 21427, nrs.40-41.

Commissie-Wiegell (vierde externe commissie van de bijzondere commissie vraagpunten) 
Naar kerndepartementen, kiezen voor een hoogwaardige en flexibele rijksdienst, TK 1992-1993, 21427 , nr. 52 .

Corstens, G.J.M.

Vroegsporing, in: DD, nr.1, 1995, pp.1-4.

Derks, A., Nus, A. van \& Simon, $\mathbf{H}$.

Het toezicht op burgers in de Awb, in: NJB, nr.43, 2 december 1993, pp.1544-1553.

Doorenbos, D.R.

Financieel strafrecht: een studie inzake strafrechtelijk gesanctioneerde voorschriften uit de banken effectenwetgeving, dissertatie KUN, serie monografieën Van der Heijden-instituut Nijmegen deel 40, Deventer, 1992, pp.22-27.

Drongelen, J.

De ontwikkeling van de Arbeidsinspectie in een veranderende wetgeving, dissertatie RL, Maastricht, 1990 , pp.566-604.

Duk, w.

- Inleiding tot het bestuursrecht, leerboek OUH, tweede druk, Alphen a/d Rijn, 1988;

- Handhaving van bestuursrecht; Capitula selecta, in: NTB, nr.4, 1988, pp. 105-110.

Franssen, A.M.

Toezicht en opsporing, het onduidelijke voortraject bij de publieke rechtshandhaving, in: $\mathrm{DD}$, nr.2, 1993, pp.99-112.

Fijnaut, C.J.C.F. (red.)

Politiezorg in de jaren '90, politiestudies nr.5, Arnhem/Antwerpen, 1991.

Goorden, C.P.J.

$\sim$ Handhaving onder regime van de Algemene wet bestuursrecht, in: Gemeentestem, nr.6959, 12 februaril 1993, pp.57-66;

- Handhaving onder het regime wan de Awb (het wetsvoorstelderde tranche), in: De Gemeentestem, 18 november 1994, nr.6998, pp.550-554.

Hazewindus, W.G.A. \& Jansen, O.J.D.M.L. (red.)

Van boeteatelier tot boetefabriek; Bijdragen wan het op 24 november 1994 te Amsterdam gehouden wetenschappelijk congres over de bestuurlijke boete, Deventer, 1995.

Helder, E. \& Rensen, T.

Bescherming door de Nationale ombudsman in het kader van besluiten, in: NTB, nr.3, 1995, pp.53-60.

Hennekens, H.Ph.J.A.M.

Het voorstel voor een nieuwe Politiewer: een bestuursrechtelijke prothese voor de politieorganisatie I, in: Gemeentestem, nr.6944, 22 mei 1992, pp.281-288.

Hoogenboom, A.B.

- Bijzondere opsporingsdiensten en de politie, ministerie van binnenlandse zaken, 's-Gravenhage, 1985;

- Het Politiecomplex; Over de samenwerking tussen politie, bijzondere opsporingsdiensten en particuliere recherche, politiestudies nr.15, Arnhem/Antwerpen, 1994.

Hulst, J.W. van der \& Rogier, L.J.J.

Handhaving van het bestuursrecht; Preadviezen van de Vereniging voor Administratief Recht, in: Trema 1995, nr.6, pp. 187-192.

Huygen, A.E.H.

Controle en opsporing, in: Facetten wan economisch strafrecht, Arnhem, 1990, pp.45-66.

Jansen, O.J.D.M.L.

- Bestuursirechten strafprocesrecht:doorwerken of afgrenzen?, in: Hoogenboom, T. \& Damen, L.J.A., In de sfeer van administratief recht; Opstellen aangeboden aan W. Kanijmenbelt, Utrecht, 1994, pp.257-283; 
- Toezicht, opsporing en de Algemene wet bestuursrecht, in: DD, nr.6, juni 1994, pp.534-552. Kleijs-Wijnobel, C.J.

Sancties, in: NTB, nr.8/9, 1993, pp.296-298.

Klinkers, L.E.M.

Milieu, nous maintiendrons?, in: RegelMaat, nr.5, 1994, pp.195-200.

Knigge, $G$.

Van opsporing en strafuordering, in: DD, nr.3, 1990, pp.195-213.

Koeman, N.S.J.

Handhaving, in: Konijnenbelt, W. (red.), Commentaar op het voorontwerp voor de derde tranche van de Awb. Alphen a/d Rijn, 1992, pp.103-110.

Kuitenbrouwer, $\mathrm{F}$.

- Als particulieren gaan bekeuren spekken de gemeenten hun kas, in: NRC, 1 oktober 1993, p.9;

- Eenmanszaak, in: BB, nr.42, 22 oktober 1993, p.13.

Kuus, A.H.J.

De Registratiekamer may be watching you!, in: Computerrecht, nr.3. 1990, pp. 123-126.

Langbroek, P.M., Wulffraat-Wan Dijk, M.S.E., Hagelstein, G.H., Spelt, N.M., Addink, G.H., Sluijs, M.J.

Bouwen aan de Awb; Het voorontwerp derde tranche verkend, in: NJB, nr. 15, 9 april 1992, pp. $473-477$.

Lefêre, $\mathrm{H}$.

Toezicht en bestuursrechtelijke handhaving in de Awb (derde tranche), in: RegelMaat, nr.5, 1994, pp.208-212.

Male, R.M. van

Onvoltooid recht; Over rechtsbetrekking, bestuursrechten bestuursprocesrecht, oratie EUR d.d. 3 juni 1993, Zwolle, 1993.

Meeus, T.J.

'Bijklussen politie is gevaarlijk', in: NRC, 17 december 1993, p.3;

- Topambtenaar mengt belangen bij privatisering, in: NRC, 7 oktober 1994, pp.1-2;

- Privatisering in Den Haag - ongelukken in een zompig proces, in: NRC, 15 december 1994 , p.15.

Meulen, B.M.J. van der

Ordehandhaving, dissertatie VU, Deventer, 1993.

Mevis, P.A.M.

Van opsporing, strafvordering en legaliteit, in: DD, nr.10, 1990, pp.937-945.

Michiels "F.C.M.A.

- De boete in opmars?, oratie VU, Zwolle, 11 februari 1994, pp.24-29;

$\sim$ Handhaving vam bestuursrecht, AA cahiers staats- en bestuursrecht deel 6, Nijmegen, 1994.

Moor-Van Vugt, A.J.C. de

Van een haringkoninkrijk en een bananenrepubliek, in: NTB, nr.5, 1995, pp.113-122.

Moorman, H.C.

Toezichthoudende bevoegdheid wan opsporingsambtenareningewolge de WED, in: $M \& R, n r .11$, december 1988 , pp. $414-423$.

Mulder, A.

Controlebevoegdheden ter opsporing, in: SEW, nr.9, oktober 1985, pp.564-566.

Mulder, A. \& Engels, M.J.A.

De positie van bijzondere opsparingsdiensten, in: Recht op scherp, Zwolle, 1984, pp.137-154.

Muijen, P. \& Pijl, D. 
Van onbezoldigd naar buitengewoon; Een reorganisatiezonder effect voor het dantal opsporing:ambtenaren?, in: APB, nr.5, 6 maart 1993, pp.11-13.

Nicolaï, P.

Kronieken; Algemene beginselen van behoorlijk bestuur, in: NTB, nr.7, 1993, pp.259-265.

Nicolai, P., Olivier, B.K., Damen, L.J.A. \& Troostwijk, H.

Bestuursrecht, derde herziene druk, Amsterdam, 1992.

Poell, J.W.E. van de

Handhaving in de derde tranche van de $A w b$, in: Bestuurswetenschappen, nr. 3, 1992, pp. 305-309.

Pront-van Bommel, S.

- Controle op de naleving van administratieve wetgeving, in: Konijnenbelt, W. (red.), Commentaar op het woorontwerp voor de derde tranche van de Awb, Alphen aan den Rijn, 1992, pp. 111-124;

- Onrechtmatig verkregen bewijs, in: Hoogenboom, T. \& Damen, L.J.A. (red.), In de sfeer wan administratief recht; Opstellen aangeboden aan Willem Konijnenbelt, Utrecht, 1994, pp. 345-363.

Raad voor het binnenlands bestuur

Advies aan de ministers Hirsch Ballin en Dales over het voorontwerp van de derde tranche Awb, mei 1992, 's-Gravenhage.

Raalte, A. van, Steenis, I. van \& Vermeeren, M.

Doorbroken driehoek, in: Evaluatie 1988-1993; Overheid en omroep in Europees perspectief, uitgave CvdM, Hilversum, 1993, pp.51-97.

Reenen, $\mathrm{P}$, van

$\sim$ De bijzondere politie: verwaarloosd onderdeel van het politievraagstuk, in: Bestuurswetenschappen, nr.5, 1986, pp.288-310;

- Het politiecomplex van Hoogenboom, in: TvP, nr.1/2, 1995, pp.25-28.

Reijntjes, J.M.

Boef of burger? Over de relatie tussen toezicht en opsporing, oratie, Arnhem, 1989, pp.39-48.

Rogier, L.J.J.

Strafsancties, administratieve sancties en het una via-beginsel, Arnhem, 1992.

Ronteltap, $\mathbb{R}$.

Para-overheid zet de auto klem, in: ANWB-Kampioen, oktober 1993, pp.26-28.

Rood, E.

Overzicht EEG-en Nederlands levensmiddelenbeleid en -recht: inhoud, organisatie, tenuitwoerlegging, handhaving. Apeldoorn/Arnhem, 1993, pp.110-119.

Sackers, H.J.B.

De Algemene wet bestuursrecht in straf(proces)rechtelijk perspectief, in: DD, nr.8, 1994, pp.802-813.

Schreuder, C.A.

Publiekrechtelijke taken, private rechtspersonen; Verzelfstandiging en privatisering in de vorm van vennootschappen en stichtingen, dissertatie RUG, serie bestuursrecht theorie en prakijk nr.16, Deventer, 1994, pp.257-262.

Schuiling, K.F.

Siaats-en bestuursrechtelijkekroniek, in: Bestuurswetenschappen, nr.4, 1992, pp.365-368, resp. nr. 5,1992, p. $452-455$.

Stapel \& De Koning

Leerboek woor de politie, deel 6, 47ste druk, Lochem, supplement 132, 1991.

Stroink, F.A.M. 
Annotatie (toezicht door regeringscommissarisop de vereniging Buma), in: JB, $\mathrm{nr}, 1,27$ januari 1995, pp.11-15.

Stroink, F.A.M. en Steenbeek, J.G.

Inleiding in het staats-en bestuursrecht, vierde herziene druk, Alphen aan den $\mathbb{R i j n}, \mathbb{1 9 9 3 .}$

Tweede Kamer

- Mvt wetsontwerp nieuwe Politiewet, TK 1992-1993, 22562; Uiteindelijke Politiewet vastgelegd bij wet van 9 december 1993, Stbl. 1993, 724;

- Notitie betreffende competentie-uitbreiding van de Nationale ombudsman, TK 1991-1992, 22731, nrs.1-2, en TK 1992-1993, 22731, nr.3;

- Wijziging van de wegenverkeerswet 1992, houdende regeling van de verzelfstandiging van de

Rijksdienst voor het Wegverkeer, TK 1992-1993, 22961, nrs.1-2;

- Flora-en faunawet, wetsvoorstel, TK 1992-1993, 23147, nr.3;

- Wijiging Wet economische mededinging (vergroting van effectiviteit), TK 1992-1993/19931994,23306, nrs.1-2 e.v

- Samenvoeging ECD en AID tot een controle-en opsporingsdienst, TK 1993-1994, 23547, nr. I:

- Wijziging Wet op de kansspelen i.v.m. instellen College van toezicht op de kansspelen, TK 1993-1994, 23605, nrs.1-21;

- Wetsvoorstel tot aanvulling Awb (derde tranche Awb), TK 1993-1994/1994-1995, 23700, nrs. 1-3/4;

- Regeerakkoord 1994: keuzes voor de toekomst, TK 1993-1994, 23715, nr.11;

- Wetsvoorstel particuliere beveiligingsorganisaties en recherchebureaus, TK 1993-1994, 23748 , nrs. $1-3$;

-Justitiebegroting 1995, TK 1994-1995, 23900 VI, nrs.1-2.

Veen, Th.W. van

Proactieve opsporing, in: RM Themis, nr.1, 1995, pp.1-2.

Verfaille, P.

Handleiding handhaving milieurecht, tweede herziene druk, Lochem, 1992.

Verheij, $N$.

Naar een wetboek wan bestuursrecht, in: Heringa, A. W. \& Verheij, N. (red.), Publiekrechtelijke bewegingen, Deventer, 1990.

Vermande studiedagen

Politie versus particulier initiatief; Een uitholling van politiële taken en bevoegdheden?, lezingenbundel symposium, Diemen, 29 april 1994.

Vermeulen, C.P.

Zwijgrecht in opspraak, in: Bank- en Effectenbedrijf, nr.6, 1995, p.37.

Vervaele, J.A.E.

$\sim$ Handen en tanden wan het (gemeenschaps)recht, oratie RUU, 18 februari 1994, Deventer, 1994;

- Recensie dissertatie Y. Buruma, in: Recht en Kritiek, mr.4, 1994, pp.392-397.

Visser, D.

Help, de toezichthouder houdt toezicht!, in: NJB, nr.9, 3 maart 1995, pp.314-315.

Voermans, W.J.M.

Werk aan de winkel voor de Registratiekamer, in: Computerrecht, nr.2, 1989, pp.72-79.

Vreeburg, F.

Wat levert 't op, hogere veiligheid of lagere werkloosheid? Toezichthouders, de nieuwe bromsnorren, in: BB-bijlage publiek donnein, nr.49, 9 december 1994, pp.2-5.

Waal, M.R. van der 
Boekenonderzaek: spreken is zilver, zwijgen is goud?, in: Bank-en effectenbedrijf, maart 1995, p. 50 .

Widdershoven, R.J.G.M.

Handhaving van sociaal-economisch recht in Nederland: teragblik en perspectief, in: RM Themis, nr.5, 1995, pp.205-218.

Woensel, S. van

Particulier krijgt opsporingsbevoegdheid voor uitvoering gemeentelijk parkeerbeleid, in: BB, nr.38, 24 september 1993, p.27. 
Hoofdstuk 12

\section{Toepassing van sancties}

\section{$\S 12.0$ Handhaving: sanctietoepassing '}

Deze vorm van handhaven betreft het optreden naar aanleiding van regelovertreding. Bestraffing van, wet- of rechtstegenstrijdig, gedrag vindt plaats. Daartoe zijn de straf-, bestuurs-, privaat- of tuchtrechtelijke weg het meest aangewezen.

De verschillende soorten handhaving zijn in te delen aan de hand van zowel formele als materiële criteria. Traditionele toets is: wie is bevoegd ${ }^{2}$ tot handelen naar aanleiding van regelschending. Kortom, wie mag eventuele maatregelen nemen? Hiernaast blijkt een inhoudelijke maatstaf interessant. De ard van de sanctie trekt dan de aandacht. Is strafoplegging situatieaanpassend- en herstellend of juist vergeldend van karakter? ${ }^{3}$

1. Conform aanwijzing woor de regelgeving 144 worden door sancties te handhaven bepalingen zo nauwkeurig mogelijk geformuleerd. Aanw. 145 . 147 geven woorschriften inzake regelgeving m. b.t. tot sanctionering wat betreft classificatie wan strafbare feiten, geldboeten en aanduiding van strafbare feiten als economisch delict. C. Borman, a.w., pp.124-127.

2. Soms is zelfs sprake wan een verplichting ter zake. O.a. art. 39, eerste lid, voorstel Flora-en faunawet (TK 1992-1993, 23147, nr.2). Maar in het bestuursrecht is sanctieoplegging meestal facultatief. P.. Nicolail e.a., a.w. p. 353 .

3. W. Duk, Maatstaven voor beoordeling wan sancties, in: AA 30 (5), 1981, pp.231-238, i.h.b. p.235, onderscheidt reparatoire en repressieve/retributieve sancties; L J.J. Rogier, Strafsancties, admikistratieve sancties en het una via-beginsel. Arrhem, 1992, pp.172-173, vindt dat reservering er van voor bestumrsreclitelijke onderscheidenlijk strafrechtelijke sancties de waarheid geweld aandoet (dissertatie, onder de nodige teleurstelling, besproken door o.a. G.J.M. Corstens, Boekbespreking, in: DD, nr. 1, 1995, Pp.6469); Ook W.G.A. Hazewindus, Administratieve sancties en vreendelingenrecht, diss. UvA, Amhem, 1994, pp.15-25, kan zich niet volledig verenigen met de indeling wan Duk. Met wardering voor de "charme van de eenvoud" er van, vindt auteur de indeling ongeschikt woor de grote groep sancties, bestaande uit het intrekken van begunstigende beschikkingen bij wijze van sanctie, als mede voor de administratieve dwangsom. Hazewindus onderscheidt administratieve sancties van puur punitieve en van puur situatieve (waaronder treparatoire) aard. I.g.V. bij voorbeeld vergunningintrekking moet voor het bepalen wan het sanctiekarakter erwan weer gekeken worden of de overtreden norm bij draggt aan verwezenlijking wan de door dle vergunning te dienen belangen. 


\section{$\S$ 12.1. Strafrechtelijke handhaving}

Strafrechtelijk handhavingsinstrumentarium is vooral te vinden in het wetboek van strafrecht en de wet economische delicten. De daarin vermelde regels aangaande controle, opsporing (artt. 140-159 WvSv junctis artt. 17-27 WED ${ }^{4}$ ), vervolging en berechting ${ }^{5}$ corresponderen ten dele.

Oplegging van strafsancties betekent, in grote lijnen, vrijheidsberoving of vermogensonttrekking. ${ }^{6}$

De ene vrijheidsbeneming is de andere niet. Er bestaat een gradueel verschil tussen gevangenisstraf, (voorlopige) hechtenis, gijzeling, plaatsing in een psychiatrisch ziekenhuis (of ter beschikkingsstelling) en dienstverlening. "

Handhaving met vermogensrechtelijke consequenties geschiedt bij woorbeeld via geldboete, ontneming van wederrechtelijk genoten voordeel, verbeurdverklaring, schadevergoeding, herstel in oude toestand, onttrekking aan het verkeer of stillegging van een onderneming.

Een en ander is, al dan njet voorwaardelijk, hoofdzakelijk of bijkomend op te leggen.

Het bijzonder strafrecht van de WED bestrijkt in belangrijke mate taakgebieden van zelfstandige bestuursorganen. Juist uitoefening van toezichtsbevoegdheden als mede nakoming van geheimhoudingsverplichtingen worden herhaaldelijk via de dwingende WED-bepalingen van economisch strafrecht veilig gesteld.

Als economische delicten zijn aangewezen bepaalde voorschriften gesteld bij of krachtens o.a. de Wet toezicht kredietwezen als mede de Wet toezicht beleggingsinstellingen (de Nederlandsche Bank nv), de Wet tarieven gezondheidszorg (Centraal Orgaan Tarieven Gezondheidszorg), de Wet toezicht effectenverkeer (Stichting Toezicht Effectenverkeer), de Wet op de kansspelen (Raad voor de Casinospelen), de Zaaizaad- en plantgoedwet (Nederlandse Algemene Keuringsdienst voor Groente- en bloemenzaden), de Wet (auto)vervoer personen/Wet goederenvervoer over de weg (Stichting Inschrijving Eigen Vervoer) ${ }^{\sharp}$, de Wet autovervoer goederen (Raad voor het vergunningenbeleid/Commissie

4. Wet van 22 juni 1950, Stbl, 1950, 258, gewijzigd 10 dec. 1992, Stbl. 1993, ㄴ1.

5. Voor buitengerechtelijke afdoening zijn specifieke (bestuursrechtelijke) regels toepasselijk. Zie de Wer administratiefrechtelijke handhawing verkeerswoorschriften, wet van 3 juli 1989, Stbl. 1990, 300, gewijz. 23 dec. 1992, Stbl. 1992, 722, onderscheidenlijk het Besluit politietransactie, d.d. 18 april 1978, Stbl. 1978, 192, gewijz. 13 nov. 1991, Stb1. 1991, 642, onderscheidenlijk de Richtlijn voor het transactie- en strafvorderingsbeleid van het OM inzake kantongerechtsovertredingen, d.d. 1 nov. 1991.

6. Y. Buruma, a.w., pp. 289-309, geeft een catalogus van, ower rechter en bestuur verdeelde, afdioeningsmodaliteiten (vermeld in bijzondere wetten) die vrijheid-, geld- of goedontnemend dan wel handelingsbeperkend zijn.

7. Voor niet-volwassenen: jeugddetentie (voorheen: tuchtschool en arrest) of plaatsing in een inrichting woor jeugdigen (voorheen; jeugd-tbs en pibb) en ondertoezichtstelling, dienstverlening, herstelarbeid en het volgen van een leerproject.

8. Imgesteld bij Wet goederenvervoer ower de weg d.d. 12 maart 1992, Stbl. 1992, 145. 
vergunningen wegvervoer)", de Bestrijdingsmiddelenwet (Commissie voor de toelating van bestrijdingsmiddelen), de Landbouwkwaliteitswet (Stichting Vleeswaren Kontrole, Controlebureau voor Pluimvee, Eieren en Eiprodukten, Stichting Centraal Orgaan Zuiwelcontrole, of het Kwaliteits-Kontrole-Bureau groenten en fruit, Stichting Skal), de Arbeidsvoorzieningenwet (Centraal Bestuur voor de Arbeidswoorziening) en de Wet toezicht verzekeringsbedrijf (Stichting Verzekeringskamer).

Deze zelfstandige bestuursorganen zijn in principe niet met de opsporing van (economische) delicten belast. Specifiek voor opsporingsactiviteiten uitgerust zijn de bijzondere opsporingsdiensten als ECD en AID. Stuiten zelfstandige bestuursorganen bij hun werkzaamheden op vermeende strafbare feiten, tot opheldering waarvan alleen uitoefening van opsporingsbevoegdheden geoorloofd en toereikend is, dan kunnen zij daarvan de bevoegde autoriteiten op de hoogte stellen (en in beperkte gevallen overleg voeren over opsporings- en afdoeningsmethodieken 19 ).

Zelfstandige bestuursorganen zijn in beginsel niet verplicht tot het doen van aangifte van geconstateerde misdrijven of overtredingen. In gevolge art. 162, eerste lid, WvSv zijn slechts "openbare colleges en ambtenaren die in de uitoefening van hun bediening kennis krijgen van een misdrijf van een opsporing waarvan zij niet zijn belast, verplicht daarvan onverwijld aangifte te doen, met afgifte van de tot de zaak betrekkelijke stukken, aan de officier van justititie of aan een van zijn hulpofficieren". Volgens het vierde lid van dat artikel rust op "rechtspersonen of organen van rechtspersonen wier taken en bevoegdheden zijn omschreven bij of krachtens de wet, voor zover daartoe bij algemene maatregel van bestuur aangewezen" gelijke verplichting.

Bij zelfstandige bestuursorganen, in het bijzonder die met een toezichthoudende taakstelling waardoor ze een -vooral via geheimhoudingsplichten gegarandeerde-vertrouwenspositie genieten, bestaat van hogerhand vaak weerstand om ze bij amvb aangifteplichtig te verklaren. "Zo wordt, sinds de verzelfstandiging van de Verzekeringskamer, deze toezichthouder op het verzekeringsbedrijf niet meer als openbaar college in de zin van art. 162 WvSv aangemerkt. In de vertrouwenspositie, waarin de tegenwoordige stichting Verzekeringskamer verkeert, wordt zij niet verplicht om aangifte te doen van misdrijven die tot haar kennis komen; Zij heeft echter wel de bevoegdheid tot het doen van aangifte als zij dit verenigbaar vindt met haar wettelijke toezichtstaak. ${ }^{12}$ Haar toezichtstaak, in

9. Sünds 1 mei 1992 is, vanaf die datum geldende kwalite its bevonderende Wet goederenvervoer over de weg. de stichting Nationale en Internationale Wegvervoer Organisatie als vergunningverfenend orgaam voor bimnenlands en grensoverschrijdend vervoer aangewezen. In praktijk delegeert het NWWO, ex art. 4 statuten, de bevoegdheid tot verstrekking van Wgw-, communautaire, Conférence Europeénne des Ministres de Transport-, cabotage- , en billaterale vergunningen, weer aan de nieuwe Commissie vergunningverlening beroepswerwoer. NIWO, Jaluerslag 1992, pp.5-6/26.

10. Denk aan 0.a. Stichting Keur Alternatief voortgebrachte Landbouwprodukten. Zie paragraf 17.2.6.

11. De Nederlandsche Bank nv dient tot voorbeeld. Zie uitspraken over DNB, i.v.m. wijzigigüng van art. 162 WwSv, van minister van justitie Korthals Altes, tijdens handelingen van de Tweede Kamer, 28 augustus 1985, pp.6293-6294; Gelet echter op het ontbreken wan een aangifteplicht in het licht van de Wifd en de Wom, bepleit D.R. Doorembos, Funancieel strafrecht, diss. KUN', 's-Graventhage, 1992, pp. 153-164, het bij amvb - als bedoeld in art. 162 , vierde lid, WvSv - geclausuleerd aanwijzen van DNB nv alls aangifteplichtilg (p.164).

12. Mwt Informatie-uitwisselingswet, TK 1993-1994, 23170, nr.3, p.16. 
hoofdzaak gericht op financieel solvabiliteitstoezicht, staat voorop. De stichting Verzekeringskamer beschouwt zich zelf namelijk terecht niet als een justitiële opsporingsautoriteit als politie, FIOD of ECD. Bij haar reguliere controlewerkzaamheden stuit de toezichthouder op de verzekeringsmarkt wel eens op 'signalen van fraude' of overige 'ongerechtigheden'. Hoewel zij betrokken bedrijven de eerst aangewezenen vinden om in actie te komen, doet de stichting Verzekeringskamer in bepaalde gevallen wel zelf aangifte als "sprake is van een sterk vermoeden van een misdrijf en in het geval er anders niet gemeld zou worden". 13

Plicht of niet, de uitwoering van een toezichthoudende taak brengt vaak het doen van aangifte van gepleegde delicten met zich mee. Met andere woorden, "het doen van aangifte behoort tot de uitoefening van de taak van de toezichthouder". ${ }^{14}$

Zelfstandige bestuursorganen, die buiten boven genoemde bepalingen vallen, zijn overigens altijd bevoegd tot het doen van aangifte ex art. $161 \mathrm{WvSv}$.

Met de WED-bepalingen zijn typisch bestuurlijke elementen aan het commune strafrechtelijk handhavingsarsenaal toegevoegd. Van uit bezorgdheid over de aflatende kwaliteit van het reguliere strafrecht vat de gedachte vlam om het primaat van handhaving van vooral sociaal-economische wetgeving te verleggen naar het bestuursrecht. is In deze visie boet art. 5 WED aan waarde in. Het van oudsher "geproclameerde primaat van strafrechtelijke handhaving" woldoet niet meer, omdat de rechtsbescherming in het bestuursrecht zich tegenwoordig ook op een aanvaardbaar niveau bevindt. ${ }^{16}$

De wet zelf geeft trouwens terecht nu al een aanzet tot oriëntatie op het bestuur. Art. 58 WED luidt: "In overleg met onze minister van justitie kunnen lichamen met een publieke taak belast, hiertoe bevoegd verklaard door een onzer andere ministers, wie het aangaat, ten dienste van de opsporing ; vervolging en berechting van economische delicten ambtenaren benoemen, die het contact onderhouden met het openbaar ministerie."

Mede gegeven de groeiende grensvervaging, tussen straf- en bestuursrechtelijke handhaving in het algemeen, is het van belang het goede van elkaar af te kijken. Alleen zo kunnen straf-en bestuursrecht een "lat-relatie" 17 aangaan. In dit verband is het bela-

13. Stichting Verzekeringskamer, Tweede sussentids verslag inzake Vied"Or, Apeldoom, 190kt. 1994, p.62.

14. Bepaald voor toezichthoudend zbo STE, conform Whe, TK 1989-1990, 21038, nr. 12, p, 10.

15. W. Wladimiroff, Niets bijzonders. Een beschouwing ower de dominantie wan het bijonder strafrechi bij de handhaving van social-economische normen, oratie RUU, 15 febr. 1989, Dewenter, 1989, p.25; 0.0 W.G.A. Hazewindws, a., w., p. 38.

16. D.R. Doorembos, Financieel strafrecht, diss. KUN, serie monografie Van der Heijden-instimut Nijmegen deel 40, Deventer, 1992, p.21.

17. C.J. Kleijs-Wijnnobel, Biestuurs-en strafsancties; Eer LAT-relatie, in: C.P.J. Goorden e.a., Kroniek vam her bestuursrecht 1987-1992, Zwolle, 1993, pp.37-54, i.h.b. p.55; Vgl. H.J.B. Sackers, Strafrecht en bestwursrecht, twee gelowen op een kussen?, in: H.J.A.M. van Geest e.a., Bestuursrecht aan de horizon, Zwolle; 1994, pp. 101-121; W.G.A. Hazewindus, Administratieve sancties en vreemdelingenrecht, diss." UvA, Arnhern, 1994, p.262, die geen principieel bezwaar heeft tegen overheveling van sancties van uil strafrecht naar bestuursrecht (mits de noodzaak van overheveling wordit aangetoond, de sanctie niet te zwaar is en de waarborgen van bestuumlijke sanctieoplegging niet onderdoen voor de strafrechtelijke zekemeden - p.136), vervangt de typering "lat-relatie" liewer door de term "woningdelers" bestuurs- en strafsancties bewonen het zelfde pand, handhaving geheten, ze maken gebruik van gemeenschappelijke huishoudelijke artikelen en lenen elkaars spullen"m 
den ${ }^{18}$ begrip bestuursstrafrecht bekend. ${ }^{19}$ Van uit de gedachte dat de verwantschap tussen administratief sanctierecht en strafrecht steeds nauwer wordt, luidt het pleidooi te komen tot een "integratieve bestudering van het publieke sanctierecht" . ${ }^{20}$

\section{$\$ 12.2$ Bestuurlijke handhaving}

Bij bestuurlijke ${ }^{21}$ handhaving roept niet de rechter, maar het bestuur ${ }^{22}$ burgers tot de orde. Op een enkele vrijheidssanctie ${ }^{23}$ na, zijn hier veel handhavingsmiddelen te vinden, die een flinke aanslag op de beurs kunnen betekenen. Bovendien hebben bepaalde bestuurlijke sancties van recente datum, als de sanctie van bestuurlijke boete, een min of meer punitief karakter.

Bij sanctionering via het bestuursrecht is te denken aan onder andere:

a. uitvaardiging van een sluitingsbevel;

b. toepassing van bestuursdwang (bij voorbeeld ex afdeling 5.2 Wetsvoorstel $\mathrm{Awb}$ ) ${ }^{24}$;

c. oplegging, vaststelling en invordering van een dwangsom (bij voorbeeld ex afdeling 5.3 wetsvoorstel Awb) ${ }^{25} 26$;

d. aanbrenging van een wielklem (ex art. $43 \mathrm{~b}$ Wegenverkeerswet ${ }^{27}$ );

18. Terecht acht M.J.H. T. Rikmenspoel, Boe(te)! , in: NJB, nr.42, 25 now .1994, pp. 1456 1457, de term bestuursstrafrecht "niet zo gelukkig, omdat dit de verkeerde suggestie wekt dat het zou gaan om strafrecht $_{y}$ terwijl het hier gaat om een andere worm wan sanctierecht: punitief bestuursrecht" "Instemming van R.J.G.M. Widdershoven, Handhaving wan sociaal-economisch recht in Nederland: terugblik en perspectief, in: RM Themis, nr.5, 1995, pp.205-218, i.h.b. p.210.

19. Hiervoor geeft C.J. Kleijs-Wijnobel (1993), t.a.p., pp.43-45, uitgangspunten, grenzen, materieel rechtelijke en procedurele beginselen.

20. $\mathbb{L}$. Rogier en A. Hartmann. Verschillern en overeenkomsten tussen strafrecht en bestuursrecht, in: DD, nr. 10. 1993, pp. 1042-1058, zie ook I.J.J. Rogier en A.R. Hartmann, Verschillen en avereenkomsten wassen strafrecht en beswursrecht, in: $\mathbf{H}$. de Doelder en L.J.J. Rogier (red.), Opstellen over bestuwrsstrafrecht, SI-EUR-reeks deel 3, Amhem, 1994, pp.1-20; Instemming wan H.J.B. Sackers, De Awb in straf (proces)rechtelijk perspectief, in: DD, nr.8, 1994, pp.802-813, i.t.b. p.813; Vergelijk, wat betreft de sectoren van respectievelijk saciale zekerheid en belastingen., J. Roording. Sanctierecht in de belastingen en de sociale zekerheid, diss. KUN, Nijmegen, 1994, die spreekt wan éên geîntegreerd bestuurlijk sanctiereclyt (als samensmelting van het administratieve en het strafrechtelijke sanctiestelsel).

21. In navolging van M.J.M. Brand-Koolen, J.R.H. Kuyper e.a., Strafrechs en rechtshandhaving, Telderstichting geschrift nr.67, "s-Grav., 1988, p. 37. Auteurs prefe ren de terminologie "gdministratieve handhawing" (d.w.z. sanctieoplegging geschiedt door bestursorganen die ook verantwoordelijk zijn voor bele id) boven "adminustratiefrechtelijke handhaving".

22. Zie over de keuze tussen rechter en administratie, bij toepassing wan sancties wegens overtreding wan een bestuursrechtelijlke regel, W. Duk, Handhaving van bestuursrecht, t.a. p., pp.107-109; Vgl. Y. Bumma, a. 2 . p. 264-289.

23. Uitzetting van illegaal in Nederland verblijvende vreemdelingen. Zie art. 44 Vreemdelingenwet (wet van 13 jan. 1965, gewijz. 21 mei 1992, Stbl.. 1992, 244).

24. Zie voor modelbepaling ter zake C. Borman, a.w. pp. 121-123 (aanwijzing 142).

25. Züe aanwijzing 143, C. Borman, a.w., pp.123-124; Over karakter er van W.G.A. Hazewindus, De administratieve dwangsom; Een situatieve en een punitieve sarctie, in: NJB, nr.33, 24 sept. 1992, pp. 1068-1072 (ind. literatunurlijst).

26. Ower 0.a. discongnentie tussen bestuursd wang en dwangsom M.J. Sluijs, Lastige bestuurssancties, in:" Gst. "nr.6984, 1 april 1994, pp.141-149.

27. Wett wan 13 sept. 1935, Stbl. 1935, 554, gewijz. 24 dec. 1992, Stbl. $1992,709$. 
e. vermindering/herziening van zendtijd (ex artt. 44-47 Mediawet $^{28}$ junctis artt. 2-3 Sanctieregeling omroep ${ }^{29}$ );

f. intrekking/schorsing/wijziging van typegoedkeuringen voor voertuigen, intrekgking als mede ongeldig verklaring van kenteken- en rijbewijzen ${ }^{30}$ (ex art. 3b e.v. Wetsvoorstel van wijziging van de wegenverkeerswet 1992 , houdende regeling van de verzelfstandiging van de Rijksdienst voor het wegverkeer ${ }^{31}$ );

g. intrekking van een vergunning voor effectenuitgifte, -beheer, -bemiddeling en -transactie (ex art. 14 jo. art. 16 Wet toezicht effectenverkeer ${ }^{32}$ );

h. intrekking van een vergunming om respectievelijk een assurantiebedrijf en een kredietinstelling wit te oefenen (ex art. 24 junctis artt. 146-152 Wet toezicht verzekeringsbedrijf ${ }^{33}$ en art. 8 jo. art. 15 Wet toezicht kredietwezen ${ }^{34}$ );

i. aanwijzing met de mogelijkheid van zowel, weliswaar privaatrechtelijk gesanctioneerde, 'stille curatele' (dat wil zeggen, de bestrafte mag zijn bevoegdheden slechts uitoefenen na goedkeuring van degene die de aanwijzing heeft gegeven) als publikatie van die aanwijzing - en alle correspondentie tussen de strafoplegger en de regelovertreder naar aanleiding van de aanwijzing - in de Staatscourant en in een of meer dagbladen ter keuze van de sanctieoplegger (ex art. 54 Wet toezicht verzekeringsbedrijf $1993^{35}$ of, soort gelijk, ex art. 14 jo. art. 28 Wet toezicht kredietwezen ${ }^{36}$ );

28. Wet van 1987, Stbl. 1987, 249, gewijz. 4 juni 1992, Stbl. 1992, 422 .

29. CvdM. Sancrieregeling omroep 1993, H'sum, 1993, pp.1-13, i.h.b. p.2, vermeld in: Stcrt. 24 sept. 1993, 183. Deze sanctieregeling theeft het karakter van een beleidsregel. Zie MF, nr.11/12, 1993, p. 120; Bij besluit van het CvdM d.d. 9 maart 1994 is de nieuwe, op de Awb toegespitste, Sanctieregeling omroep 1994 vastgesteld.

30. De bevoegdheid tot intrekking/schorsing van een beschikking (bij wijze van sanctie) moet uitdmkkelijk worden geregeld. Daamaast is specificatie van de gronden, die tot toepassing leiden nodig. Zie $C$. Bornaan, a.w. pp. 120-121 (aanwijzingen 140 en 141).

31. Per 1994 omgezet in het, rechtspersoonlijkheid bezittende, zbo Dienst Wegverkeer ex TK 1992-1993, 22961, nr.2, p.2 e.v.

32. Wet van 7 mart 1991, Stbl. 1991, 141. Hiertoe heeft de minister van financièn zijn bevoegdheden, ex art 25 Wte, overgedragen aan de STE. Zie Delegariebesluit Wte, $18 \mathrm{dec}$. 1991, Stbl. 1991, 751; Zie ook int. 40 woorstel Wte 1995. TK 1993-1994, 23874, nrs.1-2.

33. Voorstel van wet tot verwanging Wet toezicht verzekeringsbedrijf door de Wh 1993, TK 1992-1993, 231199, nrs .1-2, uiteindelijk Wtv in Stbl. 1994, 252. Ex art. 2 is de stichring Verzekeringskamer met het toezicht op verzekeraars, dat uit genoemde wet voort wloeit, belast.

34. Wet roezicht kredietwezen 1992, Stbl. 1992, 722, Ex art. 2 junctis artt. $18-27$ Wtk ojunctis art. 9, dende lid, Bankwet van 18 jan. 1952, Stbl. 1952, 35, gewijz. 30 okt. 1985, Stbl. 1985, 603, later gewijzigd 9 dec. 1993, Stbl. 1993, 676, opnieuw gewijzigd d.d. 9 dec. 1994, Stbl. 1994, 676 en art. 9, dende lidd, Statuten DNE nv d.d. 5 sept. 1988) heef DNB nv het monetair-, solvabiliteits-, liquiditeits- administra* tief- en structum moezicht. Lezenswaardig R. Smits, Aspecten van de nieuwe Wtk, in: SEW, nr. 1, 1994, pp.5-25; V.P.G. de Serière, Enige opmerkingen over de Wik 1992, in: NV jan. 1994, pp.10-14; D.R. Doomenbos, Financieel strafrecht, diss. KUN, Deventer, 1992, pp.87-136.

35. Over de ineffectiviteit van de aanwijzing (m.a.w., deze maatregel houdt geen garantie in voor herstêl van de financieel-economische positie van betrokken verzekeringsmaatschappij) o.a. Ph.H.J.G. van Huizen, Versterking van de toezichtsbevoegdheid' van de Verzekeringskamer, in: Het verzekerings-archief, deel L.XVII, 1990 , pp. 3-18, i.h.b. pp.9-18.

36. Wet toezicht kredietwezen 1992, Stbl. 1992, 722. DNB nv geeft de aanwijzing. 
j. openbaarmaking van een besluiten en feiten die een adequate functionering van de effectenmarkten en de positie van beleggers op die markten kunnen schaden (ex art. 23 Wet toezicht effectenverkeer ${ }^{37}$ );

k. aanwijzing aan beurshouders met betrekking tot de aanstootgevende gedragslijn van een effectenbemiddelaars of vermogensbeheerders die vrijgesteld zijn van de vergunningplicht tot uitoefening van het effectenbedrijf omdat zij vallen onder de zelfregulering van een erkende effectenbeurs, maar die zich niet aan die beursregels houden- (door de STE ex respectievelijk art. 8, derde lid, Wte en art. 12, derde lid, Wte);

I. intrekking van een (tijdelijke) vergunning tot het organiseren van een speelcasino in bepaalde ge meenten (ex art. $27 \mathrm{p}$ tot en met art. $27 \mathrm{q}$ jo. art. $27 \mathrm{u}$ Wet op de kansspelen ${ }^{38}$, onderscheidenlijk kansspelautomaat, aanwezigheidsvergunning of exploitatievergunningen ex artt. 30-30y Wk jo. art. 8 Speelautomatenbesluit ${ }^{39}$ ) als ook intrekking van een machtiging om personeel te werk te stellen in (gok)inrichtingen ten dienste van de daarin georganiseerde casinospelen (ex art. $27 \mathrm{r}$ jo. art. $27 \mathrm{~s}$ Wk) ${ }^{40}$;

m. geen continuering van subsidie (bij voorbeeld afd. 4.2.6 Wetsvoorstel Awb);

$\mathrm{n}$. beëindiging steunverlening of terugvorclering van uitgekeerd krediet (ex art. $67 \mathrm{Me}$ diabeslluit ${ }^{41}$ );

o. korting op sociale zekerheidsuitkering (ex bij voorbeeld art. $27 \mathrm{WW}$ of art. 1, tweede lid, ABW) dan wel strafverhoging in de vorm van een - mogelijk gefixeerd- percentage gerelateerd aan niet nagekomen financiële verplichtingen in de sociale zekerheid (ex art. 12 Coördinatiewet Socialle Verzekeringen) ${ }^{42}$;

37. Wet van 7 maart 1991, Stbl. 1991, 141, gewijz. 23 dec. 1992, Stbl. 1992, 722. De STE gaat zo nodig over tot deze preventief bedoelde publikatiemaatregel.

38. Wet op de kansspeten, Stbl. 1964, 483, gewijz. Stbl. 13 nov. 1985, 600. Hiertoe kunnen de ministers van justitie en economische zaken slechts owergaan, nadat zij de Raad voor de Casinospelen hebben gehoord.

39. Spelchutomatenbeslüt, 24 now. 1986, Stb1. 1986, 589.

40. Intrekking geschiedt door het wroegere zbo Raad voor de Casinospelen. Haar taakstelling wloeit voort uit art. $27 \mathrm{~h}$ Wk. (Organisatie)regels aangaande dit hoofdzakelijk adviserend orgaan zijn neergelegd in o.a. artt. $27 \mathrm{i}-27 \mathrm{n} / 27 \mathrm{v}-27 \mathrm{ij}$ Wk jo. het Besluit inz, schorsing en onislag van de leden van de RvdC, 27 febr. 1975, in: RudC, Casinoregelen RvdC, "s-Graw., 1990, pp.75-76, jo. het Huishoudelijk reglement RvaC. Stbl. 1975,63, goedgekeurd d.d. 31 dlec. 1987.

41. Beschikking geplaatst in Stbl. 1987, 573, gewijz. 22 juni 1992, Stbl. 1992, 334. Tot een of andler is bevoegd hat zbo Bedrijfisfonds voor de Pers (rechtspersoon in gevolge art. 123 Mediawet).

42. Volgens voorstel van minister Melkert en staatssecretaris Linschoten van sociale zaken, die medio 1994 zitting nemen in het nieuwe kabinet-Kok, moeten uitvoeringsorganen in de sociale zekerheid, waaronder bedrijfswerenigingen, de verplichting krijgen om bij constatering, dat cen alanvrager van een uitkering onjuiste of onvolledige informatie (die van belang kan zijn woor het recht op uitkering) werschaft, aan betrokken overtreder een boete van maximaal vijfduizend gulden op te leggen. In dat geval geschied geen aangifte van overtreding bij politie en justitie. Owerigens móeten de uitvoeringsorganen in alle gevallen, waarin een uitkering sgerechtigde zijn verplichtingen niet of onvoldoende nakomt, administratieve maatregelen opleggen. Geïntraduceerd wordt de verplichting voor bestuursorganen een besluit tot toekenning. van een uitkering the herzien of in te trekken indien ontoelaatbaar gedrag van een uitkeringsgerechigde er toe heeft geleid tot het ten onrechte toekennen wan een uitkering. Hiernaast blijft de mogelijkheid van tijdelijke of blijwende weigering van een (gedeelte van een) uitkering bij plichtschending en nalatigg gedrag 
p. bevel tot betaling van een bestuurlijke boete ${ }^{434}$ (ex bij voorbeeld artt. 135$137 / 140$ Mediawet junctis artt. 2/8-18 Sanctieregeling omroep) ${ }^{45}$.

Het is jammer te moeten constateren dat frequent voorkomende handhavingsinstrumenten niet voorkomen in het wetsvoorstel $\mathrm{Awb}{ }^{46}{ }^{46}$, net zo min als dat het geval is in het eerder verschenen voorontwerp Awb ${ }^{47}$. Denk aan sancties als bestuurlijke boete, intrekking

42. $\rightarrow$

wan witkeringsgerechtigheid. Aldus Wetswoorstel tot wijziging van de sociale zekerheidswetten i. w. mu. de nadere vaststelling van een stelsel van administratieve sancties als ook tot wijziging van de dawarin werwatte regels tot terugvordering van ten on rechte betaalde witkeringen en de invordering daarwaw (Wet boeten, maatregelen en terug- of inwordering sociale zekerheid). TK 1994-1995, 23909, nrs. 1-3 en mr.9 (gewijzigd woorstel van wet); Daarover Kabinet: baete wow fouten in aanwraag sociale uitkering, int" NRC, 22 sept. 1994, p.10. Ook Onjwiste informatie bij aanvraag witkering bestraft met boete, in: NJB, nr.34, 30 sept. 1994, p.1187. Tevens J.P. de Jong. Nieuwe sanctiebepalingen in de sociale zekerheidswetgeving, in: NTB, nr. 10, 1994, pp.326-327; Interessant spreekt J. Roording, Naar een geintegreerd sanctierech, in: AA, nr. 1, 1995 , pp. $82-85$, i.h.b. p. 84 , ther van vercelfstandiging van de administratieve sanctionering uit het proces van de beleidsuitvoering. Daarmee kan, volgens auteur, logische aansluiting

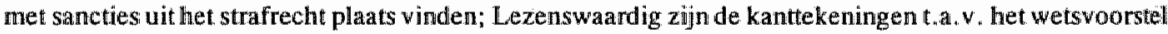
wan J.F. Bandringa, E.L. Benetreu, A. B.J. van der Ham en M.J. Sluijs, Bestuurlike boeten in de sociale zekerheid, in: Sociaal Recht, nr. 1, 1995, pp. 10-14. Auteurs vrezen dat door het imperatieve karakter van de boete andere sancties (d.w.z. maatregelen) onterecht te weinig nadink krijgen. Overigens vragen zij atandacht woor de onderscheiden sanctiegronden, de noodzavk van een bepaling inzake samenloop tussen. boeten en matregelen als mede tussen matregelen onderling, en de relewantie om een voornemenprocedure ex art. 3:14 Awb vooraf te laten gaan aan oplegging wan bepaalde maatregelen. Owerigens achten auteurs de geboden rechisbescherming te minimal, watrdoor zij aanvulling met een bepaling inzake schorsende werking van bezwar em beroep als mede schrapping wan de mogelijkheid van reformatio in peius wenselijk achten.

43. Hierover 0.a. A.W.M. Bijlloos "Administratieve boete en art. 6 EVRM in Nederland, preadvies VVSR, Zwolle, 1989; W.G.A. Hazewindus en O.J.D.M.L. Jansen (red.), Van boeteatelier tot boetefabriek, Deventer , 1995; FF.C.M.A. Michiels, De boete in opmars?, oratie VU, Zwolle, 11 febr. 1994; A. Mulder, Geldboete, en eigen middel van de EG, in: SEW, nr.6, juni 1989, pp.459-478; A. Mulder, De bestum thike boere als middel tot bestrijding wan economische delicten, in: SEW, nr.4, 1994, pp.219-235; 1.Y. de Rant, De bestwurlijke boete in het milieurecht, in: AA, nr,6, 1993, pp.443-450; M.I.H.T. Rikmenspoel, De bestuursrechtelijke boete: traditie, trend en toekomst, in: Gst., 1994, nr. 6990, pp. 321-325; E. Rood, Overzich EEG en Nederlands levensmiddelenbeleid en wech., Apeldoorn/Amhem, 1993, pp. 180-185 (plausibel pleidooi voor boetebelleid i.p.v. schikkingsbeleid in levensmiddelensector); M.J. Sluijs, De bestwurlijke boete: naar nieuwe grewzen, in: BWn, nr.6, 1991, pp.420-434; M.J. Sluijs. Admivistratiewe sancties in een strafrechtetijke context. in: NJB, n. 16, 23april 1988, pp.522-528, J.A.E. Vervaele en R.J.G.M. Widdershoven, a.w., pp.50-79.

44. M.b.t. tot de bestuurijike boete geldt dat de bevoegdheid tot het nemen van een besluit tot boeteoplegging: hoewel dit niet steunt op een geschreven regel, op een wettelijke grondslag moet bensten. Aldus Bevoegdheid tot boeteoplegging (wegens i.c. niet-nalewing voanwarden rentesubsidie) zonder wettelijke grondslag, ARRS 4 nov. 1993, AB 1994, 182, m.nt. N. Verheij, die aantekent dat art. 89 Gw uitbreiding naar bestuurlijke boeten verdient.

45. De maximale boete betreft een w.d. geldboetecategorieen ex art. 23, vierde lid, WvSr. C. Borman, a. w. . p.126 (anwijizing 146 , tweede lid).

46. Mvt wetswoorstel derde tranche Awb, TK 1993-1994, 23700, nr.2.

47. C.P.J. Goorden., Handhaving ander her regume van de Awb, in: Gst, nr. 6959, 12 febr. 1993, pp.57-66, i.h.b. p.59; C.J. Kleijs-Wijnnobel, Krowieken. sancties, in: NTB, nr.4, 1992, pp.134-141, i.h.b. p. 135; P.M. Langbroek, M.S.E. Wulffraat-van Dijk, G.H. Hagelstein, N.M. Spelt, G.H. Addink en M.J. Sluijs, 
positieve beschikking, bestuurlijke waarborgsom ${ }^{48}$, bijzondere (financiële) lastgeving ${ }^{49}$, (tijdelijke) uitsluiting van een bij bepaalde regeling toegekende geldelijke voordelen ${ }^{50}$ en de imperatieve sanctie, dat wil zeggen de niet-uitbetaling dan wel terugvordering van premies of terugvordering van ten onrechte ontvangen gelden ${ }^{51}$, aan populariteit winnen.

Toegegeven, beterschap is in zicht. Van ministeriële zijde luidt de mededeling, dat de Awb-wetgever nog zal voorzien in een algemene regeling inzake bestuurlijke boete. ${ }^{52}$ Denkbaar is een boeteregeling in de Awb of, als alternatief, in de aanwijzingen/modelbepalingen voor de regelgeving. ${ }^{53}$

Van uit ontevredenheid over de ineffectieve strafrechtelijke handhaving van visserijweten regelgeving, worden de mogelijkheden van bestuursrechtelijke (visserij)sancties onderzocht. ${ }^{54}$ Naar aanleiding van de positieve uitkomst daarvan, presenteert een interdepartementale projectgroep op 1 juli 1993 het Wetsvoorstel bestuurlijke boeten visserij, waarmee strafrechtelijke handhavingsinstrumenten en -actoren over boord worden gegooid; Hiermee instemmend, adviseert de commissie voor de toetsing voor wetgevingsprojecten op 12 januari 1994 in positieve zin over de administratieve boete als handhavingsmiddel voor het bestuurlijk ordeningsrecht in het algemeen. Aan wetten die in aanmerking komen voor handhaving met de bestuurlijke boette, d.w.z. "de verplichting om aan de Staat of een andere publiekrechtelijke rechtspersoon een geldsom te betalen wegens overtreding van het bij of krachtens enig wettelijk voorschrift bepaalde", stelt de commissie eisen: de wettelijke norm heeft geringe normatieve lading; de overtreding brengt geen letsel aan personen of schade aan goederen toe; de norm is zo duidelijk, dat daarop in praktijk een vaste gedragslijn wordt ontwikkeld; degenen die belast zijn met de handhaving van de wet zijn voldoende deskundig; en, voor normhandhaving zijn geen

$47 . \rightarrow$

Bouwen nan de Awb; Het woorontwerp derde ranche verkend, in: $\mathbb{N}$ IB, nit, 15,9 april 1992, pp.473-477, i.h., b. p.476; G.H. Addink en M.J. Sluijs, De Awb op scherp: Kanttekeningen bü het hoofdstuk Handhaving, in: NTB, nr,2, 1992 , pp.33-45, i.h.b. p.34; N.S.J. Koeman, Handhaving, in: W. Konijnenbelt, Commentaar op het vooronnwerp derde tranche Awb, Alphen a/d Rijn, 1992, pp.103-110, i.h.b. pp. 108109; Rbb, Aldvies over woorontwerp derde tranche Awb, "s-Gravenhage, mei 1992. p. 18.

48. J.A.E. Verwate en R.J.G.M. Widdershoven, Bestuurlijke handhaving van visserijregelgeving, Utrecht, 1991, pp.92.97; A.J.C. de Moor-Van Vugt, Kronieken: Europees bestuursrecht, in: NTB, ni.5, 1992, pp.173-182, i.h.b. pp. 180-181; A.J.C. de Moor-Van Vugt, Symbiose van evenredigheidstoetsen?. in: NTB, nr. 1, 1993, pp. 26-37, i.h.b. pp.31-32.

49. A.J.C. de Moor-Van Vugt (1993), t.a.p., p. 29 .

50. R.I.G.M. Widdershoven, Gemeenschapsrecht bestuursrechtelijk gehandhaafd, in: NTB, nr.1, 1993 , pp.47-58, i.h.b. p.49/51-52; K.A.M. Blecker, Verantwoorde communautaire sanctionering wan het gemeenschopsrecht?, in: NJB, nr. 28, 5 aug. 1993, pp.1009.1013.

51. C.J. Kleijs-Wijnnobel, Kronieken: sancties, in: NTB, nr.3, 1993, pp.128-133, i.h.b. p.133.

52. Begroting 1994, TK 1993-1994, 23400 VI, nr. 2, pp.15/22-23.

53. G.H. Addink en M.J. Sluijs, Het vijfde hoofdstuk van de Awb: handhaving in materieel perspectief. in: NJB, nr. 35, 7 okt. 1994, pp. 1201-1208, i.h.b. p.1205-1206, vinden dat de Awb-wetgever "het voortouw" mot nemen voor een "facultatieve" regelling met drie soorten bestuurlijke boeten, die procedureel en inhoudelijk verschillen afhankelijk van dle aard van de overtreding en de hoogte van de boete.

54. J.A.E. Vervale en R.J.G. Widdershoven, Bestuurlijke handhaving van visserijregelgeving, Utrecht, 1991. 
vrijheidsbenemende of andere ingrijpende dwangbevoegdheden nodig; Deze eisen worden mogelijk aangevuld als volgt: de overtreding leent zich voor vast afdoeningstarieven; documentatie i.v.m. recidive is niet nodig; en de overtreding wordt niet door of ten behoeve van criminele organisaties gepleegd. ${ }^{55}$

Het kabinet neemt in grote lijnen het advies van de CTW inzake bestuurlijke boeten over. ${ }^{56}$ Het kabinet meent dat het op grote schaal invoeren van de bestuurlijke boete de kwaliteit van de rechtshandhaving kan verbeteren: a. het bestuur wordt directer bij de rechtshandhaving betrokken (stimulans betrokkenheid); $b$. het bestuur is vaak, door deskundigheid en ervaring, het meest geschikt woor de handhaving zorg te dragen (bevordering efficiëntie en effectiviteir); en c. de mogelijkheid van bestuurlijke boeteoplegging vult de strafrechtelijke handhaving belangrijk aan (activering alternatieve handhaving). De bestuurlijke boete kan twee gedaanten aannemen: a. op grond van een wettelijk wastgelegd onderscheid tussen strafrecht en bestuursrecht kan de boete een gefixeerde vorm krijgen, waarvan het bestuur slechts in bijzondere gevallen mag afwijken; en b. op grond van het in het midden laten wanneer strafrechtelijk dan wel bestuursrechtelijk moet worden opgetreden heeft het bestuur de beleidsvrijheid, beneden een door de wet gesteld maximum, te bepalen welke boete zij wil opleggen. In de lijn van de CTW spreekt het kabinet voorkeur uit voor eerst genoemde optie en acht daarnaast een mix van beide modellen denkbaar. ${ }^{57}$

Voornoemde regelingen staan model voor de voorgenomen Awb-regeling inzake bestuurlijke boete op te nemen in de vierde ${ }^{58}$ tranche Awb. ${ }^{59}$

Intrekking, wijziging of schorsing van vergunningen of begunstigende beschikkingen ${ }^{60}$ laat de Awb-wetgever aanvankelijk ook links liggen. In het uiteindelijke wetsvoorstel

55. Aldus CTW-jaarverslag/justitiebegroting, TK 1993-1994, 23400 VI, nr.49, zie voor Kabinetsstandpunt ower CTW-advies' 'Handhaving door bestwurlijke boeten', TK 1993-1994, 23400 VI, nr.48., Hierbij plaatst A. Mulder, De bestuwrlike boete ats middel ton bestrijding van economische delicten, in: SEW, nr.4, april 1994. pp. 219-235, de nodige kanttekeningen.

56. Regeringsstandpunt over CTW-advies inzake handhaving door bestuurlike boeten. TK 1993-1994, 23400 VI, nr. 48.

57. Kabinetsstandpun bestuurlike boeten, TK 1993-1994, 23400 VI, mr.48, pp.4/11-12.

58. E. Alders, De handhaving man het bestuurstecht wia toezicht en de gemiste kans van de derde tranche Awb, in: NTB, nt 2, 1995, pp, 25-29, prefereert opneming van de mogelijkheid tot oplegging van (woorwaardelijke) bestuurlijke boete in de derde tranche Awb. Daardoor is het z.i. niet meer nodig dat het "OM op een oneigenlijke manier van stal wordt gehaald"; Ook de PvdA-fractie werpt de vraag op of de bestuurlijke boete (als mede intrekking en wijziging van begunstigende beschikkingen) niat plaats moet krijgen in de derde tranche van de Awb, zle Verslag aanvwling derde tranche Awb. TK 1994-1995, 23700, nr.4, p.20; Even zo bepleiten O.J.D.M. L. Jansen en W.G.A. Hazewindus, Inlerding. de bestuw. lijke boere in de derce tranche, in de onder hun nedactie staande bundel Van boeteatelier tor boetefobriek, Deventer, 1995, pp.114, terecht regeling van de bestuurlijke boete in de derde tranche Awb.

59. Het kabinet meent dat de bijzondere regelingen die op korte termijn voor bestuurlijke boeten zijn te treffen, in later stadium nut kunnen bewijzen bij het opstellen van een algemene regeling ter zalke in de A wb (waarbij in elk geval onderwerpen als zwijgrecht, schorsende werking bezwaar/beroep, invordering en verjaring worden geregeld). Kabinetsistandpunt bestuwrijke boeten, TK 1993-1994, 23400 VI, nr.48, p.ll.

60. Z̈e 0.a. W.G.A. Hazewindus, Administratieve sancties en vreemdelingenrecht, diss. UvA, Armem, 1994 , pp. 115-132. 
Awb wordt dan toch het nodige opgemerkt: "Van de intrekking van een positieve beschikking bij wijze van reactie op een overtreding van wettelijke voorschriften wordt in de rechtspraktijk aangenomen dat deze sanctie ook zonder uitdrukkelijke grondslag in de wet mogelijk is, tenzij uit het wettelijk stelsel het tegendeel blijkt. Dit laat overigens onverlet dat het gewenst is om de bevoegdheid tot intrekking van een beschikking uitdrukkelijk te regelen (vgl. aanwijzing 140 van de Aanwijzingen voor de regelgeving)." 6162

Omgekeerd geldt wel, dat áls een bevoegdheid tot intrekking van een begunstigende beschikking wettelijk wordt verleend, bij voorbeeld de bevoegdheid ex art. 30f Wet op de kansspelen van de burgemeester om in dringende gevallen een toegekende vergunning bij vrees voor ernstig gevaar voor openbare orde, veiligheid of zedelijkheid in te trekken, deze intrekkingsbevoegdheid niet door een convenant kan worden te niet gedaan. ${ }^{63}$

Het is de bedoeling in de vierde tranche Awb een regeling te treffen met betrekking tot intrekking bij wijze van sanctie. ${ }^{64}$ Herhaald wordt: bij wijze van sanctie. Een algemene regeling van wijziging en intrekking van beschikkingen ligt kennelijk nog niet in de rede. ${ }^{65}$

61. Mwt wetswoorstel derde tranche Awb, TK 1993-1994, 23700, nr. 3, pp.130-131.

62. Aarwijzing 140 stelt: 'Indien intrekking of schorsing van een beschikking bij wijze van sanctie mogelijk moet zijn, wordt de bevoegdheid daartoe uitdrukkelijlk gerege ld". Daarnaast is aanwijzing 130 relewant woor intrekking of wijziging wan beschikkingen, zij het niet specifiek als sanctionering. Aanwijzing 130 , vergelijkbaar met alanwijzzing 141 , vermeldt: "De gronden die kunten of moeten leiden tot het intrekken of wijzigen van een beschikking, worden in de regeling gespecificeerd'. De toelichting noemt gronden, voor uitoefening van een bij voorkeur facultatieve intrekkings- of wijzigingsbevoegdheid, als: "werstrekte gegevens blijken zo danig onjuist of onvolledig dat op cle aanvraag een andere beslissing zou zijn genomen, indien bij de beoordeling daarwan de juiste gegevens bekend waren geweest; de beschikking is in strijd met wettelijke voorschriften gegewen; van de beschikking is gedurende een bepaalde achtereenvolgende periode geen gebruik gemaakt; of, i. . .m. verandering van wetgeving, gewijzigde omstandigheden of gewijzigde inzichtem moet de bescherming van de belangen met het oog waarop het vereiste van de beschikking is gesteld, zwaarder wegen dan het belang van de betrokkene bij een ongewijzigde beschikking" . C. Borman, a.w., pp.114-115/120-121.

63. Vz CBB 24 juli 1992, in: de Gemeentestem, nr.6961, mint. C.P.I. Gioorden.

64. Mwt wetswoorstel derde tranche Awb, TK 1993-1994, 23700, mr.3, p. 132.

65. G.H. Addink en M.J. Sluijs, Het wijfde hoofdstuk wan de Awb: handhaving in materieel perspectief, in: NJB, nr. 35, 7 okt. 1994, pp.1201-1208, i.h.b. p.1202. 


\section{\$12.3 Privaatrechtelijke handhaving ${ }^{66}$}

In geval van privaatrechtelijke handhaving is er veelal een op de burger neergelegde zorgplicht die wordt afgedwongen middels een actie uit onrechtmatige daad ex art. 6:162 $B W$. Degene die zich hierop beroept moet wel een concreet belang bij regelnaleving hebben.

Te denken is aan wet- en regelgeving waarmee bij voorbeeld de zbo's zijnde Kamers van Koophandel en fabrieken werken. In het bijzonder de Vestigingswet Detailhandel, de Drank- en Horecawer en de Vestigingswet Bedrijven 1954. Is voldaan aan de daarin omschreven vereisten van kredietwaardigheid, handelskennis en vakbekwaamheid, dan geeft de KvK aan de aanvrager een vergunning af. Wat betreft de voorloper van de Vestigingswet Bedrijven, te weten de Vestigingswet Kleinbedrijf 1937, heeft de rechter onrechtmatige daad-constructie toegepast. Namelijk, een ondernemer die zonder een vergunning een bedrijf voert, handelt niet rechtmatig ten opzichte van zijn, legaal werkzame, concurrenten. ${ }^{67}$

Andere wijzen wan civielrechtelijke handhaving zijn nog de actie uit onverschuldigde betaling ex art. 6:203 $\mathrm{BW}$ en de actie uit ongerechtvaardigde verrijking ex art. 6:212 BW. Ook mogelijk is het eisen van schadevergoeding in geval van niet-nakoming van een verbintenis ex art. 6:74 BW e.v. juncto art. 6:95 BW e.v. Bij wanprestatie van een betrokken partij kan de andere gedupeerde partij nietigheid, vernietigbaarheid of ontbinding van de betreffende overeenkomst inroepen.

Zo kan het Bedrijfsfonds voor de Pers, dat toezicht houdt op de naleving van de aan het verstrekken van financiële (pers)steun gestelde voorwaarden, privaatrechtelijk sanctioneren als een, door met een bepaald persorgaan gesloten, kredietovereenkomst niet wordt nagekomen door de wederpartij. Niet-nakoming constateert het fonds zelf of de wanprestatie wordt ontdekt tijdens de regelmatige controles op naleving wan kredietvoorwaarden die zijn uitbesteed aan de Nationale Investeringsbank. Overigens maakt het Bedrijfsfonds voor de Pers "slechts in uiterste situaties" gebruik van de hem ter beschikking staande sanctiemogelijkheden. ${ }^{68}$

66. Aantekening werdient dat privaatrechtelijke (handhavings)bevoegdheden niet oneigenlijk mogen worden gebnikt. Verwezen wordt hier naar de zgn. tweewegenleer (met de criteria: a, is via publiekrectht een vergelijkbaar resultaat -als middels het privaatrectht is te bereiken-te verkrijgen; en b. is sprake van een onaanvaardbare doorkmising van het publiekrecht) die door recente rechtspraak lijkt te zijn achterhaald, Zie paragraaf 10.2 ; Nota bene, creëert een rechtsvordering met basis in $\mathrm{BW}$ wan oudsher een schuld vordering, waardoor het bestuur via art. 112 Grondwet naar de burgerlijke rechter kan stappen. In Staat ws. Kabayel c.s., HR 18 febr. 1994, RvdW 1994, 58, biedt de rechter nog meer ruimte. Volgens H.J. Simon,

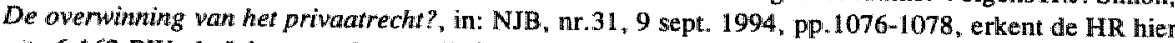
art. $6: 162 \mathrm{BW}$ als "algemene bevoegdheidsgrondslag voor de overheid ter bescherming wan publieke belangen" (zelfs daar waar elke publiekrechtelijke bevoegdheid onbreekt). In casu tolereert de HR het gebnuik van het kort geding als privaatrechtelijk instrument in geval een bestuursrechtelijk instrument ontbreekt.

67. HR 30 oktober 1959 , NJ 1961, 574 .

68. Aldus antwoordt het Bedrijfsfonds voor de Pers bij brief d.d. 7 meil 1993, p.4. 
Daarnaast bestaan mogelijkheden als het vragen aan de civiele rechter om uitvaardiging van een verbod, oplegging van een gebod of uitspreking van een declaratoir vonnis. Dit komt veelal voor in aanvulling op de toezichthoudende activiteiten van handhavende zelfstandige bestuursorganen. Denk aan de Stichting Toezicht Effectenverkeer of de Registratiekamer.

\section{$\$ 12.4$ Tuchtrechtelijke handhaving}

Tuchtrechtelijke handhaving kent zowel een inhoudelijk als een procedureel element. Tuchtrecht is namelijk "het sanctierecht, waaraan de leden van een groep zijn onderworpen en dat de procedure regelt volgens welke een tuchtcollege aan een tuchtrechtelijk rechtssubject dat een tuchtnorm heeft overtreden een tuchtsanctie kan opleggen". ${ }^{69}$ Snelle berechting in een zakelijke en soms informele sfeer wordt als voordeel van tuchtrecht gezien. ${ }^{70}$ Berechting geschiedt door onder meer raden van tucht en raden van beroep. Tuchtrecht geldt meestal, meer of minder vrijwillig, zo niet hiërarchisch ${ }^{7}$, voor een vereniging of een beroepsgroep.

De door verenigingen of beroepsgroepen gehanteerde normen moeten wel breed draagvlak bij de bevolking hebben. Hier ligt waarschijnlijk een probleem wat betreft de Koninklijke Nederlandse Jagers Vereniging. Zij voert een tuchtrecht in voor aktehoudende jagers die zich 'onweidelijk' gedragen. Dat ziet zij graag in de Flora- en faunawet ${ }^{72}$ (d.i. de voor het Jachtfonds relevante wet) opgenomen. ${ }^{73}$

In de sfeer van functionele decentralisatie (naar met name zbo's) zijn er verschillende soorten tuchtrecht. Denk aan de tuchtrechtspraak door de Raad voor de Luchtvaart ${ }^{74}$ ex artt. 1-2 Luchtvaartongevallenwet ${ }^{75}$ en de Raad voor de Scheepvaart ${ }^{76}$ ex art. 13 junctis art. 23 en art. 48 Schepenwet. Overigens is het de bedoeling beide zelfstandige bestuursorganen, samen met de Spoorwegongevallenraad ${ }^{T 7}$, ex artt. $2 \mathrm{a} / 27 \mathrm{a}$ Spoorweg-

69. M.J.C. Leijten, Samenloop van sancties bezien wanait het wettelijk geregelde tuclitrecht, in: NJB, 19 nov. 1992, nr.41, pp.1387-1394, i.h.b. p.1388; Ook M.1.C. Leijten, Tuchtrech geroetst, diss. KUB, Gouda/Armbem, 1991, pp. 30-44.

70. K. Hellingmane.a., Economisch publiekrecht; Rechtswarborgen en rechtsinstrumenten, Deventer, 1989 , p. 246 .

71. H. de Doellder. Terrein en beginselen wan tuchtrecht, Alphen a.d. Rijn/Brussel, 1981, pp 40-46/197-205.

72. Hierover J. Verschumen, Het ontwerp Flora-en fawnawet: implemestatie en inegratie, in: RegelMaat, n.r.1, 1994, pp.9-15.

73. Zie Jagersvereniging woert tuchtrecht voor jagers in, in: NRC, 15 sept. 1993, p.2. Zie ook Stcrt. 1993, 176.

74. Ingesteld ex art. 1 Luchtvaartrampenwet van 10 sept. 1936, Stbl. 1936, 522. gewijzigd d.d. 8 mel 1969 , Stbl. 1969,191 .

75. Overigens is in de Luchtongevallenwet (TK. 19854) het tuchtrecht, vervat in arti. 37-40 Luchtvaartram penwet, vervallen.

76. Hierover $\mathrm{R}$. Cleton, De raad voor de scheepvaart, in: H.J. Snijders, C. Fijnaut, H. Th. J.F. van Maarseveen en R. Zwitser, Overheidsrechter gepasseerd; Conflictbeslechring buiten de overheidsrechter om, Amhen, 1988, pp.313-320.

77. Ingesteld bij wet van 6 jan. 1956, Stbl. 1956, 26. 
wet, de Commissie Binnenvaartrampenwet ${ }^{78}$ ex art. 3 Binnenscheepvaartrampenwet en de Nederlandsche Marineraad ${ }^{79}$ ex art. 2 Marinescheepsongevallenwet, in de toekomst te integreren in een overkoepelende Raad voor de ongevallen. ${ }^{80}$

Ook in de onderwijssfeer wordt tuchtrecht, ten aanzien van personeel en leerlingen, op grote schaal toegepast. Denk aan de kringenrechtspraak door de commissies van beroep in het bijzonder onderwijs ${ }^{\text {s1 }}$ en het optreden van de instellingen ten behoeve van de verschillende soorten onderwijs.

Ook het accountantswezen valt onder een tuchtregime. Het openbaar lichaam Nederlands Instituut voor Registeraccountants ${ }^{8283}$ heeft vooral tot taak de bevordering van een goede beroepsuitoefening door registeraccountants. In gevolge art. 33, eerste lid, Wet op de registeraccountants ${ }^{84}$ heeft de tuchtrechtspraak in casu "ten doel het weren en beteugelen van misslagen van registeraccountants in de uitoefening van hun beroep en van inbreuken op verorderingen van de Orde en op de eer van de stand der registeraccountants". De meest bekende tuchtrechtelijke maatregelen komen hier voor. Te weten: schriftelijke waarschuwing, schriftelijke berisping, tijdelijke schorsing in beroepsuitoefening en definitieve doorhaling in het beroepsregister. Ook de openbaarmaking van de tuchtbeslissing kan diffamerend werken. Zie art. 34 Wet op de registeraccountants.

Andere tuchtrechtelijke handhavingsmiddelen komen voor bij verschillende privaatrechtelijke landbouwkwaliteitscontrole-instellingen. ${ }^{85}$ Bij voorbeeld art. 8 Tuchtreglement op de tuchtrechtspraak van de stichting Nederlandse Vleeswaren Kontrole ${ }^{86}$ spreekt (naast mondelinge of schriftelijke berisping - d.w.z. vermaan in verband met de begane overtreding - en, daarnaast, openbaarmaking van de tuchtbeschikking op kosten van de aangeslotene) over oplegging van een geldboete van minimaal "vijftig cents" en maximaal tienduizend gulden. Hiernaast kent het tuchtrecht van dit zelfstandig bestuursorgaan als extra maatregel: het stellen van een aangeslotene onder verscherpte controle op zijm kosten woor ten hoogste twee jaren. Naast deze maatregel, die overigens vaker bij rechts-

78. Ingesteld ex art. 3 Binnenvaartrampenwet van 9 juli 1931, Stbl. 1931, 289, gewijzigd d.d. 30 juni 1967 . Stbl. 1967, 377.

79. Ingesteld bij Marine Scheepsongevallenwet van 16 maart 1928, Stbl. 1928, 69, gewijzigd d.d. 24 dec. 1970, Stbl. 1970, 612.

80. M. van Duin, Na elke ramp volgt een onderzoek, maar vaak door een andere instantie: ëen raad woor alle ongelukken kan versnippering voorkomen, in: $1 \mathrm{HB}, 18$ dec. 1992, pp.24-25.

81. 1. Snoor, Commissie van beroep in het bijonder ondenwijs, in: H.J. Snijders e.a., a.w., pp.181-196.

82. Ingesteld bij Wet op de registeraccountants wan 28 juni 1962 , Stbl. 1962, 258.

83. Vgl. de Nederlandse Orde voor Accountants-Adminisrratieconsulenten, ingesteld ex art. 2, eerste lid, herziene Wet accountantants-administratieconsulenten wan 6 aug. 1993, Stbl. 1993, 465.

84. Wet van 28 juni 1962, Stbl. 1962, 258, gewijz. 25 okt. 1989, Stbl. 1989, 490.

85. Tuchtrechbeshuit Landbouwkwaliteitswet 12 juli 1979, Stbi. 1979, 455; Tuchtreglement stichting COZ (sinds 13 dec. 1990 Central Orgaan Kaas- en Zuivelcontrole), Stcrt. 1982, 17; Tuchtregl. KCB (Kwaliteits-Controle-Bureau groenten en fruit). Stcrt. 1980, 43; Tuchtregl. stichting Sicharreleierencontrole (sinds 12 april 1993 Controllebureau voor pluimvee, eienen en eiprodukten), Stcrt. 1979, 170; Tuchtragl. stichting Bloembollenkeuringsdienst, Stcn. 1983, 241; Tuchtregl. Stichting Keur Alternatief woontgebrachre Landbouwprodukten, Stcrt. 1993, 73 .

86. D.d. 4 now. 1982, Stbl, 1983, 38. 
personen in de sfeer van privaatrechtellijke landbouw - of zaaizaad-en plantgoedkwalliteitscontrole voorkomt, maakt een enkele controle-instelling melding van een vijfde tuchtmaatregel in de vorm van beëindiging van aansluiting bij de betrokken controle-instelling. 87

Ook wat betreft tuchtrecht geldt dat dubbele berechting en bestraffing zo mogelijk worden vermeden. In de afzonderlijke regelingen wordt meestal aan de officier van justitie een beslissende rol ter zake toebedeeld. Nog maals de stichting Nederlandse Vleeswaren Kontrole als voorbeeld. Art. 10, vijfde lid, Tuchtreglement jo. art. 23 van haar statuten ${ }^{88}$ maken duidelijk, dat een zaak niet aanhangig wordt gemaakt voordat overlleg met de officier van justitie plaats vindt. ${ }^{89}$

Bovendien geeft art. 5 WED de volgende basisregel. "Tenzij bij wet anders is bepaald, kunnen ter zake van economische delicten geen andere voorzieningen met de strekking van straf of tuchtmaatregel worden getroffen dan de straffen en maatregelen, overeenkomstig deze wet op te leggen."

In verre weg het merendeel van overtredingen die tuchtrechtelijk afhandeling kunnen vinden, besluit het openbaar ministerie de tuchtrechtelijke weg te volgen. De verschillende procedures voor deskundige tuchtgerechten ${ }_{\psi}$ die bevoegd zijn sancties op te leggen die overtreders vaak meer dan strafrechtelijke sancties treffen, verminderen de werkdruk van de officieren van justitie. Na een tuchtrechtelijke procedure vindt terecht vrij wel geen toepassing van het strafrecht meer plaats.

Dat tuchtrechtelijke zaken dan ook serieus behandeling verdienen blijkt uit jonge jurisprudentie. In een tuchtprocedure op grond van de Landbouwkwaliteitswet wordt een als op zich zelf evenredig te beschouwen tuchtmaatregel opgelegd. Pas meer dan twee jaar na de uitspraak doet het tuchtgerecht de tuchtbeschikking aan de door de maatregel getroffen persoon toekomen. Gedurende de tijd dat laatst genoemde de beschikking niet in zijn bezit heeft, wordt hem de mogelijkheid van beroep ontnomen. Als hij dan na ruim twee jaar eindelijk beroep in kan stellen en dat ook doet, wordt hij hinderlijk geconfronteerd met een ernstige zaaksvertraging die optreedt doordat het tuchtgerecht bij het toezenden van de stukken æan het College van Beroep voor het Bedrijfsleven de wettelijk bepaalde termijn met circa zeven maanden overschrijdt. Het CBB acht appellant geschaad in zijn (verdedigings)recht op zaaksbehandeling binnen een redelijke termijn. Dit vloeit voort uit art. 6 EVRM, nu het CBB de tuchtprocedure aanmerkt als een 'criminal charge" in de zin van art. 6, eerste lid, EVRM omdat: a. de overtreding een strafrechtelijk stempel draagt; $b$. de overtreden norm zich mede richt tot anderen dan aangeslotenen bij de BKK; en c. gelet op de zwaarte van de op de overtreding gestelde sanctie. ${ }^{90}$

87. Voor de stichting Internationale Scharrelvlees Controle ligt dit vast in art. 8, eerste lid, sub d, Reglement voor de commissie van beroep van de ISC, in: ISC, ISC-scharrelvlees documentatie, jan. 1991, p.54.

88. Gewijzigd d.d. 29 sept. 1988 , Stcrt. 5 jan. $1989,4$.

89. Wgl. art. 98 Zaaizaad-en Plantgoedwet van 6 okt. 1966, Stbl. 1966, 455, gewijz. 26 juni 1986 , Stbl. 1986, 388; Art. 18 Landbouwkwaliteitswet, 8 april 1971, Stbl. 1971, 371, gewijz. 8 april 1976, Stbl. 1976., 229.

90. Tuchiprocedure LKw, CBE 28 maart 1995, in: NIB, nr.26, 3 juni 1995, rechtspraakkatern nr.23, p.352 (bijlage). 


\section{$\S 12.5$ Art. 6 EVRM}

Het, in paragraaf 12.1 en in paragraaf 12.2 vermelde, vervagende onderscheid tussen strafrechtelijke en bestuursrechtelijke handhaving is inmiddels door de rechter onder ogen gezien. Wat betreft de toegang tot een onafhankelijke ${ }^{91}$ en onpartijdige rechter en de daaraan verbonden verdedligingsrechten ${ }^{92}$ ex art. 6 EVRM ${ }^{93}$, volgt uit jurisprudentie van het Europese Hof voor de Rechten van de Mens dat het recht op een eerlijk proces niet alleen geldt in een civiel- of strafrechtelijke procedure. Ook in bestuursrechtelijke ${ }^{\text {gh }}$ en tuchtrechtelijke ${ }^{95}$ zaken is, in principe, aanspraak op de rechten van art. 6 EVRM mogelijk.

Tot dit ruime toepassingsgebied komt de EHRM door zijn autonome invulling van het, in art. 6 EVRM, naast 'determination of the civil rights and obligations' gehanteerde, begrip 'criminal offence'. Hiertoe gebruikt het EHRM, onder verwijzing naar het onderwerp en doel van het EVRM, drie criteria. Ten eerste, wordt het begane delict naar het nationale recht van de betrokken lidstaat als strafrechtelijk aangemerkt. Ten tweede, het

91. Conform de belangrijke Benthem-rechtspraak staat nu als paal bowen water dat het CBB -althans het CBB onder vigeur van de oude wet-Arob, ondat de Kroon kon besluiten on aan een uitspraak van dat CBB geen gewolg te geven- geen onafhankelijk gerecht in de zin van art. 6 EVRM is. In Van der Hurk ws. Nederland, EHRM 19 april 1994, series A, vol. 288, in: NJB, nr.18, 5 mei 1995, rechtspraakbijlage sr. 16, p.237 (katern), ook in: NJCM bulletin, nr.19-4, 1994, pp.389-404 en tevens in: JB 1994, 110 , maakt het hof uit dat een orgaan alleen onafhankelijk is als het bindende beslissing kan nemen, die miet kunnen worden gewijzigd door een niet-rechterlijke autoriteit ten nadele wan de individuele procespartij. Gaat die voorwaa rde niet in verwulling. dan moet er een duidelijke wettelijke regel bestatan die voorschwijft dait als nog bij een andere rechter kam worden aangeklopt. R.J.G.M. Widdershoven en M.S.E. WulffraatVan Dijk, Bestursprocesrecht, in: NTB, nr.8, 1994, pp.281-294, i.h.b. p.283.

92. Te weten: a. het recht op woldoende informatie; $b$. het recht op voldoende tijd en faciliteiten; $c$. het recht om zich zelf te werdedigen of het recht op juridische bijstand; $d$. het recht om getuigen te (doen) ondervragen; e hat recht op een tolk; en f. het recht om ter terechtziting aanwezig te zijn.

93. Europees Verdrag tot bescherming wan de Rechten wan de Mens en de fundamentele wrihheden, 4 november 1950. Trbl. 1951, 154. Over art. 6 EVRM uitvoerig 0.2. A. den Hartog, Artikel 6 EVRM. grenzen aun het streven de straf eerder op de daad te doen volgem, Antwerpew/Apeldoorn, 1992; A.E. Harteveld., B.F. Keulen en H.G.M. Krabbe, Het EVRM en het Nederlandse strafprocesrech, Groningse strafrechtstudies 1, Groningen, 1992, pp.73-122; M.L.W.M. Viering, Het roepassingsgebied van art. 6 EVRM, diss. 耼UU, Zwolle/Utrecht, 1994, besproken door A. den Hartog, in: DD, nr.3, 1995, pP.251-261,

94. Deweer, EHRM 27 febr. 1980, Publ. ECHR 1980, series A, vol. 35; Örürk, EHRM 21 felbr. 1984, NJ 1988, 937; Lutz, EHRMI 25 aug. 1987, NJ 1988, 938; HR 3 mei 1989, NJ 1991, 167 ('minor offences' in eerste instantie bij bestuur, maar daarna moet beroep bij een rechter die voldoet aan de eisen wan art. 6 EVRM openstan); Denk ook aan i.h. b. sociale zekerheidsrecht-zaken als Feldbrugge, EHRM 20 mei 1986, NJ 1987, 432, Schouten en Meldrum vs. Nederland, in: J13, nr.2, 17 febr. 1995, pp.157-165 (inzake sociale verzekeringen), ook in: NJB, nr.17, 21 april 1995, pp.B217-B218 (rechtspraakbijlage mr. 15) en Salesi ws. Italie, EHRM 26 febr. 1993, A, 257-E, in: NJB, mr.5, 3 febr. 1995, bijlage rechtspraak nr. 10, pp.B63-1364 (inzake sociale bijstand).

95. Engel, Van der Wiel, De Wit, Dona en Schul, EHRM 23 juni 1976, Publ. ECHR, series A, vol. 22, nok in NJ 1978, 223 en 224 m.nt. D.H.M. Meuwissen; Campbell, EHRM 28 juni 1984, Publ. ECHR, series A, vol. 80; Weber, EHRM 22 mei 1990, Publ. ECHR, series A, vol. 177; Demicoli, EHRM 27 aug. 1991. Publ. ECHR, series A, vol. 210; Uhtwoerig over tuchtrecht en art. 6 EVRM M.M.C. Leijten, a.w., pp. 142-165. 
karakter van de overtreding. Ten derde, de aard en de zwaarte van de sanctie, die op het strafbaar feit is gesteld. De Straatsburgse instanties benadrukken beide laatst genoemde maatstiaven. Het eerste criterium is ondergeschikt. Het is immers onverschillig welk etiket, door een bepaalde nationale staat, op het te vervolgen delict is geplakt. De wijze waarop een nationale staat een bepaalde overtreding naar soort recht indeelt, is volgens het Hof niet beslissend voor toepasselijkheid van art. 6 EVRM. Oordeelt een nationale staat dat een bepaald vergrijp niet-strafrechtelijk is, dan kan daarentegen het EHRM dit delict juist wêl een strafrechtelijk, punitief karakter toekennen en daarmee art. 6 EVRM toepasselijk achten. Het tweede en het derde criterium lijken zo'n nadruk te krijgen, dat tegenwoordig, in afwijking van voornoemde vroegere rechtspraak, zowel de aard van de overtreding als de aard en zwaarte van de sanctie kennelijk cumulatief, in plaats van alternatief, worden vereist voor toepasselijkheid van art. 6 EVRM. ${ }^{96}$ Daarmee (via het arrest-Bendenoun - JGLVN) draait, bedoeld of onbedoeld, het EHRM weliswaar niet zelf de rechtsbeschermingsklok terug, maar mogelijk geschiedt dit in de toekomst wel door de mationale wetgever. ${ }^{97}$

Of de Nederlandse wetgever de ruime toepassing van art. 6 EVRM door het EHRM zal beperken, is nog toekomstmuziek. Overigens is nu al wel duidelijk dat niet elke Nederlandse réchter altijd bereid is tot toepassing van art. 6 EVRM.

Wat betreft de sanctieoplegging ex art. 27 WW door een bepaalde bedrijfsvereniging, te weten het - wegens fraude - blijvend geheel weigeren van een werkloosheidsuitkering aan betrokkene, doorbreekt de Centrale Raad van Beroep eigen stilzwijgen door de volgende uitspraak. ${ }^{9}$ De rechter concludeert dat in casu geen sprake is van een strafvervolging in de zin van art. 6 EVRM. ${ }^{99}$ Hierbij dienen de bekende Öztürk-criteria als toetstenen. De zwaarte van de WW-sanctie is volgens de rechter niet gelijk te stellen met die van de zwaarte van een straf op overtreding of misdrijf als gesteld in het WvSr. Het rechterlijk oordeel houdt, wat betreft de bepaling van de strafzwaarte, rekening met de

96. Aldus de mening van M.L.W.M. Viering, Het arrest Bendenoun. een stap terug?, in: NJB, nr.31, 9 sept. 1994, pp.1061-1063, over de belastingzaak Bendenonm vs. Frankrijk, EHRM 24 febr. 1994, series A, vol. 284, NJ 1994, 496 (bestuurlijke afdoening is toelaatbaar 'even if the surcharges imposed as a penalty are larges ones", kortom verwolging en bestraffing kunnen ook bij hoge boeten -in casu betreft het fiscale boeten- aan de administratie worden opgedragen). Auteur neemt het het hof kwalijk dat de stap teng niet duidelijk wordil gemotiveerd.

97. Aldus, anders dan Viering, de beter te accepteren opinie van A.R. Hartmann, P.M. wan Russen Groen, "Criminal charge" wigekleed?; Bendenoun gerelativeerd, in: NJB, nr.44, 9 dec. 1994, pp. 1520-1526, mel overwegend instemming van P. van Dijk, Bendenown binnen proporties, in: NHB, nr.44, 9 dec. 1994, pp.1526-1527, en gemuanceerd hun mening niet delend P.J. Wattel. Bendenown, boeten en belastingen, in: NJB, nr.44, 9 dec. 1994, pp. 1527-1528. Hartmann en Van Russen Groen zien overigens, wederom i.t.t. Viering, geen plaats voor culumlatieve werking van de criteria van art. 6 EVRM.

98. WW-sanctie en art. 6 EVRM, CRVB 21 dec. 1993, WW 1992, 252, in: NJB-rechtspraak, nr. 13, 1 april 1994, pp.162-163, in: AB/WW 1991, 203, en in: NJ 1994, 303, m.nt. WASD.

99. E.E.V. Lenos, Art. 6 EVRM, ne bis in idem en sanctiebesituiten in de sociale zekerheid, in: SR, nr.6. 1994, pp. 172-176. 
mogelijkheid van het einde van werkloosheid door werkhervatting. ${ }^{100}$ Daardoor verdwijnt feitelijk het effect van de sanctie.

Nadat de CRwB de reikwijdte van art. 6 EVRM aangaande strafkorting aldus aanzienlijk beperkt, trekt het CRvB de zelfde strakke lijn door wat betreft disciplinaire straffen gebaseerd op het ambtenarentuchtrecht. Het opleggen van dergelijke disciplinaire maalregelen merkt het $\mathrm{CRvB}$ niet aan als strafvervolging in de zin van art. 6 EVRM. ${ }^{101}$

Wat betreft sanctiebeleid van bedrijfswerenigingen wordt ook in ander opzicht gerefereerd aan art. 6 EVRM, in het bijzonder aan het daaruit voort vloeiende recht op een eerlijk proces. Het sanctiebeleid van de uitvoeringsorganen op het gebied van de sociale zekerheid, betreffende de uitvoering van de in 1992 ingevoerde bonus/malusregeling, blijkt de rechter een doorn in het oog. De bonus/malusregeling moet werkgevers stimuleren om (gedeeltelijk) arbeidsongeschikten in dienst te nemen of te houden. De malus - ex art. 59i AAW - is de "boete" die de werkgever krijgt opgelegd als hij een arbeidsongeschikt geraakte werknemer niet binnen een jaar aan passend werk helpt. Wanneer een werkgever een (gedeeltelijk) arbeidsongeschikte in dienst neemt, krijgt hij daarvoor een bonus. Medio 1994 bepaalt de president van de rechtbank te Assen, dat -in elf van de hem voorgelegde twaalf beroepszaken tegen bedrijfsverenigingen- de door de uitvoeringsorganen opgelegde WAO-boeten rechtens onaanvaardbaar zijn. De oplegging van de malus is niet aan te merken als een criminal charge in de zin van art. 6 EVRM, omdat geen sprake is van een reactie op een handelen of nalaten bestaande uit overtreding van een wettelijke norm van uit het oogmerk van handhaving van die norm en de regeling niet is gebaseerd op enig verwijt. ${ }^{102}$ Omdat betrokken bedrijfsverenigingen hebben geweigerd om de werkgevers inzage in medische dossiers van de werknemers te verschaffen, vernietigt de rechter de WAO-'boeten'. 103

Een andere uitspraak, van de president van de rechtbank te Amsterdam, volgt duidelijk de lijn van de de rechter in Assen. Opnieuw staat het recht op gelijke informatie van partij en wederpartij ex art. 6 EVRM centraal. In casu botst dit grondrecht met het grondrecht van art. 8 EVRM, $t$.w. het recht op privacy. Dit probleem is mogelijk te verhelpen, als de werknemers er in toe stemmen dat de werkgevers hun medische gegevens inzien of, anders, de werknemers het goed vinden dat zij opnieuw medisch worden onderzocht. De rechter stelt vast dat in het concrete geval geen sprake is van (het vragen

100. Hierover kritisch P. Hazewindus, WW-sanctie: gêên criminal charge!, in: NJB, nr.13, 1 april 1994, p.440, en Naschrift, in: NJB, nr.22, 3 juni 1994; Daarentegen ontkent $V$. Lenos, WW-sanctie tereckit geen criminal charge?, in: NJB, nr.22, 3 juni 1994, pp.751-753, dat de mogelijkheid van werkhervatting 's Hoge Raadis enuciale overweging is

101. CRvB 28 april 1994, TAR 1994, 143, ook gepubliceerd in: NJB-bijlage rechtspraak nr.27, p.383. Hat CRVB meent dat het ambtelijk tuchtrecht exclusief geldt binnen de bijzondere a rbeidsverhouding tussen ambtenat en openbat lichaam, terwijl de (reparatoire!) strafoplegging verzekering of herstel van een juiste en behoorlijke taakvervulling wan de ambtenat beoogt.

102. Rechtbank Assen 17 mei 1994, RSV 1994, 7, ook in: JB 1994, p.141 e.v.; Vgl. rechtbank Rotterdam, RSV 1994, 6.

103. Rechter mijst WAO-boetes werkgevers af; Kritiek op bedrijfsvereniging, in: NRC, 19 meil 1994, p. 1. 
om) toestemming. Daarom acht de rechter zich niet in staat de opgelegde WAO-'boeten" te toetsen op rechtmatigheid en vernietigt deze uiteindelijk. ${ }^{104}$

Hoewel volgens de voorzitter van de Sociale Verzekeringsraad op grond van eerdere jurisprudentie van de Hoge Raad de uitspraken van de rechtbankpresidenten geen stand kunnen houden, kondigt hij aan dat het toezichthoudend zbo Toezichtkamer van de Socialle Verzekeringsraad de uitwoering van de bonus/malusregeling gaat onderzoeken. ${ }^{105}$ Deze Toezichtkamer vindt in de rechtbankvonnissen aanleiding voor een noodmaatregel. De maatregel moet voorkomen dat een bedrijfsvereniging onnodig een geldelijke bijdrage int van een bedrijf, waar een werknemer arbeidsongeschikt is geworden. De maatregel stelt de bedrijfsvereniging in staat om zelf de termijn, waarbinnen een geldelijke bijdrage in de kosten van voortdurende arbeidsongeschiktheid van een werknemer moet worden geïnd, te bepalen. Daarin kan de bedrijfsvereniging de periode, die is gemoeid met een eventueel beroep van de werkgever bij de rechtbank, verdisconteren. ${ }^{106} \mathrm{Na}$ onderzoek neemt de Toezichtkamer het volgende standpunt in. Bedrijfsverenigingen mogen financiële lasten blijven opleggen. Slechts bij het instellen van beroep van een werkgever, die daartoe over krachtige inhoudelijke argumenten beschikt, kan een bedrijfsvereniging inning van geldelijke bijdragen uitstellen tot de Centrale Raad van Beroep uitspraak doet. ${ }^{107}$

Uiteindelijk doet de Centrale Raad van Beroep dan uitspraak. Inderdaad draait de raad zeventien aan werkgevers opgelegde WAO-'boeten" terug. De door de raad in hoger beroep gedane uitspraak houdt niet in dat de raad oplegging van malussen, welke oplegging de CRvB trouwens niet aanmerkt als 'criminal charge' maar wel als 'civil obligation' in de zin van art. 6 EVRM, helemaal verbiedt. De Centrale Raad voor Beroep vindt dat bedrijfsverenigingen wel financiële lasten kunnen opleggen, maar dat zij beslissingen tot malussen nauwkeuriger, d.w.z. deugdelijk en zorgvuldig per individueel geval, moeten motiveren. ${ }^{108}$ Een op het zaaksgeval toegesneden motivering stelt de rechter, in mogelijk geding, in staat om per geval te oordelen of en tot hoe ver het - tegenover het belang van de werkgever bij een eerlijk proces staande - belang van de bescherming van de persoonlijke levenssfeer van betrokken werknemer moet leilden tot uitsluiting of tot enige vorm wan beperkte kennisname als geregeld in art. 8:29 en art. 8:32 Awb.

In reactie op de uitspraak van de CRvB wenst een meerderheid van de Tweede Kamer (CDA, VVD en D'66) de WAO-'boeten' op korte termijn af te schaffen. ${ }^{109}$ Ook het Tijdelijke instituut voor Coördinatie en afstemming, dat de bedrijfsverenigingen weliswaar in elk geval adviseert de motivering van de beslissing tot oplegging van de malus uit te breiden, twijfelt er ernstig aan of een doelmatige uitvoering van de mallusregeling

104. Rechter acht boetes Wao onrechtmatig, in: NRC, 27 mei 1994, p.11.

105. Sudte vaar oplaggen WAO-boetes, in: NRC, 24 mei 1994, p.11.

106. Bedrijuen zoeken noodmaatreget woor WAO-boete, in: NRC. 14 juni 1994, p.20.

107. Werkgever blijf beboet voor WAO, in: NRC, 15 juli 1994, p.11.

108. Malusbeslissingew, CRvB 15 februari 1995, in: JB, nr. 3.10 malant 1995, pp .223-238 (rech ispraakbijlage nr.64), ook in: NJB, ar. 11, 17 mart 1995, rechtspraakbijlage nr.5, pp.B137-B139. Hierover G. I. Heerma wan Voss, De Centrale Raad over de halusregeling. wie neemt wie in de maling?, in: NJB, nr. 11,17 maart 1995, pp.413-414.

109. Kamer wil sinel of wan WAO-baetes, in: NRC, 16 febr. 1995, p.17. 
Toepassing van sancties

ooit mogelijk is. ${ }^{110}$ Eind april 1995 komt het kabinet dan ook terecht de Tweede Kamer tegemoet door bij klinkende hamerslag te besluiten tot afschaffing van de malusregeling per 1 juli 1995. ${ }^{111}$

110. Vraagrekens bij doelmatige uitwoering malusregeling, in: NJB, nr. 13, 31 maant 1995, p.509. 


\section{Geraadpleegde literatuur}

Addink, G.H. \& Sluis, M.J.

- De Awb op scherp; Kanttekeningen bij het hoofdstuk handhaving, in: NTB, nr.2, 1992, pp.3345;

- Het viffle hoofdstuk van de Awb: handhaving in materieel perspectief, in: $\mathbb{N J B}$, nr.35, 7 oktober 1994 , pp.1201-1208.

Bandringa, I.F., Benetreu, E.L., Ham, A.B.J. van der \& Sluijs, M.J.

Bestuurlijke boeten in de sociale zekerheid; Kanttekeningen bij een omslag, in: Sociaal Recht, nr.1, 1995, pp.10-14.

Bleeker, K.A.M.

Verantwoorde communautaire sanctionering van het gemeenschapsrecht?, in: NJB, nr.28, 5 augustus 1993, pp.1009-1013.

Borman, C.

Aanwijzingen voor de regelgeving en andere voor de regelgeving relevante aanwijzingen, $\mathrm{Z}$ wolle, 1993.

Brand-Koolen, M.J.M., Kuyper, I.R.H., e.a.

Strafrecht en rechtshandhaving, Telderstichting geschrift nr.67, "s-Gravenhage, 1988.

Buruma, $Y$.

De strafrechtelijke handhaving wan bestuurswetten, dissertatie RL, Amsterdam, 1993.

Bijloos, A.W.M.

Administratieve boete en art.6 EVRM in Nederland, preadvies VVSR, Zwolle, 1989.

Conmissariaat voor de Media

Sanctieregeling omroep 1993, in: Stcrt. 24 september $\mathbb{1 9 9 3 .}$

Doelder, $H$. de

Terrein en beginselen van tuchtrecht, Alphen aan de Rijn/Brussel, dissertatie EUR, 1981.

Doorenbos, D.R.

Financieel strafrecht: een studie inzake strafrechtelijk gesanctioneerde woorschriften wit de banken effectenwetgeving, dissertatie KUN, serie monografieën Van der Heijden-instituut Nijmegen deel 40. Deverter, 1992, pp.7-22.

Duk, W.

- Maatstaven voor beoordeling van sancties, in: AA, nr.5, 1981, pp.231-237;

- Handhaving wan bestuursrecht; Capitula selecta, in: NTB, nr-4, 1988, pp.105-110.

Dijk, $\mathbf{P}$. van

Bendenoun binnen proporties, in: NJB, nr.44, 9 december 1994, pp.1526-1527.

Goorden, C.P.J.

Handhawing onder regime van de Algemene wet bestuursrecht, in: De Gemeentestem, nr.6959, 12 februari $1993, \mathrm{pp} .57-66$.

Harteveld, A.E., Keulen, B.F. \& Krabbe, H.G.M.

Het EVRM en het Nederlandse strafprocesrecht, Groningse strafrechtstudies 1, Groningen, 1992, pp. $73-122$.

Hartmann, A.R. \& Van Russen Groen, P.M.

"Criminal charge" uitgekleed? Bendenoun gerelativeerd, in: NJB, nr.44, 9 december 1994, pp. $1520-1526$.

Hartog, A. den

- Artikel 6 EVRM: grenzen aan het streven de straf eerder op de daad te doen volgen, Apeldoorn, 1992;

- Recensie dissertatie M.L.W.M. Viering, in: DD, nr.3, 1995, pp.251-261.

Hazewindus, W.G.A. 
- De administratieve dwangsom; Een situatieve en een punitieve dwangsom, in: NJB, nr.33, 24 september 1992, pp.1068-1072;

- Administratieve sancties en het vreemdelingenrecht, dissertatie UvA, 14 april 1994. Arnhem, 1994;

- WW-sanctie: géén criminal charge, in: NJB, 1 april 1994, zie ook Naschrift, in: NJB, nr.5, 3 juni 1994, p.753.

Hazewindus, W.G.A. \& Jansen, O.J.D.M.L. (red.)

Van boeteatelier tot boetefabriek; Bijdragen van het op 24 november 1994 te Amsterdam gehouden wetenschappelijk congres over de bestuurlijke boete, Deventer, 1995.

Hellingman, K. \& Mortelmans, K.J.M.

Economisch publiekrecht; Rechtswaarborgen en rechtsinstrumenten, Deventer, 1989, pp.232286.

Huizen, Ph.H.J.G. van

Versterking van de toezichtsbevoegdheid van de Verzekeringskamer, in: Het Verzekeringsarchief, dl. LXVII, 1990, pp.3-18.

Jong, J.P. de

Sanctiebepalingen in de sociale zekerheidswetgeving, in: NTB, nr.10, 1994, pp.326-327.

Kleijs-Wijnnobel, C.J.

$\sim$ Bestuurs- en strafsancties; Een lat-relatie, in: C.P.J. Goorden, Kroniek van het bestuursrecht 1987-1992, Zwolle, 1993, pp.37-54;

- Kronieken: sancties, in: NTB, respectievelijk nr.3, 1993, pp.128-133, nr.4, 1993, pp.134141 , en nr.8/9, 1993, pp.290-298;

$\sim$ Kronieken: handhaving van bestuursrecht, in: NTB, nr.8, 1994, pp.273-280.

Koeman, N.S.J.

Handhaving, in: Konijnenbelt, W. (red.), Commentaar op het voorontwerp voor de derde tranche van de Awb, Alphen a/d Rijn, 1992, pp.103- \10.

Kuyper, J.R.H. e.a.

Strafrecht en rechtshandhaving, Telderstichting geschrift nr.67, 's-Gravenhage, 1988.

Langbroek, P.M., Wulffraat-van Dijk, M.S.E., Hagelstein, G.H., Spelt, N.M., Addink, G.H., Sluijs, M.J.

Bouwen aan de Awb; Het woorontwerp derde tranche verkend, in: NJB, nr.15, 9 april 1992 , pp. $473-477$.

Lenos, $\mathrm{V}$.

WW-sanctie terecht geen criminal charge?, in: NJB, nr.22, 3 juni 1994, pp.751-753.

Leijten, M.J.C.

- Tuchtrecht getoetst; Een onderzoek naar de betekenis van grondrechten voor de wettelijke regeling van tuchtrecht en van de tuchtprocedure, dissertatie KUB, Gouda/Arnhem, 1991;

- Samenloop van sancties bezien vanuit het wettelijk geregelde tuchtrecht, in: $\mathbb{N J B}$, nr.41, 19 november 1992, pp.1387-1394.

Michiels, F.C.M.A.

De boete in opmars?, oratie VU, Zwolle, 1994.

Mulder, A.

- Geldboete, een eigen middel wan de Europese Gemeenschappen, in: SEW, nr.6, juni 1989. pp.459-478;

- De bestuurlijke boete als middel tot bestrijding van economische delicten, in: SEW, nr.4, 1994, pp.219-235.

Moor-Van Vugt, A.J.C. de

- Kronieken: Europees bestuursrecht, in: NTB, nr.5, 1992, pp.173-182;

- Symbiose van evenredigheidstoetsen?, in: NTB, nr.1, 1993, pp.26-37. 
Nicolaï, P., Olivier, B.K., Damen, L.J.A. \& Troostwijk, H.

Bestuursrecht, derde herziene druk, Amsterdam, 1992.

Raad voor het binnenlands bestuur

Advies aan de ministers Hirsch Ballin en Dales over her voorontwerp van de derde tranche Awb, mei 1992, "s-Gravenhage.

Raat, I.Y. de

De bestuurlijke boete in het milieurecht, in: AA, nr.6, 1993, pp.443-450.

Rikmenspoel, M.J.H.T.

- De bestuursrechtelijke boete: traditie, trend en toekomst, in: De Gemeentestem, 1994, nr.6990, pp.321-325;

$\sim$ Boe(te)l, in: NJB, mr.42, 25 november 1994, pp.1456-1457.

Rogier, L.J.J.

Strafsancties, administratieve sancties en het una via-beginsel, Arnhem, 1992.

Rogier, L. \& Hartmann, A.

Verschillen en overeenkomsten tussen strafrechten bestuursrecht, in: DD, nr. 10, 1993, pp.10421058.

Rood, E.

Overzicht EEG- en Nederlands levensmiddelenbeleid en -recht: inhoud, organisatie, tenuitvoerlegging, handhaving, Apeldoorn/Arnhem, 1993, pp.180-185.

Roording, $J$.

Naar een geintegreerd sanctierecht, in: AA, nr.1, 1995, pp.82-85.

Sackers, H.J.B.

Strafrecht en bestuursrecht, twee geloven op een kussen?, in: H.Ph.J.A.M. Hennekens e.a., Bestuursrechtaan de horizon; Opstellen over materieel strafrecht t.g. $\nu$. de tachtigste verjaardag van professior mr S.F.L. baron van Wimbergen, Zwolle, 1994, pp.101-121.

Sluijs, M.J.

$\sim$ Administratieve sancties in een strafrechtelijke context, in: NJB, nr.16,23 april 1988, pp.522528;

- De bestuurlijke boete: naar nieuwe grenzen, in: Bestuurswetenschappen, nr.6, 1991, pp.420434;

- Lastige bestuurssancties, in: De Gemeentestem, nr.6984, 1 april 1994, pp.141-149.

Snijder, H.J., Fijnaut, C., Maarseveen, H.Th.J.F. van \& Zwitser, R.

Overheidsrechtergepasseerd; Conflictbeslechting buitende overheidsrechterom, Arnhem, 1988, pp. $181-196 / 313-320$.

Stichting Nationale en Internationale Wegvervoer Organisatie Jaarverslag 1992, Rijswijk.

Tweede Kamer

- Wijziging van de wegenverkeerswet 1992, houdende regeling van de verzelfstandiging van de Rijksdienst voor het Weguerkeer, TK 1992-1993, 22961, nrs.1-2;

- Flora-en faunawet, wetsvoorstel, TK 1992-1993, 23147, nr.3;

- Wetsvoorstel inzake opneming in de Wtk, Wtv, Wtb en Wte van bepalingen betreffende de informatieuitwisseling tussen Nederlandse en buitenlandse instanties die belast zijn met het toezicht op financiele markten of op natuurlike personen en rechtspersonen die op die markten werkzaam zijn. TK 1992-1993/1993-1994, 23170, nr.1-11/268;

- Voorstel van wet tot vervanging Wtu door de Wtw 1993, TK 1992-1993, 23199, nrs. 1-2;

- Jaarverslag/begroting Toetsingscommissie voor wetgevingsprojecten, TK 1993-1994, 23400 VI, nrs.5/49, zie ook Kabinetsstandpunt over advies wan de CTW inzake bestuurlijke boeten, TK 1993-1994, 23400 VI, nr.48;

-Begroting 1994, TK 1993-1994, 23400 VI, nr.2, pp.15/22-23; 
- Wetsvoorstel derde tranche Awb, TK 1993-1994, 23700, nrs.1-3.

- Wetsvoorstel tot wijziging van de sociale zekerheidswetten $i$. v.m. de nadere vaststelling van een stelsel van administratieve sancties, als ook tot wijziging van de daarin vervatte regels tot terugvordering van ten onvechte betaalde witkeringen en de invorderingdaarvan, TK 1994-1995, 23909, nrs. 1-3.

Vervaele, J.A.E.

Handen en tanden van het (gemeenschaps)recht, oratie RUU, 18 februari 1994, Deventer, 1994. Verwaele, J.A.E. (red.)

Bestuursrechtelije toepassing en handhaving van gemeenschapsrecht in Nederland, Europese monografieën, Deventer, 1993.

Vervaete, J.A.E. \& Widdershoven, R.J.G.M.

Bestuurlijke handhaving van visserijregelgeving; Een studie naar de relatie tussen EEG-recht en nationale handhaving, Utrecht, 1991;

Viering, M.L.W.M.

- Het toepassingsgebied wan artikel 6 EVRM, dissertatie RUU, Zwolle/Utrecht, 1994;

- Het arrest Bendenoun: een stap terug?, in: NJB, nr.31, 9 september 1994, pp.1061-1063.

Wattel, P.J.

Bendenoun, boeten en belastingen, in: NJB, nr.44, 9 december 1994, pp.1527-1529.

Widdershowen, R.J.G.M.

Gemeenschapsrecht bestuursrechtelijk gehandhaafd, in: NTB, nr.1, 1993, pp.47-59.

Wladimiroff, W.

Niets bijzonders; Een beschouwing over de dominantie van het bijzonder strafrecht bij de handhaving van sociaal-economische normen, oratie RUU, 15 februari 1989, Deventer, 1989. 


\section{Communautaire rechtshandhaving}

\section{$\$ 13.0$ Communautaire rechtshandhaving}

De invloed van art. 6 EVRM op Nederlands recht is al duidelijk. Meer in het algemeen is de dynamiek van het Europees recht, voor de verschillende soorten nationale rechtshandhavingssytemen, niet te veronachtzamen. Weliswaar ontbreken in met name Europese verordeningen nog vaak voorschriften inzake handhaving en voorschriften waarin de nationale instanties die met de uitvoering en toepassing van een verordening worden belast zijn aangewezen, zo dat de nationale wetgever daarin bij gebrek aan beter moet voorzien. ' Bij uitoefening van hun controle-, opsporings- en sanctiebevoegdheden hebben \idstaten toch rekening te houden met bij voorbeeld beginselen van gemeenschapsrecht, sanctietoepassing door de Europese Commissie en het optreden van Euro-controleurs.

Het belang van deze Europese dimensie voor het Nederlandse wetgevings- en handhavingsbeleid is serieus te nemen. De Europese impuls komt van uit de Europese Gemeenschappen. De Europese Gemeenschappen zijn van oudsher: de Europese Gemeenschap voor Kolen en Staal; de Europese Gemeenschap voor Atoomenergie; en de Europese Economische Gemeenschap. Vooral de Europese Economische Gemeenschap is relevant. Overigens bepaalt het, per 1 november 1993 in werking zijnde, Verdrag van Maastricht ${ }^{2}$, dat het Verdrag tot oprichting van Europese Economische Gemeenschap ${ }^{3}$ voortaan het Verdrag tot oprichting van de Europese Gemeenschap heet. ${ }^{4}$ Het Verdrag van

1. J. Bonnes, Uitoering van EG-verordeningen in Nederland, diss. KUB, Zwolle, 1994, pp.56/126- 28 . Auteur geeft aan dat de relatiewe wrijheid van nationale staten, om uitvoerings- en handhavingsinstanties aan te wijzen, grenzen kent: instanties moeten capabel zijn om EG-regelgeving volledig en effectief toe te passen; het handielen wan dergelijke instanties moet worden gecoördineerd; en instanties moetten voldoen aan van uit de EG daarvoor gestelde werkwijze- en inrichtingseisen.

2. Verdrag van Maastricht betreffende de Europese Unie met protocollen. 7 febr. 1992, Tibl. 1992, 74.

3. Verdrag tot opriching van de Europesche Ecomomische Gemeenschap, Rome, 25 maart 1957, Trbl. 1957, 91. Zie de Nederlandse wertaling, in de -bij Europese akte d.d. 17/28 febr. 1986, Pub1. 1987, 169-gewijzigde worm..

4. In gewolge art. $G_{m}$ sub a, Verdrag van Maastricht, verander de aanduiding Europese Economische Gemeenschap in Europese Gemeenschap. 
Maastricht wijzigt het oude EEG-verdrag in bellangrijke mate. Meest opvallende uitvloeisel van het verdrag van Maastricht is het vernieuwende voorstell een Europese Unie ${ }^{5}$ op te richten. Deze Unie is, ex art. A VvM, gegrond op de Europese Gemeenschappen, aangevuld met het beleid en de samenwerkingsvormen die bij het VwM worden ingesteld. De Unie heeft de opdracht orm de betrekkingen tussen de lidstaten en tussen de volkeren van de lidstaten samenhangend en solidair te organiseren.

Geconfronteerd met een enerverende Europeanisering, neemt de toetsingscommissie voor wetgevingsprojecten de gevolgen van de Europese integratie voor de Nederlandse rechtsorde ter hand. Belangrijke onderwerpen van deelonderzoek voor de commissie zijn: a. de (tijdige en juiste) implementatie van 'horizontale' EG-richtijnen ${ }^{67}$; b. de kwalliteit van EG-regelgeving; en $c_{\text {. }}$ het toezicht op de naleving van EG-regelgeving ${ }^{8} .9$

5. Hoewel de tern Europese Unie reeds gangbaar is (zie o.a. de door minister-president Lubbers opgestellde richtlijnen inzake terminologie Europese Unie d.d. 20 juli 1994, Stcrt. 1994, 148), gaat in het hierma volgende nog voorkeur uit naar het overkoepelende EG-begrip. Dit begrip wordt namelijk nog veel gehanteerd in, in volgende hoofdstukken vermelde, Europese regelgeving van oudere datum. Het EG-begrip verwijst nazr zowel Europese Gemeenschap alls Europese Unie.

6. Hierover C.H. van Marle en T.A.H. de Nijs, Europees rech en Nederlandse decentrale overheden, VNO, 's-Grav. 1991; J.H. Hoogteijling, Nederland en de EG: knetpunten en oplossingen, in: OB, nr. 12, 1993, pp. 13-19.

7. Met scherpe pen aver implementatie, in het licht van de CTW-adwiezen (m.n. Implemenatie van EG regelgewing in de nationale rechtsorde: witvoring van EG-richlijhen, CTW 90/22, TK 1990-1991, 21 109), interessamt H.H. Maas en J.C. van Haersolte, Tydige witvoering van EG-regelgeving in Nederiand door middel van wetgeving, in: SEW, nr. 11, 1994, $\mathrm{pp}_{\mathrm{n}} 703-726$. M.b.t. tot de rol van decentralle overheden bij implementatie (conform correcte opinie auteurs is dat: het in overeenstemming brengen van nationale regelgeving met EG-regelgeving, als mede her omzetten wan EG-regelgeving in nationaal recht en loet creëren van structuren voor toepassing en handhaving dararvan; vgl, trouwens aanwijzing voor de regelgeving 328 -zie ook art. 1:7 Awb- dat onder implenentatie verstaat: "de uitvoering van een bindend bestuit wan de Rad of de Commissie van de $\mathrm{EG}$ in het nationale recht d.m. . het waststellen van algemeen verbin dende voorschriften") achten auteurs het "onduidelijk hoe territoriaal gedecentraliseerde overheden ingeschakeld zouden moeten worden om de achterstand in implementatie weg te werken" . Wel menen auteurs terecht dat, "voor bepaalde onderwerpen, een relatief klein aantal EG-richtijnen wordlt omgezet door functioneel gedecentraliseerde overheden" (p.724). Wat betreft toezichthoudende zbo $s$ valt hierbij te denken aan bij voorbeeld de Stichting Toezicht Effectenverkeer waatain o.m. regelgevende bevoegdheden zijn gedelegeerd. Volgens anwijzing voor de regelgeving 339 is het zo dat "bij de afweging op welk niveau van regeling de implementatie dient plaats te vinden delegatie van regelgevende bewoegdheid eerder in aanmerking kont natmate: a. het te implementeren besluit de Nederlandse wetgever bij de uityoering minder ruimte lat voor het maken van keuzen van beleidsinhoudelijke aard; $b$. het te implementerien besllut gedetailleerder wan aard is; c. de tenmijn waabinnen volgens het te implemerteren besluit de implementatie moet geschieden korter is; $d$. vaker verwacht mag worden dat in dle toekomst het te implementeren beshuit wijzigingen zal ondergaan; $e$. in het bestaande systeem van regelgeving waarin de implementatieregeling een plaats zal krijgen, waker is gekozen voor delegatie van regelgevende bevoegdheden. "; Overigens is het niet zo dat implementatie altajd via de, waak omslachtige, officiële weg van nationale wet- en negelgeving wordt omgezet (hoewel gedelegeerd wetgeven via avv-door bij voorbeeld de STEnatuurlijk al sneller kan). P.J. van der Flier en J.S. van den Oosterkamp, Voortvarende implementarie van EGrichrlijnen, mede in het licht van de Awb en de Aanwijatigen voor de regelgeving. in: SEW, nr. 11 , 1994, pp.727-752, i.h.b. p.741, verdedigen aannemelijk dat ïmplementatie van een EG-richtlijn via. convenant mogelijk is als de omzetting "permanent, bindend en doorzichtig" geschiedt, ook "ndien die richtijn de mogelijkheid daartoe niet opent. Aldus verloopt implementatie wlotter. 
Helaas verloopt de integratie nog niet naar wens. De "Europese integratie lijkt op een papieren tijger zonder tanden", waarbij het de nationale overheidsorganen in de regel zijn die "niet alleen de handen en voeten, maar tevens de tanden van het gemeenschapsrecht" vormen. ${ }^{10}$ Een te grote vrijheid van nationale staten bij communautaire rechtshandhaving en een te beperkte invloed ter zake van verkokerde Europese overheden leveren een complexe gemeenschappelijke rechtsorde op die vrij wel voortdurend conflicteert met het ideaal concept van een "geüntegreerd handhavingsbeleid" ", d.w.z. "het ontwikkelen wan proactieve en reactieve handhavingsstrategieën met aandacht woor alle factoren (regelgeving, handhavingsorganisatie, handhavingsinstrumenten) en actoren (toezichtsen opsporingsorganen, rechters)". ${ }^{12}$ Hierbij richt een proactieve handhavingsaanpak zich op het "beïnvloeden van de condities waaronder regelovertreding ontstaat en handhaving plaatsvindt", hetgeen gestimuleerd kan worden door formalisering van sociale controle en eigen verantwoordelijkheden middels convenanten, zelfregulering, bedrijfsinterne milieuzorgsystemen of versterking van uitvoeringsnetwerken. ${ }^{13}$ En in een reactieve strategie staat niet zo zeer het proces van handhaving, maar het resultaat daarvan centraal. Een reactieve aanpak weronderstelt dat sanctionering, door haar afschrikwekkend karakter, het handhavingsresultaat beïnvloedt. ${ }^{\text {14 }}$

Om een deugdelijk niveau van Europese integratie te bereiken luidt het voorstel "nationale handhavingsbepalingen, waar nodig, te harmoniseren en dit aan te vullen met samenwerkingsvoorzieningen tussen de lidstaten onderling en tussen de lidstaten en de Europese Commissie". ${ }^{15} 16$

\section{7. $\rightarrow$}

Auteurs noemen, naast convenanten, als alternatieven voor implementatie: cao ${ }^{\circ}$ s, beleid sregels, zelfregulering (bij voorbeeld regelgeving door de Vereniging voor: Effecterlhandel); In voomoemd kader ook interessant Wetsvoorstel tot versnelling van de implementatie van EG-richtlijnen, TK 1991-1992, 22690, nrs. I-3.

8. Uitgebreid I.A.E. Vervaele (red.), Beshurstechtelijke toepassing en handhaving van gemeensichapsrech in Nederland, Europese monografieën nr. 41, Deventer, 1993; M.b.t. het toezicht op de nalewing van EGrecht werwachten H.H. Maas en J.C. van Haersholte (1994), t.a.p., p.718, meer dan van de "vele gremia die er wel iets mee te maken bebben" heil van een "centrale instantie die systematisch, zowel formeel als inhoudelijk, toezicht houdt op de uitvoering, wan EG-regelgeving".

9. Toetsingsommissie wetgeving, Jaarverslag 1992, TK 1993-1994, 23400 VI, nr.5; Zie ook Vaststelling justitiebegroting 1994, TK 1993-1994, 23400 VI, nr.49, pp.7-9. i.h. b. CTW-advies inzake implementatie, nr. $93 / 13$.

10. J.A.E. Vervaele, Handen en tanden wan her (gemeenschaps)recht, oratie RUU, 18 febr. 1994, Deventer, 1994, pp. 26-27.

11. Ower het terrein, waar deze aanpak zich voor het eerst doet gevoelen, te weten de wisserijsector, interessant A.J. Berg, Herziening Visserijcontrolebeleid: naar een Europees Handhawingssysteem?, in: SEW, nr. 12,1994, pp. $800-818$.

12. J.A.E. Vervaele, Handen en tanden van het (gemeenschaps)recht, a.w., pp.28/9.

13. A. Vos, P.P.J. Driesen en P. Glasbergen, Handhaving in overweging; Strategische afwegingen bij de handhaving van milieuwetgeving, uitgave Stichting Maatschappij en Politie, Arnhem, maart 1993, pp. 12/19/25-27/66-69.

14. A. Vos, P.P.I. Driesen en P. Glasbergen ${ }_{n}$ a.w., pp. 19/25-26.

15. J.A.E. Vervaele, Handen en tanden wan het (gemeenschaps)recht, a.w., p.36. 
In elk geval dient het toezicht op de naleving van nationale wet-en regelgeving te worden uitgeoefend met inachtneming van de in gemeenschapsrecht neergelegde voorwaarden als mede de door het Europese Hof van Justitie ontwikkelde jurisprudentie aangaande rechtshandhaving. it

\subsection{Gemeenschapstrouw}

In gevolge art. $5^{18}$ juncto art. $169^{19} \mathrm{E}(\mathrm{E}) \mathrm{G}$-verdrag ligt ook op Nederland, als verdragsiddstaat, de juridische plicht om middels algemene of bijzondere maatregelen uitvoering en naleving van gemeenschapsrecht, conform (verdrags)doelstelling, te realiseren, 2

Deze uitwoeringsplicht rust op Nederland, als lidstaat, in al zijn geledingen. In het bijzonder waar het taakuitoefening door zelfstandige bestuursorganen betreft, geldt het volgende. Ook functioneel gedecentraliseerde zelfstandige bestuursorganen met publiekrechtehijke bevoegdheden moeten de verplichtingen van gemeenschapsrecht naleven. In ellk geval op grond van de, wettelijk vastgelegde, ministeriële politieke verantwoordelijkheid voor het handelen of nalaten van zelfstandige bestuursorganen, kan de centrale overheid worden aangesproken op de door betrokken orgaan van functioneel bestuur onvoldoende of onjuiste invulling van EG-verdragsrecht. Bij informatieverzoeken van de Europese Commissie of het Europese Hof van Justitie verschaft de Nederlandse rijksoverheid de nodige gegevens en inlichtingen inzake de gedragingen van het zelfstandig bestuursorgaan.

16. D. van der Landen, Natur een GeUNIEficeerd strafrecht?, in: DD, nr.9. 1994, pp.921-939, bepleit -in het kader wan een effectievere rechtshandhaving op Furopees niwean- harmonisatie van strafprocesrecht met respect woor de natiomale soevereiniteit op strafrechtelijk gebied. Daarbij windt auteur goede aanknopingspunten in het subsidiariteitsizeginsel.

17. Daarover Notitie over verhouding tussen het gemeenschapsrechr en het strafrecht. TK 199141992, 22300. VI, $\operatorname{ar}, 39$.

18. H.G. de Jong, Vitwoering van EG-beleid door decentrale overheden, in: BK, nr.4, 1.993, pp .209-215, laat zien dat dit verdragsartikel ook consequenties heeft voor i.h.b. decentrale overheden; Zie ook 0 . Dure Art. 5 EEG verdrag; een bepaling met een federaal karakter, in: SEW, nr.5, 1992, pp.355-366. Volgens auteur stijgt het belang van art. 5 ver uit boven dat van het 'pacta sunt servanda' -beginsel in het volkerenrecht.

19. Deze sanctiebepaling (op niet-nalewing van art. 5 EEG-verdrag) vindt nauwelijks toepassing wegens tekort aan menskracht en sanctiemogelijkheden vari de Europese Commissie. Zie H.R.B.M. Kummeling en J B. Mus, De invloed van het gemeenschapsrecht op de nationale rechisorde, in: M.C. Burkens en H.R.B.M. Kummeling (red.) e.a., EG en grondrechten; Gevolgen van de Europese integratie voor de nationale grondrechtentescherming, Zwolle, 1993, pp. 1-33, i.h.b. p.31.

20. Met referentie aan het arrest Von Munster, HuJ EG (C-165/91), 5 okt. 1994, leidt S. Prechal, Kroniek wan het Europees recht, in: NJB, nr. 10, 10 maart 1995, pp.364-370, i.h.b. p.366, uit art. 5 E(E)G-verdrag, naast de samenwerkingsverplichting, de verplichting af tot gemeenschapsrecht conforme toepassing van het nationale recht door zowel uitwoeringsinstanties als de nationale rechter af. Auteur breidt zo het leerstuk van richtlijn conforme vitleg (zie paragraaf 13.3) interessant vit tot algemeen gemeenschapsrecht conforme interpretatie. 
Aan vermelde uitvoeringsplicht kan een lidstaat zelf of in samenwerking met andere lidstaten voldoen. In toenemende gevallen móet een lidstaat de samenwerking met andere landen in de EG zoeken. Hoewel de uitwoering van gemeenschapsrecht in de verschillende lidstaten kan verschillen, dwingt art. $5 \mathrm{E}(\mathrm{E}) \mathrm{G}$-verdrag er toe om elkanders (weliswaar gelijkwaardige) uitwerking van gemeenschapsrecht te respecteren. Art. $5 \mathrm{E}(\mathrm{E}) \mathrm{G}$ verdrag beveelt de lidstaten, in bepaalde situaties, om bij voorbeeld elkaars vergunningenstelsel of elkaars controlesysteem wederzijds te erkennen ${ }^{21}$. Art. 5 E(E)G-verdrag strekt zo tot een algemene samenwerkingsplicht ${ }^{22} .{ }^{23}$

Met oog op een goede uitwerking van zo'n samenwerkingsplicht is het nodig dat handhavende entiteiten in een lidstaat zorg dragen voor efficiënte onderlinge (afstemmings) contacten. Daarnaast moeten zij samenspraak met handhavende entiteiten in andere lidstaten hebben. Tevens houden zij een communicatielijn met de Europese Commissie open. Zij houden zowel de andere lidstaten als de Europese Commissie op de hoogte van hun doen en laten. Ze informeren frequent over controlemaatregelen en -procedures en stellen bij voorkeur een meldpunt aan, waar zowel de andere lidstaten als de commissie vragen kunnen deponeren.

Aan genoemde samenwerkingsplicht wordt met succes geappelleerd voor een Nederlandse rechter in de volgende kwestie. ${ }^{24}$ De zaak betreft de import van een bestrijdingsmiddel van Frankrijk, waar het reeds is toegelaten, naar Nederland. Het verzoek om produkttoelating in Nederland wordt afgewezen, omdat op het aanvraagformulier - voor toelating relevante - (wetenschappelijke, technische en chemische) gegevens ontbreken. De Nederlandse toelatingsautoriteit draagt betrokkene op om de benodigde aanvullende informatie zelf op te vragen bij de tot toelating bevoegde Franse instantie. Deze passieve houding vindt weinig waardering bij de Nederlandse rechter. Weliswaar onder de erkenning, dat lidstaten moeten bijdragen aan verlichting van controles in het intracommunautaire

21. Over wederzijdse erkeuning, distorsie van mededingingsvoorwaarden (d.w.z. martkaandeel wordt niet bepaald door prestatieconcurrentie, maar door -van wege de owerheid uit protectionistische owerwegingen opgelegde-lasten die in verschillende mate drukken op ondernemingen) en de Cassis-de-Dijon-regel, die alle drie vergelijkbare procedurele eisen en bewijsregels kennen wat betreft afzetverboden en -controles, interessant B. van der $\mathbb{E}$ sch, De voltooing van de interne markt voor goederen en diensten volgens art. \$A EEG whet Witboek wan $1985_{\text {. }}$ mkele juridische kanttekeningen, in: SEW, nr.9, sept. 1994, pp. 559. 578. Auteur constateert dat, zo lang sprake is van gedeeltelijke of onvolledige harmonisatie, nuimte is voor uiteenlopend gebruik van nationale bevoegdheden waardoor dispariteiten, indien gerechtvaardigd o.g.v. artc. $30-36,52$ en 59 E(E)G-verdrag. mogelijk blijven. Vraag is of dexe verschillen dubbele (lidstagt-interne) controles rechtvaardigen (in afwachring van het harmonisatie) of dat de jurisprudentie van het HVI EG inzake wederzijose erkenning toepasselijk is. Auteur laat aan de hand van woorbeelden in o.a. de banksector en de levensmiddelensector zien dat het gemeenschapsrecht nog niet ultiem (gevordend) is.

22. Frans-Nederlandse Mautschappij voor Biologische produkten bv, HWJ EG (272/80) 17 dec. 1981, Iur. $1981_{\text {"p. }}$. 3277.

23. De invulling van samenwerking kan verschillende vormen aan nemen. Te dienken is aan het wederzijds erkeninen van elkaars vergunning- en toezichtssystemen, aan het onderling uitwisselen van informatie en misschien ook aan het over en weer wragen watn advies. Bij de toenemende mogelijkheid van gegevensuit:wisseling gelden geheimhoudingsplichten.

24. Chemische fabriek Brabant $J$. W. Voorbrak bu te Oosterhout ws. staatssiecretaris $L N V$, CBB 13 november 1992, 91/2548/060/029, geannoteerd door H.A.G. Temmink, in: SEW, nr.6, 1992, pp.450 456. 
verkeer, vindt de rechter het juist de taak van de Nederlandse toelatingsautoriteit zelf om, in het kader van de (administratieve) samenwerkingsplicht tussen lidstaten waar weer wederzijdse informatieplichten uit voort vloeien, op actieve wijze bedoelde informatie in te winnen bij het betrokken Franse gezag. Volgens het rechterlijk oordeel levert de houding van het Nederlandse overheidsorgaan "een handelwijze op, die een beperkende werking op de import van bestrijdingsmiddelen uit andere lidstaten heeft of kan hebben. Art. $36 \mathrm{E}(\mathbb{E}) \mathrm{G}-$ verdrag kan niet worden ingeroepen ter rechtvaardiging van een handelwijze, waaryan de beperkende elementen hun oorzak vinden in de zorg de belasting van de administratie te verminderen, tenzij, i.c., het richten van een verzaek als hiervoor bedoeld aan de Franse autoriteiten duidelijk de grenzen zou overschrijden van wat in redelijkheid kan worden verlangd. " 25 26

De (zowel positieve als negatieve) uitwoeringsplicht, die is neergellegd in art. $5 \mathrm{E}(\mathrm{E}) \mathrm{G}-$ verdrag, impliceert een handhavingsplicht. ${ }^{27}$ De nationale staten genieten, wat betreft invulling van hun handhavingsplicht, een relatieve vrijheid die past binnen Europese kaders.

Die vrijheid is bij voorbeeld gegeven daar waar lidstaten (op overtredingen van gemeenschapsrecht) - naar hun oordeel gebruikelijke - sancties mogen stellen, terwijl hiertoe geen specifieke bepaling bestaat. ${ }^{28}$

Die vrijheid wordt ten dele weer terug genomen als bepaalde beginselen van handhaving aan de lidstaten worden opgelegd. De handhavingsverplichting is namelijk niet alleen instrumenteel, maar ook "normatief doelgebonden". ${ }^{29}$ Bekende jurisprudentie leert, over door lidstaten te nemen passende maatregelen ter verzekering van doeltreffende toepassing van gemeenschapsrecht, als volgt: "Hiertoe dienen de lidstaten er met name op toe te zien, dat overtredingen van het gemeenschapsrecht onder gelijke materiële en formele voorwaarden worden bestraft als daarbij vrij in hun keuze van de op te leggen straffen, maar deze moeten wel doeltreffend, evenredig en afschrikkend zijn." ${ }^{30}$ Met

25. Het CBB werwijst hier naar het arrest De Peijper, HvJ EG (104/75), Jur. 1976, p.635.

26. E. Rood, Onerzich EEG en Nederlands tevensmiddelenbeleid en -recht, Apeldoorn/Antwerpen, 1993. Pp. 191 198, verwijst naar soort gelijke arresten wan het $\mathrm{HvJ}$ EG warin handhavingsaspectep ook worden getoetst aan artt. 30-36 E(E)G-verdrag. Daaruit concludeert zij correct dat dubbele controle onwenselijk is. Alleen bij ernstig vermoeden van onregelmatigheden van, een uit documenten blijkende, (sanitaire) controle in het exportland, mag het importland opnieuw controleren. Deze inspectie mag slechts steeksproefgewijs geschieden en de controlekosten mogen niet worden doorberekend aan betrokken importeur..

27. R.M.A. Guldenmund, Strafrechtelike handhaving van gemeenschapsrecht; Een analytisch overzilcht van de strafrechlelike handhaving van het afgeleide gemeenschapsrecht in de Nederlandse rechrsorde, Arnhem/Utrecht, 1992, pp.11-17.

28. Amsterdam Bulb bv versus Produktschap voor siergewassen, HvJ EG (50/76) 2 febr. 1977, Jur. 1977. p. 137.

29. J.A.E. Vervaele, EEG-fraude en Europees economisch strafrech, Deventer, 1991, p.13.

30. Griekse mais, Hw EG (68/88) 21 sept. 1989, Jur. 1989, p.2965, ook 13 dec. 1990, gepubliceerd in: SEW, 1993, pp.801-804; Tevens Hansen, HvJ EG (C-326/88) 10 juli 1990, Jur. 1990, p. I-2911; Ook Vondevenne, HwJ EG (C-7/90) 2 okt. 1991, Jur. 1991, p.1-4371; Herhald in Commissie vs. Verenigd Koninkrijk van Groot-Brittanie en Noord-lerland, HvJ EG (C-382/92 en C-383/92) 8 juni 1994, NJ 1995, 194/195; I.c. handhaving v.e. verordening. De criteria gelden ook voor handhaving van richtlijnen. Von: Colson en Kamamm, HIJ EG (14/83) 10 april 1984 , Jur. 1984, p.1891. 
andere woorden, bij nakoming van hun handhavingsplicht moeten lidstaten in elk geval deze algemene beginselen van gemeenschapsrecht, te weten het assimilatie-, proportionaliteits- en effectiviteitsbeginsel ${ }^{31}$ in acht nemen.

\subsubsection{ASSIMLATIEBEGINSEL}

Vrij vertaald betekent het assimilatiebeginsel het volgende: behandel de buurjongen als eigen kind. Mede in het licht van het gelijkheidsbeginsel is het essentieel dat lidstaten onderling ongeveer overeenkomende maatstaven hanteren bij uitwoering van hun handhavingsbeleid. Uitgangspunt is dat nationale staten overtredingen en misdrijven van communautair recht, "even zorgvuldig" 32 of "vergelijkbaar met" 33 de wijze waarop (naar aard en belang) gelijksoortige delicten in eigen land worden behandeld, beoordelen. ${ }^{34}$

Dit beginsell van assimilatie is neergelegd in bij voorbeeld art. 209a EG-verdrag: "De Lid-Staten nemen ter bestrijding van fraude waardoor de financiële belangen van de Gerneenschap worden geschaad, de zelfde maatregelen als die welke zij treffen ter bestrijding van fraude waardoor hun eigen financiële belangen worden geschaad."

Het assimilatiebeginsel laat de mogelijkheid open, dat strengere nationale regels dan communautaire regels worden gesteld. Zo kan een inbreuk op het gemeenschapsrecht dubbel worden bestraft. Bestraffing kan ontleend zijn aan zowel Europees recht als nationaal recht. In dit verband is aandacht voor het 'ne bis in idem'-beginsel terecht. "Het feit dat de Nederlandse overheid en de EEG eenzelfde doel nastreven in een 'criminal charge'-procedure als mede de strekking van de [...] internationale verdragen wettigen de conclusie dat een dubbele vervolging in beginsel niet toegestaan lijkt." 35

\subsubsection{EVENREDIGHEIDSBEGINSEL}

De relatie tussen de ernst van het strafbaar feit en de zwaarte van de sanctie staat in het teken wan evenredigheid. Dit is het aspect van proportionaliteit ${ }^{36}$ in het evenredigheidsprincipe. Hiernaast zijn twee andere (evenredigheids)elementen te onderscheiden, te weten: "of de genomen maatregel nuttig of relevant is om het doel te bereiken, en of hij

31. O.a. I.A.E. Vervaele en R.J.G.M. Widdershowen, a.W., p.29; Ook R.J.G.M. Widdershoven (1993), t.a.p.; Pp. 53-55, die als vierde eis apart 'afschrikwekkendheid' onderscheidt; En R.M.A. Guldenmund, a. w. pp. 18-20, die dat niet doet, maar terecht het kembaarheidsvereiste als vierde handhavingsbeginsel noent; Ook J. Bonnes stelt deze eis, a.w.. pp.72/110.

32. Fromme, HvJ EG (54/81) 6 mei 1982, Jur. 1982, p. 1449.

33. Pieck, HwJ EG (157/79) 3 juli 1980, Jur. 1980, p.2171.

34. Commissie ws. Griekenland, t.a.p., p.2965; Watson, HwJ EG (118/75) 7 juli 1976, Jur. 1976, p.1185; Arthlagemyndigheden et Hansen \& Sön I/S ws. HvJ EG, HvJ EG (326/88), t...a.p., 5 dec. 1989.

35. H. de Doelder en J.W. van der Hulst, EEG-sancties en ne bis in idem, in: SEW, nr. 11, 1993, pp.722733. Auteurs pleiten woor niet-ontvankelijkheidverklaring in geval een (rechts)persoon reeds is bestraft i.o.v. de Europese Commissic. En anders zien zij graag dat de Nederlandse rechter bij strafibepaling rekening houdt met de Europese administratieve sanctie (p.733)

36. Sancties mogen niet. onevenredig zwaar of licht zijn. Zie Pieck, t.a.p., p. 2171; Watson, t.a.p., p.1185. 
onmisbaar is dat wil zeggen niet door een andere, voor een ander belang minder schadelijke maatregel kan worden vervangen". ${ }^{37}$

In Nederlands recht is een evenredigheidsbeginsel neergelegd in art. 3:4, tweede lid, Awb. Op het gebied van rechtshandhaving fungeert het evenredigheidsprincipe "enerzijds als beginsel van behoorlijke bestuurlijke straftoemeting als het gaat om het opleggen van punitieve sancties, en anderzijds als beginsel van evenwichtige belangenafweging als het gaat orm handhaving ${ }^{38}$ van het objectieve recht". ${ }^{39}$ Hierin is inderdaad het beleid, dat de (administratieve) rechter hanteert, herkenbaar.

Wat betreft de weigering tot toelating van een bestrijdingsmiddel door de Commissie Toelating Bestrijdingsmiddelen ${ }^{40}$ betrekt het College van Beroep voor het Bedrijfsleven, in zijn oordeel daarover, het evenredigheidsbeginsel. ${ }^{41}$ Wat betreft de intrekking van een erkenning van een APK-station door de Dienst Wegverkeer neemt de voorzitter van de Afdeling Rechtspraak/Bestuursrechtspraak van de Raad van State in zijn oordeelsvorming hierover ook de evenredigheid ter hand. ${ }^{42}$ Wat betreft strafkorting op de WWuitkering als sanctieoplegging door besturen van bedrijfsverenigingen doet de Centrale

37. W. van Gerven, Het ewenredigheidsbeginsel: een beginsel met een groor verleden en een grote toekomst". in: In het nu, wat worden zal, opstellen H.C.F. Schoordijk L.g.v. afscheid als hoog\|eraar a/d KUB, Deventer, 1991, pp.75-86, i.h.b. p.77.

38. De zwaarte van thet handhavingsbelang speelt een rol in de vitspraken van de ARRS (aangaande subsid intrekking). Bij voorbeeld de uitspraak vermeld in: AB 1993, 350-352.

39. A.J.C. de Moor-Van Vugt, Symbiose van evenredigheidstoersen?, in: NTE, nr. 1, 1993, pp. 26-37, i. h. b. p. 33. Auteur voert een pleidooi om de door het $\mathrm{HWJ}$ gehanteerde "doel-middeltoetsing aan de hand van ijkpunten (legitieme) doelstelling. geschiktheid en noodzakelijkheid van het toe te passen instrument en de mate warin individuele belangen getroffen worden door deze toepassing, de evenredigheid in enge zin" als concept voor de Nederiandse administratieve rechter in te voeren; Uitvoerig A.J.C. de Moon-Wan Vugt, Maten en gewichren "Het evenredigheidsbeginsel in Europees perspectief, diss. KUB, Schoordijk. Instituut: Centum voor wetgevingsvraagsiukken, 1995.

40. Per 1 jan. 1993 zbo-status: College voor de Toelating van Bestrijdingsmiddelen (Stcrt. 1992, 252). Zie M.W.L. Simons-Vinckx, Toelating van bestrijdingwhiddelen, Toekomstige regelgeving, in: AR, nr.8, aug. 1993 , pp. 387-397.

41. CBB 24 jan. 1992, AB 1992, 253.

42. Vz ARRS 26 febr. 1990, R01.90.091/S59; Vz ARRS 27 aug. 1992, AB 1993, 1.50; Vgl. het oordeel over de uitspraak van de President rechtbank R'dam, 11 mei 1994, KG 1994, 248 (uitspralk luidt: feitelijk vindt geen emkele belangenafweging ex ar. 3:4, eerste lid, Awb plaats omdat het algemeen belang van de verkeersweiligheid altijd zwaarder weegt dan het economisch bellang van de erkenninghouder wiens erkenning i.c. Irouwens tijdelijk is ingetrokken, wainit president concludeert dat het door de rijksdienst wegverkeer gehanteerde sanctiebeleid strijdig is thet art. 3:4 Awb)-door de ABRS 3 now. 1994, ministerie wan verkeer en waterstaw ws. pres. rb. R'dam in het geschil tussen automobielbedriff Bas Blaak bw. AB 1994, 13. De ABRS acht het "niet onredelijk dat-als onderdeel van het (sanctie)beleid bij de gwedkeuring van apert onveilige voertuigen- an het belang van de verkeersveiligheid, gelet op dle mogelijkheid van deelneming van een apert onveilig voertuig aan het verkeer, altijd een zeer groot belang wordi toegekend in wergelijking met andere belangen, watronder de economische belangen van de erkenninghouder". Het erkenningenstelsel is namelijk juist in het leven geroepen ter bescherming van het belang, van de verkeersveiligheid. De ABRS stelt dat "'gelet op art. 3:4 Awb nast de belangenafweging die aan het sanctiebeleid ten grondslag ligt, tevens is onderzocht of er bijzondere belangen waren die noopten tot afwijking van het beleid" 
Raad van Beroep in toenemende mate beroep op de evenredigheidsregel. ${ }^{43}$ Hier wordt, even als in het voorgaande voorbeell, het evenredigheidsprincipe als beginsel van behoorlijk bestuur gehanteerd.

Daamaast gebruikt de rechter het evenredigheidsprincipe als rechtvaardige richtlijn voor straftoepassing. Denk aan de toetsing, door de woorzitter van de Afdeling Rechtspraak van de Raad van State, van onder meer (van wege het Commissariaat voor de Media) opgelegde omroepboeten.

Ex art. 8 Sanctieregeling omroep $1993^{4}$ moet het Commissariaat voor de Media, bij de beoordeling van de vraag of en in welke mate een vastgestelde overtreding dient te worden getroffen door het nemen van een sanctie, rekening houden met alle relevante omstandigheden, waaronder de aard en de ernst van de overtreding, de mate van schuld van de overtreder ${ }^{45}$ en de omstandigheden waaronder deze tot stand is gekomen ( $0 . a$. de mate van nadruk bij het uitzenden reclameboodschappen of -uitingen ${ }^{46}$ ).

Bij voorbeeld, bij een liwe-uitzending kan een bepaalde omroepvereniging intern vertrouwen schenken aan bepaalde werknemers-presentatoren, maar formeel blijft zij verantwoordelijk woor de daden van degenen die zij inschakelt voor de uitoefening van haar werkzaamheden. In concreto neemt de omroepvereniging hiermee (on)bewust het risico, dat reclameregels worden overtreden. ${ }^{47}$ Het afwegen van de redelijkheid van een feitencomplex betreffende optreden voor een omroep mag echter niet zo ver gaan, dat daardoor alle spontaniteit die inherent is aan een bepaalde televisie- of radiopresentatie de kop in wordt gedrukt. Zo zijn reclame-uitingen, die zijn opgenomen in het kader van een evenwichtige registratie en presentatie en in redelijke verhouding staan tot het met het programmaonderdeel beoogde niet-commerciële doel, in de ogen van het Commissariaat voor de Media geoorloofd. Als rellevante omstandigheden, die meetellen bij onder andere boeteoplegging of zendtijdintrekking, merkt het Commissariaat voor de Media onder meer aan: het aantal overtredingen al dan niet gerelateerd aan het tijdsbestek

43. CRvB 30 mei 1990, RSV 1990, 211, ook in: AB 1991, 1; CRvB 31 juli 1990, RSV 1990, 354, ook in: AB 1991 . 3. Zie W.G.A. Hazewindus, Administratieve sancties en vreendelingenrecht, diss. UvA, Arnhem, 1994, pp.61 65.

44. Met regelmaat keert de zinsnede, dat "het boetestelsel als neergelegd in de Sanctieregeling Omroep niet

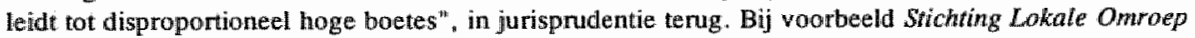
Landsmeer e.a. ws. CvdM', ARRS 8 now. 1993, R01.91.0316/7/8, in: Mediaforum-bijlage nr.6, jar. 1994, pp.B6-B7/12, wok in: AB 1995, 98. Bij dit arrest merkt annotator AFMB op dat de ARRS sancties zowell abstract als concreet toetst: "het sanctiestensel leidt niet tot disproportionelle boetes en bovendien is niet aannemelijk gemaakt dat de sancties t.a.v. de betrokken omroepen individueel bezien tot anevenredige gevolgen (voortbestaan dan wel. programmeringsmogelijkheden van omroepen - JGLvN) leidt".

45. Ex art. 15 So toetsing aan subjectieve en objectieve vermijdbaarheid van reclame-uitingeth.

46. Toetsing ex art. 14 So op o.a. herhaling en dutr reclame, wijze uitzending (beeld of geluid of beide), plaats van reclame in gehele uitzending, grootte en impact van reclame-uitingen, territoriale bereik reclame-uitcending.

47. O.g.V. NCRVvs. CwdM (lunchpakket) , deskundigenadvies 2 okt. 1991, betrekt het CvdM deze evenredigheidsaspecten in zijn -d.d. 24 okt. 1991 gevelde- oordeel aangaande boeteoplegging. Zie J.J.C. Kabel en M.M. Rejjntjes, Publieke omroep en commercie; Adwiezen en witspraken. Amsterdam, 1993, pp.447-451.

48. Aldus Tros-Neuwsshow, besluit CwdM 19 sept. 1990 en VoO-Veromica Sparradio, besluit CvdM 14 juli 1992, in: $\mathbb{J} . J . C$. Kabel en M.M. Reijntjes, a.w., pp.362-363 en pp.514-516; Oriënt Express, ARRS 16 dec. 1993, R01.91.0654, in: MF, nr.5, 1994, pp.B45-B46. 
waarbinnen ze plaats vinden ${ }^{49}$ of het door de omroeporganisatie actief verlenen wan medewerking aan wervende (advertentie) boodschappen ${ }^{50}$.

Dit sanctiebeleid, waarbij rekening wordt gehouden met alle relevante omstandigheden, wordt geaccepteerd door de Afdeling Rechtspraak van de Raad van State. ${ }^{51}$ Desondanks zijn de administratieve rechter en het Commissariaat voor de Media niet altijd gelijk gestemd in hun oordeel over (dis)proportionaliteit van sanctieoplegging. Toepassing wan het evenredigheidsbeginsel door de Afdeling Rechtspraak van de Raad van State brengt niet zellen vernietiging van besluiten van het zelfstandig bestuursorgaan voor de omroep met zich mee. ${ }^{52}$ Vooral in het licht van art. 10 EVRM past de administratieve rechter de proportionaliteitseis resoluut toe. ${ }^{53}$

Van uit Europese hoek klinkt instemming met toepassing van deze evenredigheidstoetsing door de nationale rechter wat betreft sanctieoplegging in het vrije mediaverkeer in het bijzonder ${ }^{54}$ en ook in het vrije goederenverkeer in het algemeen ${ }^{55}$.

\subsubsection{EFFECTIVITEITSBEGINSEL}

Ex art. 5 E(E)G-verdrag rust op alle lidstaten de plicht om regels daadwerkelijk te handhaven. Regels, die niet worden nageleefd, zijn immers zinloos. Daarom dragen nationale

49. Zwaluwse Onroep Stichting, besluit CvdM 24 mei 1991, in: J.J.C. Kabel en M.M. Reijntjes, a, wh", pp.435-438.

50. VOO-Modespecial, besluit CvdM 18 mei 1989, gewijz. 12 juni 1990 en 30 juli 1990 , in: J.J.C. Kabel en M.M. Reijntjes, a.w., pp.133-136.

51. O.a. TROS vs. CudM (Walkman), ARRS 8 aug. 1991, R01.89.6537, in: MF, nr.1, 1992, pp.B8-B9. (rechtspraakbijlage); TROS vs. CvdM (Way of life), ARRS 8 aug. 1991, R01.89.1177, in: MF, mr.1. 1992, pp.B9-B11 (rechtsprakbijlage); VOO vs. CvdM (Q8), ARRS 8 aug. 1991, R01.89.0485, in: MF. n. 1, 1992, pp.B3-B5 (rechtspraakbijlage); TROS vs, CudM (De punties op de E; Citroën), ARRS 21 meï 1991, in: MF, nr.7-8, 1991, pp.B63-B65 (rechtsprakbijlage); Lokale sluikmeclame, ARRS 21 meil 1991. S01.91.0064/5/6, in: MF, nr.7-8, 1991, pp.B61-B65 (rechtspraakbijlage); Voo ws. CvdM (Oriènt Express). ARRS 16 dec, 1993, R01,91.0654, in: MF, nr.5, 1994, pp.B45 B46 (rechtspraakbijllage),

52. O.a. AVRO vs. CvdM (Een andere wijze), ARRS 22 maart 1993, R01.92.2460/Q01, in. NJB, nr.20, 20 mei 1993, pp.256-258 (rechtsprakkatern): Natuurlijk genezen $M_{*}$. ARRS 7 jan. 1993, R01.92.2487/Q01, in: MF, nt.5, 1993, pp.B66-B67 (rechtspraakbijlage); NCRV ws. CvdM, ARRS 21 maant 1993. R01.92.2487/Q01, in: NJ 1994, 23, pp.99-101.

53. VOO vs. CvdM (Véronique MI), ARRS 29 juni 1993, R01.90.5155, in: MF, nr.9, 1993, pp.B77-B79 (rechtspraakbijlage). Overigens bepalt de rechter , dat het onrechtmatig verkregen voordeel niet de enige en mitsdien allesbepalende factor bij het bepalen van de omvang van de sanctie (i.c. boete en -ten dele voorwaardelijke!-zend tijdintrekking) mag zijn; Ook F. Kuitenbrouwer, Verschijningsverbod dupenert ook ruim een miljoen Veronica-leden, in: NRC, 5 febr. 1993, p.7, wijst er op dat zendtijd "meer is dan een simpele rekensom. Het is de munteenheid van de pluriformiteit die het hogere doel is van helt ommoepbestel". Z.i. heeft het CvdM het "argument van de collectieve uitingsvrijheid genegeend".

54. NOS vs. Nederland, ECRM 13 okt, 1993, in: MF, nr.6, jan. 1994, p.B11 (rechtspraakbijlage), Naast de proportionaliteit benadnkt de ECRM, ter beoordeling van de beperking van uitingsivrijheid, de Nederlandse "margin of appreciation" en de redelijkheid; Over arrest EC: reclameverbod niet in strijd met mensenrechtenverdrag, in: Comedia, nr. 27, dec. 1993, p.2.

55. A. Richardt en 'Les Accessoires Scientifiques' Vof, HvJ EG (367/89), 4 okt. 1991, in: SEW, nr.4, 1994,
pp.253-255. 
staten niet alleen zorg voor het creëren van sanctiebepalingen ${ }^{56}$, maar ook voor de feitelijke nalleving ${ }^{57}$ daarvan. ${ }^{58}$

Lidstaten treffen dus de nodige maatregelen ter verzekering van de uitvoering en de handhaving van richtlijnen. ${ }^{59}$ Het zelfde geldt meestal ook voor verordeningen, hoewel verordeningen ex art. $189 \mathrm{E}(\mathrm{E}) \mathrm{G}$-verdrag op zich al verbindend in al hun onderdelen en rechtstreeks toepasselijk in elke lidstaat zijn.

In het licht van het effectiviteitsbeginsel staat bij voorbeeld het pleidooi voor een, in afdeling 5.1 van de derde tranche Awb op te nemen, zorgplicht voor overheidsorganen belast met bestuurlijke handhavingstaken: "Het tot handhaving bevoegde bestuursorgaan draagt zorg voor de bestuurlijke handhaving van het bij of krachtens de betrokken wetten bepaalde" ${ }^{60}$ Hiermee krijgen handhavingsactiviteiten een wettelijke basis. Maar bovenal brengt een dergelijke zorgplicht tot uitdrukking dat de overheid, naast het stellen van (sanctie)normen, tot taak heeft een maal gegeven normen daadwerkelijk te handhaven.

\subsubsection{AFSCHRIKWEKKENDHEIDSBEGINSEL}

Sommige sancties treffen alleen doel als zij een afschrikwekkend ${ }^{61}$ karakter hebben. ${ }^{62}$ Afschrikwekkende straffen moeten zowel betrokken regelovertreder als potentiële toekomstige normschenders er van weerhouden delicten te begaan.

56. Commissie vs. Duitsland, HvJ EG (C-361/88, 59/89) 30 mei 1991, in: SEW. mr.3, 1994, pp.178-180, m.nt. A.M.M. Teubner, ook in: M\&R, nr.3, 1994, 30; Vgl. Commissie ws. Frankrijk, in: M\&R, nr.3, 1994, m.nt. Jans.

57. Drinkwater Venvers, Hv EG (42/89) 3 juli 1990, in: M\&R, nr.31, 1991, in.: R.J.G.M. Widdershoven, t.a.p., P. 54.

58. Vougens R.J.G.M. Widdershoven, t.a.p., p.55, grenzen sommige gedoogsituaties zo aan het ontoelaatbare. Auteur acht het fnuikend dat juist de naleving van nationale normen, waarin rechtstreeks werkende Europese richtilinen zujn ongezet, in praktijk niet altijd wordt afgedwongen; Vgl. H.R.B.M. Kummeling en J.B. Mus, t.a.p., p. 31 .

59. In Paolo Faccini Dori/Recreb. HvJ EG (C-91/92) 14 jull 1994, Jur. 1994, wordt de horizontale werking van richtijnen nog afgewezen. Hierover, met uivoerige bronvermelding, K.J.M. Mortelmans en H.A.G. Temmink, De rechtstreekse en onrechtstreekse werking wan EG-richtlijnen, in: AA, nr. 12, 1994, pp.845859. Auteurs begrijpen de "pas op de plats" van het HvJ wel, van wege de geboden compensatie door werwijzing naar andere wegen. Wel betreuren zij het dat het hof, dat een wel zeer summiere en tekstueel niet overtuigende motivering bij het arrest geeft, de kans niet aangrijpt randvoorwaarden woor een richtlijn conforme uitleg te geven.

60. G.H. Addink en M.J. Sluijs, Het vijfle hoofdsiuk van de Awb: handhaving in materieel perspectief, in: NIBB, na.35, 7 okt. 1994, pp. 1201-1208, i.h.b. p.1204.

61. Von Colson en Kamann, t.a.p., p.1891. I.c. is sprake van discriminatoire sollicitatieprocedure, Rechtstegenstrijdig wordt een vrouwelijke kandidate voor een bepagide functie gepasseerd. Dit wordt bestraft mett slechts een, aan de achtergestelde vrouw te betalen, geringe reis en onkostenvergoeding. Z Z $n$ lichte sanctie weerhoudt een volgende werkgever niett voldoende om op de zelfde wijze te handelen.

62. Zie 0.a. art. 25 Ontwerprichtijn Privacybescherming: "Elke lidstaat bepaalt dat op een iedler die de nationale bepalingen waarbij deze richtijn toepassing vindt, niet naleeft, sancties met afschrikkende werking worden toegepasit." 


\subsubsection{KENBAARHEIDSBEGINSEL}

Logisch uitvloeisel van de uitvoeringsplicht van art. $5 \mathrm{E}(\mathrm{E}) \mathrm{G}$-verdrag is dat de afzonderlijke lidstaten duidelijk moeten maken welke rechtsregels zij wensen te handhaven. Met andere woorden, de met controle en opsporing van strafbare feiten belaste bestuursorganen als mede particuliere toezichthouders, en niet te vergeten de justitiabelen zelf moeten bekend zijn met de inhoud van het in de nationale staten na te leven gemeenschapstrecht. Personen., die actief moeten deelnemen in een democratische samenleving, moet het niet ontbreken aan "tijdige en adequate informatie over ontwikkelingen in die samenleving, omdat zij zonder die informatie niet behoorlijk aan het maatschappelijk proces kunnen deelnemen ${ }^{\prime \prime}{ }^{63}$. Op overheden en semi-overheidsinstellingen met publiekrechtelijke bevoegdheden rust dan ook in elk geval een informatieplicht. Bovendien is het tegenwoordig gerechtvaardigd eveneens particuliere organisaties, zeker die zich op handhavingsterrein begeven, te confronteren met een publikatieplicht ter zake.

Tegenwoordig is het gebruikelijk het kenbaarheidsvereiste bij standaardformulering te regelen. ${ }^{6}$ Dit past in het streven naar modelbepalingen voor Europese wet- en regelgeving in het algemeen. ${ }^{65}$

Bij de uitvoering van de Nederlandse sociale zekerheidswetgeving ligt een belangrijk accent op adequate voorlichting over beleidstoepassing door uitvoeringsorganen aan betrokken burgers. Zo komt het bellang van het - i.c. door een bedrijfsvereniging "jarenlang op gezette tijden in informatiebulletins voorlichting verstrekken" (in het voorliggende geval aangaande de aan- of afwezigheid van verzekeringsplicht van gelegenheidsarbeiders in de land- en tuinbouw) naar boven daar, waar de rechter een beroep door de betrokken premieplichtige op het vertrouwensbeginsel afwijst. ${ }^{6 / 2}$ In zijn conclusie, dat betrokkene op de hoogte heeft kunnen zijn van de nieuwe beleidstoepassing omdat de betreffende bedrijfsvereniging dit herhaaldelijk - zij het niet altijd even helder en eenduidig - kenbaar heeft gemaakt, geeft de rechter blijk van een juist inzicht. Met referentie aan de regelmatig door het bestuur van de Bedrijfsvereniging voor Tabakverwerkende en Agrarische Bedrijven gegeven inlichtingen passeert hij het beroep wan de wederpartij op in redelijkheid opgewekte verwachtingen.

Het niet naleven van het kenbaarheidsbeginsel wordt uitdrukkelijk als schrijnend ervaren. Omdat gedetailleerde regelgeving in de sfeer van sociale zekerheid meestal ontbreekt, moeten bedrijfsverenigingen in voorkomende gevallen eigen handhavingsbelleid ${ }^{67}$ ont-

63. R. Hermann, Van drukpers tot telematica; Notities over wrijheid van informatie en technologische onnwikkelingen: mogelijkheden en belemmmeringen, Deventer, 1986, p.13.

64. Aldus R.M.A. Guldenmund, a. w., p.19.

65. J.M. Bonnes, Column; Een modelbepaling voor de communautaire regelgeving?, in: RegelMaat, ar. 1, 1994, pp. 16-17.

66. Het besiutur wan de Bedrijfswereniging voor Tabakverwerkende en Agrarische Bedrüven vs. $X, \mathrm{CRvB} 23$ maart 1994, AB 1994, 394, m.nt. WASD.

67. Omdat een heldere integrale sturing van handhawing door de afzonderlijke bedrijfswerenigingen tot woor kort ontbrak, staat de Sociale Verzekeringsraad meer coördinatie inzake preventie "controle ${ }_{\text {" }}$ opsponing en afdoening van oneigenlijk gebruik, misbnik en fraude in de sociale zekerheid voor. Zie SVr. Nota 
wikkelen. Voor een groot deel nemen zij de sanctiebelleidsadviezen van de Federatie voor Bedrijfsverenigingen over. Voor het resterende deel bestaat geen vast omlijnd handhavingsbeleid. Daarin moeten de uitvoerende zelfstandige bestuursorganen werkzaam in sociale zekerheidssector van oudsher zelf voorzien. Laten de besturen van de bedrijfsverenigingen dit na, dan neemt de rechter hen dlat zeer kwalijk. In een relevant arrest luidt de cruciale overweging dat de rechter "het weinig gelukkig acht dat gedaagde m.b.t. de sanctionering van overtredingen van het betreffende controlevoorschrift geen beleid heeft geformuleerd, nu dat woorschrift reeds vele jaren van kracht is, overtreding daarvan - naar het de rechter voorkomt - meer dan incidenteel plaats vindt en de bedrijfsvereniging bij de sanctionering van een dergelijke overtreding een keuze heeft uit een breed scala aan mogelijke sancties". ${ }^{6}$

Het sanctiebeleid van bedrijfsverenigingen moet de toetsing aan algemene beginselen van behoorlijk bestuur, waaronder het rechtszekerheids-en rechtsgelijkheidsbeginsel, kunnen doorstaan. ${ }^{69}$ Daarom concludeert het bestuur van de Bedrijfsvereniging voor de Havenen aanverwante bedrijwen, binnenscheepvaart en visserij in 1993, dat het tijd is om te komen tot voorstellen voor de wijze waarop haar sanctiebeleid wordt gepubliceerd. De bedrijfsvereniging heeft het voornemen haar "totale sanctiebeleid in de vorm van beleids(besluiten) op een daartoe geëigende wijze afzonderlijk publiceren". ${ }^{70}$

Hierbij refereert zij aan afdeling 3.6 Awb. Overigens bevredigen deze publikatievoorschriften niet iedereen. De Awb staat namelijk verschillende wijzen van bekendmaking van wet- en regelgeving toe. Hierdoor creëert de Awb een "grote mate van onhelderheid" ter zake; Art. 3:42 Awb, waarin is bepaald dat de bekendmaking van besluiten die niet tot een of meer belanghebbenden zijn gericht, geschiedt door kennisgeving van het besluit of van de zakelijke inhoud ervan in een van overheidswege uitgegeven blad of een dag-,

67. $\rightarrow$

handhavingsbeleid SVr, aug. 1993; Eerder SVr, Tussen schroom en daad; signalering , behandeling en afdoening wan sociale zekerheidsfraude, maart. 1991; Ook het toezicht door de SVIr zelf schiet tekort, Rappon Algemene rekenkamer, TK 1991 1992, 22555; Oplossing van dle, door o a . E. ter Veld "Handhaving, 10 juli 1991 , pp.1-10. gesignaleerde handhavingsproblematiek vereist bestutrijike vernieuwing. Hierover bij woorbeeld PS-specials, Evenwicht en tegenwicht; Beschouwing van de analyse en aanbevelingen van de Parlementaire Enquêtecommissie, nr.24, 3 now. 1993, pp.1919-2062, als mede Vitwoering in wirvoering; De organisatie wan sociaal-rechrelijk Nederland, nr.15, 28 juli 1993, pp.1115-1311; Parlementaire enguête sociale zekerheid", TK 1992-1993, 22730; Wijziging witwoeringsorganisaties sociale zekerheid, TK 1993-1994, 23141; Zie voor oprichtimg van Tijdelijk Instituut voor Coördinatie en Afstemming (van de werkzaamheden van de bedriffswerenigingen), Wetswoorstel Inwoering Organisatiewer Sociale Verzekeringen, TK 1993-1994, 23775, nrs. 1-3. Zie voor de witeindelijke Wet houdende aanpassing wan de uitwoeringsorganen sociale verzekeringen, d.d. 27 okt. 1994, Stbl. 1994, 790, welke welt werkt vanaf 1 jan. 1995, zie inwerkingtredingsbesluit wan 19 dec. 1994, Stbl. 1994, 918 en het daarbij horende Beslait houdende inwoering van de Inwoeringswet Organisatiewet sociale verzekeringen, d.d. IS dec. 1994, Stbl. 1994, 916, geldend sinds 1 jan. 1995 op grond van het inwerkingstredingsbesluit d.d. 19 dec. 1994, Stbl. $1994,917$.

68. Sanctiebeleid bestuur /d Nieuwe algemene bedrijfsvereniging, CRvB 9 nov. 1993, AAW 1991/269, AB 1994, 22:.

69. F.J.C.M. de Kok, Administratieve sancties in het saciaal zekerheidsrecht, Dewenter, 1989, p.23.

70. Bedrijfsvereniging voor de haven-en aanverwante bedrijven, binnenscheepvaart en visserij, De schroom voorbij, aan de daad het woord; Beleidsplan handhawing 1993, Amsterdam, 1993, p. 32. 
nieuws- of huis-aan-huisblad, dan wel op een andere geschikte wijze, maakt het rechter niet transparanter op. ${ }^{71}$

Handhawingsbeleidsregels kunnen de kenmerken van beleidsregels dragen. Zo merkt het Commissariaat woor de Media zijn sanctiereglement zelf uitdrukkelijk aan als beleidsregel. Daarop is dan titel $4.4 \mathrm{Awb}^{72}$ van toepassing.

Afgezien van respectievelijk Awb en Bekendmakingswet (4 febr. 1988, Stbl. 18), zijn regels inzake bekendmaking- en mededeling, van bij wet, algemene maatregel van bestuur of (bijlage van een) ministeriële regeling van wege het rijk vastgestelde algemeen verbindende voorschriften en andere besluiten, ook te vinden in de aanwijzingen voor de regelgeving. ${ }^{73}$ Hier keert de hoofdregel, van plaatsing in staatsblad of staatscourant, terug. Daarnaast zijn uitzonderingen mogelijk. Bij voorbeeld publikatie van bij ministeriële regeling vastgestelde algemeen verbindende voorschriften in een ander van overheidswege verkrijgbaar gesteld publikatieblad dan de staatscourant, indien de voorschriften van betekenis zijn voor een duidelijk afgebakende kring van personen onder wie het publikatieblad wordt verspreid (aanwijzing woor de regelgeving 186). Dit geldt tevens voor een daarbij horende bijlage, mits die bijlage slechts voor een kleine groep personen van belang is of de kenbaarheid voor alle belanghebbenden op een andere wijze voldoende is verzekerd (aanwijzing voor de regelgeving 187). Beide aanwijzingen gelden tevens voor de andere afwijking van het basisprincipe, als neergelegd in aanwijzing voor de regelgeving 189 . Hierin is sprake van andere, dan bij wet, amvb of ministeriële regeling van wege het rijk vastgestelde algemeen verbindende voorschriften. Volgens de toelichting bij betreffende aanwijzing is te denken aan algemeen verbindende voorschriften die worden uitgevaardigd door zelfstandige bestuursorganen als de stichting Verzekeringskamer, het Commissariaat voor de Media ${ }^{74}$ of de Stichting Toezicht Effectenverkeer $^{75}$. Aanwijzing voor de regelgeving 20, tweede lid, maakt vaststelling van algemeen verbindende voorschriften door zelfstandige bestuursorganen mogelijk, voor zover daarin details van andere door het rijk vastgestelde voorschriften nader worden uitgewerkt (o.a. regelgeving omtrent het functioneren van de eigen organisatie).

\section{$\S 13.2$ Gemeenschappelijke grondrechten}

De door de lidstaten te respecteren, en te handhaven, regels van gemeenschapsrecht liggen in het verlengde van de bescherming van de rechten van de mens en de fundamentele vrijheden waarin thet EVRM voorziet. Te denken is vooral aan anti-discriminatoire

71. Y. Buruma, a.w. p. 96 .

72. Zie Voorstel derde tranche Awb, TK 1993-1994, 23700, nrs.1-2, p.16. Art. 4.4,4 Awb inzake bekendmaking wan belleidsregels bepaalt dat zo mogelijk het wettelijk voorschrift wordt vermeld waanuit de (een. bestuursorgaan toekomende, onder zijn verantwoordelijkheid uitgeoefende of door hem gedelegeerde zie art. $4.4 .1 \mathrm{Awb}$ ) bevoegdheid, waarop de beleidsregel betrekking heeft, voort vloeit.

73. C. Borman., a.w., pp.153-155 (aanwijzing 186 tot en met 192).

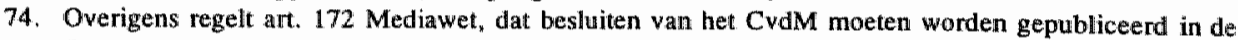
Staatscourant.

75. Art. 35 Wte eist publikatie van STE-besluiten (inz. vrijstelling/wergunnimg/erkemning/ontheffing/intrekking) in de Staatscourant. Idem dito art. 59 van het voorstel Wte 1995 , TK 1994-1995, nr.9. p.26. 
vrijheidsbepalingen. Zo mogen nationale staten de regels betreffende vrijheid van vestiging, vrijheid van beweging, vrijheid van handeling, vrijheid van dienstverlening, vrijheid van kapitaal- en betalingsverkeer of vrijheid van (goederen- en personen)vervoer niet veronachtzamen. Hiernaast zijn natuurlijk EG-regels, ter bescherming van onder meer handel, economie, veiligheid of kwaliteit van milieu en mens, gegeven. In de volgende hoofdstukken volgen voorbeelden.

\section{\$13.3 Versterking Europees handhavingskader ${ }^{76}$}

Op verschillende terreinen is er de laatste jaren actief op aangedrongen dat de EG-lidstaten hun handhavingswerplichtingen, die voort vloeien uit gemeenschapsrecht en daarmee vaak tevens uit nationaal recht ${ }^{77}$, nakomen.

Geconfronteerd met een al maar afnemende moraal van onder het recht gestelden, wordt de rol van de overheid als controleur en sanctietoepasser benadrukt. Voor uitoefening van deze handhavingstaak stelt de Nederlandse staat veelal een specifiek toezichthoudend overheidsorgaan aan.

Deze nationale rechtshandhaving komt in toenemende mate overeen met de handhaving door de Europese commissie. In secundaire gemeenschapsregelgeving normeert zij de inrichting en uitvoering van nationale rechtshandhaving. De commissie ziet er op toe, dat de afzonderlijke lidstaten hun gemeenschapsverplichtingen nakomen. Lidstaten zijn niet meer vrijblijvend in hun naleving van gemeenschapsverplichtingen. De Europese rechter neemt namelijk een op gemeenschapsrecht, en tevens op art. $5 \mathrm{E}(\mathrm{E}) \mathrm{G}$-verdrag, gebaseerde aansprakelijkheidsplicht op grond van onrechtmatige daad aan bij schending van gemeenschapsrecht, hetzij een ríchtlijn hetzij een verordening ${ }^{78}$, door een lidstaat. ${ }^{79}$ Bovendien kan het Hof van Justitie, ex art. 171 EG-verdrag, op vordering van de Europese commissie een nalatige lidstaat veroordelen tot betaling van een dwangsom of forfaitaire som. In de zelfde lijn ligt het arrest waarin is beslist, dat een lidstaat zich - zo lang een richtlijn niet juist is geïmplementeerd ${ }^{80}$ - niet kan beroepen op (schending van)

76. Hiverover Y. Bunuma, a., ., pp.339-388, i.h.b. p.363 e.v *

77. R.J.G.M. Widdershoven, t.a.p., p.55, ziet het zo: "het national recht wordt als het ware communatair "ingekleurd"

78. Wat betreft de voorwaarden en de consequenties wan het arrest-Francowich stelt J. Bonnes, a.w., p.197. uitwoering wan verordeningen hier gelijk aan implementatie van richtlijnen.

79. A. Francowich en D. Bonifaci e.a. ws. Italiaanse Republiek, HvJ (C-6/90, C-9/90) 19 mov. 1991, Jur. 1991, p.I-5357, ook in: AB 1994, 482, m.nt. F.H. van der Burg. Het, rechtstreeks op basis van gemeen schapsrecht aan particulieren toekomende, recht op schadevergoeding is ten volle gegeven bij het voidoen aan de drie volgende voorwaarden: "a. het door de richtlijn voorgeschreven resultaat moet bestaan in de toekenning van rechten aan particulieren; $b$. de inhoud van die recthten moet kunnen worten vastgesteld op basis wan de bepaling van de richlinj; en $c$. er moet een causaal werband bestaan tussen de scheruding van dle op de staat rustende verplichting en de door de benadeelde persoon geleden schade "

80. P.J. Wan der Flier en J.S. van den Oosterkamp, Voortwarende implementatie van EG-richtijnen, mede in het licht wan de Awb en de Aanwijzingen woor de regelgeving, in: SEW, nr.11, 1994, pp.727-752, i.h.b. pp.750-751, betogen om bij het ontbreken van een bijzondere wettellike delegatiemogelijkheid -ter prevertie van ontijdige implementatie- in de Awbeen algemene voorziening op te nemen voor implemen- 
nationale procedureregels, in het bijzonder beroepstermijn(overschrijding), om particulieren rechten te ontzeggen welke zij aan die richtlijn ontlenen. ${ }^{8182} 83$ De noodzaak

80. -

tate d.m.v. gedelegeende regelgeving. Daandoor is implementatic van EG-regelgeving voorlopig velug te stellen door bij voorbeeld tijdelijke amvb's, in afwachting vam definitiewe formeel-wettelijke regelgewing of een adequate bijzondere wettelijke, specifieke delegatiemogelijkheid.

81. Emmon, HWJ EG (C-208/90) 25 juli 1991, Jur. 1991, p.I-4269; SEW 1992, p.783; Aangehaald door N.E. Bracke, Jurispradentie "in: RegelMatt, nr.2, 1994, pp.69-77, i.h.b. p.74; E.H. Pljnacker Hordijk, Enmont, en hoe verder? in: NJB, nr. 15,15 april 1994, pp.499-504, bespreekt ver gaande consequenties via claims m.b.t, een ver verleden. In dit verband is het terugwerkende-kracht-ontzeggende arrest Steenhorst Neerings. HvJ EG (C-338/91) 27 okt. 1993 relevant; Zie ook S. Pruchal, Kroniek van het Europues recht, in: NJB, nr.10, 10 maart. 1995, pp.364-370, i.h.b. p.365. Auteur acht her verdedigbaar dat onder de ratio van het Emmot-arrest allerlei soorten termijnen vallen, denk aan werjaringstermijnen, termijnen voor het maken van be zwaar e.d. De methode om het mime en geabstraheerde toepassingsbereik wan het Emmot-arrest in die zin te beperken dat de Emmot-uitspraak niet opgaat voor nationale bepallingem die het tijdvak beperken warover achterstallige uitkeringen kunnen worden verkregen, welke methode de rechter hanteert inzake Steenhorst-Neerings en bevestigt in het arrest Johnson II, HvJ EG (C-410/92), 6 dec. 1994, acht auteur terecht "weinig elegant".

82. G. Betlem, Richtlijnconforme witleg. interpretatieve doomerking van het EG-recht, in: IER, nr.4, 1994 , pp. 104-110, wijst er op dat particulieren zich weliswaar jegens de overtheud op richtlijnbepalingen kumnen beroepen, maar alléen i.g.v. incorrecte of niet-tijdige implementatie (bovendien pas na afloop van de omzettingstermijn). Kleven aan omzetting inderdaad gebreken, dan is thet ook mogelijk dat de ene burger de andere burger in geding confronteert met de plicht tot uideg wan hel nationale recht overeenkomstig eisen van gemeenschapsrecht. Heabij bhift helatas "onzekerheid omtrent de intensiteit van de richthijnconforme uitleg". Vandar pleit auteur voor "aanwaarding wan horizontale directe werkung van richthinen" (p.110); Zie ook N.E. Bracke, Horizontale werking van richtlymen?, in: RegelMaat, nr.5, 1994, pp.205* 208. die stelt dat de nationale rechter, die -door het ontbreken van horizontale werking van richtlijnen (deze horizontale werking wordt categorisch afgewezen in Faccini Dori, HvJ EG, C-91/92, Jur. 1994, p.I-3325, in: SEW, nr.9. 1994, ook in: TVVS, nr.2, 1995, p.53, tevens in: AA, 1994, p.845 e.\%. Ju niet van de plicht wordt ontslagen nationalal recht zo veel mogelijk verzoenend te interpreteren, vervelend wordt opgezadeld met het trekken van de grens tussen de verplichting verzoenend uit te leggen en thet verbod op horizontale werking van richtijnem; Overigens maakt het arrest W. A.A.C. vasn Ingen Scholhen ws. Informatie Beheer Groep, College wan Beroep Studiefinanciering 7 nov. 1994, in: SEW, nw .4, 1995, pp.292-298, widelijk dat het niet altijd om richtijnen gat. I.c. laat de rechter ruimte woor uitleg varn nationaal recht in het licht van doelstellingen en bewoordingen wan een communau ir sui generis besluit: Als a anverwante kwestie is nog te wijzen op de al dan niet rechistreekse werking van, op richtijnen gebaseerde, informatio - en overlegplichten van decentrale owerheden. Hierover R. Seerdiem, Publiekrechse. like grensoverschrijdende samenwerking wssen decentrale overheden, diss. $\mathbb{R L}, 1993,0.62-65$. Autenr malakt annemelijk dat, daar waar decentrale overheden discretionaire bewoegdheden bezitten om samenwerking vorm te geven, particulieren zich waarschijnlijk moeilijk op samenwerkingsbepalingen kunnen beroepen van wege het ontbreken wan rechtstreekse werking van de samemwerkingsbepalingen.

83. Afzonderlijk vermelding verdient het arrest Afwalstoffen Terminal Moerdijk bu ws. minister van VRON, ABRS 15 dec. 1994, G05.93.2307, in: NJB, nr.9, 3 mart 1995, rechtspraakbijlage nr.9, p.B115-B116. In casu wordt appellante, die vindt dat art. $10.36 \mathrm{a}$ Wet milieubeheer te nume mogelijkheden creeert tor. bezwarmaking tegen witwoer van een bepaalde hoeveelheid verfafvall naar het buitenland (terwijl de aan de Wm-bepaling tengrondslag liggende Richtlijn $84 / 631 /$ EEG van 6 dec. 1984 inzake toezicht en controle op de grensowerschrijdende overbrenging van gewaarlijke afvalstoffen een strengere maatstaf hanteert), in het gelijk gesteld. De rechter erkent wel dat de richtlijn lidstaten een zekere belteidsv rijheid (m. b.t. tot het gebruik maken van de bevoegdheid tot het maken van bezwas') hat. Maar dit doet niet af aan het feit dat in casu sprake is wan een onvolkomen implementatie van communautair recht. Deze onvolkomenheid kan, gelet op de aard en de omvang daarvan, worden weg genomen door het betreffende artikeldeel te 
tot naleving van gemeenschapsrecht als mede van de daarop gebaseerde jurisprudentie van het Europese hof wordt dus steeds klemmender.

Het communautair toezicht ${ }^{84}$, dat voort vloeit uit in het bijzonder art. 155 junctis art. $169 \mathrm{E}(\mathbb{E}) \mathrm{G}$-verdrag en art. $171 \mathrm{EG}$-verdrag, is in het algemeen tweeerrlei. Zij kent "een toetsingsaspect (observerend toezicht) en een correctieaspect (redresserend toezicht)" ${ }^{\mathrm{m}}{ }^{85}$ Het eerste element betreft het feitelijk gebruik maken van toezichtsbevoegdheden. Het tweede element is de imbreukprocedure. Dat wil zeggen de commissie maakt een niet in der minne te schikken zaak aanhangig bij het Hof van Justitie van de EG.

De Europese commissie kan, in het kader van de uitvoeringstaak ex art. 155 jo. art. 145 E(E)G-verdrag ${ }^{86}$, direct (sanctionerend ${ }^{87}$ ) optreden tegen rechtspersonen en natuurlijke personen. De zelfstandige communautaire handhavingsbevoegdheden kunnen alleen op het gebied van de mededinging worden uitgeoefend. ${ }^{88}$ Daarvoor bepalend zijn de artt. $85 / 86^{89}$ jo. art. 87 , tweede lid, sub a, E(E)G-verdrag ${ }^{90}$. ${ }^{91}$ Bij verboden overeenkomsten of misbruik van machtsposities heeft de commissie de bevoegdheid betrokken overtreders geldboeten of dwangsommen op te leggen. Ter uitwerking daarvan zijn, en

83. $\rightarrow$

interpreteren conform de tekst en strekking van de toepasselijke richtlijn. Kortom, de ABRS acht ter zake richtijnconforme interpretatie mogelijk.

84. H.A.H. Audretsch, Communautaire controle; Het toezicht in de EG op de naleving wan de verdragswerplichringen door de lidstaten, diss. RUU, Europese monografieën nr.20, Deventer, 1975; T.P.J.N. wan Rijn, Interne controle EC, in: J.A.E. Vervaele, Bestuursrechtelijketoepassing en handhaving wan gemeenschapsrecht in Nederland, Deventer, 1993, pp.149-165.

85. R.M.A. Guldenmund, a.w., p.22.

86. Duitsland ws. Commissie, HvJ EG (C-240/90) 27 okt. 1992, in: NJB-rechtspraak, nr.2, 1993, p.2.

87. Zie J.A.E. Vervaele, Administratieve sanctiebevaegdheden van en in de Gemeenschap. Naar een systeem wan Europese bestuurssancties?, in: J.A.E. Vervaele (1993), a.w., pp.167-211/pp.39-82 (B.P. Vermeuleny.

88. A.J. Berg; t.a.p., p.815, wijst op de (overigens onstheden), via art. 172 EG-verdrag gecreëerde, mogelijkheid on bunten het terrein van de mededinging autonome handhavingsbevoegdheden toe te kennen aan de Raad, die deze bevoegdheden ex art. 155 jo. ant. 145, derde lid, EG-verdrag kan delegeren aan de Europese commissie. Auteur haalt hierbij het arrest Fiskano AB ws, Commissie, HvJ EG (135/92), 29 juni 1994, aan. In deze uitspraak wordt de, buiten het gebied van mededinging, ontstane zelfstandige handhaving van de commissie aangevochten. Wegens het niet-ontvankelijk verklaren wan eiser (die het onwettigheidsargument kennelijk ie laat in de strijd werpt) komt het hof niet toe aan een oordeel ter zake.

89. De nationale rechter, die wordt verzocht een voorlopig getuigenverhoor te bevelen vooraf gaand aan de civiele procedure ex artt. $85 / 86 \mathrm{E}(\mathrm{E}) \mathrm{G}$-verdrag, kan het beginsel -dat een onderneming niet verplicht is te antwoorden indien beantwoording erkenning van een kartelrechtelijke inbreuk inhoudt- ter zijde schuiven. Zie Onto bv vs. Postbank nv, HvJ EG (60/92) 10 nov. 1993, in: NJB, nr.44, 9 dec. 1993, p.549 (rechtspraakbijlage), ook in: TVVS, nr.12, 1993, p.333.

90. Vgl. artt, 64-66 EGKS-verdrag, art. 83 Euratom-verdrag en artt. 85-90 EER-verdrag (dit verdrag inzake de Europese Economische Ruimte werkt sinds 1 jan. 1994).

91. Zie de uitwoerige, en voor de praktijkjurist nuttige, beschouwing van D. Debruyne, De grenzen vam de onderzaeksbevoegdhedes, wan de Europese Commissie in mededingingszaken, Een juridische benadering. Antwerpen/Apeldoorn, 1992. 
worden in verontrustende mate, sanctieregels voor specifieke situaties gegeven. Bij voorbeeld in de artt. 15/16 Kartelverordening. ${ }^{92}$

De boeten of dwangsommen, die de commissie - in gevolge genoemd verordeningsartikel - bij beschikking aan (verenigingen van) ondernemingen kan opleggen, moeten niet worden onderschat. Als woorbeeld geldt de aan 19 kartonproducenten, wegens ongeoorloofde prijsafspraken, opgelegde boete van 285 miljoen gulden. ${ }^{93}$ Deze boete is, medio 1994, de hoogste boete die door de Europese Commissie als strafmaatregel is toegepast: Dat zelfde jaar nog overtreft de Europese Commissie deze tot dan toe hoogste boete. Eind 1994 legt zij, wegens illegale kartelafspraken in de cementindustrie, aan 33 bedrijven, 8 nationale organisaties en een overkoepelende Europese associatie de flinke boete op van maar liefst 540 miljoen gulden (of 248 miljoen ecu) ${ }^{94} .{ }^{95}$

De hoogte van dergelijke boeten bepaalt de Europese commissie op grond van criteria als de duur van de overtreding, de aard van de afspraken, de prijsstijgingen en de mate waarin bedrijwen meewerken aan het onderzoek van de commissie. De boete betreft maximaal tien procent van de wereldomzet ${ }^{\%}$ van de betrokken branche. De boete lijkt zwaar, maar kennelijk doen de boeten "nog lang niet genoeg pijn". ${ }^{97}$ Het belangrijkste effect van boeteoplegging is de publiekelijke aantasting van het imago van een bedrijf dat kartelregels heeft geschonden.

Van uit het oogpunt van rechtsstatelijkheid, past de volgende kanttekening. Er heerst namelijk spanming tussen het feit, dat nergens wordt gesteld dat de commissie dergelijke sanctieregelingen mag vaststellen, en het gegeven dat art. $89 \mathrm{Gw}$ de Nederlandse wetgever de hoofdrol ten aanzien van door straffen te handhaven algemeen verbindende voorschriften toedeelt. Deze overweging voert tot een pleidooi woor "een solide grondslag in het Unie-Verdrag met betrekking tot de uitoefening van communautaire bevoegdheden

92. Eersie verordening over de toepassing wan de art. 85 en 86 wan het Verdrag $n r .17$, Publ. EG L 204 . 013.21.02.62, gewijz. bij Publ, EG 058, 10 juli 1962, Publ. EG P 162, 7 nov. 1963 en Publ. EG L 285. 29 dec. 1970.

93. W. Brummelnnun, Zware boetes woor kartonfabrikanten, in: NRC, 14 juli 1994, p.12; Uit Fabrikant in: beroep tegen kartel-boete, in: NRC, 15 juli 1994, p.14, blijkt dat een van de bedrjiven (een kleine Nederllandse fabrikant) sanctieoplegging aanvecht.

94. Buj beschikking Europese Commissie d.d. 13 juli 1994, Publ. EG, 19 sept. 1994, L 243/1; Ook hier stelt een Nederlands bedrijf ( $t$. w. de Eerste Nederlandse Cement Industrie samen met de brancluevereniging Vereniging Cementindustrie) beroep in bij het Europese Hof van Luxemburg tegen de aan de haar opgelegde boete van 15,8 miljoen gulden. ENCF en VNC in beroep, in: NRC, 21 jan. 1995, p. 19.

95. Hierover EU treed hard op tegen cementkartel, in: NRC, 1 dec. 1994, p. 19; Besproken door M.R. Mok, Kartel kartonfabrikanten verboden, in: TVVS, nr. 12, 1994, pp 328-329. Auteur verbaast zich er trouwens over dat de EC de "eigenlijke juridische grondslag van het Europees kartelbeleid tw w. art. 85, derde lid, $\mathrm{E}(\mathrm{E}) \mathrm{G}$-verdrag" niet noemt. Wat de EC, wolgens Mok, wel opvallend duidelijk maakt is dat het begrip onderneming niet per se duidt op een wennootschap met eigen persoonlijkheid, maar dat de term betrekking heeft op elke entiteit die commerciele activiteiten bedrijt.

96. In praktijk is slechts de omzet in Europa uitgangspunt.

97. Aldus C.D. Ehlermann, hoofd van het directoraat-generaal mededinging DG4 te Brussel geciteerd door F. de Raat, Brussel deelt harde klappen uit aan kartels, im: NRC. 28 juli 1994, p.11. 
op handhavingsgebied, warin tevens is voorzien in een deugdelijke parlementaire controle daarop". 98

Dit kritiekpunt verdient aandacht. Zeker nu de commissie, meer dan voorheen, gebruik maakt van sanctiebevoegdheden. Deze bedeelt zij zich zelf in toenemende, en verontrustende ${ }^{9}$, mate toe via verschillende verordeningen. Enigszins voorbarig eigent de commissie zich zo belangrijke bevoegdheden toe in het verordeningswoorstel inzake controleen sanctiebeleid m.b.t. llandbouw en visserij. ${ }^{100}$ De controlebevoegdheden zijn wrij wel identiek aan de standaardmaatregelen genoemd in art. 14 Kartelverordening ${ }^{101}$ jo. art. 2 , tweede lid, Uitwoeringswer Kartelverordening ${ }^{102}$. Dat wil zeggen de volgende - ex art. 20 Kartelverordening jo. art. 5 Uitvoeringswet Kartelverordening onder geheimhoudingsplicht van de Commissie uit te oefenen ${ }^{103}$ - toezichtsbevoegdheden: inzage van bedrijfsboeken en -bescheiden, het maken van afschriften of uittreksels van deze boeken en bescheiden, het ter plaatse vragen van mondelinge inlichtingen en het betreclen van alle

98. K.A.M. Bleeker, Verantwoorde commumautaire sanctionering van het gemeenschapsrecht?, in: NJB, nr. 28, 5 aug. $1993, p p .1009-1013$. Auteur dringt, gelet op rechtsbescherming, ook an op opheldering van het karakter van gemeenschapssancties. Zie in dit verband $\mathbb{R}$. Barents, Reactie sonctionering gemeenschapsrecht, in: NJB, ar.40, I1 nov. 1993, pp.1447-1448.

99. Y. Buruma, De repressieve kant wan de Europese Unie, in: JV, nr. 1, 1995, pp. 37-60, uit bezorgdheid over de weliswaar nog niet strafrechtelijke sanctionering door de -mota bene niet democ ratische gelegitimeerde- EC. maar wel meer en meer punitiever wordende bestuursrechtelijke handhaving van uit Brussel. Ook vreest anteur dat door het complex vath, met rechtshandhaving belaste, EC-ambtenaren en nationale ambtenaren de relatie met justitiabelen verslechtert, terwijl de basis van vertrouwen van butger in bestuur e. 0 . juist bij bijzondere wetgeving (met wergunningenstelsels) onmisbaar is.

100. Voorstel van verordening inzake controles en sancties in het kader wan het gemeenschappetijk landbouwen visseribeleid, COM (90), 126, Publ. EG 6 juni 1990, C 13710, gewijz. COM (91), 378 def., Publ. 1991, C 294/17; Vgl. de nieuwe Controleverordening visseri, Vo. 2847/93, besproken door A.J. Berg, t.a.p. Pp. $811-813$.

101. Het FW laat bescherming van verdedigingsrechten, bij uitoefening van onderzoeksbewoegdheden ex art. 14 Vo, aan de nationale wetgewer over zonder concrete grenzen aan te geven. Zie kritiek M.E. Schermerhom, Verificatie-bevolgdheid EG-Commissie: na Hoechst en Dow meer davidijkheid? in: SEW, nr. 1,1994, pp $27-44$.

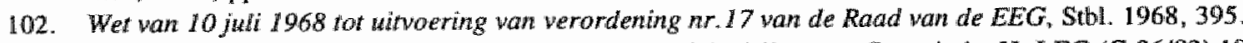

103. Het arrest NV Samenwerkende Elekriciteits Produktiebedriven w. Commissie, HvJ EG (C-36/92) 19 mei 1994, in: TVVS, nr.8, 1994, pp.224-225, verbindt de nodige consequenties aan die geheimhoudingsplicht. Bij het verkrijgen yan informatie over kantelzaken door de Commissie via een door haar ingesteld onderzoek nat mogelijke inbreuk op kartel recht, moet degene die wordt verplicht inlichtïngen te verstrekken er van op aan kunnen dat de door hem of haar overlegde documentatie niet automatisch door de Commissie ex art. 10 , eerste lid, Kartelverordening wordt doorgestuurd naar bevoegde nationale autoriteiten. "Wanneer een onderneming tegenower de Commissie heeft angevoerd dat een bepaald document wegens het bevatten van zakengeheimen niet in handen van de bevoegde nationalie autoriteiten mag vallen, en wanneer die bewering niet volstrekt ongegrond is, kan de in gevolge art. 10, eerste lid, Karte lyerordening op de Commissie rustende verplichting om het betrokken document aan de nationale autoritteften te zenden, door het algemene beginsel van bescherming van zakengeheim worden beperktt. Wil de Commissie in zulk een geval een document toch aan de nationale autoriteiter zenden, dan dient zij daartoe, na de betrokken ondememing te hebben gehoord, een afzonderljike beschikking wast te stellen, waartegen die onderneming in beroep kan gaan." 
lokaliteiten, terreinen en vervoermiddelen van de betrokken ondernemingen. ${ }^{104} \mathrm{De}$ sanctiebevoegdheden zijn verval in art. 4 van het verordeningsvoorstel aangaande landbouw- en visserijpolitiek. Tot een ongelimiteerde lijst van sancties, die economisch nadeel brengen, behoren de volgende sancties: geldboete, uitsluiting van bij EG-regelingen toegekend voordeel ${ }^{105}$, weigering of intrekking van het voordeel voor een langere termijn, dan de tijd waarin inbreuk plaats vindt, in geval van onbetrouwbaarheid van begunstigde. 106

Belangrijke vraag is hoe ver afstemming plaats vindt van de bevoegdheden van de Europese Commissie en de bevoegdheden die aan nationale toezichthouders en opsporingsambtenaren in het kader van mededingingsbeleid worden toebedeeld.

Wat Nederland betreft vindt in april 1994 aanbieding aan het parlement plaats van het gewijzigde wetsvoorstel houdende wijziging Wet economische mededinging ${ }^{107}$. Deze nieuwe Wem, die tegenwoordig wet is ${ }^{10}$, in kern neerkomend op een verbod op alle concurrentiebeperkende afspraken tussen ondernemers behoudens ontheffing of vrijistelling, is een van de verschillende uitvloeiselen van het voornemen het mededingingsbeleid te intensiweren. ${ }^{10 y}$ De gewijzigde Wem beoogt de "effectiviteit van de bestaande wet en de daarop gebaseerde maatregelen te vergroten en vooral de handhaving daarvan te verbeteren". "I0 In het licht van deze doelstelling introduceert de herziene Wem twee noviteiten: een ambtelijke dienst en een bestuursrechtelijke handhaving van de Wem. "II

104. Soort gelijke bevoegd hedlen zijn neergelegd in de vervoersverordeningen $1017 / 68,4056 / 86 \mathrm{en} 3975 / 87$, en cok in de EG-verordening van 21 dec. 1989 inzake controle op concentraties van ondernemingen 4064/89, Publ. EG, L. 257, 1990.

105. Denk aan de -wergeefs-aangevochten korting op het woorschot voor de witgaven die door het Europees Oriêntatie- en Garantiefonds woor de Landbouw. De korting is door de Europese Commissie aangebracht, omdat betrokken lidstatat tijdens een bepaald boekjaar heeft nagelaten de nodige heffingen in het kader vand de melkquota-regelingen te innen. Duitsland ws. Commissie "Hw EG (342/89), 17 okt. 1991 , ftrr. 1991, I-5031, in: SEW, mr.4, 1994, pp. 255-256.

106. Over deze controle- en sanctie mogelijkheden J. Vervaele, Harmonisatie van het economisch straf(processyecht in de EEG, in: H. de Doelder (red.). Bestrijding van EEG-frande, Arnhem/Antwerpen, 1991, pp.129-142, 1.in.b. pp.134-137; Ook 1.A.E. Vervaele, EEG-fraude en Europese econontisch strafrecht, a.w., pp. 19-23.

107. Wets worstel houdende wijziging van de Wet economische mededinging (wergroting wan de effectiviteit) TK 1992-1993/1993-1994.23306, nr.354.

108. Wet Economische Mededinging, 2 november 1994, Stbl. 1994, 801.

109. Mvt woorstel Wem, Th 1992-1993, 23306, nr.3, p.1.

110. Mvi woorstel Wem, TK 1992-1993, 23306, nr.3, pp.15-16.

111. Volgens voorstell van de CTW inzike handhaving door bestuurlijke boeten kan schending van bepaalde Wen-bepalingen met boete worden bestraft. De discretionaire bevoegdheid tot sanctieoplegging komit toe aan bedoeld bestunrsorgaan. De optie van handhaw ing van de totäle Wem middels bestuursrecht is, volgens A.D. Ham, Op weg naar een nieuwe Wem, in: SEW, ar.7/8, juli/augustus 1994, pp.492-508, i.h.b. p.506, vatbaar voor kritiek. Deze gedachte "miskent dat het systeem van "checks and balances" emstig wordit verstoord, als de burger er niet op kan rekenen, dat hij een onafhankelijke-door de rechter te geven-beslissing kan krijgen". Met name in mededingingszaken wal "interpretatieverschillen frequent en de weegfactoren voor de hoogte van de boeten ingrijpend "zijn, moeten onderzoek, vervolging en uitspraak niet in een hand liggen. Goed en wel gaat de auteur hier te stellig voorbij ran de gang naar de Afteling Bestuursrechtspraak van de Raad van State. 
In de strijd tegen misbruik van economische machtsposities door kartelvorming wordt een ambtelijke dienst voor de mededinging ingesteld. Deze dienst valt onder politieke verantwoordelijkheid van de minister van economische zaken. Deze minister gaat, al dan niet, alkkoord met het werkplan van de dienst. Bij goedkeuring van het plan kan hij regelmatig informatie over de daadwerkelijke taakuitwoering van die dienst vorderen. De bewindspersoon mag slechts terughoudend gebruik maken van zijn bevoegdheid tot het geven van algemene of bijzondere instructies. ${ }^{112}$ De bedoeling de dienst zo zelfstandig te doen zijn, gaat "echter ook weer niet zo ver" dat gekozen is voor een zo genaamd zelfstandig bestuursorgaan" $14{ }^{115}$ De dienst wordt gevormd door deskundige ambtenaren die, in gevolge art. 41 , eerste lid, Wem door de minister van economische zaken en de minister(s) die het aangaat, bij in de Staatscourant gepubliceerd besluit (tweede lid), zijn aangewezen om toezicht te houden op de naleving van het bij of krachtens de Wem bepaalde.

Ter taakuitoefening krijgen zij de beschikking over de bevoegdheid: tot het aan een ieder vragen van inlichtingen (art. 41 , derde lid, Wem); tot het te allen tijde betreden van alle plaatsen, uitgezonderd een woning zonder toestemming van de bewoner (art. 41, vierde. lid, Wem); tot het vorderen van inzage van boeken en andere zakelijke bescheiden en van gegevens die langs geautomatiseerde weg zijn vastgelegd, als mede - met het doel afschriften te maken - voor korte tijd afgifte daarvan vorderen of schriftelijke vastlegging en afgifte er van vorderen (art. 41, vijfde lid, Wem). Toekenning van bevoegdheden vindt plaats onder de restrictie, dat uitoefening van de bevoegdheden slechts geoorloofd is woor zover dat redelijkerwijs nodig is voor vervulling van de toezichtstaak: zowel proportionaliteits- als subsidiariteitsbeginsel moeten in acht worden genomen ${ }^{116}$. Toezichthouders kunnen, bij hun taakuitoefening, hulp van de sterke arm inroepen ex art. 41, zesde lid, Wem. Op een ieder, die wordt geconfronteerd met dit mededingingstoezicht, rust in beginsel een medewerkingsplicht ex art. $41 \mathrm{a}$, eerste lid, Wem. Deze verplichting is door de vermelding in de Wet economische delicten strafrechtelijk gesanctioneerd. De medewerkingsplicht lijdt, in gevolge art. 41a, tweede lid, Wem, uitzondering indien betrokkenen, uit hoofde van hun stand, beroep of ambt, geheimhouding moeten betrachten. De opsporing van de, als economische delicten in de zin van de Wet economische delicten aangemerkte, overtredingen van de Wem is van oudsher in handen van de ECD en AID. Deze opsporing vereist een redelijk vermoeden van niet naleving van wet- of

112. Vgll. de politieke ministerièle veranwoordelijktheid voor het openbaar ministerie.

113. Omdat sprake is van een z.i. "wel heel hichte vorm van zelfstandigheid", stelt A.D. Ham, t.a.p., p.508, voor de minister "alleen aanwijzingsbewoegdheid te geven in bepaalde concrete situaties", waradoor de zelfstand igheid nog enig reliêf krijgt.

14. D.C.B. Nieume mededingingswet: adviesaammag aan de SER en de Commissie ecanomischemededinging, in: TVVS, nr.5, 1994, pp. 124-125.

115. J.S. van den Oosterkamp, Een nieuwe mededingingswet. de adviezen van de Sociaal Economische Racd en de Commisste economische mededinging, in: SEW, nr.5, 1995, pp.336 356, i.h.b. pp.350-351, wit voorkeur voor een zbo-vorm ter zake. Auteur is angstig dat -nu sprake is wan een ambtelijke dienst-biji politiek gevoelige mededingingsdossiers de minister zich snel en ongeremd met zaken gaat bemoeien. Volgens auteur is het beter om het mededingingsbeleid te intensiveren door instelling van een zbo dat zich kermerkt door autonomie, met weliswaar de mogelijkheid van minusteriele aanwijzingen die (voorzien van omschrijwing van de aard van de aanwijzingen) wettelijk wordt wastgelegd.

116. Mvt voorstel Wem, TK 1992-1993, 23306, nr.3, p.13. 
regelgeving. Maar ook een concrete aanwijzing, dat een economisch delict niet wordt nageleefd, kan voldoende zijn voor opsporing ex art. 23 Wet economische delicten. ${ }^{117}$ Op geen van beide situaties zijn de artt. 41-41a Wem toepasselijk. De daarin neergelegde bevoegdheden zijn "toezichthoudende bevoegdheden". "18 Voor een "effectieve handhaving van de Wem, die van bijzonder belang is in verband met de generieke onverbindendverklaringen van zware mededingingsregelingen" ${ }^{119}$, zijn toezichtsbevoegdheden onmisbaar: "Door ambtenaren een bevoegdheid te geven tot toezicht op naleving van de Wem kan het vinden van voldoende concrete feiten, waarop een redelijk vermoeden kan worden gebaseerd, worden vergemakkelijkt" ${ }^{420}$. Als ambtenaren worden aangewezen ambtenaren van de ECD (samen met de AID). ${ }^{121}$ Met oog op het toezicht op de naleving van de Wem heeft het personeel van de ECD reeds uitbreiding ondergaan en de nodige opleidingen gevolgd. ${ }^{122}$ Voor oneigenlijk gebruik van toezichtsbevoegdheden, dat achteraf door de strafrechter kan worden beoordeeld, bestaat geen echte vrees. De uitvoeringspraktijk van andere wetten van recente datum, waarin ook toezichtsbevoegdheden zijn gecreëerd, geeft geen aanleiding tot zorg ter zake. En het feit dat de Awb-wetgever toezichthoudende bevoegdheden in het algemeen regelt, "wijst er op dat toezichthoudende bevoegdheden in feite heel gebruikelijk zijn". "233 Bovendien hebben zowel ECD als AID er "in het verleden blijk van gegeven zorgvuldig om te gaan met de, uit hoofde van andere wettelijke regelingen, aan hen verleende toezichthoudende bevoegdheden". 124

De toezichthouders zijn verplicht , alle gegevens die zij in hun hoedanigheid als toezichthouder kennen of redelijkerwijs moeten vermoeden, geheim te houden. In tegenstelling tot de aanvankelijke bedoeling, is in de Wem geen uitzonderingsregeling op de geheimhoudingsplicht getroffen voor het verschaffen van informatie door de Nederlandse staat aan de Europese Commissie. Dit ten behoeve van de afstemming van het nationale op het Europese mededingingsbeleid in het bijzonder de artt. 85/86 E(E)G-verdrag. ${ }^{125}$ Toereikend voor zowel ambtelijke als niet-ambtelijke toezichthouders zijn het bestaande art. 125a, derde lid, Ambtenarenwet en art. 2:5 Awb, waarmee de geheimhoudingsplicht kan

117. HR 9 maart 1993, 93577E/93583E/93581E.

118. Mut woorstel Wem, TK 1993 1994, 23306, nr.7, p.9.

119. Mut woorstel Wem, TK 1992-1993, 23306, nr.3, p.13.

120. Mvt woorstel Wem, TK 1992-1993, 23306, nt.3, p.13.

121. Mvt woorstel Wem, TK 1992-1993, 23306, nr.3, p.22.

122. Mva voorstel Wem, TK 1993-1994, 23306, nr.5, p.14.

123. Mwa voorstel Wem, TK 1993-1994, 23306, nr.5, p.14.

124. MM voorstel Wem, TK 1992-1993, 23306, nr.3, p.13.

125. Over die aftstemming regent het klachten. Volgens o.m. P.V.F. Bos, Van onwoogding naar ontgoocheIing of van interstatelijkheid naar commumautaire dimensie?, in: $\mathrm{NJB}, \mathrm{nr} .27,15$ juli 1994, pp.906-911, ligt het probleem als volgt. In de hang maar hamonisatie van regelgeving, staam nationale staten toe dat Inun (verouderde) mededingingsstelsels in toenemende mate aan (modern) conmunautair mededingingsrecht worden aangepast. Zo doet Nederland zijn best met de vernieuwde Wem. Bij deze tendens is. simultane toepassing van nationaal en communautair mededing srecht niet uitgesloten. Daandoor ontstaar. strijd met thet subsidiariteitsbeginsel ex art. 3B VwM. Om uit deze impasse te geraken, moeten de: bevoegdheden (in gevolge 0.a. de Kartelverordening) van de Europese Commissie worden "ingeperkt door de invoering van communautaire dimensie als bevoegdheidsnorm ook in het gewóne kante] recht". Aldus krijgen lidstaten meer speelruimte voor eígen mededingingsbeleid. 
worden doorbroken. De noodzaak tot mededelen ligt in het "met oog op het belang van een goede toepassing van de Wem verschaffen van informatie aan de Europese Commissie". ${ }^{126}$ In deze optie kunnen nationale toezichthouders, middels overleg met de Europese Commissie, gebaseerd op de samenwerkingsverplichting van art. $5 \mathrm{E}(\mathbb{E}) \mathrm{G}$-verdrag, de voor de Europese Commissie relevante ${ }_{*}$ inlichtingen verstrekken. Volgens deze notie moeten nationale toezichthouders ook meer in het algemeen, indien de Europese Commissie er om verzoekt, behulpzaam zijn bij het verrichten van verificaties bij ondernemingen en ondernemingsverenigingen. ${ }^{127}$ Echter, art. $5 \mathrm{E}(\mathrm{E}) \mathrm{G}$-verdrag "kan niet zo ruim worden uitgelegd dat het nationale ambtenaren maakt tot 'geheim agenten' van de Commissie die haar dankzij nationale bevoegdheden aan dossiers helpen". ${ }^{128}$ Immers, bij het inwinnen van inlichtingen en het verrichten van verificaties moet de Europese Commissies haar vermoeden duidelijk omschrijven. Daarentegen worden de zelfde bewoegdheden in de Wem er juist toe gegeven om materiaal te verzamelen om een vermoeden op te baseren. De methode die er toe strekt om de Europese Commissie tussenkomst van nationale toezichthouders, van gegevens te voorzien die zij zelf nooit kan bemachtigen, is dus oneigenlijk en niet geoorloofd.

\section{\$13.4 Euro-toezichthouders}

De controle op de naleving van EG-regels in de nationale staten wordt niet alleen meer uitgevoerd door toezichthouders van de lidstaten zelf, maar tegenwoordig tevens door Euro-inspecteurs. Deze Euro-controleurs zijn bekend uit de visserij-, olijf- en landbouwsector ${ }^{129}$ en binnenkort wellicht uit de milieusector ${ }^{130}$. Natuurlijk is ook te denken aan de, al sinds 1988 werkzame, controleurs en werknemers van de eenheid van de Europese Commissie die zich bezig houden met fraudebestrijding. ${ }^{131}$ En daarnaast aan de Euro-controleurs in de wijnbouwsector. De preambule van EG-regelgeving inzake

126. Mvt woorstel Wem, TK 1992-1993, 23306, nr.3, p.14.

127. Mu voarstel Wem, TK 1993-1994, 23306, nr 5, p.IS.

128. T.R. Ottervanger en M.T. Nijhuis, Wijziging Wem ter vergroting wan de effectiwiteit, in: SEW, nr.7/8, juli/augustus 1994 , pp. $481-491$, i.h.b. p.490. Auteurs zien zelfs helemaal geen plaats voor, in het kader van national (Werm-)toezicht passende, plichten of rechten to informatieverschaffing aan de Europese Commissie.

129. E Rood, a.w, p.203, noemt de onderdelen: groenten en fruit, vers wlees, vlesprodukten, melk/melkprodukten, en -het volgens haar geen levensmiddel zijnde onderdeel- tabak. Auteur bespreekt op pp. 212 220 de volgens haar ver gaande bevoegdheden wan een mogelijk op te richten Euro-inspectie voor de levensmiddelensector in het algemeen.

130. R.J.G.M. Widdershowen, t.a.p., p.57, maakt melding wan hell woo memen een Europese milieu-inspectie op te richten.

131. Zie over deze zgn. UCLAF Y. Bunuma, E.M. de Koning-De Jong en $Y$. van Wieringen, a.w., p. 55 ; Ook E. Mennens, De UCLAF, in: H, de Doelder (red.), Bestrijding van EEG-fraude, Antwerpen, 1991 , pp. 33-44; E. Boersma, Fraudebestrijding staat bij EG hoog in het vaandel, in: AP, nr.6, 19 maart 1994; Zie bovendien belangwekkende beschouwing wan meer algemene alard door C. Fijnaut., L. Huybrechts en Ch. van den Wijngaert (red.), EG-fraudebestrijding in de prakrijk, Centrum woor de studie van toepassing van het gemeenschapsrecht in financiêle en strafrechtelijke arangelegenheden, Antwerpen/Apeldoom/Brussel, 1994. 
grensoverschrijdende wijnbouwcontrole ${ }^{132}$ stelt dat "gezien de ernstige fraudes [...] het optreden van met wijnbouwcontroles belaste communautaire ambtenaren moet worden gezien als een absolute noodzaak om zorg te kunnen dragen voor het op eenvormige wijze toepassen van de voorschriften en voor een doeltreffende bijstand aan hun collega"s in de lidstaten"'. 133

Gelet op art. $5 \mathrm{E}(\mathrm{E}) \mathrm{G}$-verdrag is het essentieel dat Europese en nationale controleurs samenwerken. In veel gevallen bestaan voor nationale controleurs plichten tot het verlenen van (administratieve/informatieve) bijstand aan Europese inspecteurs in de uitoefening van hun controletaak. ${ }^{134}$ Omgekeerd moet het mogelijk zijn, rapporten of getuigemissen van Euro -Controleurs te gebruiken voor national controle- en opsporingsonderzoek. " ${ }^{135}$ Maar het kan nooit de bedoeling zijn, dat Euro-inspecteurs de taken en bevoegdheden van de toezich thouders in de verschillende lidstaten overnemen. Voorop staat de exclusieve bevoegheid van nationale toezichthouders op het gebied van de handhaving. ${ }^{136}$ Kortom, de leiding van een controle- en opsporingsonderzoek blijft voortdurend in nationale handen. Hoewel EG-controleurs wel toegang hebben tot informatie, die door nationale toezichthouders en opsporingsambtenaren via rechtmatige ondervraging, binnentreding, huiszoeking e. $\mathrm{d}_{\text {. }}$ worden verkregen, mogen de ambtenaren van de Europese Commissie nooit zelf, op eigen initiatief, de aan nationale toezichthouders of opsporingsambtenaren toegekende controle- of opsporingsbevoegdheden uitoefenen. Het optreden van Euro-controleurs, eerst mogelijk na vooraf gaande melding, moet er op gericht zijn nationale toezichthouders te assisteren en te vergezellen.

Ten slotte is, in het licht van de samenwerking tussen nationale en Europese toezichthouders, terecht de vraag opgeworpen op grond van welke bepalingen deze toezichthouders hun werk doen: EG-verordeningen, nationaal recht waaronder de ver strekkende afdeling 5.1 derde tranche Awb of een combinatie van beide? ${ }^{137}$ In tegenstelling tot het voorontwerp afdeling 5.1 derde tranche Awb, verschaft de toelichting op art. 5.1.5 wetsvoorstel derdle tranche Awb enige duidelijkheid ter zake. In gevolge het derde lid van art. 5.1.5 kunnen toezichthouders zich laten vergezellen van door hen aangewezen personen, bij voorbeeld technisch deskundigen in verband met monsterneming. Ook EG-ambtenaren, atan wie in bepaalde EG-regelingen wordt opgedragen toe te zien op de toepassing

132. Verordening v.d. Raad v.d. EG houäende algemene regelen m.b.t. de controles in de wijnbouwsechor, 2048/89, Publ. EG L 202, 1989.

133. Aldus cital weer gegeven door J.A.E. Vervaele, EEG-frande en Europees economisch recht, a.w.., p. 17 .

134. Zie o.a. art. 15 EEG-Verordening biologische produktiemethode $\mathbb{1}$.d. 24 juni 1991, 2092/91, Publ. EG 1991, L 198.

135. R.J.G.M. Widdershowen, t.a.p., p.57, verwijst naar Zwarrweld, HvJ EG (C-2/88) 13 juli 1990 , SEW, nr.11, 1990, pp.824-830, als mede het vergelijkbare Weddel, HwJ EG (54/90) 18 febr. 1992, in: NJBrechtspraak, ni. 7, p. 168 .

136. I. Vervaele, Bijzondere opsporingsdiensten: rechtshandhawing wan het Europees economisch recht evt EEG-fraude, in: C.J.C.F. Fijnaut en F.G.A. Lely (red.), t.a.p., pp.97-111, i.h.b. p.107, v reest aantasting er van door Euro-controleurs; Ook J.A.E. Vervaele, EEG-fraude en Europees economisch strafrecht, a.w., pp.15-19, i.h.b. p.19; Vgl. J.A. Hofman e.a., Beginselen wan Europees constitutioneel recht, Deventer, 1993, p.57.

137. A.J.C. de Moor-van Vugt, Zo begrijpt Bonnes er niks van, in: NTB-speciall, jan. 1994, pp.25-26, i.h.b. p. 26; J. Bonnes, a.w., pp.162-178. 
of handhaving van die regelingen, kunnen nationale toezichthouders vergezellen bij hun taakuitoefening. Herhald wordt dat de aan nationale toezichthouders toekomende bevoegdheden niet kunnen overgaan op EG-ambtenaren. Het vergezellen van nationale toezichthouders kan hoogstens hulpverlening omvatten. De ex art. 5.1.5, derde lid, Awb aan EG-ambtenaren toekomende "bevoegdheid tot "controle op controle" houdt dus niet het recht in om zelf rechtstreeks toezicht uit te oefenen op burgers en bedrijven" 138,139

138. Mvt voorstel derde tranche Awb, TK 1993-1994, 23700, n. 3, p. 144.

139. $\mathrm{Y}$. Buruma, De bijzondere politiediensten in het spanningsveld tussen nationale en unionaire onnwikkelïngen, in: DD, nr.10, 1994, pp.1031-1055, houdt hier zijn hart wast. Juist het, ex art. 5.1.3 Awb aan Nederlandse toezichthouders gestelde, magere en onafgebakende noodzakelijkheidscrite rium boezemt auteur angst in voor een wel zeer vrijelijke invloed wan EG-ambtenaren. Ten gevolge van "buitengewoon weinig beperkingen" in Nederlandse wetgeving hebben toezichthouders hier te lande "wauwelijks argumenten om verzoeken van EG-ambtenaren te weigeren" (p.1053). 


\section{Geraadpleegde literatuur}

Addink, G.H. \& Sluis, M.J.

- De Awb op scherp; Kanttekeningen bij het hoofdstuk handhaving, in: NTB, nr.2, 1992, pp. $33-45$;

- Het vijfde hoofdstuk van de Awb: handhaving in materieel perspectief, in: NJB, nr.35, 7 okt. 1994, pp. 1201-1208.

Audretsch, H.A.H.

Communautaire controle; Het toezicht in de EG op de naleving van de verdragsverplichtingen door de lidstaten, Europese monografieën nr.20, dissertatie RUU, Deventer, 1975.

Barents, R.

Reactie sanctionering gemeenschapsrecht, in: NJB, nr.40, 11 november 1993, pp.1447-1448.

Bedrijfswereniging voor de haven- en aanverwante bedrijven, binnenscheepvaart en visserij

De schroom voorbij, aan de daad het woord: beleidsplan handhaving 1993, A'dam, 1993.

Berg, A.J.

Herziening Visserijcontrolebeleid" naar een Europees Handhavingssysteem?, in: SEW, nr.12, 1994, pp.800-818.

Betlem, G.

Richtlinconforme witleg: interpretatieve doorwerking van EG-recht, in: IER, nr.4, 1994, pp. 104110.

Bleeker, K.A.M.

Verantwoorde communautaire sanctionering van het gemeenschapsrecht?, in: NJB, nr.28, 5 augustus 1993, pp.1009-1013.

Bonnes, J.M.

- Uitvoering van EG-verordeningen in Nederland, dissertatie KUB, Zwolle, 1994;

〜 Column; Een modelbepaling voor de communautaire regelgeving?, in: RegelMaat, nr.1, 1994 , pp. 16-17;

- Europese berichten: EG-rechtelijke tips woor de decentrale wetgever, in: RegelMaat, nr.1. 1995, pp. $42-48$.

Bos, P.V.F.

Van ontwoogding naar ontgoocheling of van interstatelijkheid naar communautaire dimensie?; De adviesaanvraag aan de Sociaal-Economische Raad en de Commissie economische mededinging inzake een nieuwe Mededingingswet, in: NJB, nr.27, 15 juli 1994, pp.906-911.

Bracke, N.E.

Horizontale werking van richtlijnen?, in: RegelMaat, nr.5, 1994, pp.205-208.

Brummelman, W.

Zware boetes voor kartonfabrikanten, in: NRC, 14 juli 1994, p. 12.

Buruma, $Y$.

- De bijzondere politiediensten in het spanningsveld tussen nationale en unionaire ontwikkelingen, in: DD, nr.10, 1994, pp.1031-1055;

- De repressieve kant van de Europese Unie, in: JV, nr.1, 1995, pp.37-60.

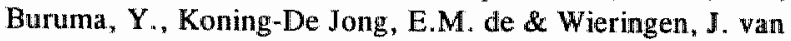

Bijzondere opsporingsdiensten; Inleiding in de sociaal-economische fraudebestrijding, Arnhem, 1990.

Doelder, H. de \& Hulst, J.W. wan der EEG-sancties en ne bis in idem, in: SEW, nr.11, 1993, pp.722-733.

Due, 0 .

Artikel 5 van het EEG-verdrag, Een bepaling met een federaal karakter?, in: SEW, nr.5, 1992, pp.355-366. 
Esch, B. van der

De woltoouing van de interne markt voor goederen en diensten volgens art. $8 A$ EEG en het Witboek van 1985; enkele juridische kanttekeningen, in: SEW, nr.9, september 1994, pp. 559-578.

Flier, P.J. van der \& Oosterkamp, J.S. van den

Voorvarende implementatie van EG-richtlijnen, mede in het licht van de Awb en de Aanwijzingen voor de regelgeving, in: SEW, nr.11, 1994, pp.727-752.

Fijnaut, C., Huybrechts, L. \& Wijngaert, Ch, wan den (red.)

EG-fraudebestrijding in de praktijk, centrum voor de studie van de toepassing van het gemeenschapsrecht in financiële en strafrechtelijke aangelegenheden, Antwerpen/Apeldoorn/Brussel, 1994.

Guldenmond, R.M.A.

Strafrechtelijke handhaving van gemeenschapsrecht; Een analytisch overzicht van de strafrechtelike handhaving van het afgeleide gemeenschapsrech in de Nederlandse rechtsarde. Arnhem, 1992.

Ham, A.D.

Op weg naar een nieuwe Wem, in: SEW, nr.7/8, juli/augustus 1994, pp.492-508.

Hermann, R.

Van drukpers tot telematica; Notities over vriheid van informatie en technologische ontwikkelingen: mogelijkheden en belemmeringen, Deventer, 1986.

Hofman, J.A., Sap, J.W. \& Sewandono, I.

Beginselen van Europees Constitutioneel Recht, Deventer, 1993.

Hoogteijling, J.H.

Nederland en de EG: knelpunten en oplossingen, in: OB, nr.12, 1993, pp.13-19.

Kummeling, H.R.B.M. \& Mus, J.B.

De inviloed van het gemeenschapsrecht op de nationale rechtsorde, in: Burkens, M.C. \& Kummeling. H.R.B.M. e.a., EG en grondrechren; Gevolgen van de Europese integratie voor de nationale grondrechienbescherming, Zwolle, 1993, pp.1-33.

Landen, D. van der

Naar een GeUNIEficeerd strafrecht?, in: DD, nr.9, 1994, pp.921-939.

Maas H.H. \& Haersholte, J.C. van

Tijdige wïvoering van EG-regelgeving in Nederland door middel van wetgeving, in: SEW, wr.11. 1994 , pp.703-726.

Marle, C.H. van \& Nijs, T.A.H. de

Europees recht en Nederlandse decentrale overheden, VNG, 's-Gravenhage, 1991.

Mennens, $\mathbb{E}$.

De UCLAF, in: Doelder, H. de (red.), Bestrijding wan EEG-fraude, Arnhem/Antwerpen, 1991 , pp. $33-44$

Mok, M.R.

Kartel kartonfabrikanten verboden, in: TVVS, nr.12, 1994, pp.328-329.

Moor-Van Vugt, A.J.C. de

- Symbiose van evenredigheidstoetsen?, in: NTB, nr.1, 1993, pp.26-37;

- Zo begrijpt Bonnes er niks van, in: NTB-special, nr.1, januari 1994, pp.25-26;

- Maten en gewichten; Het evenredigheidsbeginsel in Europees perspectief, dissertatie KUB, uitgave Schoordijk Instituut: Centrum voor wetgevingsvraagstukken, 1995.

Moor-Van Vugt, A.J.C. de \& Vermeulen, E.M.

Kroniek: Europees bestuursrecht, in: NTB, nr.1, 1995, pp.10-18.

Mortelmans, K.J.M. 
De interne markt en het facettenbeleid na het Keck-arrest: nationaal beleid, vrij werkeer of harmonisatie, in: SEW, nr.4, 1994, pp.236-250.

Mortelmans, K.J.M.\& Temmink, H.A.G.

De rechtstreekse en onrechtstreekse werking van EG-richtlijnen, in: Ars Aequi, $\pi \mathrm{r} .12,1994$, pp. 845-858.

Oosterkamp, J.S. van den

Een nieuwe mededingingswet: de adviezen van de Sociaal-Economische Raad en de Commissie economische mededinging, in: SEW, nr.5, 1995, pp.336-356.

Ottervanger, T.R. \& Nijhuis, M.T.

Wijziging Wem ter vergroting van de effectiviteit, in: SEW, nr.7/8, juli/augustus 1994, pp.481-491.

Pisuisse, C.S.

Elementair Europees Gemeenschapsrecht, Groningen, 1991.

Pijnacker Hordijk, E.H.

Emmot, en hoe verder?, in: NJB, nr.15, 15 april 1994, pp.499-504.

Prechal, S.

Kroniek van het Europees recht, in: NJB, nr.10, 10 maart 1995, pp.364-370.

Raat, F. de

Brussel deelt harde klappen uit aan kartels, in: NRC, 28 juli 1994, p.11.

Rood, E.

Overzicht EEG-en Nederlands levensmiddelenbeleid en -recht: inhoud, organisatie, tenuitvoerlegging, handhaving, Apeldoorn/Arnhem, 1993.

Schermerhorn, M.E.

Verificatie-bevoegdheid EG-Commissie: na Hoechst en Dow meer duidelijkheid, in: SEW, nr.1, 1994, pp.27-44.

Simons-Vinckx, M.W.L.

Toelating van bestrijdingsmiddelen; Toekomstige regelgeving, in: AR, nr.8, augustus 1993 , pp.387-397.

Tweede Kamer

- Notitie over verhouding gemeenschapsrecht tot strafrecht, TK 1991-1992, 22300 VI, nr.39;

- Wetswoorstel wijziging Wet economische mededinging. TK 1992-1993/1993-1994, 23306, ars. 2/354;

- Jaarverslag/begroting Toetsingscommissie voor wetgevingsprojecten, TK 1993-1994, 23400 VI, nrs. 5/49;

- Notitie over samenwerking op het gebied van justitie en binnenlandse zaken in het kader van het Unie-verdrag, TK 1993-1994, 23651, nr.1;

Verwaele, J.A.E.

- EEG-fraude en Europees economisch strafrecht, Deventer, 1991, pp.1-23/165-177;

$\sim$ Bijzondere opsporingsdiensten. rechtshandhaving van het Europees Economisch rechten EEGfroude, in: Fijnaut, C.J.C.F. \& Lelly, F.G.A. (red.), ECD-bundel economisch strafrecht en justitieel politie-optreden, Lochem, 1990, pp.97-111;

- Handen en tanden van het (gemeenschaps)recht, oratie RUU, 18 februari 1994, Deventer, 1994.

Vervaele, J.A.E. (red.)

- Harmonisatie van het economisch straf(proces)recht in de EEG, in: Doelder, $\mathrm{H}$. de, Bestrijding van EEG-fraude, Arnhem/Antwerpen, 1991, pp.129-142;

$\sim$ Bestuursrechtelijke toepassing en handhaving wan gemeenschapsrechtin Nederland, Europese monografieën nr.41, Deventer, 1993.

Vervaele, J.A.E. \& Widdershoven, R.J.G.M.. 
Bestuurlijke handhaving van visserijregelgeving; Een studie naar de relatie tussen EEG-recht en nationale handhaving, Utrecht, 1991.

Vos, A., Driessen, P.P.J. \& Glasbergen, P.

Handhaving in owerweging; Strategische afwegingen bij de handhaving van milieuwetgeving, uitgave stichting maatschappij en politie, Arnhem, maart 1993.

Widdershoven, R.J.G.M.

Gemeenschapsrecht bestuursrechtelijk gehandhaafd, in: NTB, nr.1, 1993, pp.47-59. 
Hoofdstuk 14

\section{Commissariaat voor de media}

\section{$\$ 14.0$ Communicatievrijheid ten aanzien van radio- en televisie- uitzendingen ${ }^{\text {t }}$}

Het Commissariaat voor de Media in zijn besluitvorming rekening houden met de vrijheid van meningsuiting, die is gegarandeerd in art. 10 EVRM jo. art. 7 Grondwet. Uit onder meer de jurisprudentie op dit verdragsartikel is het volgende af te leiden.

Ten eerste, de lidstaat onthoudt zich van het maken van inbreuk op het grondrecht van communicatievrijheid. En de mogelijkheden, beperkingen aan bedoeld recht te stellen, zijn geclausuleerd.

Ten tweede, een regulerend en toezichthoudend overheidsorgaan ${ }^{2}$, als de rechtspersoon Commissariaat voor de Media ${ }^{3}$, draagt zorg $^{4}$ voor een pluriforme, toegankelijke en een door continuïteit ${ }^{5}$ en kwaliteit gekenmerkte omroep. Volgens traditionele opvatting is dat een zorg in die zin, dat de daarvan uitgaande overheidsinterventie in de vorm van ordeningsrecht en economische steun bij draagt aan een rechtvaardige verdeling van de schaarse ${ }^{6}$ distributiekanalen ${ }^{7}$ en orde in de ether. En naar modernere mening richt die zorg zich op stimulering van sociaal-culturele doelstellingen ${ }^{8}$. Hiertoe geniet het Com-

1. J. van den Beukel ,Omroep in de EG. integratie en culthreel protectionisme, in: AA, nr.5, 1989, pp. 101106; J. van den Beukel, Kroniek EG en omroep, in: MF, nr.6, 1995, pp.71-75; J" van den Beukel, Toegang tot de velewisiemarkr, Overheidsbeperkingen van de toetreding wan programma-aanbieders in Nederland. Groot-Brittanië en Duitsland in her licht wan her EG-recht, diss. UWA, Deventer, 1995; P.J. Boon, Zonder voorafgaand werlof, AA staats-en bestunursrecht nr.2, vijfde dnak, 1993, pp .45-79/104-113: M.C. Burkens en H.R.B.M. Kummeling, Gemeenschapsrecht en de omroep, in: M.C. Burkens en H.R.B.M. Kummeling (red.), a.w., pp.259m297; N.A.N.M. van Eijk, Omroepvrijheid en overheidsbe moeienis, diss. UvA. A'dam, 1992, pp.135-182; M.A. Fierstra, A.C.M. Nugter en W.F. Korthals Altes, Vrij verkeer wan informatie in Europa, preadviezen NVE, NVIR en VMC, 15 nov. 1991, A'dam, 1991 , pp.9-38/63-83; A. W. Hins, Ontvangstwripheid en buitentandse omroep, Deventer, 1991; W. Hins, Her HuJ als hoeder van grondrechten, in: MF, ar.7/8, 1993, pp.74-76; M. Kohnstamm, De nationale televisiewoortiening en cultuurpolitieke argumenten in het Europees recht, in: NJB, nr.35, 15 okt. 1988, pp.1267$1271_{*}^{*} \mathrm{~J}, \mathrm{M}$. de Meij, Uitingsvrijheid; De urije informatiestroom in grondwettelik perspectief, A 'dam, 1989 , pp. 175-187: J.J.A. Pelle, Juridische marges voor het Nederlandse omroepbeleid, diss. EUR, Zwolle, 1993, pp.68-129, L. van Vollenhowen, Omroep en pers, in: F.W. Grosheide, Hoofdstukken mediarecht, Alphen a/d Rijin, 1991, pp.11-46, i.h.b. pp. 23-30. 
missariaat zekere beleidsruimte. Die ruimte is ten aanzien van binnenlandse omroep weer groter dan voor buitenlandse programma's die op het grondgebied van de Nederlandse staat worden doorgegeven.

\section{$\S 14.1$ Overheid op afstand en deregulering}

Met instelling van het Commissariaat voor de Media krijgt het adagium "overheid-opafstand" gestalte. Het kabinet meent dat sprake is van afstandelijkheid in de zin dat "het kabinet wil pogen het dagelijks reilen en zeilen van zendgemachtigden en het toezicht op de nalleving van bepalingen inzake de media enigermate te depolitiseren om elke schijn van programma-inmenging tegen te gaan. Bovendien zal beperking van het aantal toezichthoudende instanties de doelmatigheid kunnen vergroten." 9

Het afstandelijkheidsbeginsel kan problemen oplossen, maar roept tegelijkertijd mogelijk nieuwe problemen op. Gevreesd is dat uitoefening wan, de aan regering, minister en

2. In gevolge de, harmonisatie beogende, Europese richtlin van 3 oktober 1989 inz. coördinatie van bepaalde wettelike en bestwurstechtelijke bepalingen in de lidstaten inzake de uiroefening van omroepactiviteitent (Televisterichtlyn) (89/552/EG, Publ. EG, L 298/23, 17 okt. 1989) is elke lidstalat verplicht eem met controle en toezicht belast orgaan te benoemen of aan te wijzen. De zelfde verplichting is opgenomen in overwegend gelijk tuidende Europese convertie inzake grensoverschrijdende televisie (Europeall Treaty Series mr. 132, dec. 1989. Trbl. 1989, 103). Nederlandse toetreding tot die conventie is niet te verwachtem. Toetreding is ook weinig zinwol volgens M.C. Burkens en H.R.B.M. Kummeling, t.a.p. , p.269.

3. Ex, i.h.b., art. 9 junctis art. 134 en artt. 138-139 Mediawet. Zie overigens de Beschikking CvdM 6 april 1988 houdende vaststelling besluitworming en werkwijze College CvdM, Stcrt. 1989, 93.

4. Over deze, mede uit art. $7 \mathrm{Gw}$ juncto art. $22 \mathrm{Gw}$ voort vloeiende zorgplicht o.a. J.C. Ambak, IIJ. van Cullenburg en E.J. Dommering, Verbinding en ontwlechting in de communicatie, $A^{\prime} \mathrm{dam}, 1990 ; \mathbb{P}^{\prime} \mathrm{J}$. Boukema, Massamedia en grondrechten, in: E.M.H. Hirsch Ballin, M.H. Kobussen, A.J.C. de Moor-van Vugt en J.A.F. Peters (red.), Massamedia en staatsrecht, staatsrechtconferentie 8 dec. 1988, KUB, Zwolle, pp. 10-25, i.h.b. p.15, vgl. pp.2-3 en pp.78-79; F.J.P.M. Hoefnagel, Wetgever en cuituur, Zwolle, 1988, pp.79-93/156-194/281-319; A.J. Nieuwenhuis, Perswrijheid en persbelteid, A'dam, 1991, p.76; G.W. Noomen, Overheid en ommoep, in: H. van der Graaf en J.P. Verhoogt, Minder staat, meer somenleving; Beschouwingen over de terugtredende verzorgingsstaat, VU-studie over politiek, bestuur en communicatie, A'dam, 1990, pp.71-82; T. Pronk, De grondwet als culturele opdrachrgever, in: "T. Pronk en G.A.I. Schuijt (red.), Hoe wrij is de kunst? Onderdrukking, censuur en andere beperkingen aan de wrijheid wan expressie. A "dam, 1992, pp.87-92.

5. J.C. Ambak, J.J. van Cuilenburg. E.J. Dommering e.a., Verbinding en Ontwlechting in de Communicatie, Amsterdam, 1990, pp.71-72.

6. Weliswaar is de technische schaarste tegenwoordig grotendeels voorbij. Aldus meent o.a. de Mediaraad, Advies inzake herstructurering beleid informatievoorziening, Deel IT. de informatieproduktie, 27 jan. 1994 . p.11, die concludeert dat daandoor de ratio voor vergunningverlening voor de exploitatie van sommige elektronische informatiediensten vervalt. Verdwijnt zo de technische scharste, nu is er wel (mede) economische schaarste die vooral nieuwe private partijen, die de omroepmarkt willen betreden, voelen. N.A.N.M. van Eijk, Omroepwrijheid en onroepbemoeienis, Amsterdam, diss. UvA, 1992, p. 187.

7. Publieke ontroep in Nederland, TK 1990-1991, 22147, nr.2, p.7.

8. Aldus is de oude opvatting achterhaald in ogen van D"66 kamerlid Wolffensperger, UCV d.d. $7 \mathrm{dec}$. 1992. Hij vervangt publieke ommop door publieke programmering. In zijn optie draagt de overheid zorg voor financiering van bijzondere pluriformiteitsbevorderende programma's. Overige programmering is alleen rijp voor blootstelling aan marktwerking.

9. Medianota, TK 1982-1983, 18035, nr.1, pp.8-10; Vgl. Mvt Mw, TK 1984-1985, 19136, nirs.1-3, pp. 101-102. 
parlement nog voorbehouden, belangrijke algemeen ordenende en budgettaire bevoegdheden het deregulleringsprincipe geweld aan doet. ${ }^{10}$ Externe verzelfstandiging versterkt zelfs de noodzaak tot meer en gedetailleerde regelgeving. ${ }^{11} \mathrm{Bij}$ een evaluatie ter gelegenheid van het eerste lustrum van het Commissariaat voor de Media blijkt inderdaad dat "de regelgeving betreffende de omroep, waarmee het commissariaat nu moet werken, wel heel gedetailleerd is". ${ }^{12}$ In dat kader is trouwens gepleit om aan het Commissariaat voor de Media ruimere en ook regelgevende bevoegdheden toe te delen. Hierdoor kan het commissariaat mede flexibeler optreden in het snel veranderende medialandschap.

De term overheid op afstand, aangewend in omroepland, doet kennelijk weinig goed. Zij wordt al snel een "loze kreet" genoemd. ${ }^{13}$ Bovendien wordt opgemerkt dat het principe van uit de omroep bezien niet meer betekent dan "lood om oud ijzer". " De term overheid op afstand is kortom "misleidend", de oude meester wordt "vervangen door nieuwe meesters en het is nog maar de vraag of de laatst genoemde minder streng zullen zijn". 15

Het CvdM vindt dat het afstandelijkheidsprincipe "nog al eens met voeten wordt getreden". ${ }^{15}$ Het commissariaat acht het wenselijk dat de "consequentie van het instellen van een zelfstandig bestuursorgaan ruimhartiger getrokken dient te worden". " En bij het voltooien van de veranderingen in de mediawetgeving acht het Commissariaat voor de Media het "verbazingwekkend", dat de "in 1988 gecreërde afstand ijlings is teruggenomen". 18:

Nare bijkomstigheid bij dit alles is, dat de communicatie tussen het Commissariaat voor de Media en het betrokken departement de laatste jaren spaak loopt. ${ }^{19}$

\section{$\S 14.2$ Taakstelling Commissariaat voor de Media}

In de eerste fase van wijziging van de Mediawet, waarin ruimte wordt gecreëerd voor commerciële omroep, komen de hoofdzakelijk repressieve ${ }^{20}$ werkzaamheden van dit Commissariaat voor de Media neer op het volgende.

Het commissariaat is, volgens aanvankelijk voorstel, in elk geval belast met:

10. F.I.P.M. Hoefnagel, Wetgever en cultum, 1988, Zwolle, p.1911, Vgl. J.P. Balkenende, a.w., pp.170-177; Vgl. A. W. Hins e.a., De Mediawet: onde wijn in lekke zakken, in: NJB, nr.41, 22 now. 1986, pp. 1301 w 1305, i.h. b. p.1301.

11. N.A.N.M. van Eijk, a.w., p.225.

12. E. Lambooy, I. van Steenis, A. van Raalte en M. Vermeeren, Uittreksel verslag serminar 'Her CvdM als $z b 0^{*}$ "Gerard Heijne den Bak-symposium, Hilwersum, 21 april 1993, p.4.

13. B. Hugenholtz, De Mediawet: wier wetten voor de prijs van een, in: AMR, nr.2, april 1985. pp.26-27.

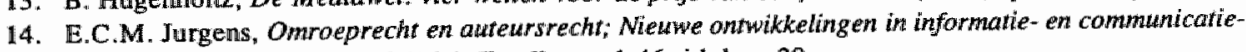
recht, preadivies CJV, 7 mei 1986, Zwolle, pp.1-46, i,h.b. p. 30.

15. A.W. Hins, Owerheid op afstand?, in: AMI, nr.1, febr. 1986, pp.5-7, i.h.b. p.5.

16. CvdM, Jaanverslag 1991, Hilversum, 1992, p.6.

17. CraM, Jararverslag 1992. Hilversum, 1993, p.5.

18. CvdM, Jaarverslag 1993, Hilversum, 1994, p.6.

19. Piet nan der Sanden. het is mooi geweest, in: Comedia, nt 34, sept. 1994, p.5.

20. Wat betreft toezicht op reclameboodschappen en -uitingen uitgemaakt in Q8, ARRS 8 aug. 1991 , R.01.89.0485, in: MF, nr.1, 1992, rechtsprakbijlage pp.3-5, i.h.b. p.4. 
a. toewijzing en verdeling van zendtijd op landelijk, regionaal en lokaal niveau (ex artt. $31-43 \mathrm{~d} \mathrm{Mw^{21 }}$ junctis artt. 2-6/18-22 Mediabesluit ${ }^{22}$ );

b. intrekking hiervan ${ }^{23}$ of andere boeteoplegging mogelijk onder dwangbevel waartegen verzet mogelijk is (ex artt. 44-47 Mw junctis artt. 134-137 Mw, artt. 23-24 Mb en artt. 2-4 Sanctieregeling omroep ${ }^{24}$, als mede ex artt. $135-137 \mathrm{Mw}$ junctis artt. 8-15 So). De aan het commissariaat toekomende sanctiebevoegdheden tot oplegging van een administratieve boete ${ }^{25}$ volgens een puntensysteem-leidraad berekend tot maximaal $f 200.000,00$, intrekking van verleende toestemming of ontheffing, vermindering van zendtijd, intrekking van zendtijd, en intrekking van de vergunning voor het verzorgen van abonneeprogramma's voor televisie voor uitzending door middel van een draadomroepinrichting, moeten zorgvuldig worden gehanteerd, d.w.z. sanctionering moet voldoen aan eisen van rechtszekerheid, gelijkheid, voldoende motivering en het willekeurverbod ${ }^{26}$;

c. verlening vergunning voor abonneeomroep op de kabel (ex art. $73 \mathrm{Mw}$ ) of vanaf 1996 tienjarige zendtijdconcessieverlening voor binnenlandse commerciële landelijke omroep (ex artt. 71a-7॥d $\mathrm{Mw}$ junctis artt. 52-52a Mb) ${ }^{27}$ en intrekking er van (ex art. $71 \mathrm{e} \mathrm{Mw);}$

d. onverbindendverklaring van NOB-besluiten wegens strijd met het recht of het algemeen belang ${ }^{28}$, als mede het verzoek aan de betrokken minister om een besluit van de Wereldomroep te vernietigen of te schorsen wegens strijd met het recht (ex art. 80 , derde lid, Mw);

e. verdeling geldelijke middelen over zowel landelijke als regionalle omroepen (ex artt. 100-109 Mw), beheer van omroepreserves en overig financieel toezicht (ex artt. 11$17 \mathrm{Mb}$;

f. toezicht op reclame- en nevenactiviteiten door omroepen (ex artt. 52/55-57/64/71 Mw junctis artt. 25a-32 Mb en artt. 16-17 So, als mede ex artt. $711 / 72$, zevende lid, $\mathrm{Mw}$ junctis art. $128 \mathrm{Mw}$ en artt. $52 \mathrm{~b}-52 \mathrm{M} \mathrm{Mb}$ ), daarnaast controle op naleving van volledige programmavoorschriften (ex art. $50 \mathrm{Mw}$ junctis artt. $8 / 24 \mathrm{a} \mathrm{Mb}$ ) en controle op naleving van regels betreffende het omroepaandeel van eigen produkt. ${ }^{29}$

21. Mediawet, Stbl. 1987, 249, gewijz. 4 juni 1992, Stbi., 422.

22. Mediabes/wit. 2 december 1992, Stbl. 1992, 617.

23. Met inachtneming van de abbb in gevolge $M$ va $M$ w, TK 1985-1986, 19136, nr.7, p.72.

24. CvdM, Sancheregeling omroep 1993 (1994), Hilversum, 8 sept. 1993, aangepast aan Awb-termijnend.d. 9 maart 1994

25. Het administratieve boetestelsel is verkozen uit "oogpunt van uniformiteit voor een gelijk stelsel m. b.t. omroepinstellingen". Bij strafrechtelijke sanctionering moeten "werschillende rechterlijke colleges oondelen over inhoudelijk gelijke problemen hetgeen onwenselijke verbrokkeling in de rechtspraak teweeg zou brengen". Mwt Mw, "TK 1984-1985, 19136, nrs.1-3, p.97; Zie over deze, aan het CvdM toekomende, sanctiemogelijkheid J.J.C. Kabel, Bestumrlike boetes en de Mediawet, in: W.G.A. Hazewindus en O.J.D.M.L. Jansen, Van boeteatelier tot baetefabriek, Deventer, 1995, pp.143-164.

26. Sanctieregeling omroep 1994, p.9.

27. De tweede fase van wijziging van de Mediawet makt overigens korte metten met deze termijn en deze takstelling.

28. NCRV vs. CVdM, Vz ARRS 25 febr. 1993, KG 1993, 166

29. Zie de verschillende CvdM-jaarversłagen woor de, nog al eens indringende, mate warin deze taken worden gerealiseerd. 
Het (overigens tegenwoordige) toezicht dat het commissariaat, als uitvloeisel van laatst genoemde controletaak, uitoefent op sponsorreclame vindt tegenwoordig afzonderlijk regeling in de wetsvoorstellen inzake sponsoring bij de publieke omroep. ${ }^{30}$ Bewust kiest de regering voor een wettelijke basis van sponsorregels. Ter wille van de bescherming van de consument, waartoe de in de wetsvoorstellen opgenomen plicht tot sponsormelding en de plicht een programmastatuut tot stand te brengen (ter waarborging van in elk geval redactionele onafhankelijkheid) dienen ${ }^{31}$, wordit het beginsel van zelfregulering verlaten. ${ }^{32}$

De voorstellen betekenen versterking van het toezicht op externe producenten. ${ }^{33}$ Het wettelijk instrumentarium van het Commissariaat voor de Medlia wordt verduidelijkt en aangescherpt. Het commissariaat krijgt toezichtsbevoegdheden die het reeds heeft ten aanzien van binnenlandse omroepinstellingen en verzorgers van abonneeprogramma's als mede programma's bedoeld in art. 167 , eerste lid, Mw. ${ }^{34}$ Het reeds bestaande art. 138 is geredigeerd in de zin van de standaardbepalingen van de aanwijzingen voor de regelgeving. ${ }^{35}$ De belangrijkste wijziging biedt het overeenkomstig de motie-Van Nieuwenhoven/Beinema ${ }^{36}$ veranderde art. $139 \mathrm{Mw},{ }^{37}$

30. Woarstel wan wet tot wijziging van bepalingen van de Mediawet met het oog op de witwoering van richtijin 89/552/EEG van de Raad van de EG d.d. 3 okt. 1989 betreffende de coñdinatie van beparalde wentelijke en bestuntsrechtelijke bepalingen in de lidstaten inzake de uitoefening van televisie-activiteiten (Publ. EG L 298) en het stellen wan overeenkomstige regels inzake de witoefening wan radio-omroepactiviteiten. TK 1993-1994, 23752, nrs.1-3 e.v. , zie ook gewijzigd wetsvoorstel EK 1994-1995, 23752, nr. 199.

31. Zie respectievelijk art. $52 \mathrm{~b} \mathrm{Mw}$ en art. $64 \mathrm{~b} \mathrm{Mw}$.

32. Wijziging $M$ w i.v.m. sponsoring, TK $1993-1994,23752$, nr.3, p.4.

33. Sponsoring publieke onroepen beperkt, in: NRC, 13 maart 1993, p.2: N. van Eijk, Omroepen behoeven nieuwe regels over sponsoring, in: NRC, 7 april 1993, p.8; J.J.C. Kabel, Geld en grammatica: rechtsvindingsmethodiek wan de ARRS inzake sponsoring en art. 56 Mw, in: MF, nr.7/8, 1993, pp.77-80.

34. In geschil over definities televisie- en teletekstprogramma's (i.w.m. het gebruik van televisiefrequenties voor verzending van alfanumerieke boodschappen, videotex en beeldkrart) blijki duidelijk dat, in onderlinge samenhang bezien, sprake is van een geslotern systeem van de Mediawet en de Wet telecommumicathevoorzieningen, welke wetten trouwens we! onderling af te bakenen gebiedlen bestrijken. Zie 0 .a. Afwijing voorkeursrecht Nozema, CBB 27 jan. 1993, in: NJB, nr.22, 3 juni 1993, pp.281-282 (rechtspraakbijtage nr.19), zie ook: Mediaforum, nr.5, 1993, pp. B-57-B61; Naar aanleiding van die uitspratk ARRS 19 maart 1993, in: Computerrecht, nr. 3, 1993, pp. 124-128; Zie ower verhouding wan be ide wetten ook De Vrije Ether en Ceryx ws. ministerie van VoW (est Sky Radio Ldd.). CBB 22 juni 1994, in: Mediaforum, nr.9, 1994, pp.B78.B81.

35. Zie Gewijzigd woorstel inzake verandering en aanvulling Mw i.w.m. sponsoring. TK 1994-1995, 23752 , nr. 199 , pp.8-9. Art. $138 \mathrm{Mw}$ geeft het CvdM een inlichtingenbevoegdheid, voor zover dat redelijkerwijs is vereist. Art. 138a Mw voorziet in een inzagebevoegdheid, met copieermogelijkheid (waarvoor papieren cijdelijk kunnen worden meegenomen ${ }_{\text {, }}$ onder afgifte wan schriftelijk bewijs), voor zover dat redelijkerwijs modig is. Art. $1386 \mathrm{Mw}$ makt plaatsbetreding (eventueel met vergezelling van door het CvdM aangewezen personen) mogelijk, voor zover redelijk. Art. $138 \mathrm{c} \mathrm{Mw}$ bewat een medewerkingsplicht woor onder toezicht gestelden. Art. 138d Mw legt onder toezicht gestelden de plicht op om programma "s twee weken na uitzending te bewaren en desgevraagd ter beschikking te stellen van het CvaM. Art. 138e, eerste lid. Mw verklaant voorgaande bepalingen van toepassing op de We rellomroep. Het tweede lid daarvan slluit ze uit voor abonnee- of art. 167-programmaverzorgers, die onder de bevoegdheid wallen van een andere EG-lidstaat dan Nederland of van een andere staat die partij is bij de overeenkomst inzake de EER. Ten slotte, bij uitoefening van haar toezichtsbevoegdheden moeten leden of medewerkers van het Cw $\mathrm{dM}$ zich. ex het nieuw ingevoerde art. 134a Mw, kunnen legitimeren.

36. TK 1992-1993, 22800 XVI, nr.30. 
Daardoor zijn de omroepinstellingen voortaan verplicht er voor te zorgen dat het Commissariaat voor de Media, weliswaar uitsluitend bij een (vermoeden van een) limitatief in de Mediawet opgesomd aantal overtredingen, inzage wordt verschaft in de boeken van de producenten, die reclamegevoelige programma's maken. ${ }^{38}$ Deze bevoegdheid wordt het commissariaat toegekend in een derdenbeding ${ }^{39}$, dat een omroepinstelling daartoe met een externe producent moet sluiten. Dit contract geldt ook tegen een persoon aan wie een betrokken externe producent zelf weer een deel van de produktie uit besteedt (kettingbeding).

De sponsorregels beogen consumenten op neutrale wijze informatie te verstrekken over financiële betrokkenheid van derden bij totstandkoming van sportprogramma's en programma's van culturele aard. De regeling inzake sponsoring, in het bijzonder art. $52 \mathrm{~b}$ $\mathrm{Mw}$, bepaalt dat in de eerste of in de laatste vijf seconden van gesponsorde programmauitzendingen, niet beeldvullend en -voor zover vermelding niet staat op aftitelrol (of aantitelrol)stilstaand vorm gegeven, namen of handelsmerken en logo's of beeldmerken ${ }^{40}{ }^{41}$ van alle sponsors bekend worden gemaakt. Hoewel, ex art. $52 \mathrm{a} \mathrm{Mw}$, nieuws, actualiteiten, politieke informatie, kinder- en consumentprogramma's, even als sluikreclame en commerciële publiciteit verweven in dialogen of met lokaties, altijd zijn uitgesloten van sponsoring, bestaan mogelijkheden sponsoractiviteiten ten aanzien van educatieve en verstrooiende programma's uit te breiden. Speciaal voor commerciële omroepen geldt de sponsorregel dat aan begin of eind van een programma altijd de naam of het beeldmerk van de sponsor moet worden vermeld. Voor commerciële omroepen geldt t.a.v. nieuws-, journaal- en actualiteitenberichtgeving een zelfde verbod van sponsoring als voor de publieke omroepen.

37. Tenecht meldt de Mvt woorstel verandering of aanvalling Mwi.v.m. sponsoring, TK 1993 1994, 23752, nr.3, p.14, dat het niet naleven wan het gestelde in art. $138 \mathrm{c}$. Mw (medewerkingsplicht), ant. $138 \mathrm{~d}$ Mw (programmabewaarplicht) of art. $139 \mathrm{MW}$ (sponsomeldingsplicht) er toe kunnen leiden dat het CWdM overgant tot beshurlijk boeteoplegging.

38. Zie klacht ter zake door CvdM, Jaarversiag 1989, Hilversum, 1990, p.7.

39. Onjuist spreekt de Mvt woorstel vam wijziging Mwi.w. w. sponsoring. TK 1993-1994, 23752, ne 3, p. 13, van kettingbeding. Bedoeld wordt hier eenderdenbeding ex art. 6:253 BW, verstevigd door een ketringbeding dat ook partijen, betrokken bij avereenkomsten met de producent, er woe dwingt het CwdM inzage te. geven.

40. Het verschil tussen vermelde vormen moet het CvdM zelf nader invullen. Daartoe geniet het comissariaat zekere beleidsnimte. Onder meer daarover wit M. Dellebeke, Eindelijk een sponsonwet voor de publieke omroep, in: MF, nr.9, 1994 pp.90-92, ongenoegen. Vergelijkbaar is de negatieve reactie ter zake wan Tweede Kamerlid Verkerk (AOV) tijdens sponsordebat d.d. 31 jan. 1995, Hand. TK 42-2866. Volgens Dellebeke ondergraven de voorstellen inzake sponsoring trouwens de positie wan de publieke omroep. Het sponsorgeld verdwijnt vermoedelijk natar Luxemburg.

41. Aanvankelijk wordt vermelding van logo of beeldmerk niet toegestaan. Na amendementen ter zalke (zie TK 1994-1995, 23752, nrs.15-18, besluit echter een meerderheid van de Tweede Kamer (VVD, D'66. PvdA en drie ouderenpartijen) begin februari 1995 tot een verruiming:" niet alleen middels naam of handelsnaam, maar ook via logo's reclame mag worden gemaakt. Publieke omroepen mogen programma's latens sponsoren, in: NRC, 9 febr. 1995, p.7. 


\subsubsection{TOEZICHTSBEVOEGDHEDEN COMMISSARIAAT VOOR DE MEDIA}

Ter taakuitoefening beschikt het Commissariaat voor de Media over bepaalde toezichtsbevoegdheden. Binnenlandse omroepen en abonneeprogrammaverzorgers verstrekken het Commissariaat voor de Media zo alle inlichtingen die het Commissariaat redelijkerwijs voor de vervulling van zijn taak nodig oordeelt (ex art. $138 \mathrm{Mw}$ ).

Bovendien verlenen binnenlandse omroepen, ex art. $138 \mathrm{a} \mathrm{Mw}$, leden en daartoe aangewezen medewerkers van het Commissariaat voor de Media inzage van zakelijke gegevens, boeken of bescheiden, en verschaffen zij toegang tot de gebouwen. De herziene Mediawet breidt dit, wat betreft het toezicht op sluikreclame en ongeoorloofde inkomsten uit sponsoring, ex art. $138 \mathrm{~b} \mathrm{Mw}$ uit tot de bevoegdheid alle plaatsen, in gebruik bij omroepinstellingen, the betreden.

Daarnaast zijn binnenlandse omroep-en abonneeprogrammainstellingen, in gevolge art. $139 \mathrm{Mw}^{42}$, verplicht programma"s gedurende twee weken na uitzending er van te bewaren. Desgevraagd stellen zij de programmaopnamen ter beschikking van het Commissariaat voor de Media.

Nu voor het Commissariaat voor de Media, door -praktisch onmisbare- wetswijzigingen, het novum bestaat om bij derden (d.w.z. externe programmaproducenten) in de boeken te snuffelen, is reorganisatie van het toezichtssysteem noodzakelijk. De controle richt zich in de toekomst namelijk niet alleen meer op zichtbare en hoorbare overtredingen, maar volgens verwachting vooral op (boeken)onderzoek.

Van oudsher kent het Commissariaat voor de Media een kijk-en luisterdienst, die bestaat uit medewerkers die thuís radio-en televisieuitzendingen ter controle aan hun waarneming onderwerpen. Dit stelsel van toezicht voldoet niet meer. De controle verloopt over veel schijven, het toezicht is complex en daardoor tijdrovend. Bovendien gaat het monitoren commerciële beïnvloeding niet afdoende tegen. Vandaar bestaat voldoende reden voor invoering van een meer adequaat, efficiënt en doeltreffend toezicht. ${ }^{43}$ Tot het denken over een nieuwe vorm van toezicht wordt van regeringswege aanleiding gegeven: "Wat de kijkdienst betreft: de vraag verdient uitwerking of toepassing van geavanceerde statistische technieken leidt tot kostenbesparing, met behoud van de hoge betrouwbaarheidsgraad van het toezicht." 4 4

Zo wordt de vroegere kijk- en luisterdienst ${ }^{45}$ omgezet in een afdeling Zendtijd- en Toe-

42. Let wel, in de Voorstellen tor wijziging van de Mwi.w.m. sponsoring, TK 1994-1995, 23752, nr.199, p.9, wordt dit art. $139 \mathrm{Mw}$ vernummerd tot art. $138 \mathrm{~d} \mathrm{Mw}$. Art. 138c onvat dan een plicht voor onder toezicht gestelden tot het verlenen van medewerking aan het CvdM bij uitoefening van haar bevoegdheden ex artt. 138-138b Mw. Hetnieuw voorgestelde art. $139 \mathrm{Mw}$ voorziet in de bevoegdheid van het CvdM om inzage te krijgen bij externe producenten die medewerken aan programma-onderdelen die een bepaalde omroepinstelling uitzendt. Zie paragraaf 14.2.

43. Reorganisatie toezicht, in: Comedia, nr. 34, 1994, p.1 (aldus W. Moerer, hoofd Zendtijd-en toezichtstaken (VvdM).

44. Publieke ommop in Nederland, TK 1990m1991, 22147, ar..2, p.40.

45. Ter indicatie de volgende cijfers. Eind 1993 omwat het CvdM-personeel in hoofdzaak: 1 voorzitter; 1 commissaris tinanciële en technische zaken; 5 medewerkers afdeling financiële en technische zaken; 1 
zichttaken. Het bereiken van een kwalitatief hoogstaand toezicht noopt tot optimale samenwerking van controlefunctionarissen (onderverdeeld in drie taakgroepen varn respectievelijk landelijke telewisie, landelijke radio en lokale/regionale radio en televisie) en financiële medewerkers. Daarom huizen alle medewerkers landelijk toezicht na de reorganisatie, die eind 1994 voltooing vindt, in het CvdM-gebouw.

Zij houden samen toezicht op de landelijke publieke omroep, maar niet te vergeten ook op de commerciële binnenlandse omroep, de buitenlandse omroep die zich op Nederland richt en de verschillende abonnee-omroepen. De medewerkers controleren, duo-gewijze de publieke televisiezenders. $Z_{i j}$ zijn vaste contactpersonen voor de betrokken zenders. Een zelfde reorganisatie, als dus het televisietoezicht ondergaat, treft trouwens ook het radiotoezicht.

Naast de werkorganisatie ondergaat ook de werkmethode verandering. Voortaan staat een snelle, geïntegreerde zaaksafhandeling door een en de zelfde CvdM-medewerker centraal. Het schoon maken van de werkvloer staat in het teken van doeltreffendheid, doelmatigheid en snelheid. Verklaarbaar is daarom het streven selectiever en gerichter te kijken en te luisteren. Opvallend aan het veranderde toezicht is dat het als apart aandachtspunt kent: het meer gebruik maken van financiële gegevens waarover het commissariaat beschikt. Gegeven de herziening van de Mediawet, die meer toezichtsmogelijkheden biedt (bij met name externe producenten), doet het Commissariaat voor de Media er alles aan zo veel mogelijk produktiecontracten op te vragen en te bestuderen.

Tekenend voor het nieuwe toezicht is dat de omroepen van af de reorganisatie "wekelijks worden geỉnformeerd over mogelijke overtredingen die in de daaraan vooraf gegane week zijn geconstateerd". ${ }^{46}$

\section{$\S 14.3$ Overheid verder op afstand}

In de tweede fase van verandering van Nederlandse mediawetgeving ${ }^{47}$ staat (concurrentie)versterking van de publieke omroep ${ }^{48}$ centraal. In de hang naar een bedrijfsmatiger vermogen en werkwijze van ormroepen moeten omroepen veranderen in verzelfstandigde organisaties, die zich zelf substantieel kunnen financieren en overigens steun genieten van een bepaalde maatschappelijke achterban. ${ }^{49}$ Politieke voorkeur gaat nog niet uit naar het vrije spel van economische krachten die de omroeporganisatie vorm geven, maar naar

45. $\rightarrow$

commissaris zendtijd-en toezichtzaken; 12 medewerkers afdeling zendijd-en toezichtzaken; 11 medewerkers kijkdienst; 8 medewerkers luisterdienst; 10 medewerkers secretariaat; en 2 medewerkers bureau public relations en voorlichting. CvdM, Jaarverslag 1993, Hilversum, 1994, pp.9/67; Eind 1994 laat enige inkrimping van personeel zien: financiële en technische zaken (4); zendtijd- en toezichtzaken (15); public relations en worlichting (2); secretariaat (8). Aldus CvdM, Jaarverslag 1994, Hilversum, 1995; p.67.

46. Commissariaat verandert werkwijze, in: Comedia, me.37, december 1994, p.1.

47. Beginnend bij de Nota publieke omroep in Nederland, TK 1991-1993, 22147, nrs.1-37.

48. Betwijfeld door E.J. Dommering, De berichtgeving komt straks in poltiteke handen. in: NRC, 6 ok. 1993 . p.9; Genuanceerder B. Geersing. Niet wijzigen Mediawet is in het belang van de commercie, in: NRC. 13 jan. 1993, p.11.

49. Brief minister van wwc inz. publieke omroep in Nederland, TK 1990-1991, 22147, nr.1, pp.2-3. 
- zich naar tijd verschillend profilerende - identiteitsgebonden zelfstandige maatschappelijke organisaties die coöperatief functioneren binnen condities van voorwaardenscheppend omroepbeleid. De publieke functie van de Nederlandse omroep moet zo haar wortels vinden in een, door non-profit privaatrechtelijke instellingen gekenmerkt, publiek bestel. ${ }^{50}$ Dit bestel heeft in programmatisch opzicht de opdracht: "het presenteren van een veelzijdig aanbod voor een breed publiek, gebaseerd op een eigen standaard voor de pluriformiteit en de kwaliteit van dat aanbod, daarbij rekening houdend met de concurrentiepositie van dat bestel" ${ }^{51}$

Deze fraaie doelstelling van het bestel ten spijt, blijkt de praktijk problematisch. Kennelijk is het nog onmogelijk de juiste combinatie te vinden tussen concurrentie en kwaliteit. De publieke omroepen, die bijna alles op alles moeten zetten om hun 'tegenstanders', d.w.z. de private commerciële omroepen, op de huid te zitten, kunnen in deze machtsstrijd snel aan kwaliteit verliezen. Geconstateerd wordt "dat de louterende werking van de markt niet in alle gevallen kwaliteitsverhogend werkt. Net als op de wasmiddelenmarkt hebben produkten nog al eens de neiging juist minder onderscheidend te worden en zelfs aan kwaliteit te verliezen. Wat dan resteert is een prijzenoorlog. " ${ }^{52}$

In navolging van de Medianota begin jaren tachtig blijft het "beleid gericht op vergroting van het zelfstandig functioneren van de publieke omroep en het op verdere afstand plaatsen van de overheid". ${ }^{53}$ Als ijkpunten van het Commissariaat voor de Media als rijksoverheid op afstand noemt de betrokken minister: "a. politieke verantwoording versus functioneren van de overheid op afstand; $b$. flexibiliteit van regelgeving; $c$. adequate informatievoorziening; en d. mogelijkheden van zelfregulering ${ }^{n} .{ }^{54}$

\subsubsection{OVERHEIDSTOEZICHT EN ZELFREGULERING}

Bij verdere functionele decentralisatie van overheidsbevoegdheden naar het Commissariaat voor de Media dient, onder inachtneming van deze wezenlijke aspecten, zorgvuldig te worden bekeken waar het commissariaat zich bevindt op de lijn minister - omroeporganisaties. De bewindspersoon wenst daarbij doelbewust taken betreffende organisatie en financieel beheer naar de omroepen (als geheel) door te schuiven als mede mogelijkheden van zelfregulering te optimaliseren op het gebied van toezichtsbeleid. ${ }^{55}$ Niet iedereen onderschrijft deze gedachte om de omroepen meer zaken zelf te laten regelen. Zelfregule-

50. Publieke omroep in Nederland, TK $1990-1991,22147, \mathrm{nr} .2$, p.5.

51. Publieke amraep in Nederland, TK 1990-1991, 22147, nr.2, p.9.

52. Aldus OCW-staatssecretaris Nuis geciteerd in Nuis: kwaliteit omroep haaks op concurrentie, in: NRC, 21 sept. 1994, p.3. Daarom wil Nuis de kwaliteit van programma's stimuleren of belonen en acht hij samenwerking van omroepen net zo belangrijk als concurrentie. Deze stimulans tot samenwerking van niet winst gerichte met commerciële omroepen deelt de NOS-voorzicter Van der Louw, die spreekt van een niet-programmatische "straceg ische alliantie" tussen beide, opdat de verschillende omroepen niet tegen elkaar worden uitgespeeld. Van der Louw: alliantie nodig van commerciele en publieke zenders, in: NRC. 22 sept. 1994, p. 10 .

53. Mut wijziging Mediawet, TK 1992-1993, 23257, nr.3, pp.5/9; Oorspronkelijk Publieke omroep in Nederland, TK 1990-1991, 22147, nr.2, p.8.

54. Publieke omroep in Nederiand, TK 1990-1991, 22147, nr.2, p.39.

55. Publieke omroep in Nederiand, TK 1990-1991, 22147, nr.2, p.40. 
ring door omroepverenigingen moet aan grenzen zijn gebonden. En voor toezicht op de naleving van de mediawet en de daarbij behorende sanctietoepassing door onder toezicht gestelden is "per definitie" geen plaats. ${ }^{56}$

In de eerder genoemde beleidsdoelstelling past niet, "dat tegelijkertijd met de terug tredende rijksoverheid (minister, parlement) de taken en bevoegdheden van de overheid in de vorm wan het Commissariaat voor de Media worden uitgebreid"'. ${ }^{57}$ Volgens de minister van WVC moet worden voorkomen, dat het Commissariaat voor de Media zich ontwikkell "tot een soort superbestuur van de publieke omroep". 58

\subsubsection{Taken Commissariaat voor de Media niet uitgebreid}

Zo ziet het Commissariaat voor de Media de, door hem zo graag gewilde, taken van advisering (met name over uitvoeringsaspecten van nieuwe regelgeving) aan de minister $^{59}$ als mede inning van omroepbijdragen ${ }^{60}$ aan zijn neus voorbij gaan.

Wat betreft een wettelijke adviestaak, waarmee de VVD-fractie het werkgebied van het commissariaat wenst te verbreden, reageert de minister van WVC, met referentie aan het rapport van de commissie-De Jong over de beperking van het aantal adviesraden ${ }^{61}$, afwijzend. ${ }^{62}$

Wat betreft de (omroepbijdragen)inningstaak heeft de minister ook andere plannen. De bewindspersoon voelt er niets voor de Dienst Omroep Bijdragen, die met deze taak is belast, buitendienst van het Commissariaat voor de Media te maken. De DOB is onderdeel van de Koninklijke PTT Nederland nv. Haar werk is rond uit succesvol te noemen. Voornamelijk ten gevolge van de bekende zwartkijkerscampagne heeft zij in 1992 zelfs een "oogstjaar" gehad. ${ }^{63}$ Resultaat:" weliswaar is de DOB door een onvolledig compu-

56. A. van Raallte e.a.., Verslag G.H. den Bak-sympositwm. het CvdM als zbo, Hillwersum, 21 april 1993, pp.56.

57. Mvt wijziging Mediawet. TK 1992-1993, 23257, nr.3, p.30.

58. Mva wijziging Mediawet, TK 1993-1994, 23257, nr.6, p.3.

59. Commissatiaalt voor de Media, Evaluatie 1988-1993; Overheid en onroep in Europees perspectief; Hilversum, 1993 , p.21.

60. Commissariant voor de Media, a.w., p.16.

61. Voortbouwend op cie. De Jong will het kabinef de 108 adwiesraden per 1 jan. 1997 opheffen. Daarvoor in de plaats komen 11 beleidsclusters, warbinnen op hoofdlijnen wordt geadviseerd. Herziening adviesstelsel, TK 1993-1994, 23725, nr. 1 e.v.; Conform deze gedachte schaft het wetsvoorstel, 10 nov. 1994, TK 1994-1995, 23983, nrs.1-3 (zie ook nr.242 voor gewijzigd wetsvoorstel aanpassing Awb en andere wetten) , de meeste wettelijke adviesplichten af. Hierover A. van Dam en W. Sloots, Adviesorganen: beter met minder, in: $\mathrm{OB}, \mathrm{nr}, 2,1995$, pp.2-6; Overigens stelt de Rbb voor de sanering van het bestaande stelsel adviesraden te doen resulteren in -in elk geval-een, de Rbb en de Ratad voor gemeentefinanciën vervangend, nieuw adviesorgaan dat zich bezig houdt met de organisatie en de werking van de overheid. Adviesargaan over organisatie van de overheid, in: BB, nr.38, 23 sept. 1994, p.4; Een dergelijke Raad voor het openbaar bestuur krijgt echter een zeer breed werkternein, dat niet alleen territoriaal bestuur bestrijkt maar dat zich ook uitstrekt over de "baaierd van zbo's en uitwoeringsorganen". Zie Rgf niet tevreden met 'opwolger'; Maak ongevraagd adviseren niet onmogelijk, in: BB, nr.19, 12 mei 1995, p.5.

62. Mva Hüziging Mediawet, TK 1993-1994, 23257, nr.6, pp.41/46.

63. DOB, Toelichting op de jaarafrekening DOB 1992, "s-Gravenhage, 1993, pp 1-15. 
terbestand circa 75 miljoen gulden mis gelopen ${ }^{64}$, toch is in totaaloverzicht sprake van maar liefst een $12 \%$-stijging of wel een meeropbrengst van ruim honderd miljoen gulden. Daarmee nadert de jaarlijkse bruto-opbrengst van omroepbijdragen het miljard. Gelet op dit succes, de aard van het werk, de omvang er van en de vestigingsplaats van de DOB acht de bewindspersoon "geen mediapolitieke redenen aanwezig om deze anders te positioneren"; "Indien de DOB verder verzelfstandigd zou moeten worden, dient gegarandeerd te zijn dat de inning van de omroepbijdragen daardoor niet negatief beïnvloed worden. Een interne verzelfstandiging binnen de KPN nv ligt dan eerder in de rede. Vervolgens zou bezien kunnen worden of een verdere verzelfstandiging tot zelfstandig bestuursorgaan aangewezen is." 65 Nu naar alle waarschijnlijkheid de weg wordt ingeslagen de $\mathrm{DOB}$ inderdaad om te vormen tot een zelfstandig bestuursorgaan ${ }^{66}$, blijft toekenning aan de $\mathrm{DOB}$ van de bevoegdheid besturlijke boeten op te leggen voorlopig uit. 67

\subsubsection{Taken Commissariaat voor de Media zelfs beperkt}

Het mag dus niet een beetje meer zijn. In tegendeel, het moet zelfs behoorlijk minder worden. In het veranderde wetsvoorstel nemen de taken en bevoegdheden wan het cornmissariaat af.

Opvallend in de herziene wetgeving is de terugtred van het Commissariaat voor de Media ten gunste van de minister van WVC. ${ }^{68}$ Verklaring daarvoor is te vinden in een van de uitgangspunten van het wetsvoorstel: de minister draagt verantwoordelijkheid voor de essentiële elementen van het mediabeleid. ${ }^{69}$ Met de aanvankelijke gedachte, waarin de minister van WVC de totale hoeveelheid zendtijd vaststelt en het commissariaat zendtijd verleent, wordt flink de vloer aangeveegd.

Overigens heeft niet iedereen moeite met deze terreinverschuiving. De communicatie met de minister zou minder bedreigend zijn dan die met het commissariaat. Van uit de kennelijk negatieve ervaring, dat het Commissariaat voor de Media aanvankelijk een "redelijk duidelijk en verstandige communicatie met omroeporganisaties heeft opgebouwd, maar

64. Rekenkamer: overheid loopt miljoenen mis, in: NRC, 31 maart 1994. p.3.

65. Mra wijziging Mediamet, TK 1993-1994, 23257, ne.6, p.51.

66. Dits neemt niet weg dat de betrokken minister het nog te vroeg vindt om de DOB, als onderdeel wan KPN nw, zonder meet aan te merken als zbo. Deze uitspraak is de reactie op het feit dat de Algemene Rekenkamer, Zbo's en minwsterielle verantwoordelijkheid. TK 1994.1995, 24130, nt.3, P.16, de DOB nv in een door haar wirgevoerd zbo-onderzoek waarvoor zij als peiljaar 1993 hanteert, al als zbo aanduidt.

67. Kabinetsstandpunt over CTW-advies inzake bestuurlijke boeten, TK 1993-1994, 23400 VI, nr.48, p.28. Het kabinet is voomemens de operaties, wan respectievelijk verzelfstandiging van de DOB en inwoering Wan bestuurlijke boete voor zover het gaat om overtredingen van regels aangaande omroepbijdragen (welke overtredingen weinig of geen normatieve lading hebben), synchroon te laten verlopen. Het parallel behandelen mondt dan mogelijk uit in een en het zelfde wetsvoorstel. Het kabinet acht de DoB de meest aangewezen instantie, als gespecialiseende dienst met rume expertise, voor het opleggen van besturrlijke boeten. Bovendien ziet het kabinet voldoende mogelijkheden om "binnen deze dienst in feitelijjke zim scheiding aan te brengen tussen degenen die de overtredingen constateren en de ambtenaren die de boeten opleggen".

68. A. Geuntsen, De bijna-nationalisering yan de omroep, in: NRC, 25 okt. 1993, p.9.

69. Mwt wijziging Mediawet, TK 1992-1993, 23257, nr.3, p.30. 
later "minder communiceerde en meer verordonneerde", wordt de volgende vraag op geworpen. Is het commissariaat "niet te veel bezig is geweest als rijkszedenmeester te opereren in plaats van als orgaan dat terecht moet proberen een ontwikkeling in de richting van een te ver doorschietende commercie van de publieke omroep tegen te gaan $^{\text {" }}{ }^{70}$ In deze optie heeft het commissariaat de vrijheid van de omroepen beknot; terwijl het "op afstand zetten van de overheid" die vrijheid idealiter beoogt. Bij het Commissariaat voor de Media leeft het besef dat de relatie van het commissariaat met de omroepen, die gaande weg inderdaad meer rechtstreeks zaken met het departement zelf zijn gaan doen, beter kan. Verstandige voornemens wormen zich om wat aan die verslechterde verhouding te doen. ${ }^{71}$

Ook moet het commissariaat terrein afstaan aan de NOS. Daartoe moet het Commissariaat voor de Media, als aangekondigd, direct aan de bedrijfswoering rakende taken betreffende organisatie en (financieel) beheer aan de gereorganiseerde NOS overdragen. In gevolge art. 16, eerste lid, van de gewijzigde Mediawet is de Nederlandse Omroep Stichting het samenwerkings- en coördinatie-orgaan van de instellingen die zendtijd hebben verkregen voor landelijke omroep. De nieuwe NOS, onderverdeeld in vier organen te weten een algemeen bestuur, een dagelijks bestuur, een voorzitter met zelfstandige bevoegdheden en een geschillencommissie ${ }^{72}$, heeft als taken: bestuurlijke samenwerking; coördinatie van de programmanetten en programma's en de indeling van zendtijd; levering van gemeenschappelijke diensten ${ }^{73}$; en verzorging van programma's die bij uitstek geschikt zijn voor gemeenschappelijke verzorging. ${ }^{74}$ De zendtijdindeling wordt niet meer door het Commissariaat voor de Media geregeld, maar geschiedt voortaan grotendeels door het dagelijks bestuur van de NOS. De opdracht om zendtijd in te delen blijft een "taak van openbaar bestuur". ${ }^{75}$ Het zelfde geldt trouwens ook voor de programmacoördinerende taak van het NOS. Middels uitoefening van beide taken kan de

70. Aldus G.C. Wallis de Vries, in zijn functie als Avro-voorzitter, geciteend in Gerard Wallis de Vries: publieke armroep moet meer speelruimte hebbev, in: Comedia, rw. 32, mei 1994, p.4.

71. CvdM-voorxitter A. Geurtsen, Het CvaM over zijn voornemens voor 1995, in: Comedia, nr.38, januari 1995 , p.4, vindt dat omroepen echt beter byj het CwdM terecht kunnen: "Je zit daar (direct bij het depantement - JGLvN) weel te dicht bij de politiek en dat betekemt dat voor alles wat je krijgt je iets moet geven. Koehandel. En dan maar afwachten wat die koe wastd is. Zo als die tienjarige concessie, die opeens een $v$ jjfjarige werd. Ik vind dat de publieke omroep uit het politieke krachtenveld moet blijven. Laat Dern Haag met rust, dan laat het joti ook met rust. Dan kan de publieke omroep zijn krachten bundelen en läa het dan een keer woorkomen dat een omroep zijn eigen bestaan ondergeschilkt moet maken aan het algemeen belang. So what?"

72. Overwogen is die commissie zbo-status te geven. Mondeling overleg wijziging Mfw. TK 1993-1994. 23257 , nir 64 , pp. $7-10$ 。

73. Zie wijziging van de Mediawet (vooral artt. 86/89-90 Mediawet, i.v.m. herstructurering van de beheertalken (d.w.z.n de instandhouding omroeporkesten en-koren en audio wisueel archief, als mede het uitzendgereedmakem en doen uitzenden van de programma's van de landelijke publieke omroep) van in het bijzorn der het Nederlands Omroepproduktie Bedrijf $n v$, TK 1993-1994, 23793, nrs. 1-2. Bij wet van 21 dec. 1994, Stbl. 1994, 945, worden dan taken van NOB geschrapt (art. 86 Mw).. Daardoor kunnen het, meer markt gerichte, Muziekcentrum van de omroep en het Audiowisueel archiefcentrum worden ondergebracht in twee zelfstandige stichtingen, die rechtstreeks worden gefinamcierd door het ministerie van $O C W$.

74. Mvt wiziging Mediawer, TK 1992-1993, 23257, mr.3, p.15.

75. Mvt wöziging Mediawer, TK 1992-1993, 23257, nr.3, p.12. 
NOS eenzijdig de rechtspositie van andere rechtssubjecten bindend bepalen. Hoewel de NOS dus niet publiekrechtelijk wordt opgericht, valt de stichting toch onder art. 1:1, eerste lid, sub b, Awb van wege haar openbaar gezag. De subcommissie-Verzelfstandigingen van de Adviescommissie voor de rijksdienst concludeert zelfs dat de NOS partieel, dus voor zover zij de twee voomoemde taken uitoefent, aangemerkt kan worden als zelfstandig bestuursorgaan. ${ }^{76} \mathrm{Het}$ "ligt voor de hand met betrekking tot bovenbedoelde besluiten [...] aan de Kroon de bevoegdheid te geven deze besluiten te vernietigen wegens strijd met het recht of het algemeen belang ". ${ }^{77}$

\section{$\$ 14.4$ Toezicht op naleving van mediawet- en regelgeving}

Inhoudelijk omvat het nieuw gelanceerde voorstel van wet het volgende.

In het nieuwe voorstel van de Mediawet $^{78}$, sinds 28 april 1994 status van wet bezittend ${ }^{79}$ en als wet in werking vanaf 1 januari $1995^{8081}$, krijgt het Commissariaat voor de Media het toezicht op de naleving van mediawet- en regelgeving als primaire taak toebedeeld. Dit toezicht is inclusief beroep en vernietigingsrecht voor zover geregeld. Daarnaast zijn zijn werkzaamheden: het verlenen van zendtijdtoewijzing aan publieke landelijke, regionale en lokale omroepinstellingen; het verlenen van vergunningen voor abonneetelevisie; het (vanaf $\mathbb{1}$ juli 1995) verlenen wan toestemming voor landelijke commerciele omroepinstellingen ${ }^{82}$; als mede het eventueel regelen van consequenties daarvan in termen van zenđtijd en geld, èn de uitvoering van en controle op financiële beslissingen. ${ }^{83}$ Het betreft "taken op uitvoerend niveau en taken die een directe relatie met de inhoud op concrete programma-onderdelen hebben: een politieke afweging is in die gevallen niet nodig respectievelijk gewenst".${ }^{84}$

76. Mvt wijziging Mediawet, TK 1992-1993, 23257, ni. 3, pp.12-13.

77. Mut wijziging Mediawet, TK 1992-1993, 23257, nr. 3, p.35; Mwa, TK 1993-1994, 23257, nr.6, p.37.

78. Wiziging bepalingen Mediawert, w.m. het versterken van de organisatie van de landelike publieke omroep en het bieden wan langdurige zekerheid a ar omroepwerenigingen, TK 1992-1993, 23257, nrs. 1-73, i.h.. b. nrs. $1 \cdot 2 / 72-73$.

79. Mediawet, 28 april 1994, Stbl. 1994, 385/386.

80. Besluit van 4 juli 1.994, Stbl. 1994, 516.

8.1. I. w.m. de inwerkingtreding van de nieuwe Mw vindt, d.d. $19 \mathrm{dec} .1994$, ook wijziging van het Mediabesiuit, als grotendeels ook per 1 januari 1995 geldend, plaats. Zie Stbi $1994,914$.

82. In het worjalar wan 1995 stuurt de verantwoordelijke staatssecretaris een wetsvoorstel -inzake witbreiding van de mogelijkheid wan commerciële omroep, reeds in het leven geroepen voor landelijke omroep (watartoe de mimister van $\mathrm{OCW}$, in plaats van het $\mathrm{CWdM}$, nu nog de benodigde concessies verleent), naar regionale en lokale omroep- nagr de Tweede Kamer. Nuis: status lokale en regionale omroep wrij, in: NRC, 15 maart 1995, p.3.

83. Mw wijziging Mediawet, TK $1992-1993,23257$, nr.3, pp. 13-14.

84. Mwt wijziging Mediawet, TK 1992-1993, 23257, nr.3, p.31. 


\subsubsection{ZENDTUDTOEWUZING, -VERMINDERING, -INTREKKING EN -VERDELING}

Wat betreft de Nederlandse Omroepstichting (art. 39d Mw), educatieve omroepinstellingen die een concessie voor educatieve omroep hebben (art. $39 \mathrm{e} \mathrm{Mw})^{85}$, kerkgenootschappen en genootschappen op geestelijke grondslag dan wel een rechtspersoon waarin twee of meer van deze genootschappen samenwerken (art. $39 \mathrm{f} \mathrm{Mw),} \mathrm{politieke} \mathrm{partijem}$ en groeperingen die bij de laatst gehouden verkiezingen van de Tweede Kamer een of meer zetels hebben verworven (art. $39 \mathrm{~g} \mathrm{Mw}$ ), overheidsvoorlichtingsinstellingen (art. $39 \mathrm{~h} \mathrm{Mw}$ ) geldt dat zij aangewezen blijven op toewijzing van, de overigens ex art. $39 \mathrm{c}$ Mw jaarlijks door de minister in hoeveelheid bepaalde, zendtijd voor landelijke omroep door thet Commissariaat voor de Media.

De zendtijd, waarop de NOS aanspraak kan maken, is verbonden aan een wettelijk minimum. Daarnaast kan de NOS, in plaats van of naast de zendtijd voor educatieve omroepinstellingen of kerk- en geestelijke genootschappen, zendtijd krijgen van het commissariaat. Daartoe moet de minister van welzijn, volksgezondheid en cultuur goedkeuring geven. Indien in een educatieve omroepinstelling twee of meer organisaties samenwerken, bepaalt het commissariaat mogelijk naar rato welk percentage wordt aangewend voor de verzorging van het programma. Met toestemming van de betrokken minister, kan het commissariaat aan zendtijdtoewijzing voorschriften, ten aanzien van de coördinatie van educatieve programmaonderdelen en de samenwerking tussen educatieve omroepinstellingen, verbinden. Eveneens met instemming van de bewindspersoon kan het Commissariaat voor de Media in bijzondere gevallen of voor bijzondere doeleinden extra zendtijd toewijzen ex art. 391 Mw.

De Nederlandse Programmastichting (art. 39a Mw) en de Stichting Etherreclame (art. $39 \mathrm{~b}$ Mw) krijgen krachtens de wet zendtijd.

Het Commissariaat voor de Media kan niet alleen zendtijd (tussentijds) toewijzen. In gevolge de artt. 44-47 Mw kan het commissariaat ook verkregen zendtijd (in bepaalde gevallen voor maximaal twaalf weken) intrekken en evenredig verminderen. Daaraan hoeft hij geen recht op vergoeding te koppelen. Zo nodig wordt toegewezen zendtijd herzien. Een andere omroepinstelling die, in plaats van de omroepinstelling wier zendtijd is ingetrokken, binnen twee jaar zendtijd krijgt, wordt gezien als rechtsopvolger onder algemene titel van laatst genoemde.

Zendtijdverdelling moet de toets der redelijkheid kunnen doorstaan. Dit geldt voor verschuiving van tijdstippen waarop uitzending plaats vindt. ${ }^{86} \mathrm{Bij}$ toewijzing van zendtijd eist de redelijkheid dat ongewenste versnippering van zendtijd wordt tegengaan. In dit licht is de voorwaarde te zien, dat een verzoeker van zendtijd o.a. moet beschikken over een noodzakelijk maatschappelijk draagvlak. Bij voorbeeld in de zin van een voldoende

85. Zonder succes dient PvdA'er Van Nieuwenhoven een amendement in, waarin wordt voorgesteld de zendtijd voor educatieve omroep niet per concessie te regelen, maar via toewijzing door het CVdM. TK 1993-1994, 23257, mr. 28, pp 1-2.

86. O.a. IKON en VARA ws. CvdM, VI ARRS, 2 okt. 1992, S01.92.04303, AB 1994, 73. Daarin let de techter op het, voor betrokkene, door zendtijdwijziging mogelijk omtstane nadeel ten op zichte van de oude situatie. 
grote representatieve achterban, of als het gedachtengoed van de aanvrager is te vinden bij een of meer instellingen waaraan reeds zendtijd is toegewezen. ${ }^{87}$

\subsubsection{ZENDTUDCONCESSIE VOOR LANDELUKE PUBLIEKE OMROEP}

Wat betreft de publieke omroepen verandert het regime van zendtijdtoewijzing fundamenteel. Niet het Commissariaat voor de Media, maar de minister van WVC zelf, ter zake geadviseerd door deskundigen ex art. $34 \mathrm{Mw}$, verleent de publieke omroepen mogelijk zendtijdconcessie voor landelijke omroep conform de artt. 31-36c Mw, of anders voorlopige zendtijdconcessies voor landelijke omroep volgens de artt. 37-37f Mw. De klacht, dat concessieverlening door de minister minder objectief dan verlening door het Commissariaat voor de Media zou zijn, vindt geen gehoor. Tegen de klacht in wordt het argument gebracht, dat de gronden voor concessieverlening in de voorgestelde Mediawet zijn opgenomen. Toch wordt het onjuist gewonden, dat hier geen taak is weggelegd voor het Commissariaat voor de Media. Met referentie aan het rapport van de commissieScheltema inzake ministeriële verantwoordelijkheid, wooral waar de wenselijkheid van scheiding van beleidsvorming en -uitvoering ter sprake komt, luidt een opmerking van politieke zijde, dat het voorstel Mediawet "heldere criteria dient te bevatten ten aanzien van het voldoen aan de eisen van de concessie, zodat een bestuursorgaan, in casu het Commissariaat voor de Media, belast kan worden met de wettelijke uitvoeringstaak van het verstrekken van een concessie". ${ }^{89}$ Kennelijk raakt de betrokken minister niet overtuigd. Van wege het politiek en maatschappelijk belang van concessieverlening vindt de bewindspersoon het commissariaat niet het aangewezen orgaan dat daarmee belast mag worden.

Nieuwe concessies zijn aan te vragen op een bij amvb te bepalen tijdstip (art. $33 \mathrm{Mw}$ en art. $37 \mathrm{~b} \mathrm{Mw}$ ). En in beide jaren, vooraf gaande aan het verstrijken van de concessietermijn, kunnen potentiële kandidaten voorlopige concessies aanvragen. Bedoelde amvb tot wijziging van het Mediabesluit schrijft voor dat de allereerste concessies, die de minister vóór 1 juni 1995 verleent ${ }^{\text {gn }}$, per 1 september 1995 geldingskracht hebben. ${ }^{9 t}$

87. Osho vs. CwdM, ARRS 8 maart 1993, R01.90.3523, in: MF, nr.6, 1993, pp.B71-B72 (rechtspraakbijlage).

88. Mva wijziging Mediawet, TK 1993-1994, 23257, nr.6, p.30.

89. Zie GPV-opvatting in Eindverslag wijziging Mw, TK 1993-1994, 23257, nr.7, p.4; Vgl amendement $\mathrm{E}$. van Middelkoop tot het belasten wan het CvdM met de besturlijke organisatie van concessieverlening, TK 1993-1994, 23257, nr. 23, pp. 11.4 .

90. Hiertoe wint de minister advies in van de commissie concessieananragen zendtijd landelijke omroep (onder voorzitterschap van P. van Dijke). Deze commissie brengt medio april 1995 positief advies uit ower de concessie-aanvragen yan AVRO, EO, KRO, NCRV, TROS, VARA en VPRO. Nuis wil advies commissie aver concessies omroepen, in: NRC, 17 jan. 1995, p.2, Concessie. in: NRC, 19 april 1995, p. 2; In haar advisering betrekt de commissie haar oordelen inzake: tot uitdrukking gebrachte identiteit van de concessieaanvrager; onderscheidend vermogen van inhoud en kwaliteit wan programma"s van concessieaanwrager t.o. $\mathrm{W}$. andere binnenlandse gegadigden en binnen- en buitenlandse commerciele: omroep; vorm en intensiteit van samemwerking van concessieaanvrager met zendgemachtigden op het zelfde net. Zie Behandeling concessie-aanvragen ü wolle gang, in: Comedia, mr.39, febr. 1995, p.1; De commissie-Van Dijke wint advies in van het CvdM inzake het inhoudelijke en kwalitatieve onderscheid 
Of alle, tot 15 januari 1995 met oude publieke status functionerende, omroepen - die op die datum kenbar moeten maken of zij in aanmerking willen komen voor zendtijdconcessieverlening - in het nieuwe omroepsysteem de status van publieke omroep blijven houden, is al snel onzeker.

Zo twijfelt bij voorbeeld Veronica van wege vooral de lange zendtijdconcessietermijn. Bovendien vindt Veronica het omroepregime "sowieso knellend". "22 De omroepvereniging heeft in het bijzonder moeite met de verplichting om tien procent zendtijd aan kunst te wijden. Volgens Veronica heeft dit een negatieve invloed op het marktaandee] van de publieke omroep. Kiest Veronica in oktober 1994 inderdaad voor de commerciële status, dan zijn de gezamenlijke publieke omroepen bereid om via een financieel lokkertje van 70 tot 80 miljoen gulden (jaarlijks gedurende een termijn van vijf jaar) ${ }^{93}$ televisieprogrammaproducent Endemol weg te halen bij het Luxemburgse RTL ${ }^{94}$. Bedoeling daarvan is Endemol te laten over stappen naar het commerciële Veronica en daarnaast de publieke omroep zelf. ${ }^{95}$ Kortom, de publieke omroep is er niet vies van om, middels een dergelijke afnamegarantie, een 'pact met de duivel' te sluiten ten einde te kunnen scoren met publiek trekkende programma's. ${ }^{96}$

Op 8 oktober 1994 maakt Veronica Omroep Vereniging bekend dat zij inderdaad op 1 september 1995 uit het bestel stapt. ${ }^{97}$ Deze uittreding is mogelijk in gevolge art. $71 \mathrm{~m}$ Mediawet junctis art. 46a Mw en art. 153, vierde lid, Mw (welke artikelen overigens niet meer gelden of zijn gewijzigd per $\mathbb{1}$ januari 1995). Begin januari 1995 dient Veronicat trouwens wel, om zekerheid achter de hand te hebben als de commerciële status niet op tijd wordt verleend, een 'pro forma' aanvraag voor een zendtijdvergunning voor de publieke omroep in bij het ministerie van OCW. ${ }^{98}$

Aanvankelijk lijkt het volgende, serieus bedoelde, scenario succes te scoren. Veronica Omroep Organisatie richt samen met Endemol een commercieel televisiestation (en twee

90. $\rightarrow$

wssen publieke en commercièle omroep. Het CvdM geeft aan dac het onderscheidende element ligt in lhet, door de publieke omroepen aangehangen, beginsel van noth-commercialiteit. Overigens vindt het $C$ w $M$ dit een verkeerde vraagstelling omdat publieke omroep het uitgangspunt moet bljiven en meer dan een aanvullende roll moet spelen. Concessies omroepverenigingen, in: Comedia, nr.40, maart 1995, p.3.

91. Omroepen to" "95 de tijd in het bestel te blijven; Concessies in juni toegewezen, in: NRC, 18 juniü 1994, p.2.

92. Veronica bestuit snel over commerciële status, in: NRC, 31 aug. 1994, p.2.

93. A. van der Louw. Publieke omroep moet de markt wel op, in: NRC, 7 okt. 1994, p. 7, tekent aan dat dit volumebedrag nog niet eens tien procent van het, voor telewisie bestemde, budget wan de landelijke publieke omroep betreft.

94. Over wat J. de Mol het "prisoners dillemma" noemt o.a. Z. Luyendijk, 'Politiek' en 'Gevoel" hebben doorslag gegeven: Gesprek met De Mol en Van de Reijden, in: NRC, 10 okt. 1994, p.2 en Z. Luyrendijk, RTL treurt niet over mogelijk verlies Endemol, in: NRC, 8 okt. 1994, p.3.

95. Publieke omroep wil Endemol binnenhalen, in: NRC, 28 sept. 1994, p.3.

96. Z. Luyendijk, Omroepen proberen buit Endemol binnen te halen, in: NRC, 29 sept. 1994, p.3.

97. Veronica treedt uit publieke omroepbestel, in: NRC, 10 okt. 1994 , pp.1/3.

98. Veronica wil pro forma zendtijd publiek bestel, in: NRC., 14 jan. 1995., p.3. 
radiostations) ${ }^{99}$ op. Daartoe nemen Veronica en Endemol, ieder voor de helft, deel in een nieuwe holding. Beide partners leggen honderd miljoen gulden startkapitaal op tafel. ${ }^{100}$

De samenwerking tussen de publieke omroepen (uitgezonderd de weigerachtige VPRO en de TROS ${ }^{101}$ ) en de andere omroepen wordt beheerst door een raamovereenkomst. Deze overeenkomst houdt het volgende in: de uitwisseling van programmagegevens met het blad van Veronica ${ }^{102}{ }^{103}$; een afnamegarantie voor Endemol, die definitief 49 miljoen per jaar bedraagt; en een aandeel van 25 procent voor Veronica/Endemol in de sportrechten van de publieke omroepen.

Over bedoelde samenwerking tussen de publieke omroep en Endemol/Veronica, in paragraaf 14.3 eerder aangeduid als 'strategische alliantie', is niet iedereen te spreken. De ondernemingsraad van de TROS, die zich voor deze 'uitverkoop' van het publieke omroepbestel voorlopig 'wonderbaarlijk bekeert" 104 105, acht de programma-afnamegarantie bedreigend en bedriegend: de vrees van verlies van werkgelegenheid is reëel; het achterhouden van Endemol van zijn beste programma's woor zich zelf is aannemelijk; het contract brengt slechts korte-termijn-voordeel; met het vrij geven van alle programmagegevens aan Veronica (ten behoeve van de VOO-televisiegids, die overigens goed is voor een nettowinst van 18 miljoen gulden) ondermijnt de publieke omroep haar eigen

99. Afgezien hiervan neemt Veronica per 1 september 1995 bovendien deel in de commerciële radionieuwszender van de Dagbladunie en Quote Beheer. Dat radiostation, waarvoor begin 1994 een middengolffrew quentie wordt toegewezen, zendt 24 per etmal nieuws of anders actualiteiten uit en concurreert direct met de publieke Radio 1. Veronica neemt deel in commerciële nieuwszender, in: NRC, 6 dec. 1994, p.3.

100. ABN Anno, die samen met de Nationale Inwesteringsbank 5 procent aandelen van Endemol in handen heeft, verstrekt Endemol betreffend beginbedrag. ABN Amtro leent Endemal geld voor Nistation, in: NRC, 11 okt. 1994, p.15.

101. Z. Luyendijk, VPRO en TROS blijwen buiten "alliamtie', in: NRC, 22 okt. 1994, p.3.

102. Hiertoe contracteert elke betrokken publieke omroep afzonderlijk met de commerciële stations, weliswaar onder de voorwaarclen en bedragen als vermeld in de raamovereenkomst van de gezamenlijke publieke omroep.

103. Dat een commercieel Veronica als nieuwe "marktpartij" niet mag worden betemmerd en daarom niet de programmagegevens mag worden onthouden is voor Veronica een 'gunst' die vooral veel woordeel kan opleveren. Aldus E.J. Dommering, aangehaald door 2 . Luyendijk, 'Contract Veronica haal' bestel onderwit, Mediajurist E.J. Dommering over televisiegidsen, in: NRC, 26 okt. 1994, p.7. Dommering vind thet beroep op bescherming van omroepgegewens wel een beetje oneigenlijk nu de publieke omroepen hun eigen bevoorrechte positie ondergraven door mogelijk zelf contracten ter zake af te sluiten. Daardoor wordt het getergde publieke omroepbestel, dat toch al veel te lang op zijn laatste benen loopt, helemat onder uit gehaald. Ove rigens is Dommering benieuwd of licentiëring van omroepgegevens ook door andere commerciële omroepen dan Veronica is af te dwingen. Over dit aspect van het auteu rs recht van de verschillende publieke omroepen moet het Europese Hof van Justitie zich nog uitspreken. Dommering denkt dat het hof de omstandigheid, dat in casu slechts aan een gegadigde (t.w. Veronica) programmagegevens worden verkocht, zwaar laak wegen.

104t. K. Van Twist, Met dealen is de publieke omroep niet te redden, in: NRC, 12 okt. 1994, p.7.

105. De onmezwaai van de TROS lijkt echter wan korte duur. Ook de TROS zelf rïcht mogelijk, in samenwerking twet RTL, een nieuw commercieel felevisiestation op. Zie TROS anderhandelt met RTL over nieww station, in: NRC, 9 nov. 1994, p.3. Dit aanvankelijk sterke woornemen is echter vam baan als de TROS het met RTL en VNU niet eens kan worden over de mate van futonomie van de TROS bij commercialisering, TROS blijft binnen publiek omroepbestet, in: NRC, 1 dec. 1994, p.7. 
financièle positie, dit geldt idem dito voor het meedelen in de dure sportrechten; en de overeenkomst is vermoedelijk strijdig met in het bijzonder art. $55 \mathrm{en}$ art. $71 \mathrm{~m}$ Mediawet en Europese regelgeving. ${ }^{106}$ De VPRO ${ }^{107}$ en in mindere mate de EO, omdat de EO de omroepovereenkomst vooral zakelijk ziet en als wapen inzet in de strijd om het behoud

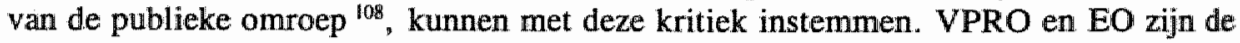
beide publieke omroepverenigingen die zich niet willen verplichten tot het afnemen van programma's van Endemol.

Vooral laatst genoemd argument doet ook het Commissariaat voor de Media ${ }^{109}$ argwanend staan tegenover het voorgenomen voorstel van coöperatie tussen commerciële en niet-commerciële omroep. Een overeenkomst tussen publieke omroep en Veronica/Endemol vindt het commissariaat in elk geval niet passen in de geest van de Mediawet. Immers, de Mediawet kent duidelijk een tweedeling in omroepen (profit en non-profit) en schrijft samenwerking tussen publieke omroepen voor (het commissariaat betwijfelt wel of samenwerking met andere dan publieke omroepen daar dan onder valt). ${ }^{10}$ Volgens het Commissariaat voor de Media bestaat geen strijd met de letter van de Mediawet, hoewel het commissariaat daar wel het volgende bij aantekent. ${ }^{11}$ Het aparte fonds, waaruit omroepen die Endemol-produkties op de buis brengen kunnen 'trekken", kan daarvan geen gebruik makende omroepen benadelen. Daarom dient een dergelijk fonds een wettelijke basis te krijgen, bovendien zijn regels voor een eerlijke verdeling nodig. Met betrekking tot de afnamegarantie beveelt het commissariaat aan, dat deze door de minister van economische zaken moet worden getoetst aan het mededingingsrecht. Tot een dergelijke toetsing is het commissariaat zelf niet bevoegd. "12 113 Daarop zegt de minister van economische zaken toe de omroepovereenkomst tegen het licht van de Wet economische mededinging te houden. ${ }^{1 / 4}$ Het oordeel van de minister van economische zaken staat, volgens de Wem, weer open voor beroep op het College van Beroep voor het Bedrijfsleven.

In het licht van het in het wettelijk bepaalde onderscheid in omroepen vraagt ook de Tweede Kamer zich af of de voorgenomen samenwerking tussen de omroepen niet contrasteert met de Mediawet. Hierbij verwijst het parlement met name naar het verbod op

106. Z. Luyendijk, "Veronica zal worden opgestokt door het bedrïf Endemol", in: NRC, 1 okt. 1994, p.3.

107. Z. Luyendijk, Veronica stapt wrijurel zeker wit bestel, in: NRC, 8 okt. 1994, p.1.

108. Z. Luyendijk *E ziet ook positieve kant, in: NRC, 8 okt. 1994, p.3

109. Zo lang sprake is wan 'nomal economisch handelen', als in casu het feit dat de NOS in gemeenschappelijk beling van de publieke omroep comtracten met derden afsluit en daarbij binnen de kaders wan de Mediawet blijft, behoudt her CvdM zijn toezichthoudende taak. Well dient de NOS nog "'in overleg te treden met het CvdM over de wijze warop het zijn toezichthoudende functie kan uitoefenea, madat de contracten zijn getekend". Mediabeleid: uittreden VOO , TK 1994-1995, 23968, nr. 1, p.4.

110. "Verbijstering' bij TROS over samewwerking mel commencieel Veronica, in: NRC, 30 sept. 1994, p.10.

111. Contracten wan omroepen niet strijdig met wet, in: NRC, 10 nov, 1994, p.2.

112. Vraagtekens bij overeenkomsten, in: Comedia, nr.36, nov. 1994, p.2; Sicrt. 10 now. 1994, 217.

113. Commissaris financiele en technische zaken van het $\mathrm{CvdM}, \mathrm{t}$.w. W. Etty, Het CvdM ower zijn voomemens woor 1995, in: Comedia, nr.38, jan. 1995 , p.4, tekent terecht het belang aan wan goede mededingingsregels. Hij acht het taak van het commissariaat om een goede ordening aan te brengen in de ontwikkelingen op het mediagebied. Problematisch daarbij vindt hij "dat de wet nog steeds is gebaseerd op radio en $t v$, en los staat van informatica en telecommunicatie" ".

114. Wijers toetst af te sluiten amroepakkoord, in: NRC, 16 nov. 1994, p.6. 
medewerking aan 'winst door derden'. Daarnaast uiten de kamerleden zorg ower het uit handen geven aan Veronica van de, van oudsher exclusieve en voor het ledental bepalende, omroepgegevens. ${ }^{115}$ Door het vrij geven van omroepgegevens aan Veronica, na vertrek van deze omroepvereniging uit het publiek omroepbestel, achten uitgevers van tijdschriften zich trouwens ook gerechtigd om te beschikken over die omroepgegevens. " Vandaar wenst de Tweede Kamer opheldering van zaken over het "bloedverbond' van publieke met commerciële omroep. ${ }^{117}$ Bovendien wil de Tweede Kamer, in thet bijzonder de PvdA, weten hoe ver de betrokkenheid van departementsambtenaren bij het overleg over de samenwerking gaat. In reactie daarop deelt de betrokken staatssecretaris mede dat slechts sprake is van twee ambtelijke gesprekspartners, op verzoek van de omroepen, die nauwelijks iets in de melk hebben te brokkelen. Zij treden "alles behalve sturend" op. ${ }^{118}$

Naast de mogelijke strijdigheid van de alliantie met de Mediawet kan samenwerking problemen geven in Europeesrechtelijk opzicht. Het beloven van een "bruidschat" "19 aan een uittredende omroep met commerciële doeleinden, die daardoor wordt bevoordeeld ten opzichte van andere omroepen, moet kritisch worden bekeken. ${ }^{120} \mathrm{Zo}$ " $\mathrm{n}$ ruggesteun kan in de ogen van de Europese Commissie wreed aankomen, die dan - in het licht van art. 92 EG-verdrag inzake steunmaatregelen ${ }^{121}$ - mogelijk negatief over de, bij haar aan te melden, steunverlening oordeelt.

In de kring van onafhankelijke televisieproducenten in Nederland heerst ook onrust naar aanleiding van de overeenkomst tussen Endemol/Veronica en de publieke omroepen

115. Overigens lijkt terbeschikkingstelling van omroepgegevens in de toekomst onwermijdelijk, gelet op andere Europese juridlische tradities (bij woorbeeld in Ierland en Engeland sinds een negatieve uitspraak ter zake van de hoogste rechter daar in 1991) watr dergelijke monopolistische 'auteursmechten" miet meer wonden gerespecteerd. Zie expliciet de hoger beroepskwestie inzake Magil TV Guide Ltd Radio Telefis Eriean (RTE) en Independent Television Publications Limited (ITP), HvJ EG (C-241/91 P en C-242/91 P) 6 april 1994, in: NJB, nr.22, 2 juni 1995, rechtspraakkatem nr. 7, pp.283-284 (bijlage).

116. De Nederlandse Orgamisatie van Tijdschriftenuitgevers verwacht dat uitgevers de gegevensverstrekking aan Veronica als "breekijzer" gebruiken. Uitgevers bladen: gegevens omroep moeten wrij zijn, in: $\mathrm{NRC}$, 7 okt. 1994, p.3, Tevens Omroepen op eerste net onder druk van VNU, in: NRC. 14 okt. 1994, p.3; Zie ook Z. Luyendijk en M. Tamminga, "Deal' tussen omroepen en Veronica wankelt, in: NRC, 15 okt. 1994, p.3.

117. Kamer: wragen over alliantie wan omroepen, in: NRC, 4 okt. 1994, p. 3.

118. Z. Luyendijk, De koorts stijgt in Hilversum, in: NRC, 5 okt. 1994, p.2; Zite ook W. op den Brouw, Kabinet-Lubbers 3 maakre de weg vrij, in: INRC, 10 okt. 1994, p.3.

119. Verantwoordelijk staatssecretaris Nuis spreekt uit dat geen sprake is van het door Veronica meenemen van de met publieke middelen verworven goodwill door Veronica. Z.i. krijgt VOO geen bruidschat mee: "Alle kosten die verband houden met de voorbereiding van de commerciële toekomst moeten uit eigen verenigingsvermogen betaalld worden. De omroepmiddelen dienen voor de publieke programmering tot het moment van wittreding. Het houden van toezicht op de uiwoering van de wet ligt bij het: CwdM. In dit geval is dus thet CwdM de eerst aanspreekbare op de wijze waarop verder inhoud wordt gegeven aan de desbetreffende bepalingen." Uittreden VOO, TK 1994-1995, 23968 , nr.1, p.2.

120. F. Kuitenbrouwer, De vragen stapelen zich op: mediawet is zalig onbestemd, in: NRC, 5 okt. 1994, p. 3.

121. Interessant qwerzicht van de rechtspraak over steummaatregelen geven L. Hancher en P.J. Slot, Recente ontwikkelingen op het gebied yan steunmaatregelen, in: SEW, nr.5, 1995, pp.307-335. 
waarmee laatst genoemden - door het binnen halen van het "paard van Troje" - ${ }^{122}$ lij.ken te investeren in hun eigen ondergang. Bij brief laten deze producenten weten dat de samenwerking, naar hun oordeel, hett karakter draagt van een concurrentievervalsend kartel. ${ }^{123}$

In de weerstand tegen de samenwerking weerklinkt een roep om de oprichting van een nieuw (VPRO/NPS)net voor hoogwaardige informatieve, culturele en vermakelijke programma's, nu de publieke omroep identiteit lijkt in te wisselen voor rentabiliteit en. zij pluriformiteit uitspeelt tegen eenzijdigheid. ${ }^{124}$

Als zo het "oneindige feullleton getiteld 'de overlevingsstrijd van Het Bestel' ongeveer het enige televisie-programma is dat in eigen beheer wordt gemaakt", ligt de vraag voor in de mond "hoe ver een overheid voorzieningen moet treffen om een tegenwicht te kunnen bieden aan de niet te stuiten commerciële omroep". ${ }^{125}$ Zo weerklinkt de roep om een belangeloos publiek debat over de vraag "welke dienst wij in de omroep nodig blijven hebben en welke organisatie die dienst het beste kan waarborgen, en of daarnaast ook commerciële omroep in ons aardse zendernet is in te passen". 26

Moet het publiek omroepbestel wel op de markt worden gegooid en worden verkwanseld aan de hoogste bieder. Of is het beter om een politieke visie op langere termijn te ontwikkelen op de publieke omroep en duidelijk te maken wat de werkelijke waarden wan een publiek omroepbestel zijn ${ }^{127}{ }^{128}$ en hoe die waarden zo goed mogelijk in stand zijn te houden. Van uit deze gedachte dat de overheid een gezonde publieke omroep moet

122. Aldus de op een na grootste televisieproducent van Nederland $\mathrm{H}$. de Winter van ID TV, geciteerd door $T$. Rooduijn. Telewisie mag niet in te weinig handen konten; TV-producent en 'gameshow'-kaning Harry de Winter over de omroepstrij, in: NRC (zaterdag bijwoegsel), 19 mov. 1994, p.2, die kritisch is over de 'afnamegarantie' en vreest voor kartelvorming.

123. "Kartel omroepen met Endemol dreigt", in: NRC, 12 okt. 1994, p.3.

124. T. Rooduijn, Als de pulp gaat regeren wordt het tijal voor een kwaliteitsnet, in: NRC, 4 okt. 1994, p.9; B.M. Brans, We moeten ons schamevt dat her zover is gekomen, in: NRC. 8 okt. 1994, p.9, toont zich

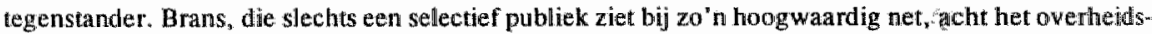
taak juist meer dan een culturele elite te bereiken. Bij het $z . i$. moodzakelijk werken aan een kwalitatief stevige publieke omroep, ziet auteur de zin van effectieve ledeninbreng.

125. M. Kranenburg. Wie maakt een eind aan Het Bestel?, in: NRC, 6 okt. 1994, p.9.

126. E. Jurgens, Omroep moet tot publieke dienst worden gedwongen, in: NJB, nr.40, 11 nov. 1994 , pp. 1384-1385. Auteur vindt dat het omroepbestel, alls van ouds, meer uit moet gaan van het gromdrecht wan de ontvanger i.p.v. dat van de zender.

127. Volgens K. van "Twist, Publieke omroep moet zijn kracht in de kunstwereld zoeken, in: NRC, 9 dec. 1994 , p.7, ligt die meerwaande van de publieke omroep in een principiele en financiële gerichtheid op kunst, film en drama.

128. Ook volgens de vroegere NOS directeur $\mathbb{E}_{\text {. van }}$ Westerloo, geciteerd door $Z$. Luyendijk, "Ower war publieke omroep is, wordt nooul gediscussieerd', in: NRC, 12 dec. 1994, p. 2, is de essentie van de publieke (omroep)taak "primair om educatie, informatie en cultuur te brengen; programma" $s$ die niemand anders zal maken". M.a.w. "essentie is adequate informatie, goede parlementaire nieuwswoor-

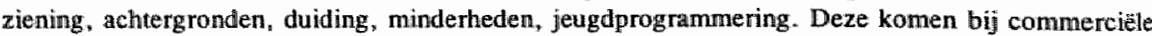
bedrijwen nauwelijks aan de orde, want dat is niet rendlabel". Hierbij ziet Van Westerloo scherp dat de publieke omroep is "als een dienstverlening, even als je elektriciteit kan afnemen, of gas". 
stimuleren, kan Engeland als voorbeeld dienen. ${ }^{129}$ In Engeland dragen commercieile zenders financieel bij aan een zuiver publieke omroep. Een, van uit deze Britse basis gevoerd, pleidooi voor Nederland luidt: "Laten de commerciële stations door licentiegelden er dan aan meebetalen, want uiteindelijk profiteren zij ook van de specifieke opdracht die de publieke omroepen vervullen, bovendien zou het in hun voordeel werken wanneer de publieke omroepen dan geheel konden afzien van reclame-inkomsten. Daarmee zouden de rollen worden omgedraaid: de publieke omroep betalen niet de commerciële omroep ${ }^{130}$, maar andersom: Veronica/Endemol en RTL hebben dan een financiële verplichting aan de publieke zaak." 131

De politiek verantwoordelijke staatssecretaris spreekt uiteindelijk het verlossende woord. Volgens hem is de, zijns insziens meer van uit een offensieve houding van Veronica/Endemol dan een defensieve attitude van de publieke omroep gesloten, puur tussen betrokken particuliere partijen geldende zakelijke overeenkomst - die past in het regeerakkoord dat een sterke en herkenbare publieke omroep voorstaat - niet strijdig met Mediawet en andere wet- of regelgeving als Wem of Europees recht. ${ }^{132}$

De Mediaraad, die - gedreven door de noodzaak van krachtig en scherp mededingingsbeleid - een andere mening is toegedaan, acht de overeenkomst wel in strijd met EG-recht. Immers, door haar concurrentiebeperkende dan wel concurrentievervalsende werking moet de samenwerkingsomroepovereenkomst worden verboden, zeker nu de door het akkoord ontstane machtspositie te danken is aan de verlening van bijzondere of uitsluitende rechten als de bescherming van programmagegevens. ${ }^{133}$

Als de discussie dan toch lichtelijk luwt, beroert Veronica opnieuw de gemoederen door een kordate koerswijziging. Veronica en Endemol zien af van de samenwerking met publieke omroepen. Rigoreus rijden beide private partijen de rit met RTL uit. Veronica en RTL willen een houdstermaatschappij oprichten, waarin vier televisienetten (met een

129. Engeland dient voligens M. Anstadt, Regering heeft omroep aan heidenen uitgeleverd, in: NRC. 11 febr. 1995. p. 9, ook tot voorbeeld voor commerciële omroepen. Om enig niveau van kwaliteit bij commercielle omroepen te warborgen moet de overheid, volgens auteur, deze omroepen an een redactiestatuut, gelijk cle Britse situatie, onderwerpen. Op zich is dit een alardige aanbeveling. Nu de commerciële omroepen zich een sterke positie hebben veroverd, is $20^{\prime \prime} \mathrm{n}$ aanbeveling echter niet meer afdoende: Auteur verwijt overigens de wetgever, dat deze bij het komen tot bet "nieuwe, gemengde, krakkemikkige omroepbestel" , onjuist witgaat van een verouderd ordening sprincipe: "Als de regering het verschijmsel wan een geleidelijke ontzuiling in haar overwegingen had betrokken, had zij i.p. $v$, onder het mom wan democratie een stringent getalscriterium in te voeren, een wettelijk kader geschapen dat woorzag in fuisies thissen organisaties met geringe onderscheidende achtergrond. Zij had het bestel niet opgezadeld met een 'stoet van dwergen' - van Rvui tot Socutera, en van Humanistisch Verbond tot Teleac-die een evenwichtige programmering verstoren."

130. VVD'er Dees vindt, dit het moeilijkst te aanvaarden punt wan de omroepovereenkomst. "Als je de constructie doorlicht, zie je dat de publieke omroep met het geld uit de omroepbijdragen de commerciële omroep subsidieerte" stelt hij in: VVD vindt één publieke zender voor tw voldoende, in: NRC, 11 nov. 1994. p.2.

131. K. Wan Twist, Met dealen is de publieke omroep niet te redden, in: NRC, 12 okt. 1994, p.7.

132. Brief staatssiecretaris Nuis aan de Tweede Kamer, 31 okt. 1994, Uitreden VOO, TK 1994-1995. 23968. nr.1. pp.3-4/5-6. Zie hienover Nuis stemt in met akkoord met Veronica, in: NRC, 1 now. 1994, p. 3.

133. Ontroepakkaord obstakel voor concurrentie, in: NRC, 4 nov. 1994, p.3. Zie ook Z. Luyendijk, 'Huildige Mediawet voldoet niet', in: NRC, 11 nov. 1994, p.2. 
gemeenschappelijke reclameverkooporganisatie) worden ondergebracht. In het overkoepelende bedrijf krijgt Veronica 26 procent aandeel, de Luxemburgse moedermaatschappij van RTL (CTL: Compagnie Luxembourgeoise de Télédiffusion SA) krijgt een zelfide aandeel, daarnaast nemen Endemol en uitgeverij $\mathrm{VNU}^{134}$ deel woor 24 procent. ${ }^{135}$ In maart 1995 wordt duidelijk dat per september inderdaad een nieuwe houdstermaatschappij Holland Media Groep met een nieuwe zender van de grond komt. Wel ligt het verhoudingsgewijs enigszins anders: RTL en Veronica/Endemol hebben aandeel in de holding voor respectievelijk 51 en 49 procent. ${ }^{136}$ Het meerderheidsbelang van RTL betekent niet dat Veronica het onderspit delft. Belangrijke beslissingen, betreffende bij voorbeeld de arbeidswoorwaarden, de werkgelegenheid, de 'format' van Veronica of de opheffing van Veronica, vereisen namelijk unanieme besluitworming. RTL en Veronica zijn vooral "complementair". ${ }^{137}$

Oorzaken voor Veronica/Endemol om de overeenkomst met de publieke omroepen eenzijdig - met het reële risico van een schadeclaim ter zake van de zijde van de betrokken publieke omroepen ${ }^{138}$ - op te zeggen zijn: "ongelooflijke traagheid" als mede "een gebrek aan vertrouwen" bij de publieke omroepen. ${ }^{139} \mathrm{Bij}$ laatst genoemde factor volgt verwijzing naar het feit, dat de publieke omroepen de bedongen afnamegarantie als 'gedwongen winkelnering' beschouwen. Door deze drastische ommezwaai van Veronica/Endemol, ontstaan misschien eerst echte kansen om te komen tot een "waarachtig publiek bestel in plaats van een imitatie-commercieel bestel" ${ }^{140}$

Door woornoemde fusie, waartegen de verantwoordelijke staatssecretaris zich niet verzet, althans deze is niet voornemens - via nieuwe wetgeving - de degens te kruisen, wordt de rol van de publieke omroep "niet marginaller, maar essentiëler". ${ }^{141}$ In haar wezenlijke taakvervulling dient de publieke omroep zich dan te spiegelen aan de commerciële omroep: samenwerking tussen publieke omroepen, in het bijzonder op Europees niveall, is bittere noodzaak. De noodzaak zich in een brede en diepgaande discussie te beraden op

134. Hiermee zit VNU zeer stevig in het zadel van zowel het, op winst gerichte, private als het, mon-profit koersende, publieke paard. M. Tamminga, Uitgever VNU spin in het web in medialand, in: NRC, 17 dec. 1994, p. 15.

135. Veronica en RTL zetten wier televisienetren op de markt, in: NRC, 9 dec. 1994, p.1,

136. Bovendien neemt RTL voor 24,9 procent deel in Endemol en bezit RTL 20 procent aandelen wan Veronica Blad. RTL en Veronica gaan definitief samenwerken, in: NRC, 24 febr. 1995. p. 3.

137. Willew van der Meer de Walcheren. we liggen op koers, in: Comedia, nr. 39, febr. 1995, p.4; Zü ook interview met W. van der Meer de Walcheren met M. Snoeijen, 'We moeten nog flink robbertje wechw ten', in: NRC, 31 maart 1995, p.7.

138. Nais: wan verloren zaak geen sprake, in: NRC, 9 dec. 1994, p.3.

139. Veronica zegt costract met omroepen op; Nu samenwerking met omroepen op * in: NRC, 8 dec. 1994, P.1.

140. Aldus VPRO-directeur H. van Beers, geciteerd door Z. Luyendijk, Brenk met Veronica/Endemol hing al even int de lucht, in: NRC, 8 dec. 1994, p.3.

141. Nuis: geen niewwe wergewing tegen media-afspraken, in: NRC, 13 dec. 1994, p. 2; Bj het uittreden wan VOO concludeert staatssecretaris Nuis all dat de "door de publieke omroep gekozen marsroute (bedoeld wordt nog de strategische alliantie tussen Veronica/Endemol en een paar publieke omroepen - JGLvN) ten woiordele van het publieke bestel zal strekken". Nuis meent dat door de gemaakte afspraken "noch de missie noch het onderscheidend programma-aanbod wordt aangetast" . Mediabeleid", TK 1994-1995. nr. 1, pp.6-7. 
de toekomstige taak en functie van de publieke omroep spoort de Nederlandse Journalisten Vereniging aan tot oprichting van een commissie ter zake. ${ }^{142}$

De nieuwe commerciële coalitie levert kennelijk minder bedreiging op voor het verdwijnen van de, in het publieke omroepbestel aan de wettelijke omroepbijdrage gekoppelde, pluriformiteit ${ }^{143}$ dan voor het weg vloeien van het reclamegeld.

Even als de eerder voorgenomen 'strategische alliantie" wordt ook bij de mega-deal tussen RTL, CTL, VNU en Veronica/Endemol aangedrongen op een toetsing er van aan Europees mededingingsrecht. ${ }^{144}$ Het kabinet besluit inderdaad de mogelijkheden te bekijken om de commerciële mediafusie te toetsen aan de Wem en de Europese mededingingsregels. ${ }^{145}$ In deze toetsing wordt dan het draagvlak van de publieke omroepen verdisconteerd. ith

Een dergelijke toetsing kent essentiële vragen: a. is het feit dat de combinatie Veronica/Endemol/CTL/VNU beslag legt op 70 procent Nederlandse reclamegelden frustrerend voor mogelijke nieuwkomers op de commerciële markt; en b. werkt de deal in ander opzicht concurrentiebeperkend (kent het samenwerkingscontract bij woorbeeld expliciete uitsluitingen). Kortom, toetsing aan art. 92 EG-verdrag inzake steunmaatregeIen is mogelijk. Daarnaast is het niet uitgesloten dat de mega-deal op juistheid wordt bekeken in het kader van de Europese verordening inzake fusies, die van toepassing is als een fusie waarin partners een gezamenlijke omzet hebben van meer dan vijf miljard ecu of circa twaalf miljard gulden. Nu de fusie tussen RTL/CTL/VNU/Veronica/Endemol beneden deze omzet blijft, kan de nationale regering - omdat vermelde verordening niet van toepassing is - de Europese Commissie verzoeken de samenwerking te onderzoeken. ${ }^{147}$

Verlening van concessies en voorlopige concessies, die voor zowell televisie en radio gelden (respectievelijk art. 31, tweede lid, Mw en art. 37, tweede lid, Mw), geschiedt onder de bepaling op welk televisienet de concessionaris zal uitzenden. Deze profileringseis is neergelegd in respectievelijk art. $35 \mathrm{Mw}$ en art. $37 \mathrm{c} \mathrm{Mw}$. Verzoeken om toekenning van concessies gaan vergezeld van a. opgave van ledenaantal van betrokken omroepverenigingen en $b$. door aanvragers ingediende beleidsplannen (respectievelijk art. 32, eerste lid, $\mathrm{Mw}$ en art. $37 \mathrm{a} \mathrm{Mw}$ ).

142. Commissie bekijkt publieke ontroep, in ${ }^{*} \mathrm{NRC}, 19 \mathrm{dec} .1994, \mathrm{p}, 3$.

143. Belangrijk beleidsmedewerker wan het CvdM, t. W. Moerer, meent dat de komst van Veronica/Endemol/CTL/VNU niet de aande onder de woeten van die publieke omroep in Nederland weg schuift. Aldhs weer gegewen door $Z$. Luyendijk, Toekomst omroepbestel in dichte mist, in: NRC, 17 dec. 1994, p.2.

144. Het verzoek om toetsing gaat, in beide gevallen, uit van Europarlementarièster Van Dijk: De minister wan economische zaken, $t$ w. G.J. Wijers, doet de Europese Commissie uiteinde lijk hett verzoek Concentrawetoetsing RTL/CTL/VNU/NOO/Endermol, bij brief d.d. 15 april 1995, als vermeld in: MF, nr.6, 1995, p. 884 (rechtspraakkatern).

145. Stcrt. 21 dec. $1994,246$.

146. Kabinet: roetsing van mediafusie aan regelgewing, in: NRC, 19 dec. 1994, p.3.

147. Minister wan economische zaken, t.w. G.J. Wijers, verzoekt o.g.v. art. 22, derde lid, Fusiecontroleverordening (Vo. 4064/89, Publ. 1990, L 257) de Europese Commissie orm Concentratietoetsing RTL/CTLNWUNOO/Endemol, bij brief d.d. 19 aprill 1995, vermeld in: MF, nr.6, 1995 , p.B84 (bijlage); Volgens voomemen komt de EC eind september 1995 met een definitief oordeel ter zake. Brussiet stelt onderzoek in naar mediafusie, in: NRC, 26 mei 1995, p.16. 
Het ledenaantal van minimaal 150.000 of 60.000 (ex respectievelijk art. 31, vierde lid, sub b, Mw en art. 37, vierde lid, sub b, Mw) wordt, op een door de minister te bepalen datum, door het Commissariaat voor de Media, niet tegenstaande de mogelijkheid van juridisch beroep ${ }^{148}$, vastgesteld (respectievelijk art. 32 , eerste lid, sub b, en derde lid, Mw en art. 37a, eerste lid, sub b, Mw). Daartoe kan het commissariaat madere regels stellen (respectievelijk art. 32, vierde lid, Mw en art. 37a, derde lid, Mw). Feitelijke ledentelling is niet nodig. Een accountantsverklaring betreffende het ledenaantal volstaat. ${ }^{149}$ Bedoelde beleidsplannen, die conform respectievelijk art. 36a Mw en art. 37e Mw gewijzigd kunnen worden, omvatten een programmatisch identiteitsgebonden aanbod en voornemens aangaande samenwerking met andere omroepverenigingen, educatieve omroepinstellingen en de Nederlandse Programma Stichting (respectievelijk art. 32, tweede lid, Mw en art. 37a, tweede lid, Mw). Het volledig programmavoorschrift blijft gehandhaafd in art. $50 \mathrm{Mw}: 20 \%$ cultuur (waarvan 10\% cultuur) en $30 \%$ informatief en educatief. Bij samenwerking van omroepen, resulterend in oprichting van een rechtpersoon, moeten zij slechts gezamenlijk aan de regels inzake programmering voldoen (artt. 34a/34b Mw juncto art. $51 \mathrm{Mw}$ ). Het gegeven dat door het - tot op percentages en (European System for the Classification of Radio and Television-)categoriseringsstelsel $\mathrm{af}^{i 50}$ - nauwkeurig omschrijven van programma-aanbod de 'overheid-op-afstand-relatie' steeds dwingender is geworden ${ }^{151}$, verhindert dus niet dat de wetgever opnieuw, nu nota bene in de Mediawet zelf, voorwaarden stelt met betrekking tot de programmering.

Het verlenen van zendtijdconcessies aan de landelijke omroep is "geen doel op zich"; "De rechtsfiguur van de concessie wordt gezien als een instrument om zekerheid voor langere termijn te bieden aan omroeporganisaties." 152

148. Mvt wijziging Mediawet, TK 1992-1993, 23257, nr.3, p.37.

149. Mw wijziging Mediawet, TK 1992-1993, 23257, nr.3, p.37.

150. Wat betreft de $50 \%$-quotering voor Europese programama's op landelijke en regionale televisie (zie ant. 54 voorstel wijziging $M w$ i. w.m. sponsoring, TK 1993-1994/1994-1995, 23752, mrs. $1-3 / 199$, vgl. antit. $52 \mathrm{k}-521 \mathrm{Mb} 1992$ als geldend voor de binnenlandse commetcielle omroep, zie ook art. $4 \mathbb{E G}$-richtlign inzake grensoverschrijdende televisie) stelt de Europese commissaris van cultuur- en mediabeleid, w... w. M. Oreja voor de hwidige Europese quota na een gelimiteerde periode van circa tien jaar te schrappen. EU-commissaris wil einde quota tw-programma, in: NRC, 1 maart 1995, p.5; Hoewel B. de Witte, Nieuwe controverse over de Europese quota's, in: MF", nr. 3, 1995, p.29, zo geen verscherping van de Europese filmindustrie verwacht, ligt volgens them drastische vermindering van bescherming van die

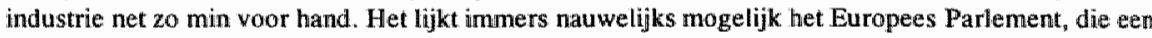
verhoogde bescherming van de Europese filmindustrie altijd heeft gesteund, te passeren in de voor een eventuele wijziging van art. 4 EG-richtlijn noodzakelijke codecisieprocedure; Eind maart 1995 komi dan toch het bericht dat de Europese Commissie de minimumquota's, die gaan gelden voor tien jaar, wil aanscherpen. Brussel: aanscherping van quota voor N-progranuna's, in: NRC, 23 maart 1995, p.21; De discussie daarover stelt Frankrijk, dat de eerste helft van 1995 de Europese Unie voarzit, waarschijnlijk bang voor gezichtverlies (Frankrijk is fel voorstander van verscherping van wetgeving terwiji de meeste andere Europese landen daar anders over denken), uit. B. Donker, Minimumquota ap telewisie: debat afgelasi, in: NRC, 4 april 1995, p.5.

151. G.W. Noomen, t.a.p., p.79.

152. Mvt wiziging Mediawet, TK 1992-1993, 23257, mr.3, pp. 10/19. 
De duur van de ministeriële concessieverlening bedraagt aanvankelijk tien jaar (respectievelijk art. 31, derde lid, Mw en art. 37, derde lid, Mw). In geval van concessieverlening vindt, ex art. $36 \mathrm{~b} \mathrm{Mw}$, na vijf jaar evaluatie plaats. Blijkt dat beleidsplannen niet of niet naar behoren zijn uitgevoerd, of heeft het Commissariaat voor de Media binmen een periode van een jaar minimaal twee keer een sanctie wegens wetsovertreding -waaronder zendtijdintrekking van ten hoogste twaalf weken- opgelegd, dan wordt een verlleende concessie mogelijk ingetrokken (respectievelijk art. 36c Mw en art. $38 \mathrm{Mw}$ ).

De aan een concessie verbonden termijn kent de nodige kritiek. Zij zou leiden tot identiteitsverlies bij de omroepen ${ }^{153}$, "stiefmoederlijke behandeling" van verschillende medi$a^{154}$ en ongewenste verstarring. Gewezen is op de "associatie met Rembrandts schilderij 'De anatomische les': de omroep op de snijtafel en mevrouw d'Ancona als een vertwijfelde professor Tulp, die doceert dat het in coma verkerende lichaam tien jaar in een zuurstoftent tot rust moet komen. Zij het, dat eerst de lever moet worden gesplitst (d.w.z. splitsing radio- en televisieprogramma's in een NOS en een NPS - JGLvN)". ${ }^{155}$ Bedoelde "goudgerande garantie voor zendtijd zou het belang van een breed en gevarieerd informatie-aanbod wel eens kunnen schaden". ${ }^{156}$ En met termijnstelling geeft de minister aan de omroepen een "alibi om door te gaan met ruziën, vergaderen en geld verkwisten"; M.a.w. het Nederlandse "ondoelmatige omroepbestel wordt kunstmatig op de been gehouden". ${ }^{157}$

In de discussie wordt al snel een politieke voorkeur voor een periode van vijf jaar uitgesproken. ${ }^{158}$ Desondanks houdt de verantwoordelijke minister van WVC voet bij stuk. ${ }^{159}$ In het debat luidt het oordeel van het kabinet-Lubbers III als volgt. De publieke omroepen krijgen een "concessie met een uitzendgarantie van tien jaar op voorwaarde dat zij een samenwerkingsplan opstellen". . ${ }^{160}$ Ontbreekt zo'n plan, dan kan slechts concessieverlening yoor vijf jaar plaats vinden. Daarvan is wel conversie in een tienjaarlijkse termijn mogelijk, indien binnen twee jaar als nog een samenwerkingsplan aanwezig is. ${ }^{161}$

Het in het prille najaar van 1994 aantrediende kabinet-Kok gooit de boel dan toch weer in de war. PvdA, VVD en D'66 stellen in hun regeerakkoord vast dat, met oog op het

153. B. M. Brans, Nationale omroep is al in de maak, in: NRC, 21 april 1993, p.7; B.M. Brans, De nationale omroep dreigt er aan te komen, in: NRC, 12 jan. 1994, p.11.

154. Raad voor de Kunst: voorstel mediawet slecht woor de kunst, in: NRC, 30 nov. 1993, p.6.

155. L. Kool, De omroep op de smijtafel mes d'Ancona in de rol van prof. Tulp, in: NRC, 20 febr. 1993, p.9.

156. A. van der Louw, Bü goudgerande omroepgaranties is kijker nier gebaat, in: NRC, 5 now. 1993, p.9.

157. F. Bolkestein, Van de mediawet geen mieuws, in: NRC, 20 now. 1993, p.9.

158. Mva wijziging Mediawet, TK 1993-1994, 23257, nr.6, p.28; Daartoe vindt indiening plaats van het ameidement-Wolffensperger (D"66), TK 1993-1994, 23257, nr.26, pp.1-2.

159. Z. Luyendijk, d'Ancona eigengereid' in mediadebat, in: NRC, 11 febr. 1994, p.2 en ook Her bestel geprolongeerd, in: NRC, 11 febr. 1994, p.9.

160. Kamer "dwingt" amroepen tot samenwerking, in: NRC, 24 febr. 1994, p.3.

161. Zie amendement-Van Nieuwenhoven, TK 1993-1994, 23257, nr.29, pp.1-3, gewijzigd bij nr,65 en mir.69, pp. 1.3 . 
veranderende medialandschap, omroepen een concessie voor vijf jaar moeten krijgen. ${ }^{162}$ Daarom vindt opnieuw ${ }^{163}$ wijziging van de nog zo verse Mediawet plaats. ${ }^{164}$ Art. 31, derde lid, Mw luidt voortaan: Concessies worden een maal in de vijf jaren verleend voor een, voor alle concessionarissen tegelijk aanvangende, periode van vijf jaren. De concessies vervallen na afloop van de concessieperiode. Ex art. 36 , tweede lid, $\mathrm{M} w \mathrm{k}$ an de minister van $\mathrm{OCW}$ een verleende concessie intrekken, indien hel CvdM aan de concessionaris binnen een periode van een jaar ten minste twee maal ter zake van overtreding van het bepaalde bij of krachtens deze wet een sanctie heeft opgelegd, waaronder ten minste een keer een sanctie als bedoeld in art. 46 , eerste lid, $M w$. Ten aanzien van voorlopige concessies bepaalt art. 37 , derde lid, $\mathrm{Mw}$, dat deze een keer in de vijf jaar worden verleend voor een, voor alle houders van een voorlopige concessie gelijke, periode van twee jaren, samenvallen met de laatste twee jaren van de concessieperiode, bedoeld in art. 31, derde lid, eerste zin, Mw. Ook voorlopige concessies vervallen na afloop van de concessieperiode. Ex art. 39, derde lid, Mw hebben omroepverenigingen met voorlopige concessie uitsluitend zendtijd in de laatste twee jaren van de concessieperiode, bedoeld in art. 31, derde lid, eerste zin, Mw. De aldus veranderde Mediawet bevat ook overgangsbepalingen die bepalen dat, vóór de datum van inwerkingtreding er van, verleende tienjarige concessies van rechtswege worden omgezet in, of met terugwerkende kracht te beperken tot, vijfjarige concessies. ${ }^{16.5}$

De preferentie van een vijfjarige boven een tienjarige concessietermijn krijgt als volgt toelichting. Een vijfjarige concessietermijn "combineert het bieden van een veeljarige zekerheid met de mogelijkheid om tijdig in te spelen op nieuwe ontwikkelingen die naar verwachting in de komende jaren zullen afkomen op de omroepsector". "16. Het concessiestelsel, gebonden aan vijfjarige termijnen, biedt dus meer flexibiliteit. Bovendien valt het voordeel van het wegvallen van tussentijdse toetsing van (tienjarige) concessies op. Hoewel verschillende politieke partijen verongelijkt mopperen over het feit dat de voor-

162. Regeerakkoord 1994: kelazes voor de toekomst, TK 1993-1994, 23715, nr.11, p.32. Hierbij geldt: "Ila de komende kabinetsperiode wordt bezien of tatk en functie van de publieke omroep in een veranderend medialandschap veranderitugen in haar organisatie, financieringsstructumr en omvang na die wijfarige periode noodzakelijk maken."

163. RPF en GPV spreken "refererend aan eisen wan behoorlijk bestum, in scherpe bewroordingen terecht veroordelend wan een "zig-zag-beleid". TK 1994-1995, 23978, nr.4, p.3. Staatssecretaris Nuis reageent daarop nog al luchtig. Weliswaar erkent hij dat "het proces (van wetgeving - JGLvN) wellicht fratier had gekund, doch gezien de publieke en maatschappelijke actualiteit onortkoombar is " (welk proces. z.i., bovendien, woor de omroep "niet tot schade in financieel-economische zin leidt"). Maar de betrouwbarheid wan politiek en wetgever acht hij niet aangetast. TK 1994-1995, 23978, nr.5, p.3.

164. Zic Wijzigingen wan de Mediawet i. w. hat beperken van de dw wrarvoor concessies voor omwopuerenigingen, zendrijdtoenwizigingen woorkerkgenootschappen en genootschappen op geesrelijke grandslag: en woesfemmingen voor commerciële omroepinstellingen worden verleend, tot een periode van vifjarew TK 1994-1995, 23978, ars.1-2, zie voor de uiteindelijke, per 30 dec. 1994 werkende, wet van 23 dec. 1994, Stbi. 1994, 946.

165. Volgens de PVdA-fractie verdient het aldus terug draaien van tienjarige concessies "geen schootheidsprijs". Staatssecretaris Nuis lacht alle bezwaren laconiek weg door te wijzen op het "belang van eert voortvarende behandeling " van het wetsvoorstel, waardoor de overgangsbepalingen waarschijnlijk geen toepassing krijgen. Nota n.a.v. verslag voorstel wijziging Mw i.v.m. concessietermiji, TK 1994-1995, 23978, nr.5, p. 3, zie voor PvdA-kritiek nr.4, p.1.

166. Mu woorstel tof wijziging Mediawet i.v.m. concessietermijn. TK 1994-1995, 23978, nr.3, p.2. 
keur van een vijfjarige termijnstelling niet duidelijk uit de verf komt, meent de politiek verantwoordelijke staatssecietaris dat de argumenten al afdoende zijn aangestipt. In het kort biedt een kortere termijnstelling voordelen van: flexibiliteit; openheid van en snellere toetreding tot het publieke omroepstelsel; eenvoudiger en doorzichtiger procedure van concessieverlening; en meer eenheid in termijnstelling voor verschillende omroepverenigingen (elke soort omroepinstelling heeft nu te maken met een vijfjarige termijn). ${ }^{167}$

Over de in thet kader van de concessies genoemde samenwerking het volgende. Er is wat tegen ${ }^{16 \%}$, maar ook wat voor samenwerking te zeggen. Dat is wel de "zwakke schakel van het wetsontwerp" genoemd: "gaat de opgelegde samenwerking tussen de omroepverenigingen zo ver, dat in feite de programmatische autonomie en verscheidenheid worden aangetast, dan valt wellicht ook de juridische grondslag weg voor de toedeling van drie televisienetten en vijf radiozenders aan deze publieke omroep. Laat het wetsontwerp echter ruimte aan de omroepverenigingen om een eigen weg te gaan en de beloofde samenwerking te boycotten dan is een eindeloze rij juridische procedures te verwachten voor de geschillencommissies, maar is de grondslag voor het verlenen van een zo veel jarige concessie verdwenen, nog afgezien van de vraag of de grote verliezer niet de kijker en de luisteraar zal zijn"." 169

De omroepverenigingen zelf zien de zin van samenwerking trouwens wel in. De drie omroepen op het Nederlandse derde televisienet, t.w. VARA, VPRO ${ }^{170}$ en NPS (inclusief RVU), achten zells een nog verder gaande samenwerking dan de samenwerking, die concessieverlening vereist, nodig. Daarom ligt het in hun bedoeling binnen vijf jaar één omroeporganisatie te vormen met gemeenschappelijk programmastatuut en gezamenlijke huisvesting. 171

Ook de zendgemachtigden op het eerste televisienet, t.w. KRO, AVRO en NCRV, gaan nauwer samenwerken. Hoewel zij hechten aan eigen identiteit, zijn zij voornemens hun programmering onderling af te stemmen en gebruik te maken van elkaars facilitaire voorzieningen. Ten einde te komen tot een optimale programmatische samenwerking te komen, opdat het eerste televisienet zijn marktaandeel goed kan verdedigen, wordt een "channel manager" aangesteld. ${ }^{172} \mathrm{Zij}$, en ook de andere publieke omroepen, voeren deze samenwerking, met ingang van 1 september 1995, bij voorkeur ook door voor de nieuwsvoorziening op de radio. ${ }^{173}$ Daardoor onstaan dan, wat betreft radio 1 , drie groe-

167. Nota na.w. verslag over wijziging Mediawet i, w.m concessietermijn, TK 1994-1995, 23978, wr.5, p.3.

168. Bij voorbeeid, C. Wolzak, Voetbal en omrocp.: een paarse coalitie?, in: Mediaforum, nr.7/8, 1994, p. 77 , acht de samenwerkingseis onder gelijktijdige handhaving van de voorwarde van pluriformiteit een "regel rechte gotspe".

169. W. Hins en G. Schuijt, Samen, maar toch apart; Commentaar op het wetswoorstel verterking publieke omroep, in: Mediaforum, nr.10, 1993, pp.101-104, i. h. b. p.104.

170. Owerigens is het onzeker of de VPRO in huidige, zelfstandige hoedanighet blift. Onderzoek voortbestaan van WPRO, in: NRC, 27 febr. 1995, p.3.

171. M. Snoeijen, Omroepen op derde net werken aan fusie: VPRO minder enthowsiast dan Vara en NPS, in: $\mathrm{NRC}_{2} 25$ febr, 1995, p.1.

172. Manager voor zender Nederland 1, in: NRC, 28 febr. 1995, p.3.

173. Nieuwsprogramma's ap radio samengevoegd, in: NRC, 30 maart 1995, p.2; Nieuwsredacties radio in clusters, in: NRC, 31 maart 1995, p. 3. 
pen die elk afzonderlijk, van uit én studio, een redactie vormen met vaste presentatoren. Het algemeen bestuur van de NOS doorkruist echter dit laatste plan. In plaats van drie, op bescherming van identiteit gerichte, redacties kiest de NOS voor een centrale piekurenredactie voor de nieuws- en actualiteitenzender radio $1 .{ }^{174}$ Dit NOS-besluit roept reactie op bij de publieke omroepverenigingen, die dan ook in meerderheid (AVRO, KRO, NCRV, EO en TROS) protest aan tekenen tegen dat besluit. ${ }^{175}$

Als dergelijke samenwerking vooral gericht is op kwaliteitswerhoging en garantie van volwaardige programmering, en minder op herkenbaarheid, dan kan dat redding van de publieke omroepen, die zich alleen zo kunnen meten met de commerciële omroepen, betekenen. Bovendien, "een verdere kwalitatieve profilering vormt op termijn ook de voornaamste legitimering van een mediastelsel dat uit publieke middelen wordt gefinancierd" 176.177

Naast intensieve samenwerking krijgt de kwaliteit van de publieke omroep impuls van een mogelijk op te richten vierde zender, te weten een satellietzender. ${ }^{178}$

Overigens is het, door de minister gedane, appèl aan de aanvankelijk tienjarige, maar uiteindelijk vijfjarige, termijn verbonden aan zendtijdconcessieverlening bij de commerciële omroep oneigenlijk. "De vergelijking is misleidend. De toestemming voor commerciële omroep impliceert geen aanspraak op feitelijke uitzending: noch via de kabel, noch via een zender. Van een recht op subsidie is evenmin sprake." ${ }^{179}$ Daarentegen verschaft een concessie voor landelijke omroep aan een betrokken publieke omroepvereniging het recht op zendtijd als mede een financiële bijdrage voor de verzorging van haar programma (respectievelijk art. 31, vijfde lid, Mw en art. 37, vijfde lid, Mw). Tegelijkertijd verplicht de concessionaris zich een programma voor landelijke omroep te verzorgen (respectievelijk art. 31, zesde lid, Mw en art. 37, zesde lid, Mw).

174. NOS-bestum stelt centrale redactie voor Radio it in, in: NRC, 22 apuil 1995, p. 3.

175. Meeste omroepen tegen 'piekredactie", in: $\mathrm{NRC}_{\text {. }} 24$ april 1995, p.8.

176. J. Schoonenboom , Publieke omroep moet a anvalien, wier werliezen, in: NRC, 28 febr. 1995, p.8. Auteur dringt a an op een "nationale om roep". Auteur beveelt aam om bij de concessieverlening" volgend op de allereerste concessieverlening, concessies "nog uitsluitend te verlenen aan een netorganisatie, en dxarbifi] het karakter per net te definièren". Zo"n nationale ommep bestaat uit segmenten Nederland 1 met algemene programmering woor een breed publiek; Nederland 3 met algemene programmering voor een geselecteerd publiek; en Nederland 2 met min of meer geestelijke programmering. De, per net werschillend opgebrachte, reclameopbrengsten komen alle netten ten goede. Overigens pleit auteur voor een. algemene programmaradd ("NOS-nieuwe-stijl"), die bepaalt of de algemene progranma-eis voor het geheel of voor elk net afzonderlijk geldr.

177. G. Hulshof, Kijkers willen herkenbare telewisienetten met een visioer, in: NRC, 31 maart 1995, p.9, bepleit, i.p.v. één nationale publieke omroep, de noodzaak van zenderkleuring door nauwe samenwerking tussen publieke omroepen per tv-net; Wolgens J. Blokker, De 'woorzittersomroep" is failiet, in: NRC, 4 april 1995, p.9, behoort Hulshof tot de vele omroepfunctionarissen "die een modeme TGW" laten rijden, maar woor de zekerheid nog altijd een machinist en een kolentremmer atn boord houden". Blokker bepleit accentverlegging van omroepverenigingem en hun woorzitters naar programmaspecialisten. Z.i. moet de overheid "de zendmachtiging gunnen an een raad van professionele programmadeskundigen die onder een aantal strikte woorwaarden (waaronder om te beginnen die van de allom gewenste pluriformiteit), en met een stevig en coalitiebestendig statuut als dekschild, zijn gang kan gaan" .

4.78. NOS wil onderzoek war satellietzender voor publieke omroep, in: NRC, 11 maart 1995, p.3.

1.79. W. Hins en G. Schuijt, t.a.p., p.103. 
In alle tumult bij de introductie van het concessiestelsel wordt kennelijk vergeten dat in het verleden al fraai is vooruit gelopen op invoering van een machtigingssysteem voor de omroepen. ${ }^{i 80}$ Vergeleken met het huidige stelsel is er wel een fundamenteel verschil. In bedoeld plan van oudere datum heeft een omroep bestaansrecht als publieke dienst. De keuze voor de term concessie is bedoeld om nadruk te leggen op de analogie mett andere instellingen van openbaar nut, die geacht worden rendabel te functioneren binnen de grenzen van het allgemeen belang waarvoor zij hun concessie hebben verkregen. Concessieverlening geschiedt niet door een bestuursorgaan, maar door een instantie die onderdeel is van de omroeporganisatie. Deze zendgemachtigde, in principe een zendgemachtigde per televisie- of radiozender, verzorgt zelf geen televisie- of radioprogammauitzendingen. De instantie, waaraan zelf een machtiging is toegekend, verstrekt weer op grond van overeenkomsten submachtigingen aan een of meerdere omroepinstellingen voor het doen van (een reeks) uitzendingen. Hierbij stelt de centrale zendgemachtigde neutrale criteria inzake pluriformiteit en representativiteit. Op niet-nakoming van de aan de concessie gestelde voorwaarden stelt de zendgemachtigde sancties. De overheid, die in dit plan echt op afstand blijft, oefent samen met de rechter of arbiter algemeen toezicht op de gedragingen van de centrale zendgemachtigde.

Dat, in het omroepstelsel, vergunningverlening plaats maakt voor concessieverlening heeft als voornaamste oorzaak, dat een concessiesysteem beter past in een commercieel klimaat. Middels toekenning van een concessie bewerkstelligt de overheid dat een taak, die zij zelf om redenen niet vervult maar waarvan ze wel duidelijk het algemeen belang in ziet, wordt doorgeschoven naar een of meer veelal privaatrechtelijke rechtspersonen, die de behartiging van de publiekrechtelijke taak zo veel mogelijk bedrijfseconomisch aanpakken. Omdat concessies tijdelijk van aard zijn, kan de concessieverlener op den duur kiezen uit verschillende opties. Een verleende concessie kan worden verlengd. Is van verlenging geen sprake, dan vervalt een gegeven concessie en is de weg vrij voor concessieverlening aan een andere taakuitwoerende instantie.

Hoewel degene die de concessie verkrijgt, enige vrijheid inzake het streven naar een redelijke winst wordt gelaten, bouwt de overheid als concessieverlener vaak wel clausules in. Die condities staan dan in het teken van het openbaar belang, waarop de concessiegebonden taakbehartiging gericht is. Door de nadruk op dat algemene, publieke belang onderscheidt concessieverlening zich van vergunningverlenging. Daarnaast is, grof weg gesteld, concessieverlening (door verplichtingoplegging naar de concessieaanvrager toe) tweezijdig van aard en heeft vergunningverlening vooral een eenzijdig karakter (tenzij de vergunning flink voorzien is van voorwaarden, die moeten worden geaccepteerd door de vergunningaanvrager . Grof weg gesteld dan, want nu het publiekrechtelijk concessiestelsel voor de publieke omroep wettelijk wordt verankerd, heeft het er alle schijin van dat de tanden van de wet knagen aan de tweezijdigheid die concessieverlening kenmerkt.

180. E.C.M. Jurgens, Omroeprechr en auteursrecht: Nieuwe ontwikkelingen in informatie-en communicatierecht, preadvies CJV, 7 mei 1986, Zwolle, 1986, pp.1-46. 


\section{$\$$ 14.6 Verslag- en meldplichten omroepinstellingen}

Wat betreft het toezicht op de mediawet, voor het Commissariaat van de Media neergelegd in art. $134 \mathrm{Mw}$, kent het huidige wetsvoorstel nog niet te veronachtzamen verslagen meldplichten.

Zo moeten de statuten van de, door bepaalde omroepverenigingen op te richten, rechtspersoon en andere bescheiden waaruit de samenwerking tussen deze deelnemende omroepinstellingen blijkt, worden overlegd aan het Commissariaat voor de Media (art. 51, tweede lid, sub c, Mw).

Ook van een overeenkomst, die een lokale omroepinstelling - met oog op samenwerking bij programmaverzorging - met een regionale omroepinstelling, in wier gebied zij werkzaam is, sluit, moet het commissariaat in kennis worden gesteld (art. 51f, derde lid, $\mathrm{Mw}$ ).

Inkomsten uit sponsoring, de gesponsorde programmaonderdelen en de hoedanigheid van de sponsors, gespecificeerd per programma-onderdeel, moeten aan het CvdM elk jaar bekend worden gemaakt ex art. 64c, eerste lid, Mw. Hierbij kan het commissariaat, ex art. $64 \mathrm{c}$, tweede lid, $M w^{181}$, nadere regels stellen omtrent de inrichting van het verslag, de termijn waarbinnen het verslag moet worden uitgebracht en de periode waarop het verslag betrekking heeft.

$\mathrm{En}$, is een publieke omroepvereniging, in bezit van een zendtijdconcessie voor landelijke omroep, voornemens toestemming aan te vragen of een belang te verwerven in een commerciële omroepinstelling, dan moet zij dit eveneens melden bij het Commissariaat voor de Media (art. $71 \mathrm{~m}$, eerste lid, $\mathrm{Mw}$ ).

Voorts doen (niet-overheids)instellingen met zendtijd voor landelijke omroep en de Wereldomroep jaarlijks hun jaarrekening ${ }^{182}$ aan het commissariaat toekomen (art. $109 \mathrm{Mw})$.

De Stichting Etherreclame - die er voor zorgt dat zij is aangesloten bij de Nederlandse Reclame Code of een vergelijkbare door de Stichting Reclame Cade tot stand gebrachte regeling waardoor zij onder toezicht staat van de SRC, van welke aansluiting zij ex art. $61 \mathrm{a} \mathrm{Mw}{ }^{183}$ aan het $\mathrm{CvdM}$ kennis geeft door overlegging van een door het SRC verstrekte schriftelijke verk لaring van aansluiting - geeft, via de minister, aan het commissariaat op hoeveel inkomsten zij naar verwachting in een volgend kalenderjaar zal verwerven (art. 28a Mw). Dit geldt idem dito voor de Koninklijke PTT Nederland nv ex art. 122a Mw.

En de NOS (art. 99, eerste lid, Mw, vergelijk verslagplichten ex art. 16, derde lid, Mw) en de Wereldomroep (art. 108, eerste lid, Mw) rapporteren hun meerjarenplannen aan

181. Gewijzigd voorstel verandering en aanwilling Mw i.v.m. sponsoring. TK 1994-1995, 23752, nr. 199,

182. Naar aanleiding van miswerstanden bij de lokale omroepen die reclameboodschappen uitzenden, is bepaald dat het niet voldoende is dat een jaarrekening door een registeraccowntant of een accountantadministratieconsulent is opgesteld. Eis is, dat aan de jaarrekening een aparte verklaring van eén wam Comedia, nr. 32, mei 1994, p.2.

183. Gewijzigd woorstel wan verandering en aanvuling wan Mw i.v.m. sponsoring. TK 1994-1995, 23752 ,
nt.199, p.6. 
het commissariaat. Het commissariaat zendt de plannen, met zijn opmerkingen, door naar de minister. Bij niet tijdige indiening van de meerjarenplannen door NOS en Wereldomroep, vermindert het commissariaat de verstrekking van bevoorschotting met twintig procent (respectievelijk art. 106, derde lid, Mw en art. 108a, derde lid, Mw). De verdeling van financiële middelen, aan te wenden voor omroepprogramma's, ligt namelijk ook in handen van het Commissariaat voor de Media (art. $102 \mathrm{Mw}$ e.v.). ${ }^{184}$

Bovenstaande bekeken is te verwachten, dat van de opgedane ervaring met het controleren van jaarstukken een heilzame werking uitgaat. Schrijnend is de situatie, waarin het inzien van de jaarrekeningen over 1988 van respectievelijk AVRO, KRO, NCRV, TROS, VOO, VPRO en VARA pas medio 1994 kan worden gerealiseerd. Vertragende factor blijkt in casu de procedure, voor de Raad van State, over de volgens het Commissariaat voor de Media onjuiste categorisering van de opbrengsten uit de losse verkoop van programmabladen als verenigingsactiviteit (waarbij het geld ten goede komt van de verenigingskas) in plaats van nevenactiviteit (waardoor bedoelde omroepen het opgebrachte geld moeten aanwenden voor de verzorging van programma's). ${ }^{185}$ De stelling van de toezichthouder scoort. De bestreden beschikking van het commissariaat windt bevestiging.

Dit vervelende voorbeeld, dat hoe dan ook geen herhaling verdient, wordt wel gerekend tot een van de, al dan niet kwalijke, "kinderziekten" inherent aan "dit soort nieuwe wetgeving met nieuwe zelfstandige organen". ${ }^{186}$

\section{$\S 14.7$ Cijfermatige gegevens werkzaamheden Commissariaat voor de Media}

Cijfermatige gegevens van de werkzaamheden van het Commissariaat van de Media zijn te vinden in de jaarlijkse rapportages. ${ }^{187} 188$ Daarom worden ter illustratie de, in het kader van toezicht op naleving van de mediawet- en regelgeving meest interessante, resultaten weer gegeven. Het bestraffend optreden van het Commissariaat voor de Media, dat zo nodig rechterlijke toetsing moet kunnen doorstaan, is het meest merkbaar bij overtreding van reclamevoorschriften.

Het Commissariaat voor de Media brengt naar aanleiding van geconstateerde overtredingen in televisie-uitzendingen van het reclameverbod herhaaldelijk zijn voornemen tot

184. Voor de duidelijkheid: per 1 jan. 1995 vervall art. $103 \mathrm{Mw}$ inzake de, aan t.t.v. landelijke omroepverenigingen uit te keren, financiele tegemoetkoming voor gebouwen en de geldelijke vergoeding voor investeringen woor nieuwbouw.

185. Jaarrekeningen 1988, in: Comedia, nr.34, sepi. 1994, p.3.

186. Piet wan der Sanden." het is mooi geweest, in: Comedia, nr. 34, sept. 1994, p.5.

187. De dioor A van Raalte e.A., Doorbroken driehoek, in: CvdM, Evalhatie 1988-1993, Hillersum, 1993, p.84, gepresenteerde tabel bevat een onjuist overzicht van die cijfers in de jaarwerslagen. De genoemde

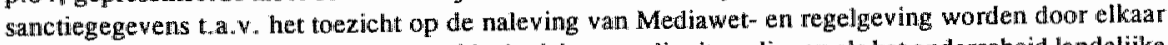
gehasdd wat betreft zowel het onderscheid televisie- en radiouitzendingen als het onderscheid landelijke en lokale of regionale omroepinstellingen.

188. Sinds het najaar vam 1994 publiceert het $\mathrm{CwdM}$ zijn besluiten ook in maandelijkse owerzichten in Comedia. 
sanctieoplegging ter zake aan landelijke omroepinstellingen bekend. In 1988 gebeurt dat maar liefst 60 keer, waarvan na het horen van de betrokken omroepinstellingen al 29 zaken wordlen geseponeerd wegens onder meer afwezigheid van schuld van de omroepinstelling of het treffen van maatregelen om herhaling te vermijden door de omroepvereniging, bovendien wordt na deskundigenadvies van 9 andere zaken afgezien ${ }^{189}$ en later nog eens in 12 gevallen tot seponering besloten ${ }^{190}$. In 1989 maakt het commissariaat 26 keer zijn sanctievoormemens bekend. ${ }^{19 \|}$ In 16 van die gevallen is uiteindelijk sprake van seponering, vooral op grond van het feit dat de reclame-uiting niet duidelijk identificeerbaar of herkenbaar in beeld is gebracht. ${ }^{192}$ In 1991 constateert het commissariaat bij landelijke omroepinstellingen 4 keer overtreding van de regel om vermijdbare televisiereclame tegen te gaan, en wat radio-uitzendingen door landelijke omroepverenigingen betreft wordt in elk geval 2 keer regeloverschrijding gesignaleerd. ${ }^{193}$ In 1992 behandelt het commissariaat 15 oude en nieuwe overtredingen ter zake in televisie-uitzendingen en 1 in een radio-uitzending. ${ }^{194}$ In 1993 zijn dat er respectievelijk 14 en 6 (3 van de zes laatst genoemde zaken betekenen - wegens wijziging van de Sanctieregeling - verlaging van eerder opgelegde boeten). ${ }^{195}$

In 1988 legt het commissariaat 9 keer een boete wegens overtreding van reclameregels in televisie-uitzendingen ${ }^{196}$ op, t.w. f $6.000,00(3 \mathrm{x})$, f $7.000,00(3 \mathrm{x}), \mathrm{f} 8.000,00(1 \mathrm{x})$, f $50.000,00(1 \mathrm{x})$ en f $60.000,00(1 \mathrm{x}) .{ }^{197} \mathrm{In} 1989$ legt het Commissariaat voor de Media 3 dergelijke reclameboeten op, t.w. f $60.000,00(2 x)$ en $f 70.000,00(\mathbb{x})^{198}$, bovendien beboet het commissariaat een omroepvereniging wegens ongeoorloofde ledenwervingsacties met $\mathrm{f} 100.000,00$ welk bedrag uiteindelijk bij rechterlijke uitspraak wordt gehalveerd ${ }^{199}$. In 1990 legt het Commissariaat voor de Media wegens reclameboodschappen en -uitingen boeten op van $\mathrm{f} 40.000,00(1 \mathrm{x})$, f $70.000,00(2 \mathrm{x})$ en $\mathrm{f} 130.000,00$ (plus f $25.000,00$ ), bovendien scheldt het commissariaat een boete van $f 70.000,00$ kwijt. 200

Het in 1989 ingevoerde toezicht op reclame in radio-uitzendingen van landelijke omroepinstellingen resulteert in 11 voornemensbrieven, waarvan het verweer daartegen 7 keer tot sepot leidt en na deskundigenadvies 3 zaken ongegrond $z_{i j n}$, overigens is sprake van

189. CvdM, Jaarwersiag 1988, Hilversum, 1989, p.43.

190. CudM, Jaarverslag 1989, Hilversum, 1990, p.37.

191. CydM, Jaarversilag 1989, Hilversum, 1990, p.37.

192. CvdM, Jaanierslag 1989, Hilversum, 1990, p.37.

193. CvaM, Jaarverslag 1991, Hilversum, 1992, pp.36-37.

194. CvaM, Jaarversilag 1992, Hillversum, 1993, pp.40-42.

195. CvdM, Jaarwerslag 1993, Hillversum, 1994, pp 3941.

196. Frappant feit is dat een omroepinstelling als de TROS tegenwoordig zelf medewerkers in dienst heeft, die gestructureerd toezicht houdlen op reclameovertredingen in programma's. Dit bespaart de TROS boeten van het CWdM. En ook bewijst de TROS zo dat overtredingen niet opzettelijk wordem begaan. Zie interview met de TROS-controleuse ter zake, t. w. J. Kruys, in "Leak hoar, die aflevering van wipew! t", in: Comedia, ar. 36, nov. 1994, p.5.

197. CvdM, Jaarverslag 1988, Hilversum, 1989, p.44.

198. CvdM, Jaarwerslag 1989, Hilversum, 1990, p.38.

199. CudM, Jaanerslag 1989, Hilversum, 1990, p.38.

200. CvdM, Jaarverslag 1990, Hilversum, 1991, pp.36-39. 
een boeteoplegging van $f 500,00 .{ }^{201}$ In 1991 deelt het commissariaat 2 keer een boete van $\mathbf{f} 50.000,00$ uit $_{\text {, }}$ omdat landelijke omroepinstellingen hebben verzuimd te vermijiden om in radio-uitzendingen reclameboodschappen en -uitingen te vermijden. ${ }^{202}$

In 1992 maakt het commissariaat melding van boeteoplegging wegens overtreding van reclameregels in televisie-uitzendingen van $f 10.000,00(1 \mathrm{x}), f 70.000,00(3 \mathrm{x})$, f $90.000,00(1 \mathrm{x})$, f $100.000,00(1 \mathrm{x}$ voorwaardelijk) en $\mathrm{f} 150.000,00(1 \mathrm{x})$, daarnaast in een radio-uitzending van $f 70.000,00(1 \mathrm{x}) .{ }^{203} \mathrm{Uit} 1993$ betreft het boeteoplegging voor televisie-uitzendingen van $f \quad 6.000,00(1 \mathrm{x})$, f $10.000,00(4 \mathrm{x}), \mathrm{f} 60.000,00(1 \mathrm{x})$, f $70.000,00(2 x)$, f $80.000,00(1 x), f 90.000,00(2 x)$, f $100.000,00(1 x)$ en $f 140.000,00$ (1x), bovendien zijn er voor radio-uitzendingen boeten van $f 6.000,00(1 x), f 8.000,00$ $(1 x), f 14,000,00(1 x)$ en $f 20.000,00(1 x){ }^{204}$

Wegens overtreding in televisie-uitzendingen door landelijke omroepen van het verbod dienstbaar te zijn aan het maken van winst voor derden treedt het commissariaat ook op. In 1989 beboet het commissariaat drie omroepen met bedragen van $f \quad 30.000,00$, f $40.000,00$ en $\mathrm{f} 15.000,00$ welke laatst genoemde boete het commissariaat uiteindelijk heroverweegt waarna het commissariaat als nog tot seponering overgaat. ${ }^{205}$

Voor het nalaten er voor te zorgen, dat de door omroepinstellingen ingeschakelde externe producenten geen sponsorinkomsten verband houdend met het programma kunnen genereren, legt het commissariaat 5 keer een boete van $f 10.000,00$ aan landelijke omroepinstellingen op. ${ }^{206}$

Voor de niet toegestane bewuste betrokkenheid van een amroeporganisatie bij de oprichting van een concurrente satellietzender in het buitenland kondigt het commissariaat in 1990 een boete van f 50.000,00 af en trekt daarnaast toegewezen zendtijd voor radio en televisie in voor de duur van 13 weken waarvan 6 weken voorwaardelijk ${ }^{207} \mathrm{Na} \mathrm{sanc-}$ tiebesluitvernietiging neemt het commissariaat een nieuwe beslissing, waarin rekening wordt gehouden met afdracht van de betrokken omroepinstelling van het door haar verkregen onrechtmatig voordeel ter waarde van 15 miljoen gulden: 20 uur televisiezendtijdintrekking in combinatie met voorwaardelijke zendtijdintrekking met een proeftijd van twee jaar. ${ }^{208}$

201. CwdM, Jaanverslag 1990, Hilversum, 1991, p.40.

202. CxdM, Jaanversiag 1991, Hilversum, 1992, p.37.

203. CudM, Jaarversiag 1992, Hilwersum, 1993, pp.40-42.

204. CwdM, Jaarverslag 1993, Hilversum, 1994, pp.39-41.

205. CwdM, Jaarverslag 1989, Hilversum., 1990, pp.43-44.

206. CvdM, Jaanerslag 1993, Hilversum, 1994, p.43.

207. CvdM, Jaanvers!ag 1990, Hilversum, 1991, p.45.

208. CvdM, Jaanverslag 1993, Hilversim, 1994 , p.44. 
Na een voor de omroepen leerzame gewenningsperiode van informeel toezicht ${ }^{20 \%}$ "start het Commissariaat voor de Media -op 1 januari 1990 met het daadwerkelijke formele toezicht op naleving van mediawet- en regelgeving door lokale en regionale omroepen. In 1990 houdt het commissariaat 414 controles bij etherradio, 140 controles bij kabelradi$o$, en 75 controles bij kabeltelevisie, hierbij constateert het commissariaat 38 overtredingen, waarna 6 waarschuwingen, 24 sepots en 5 boeten, t.w. f $1.500,00(3 x), f 2.000,00$ (1x) en $\mathrm{f} 5.000,00(1 \mathrm{x})$, worden gegeven. ${ }^{210}$ In 1991 voert het commissariaat controle ter zake als volgt uit, $t$. $w .625$ bij etherradio, 110 bij kabelradio en 200 bij kabeltelewisie, afhandeling krijgend in de vorm van 11 waarschuwingen, 4 sepots, 1 voorwaardelijke boete en 7 onvoorwaardelijke boeten $t$.w. f $1.500,00(2 x), f 1.750,00(4 x), f 2.000,00$ $(1 \mathrm{x})$ en $\mathrm{f} 3.000,00(1 \mathrm{x})$, en 1 boete met voorwaardelijke intrekking van zendtijd $\mathrm{t} . \mathrm{w}$. f 5.000,00 gerelateerd met voorwaardelijke zendtijdintrekking van 4 weken met een proeftijd van 2 jaar. ${ }^{211}$ In 1992 controleert het commissariaat 846 keer bij etherradio, 67 bij kabelradio en 393 keer bij kabeltelevisie, waarbij 19 overtredingen worden geconstateerd in welke gevallen 13 waarschuwingen en oplegging van 2 boeten $t . w .11 .750,00$ $(2 x), 2$ boeten ten dele voorwaardelijk t.w. resp. f $2.500,00$ waarvan $f 1.250,00$ voorwaardelijk ( $1 \mathrm{x}$ ) en $\mathrm{f} 1.500,00$ warvan $\mathrm{f} 1.000,00$ voorwaardelijk $(1 \mathrm{x})$, en 2 voorwaardelijke boeten t.w. $1.750,00(1 \mathrm{x})$ volgen. ${ }^{2 / 2}$ In 1993 verricht het commissariaat controle als volgt: 979 bij etherradio, 35 keer bij kabelradio en 380 keer bij kabeltelevisie, waarbij 24 overtredingen wegens het overtreden van programma- of reclamevoorschriften als mede niet naleving van de programmabewaarplicht worden geregistreerd die leiden tot in elk geval 9 waarschuwingen en 5 sancties t.w. boeten van $f 1.250,00$ ( 1 x onvoorwardelijk; $1 \mathrm{x}$ onvoorwaardelijk gecombineerd met voorwaardelijke intrekking van 4 weken zendtijd met een proeftijd van 2 jaar; en $3 x$ voorwaardelijk) en $f 5.000,00$ waarvan f $4.500,00$ voorwaardelijk (1x). ${ }^{213}$

Na een periode van terughoudend toezicht deelt het commissariaat in 1992 mede dat het toezicht op de naleving van de voorschriften inzake volledig programma en eigen produkt, zo nodig, daadwerkelijk middels sanctieoplegging wordt geëffectueerd. ${ }^{214} \mathrm{De}$ noodzaak daartoe wordt ingegeven door het feit dat in een toenemend concurrende en grenswervagendle omroepmarkt publieke omroepen zich moeten onderscheiden van

209. In 1988 bestaat een periode van informeel toezicht op de publieke omroepen, waarin het jonge $\mathrm{C}$ aM enkel waarschuwingen uitcleelt maar nog niet beboet. De reden daarvan, namelijk dat de Mediawet. "even wennen moet", dat het een overgangsperiode betreft en dat onduidelijk is hoe het CvdM de mediawretgeving interpreteert, geldt in 1994 niet voor de -in de kinderschoenen staande-commerciele omroepen. Het verzoek van hei commerciële televisiestation Euro 7, om een dergelijke proefperiode wan wier maanden, wijst het CvdM dan ook terecht af. De wettelijke regels worden inmiddels bekend verondersteld. Geen proefperiode nieuwe omroepen, in: Comedia, mi. 36, nov. 1994, p.3.

210. CwdM, Jaarverslag 1990, Hilversum, 1991, p.40.

211. CwdM, Jaarverslag 1991, Hilversum, 1992, pp.37-38.

212. CwdM, Jaarverslag 1992, Hilversum, 1993, p.43.

213. CwdM, Jaarwerslag 1993, Hilwersum, 1994, pp.40-41.

214. CwdM, Jaarverslag 1992, Hilversum, 1993, p.46. 
commerciële omroepen. Als donderslag bij hemel voldoen daama alle ormroepinstellingen aan hun programmeringsplichten. ${ }^{215}$

In het kader van het toezicht op naleving van de verplichting voor kabelbeheerders tot het doorgeven van lokale omroepprogramma's legt het Commissariaat voor de Media in 1993 een boete op van $\mathrm{f} 20.000,00$, vermeerderd met $\mathrm{f} 1.000,00$ voor elke dag dat betrokken overtreder in gebreke blijft. ${ }^{216}$

En de overtreding van een beheerder van een draadomroepinrichting, bestaande in het op een informatiekanaal als onderdeel van een zo genaamd mozaïekbeeld door geven van een kabelkrantprogramma, bestraft het Commissariaat voor de Media in 1993 met een boete van ff $5.000,00.2 ! 7$

\section{$\S 14.8$ Toezicht Commissariaat voor de Media onvoldoende}

Het toezicht door het Commissariaat voor de Media is "ondeugdelijk" genoend. Dit oordeel wortelt in de volgende bodemlagen: a. delen de partijen waarvoor de voorschriften zijn bedoeld, de achterliggende bedoelingen wel in afdoende mate; $b$. de programmavoorschriften zijn onrealistisch of onvoldoende op de specifieke situatie gericht; en c. de programmavoorschriften hebben merendeels een algemeen karakter. ${ }^{218}$ De kritick is onhoudbaar. De omroepinstellingen hebben hun zegje mogen doen bij het opstellen van de categorieèn van programma's. De ruime categorisering biedt mogelijkheden naar believen af te wijken. En een aanscherping van de categorieën komt al snel neer op strijd met de communicatievrijheid.

Een oplossing voor het vermeende ondeugdelijk toezicht door het commissariaat wordt gezien in een, op Frans mediarecht gebaseerde, convention tussen publieke of private omroepinstellingen en het regulerende, toezichthoudende overheidsorgaan. ${ }^{219}$ Via zo'n convention, vaak voorzien van sanctiebepalingen, kunnen de algemene regels op flexibele wijze worden ingepast in de concrete situatie. Toezichthouder en onder toezicht gestelden kunnen elkaar conditioneren. Via een dergelijke zelfregulering zijn afspraken mogelijk over bij voorbeeld concurrentieverhoudingen tussen programma-aanbieders. Overigens voegt dit systeem voor Nederland niet echt veell toe aan reeds bestaande mogelijkheden. Het zelfde is te bereiken via rechtsfiguren als het verbinden van voorschriften of voorwaarden aan vergunningen of het sluiten van een privaatrechtelijk af te dwingen overeenkomst inzake concessieverlening. ${ }^{220}$

215. CwdM, Jaarwerslag 1993, Hilversum, 1994, p.42.

216. CvdM, Jaarverslag 1993, Hilversum, 1994, p.37.

217. CviM, Jaarverslag 1993 , Hilversum, 1994, p.36.

218. N.A.N.M. van Ejjk, a.w., pp.216-217. Auteur voelt meer voor een zbo met uitgebreide discretionaire bewoegd heden, waarbij het accent niet zo zeer ligt op programmavoorschriften, maar op toegangscriteria en evaluatie.

219. N.A.N.M. van Eijk, a.w., pp.205-206/217.

220. H.M. Linthorst, Omroepwrijhetd en overheidsbemoeienis, im: MF, nr.5, 1993, pp.57-59. 


\section{$\$ 14.9$ Rechtsbescherming en klachtbehandeling}

Door het Commissariaat voor de Media genomen besluiten, waartegen beroep kan worden ingesteld bij de sector bestuursrecht van de rechtbank ${ }^{221}$ en hoger beroep open staat bij de Afdeling bestuursrechtspraak van de Raad van State, staan ex art. 13 Mediawet bloot aan vernietiging of schorsing ${ }^{222}$ door de minister van welzijn, volksgezondheid en cultuur. Sinds september 1994 heet WVC overigens Volksgezondheid, Welzijn en Sport. Bovendien is het cultuurbeleid verhuisd naar het nieuwe ministerie van Onderwijs, Cultuur en Wetenschappen waarover minister Ritzen (PvdA), samen met de staatssecretarissen Netelenbos (PvdA) en - specifiek voor cultuur - Nuis (D'66), de scepter zwaait. ${ }^{223}$

Is sprake van een sanctie, waarvan het voornemen er toe eerst - alvorens de formele procedure te starten - aan betrokken overtreder wordt medegedeeld ex art. 4, eerste lid, So (mogelijk ter verkrijging van nadere informatie waardoor de overtreding waarop sanctie is gesteld misschien in een positief daglicht wordt gesteld, zie art. $138 \mathrm{Mw}$ ), dan staat de weg van het indienen van een bezwaarschrift als bedoeld in de Awb open. De adviescommissie bezwaarschriften neemt deze vervolgens in behandeling (ex art. 4, tiende tot en met dertiende lid, So junctis artt. 1-9 Reglement Adviescommissie bezwaarschriften ${ }^{224}$ ). Belangrijke bestaansredenen van dit adviescollege van deskundigen zijn gelegen in eisen van rechtsstatelijkheid. Uit oogpunt van toepassing van beginselen van een eerlijk proces, denk aan het principe van hoor en wederhoor, vindt het commissariaat het beter dat een zekere machtsverdeling plaats vindt. Bovendien staat het feit, dat het commissariaat de rollen vervult van zowel de toezichthoudende en opsporende als de vervolgende en berechtende instantie (politieagent-ovj-rechter) ${ }^{225}$, een vriendschappelijke verhouding tussen het commissariaat en de omroeporganisaties in de weg. Mede van uit het gezichtspunt van aanvaardbaarheid van zijn beleid en besluiten, acht het commis-

221. Benadrukt door de WVC-adviescommissie bezwaarschriften Awb in hatar advies, gev raagd door de mimister van WVC $m$. b.t. het door Sky Radjo Ltd. ingediende bezwaarschrift inzalke etherfrequentiewer. deling, weergegeven in: MF, nr.9, 1994, pp.BB84-B88, i. h.b. p. B87 (rechtspraakbijlage). "Omwille warl dle rechtszekerheid" worden, volgens de commissie, beroepen (inzake frequentieverdeling, zie resp. arth. $167 / 167 \mathrm{~A} \mathrm{MW}$ en art. $17 \mathrm{~W}$ W - JGLVN) in her kader vam de Mediawet bij de rechtbanken beoordeeld en beroepen in het kader van de Wet telecommunicatievoorzieningen bij het CBB behandeld.

222. Na lange tijd van non-usus is het schorsingsmiddel weer gebruikt t.a.v. de, door het CvdM uitgesproken, onverbindendverklarimg van de moeizaam tot. stand gekomen zenderindeling over drie netten. Schorsingsbesiluit zendernetindeling, 25 mei 1993, in: MF, mr 7/8, 1993, pp. B74-76 (rechtspraakbijlage); Minster schorst bestwit CwdM, in: NRC, 26 mei 1993, p. 10 en Z, Luyendijk, Commissariaat gooit stenen door rwit van a "Ancona, in: NRC, 27 mei 1993, p. 7; Een vroegere commissaris wan het CvaM, $P$. van der Sanden, vindt de wijze waarop de minister het schorsingsinstrument toepast, mede ir het licht van de verslechterde verhouding tussen departement en CvdM, zorgwekkend: "De wetgever heeft de minister dat instrument gegeven en dan heeft de minister vervolgens de verantwoondelijkheid dat instrument te hanteren op correcte gronden. En daar heb ik mijn twijfels over." Zie Plet wan der Sanden: het is mosi geweest, in: Comedia, sept. 1994, nr. 34, p. 5 .

223. Stcrt. 17 aug. 1994, 156; Stcrt. 22 aug. 1994, 159; Stcrt. 31 aug. 1994, 166; Stcrt. 7 sept. $1994,171$.

224. Reglement Adviescommissie bezwoarschriften, d.d. 24 febr. 1993 vastgesteld, Stcrt. 15 maart $1993,51$.

225. Rechtsstatelijke kritiek daarop bij J.Th.J. van den Berg. Verantwordelijkheid in een polycentrische samenleving; Een nabetraciting, in: M.A.P. Bovens e.a., Verantwoordelijkheid: retariek of realiteit. Zwolle, 1989, pp.177-195, i.h.b. p.186. 
sariaat het nodig deskundigen bij het sanctieoordeel te betrekken. Het commissariaat veronderstelt dat daardoor de, door de verschillende rollen van het commissariaat ontstane, "kwetsbare relatie tussen het commissariaat en de omroep met mogelijke repercussies voor de verstandhouding op andere terreinen" wordt verbeterd. 226

Tijdens de periode van bezwaarschriftbehandeling, en ook tot afhandeling van een werzoek tot schorsing van een bepaalde sanctie bij de voorzitter van de afdeling bestuursrechtspraak, int het Commissariaat voor de Media geen boeten. ${ }^{227}$

Overigens valt het commissariaat in zijn handelen en nalaten onder de competentie van de nationale ombudsman en onder het orgaanbegrip in de zin van de Wet openbaarheid van bestuur ${ }^{228}$.

\section{$\$ 14.10$ Kostenverhaal en (financiële) verslaglegging}

De kosten van het Commissariaat voor de Media worden, zo blijkt uit art. 12 Mediawet, door de minister van Onderwijs, Cultuur en Wetenschappen (voorheen: welzijn, volksgezondheid en cultuur betaald. Het commissariaat vraagt aan de omroepen een, aan zendtijd gerelateerde en door de betrokken bewindspersoon vastgestelde, vergoeding voor het uit te oefenen toezicht, welke vergoeding de omroepen moeten afdragen aan het ministerie van $\mathrm{OCW}$.

Art. $12 \mathrm{Mw}$ bepaalt tevens, dat de door het Commissariaat op te stellen begroting en jaarrekening ministeriële goedkeuring behoeven. Bovendien verplicht art. 9 , tweede lid, Mw het Commissariaat tot het maken van een verslag van zijn werkzaamheden, als "extra hulpmiddel" om de betrokken minister de nodige inlichtingen te verschaffen ${ }^{229}$. $^{230}$ Een algemene ministeriële aanwijzingsbevoegdheid is neergelegd in art. 36, derde lid, Mw.

\section{$\$ 14.11$ Beperking van de communicatievrijheid t.a.v. radio- en televisieuitzendingen in het licht van harmonisatie van nationale regelgeving ter zake}

Het hier te lande vigerende vergunningenstelsel voor de omroep, dat wettelijk is geregeld, kan in principe door de beugel van art. 10 EVRM. Wel moet goed in de gaten worden gehouden dat de van overheidswege gestelde beperkingen, aan het recht om (on)betamelijke ${ }^{231}$ inlichtingen of denkbeelden te koesteren, te ontvangen en te ver-

226. CvalM, Jaarverslag 1988, Hilversum, 1989, p.10.

227. Brief CudM, 5 april 1993, ZTZ/JV/1626/AdG.

228. Beslwit van 16 okt. 1993, hovd aanwijing van bestuursorganem als bedoeld in de Wob en de Who, Stbl. 1993,535, p.9.

229. Nota na.v. eindwerslag Mw, TK 1985-1986, 19136, nr.13, p.34.

230. N.A.N.M. van Eijk, a.w., pp.202-203, vindt het CvdM-jaarverslag nauwelijks toereikend, omdat het "hoofdzakelijk van feitelijke aard is en slechts beperkt ingaat op beleidsaspecten. Beleidsworming en transparamtie t.a. $v$. de genomen besluitem zijn echter noodzakelijke rand woorwaarden ${ }^{*}$. Auteut mist ook een "algemeen toegankelijk overzicht van CvdM-besluiten". Handyside, EHRM 7 dec. 1976, Publ. ECHR, series A, vol. 24. 
strekken inclusief het recht om via kabel of ether (commerciële) omroepactiviteiten te realiseren, woldoen aan de in art. 10, tweede lid, EVRM gestelde condities. ${ }^{232}$ Buiten twijfel staat, dat de beperkingen noodzakelijk moeten zijn in een democratische samenleving. ${ }^{233}$ Dit noodzakelijkheidscriterium wordt met voeten getreden door bij voorbeeld een monopolie voor de publieke omroep, waardoor aan derden geen uitingsmogelijkheid via de omroep wordt geboden. Daarom conflicteert een dergelijk alleenrecht met art. 10 EVRM. ${ }^{234}$

De overheid heeft wel enige discretionaire bevoegdheid in haar appreciatie van doeleinden waarmee beperkingen aan de communicatievrijheid worden gesteld. Oplegging, van maatregelen die beogen een -middels een vergunningenstelsel geregeld-omroepbestel te handhaven, kan worden gerechtvaardigd door bij voorbeeld beroep te doen op de bescherming van de rechten van anderen ${ }^{235}$ of voorkoming van wanordelijkheden.

Overigens kan het verkrijgen van een vergunning afhankelijk worden gesteld van technische aspecten, het karakter en doel van de omroep, het potentiële publiek op nationaal, regionaal of lokaal miveau, de rechten en behoeften van bijzondere groepen luisteraars of kijkers en de verplichtingen wolgend uit internationale wettelijke instrumenten. ${ }^{236}$

232. Zie de bekende zaken Groppera rodio $A G$, EHRM 28 maart 1990 , Publ. ECHR , series A, wol. 173, ook in: NJ 1991, 739; Autronic AG, EHRM 22 mei 1990, Publ. ECHR, series A, vol. 178, oak in: NJ 1991,740 .

233. Sunday Times, EHRM 26 april 1979, Publ. ECHR, series A, wol. 30, waarin "a pressing social need" wordt geảst; Lingens, EHRM 8 juli 1986, Publ. ECHR, series A, woll. 103; Vgl. Spycatchers-mémoires, EHRM 26 mov. 1991. NJ 1992, $457 \mathrm{~m} . \mathrm{nt}$. EJD; Over deze en analoge arresten E.J. Dommering e. ., Kroniek informatierecht: Media- en telecommunicatierecht, in: AA, dec, 1992, pp. 2072-2074; $S$. vs. Zwitserland, ECRM 14 jan. 1993, in: MF, nr.1, 1994, p.11.

234. Informationswerein Lentia w. Oostenrijk, EHRM 24 november 1993, in: MF, nr. 2, febr. 1994, pp. Bil3. B16 (rechtspraakbijlage), in: NJ 1994, 559, m.nt. E.J. Dommering, en in: NJCM-bulletin 1994, 19-8. m.nt. S. van Lammeren. I.c. is de inmenging in de wrijheid van meningsuiting disproportioneel t.o.,. thet nagestreefde doel en niet noodzakelijk in een democratische samenleving. Een volstrekit monopolie van de publieke omroep is niet langer gerechtwatrdigd gegewen: a. de technologische ontwikkelingen (er is geen scharste meer van etherfrequenties); b. het feit dat doorgifte van, de inmiddels verveelwoudigde, buitenlandse programma's via de kabel door de rechter is gesanctioneerd; c. de mogelijkheid wan alternatiewe, minder vergaande middelen om het, uit de vrijheid van meningsuitging voortwloeiende, pluraliteitsbeginsel te realiseren; en d. de ervaring in andere met Oostenrijk qua ornvang vergelijkbare landen watr commerciële, private zenders goed samen gaan met de publieke omroep, in welke landent regelgewing bestaat die het ontstaan wan evidente machtsposities van de commerciele omroep moeten woorkomen. De annotator bij het Lentia-arrest realiseert zich de, na de uitspraak in het bijzonder wor Nederland -waar een beperkte interne concurrentie tussen publieke en private ommoep word.t toegelattennog openstaande, volgende vragen: "Moet de commerciele omroep een aan de publieke omroep gelijkwardige toegang worden geboden, zijn de vergunningprocedures voor de toegang in overeenstemming met art. 10, weede lid, EVRM, is de handhaving van publieke monopolies op lokaal en regionaall

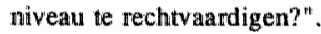

235. VoO ks. CudM (Véronique III), ARRS 29 juni 1993, R01.90.5255, in: MF. nr.9 1993, pp.B77-B79 (rechtspraakbijlage); Ook E.J. Dommering e.a., Kroniek informatierecht; Media-en telecommunicarierecht, in: AA-katern 49, dec. 1993, pp.2299-2301.

236. Lentia e.a. ws. Oostenrijk. EHRM 24 now. 1993, series A, wol. 276, ook in: NJ 1994, 559. 


\subsubsection{MEDEDINGINGSRECHT EN REGULERING}

Bij het bovenstaande is het verstandig zich het volgende te realiseren.

Van oudsher heeft de wet- en regelgever hier te lande weinig op met concurrentie. In de Nederlandse wet- en regelgeving, waaronder mediawet-en regelgeving, is mededinging altijd een beetje als besmet begrip beschouwd. Tekenend voor de oude doctrine is dan ook het volgende uitgangspunt. De overheid stimuleert uitbreiding van verschillende exclusieve rechten onder gelijktijdige beperking van de mededinging. Dit uitgangspunt behoeft wijziging. De Nederlandse staat heeft geen geisoleerd bestaan meer. In een dynamische wereld kan de rijksoverheid eigenlijk niet anders dan "het toekomstdenken sterker in een economisch perspectief plaatsen". ${ }^{237}$ Dat het klassieke denken in natuurlijke monopolies plaats moet maken voor een moderner technisch-economisch denken, waarin de toegang tot de mediamarkten en de mogelijkheid om nieuwe technologie te gebruiken central staan, geldt in het bijzonder voor het telecommunicatie- en het omroeprecht. ${ }^{23.8}$

Tegenwoordig zijn de mogelijkheden van de centrale overheden, om de omroep te reguleren, aanzienlijk ingeperkt. Nationale staten moeten hun omroepbeleid in toenemende mate afstemmen op Europese regels. De doelstelling van de Europese Gemeenschap, die hier domineert, is in gevolge art. $3 \mathrm{~g}$ jo. art. $3 \mathrm{~A}$, eerste en tweede lid., EG-verdrag het tot stand brengen van een regime waardoor wordt verzekerd dat de mededinging binnen de interne markt niet wordt vervalst. Nederland nu is te beschouwen als een "onderdeel van de Europese markt". ${ }^{239}$ Gegeven de groeiende economische waarde van omroepconcessies is het evident "dat het reguleringsmodel opschuift in de richting van een vrije mededingingsmodel". ${ }^{240}$ Ook bij bij voorbeeld overtreding van regels inzake sluikreclame kan mededingingsrecht in belangrijke mate bijdragen aan rechtshandhaving, omdat daarbij concurrentiebelangen kunnen worden geschaad. ${ }^{241}$ Overigens zijn in de sfeer wan vrije mededinging op omroepgebied zaken, als toelating en concurrentievoorwaarden,

237. Voor een dergelijke verandering wan attitude pleit terecht $\mathrm{T}$. Koopmans, Intellectuele eigendom, economie en politiek, in: Informatierecht/AMI, nr.6, mei/juni 1994, pp.107-111, i.h.b. p.111.

238. Hibrower o a. C. A . Abak, Economic and Policy Issues the Regulation of Conditions for Swbrcriber Access and Market Entry to Telecommunications, in: W.F. Korthals Altes, E.J. Dommering. P.B. Hugenholtz, en J.J.C. Kabel (red.), Information law towards the 21 st century, Information Law Series nr.2, Deventer/Boston, 1992, pp.711-81, wgl. in de zelfde bundel E. Mackaay, An Economic View of Information Law, pp.43-65; Zie in dit verband ook E.J. Dommering, Article 90 of the EEC Treaty and the relecommunications, broadcasting and postal services sectors, in. J.H. V. Stuyck en A.J. Vossestein., State entreprenewrship, national monopolies and europeas community law, DeventeriBoston, 1993, pp. 53-72.

239. Publieke omroep in Nederland, TK 1990-1991, 22147, nr.2, p.6.

240. E.J. Dommering, De informatiedriehoek; Enige beschouwingen over de regulering van informariestromen, oratie UvA, 20 okt. 1989, Dewenter, pp. 1-33, i.th.b. p. 25.

241. J.J.C. Kabel., Toepassing wam de art. 52 en 55 Mw door de ARRS: overzicht periode 1988-1992, in: MF, nr. 1,1992 , Pp. $4-7$, i.h.b. p.6. Auteur vindt voorzichtigheid ter zake geboden, omdat reelameverboden in het publiek belang zijn. 
te regelen. ${ }^{242} \mathrm{Bij}$ het liberaliseren van media- en informatiemarkt ${ }^{243}$, waarbij in de overgangsfase naar een vrijere markt voorzichtig winstprikkels kunnen worden ingebouwd, moet de overheid vooral in die eerste gewenningsperiode haar functie als regelgever en toezichthouder (inzake concurrentie) versterken. ${ }^{244}$

Bij de gedachte aan toepassing van mededingingsrecht voor de omroepen komen vooral de artt. 59/60 E(E)G-verdrag in beell. ${ }^{245}$ Daarin wordt het vrije dienstenverkeer gewaarborgd. Conform relevante jurisprudentie zijn in elk geval televisieuitzendingen bevattende reclameboodschappen aan te merken als dienstverrichtingen als bedoeld in art. $59 \mathrm{E}(\mathrm{E}) \mathrm{G}$-verdrag. ${ }^{246}$ Ook indien het illegalle doorgifte van omroepprogramma's via de kabel betreft. ${ }^{24.7}$

Met oog op de beoogde harmonisatie van regelgeving van EG-lidstaten zijn uitgesproken omroepmonopolieposities onhoudbaar. Het beroep van een nationale staat op art. 90 E(E)G-verdrag wordt steeds strenger getoetst aan concurrentieregels. ${ }^{248}$ Exclusieve

242. J.H.J. van den Hewwel, Mediabeleid in de interventiestaat, in: E.M.H. Hirsch Ballin e.a., Massamedia en staatsrecht, verslag staatsrechtconferentie 8 dec. 1988, Zwolle, 1989, pp.76-89, i.h. b. p.85. Auteur bepleit liberalisering van de openbare informatievoorziening. Licentieverstrekking -onder strikte doelstellingen van non-commercialiteit, onafhankelijkheid en pluriformiteit- en basisfinancierüg door de overheid aan publieke omroepinstellingen blijven mogelijk. De rest moet naar de vrije markit, middels werkoop van zendwergunningen aan zelfstandige en niet publieksomroepgebonden (commercièle) organisaties. De opbrengst daarvan komt mogelijk omroepinstellingen met publieke taken ten goede.

243. In zijn enthousiasme voor liberalisering wan i.h.b. de telecommunicatiemarkit concludeert D.F. Edens, The concept of liberalisation oftelecommurications services in the commission directive of june 28,1990 $(90 / 388 / E E C)$ on the comperition in the market for telecommunications services, in: $\mathbf{J}$.H. V. Stuyck en A.J. Vossestein, State entrepreneurship, national monopolies and european communiry law, Dewenter/Boston. 1993. pp.87-90, i.h. B. pp.89-90. "that the legal notion of telecommunications organisations should not be defined in terms of special or exclusive rights, but in terms of entrustment of a public task (task in the general economic interest) for the prowision of public telecommunications infrastructure and services [...] The national regulations should be restricted to a minimum set of rules, of which the elements should be laud down in a limitative way by harmonisation directives of the community (a community definition of the universal telecommunications infrastructure and services to be supplied by telecommunication organisations should be restricted to the provision of a basic infrastruelure and basic service for voice telephony, mational and international, via fixed networks as well as via mobile sysiems and to the provision of leased lines). The establishing of prices and quality levels should be left to the competition in this market."

244. W. de Boer, Hoe communicatief is de EG?; Het media-en informatiebeleid, in: J. Muysken en L.L.G. Soete, Macstricht kritisch beschowwd, preadviezen Koninklijke Vereniging Staathuiskunde, Utirecht, 1993, pp.87-106, i.h.b. pp.102-105.

245. Hiemaast zijn belangrujke bepalingen: art. 52, tweede lid, art. 57, tweede lid, art. 48 en artt. $85-86$ $\mathrm{E}(\mathbb{E}) \mathrm{G}$-verdrag.

246. Sacchi, HwJ EG (155/73) 30 april 1974, Jur. 1974, p.409.

247. Debauwe, HwJ EG (52/79) is maart 1980, Jur. 1980, p.833.

248. Ellinki Radiophonia Thléorassi AE vs. Dimotiki Etiaria Pliroforissis c.s., HyJ EG (C-260/89) 18 juni 1991, Jur. 1991, p.2951; Vgl. Sacchi, HvJ EG (155/73) 30 april 1974, Jur. 1974, p.409, waran weliswaar mog wordt toegestaan dat lidstaten uitsluitemde rechten verlenen m.b.t. radio-en tv-uitzendingen om niet-economische redenen van openbaar belang; Zie ook Hins \& Hugenholtz ws. Minister von verkeer en waterstaat (De wrije ether), CBB 5 jan. 1994, nr.93/0755/090/195, in: SEW, nr.1, 1995, 
rechten ter zake worden schaars. Misbruik van machtspositie wordt daar waar nodig direct afgestraft.

Met kunstmatige monopolies wordt al snel korte metten gemaakt. En ook natuurlijke monopolies, die in principe bestaansrecht hebben, ontkomen in praktijk niet altijd meer aan het proces van van demonopoliseren. Langzaam maar zeker wordt de geleidelijke afbrokkeling van monopolies, die van oudsher natuurlijk zijn omdat competitie technisch onmogelijk of economisch onwenselijk is, zichtbaar. ${ }^{249}$

Ook buiten het omroeprecht is de strenge toetsing van mededingingsregels ex artt. $85 / 86$ $\mathrm{E}(\mathrm{E}) \mathrm{G}$-verdrag ${ }^{250}$ aan art. $90 \mathbb{E}(\mathrm{E}) \mathrm{G}$-verdrag waar te nemen.

Zo moet bij voorbeeld een onderneming, die krachtens een publiekrechtelijke niet-exclusieve concessie tot taak heeft de elektriciteitsvoorziening op een deel van het nationaal grondgebied te verzorgen, in principe regelen dat "binnen het gehele gebied dat haar is toegewezen, alle verbruikers, zowel lokale distributeurs als eindverbruikers, ononderbroken van de op elk moment door hen gewenste hoeveelheid elektriciteit worden voorzien, een en ander tegen uniforme tarieven en op voorwaarden die slechts variëren, voor alle afnemers geldende criteria"; "Beperkingen van de mededinging van andere marktdeelnemers (i.c. een aan lokale distributeurs opgelegde exclusieve-afnameclausule in de algemene voorwaarden voor de levering van elektrische energie aan gemeenten met een eigen distributiebedrijf in het concessiegebied van bedoeld regionaal energiebedrijf - JGLvN) moeten worden toegestaan, voor zover zij noodzakelijk zijn om de met een dergelijke taak van algemeen belang belaste onderneming in staat te stellen, die taak te vervullen.

248. $\rightarrow$

pp.65-70, besproken door K.J.M. Mortelmans, die het onterecht acht dat het CBB art. 90 EG-werdrag buiten beschouwing laat, idem dito als Reservering frequenties voor publieke regionale omroep Alknoar niet strijdig mes EG-verdrag, CBB 5 jan. 1994, in: NJB, nr.17, 29 april 1994, pp. $116-217$ (rechtsprankbijlage) en in: MF, nr.6, 1994, Pp.B21-B23; Met referentie an het ERT-armest en het Lentia-arrest konit toetsing aan art. 90 jo. art. $59 \mathrm{EG}$-verdrag (naast toetsing, aan art. 17 Wrw en art. 3:4 Awb) wel witdnkkelijk alan bod in Sky Radio ws. Minister van verkeer en waterstaa" "Classic FM plc. North Sea Mfedia Network bu ,Publimusic bv en Radio 10 Groep bv, CBB 22 maart 1995, in: NJB, nr.21, 26 mei 1995. pp.273-275 (rechutspraakbijlage).

249. L. Gyselen, National monopolies - An evolving state action doctine under article 90 EEC, in: J.H.V. Stuyck en A.J. Vossestein, State entrepreneurship, national monopolies and european commumity law, Kluwer/Boston, 1993, pp.1-13.

250. C.C.W. Lange, De Europeesrechtelijke niefigheid en de met artikel 86 EEG-Verdrag strijdige overeenkowsten, in: SEW, nr.9, 1994, pp.428-448, concludeert dat een overeenkomst, die rechtstreeks een neerslag vormt van een door art. 86 EEG-verdrag verboden gedraging, een verboden overeenkomst is ex art. 85, eerste lid, EEG-verdrag. Dit geldt ook voor een netwerk wan overeenkomsten. De v rijstelling van ant. 85 , derde lid, EEG-verdrag biedt hier geen oplossing Za kan de Europeesrechtelijke nietigheidssanctie ex art. 85, tweede lid, EEG-verdrag toepasselijk zijn. Well geeft auteur aan datt voor het realiseren daarvan in Nederland de nodige "horden" moeten worden genomen: a. volgens Europese matstaven is alleen dat gedeelte van de overeenkomst wat strijdig is met art. $85 \mathrm{EEG}$-verdrag nietig. in Nederland kan dit worden opgelost door partiële nietigheid ex art. $3: 41 \mathrm{BW}$; b. nietigheid is eerst effectief alls partijen nietigheid inroept, wat niet per definitie gebeurt omdat partijen daarvan ook nadeel kwnnen ondervinden; en c. de natiomale rechter is als enige bewoegd de nivetigheidsactie toe te passen, het Nederlandlse recht imzake nietigheidsacties moet daarbij (nog) op Europeesrechtelijke leest worden gestoeld. 
In dit verband moet rekening worden gehouden ${ }^{251}$ met de economische condities waarin de onderneming opereert, in het bijzonder de kosten die door haar moeten worden gemaakt en de regelingen, vooral op milieugebied, waaraan zij is onderworpen." 252253

Het algemeen belang staat ook centraal in de volgende toonaangevende casus. De zaak betreft de bezwaarmaking van de Vereniging van Nederlandse Installatiebedrijven c.s. tegen de nevenactiviteiten van de Veluwse Nutsbedrijven $n v, t$. w. het verkopen, verhuren en onderhouden van centrale verwarmingsketels. De VNB richt daartoe geen aparte vennootschap op. De daardoor ontstane concurrentie die een onwaarachtig karakter heeft, omdat de VNB een (semi-)overheidsorgaan is met talrijke concurrentievoordelen als vrijstelling van vennootschapsbellasting wat betreft nevenactiviteiten of het vrij gebruik van faciliteiten die binnen het overheidstakenpakket vallen, denk aan telefoon, adressenbestand, incasso-apparaat, reclame-ondersteuning e.d., schiet de VNI in het verkeerde keelgat. Weliswaar ziet de rechter hier nog geen strijd met art. 86 EG-verdrag, nu er niet voldoende aanknopingspunten zijn om te veronderstellen dat de tussenstaatse handel negatieve beïnvloeding van het optreden van VNB ondergaat. Maar wel vindt de rechter dat de overweging, dat een monopolist die zijn positie op een aanverwante markt versterkt door gebruik te maken van andere middelen (dan bij op basis van ondernemersprestaties berustende normale mededinging wan goederen of diensten gebruikelijke middellen) mogelijk misbruik van zijn machtspositie maakt, moet doorwerken in de Nederlandse woorliggende verhouding. Daarom overweegt de rechter uiteindelijk als volgt: het "belang van het energiedistributiebedrijf VNB, om een relevant marktaandeel in de regionale installatiemarkt te verwerven en daartoe met gebruikmaking van haar voorsprong als voormeld nevenactiviteiten te ontplooien concurrerend met activiteiten welke de particuliere ondernemingen op de installatiemarkt plegen uit te voeren, weegt minder zwaar dan het belang van de VNI om daartegen beschermd te worden, tenzij VNB voor die activiteiten een rechtvaardiging vindt in het dienen van een bijzondere taak van publiek belang

251. In de, in: TVVS, nr.8, 1994, pp.222-224, gepubliceende, noot bij dit arresti wordt een versoepeling waln toetsing ter zake door het HvJ EG geconstateerd. Annotator volgt de lijn van het ERT-arrest (concurrentiebeperking is onverenigbat mel de verwulling van de dienst van algemeen economisch belang), via het Corbeau-arrest (slechts verband tussen beide elementen alls voornoend geeist), naar het Almelo/E. nergiebedrijf farrest (rekening houden met situatie waarin taakvervulling geschiedt).

252. Gemeente Almelo e.a. vs. NV Energiebedrijf ISselmij., HvJ EG (C-393/92) 27 april 1994, in: NJB, nr.23, 10 juni 1994, pp.287-288 (NJB-rechtspraak), ook in: TVVS, nr.8, 1994, pp.222-224 en in: NJ 1995,93 .

253. Wat betreft de elektriciteit- en gassector beveelt I.L. Buendia Sierra, The concept of "Third Party Access" under the EEC Treaty rules, in: J.H.V. Stuyck en A.J. Vossestein. State entrepreneurship. notional monopolies and european commumity law, Deventer/Boston, 1993, pp.41-46, i.h.b. p.46, aan "to introduce the principles already existing in the EEC Treay into Community legislation and to create a coherent system uncluding transitional provisions and a complete view of the practical issues. People opposed tot the Commissioner's proposals for directives should consider carefully whether they would really prefer the risk of a Cassis de Dijon-like judgement in the field of energy rather than cliear legisliation based on full appreciation of the issues involved". 
en de wijze van concurrentie met gebruikmaking van die voorsprong ook geëigend is tot de vervulling van die bijzondere taak"t..$^{254}$

Ander treffend voorbeeld, waarin de rechter overigens verwijst naar het ERT-arrest inzake omroeprecht, is de kwestie betreffende een wettelijk monopolie van een Italiaanse havenondermeming. ${ }^{255}$ Op zich is een, door het verlenen van uitsluitende rechten als bedoeld in art. 90 , eerste lid, E(E)G-verdrag gecreëerde, machtspositie niet onverenigbaar met ant. $86 \mathrm{E}(\mathrm{E}) \mathrm{G}$-verdrag. Maar strijd met de in beide bedoelde bepalingen vervatte verboden ontstaat wel, wanneer een onderneming door de enkele uitoefening van de haar toegekende uitsluitende rechten misbruik van haar machtspositie maakt, of indien deze rechten een situatie kunnen creëren waarin een onderneming tot een dergelijk misbruik wordt gebracht. De handel tussen lidstaten kan ongunstig worden beïnvloed als een onderneming door de haar toegekende uitsluitende rechten er om die reden toe wordt gebracht betaling te verlangen voor diensten waarom niet is gevraagd, buitensporige

254. Vereniging Nederlandsie Installatiebedrijven c.s. us. Veluwse Nutsbedrijven nw, Rechtbank Zutphen, 19 meil 1994, rolnr. 769b-92 (niet gepubliceend), weer gegeven door W.B.J. Overbeek. De zaak Vierhand/NV Databank; Enkele mededingingsrechteljke beschowwingen inzake de nevenactiviteiten van (semi-)overheidsorganen, in: CR, nr. 1, 1995, pp.23-25, i.h.b. pp.24-25. Auteur acht deze uitspraak terecht relevant voor (semi-)overheidsorgamen die zelf de vrije markt op willen. Denk aan de NV Databank in de vermelde zaak Vierhand bv ws. NV Databank Kamers wan Koophandel en fabrieken en KVK woor Haarlem en omstreken. Hof Amsterdam, 21 april 1994, CR, nr.1, 1995, pp.28-31. NV Databank krijgt, bij uitsluiting "kosteloos overheidsinformatie aangelevend van de Kamers wan Koophandel en fabrieken (die wettelijk bevoegd of verplicht zijjn on over die informatie te beschikken. NV Databank verstrekt tegen basistarief gegevens aan haar afnemers. Als die afnemers zelf ook weer doorleveren, brengt zij een hoger bedrag dan het basistarief in rekening. Op gegeven moment verhoogt NV Databank deze doorleveringstoeslag flink. Het wordt het doorleverende direct marketing bedrijf Viemand bv te gortig. Jammer genoeg woor Vierhand bv vindit het A damse gerechtshof niet dat NV Databank handelt in strijd met ant. 85 , eerste lid, EG-verdrag: de concurrentie die NV Databank aangaat met de direkt marketing bedrijwen kan de consument tot woordeel strekken. Het feit dat NV Databank een monopoloide (semi-yoverheidsinstelling is niet relevant voor het hof. Volgens het hof mag ook een monopolist opzeggen. NV Databank zegt tijdig op, hanteert geen uitzonderlijk hoge tarieven, en alle afinemers moeten de (toeslag)tariewen betalen. Bij 's-hofs oordeel zet Overbeek de wolgende w raagtekens. Weliswar acht ook auteur art. 85 EG-verdrag niet zonder meer toepasselijk, omdat het de vraag is of de tussenstaatse handel ongunstig wordi beïnloed door de werkwijze van NV Databank (overigens stelt auteur wel dat EG-rechtelijke normen kunnen "doorsijpelen in art. 6:248 BW of art. 6:162 BW"). Maar volgens auteur gaat het hof te eenvoudlig voorbij aan het feit, dat NV Databank de concurrenten weinig fraal in het vaarwater zit omdat zij de gegevens gratis krijgt aangeleverd en een doorleveringstoeslag v raagt. Bovendien onstaat het verschil in tarifering niet in praktijk (di.w.z. er staat een andere economische tegenprestatie of kostprijs tegenover), maar komt de NV Databank zélf tot de prijsdifferentiatie.

255. Merci convenzonali parto di Genova SpA ws. Siderurgica Gabrielli SpA. HwJ EG (C- $179 / 90) 10$ dec. 1991. NJ 1994, 402; Analoge betekenis, namelijk discriminatie van gelijkwaardige handeispartners en prestaties door differemtiatie in tariefstelling, heeft het, ook op de haven van Genua betrekking hebbende, arnest Corsica Ferries Itallia Srl vs. Corpo dei piloni del porto di Genowa, HwJ EG (C-18/93), 17 mei 1994, Jur. 1994, 1-1783/1812, NJ 1995, 168, besproken in: TVVS, nr.12, 1994, pp .336-337, ook weergegeven en geannoteend door P.J. Slot, in: SEW, nr.1, 1995, pp. 58-65". "Ant. 90, eerste lid, en art. 86. EG-verdrag verbieder een nationale instantie een ondememing die uitsluitend recht heeft op een wezenlijk deel van de gemeenschappelijke markt lood sdiensten aan te bieden, in stat te stellen verschillende tarieven toe te passen op zeevervoerbedrijven, nat gelang zij vervoendiensten verrichten tussen lidstaten dan wel tussen thavens op het mationale grondgebied, voor zover de handel tussen lidstaten daardoor ongunstig wordt beïnvloed." 
prijzen in rekening te brengen, weigert gebruik te maken van moderne technologie waardoor de kosten van werkzaamheden hoger uitvallen en woor de uitwoering een langere termijn nodig is , of aan bepaalde gebruikers kortingen verleent die worden gecompenseerd door een gelijktijdige verhoging van de prijzen die aan andere gebruikers in rekening worden gebracht. Hiervan blijkt in casu, bij het lossen van goederen in de haven van Genua, sprake te zijn. De betrokken havenonderneming heeft de, overigens door de overheid bekrachtigde, tarieven voor verplicht gebruik van diensten, waarop zij een monopolie heeft, onnodig extra hoog gesteld en daarmee de importhandel nadeel bezorgt. De rechter bepaalt in zijn uitspraak tevens dat art. 30 , art. 48 en art. 86 zelfs in het kader van art. $90 \mathrm{E}(\mathrm{E}) \mathrm{G}$-verdrag rechtstreeks rechten voor particulieren in het leven roepen die door nationale rechters moeten worden beschermd.

Vergelijkbaar met deze Genua-casus is de volgende situatie. ${ }^{256}$ In het Deense Rödby exploiteert DSB (staatsspoorwegorganisatie) als enige de haven van Rödby. Daardoor geniet zij een machtspositie. Een tot het Stena-concern behorende onderneming vraagt de Deense minister van verkeer en waterstaat om toestemming om in de onmiddelijke omgeving van bedoelde haven een particuliere commerciële (veer)haven te bouwen en om van uit de bestaande installaties van Rödby werkzaamheden te verrichten. De minister weigert toestemming. De Europese Commissie oordeelt dat DSB een machtspositie bezit en dat de ministeriële onthouding van goedkeuring ter zake aan de Stena-dochter misbruik van machtspositie oplevert omdat het Stena-bedrijf als potentiële concurrent geen kans krijgt. Bedoelde weigering is daarom in strijd met art. 90 , eerste lid, jo. art. $86 \mathrm{E}(\mathbb{E}) \mathrm{G}$ verdrag. Art. 90, tweede lid, $\mathrm{E}(\mathrm{E}) \mathrm{G}$-verdrag is niet van toepassing. Concurrentie staat niet in de weg aan de (vervulling van de) bijzondere taak van het overheidsbedrijf DSB.

Met oog op de toetsing aan art. 90 , eerste lid, $E(E) G$-verdrag is het volgende besef belangrijk. Slechts ondernemingen in de zin van voornoemd verdragsartikel kunnen worden onderworpen aan toetsing op vermeend misbruik van machtspositie. Art. 90, eerste lid, $E(E) G$-verdrag ziet wel op opembare bedrijven of eenheden die economische activiteiten uitoefenen, ongeacht hun rechtsworm en wijze van financiering. ${ }^{257}$ Mar onder haar werking vallen geen entiteiten die - gelet op aard en doel van hun werkzaamheden en de regels waaraan zij zijn onderworpen - typisch overheidsprerogatieven, bij voorbeeld het vaststellen en innen van heffingen, uitoefenen. ${ }^{258}$ Met referentie aan het hierboven aangehaalde Genua-arrest, waarbij het betrokken havenbedrijf nota bene in bezit is van een publiekrechtelijke havenconcessie en toch als onderneming/openbaar bedrijf in de zin van art. 90 , eerste lid, E(E)G-verdrag wordt beschouwd, werpt een

256. Zie Toegang tot haven Rödby, beschikking EC van 21 dec. 1993, Publ. EG, d.d. 26 febr. 1994, L 35/52, met referentie aan Sea Container/Stena Sealink, beschikking EC wan 21 dec. 1993, Publ. EG d.d. 18 jan. 1994, L 15/8, besproken door M.R. Mok, in: TVVS, nr. 10, 1994, pp.273-275.

257. Höfner en Elser, HvJ EG (C-41/90) 23 april 1991, Jur. 1991, p.I-1979, in: TVVS, 1991, pp.327-328.

258. SAT Fuggeselischaft mbH ws. Onganisation européenne pour la sécurité de la nawigation aérienne (Eurocontrol). HvJ EG (C-364/92) 19 januari 1994, in: TVVS, ar.7, 1994, pp. 195-196. Bij, het bij werdrag opgerichte, Eurocontrol betreft het prerogatieven inzake controle en politie van het luchutruim van de verdragsluitende staten. 
criticus terecht twijfels over het criterium overheidstaak op. ${ }^{259}$ Privatiseringsprincipes en verzelfstandigingsvormen in ogenschouw nemende, is het inderdaad niet ondenkbaar dat de gekozen maatstaf problemen geeft. Wat is nu nog overheid te noemen? ${ }^{260} \mathrm{De}$ noodzaak van het duidelijk definiëren van datgene, wat wordt verstaan onder (niet-econo* misch) overheidshandelen, is evident. Deze doet zich ook gelden bij toezichthoudende verzelfstandigde entiteiten. Ook zij kunnen worden uitgerust met politiebevoegdheden, bevoegdheden om heffingen vast te stellen en te innen of bevoegdheden om concessies, licenties en vergunningen ${ }^{26:}$ te verstrekken. Hebben zij een privaatrechtelijke status, dan is in het concrete geval uit te maken of zij als commerciële onderneming, die een machtspositie kan misbruiken, zijn aan te merken. Dat kan voor de rechter wel eens een zware dobber betekenen.

Het zelfde probleem doet zich voor bij art. 90 , tweede lid, E(E)G-verdrag, waarnaar het baken van het, lang dienst doende, art. 90 , eerste lid, E(E)G-werdrag zich verzet volgens het arrest inzake een Belgisch postmonopolie. Daarin spreekt het Europese Hof van Justitie zich uil over de vraag van verenigbaarheid van art. $90 \mathrm{E}(\mathrm{E}) \mathrm{G}$-verdrag met een nationale regeling die een monopolie -wat betreft het ophalen/verzamelen, transporteren en uitreiken van postzendingen- toekent aan een overheidsinstelling, in casu de Belgische Regie der Posterijen, en een (strafrechtelijk gesanctioneerd) verbod oplegt aan economische entiteiten, als in casu Corbeau, om bepaalde diensten op die gemonopoliseerde markt te leveren, welke diensten kunnen worden onderscheiden van de basispostdienst en waarbij bijkomende prestaties worden geleverd die de traditionele postdienst niet biedt. Volgens het Hof kan een dergelijke beperking (mits proportioneel) bestaan indien en voor zover de levering van bedoelde extra diensten het economisch evenwicht van de dienst van het algemeen economisch belang, waaraan een exclusief recht is verleend

259. M.R. Mok, Annotatie SAT Fluggesellschaft, in: TVVS, nr.7, 1994, pp.195-196. Auteur wijst op publieke takuitoefening door particuliere postkantoren, meetimstituten e.d., die voor hun privatise ring in owerneidshanden waren.

260. Ook M. Bense en $\$$. Zijlstra, Het begrip bestuursorgaan, in: NTB, nr.9, 1994, pp.253-270, i.h.b. pp. 266-267, vragen alert andacht voor de onderbelichting in de discussic (over het toepassingsgebied van ant. $1: 1$, eerste lid, Awb) van de Europese dimensie van wat wel en wat niet onder overheid moet worden verstaan. Auteurs verwijzen hiernaarhet Europees meded ingingsrecht inzake overheidsopdrachten. In thet Besluat overheidsarbestedingen, Stbl. 1993, 305, warin de Richtijn 89/440/EEG van 18 juli 1989. Publ. EG, L 210 , d.d. 21 jull 1989 is geimplementeerd, staat "alanbestedende dienst" voor "iedere instelling die is opgericht mett het specifieke doel te voorzien in behoeften van algemeen belang andere dan die van industriële of commerciële aard, net rechtspersoonlijkheid, en waarvan hetzij de actiwiteiven in hoofdzaak door de Staat, de territoriale of andere publiekrechtelijke instellingen worden gefinancierd, hetzij het beheer is onderworpen aan het toezicht door deze laatste, hetzij de leden van de directie, de raad van bestuur of van toezicht voor meer dan de helft door de Staat, de territoriale lichamen of andere publiekrechtelijke instellingen zijn aangewezen".

261. Denk aan de toezichthouders op de financiele markten. Wat betreft het verzekeringsbedrijf is het zaaksgeval van de provisiewerbiedende overheidsmaatregel van de Duitse toezichthoudende autoriteit op het assurantiewezen ( $\mathrm{vgl}$. de stichting Verzekeringskaner in Nederland), gelet op mogelijke strijdigheid met Europese mededingingsregels, interessant. Zie respectievelijk $W$. W. Meng, HWJ EG (C.-2/91) 17 nov. 1993, Jur. 1993, p.I-5751, Ohra schadeverzekeringen nv, HvJ EG (C-245/91) 17 nov. 1993, Jur. 1993 , p.I-5851 en Bundesanstait für den Gilterfernverkehr vs. Gebrader Reiff GmbH \& Co. KG, Hv] EG (C-185/91), Jur. 1993, p.I-5801, met gecombineerde noot van L. Hancher en F.M. du Prê, in: SEW, nr.10, 199.4, pp,686-700. 
(onder de conditie dat de monopoloüde dienst haar diensten aan iedereen aanbiedt tegen gelijke kwaliteit/voorwaarden en uniforme tarieven), in het gedrang brengt. Concrete beoordeling hiervan komt aan de nationale rechter toe. ${ }^{262}$ Een annotator van dit arrest ziet de door het Hof hier direct toegepaste toetsing aan art. 90 , tweede lid, E(E)G-verdrag als winstpunt boven de bekende betwisting van exclusieve of bijzondere rechten via de lastige omweg van misbruik ex art. 90 , eerste lid jo. art. $86 \mathrm{E}(\mathrm{E}) \mathrm{G}$-verdrag. Art. 90, tweede lid; $E(E) G$-verdrag wordt kennelijk niet langer gebezigd als aanhangsel van het eerste lid van dat artikel. In tegendeel, deze bepaling heeft een "autonome normatieve inhoud", aan de hand waarvan het bestaansrecht en de reikwijdte van een monopolie worden afgewogen: afgezien van de harde kern van activiteiten die in elk geval wordt voorbehouden aan een onderneming die is belast met een taak van algemeen economisch belang ${ }^{263}$, is "uitschakeling van mededinging enkel in zo verre gerechtvaardigd als noodzakelijk is om te verzekeren dat de betrokken onderneming haar taak van algemeen belang onder economisch aanvaardbare omstandigheden kan uitoefenen". ${ }^{264}$ Consequenlie van dit arrest is dus dat drie deuren open kunnen gaan om exclusieve rechten aan te vechten. Ten eerste, de optie van art. 90 , eerste lid, E(E)G-verdrag jo. art. $86 \mathrm{E}$ (E)Gverdrag. ${ }^{265}$ Ten tweede, de mogelijkheid van art. 90, tweede lid, E(E)G-verdrag. En ten derde staan de verdragsbepalingen inzake het vrij verkeer van goederen en diensten open.

Aanvankelijk worden, van uit de nationale staten aan de uitingsvrijheid gestelde, nondiscriminatoire beperkingen (mits niet-economisch, proportioneel en noodzakelijk) nog getolereerd. ${ }^{26 \%}$ Maar naar mate harmonisatie van wetgeving meer gestalte krijgt, vinden de verschillende 'Cassis de Dijon' ${ }^{267}$ excepties moeilijker toepassing. De afzonder. lijke lidstaten kunnen nog slechts in beperkte mate het vrije verkeer van diensten belemmeren door nationale regelgeving en regeltoepassing als zij zich succesvol kunnen beroepen op een exceptie van bij voorbeeld handhaving van een bepaalde (programma)cul-

262. Openbaar Ministerie vs. Paul Corbeaw, HvJ EG (C-320/91) 19 mei 1993, in: SEW, nr.7/8, juli/aug. 1994, pp.515-519, ook weer gegeven als Addendwm: Corbeau and Transparancy-Communication Judgements, in: J.H.V. Stuyck en A.J. Vossestein, State entrepreneurship, National Monopolies and European Community Law, Deventer/Boston, 1993, pp. 123-129; De Corbeau-uitspraak is bepalend woor het arrest DC ws. Belgacom, president rechtbank van koophandel te Bussel, 22 juli 1994, met kritische noot weer gegeven door S. Katus, in: CR, nr,6. 1994 , pp 250-254. Datarin accepteert de rechter dat Belgacom gerechtigd is om concurrentiebeperkende maatregelen te treffen, omdat zij in het algemeen belang krachtens wettelijke exclusieve concessie publieke telefoons installeert.

263. Het allgemeen economisch belang is van tijd tot tijd verschillend.

264. H.M. Gilliams, Annotatie, in: SEW, nr.7/8, juli/augtustus 1994 , pp.519-530, i.h.b. p.521.

265. H.E. Akyürek-Kievits, The application of article 86 of the EEC Treaty to state monopolies, in: J.H.V. Stuyck en A.J. Vossestein, State entrepreneurship, national monopolies and european community law, Deventer/Boston, 1993, pp.91-101, vindt de interpretatie van de Europese rechter (HWJ EG) te muim daar, waar hij beide bepalingen toepast terwijl niet (langer) een reëel werband bestaat tussen machtspositie en misbruik daarvam.

266. Kabelregeling; HvJ EG (352/85) 26 april 1988, Jur. 1988, p.2085, ook in: NJ 1988, 982; Hie rower I.E. Schwarz, J.P.H. Donner, E.J. Dommering en E.C.M. Jurgens, Omroep zonder grenzen; Beschouwhgen ower het Kabelregeling-arrest van her $H W J$ van de EG, uitgave IvI UvA en VMC, A "dam, 1988.

267. Cassis de Dijon of Rewe vs. Buntesmonopolverwaling für Brontwein. HvJ EG (120/78), Jur. 1979, p.649. 
tuurkwaliteit ${ }^{268}$, een pluriform en a-commercieel omroepbestel ${ }^{269}$, het algemeen belang ${ }^{270}$, protectie auteursrechten ${ }^{271}$, taalbescherming ${ }^{272}$ of volksgezondheid ${ }^{273}$.

268. Hier heerst nog voorzichtigheid. Goudse antenne, HvJ EG (288/89) 25 juli 1991, Jur. 1991, p.2951; Zie, betreffende fulm, Cinéthèque, HvJ EG (61/84) 11 sept. 1985, Jur. 1985, p.2618; Afwijzend

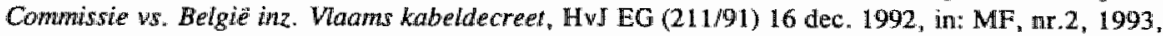
p. 23 ; Art, 3 p, einde jo, art. 128, eerste lid, EG-verdrag vraagt wel eerbiediging van de nationale en regionale verscheidenheid van de culturen van de verschiltende lidstaten, mar legt tegelijk ook de nadruk op het genneenschappel ijk cultureel erfgoed. Deze bepaling garandeert geen juridische afdwing baarheid. W. de Boer, t.a.p., p.105, ziet dit EG-cultuurbeleid als mogellike belemmering van de vrije media- en informatienarkt.

269. Mediawerzaak, IFJ EG (C-353/89) 25 juli 1991, in: MF, okt. 1991 (rechtsprakkbijlage).

270. Stichting Collectiewe antenneworziening Gouda ws. CwM, HwJ EG (288/89) 25 jull 1991, in: MF, okt. 1991, pok in: NJB 1991, pp.1 152-1166; Webb, HrJ EG (279/80) 17 dec. 1981, Jur, 1981, p.3305; Van Wesemael, Hw EG (111/78); Nationale beperkingen afgewezen in Commissie vs. Spanje (beroepshwalificatie gidsen), HvJ (C-375/92) 22 maart 1994, in.. NJB, nr. 19, 13 mei 1994, p 241 (rechtspraakbijlatge), gebaseerd op Italiaanse gidsen, HwJ EG (180/89).

271. Coditel 1, HWJ EG 18 maart 1980, NJ 1980, 581/531; De in dit arrest voorgestane territoriale exclusiviteit is acluterhaald door de Richulijn $v$.d. Raad v.d. EG tot coördinatie van bepaalde voarsichriften betreff. auteurstech en naburige rechten op het gebied vam satellietomroep en doorgifie via de kabel, 93/83/EEG, Publ. EG L 248/15, 27 sept. 1993. Hierover P. B. Hugenholtz. De Eur. richtlin inzake satellietomroep en kabeldoorgiffe, in: Informatierechu/AMI, nr.5, mei 1994, pp.87-90.

272. Groener, HvJ EG (379/87) 28 now. 1989, Jur. 1989, p.3967.

273. Société Labaratoire de prothèses oculaires t. Union nationale des syidicats d'opticiciens de France e.a., HvJ EG (C-271/92) 25 mei 1993, in: SEW, nr.6, juni 1994, pp.437-438. Volgens het hof is verkoop van contactlenzen geen gewone handelsactiviteit. Een nationale regeling die verkoop van contactlemzen en aanverwante produkten slechts aan (beroeps)gekwallificeerde opticiens toestaat gaat haar doel niet woorbij en is gerechtvaardigd van uit het oogpunt van wolksgezondheid; Conform art. 30 jo. art. 129 , eerste lid, EG-verdrag zijn de eisen inzake volksgezondheid bestanddeel wan het gemeenschapsbeleid ther zake. Beoogd wordt een hoog niveau van bescherming van de volksgezondheld te verzekerem door bevordering en ondersceuning wan samenwerking tussen lidstaten; Ook in Lucien Ortscheit GmbH vs. Eurim-Pharm Aroneimitel GmbH, HvJ EG (C-320/93) 10 nov. 1994, in: NJB, 2 dec. 1994, nr. 43, rechtspraakkatem nr.29, pP.572-573 (bijlage), ook in: SEW, mr.2, febr. 1995, Jurispnidentie EG nr.1, pp.5-6 (JEG). keurt het hof een nationale beschermingsmaatregel goed. Gegeven de, tijdens de uit spraak, gegeven stand wan hamomisatie, bij gebreke van communautaire toelatingsprocedures of wrederzijdse erkenning van nationale toelatingen, oordeelt het hof het met het EG-verdrag verenigbaar dat "een nationalle regeling of praktijk die een beperkende invloed heeft of kan hebben op de invoer van farmaceutische produkten [...] voor zover zij nodig is om de gezondheid en het leven van de persomen doeltreffend te beschermen en deze miet ewen doeltreffend kunnen worden beschermd door matregelen die tussenstaatse handel minder beperken". I.c. betreft de nationale belemmering wen verbod van reclame voor geneesmiddelen warwan de import in de betreffende nationale staat, $t, w$. Duitsland, in principe niet wordit toegellaten. Inwoer is slechts mogelijk als de medicijnen in het land van oorsprong worden toegestaan, en, in beperkte hoeveelheid, worden besteld door apothekers op voorschrift van artsen. Bedoeld Duits reclameverbod is volgens het hof 'noodzakelijk voor de doeltreffendheid van het stelsel van mationale toelating", omdat het verbod beoogt "het uitzonderingskarakter van individuele invoer yan niet-toegelaten geneesmiddelen in stand te houden ten einde te woorkomen, dat het basisvereiste van nationalle goedkeuring in de Duitse wetgeving systematisch wordt omzelld"; Vgl. Vicks pastilles, HR 14 juni 1994, strafkamer nr.96.869E, weer gegeven door A. Mulder, in: SEW, mr.2, 1995, pp. 140-146. In casu betreft het import in Nederland van pastilles, waaraan in lichte mate C villamines zijn toegevoegd, vam uil Duitsland. De waren voldoen aan de Duitse kwaliteitseisen. In Nederland wordt Richardson Vicks bv veroordeeld tot een geldboete, omdat niet conform de nationale wetgeving van te voren importtoestemming is gevraagd. Echter, de in het geding zijnde Nederlandse 
De 'Cassis de Dijon'-rechtspraak ${ }^{274}$ schrijft, wat betreft het vrije goederenverkeer, aanvaarding van belemmering van het intra-communautair verkeer als gevolg van dispariteiten (van nationale wettelijke regelingen op verhandeling van produkten) voor, woor zover dringende behoeften ze noodzakelijk maken. De regel is niet limitatief. Aangenomen wordt, dat deze "rule of reason' ${ }^{275}$ mede van toepassing is op de vrijheid van dienstenwerkeer.

Door de uiteindelijk toch "ruime uitleg die niet zo zeer ín het arrest-Cassis de Dijon aan art. 30 , maar áán dat laatste arrest is gegeven" ${ }^{276}$ "heeft het hof van justitie zijn rechtspraak 'gecorrigeerd'. ${ }^{27}$ Het arrest, dat komt op "een moment dat de trein uit de bocht begon te lopen" ${ }^{278}$, houdt de volgende essentiële overweging in. Als een, door een mationale staat aan de vrijheid wan goederenverkeer ex art. $30 \mathbb{E}(\mathrm{E})$ G-verdrag gestelde geoorloofde beperking is niet te beschouwen "de toepassing op produkten uit andere lidstaten van nationale bepalingen die bepaalde verkoopmethoden (hersteld als: verkoopmodaliteiten - JGLVN) ${ }^{279}$ aan banden leggen of verbieden, mits die bepalingen van toepassing zijn op alle marktdeelnemers die op het nationale grondgebied activiteiten ontplooien, en mits zij zowel rechtens als feitelijk de zelfde invloed hebben op de verhandeling van nationale produkten en op die van produkten uit andere lidstaten". 280281

273. $\rightarrow$

warenwetmaatregel op de verhandeling van waren waaraan vitamine $\mathbb{C}$ is toegevoegd, die invoer verbiedt behoudens vooraf gaande individuele toestemming van de betrokken minister, is niet langer gerechtvaardigd nu een dergelijke preventieve controle niet wordt vereist door het streven naar gezondheidsbescherming. Er bestaat striijd met het evenredigheidsbeginsel. Even doeltreffende bescherming kan namelijk worden bereikt door repressief toezicht, dat het intracommunautair verkeer minder belemmert. Nu de Nederlandse wetgever, anticiperend op het harmoniseren van regelgeving ter zake in $\mathbb{E G}$ verband, overweegt een algemene regeling te treffen waarbij de verhandeling van vermelde waren wordt vrijgegeven, mits die waren voldoen aan aanduiding* en etiketteringsvoorschriften, verklaart de rechier de betrokken importeur niet strafbaar.

274. Vgl. Dassonville. HvJ EG (8/74) 11 juli 1974, Jur. 1974, p.837; v.Tiggele, HwJ EG (82/77) 24 jan. 1978, Jur. 1977 , p.901.

275. De "rule of reason" betekent optionele harmonisatie. Daarmee wertegenwoordigt zij het stadium tussen minimale en totale harmonisatie. Hierover C.S. Pisuisse, Elementair Europees Gemeenschapsrecht, Groningen, 1991, pp.81-89.

276. M.R. Mok, Bespreking arrest Keck ws. Mithouard, in: TVVS, nr.1, 1994, pp.20-21.

277. Overigens meent J.M.I.J. Zijlmans, Het Keck-arrest; Een storm in een glas water of . . ? in: NJB, nr.7, 17 febr. 1995, pp.248-250, eigenzinnig dat daar waar het hof stelt dat het afwijkt van eerdere rechlsprak niet naar het Cassis-de-Dijon-arrest verwijst, maar naar over verkoopmethoden handelende arresten als Buet, Stone-on-Trent e.d.

278. M.B.W. Biesheuvel, Een tussensfand in het Europese recht, in: De staat van het rechr, NJB-kronieken 1 aug. 1993 - 1 aug. 1994, als bijlage van NJB, nr.33. 23 sept. 1994, pp.41-45, i.h.b. p.44.

279. Hiervoor hanteert annotator K.J.M. Mortelmans de bredere term "marktomstandighedenregelingen", in: SEW, nr.2, 1994, pp.120-129, i.h.b. p.123.

280. Keck ws. Mithouard, HvJ EG (C-267-268/91) 24 nov, 1993, in: TVVS, nr.1, 1994, pp 20-21, ook in: SEW, nr.2, 1994, pp.115-120, tevens in: NJ 1994, 470 en in: 'TvC 1994, p.22 e.v.; Tevens Hänermund" e.a. ys. Landesapothekerkammer Bader-Würtemberg. HvJ EG (C-292/92) 15 dec. 1993, in: NJB, nr.6, 11 febr. 1994, p. 72 (NJB-rechtspraak), ook in: TvC 1994, p. 85 e.v. en in: SEW, nr. 3, 1995, pp.206207; Herhaald in Verband Sozialer Wertbewerb eV vs. Clinique Laboratories SNC en Estée Lauder Cosmetics GmbH, HvJ EG (C-315/92) 2 febr. 1994, in: NJB, nr.8, 25 febr. 1994, pp.93-94 (rechtspraakbijlage), ook in: TvC 1994, p.86 e.v., tevens in: TVVS, nr.9, 1994, pp.253-254 en in: SEW, 
Afgezien van deze Cassis de Dijon-jurisprudentie, is inmiddels ook een standaardarrest ${ }^{282}$ gewezen, dat niet slechts op afgeleide wijze, maar direct betrekking heeft op de vrijheid van dienstenverkeer. In deze uitspraak, waarin het organiseren van loterijen (en andere kansspelen als bingo' $\mathrm{s}_{\text {* }}$ draverijen en casinospelen) als economische activiteit wordt aangemerkt, wordt bepaald dat lidstaten het vrij verkeer van de kansspelmarkt kunnen beperken in verband met de bestrijding van gokverslaving, gokfraude en dergelij-

280. $\rightarrow$

nr.3, 1995, pp. 208-211, met gecombineerde noot inzake Hünermund, Clinique en Ortscheit wan J.H. Jans, in: SEW, nr. 3, 1995, pp.214-217; Opnjeuw bevestigd in Resp. tankstation "t Heaske v. of. en Boermans (Nederlandse winkelssluitingswetgeving), HvJ EG (C-401/92 gevoegd met C-402/92) 2 juni 1994, NJ 1995, 181, ook in: NJB, nr.27, 15 juli 1994, p.335 (NJB-rechtspraak), ook in: TwC 1994, p.71 e.v., tevens in: TVVS, nr.9, 1994, p.254 en in: SEW, nr.3, 1995, pp. 199-202; De strafkamer wan de HR 10 januari 1995, in: NJB, nr.13, 31 maart 1995, rechtspraakkatern nr.49, pp. 169-171 (bijlage), die meent dat art. 3 Vrijstellingsbesluit winkelsluitingswet (waarin rekening wordt gehouden met bepaalde verschillen tussen plaatselijke omstandigheden van winkels in benzinestations en andere winkels en tussen winkels in benzinestations onderling) geen strijd oplevert met art. 1 Grondwet, doet deze uitspraak met een beroep op 't Heuske-arrest; Aan 't Hewske-arrest vrij wel gelijk is Punto Casa ws. Sindaco del Comune di Capena, Promozioni Polivalenti Venete Soc. coop. arl, en Sindaco del Connune di Torri di Quartesolo (Italiaanse zondagssluitingswetgeving), HvJ EG (C-69/93 en 258/93) 2 juni 1994, NJ 1995, 180, ook in: TVVS, nr.9, 1994, p.254 en in: SEW, nr.3. 1995, pp.202-204, met gecombineerde noot inzake 't Heuske, Stoke-on-Trent en Punto Casa van J.H. Jans, in: SEW, nr.3, 1995, pp. 204-206; In Council of the Ciry of Stoke-on-Trent, Norwich City Council vs. BdQ plc, HwJ EG (C-161/91) 16 dec. 1992, in: SEW, nr.3, 1995, pp.196-197, acht het hof een nationale regeling, die detailhandelaren verbiedt hun winkels op zondag open te stellen, niet strijdig met art. 30 EG-verdrag. Zo'n regeling raakt de verkoop van zowel nationale als. ingevoerde produkten. Bovendien is het doel van de regeling gerechtvaandigd, nu de lidistaten in zo'n regeling (met inachtneming van $o . m$. het evenredigheidsbeginsel) een keuze tot uiting brengen die verband houdt met nationale of regionale sociaal-culturele eigenheden; Over specifiek een stelsel van prijsvoorschriften (wraarwan parafiscale heffingen, die importeurs benadelen, onderdeel uitmaken) in thet licht van art. 30 EG-verdrag Sociétes Compagnie commerciale de l"Onest e.a. vs. Receveur principal des douanes de La Pallice-Port, HvJ EG (C-78-83/90), 11 maart 1992, met noot van A.M.M. Teubner, in: SEW, nr.3, 1995, pp.187-194; En specifiek wat betreft het mediarecht krijgt de Keck-jurisprudentie bevestiging in Importmaatschappij Ëdouard Leclerc-Siplec us. TFI publicité SA en Mo Publicité SA, HvJ EG (C-412/93) 9 fébr. 1995, in: NIB, nr.21, 26 mei 1995, rechtspraakkatern nr.5, p.267 (bijlage). I.c. toetst het hof een nationale regeling inhoudende een werbod tot uitzending van reclameboodschappen ten behoeve van de distributiesector door op het grondgebied van de lidstaat gevestigde televisie-omroepinstellingen. Het hof oordeelt dat "de toepassing op produkten uit andere lidstaten van nationale bepalingen als de onderhavige die bepaalde verkoopmodaliteiten aan banden leggen of verbieden, in casu doordat een bepaalde vorm van werkoopbevordering (televisiereclame) voor een bepaalde vorm van verhandeling (distributie) van. produkten wordt verboden, niet een maatregel vormt die de handel tussen de lidstaten all dan niet rechtstreeks, daadwerkelijk of potentieel, kan belemmeren in de zin van de Dasson-ville-rechtspraak. Voorwaarde daarbij is dat die bepalingen van toepassing zijn op alle marktdeelnemers die op het nationale grondgebied activiteiten ontplooien, en dat zij zowel rechtens als feitelijk de zelfde invloed hebben op de verhandeling van mationale produkten en op die van produkten uit andere lidstaten."

281. E. Steyger. Nogmaals het Keck-arrest: De nieuwe onduidelijkheid in de toepassing van artikel 30 EGverdrag, in: NJB, nr.25, 23 juni 1995, pp.933-935, levert interessante kritiek op het Keck-arrest en de in het verlengde van die uitspraak liggende jurisprudentie. Hierbij neemt auteur art. $100(A)$ en art. 235 EG-verdrag als uitgangspunt voor het betoog.

282. Schindler vs. Her Majesty"s Customs and Excise, HvJ EG (C-272/92) 24 maant 1994, in: NJB, nr.18, 6 mei 1994, pp.225-226 (NJB-rechtspraak), ook in: TvC, nr.3, 1994, pp.208-221, m.nt. K.J.M. Mortelmans, en in: NJ 1995, 57. 
ke. In casu is het, uit overwegüngen van sociaal beleid en fraudebestrijding, zelfs geoorloofd om een nationaal verbod tot het houden van grootschalige loterijen uit te vaardigen. Volgens het hof mag elke lidstaat, in het licht van eigen maatschappelijke en culturele omstandigheden bepalen hoe, in welke mate en met welk doel loterijen worden georganiseerd. ${ }^{283}$

Ten slotte, het beginsel van vrijheid van dienstenverkeer staat in de weg aan de zgn. $U$ bochtconstructie. Met dergelijke constructies wordt niets anders beoogd dan grensoverschrijdend te werken ten einde aan de (strengere) regels geldend in het land van herkomst te ontkomen. Een lidstaat mag niet het recht kan worden ontzegd "maatregelen te treffen om te verhinderen dat de door het verdrag gewaarborgde vrijheden door een dienstwerrichter wiens werkzaamheid geheel of voornamelijk op zijn grondgebied is gericht, worden gebruikt om zich te onttrekken aan de regels die, zou hij op het grondgebied van die lidstaat zijn gevestigd, op hem van toepassing zouden zijn (daar op zodanige situatie het hoofdstuk betreffende het recht van vestiging en niet dat betreffende de dienstverrichting van toepassing zou kunnen zijn)." ${ }^{284}$ Hier ligt het probleem van een omroepinstelling, die zich slechts pro forma in lidstaat $x$ vestigt, maar haar omroepactiviteiten vrij wel geheel richt op lidstaat $y$. Bekend is de in het verleden verleende (feitelijke en financiele/juridische) medewerking van een Nederlandse omroepvereniging, aan de oprichting in Luxemburg van een op Holland gerichte commerciële televisiezender. In principe valt dit onder de vrijheid van dienstverrichting. "Door de nationale omroepinstellingen te verbieden steun te verlenen bij de oprichting in het buitenland van commerciële omroepbedrijven, met het doel aldaar diensten te verrichten die gericht zijn op de Nederlandse markt, verhindert de Nederlandse wet juist dat die instellingen zich dankzij de uitoefening van de door het verdrag gewaarborgde vrijheden kunnen onttrekken alan de uit de nationale wettelijke regeling voortvloeiende verplichtingen betreffende pluriforme en niet-commerciêle inhoud van de programma"s. " 285 In het verlengde daarvan ligt recentere rechtspraak. Hierin staat voorop dat de Nederlandse Mediawet strekt tot handhaving van een pluriform en niet-commercieel omroepbestel. Aldus sluit de nationale wetgever zich aan op een, in het algemeen belang gevoerd, cultuurbeleid dat is gericht op het behoud in de omroepsector van de vrijheid van meningsuiting. In dit kader komt de Europese rechter tot de conclusie: "De verdragsbepalingen inzake het vrij verrichten van diensten staan er

283. K.J.M. Mortelmans, Annotarie Schindler, in: TvC, nr.3, 1994, pp. 216-221, mist in deze uitspraak, waarin een niet-economische activiteit met economische gevolgen onder de werkingssfeer valt wan het EG verdrag coifform de dartoe bij het Verdrag van Maastricht gecrecerde mogelijkheid, een referentie aan de Keck-norm wan onderscheid tussen produktwoorschniften en verkoopmodaliteiten. Auteur stelt dat het Sichindler-arrest wel van groot belang is woor de interpretatie van de Keck-norm, omdat het arrest, zijns insziens overigens te restrictief, inwulling geeft ann "feitelijke discriminatie"'. Het hof gaat namelijk, aan de hand van de regel dat ongelijke gevallen ongelijk behandeld moeten worden, na of de nationale beperkende maatregel in werkelijkheid discriminerend is. Ten slotte werwijt annotator het hof, dat de rechterlijke interpretatie van de Schindler-excepties een expliciete proportionaliteitstoets ontbert.

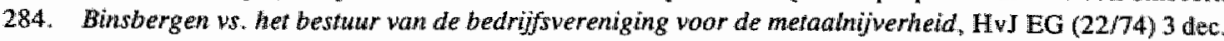
1974, Jur. 1974, p. 1299; Vgl. Coenen, HwJ EG (39/75) 26 nov. 1975, Jur. 1975, p.1547.

285. VOOws. CudM (RTL-Peronique), HwJ EG (C-148/91) 3 febr. 1993, in: TVVS, nr.8, 1993, pp.214-215, ook: NJ 1994, 29. 
niet aan in de weg dat een lidstaat een naar het recht van een andere lidstaat opgerichte en in đeze staat gevestigde omroepinstelling, wier activiteiten evenwel geheel of hoofdzakelijk zijn gericht op het grondgebied van de eerste staat, gelijk stelt met een nationale omroepinstelling, in geval die vestiging heeft plaats gevonden om zich te onttrekken aan de regels die op deze instelling van toepassing zouden zijn, wanneer zij op het grondgebied van de eerste staat was gevestigd." 286

Bovenstaande in aanmerking nemende, doet het pleidooi ${ }^{287}$ voor het zoeken naar een evenwicht tussen Europees vrij verkeer en nationaal facettenbeleid niet vreemd aan. Het streven naar een geharmoniseerde communautaire interne markt is niet los te zien van de aanscherping van nationale excepties op de verschillende vrijheden. Wetgevers, beleidmakers en rechters moeten exoneraties verdisconteren in gemeenschapsrecht. ${ }^{288}$

Echt uniform gemeenschapsrecht, inzake eigendomsverhoudingen op mediagebied, blijft voorlopig even toekomstmuziek. Medio 1994 talmt de Europese Commissie nog met voorstellen ter bevordering van de harmonisatie van nationale wet- en regelgeving aangaande mediaconcentraties en pluralisme. ${ }^{289}$ Voordat zij tot concrete daden komt, wil zij het bedrijfsleven polsen over de wenselijkheid van het liberaliseren en het harmoniseren van het in de Europese lidstaten heersende mediarecht, dat niet alleen pluriformiteit van media-aanbod, maar ook open en gelijke kansen voor mediabedrijven moet garanderen. Weliswaar stemt de afzwaai ter zake van de Europese Commissie het bedrijfsleven tot tevredenheid, daar zij vreest dat Brusselse (interne markt)interventie ter zake indringend is. Tegelijkertijd bestaat het besef dat de huidige nationale wet-en regelgeving, die soms krampachtig een fundamentale vrijheid als de vrijheid van meningsuiting wil beschermen en daardoor mogelijk marktverstorend werkt, te kort doet aan de concurrentiepositie van mediabedrijven.

286. TV 10 SA us. CNdM, HVJ EG (C-23/93) 5 okt. 1994, in: NJB, nr.40, 11 nov. 1994, rechtspraakkaterm nr.26, pp:523-524 (bijlage), ook in: SEW, november 1994, pp.26-28 (Jurisprudentie EG); Na de uitsprask van het HWI $\mathbb{E G}$, n.a.v. prejudicièle wragen van de ARRS, doet de ABRS (met referentie aan "s-hofs arrest) witspraak, TW 10 SA ws. CWdM, 1 maart 1995, in: NJB, nt 14, 7 april 1995, rechtspraakkattern nr. 14, pp.180-181 (bijlage).

287. K.J.M. Mortelmans, De interne markt en het facettenbeleid na het Keck arrest: nationaal beleid, wrij verkeer of harmonisatie, in: SEW, mr.4, 1994, pp.236-250.

288. H.A.G. Temmink, Minimumnormen in EG-richtlinen, in: SEW, nr.2, febr. 1995, pp.79-106, pleit er in zijm lezenswaardig opstel voor dat nationalle wetgevers met een voonuitstrevend (facetten)beleid valker de handen ineen slaan om gezamenlijk tot verder gaand beleid (d.w.z. nationale maatregelen of beperkingen die strenger zijn dan de minimumnormen in Europese richtijnen, welke normen zijn geharmoniseerd met marktintegratie als achterliggend motief of die zijm geharmoniseerd uit oogpunt van bescherming van algemene belangen van niet economische aard - JGLVN) te komen. 


\subsubsection{SAMENWERKING EN INFORMATIE-UITWISSELING MET EUROPESE (EN NIET-EUROPESE) STATEN}

Het is redelijk te stellen dat "steeds meer van het toezicht dat het commissariaat uitoefent toezicht op de naleving van Europese richtlijnen is". ${ }^{290}$ Daarom zijn twee elementen essentieel. Ten eerste moeten de organen, die zijn belast met het toezicht op de naleving van mediawetgeving in de verschillende lidstaten ${ }^{291}$, een zo veel mogelijik uniforme Europese toezichtspraktijk ontwikkelen. Ten tweede is het noodzakelijk dat de voorbereiding van Europees recht ter zake geschiedt van uit de ervaring van de uitvoeringspraktijk.

Het is niet alleen zinvol om Europees en nationaal mediarecht op elkaar aan te passen. Ook het Nederlands omroepbestel moet kennelijk een passend Europees "driedelig pak" worden aangemeten. ${ }^{292}$ In dit pleidooi voor drieërlei omroep, t.w. publieke omroep, private omroep commercieel en private omroep zonder winstoogmerk, wordt gewezen op een geweldige paradox in het omroepwezen. "Wil men 'Hilversum" als publieke omroep bevoordelen en beschermen tegenover de commerciële omroep, dan zal dat volgens EG-recht een rechtvaardiging moeten krijgen door een doelstelling als de weerspiegeling van de maatschappelijke pluriformiteit en de voorziening in pluriforme behoeften. Dat zal tot uitdrukking komen in meer programma-voorschriften dan ten aanzien van de commerciële omroep gesteld kunnen worden. Maar met die programma-voorschriften komt men, als men die aan particuliere verenigingen met particuliere doelstellingen wil opleggen, in conflict met de in het EVRM gewaarborgde uitingsvrijheid. [...] De juridische kern van het verhaal is: probeer particuliere omroepinstellingen met particuliere doelstellingen niet op te zadelen met een publieke taakstelling. Dat leidt tot een beknotting van de omroepvrijheid. Probeer ook niet een verkapte commerciële doelstelling na te streven, want dan loopt het stuk op het EG-recht. Maak een echte publieke omroep voor die behoeften die niet worden bevredigd door de private, de commerciële en de nietop-winst-gerichte omroepinstellingen." 293 Overigens spreekt niet iedereen deze overweging aan. De waarde van het pleidooi is minimaal, want de toetsingspunten waaraan publieke omroep wordt gestaatid zijn als volgt te bestrijden: a. het publiekrechtelijk karakter wordt, onder verwaarlozing van programmavoorschriften, financiële condities e.d., verengd tot toegang tot omroepactiviteiten; $b$. betoger stelt zonder nuance dat het publiek belang evengoed door commerciële omroepen als publieke omroepen wordt gediend; c. de omroepbijdrage is niet zoals beweerd een subsidie, maar gewoon retributieheffing; d. gegeven de programma-eisen in de Mediawet levert de stelling, dat particuliere omroepen slechts private doelstellingen hebben en geen enkel publieke taak hebben, een "schijnconstructie" op; e. onbegrijpelijk is het, in het betoog, niet noemen van de

290. E. Lambooy, I, van Steenis, A. van Raalte en M. Vermeeren, Het CvdM als zbo, verslag Gerard Heijne den Bak-symposium d.d. 21 april 1993, pp. 1-6, i.h.b. p.5.

291. Hierover F. Jongen, Omroepregulering in Europa; Een vergelijkend onderzoek naar de regulerende instanties op omroep-gebied in Europa, in: CvdM, Evaluatie 1988-1993, Hilwersum, 1993, pp.99-150.

292. G,A.I. Schuijt, Elk volk krijgt de omroep die het verdient, in: NRC, 20 april 1993, p.8.

293. G.A.I. Schuijt, t.a.p., p.8; G.A.I. Schuijt, Publieke omroep. Hoezo publiek?, oratie RUL, Deventer, 20 april 1993. 
samenwerkingsorganisatie NOS: en $f$. de mythe-verklaring van non-commercialiteit berust op ondeugdelijke motivering en getuigt van verkeerd inzicht. ${ }^{294}$

\subsubsection{WERKING VAN DE VRIJE MARKT IN PLAATS VAN OVERHEIDSTOEZICHT}

In het verlengde van voorgaande mag de kritiek op het mediavergunningenstelsel niet onvermeld blijven. De Mediaraad ${ }^{295}$, die economisering van informatie bepleit, is uitgesproken tegenstander van het opleggen van vergunningen en voorwaarden aan, in het bijzonder commerciële, informatieverstrekkers. ${ }^{296}$ De raad huivert van de nieuwe $\mathrm{Me}$ diawet, waarin slechts de publieke omroep wordt benadrakt. Zo heeft het winst gerichte omroepwezen te weinig mogelijkheden zich te ontplooien. Kortom, de voor de Mediawet verantwoordelijke minister moet modemer denken. Volgens de Mediaraad bepaalt binmenkort de markt de produktie en consumptie van informatie. Om te komen tot een noodzakelijk pluriform aanbod van informatie bepleit de Mediaraad afschaffing van het vergunningbeleid ter zake. De enige, mogelijk aan mediabedrijven op te leggen, beperkung mag liggen in de voorwaarden die internationale verdragen stellen of in wat nationaal noodzakelijk wordt geacht, bij voorbeeld uit een oogpunt van consumentenbescherming. De Mediaraad die nadruk legt op het marktmechanisme acht slechts stimulering van de economische activiteit in de informatiesector een overheidstaak. Daartoe ziet zij drie, mogelijk naast elkaar te hanteren, beleidsinstrumenten: a. volledige marktwerking (financiering via prijsmechanisme annex voorwaardenscheppende en toezichthoudende rol van de overheid); b. produktfinanciering (financiering deels via prijsmechanisme en deels via overheid); en c. aanbiedersfinanciering (financiering via overheid die een of meer aanbieders aanwijst).

Nota bene, in de optie van de Mediaraad moet een, zowel voor elektronische als nietelektronische diensten geldende, flexibele, doorzichtige en slagvaardige Wet op de informatieproduktie (gericht op zowel exploitatie van informatiediensten als beschikbaarheid en toegankelijktreid van informatieprodukten) de, te eenzijdig op de publieke omroep georiënteerde, Mediawet vervangen. Daarbij acht de raad vervanging van het het huidige zbo Bedrijfsfonds voor de pers nodig. Hiervoor in de plaats kan het meer omvattende Bedrijfsfonds woor de Informatieproduktie komen. Ook de taak van dit bedrijfsfonds is

294. Zie felle kritiek vian B. Geersing. De oratie van Schüjt: een pwblieke vergissing , in: MF, nr.7/8, 1993, pp. 81 - 83 .

295. Begin juli 1995 wordt een Raad voor het cultuurbeleid ingesteld. Deze raad adviseert over de hoofdlijnen van het rijksculturubeleid. Advisering spreidt zich uit over het niveau van algemene sectorale beleidsvraagstukken, het niveau van sectorale beleidsvraggsukken en het niveau van de afzonderlijke instellingen. De adviesterreinen zijn: archeologie, archieven, architectuur, beeldende kunsten en vormgeving, bibliotheken " dans, film, letteren, morumenten, musea, muziek/muziektheater, omroep/pers/nilenwe media en theater. De rad vervangt respectievelijk de Raad voor de Kunst, de Mediaraad en de Raad voor hell cultuurbeheer. Dit past dus in het regeringsvoornemen adviesorganen van de rijk soverheid te werminderen. Wetswoorstel tor wijziging van de Wet op het specifiek cuitururbeleid $i$. v.m. de instelling wan een adviesorgaan voor het beleid op het terrein van de cultuwr, TK 1994-1995, 24090. nis.. 1-3.

296. Mediaraad, Advies inzake herstucturering beleidinformatievoorziening; Deel IIDe informatieproduktie 27 jan. 1994, pp.11/16; Herover Mediaraad wil groei wan informatiediensien, in: NRC, 29 jan. 1994. p. 2 . 
gelegen in het, op grond van andere dan aan produktfinanciering te stellen criteria, bieden van financiële ondersteuning van aanbieders van (nieuwe) informatiediensten voor de exploitatie van deze diensten (bij voorbeeld videotex, audiotex, krant, omroep). ${ }^{297}$

Dat het huidige kabinet-Kok zich overigens goed in de gedachte van vrije marktwerking vindt, blijkt uit een eind december 1994 gepresenteerd actieprogramma. ${ }^{298}$ Daarin geeft het kabinet concrete stappen aan voor het liberaliseren van de markt van communicatie en informatieverschaffing. Voor de ontwikkeling van die markt is het noodzaak te zorgen woor: a. een brede toegang tot de communicatiemedia; b. een ruimte voor initiatief in de marktsector; en c. een kader voor (zelf)regulering, dat juridische randvoorwaarden waarborgt. Om dit proces in banen te leiden heeft de overheid een stimulerende en richtinggevende rol. Daartoe richt zij zich op zowel het spoor van liberalisering van de telecommunicatie- en mediamarkt als het spoor van herbezinning op, de op haar rustende, bijzondere zorgtaak voor de informatievoorziening in de publieke sector.

Het wolledig liberaliseren is mogelijk door afschaffing wan belemmerende wet-en regelgeving. In bedoeid plan past dan ook het voorstel om de toch al aan hevige schommelingen onderhevige Mediawet maar weer eens aan te passen: de wet wordt ontdaan van bepalingen die leiden tot onnodige beperkingen voor de ontwikkeling van diensten in de marktsector. Deze aanpassing van de Mediawet moet kennelijk zo ver gaan dat de met de Wet op de telecommunicatie voorzieningen en de Radio omroep zenderwet wordt geïntegreerd in één wettelijk regime. Een dergelijke wettelijke inkadering maakt concurrentie op de vaste infrastructuur en een volledig vrije markt voor telecomdiensten en infrastructuur mogelijk. Hierbij acht de regering nog wel onafhankelijk toezicht op het functioneren van die markt nodig.

\section{Ten slotte}

Terecht is het Commissariaat voor de Media op zoek naar moderne modules van het door het commissariaat uit te oefenen overheidstoezicht op de omroep, voort vloeiend uit de grond- en verdragsrechtelijk verankerde zorgplicht de communicatievrijheid van zender en ontwarnger te garanderen. Ten einde - in een moderne mediawereld - voldoende voorwaarden te scheppen en mogelijkheden te creëren voor zowel publieke als private omroep uit binnenland en buitenland ten aanzien van gelijkwaardige (non-discriminatoire) toegankelijkheid, duurzaamheid en kwaliteit, moet het Commissariaat voor de Media zich een bekwaam toezichthouder tonen.

Bovendien moet het commissarialat meer dan nu regelgever mogen zijn. Meestal is het, boven op media-mensen en informatie-infrastructuur zittende, Commissariaat voor de Media (meer dan de trage formele wetgever) capabel om prospectieve regels te stellen.

297. Mediaraad, a.w. . p.23.

298. Minister-president Kok, ministers Wijers (EZ) en Jorritsma (W\&W), staatssecretarissen Nuis (OCW) en Kohnstamm (BiZa), Actieprogramma Elektrowische Snelwegen; 'Van metafoor noar actie', d.d. 21 dec. 1994 aangeboden aan Tweede Kamer, TK 1994-1995, 23900, nr. 20; Dit plan kenmerkt zich door de zelfde uitgangspunten alls het d.d. 20 dec. 1994 door de ministers Wijers (EZ) en Sorgdrager (justitie) ontvouwde plan van aanpak Markwerking, deregulering en wetgevingskwaliteit, TK 1994-1995, 24036, nr. 1, walarover: NRC, 20 dec. 1994, pp.1/17, zie ook: NJB, nr.1, 6 jan. 1995, pp.35-36. 
Het commissariaat kan rekening houden met technologische ontwikkelingen die met de dag woort denderen. Kortom, het commissariaat kan, van tijd tot tijd, terugkoppelen van theorie naar praktijk. Voordeel daarbij is dat het commissariaat regelgeving sneller (dan de formele wetgever) kan aanpassen aan de actualiteit. En, als het commissariaal als. toezichthoudend zelfstandig bestuursorgaan meer ruimte voor regelgeving wordt geboden, hoeft de formele wetgever minder detaillistisch te reguleren waardoor deregulering meer perspectief krijgt.

$\mathrm{Na}$ in de eerste jaren van zijn bestaan te worden geconfronteerd met beginnersproblemen, slaagt het commissariaat er eindelijk in om, wia een rigoreuze reorganisatie, verouderde kijk-en luisterdiensten om te zetten in vernieuwende toezichtsafdelingen. Ook de verslaglegging van toezichtsactiviteiten verbetert zich. Door deze frisse wind door de geledingen van het commissariaat kan het toezichthoudend zelfstandig bestuursorgaan efficiënter en effectiever omgaan met de in de tijd aangepaste (Media)wettelijke bepalingen inzake toezicht via boekenonderzoek bij derden, waarbij op onder toezicht gestelden in elk geval een sponsormeldingsplicht, een medewerkingsplicht en een programmabewaarplicht rusten.

In andere opzichten zit het het commissariaat minder mee. Anders dan de bedoeling van overheid op afstand, trekken de betrokken minister en niet te vergeten de onder hem ressorterende ambtenaren veel invloed aan zich. Het Commissariaat voor de Media, dat toch al kampt met een moeilijke communicatie met departementaal Den Haag (dat tot overmaat van ramp ook nog eens direct onderhandelt met de omroepen zelf, die in toenemende mate niet meer de stap naar het commissariaat zetten), ziet zijn macht afnemen. Voor uitbreiding van het takenpakket van het Commissariaat voor de Media met , voor terugkoppeling van beleid onontbeerlijke, adviestaken ziet de minister miskennend geen plaats. Ook voor het verlenen van de vijfjarige landelijke omroepconcessies (waarin de van uit het rechtszekerheidsbeginsel overigens veel te vaak gewijzigde en van uit het dereguleringsprincipe veel te gedetailleerde- huidige Mediawet, frappant voorbij gaand aan het tweezijdige karakter van concessies, voorziet) ziet de betrokken bewindspersoon teleur stellend nog geen plaats voor het commissariaat. Het komt zelfs niet in het hoofd van de minister op om op zijn minst advies omtrent concessieverlening in te winnen bij het commissariaat, dat volgens voorstel misschien in later stadium concessies mag verlenen. Kennelijk is het Commissariaat voor de Media niet gezaghebbend genoeg voor zowel departement als omroep.

Het is spijtig dat de positie van het commissariaat ten dele wordt ondergraven. Juist in een door liberalisering van de markt en harmonisatie van wetgeving gekenmerkt tijdperk, waarin politicici er alles aan lijken te willen doen om winstprikkels in te bouwen, bestaat belang bij een op afstand van de politiek staand zelfstandig bestuursorgaan dat, ter realisering van een geleidelijke overgang naar vrijere concurrentie, streng toezicht op de publieke sector maar vooral ook op de private sector houdt.

Zinvol is het dan ook dat het Commissariaat voor de Media haar autoriteit terugkrijgt. Zeker als de plausibele plannen doorgaan, om de Mediawet te integreren met andere 
wetgeving inzake de (elektronische) informatievoorziening, waardoor de waarschijnlijkheid van een, terecht in het teken van zelfregulering staand, (op de leest van het CvdM geschoeid) toezichthoudend zelfstandig bestuursorgaan voor de communicatie -meer omvattend dan het huidige Commissariaat voor de Media- toeneemt. 


\section{Geraadpleegde literatuur}

\section{Akyürek-Kievits, H.E.}

The application of article 86 of the EEC Treaty to state monopolies, in: Stuyck, J.H.V. \& Vossestein, A.J., State entrepreneurship, national monopolies and european community law; Competition and free movement in the energy, postal and telecommunications markets in the $E E C$, european monographs nr.6. Deventer/Boston, 1993, pp.91-101.

Anstadt, $M$.

Regering heeft omroep aan heidenen uitgeleverd, in: NRC, 11 februari 1995, p.9.

Armbak, J.C.

Economic and Policy Issues in the Regulation of Conditions for Sybscriber Access and Market Entry to Telecommunications, in: W.F. Korthals Altes, E.J. Dommering, P.B. Hugenholtz en J.J.C. Kabel (red.), Information law towards the 21 st century, Information law series nr.2, Deventer/Boston, 1992, pp.71-81.

Arnbak, J.C., Cuilenburg, J.J. van \& Dommering, E.J.

Verbinding en Ontvlechting in de Communicatie; Een studie naar toekomstig owerheidsbeleid voor de openbare elektronische informatievoorziening. Amsterdam, 1990.

Bense, M. \& Zijlstra, S.

Het begrip bestuursorgaan; Berekenis en strekking van art. $1: 1$, eerste lid, $A w b_{\text {, }}$ in: NTB, nr.9, 1994, pp. 253-270.

Berg. J.Th.J. van den

Verantwoordelifkheidin een polycentrische samenleving; Een nabetrachting , in: Bovens, M.A.P. e.a., Verantwoordelijkheid: retoriek of realiteit, Zwolle, 1989, pp.177-195.

Beukel, J. van den Omroep in de EG; integratie en cultureel protectionisme, in: AA, nr.5, 1989, pp. 101-106.

Biesheuvel, M.B.W.

Een tussenstand in het Europese recht, in: De staat van het recht, NJB-kronieken 1 augustus 1993 - 1 augustus 1994, als bijlage van NJB, nr.33, 23 september 1994, pp.41-45.

Blokker, J.

De 'poorzittersomroep' is failliet, in: NRC, 4 april 1995, p.9.

Boer, W. de

Hoe communicatief is de EG?; Het media- en informatiebeleid, in: Muysken, J. \& Soete, L.L.G. (red.), Maastrichtkritisch beschouwd, preadvies Koninklijke Vereniging voor Staathuishoudkunde, Utrecht, 1993, pp.87-106.

Bolkesteir, $F$. Van de mediawet geen nieuws, in: NRC, 20 november 1993, p.9.

Boukema, P.J. Massamedia en grondrechten, in: Hirsch Ballin, E.M.H., Kobussen, M.H., Moor-van Vugt, A.J.C. de \& Peters, J.A.F. (red.), Massamedia en staatsrecht, statsrechtconferentie d.d. 8 december 1988, KUB, Zwolle, pp.10-25.

Brans, B.M.

- Nationale omroep is al in de maak: Omroepen verliezen hun identiteit in slag met commercie, in: NRC, 21 april 1993, p.17;

$\sim$ De nationale omroep dreigt er aan te komen, in: NRC, 12 januari 1994, p.11;

- We moeten ons schamen dat het zover is gekomen, Het ging fout toen handige mensen ontdekten dat je met omroep geld kunt verdienen, in: NRC, 8 oktober 1994, p.9;

- Publieke omroep voor elite maakt geen enkele kans, in: NRC, 3 januari 1995, p.8.

Brouw, W. op den

- Kabinet-Lubbers 3 maakte de weg vrij, in: NRC, 10 oktober 1994, p.3; 
- Politiek zoekt contouren van nieuwe omroepbestel, in: NRC, 28 oktober 1994, p.2. Buendia Sierra, J.L.

The concept of 'Third Party Access' under the EEC Treaty rules, in: Stuyck, J.H.V. \& Vossestein, A.J., State entrepreneurship, national monopolies and european community Law; Competition and free movernent in the energy, postal and telecommunications markets in the $E E C$, european monographs mr.6, Deventer/Boston, 1993, pp.41-46.

Burkens, M.C. \& Kummeling, H.R.B.M.

Gentenschapsrecht en omroep, in: Burkens, M.C. \& Kummeling, H.R.B.M. (red.)

EG en grondrechten; Gevolgen van de Europese integratie voor de nationale grondrechtenbescherming, Zwolle/Utrecht, 1993, pp.1-70/219-296.

Commissariaat voor de Media,

- Jaarverslagen 1988/1989/1990/1991/1992/1993/1994, Hilversum;

Comedia 1992/1993/1994/1995, Hillversum;

- Evaluatie 1988-1993: overheid en omroep in Europees perspectief, Hilversum, 1993;

- Uittreksel verslag Gerard Heijne den Bak-symposium; Het CvdM als zbo, 21 april 1993, pp.1-7.

Dam, A. van \& Sloots, W.

Adviesorganen: beter met minder, in: Openbaar Bestuur, nr.2, 1995, pp.2-6.

Dellebeke, $\mathbf{M}$.

Eindelijk een sponsorwet woor de publieke owroep, in: Mediaforum, nr.9, 1994, pp.90-92.

Dienst Omroep Bijdragen

Toelichting op de jaarrekening DOB 1992, "s-Gravenhage, 1993, pp.1-15.

Dommering, E.J.

- De informatiedriehoek; Enige beschouwingen over de regulering van informatiestromen, oratie UvA d.d. 20 oktober 1989, Deventer, 1989, pp.1-33;

- Article 90 of the EEC Treaty and the telecommunications, broadcasting and postal services sectors, in: Stuyck, J.H.V. \& Vossestein, A.J., State entrepreneurship, national monopolies and european community law; Competition and free movement in the energy, postal and telecommunications markets in the EEC, european monographs nr.6, Deventer/Boston, 1993, pp.53-72.

Dommering, E.J., Eijk, N.A.N.M., Groeneveld, C. \& Schuijt, G.A.I.

- Kroniek informatierecht; Media- en telecommunicatierecht, in: AA-katern, december 1992, pp.2072-2074;

- De berichtgeving komi straks in politieke handen, in: NRC, 6 oktober 1993, p.9;

- Kroniek informatierecht; Media- en telecommunicatierecht, in: AA-katern 49, november/december 1993, pp.2299-2301.

Donker, $B$.

Minimumquota op televisie: debat afgelast; Parijs wil discussie nog niet, in: NRC, 4 april 1995. p.5.

Edens, D.F.

The concept of liberalisation of telecommunications services in the commission directive of jume 28,1990 (90/388/EEC) on the competetion in the market for telecommunications services, in: Stuyck, J.H.V. \& Vossestein, A.J., State entrepreneurship, national monopolies and europear community law; Competition and free movement in the energy, postal and telecommunications markets in the $E E C$, european monographs nr.6, Deventer/Boston, 1993, pp.87-90.

Eijk. N.A.N.M. van

- Europese mediaregels" Een terugkeer naar overheidstoezicht op omroepprogramma's?, in: NJB, nr.2, 14 februari 1989 , pp.47-51; 
- Omroepvrijheid en overheidsbemoeienis; Een vergelijkende studie noar de Nederlandse, Franse en Europese regels m.b.t. toegangscriteria en programmavoorschriften voor de omroep, dissertatie UvA, Amsterdam, 1992 ;

- Omroepen behoeven nieuwe regels over sponsoring, in: NRC, 17 april 1993, p.8.

Eijk, N.A.N.M. van, Hins, A.W., Schuijt, G.A.I. \& Meijboom, A.P.

Katern media- en telecommunicatierecht, in: Ars Aequi (katern nr.53), n.r.11/12, 1994, pp.25162519, ook Ars Aequi (katern nr.54), nr. 2, 1995, pp.2570-2572.

Fierstra, F.M., Nugter, A.C.M. \& Korthals Altes, W.F.

Vrij verkeer van informatie in Europa, preadviezen t.b.v. gezamenlijke studiebijeenkomst van de NVE, NVIR en VMC, A'dam, 15 november 1991, pp.9-38/63-83.

Geersing, B.

- De oratie van Schaijt: een publieke vergissing, in: Mediaforum, nr.7/8, 1993, pp.81-83;

- Niet wijzigen Mediawet is in het belang van de commercie, in: NRC, 13 oktober 1993, p.11.

Geurtsen, A.

De bijna-nationalisering van de omroep, in: NRC, 25 oktober 1993, p.9.

Gyselen, L.

National monopolies - An evolving state action doctrine under article 90 EEC, in: Stuyck. J.H.V. \& Vossestein, A.J., State entrepreneurship, national monopolies and european community law; Competition and free movement in the energy, postal and telecommunications markets in the EEC, european monographs nr.6, Deventer/Bioston, 1993, pp.1-13.

Hancher, L. \& Pré, F.M. du

Gecombineerde noot bij OHRA, Meng en Reiff, in: SEW, nr.10, 1994, pp.686-700.

Heuvel, J.H.J. van den

Mediabeleid in de interventiestaat, in: Hirsch Ballin, E.M.H. e.a., Massamedia en staatsrecht, verslag staatsrechtconferentie d.d. 8 december 1988, Zwolle, 1989, pp.76-89.

Hins, A.W.

- Overheid op afstand?, in: AMI, nr.1, februari 1986, pp.5-7;

- De Mediawet: oude wijn in lekke zakken, in: NJB, 22 november 1986, nr.41, pp.1301-1305;

- Ontwangstvrijheid en buitenlandse omroep, dissertatie UvA, Deventer, 1991;

$\sim$ Het Hof van Justitie als hoeder van grondrechten, in: Mediaforum, nr.7/8, pp.74-76.

Hirs, W. \& Schuijt, G.

Samen, maar toch apart; Commentaar op het wetsvoorstel versterking publieke omroep, in: Mediaforum, nr.10. 1993, pp.1010-104.

Hoefnagel, F.M.P.M.

Wetgever en cultuur; Uitgangspunten en beginselen van de wetgeving op de terreinen van het onderwijs, de wetenschap, de publieke omroep, het apenbare bibliotheekwerk, het sociaalcultureel werk, de kunsten en de musea in de jaren 1973 tot eind 1987, Zwolle, 1988.

Hugenholtz, P.B.

- De mediawet: vier werten voor de prijs van een, in: AMR, ar.2, april 1985, pp.26-27;

- De Europese richtlijn inzake satellietomroep en kabeldoorgifte, in: Informatierecht/AMI, nr.5. meil 1994, pp.87-90.

Hulshof, G.

Kijkers willen herkenbare televisienetten met een visioen, in: NRC, 31 maart 1995, p.9.

Jongen, $F$.

Omroepregulering in Europa; Een vergelijkend onderzoek naar de regulerende instanties op omroep-gebied in Europa, in: CvdM, Evaluatie 1988-1993, Hilversum, 1993, pp.99-150.

Joosten, $M$.

Delors, Bangemann en de Europese Informatie Infrastructuur, in: Mediaforum, nr.3, 1995, pp.35-37. 
Jurgens, E.C.M.

Omroeprecht en auteursrecht; Nieuwe ontwikkelingen in informatie- en communicatierecht, preadvies CJV, 7 mei 1986, Zwolle, pp. 146.

Kabel, J.J.C.

- Geld en grammatica: de rechtsvindingsmethodiek van de ARRS inzake sponsoring en art. 56 Mw. , in: Mediaforum, nr.7/8, pp.77-80;

- Toepassing van de artt. 52 en 55 Mw door de ARRS, overzicht periode 1988-1992, in: Mediaforum, nr. I, 1992, pp.4-7:

$\sim$ Bestururlike boetes en de Mediawet, in: Hazewindus, W.G.A. \& Jansen, O.J.D.M.L. (red.), Van boeteatelier tot boetefabriek; Bijdragen van het op 24 november 1994 te Amsterdam gehouden wetenschappelijk congres over de bestuurlijke boete , Deventer, 1995, pp..143-164.

Kabel, J.J.C. \& Reijntjes, M.M. (red.)

Publieke omroep en commercie; Adviezen en uitspraken 1988-1992, Amsterdam, 1993.

Klleijwegt, A.

Nederlanders wilden na oorlog oude omroepbestel niet terug, in: NRC, 23 februari 1995, p.8.

Kohnstamm, M.

De nationale televisievoorziening en cultuurpolitieke argumenten in Europees recht, in.. NJB, nu.35, 15 oktober 1988, pp.1267-1271.

Koot, L.

De omroep op de snijtafel met d'Ancona in de rol van professar Tulp, in: NRC, 20 februari 1993, p.9.

Koopmans, T.

Intellectuele eigendom, economie en politiek, in: Informatierecht/AMI, nr.6, mei/juni 1994, pp. 107-111.

Kranenburg, $M$.

Wie maakt een eind aan Het Bestel?, in: NRC, 6 oktober 1994, p.9.

Kuitenbrouwer, $\mathrm{F}$.

- Verschijningsverboddupeert ook rwim een miljoen Veronica-leden, in: NRC, 5 februari 1993. p.7;

$\sim$ De vragen stapelen zich op: mediawet is zalig onbestemd, in: NRC, 5 oktober 1994, p.3.

Lambooy, E., Steenis, I. wan, Raalte, A. van \& Vermeeren, M.

Het CvdM als zbo, verslag Gerard Heijne den Bak-symposium d.d. 21 april 1993, pp.1-6.

Lange, C.C.W.

De Europeesrechtelijke nietigheid en de met artikel 86 EEG-Verdrag strijdige overeenkomsten, in: SEW, nr.9, 1994, pp.428-448.

Linthorst, H.M.

Omroepvrigheid en overheidsbemoeienis, in: Mediaforum, nr.5, 1993, pp.57-58.

Louw, A. van der

- Bij goudgerande omroepgarantie is kijker niet gebaat, in: NRC, 5 november 1993, p.9;

- Publieke omroep moet de markt wel op, in: NRC, 7 oktober 1994, p.7.

Luyendijk, $\mathrm{Z}$.

- Commissariaat gooit steen door ruit van d'Ancona, in: NRC, 27 mei 1993, p.7;

- 'Hartekreet' over geweld op televisie wekt verbazing, in: NRC, 22 december 1993, p.6;

- d'Ancona eigengereid in mediadebat, in: NRC, 11 februari 1994, p.2;

- Omroepen proberen buit Endemol binnen te halen, in: NRC, 29 september 1994, p.3;

- 'Veronica zal worden opgeslokt door het bedrijf Endemol", in: NRC, 1 oktober 1994, p.3;

- De koorts stijgt in Hilversum, in: NRC, 5 oktober 1994, p.2;

- Veronica stapt vrijwel zeker unt bestel, in: NRC, 8 oktober 1994, pp.1/3;

$\sim$ RTL treurt niet over mogelijk verlies Endemol, in: NRC, 8 olktober 1994, p.3; 
- "Politiek" en 'Gevoel" hebben doorslag gegeven, in: NRC, 10 oktober 1994, p.2;

- Publiek bestel hangt aan dun draadje, in: NRC, 10 oktober 1994, p.3;

- VPRO en TROS blijwen buiten 'alliantie', in: NRC, 22 oktober 1994, p.3;

'Contract Veronica haalt bestel onderuit'; Mediajurist E.J. Dommering over televisiegidsen, in: NRC, 26 oktober 1994, p.7;

- Huidige Mediawet woldoet niet'; Onderzoek naar "deal" van publieke omroep en Veronica, in: NRC, 11 oktober 1994, p.2;

- Breuk met Veronica/Endemol hing al even in de lucht, in: NRC, 8 december 1994, p.3;

- "Over wat publieke omroep is, wordt nooit gediscussieerd", in: NRC, 12 december 1994, p.2;

$\sim$ Toekomst omroepbestel in dichte mist, in: NRC, 17 december 1994, p.2.

Luyendijk, $\mathbf{Z}$. \& Tamminga, $M$.

- 'Deal' tussen omroepen en Veronica wankelt, in: NRC, 15 oktober 1994, p.3.

Mackaay, E.

An Economic View of Information Law, in: W.F. Korthals Altes, E.J. Dommering, P. B. Hugenholtz en J J.C. Kabell (red.), Information law towards the 21 st century, Information law series nr.2, Deventer/Boston, 1992, pp.43-65.

Mediaraad

Advies inzake herstructurering beleid informatievoorziening; Deel II De informatieproduktie, "sGravenhage, 27 januari 1994.

Meij, J.M. de

Uitingsurijheid; De vrije informatiestroom in grondwetteligk perspectief, Amsterdam, 1989 , pp. 149-187.

Minnaar, J.

Communicatiewrijheid in he tomroepbeleid , doctoraalscriptie faculteit der sociale wetenschappen, studierichting communicatiewetenschap, KUN, mei 1993.

Mok, M.R.

- Bespreking arrest Keck vs. Mithouard, in: TVVS, nr.1, 1994, pp.20-21;

- Bespreking arrest Eurocontrol, in: TVVS, nr.7, 1994, pp.195-196.

Mortelmans, K.J.M.

$\sim$ Annotatie, in: SEW, nr.2, 1994, pp.115-120;

-De interne markt en het facettenbeleid na het Keck-arrest: nationaal beleid, vrij verkeer of harmonisatie, in: SEW, nr.4, 1994, pp.236-250;

-Annotatie Schindler-arrest, in: TvC, nr.3, pp.216-221.

Nieuwenhuis, A.J.

Persvrijheid en persbeleid, Amsterdam, 1991.

Noomen, G.W.

Overheid en amroep, in: Graaf, H. van der \& Verhoogt, J.P., Minder staat, meer samenleving; Beschouwingen over de terugtredende verzorgingsstaat, VU-studie over politiek, bestuur en communicatie, Ansterdam, 1990 , pp. $71-82$.

Overbeek, W.B.J. van

De zaak Vierhand/NV Databank; Enkele mededingingsrechtelijke beschouwingen inzake de nevenactiviteiten van (semi-foverheidsorganen, in: CR, nr.1, 1995, pp.23-25.

Pronk, T.

De Grondwet als culturele opdrachtgever, in: Pronk, T. \& Schuijt, G.A.I. (red.), Hoe vrij is de kunst? Onderdrukking, censuwr en andere beperkingen aan de vrijheid van expressie. Amsterdam, 1992, pp.87-92.

Pelle, J.J.A.

Juridische marges voor het Nederlands omroepbeleid, dissertatie EUR, Zwolle, 1993.

Rooduijn, T. 
Als de pulp gaat regeren wordt het tijd voor een kwaliteitsnet, in: NRC, 4 oktober 1994, p.9. Schoonenboom, $J$.

Publieke omroep moet aanvallen, niet verliezen, in: NRC. 28 februari 1995, p.8.

Schumit, G.A.I.

- Ek volk krijgt de omroep die het verdient, in: NRC, 20 aprill 1993, p.8;

- Publieke omroep. Hoeze publiek?, oratie RUL, Deventer, 20 aprill 1993.

Schwartz, I.E., Donner, J.P.H., Dommering, E.J. \& Jurgens, E.C.M.

Onwoep zonder grenzen;" Beschouwingen over het Kabelregeling-arrest van het HWJ'v.d. EG

IwI/NMC . Amsterdam, 1988.

Snoeijen, $M$.

- Morgana moet plaats Veronica innemen, in: NRC, 1 november 1994, p.3;

- Omroepen op derde net werken aan fusie; VPRO minder enthousiast dan Vara en NPS, in:

NRC, 25 februarii 1995, p. 1 ;

- 'We moten nog flink robbertje vechten', in: NRC, 31 maart 1995, p.7.

Staatsbiad

Besluit van 16 oktober 1993, houdende aanwijzing van bestuursorganen als bedoeld in de Wob en de Who, Stbl. 1993, 535, pp.1-15.

Tamminga, $\mathrm{M}$.

- Veronica ontketent uitputtingsslag op turbulente tw-markt, in: NRC, 13 okt. 1994, p.19;

$\sim$ Uitgever VNU spin in het web in medialand, in: NRC, 17 dec. 1994, p. 15.

Temmink, H.A.G.

Minimumnormen in EG-richtlijnen, in: SEW, nr.2, 1995, pp.79-106.

Tweede Kamer

- Medianota, TK 1982-1983, 18035, nr.1 e.v.;

- Publieke omroep in Nederland, TK 1990-1991, 22147, nrs.1-37;

- Wijziging van bepalingen van de Mediawet i.v.m. het versterken van de organisatie van de landelijke publieke omroep en het bieden wan langdurige zekerheid aan omroepverenigingen, TK 1992-1993/1993-1994, 23257, nr.1-73;

- Regeerakkoord 1994: keuzes voor de toekomst, TK 1993-1994, 23715, nr.11;

- Herziening adviesstelsel, TK 1993-1994, 23725, nr.1;

- Wijziging Mediawet met oog op de uitvoering van richtlijn 89/552/EEG van de raad van EG 4.d. 3 okt. 1989 bretreffende de coördinatie van bepaalde wettelijke en bestuursrechtelijke bepalingen in de lidstaten inzake de uitoefening van televisie-omroepactiviteiten ( $P b E G L 298$ ), en het stellen wan overeenkomstige regels inzake de uitoefening van radio-omroepactiviteiten (anders gezegd: wijziging Mw i.v.m. sponsoring), TK 1993-1994/1994-1995, 23752, nrs.1 -3/15-19 en 199;

- Brief staatssecretaris van $O C W$ inzake wittreden van Veronica Omroeporganisatie en oprichting van cammerciële omroep van VOO en Endemoi Entertainment International bv, TK 1994$1995,23968, \mathrm{nr} .1$;

- Wijzigingen van bepalingen wan de Mediawet i.v.m. het beperken van de duur waanvoor concessiesvoor anroepverenigingen, zendtijdtoewijzigingenvoorkerkgenootschappenengenootschappen op geestelijke grondslag en toestemmingen voor commerciële omroepinstellingen kumen worden verleend, tot een periode van vijf jaren, TK 1994-1995, 23978, nrs.1-5;

- Brief van de ministers van economische zaken en van justitie over het project Marktwerking, deregulering en wetgevingskwaliteit ter verstrerking van de economische dynamiek. TK 19941995, 24036, nr.1;

- Wetswoorstel tot wijziging van de Wet op het specifiek cultuurbeleid i.v.m. de instelling van een adviesorgaan voar het beleid op het terrein van de cultuur, TK 1994-1995, 24090, nrs 1-3. Twist, K. van 
- Met dealen is de publieke amroep niet te redden, in: $\mathrm{NRC}, 12$ oktober 1994, p.7;

- Publieke omroep moet zijn kracht in de kunstwereld zoeken, in: NRC, 9 december 1994, p.7. Vollenhowen, L. van

Omroep en pers, in: F.W. Grosheide (red.), Hoofdstukken mediarecht, Alphen a/d Rijn, 1991, pp.11-46.

Witte, B. de

Nieuwe controverse over de Europese quota's, in: Mediaforum, nr. 3, 1995 , p.29.

Wolzak, C.

Voetbal en omroep: een paarse coalitie?, in: Mediaforum, nr.7/8, 1994, p.77.

Zijlmans, J.M.I.J.

Het Keck-arrest; Een storm in een glas water...?, in: NJB, nr. 7, 17 februari 1995, pp.248-250. 
Hoofdstuk 15

\section{Nederlandse Filmkeuring}

\section{$\$ 15.0$ Communicatievrijheid ten aanzien van filmvertoningen}

Met betrekking tot het uitzenden van (gedeelten van) films geldt de vrijheid van meningsuiting, neergelegd in art. 7, derde lid, Gw. Ter bescherming van de goede zeden bestaat in Nederland een zelfstandig bestuursorgaan belast met filmkeuring ex art. 2, eerste lid, Wet op de filmvertoningen ${ }^{1}$ junctis artt. 6-13 Besluit op de filmvertoningen ${ }^{2}$.

\section{$\$ 15.1$ Taakstelling Nederlandse Filmkeuring}

De Nederlandse Filmkeuring heeft, in het licht van haar verantwoordelijkheid voor filmvoorlichting aan een jeugdig publiek, ex art. 2, eerste lid, Wf, tot taak te beoordelen of de vertoning van een haar ter keuring aangeboden film al dan niet schadelijk is voor personen beneden de leeftijd van respectievelijk twaalf en zestien jaar. ${ }^{3}$

\section{$\$ 15.2$ Overheidstoezicht of zelfregulering}

Het verdient aantekening, dat hell belang van een dwingend voorgeschreven filmkeuring tegenwoordig minder wordt ingezien. ${ }^{4}$ Van uit het ministerie van welzijn, volksgezondheid en cultuur (tegenwoordig ministerie van onderwijs, cultuur en welzijn geheten) komen al geluiden, dat de Nederlandse Filmkeuring wordt "ervaren als een overbodig instituut" en bovendien als een institurut "dat met een kanon schiet op een mug " ${ }^{5}$ De

1.. Wet tot afschaffing van de filmkewring van yolwassenen, invoering wan een nieuw siystem wan kew ring voor jeugdigen, an intrekking van de benogdheid van de burgemeester ex art. 221 "weede lid, Gemeentewet van 5 jan. 1977, Stbl. 1977, 170.

2. Besluit op de filmwertoningen, 30 juni 1977, Sibl. 1977, 385 .

3. Zie NFK, Filmlijst; Oyerzicht van door NFK gekestede jilms van jan. 1977 - maart 1992 (suppl. aug. 1993), Rijswijk.

4. Tegengesteld aan dit kabinetsstandpunt C.N. Crans, Filmkeuring heef breed araagvlak, in: NRC, 19 febr. 1993, p.9; A.H. de Wild, Filmkeuring wordt helemaal niet afgeschaft, maar juist werscherpt, in: NRC, 30 jan. 1993 , p.7.

5. Aldus minister H. d'Ancona, geciteerd in: Jaarwerslag NFK 1992, Rijswijk, 1993, pp.7/17. 
nodige plannen liggen klaar om een filmcontrolesysteem in de sfeer van geconditioneerde ${ }^{6}$ zelfregulering te creëren. ${ }^{7}$

Volgens voorstel gaan de filmmaatschappijen ${ }^{8}$ zelf, op in tijd verschillende criteria - waarover consensus bestaat - berustende, classificaties uitvoeren. Om zo'n zelfreguleringssysteem optimaal te laten functioneren is het raadzaam een een commissie van

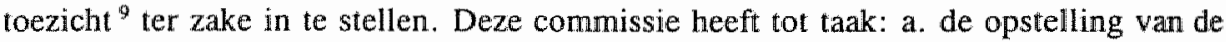
criteria en regels; b. het toezicht op de naleving; en $c$. het behandelen van klachten. " De commissie wordt voldoende pluriform samengesteld. Naast het bedrijfsleven ${ }^{12}$ moeten ook onafhankelijke ${ }^{13}$ deskundigen, en -in elk geval gedurende de eerste jaren- bovendien een vertegenwoordiger namens de rijksoverheid, in de commissie zitting te nemen. Dit keuringsstelsel biedt voor de overheid voordelen van deregulering, efficiency en privatisering van overheidstaken, als mede het weliswaar "weinig indrukwekkend" en "onzinnig" 14 gevonden voordeel van verlaging van overheidsuitgaven ${ }^{15}$. "16 Voordat invoering van het nieuwe keuringsstelsel feit is, wordt het leggen van verantwoordelijkheid bij burger en bedrijf eerst drie jaren beproefd. Deze tijdelijke test geschiedt, met

6. Tijdens het Mondeling overleg filmkewring en wideovoorlichting, d.d. 9 maart 1993, TK 1992-1993, 23001, nr.2, PP.5-6. geeft Van Nieuwenhoven (PvdA) voorkeur aan zelfregulering die "niet geconditioneerd" is. Zij ziet slectlits plaats voor exn onafhankelijke controle, waarmee geen enkele ambtenaar bemoeienis heaft, op zelfregulering.

7. Filmkeuring en videavoorlichting, TK 1992-1993, 23001, nrs. 1-4, i.h. b. nr.1, Pp. 1-10; Vgl. pleidooi J. van der Burg en J.H.J. van den Heuvel, Van overheidscensuur naar zelfregulering; Film ev averheidsbe* leid ter bescherming van de jeugd, in: Best.w. nr.4, 1991, pp.289-300, I.H.J. w.d. Heuvel "Filmkeuring en confessionele dominantie, in: T. Pronk en G.A.I. Schuijt, Hoe vrij is de kunst? Onderdrakking. censuur en andere beperkingen aan de vrijheid van expressie, Amsterdam, 1992, pp.58-67; J.H.J. V.d. Heuvel, Laatste dagen wan de filmkeuring zijn geteld, in: $\mathrm{NRC}_{*} 6$ febr. 1993, p.9.

8. Verschillende politieke pleidooien woeren terecht tot werplichte aanshüting van álle detaillisten en exploitanten. Filmkeuring en videovoorliching, TK 1992-1993,23001, nr.2, pp.34/7.

9. D'66-er Versinel-Verschmidt opteert hier voor de juridische vorm van zbo. In een dergelijke "beshurlijke heldere structuur ${ }^{\text {rt }}$ kan de minister aanwijzingen geven. En de kamer kan weer de ninister controleren. "TK 1992-1993, 23001, nr.2, p. 7" Van deze suggestie neemt de minister kennis, Fulmkeuring ev" wideovoorlichring. TK 1992-1993, 23001, nt.2, p.10.

10. Filmkeuring en videoveorliching. TK 1992-1993, 23001, nr.1, p.7.

11. In antwoord op de kritiek dat deze drie taken niet samengaan. stelt de minister dat een instantie woor het opstellen van criteria op de hoogte moet zijn vam het type klachten die voorkomen en kenbaar worden gemaakt. Fibnkeuring en videovoorlichting, TK $1992-1993,23001$, nr.2, pp .5/10.

12. Hier tegenover staat Lankhorst (Groen Links) afwijzend. Hij pleit voor een echt onafhankelijk institumi dat kan worden "aangehangen" bij het Commissariaat voor de Media. Filmkeuring en wideovoorlichring. TK 1992-1993, 23001, ar. 2, p.6.

13. Onafhankelijkheid onvoldoende gewaarborgd volgens motie-Van der Heijden, 17 maant 1993, TK 19921993, 23001, nt.4; Eerder dringt de NFK al aan op het van te voren aangeven hoe die onafharklijkheid wordt gewaarborgd. Zie NFK-brief van 21 jan. 1993, afgednkt in: NFK, Jaarversiag 1993, $\mathbb{R}$ ijswijk, dec. 1994, p.20.

14. Filmkewring en videowoorlichting, TK 1992-1993, 23001, nr.2, pp.3/6.

15. Dit betekent ook besparing voor het bedrijfsleven. Denk aan de afschaffing wan keuringsgelden en de vereenvoudiging van de classificatieprocedure.

16. Filmkeuring en videowoorlichting. TK 1992-1993, 23001, nr. 1, pp.4/7. 
medewerking van een raad(/commissie) van toezicht, op basis van een convenant van de politiek verantwoordelijk minister met de film- en videobranche. ${ }^{17}$

Ervaring met een dergelijk keuringssysteem bestaat in de video(film)sector. Bij de produktie of verhandeling van video(film)banden betrokken personen, verenigd in de Nederlandse Video Detaillisten Organisatie, classificeren, aan de hand van vaste criteria (bij voorbeeld bruut geweld, pornografie, of horror) hun produkten. ${ }^{18}$ Hun classificatierapport sturen zij naar de Raad van toezicht van videovoorlichting ${ }^{19}$. Deze raad krijgt in 1991, door het ministerie van welzijn, volksgezondheid en culluur (nu dus": ministerie van OCW), de eerste adem in geblazen met het doel om toezicht te houden op bedoelde videoclassificatie. Naar eigen zeggen van de raad, en naar het allgemene oordeel van de Tweede Kamer, is dleze toezichtsmethode efficiënt. De raad kampt nog slechts met kleine problemen. Zij heeft "geen zicht op het gentlemen's agreement met de videoverhuurders de films die niet geschikt worden geacht voor kinderen wat hoger op de planken te zetten. Een ander probleem dat zich aandient is de verkoop van videofilms door tankstations en sigarenwinkels. Deze onttrekken zich aan het gentlemen's agreement. Ook zou de raad computerspelletjes in zijn 'takenpakket" kunnen opnemen." 20 Deze wens van de raad, om toe te zien op een door het NVDO uitgevoerde leeftijdskeuring van video-en computerspelletjes, is tegenwoordig werkelijkheid. ${ }^{21}$

\subsubsection{VERSTERKING HANDHAAFBAARHEID WET- EN REGELGEVING}

Het idee geconditioneerde zelfregulering bij film- (en video-)importeurs en -producenten te introduceren, onstaat vooral van uit de gedachte, dat een nieuw geharmoniseerd systeem van film-en videoclassificatie beter voldoet aan handhafbaarheid van wet-en regelgeving. ${ }^{22}$ Het bekende probleem van de Nederlandse. Filmkeuring is namelijk, dat er "geen controle bestaat op de naleving van wat de filmkeuring verordonneert". ${ }^{23}$ Vandaar is het streven binnenkort een "verplichtende filmkeuring of leeftijdsclassificatie

17. Met het hierbij gebezigde gentlemen's agreement (met de bedrijfstak dus) heeft de NFK moeite. In de NFK brief van 21 jan. 1993 stelt zij dat een "buitengewoon ongelukkige term" te vinden "nu verplichtirngen uit een "gemtlemen's agreement niet affiwingbaar zijn. Het dunkt de NFK dat hier een keiharde overeerkomst moet worden angegaan waarin de verplichtingen van de bedrijfstak naw wheurig uiteen zijn gezet." Zie NFK, Jaarverslag 1993, Rijswijk, dec. 1994, p.21.

18. Die classificatie wordt ontdoken. M. Snoeijen "Geweldadige video 's populair bij jeugd, in: NRC, 8 febr. $1994, \mathrm{pp} .1 / 7$

19. Deze raad moet, volgens voornemen, samenwerken en mogelijk integre ren met de toexichthouder in de filmbranche. Overigens lijkt het zinvol om de classificatiesystemen van beide instanties te harmoniseren.

20. Z. Luyendijk, "Hartekreet" over geweld op televisie wekt verbazing, in: NRC, 22 dec. 1993, p.6.

21. Leefijdskeuring videospelletjes, in: NRC, 31 maart 1994, p.3.

22. Filmkeuring en videowoorlichring, TK 1992-1993, 23001, nr. 1, pp.5-6, noemt daarnaast alls basisvoorwaarden voor een nieuw geharmoniseerd sy steem van film-en videociassifucatie: dat het syste im controleerbaar moet zijn en waar nodig wordt bijgesteld door een onathankelijk orgaan, aan de uitspraken waarvan het bedrijfsleven zich conformeer; en dat het systeem dekkend moet zijn voor dle branche, d. w 2 . alle uitgebrachte (video)films worden geclassificeerd.

23. P.J.M. van Lierop, Publieksvoorlichtirg, in: NFK, Tien jaar filmkeuring, 15 okt. 1987, pp. 11-13, i.h.b. p.13. 
met verplichtende gevolgen op zelfregulerende grondslag" te realiseren. ${ }^{24} \mathrm{Zo}$ is de betrokken branche zelf mogelijk effectiever in sanctieoplegging. De branche in casu is de Nederlandse Federatie voor Cinematografie. Zij heeft een zeer hoge organisatiegraad. Bovendien voorziet zij al jaren in doeltreffende sancties als berisping, geldboete en (tijdelijke) uitsluiting.

Deze sanctionering laat de (repressieve) strafrechtelijke handhaving via o.a. de artt. 240 $240 \mathrm{~b}$ WvSr onverlet. Of deze strafrechtelijke aanpak zo efficiënt en hanteerbaar is, als wel wordt gedacht, is aan twijfel onderhevig. Toepassing van art. $240 \mathrm{a}$ WvSr, d.w.z. twee maanden hechtenis of een geldboete van de tweede categorie ${ }^{25}$, vereist dat een bepaalde filmvertoning in het algemeen (!) schadelijk is te achten (!) voor een bioscoopbezoeker beneden de 16 jaar, van wie verdachte bovendien weet of vermoedt dat die persoon inderdaad niet ouder is dan vermelde leeftijd; Afgezien van deze op hun schouders gelegde bewijslast, genieten bedoelde minderjarigen niet $20^{\prime} \mathrm{n}$ absolute bescherming als elders in de zedenwetgeving. ${ }^{26}$ Overigens vinden de strafbepalingen, sinds 1977 , geen toepassing.

Met oog op sanctionering betoogt de NFK, die het systeem van geconditioneerde zelfregulering onder strenge uitwerking er van in principe kan accepteren, dat de huidige wettelijke strafbepalingen ontoereikend zijn om naleving van de uiteindelijk nog steeds niet ingetrokken Wf af te dwingen. Volgens de NFK is het "beter wanneer ter zake een vergunningbeleid zou worden gevoerd om het kaf van het koren te scheiden" ${ }^{27}$

Ondanks het feit dat de verplichte overheidsfilmkeuring volgens de kamerstukken ${ }^{28}$ op sterven na dood is, blijft de essentie van filmkeuring, als waarborg tegen schadelijke filminvloeden, op zich overeind. Daar ligt dan ook op Europeesrechtelijk terrein de grens.

\section{$\S 15.3$ Rechtsbescherming en klachtbehandeling}

Aan de Nederlandse Filmkeuring worden filmen voorgelegd ter keuring (ex artt. 14-15 Bf), herkeuring (ex artt. 16-18 Bf) of nadere beoordeling (ex artt. 19-21 Bf). Zo bestaat via herkeuring en nadere beoordeling zekere juridische protectie tegen het optreden van de Nederlandse Filmkeuring.

Aan de hand van een matrix stelt de directeur van de NFK vijftallige keuringscommissies vast. Elke commissie kiest een eigen voorzitter. Als ten minste twee leden van de keuringscommissie overwegende bezwaren hebben tegen de keuringsuitslag, is herkeuring.

24. W.J. Blauw, Wet op de fitmwertoningen, in: NFK, Tien jaar NFK, Rijswijk, 15 okt. 1987, pp.21-23, i.h.b. p. 23 .

25. Zite strafbepaling van art. 6, eerste lid, Wf, gewijzigd bij Wet howdende herziening wan enige wetten i. v.m. de indeling van strafbare feiten in geldboetecategorieën van 11 febr. 1988, Stbl. 1988, 77.

26. P.A.M. Hendriks, Pornowetgeving en filmkewring, in: NFK, Tien jaar NFK, 15 akt. 1987, pp.14-15.

27. NFK-brief van 21 jan. 1993, afgediukt in: NFK, Jaarverslag 1993, Rijswijk, dec. 1994, p.21.

28. Minister Hirsch Ballin lijkt terug te komen op het principebesluit wan de Tweede Kamer. Zie Z Luyendijk, t.a.p., p.6. 
mogelijk. Niet alleen leden van de keuringscommissie, maar ook verhuurders van ter keuring aangeboden filmen kunnen beroep tegen de keuringsuitslag aantekenen. Niemand van de keuringscommissie neemt zitting in de herkeuringscommissie, wier besluit dat van de keuringscommissie vervangt.

In 1992 komen 61 keuringscommissies bijeen, in 1993 vergaderen 55 keuringscommissies en 3 herkeuringscommissies. ${ }^{29}$ Het aan de NFK ter keuring aangeboden filmmateriaal (hoofdfilms, voorfilms en korte films) laat een afname zien. De NFK ziet als reden daarvoor de onzekerheid, over het mogelijk verdwijnen per 1 januari 1994 van de NFK, na de discussie in de Tweede Kamer en na absolute uitspraken in de media waardoor de herkenbaarheid van de NFK overigens wordt vergroot. ${ }^{30}$ Wel wijst de NFK er op dat het aanbod sinds het begin van de jaren negentig stijgt. Het, in 1993 weliswaar sterk, verminderde aanbod beschouwt de NFK dan ook als incidenteel en tijdelijk.

De Nederlandse Filmkeuring valt, wat betreft de verwulling van haar wettelijke taak, onder het toepassingsgebied van de Wno en ook van dat van de Wob. ${ }^{31}$

\section{$\S 15.4$ Kostenverhaal en (financiële) verslaglegging}

Filmkeuring door de Nederlandse Filmkeuring geschiedt tegen betaling van $f 20,00$ per wijf minuten speelduur of gedeelten daarvan. Keuringskosten worden dus doorberekend aan betrokkenen.

De Nederlandse Filmkeuring brengt jaarlijks verslag uit omtrent haar werkzaamheden en presenteert tevens haar beleidslijnen voor elk komend jaar ex art. 7, vierde lid, Bf.

\section{$\S 15.5$ Beperking van de communicatievrijheid t.a.v. filmvertoningen in het licht van harmonisatie van nationale regelgeving ter zake}

De Europese erkenning van de belangrijke functie van de massamedia staat voorop. In beginsel heeft elk kind recht op "toegang tot informatie, vooral informatie gericht op bevordering van zijn of haar sociale, psychische en morele welzijn en zijn of haar lichamelijke en geestelijke gezondheid". ${ }^{32}$ Maar dit recht op communicatie is niet onbeperkt. In gevolge art. 22 Televisierichtlijn rust op de lidstaten de plicht passende maatregelen te nemen ter bescherming van het kind en zijn welzijn tegen schadelijke invloeden van televisieuitzendingen met (gedeelten van) filmvertoningen.

Duidelijk voorbeeld zijn de maatregelen die, mede naar aanleiding van de -mogelijk op een gewelddadige videofilm geïnspireerde- moord op een driejarige Engelse peuter, april 1994 in Groot-Brittanië worden genomen. Voorstel is te komen tot een wetswijziging

29. NFK, Jaarverslag 1993, Rijswijk, dec. 1994, p.6.

30. NFK, Jaanwerstag 1993, Rijswijk, dec. 1994, pp.7/9.

31. Aanwizingsbesluit bestuursorganen Wob en Who d.d. 16 okt. 1993, Stbl. 1993, 535, p.9.

32. Zie ant $17 \mathrm{VN}$-verdrag inzake de rechten wan het kind als angehald in: Filmkeuring en videovoorlichtüg, a. n... ni. 1, p.8. 
waardoor de Britse filmkeuring voortaan ook potentieel psychologische schade aan kinderen in haar oordeel over classificatie van videofilms moet betrekken. ${ }^{33}$

En in Nederland bestaat de politieke bereidheid om maatregelen te nemen om te voorkomen dat jongeren onder de zestien jaar extreem gewelddadige videofilms zien. ${ }^{34}$ Deze maatregelen zijn een reactie op de verhuur wan de feit en fictie vermengende videoreeks 'Faces of death' met beelden van echte executies en dergelijke. Met betrekking tot de serie zelf bestaat het voomemen tot een verbod daarvan te komen. ${ }^{35}$ De Nederlandse Video Detaillisten Organisatie komt ten dele tegemoet aan dit departementale denken door er bij haar leden op an te dringen terughoudend te zijn bij verhuur van extreem gewelddadige videofilms. ${ }^{36}$

\subsubsection{SAMENWERKING EN INFORMATIE-UITWISSELING MET EUROPESE (EN NIET- EUROPESE) STATEN}

De Europese verplichting is in Nederlandse wetgeving geïncorporeerd middels invoering van art. 53 en art. 72 , derde lid, Mediawet. Uit deze wettelijke bepalingen blijkt dat - gelet op de mogelijke schadelijke invloed daarvan op jongeren - een film, die door de NFK niet is toegelaten voor personen onder respectievelijk twaalf en zestien jaar, via de televisie niet mag worden uitgezonden vóór respectievelijk 20.00 uur en 21.00 uur. Tot eigen teleurstelling constateert de NFK bezorgd ${ }^{37}$, dat deze bepalingen van de Mediawet met verschillende voeten worden getreden. Door deze duik in illegaliteit heeft de NFK het gevoel dat de zaak totaal uit de hand loopt. Zeker als zij beseft dat de sombere situatie nog eens wordt verergerd door de probleem gevende situaties via STER-blokken, filmladders, bioscopen en commerciële zenders die een door de NFK niet voor elke leeftijd goedgekeurde film, of gedeelten daarvan, in strijd met Mediawetbepalingen op willekeurige tijdstippen uitzenden. Vandaar groeit de gedachte overtreders persoonlijk aan te pakken. Daarom besluit de NFK "na ampele overwegingen [...] een officiële klacht in te dienen bij de Reclame Code Commissie. Het doel is uiteraard meer dan alleen maar een vorm van protest. Het bestuur (van de NFK - JGLvN) hoopt op deze manier een bijdrage te leveren aan het actualiseren van de Wet op de filmvertoningen ${ }^{38}$. Er onstaat op die manier ook jurisprudentie." ${ }^{39}$ Het strenger toezien op het op grote schaal

33. Britse rem op verhutr vechrwideo aan jeugd; Filmkeuring moet royaler snijden, in. NRC, 13 april 1994, pp. 115 .

34. Terpstra will stappen tegen geweldswideo 's, in: $\mathrm{NRC}_{4} 9$ mei $1995, \mathrm{p} .3$.

35. Anders dan PwdA-kamerlid M. Vliegenthart die zich woor zo" n verbod uitspreekt, voelt H. Beunders, Videogeweld verbieden is zinloos, in: $\mathbb{N R C}, 18$ mei 1995, p.11, er meer voor om kinderen les te geven in 'beeldtalal'.

36. Waarschuwing woor video's met geweld, in: NRC, 16 mei 1995 , p.3.

37. Volgens een brief aan het NOS-bestuur d.d. 2 sept. 1993 deelt het Commissariaat voor de Media die zorg.

38. Aanpassing van respectievelijk Wf en Bf aan de praktijk thanteent de NFK trowwens als officiäle beleidslijn. Zie beleidslijn nr.8 tussen de andere beleidslijnen 1993-1994, in: NFK, Jaarverslag 1993, Rijswijk. dec. 1994, p. 19.

39. NFK, Jaaversiag 1993, Rijswijk, december 1994, p.4. 
geen gehoor geven aan de Wet op de filmvertoningen doet de werkdruk van de NFK overigens onevenredig toenemen. 40

Het, via filmkeuringen, aanbrengen van beperkingen op bedoelde communicatievrijheid moet geschieden in overeenstemming met Europese maatstaven. Niet voor niets hanteert de Nederlandse Fillmkeuring al enige tijd de volgende beleidslijn. Zij "zal bij de uitvoering van haar taak overleg voeren met soort gelijke organisaties binnen de EG". ${ }^{41} \mathrm{Bo}$ vendien ligt prioriteit bij een onderzoek met betrekking tot schadelijkheid op Europees niveau. ${ }^{42}$

Op nationaal niveau wordt eind 1991 een dergelijk onderzoek gerealiseerd. Daarvan zijn de vollgende onderzoeksresultaten interessant. " 1 . Wanneer een film voor a(lle).1(eeftijden). is gekeurd, dan is deze niet geschikt voor a.1. ${ }^{43} ; 2$. De volgende criteria geldend voor de leeftijdsgroep tot 12 jaar worden als schadelijk tot erg schadelijk aangemerkt: identificatiegevaar, horroreffecten, geen ontsnappingsmogelijkheid voordekijker, eenzijdige benadering van sexualiteit, discriminatie van een persoon/personen, vrouwonvriendelijk, psychologische druk, overmatig geweld, onverschilligheid t.a.v. geweld en wraakzuchtig geweld; 3 . De volgende criteria geldend voor de leeftijdsgroep tot 16 jaar worden als schadelijk tot zeer schadelijk aangemerkt: discriminatie van een persoon/personen, onverschilligheid t.a.v. geweld, overmatig geweld, vrouwonvriendelijk en wraakzuchtig geweld." 4 "4

\section{$\S 15.6$ Onafhankelijk overheidstoezicht}

Niet in de laatste plaats van wege die Europese erkenning, betekent afschaffing van de Nederlandse Filmkeuring, volgens voorstanders ${ }^{45}$ er van, geen ultieme oplossing. In plaats van opheffing luidt hun aanbeveling "de taak van het instituut niet te beperken tot leeftijdsclassificatie, maar uit te breiden met voorlichting en produktinformatie over films". ${ }^{46}$ De Nederlandse Filmkeuring zelf prefereert een regeling van film- en video-

40. NFK, Jaarverslag 1993, Rijswijk, dec. 1994, p.9. Dit gegeven relaterend aan de dnukte die onstaat door mogelijke oplueffing op korte termijn van de NFK zal dan moeten verklaren waarom het NFK-jaarverslag wer 1993 zo laat verschijnt.

41. Beleidslijn 9 in: C.N. Crans en T. Zijlstra, Jaarverslagen NFK 1991/1992, Rijswijk/Zutphen, 1991, respectievelijk p. 23 en p. 31.

42. Jaurverslag NFK 1991, a.w. p. 12.

43. Met de Nederllandse bioscoopbond is, ter verbetering van de publiekswoorlichting, het volgende gentlemen's agreement bereikt. Films, die woor a.l. worden toegelaten en door de NFK kinderwiendelijk worden gewonden, krijgen om de aanduiding a.l. in de weekladders van filmwoorstellingen een vierkantje. NFK, Brochure NFK, Rijswijk, april 1985.

44. Verslag werkzaamheden F. Assink in: NFK, Jaarverslag 1992, Rijswijk, pp.28-29, i.h. b. p.28.

45. O.a. kamerleden Middelkoop (GPV) en Van der Hejjden (CDA). Zie hun motie van 17 maart 1993, TK 1992-1993, 23001, nr.3. Daarin bepleiten zij handhaving van de NFK.

46. NFK, Jaanverslag 1992, Rïjswijk, p.18. 
classificatie ineen. Die classificatie geschiedt dan, op objectieve en belangeloze wijze, door een "onafhankelijk orgaan, thans de Nederlandse Filmkeuring geheten". "7

\section{Tien slotte}

Na jaren van beschaduwd bestaan, schijnen scherp felle lichten op het toezichthoudend zelfstandig bestuursorgaan genaamd Nederlandse Filmkeuring. Hamvraag is of de Nederlandse Filmkeuring, in de staat waarin zij nu verkeert, nog recht om voort te bestaan heeft. Haar bestaansrecht lijkt gerechtvaardigd, van uit het oogpunt van bescherming van; vooral jonge, justitiabelen tegen schadelijke filminvloeden. Twijfel overheerst echter om de Nederlandse Filmkeuring voort te laten bestaan in haar huidige staat. Duidelijk is dat de Nederlandse Filmkeuring geen autoriteit uitstraalt, welk aspect nu juist kenmerkend moet zijn voor een toezichthoudend overheidsorgaan.

Terecht trekken verfrissende vootstellen inzake geconditioneerde zelfregulering de aandacht. Volgens plan moet een commissie van toezicht, waarin deskundigen, belanghebbenden uit het bedrijfsleven en een vertegenwoordiger van de rijksoverheid zitting hebben, de zelfregulering in banen leiden. Een fraai voorstel uit oogpunt van verbetering van rechtshandhaafbaarheid. Belangrijk minpunt in het voorstel is dat de toezichthoudende commissie niet onafhankelijk is. Het bedrijfsleven kan in praktijk wel eens te dominant aanwezig zijn. Om dit risico uit te sluiten is het zinvoller, om in plaats van zo'n commissie, de Nederlandse Filmkeuring toe te laten zien op zelfregulering in de filmsector. Dat is in elk geval een onafhankelijk instituut. Pragmatische overwegingen nopen er dan toe de Nederlandse Filmkeuring, wier taakstelling ten dele uit de Mediawet is af te leiden, aan te hangen bij het Commissariaat voor de Media, dat toch al ziet op naleving van de Mediawet.

Nu de werkelijkheid - om de Mediawet om te zetten in een integrale wet, die ziet op veel soorten van (elektronische) informatievoorziening, met daaraan gekoppeld een onafhankelijk toezichthoudend zelfstandig bestuursorgaan - dichterbij komt, is te overwegen de huidige Nederlandse Fill mkeuring als sectieonderdeel van zo'n zelfstandig bestuursorgaan een plaats te geven. Als Commissariaat voor de Media en Nederlandse Filmkeuring, weliswar als te onderscheiden secties, op die wijze versmelten binnen een overkoepelend orgaan ontstaat mogelijk het voordeel dat de nieuw te creëren filmsectie zich niet alleen bezig houdt met filmkeuring, maar ook bij voorbeeld met het toezicht op de (Europese) quota voor televisiefilmprogramma's.

47. NFK, Jaanverslag 1992, Rijswijk, p. 18; Ook J.W. Ooms, Spanningsveld van wrijheid en bescherming. in: Filmkeuren in Europees perspectief, 's-Gravenhage, 20 april 1989, pp.19-22, i.h. b. p. 22; Tevens NFK-brief aan politiek verantwoordelijk minister van 21 januari 1993, afgedrukt in: NFK, Jaarwerslog 1993, Rijswijk, 1994, p.20. 


\section{Geraadpleegde literatuur}

\section{Blauws; W.J.}

Wet op de filmvertoningen, in: NFK, Tien jaar filmkeuring, "s-Gravenhage, 15 oktober 1987 , pp. $21-23$.

Burg, J. van der \& Heuvel, J.H.J. van den

Van overheidscensuur naar zelfregulering; Film en overheidsbeleid ter bescherming van de jeugd, in: Bestuurswetenschappen, nr.4, 1991, pp.289-300.

Crans, C.N.

Filmkeuring heeft breed draagvlak, in: NRC, 19 februari 1993, p.9.

Hendriks, P.A.M.

Pornowetgeving en filmkeuring, in: NFK, Tien jaar filmkeuring, 's-Gravenhage, 15 oktober 1.987, pp. 14-15.

Heuvel, J.H.J. van den

- Filmkeuring en confessionele dominantie, in: Pronk, T. \& Schuijt, G.A.I., Hoe vrij is de kunst? Onderdrukking, censuur en andere beperkingen aan de vrijheid van expressie, uitgave Instituut voor Informatierecht, UvA i.s.m. Boekmanstichting, Amsterdam, 1992, pp.58-67;

- Laatste dagen van de filmkeuring zijn geteld, in: NRC, 6 februari 1993, p.9.

Lierop, P.J.M. van

Publiekswoorlichting, in: NFK, Tien jaar filmkeuring, "s-Gravenhage, 15 oktober 1987 , Pp.11-13.

Luyendijk, $\mathrm{Z}$.

'Hartekreet' over geweld op televisie wekt verbazing, in: NRC, 22 december' 1993, p.6.

Nederlandse Film Keuring

- Nederlandse Film Keuring, Rijswijk, april 1985;

- Tien jaar NFK, 's-Gravenhage, 15 oktober 1987 ;

- Filmkeuring in Europees perspectief; Europa 1992, "s-Gravenhage, 20 april 1989;

- Jaarverslagen 1990/1991/1992/1993, Rijswijk/Zutphen;

- Filmlijst; Overzicht van door de NFK gekeurde films wan januari 1977 tot en met maart 1992, Rijswijk.

Ooms, J.W.

Spanningsweld wan vrijheid en bescherming, in: NFK, Filmkeuring in Europees perspectief, "sGravenhage, 20 april 1989. pp.19-22.

Snoeijen, $M$.

'Soms wil je een verhaal, soms gewoon slachten "; Gewelddadige video's populair bij de jeugd, in: NRC, 8 februari 1994, pp.1/7.

Tweede Kamer

Filmkeuring en videovoorlichting, TK 1992-1993, 23001, nrs.1-4;

Wild, A.H. de

Filmkeuring wordt helemaal niet afgeschaft maar juist verscherpt, in: NRC, 30 januari 1993 , p. 7. 


\section{Registratiekamer}

\section{\$16.0 Vrijheid van persoonsgegevensverkeer}

Ter bewaking van de vrijheid van persoonsgegevenstransport is, in Nederland, de Registratiekamer ingesteld. Ex art. 6, tweede lid, junctis artt. 18/28/30 Ontwerp-richtlijn priwacy ${ }^{\prime}$ en artt. 15/19 junctis artt. 24-25/34/37-46/50 Wet persoonsregistraties ${ }^{23}$ en

1. Ontwesp-Richtlyn van 15 oktober 1992 betreffende de bescherming von notuurlike personen in verband met de behandeling van persoonsgegevens en berreffende het wije verkeer van die gegevens, COM (92), 422, def. SYN 287, Publ. EG L $330 / 30$ 1992, vermeld in: CR. nr.6, 1992, pp.248-252; Zie voor parlementaire bespreking van de richtlijn TK 1993-1994, 23400 VI/23900 VI, nrs.9/11.

2. Wet persoonsregistraties, Stbl. 1988, 665, gewi zigd 25 okt. 1989, Stbl. 1989, 480, aangepast aan Awbidioom bijl Stbl. 1992, 422 en Stbl. $1993,690$.

3. Over sllechte afstemming van de $W_{\mathrm{pr}}$ en de ontwerp-Privacyrichtijn (die wan wege har uitgebreide en gedetailleerde opzet, bovendien bureaucratische en daardoor kostbare basis -getuige de in de Staatcourant 4.d. 14 jumi 1994 gepubliceerde voorspelling van het Economisch Institum woor het Midden- en Kleinbedrijf dat Nederlandse banken, verzekeraars en directmarketingbedrijven 1,3 miljard gulden kwijt zijin aan eenmalige kosten die de irwoering van de ontwerp-Privacy richtlijn met zich mee brengt-n als mede an talgebruik dat werre van eenduidig is, moeilijk naar Nederilands recht is over te brengen) $R$. Offreins, $R$. Ketellaar en J. Holvast, EG: gevolgen voor de WPR, in: P\&R, nr 3, 1992, pp. 16-19, en EG: achtergronden bij de Europese richtlijen syn 287 en syn 288, in: P\&R, nr.3, 1992, pp.13-15; J.M.A. Berkvens en M.

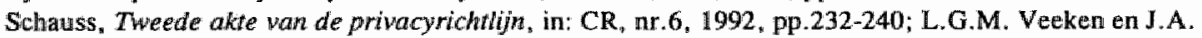
Knigge, De EG-richlijn bescherming persoonsgegevens; Knelpunten en kosten voorhet bedrijfsleven, EIMarbeidsw raagstukkenreeks, Zoetermeer, april 1994; F. Kuitenbrouwer, Hoge kosten richtlin, in: $C R_{1}$, nr.5, 1994, pp.221-222; Overigens meldt de zelfde F. Kuitenbrouwer, Sirijd om het 'kostenplaatije" van de priwacyichtijn, in: CR, nr.1, 1995, pp.38-39/89-91, dat tecentere rapportages inzake financiele implicadies van de richtlijn minder verontrustend zijn; Zie inderdaad de rapportage van C. G.M. van Oosteren en J.S. van Vliet, Kosten woor de overheid wan de Europese privacyrichulim, IO0-onderzoeksreeks nr.64, "sGrawenhage, now. 1994, pp.7-9. Auteurs schatten dat de initiele kosten slechts 25 à 30 miljoen gulden betreffen (i.v.m. instellen openbaar register bij de Registratiekamer en praktijkaanpassing door o.a. uitgebreidere aanmeldingsplicht van verwerking wan persoonsgegevens em formulieren aanpassen aan bij voorbeeld de antwoordplicht) en dat de structurele kosten neerkomen op circa 1 miljoen gulden per jaar (d.w.z. 450.000 gulder voor het werwerken van mutaties in bestanden wan zorgverzekeraars en 500.000 gulden woor het bijhouden van het openbaar register door de Registratiekamer en ook voor de extra bevoegdheden van de Registratiekamer als de mogelijkheid om vooraf onderzoek te doen naar verwerkingen of de mogelijkheid om gerechtelijke procedures te starten). Auteurs wijzen trouwens op de, op langere 
art. 1-5 Besluit uitvoering Wpr ${ }^{4}$ wijst Nederland, even als elke EG-lidstaat, een onafhankelijke overheid aan die bevoegd is het toezicht op de bescherming van persoonsgegevens te waarborgen. 5

Volgens art. 30, tweede lid, Ontwerp-richtlijn Privacybescherming dient de Registratiekamer, gelijk alle andere onafhankelijke autoriteiten die toezicht houden op het persoonsgegevensverkeer in de verschillende lidstaten, beschikken over: "onderzoeksmiddelen, als het recht van toegang tot gegevens die het voorwerp vormen van door deze richtijn bestreken handelingen en het recht alle inlichtingen in te winnen die voor de uitoefening van haar controletaak noodzakelijk zijn; de bevoegdheid daadwerkelijk in te grijpen, als afscherming of verwijdering van gegevens gelasten, een behandeling of verwerking voorlopig of definitief verbieden, een gegevensdrager vernietigen of tot de voor de behandeling verantwoordelijke een waarschuwing richten; de bevoegdheid een zaak bij de rechter aanhangig te maken wanneer zij inbreuken op de nationalle bepalingen ter toepassing van deze richtlijn vaststelt". ${ }^{6}$ Art. 18 Ontwerp-richtlijn Privacybescherming kent ook nog, verder gaand dan de Wpr, een preventieve onderzoeksplicht en, zo nodig, een goedkeuringsplicht aangaande voorgenomen(!) behandelingen van persoonsgegevens die gevaar kunnen op leveren voor de privacybescherming (art. 18, respectievelijk wierde

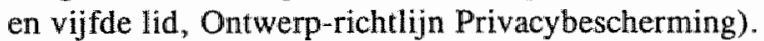

Elke $^{7}$ toezichthouder brengt, conform art. 30, vierde lid, Ontwerp-Privacyrichtlijn jaarlijks - een te publiceren - verslag uit van toezichtsactiviteiten. En het vijfde lid verplicht alle toezichthoudende autoriteiten in de versichillende lidstaten zorg te dragen voor

3. $\rightarrow$

termijn, te verwachten baten voort vloeiend uit de richtlijn (via tussenstaatse informatie-uitwisseling) die mogelijk vergelijkbaar zijn met de initiële kosten er van; Zie ook C. van Oosteren, Kosten van de Ewropese priwacyrichrijin, in: P\&R, nr. 1.1995, pp.15-18.

4. Beshit van 5 aug. 1989, houdende uitwoering van art. 40, eerste lid, Mpr, Stb1. 1989, 335.

5. Miernaast bestaat, ex art. 32 Ontwerp-richtlijn Privacy bescherming, een communautair controleorgaan met advies- en anbevelingsbevoegdheden. Deze conform art. 31 ingestelde onafthankelijke Groep woor de bescherming van personen i.v.m. de behandeling van persoonsgegevens coördineert de uitvoering van de richtijn op national niveau en geeft raad over 0. .a. (wijziging) van wet- en regelgeving/richtijnen als mede over communautaire gedragscodes. De instelling wan deze groep wordt ook geregeld in art. 17 Gewijzigd voorstel richtlijn inzake de bescherming van persoonsgebonden gegevens en van dle persownlijke gegevenssfeer in het kader van digitale netwerken voor geintegreerde diensten (ISDN) en van digitale mobiele netwerken, 94C-200/04, COM (94), 128 def.-COD 288, als gepubliceerd in: CR, nr.6, 1994 , pp. $242-243$.

6. Dehiergeboden interventiemogelijkheden strekken verderdan de Wpr-bevoegdhedeu van de Registratiekamer. Daardoor vezen J.M.A. Berkvens en M. Schauss, t.a.p, p.237, aantasting van haar min of meer neutrale positie.

7. Ex art. 30, eerste lid, Ontwerp-richtlijn Privacybescherming kan een lidstaat verschillende toezichthouders aanwüjzen. In Nederland is dat er, in gevolge de Wpr, maar én: de Registratiekamer. Wel bestaan, op lokaal niveau, nog registratiecommissies. R.L. Timmermans pleit, in het kader van deregulering, woor versterking van het intern toezicht door deze commissies. Volgens hem bied toezicht door lokale registratiecommissies, meer dan het externe toezicht door de Registratiekamer die in praktijk inderdaad her lokant bestuur wat betreft hun Wpr-verplichtingen flink op de huid moet zitten, gemeenten het voordeel wankorte lijnen, gutoriteit en kennis. Zle mening wan Timmermans, als weer gegeven door P.A.M. Vunderink, Verslag van het 8e Nationale Privacy Symposium, in: CR, nr.1, 1995, pp.41-42, i.h.b. p.41. 
de "'nodige onderlinge samenwerking met oog op de vervulling van hun controletaken, met name door de uätwisseling van nuttige informatie of door de aanwending van de onderzoeksmiddelen of van de bevoegdheid tot ingrijpen". Bij informatie-uitwisseling moet naturlijk wel rekening worden gehouden met de in art. 30, zesde lid, Ontwerprichtlijn Privacybescherming neergelegde geheimhoudingsplicht van de toezichthoudende autoriteit, haar leden en personeelsleden.

Een opdracht tot internationale hulpverlening, bijstand en andere samenwerking is ook uitdrukkelijk te lezen in art. 13 sub $2 \mathrm{a}$ van het, niet een ieder verbindende bepalingen omvattende, Europees Dataverdrag ${ }^{8}$, dat de Registratickamer als nationale, tot toezicht op persoonsregistraties bevoegde, autoriteit aan wijst. De Registratiekamer moet deell nemen aan de activiteiten die de, o.g.v. het Europees Dataverdrag, ingestelde Voorlopige Gemeenschappelijke Controle Autoriteit onderneemt. Taak van die VGCA bestaat hierin, dat zij vooruit lopend op het aanvullend akkoord van Schengen controle uitoefent op de technische ondersteuningseenheid van het Schengen Informatie Systeem ${ }^{9}$ te Straatsburg.

\section{$\S 16.1$ Taakstelling Registratiekamer}

De Registratiekamer heeft tot belangrijkste opdracht "het beoordelen van afzonderlijke persoonsregistraties aan de hand van beginselen die zijn neergelegd in de wet ${ }^{10 "}$ (bedoeld is de Wpr, daarnaast is het onathankelijk toezicht door de Registratiekamer bijna

8. Verdrag rot bescherming wan personen m.b.t. de geautomatiseerde werwerking wan persoonsgegevens, European Treaty Series nr.108, Trbl. 1988, 7, goedgekeurd d.d. 27 nov. 1991, Stbl. 1991, 654, geldt in Ned, sinds 1 dec. 1993.

9. De, bij dit informatiesysteem essentiele, combinatie van informatie ter bestrijding van georganiseerde misdaad kan worden gefrustreerd door cryptografie. D.w.z. crimimelen beveiligen hun informatie, zodat opsporingsonderzoek zinloos is tenzij justitie de gegevens wia een decoderingssleutel toegankelijk kan maken. Vertwijfeld stelt de Nederlandse wetgever een cryptografievergunningenstelsel voor. Hienover kritisch I. Dumortier, Regulering van cryptografie: moet men ook het broodmes werbieden?, in: CR, nr.4. 1994, pp. 150-157; R. van den Hoven van Genderen, Het voorlopig voorontwerp tor werbod wan cryptografie; De horror wacui van de ondoorbreekbare beveiliging, in: CR, nr. 4, 1994, pp. 157-162; F. Kutenbrouwer, Losse einden van de privacybescherming, in: CR, ar.3, 1994, pp.89-93, i. H. b. pp.90-91; A. Patijn, Crypto. een zege of een bedreiging? in: CR. nr.4, 1994, pp. 144-150; Interessant is dat, in het Vowrstel wan wijziging wan de Wet op de telecommunicatievoorzieningen $i$. w. m. her gebruik vam cryptografie, in: Mediaforum, nr.6, 1994. pp.B49-B55, ant. 30d, eerste lid, Wtv voorziet in de instelling van een naar het lijkt toezichthoudend zelfstandig bestuursorgann, tw. wet beheersorgaan cryptografie. De. rechtstreeks uit het tweede lid voort vloeiende, passieve en uitvoerende tatak van dit organ is de cryptografie en de informatie daaromtrent die an hem ter beschikking zijn gesteld of wallower het anderszins beschikt, te beheren en stelt, in gevolge het derde lid, beide ter beschikking van overheidsorganen voor zover deze die behoeven woor de nitoefering van de hun bij of krachtens te wet opgedragen taak, tenzij de minister van verkeer en waterstal in het belang van de stat of van zijn bondgenoten anderszins bepaalt. De minister van verkeer en waterstaat, die bedoeld beheersorgaan in stand houdt "kan ex art. 30d, vierde lid, Wtw (al dan niet na overleg met andere betrokken ministers, zie vijfde lid), a. bij ministeriële regeling waarborgen verbinden aan het gebruik en het beheer van de overeenkomstig het derde lid ter beschikking gestelde informatie en b. het beheersorgaan aamijzingen geven omtrent taakuitoefening. Daarom dicht de mvr het orgaan een rol toe als 'thrusted third party'.

10. Ontwerp Wpr, TK 1981-1982, 17207, nr.3, p. 19; Volgens Mvt voorstel Wpr. TK 1984-1985, 19095, nr. 3, pp. 16/29/31, omvat dat: toezichthouden op naleving Wpr, advisering aan regering, klachtbehandeling en bemiddeling in rechtsgeschillen. 
eender geregeld in o.a. art. 1, sub i, junctis artt. 26-28 Wet politieregisters", de wet Gemeentelijke basisadministratie ${ }^{12}$ en de Wet Geneeskundige behandelingsovereenkomst $^{13}$ - JGLWN).

De door toereikende toezichthoudende bevoegdheden gewaarborgde "overheidstaken", die ziji in dat kader vervult, zijn: "toezien, onderzoeken, adviseren, registreren, toetsen, controleren en bemiddelen". ${ }^{14}$ Bij haar taakuitoefening heeft de Registratiekamer kennelijk "voldoende" speelruimte, hoewel deze van uit de doorgevoerde scheiding tussen beleidsbepaling en -uitwoering niet verder kan gaan dan "prioriteiten stellen". ${ }^{15}$

Als "countervailing power" in een ingewikkeld democratisch stelsel van checks and balances houdt de Registratiekamer, in een meer dan voorheen actieve rol ${ }^{16}$, zich zo bezig met wetshandhaving en dienstverlening. ${ }^{17}$

Deze dienstverlening bestaat in belangrijke mate uit adviserende en voorlichtende activiteiten van de Registratiekamer. Wat betreft de Wpr brengt de Registratiekamer van 1992 tot 1993 acht keer op verzoek advies uit aan een rechtbank, daarnaast adviseert zij vijftien keer de regering inzake bij voorbeeld misbruik van 06-11 alarmcentrales, kentekenregistraties, registratie van etnische gegevens van werknemers en justitiële documentatie. ${ }^{18}$

1. 1. Wetsyoorstel Wpolr, TK 19589; Wpolr. Stbl. 21 juni 1990, 414, gewijz. conform A wb-terminologie Stbl. 1993, 399, jo. Bestuit politieregisters, Stbl. 14 febr. 1991, 56, gewijz. Stbl. 18 april 1994, 335; Ower verschil Wpr en Wpolr P.J.D.J. Muijen en R.A. van Raaij. Handleiding politie \& privacy, Lochem. 1991.

12. Tweede nader gewijzigd woorsiel van wet Gba, TK 1992-1993, 21123, nr.214; Hierover themanummer P\&R, nr.2, 1993; Ook E. R. Brouwer e.a., Juridische aspecten van het GBA-project, Amsterdam, 1992: Derde nota van wijziging acaptassingswet $i$ w.m. invoering wet Gba, TK 1993-1994, 21147 , nis. 11-12; Uitzindelijk als Wer Gba. Stbl. 1994, 405/494/565, tie ook Aanpassing Gba geldend per 1 now. 1994. inwerkingtreding sbesluit d.d. 12 sept, 1994, Stbl. 1994, 691, vergelijk Amvb ter uitvoering wan wet Glod d.d. 8 sept. 1994, Stbl. 1994, 690, als gewijzigd Stbl. 1994, 698, integraal in Stbl. 1995, 30,; De (Aanpassings)wet Gba en het Besluit Gba werken grotendeels sinds 1 okt. 1994, zie besluit in Stbl. 1994, 707; J. wan Casteren en P. Ippel, Schending geheimhouding wet GBA komt woor en dupeen burgers; Overhetid mag vertrouwen niet beschamen, in: BB, nr.13, 31 maart 1995, p.25, betogen -aan de thaird wan twee concrete schrijnende vootbeelden- dat het zaak is dat gemeenteambtenaren zich wan de beschernerude betekenis wan het recht op geheimhouding bewust zijn en dit recht in de dagelijkse praktijk niet uit het oog verliezen; Volgens C.A. Herstel, GBA bij gemeenten in goede handen, in: BB, nr.19, 12 mei 1995. p.23, hanteren Van Casteren en Ippel verkeende voorbeelden en kiezen zij een onjuist adressaat.

13. Wetsonwerp Geneeskundige Behandelingsovereenkomst, TK 1992-1993, 21561; Later als, per 1 aprith 1995 in werking zijnde, wet in Stbl. 1994, 837; Over deze wet J. Legemaate (red.), De WGBO. wan reks; naar toepassing. Houten, 1995.

14. B: Crouwers in antwoond namens de Registratiekamer, bij brief, d.a. 7 juli 1993, p.2.

15. B. Crowwers in antwoond namens de Registratiekamer, bij brief, d.d. 7 julli 1993, p. 2.

16. In 1993 verdringt de Registratiekamer haar reactieve rol. Zij richt zich niet alleen meer op de gevalgen wan de technologische ontwikkeling inzake priwacy, maar juist ook op die ontwikkeling zelf. Aan die ontwikkeling wil zij stimulans geven en een, vooraf verdisconterend, normatief raamwerk bieden. Regiistratiekamer, Jaarverslag 1992-1993, Rijswijk 1994, p.7.

17. Registratiekamer, Jaarwershag 1992-1993, Rijswijk, 1994, pp.1-2.

18. Registratiekamer, Jaarverslag 1992-1993, Rijswijk, 1994, pp.11-15/95. O.g.v. de Wpolr luidende cijfers respectievelijk 2 en 8, zie Registratiekamer, Jaarverslag 1992-1993, Rijswijk, 1994, pp. $25-28$. 
De steeds intensievere ${ }^{19}$ informatieve functie, die vroeger vooral van formele en procedurele aard was, heeft tegenwoordig ook cen meer inhoudelijk karakter. ${ }^{20}$

Ten behoeve van haar publieke taak beschikt de Registratiekamer niet over regelgevende bewoegdheden. Overigens wordt toedeling van regelgevende bevoegdheden aan een onafhankelijk toezichthouder, in het algemeen ter bewaking van het zuiver en zorgvuldig omgaan met persoonsgegevens, niet altijd uitgesloten. In een regelstructuur, waarbij sprake is van algemene basiswetgeving die a. ruimte laat voor tijdgebonden specifieke voorzieningen in bijzondere concrete situaties en $b$. een wijd verspreide verdeling van controlemachten (ook naar de, al dan niet georganiseerde, particuliere sector) vereist, past kennelijk wel een "independent authorithy, perhaps endowed with legislative powers to adapt the principles of the general clauses to new or particular situations". ${ }^{21}$ Regelgevende bevoegdheden stellen zo'n onafhankelijk toezichthoudend orgaan er toe in staat om, uitgaande van de wet- en regelgeving van algemene aard, steeds opnieuw adequaat te reageren op dynamische ontwikkelingen en voortdurende veranderingen die het persoonsgegevensverkeer betreffen. ${ }^{22}$

Na een pioneersperiode krijgt de Registratiekamer kennelijk "een bestendige structuur" en zijn voorwaarden aanwezig voor een "effectieve en doelmatige uitvoering van taken". ${ }^{23}$ Het medio 1992 ingevoerde systeem van, door opleidingen ondersteunde, gecoardineerde secties, te weten: a. publieke sector; b. particuliere sector; en c. de politiesector, levert positieve ervaringen op.

Eind 1993 komt komt de personeelsbezetting van de Registratiekamer neer op: 2 leden wan de centrale afdeling; 3 plaatsvervangende leden; 7 buitengewone leden; 1 directeur; 15 beleidsmedewerkers/onderzoekers; en 19 staf- of secretariaatsmedewerkers. ${ }^{24}$

\section{$\$ 16.2$ Overheidstoezicht als aanvulling op zelfregulering}

De Registratiekamer houdt in feite controle op de (wettelijke bepalingen in- of aanvullende ${ }^{25}$ ) zelfregulering wan persoonsgegevenswerkeer. Kortom is sprake van toetsbare of "controleerbare zelfregulering". ${ }^{26}$ De "bemoeienissen van de Registratiekamer zullen niet afdoen aan de eigen verantwoordelijkheid die houders wan persoonsregistraties thans

19. In het Jaarverslag 1992-1993, meldt de Registratiekamer nim 400 schnrftelijke informatieverzoeken en weelvuldig gebruik van het telefonisch spreekuur (pp. 10/23-24).

20. Registratiekamer, Jaanverslag 1992-1993, Rijswijk, 1994 pp.9-10.

21. S. Rodota, Protecting Informational Privacy. Trends and Problems, in: W. F. Korthals Altes, E.J. Dom mering. P.B. Hugenholtt en J.J.C. Kabel (red.) , Information law towards the 21 st century, Information law series mr. 2, Deventer/Boston, 1992, pp. 261-272, i.h.b. p.271.

22. De rol van rechterlijke interpretatie is hier eveneens evident.

23. Registratiekamer, Jaarverslag 1992-1993, Rijswijk, 1994, p.91.

24. Registratiekamer, Jaarverslag 1992-1993, Rijswijk. 1994, p.101.

25. B.R. Ziegler-Jung, Elementen wan reflexief recht in de Wpr?, in: N.I.H. Hulst en H.D. Stout, Reflecties op reflexief rech, Zwolle, 1992, pp.131-142. Gedragscodes zijin wooral aanvullend. Reglementen en meldingen zifin vooral invullend.

26. Mut woorstel Wpr, TK 1984-1985, 19095, mr.3, p.16. 
bezitten. Dit is vooreerst het geval omdat houders van registraties volledig verantwoordelijk blijwen voor de activiteiten die zij met behulp wan die registraties verrichten. Een wettelijke regeling ter bescherming kan slechts randvoorwaarden stellen waarmee bij het opzetten en beheren van de registraties rekening moet worden gehouden. Bovendien vloeit uit het beginsel van de zelfregulering voort, dat de verantwoordelijkheid voor de gewenste belangenafweging rond de werking van een persoonsregistratie ook in eerste instantie bij de houdler van die registratie berust." 27

In de ogen van de regering bevordert zelfregulering, op het gebied van privacy, het toezicht op de uitvoering en de naleving van de Wet persoonsregistraties. Daarnaast voert ze, ter verdediging van de keuze voor zelfregulering, argumenten aan als: het benutten van kennis van de houder van de inhoud en het gebruik van de persoonsregistratie; het stimuleren van de eigen verantwoordelijkheid van die houder; het ondersteunen van initiatieven die in andere sectoren al tot ontwikkelling zijn gekomen; en het flexibel maken van regelgeving. ${ }^{28}$

De Wet persoonsregistraties kenmerkt zich zo door wettelijk geconditioneerde zelfregulering, waarbij geen plaats is voor een "centraal en regulerend optredende Registratiekamer". ${ }^{29}$ Dit stelsel van zelfregulering is wel onderhevig aan toetsing achteraf door de Registratiekamer.

\section{$\S 16.3$ Repressief toezicht}

Persoonsgegevens mogen ex art. 4, eerste en tweede lid, Wpr slechts worden opgeslagen voor een niet met wet, openbare orde of goede zeden strijdig doel waartoe het belang van de houder redelijkerwijs aanleiding geeft. ${ }^{30}$ Voor nakoming hiervan draagt de Registratiekamer zorg. Immers, de Registratiekamer ziet toe op de naleving van voorschriften ten

27. MW Wpr. TK 1981-1982, 17207, nr.3, p.20.

28. Mut voorstel Wip, TK 1984-1985, 19095, nr.3, pp.20/25.

29. Th.J.M. Lindner, Actuele wetgeving: Wpr, in: NTB, nr.2, 1989, pp.65-66. Well kan de Registratiekamer regelstelling belangrijk beïnloeden, omdat zij ex art. 3, tweede lid, jo. ant. 7 , derde en vierde lid, jo. art. 16 Wpr (met oog op het een ieder in stat doen stellen om schriftelijk bezwaren of opmerkingen te maken) gehoond moet wortlen over, op untvoerings- of regelgevingsamwb's gebaseerde, wetsontwerpen en -woorstellen. Omdat, volgens auteur, de geboden amvb-nogelijkheden het primat van de fomele wetgever aan tasten. vind auteur het nodig hoge eisen te stellen an de Registratiekamer.

30. Art. 8, derde lid, Ontwerp-ricthtlijn Privacybescherming voorziet in een uitzondering op het, in het eerste lid van de zelfde bepaling neergelegde, verbod van behandeling van gevoellige gegevens. Het werwerkew van dergelijke persoonsgegevens is daandoor mogelijk 'om redenen van zwaarwegend algemeen belang $0 . \mathrm{g}$. W. een nationale wettelijke bepaling of $0 . \mathrm{g.v}$. een besluit wan de toezichthoudende autoriteit'. Deze eisen zijn strenger dam de voorwaarden die de Wpr aan de exoneratie stelt.. Als de richlijn regeent, word. het dus moeilijker vermeld verbod te omzeilen. 
aanzien van persoonsgegevens ${ }^{31}$, die herleidbaar ${ }^{32}$ zijn tot individuele natuurlijke persomien $^{33}$.

De eis van herleidbaarheid omvat in het licht van art. 2 Europees Dataverdrag, dat gegevens door systematische vergelijking en onderzoek tot een bepaalde persoon kunnen worden herleid, behalve indien een onevenredige hoeveelheid tijd, geld, menskracht nodig zijn om die herleiding mogelijk te maken. ${ }^{34}$ of de identiteit van een bepaald persoon redelijkerwijs kan worden vastgesteld, hangt af van zowel de (naar het maatschappelijk verkeer identificerende) aard van de gegevens en de samenhang waarin ze voorkomen als de mogelijkheden die de houder ten dienste staan om de gegevens te herleiden. ${ }^{35}$

Voor haar hoofdzakelijk repressieve controleactiviteiten ${ }^{36}$ beschikt de Registratiekamer over belangrijke advies- en onderzoeksbevoegdheden.

Op de verschillende registratiehouders ${ }^{37}$ rust een zorgplicht ${ }^{38}$ aangaande onder meer doell, inhoud, derdenverstrekking ${ }^{39}$, opnamemedelingen en beveiliging ${ }^{40}$ van persoonsregistraties ${ }^{41}{ }^{42}$, niet zijnde persoonsregistraties als gegeven in art. $2 \mathrm{Wpr}$. De

31. Het risico bij het registreren van persoonlijke gegevens is dat informatie snel veroudert. Op dit gevaar wijst o.a.F. Kuitenbrouwer, Veel gegevens in bestanden a an bederf onderhevig, in: NRC, 31 okt. 1992, p. 2 .

32. J. Berkvens (1993), t.a.p., p.232, ziet problemen als technische gegevens herleidbaar zijn zonder dat "engenaren" daarvan dat ooit hebben beoogd. Daarom eist hij ook een "rechtens relevant verband".

33. E.H.A. Verbraeken, Wpr, in: TVVS, nr.8, 1989, pp.185-189, i.h.b. p.185, wil terechtook gegevens van rêchtsparsonen onder de Wpr brengen; Vgl. J. Holvaste. a., Privacybescherming in de particuliere sector, Zwolle, 1991, pp.34-35.

34. Mw woorstel Wpr, TK 1984-1985, 19095, nr.3, p.35.

35. Registratiekamer, Jaarverslag 1992-1993, Rijswijk, 1993, pp.52-57.

36. Mwt Wpr, TK $1984-1985,19095$, nrs.1-3, p.29.

37. R. Ketelaar, J. Holvast en K. de Bakker, Priwacygids; Handboek voor gengistreerden, Amsterdam, 1989 , pp.95-100, geeft een aardig overzicht wan de diverse persoonsregistrathehouders.

38. R. Ketelaar, J. Hollvast en K. de Bakker, Privacygids; Handboek voor geregistreerden, Amsterdam, 1989, p. 42 .

39. Soms verdient het gegevenswerstrekkingenregime aan derden in een specifieke wet woorkeur boven de algemene Wpr-regeling ter zake. Denk aan art. $\$ 1$ Wtv, dat melt afdoende waarbotgen portefeuille-en gegevensoverdracht nussen verzekeraars regelt. Zie Registratiekamer, Jaarverslag 1989-1991, Rijswijk, 1993, p.51.

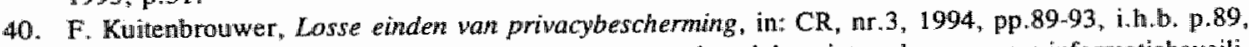
moppert terecht dat een lijst van aandachtspunten voor het al dan niet aanbrengen van imformatiebeveiliging ontbreekt. Daarnaast vindt hij het yreemd dat de Registratiekamer wel bij gedragscodes, maar niet bij meldings- of reglementsplichten op beveiliging let. En hij mist een evaluatiebepaling inzake beveiligingsmaatregelen, als de OESO woor ogen heeft (zie paragraaf 16.6.1).

41. Aan het begrip persoonsregistratie kleeft het bezwaar van onduidelijke definiering. Zie o.a. J. Berkvens, 1t.a.p. , p.232, als mede De antwikketing van het begrip persoonsregistratie, in: CR, nr.2, 1989, p.69 e.v." Illustratief is de enige tijd omstreden status van de dossierverzamelingen en bijbehorende kaartsystemen van de (Utrechtse) Raad voor de Kinderbescherming. Uiteindelijk oordeelt de arrondissementsrechtbank Utrecht d.d. 12 mei 1993 (weer gegeven in: CR, nr.6, 1993, pp. 259-261), dat het sociale deel van de (zowel financieel als sociaal te karakteriseren) dossierverzameling en bedoelde kaartsystemen een persoonsregistratie in de zin van art. 1 Wpr is. Art. 1 Wpr, dat een laagdrempelige toegankelijkheid tot de rechter beoogt, krijgt ruime interpretatie. Bespreking door E. Wunderink, Hoopwolle rechterlijke wit- 
houder is, overeenkomstig artt. 9-10 Wpr jo. antt. 4-8 Wpr, (risico-)aansprakelijk voor het nakomen van die zorgplicht. ${ }^{43}$ De zorgplicht is in algemene normen vervat in wooral artt. 4-8/18 Wpr. ${ }^{44}$

41. $\rightarrow$

spraak, in: P\&R, nr.3, 1993, p.31, en J.M.A. Berkwens, Noot, in: CR, nr.6, 1993, pp.261-263. Wat betreft eigen jurisprudentie conformeert de Registratiekamer, Jaarverslag 1992-1993, Rijswijk, 1994, p.58, zich aan de hier nelewante rechterlijke uitspraak; Ook de casus Nationale Auto Pas, Registratiekamer, 23 febr. 1994, met kritische noot weer gegeven door J. Holvast in: CR, ni. 6, 1994, pp. 257-260, toont triest de onduidelijkheid van de term persoonsregistratie aan. De Registratiekamer merkt de registratie van gereden kilometers bekend als Nationale Auto Pas aan als persoonsregistratie. Zij bevat inmers gegevens omtrent een bepaalde persoon van wie de identiteit bekend is of zonder veel moeite kan worden vastgesteld. Annotator Holvast is niel overtuigd. Volgens hem bevat de registratie geen identificerende gegevens, mar slechts het aantal gereden kilometers, de frequentie van onderhoud, het inkomen afgeleid van type en uitvoering van auto en de verkoop van de auto, waarbij kan worden wastgesteld of de kentekenhouder bona fide is. Omdat de Registratiekamer de herleidbaarheid van de gegevens niet aantoont. bovendien niet overtuigend stelt dat de gegevens bepalend zijn woor de wijze waarop een betrokken persoon in het maatschappelijk verkeer wordt beoordeeld en behandeld, en het daarnaast zo is dat kentekenhouder en gebruiker niet per se een en de zelfde persoon zijn, verenigt auteur zich niet met het oondeel van de Registratiekamer.

42. De Ontwerp-richtijn Priwacy bescherming gaat niet uit van het begrip persoonsregistratie. Haar werkingssfeer is ruimer dan die wan de Wpr, omdat art. 3 , eerste lid, van het ontwerp de richtlijn toepasselijk achut op zowel al dan niet geheel geautomatiseerde behandeling van persoonsgegevens als niet-geautomatiseerde behandeling van persoonsgegevens die in bestanden zijn opgenomen of die zijn bestemd om daarin te worden opgenomen. Daarmee omvat de richtlijn gegevens in bestanden en andere gegevens. Conform ant. 2, sub c, ontwerp-richtlijn is een bestand "elk gestructureerd geheel wan op één plaats samengebrachne of over verschillende plaatsen verspreide persoonsgegevens die volgens bepaalde criteria toegankelijk zijn, met als doel of als gewolg dat het gebruik en het met elkaar in werband brengen van gegevens betreffende de betrokkene worden yergemakkelijkt'. En art. 2, sub b, ontwerp-richtlijn verstaat onder behandeling of verwerking van persoonsgegevens veel. $0 . a_{n}:$ verzamelen, vastleggen, ordenen, bewaren, uitwerken, wijzigen, opvraagbaar maken, raadplegen, gebruiken, verstrekken d.m.w. doorzending, verspreiding of enige andere worm van terbeschikkingsielling, samenbrengen, met elkaar in verband brelggen, afschermen, verwijderen of vernietigen van gegevens. De verbreding van perspectief noodzaakt tot het spreken over een 'woor behandeling verantwoordelijke' en een 'betrokkene" (i.p.w. houder en geregistreerde). Het feit dat de ontwerp-richtlijn reeds verzamelen aanmerkt als verwerking van persoonsgegevens, waarvan betrokkene in kennis moet worden gesteld, impliceert niet dat de naleving wordt vergemakkelijkt. Blijff de voor gegevensverwerking verantwoordelijke in gebreke met zijn informatieplicht naar betrokkene toe. dan weet betrokkene nergens wan met alls gevolg dat hij, in onwetendheid, zijn recht van verzet ongebruiki laat. In dergelijke gevallen wan het niet op de hoogte brengen van betrokkene van de gegevensverwerking kan de Registratiekamer geen gerechtelijke procedure starten.

43. Vgl. de aansprakelijkheidsregeling in art. 23 Ontwerp-richtlijn Privacy bescherming.

44. Vergelijk het ruimere: art. 6 Ontwerp-richdijn Priwacybescherning inzake de, op de voor de behandeling van persoonsgegevens verantwoordelijke rustende, plicht tot kwal ite itsbe waking vande persoonsgegevens: art. 11 Ontwerp-richtlijn Privacybescherning wat betreft de, op de voor de behandeling van persoonsgegevens werantwoordelijke rustende, informatieplicht (tenzij betrokkene reeds op de hoogte is of kan zijn) inzake ten minste opneming, doele inden opneming persoonsgegevens, ewentuele verplichting om gege wens te verstrekken, en personen of categorieẻn personen voor wie gegevens zijn bestemd; art. 12 Ontwerprichtijin Privacybescherming wat betreft de, op de voor de behandeling van persoonsgegevens verantwoordelijke rustende, informatieplicht inzake derdenverstrekking van persoonsgegevens; en art. 17 Ontwerp-richtlijn Privacybescherming wat betreft de, op de voor de behandeling wan persoonsgegevens verantwoordelijke rustende "plicht tot beveiliging van persoonsgegevens. 
Is sprake van een specifieke persoonsregistratie, dan is het standaardregime van het Besluit genormeerde vrijstelling ${ }^{45}$ van toepassing. Het feit, dat een bijzondere persoonsregistratie onder dat besluit valt, laat de toepasselijkheid van de Wpr onverlet. ${ }^{46}$ Conform de artt. 24-27 Wpr moeten persoonsregistraties op het gebied van bedrijf en beroep en op overige gebieden middels een formulier worden aangemeld bij de Registratiekamer. ${ }^{47}$ Helaas blijft de particuliere sector op grote schaal nalatig in de vereiste aanmelling. Dit is onder meer te wijten aan gebrekkige publieksvoorlichting ter zake. ${ }^{48}$ Overigens verzorgt de Registratiekamer de publiekswoorlichting, die tot 1993 onder verantwoordelijkheid van het ministerie van binnenlandse zaken en het minsterie van justitie valt, tegenwoordig zelf. ${ }^{49}$

En in gevolge art. 19 junctis artt. 20-22 Wpr geldt specifiek voor overheidsinstanties, dat zij een privacyreglement opstellen. ${ }^{50}$ Daarin staat, ex art. $20 \mathrm{Wpr}$, de regeling van in elk geval het registratiedoel, het opnemen of verwijderen van gegevens, de toegang tot en het verstrekken van gegevens uit de registratie. Op de bestuursorganen rust, ex art. 19, tweede lid, Wpr, de plicht elk reglement te publiceren en ter inzage te leggen.

De wet voorziet jammer genoeg niet in een eenduidige wijze van publikatie. Daarnaast ontbreekt het haar aan regels aangaande mogelijke instelling van een centraal openbaar register, waarin alle persoonsregistraties zijn terug te vinden. ${ }^{51}$

45. Besluit genormeerde vrijstelling, Stbl. 1990, 16, gewijz. conform Awb-terminologie Stbl. 1993, 399.

46. A. Mosshammer, Wpr: anbekend maakt onbemind, in: Rechtshulp, nr.4, 1994, pp.8-13, i.h.b. p.11.

47. Art. 18, eerste lid, Ontwerp-richtlijn Privacybescherming legt de voor behandeling verantwoordelijke, of zijn wertegenwoordiger, een plicht op tot aanmelding van (de door hem woorgenomen) gegevenswerwerking bij de toezichthoudende autoriteit. Conform art. 18, tweede lid, Ontwerp-richtijn Privacybescherming behelst die aanmelding ten minste: naam en adres van de woor verwerking verantwoordelijke; doeleinde van behandeling of verwerking; categorieèn van betrokkene(n); een beschrijving van (categorieiw) gegevens waarop verwerking betrekking heeft; categorieën van derden asan wie gegevers worden. werstrekt; de t.a. $v$. dende landen voorgenomen overdrachten van gegewens (zie over deze doorgifte artt. 26-27 Ontwerwilichtlijn Privacybescherming); en een beschrijwing wan de maatrege len om de beveiliging wangegevens te wathorgen. Beide laatst genoemdle inhoudsonderdelen van aanmelding kent de: Wpr niet. Art. 19, tweede lid, Ontwerp-richtijn Privacybescherming maakt het mogelijk dat aanmelding ve reenwoudigd kan geschieden of dat daarwan vrijstelling wordt gegeven. Vereenwoudigings- of vrijstellingsmaatregelen worden door de toezichthoudende autoriteit zelf genomen of na inwinning van advies van de touzichthoudende autoriteit getroffen.

48. Volgens onderzoek verricht in nov. 1992 aan de RL. Zie H.M. Spelthaen en A.J. van Reeken, Zoeklicht op de Registratiekamer, in: P\&R, nr.4, 1993, pp.7-11, i.h.b. p.10.

49. Registratiekamer, Jaarverslog 1992-1993. Rijswijk, 1994, p.10.

50. De Ontwerp-richtijn Privacybescherming, die wat betreft aanmelding geen onderscheid makkt tussen bedrijfsleven en overheid, rept niet van reglementen.

51. Zie suggestie van D.E. Bunschoten, Kraniek Nederland: de Wpr, in: TVBP, 1989, pp.459,463, i.th. b. p.462; Eerder L. Verhey, Beoordeling van Wpr, in: NJCM-bulletin 11-1, jan. 1986, pp.90-99, i.h.b.

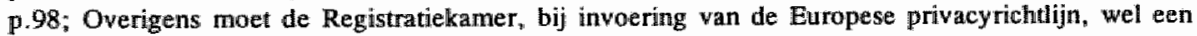
openbaar register van aangemelde behandelingen van persoonsgegevens bijhouden. De daarim op te nemen informatie is inclusief de noodzakelijk in azmellingen woorkomende mededelingen over 0. m.: de inhoud van de gegevens; de voou behandeling of werwerking verantwoondelijke; de doeleinden van verwerking; de personen aan wie gegevens worden verstrekt; de termijn van bewaring van persoonsgegevens; de voongenomen overdrachten van en naar landen, niet zijnde lidstaten. Zie art. 21 Ontwerp-richtlijn Privacybescherming. 
Na de eerste periode van functioneren beschikt de Registratiekamer in 1991 over 36.000 aarmeldingen van registraties en reglementen in de zin van de $\mathrm{Wpr} .{ }^{52}$ Per 31 december 1993 bedraagt het aantal aanmeldingen van persoonsregistraties en privacyreglementen in totaal $48.897 .{ }^{53}$

Wat betreft de Wpolr ontvangt de Registratiekamer in het tijdsbestek 1989-1991 251 reglementen met hoorbepalingen ${ }^{54}$, waarover zij ex respectievelijk art. 5 Wpolr jo. art. 3 Besluit politieregisters en artt. 6/20-21 Wpolr jo. art. 14 Besluit politieregisters moet worden geraadpleegd. ${ }^{55}$ In de periode 1992-1993 liggen ruim 350 reglementen ter toetsing van de Registratiekamer klaar. ${ }^{56}$

Afgezien van voornoemde reglementen krijgt de Registratiekamer van 1989 tot 1992 nog 40 vastgestelde reglementen voorgelegd en melden de nodige gemeentepolitiekorpsen hun, conform modelreglementen opgestelde ${ }^{57}$, reglementen bij haar aan. ${ }^{58}$ In 1992 geschiedt, in het kader wan de Wpolr, aanmelding van 73 reglementen en 185 modelreglementen (aangaandeo.a. arrestatiebevelen, bekeuringsafhandelingssysteem of vakantiecontrolekaarten) ${ }^{59}$; In 1993 zijn dat er respectievelijk 29 en 53, waar nog 7 reglementen en 166 model reglementen (inzake o.a. aandachtvestigingingenregister, fraudebestrijding, milieudelicten, vandalismebestrijding en in bewaring genomen goederen) ${ }^{60}$ betreffende provinciale politieregisters bij komen. ${ }^{61}$

\subsubsection{DWINGEND HANDHAVEN}

Hoewel de Registratiekamer all tot medio 1990 uitstel van executie geeft, constateert zij spijtig dat op 1 juli $1992.65 \%$ van de Nederlandse gemeenten nog geen enkel reglement aan haar heeft aangeboden. Dit gegeven noopt de Registratiekamer, die vindt dat de voorbeeldfunctie van (plaatselijke) overheden ter zake verloren gaat, tot maatregelen. $\mathrm{Zij}$ denkt zelfs aan het toepassen van strafbepalingen ter zake in de Wpr (conform art. 50, eerste lid, sub a Wpr). ${ }^{62}$

Het aldus dwingend handhaven van de regel, een privacyreglement op te stellen, voert ver. Ten eerste, het opstellen van privacyreglementen is niet eenvoudig. Overigens stelt

52. Registratiekamer, Jaarwerslag 1989-1991, Rijswijk, 1994, p.13.

53. Registratiekaner, Jaarverslag 1992-1993, Rijswijk, 1994, p. 19.

54. In een hoorprocedure toetst de Registratiekamer bepalingen op rechtmatigheid en, margirnaal, op doelmatigheid.

55. Registratiekamer, Jaarwerslag 1989-199I, Rijswijk, 1994, p.19.

56. Registratiekaner, Jaarwerslag 1992-1993, Rijswijk, 1994, p.29.

57. Van door de politie zelf ontwikkelde modellen voor de meest voorkomende politieregisters worden 29 modelreglementen, na toetsing door de Registratiekamer, gepubliceerd in de Staatscourant. Registratiekamer, Jaarwerslag 1992-1993, Rijswijk, 1994, p.6. De modelreglementen passen in het streven wan eert in 1994 veranderende politieorganisatie (samenwerking gemeente- en rijkspolutiekorpsen met oog op regiovorming) om op redelijke uniforme wijze informatie te registreren.

58. Registratiekamer, Jaanverslag 1989-1991, Rjiswijk, 1994, pp.20-21.

59. Stert. 1992, 78 .

60. Zie Stcrt. 1993, 73 als mede Stcrt. 1993, 129, 182, i.h.b. 103.

61. Registratiekamer, Jaarverslag 1992-1993, Rijswijk $\mathrm{k}$, pp.28/30-31.

62. Bijna helft van alle gemeemen heeft nog niet het verplichte privacy-reglement, in: BB, 2 okt. 1992, p.3. 
de Registratiekamer daartegenover dat goed gebruik is te maken van een modelreglement ${ }^{63}$, mogelijk met geringe aanpassingen. ${ }^{64}$ Ten tweede maken burgers in praktijk vrij wel geen gebruik van hun recht op mededeling van eerste opname van hun persoonsgegevens in een persoonsregistratie (art. $28 \mathrm{Wpr}$ ), hun recht op inzage van eigen persoonsgegevens mogelijk met daaraan gekoppeld hun recht op inlichtingen over de herkomst van die gegevens ex art. 29, tweede lid, Wpr (art. 29 Wpr), hun recht op correctie, d.w.z. verbetering, aanvulling of verwijdering, van persoonsgegevens (art. $31 \mathrm{Wpr}$ jo. art. $35 \mathrm{Wpr}$ ), en hun recht op verstrekking daarvan aan derden (art. $32 \mathrm{Wpr}$ ). ${ }^{65} 66$ Overigens is het waarschijnlijk niet zo, dat justitiabelen hiervan afzien uit financieel oogpunt. Weliswaar mag maximaal f $10,00^{67}$ voor verzoeken, als bedoeld in respectievelijk art. $29 \mathrm{Wpr}$ en art. $32 \mathrm{Wpr}$, om inzage, correctie en mededelingen aangaande derdenverstrekking van persoonsgegevens in een persoonsregistratie, worden gevraagd. ${ }^{68}$ En inderdaad bestaat aanvankelijk de vrees, dat dat drempelverhogend werkt. ${ }^{69}$ Maar in realiteit is voor veel overheidsorganen het feit, dat bedoeld bedrag ex art. $36 \mathrm{Wpr}$ terug moet worden gestort bij inwilliging van een verzoek om gegevenscorrectie, reden af te zien van het vragen van een vergoeding. ${ }^{70}$

Van wege beide redenen doet de Registratiekamer, spelende met het idee van strafrechtelijke handhaving van privacywetgeving, denken "aan een papieren tijger die brult" ${ }^{* 1}$ Uiteindelijk overtuigt de Registratiekamer op minder rigoreuze wijze (te weten: het rechtstreeks contact opnemen met burgemeesters, het stellen van termijnen en het dreigen van publikaties in de Staatscourant ${ }^{72}$ ) ${ }^{73}$ de lokale overheden van het nut privacyregle-

63. Zie bij woorbeeld het modelreglement van de VNG, dat adn de Awb is aangepast. J.M. van Os, R.L. Timmermans en J. W. Edinga, Awb eerste tranche: consequenties voor de gemeentelijke praktijk, VNGuitgave, "s-Gravenhage, 1992 , pp. $115 \% 116$.

64. Registratiekamer, Jaarwerslag 1989-1991, Rijswijk, 1994, p.12.

65. J. Berkwens, t.a.p. p. 231 .

66. Zie analoge rechten in de anti. $20-22$ Wpolr als mede vergelijkbare rechten op inkennisstelling/opnamemededeling (uizzondering daarop), inzage/toegang, correctie/verwijdering/afscherming, inkennissteling wan met de gegevens gecontronteerde derden van correctie/verwijdering/afscherming, inkennisstelling van redeneringen die xijn gevolgd bij geautomatiseerde gegevensbehandeling waarvan resultaten betrokkene worden tegengeworpen en het -t.a.v. de Wpr rumere- recht tot verzet tegen behandeling van gegevens, ex respectievelijk ant. 13, eerste lid (art, 14), art. 13, tweede lid, art. 13, derde lid, art. 13 , vierde lid. art. 13, vijfde lid, en art. 15 Ontwerp-richtlijn Privacybescherming.

67. W.J.E. Kreikamp, Enkele kostenaspecten van de Wpr, in: CR, nr. 2, 1990, pp.64-67, laat zien dat dit een symbolisch bedrag is. Ook constateert auteur kostenverschil in Wpr en Wob. En zij vindt de kostemlimiterings regeling ondurielijk.

68. Besiwir van 5 jult 1989 , houdende vaststelling van de maximale vergoeding van de kasten van een bericht als bedoeld in de art.. 29 en 32 Wpr, Stbl. 1989, 281.

69. Aldus PPR, TK 1985-1986, 19095, nr.5, p. 19; Ook J. Holvast, Wpr: keurslijf of vrijbrief?, in: CR, nr.2, 1989, pp.65-68, i.h.b. p.67. Hij vindt kostenvergoeding strijdig met het Wpr-doel het verschijnsel persoonsregistratie doorzichtig te maken.

70. J. Holvast, Wpr: een wer die (nog) nien leeft bij de registratiehouders, in: Informatie, Automatisering en Recht, nr. 11, 1993, pp.697-701, i.h.b. p.699.

71. A. Middelveld, Wpr is ketrstijf woor gemeenten; Regisinatiekamer schiet met kanon op mug, in: BB, 29 jan. 1993, p. 22 .

72. Op 24 maart 1993 worden inderdaad de namen van nalatige gemeenten bekend gemaakt in Stcrt. 1993 , 58.

73. Registratiekamer, Jaanerslag 1992-1993, Rijswijk, 1994, pp.19/42-43. 
menten op te stellen. Medle naar aanleiding van een ministeriële aanschrijving ${ }^{74}$, gaan de meeste gemeenten over tot aktie. ${ }^{75}$ Eind 1993 staan een of meer aanmeldingen van 97 procent van de Nederlandse gemeenten geregistreerd. ${ }^{76}$

Door deze massale aanmelding van persoonsregistraties door gemeenten komt het aantal aanmeldingen vanuit de publieke sector medio 1993 op 15.000. ${ }^{77}$ Bovendien denkt de voorzitter van de Registratiekamer" dat "nog eens een groei van vijftig procent (van aanmelding van persoonsregistraties door zowel (semi)overheid als niet-overheid - JGLVN) mogelijk is". ${ }^{78}$

De ijver, die de Registratiekamer aan de dag legt, om persoonsregistraties binnen te krijgen, is niet voor iedereen begrijpelijk. Lijnrecht tegenover de Registratiekamer ageren afvalligen van aanmeldingsplichten wan persoonsregistraties en privacyreglementen tegen toenemende administratieve rompslomp die dergelijke plichten met zich meebrengen. Aanmeldingsplichten zijn in hun optie in strijd met de geest van de wet. Leidende gedachte is immers vooral bescherming van privacy, als zorgvuldige omgang met vertrouwelijke gegevens. Met te veel nadruk voor "overbodige administratieve procedures" wordt die geest van de wet veronachtzaamd. ${ }^{79}$

\subsubsection{TOEZICHTSBEVOEGDHEDEN REGISTRATIEKAMER}

De Registratiekamer kan verzoeken om verstrekking van gegevens uit persoonsregistraties. Desgevraagd zijn de houder van een persoonsregistratie en de personen die bij de werking van een persoonsregistraties zijn betrokken ${ }^{80}$ verplicht de Registratiekamer, de ambtenaren van het secretariaat en andere, door de kamer daartoe aangewezen, personen ${ }^{81}$ alle inlichtingen en overige medewerking die nodig zijn voor adequate controle te geven (ex art. 45, tweede 1 id, Wpr jo. art. $50 \mathrm{Wpr}$ ). Hiernaast hebben de personen,

74. Brief van de ministers van justitie en binnenlandse zaken over de nateving van de Wpr door gemeenter"

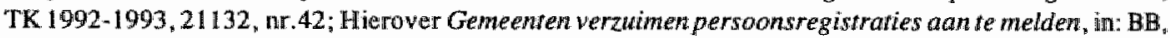
19 febr. 1993 , p. 10.

75. Actie Regirtratiekamer sorteet effect, in: BB, nir. 13, 2 april 1993, p.9.

76. Registratiekamer, Jaarverslag 1992-1993. Rijswijk, 1994, pp.19/42-43.

77. Daanaast doet het bedrijfsleven 30.000 aanmeldingen. Zie Privacy-wet en Registratiekamer niet Iandeloos", in: BD, 30 maart 1993, p. 13; De fon macht van de Registratiekamer, in: OMn, mr.6, 1993, p.169.

78. P.J. Hutinx, geciteerd door C. Visser, Bescherming privaxy is zo sterk als de zwakste van de 646 gemeentelijke schakels, in: BBM, 30 maart 1993, pp.8-13, i.th.b. p.11.

79. Aldus de Nationale Raad voor de Volksgezondheid. Functionerent Wpr in de zorgsector, maart 1995. Overigens stelt de NRV voor zijn advies, om administratieve verplichtingen af te schaffen en een algemene gehe imhoudingsplicht te introduceren voor degenendie in het kader van de Wpr met persoonsgegevens omgaan, mee te nemen ín de herziening van de Wpr.

80. Bij voorbeeld degene die apparatuur onder zich heeft, waarmee een persoonsregistratile waarvan hilj niet de houder is, wordt gevoerd, m.a.w. een bewerker als bedoeld in ant. 1 Wpr. Aanmerking verdient, dat het onder zich hebben van een terminal alleen ter raadpleging van een persoonsregistratie niet per se leidt tot bewerkerschap. Even als de bezitter of houder bedoeld in het derde boek van het BW, dient de bewerker feitelijke macht uit te kunnen oefenen. Registratiekamer, Jaarverslag 1992-1993, Rijswijk, 1994, p.60.

81. Zie, over toezichthouders (controlleurs en opsporingsambtenaren) van de Registratiekamer, paragraaf $11,1.7$. 
belast met het toezicht op naleving van wet- en regelgeving inzake persoonsregistraties, toegang tot alle ruimten waar zich een persoonsregistratie of een deel daarvan bevindt of waar de registratie toegankelijk is (ex art. 45, derde lid en vierde lid, Wpr). Zij zijn bevoegd apparatuur, programmatuur, boeken en bescheiden te onderzoeken en zich de werking van apparatuur en programmatuur te doen tonen, voor zover dit redelijkerwijs voor de uitoefening van hun taak nodig is. Bovendien kan zij, daar waar nodig, daadwerkelijk ingrijpen. Als naar het oordeel van de Registratiekamer de gevraagde medewerking onvoldoende wordt verleend, kan zij op kosten van de nalatige de nodige maatregelen (ex art. 45 , vijfde lid, Wpr).

Met oog op het tegen zich laten gelden wan al deze toezichtsbevoegdheden mogen personen met een geheimhoudingsplicht als advocaten, artsen e.d. in gevollge art. 45 , zesde lid, Wpr ${ }^{82}$ niet altijd zwijgen. Voor zover inlichtingen en medewerking nodig zijn in verband met eigen betrokkenheid bij de werking van een persoonsregistratie, kunnen zij de geheimhoudingsplicht niet inroepen.

Ten behoeve van het toezicht op de naleving van de Wpr kan de Registratiekamer ex art. 46, eerste lid, Wpr ${ }^{83}$ ambtshalve of op verzoek van belanghebbenden een onderzoek instellen naar de wijze waarop ten aanzien van een persoonsregistratie toepassing wordt gegeven aan datgene wat de Wpr en nadere regelgeving bepalen. Conform het derde lid geeft zij, als de onderzoeksuitslag daartoe noopt, een aanbeveling. ${ }^{84} \mathrm{De}$ persoonsregistratiehouder moet well eerst de mogelijkheid worden geboden om zijn verhaal te doen. In de periode 1992-1993 stelt de Registratiekamer naar aanleiding van klachten 6 keer onderzoek in, waarvan openbare rapporten verschijnen, en 3 onderzoeken verricht zij op eigen initiatief bij adviesaanvraag. ${ }^{85}$

Bedoelde toezichtsbevoegdheden, als vooral vermeld in art. $45 \mathrm{Wpr}$, staan de Registratiekamer alleen ter beschikking in het kader van haar toezicht op de naleving van het bij of krachtens de Wpr bepaalde. De bevoegdheden, die het "sluitstuk" van de Wpr vormen, strekken er toe "te voorkomen dat een kwaadwillende houder zich zou kunnen onttrekken aan de werking van de regels gegeven bij of krachtens de Wpr". ${ }^{86}$ De Registratiekamer kan deze bevoegdheden niet aan wenden voor het, ook in art. 37 , tweede lid, vastgelegde algemene toezicht in het belang van de bescherming van de persoonlijke levenssfeer.

Tussen 1989 en 1991 maakt de Registratiekamer "slechts incidenteel" gebruik van haar formele onderzoeksbevoegdheden. Bovendien heeft zij zich in beperkte mate de werking

82. Vgl de geheimhoudingsbepaling, ex art. 11, derde lid, wpr, bij derdenwerstrekking. Mede in het licht van art. 2:5 Awb is de geheimbouding splicht tegenwoordig "minder absoluut". Reg istratiekamer, Jaarversag 1992-1993, 1994, Rijswijk, p.73.

83. Vgl. analoge onderzoelksmogelijkheid conform art. 27 Wpolr.

84. In haar Jaarversiag $1992-1993$ (p.80) meldt de Registratiekamer één aanbeveling, die het beoogde succes heeft.

85. Registratiekamer, Jaarverslag 1992-1993, Rijswijk, 1994, pp.9/11/19-22.

86. Mut Wpr, TK 1984-1985, 19095, nr.3, p.30. 
van apparatuur en programmatuur doen tonen. ${ }^{87}$ In de zelfde periode constateert de Registratiekamer, dat zij bij haar taakuitoefening meestal alle medewerking krijgt. Frappant is dat tot eind 1993 nog nooit verbaliserend is opgetreden. Dit is opmerkelijk, omdat de Wpr-bepalingen aan massale en vaak bewuste schending bloot staan. Evident is bij woorbeeld de opzetielijke weigering van de gefuseerde ABN AMRO-bank om haar samengevoegde cliëntenbestand bij de Registratiekamer aan te melden. Hiermee maakt zij zich schuldig aan het misdrijf van art. 50, tweede lid, Wpr. Pas na een daartoe ingediende klacht ${ }^{89}$ over de obstructie stelt de Amsterdamse officier van justitie een onderzoek in.

De Registratiekamer heeft, in gevolge art. 34, derde lid, Wpr, een bemiddelings- en adviesfunctie in geschillen tussen een houder van een persoonsregistratie en geregistreerde cliënt voor een arrondissementsrechtbank. Die conflicten betreffen verzoeken aan de registratiehouder betreffende het doen van mededelingen over opname in een registratie, om verbetering/aanvulling/verwijdering van persoonsgegevens, of over het doen van mededelingen over verstrekkingen aan derden. In de periode 1989-1991 zijn ruim 200 zaken behandeld. ${ }^{90}$ In de daarop volgende periode heeft de Registratiekamer dubbel zo veel werk: ruim 400 zaken vinden naar tevredenheid behandeling. ${ }^{91}$ De uitspraken van de Registratiekamer in dergelijke geschillen hebben geen formele rechtskracht. De gang naar de gewone rechter blijft, ook na behandeling van een geschil voor de Registratiekamer, open staan. ${ }^{92}$

Het ontbreken van bindende kracht aan uitspraken van de Registratiekamer neemt niet weg dat zij indringend invloed kan uitoefenen. Zeker als het zaaksbehandeling ex art. 34 Wpr of ex art. $46 \mathrm{Wpr}^{93}$ betreft. Deze zaaksbehandeling resulteert namelijk in een uitgebreid onderzoek naar bepaald persoonsregistratie en persoonsgegevensgebruik waarvan de uitkomst, indien het toepassing van art. $46 \mathrm{Wpr}$ betreft, in de regel openbaar wordt gemaakt. Dit optreden van de Registratiekamer wordt mogelijk als autoritair en vervelend ervaren. "Gezaghebbend omdat ze (de zaaksrapporten - JGLvN) uiteindelijk berusten op de wet. Lastig omdat ze goed bedoelde plannen of maatregelen doorkruisen. Het lot van

87. Registratiekamer, Jaarwerslag 1989-1991, Rijswijk, 1994, pp.13-14.

88. Registratiekamer, Jaarwerslag 1989-1991, Rijswijk, 1994, p.53.

89. Afkomstig van $\mathrm{D}$. Berts, Minister slaagt erin ondeugdelijke Wprnog verder te miswormen, in: $\mathrm{P} \& \mathrm{R}, \mathrm{nr}, 4$, 1993 "pp. 15-16. Teleur gesteld spreekt hij van de Wpr als een "gedrocht" en verbastert die natam tot "We" proliferatic registraties ${ }^{\text {et }}$.

90. Registratiekamer, Jaanverslag 1989-1991, Rijswijk, 1994, p.5.

91. Registratiekamer, Jaanverslag 1992-1993, Rijswijk, p.11.

92. W.J.M. Voermans, Werk aan de winkel voor de Registratiekamer, in: $\mathrm{CR}_{4}$ nr.2, 1989, pp.73.79, i.h.b. pp. 73-74, wijst terecht op de zeeffunctie vam de Registratiekamer ter zake. Maar of de dubbele proceduremogelijkheid nu wel of niet wordt benut, bestaansrecht van beide ligt z.i. in hun verschillende aard. Anders dan de burgerlijke rechter is de Registratiekamer: a. niet gebonden an enkel een rechtmatigheidstoetsing; $b$. actief en deskundig; $c$. niet bindend in haar uitspraken; $d$. onder de nodige geheimhouding. op ombudsachtige wijze gemachtigd tot publikatie van onderzoeksresultaten; en e. informeel.

93. On doelmatig- en doeltreffendheidsredenen ontwikkelt de Registratiekamer richtlijnen en procedures (bij woorbeeld: hoor en wedethoor) voor afhandeling van dit soort zaken. Registratiekamer, Jaarverslag 1992 1993, Rijswijk 1994 , p. 10. 
een waakhond is dat hij niet altijd vriendelijk kan blijven." 44 In het verlengde hiervan ligt de volgende opmerking: "Wanneer echter het belang waarvoor de Registratiekamer is ingesteld in het gedrang komt, zal de waakhond blaffen. Het gaat immers om het realiseren van een in de Grondwet en internationale verdragen vastgelegd grondrecht." $"$ is

\subsubsection{GEDRAGSCODE}

Ex art. 15 Wpr kan de Registratiekamer worden gevraagd een, door een of meerdere representatieve organisaties zorgvuldig vastgestelde, gedragscode ex art. 1 Wpr genoegzaam te verklaren. Dat wil zeggen: de code is in overeenstemming met het bij of krachtens het bepaalde in de Wpr als mede met redelijkerwijs te stellen eisen aan de bescherming van de persoonlijke levenssfeer. ${ }^{96}$ Daarvoor hoeft de Registratiekamer, die hier een grote discretionaire bevoegdheid heeft, geen minimumtermijnen in acht te nemen. ${ }^{97}$ De beslissing van de Registratiekamer, die ex art. 15, vierde lid, Wpr via opneming er van (samen met de betreffende gedragscode) in de Staatscourant bekendmaking krijgt, wordt ex art. 15, zevende lid, Wpr uitgesloten van de administratieve rechtsgang.

Ter verzachting van de daaraan klevende bezwaren is de gedachte dat de Registratiekamer - lopende of vooraf gaande aan de procedure van art. $15 \mathrm{Wpr}$ - met de, om een verklaring verzoekende, organisatie als belanghebbende in reële betrokkenheid van gedachten wisselt omtrent concrete invulling van de aan de gedragscode te stellen eisen. Deze conditie ligt eigenlijk al besloten in art. 15, tweede lid, Wpr. Dit artikel bepaalt dat de Registratiekamer een verzoek om een gedragscode 'woor accoord' te verklaren pas behandelt, als zij oordeelt dat voldaan is aan: a. eisen van representativiteit van de betrokken sector; $b$. nauwkeurige bepaling in de gedragscode van die sector; en $c_{\text {" }}$ zorgvuldige voorbereiding van de code door die sector. Bovendien toetst de Registratiekamer de gedragscode, overigens niet tot ieders genoegen, op conformiteit (d.w.z. de interpretatie van een gedragscode mag niet voor meerdere uitleg vatbaar zijn) en substantialiteit (d. w. $z$. de gedragscode moet in voldoende mate regelen wat voor de betreffende branche in redelijkheid hoort te worden geregeld).

Hoewel de beslissing op het verzoek om een verklaring van genoegzaamheid niet is aan te vechten bij een administratieve rechter, bestaat wel de mogelijkheid om ter zake via een actie uit onrechtmatige daad ex art. 6:162 BW bij de civiele rechter recht te halen.

Overigens luidt de aardige aanbeveling aansluiting te zoeken bij de Awb. Wat betreft het werstrekken van een verklaring van genoegzaamheid voor een bepaalde gedragscode moet

94. B. Crowwers en P.C. Ipped "Gegeven het indiwidu. Het belang van de Registratiekamer, in: JV, nr.5. 1994, pp.8-21, i.h.b. p.16.

95. B. Crouwers en P.C. Ippeí, t.a.p., p.20.

96. Onverlet de mogelijkheid wan nationalle gedragscodes, moedigt art. 29 ontwerp-Privacy richtijin het opstellen wan communatitaire gedragscodes aan.

97. Tot ontevredenheid wan F. de Graaf, Haken en ogen aan de gedragscode voor persoonsregistraties, in: CR, ar.3, 1991, pp.119-123, i.h.6 p.122. Ook acht hij de positie v/d organisatie, wier gedragscode de Registratiekamer afkeurt, zwak. 
de Registratiekamer zich dan, als bestuursorgaan ex art. 1:1, eerste lid, Awb, houden aan de algemene regels voor het bestuursrecht. Zo is vermelde verklaring aan te merken alls een besluit ex art. 1:3, eerste lid, Awb. De algemene bepalingen inzake besluiten zijn dus toepasselijk. Zo kan de in de Wpr neergelegde procedure aangaande gedragscodes uiteüdelijk invloed ondergaan van zowel geschreven als ongeschreven recht. Bij de voorbereiding van de verklaring van genoegzaamheid dient de Registratiekamer acht te siaan op algemene beginselen van behoorlijk bestuur als het zorgvuldigheidsbeginsel ex art. $3: 2$ Awb, het détournement de pouvoir ex art. 3:3 Awb, het belangenafwegingsbeginsel ex art. 3:4, eerste lid, Awb en het evenredigheidsbeginsel ex art. 3:4, tweede lid, Awb. Daarnaast dient een dergelijk besluit te berusten op een deugdelijke en kenbare motivering. En de lacune in termijnstelling voor een verklaring van genoegzaamheid vindt mogelijk invulling door analoge toepassing van art. 3:28 Awb. Daaruit volgt dat besluitvorming zo spoedig mogelijk geschiedt, maar uiterlijk binnen zes maanden na ontvangst van de aanvraag tot het nemen van een besluit.

Via de maximaal vijf jaren geldige (art. 15, vijfde lid, Wpr) en overigens voor de rechter niet-bindende (art. 15, zesde lid, Wpr) verklaring van genoegzaamheid van de Registriatiekamer, zijn de codes van de volgende organisaties goedgekeurd. De eerste verklaringen, die de Registratiekamer verstrekt in respectievelijk de periode 1989-1991 en 19921993 zijn ten behoeve van: Organisatie van adviesbureaus voor werving en selectie, Cosso branchevereniging voor informatietechnologie, Vereniging van onderzoek instituten, Vereniging voor marktonderzoekbureaus en de Nederlandse vereniging van marktonderzoekers, Direct marketing instituut Nederland, Nederlandse associatie van de farmaceutische industrie, Vereniging van fabrikanten en importeurs van diergeneesmiddelen in Nederland, Nederlandse postorderbond en de Vereniging van handelsinformatiebronnen. Daarnaast worden de gedragscodes van de volgende organisaties ter goedkeuring aan de Registratiekamer voorgelegd. T.w.: het Verbond van Verzekeraars, Nederlandse vereniging van Banken, de bond $\mathrm{KBO}$, en de Nederlandse Organisatie van Tijdschrift Uitgevers.

Met oog op het antwoord op de wraag in welke mate gecertificeerde gedragscodes in praktijk succes opleveren, is concrete effectmeting zinvol. De, in binnen- en buitenland opgedane, algemene ervaringen met gedragscodes zijn in elk geval al indicatief. Het resultaat van gedragscodes blijkt niet altijd datgene wat wordt beoogd. Het komt woor dat een gedragscode: a. te gedetailleerd en daardoor te statisch is, kortom flexibillteit mist; b. te (elitair-)eenzijdig voorbij gaat aan culturele en socialle verschillen in een samenleving; $c$. te veel 'papegaaibepalingen' bevat; of $d$. een sanctieregeling ontbeert.

Bij het opstellen van gedragscodes werkt de Registratiekamer evident aanvullend op zelfregulering. Bij een gedragscode gaat het om een "in potentie effectieve vorm van collectieve zelfregulering". Dat dit zelfreguleringsproces niet vlekkeloos verloopt, is inmiddels duidelijk. Deuken tekenen zich vooral af in het driekhoeksoverleg tussen sectororganisatie, belangenorganisatie en de Registratiekamer, dat nodig is om een gedragscode te kunnen voorbereiden en goed te keuren. Op de wettelijke weg tot het realiseren van gedragscodes liggen de volgende spijkers voor het op scheppen. Het kardinale knelpunt is dat de beslissingsautonomie van de betrokken sectororganisatie snel 
in het gedrang komt, omdat zij in eerste instantie met de belangenbehartigers en in tweede instantie met de Registratiekamer overeenstemming moet bereiken over een gedragscode. De regelingsvrijheid van de sectororganisatie conflicteert mogelijk met de toetsingsbevoegdheid en beleidsruimte van de Registratiekamer. Daarnaast zujn frusterende factoren: onvoldoende helderheid in uitgangspunten van de Wpr (autonomie van zelfregulerende marktpartijen versus autoritair toezicht door regulerende Registratiekamer); meervoudig te interpreteren en tegenstrijdige kernbegrippen in de Wpr; personele wisselingen bij de Registratiekamer en daarmee samenhangende beleidswijzigingen. Al met al is een belangrijke vraag of het wel de moeite loont, via een van zowel betrokken organisaties als Registratiekamer veel inspanning vergende weg, een gedragscade op te stellen.

\section{\$ 16.4 Rechtsbescherming en klachtbehandeling}

Formeel gezien staat ex art. 46, vierde lid, Wpr geen voorziening van administratieve rechtspraak open tegen afwijzing van een, in gevolge art. 46 , eerste lid, Wpr aan de Registratiekamer gedaan, verzoek een onderzoek in te stellen naar de wijze waarop ten aanzien van een persoonsregistratie toepassing wordt gegeven aan het bij en krachtens de Wpr bepaalde. Evenmin tegenover door de kamer over dergellike onderzoeken gedane mededlelingen, berichten of aanbevelingen. Wat betreft gedragscodes verhindert art. 15 , zevende lid, Wpr op gelijke wijze de toegang tot de bestuursrechter.

Wél kan sinds de inwerkingtreding van de (eerste) aanpassingswet van de Awb (Stbl. 1992, 422) inzake de handelwijze van de Registratiekamer een klacht bij de nationale ombudsman worden ingediend, en eerder waren de openbaarheidsregels al toepasselijk.

Benodigd budget en initiatief, om een kostbare en moeilijke rechtsgang voor de burgerlijke rechter, welke rechtsgang de Wpr prefereert boven strafrechtelijke rechtshandhaving, te beginnen, liggen kennelijk lelijk op het bord van de burger. Het principe van wettelijk geconditioneerde zelfregulering wordt de burger eenvoudig weg de keel ingegoten. Het lijkt slikken of stikken.

De enige nuance die hier past is de volgende. De noodzaak van actiebereidheid van de individuele burger, of van een groep justitiabelen (art. 10, tweede lid, Wpr), weegt bij nader inzien misschien niet zo zwaar. De balans kan immers ten voordele van de belaste burger uitslaan. Bijna vergeten is het feit, dát de burger altijd een civiele rechtsgang kan beginnen.

Kortom, ondanks aanmelding, reglementering, gedragscode e.d. loopt de persoonsregistratiehouder het uiteindelijke risico wan een rechterlijke beoordeling op basis van vage, multi-interpretabele, materiële normen. "Het risico van de vage normen ligt eerder bij de registratiehouders dan bij de geregistreerden." De mogelijkheid van een, gelet op de open normstelling bij voorkeur marginale, en door belangenafweging gekenmerkte, rechterlijke toetsing achteraf werkt "preventief"; "Als de relatief kleine kans op een rechterlijk verbod of bevel zich verwezenlijkt, kunnen de gevolgen zeer hard aankomen: het zwaard van Damocles. Het verbod of bevel zal bij voorraad uitvoerbaar zijn, en bij niet-nakoming zal een dwangsom verbeurd worden. De termijn om aan het bevel of verbod te voldoen zal in de regel niet langer zijn dan de inderdaad minimaal noodzakelijke termijn." Wel is de dreiging van dit zwaard van Damocles terecht sterk gerelativeerd: 
tegenover de sanctie van de burgerlijke rechter kan bij voorbeeld een grote besparing

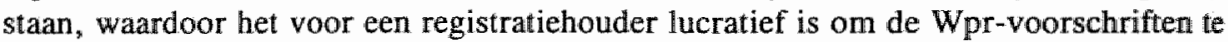
ontduiken.

Uit oogpunt van verbetering van handhaafbaarheid van privacywet- en regelgeving wenst de Registratiekamer de mogelijkheid te krijgen zêlf een procedure bij de rechter aanhangig te maken. Als gezegd is dat voor belanghebbenden, en zelfs voor de failliet verklaarde Stichting Waakzaamheid Persoonsregistraties, vaak te duur. In de toekomst wordt de wens van de Registratiekamer ingewilligd als art. 30, tweede lid, Ontwerp-richtlijn Privacybescherming toepassing krijgt.

Daarnaast is een andere maatregel, om de handhaafbaarheid te wersterken, het overwegen waard: het invoeren van heffing voor aanmelding van persoonsregistraties. Daartegen bestaan bij de Registratiekamer weliswaar bezwaren. Maar zo'n heffingsmaatregel kent toch een "interessant element: de mogelijkheid van een administratieve boete bij nietaanmelding".

\section{$\S 16.5$ Kostenverhaal en (financiële) verslaglegging}

Van al haar werkzaamheden maakt de centrale afdeling (d.w.z. - ex art. 43, eerste lid, Wpr - de voorzitter en twee leden) van de Registratiekamer een jaarverslag ex art. 44 Wpr op. Bedoeling van een dergelijke verplichting tot periodieke rapportage is een "geregelde terugkoppeling van het gevoerde beleid, met tijdige doorstroming van informatie over nieuwe ontwikkelingen, naar regering en parlement" te verzekeren.

Met de jaarverslaglegging maakt de Registratiekamer in elk geval een slechte start. Ondanks anders luidende beloften, presenteert zij pas vier jaar na haar oprichting een meerjarenrapportage van haar werkzaamhedem. Het oordeel over dit jaarverslag is gematigd positief. In het verslag ontbreekt het aan zaaksbeschrijvingen, bronvermeldingen of cijfermatige overzichten, aan conclusies of beleidsvoornemens en aan voldoende aandacht voor klachtenbehandeling.

Art. 37, vijfde lid, Wpr bepaalt dat de Registratiekamer jaarlijks aan de minister van justitie openbaar verslag van haar werkzaamheden en bevindingen doet.

Niet voor publikatie geschikt zijn, op grond van de Wpr verkregen, vertrouwelijke gegevens. Het verbod van verslaglegging ter zake is te vinden in art. $51 \mathrm{Wpr}$ : "Een ieder die betrokken is bij de uitvoering van de wet en daarbij de beschikking krijgt over gegevens waarvan hij het vertrouwelijke karakter kent of redelijkerwijs moet vermoeden, en voor wie niet reeds uit hoofde van ambt, beroep of wettelijk voorschrift ter zake van die gegevens een geheimhoudingsplicht geldt, is verplicht tot geheimhouding daarvan behoudens voor zover enig wettelijk voorschrift hem tot bekendmaking verplicht of uit zijn taak bij de uitvoering van de wet de noodzaak tot bekendmaking voortvloeit." Wat betreft specifiek de openbaarmaking van de bevindingen van een (ambtshalve of op verzoek verricht) onderzoek door de Registratiekamer, bepaalt art. 46, tweede lid, Wpr dat a. mededeling van onderzoeksresultaten niet onverenigbaar mag zijn met het doel van de registratie of de aard van de persoonsgegevens en $b$. mededeling geen onevenredig nadeel brengt aan anderen dan degene die om onderzoek heeft verzocht. 
Het goed functioneren van de Registratiekamer kost geld. Afgezien van de rijksgelden die daarmee zijn gemoeid (denk aan vergoedingen van bezoldigings-, reis- en verblijfkosten van het bestuur van de Registratiekamer ex art. 40 Wpr), wordt (gedeeltelijk) kostenverhaal op betrokkenen "redelijk" geacht. Daarom wordi , in een wetsvoorstel in voorbereiding bij het ministerie van justitie, het vaststellen van privacy reglementen in de (semi-) publieke sector en het aanmelden van een persoonsregistraties door het bedrijfsleven, als mede het overleg in het kader van het vaststellen van gedragscodes naar tarief doorberekend aan betreffende cliënten.

Het regeringsstandpunt bij instelling van de Registratiekamer doet nog anders vermoeden. De politiek staat gereserveerd tegenover aan wetsuitvoering te verbinden kosten: "Evenmin (als het met de kosten van de uitvoering van de wet belasten van houders, die bij de Registratiekamer verplicht melding moeten maken van slechts een betrekkelijk kleine minderheid persoonsregistraties - JGLVN) lijkt het wenselijk enigerlei heffing of retributie te vragen voor specifieke handelingen van de Registratiekamer, zo als het verzoek tot het afgeven van een verklaring omtrent een gedragscode als bedoeld in artikel 15 , of een verzoek een onderzoek in te stellen, als bedoeld in artikel 46 . In beide gevallen zal de te verwachten opbrengst van retributies te verwaarlozen zijn in verhouding tot de totale kosten van de Registratiekamer. Met betrekking tot dit laatste geval moet nog worden bedacht dat een retributie van enige betekenis een drempel kan blijken voor het inschakellen van de Registratiekamer, die een goede taakvervulling van die instelling nadelig zou kunnen beïnvloeden."

Uit de houding ter zake van de Registratiekamer zelf spreekt ook voorzichtigheid. Zij vreest dat het invoeren van heffingen verschuldigd voor toetsing van gedragscodes en vaststelling van reglementen de stimulans tot zelfregulering door registratiehouders aanzienlijk remt. Volgens de Registratiekamer volgt dan wellicht wetsontduiking, waardoor zij weer harder aan bel moet trekken. "Handhaving zou betekenen dat de Registratiekamer tot incasso-maatregelen moet overgaan en dat de toezichthoudende taak van de Registratiekamer wordt gefrustreerd."

\section{$\$ 16.6$ Beperkingen van de vrijheid van persoonsgegevensverkeer in het licht van harmonisatie van nationale regelgeving ter zake}

Duidelijk is, dat de uitvoeringswerkzaamheden en het handhavingsbeleid van de Registratiekamer in belangrijke mate onderhevig zijn aan Europese regelgeving. Niet zonder betekenis is de Europese erkenning van het recht op privacy. Dit fundamentele grondrecht is neergelegd in art. 8 EVRM (junctis art. 17 IVBPR en art. $10 \mathrm{Gw}$ ). Elementaire jurisprudentie biedt helaas geen optimale bescherming van het recht op een privéleven. In de (evenredigheids) toetsing aan art. 8 EVRM speelt het element, dat een de persoonlijke levenssfeer beperkende regeling bij de wet moet zijn voorzien. Dat betekent in elk geval, dat de regeling voor iedereen kenbaar en voorzienbaar moet zijn. De in art. 8 EVRM geboden grondrechtbescherming komt vooral aan de orde in arresten aangaande verificatie of huiszoeking. Enige twijfel hierbij is of art. 8 EVRM nu wel of niet geldt voor ondernemingen/bedrijfsruimten. 
Voor toepassing van het privacyrecht is het vollgende belangrijk.

Ten eerste, uitgaande van een ruime interpretatie van art. $59 \mathrm{E}(\mathrm{E}) \mathrm{G}$-verdrag, is het logisch grensoverschrijdend gegevensverkeer onder de garantie van vrij dienstenverkeer te doen vallen. Ten tweede, met oog op de in-en uitvoer van data zijn onder voorwaarden (namelijk voor zover informatie op geld waardeerbaar is en als zodanig voorwerp van handelstransacties kan vormen, of anders gezegd, stoffelijk is) ook de artt. 30-37 $\mathbb{E}(\mathbb{E}) \mathrm{G}$-verdrag van toepassing. Daarin is de vrijheid van goederenverkeer geregeld. Deze vrijheid verhindert niet dat verboden of beperkingen van invoer, uitvoer of doorvoer geoorloofd zijn via een succesvol beroep op de 'rule of reason' (met andere woorden: de Cassis de Dijon-formule) of dat ze gerechtvaardigd zijn op basis van de uitzonderingsgronden genoemd in art. 56 juncto art. $66 \mathrm{E}(\mathrm{E}) \mathrm{G}$-verdrag en art. $36 \mathrm{E}(\mathrm{E}) \mathrm{G}$-verdrag. De bepalingen betreffende beide voornoemde verdragsvrijheden zijn mogelijk toepasselijk op grensoverschrijdend gegevensverkeer voor zover dit zelfstandig van aard is. Soms is het karakter van dataverkeer niet zelfstandig, maar juist accessoir. Dat wil zeggen, gegevensverkeer hangt een andere economische activiteit aan. Is hiervan sprake, dan komen (naast goederen-en dienstenverkeer) het vrij verkeer van personen en dat van kapitaal in beeld.

Bij dit alles levert het harmoniseren van wet- en regelgeving van de EG-lidstaten de nodige spanningen op. Een aantal hiervoor relevante regelingen springen in het oog. In de eerste plaats is er de Uitvoeringsovereenkomst van het Verdrag van Schengen. In het kader van een adequate gegevensuitwisseling tussen verdragsstaten zijn deze staten, ex art. 126, eerste lid, van bedoeld besluit, verplicht in hun nationale wet- en regelgeving de nodige maatregelen te nemen ter verwezenlijking van een acceptabele graad van gegevensbescherming, uniform aan het niveau van de instructienormen van het (als uitwerking van art. 8 EVRM bedoelde) Europees Dataverdrag. Hoe ver Nederland is gebonden aan deze en andere bepalingen van bedoelde Uitwoeringsovereenkomst is nog de vraag. De Nederlandse regering erkent weliswaar dat de regels van de Uitwoeringsovereenkomst prioriteit krijgen boven nationale regels. Maar gegeven de openheid en vaagheid van de privacybepalingen van de Uitvoeringsovereenkomst is het niet zeker of zij het predikaat van een ieder verbindende bepalingen ex art. $93 \mathrm{GW}$ verdienen. Met een andere Europese regeling inzake persoonsgegevensverkeer is dat wél het geval.

In de tweede plaats bestaat namelijk de ontwerp-richtlijn privacybescherming. Deze ontwerp-richtlijn stoelt op art. 100A, eerste lid, EG-verdrag juncto art. $100 \mathrm{~A}$, tweede tot en met vijfde lid, E(E)G-verdrag. Deze grondslag maakt duidelijk, dat de richtlijn een hoogwaardig en gelijkwaardig niveau van privacybescherming in elke lidstaat beoogt. Overigens mag een beroep van een nationale staat op art. $100 \mathrm{~A} \mathrm{E}(\mathrm{E}) \mathrm{G}$-verdrag niet leiden tot willekeurige discriminatie of verkapte beperking van de handel tussen lidstaten. Voor toepassing van een nationale regeling die afwijkt van geharmoniseerde normen is uitdrukkelijke toestemming van de Europese Commissie, die over de concrete afwijking niet in algemene termen maar ex art. $190 \mathrm{EG}$-verdrag gemotiveerd met vermelding van feitelijke en juridische gronden moet beslissen, vereist.

Art. 1, tweede lid, Ontwerp-richtlijn Privacybescherming bepaalt letterlijk, dat lidstaten het vrije verkeer van persoonsgegevens om redenen, die met de uit hoofde van de be- 
scherming van de rechten en vrijheden van natuurlijke personen, met name het recht op bescherming van de persoonlijke levenssfeer verband houden, mogen beperken noch verbieden. Deze regel staat, nog voor definitiebepaling van de in de richtlijn gebruikte begrippen, opvallend voorop. Er lijkt geen ontkomen aan. Bij nader inzien brengt art. $100 \mathrm{~A}$, vierde lid, E(E)G-verdrag uitkomst. Ondanks met gekwalificeerde meerderheid van stemmen genomen harmonisatiemaatregelen, mogen nationale staten noodzakelijke beperkingen aanbremgen "die hun rechtvaardiging vinden in gewichtige eisen als bedoeld in art. 36 of verband houdend met de bescherming van het arbeidsmilieu of het milieu". Zo'm beperking is "onder omstandigheden de bescherming van de informationele privacy"t.

Ter verduidelijking, bij informationele privacy gaat het, in tegenstelling tot de - tevens in art. 10 Grondwet gegarandeerde - relationele privacy (d.w.z. het recht om met rust te worden gelaten door bij voorbeeld de pers), om "het recht om selectief te zijn in het gebruik dat anderen maken van gegevens over de rechthebbende en niet om het recht orn zich zelf af te zonderen van contacten met anderen". Kortom, het recht op informationele privacy betreft het recht van een datasubject om zelf te bepalen wat er met diens persoonsgegevens gebeurt.

\subsubsection{SAMENWERKING EN INFORMATIE-UITWISSELING MET EUROPESE (EN NIET-) EUROPESE) STATEN}

Ten slotte, de Registratiekamer onderhoudt uitdrukkelijk internationale contacten. Art. 30 , vijfde lid, ontwerp-Privacyrichtlijn biedt daartoe, onder waarborging van de nodige geheimhouding volgens het zesde lid, een belangrijke basis.

De Registratiekamer neemt bij voorbeeld jaarlijks deel aan de Internationale Conferenties van Data Protection Commissioners. Sinds 1991 heeft zij, in het kader van het ontwerpPrivacyrichtlijn, ook elk jaar contact met EG-autoriteiten, die even als de Registratiekamer zelf toezicht houden op de naleving van privacywet- en regelgeving. Tijdens de Europese Conferentie van Data Protection Commissioners wordt een werkgroep geinstalleerd, die onder permanent voorzitterschap van de Registratiekamer aan de slag gaat met uitwoeringsaspecten van het aanvullend akkoord van Schengen en alle aspecten van internationale politiesamenwerking op het terrein van de douane.

Tevens bezoekt zij de de evaluatiebijeenkomsten over gegevensverkeer georganiseerd door de Organisatie voor Economische Samenwerking en Ontwikkeling. De OESO is onder meer verantwoordelijk is voor de richtlijnen voor persoonsregistratiebeveiliging. Leidraad daarin vormen beginselen betreffende: a. verantwoordelijkheid (ieders bevoegdheden en aansprakelijkheden t.a.v. persoonsregistraties); b. ethiek (bescherming van rechten en belangen van derden); $c$. integratie (coherente opbouw technische/organisatorische persoonsregistratiebeveiligingsmaatregelen); en $\mathrm{d}$. evaluatie (periodieke toetsing beschermingsmatregelen).

Daamaast kent de Registratiekamer samenwerkingsverbanden met de nationale controlleautoriteiten in de overige Europese lidstaten.

Bovendien heeft de Registratiekamer bilaterale afspraken met zusterorganisaties als mede instanties die zich bezig houden met wet- en regelgeving op het gebied van gegevensbescherming. 
Nog in ander opzicht is het buitenland belangrijk. Niet te onderschatten is namelijk de mogelijkheid van 'transborder data flow'. Door het in hoog tempo toenemen van gegevenstransportsystemen, die steeds ingenieuzer worden, bestaat het volgende gevaar. Persoonsregistraties, die in Nederland onder de Wpr vallen, worden overgebracht naar landen waar dat wetsregime niet van toepassing is. Vandaar uit kan de informatie dan worden ingezien. Deze transborder data flow is zeer moeilijk te controleren.

De wettelijke voorziening ter zake is art. $49 \mathrm{Wpr}$. Art. 49 , eerste lid, Wpr verplicht degene, die van uit Nederland toegang heeft tot een buitenlandse persoonsregistratie, om die toegang te beveiligen. En art. 49 , tweede lid, Wpr, bevat een verbod om van uit Nederland gegevens te verstrekken aan of te betrekken van een zich elders bevindende persoonsregistratie waarop de Wpr niet van toepassing is. Art. 49, tweede lid, Wpr wordt mogelijk met een geldboete van de tweede categorie gesanctioneerd via art. 50 , eerste lid, sub c, Wpr. Problematisch aan art. 49, tweede lid, Wpr is helaas, dat het verbod slechts geldt voor zover bij algemene maatregel van bestuur is verklaard dat door zodanig werstrekken of betrekken de persoonlijke levenssfeer van de betrokken personen ernstig kan worden benadeeld. De bepaling lijkt dus niet meer dan een lege dop te bieden.

Niet alleen in de particuliere sfeer, vooral ook in (semi-)publieke sector is persoonsgegegevensuitwisseling geen vreemde eend in de bijt. Zie artt. 17-18(22) Wpr, welke bepalingen soms op gespannen voet met de geheimhoudingsibepalingen van de Wpr staan.

Weliswaar staan bij, al dan niet wederzijdse, gegevensoverdracht tussen personen of instanties met een publiekrechtelijke taak, waarbij een geregistreerde meestal niet om medewerking op vrijwillige basis wordt gevraagd, doelgebondenheid en schadepreventie voorop. Niet altijd wordt voorkomen dat een dergelijke 'free flow of information' wel benadeling van de persoonlijke levenssfeer van een betrokken geregistreerde oplevert. Desondanks worden mogelijkheden tot koppeling van gegevensbestanden op grote schaal benut. Om de kans op misbruik en oneigenlijk gebruik van gegevensuitwisseling minimaliseren is het verstandig te komen tot een registratiesysteem, waarin gegevens eenmalig worden opgeslagen. Deze gegevens kunnen dan, van uit een beperkt aantal basisadministraties, worden doorgeleverd aan en meervoudig worden gebruikt door (overheids)organisaties. Daarnaast luidt, gegeven de gevaren van (gemeentelijke) koppeling van persoonsregistraties, een pleidooi te komen tot het meer transparant en daarmee controleer maken van koppeling. D.w.z. stadsbestuurders moeten openbare afspraken over koppelingen tussen persoonsregistraties maken, waardoor de gemeenteraad in staat is daarop toezicht te houden. Naast het creëren van inzichtelijkheid van persoonsregistratiekoppeling is het zinvol contactpersonen in gemeenten aan te stellen, die een ombudsfunctie wat betreft persoonsregistratie(koppeling) vervuilen.

Ten slotte, voor een adequate informatie-uitwisseling en samenwerking op het gebied van de rechtshandhaving is formeel art. 14 Wpolr relevant. Deze wettelijke bepaling biedt helaas weinig soelaas. De verstrekking van gegevens van de politie aan rechtshandhavende algemene/bijzondere opsporingsambtenaren (in dienst van een politiekorps dan wel buitengewone opsporingsambtenaren), openbare diensten/organen of private ondernemingen kent twee belangrijke beperkingen. Ten eerste, informatieverstrekking geschiedt alleen ten behoeve van opsporing van strafbare feiten, dus niet ten dienste van administra- 
tiefrechtelijke zaaksafdoening. Degenen, die naast een opsporingstaak ook een toezichtstaak hebben, kunnen wat betreft hun controle- of inspectieopdrachten met de Wpolr niet (gemakkelijk) uit de voeten. Ten tweede, voordat een opsporingsonderzoek start, kan geen informatie uit politieregisters worden verkregen. Kortom, proactieve informatievoorziening is onmogelijk. Een gedurfd pleidooi, om beide beperkingen uit de weg te ruimen, luidt daarom: integreer de Wpolr in de Wpr.

\section{$\$ 16.7$ Verhouding Wet persoonsregistraties-Burgerlijk Wetboek}

Het besef leeft, dat de informatietechnologie een zeer snelle ontwikkeling door maakt. De vraag rijst of de, uit 1988 stammende, Wpr nog voldoende privacyprotectie biedt. Eind 1994 is de Wpr, nadat de wet vanaf 1988 vijf jaar in werking is, aan evaluatie toe. Veronderstelde vragen zijn vooral: is de wet nog effectief; is de Wpr niet gedateerd; en bestaat - naast de bescherming van de Wpr - andere, ja zelfs betere, bescherming van informationale privacy.

Met innovatieve indringendheid krijgt het privaatrecht prioriteit boven de kennelijk minder waardevol wordende Wpr.

In deze optie kan het recht op informationele privacy -viervoudig op te splitsen in het recht op beschikbaarheid van informatie, het recht op integriteit van informatie, het recht op exclusiviteit van informatie, en het recht op transparantie van informatie- een vermogensrecht opleveren. Presumptie daarbij is dat de informatiedrager, waarop persoonsgegevens staan, een zaak in de zin van art. 3:2 BW is. Het eigendomsrecht, dat iemand conform art. 5:1 BW als meest omvattend recht op die zaak kan hebben, is in beginsel overdraagbaar. Bij het recht op informationele privacy, in het bijzonder het deelrecht daarvan om over persoonsgegevens te beschikken, gaat het niet zo zeer om overdraagbaarheid ex art. 3:83 BW junctis art. 3:6 BW, art. 3:40 BW, art. 3:13 BW en art. $3: 84 / 86 \mathrm{BW}$, maar meer om het, mogelijk onder voorwaarden, al dan niet op grond van een overeenkomst ex art. 6:248 BW, ter beschikking stellen van persoonsgegevens. Het volgende citaat werkt wellicht verhelderend: "Er bestaat voor een ieder de rechtsplicht om geen inbreuk te maken op de informationele privacy van een ander. Zodra persoonsgegevens over persoon $A$ ter beschikking komen van $X$ concretiseert deze algemene rechtsplicht zich in een verplichting van $X$ om tegenover $A$ zorgvuldig met deze gegevens om te gaan, indien we deze rechtsplicht als een verbintenis beschouwen, kunnen we het subjectieve recht van $\mathrm{A}$ jegens $\mathrm{X}$ duiden als een vermogensrecht, dat niet overdraagbaar is gezien het persoonlijke karakter van dit recht. Inbreuk op de informationele privacy heeft een niet nakoming van een verbintenis tot gevolg. "Bij toepasselijkheid van het BW betekent inbreuk op de informationele privacy een onrechtmatige daad ex art. 6:612 BW. Hierbij is het instellen van acties ter verkrijging van (immaterielle) schadevergoeding ex art. 6:106 $\mathrm{BW}$, herstel in de oude toestand ex art. 6:103 $\mathrm{BW}$, een declaratoir vonnis, of een rechterlijk verbod ex art. 3:296 BW, denkbaar.

Al met al lijkt het er op dat de stemmen, die op gaan voor een BW-benadering van het recht op informationele privacy, niet meer afkomstig zijn van roependen in de woestijn. Zij worden zeker gehoord en zijn zelfs niet meer te verwaarlozen. 


\section{Ten slotte}

De Registratiekamer ontleent haar publiekrechtelijke taken en bevoegdheden, om toe te zien op de bescherming van persoonsregistraties, aan de weliswaar jonge, maar duidelijk al gedateerde Wpr. De, bij voorkeur door plaatselijke registratiecommissies gesteunde, Registratiekamer houdt via actief sturingstoezicht, waarbij zij streng de hand houdt aan bij voorbeeld aanmeldingsplichten van persoonsregistraties, de naleving van wet- en regelgeving inzake persoonsgegevens in de gaten. Haar doel is conflicten betreffende persoonsgegevensregistratie te voorkomen of, zo ze ontstaan, daarin te bemiddelen. Hiernalast waakt zij in het kader van persoonsgegevensbescherming tegen inbreuken op rechten en belangen van justitiabelen. Haar toezicht is toezicht op zelfregulering via gedragscodes.

De Registratiekamer wil het, na een moeilijke start, goed aanpakken. Helaas wordt zij bij haar functioneren belemmerd door een wet die snel veroudert. Bovendien biedt de wet slechts bescherming in een notedop. En ook het gezag van de Registratiekamer is niet optimaal, omdat aan belangrijke beslissingen van haar geen bindende kracht wordt toegekend, waardoor tot overmaat van ramp ook nog justitiabelen in hun rechtsbescherming worden geschaad. Om uit deze impasse te geraken kan via de Awb als nog juridische protectie worden geboden, maar het getuigt van wijzer beleid als de wetgever een principièle keuze maakt. Deze noodzaak wordt trouwens al ingegeven door het in de maak zijnde Europees recht ter zake.

De ontworpen richtlijn inzake privacybescherming, die er duidelijk van lijkt te getuigen dat informationele privacybescherming een in het algemeen belang uit te oefenen overheidstaak is en in het verlengde daarvan lidstaten oplegt een entiteit belast met het toezicht op het persoonsgegevensverkeer aan te wijzen, noopt namelijk al tot aanpassing van de Wpr. Voor de Registratiekamer brengt dit Europees recht mee, dat haar toezicht een indringender karakter krijgt. Volgens voorstel wordt zij bevoegd: preventief onderzoek te verrichten, zelf gerechtelijke procedures te starten en een openbaar register van aanmeldingen - die uitgebreider moeten geschieden - aan te houden. Daardoor komt zij steviger in het zadel te zitten, maar moet zij ook krachtiger koers kiezen. Competentieuitbreiding mag niet haar neutrale onafhankelijkheid, die haar positie als toezichthouder kenmerkt, in het geding brengen.

Met deze, waarschijnlijk, toekomstige taakverbreding van de Registratiekamer heeft de wetgever rekening te houden bij het opstellen van nieuwe wetgeving die de huidige tekort schietende Wpr moet vervangen. Indien trouwens, als de huidige voornemens doen vermoeden, de wetgever terecht de gedachte blijft aanhangen dat het toezicht op bescherming van persoonsgegevens een overheidstaak is die uitgevoerd moet worden door een, daartoe met publiekrechtelijke bevoegdheden toegerust, bestuursorgaan, dan wordt het tijd om inderdaad een bres te slaan voor een brede positionering van dat orgaan.

Zo is het, juist met oog op het dynamische karakter van de (persoons)informatie-infrastructuur, zinvol dat de Registratiekamer, die meer in huis moet hebben dan enkel juridische specialisten, regelgevende bevoegdheden krijgt. Zo kan zij bij voorbeeld al wast anticiperen op komende nationale wetgeving, voor welke anticipatie mogelijk zelfregule- 
ring belangrijke basis vormt waardoor overheidstoezicht weer sneller wordt aanvaard, of de implementatie van Europees recht bespoedigen.

Ook toerusting van de Registratiekamer met de bevoegdheid tot het opleggen van bestuurlijke boiete is, uit oogpunt van handhaafbaarheid van wetgeving inzake persoonsgegevensbescherming, toe te juichen. De boeten moeten binding hebben met maximumtarieven, die in overleg met het openbaar ministerie worden bepaald.

Ander financieel aspect betreft het vragen van een kleine vergoeding voor verrichtingen - bij voorbeeld het opnemen van een aanmelding, het corrigeren van persoonsgegevens e.d. - door de Registratiekamer. Hier moet terughoudendheid uitgangspunt zijn. De grondslag van het vragen van vergoedingen moet bij voorkeur publiekrechtelijk zijn. Overigens kan kostendoorberekening (hoe minimaal ook) aan onder toezicht gestelden er toe leiden dat het, in Europees recht voorziene, openbaar register het risico van veroudering en onvolledigheid vertoont. Althans, zo lang het weigerachtig blijven met aanmelding van persoonsgegevens - in dit geval wegens de aan aanmelding verbonden financiële verplichting - niet gesanctioneerd wordt door bestuurlijke boeteoplegging.

In het licht wan financiële, en ook andere feitelijke, inhoudelijke en beleidsmatige verantwoording is het bellangrijk, dat de Registratiekamer in de toekomst zorgvuldiger dan tot nu toe haar verslaglegging en rapportages op orde brengt.

Naast het bestuursrecht, dat hier een primaire functie heeft, is een interessante, aanvullende rol voor het civiel recht weg gelegd.

Het - onder de presumptie, dat informationele privacy een vermogensrecht oplevert, gevoerde - pleidooi om, wat bescherming van informationele privacy betreft, het privaatrecht in de plaats te stellen van het publiekrecht is prachtig. Niets dan lof daarvoor. Het blijft alleen de vraag of het, weliswaar aan het nationale dereguleringsdoel en het Europese harmonisatiestreven tegemoet komende, gebruik van open normen uit het privaluatrecht zo veel recht doet aan de rechten van geregistreerden. Deze stelt zich, in geding, immers bloot aan marginale rechterlijke toetsing. Wie garandeert hem dat de belangen van de registratiehouder niet zwaarder wegen dan de zijne? Het komt dus aan op een belangenafweging, die niet risicoloos is voor het individu of de groep van wie persoonsgegevens staan geregistreerd.

Gegeven de zwaarwichtigheid van bescherming van persoonsgegevens en het gebruik er van, lijkt uit overwegingen van rechtszekerheid de overheid voorlopig - dat is in elk geval zo lang de technologische informatie(dragers)maatschappij zich nog niet volledig heeft uitgekristalliseerd - het meest aangewezen om protectie te bieden door uitoefening van, soms streng, overheidstoezicht.

De tijd zal leren of en, zo ja, wanneer het in Europa mogelijk te uniformeren privaatrecht de sterkste positie inneemt. 


\section{Geraadpleegde literatuur}

Bakker, P. \& Hoütepen, E.

De Registratiekamer: een luisterend oor, in: P\&R, nr.3, 1990, pp.5-8.

Beers, A.A.L.

Informatierechten van Wpr en Wob vergeleken, in: De Gerneentestem, nr.6899, pp.201-205.

Bentinck van Schoonheten, J.U.

Direct marketing en privacy-zelfregulering, in: $P \& \mathbb{R}, \mathrm{nr} .2-3,1994, \mathrm{pp} .20-23$.

Bergfeld, J.P.R.

- NGI: Zevende Nationale Privacy Symposium, in: Computerrecht, nr.1, 1994, pp.32-34;

- Rechtspraakrubrieken, Computerrecht, wanaf januari 1994;

- VNG-congres "5 jaar WPR, hoe gaan gemeenten verder?", in: Computerrecht, nr.1, 1995. pp. 39-41.

Berkvens, J.

- Van normen en waarden, in: Computerrecht, nr.6, 1993, pp.230-237;

- Annotatie arrondissementsrechtbankUtrechtd.d. 12 mei 1993, in: Computerrecht, nr.6, 1993. pp. 261-263;

- Privacy, zelfregulering en bankwezen, in: P\&R, nr.2-3, 1994, pp.24-28.

Berkvens, J.M.A. \& Schauss, M.

Tweede akte van de privacyrichtilin, in: Computerrecht, nr.6, 1992, pp.232-240, zie Ontwerpm richtlijn privacybescherming gepubliceerd in: Computerrecht, nr.6, 1992, pp.248-252.

Berts, D.

Minister slaagt erim ondeugdelijke Wpr nog verder te misvormen, in: $\mathrm{P} \& \mathrm{R}, \mathrm{nr} .4,1993$, pp.15-16.

Boswinkel, B.J.

De privacyrichtlijn begrensd, in: SEW, nr.7/8, 1993, pp.550-592.

Brouwer, E.R. e.a.

Juridische aspecten van het GBA-project, Amsterdam, 1992.

Bunschoten, D.E.

Kroniek Nederland: de Wpr, in: TvBP, 1989, pp.459-463.

Casteren, J. van \& Ippel, P.

Gedragscodes: terugblik en perspectief, in: Privacy en Registratie, nr.2-3, 1994, pp.10-15;

$\sim$ Schending geheimhouding Wet GBA komt voor en dupeert burgers; Overheid mag vertrow wen niet beschamen, in: BB, nr.13, 31 maart 1995, p.25.

Claessen, P.D.A., Wisselink, M.A., Hondius, F.W., Kleve, P. \& Schelven, P.C. van Voorschriften privacybescherming, VUGA-bundel, mei 1991.

Combe, L. de la \& Wesseldijk, J.M.

High tech, low touch; Koppeling bij de bestrijding vars sociale zekerheidsfraude, in: Justitiële Verkenningen, nr.5, 1994, pp.35-49.

Crouwers, B. \& Ippel, P.C.

Gegeven het individu; Het belang van de Registratiekamer, in: Justitiële Verkenningen, nr. 5 , 1994, pp.8-21.

Esch, R.E. van \& Berkvens, J.M.A.

Het BW als Wor, in: Computerrecht, ar.3, 1994, pp.93-101.

Eijk, D. van

Ruimte voor eigen intitatief bij koppelen wan bestanden, in: NRC, 29 december 1994, p.3.

Fierstra, M.A.

De communautairrechtelijke status van grensoverschrijdendgegevensverkeer, in: Fierstra, A.M., Nugter, A.C.M. \& Korthals Altes, W.F., Vrij verkeer van informatie in Europa, preadvies t.b. . bijeenkomst NVE, NVIR en VMC d.d. 15 november 1991, Amsterdam, pp.9-38. 
Goos, M.

Two is a crowd?, in: Computerrecht, nr.5, 1994, pp.188-192.

Graaf, F. de

Haken en ogen aan de gedragscode voor persoonsregistraties, in: Computerrecht, nr. 3, 1990 , pp. 119-123.

Herstel, C.A.

GBA bij gemeenten in goede handen, in: Binnenlands Bestuur, $\mathrm{nr} .19,12$ mei 1995, p.23.

Holvast, $\mathrm{J}$.

- Wpr: keurstijf of vrijbrief?, in: Computerrecht, nr.2, 1989, pp.65-68;

- Wpr: een wet die (nog) niet leeft bij de registratiehouders, in: Informatie (Automatisering en Recht), nr. 11 , 1993, pp.697-701;

-ISDN: digitale snelweg en de consument, in: Computerrecht, nr.5, 1994, pp.226-230;

- Wetenschappelijk onderzoek en privacy, een overzicht van wettelijke en andere maatregelen, in: Privacy en Registratie, nr.1, 1995, pp.4-8.

Holvast, J., Dijk, H. van \& Schep, G.J.

Privacy doorgelicht, Stichting wetenschappelijk onderzoek konsumenten aangelegenheden i.s.m. Stichting waakzaamheid persoonsregistratie, 1989.

Holvast, J., Kabel, J.J.C., Overkleeft-Verburg, G., Sneep, J.H., Tubbing, A.M.C.C. \& Zanden, H.A. v.d.

Privacybescherming in de particuliere sector, Zwolle. 1991.

Holvast, I. \& Ketelaar, R.

Zelfregulering en gedragscodes, een kritische analyse, in: Privacy en Registratie, nr.2-3, 1994, Pp. 16-19.

Hoogendijk, A.

- Wet persoonsregistraties, in: het Verzekeringsarchief, deel 64, LXIV, 1987, pp.257-276;

- Persoonsregistratieen verzekeringsbedrijf, in: het Verzekeringsarchief, deel 66, 1989, pp.263276.

Hulst, L. van

Niets aan de hand? Privacy-wetgeving biedt onvoldoende bescherming, in: Intermediair, nr.39, 30 september 1994, p.53.

Ippel ${ }_{n}$. .

Slordig mag niet (reactie interview H.J. de Ru), in: NJB, nr.3, 21 januari 1994, pp.100-101.

Junge, A.S.

Centrale persoonsregistratie in Denemarken, in: Justitiële Verkenningen, nr.5, 1994, pp.65-83.

Kabel, J.J.C.

Informationele privacy als heilige koe?; Enkele beschouwingen n.a.v. Kuitenbrouwers boek 'Over privacy", in: Informatierecht/AMI, nr.3, februari 1993, pp.23-25.

Ketelaar, R., Holvast, J. \& Bakker, J, de

Privacygids: Handboek voor geregistreerden, stichting waakzaamheid persoonsregistraties, Amsterdam, 1989.

Kaoij, H.M. \& Overkleeft-Verburg, G.

O, die codes!, in: P\&R, mr.4, 1993, pp.17-19.

Kreikamp, W.J.E.

Enkele kostenaspecten van de Wpr, in: Computerrecht, $\mathrm{nr} .2,1990, \mathrm{pp} .64-67$.

Kuitenbrouwer, F.

- Veel gegevens in bestanden erg aan bederf onderhevig, in: NRC, 31 oktober 1992, p.2;

- Losse einden van de privacybescherming, in: Computerrecht, nr.3, 1994, pp.89-93;

- Hoge kosten Richtlijn, in: Computerrecht, nr.5, 1994, pp.221-222;

- Strijd om het 'kostenplaatje' van de privacyrichtilin, in: Computerrecht, nr. 1, 1995, pp.38-39. 
Kuus, A.H.J.

De Registratiekamer may be watching you!, in: Computerrecht, nr.3, 1990, pp. 123-126.

Lindner, Th.J.M.

Actuele wetgeving: Wpr, in: NTB, nr.2, 1989, pp.65-66.

Lindo, C.M.Th.

Prikkelend privatrecht als alternatief woor wetgeving: Het systeem De Ru, in: NJB, nr.39, 4 november 1993, pp.1406-1410.

Middelveld, A.

Wpr is keursliff voor gemeenten. Registratiekamer schiet met kanon op mug, in: BB, nir.4, 29 januari 1993, p.22.

Mosshammer, A.

Wpr: onbekend maakt onbemind, in: Rechtshulp, nr.4, 1994, pp.8-13.

Mosshammer, A. \& Houtepen, E.

- Smart card: (zo gek) nog niet!, in: P\&R, nr.1, 1994, pp. 13-20;

- Over de risico's van persoonsregistratie, in: Justitièle Verkenningen, nr.5, 1994, pp.22-33.

Mutsaers, L.

De Wpr in universitair Nederleand, in: P\&R, nr.2-3, 1994, pp.29-32.

Muijen, P.J.D.J. \& Raaij, R.A. van

Handleiding politie \& privacy, Lochem, 1991.

Nugter, A.C.

Transborderflow of personal data within the EC; A comparative analysis of the privacy statutes of the Federal Republic of Germany, France, the United Kingdom and The Netherlands and their impact on the private sector, Deventer/Boston, 1990.

Offreins, $R$.

'Schengen' en privacybescherming, in: P\&R, nr.3, 1992, pp.4-10.

Offreins, R., Ketelaar, R. \& Holvast, J.

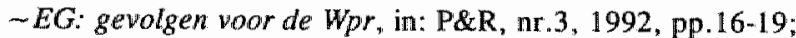

$\sim$ EG: achtergronden bij de Europese richtlijnen Syn 288/288, in: P\&R, nr.3, 1992, pp.13-15.

Oosteren, C. van

Kosten wan de Europese privacyrichtlijn, in: Privacy en Registratie, nr.1, 1995 , pp.15-18.

Oosteren, C.G.M. van \& Vliet, J.S, van

Kosten voor de overheid van de Europese privacyrichtlijn, IOO-onderzoeksreeks nr.65, "sGravenhage, november 1994.

Overkleeft-Verburg, G.

- Privacy en persoonsregistraties in Europees perspectief, preadvies Nederlandse vereniging voor rechtswergelijking, 1991;

$\sim$ De Registratiekamer: taken, activiteiten en beleid, in: Holvast, J., Kabel, J.J.C., OverkleeftVerburg, G., Sneep, J.H., Tubbing, A.M.C.C., en Zanden, H.A. van der, Privacybescherming in de particuliere sector, serie praktijkhandleidingen, Zwolle, 1991, pp.39-49;

- O, die codes!, in: P\&R, nr.4, 1993, pp.17-19;

- Enkele bestuursrechtelijke aspekten van kennissystemen bij de overheid, in: NTB, ar. 10, 1993. pp. 311-320;

- De Wpr-gedragscode als vorm van wettelijk geconditioneerde zelfregulering, in. Privacy en Registratie, ur.2-3, 1994, pp.4-9.

Patijn, A.

Wet politieregisters, in: AA, nr.2, 1992, pp.101-108.

Pous, V.A. de

Wpr op 1 juli 1989 wan kracht, in: Tijdschrift voor Politie, nr.6, 1989, pp.283-285.

Prins, J.E.J. 
Overtallig recht inzake informatietechnologie; Privaatrecht en informatisering in het zicht van een nieuw millemium, oratie KUB, Deventer, 3 februari 1995.

Registratiekamer

- Jaarverslag 1988-1991, Rijswijk, 1994;

- Jaarverslag 1992-1993, Rijswijk, 1994.

\section{Rodotà. $S$.}

Protecting Informational Privacy: Trends and Problems, in: W.F. Korthals Altes, E.J. Dommering, P.B. Hugenholtz en I.J .C. Kabel (red.), Information law towards the 2I st century, Information law series nr.2, Deventer/Boston, 1992, pp.261-272.

Schendel, P.W. van

Privacy - Handmatige dossierverzameling, in: Computerrecht, nr.6, 1993, pp.259-261.

Sentrop. J.W.

Stichting Waakzaamheid Persoonsregistratie failliet verklaard, in: Computerrecht, nr.4, 1994. p.181.

Spelthaen, H.M. \& Reeken, A.J. van

Zoeklicht op de Registratiekamer, in: P\&R, nr.4, 1993, pp.7-11.

Temmink, H.A.G.

Minimumnormen in EG-richtlinen, in: SEW, nr.2, 1995, pp.79-106.

Tweede Kamer

- Wet persoonsregistraties, TK 1981-1982, 17207, nrs.1-3, en ook TK 1985-1986, 19095, nrs. 1-3;

-Tweede nader gewijzigd voorstel van wer GBA, TK 1992-1993, 21123, nr.214, als mede Derde nota van wijziging aanpassingswet i.v.m. invoering wet GBA, TK 1993-1994, 21147. nrs. 11-12;

- Brief van de ministers wan justitie en binnenlandse zaken over de naleving van de wpr door gemeenten, TK 1992-1993, 21132, nr.42;

- Wetsontwerp Geneeskundige behandelingsovereenkomst, TK 1992-1993, 21561.

Vandenberghe, G.P.V.

De Wpr in hoofdlijnen, in: Computertecht, nr.2, 1989, pp.58-63.

Verbraeken, E.H.A.

Wet persoonsregistraties, in: TVVS, nr.8, 1989, pp.185-189.

Verhey, L.F.M.

- Beoordeling ontwerp van Wpr, in: NJCM-bulletin, nr.11-1, januari 1986, pp.90-99;

- Horizontale werking van grondrechten, in het bijzonder wan het recht op privacy, Zwolle/Utrecht, 1992, pp.345-442;

- Europese integratie en privacybescherming, in: Burkens, M.C. \& Kummeling, H.R.B.M. (red.), EG en grondrechten: Gevalgen van de Europese integratie voor de mationaie grondrechtembescherming, Zwolle/Utrecht, 1993, pp.219-258.

Verkade, D.W.F.

Nederlandse privacywetgewing: licht aan het einde van de tunnel, in: I\&R, pp.3-10.

Visser, $C$.

Bescherming privacy is zo sterk als de zwakste van de 646 gemeentelijke schakels, in: BBM, 30 maart 1993. pp.8-13.

Voermans, W.J.M.

Werk aan de winkel voor de Registratiekamer, in: Computerrecht, nr.2, 1989, pp.72-79.

Vunderink, E.

- Hoopvolle rechlerlijke uitspraak, in: Privacy \& Registratie, 1993, nr.3, p.31:

- De Registratiekamer: rwee publikaties, in: P\&R, nr.1, 1994, pp.31-33.

Vunderink, P.A.M. 
Verslag van het Be Nationale Privacy Symposiam, in: Computerrecht, nr.1, 1995, pp.41-42. Ziegler-Jung, B.R.

Elementent van reflexief recht in de Wpr?, in: Hulst, N.J.H. \& Stout, H.D., Reflecties op reflexief recht, Zwolle, $1992, \mathrm{pp} .131-142$. 


\section{Kwaliteitscontrole-instellingen:}

\section{SKAL, KCB, COKZ, NVK, ISC, NAKG}

\section{$\$ 17.1$ Vrij handelsverkeer van landbouwprodukten en zaai- en plantgoed}

De agrarische en -tuinbouwsector moet, in het Europa 'zonder grenzen', rekening houden met de vrije handelsmarkt van goederen en diensten. De mate waarin implementatie of omzetting van EG-regelgeving in nationale regelgeving voorkomt, staat uitvoerig beschreven in relevante rubricerende catalogi. ${ }^{1}$

Het gemeenschappelijk landbouwbeleid ex art. 2 jo. art. 3, aanhef onder sub d, junctis artt. 38-47 E(E)G-verdrag ${ }^{2}$, dat een hoog beschermingsniveau kent, is al in ver gaande mate geharmoniseerd. Deze harmonisatie staat in het teken van het opheffen van handelsbelemmeringen. Daaraan dragen de volgende aspecten bij: a. vergelijkbare procedures in de lidstaten bij de beoordeling van produkten; b. identieke eisen voor keurings- en certificatie-instellingen; en c. verbetering wederzijdse erkenning van vrijwillige keuringen. ${ }^{3}$ Hiervan getuigt onder meer art. 12 EEG-verordening inzake de biologische produktiemethode ${ }^{4}$. Dat artikel bepaalt dat lidstaten het in de handel brengen van in die verordening bedoelde produkten mogen beperken noch belemmeren om redenen die verband houden met de produktiemethode, de etikettering of de presentatie...

1. O.a. indrukwekkend J.C. vam Haersolte, Uitvoering EEG-richtligner in Nederland' '58- "92, "s-Gravenhage, 1993.

2. E. Rood, Overzicht EEG-en Nederlands levensmiddelenbeleid en -recht: inhoud, organisatie, tenuitvoerlegging, handhaving, Apeldoorn/Antwerpen, 1993, pp.4-47, bakent dit, vooral economisch gerichte, GLB af tegenover het ruimere EEG-levensmiddelenbeleid met een meer naar de burger toe beschermend karakter.

3. Normen, Certificaten en Open Grenzen, TK 1994-1995, 21670, nrs.7-8, p. 12.

4. Verordening $w / d$ raad $v / d$ EG, 24 juni 1991 , inz. biologische produktiemethode en aanduidingen dienaamgaande op landbouwproduktent ent levensmiddelen, nr.2092/91, Publ. EG 1991, L 198, im: Skal, a.w., pp.1-34 (pui.1). 
Dit harmonisatiebeleid concentreert zich op zo genaamde horizontale regelgeving, die-in tegenstelling tot verticale regelgeving- ${ }^{5}$ voor alle produktgroepen geldt. ${ }^{6}$ Deze regelgeving, neergelegd in vooral horizontale kaderrichtlijnen ${ }^{7}$, vindt haar basis in volksgezondheid ${ }^{8}$, eerlijkheid in handel en informatievoorziening van de consument. In concreto: voorschriften inzake etikettering, sortering, inhoudsgewichten, houdbaarheid, versheid, voedingswaarde, smaak, additieven, generatie schadelijke stoffen, produktieproces en dergelijke. Kortom, bedoelde regelgeving betreft kwaliteitsbewaking.

Al met al zijn de harmonisatie en de normalisatie van onderlinge landbouwbetrekkingen in een gevorderd stadium. ${ }^{9}$ Hiervan getuigen de horizontale richtlijnen, die de wederzijdse erkenning van (all dan niet vrijwillige) regelgeving nader gestalte geven. Het zich succesvol beroepen op een 'Cassis de Dijon' -exceptie wordt er niet gemakkelijker op.

\subsubsection{EXTRA KWALITEIT(SCERTIFICERINGS)EISEN}

Daarom prefereert Nederland een vrijwillig, 'extra'-kwaliteit beogend en produktautonomie bevorderend, stelsel voor de land- en tuinbouwsector. Zo'n systeem vormit geen belemmering voor het intracommunautaire handelsverkeer. In dit controlestelsel zijn

5. Verticale richtlijnen gelden voor afzonderlijk bepaalde levensmiddelen of groepen daarvan. Daaremtegen gelden horizontale richtlijnen in de regel woor alle levensmiddelenprodukten of groepen daarvan.

6. Ministerie van landbouw, natuurbeheer en visserij, beleidswoornemen Van meer naar beter; Kwalifeit en! kwaliteitsbeleid in de agrarische sector, "s-Gravenhage, mei 1992, pp. 37-39/91-92.

7. P.J. van der Flier en J.S. Wan den Oosterkamp, Voortwarende implementatie van EG-richlijnen, wede in het licht wan de Awb en de Aanwijzingen woor de regelgeving, in: SEW, nr.11, 1994, pp.727-752, i.h.b. p.740, wijzen er op clat de urgentie van omzetting van EG-recht meer, dan bij rechtsgebiedlen warbuj het onderwerp vooral mationaal rechtelijk van aard is, dringt bij richtlijnen die -gemeenschapsrechtelijk geziendeel zijn van een samenhangend geheel van bepalingen (denk aan de samenhang tussen keuringswoorschriften voor voedingsmiddelen en wrij verkeer van landbouw produkten).

8. O.a. regels voor vergunningintrekking en bedrijfserkenning op fytosaniatair en veterinair gebied. LNW, a.w., pp.39/51/91.

9. Er is sprake wan totale harmonisatie in bij voorbeeld Procter and Gamble Benelux vs. Produktschap wowr groewten enfrwit. CBB 18 juni 1993, 91/2926/009/013, m.nt. K.J.M. Mortelmans, in: SEW, nr.4, 1994, pp. $265-268$.

10. Wel blijft plaats voor uitzonderingen zo lang geen sprake is van geharnoniseerde kwaliteitzinormen. Zie Champignon-conserven, HR 11 jarn. 1994, NJ 1994, 409, besproken door A. Mulder in: SEW, nr.2, 1995, pp. 138-146. I.c. worden bjj een bedrijf, dat champignon-conserven bereidt voor export raar Duitsland, produktpartijen aangetroffen die weliswatr in overeenstemming zijn met de Duitse eisen inzake uitlekgewicht en toegevoegde hoeveelheid benzoëzunt, maar niet voldoen aan de kwalliteitseisen ter zake van de in Nederland geldende Verordening wan het Produktschap voor groenten en fruit. De HR oordeelt dat nu geen sprake is van communaukaire kwaliteitsnormen, strenge eisen van nationale regelgeving (i.c. de maatregel die de verhandeling verbiedt wan champignon-conserven waaraan benzoézuur is toegewoegd of warin meer dan $10 \mathrm{mg}$ zwaveldioxyde per $\mathrm{kg}$ nettogewicht aanwezig is) miet onverenigbaar zijn met art. 34 EG-verdrag, omdiat er geen verschil in behandeling ligt besloten tussen voor uitvoer bestemde en in Nederland werhandelde champignon-conserven. Annotator Mulder werwijst naar Jongeneel Kaas bv, HvJ EG (237/82) 7 febr. 1984, Jur. 1984, 483, besproken in: SEW, 1984, p.760 e.v "Daarin wordt beslist dat nationale maatregelen, die uitgaand goede renwerkeer beperken, alleen tot ongelijke behandeling tussen staten kunnen leiden als zij een bijzonder voordeel voor de nationale markt opleveren. Het hof oordeelt dit niet het geval "met bepalingen die minimum-kwaliteitsno men voor de kaasbereiding belvelzen, zonder onderscheid te maken naar gelang de kaas voor de binnenlandse markt dan well voor de vitwoer is bestemd" (p.145). 
privaatrechtelijke keuringsinstellingen belast met toezichthoudende taken. In het stelsel staat de externe ${ }^{11}$ beoordeling door een onafhankelijk overheidsorgaan centraal. Biy die externe keuring door een controle-instelling worden bepaalde normen gehanteerd. Deze normen betreffen wooral conceptregells van het zgn. Integrale-Keten-Zorg-systeem, d.W.z. controle op de produktieketen vanaf grondstof tot aan het consumentenprodukt. ${ }^{12}$ Hiernaast is te denken aan de NEN ${ }^{13} / 1 S O$-normen uit de 9000 - en 45000-serie waarvan het IKZ een uitwerking is. ${ }^{14}$ De International Organization for Standardization 9000-normserie bevat "algemeen geldende minimumeisen die aan de inrichting en werking van de organisatie moeten worden gesteld, maar voorall ook derden, de zekerheid te bieden dat die organisatie in staat is de overeengekomen kwaliteit te leveren ". ${ }^{15} \mathrm{De}$ normen hebben betrekking op onafhankelijkheid, onpartijdigheid, deskundigheid en (betaalbare) kwaliteit van dienstverlening. Een kwaliteitscertificaat onderscheidt zich van produkt- of dienstcertificering omdat het niet produkten of diensten zelf aangaat, maar betrekking heeft op de kwaliteit van de organisatie waarbinnen produkten of diensten worden voortgebracht of verhandeld. Bedrijfsmatig werkende eenheden maken aanspraak op een kwaliteitscertificaat (of anders op een produktcertificaat ${ }^{16}$ of een dienstcertificaat) als zij voldoen aan de $\mathbb{I S O}$-normen.

11. Producenten dragen zelf de primaire verantwoordelijkheid wan intern kwaliteitstoezicht binnen hun bedrijf.

12. Niet meer te verwaarlozen is de zwarte markt die zich, buiten de strenge maatstaven van integrale ketenbewakening om, ontwikkelt. De vlucht in de illegalite it is de keerzijde van het Europese harmonisatieproces. Een verklaring ligt hierin, dat bij het streven haar gelijkwaardige regelgeving geen van de lidstaten genoegen neemt met een gemiddelde van alle in de verschillende lidstaten gelldende eisen. Harmonisatie betekent zo een cumulatie van de meest strenge regels per lidstal. Zo"n systeem van strenge normen lokt smel regelontduiking uit. Zie interwiew met J. van Hemelrijck, door B. Pols, Strenge Europese eisen bedreigen produktie diergeneesmiddelem, in: NRC, 13 juli 1994, p.16.

13. Het Nederlands Normallisative Instituut te Delft doopt de Eu ropese Norm-reeks on in een Nederlandse ENreeks. Het NNI draagt zorg voor een actieve inbreng bij het tot stand komen van Nederlandse, Europese

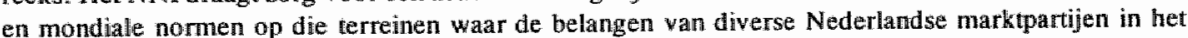
geding zijn. Daamaast bevordert het NNI de toepassing van nomen en functioneert als goed aanspreekbaar kennis- en informatiecentrum op dit gebied. Daut dit NNI een steeds belangrijker tol in het normalisatiestreven wordt aangekondigd in de nota Normen, Certificaten en: Open Grenzen. TK 1994-1995, 21670, nrs.7-8, pp.23/25/33. Het NNI, dat in 1992/1993 reorganisatie ondergaat (met als kenmerkem: concentratie op kerntaken; actieve en duidelijke commumicatie met belanghebbenden; en internationalisering van actiwiteiten), moet meer markt gericht gaan werken.

14. Hierower LNV, a.w., pp.30-34/39/52/77; J.P.M. Hendriks en A de Zeeuw, Op weg naar een gezonde kwaliteit; Advies m.b.t. een evenwichtige taakverdeling tussen de departementen wan LNV en WVC op het rerrein van de levensmiddelenwetgeving en -conrole, sept. 1992, pp.21-23; De Awb kan bij overheidsorganisaties invoering van de preventieve ISO-normen bevonderen. Th.A.P.M. Geurts, Klawtwriendelijker wet Awb, in: BB, nr.23, 10 jun 1994, p.27.

15. B.P.D. Appels en C.A. Visser, Niemand is negen kwaliteir - waar bijiven de woorstanders?; Advocatuur en $15 O$-certificatie, in: Adwocatenblad, nr.12, 10 juni 1994. pp.50-52.

16. Illustratief is het zbo stichting Nederlands Institurut voor Lifttechniek. Die stichting woert, wettelijk verplichte en vrijwillige, veiligheidskeuringen wan personen-en goederenliften, hijskranen, kermistoestelllen, transportsystemen e.d. wit en geeft bij positieve bevindingen certificaten af. De NIL wordt sinds 1 jan. 1993 door de Raad voor de Certificatie woor produktcertificatie. Deze erkenning houdt in dat de NIL volloet aan strenge internationale Europese geharmoniseerde kwaliteitsborgingsnormen (t, $w$. $\mathbb{E N} 45011$ en pr EN 45005) woor inspectie- en centificatie-instellingen. Op basis van deze erkenming wijst de Nederlandse regering de NIL ook aan als 'notified body". Daardoor kan de NIL EG-typeonderzoek voor de Nederlandse industrie uitvoeren. Zie persberichten NIL, Amsterdam, 3 juni 1993. 
De bedoeling is controle-instellingen, zelfs wereldwijd, in 1995 te certificeren. ${ }^{17}$ Dit geschiedt van uit de erkenning dat een certificeringssysteem, veelal in combinatie met een collectief keurmerk, een "'geëigend instrument kan zijn om bepaalde maatschappelijk gewenste doeleinden te realiseren". ${ }^{18}$

De stichting Raad voor de Certificatie ${ }^{191}$ te Driebergen kan voor drie jaar een certificaat af geven. Feitelijk geschiedt certificatieverlening door een van de ruim dertig, door de raad erkende, certificatie-instellingen ${ }^{20}$. De certificerende instantie ziet, door middel

17. KCB, Jaarverslag 1993, 's-Grawenhage, 1994, p.8.

18. Skal, Jaanverslag 1993, Zwolle, 1994, p.10. Volgens Skal kenmenkt de situatie -vóór inwoering van certificeningzich door wrewel. Produktieprocessen veroorzaken vaak neveneffecten, die maatschappelijk ongewengit zijn. Het protest wan uit overheid en samenleving daartegen en het, door angst voor concurrentieverslechtering ingegeven, terughoudende gedrag van de producent om het produktieproces, naar maatschappelijke behoette aan te passen, geven onvrede.

19. Deze, sinds 1981 bestaande, raad us een samenwerking swerband van overheid, bedrijfsleven, wetenschappelijke instellingen en consumentenorganisaties. De rad heeft een regulerende, coördinerende en adviserende functie op het gebied van kwaliteits(zorg)beoordeling en accreditatie in meest ruime zim; De Algemene Rekenkamer, Zelfstondige bestuursorganen en ministeriele verantwoordelijkheid, TK 19941995,24130, nr. 3, p. 83 , meent dat, wat betreft het verstrekken van notified body-certificaten door de stichting $\mathrm{RvC}$, de stichting als zbo moet worden aangemerkt (verbazing en ontevredenheid daarover bij L. Valkenburg, De EZ-nota "Normen, Cenificaten en Open Grenzen, in: RegelMaat, nr. 3, 1995, pp. 100107, i.h.b. p. 106; ; Kennelijk is een accreditatie-organisatie te beschouwen als een bestuursorgatin in de: zin vande $\mathrm{Awb}$, omdatacereditatieverlening -indienaccreditering expliciet wettelijk wardt voomgeschrevenvalt aan te merken als een besluit in de zin van Awb, zie de nota Normen. Certificaten en Open Grenzen. TK 1994-1995, 21670, nrs. 7-8, pp.5-27; Uit die nota Economie en open grenzen. TK 1994-1995, 21670, nrs.7-8, pp.9/15-16/26/33/35, blijkt ook dat de minister wan economische zaken streeft naar versterking van de infrastructur inzake instanties die certificatie-instellingen, laboratoria en inspectiediensten op deskundigheid, onafhankelijkheid en betrouwbaarheid toetsen. Naast de RvC bestaat sinds $1986.00 \mathrm{k}$ de Nederlandse Stichting voor de erkenning wan kalibratie (d.t.: meet-) en testlaboratoria en inspectieinstellingen (NKO/STERIN/STERLAB), welke organisatie zich, anders dan de RvC, uitsluitend op Nederlands territoir richt. I. $w$.m. afstemmings- en coördinatieproblemen tussen beide organisaties is thet de bedoeling op korte termijn te komen tot eén Nederlandse accrediteringsorganisatie. Aan die nieuwie organisatie, die de doorzichtigheid van de markt moet bevorderen en het algenneen belang moet dieners, worden eisen gesteld als: anslu iten bij de wettelijk verplich te keuringsregimes; nationaal en internationaal vertrouwen genieten; a fstemmingsproblemen reduceren; de effectiviteit en efficiency vergroten; duidelijktheid bieden ower de diensten die de keurings- en certificatie-instellingen mogen verwachten; en burilkbalar zijn voor de overheid als hulpmiddel bij regelgeving.

20. Andere door de raad erkende certificatie-instellingen (soms -in het kader van de temugtredende rol van de nationale overheid-door de Europese Commissie tevens aangewezen als 'notified bodies', waardioor hun verklaringen van EG-lype onderzoek geldig zijn binnen alle Europese lidstaten), die wellicht meer bekend zijin en een groter werkterrein hebben, worden in de Staatsalmanak aangemerkt als zbo's. Denk aan organisaties die keuringen verrichten $0 . \mathrm{g} . \mathrm{v}$. de Wet op de gevaartijke werktuigen (Sibl. 1952, 104): a. m.b.t. spanningsgevers voor schrikdraad en elektrisch materieel voor gebruik in explosieve omgeving: t.w. de nv tot Keuring van Elektronische Materialen; b. m.b.t. mobiele kranen en torenkranen: t. w. de stichting Keboma; c. m.b.t. liftuen en liftonderdelen: t. w. stichting Nedterlands Institumt voor Liffteclanjek: d. m.b.t. dorsmachines, stropersen en strobinders: t.w. de stichting Instituut voor Mechanisatie, Arbeid en Gebouwen; e. m.b.t. scheepscontainers: t.w. het Americam Bureau of Shipping; Llloyd's register of Shipping; Germanischer Lloyd; Nippon Kaji Kyokai; Det Norske Veritas; Registro Italiano Navale: Bureau Veritas. Niet alle instellingen beschouwen zich zelf ook als zbo; Bij navraag antwoordi $o_{*} \mathrm{~m}$. Lloyd's register of shipping, bij brief d.d. 13 mei 1993, dat de instelling "niet als een zbo kan worden aangemerkt", maar een "zelfstandige en onafhankelijke inspectie en certificatie-insteiling" is. De nota 
van in elk geval halfjaarlijkse schouwingen, toe op normnaleving door houders wan een certificaat. Bedoelde kwaliteitsnormen keren wel weer vaak terug in EG-regelgeving. ${ }^{21}$

Uit voorgaande blijkt in elk geval, dat de mogelijkheid bestaat om verder dan communautaire regelgeving gaande, dwingende (kwaliteits)regels op te stellen of keurmerken in te woeren ten aanzien van de nationale produktie en handel van levensmiddelen. Deze regels gelden dan voor aangeslotenen bij de verschillende controle-instellingen. Tegenwoordig is de tendens waarneembaar, ook op niet-aangeslotenen, in het bijzonder degenen die zich bezig houden met bedrijfsmatige handel, de normen van bepaalde keuringsinstellingen van overeenkomstige toepassing te verklaren. ${ }^{22}$ In dit verband doet het, op het extrakwaliteitstelsel gedrukte, stempel van vrijwilligheid vreemd aan.

\subsubsection{PRIVAATRECHTELIJKE KWALITEITSCONTROLE-INSTELLINGEN}

Bedoelde keuringsinstellingen dateren merendeels van vroeger. Conform art. $8^{23}$ junctis art. 15, derde lid, en art. 16 van de primair handelsbevorderende Landbouwkwaliteitswet ${ }^{24}$ kunnen een of meer privaatrechtelijke rechtspersonen met volledige rechtsbevoegdheid worden belast met: ten eerste, toezicht op de naleving door de bij hen aangeslotenen van bij of krachtens landbouwkwaliteitsbesluiten gestelde regelen; ten tweede, keuring van landbouwprodukten en toezicht daarop; en ten derde, uitvoering van de bij of krachtens landbouwkwaliteitsbesluiten gestelde regelen inzake betaling afhankelijk van de kwaliteit van produkten. Deze organen hebben in het algemeen de bevoegdheid voertuigen en andere plaatsen, waar landbouwprodukten aanwezig zijn, aan onderzoek te onderwerpen. Bovendien zijn deze organen (meestal onder betaling van schadevergoeding naar marktwaarde of waardevermindering) bevoegd monsters te nemen van die produkten. En zij hebben inzage van de bedrijfsboekhouding. Voldoen houders van landbouw-

20. $\rightarrow$

Normen, Certificaten en Open Grenzen, TK 1994-1995, 21670, nrs.7-8, p. 17, merkt dan ook terecht op dat Lloyds (en ook Veritas en in mindere mate KEMA) nooit een exclusieve, bevoorrechte positie heeft gekend in de zin dat directe binding met overheidsregelgeving, waaraan de instelling bestaansrecht ontleent, bestaat. Overigens strekt deze onafhankelijkheid er toe dat Lloyds e.d., wan oudsher nood gedwongen markt gericht, beter op concurrentie is voorbereid; En de stichting Instituut voor Mechanisatie. Arbeid en Gebouwen, antwoordt bij brief d.d. 24 mei 1993 het volgende: "Als instituut vam de Dienst Landbouwkundig Onderzoek, een onderdeel van het Ministerie van LNV, kan onze instelling niet gezien worden als ten volledig zelfstandig bestuursorgaan".

21. J.P.M. Hendriks en A. de Zeeuw, a.w., p.21, noemen bij voorbeeld de Europese richtlijn inzake algemene hygiëne biji de bereiding van lewensmiddelen.

22. Zie 0.a. Aanwijzingsbesluit verhandeling teeltmateriaal groente- en bloemgewassen (en nota van toelichting), 5 april 1967, Stbl. 1967, 219 , gewijz. 19 mei 1989, Stbl. 1989, 208/9; Vgl. Jaarverslag COZ 1991, Leusden, p.9, dat mellding maakt wan een wetswoorstel tot wijziging van de Lkw, dat de mogelijkheid biedt am controle-instellingen te belasten met de uitvoering van keuring en toezicht bij niet-aangeslotenen.

23. Bij de, in deze wettelijke bepaling geregeide, taakopdracht houdt de verantwoordelijke minister een slag on de arm. De attributie is afhankelijk van de ministeriële aanwijzing van een of meer privaatrechtelijke rechtspersonen met volledige rechtsbevoegdheid.

24. Landbouwkwaliteitswet, 8 april 1971, Stbl. 1971, 371, gewijz. 8 april 1976, \$tbl. 1976, 229. 
produkten niet (geheel) aan hun verplichtingen, dan voorzien de controle-instellingen in het nodige op kosten en risico van de houders.

De volgende zelfstandige bestuursorganen zijn onder meer aangewezen: het KwaliteitsControle-Bureau groenten en fruit ex art. 10 Landbouwkwaliteitsbesluit groenten en fruit ${ }^{25}$; het Centraal Orgaan Zuivelcontrole ${ }^{26}$ ex art. 13 Landbouwkwaliteitsbesluit boterprodukten ${ }^{27} /$ kaasprodukten $^{28}$ /poedervormige melkprodukten ${ }^{29}$ en art. 12 Landbouwkwaliteitsbesluit zuigellingenvoeding ${ }^{30}$ jo. art. 3 Statuten $\mathrm{COZ}^{31}$; de stichting Nederlandse Vleeswaren Kontrolle ${ }^{32}$ ex art. 8 Landbouwkwaliteitsbesluit Vleeswaren ${ }^{33}$; het Controlebureau voor Pluimvee, Eieren en Eiprodukten ex art. 2 Statuten $\mathrm{NEB}^{34}$; de Stichting Keur Alternatief voortgebrachte Landbouwprodukten ex art. 7 Landbouwkwaliteitsbesluit voor de biologische produktiemethode ${ }^{35}$ jo. art. 2 Statuten Skal ${ }^{36}$; de stichting Internationale Scharrelvlees Controle in gevolge art. 6 Landbouwkwaliteitsbesluit Scharrelvlees en -vleeswaar ${ }^{37}$ jo. Statuten ISC (voor controle bestaat ten dele $-t$. $w$. de controle op produktieverwerking en handel van ISC-scharrelvleeskippen en ISC-scharrelrundvlees- geen wettelijk kader); en de stichting Bloembollenkeuringsdienst in gevolge het Landbouwkwaliteitsbesluit bloembollen ${ }^{38}$.

Naast deze organisaties, is ook te denken aan controle-instellingen waarvan taken en bevoegdheden voortvloeien uit wet- en regelgeving inzake zaaizaad- en p》antgoed. Buj voorbeeld de stichting Nederlandse Algemene Keuringsdienst voor groente- en bloemzaden ex artt. 87-88/91 Zaaizaad-en plantgoedwet ${ }^{39}$ jo. art. 12 Algemeen reglement van de $\mathrm{NAKG}^{40}$ jo. art. 2 Keuringsreglement groenteplanten ${ }^{41}$. Of de stichting Nederland-

25. Landboumkwaliteitsbeslwit groenten en fruit" 5 aug. 1977, Stbl. 1977, 490.

26. Op 13 dec. 1990 vindt al installatie wan het voorlopig bestuur van de stichting Centraal Orgaan voor Kwaliteitsaangelegenheden in de Zuivel plaats. Zie COZ-Jaarverslag 1991 (p.8). De Bestuursbrief wass aanbieding van het jaamerslag 1993 meldt dat het COZ "per 16 september 1994 d.m.v. een juridisctue fusie overgaat in de stichting Centralal Orgaan voor Kwaliteitsaangelegenheden in de Zuivel (COKZ) die 8 jan. 1992 is opgericht (zie COZ-jaarverslagen 1992 en 1993, p.4).

27. Landbouwkwaliteitsbesinit boterprodukten, 3 april 1981, Stbl. 1981, 303.

28. Londbouwkwaliteitsbessitit kaasprodukten, J2976, 2 december 1981, Stbl. 1981, 726.

29. Landbouwkwaliteitsbesluit poedervarmige melkprodukten, $J 2790,1982,5 \mathrm{tbl}, 1982,632 / 667$.

30. Landbouwkwalîteitsbesluit zwigelingenvoeding. 1984, Stbil. 1984, 580.

31. Statuten stichting Centraal Orgaan Zwiwelcontrole, 1981, Stcrt. 1981, 207, gewijz. 1987, Stert. 1987, 108.

32. De NVK voert sinds medio december 1991 de controletalk van de stichting Nederlandse Baconcontrolle unit. Zie aanhef Statuten $N V K, 29$ sept. 1988, Stcrt. 5 jan. 1989, 4.

33. Landbouwkwaliteitsbesluit vleeswaren, 11774,10 sept. 1981, Stbl. 1981, 643.

34. Tot 12 mei 1993 fungeert de stichting Nederlands eiercontrole bureau nog als kwaliteitstoezichthouder.

35. Lkb biologische produktiemethode, 26 now. 1992, Stbl. 1992, 661, in: Skal, Statuten, reglemenren en. woorschriften, Zwolle, pp. 1-12 (pu. 3).

36. Statuten Skal, Stcrt. 1993, 73, in: Skal, Statuten, reglementen en voorschriften, Zwolle, suppl. aprill 1993, pp.1-17 (A.1).

37. Lkb scharrelvlees en -vleeswaar, 22 jan. 1992. Stbl. 1992, 102

38. Lkb regelen betreffende technisch en genetisch peil van de produktie van blaembollen, 24 now. 1980, Stbl. 1980,632 .

39. Zaaizaad-en plantgoedwet, 6 okt. 1966, Stbl. 1966, 455, gewijz, 26 juni 1986, Stbll. 1986, 388.

40. Algemeen reglement van de $N A K G$, bestuursbesluit 676, ministeriele goed keuring 13 febr. 1994 . 
se Algemene Keuringsdienst voor Siergewassen en de stichting Nederlandse Algemene Keuringsdienst voor Boomkwekerijprodukten. ${ }^{42}$

Zowel de rechtspersonen (als bedoeld in art. 8 Landbouwkwaliteitswet) als de keuringsinstellingen (als bedoeld in art. 87 Zaaizaad- en plantgoedwet) vallen onder het regime van de Wob en de Wno. ${ }^{43}$

Dit arsenaal van controlerende en keurende particuliere instellingen is niet compleet zonder de volgende toevoeging. Afgezien van de bovenstaande controle-instellingen op wettelijke grondslag, bestaan er ook controle-instellingen zonder zo'n basis (die in deze studie overigens buiten verdere beschouwing blijven).

De Stichting Kwaliteitsgarantie Vleeskalverensector ${ }^{44}$, bij voorbeeld, bevordert en garandeert de kwaliteit van kalwervoeders en kalfsvlees (als mede de afzet van conform geldende kwaliteitswetgeving geproduceerd kalfsvlees) ex art. 2 , eerste lid, Statuten $\mathrm{SKV}^{45}$. $\mathrm{Zij}$ doet dit echter niet uit hoofde van de Landbouwkwaliteitswet- en regelgeving. Haar oprichting dankt zij aan de Produktschappen voor respectievelijk Veevoeder en Vee en vlees. Zie respectievelijk art. 6 Verordening VVr kwaliteitscontrole vleeskalverensector 1990 en art. 5 Verordening PVV kwalititeitscontrole vleeskalverensector 1991. ${ }^{46}$ In een poging het imago van de vleeskalversector op te vijzelen, handhaaft hier het bedrijfsleven zélf eigen handel en wandel op grond van door betrokken bedrijven en belangenorganisaties, in onderling overleg, opgestelde regels. Daaronder valt het voor de keurende instelling elementaire Controle- en sanctiereglement ${ }^{474}$, op grond waarvan de SKV - conform artt. 17-19 Cr SKV - boeten kan opleggen die niet kinderachtig zijin. 49

41. Keuringsreglement groenteplanten, bestuursbesluit 667,26 april 1990 , ministeriele goedkeuring 16 aug. 1990.

42. Verontrust wijst de Algemene Rekenkamer, Zbo's en ministeriêle verantwoordelijkheid. TK 1994-1995, 24130 , nr.3, p. 21, er op dat de keuringsinstellingen voor plantaardig uitgangs/teeltmateriaal (werbonden met het ministerie van LNW) heffingen in rekening brengen die hun basis uitsluitend vinden in notarieel vastgelegde statuten. N.a.v, deze kritiek is de betrokken minister voomemens te woorzien in een publiekrechtelijke basis woor deze heffingen.

43. Aanwijzingsbesinut bestuursorganen Wob en Who d.d. 16 okt. 1993, Stbl. 1993, 535, p.8.

44. Hoewel de Algemene Rekenkamer, Zbo's en ministeriële verantwoordelijkheid, TK 1994-1995, 24130, nr. 3. p. 16, de SKV kenmerkt als zbo, maakt de minister van landbouw, natuurbeheer en visserij daartegen bezwaar.

45. SKV, Statuten, reglementen en voorschriften, 's-Graventhage, pp.66-76.

46. SKV, Staturen, reglementen en voorschriften, 's-Gravenhage, pp. 1-3 en pp.9-11.

47. Controle- en sanctiereglement SKV 199I, in: SKV, a. w, pp.77-89.

48. Om iedere onduidelijkheid amtrent, de in kort geding aangevochten, juridische status (voor in het bijzonder niet-aangeslotenen) weg te nemen, zijn de algemeen verbindende voorschriften uit bedoeld reglement opgenomen in respectievelijk het Beslwit VVr toezicht wleeskalversector d.d. 10 febr. 1992 en thet Uitvoeringsbesluit toezicht verordening PVV kwaliteitscontrole vleeskalversector d.d. 14 febr. 1992, in: SKV, a.

49. N.a.v. 2ware sanctionering door de SKV bepaalt de onafhankelijke Geschillencommissie SKV in 1992 bij herhaling, dat de "sanctieregeling van de SKV de WED (art. 5 WED - JGLWN) doorknist" "waarna vernietiging van de omstreden sanctiebesluiten volgt. Zie SKV, Jaarverstag 1992 ." s-Gravenhage, pp. 12-13 


\subsubsection{TOEZICHTSBEVOEGDHEDEN KWALITEITSCONTROLE-INSTELLINGEN}

De verschillende keuringsinstellingen kunnen de volgende handhavingsmaatregelen treffen.

Voor alle landbouwkwaliteitscontrole-instellingen geldt art. 15 Landbouwkwaliteitswet: "1. De opsporingsambtenaren ${ }^{50}$ zijn bevoegd voertuigen en andere plaatsen, waar produkten aanwezig zijn, welke aan de bij of krachtens een landbouwkwaliteitsbesluit gestelde eisen moeten voldoen, aan een onderzoek te onderwerpen en monsters te nemen van die produkten. Zij vergoeden de marktwaarde van de monsters, indien het verlangen daartoe te kennen wordt gegeven; 2 . De houder van de produkten is als dan verplicht de wan hem gevorderde medewerking overeenkomstig de aanwijzingen van de opsporingsambtenaren te verlenen, als mede, indien gevorderd, de nodige hulpmiddelen kosteloos te verstrekken. Wordt aan die verplichtingen niet voldaan, dan kunnen de ambtenaren op kosten en risico van de houder in het nodige voorzien; 3 . De bevoegdheden, in het eerste lid bedoeld, komen mede toe aan de door onze minister aangewezen personen, in dienst van een controle-instelling, voor zover het betreft voertuigen en andere plaatsen, waar aangeslotenen bij die instelling produkten voorhanden of in voorraad plegen te hebben. Het tweede lid is van overeenkomstige toepassing; 4 . Onze minister en onze ministers, wie het mede aangaat, kunnen tezamen nadere voorschriften geven betreffende de monsterneming, de verpakking, de conservering, de verzegelling , de verzending en het onderzoek der monsters." In gewolge art. $16 \mathbb{L k w}$ rust op allen, belast met controle of opsporing - op straffe van art. $272 \mathrm{WvSr}$ - een geheimhoudingsplicht.

\section{$\S 17.2$ Stichting Keur Alternatief voortgebrachte Landbouwprodukten}

Als controle-organisatie voor biologische produktiemethoden is de stichting Keur Alternatief voortgebrachte Landbouwprodukten ${ }^{51}$ aangewezen ex art. $8 \mathrm{Lkw}$ jo. art. 8 , tweede lid, EEG-verordening inzake biologische produktiemethode ${ }^{52}$.

De door het onafhankelijke Skal-bestuur (waarvan de voorzitter door de minister van LNV is benoemd ex art. 9 Lkb biologische produktiemethode) ${ }^{53}$ aangestelde directeur,

50. Ex art. IA Landbouwkwatireitsbeschikking kewring groenten en fruit, 24 aug. 1987, 57490, Stcrt. 1987. 163, zijn daarmee de ambtenaren van de Rijksdienst voor keuring van Vee en Vlees van het ministerie: van L\&V bedoeld. Voor overige opsporing, voor zover wallend onder de WED zijn de ambtenaren van de AID als opsporingsambtenaren aangewezen bij Ministeriële beschikking aanwijzing ambtenaren AMD als opsporingsambtenaren Lkw, 26 febr. 1974, Stcrt. 1974, 48.

51. Documentatiemateriaal over Skal per supplement gebundeld in: Skal, Statuten, reglementen en voorschriften, Zwolle.

52. Werordening $v / d$ raad w/d EG, 24 juni 1991, inz. biologische produktiemethode en aandwidingen diencangaande op landbowmprodukten en levensmiddelen, nr.2092/91. Publ. EG 1991, L 198, in: Skal, a.w., pp. $1-34$ (pt. 1).

53. Het valt de Algemene Rekenkamer, Zbo's en ministeriele verantwoordelijkheid, TK 1994-1995, 24130, m. .3, pp.4/41-42, op dat bij 4.1 organen (d.w.z. 28\%) van de door haar onderzochte zbo"s met een bestuur ten minste éen ambtenaar van het ministerie in het bestuur zitting heeft. Dit is vooral het geval bij het ministerie van landbouw, natuurbeheer en visserij. Wondt daarbij nog eens de mogelijkheid gerekend van ministerièle benoeming (of goedkeuring van benoemirng) en voordracht van bestuursleden, dan ligt het 
welke benoeming door de betrokken minister van goedkeuring moet zijn voorzien, heeft de bevoegdheid controleurs en inspecteurs, belast met het toezicht op de naleving van wet- en regelgeving ter zake, aan te nemen en te ontslaan ex art. 27 , derde lid, statuten Skal. Tevens verschaft hij bedoelde toezichthouders een schriftelijke lastgeving houdende een verklaring dat de desbetreffende functionarissen zijn belast met het toezicht op wetten regelnaleving.

\subsection{EUROPEES STREVEN NAAR HARMONISATIE REGELGEVING EN GELIJKWAARDIGE CONTROLE-INSTELLINGEN LIDSTATEN}

Dit strookt met het Europese streven om te komen tot een gelijkwaardig controlesysteem inzake biologische produktiemethoden in alle lidstaten. De preambule van vermelde EEGverordening stelt, dat bij "alle marktdeelnemers die produkten produceren en bereiden waarop aanduidingen voorkomen die verwijzen naar ecologische produktiemethoden, regelmatig controles dienen te worden verricht die aan communautaire minimumeisen ${ }^{54}$ voldoen en worden toegepast door daartoe aangewezen overheidsinstanties en/of door erkende en onder toezicht staande particuliere instanties". De instantie die dergelijke private organisaties kan erkennen, houdt - ex art. 9, vijfde lid, EEG-verordening biologische produktiemethode - bij het verlenen van erkenning rekening met: a. een door de om erkenning vragende organisatie ingediende standaardcontroleplan dat door haar voorgenomen toe te passen controle- en voorzorgsmaatregelen nauwkeurig beschrijft; $b$. de sancties die de organisatie mogelijk neemt; $c$. de beschikbaarheid van voldoende gekwalificeerd personeel, een adequate administratieve en technische uitrusting, ervaring op het gebied van de controle en betrouwbaarheid; en $\mathrm{d}$. de objectiviteit van de controle-instelling.

\subsubsection{TAAKSTELLING STICHTING KEUR ALTERNATIEF VOORTGEBRACHTE}

\section{LANDBOUWPRODUKTEN}

Ex art. 2, eerste $\|$ id, Statuten Skal ${ }^{55}$ beoogt de stichting door middel van het uitoefenen wan toezicht, keuring en controle, beoordeling en certificering de goede aanduiding van produkten als bedoeld in art. $1 \mathrm{Lkw}$, zijndle produkten voortkomend uit de biologische produktiemethode als mede voortkomend uit produktiemethoden die aan de Skal-normen voldoen, te bevorderen.

53. $\rightarrow$

percentage alls volgt: de ministeries zijn voor ruim twee derde wan de met hen verbonden zbo's betrokken bij de benoeming van de leden van het bestuur. De rekenkamer wijst er op dat vermenging van bestuurlijke en toezichthoudende verantwoordelijkheden van ambtelijke leden van dit besturur voor de hand ligt. Daarom doet de Algemene Rekenkamer terecht een waarschuwing uitgaan.

54. Zie bijlage III EEG-verordening Minimumeisem inzake controle en voorzorgsmaatsregelen in het kader van de in de arti. 8 en 9 EEG-verordening biologische produktiemethode bedoelde controle, over bij voorbeeld inspectieverslag, administratie, aantal inspectiebezoekem en toezichtsbevoegdheden.

55. Statuten stichting Skal, 3 maart 1993, Stcrt. 1993, 73. 
Daartoe houdt zij conform art. 3, eerste lid, Statuten Skal jo. art. 7 Lkb biologische produktiemethode toezicht op wet- en regelnaleving door bij haar aangeslotenen (d.w.z. verplicht aangeslotenen wit hoofde wan art. $4 \mathrm{Lkb}$ biologische produktiemethode ${ }^{56} \mathrm{jo}$. art. 4 Statuten Skal) keuringen te verrichten. Daarnaast reikt zij merken, tekenen of bewijsstukken uil met inachtneming van aanwijzingen voort vloeiend uit ministerieel rijkstoezicht. Tevens controleert en beoordeelt zij bij aangeslotenen de uitgeoefende produktiemethode (anders dan de biologische produktiemethode) en de daaruit voort komende produkten. Deze laatste taak werricht zij op basis van de Skal-normen als genoemd in overeenkomsten tussen $\mathbf{S k a l}$ en betrokken aangesloten. Deze, meestal rechtspersoonlijkheid bezittende, aangeslotenen zijn ex art. 4 Statuten Skal aangeslotenen uit hoofde van erkenning op basis wan: a. Skal-normen, welke normen conform art. 17, tweede lid, door het Skal-bestuur bindend kunnen worden verklaard; en b. een overeenkomst. Bovendien gaat Skal onrechtmatig gebruik van produktaanduidingen tegen. Ook voert zij contractueel overeen gekomen taken ten dienste van haar doel op het gebied van keuring, toezicht en certificatie - anders dan hiervoor bedoeld - uit. Overigens maakt zij gebruik van alle wettige en gepaste middelen welke voor het bereiken van haar doel dienstbaar kunnen zijn.

\subsubsection{Nalevingsplicht gecontroleerden}

Op elke aangeslotene rust een plicht tot stipte naleving van wet- en regelgeving. Als hij daarmee in gebreke blijft, is hij aansprakelijk ex art. 5, eerste lid, Statuten Skal, en blijft dat ex art. 6, tweede lid, Statuten Skal ook na zijn uittreden. Als uitvloeisel van de eis tot wet- en regelbetrachting moeten aangeslotenen alle verlangde medewerking verlenen aan Skal-controleurs en Skal-inspecteurs als mede aangewezen ambtenaren tijdens uitoefening van toezichtsbevoegdheden.

\subsubsection{Toezichtsbevoegdheden stichting Keur Alternatief woortgebrachte Landbouwprodukten}

Ter verzekering van een behoorlijk toezicht door Skal zijn aangeslotenen verplicht bedoelde personen en ambtenaren, in gevolge art. 3, tweede lid, Statuten Skal, toegang te verschaffen tot hun percelen, inrichting(en), opslag-en produktieruimten, de eenheid en terreinen, daarnaast moeten zij inzage verlenen van de (schriftelijke) administratie en de bescheiden bij controle of anderszins. Tot en met negen maanden na uittreding bestaat ex art. 6, vierde lid "Statuten Skal de plicht tot inlichtingenverschaffing benodigd voor de afhandeling van aangegane (contractuele) verplichtingen. Hiernaast zijn zij ex art. 4 Statuten Skal verplicht degenen die met produktenvervoer zijn belast te machtigen of zo nodig te gelasten om de Skal-controleurs en Skal-inspecteurs als mede de aangewezen toezichtsambtenaren op hun vervoermiddelen en terreinen en in hun opslagplaatsen toe te laten. En ook degenen die in hun opdracht zijn belast met produktvervaardiging kan worden toegestaan of zo nodig worden bevolen om bedoelde toezichthouders in hun

56. Landbouwkwaliteitsbeshit biologische produktiemethode, 26 nov. 1992, Stbl. 1992, 661, in: Skal, a.w., pp. $1-12$ (pu.3). 
bedrijfsruimten en op hun terreinen toe te laten. Bovendien kunnen zij produktafnemers in binnen- en buitenland verzoeken de toezichthoudende personen en ambtenaren in staat te stellen de door betrokken aangeslotenen geleverde gevignetteerde produkten in hun opslagplaatsen te inspecteren.

Ten aanzien van alles wat zij in verband met de uitoefening van hun functie omtrent de inrichting van de fabrieken, de bedrijven, de handel en andere persoonlijke en zakelijke omstandigheden van de aangeslotenen ervaren en/of te weten komen, bewaren de Skaltoezichthouders geheimhouding ex art. 27, zevende lid, Statuten Skal overeenkomstig art. 9 , zevende lid, sub b, EEG-verordening biologische produktiemethode. Deze geheimhoudingsplicht geldt ook na hun aftreden.

\subsubsection{MELD- EN BETAALPLICHTEN ONDER TOEZICHT GESTELDEN}

Wijziging van voor de controle-instelling relevante gegevens brengt een aangeslotene direct schriftelijk ter kennis van Skal ex art. 5, zesde lid, Statuten Skal.

Overigens heeft iedere aangeslotene, conform art. 9 , tweede lid, EEG-verordening biollogische produktiemethode, ex art. 5, wijfde lid, Statuten Skal junctis artt. 1-12 Bijdragereglement Skal ${ }^{57}$ de plicht om de voor toezicht, controle, keuring en certificering vereiste, naar drieërlei tarief $t . w$. eenmalige aansluitingskosten, jaarlijkse basisbijdrage en jaarlijkse variabele bijdrage ${ }^{58}$, vastgestelde financiële bijdragen te voldoen aan Skal. ${ }^{59}$ Skal is in gevolge art. $11 \mathrm{Lkw}$ juncto art. 28 , eerste lid, Statuten Skal belast met het financieel beheer als mede de inning van onkostenvergoedingen, contributies en boeten.

\subsubsection{RIJKSTOEZICHT EN (FINANCIËLE) VERSLAGLEGGING}

Inning van geldelijke bijdragen geschiedt onder toezicht van de minister van LNV. Even als op alle andere landbouwkwaliteitcontrole-instellingen oefent de minister van LNV ook op Skal rijkstoezicht uit. Ten behoeve van dit toezicht moet Skal alle inlichtingen verschaffen en alle medewerking verlenen aan de betrokken bewindspersoon ex art. 12 , vierde lid, Lkw jo. art. 47 Statuten Skal junctis artt. 1-5 Beschikking inzake het rijkstoezicht op de controle-instellingen ${ }^{60}$. Ter financiële verantwoording vooraf stelt het Skalbestuur jaarlijks een begroting op ex art. 28, derde lid, Statuten Skal.

Andere financiële verslaglegging is te vinden in het door een accountant jaarlijks uit te brengen boekhoudkundig rapport. Ex art. 29, tweede lid, Statuten Skal omvat dat minimaal een staat van baten en lasten, een balans en een bijbehorende toelichting. Bovendien stelt de directeur van Skal zelf elk jaar een jaarverslag van werkzaamheden op ex art. 30,

57. Bijdragereglememt Skal, besturursbesluit d.d. 29 april 1993, in: Skal, a.W., pp.1-4 (0.2a).

58. Tariefstructwur en tarieven Skal 1994, in: Skal, a.w., pp.1-8 (0.2b).

59. Kosten verbonden aan AID-optreden blijwen wel woor rekening van de owerheid. Gezien de primaire verantwoordelijkheid van Skal zijn deze lasten beperkt van omwang. Nota van toelichring Lkb biologische produktiemethode, a.w., p.12.

60. Beschikking inzake rijhstoezich op controle-instellingen, 15 aug. 1977, J2094, Stcrt. 1977, 159. 
eerste lid, Statuten Skal. En elk jaar wordt een lijst van aangeslotenen bijgewerkt ex art. 30, tweede lid, Statuten Skal, waarmee uitvoering wordt gegeven aan art. 8, derde lid, jo. art. 9, achtste lid, sub b, EEG-verordening inzake biologische produktiemethode. In dat register staan ex art. 9, eerste lid, Landbouwkwal iteitsregeling biologische produktiemethode ${ }^{61}$ gegevens als naam en adres van een aangeslotene, de aard en de lokatie van uitoefening van zijn activiteiten, en ook de datum waarop hij voor het laatst bij of krachtens het $\mathbb{L k b}$ niet toegestane bestrijdingsmiddelen en dergelijke heeft gebruikt.

Met de lijst van marktdeelnemers, het jaarverslag, controle-, keurings- en merkreglementen als mede organisatie-, werkwijze- en sanctieregels moet de Europese Commissie bekend worden gemaakt, opdat de commissie deze gegevens jaarlijks kan publiceren ex art. 15 EEG-verordening biologische produktiemethode.

\subsubsection{MAATREGELEN BI NIET-NALEVING: MERKVERWIJDERING OF MERKGEBRUIKS- VERBOD}

Als de stichting constateert dat betalingsverplichtingen of plichten inzake het aanduiden, vermeldingen en merken van produkten niet worden nageleefd, verplicht zij ex art. 24, vijfde lid, $\mathrm{Cr}$ biologische produktiemethode jo. art. $8 \mathrm{Lkb}$ biologische produktiemethode en voorgeschreven in art. 9, negende lid, sub a, jo, art. 10, derde lid, sub a, EEG-verordening biologische produktiemethode, de betrokken overtreder tot het verwijderen of doen verwijderen van onjuiste of ontoereikende aanduidingen. Bij evidente of langdurige overtreding bestaat, conform art. 24 , zesde $\$ id, $\mathrm{Cr}$ biologische produktiemethode waarmee gevolg wordt gegeven aan art. 9, negende lid., sub b, jo. art. 10, derde lid, sub b, EEG-verordening biologische produktiemethode, de mogelijkheid betrokken marktdeelnemer het recht te ontnemen om de aanduiding te gebruiken gedurende een bepaalde periode.

\subsubsection{TUCHT- EN SANCTIERECHT OP GROND VAN PUBLIEK-EN PRIVAAT- RECHTELUKE NORMEN}

Elke aangeslotene die niet voldoet aan bovengenoemde nalevings- en aansprakelijkheildsplicht neergelegd in art. 5 Statuten Skal, komt - voor zover de officier van justitie, na overleg met de voorzitrer en anders de directeur wan $S k a l^{62}$, niet beslist dat overtreding strafrechtelijk wordt afgedaan (art. 32 Statuten Skal jo. art. 12, vierde lid, Tuchtreglement Skal ${ }^{63}$ ) - op grond van een door een Skal-controleur opgemaakte tuchtrechtelijke verklaring ex art. 10 Tuchtreglement Skal, bevattende alle relevante feiten met betrekking

61. Landbouwkwaliteitsregeling biologische produktiemethode, 23 dec. 1992, J9219842, Stcrt. 1992, 253,

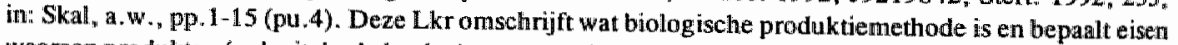
walaraan produkten (ook uit derde landen) moeten woldoen om m.b.t. die produkten aanduidingen, welke naar die produktiernethode verwijzen, te gebriken.

62. B. Wessels, Verzelfstandiging: enkele kantrekeningen wit het vermogensrecht, in: S\&V, nr.3, meitjumi 1994, pp.71-77, i.h.b. p.74, acht dit een schrijnend voorbeeld van het gegeven, dat waarschuwingen tegen het doen overgaan van strafrechtelijke bevoegdheden op (verzelfstandigkle) stichtingen en verenigingen in de wind worden geslagen.

63. Tuchtreglement Skal, bestuursbesluit 3 maart 1993, in: Skal, a.w., pp.1-10 (pu.6b). 
tot de overtreding, in aanmerking voor een tuchtmaatregel. Het door het Skal-bestuur ex art. 8 Tuchtbesluit Lkw samengestelde tuchtgerecht ${ }^{64}$ heeft ex art. 35 Statuten Skal jo. art. $13 \mathrm{Lkw}$ jo. art. 8 Tuchtreglement Skal de mogelijkheid tot: a. berisping; b. geldboete wan maximaal tienduizend gulden waaraan het bestuur ex art. 37 statuten Skal een bijzondere bestemming moet geven; c. het stellen van aangeslotene onder verscherpte controle op zijn kosten voor ten hoogste twee jaren; en d. openbaarmaking van de tuchtbeschikking op kosten van de aangeslotene. Tegen tuchtbeschikkingen is, in gevolge art. 36, eerste lid, Statuten Skal, beroep aan te tekenen bij het College van Beroep voor het Bedrijfsleven.

Andere, dan onder art. 32 Statuten Skal vallende, overtredingen van de nalevingsplicht van aangeslotenen komen in de regel voor de sanctiecommissie van Skal. Zie artt. 38-43 Statuten Skal junctis artt. 1-31 Sanctiereglement Skal ${ }^{65}$. Deze commissie heeft de zelfde sanctiemogelijkheden. Ten aanzien van haar besluiten geldt het CBB als instantie van hoger beroep. De sanctiecommissie behandelt slechts overtreding van de privaatrechtelijke Skal-normen.

De beoordeling van controlerapporten op basis van Skal-normen geschiedt tot 1993 nog door de Technische Commissie Erkenningen. Het besluiten over toelating, het opleggen van sancties en ook het intrekken van een - op aansluitingserkenning gerichte - overeenkomst met betrekking de privaatrechtelijke normen is door het Skal-bestuur opgedragen aan die commissie. Deze commissie functioneert volgens een huishoudelijk reglement. De commissie, waarin Skal-directeur, hoofdcontroleurs en een secretaris deel nemen, bespreekt alleen controlerapporten als "de afhandeling reden geeft tot discussie, of als er aanwijzingen zijn dat zwaardere sancties dan een schriftelijke waarschuwing gerechtvaardigd zijn" . ${ }^{66}$ In 1992 behandelt de TCE 52 rapporten. In 1993 gaat de beslissingsbevoegdheid, omtrent op te leggen sancties aan de hand van uitgevoerde controles op basis van geldende normen, van de TCE over op respectievelijk de sanctiecommissie en het tuchtgerecht. ${ }^{67}$

Het verschil tussen privaatrechtelijke en publiekrechtelijke regels doet zich ook voor in de verschillende controlereglementen. Het stichtingsbestuur heeft ex art. 31, tweede lid en derde lid, Statuten Skal jo. art. 4, tweede lid, Lkb biologische produktiemethode jo. art. 9 Landbouwkwaliteitsregeling biologische produktiemethode de taak om controle-, keurings- en keurmerkreglementen vast te stellen. Deze opdracht wordt aanschouwelijk met invoering van het Controlereglement biologische produktiemethode ${ }^{68}$ en het Con-

64. Over werkwingze vooral Twchtrechubesuit $L k w, 12$ juli 1979, Stbl. 1979, 455 .

65. Sanctiereglement Skal, bestuursbesluit 2 sept. 1993, in: Skal, a.w., pp.1-8 (pr.3).

66. Skal, Jaarwerslag 1992, Zwolle, 1993, p.31.

67. Skal, Joarverslag 1993, Zwolle, 1994, p.7.

68. Controlereglement bialogische produktiemethode betreffende het verloop van de contrale ent het uitreiken wan tekenen en bewijsstukken inz. de biologische produktiemethode en de daaruit voankomende produkten. in gevolge het LKb biologische produltiemethode, besturarsbesiuit 29 april 1993, in: Skal, a.w., pp.1-31 (pu. 5). 
trolereglement Skal-controle (gerelateerd aan het reglement inzake verkrijging en gebruik

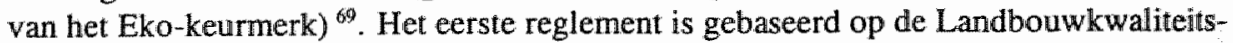
wetgeving en -besluitvorming. Het andere reglement vloeit voort uit, (nog) niet door een EEG-verordening vervangen en vervolgens evenmin in Nederlandse wet- of regelgeving. geïmplementeerde, privaatrechtelijke normen. Dergelijke Skal-normen, door het Skalbestuur mogelijk voorzien van een verbindendverklaring, worden ontwikkeld door de Norm Ontwikkelings Commissie in samenspraak met bellanghebbenden.

\subsubsection{CERTIFICERING}

Beide documenten zijn tot op zeker niveau identiek. Daarom kan het Controlereglement biologische produktiemethode alleen als voorbeeld dienen. In dat reglement staat in grote iijnen het volgende.

Voor aansluiting van akker-en tuinbouwbedrijven (m.a.w.: primaire produktie-eenheden) kan Skal bedrijfsaansluitingscertificaten ex artt. $2-6 \mathrm{Cr}$ biologische produktiemethode/artt. 2-6 Cr Skal-controle af geven. Voor aansluiting van eenheden voor verwerking, verhandeling en marktklaar maken van plantaardige produkten of levensmiddelen die hoofdzakelijk plantaardige ingrediënten bevatten (m.a.w.: secundaire produktieeenheden) verstrekt Skal zo nodig procesregistratiecertificaten ex artt. 7-11 Cr biologische produktiemethode/artt. 7-11 $\mathrm{Cr}$ Skal-controle. Met oog op de registratie van te bereiden, te verwerken of marktklaar te maken van plantaardige produkten en van levensmiddelen die hoofdzakelijk plantaardige ingrediënten bevatten, kan Skal produktregistratiecertificaten ex artt. $12-16 \mathrm{Cr}$ biologische produktiemethode/artt. 12-16 $\mathrm{Cr}$ Skalcontrole, verstrekken. In het kader van aansluiting van een importeur inzake het invoeren (inclusief uit derde landen) van plantaardige produkten en van levensmiddelen die hoofdzakelijk plantaardige ingrediënten bevatten, is Skal de bevoegde instantie om importeursaansluitingscertificaten ex artt. 17-20(21) Cr biologische produktiemethode/artt. 1720(21) $\mathrm{Cr}$ Skal-controle af te verlenen. En ten behoeve van gesloten vervoer- en gebruiksverpakkingen, ligt het in de mogelijkheden van Skal om Skal-certificaten ter vergezelling ex art. $22 \mathrm{Cr}$ biologische produktiemethode/art. $22 \mathrm{Cr}$ Skal-controle verlenen.

Vrij wel al deze certificaten worden telkens voor een jaar in origineel af gegeven ex art. 3 , tweede lid jo. art. 4, eerste lid, art. 8, tweede lid jo. art. 9 , eerste lid, art. 13 , tweede lid jo. art. 14, eerste lid, art. 18, tweede lid jo. art. 19, eerste lid, Cr biologische produktiemethode. De certificaathouder dient een authentieke verklaring te bewaren, in zijn administratie die overigens een adequate controle mogelijk moet maken ${ }^{70}$ ex art. 4 ,

69. Controlereglement Skal-controle betreffende het werloop van de controle en het witreiken van tekenen ten bewijsstukken. als bedoeld in art. 3, eerste lid, sub e, van de Statuten shal, in gevolge de in de Skalnormen amschreven produktiemethode en de daaruit voorkomende produkten, bestuursbesluit 30 sept. 1993, in: Skal, a.w., pp.1-34 (pr.2).

70. De bewijsplicht ter zake nust kennelijk op de toezichthouder. Uit Meeswaremfabriek Th.S. van der Laan bv vis. Het produktschap voor Vee en Vees, CBB 13 aug. 1993, AB 1995, 49, blijkt het wolgende. Hiet PVV wordert van een onder toezicht gestelde vleesexporteur uitvoerrestituties en monetaire compenserende bedragen terug. Het PVV vindt namelijk dat ter verkrigging daarvan zo danig onjuiste/onwolledige 
tweede lid jo. art. 5, art. 9, tweede lid jo. art. 10, art. 14, tweede lid jo. art. 15, art. 19, tweede lid jo. art. $20 \mathrm{Cr}$ biologische produktiemethode. Bij verlies kan hij geen rechten ontlenen aan het uit zijn bezit geraakte certificaat. Ook kan het uit een verleend certificaat voort wloeiende recht tot het aanbrengen van aanduidingen, vermeldingen en merken vervallien, als een certificaat ongeldig wordt door wijzigingen op het betrokken bedrijf leidend tot omstandigheden die, waren zij ten tijde van afgifte van het certificaat aanwezig en bekend geweest, certificaatverlening in de weg zouden hebben gestaan. Een ongeldig certificaat moet op eerste vordering aan een controleur worden af gegeven. Zie art. 3, vierde lid jo. art. 4, derde lid, art. 8, vierde lid jo. art. 9, derde lid, art. 13, vierde lid jo. art. 14, vierde lid, art. 18, vierde lid jo. art. 19, derde lid, Cr biologische produktiemethode.

\subsubsection{Certificaatverlenings- en controleprocedure}

In feite zijn verleningsprocedure en inhoud (rechten en plichten) van de verschillende certificaten uniform. Kort gezegd verstrekt Skal, ex art. 2, eerste lid, art. 7, eerste lid, art. 12, eerste lid, art. 17, eerste lid, vgl. art. 21, tweede lid, $\mathrm{Cr}$ biologische produktiemethode, een certificaat als blijkt, dat een betrokkene daartoe een schrifteijjk aanvraagformulier met noodzakelijke bijlagen bij het Skal-bestuur indient en hij de vereiste financiële bijdrage voldoet. Door ondertekening van dat aanmeldingsformulier verplicht de betrokkene zich, in gevolge art. 2, tweede lid, art. 7, tweede lid, art. 12, tweede lid, art. 17, tweede lid, art. 21 , weede lid, $\mathrm{Cr}$ biologische produktiemethode, tot het nakomen van de eerder genoemde verplichtingen ex art. 5 Statuten Skal. Daarom moet hij geoorloofd optreden van Skal-controleurs en -inspecteurs tegen zich laten gelden.

gegevens zijn werstrekt dat a. op de aanwratag woor de gelden anders zou zijn beslist als het PVV volledig bekend was geweest met de juiste omstandigheden dan wel b. in gevolge een toepasselijk cornmunautair woorschrift op de gevragde gelden geen aanspraak kon worden gemaakt. Wat laatst genoemd pumt betreff oondeellt het CBB, dat een verplichting tot het voeren en bewaren van een administratie pas na de feitelijke Wheesuitvoer van de onder toezicht gestelde wordt opgenomen in een nationaal In- en uitvoerbesluit landbotwgoederen. De reeds eerder tot stand gekomen EG-richtijn, waarin de administratieplicht is Verwat, kan - wolgens het aan onder meer het arrest Marshall refererende CBB-geen verplichtingen aan panticullieren opleggen. De oplossing moet dus liggen in de reguliere administratiegewoonten. In casu is de aanleiding voor thet terugvorderingsbesluit de boekhoudkundige nacontrole verricht door de AID (dat de AID daarbij stuit op een gebrekkige administratie acht thet CBB niet in geschil). Als de betrokken exporteur wia daartoe gebruikelijke formulie ren aanspraak makt op bepalalde gellden, is het an PVV om o.g. * - de controlebevindingen van de AID-aă te tonen dat de beschikbare administratieve gegevens van de exporteur miet kloppen (d.w.z. een woor juist te houden verantwoording vormen van de werkelijk uitgevoerde goederen). Daarna dient de exporteur het tegendeel te bewijzen. De door het CBB aangestelde deskundigen komen, zonder te beschikken over de onder de AID berustende controledossiers, echter tot de conclusie dat thet PVV miet heeft aangetoond dat de bij betrokken aangifte vermelde gegevens alle juist waren". Bovendien merkt met CBB aan dat" "is gesteld noch gebleken, dat de vastgestelde gebreken in de administratie wan de exporteur zo danig waren, dat zij bet aantonen dat niet kam worden aangenomen dat de bij de betrokken aangiften vermelde gegevens alle juist warem., in feite onmogelijk maakten, zodat het $\mathrm{CBB}$ aan de wraag, welke gevolgen die onstandigheid zou hebben, niet toe komt". Het CBB concludeert dat het bestreden PVV-besluit strijdig is met het algemeen beginsel wan zorgvuldige (besiuit) voorbereiding en ook met diat van deugdelijke (besluit)motivering. 
Na bevestiging door de directeur van Skal van bedrijfs- of importeursaansluiting dan well proces- of produktregistratie, verrichten Skal-controleurs inspectie bij betrokkene ex art. 2 , derde tot en met vijfde lid, art. 7 , derde tot en met vijfde lid, art. 12 , derde tot en met vijfde lid, vgl, art. 17, derde lid, $\mathrm{Cr}$ biologische produktiemethode. Hiervan wordt inspectieverslag gedaan, dat mede door de gecontroleerde wordt ondertekend. Op basis van vooral deze controle-rapporten kan de Skal-directeur het maandelijks overzicht wan toezichtsactiviteiten op stellen om dat vervolgens, ex art. 23, vierde lid, $\mathrm{Cr}$ biologische produktiemethode, ter hand te stellen van de voorzitter van Skal. Een inspectieverslag vermeldt de gecontroleerde eenheden, opslagplaatsen, percelen e.d., de afspraken van de controleur met de gecontroleerde ${ }^{71}$ en ook alle overige concrete maatregelen die nodig zijn om correcte wet-en regelnaleving daar te bewerkstelligen. Zie art. 2, vijfde tot en met zesde lid, art. 7 , vijfde tot en met zesde lid, art. 12, vijfde lid, jo. art. 23, derde lid, $\mathrm{Cr}$ biologische produktiemethode. Sinds 1993 bestaat een standaard inspectierapport. ${ }^{72}$

Als maatregel kan de betreffende controleur, volgens art. 2, derde lid en zevende lid, art. 7 , derde lid en zevende lid, art. 12, derde lid en zesde lid, jo. art. 24, eerste tot en met derde lid, $\mathrm{Cr}$ biologische produktiemethode, een aanwijzing aan het betrokken bedrijf geven. Deze aanwijzing betreft produktie- of afleveringswijze, aanduiding- of merkaanbrenging en anders aankoop- of vervoerswijze. De aanwijzing kan mede betrekking hebben op de organisatorische en administratieve voorzieningen van het gecontroleerde bedrijf.

\subsubsection{RECHTSBESCHERMING EN KLACHTBEHANDELING}

Degene die zo'n aanwijzing krijgt kan daartegen, zo snel mogelijk, een schriftelijke klacht indienen bij een hoofdcontroleur (of - i.g. v. bezwaar tegen een eerste Skal-beslissing tot ongeldigverklaring van een certificaat, een afkeuring of ontzegging van het recht aanduidingen te mogen gebruiken - bij een door laatst genoemde aangewezen assistenthoofdcontroleur), die zo spoedig mogelijk uitspraak doet. Zie art. 2 , zevende lid, art. 7 . zevende lid, art. 12, zesde lid, jo. art. $25 \mathrm{Cr}$ biologische produktiemethode. Van diens uitspraak staat weer beroep open bij de directeur van Skal. Dit geldt ook als de hoofdcontroleur direct bij de bestreden beslissing is betrokken, waardoor hij onbevoegd is om de klacht te behandelen. Degene die bezwaar aan tekent tegen een eerste Skal-beslissing tot ongeldigverklaring van een certificaat, een afkeuring van percelen, bedrijven en partijen, of ontzegging van het recht aanduidingen te mogen gebruiken kan, ex art. 25, achtstellid, Cr biologische produktiemethode, verplicht worden een (door de Skal-directeur vastgestelde) cautie te storten, welke aan Skal vervalt, indien afwijzing van het bezwaar wolgt. Tegen zo'n afwijzende beslissing kan weer beroep worden ingesteld bij de beroepscommissie van Skal ex art. 25, negende lid en tiende lid, $\mathrm{Cr}$ biologische produktiemethode.

71. Hienuit blijkt de toegenomen verantwoondelijkheid van controleurs. Skal, Jaarversiag 1992, 2wolle. 1993, p.9.

72. Skal, Jaarwerslag 1992, Zwolle, 1993, p.43. 


\subsubsection{CHFERMATIGE GEGEVEMS STICHTING KEUR ALTERNATIEF VOORTGEBRACHTE LANDBOUWPRODUKTEN}

De ijver wan de, aan de hand van controlehandboeken werkende, toezichthouders in dienst van Skal, onderverdeeld in een afdeling controle primaire produktie (pp), een afdeling secundaire produktie (sp) en een internationale afdeling, resulteert in het volgende.

Wat betreft primaire produktie is volgens het werkplan voor 1992 uitgegaan van twee controlebezoeken per aangesloten bedrijf per jaar. Niet alleen routinematige controles ter plaatse, maar ook gerichte steekproefsgewijze controles bij gevoelige branches zijn uitgevoerd. In verband met vergroting van efficiency van de Skal-organisatie sturen controleurs, sinds medio 1992, niet meer altijd een afhandelingsvoorstel na controlebezoek. Slechts in die gevallen "waarin een sanctie wordt opgelegd of het zinvol wordt geacht om een bevinding schriftelijk te bekrachtigen " ontvangt de betrokken gecontroleerde de conciusies van gedane inspectie. ${ }^{73}$ Tijdsbesparing uit zich ook het in toenemende mate geautomatiseerd verwerken van controlegegevens. Eind 1991 zijn 225 primaire producentem bij Skal aangesloten, en in 1992 zijn dat er (door aansluiting van alle biologische dynamische bedrijwen) 406. ${ }^{74}$ Bij deze producenten legt Skal-personeel in 1991 715 en in 1992671 controlebezoeken af. ${ }^{75}$ Aan primaire producenten worden in 1992 wegens verschillende overtredingen, al dan niet bij het zelfde bedrijf, 17 schriftelijke waarschuwingen gegeven, en 9 keer vindt produktafkeuring plaats. ${ }^{76} \mathrm{De}$, aan primaire producenten gelieerde, secundaire producenten die zich bezig houden met eerstelijns verwerking krijgen geen sancties opgelegd, behoudens afkeuring van enige in de handel gebrachte produkten. Overigens schrijft Skal voor de oogst over 1992 wan deze primaire produktie en daaraan gekoppelde secundaire produktie respectievelijk 293 en 236 certificaten uit. ${ }^{77}$

De volgende gegevens zijn bekend over 1993. ${ }^{78}$ In het kader van de controle primaire produktie, anders gezegd: landbouwcontrole, waarbij ook in 1993 (even als bij de controle sp) het streven naar een efficiëntere en effectieve controlewijze centraal staat - waarvan de voorbedrukte controlerapporten al dan niet met specifieke bijlagen als mede het door aangeslotenen zelf invuller van Skalbonnen inzake het gebruik van produktaanduiding getuigen - wordt conform het controlereglement minimaal een keer volledig controle verricht bij aangesloten bedrijven. Bij zowel de afdeling pp als de afdeling sp, krijgt controle worm via basiscontroles gecombineerd met steekproefcontroles. Hierbij treden controleurs, onder strikte coördinatie van een hoofdcontroleur, vooral sturend op. Zo nodig geven zij concrete aanwijzingen. Eind 1993 zijn 455 primaire producenten aangesloten bij Skal. Bij deze aangeslotenen voert Skal in 1993813 controles uit. Ten aanzien

73. Skal, Jaanerslag 1992, Zwolle, 1993, p.9.

74. Skal, Jaarwerslag 1992, Zwolle, 1993, p.10.

75. Skal, Jaanersilag 1992, Zwolle, 1993, p.11.

76. Skal, Jaarverslag 1992, Zwolle, 1993, p. 12.

77. Skal, Jaarversiag 1992, Zwolle, 1993, p.15.

78. Skall, Jaarverslag, 1993, Zwolle, 1994, pp.12-18. 
van alle daarbij geconstateerde overtredingen worden aanwijzingen gegeven. Bovendien vindt wijf keer ontzegging plaats van het recht op gebruik van het EKO-keurmerk en de aanduiding 'biologisch'.

Wat betreft de eigenlijke secundaire produktie staan controlebezoeken ook in het kader van doelmatig werken. Tijdsbesparing treedt op door bezoeken alleen af te leggen op afspraak, waardoor de gecontroleerde voorbereidingen, vooral ordening van zijn administratie, kan treffen. ${ }^{79} \mathrm{Om}$ aan eisen van efficiency en efficiëntie nog meer te voldoen, wenst Skal - wat betreft afdeling controle secundaire produktie - "het, op basis van het Lkb biologische produktiemethode, toebedelen van meer bevoegdheden aan de controleurs, waardoor meer zaken sneller en ter plekke bij het gecontroleerde bedrijf afgehandeld kunnen worden". ${ }^{80}$ Met de ruime toezichtsregeling in afdeling 5.1 Awb moet deze wens toch al redelijk zijn ingewilligd. Skal registreert eind 1991 in totaal 235 aangeslotenen waarvan 105 procesaansluitingen van secundaire producenten en eind 1992162 procesaansluitingen sp. ${ }^{81}$ Daarnaast telt Skal eind 19912000 en eind 19922469 produktaansluitingen. ${ }^{82}$ In 1992 worden 355 controles uitgevoerd tijdens 243 inspectiebezoeken. ${ }^{83}$ Voor hierbij geconstateerde wezenlijke overtredingen volgen in 19923 herhaalde schriftelijke waarschuwingen plus boete, 2 verscherpte controles, 10 boeten en 13 produktafkeuringen. ${ }^{84}$

In 1993 geeft Skal, op grond van het Controlereglement, de eerste proces-, produkt- en importeursregistratiecertificaten af aan bedrijven die biologische produkten bereiden. De afdeling $s p$, dat is de afdeling die toezicht houdt op bereiders of verwerkers van biologische produkten, controleert in 1993 gemiddeld tweejaarlijks. Skal registreert eind 1993240 aangesloten bereiders, waarbij 109 keer sprake is wan nieuwe procesaansluitingen, daarnaast telt Skal eind 1993 in totaal 2899 produktregistraties. ${ }^{86}$ Van de in 1993 443 afgelegde inspectiebezoeken legt het Skal-personeel 524 controlerapportages af. ${ }^{87}$ In hierbij geconstateerde overtredingen acht Skal het in 9 gevallen noodzakelijk een tuchtrechtelijke verklaring, of anders een verklaring van overtreding, op te leggen.

Uit efficiency-overwegingen fuseert de afdeling landbouw controle, begin 1994, met de afdeling bereiders controle. ${ }^{88}$

79. Skal, Jaarverslag 1992, Zwolle, 1993, p.17.

80. Skal, Jaarverslag 1992, Zwolle, 1993, p.44.

81. Skal, Jaarverslag 1992, Zwolle, 1993, p.18.

82. Skal, Jaarverslag 1992, Zwolle, 1993, p. 20.

83. Skal, Jaarverslag 1992, Zwolle, 1993, p. 20.

84. Skal, Jaarverwlag 1992, Zwolle, 1993, p.22.

85. Skal Nararverslag 1993, Zwolle, 1994, p.18.

86. Skal Jaarverslag 1993, Zwolle, 1994, p. 20.

87. Skal, Jaarverslag 1993, Zwolle, 1994, p.21.

88. Skall, Jaarverslag 1993, Zwolle, 1994, p.7. 
Wat betreft internationale controle schrijft Skal in $1992573^{89}$ en in $1993412^{\circ 0}$ certificaten voor importhandel uit Europese of derde landen uit. Controle in het buitenland wordt vrij wel altijd aangekondigd. Vaak voeren ook door Skal ingehuurde controleurs in het betrokken land ter plekke controle uit. Dat heeft flexibiliteits-en kwaliteitsvoordelen: a. taalbarrières verdwijnen; $b$. gevoelige projecten kunnen intensief worden gecontroleerd; en c. de controle kost minder en geschiedt sneller. ${ }^{91}$ Bij controle van projecten met grote groepen traditionele telers, geschiedt controle steeksproefsgewijs in voor ziekten en plagen gevoelige perioden, daarnaast bestaat controle op door telers zelf uitgevoerde produktkeuring. ${ }^{92}$ Het aantal internationale controles betreft in 1993 $63 .{ }^{93} \mathrm{Bij}$ geconstateerde overtredingen volgt in 1992 voor 13 gevallen en in 1993 voor 7 gevallen produktafkeuring.

Naast het op contractbasis uitvoeren van controles in het buitenland, heeft de internatiomale controleafdeling tot taak om de garantie van geïmporteerde biologische produkten te verifiëren (certificeringprocedures) ${ }^{95}$ als mede internationale contacten en overlegstructuren te ontwikkelen en uit te bouwen. ${ }^{96}$

Ten slotte geldt voor alle controleafdelingen dat zij zoeken naar de juiste taakafbakening en samenwerkingsmogelijkheden met andere keurings- en controle-instellingen als mede opsporingsinstanties waaronder de AID. ${ }^{97}$ In 1993 maakt Skal, ter versterking van elkanders controleopdrachten, praktische werkafspraken met zowel de AID als de Hoofd Inspectie Gezondheidsbescherming. ${ }^{98}$

\section{\$ 17.3 Kwaliteits-Controle-Bureau groenten en fruitprodukten}

Wat betreft groenten- en fruitprodukten ${ }^{9}$ is de vereniging Kwaliteits-Controle-Bureau Groenten en Fruit de aangewezen keuringsinstantie.

89. Skall, Jaarwerslag 1992, Zwolle, 1993, p.24.

90. Skal Jaawerskg 1993, Zwolle, 1994, p.25.

91. Skal, Jacrverstag 1993, Zwolle, 1994, p.27.

92. Skal, Jaarwerslag 1993, Zwolle, 1994, p.23.

93. Skal, Jaarverslag 1994, Zwolle, 1994, p.25.

94. Skal, Jaanerslag 1993, Zwolle, 1994, p.27.

95. Owerigens worden certificaten voor transacties binnen de EG nauwelijks nog uitgeschreven. De meeste produkten zijn tegenwoordig voorzien van de juiste aanduidingen. Zie Skal, Jaurverslag 1993, Zwolle, 1994, p.25.

96. Skal, Jaanerslag 1992, Zwolle, 1993, p.23.

97. Skal, Jaarwerslag 1992, Zwolle, 1993, p.43.

98. Skal, Jaarversiag 1993, Zwolle, 1994, pp.13/19.

99. Als vermeld in Landbouwkwaliteitbeschikking aanwijzing groenten en fruit, 9 sept. 1977, 1742 , Stcrt. 1977, 182, gewijz. 29 jan. 1986, J77, Stcrt. 1986, 25. 


\subsubsection{TAAKSTELLING KWALITEITS-CONTROLE-BUREAU GROENTEN EN FRUTT- PRODUKTEN}

In gevolge art. $10 \mathrm{Lkb}$ groenten en fruit jo. Statuten $\mathrm{KCB}^{100}$ is het $\mathrm{KCB}$ belast met het toezicht op de naleving door de aangeslotenen (veilingen of bedrijven) van het bij of krachtens dit besluit bepaalde, als mede met keuring als bedoeld in art. $7 \mathrm{Lkb}$ groenten en fruit, bij zijn aangeslotenen. Overigens is het bureau bevoegd tot het uitreiken van de merken, tekenen of bewijsstukken, bedoeld in art. 8 Lkb groenten en fruit, uitsluitend aan aangeslotenen. Begin 1993 zijn de statuten van het KCB gewijzigd als volgt. Behalve reguliere aansluiting, is nu ook speciale aansluiting als merkaanbrenger mogelijk. ${ }^{101}$

Als regulier aangeslotenen telt het KCB begin 199126 veilingen, 299 sorteer- en pakstations en 548 overigen. ${ }^{102}$ In januari 1992 liggen deze aantallen op 23, 303 en $577 .{ }^{100}$ Aanvang 1993 luiden de getallen: 22, 294 en 581. ${ }^{104}$ Bovendien worden eind december 199317 veilingen, 74 sorteer-en pakstations en 22 overigen als merkaanbrengers geregistreerd. ${ }^{105}$ Op drie na zijn deze merkaanbrengers tevens op reguliere wijze aangesloten bij het KCB.

Met het weg vallen van de binnengrenzen van de Europese lidstaten bestaat voor het KCB noodzaak ook toezicht op niet-aangesloten telers en handelaren van groenten en fruit uit te oefenen.

\subsubsection{CONTROLE}

Controle door het $\mathrm{KCB}$ vindt, meestal steeksproefgewijs, plaats op sortering (waarvoor soms specifieke apparatuur is benodigd), op inhoudsgewichten (idem dito), op verpakking, op aanduiding (d.w.z. aanwezigheid, duidelijkheid, volledigheid, betrouwbaarheid), op houdbaarheid en op produkttechnische aspecten.

\subsubsection{Cerificering}

Slechts wat betreft, bij de controle-instelling verplicht aan te melden, in Nederland geteelde of ingevoerde groenten- en fruitprodukten met bestemming buiten het verzendgebied/binnenlandse markt kan het $\mathrm{KCB}$ in elk geval zonder keuring ontvangstbewijzen (in 1990 21.297; in 1991 24.995 106; in $199231.844^{107}$ ), als mede na goedkeuring controlebewijzen (in 1990514.854 ; in $1991578.874^{108}$; in $1992626.049^{109}$; in

100. Statuten KCB woor groenten en früt, gewijz. bij bestuursbeshitu 27 nov. 1992 .

101. KCB, Jaarverslag 1993, "s-Gravenhage, 1994, p.13.

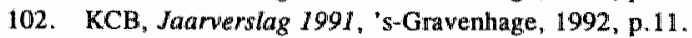

103. KCB, Jaarverslag 1992, "s-Gravenhage, 1992, p.13.

104. $\mathrm{KCB}_{\mathrm{q}}$ Jaarverslag 1993, 's-Gravenhage, 1994, p. 13.

105. KCB, Jaarverslag 1993, 's-Gravenhage, 1994, p. 13.

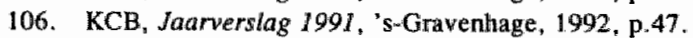

107. KCB, Jaarverslag 1992, "s-Gravenhage, 1993, p.51.

108. KCB, Jaarverslag 1991, "s-Gravenhage, 1992, p.47.

109. KCB, Jaarverslag 1992, "s-Gravenhage, 1993, p.51. 
$\left.1993232.332^{110}\right)$ en na goedkeuring en zonder bescherming tegen substitutie groene werklaringen (in 199088.663 ; in $199125.550^{111}$; in $199217.701^{112,}$; in 1993 9.436 ${ }^{\text {II }}$ ) afgeven. Zie artt. 7-14 Lkb groenten- en fruitprodukten. Daamaast verschaft het KCB mogelijk certificaten van oorsprong op verzoek van het importerende land of de exporteur op verzoek van de importeur (in $19913.676^{114}$; in $19923.983^{115}$; in $19936.444^{116}$ ), kwaliteitsverklaringen uitsluitend op verzoek van de exporteur (in $199110^{117}$; in $199216^{118}$; in $199362^{119}$ ) en tot $1993^{120}$ kwaliteitsverklaringen voor geneeskrachtige en aromatische kruiden op verzoek van de kruidenexporteur (in $199141^{121}$, in $199284^{122}$ ).

Met het per 1 januari 1993 wegvallen van de Europese binnengrenzen zijn voornoemde verplichte schriftelijke bewijsstukken niet meer nodig. In de Europese eenwording bevorderende EG-verordening inzake kwaliteitscontrole groenten en fruit ${ }^{123}$, die ondanks haar rechtstreekse werking is omgezet in een Landbouwkwaliteitsregeling controle groenten en fruit $1993^{124}$, wordt het volgende bepaald. In de EG geproduceerde groenten en fruit, die met oog op hun verse-consumptie-doel in de handel moeten worden gebracht, moeten op kwaliteit worden gecontroleerd via normcontroles. Voldoen de voor uitwoer bedoelde produkten aan daarvoor geldende communautaire produkteisen, dan kan het KCB controlecertificaten afgeven. Even als het vroegere controlebewijs bewijst een controlecertificaat dat de betrokken produkten bij een steeksproefsgewijze controle zijn goedgekeurd. In afwijking van het oude controlebewijs worden geen voorwaarden met betrekking tot het treffen van maatregelen ter voorkoming van substitutie gesteld. Ander nieuw document is het certificaat van industriële bestemming. Dit certificaat is bedoeld voor produkten die bestemd zijn om buiten de lidstaat, waar ze zijn geproduceerd, te worden verwerkt. Het certificaat kent een ontheffingsmogelijkheid voor industrielevering op contractsbasis. Bedoelde EG-verordening biedt controle-instellingen, waaronder het $\mathbb{K C B}$, een grondslag om met oog op uitoefening van toezicht aanwijzingen van de onder toezicht gestelden te verlangen over de plaats en de periode van verzending, over de bestemming van de produkten, en ook over de hoeveelheid verhandelde produkten.

110. KCB, Jaarverslag 1993, 's Graventhage, 1994, p.46.

11. KCB, Jaaverslag 1991, 's-Gravenhage. 1992, p.47.

112. KCB, Jaarverslag 1992, "s-Gravenhage, 1993, p.51.

113. KCB, Jaamerslag 1993. 's-Gravenhage, 1994, p.46.

114. KCB, Jaanverslag 1991, "s-Graventage, 1992, p.47.

115. KCB, Jaarverslog 1992, 's-Gravenhage, 1993, p.52.

116. KCB, Jaarwerslag 1993, "s-Gravenhage, 1994, p.47.

117. KCB, Jaarwerslag 1991, 's-Gravenhage, 1992, p.47.

1.18. XCB, Jaarverslag 1992, "s-Gravenhage, 1993, p. 52.

119. KCB, Jaarverslag 1993, 's-Gravenhage, 1994, p.47.

120. In 1993 windt wegens gebrek aan belangstelling beëindiging plaats. KCB, Jaarverslag 1993, 's-Grav., 1994, p. 47.

121. KCB, Jaaverslag 1991, 's-Gravenhage, 1992, p.47.

122. KCB, Jaarverslag 1992 , 's-Gravenhage, 1993, p.52.

123. EG-verondening inzake kwaliteitscontrale graenten en fruit, 2251/92, 29 juli 1992.

124. Landbouwkwaliteitsregeling controle groenten en, fruit, 16 maart $\$ 993$. 
Deze informatieplichten vinden uitwerking in de Verordening PGF Melding verse produkten 1993. De daarin opgenomen meldingsplicht heeft, met het weg vallen van de verplichte certificering bij verhandeling bínnen de $\mathrm{EG}_{\text {, }}$ als instrument voor effectieve kwaliteitscontrole aan relevantie gewonnen. Middels speciaal daartoe bestaande formulieren, vindt aan het $\mathrm{KCB}$ wekelijks achteraf bekendmaking plaats van verhandeling van verse groenten en fruit binnen de $E G$.

\section{3 .3 KEURING}

Keuring wordt steeksproefsgewijs uitgevoerd, bij voorkeur voor het verlaten van het produktiegebied, anders gezegd tijdens het verpakken of bij het laden van de produkten (art. 3 Lkb groenten en fruit). Van oudsher geschiedt keuring conform het Keuringsreglement van het KCB (art. $2 \mathrm{Lkb}$ groenten en fruit). Sinds kort moeten keuringswerkzaamheden in overeenstemming met het Controlereglement worden uitgevoerd.

Vervanging van het Keurings- door het Controlereglement ${ }^{126}$ blijkt onvermijdelijk. Redenen daarvoor liggen vooral in: a. de Europese eenwording ${ }^{127}$; b. de herinvoering van het keurmerk ${ }^{128}$; en $\mathrm{c}$. de herstructurering van het $\mathrm{K}$ waliteits-Controle-Bureau voor groenten en fruit waarbij nadruk ligt op de overgang van partijcontrole naar bedrijvencontrole met grotere verantwoordelijkheid voor de bedrijven zelf ten aanzien van de normstelling ${ }^{129}$. Bovendien gelden als andere gronden: de aandacht voor het opvullen van het 'gat' in de begroting van wege het sinds 1994 ontbreken van de structurele financièle overheidsbijdrage (met daaraan gepaard de vraag in welke mate het KCB voor groenten en fruit een overheidstaak verricht) ${ }^{130}$ en het accent op de mobiliteit, inzetbaarheid en produktenkennis van controleurs ${ }^{131}$.

Voorbeeld van het streven naar efficiënt werken en van de nadruk op zelfwerkzaamheid is de afgifte van de certificaten die het KCB - namens de Plantenziektenkundige Dienst te Wageningen -, als het importerende land daarom vraagt, verstrekt in het kader van de fytosanitaire controle op groenten en fruit van Nederlandse herkomst, voor zover deze produkten een exportbestemming krijgen. Na goedkeuring van de produkten verstrekt of waarmerkt het $\mathrm{KCB}$ de gezondheidscertificaten. Door invoering van het zelfschrijfsysteem hoeft het KCB-personeel in 1991 slechts 6.258 certificaten in te vullen en te warmerken, terwijl maar liefst 136.680 vitsluitend worden gewaarmerkt. ${ }^{132}$ In 1992 ver-

125. KCB voor groenten en fruit, Jaarverslag 1992, 's-Gravenhage, 1993 , p.8.

126. Controlereglement, bestuursbesluit van 26 oktober 1992, per 1 januari 1993 wan kracht. Ook Kwaliteitskeuring groenten en fruit, Stcr. 1993, 18.

127. Zie regeling voor $\mathbb{E G - l i d s t a t e n ~ i n ~ E G - V e r o r d e n i n g ~ i n z a k e ~ k w a l i t e i t s c o n t r o l e ~ g r o e n t e n ~ e n ~ f r u i t , ~ 2 2 5 1 / 9 2 , ~}$ 29 juli 1992. Daarin ontbreken voorgestane bepalingen over mogelijkheden tot respectievelijk controllewrijstelling en controlekostenwerhaal op de sector.

128. Zie voorschriften in respectievelijk Landbouwkwaliteitsverordening PGF 1991 Groenten ern Fruit, najaar 1992 en Reglement op het gebruik van het collectieve KCB-kwaliteitsmerk, bestursbesluit eind 1992.

129. KCB, Jaanerslag 1992, "s-Gravenhage, 1993, p.7.

130. KCB. Jaanerslag 1991, "s-Gravenhage, 1992, pp.7-8.

131. KCB, Jaaverslag 1992, "s-Gravenhage, 1993, p.18.

132. KCB, Jaarwerslag 1991, "s-Gravenhage, 1992, p. 39. 
bouden de getallen zich als 7.574 tot $152.991 .{ }^{133}$ Overigens laat 1993 een sterke daling van het totale aantal afgegeven certificaten zien, namelijk 102.754 tegen respectievelijk 160.565 in 1992 en 142.938 in $1991 .{ }^{134}$ Deze afname vindt oorzaak in de eerder vermelde vervallenverklaring van (gezondheids)certificaten voor verhandeling naar Europese lidstaten. Deze vervallenverklaring is bepaald in de, in verband met de Europese eenwording per 1 juni 1993 gewijzigde, EG-Fytorichtlijn.

\section{3 .3 .1 Zelfkeuring}

Ook de nieuwe controlemethode voor verduurzaamde champignons schakelt betrokken produktwerwerkende bedrijven in bij de controle. ${ }^{135}$ De bedrijven, die bij het KCB zijn aangesloten, voeren conform daartoe gegeven regels zelf controles uit en registereren zelf de controleresultaten. Het KCB houdt daar dan weer toezicht op.

\subsubsection{MONITOR- EN NORMTOEZICHT}

De toezichthoudende controletaak van het $\mathrm{KCB}$ is door de $\mathrm{KCB}$-organisatieherstructurering versterkt. Tegenwoordig $\mathrm{krijgt}$ het $\mathrm{kwaliteitstoezicht} \mathrm{moderne} \mathrm{invulling} \mathrm{door} \mathrm{het}$ monitoringsysteem. Daarbij "worden bedrijven op basis van resultaten van steeksproefsgewijze produktcontroles, de monitorcontroles, ingedeeld in categorieën om zo doende de controleactiviteiten efficiënt te kunnen managen " en ook de exportresultaten te kunnen registreren. ${ }^{n 36}$ De categorieën zijn eenvoudig. Het blijkt nog niet haalbaar te komen tot een ingewikkeld stelsel, waarin indelingscriteria zijn gekoppeld aan "gedifferentieerde tarifering ": ${ }^{137}$ Hierbij levert de, nog niet optimale, onderlinge vergelijkbaarheid van (buitenlandse) bedrijven problemen op. Monitorcontroles worden alleen uitgevoerd op groenten en fruit waarvoor de gecontroleerde verantwoordelijkheid draagt. In 1993 voert het KCB 133.067 monitorcontroles uit. ${ }^{138}$

Naast deze monitorcontroles, bestaan in het huidige controlestelsel, normcontroles die onder meer worden verricht bij controle op verzock. ${ }^{139}$ Ter staving van het feit, dat de normcontrole is uitgevoerd, kan een verkregen groene verklaring worden overlegd. Met oog op de normcontrole is het medio 1993 genomen $\mathrm{KCB}$-besluit om vaste tarieven te berekenen voor extra controlediensten relevant. ${ }^{140}$ Volgens dit besluit vallen onverplichte controleactiviteiten buiten de reguliere werkzaamheden van het KCB. Het doel van normcontroles is meer zekerheid omtrent produktkwaliteit te verschaffen. Omdat deze controle meestal op verzoek van betrokken producent plaats vindt, is het billijk de

133. KCB, Jaarverslog 1992, "s-Gravenhage, 1993, p.44.

134. KCB, Jaanverslag 1993, 's-Gravenhage, 1994, p.42.

135. KCB, Jaarverslag 1993, "s-Gravenhage, 1994, p.10.

136. KCB, Jaarverslag 1992, 's-Gravenhage, 1993, p.8.

137. KCB, Jaarverslag 1993, 's-Grawenhage, 1994, p.7.

138. KCB., Jaarwerslag 1993, 's-Gravenhage, 1994, p. 19.

139. KCB, Jarversiag 1993, "s-Gravenhage, 1994, p.7.

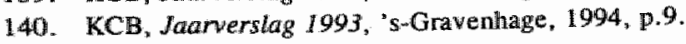


kosten daarvan op hem te verhalen. In 1993 verstrekt het $\mathrm{KCB} 649$ afkeuringsverklarin gen met betrekking tot produkten die een normcontrole hebben ondergaan. ${ }^{14 !}$

De controlemethodiek van het gereorganiseerde KCB stemt tot tevredenheid. Als intern sturingsmechanisme stelt de werkmethode het $\mathrm{KCB}$ in staat "controleprioriteiten (t.a.v. zowel te controleren produkten als te bezoeken lokaties - JGLvN) daar te leggen waar dait het meest noodzakelijk is, om zo doende effectiever en efficiènter te kunnen werken". "22 Tegen voordeelpunten als de "zuiverheid van de vastgelegde gegevens en de verhoogde kwaliteit van het werk", weegt het schaduwbeeld, dat administratieve werkzaamheden meer tijd dan voorheen op eisen, niet op. ${ }^{143}$

\subsubsection{STRENG TOEZICHT}

In de bres voor een hoogwaardige landbouwproduktie en een krachtige landbouwmarktordening trekt het KCB voor groenten en fruit in toenemende mate een streng gezicht. De controle-instelling benadrukt het belang van gedetailleerde landbouwkwaliteitswet- en regelgeving. "Adequate keuring en controle op de naleving is hierbij van cruciaal belang. In toenemende mate zal de aandacht hierbij uitgaan naar kwaliteitszorg door de gecontroleerde. Een belangrijk middel tot kwaliteitswaarborging is de registratie van controleresultaten. In verband met de huidige concurrentie en de verwachtingen van afnemers is het zaak om niet te tolerant om te springen met de tolerantiebepalingen." 144

Het Tuchtgerecht onderschrijft, dat er weinig plaats is voor vitzonderingsposities. In een principiele zaak beslist het Tuchtgerecht, dat - hoewel het gerecht begrip op kan brengen voor betrokken aangeslotene die is geconfronteerd met een slechte appeloogst - toch van aangeslotene kan worden verwacht dat hij zich inspant om de geldende kwaliteitswoorschriften volledig na te komen. Het verzoek van aangeslotene, om de voorschriften te wijzigen, wordt niet toegewezen. "Het is bij uitstek de taak van het KCB om de geldende voorschriften te handhawen en op de naleving ervan toe te zien. Het KCB kan en mag de controle niet versoepelen, omdat de situatie voor een of meer aangeslotenen zo moeilijk is. Versoepeling van de controle heeft tot gevolg althans kan tot gevolg hebben dat de concurrentie wordt vervalst." 145

\subsubsection{CIJFERMATIGE GEGEVENS KWALITEITS-CONTROLE-BUREAU GROENTEN EN FRUTTPRODUKTEN}

In 1991 zijn 107 inspecteurs, inspectie-medewerkers, hoofdcontroleurs met rayon of met afzetmarkten speciale projecten, assistent-hoofdcontroleurs in rayons of in afzetmarkten

141. KCB, Jaanverslag" 1993, "s-Graventhage, 1994, p. 20.

142. C.I.M. Arkesteijn, geciteerd in KCB, Jaarverslag 1993, 's-Gravenhage, 1994, p..8.

143. KCB, Jaanerslag 1993, 's-Grawenhage, 1994, p.7.

144. KCB, Jaanerslag' 1992, 's-Grawenhage, 1993, p.8.

145. KCB, Jaarverslag 1992, "s-Grawenhage, 1993, p.11. 
speciale projecten, controleurs, aankomend controleurs en sinds 1993 ook een kwaliteitsmanager in dienst van het KCB. In 1992 zijn dat er $97^{146}$ en in $199392^{147}$.

Het personeel zal in omvang eerder afnemen dan toenemen. Belangrijke oorzaken daarvan zijn de stopzetting van de financiële rijksbijdrage (kennelijk is de controletaak van het $K C B$ geen overheidstaak meer) en de verlaging van de reëxportvergoeding (in verband met het wegvallen van certificatieplichten voor produktverhandeling binnen de $\mathrm{EG}$ ).

Het KCB-personeel houdt toezicht op de kwaliteit van de belangrijkste vruchtgroenten (in 199141.518; in 1992 35.873; in 1993 38.681), de belangrijkste bladgroenten (in 1991 9.595 ; in 1992 8.347; in 19937.301), diverse overige groenten (in 1991 34.029; in 1992 30.604 ; in 1993 32.308), uien (in 1991 20.280; in 1992 20.191; in 199313.403 ), fruit (in 1991 25.156; in 1992 24.561; in 1993 24.146) en champignons (in 1991 9.194; in 19929.371 ; in 19937.321 ), als mede op de sortering van komkommers (in 1991918 ; in 1992659 ; in 199311.324 ), kropsla en ijsbergsla (in 1991 229; in 199279 ; in 1993 5.749 ) en hardfruit (in 1991 150; in 1992 249), en ook op de inhoudsgewichten van verschillende produkten (in 199110.655 ; in 19928.515 ; in 199316.369 ). ${ }^{148}$ Hoewel deze gegevens onvolledig zijn, geven zij wel een indicatie van de omvang van de werkzaamheden van het controlerend en keurend KCB-personeel.

Het tuchtgerecht van het KCB neemt in in 198926 , in 199038 en in 199121 nieuwe zaken (waarvan 3 schriftelijk en de overige mondeling) in behandeling. ${ }^{149}$ In 1992 worden 32 nieuwe zaken aanhangig gemaakt, daarvan worden 4 schriftelijk en alle overige ter zitting afgedaan, een zaak wordt geseponeerd. ${ }^{150}$ In $1993 \mathrm{krijgt}$ de tuchtrechter 35 nieuwe zaken voorgelegd, 11 zaken worden bij beschikking afgedaan. ${ }^{151}$

De tuchtmaatregelen in 1991 betreffen een berisping, onvoorwaardelijke boeten van f 500,00 tot $f 750,00(3 x), f 1.000,00(4 x), f 1.500,00(2 x), f 2.000,00(4 x), f 2.500,00$ $(3 x)$, f $5.000,00(1 x)$, als mede verschillende voorwaardelijke boeten of maatregelen. ${ }^{152}$ In 1992 volgt twee keer vrijspraak, wordt een keer berispt, overigens worden boeten opgelegd van $f 1.000,00(6 x)$, f $3.000,00(1 \mathrm{x})$, en $f 9.000,00(1 \mathrm{x})$, en wordt slechts een keer een voorwaardelijke boete van f $1.000,00$ gecombineerd met een onvoorwaardelijke geldboete van f 750,00 opgelegd. ${ }^{153}$ In 1993 volgt twee keer vrijspraak, wordt een keer berisping uitgesproken, overigens worden onvoorwaardelijke boeten van f 250.00 , f 500,00, f 750,00 , f $1.000,00(10 x)$, f $1.500,00(2 x)$, f $2.000,00(8 x$, waarvan drie keer in combinatie met voorwaardelijke maatregelen), $f 2.250,00(1 \mathrm{x})$ en $\mathrm{f} 3.000,00$ (1x), als mede voorwaardelijke boeten van $f 1.500,00(2 x)$ en $f 2.250,00(1 x)$ opgelegd,

146. KCB, Jaarverslag 1992, 's-Gravenhage, 1993, p.15.

147. KCB, Jaanverslag 1993, 1994, p.15.

148. Aldus cijfermateriaal woor zover gepubliceerd in jaarverslagen van het KCB over $19914 \mathrm{~m} 1993$.

149. KCB, Jaanverslag 1991, "s-Gravenhage, 1992, p.I1.

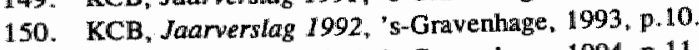

151. KCB, Jaarversiag 1993, "s-Gravenhage, 1994, p.11.

152. KCB ${ }^{2}$ Jaarverslag 1991, "s-Gravenhage, 1992, p.10.

153. KCB. Jaarverslag 1992 , 's-Gravenhage, 1993, p. 10. 
bowendien wordt een keer tenuitvoerlegging van een voorwaardelijke boete van f $1.500,00$ bevolen. ${ }^{154}$

\section{$\S 17.4$ Stichting Centraal Orgaan voor Kwaliteitsaangelegenheden in de Zuivel}

Ook de stichting Centraal Orgaan Zuivelcontrole is een controle-instelling in voornoemde zin. In afzonderlijke regelingen krijgt het toezicht op zuigelingenvoeding, boterprodukten, kaasprodukten en poedervormige melkprodukten gestalte.

Als opmerking wooraf geldt dat hieronder nog sprake is van de oude benaming $\mathrm{COZ}$, hoewel de stichting vanaf medio september 1994 door een fusie stichting Centraal Orgaan voor $\mathrm{K}$ waliteitsaangelegenheden in de Zuivel heet.

De fusie ${ }^{155}$ beoogt het toezicht op de uitbetaling naar gewicht, gehalte en kwaliteit van boerderijmelk ${ }^{156}$, over te brengen naar de stichting $\mathrm{CO}(\mathrm{K}) \mathrm{Z}$. Dit toezicht past prima in haar algemene doelstelling, l.w.: het door middel van het uitoefenen van toezicht, het uitvoeren van keuringen en (laboratorium)onderzoek en het uitreiken van merken, tekenen en bewijsstukken, de kwaliteit en de goede hoedanigheid van de in Nederland bereide melk- en zuivelprodukten bevorderen. ${ }^{157}$

Het ligt in de bedoeling om eerst eind 1994 of begin 1995 de nieuwe stichtingsnaam te verwerken in de mog te wijzigen zuivelkwalliteitswet- en regelgeving.

Deze zuivelkwaliteitswet- en regelgeving ondergaat, vanaf het ministeriêle voornemen eind 1987 daartoe, inhoudelijk flink verandering. Van aanvankelijk vier varianten voor vereenvoudiging van de zuivelkwaliteitswet- en regelgeving ( $t . w .:$ a: regelopschoning; b. nadere regelgeving op privaatrechtelijke basis; c. nadere regelgeving door het produktschap voor zuivel; en d. vrijwillige regelgeving c.q. nadere regelgeving), is -met oog op het dereguleringsbeleid van de overheid-vooral de eerste optie, al dan niet in combinatie met de vierde variant, populair. ${ }^{158}$ Aan deze algemene voorkeur geeft de betrokken bewindspersoon echter wel zeer strenge, sobere invulling. De minister ziet slechts plaats voor zuivelkwaliteitswet- en regelgeving met: a. basis gezondheidseisen $0 . g . v$. de Warenwet, met verwijzing naar de Lkw; b. aanvullende globale kwaliteitseisen o.g.y. de Lkw, uitgewaardigd door de centrale overheid; en c. mogelijk nadere kwaliteitseisen in medebewind, uitgevaardigd door het Produktschap voor Zuivel. Beide latst genoemde eisen zijn

154. KCB, Jaanverslag 1993, 's-Gravenhage, 1994, p.12.

155. Hierbij worden respectiev elijk het Centraal Orgaan Zu iwelcontrole/Controlestation voor Melkproduskten en thet Centraal Orgaan voor Melkhygiëne/de Regionale Organen voor Melkhygiëne/de Erkende Controle Instellingen samengevoegd en geìntegreerd tot de Stichting Centraal Orgaan voor Kwaliteitsaangelegenheden in de Zuivel.

156. Als neergelegd in Lkb rauwe melk en züvelbereiding m.b.t. witbetaling van boerderijnelk naar kwaliteit. Lkr witberaling boerderijmelk naar kwaliteit, en PZ-zuivelverordening 1994 witbetaling boerderijinelk naar gehalte en gewicht, die wijziging ondergaan in de zin, dat de stichting COKZ als kwaliteitscontrole-instelling bewoegd wordt verklaard.

157. COZ, Jaarwerslag 1993, Leusden, 1994, pp.4/26.

158. COZ, Jaarvershag 1989, Leusden, 1990, p.10. 
afdwingbaar bij aangeslotenen, die onder het $\mathrm{COZ}$-toezicht vallen. De onder a genoemde basisvoorwaarden gelden ook voor niet-aangeslotenen, op wie de Inspectie Gezondheidsbescherming toezicht houdt. ${ }^{159}$ Overigens ligt het in de lijn van het voorstel tot wijziging van de Lkw, dat controle-instellingen voortaan ook toezicht mogen uitoefenen op niet-aangeslotenen, ${ }^{160}$

De wijziging van zuivelkwaliteitswet- en regelgeving en de oprichting van de stichting Centraal Orgaan voor $\mathrm{Kwaliteitsaangelegenheden} \mathrm{in} \mathrm{de} \mathrm{Zuivel} \mathrm{staan} \mathrm{in} \mathrm{het} \mathrm{teken} \mathrm{van}$ zowel het versterken van de zuivelsector als het verhogen van efficiency en effectiviteit van kwaliteitscontrole. De landbouwkwaliteitscontrole-stichting, die in het bezit is van het Sterlab-certificaat ${ }^{161}$, hanteert moderne werkmethoden en stimuleert proces- of produktcertificering. In 1993 extensiveert zij, onder noodzakelijke aampassing van betrokken keuringsreglementen, in belangrijke mate onderzoeksprogramma's en boeteregelingen, waarover zij betrokkenen informeert. Daarbij houdt zij rekening met onder meer het in mindere mate afnemen van monsters, het percentage overtredingen, de informatieve waarde van onderzoeksresultaten en de vraag of er sprake is van een belangrijk economisch - dan wel volksgezondheids - belang. ${ }^{162}$

Aldus verovert dit landbouwproduktkwaliteitstoezicht zich een steeds sterkere, professionele positie.

\subsubsection{TOEZICHT ZUMGELINGENVOEDING}

Wat betreft zuigelingenvoeding zien COZ-keuringsambtenaren, als gedefinieerd in art. 12, derde lid, sub a, Lkr zuigelingenvoeding ${ }^{163}$ "er op toe, dat vrijstellingen (van het bepaalde aangaande verpakkingen als is bepaald in art. 13, eerste lid, sub $\mathrm{i} / \mathrm{n}$, juncto art. $18 \mathrm{Lkr}$ zuigelingenvoeding) niet ten onrechte worden verleend. Ex art. 2 EEG Regeling vrijstelling zuigelingenvoeding ${ }^{164} \mathrm{zijn}$ de, in art. 1 EEG-regeling vrijstelling zuigelingervoeding bedoelde, vrijstellingen gebonden aan de volgende voorschriften en beperkingen: "a. documenten m.b.t. de afzet (binnen de EEG - JGLvN) moeten worden bewaard en op verzoek aan de stichting $\mathrm{COZ}$ worden getoond; $\mathrm{b}$. nadere door de stichting $\mathrm{COZ}$ te stellen controlevoorschriften moeten worden nageleefd."

159. Mede gegeven het ministerielle woorstel de aansluitplicht te schrappen vestigt het $C O Z$ de anandacht er

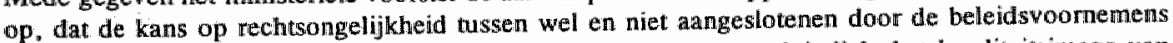
weneemt. Bovendien tast, volgens het $\mathrm{COZ}$, afschaffing van aansluiplicht het kwaliteitsimago vam Nederlandse zuivelprodukten aan. COZ-Jaarversiag 1989 (p. 11); In het Jaarverslag 1990 (p. 10 ) pleit het $\mathrm{COZ}$ voor handhawing wan de aanshuitplicht woor in elk geval kaas en boerderijmelk.

160. COZ, Jaanerslag 1991, Leusden, 1992, p. 9.

161. Dat garandeert betrou wbaarheid en hoogwaardige kwaliteit wan COZ-(1abaratorium)onderzoekstmethoden. COZ, Jaarverslag $1993^{\prime}$, Leusden, 1994, p.6. De Nederlandse Stichting vaor de Erkenning van Kalibratie-en Testlaboratoria en Inspectie-instellingen (NKO/STERIN/STERLAB) is voor certificalatagiffe verantwoordelijk.

162. Dit merkt thet $\mathrm{COZ}$, Jaanerslag 1993, Leusden, 1994, p.36, bij voorbeeld t.a.v. poederwormige melkprodukten op.

163. Landbouwhwaliteitsregeling zaigetingenvoeding, 1984, Start. 1984, 197, gewijz. 17 dec. 1985, Stcrt. $1985,247$.

164. EEG-regeling vrijstelling zuigelingenvoeding. 13 juli 1987, $\$ 6164$. 


\subsubsection{TOEZICHT BOTERPRODUKTEN}

Wat betreft boterprodukten gelden de volgende controlevoorschriften. Volgens art. 19 Landbouwkwaliteitsbeschikking boterprodukten ${ }^{165}$ zijn de door het COZ met toezicht en keuring belaste personeel als mede de ambtenaren van het rijkstoezicht ${ }^{166}$ bevoegd rijksbotermerken te verwijderen of te doen verwijderen van fabrieksboter, welke niet voldoet aan de bij deze beschikking aan boter van de desbetreffende kwaliteitsklasse gestelde eisen. Overigens treft de stichting $\mathrm{COZ}$, conform art. $20 \mathrm{Lkbg}$ boterprodukten, alle nodige maatregelen om te woorkomen dat rijksbotermerken worden aangebracht of gehandhaafd op fabrieksboter, welke in gevolge het, bij het besluit of deze beschikking, bepaalde niet of niet meer van zo danig merk mag zijn voorzien.

Het Keuringsreglement boterprodukten ${ }^{167}$ bewat concrete voorschriften als: een meldingsplicht van de houder van fabrieksboter (een telefonische mededeling is voldoende; strengere eisen bestaan voor de bereider en ompakker van fabrieksboter) ex art. $10 \mathrm{Kr}$ boterprodukten; keuringseisen omschreven in artt. 11-15 Kr boterprodukten; mogelijkheid tot schadevergoeding naar marktwaarde van genomen monsters ex art. $16 \mathrm{Kr}$ boterprodukten; afleveringsverbod ex art. $17 \mathrm{Kr}$ boterprodukten; aantekeningsplicht voor boterbereiders ex art. $18 \mathrm{Kr}$ boterprodukten; mogelijkheid tot bezwaarmaking tegen monsterneming ex art. $44 \mathrm{Kr}$ boterprodukten; mogelijkheid tot bezwaarmaking tegen keuringsuitslag ex art. $45 \mathrm{Kr}$ boterprodukten. Deze bepalingen voor fabrieksboterprodukten gelden ook voor boerenboter, halfboter, boter met eet- en drinkwaren , melkvet en boterprodukten waarwoor geen naam is vastgesteld.

\subsubsection{TOEZICHT KAASPRODUKTEN}

Wat betreft kaasprodukten is de Landbouwkwaliteitsbeschikking kaasprodukten ${ }^{168}$ uitgangspunt. Art. 16 Lkbg kaasprodukten bepaalt: "Het door of namens het COZ met toezicht en keuring belaste personeel als mede de ambtenaren van het rijkstoezicht zijn bevoegd rijkskaasmerken te verwijderen of te doen verwijderen van kaas, welke: a. niet voldoet aan de bij het besluit of deze beschikking voor de desbetreffende kaassoort gestelde algemene en bijzondere eisen; $b$, volgens redelijke verwachting na afloop van het voor de desbetreffende kaassoort in de artt. 28-62 of de artt. 90-97 voor rijping genoemde tijdvak niet zal voldoen aan de bij het besluit of deze beschikking aan de voor de desbetreffende kaassoort gestelde algemene en bijzondere eisen." Ex art. 17 Lkbg. kaasprodukten kan de stichting $\mathrm{COZ}$ alle nodige maatregelen treffen ter preventie dat niet toegestane rijkskaasmerken worden aangebracht.

165. Landbouwhwaliteitsbeschikking baterprodukten, 28 juli 1982, J4128, Stcrt. 1982, 145.

166. D.w.z. ambtena ren aangewezen in gevolge art. 2 Ministeriële besichikking. 1.5 aug. 1977, J2094, Stcrt. $1977,159$.

167. Keuringsreglement boterprodukten, Stcrt. 1982, 221.

168. Landbouwkwaliteitsbeschikking kaasprodukten, 28 dec. 1981, J7974, Stcrt, 251, gewijz. 28 okt. 1982 , Stcrt. 1982, 209, gewijz. 24 juli 1989, Stcit. 1989, 147. 
Het Keuringsreglement COZ kaasprodukten ${ }^{169}$ bepaalt, dat de door de betrokken controle-instelling uit te voeren keuring steeksproefsgewijs plaats vindt (art. 13, eerste lid, jo. art. $18 \mathrm{Kr}$ kaasprodukten), op basis van een eerste deelkeuring, omvattende onderzoek naar onder meer vochtgehalte, toevoegingen, gewicht, vorm, korst, zuivel, consistentie, kleur, geur, smaak, aanduiding en verpakking (art. 14, eerste lid en tweede lid, $\mathrm{Kr}$ kaasprodukten), en een tweede deelkeuring (artt. 15-16 $\mathrm{Kr}$ kaasprodukten). "170

Het $\mathrm{Kr}$ kaasprodukten bevat, aan het voor boterprodukten geldende keuringsreglement, analoge bepalingen.

\subsubsection{Rechten en plichten onder toezicht gestelden}

Op bereiders van kaasprodukten rusten de volgende verplichtingen.

Art. 3, derde lid, Kr kaasprodukten verplicht de bereider van kaas om een administratie te voeren omtrent het verloop van de voorraad van de aan hem verstrekte rijkskaasmerken (door stichting COZ verstrekt - JGLVN). ${ }^{171}$ Door of namens het bestuur kunnen aanwijzingen worden gegeven omtrent de wijze waarop deze administratie moet worden gevoerd. Art. $12 \mathrm{Kr}$ kaasprodukten verplicht de bereider van randenkaas, ongeperste randen of wrongelkruimels om dagelijks aantekening te houden van de door hem bereide en afgeleverde hoeveelheden randenkaas , ongeperste randen of wrongelkruimels op een door de directeur goedgekeurde wijze. Art. $21 \mathrm{Kr}$ kaasprodukten verplicht de bereider van boerenkaas tot aantekening van gegevens met betrekking tot bereiding (datum, aantal gemolken koeien, verkaasde hoeveelheid melk, kaassoort, gewicht, aantal kazen, volgnummers), aflevering aan anderen dan particulieren (datum, aantal, gewicht, afleveradres), particulier of eigen gebruik (datum, aantal, gewicht, aanduiding particulieren) als ook andere door of namens het bestuur in het belang van de controle gevraagde bijzonderheden, het bedrijf van bereider betreffende. Dagelijkse aantekening is vereist in geval van bedrijfsmatige aankoop van kaas. Met betrekking tot deze administratieverplichtingen kan het stichtingsbestuur aanwijzingen geven. Vergelijkbare aantekeningsplichten zijn opgenomen in art. $30 \mathrm{Kr}$ kaasprodukten (voor bereiders kwark en kwark met eet- en drinkwaren), art. $35 \mathrm{Kr}$ kasprodukten (voor bereiders smeltkaas en smeltkaasprodukten), art. $40 \mathrm{Kr}$ kaasprodukten (voor bereiders kaaspoeder en smeltkaaspoeder) en art. $45 \mathrm{Kr}$ kaasprodukten (voor bereiders kaasprodukten waarvoor geen aanduiding is vastgesteld).

169. Keuringsreglement kaasprodukten, 14 aprill 1982, Stcrt. 1982, 105, gewijz. Stcrt. 1984, 158.

170. Vgl. arti. 22-27/31-33/41-43/46-48 Kr kasprodukten voor kazen, andersoortig dan fabriekskazen.

171. Ut Administratieverplichtingen in het kader van controle op visserij*activiteiten, HR 27 sept. 1994, nr. $97612 \mathrm{E}$, in: NJB, nr 44, 9 dec. 1994, pp.592-593 (NJB-bijlage rechtspraak), blijkt dat onder toezicht gestelden met, zowel Europees- als nationaalrechtelijk voorgeschreven, administratieplichten ernst moeten nemen. Ook al laat wet- of regelgeving ruimte yoor het niet toepasselujk zijn van administratieplichten op bepaalde categorieën personen die bij zekere transacties zijn betrokken, de rechter respecteert die opening minder en verklaart als nog administratieplichten toepasselijk op bedoelde categorieen. Hoewel vermelde jurisprudentie de wisserijwereld betreft, lijkt zij analoog van toepassing op de landbouwwereld. Onder toezichtgestelden van verschillendelandbouwlkwaliteitscontrole-instellingen moeten er rekening mee houden. 
Art. 4, derde lid, $\mathrm{Kr}$ kaasprodukten verplicht de bereider van kaas of de opvolgende bereider, als bedoeld in art. 64 , tweede lid, van de beschikking, om onbruikbaar geworden rijkskaasmerken -van de kaas verwijderde of losgelaten merken daaronder begrepenbij het eerst volgende bezoek ter hand te stellen van het door of namens het $\mathrm{COZ}$ met keuring en toezicht belaste personeel.

Art. 11, eerste lid, $\mathrm{Kr}$ kaasprodukten verplicht de bereider van randenkaas om -t.b. $\mathrm{V}_{\text {. de }}$ controle-de door hem bereide randenkaas acht dagen na de eerste dag van bereiding ter beschikking te houden van de door of namens het $\mathrm{COZ}$ met keuring en toezicht belaste personeel, als mede van ambtenaren van het rijkstoezicht. Het tweede lid bepaalt dat ongeperste randen en wrongelkruimels slechts mogen worden afgeleverd indien de zending is voorzien van een door of namens het $\mathrm{COZ}$ afgegeven geleidebiljet.

De houder van fabriekskaas heeft, volgens respectievelijk art. 19 en art. $28^{172} \mathrm{Kr}$ kaasprodukten, mogelijk aanspraak op vergoeding van: a. de marktwaarde van de door of namens het $\mathrm{COZ}$ bij hem genomen monsters; en b. de waardevermindering van de bemonsterde kazen. Het stichtingsbestuur bepaalt de hoogte van de vergoeding.

Art. $55 \mathrm{Kr}$ kasprodukten verplicht alle, bij de controle-stichting, aangeslotenen om alle plaatsen, waar handelingen worden verricht welke ingevolge art. 12 van het besluit uitsluitend zijn toegestaan aan $\mathrm{COZ}$-aangeslotenen, onverwijld ter kennis te brengen van het $\mathrm{COZ}$ onder opgave adres en vestigingsplaats.

Naast deze plichten hebben kaashouders en -bereiders de volgende rechten.

Ex art. $50 \mathrm{Kr}$ kaasprodukten kan betrokkene zich beklagen over door de controle-instelling genomen monsters. In gevolge het eerste lid kan een aangeslotene bezwaar maken tegen: a. de wijze waarop een monster door of namens het $\mathrm{COZ}$ wordt genomen; $b$. de keuze van een monster uit de aanwezige voorraad. Het tweede lid bepaalt, dat het bezwaar onmiddellijk bij de monstememing aan degene, die het monster neemt, moet worden bekend gemaakt. Deze beslist of het genomen monster wordt gehandhaafd. Ook kan bezwaar worden ingediend tegen een keuringsuitslag of een mogelijk gedane herkeuring (artt. 51-54 $\mathrm{Kr}$ kaasprodukten).

172. Met dien verstande dat voor randmonsters geen vergoeding wordt verleend. 


\subsubsection{Rechten en plichten Centraal Orgaan Kaas- en Zuivelcontrole}

De controle-instelling verplicht zich, van haar zijde, in elk geval tot het volgende. In gevolge art. 17, tweede lid, $\mathrm{Kr}$ kaasprodukten wordt het resultaat van het in art. 14, tweede lid, sub c, en art. 15, tweede lid, bedoelde onderzoek, door het door of namens het $\mathrm{COZ}$ met keuring en toezicht belaste personeel op de plaats van keuring vermeld op een keuringsformulier in tweevoud. Daarbij bepaalt het derde lid dat, van het in het tweede lid bedoelde keuringsformulier, ten eerste, de voor de houder van fabriekskaas bestemde doorslag op de plaats van keuring wordt achtergelaten en, ten tweede, het origineel wordt opgezonden naar het $\mathrm{COZ}$.

De keuringsinstelling is gerechtigd betrokkenen een produktafleveringsverbod op te leggen. Art. $20 \mathrm{Kr}$ kaasprodukten laat geen twijfel: "1. Het door of namens het COZ met keuring en toezicht belaste personeel kan de aflevering verbieden van een bak, charge of partij fabriekskaas, welke kazen bevat, die naar het oordeel wan het genoemde personeel: a. niet voldoen aan de bij het besluit of de beschikking voor de desbetreffende kaassoort gestelde algemene en bijzondere eisen; b. volgens redelijke verwachting na afloop van het gehele voor de desbetreffende kaassoort voor rijping voorgeschreven opslagtijdvak, als bedoeld in art. 64, eerste lid, van de beschikking, niet zullen voldoen aan de bij het besluit of de beschikking aan de desbetreffende kaassoort gestelde algemene en bijzondere eisen. In voorkomend geval wordt hiervan melding gemaakt op het desbetreffende keuringsformulier; 2. Een bak, charge of partij fabriekskaas, waarvoor een afleveringsverbod is opgelegd, mag het bedrijf van de houder van de desbetreffende fabriekskaas niet verlaten, tenzij: a. aan de fabriekskaas een bestemming wordt gegeven, welke de schriftelijke goedkeuring heeft van het $\mathrm{COZ}$; b. de fabriekskaas een bewerking heeft ondergaan en vervolgens schriftelijk bij het $\mathrm{COZ}$ is aangemeld voor herhaalde keuring en blijkens het bij de herhaalde keuring afgegeven keuringsformulier door het $\mathrm{COZ}$ voor aflevering is vrijgegeven; 3 . Eventueel uit een bak, charge of partij fabriekskaas, waarvoor een afleveringsverbod is opgelegd, geselecteerde kazen, welke niet voldoen aan de bij het besluit of de beschikking gestelde eisen, mogen het bedrijf van de houder van deze kazen niet verlaten, tenzij aan deze kazen een bestemming wordt gegeven, welke de schriftelijke goedkeuring heeft van het $\mathrm{COZ} ; 4$. Bij het verstrekken van de in het tweede lid, sub a en het derde lid bedoelde schriftelijke goedkeuring kan worden bepaald, dat de desbetreffende fabriekskaas bij verzending moet zijn voorzien van een door of namens het $\mathrm{COZ}$ afgegeven geleidebiljet." ${ }^{173}$

\subsubsection{TOEZICHT POEDERVORMIGE MELKPRODUKTEN}

Wat betreft poedervormige melkprodukten zetten de artt. 18-19 Landbouwkwaliteitsbeschikking poedervormige melkprodukten ${ }^{174}$ de zelfde toon in voor rechten en plichten

173. Vgll de vrij wel gelijke artt. 29/34/39/44/49 Kr kaasprodukten voor soorten kaas, niet zijnde fabriekskaas.

174. Landbouwkwaliteitsbeschikking poedervormige melkprodukten, 15 aug. 1983, J4849, Stcrt. 1983, 200, gewijz. 24 juli 1989, Stert. 1989, 147. 
van controleurs en gecontroleerden. Vrij wel eender luiden de voorschriften inzake de verpakking door producenten en de keuring door keuringsambtenaren, waarmee - ex art. 74, derde lid, sub a, Lkbg poedervormige melkprodukten - zijn bedoeld de personen door het $\mathrm{COZ}$ belast met toezicht op het bij of krachtens het besluit bepaalde dan wel de keuringsambtenaren, als gedlefinieerd in art. 1, eerste lid, van het Hoeveelhedenbesluit (Warenwet).

Ook het Keuringsreglement poedervormige melkprodukten ${ }^{175}$, betreffende melkpoeder (in tankwagens), weipoeder (in tankwagens) en onbenoemde produkten (in tankwagens), is inhoudelijk gelijk aan de andere keuringsreglementen, als voornoemd.

\subsubsection{KOSTENVERHAAL}

Wie dle, aan controle verbonden, kosten, op zich moet nemen, wordt aangegeven in het Reglement inzake de heffing van omslagen ter dekking van de kosten van toezicht of keuring ${ }^{176}$. Daarin opgenomen zijn inhoudelijke voorschriften over jaarlijkse vaste bijdrage aangeslotenen en een omslag over de hoeveelheden bereid produkt. Voor namens of door de stichting $\mathrm{COZ}$ zelf verrichte controle zijn afzonderlijke basisomslagen verschuldigd. Uitgangspunt zijn de door of van wege het $\mathrm{COZ}$ werkelijk gemaakte kosten en een deel van de algemene kosten van het COZ. Laatst genoemde kosten worden door het bestuur vastgesteld op grond van goedgekeurde jaarstukken van het controlestation. Controleboeken, merken en andere controlebescheiden mogen aan aangeslotenen in rekening worden gebracht. Betaalt aangeslotene de door hem verschuldigde geldsom niet, dan zijn zonder ingebrekestelling vaste bijdrage en omslagen c.q. voorschotten daarop, wettelijke rente en mogelijke kosten van invordering opeisbaar (art. 7 Kostenreglement).

Overigens zet het ministerie van landbouw, natuur en visserij vanaf 1994 de overheidsbijdragen in de kosten van toezicht en keuring stop. ${ }^{177}$

\subsubsection{Toezichtsbevoegdheden Centraal Orgaan (Kaas- en) Zuivelcontrole}

Met oog op kostenverhaal worden wederom inlichtingen- en administratieplichten ten tonele gevoerd. Evident is vooral art. 6, eerste lid, Kostenreglement. Daarin wordt de aangeslotene verplicht om voor elke tot zijn onderneming behorende bereid - of opslagplaats een administratie te voeren van de jaarlijks bereide hoeveelheden produkt en zich daarbij te richten naar eventuele aanwijzingen van het bestuur. De aangeslotene verstrekt het bestuur of de door deze aangewezen personen alle gevraagde inlichtingen; desgevraagd verleent hij het bestuur of de door deze aangewezen personen inzage van de door

175. Keuringsreglement poederwormige melkprodukten, 1985, Stcrt. 1985, 3, in man wege verandende monste rmethoden noodzakelijik-gewijzigde vorm, goedgekeurd door de staatssecretaris van landbouw, natuur en visserij d.d. 27 akt. 1993.

176. Reglement heffing omslagen ter dekking kosten toezicht of keuring, 15 juni 1982, Stert. 1982, 118 , gewijz. Stcrt. 1985. 38, gewijz. d.d. 7 aug. 1990, Stcrt. 1990, 151.

177. $\mathrm{COZ}$, Jaaverslag 1993, Leusden, 1994, p.13. 
hem gevoerde boekhouding. Blijft aangeslotene nalatig, dan mag het bestuur in gevolge het tweede lid van voornoemd artikel uitgaan van veronderstellingen.

\subsubsection{RUKSTOEZICHT}

Ook de controle-instelling moet verantwoording afleggen. Op haar rust een informatieplicht ten behoeve van het rijkstoezicht. Het rijkstoezicht is gericht op: "a. de juiste uitvoering van de opgedragen taak door de controle-instellingen; $b$. het naar behoren functioneren van de controle-instelling en haar onderdelen; c. een verantwoord administratief en financieel beheer; en d. het naar behoren functioneren van het tuchtrechtelijk stelsel ${ }^{178 *}$ (art. 1 Regelen inzake het rijkstoezicht op de controle-instellingen ${ }^{179}$ ).

\subsubsection{CIJERMATIGE GEGEVENS ZUIVELCONTROLE}

De stichting COZ registreert eind 1989 een totaal aangeslotenen van 1116 , waarvan 755 boerderij-zuivelbereiders, 215 opvolgende bereiders en 146 overige bedrijven waaronder 32 zuivelondernemingen, bereiders van smeltkaas en van overige kaas- en boterprodukten, ompakkers en verwerkers. ${ }^{180}$ Eind 1990 betreffen dat er er respectievelijk 1104 , $759,207,138$ en $27 .{ }^{181}$ Eind 1991 is het beeld respectievelijk $1101,772,206,106$ en 20. ${ }^{182}$ Op 31 december 1992 bedragen alle aansluitingen bij elkaar 1088 en op 31 december 19931079.183

Bij bereid- en opslagplaatsen van aangeslotenen legt de stichting COZ in 1989, in het kader van haar toezichts- en keuringstaak, 18.650 controlebezoeken af en neemt zij 33.977 monsters af. ${ }^{184}$ Controlebezoek en monsterneming komen neer op respectievelijk: 18.470 en 56.787 in $1990^{185} ; 18.586$ en 56.333 in $1991^{186} ; 17.081$ en 52.694 in 1992, daarnaast 17.032 en 48.044 in $1993^{187}$.

Naast controlebezoeken begint de stichting COZ in 1993 met bijzondere erkenningsbezoeken. Daarmee geeft zij gehoor aan de Zuivelrichtlijn ${ }^{188}$, die de controlestichting als bevoegde autoriteit aanwijst om aangesloten ${ }^{189}$ bereiders van zuivelprodukten te erkennen. In 1993 start de stichting COZ voortvarend met, ter beoordeling van bedrijfshygiëne

178. Zie over het tuchtrecht van de controle-instellingen paragraf 12.4 .

179. Regelen rijkstoezichi op controle-instelingen, Mb J2094, 1977, Stcrt. 1977, 159.

180. COZ Jarinerslag 1989 , Leisden, 1990, p.5.

181. COZ, Jaarwerslag 1990, Leusden, 1991 , p.5.

182. COZ, Jaarwersiag 1991 , Leusden, 1992, p.5.

183. COZ, Jaarverslag 1993, Leusden, 1994, pp.6-7.

184. COZ, Jaarverslag 1989, Leusden, 1990, pp.6-7.

185. COZ, Jaarversiag 1990, Leusden, 1991, pp.6-7.

186. COZ, Jaanverslag 1991, Leusden, 1992, pp.6-7.

187. COZ, Jaarverslag 1993, Leusden, 1994, p.7.

188. Zuivelhygiênerichtlijn. EG 92/46, van kracht sinds 1 januari 1994.

189. Voor niet-aangeslotenen is de Inspectie Gezondheidsbescherming de aangewezen erkenningsinstantie. 
dienende, erkenningsbezoeken, waarbij zij in elk geval alle exporterende bedrijwen (circa 150) met oog op erkenning bezoekt. " 190

In werband met de extensivering wan de controlewerkzaamheden neemt het feitelijk aantal COZ-medewerkers lichtelijk af: 126 persioneelsleden in 1993 tegen 130 personeelsleden in 1992. 191

De tuchtgerechten behandelen in 1988991 schriftelijke en 61 mondelinge zaken, daarnaast doen zij ter zitting 10 zaken af. ${ }^{192}$ In 1989 betreffen deze aantallen 1010 , 61 en 9. ${ }^{193}$ Van 1990 zijn de cijfers 1000,48 en 8 bekend. ${ }^{194}$ In 1991 komt de telling neer op 1017,52 en $6 .{ }^{195}$ Voor 1992 gelden de getallen van respectievelijk 947, 37 en 9; voor 1993 respectievelijk 805,51 en 8.196

De verschillende tuchtrechters leggen de nodige tuchtmaatregelen op. In 1988 geschiedt boeteoplegging tot de som van f $4.272 .660,00$ en in 1989 bedraagt het boetebedrag $f$ $4.287 .550,00{ }^{197}$ In 1990 wordt een boetebedrag geteld van $f 4.245 .685,00 .{ }^{198}$ In 1991 is het totaal van boetebetaling: $f 4.780 .975,00 .{ }^{199}$ Aan tuchtboeten wordt in 1992 f $2.536 .880,00$ en in 1993 f $4.849 .325,00$ betaald. ${ }^{200}$

In 1988 is sprake van 20 berispingen en in 1989 worden 23 berispingen gegeven. In 1990 worden regelovertreders 22 keer berispt. ${ }^{202}$ In 1991 zijn er 23 gevallen van berisping. ${ }^{203}$ In 1992 en 1993 vindt geen berisping voor bij aangeslotenen geconstateerde overtredingen plaats. ${ }^{204}$

Een keer in 1988 wordt plaatsing onder verscherpte controle op kosten van aangeslotene bevolen. ${ }^{205}$

\section{$\S 17.5$ Stichting Nederlandse Vleeswaren Kontrole}

Deze landbouwkwaliteitscontrole-instelling is nadere beschouwing waard. De stichting Nederlandse Vleeswaren Kontrole ziet toe op wet- en regelnaleving aangaande vleeswaren in het algemeen en rookworst in het bijzonder. ${ }^{206}$ Bovendien neemt zij sedert me-

190. COZ, Jaarversiag 1993, Leusden, 1994, p.6.

191. COZ, Jaarverslag 1993, Leusden, 1994, p. 19

192. COZ, Jaarverslag 1989, Leusden. 1990, p.41.

193. COZ, Jaanersiag 1989. Leusden, 1990, p. 41 .

194. COZ, Jaarverslag 1990, Leusden, 1991, p. 39.

195. COZ, Jaarverslag 1991. Leusden, 1992, p.37.

196. COZ, Jaarverslag 1993, Leusden, 1994, p.44.

197. COZ, Jaarverslag 1989, Leusden, 1990, p.41.

198. COZ, Jaarverslag 1990, Leusden, 1991, p.39.

199. COZ, Jaanverslag 1991, Leusden, 1992, p.37.

200. COZ, Jaarverslag 1993, Leusden, 1994, p.44.

201. COZ, Jaanverslag 1989, Leusden, 1990, Pp.41-44.

202. COZ, Jaarverslag 1990, Leusden, 1991 , pp.40-42.

203. COZ, Jaarverslag 1991, Leusden, 1992, pp 38-40.

204. COZ, Jaarverslag 1993, Leusden, 1994, p.45.

205. COZ, Jaarverslag 1989, Leusden, 1990, p.42.

205. Zie Landbouwhwaliteitsverordening rookworst, 14 dec. 1981, VV 25, Vb. Bo, 1981, 41, 1 aug. 1988. 
dio december 1991 de controlewerkzaamheden ${ }^{207}$ van de Stichting Nederlandse Baconcontrole ter hand.

In gevolge art. 20, eerste lid, Statuten NVK stelt het bestuur (ex art. 8 jo. art. 9 zijn de leden benoemd door belangenorganisaties, de voorzitter op voordracht van het bestuur door de minister - JGLvN) een of meer inspecteurs dan wel controleurs of beiden aan, die belast zijn met de uitvoering van het toezicht op de naleving door de aangeslotenen van de voorschriften, bedoeld in art. 6, eerste lid. Conform het tweede lid verstrekt het bestuur de inspecteur(s) onderscheidenlijk de controleur(s) dan wel anderen die ingeschakeld worden bij de controlewerkzaamheden een, ex art. 3 Instructie inspecteur vleeswaren en art. 2 Instructie inspecteur bacon op verzoek van gecontroleerde te tonen, schriftelijke lastgeving houdende een verklaring, dat de desbetreffende functionaris belast is met de uitwoering van het aan de stichting opgedragen toezicht op de naleving door de aangeslotenen van de voorschriften, bedoeld in art. 6, eerste lid. Daarnaast stelt het bestuur voor de inspecteur(s) en de controleur(s) een instructie op (derde lid).

\subsubsection{TAAKSTELLING STICHTING NEDERLANDSE VLEESWAREN KONTROLE}

Art. 8 Landbouwkwaliteitsbesluit Vleeswaren ${ }^{208}$ stelt dat de stichting NVK belast is met toezicht, keuring en uitreiking merken, tekenen of bewijsstukken m.b.t. de vleesprodukten als vermeld in de artt. 1-2 Landbouwkwaliteitsbeschikking aanwijzing vleeswaren $^{209}$. Art. 4 Statuten stichting NVK ${ }^{210}$ herhaalt dat.

Conform art. 3 Statuten NVK beoogt de stichting, d.m.v. het uitoefenen van toezicht en van keuring, de goede hoedanigheid, sortering, verzorging, verpakking, vorm, afwerking of aanduiding van vleeswaren te bevorderen.

\subsubsection{RECHTEN EN PLICHTEN ONDER TOEZICHT GESTELDEN}

Ook op de schouders van degenen die onder toezicht staan in de vleeswarensector rusten een meldingsplicht en een financiële bijdrageplicht. Art. 5 Landbouwkwaliteitsbeschikking vleeswarenkeuring en -merken ${ }^{2 \mathfrak{1}}$ wijst aangeslotenen er op om het in produktie nemen van te keuren vleeswaren tijdig aan de controle-instelling te melden. Een derge-

207. Als omschreven in vooral Landbouwkwaliteitsverordening baconnuts en prepacked bacon $1978, \mathrm{Vb} 12$, 28 maart 1978, VV nr.4, gewijz, 4 dec. 1986, Vb. Bo. 1987, nr.5; Uitwoeringsbeshuit baconpekets, baconnuts en prepacked bacon, 8 mei 1979, 11413 ; Landbouwkwaliteitsbeschikking vrijstellingen, ontheffingen, en nadere voorschriften bacon, 28 matrt 1978, 11041 , Stcrt. 1978, 63; Procesregistratiebeslwit uitwoering verordening, 9 febr. 1987, Vb. Vo. 1987, 18.

208. Landbouwkwaliteitsbeshit wleeswaren, 10 sept. 1981, J1774, Stbl, 1981, 643. Vgl. art. 9 Lkb bacon, Stbl. 1978, 111 .

209. Landbowwkwaliteitsbeschikking aanwijzing vleeswaren, 14 okt. 1981, J6846, Stcrt. 1981, 204, gewijz. 12 jan. 1983, Stcrt. $1983,9 / 12$, gewijz. 27 au.g. 1986, J5487, Stcrt. 1986, 168.

210. Statuten NVK, 29 sept. 1988, Stcrt. 5 jan. $1989,4$.

211. Landbouwkwaliteitsbeschikking wleeswarenkeuring en -merken. 15 okt. 1981, J6881, Stcrt. 31 okt. 1981, 204, gewijz. 28 juni 1988, J6566, Stcrt. 1988, 126. 
lijke meldingsplicht komt ook voor in het Reglement merkuitreiking en keuring van ba$\operatorname{con}^{212}$ (art. 4), dat bovendien een administratieplicht voor aangeslotenen kent (art. 3).

En uit de artt. 21-22 Statuten stichting NVK is op te maken, dat de controle-instelling een bepaalde bijdrage voor uitoefening van haar controletaken mag heffen van haar leden, die daartegen trouwens bezwaar kunnen maken. Ex art. 5 Regeling inzake de bijdragen ${ }^{213}$ doet een aangeslotene jaarlijks opgave van het verschuldigde bedrag. De opgave gaat vergezeld van een verklaring, afgegeven door degene die gewoonlijk de externe boekhoudkundige controle verricht (art. 5, tweede lid, Regeling bijdragen). De stichting NVK kan de opgave controleren of doen controleren. Ex art. 8 Regeling bijdragen moet een betrokken aangeslotene onder schriftelijke aanmaning binnen 10 dagen betalen als hij in gebreke blijft met de overmaking van de verschuldigde som, onverminderd wettelijke executiemogelijkheden. Duurt de overtreding voort, dan volgt mogelijk schorsing ex art. 9 Regeling bijdragen.

De aangeslotenen moeten zich daarnaast aan andere elementaire verplichtingen houden.

Uit de eerste twee leden van art. 6 Statuten NVK vloeien, voor de bij de controlestichting aangeslotenen, een regelnalevings- en aansprakelijkheidsplicht voort. Overtreding van voorschriften, bedoeld in art. 6, eerste lid, zijn aan tuchtrecht onderworpen, voor zover de officier van justitie niet heeft beslist dat een overtreding strafrechtelijk zal worden afgedaan (art. 23 Statuten NVK).

Overige verplichtingen voor aangeslotenen zijn neergelegd in de leden 3 en 4 van art. 6 Statuten NVK junctis respectievelijk art. 2 Reglement merkuitreiking en keuring vleeswaren $^{214}$ en art. 8 Reglement merkuitreiking en keuring bacon ${ }^{215}$.

\subsubsection{TOEZICHTSBEVOEGDHEDEN STICHTING NEDERLANDSE VLEESWAREN KONTROLE}

Iedere aangeslotene is verplicht de inspecteur(s) dan wel de controleur(s) der stichting (ex art. 1. Statuten: een voor de stichting werkzame functionaris die belast is met de uitvoering van het toezicht op de naleving van de bij of krachtens het besluit en van de bij of krachtens deze statuten en de op grond daarvan wettig genomen besluiten gegeven voorschriften - JGLvN), als mede ambtenaren belast met het in art. 29 bedoelde toezicht, tot zijn inrichtingen, opslagruimten en terreinen toe te laten en alle verlangde medewerking te verlenen, met inbegrip van het desverlangd verlenen van inzage van boeken en bescheiden, bij controle of andlerszins.

Lid 4 bepaalt dat iedere aangeslotene gehouden is om: a. degenen, die met het vervoer van vleeswaren zijn belast, te machtigen en zo nodig te gelasten om de inspecteur(s) dan wel de controleur(s) der stichting, als mede ambtenaren belast met het in art. 29 bedoelde 
toezicht, op hun vervoermiddelen en terreinen en in hun opslagplaatsen toe te laten teneinde hem (hen) in staat te stellen de onder hen berustende vleeswaren te inspecteren; b. degenen die in zijn opdracht zijn belast met de vervaardiging van vleeswaren, te machtigen en zo nodig te bewegen om de inspecteur(s) dan wel de controleur(s) der stichting, als mede ambtenaren belast met het in art. 29 bedoelde toezicht, in hun bedrijfsruimten en op hun terreinen toe te laten ten einde de hun opgedragen taak te kunnen uitoefenen; en c. zijn afnemers van dat produkt in binnen- en buitenland te verzoeken de inspecteur(s) dan wel de controleur(s) der stichting, als mede ambtenaren belast met het in art. 29 bedoelde toezicht, in staat te stellen de hem (hen) door de betrokken aangeslotene geleverde gevignetteerde vleeswaren, in hun opslagplaatsen te inspecteren.

Van alles wat zij in verband met de uitoefening van hun functie omtrent de inrichting van de fabrieken, de bedrijven, de handel en andere persoonlijke en zakelijke omstandigheden van de aangeslotenen ervaren, hebben de bestuursleden en tevens de voorzitter, indien hij geen bestuurslid is, behoudens tegenover de minister, de met het - in art. 29 bedoelde - rijkstoezicht belaste ambtenaren aan wie alle inlichtingen moeten worden verstrekt en alle medewerking moet worden verleend, en tegenover het tuchtgerecht, een plicht tot geheimhouding ex art. 16 Statuten NVK. Dit art. 16 is van overeenkomstige toepassing op de inspecteur(s), de controleurs en het overige personeel der stichting (art. 20, vijfde lid), die zijn benoemd volgens de voorschriften van art. 20 Statuten NVK. Zo bepaalt ook art. 4 Instructie inspecteur vleeswaren ${ }^{216}$.

\subsubsection{TOEZICHT OP MERKECHTHEID EN BETROUWBAARHEID KEURINGSMETHODEN}

Functionarissen met een controle- of inspectietaak houden toezicht op merkechtheid en waken er voor dat keuringsmethoden betronwbaar blijven.

Ex art. 4, eerste lid, Lkbg vleeswarenkeuring en -merken is de controle-instelling bij uitsluiting bevoegd tot het aan de aangeslotenen verlenen van het recht om de in art. 3 bedoelde merken op vleeswaren aan te brengen. Zij treft daarbij alle nodige maatregelen ten einde te voorkomen dat de merken door anderen dan aangeslotenen op vleeswaren kunnen worden aangebracht, dan wel dat deze merken worden aangebracht op vleeswaren, die in gevolge de bij of krachtens het besluit gestelde regelen niet van een merk mogen worden voorzien. Het tweede lid vermeldt dan, dat wanneer een aangeslotene uittreedt, het recht tot het aanbrengen van het merk door de controle-instelling met onmiddellijke ingang wordt ingetrokken. De zelfde regeling is terug te vinden in de artt. 5-6 Landbouwkwaliteitsbeschikking baconmerken en -keuring ${ }^{217}$. De inspecteurs houden nauwlettend in het oog dat de merken uitsluitend worden aangebracht op bacon, bereid in de bedrijven van aangeslotenen. Wordt bacon aangetroffen waarop ten onrechte merken zijn aangebracht, dan is de directeur, die ex art. 11, achtste lid, Rkmv zelf wel een voorlopige voorziening kan treffen, verplicht daarvan de AID onverwijld in kennis 
te stellen. Zie art. 5, derde lid, Reglement voor de uitreiking van merken en de keuring van bacon.

\subsubsection{Zelfkeuring}

Aangeslotenen kunnen, met toestemming, dus zelf produkten merken. Daarnaast kunnen zij ook zelf bij produktkeuring worden ingeschakeld ex art. 6 Lkbg vleeswarenkeuring en -merken.

Het reeds vermelde Reglement merking en keuring vleeswaren bepaalt dat. Bij een correct uitgevoerde zelfkeuring heeft betrokkene een systematische, duidelijk, volledig bijgewerkte en naar waarheid ingevulde administratielijst ten minste een half jaar ter inzage gelegd op een vaste bedrijfsafdeling voor de inspecteur. Maandelijks is een afschrift van deze lijst ter inzage naar het secretariaat van de stichting NVK gestuurd. Als

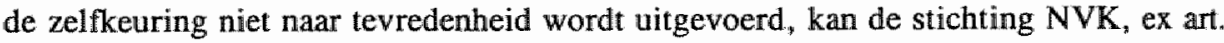
12 , tweede lid, Reglement betreffende verloop van de keuring en het uitreiken van merken inzake vleeswaren in het belang van de controle de toepassing van een systeem, als bedoeld in art. 9, eerste lid, (zelfkeuring - JGLvN) intrekken of wijzigen.

Overigens wordt de geschiktheid voor de toepassing van een zelfkeuringssysteem altijd vooraf beproefd. Art. 5, derde lid, Reglement keuring en merkuitreiking van vleeswaren bepaalt: "Zodra de verzoeker als aangeslotene is toegelaten, draagt de directeur de inspecteur op het bedrijf van de nieuw aangeslotene te inspecteren en te toetsen aan: a. de geschiktheid voor de bereiding, onderscheid. de verhandeling of het vervoer van vleeswaren; b. de eisen gesteld aan de inrichting van de bedrijven; en c. bij toepassing van het tweede lid, de geschiktheid voor de toepassing van het gekozen systeem."

Om te voorkomen dat bedoelde zelfregulering gemakkelijk fraude in de hand werkt, blijft de eindcontrole bij de stichting NVK. Over deze controle merkt art. 11 Reglement keuring en merkuitreiking vleeswaren het nodige op. Volgens art. 11, eerste lid, Rkmw juncto art. 5 Instructie voor de inspecteur vleeswaren ${ }^{218}$ vindt de controle op regelmatige doch wisselende tijdstippen en onaangekondigd plaats. De Instructie voor de inspecteurs bacon verfijnt de regel, in art. 3 , door te stellen, dat in het bedrijf van elke aangeslotene ten minste een maal per maand een inspectie plaats vindt en voor de bedrijven waar in drie op een volgende maanden geen overtreding is geconstateerd ten minste een maal per twee maanden wordt geinspecteerd.

Art. 11, derde lid, $\mathbb{R k m v}$ bepaalt dat de controle is gericht op de administratieve bescheiden, het functioneren wan de technische uitrusting, de inrichting der bedrijven, de analy. ses van het laboratorium, het fabrikageproces, de verpakking en het gebruik van de merken, en wordt verricht met inachtneming van een door het bestuur vastgestelde Instructie voor de inspecteur.

Respectievelijk art. 11, vierde lid, Rkmv en artt. 10-11 Rkmb junctis artt. 4-5 Instructie inspecteur bacon staan toe dat in het kader van inspectie monsterneming geoorloofd is. Wel moeten, op verzoek van de betrokkene, contra-monsters (indien wensellijk, ex art. 
$17 \mathrm{Rkmb}$, door een onafhankelijk onderzoeksinstituut, waardoor bij nieuwe afkeuring kosten worden berekend aan gecontroleerde) worden genomen. Na een zo geheten preventieve ondertoezichtsstelling van aangeslotene, moeten de eerste vijf achtereenvolgende produktiepartijen worden goedgekeurd, voordat het (al dan niet chemisch) preventief toezicht wordt opgeheven. De daarvoor vereiste monsterneming komen altijd voor rekening wan de kennelijk in gebreke gebleven gecontroleerde (art. 18, tweede lid, Rkmb en art. 12, derde lid, Rkmb treffen algemene regeling ter zake).

Zo nodig kan een inspecteur aan een aangeslotene, ex respectievelijk art. 11 , zevende lid, Rkmv juncto art. 8 Instructie inspecteur vleeswaren en artt. 10-11/14, tweede lid, Rkmb, aanwijzingen geven ter vermijding van onvolkomenheden in produkt, controlesysteem, gevoerde administratie of andere met het toezicht verband houdende zaken. Soms wordt een aanwijzing gegeven met mogelijkheid tot verbetering van het afgekeurde produkt. Slaagt het gecontroleerde bedrijf daar niet in, dan kan de inspecteur een afleverings- en merkwoeringsverbod uitvaardigen (art. 17, tweede lid, Rkmb).

\section{5 .5 VERSLAGLEGGING}

Van al zijn bevindingen legt elke inspecteur verantwoording af aan de directeur van de stichting NVK onder wiens toezicht hij staat (ex respectievelijk artt. 2/9 Instructie inspecteur vleeswaren en art. 1, derde lid, Instructie inspecteur bacon), met wie hij zich, ten aanzien van de inspectie, te allen tijde in verbinding kan stellen (art. 10 Instructie inspecteur bacon), en aan wie hij advies kan, en op diens verzoek móet, uit brengen (art. 11 Instructie inspecteur bacon).

Wekelijks, en bij geconstateerde overtreding onmiddellijk, wordt schriftelijk verslag gedaan aan de directeur (respectievelijk art. 11, vijfde lid, Rkmv juncto art. 7 Instructie inspecteurs vleeswaren en art. 8, derde lid, Rkmb juncto art. 7 Instructie inspecteur bacon).

Van de bedrijfsvoering van een nieuw aangeslotene binnen twee weken na eerste inspectie een schriftelijke rapportage naar de directeur gestuurd (art. 8 Instructie inspecteur bacon). In gevolge art. 6 Instructie inspecteur bacon omvat het inspectieverslag nauwkeurig: naam en adres van het bedrijf waar werd geïnspecteerd; naam en adres van de betrokken aangeslotene; de plaats waar inspectie plaatsvond; tijdstip en datum waarop inspectie plaatsvond; door hem gegeven aanwijzingen; wijze van monstering en aantal getrokken monsters; zijn bevindingen; en overige feiten of omstandigheden die hij relevant acht.

De directeur doet betrokkenen afschrift van het inspectieverslag toekomen, waarbij hij wijst op mogelijk geconstateerde onvolkomenheden of overtredingen met waarschuwing dat bij herhaling er van een tuchtrechtelijke verklaring ${ }^{219}$ wordt op gemaakt, en ook verschaft hij regelmatig algemene overzichten van controleresultaten (respectievelijk art. 11, zesde lid, Rkmv en art. 8, vierde lid, Rkmb)

249. De inspecteur makt een tuchtrechteljke verklaring op in gevallien, waarin geen proces-verbaal wordt opgemaakt doot opsporingsambtenaren van de AID of van de ter plaatse bevoegde politie. Zie ant. 9 , eerste lid, Instructie inspecteur bacon. 


\section{$\S 17.6$ Stichting Internationale Scharrelvlees Controle}

Een andere rechtspersoon, die vleeskwaliteit controleert, is de stichting Internationale Scharrelvlees Controle. Deze stichting houdt, wat betreft varkensvlees wan uit een wettelijk kader, toezicht op naleving van gestelde regels met betrekking tot het produceren, verwerken en verhandelen van scharrelvlees. De stichting ISC ontleent deze toezichtstaak aan art. 6 Landbouwkwaliteitsbesluit scharrelvlees en -vleeswaren ${ }^{220}$. De toezichthoudende bevoegdheden ten aanzien van scharrelkippevlees ${ }^{221}$ en scharrelrundvlees ${ }^{222}$ als mede groepskalfsvlees oefent de stichting ISC niet op grond van wettelijke bepalingen uit.

\subsubsection{TAAKSTELLING STICHTING INTERNATIONALE SCHARRELVLEES CONTROLE}

De toezichthoudende taak van de stichting ISC bestaat uit het uitwoeren van controlerende en inspecterende taken, het keuren, het verstrekken van zeugennummers (d.w.z. geel plastic oormerk met daarop levensnummer van zeug, door ISC aan te brengen) en merken (d.w.z. witte manchetten met de inscriptie ISC bestemd om te bevestigen bij gespeende biggen) en het uitreiken van slachtmerken (d.w.z. wit blikken merk in U-vorm met inscriptie ISC onder uniek nummer verstrekt door ISC) en stempelmerken (d.W.Z. identificatiemerk, uitsluitend te hanteren onder toezicht van ISC-inspecteurs en RVV-ambtenaren) als mede keuringscertificaten (aansluitingsbewijs ex art. 2, vierde lid, Controlereglement ISC $^{223}$ ).

Hierdoor wil de stichting ISC een zo optimaal mogelijke kwaliteit, verpakking, sortering, vorm, afwerking, aanduiding en aflevering van scharrelvlees(waar) garanderen. De aandacht voor produktie, verwerking en handel van de stichting ISC wordt, naast economische redenen, ingegeven door overwegingen m.b.t. cliënt (ecologisch verantwoord, kwalitatief hoogstaand en veilig vlees) en dier (bij het houden van scharrelvarkens zij̣ elementaire aandachtspunten: bewegingsbehoefte, lig- en rustgedrag, mestplaats, vreten/drinken, stalklimaat, hygiëne/verzorging en aflevering/transport).

De stichting ISC spreekt van controle op basis van regelgeving "waarin een dier- en milieuvriendelijke varkenshouderij wordt gecombineerd met bedrijfseconomisch goede resultaten voor varkenshouder en detaillist, en een goede garantie voor de consument". 224

220. Lkb scharrelvlees en -vleeswaar, 22 jan. 1992, Stbl. 1992, 102.

221. Medio 1993 telt de stichting ISC 11 produktiebedrijven ter zake in Nederland. De overige bedrijwen zijn in meerderheid aanwezig in Frankrijk. Daarom werkt de stichting ISC nauw samen met de controleinstelling aldaar t.w. Sociétế Coopérative Agricole des Fermiers de Loué gezeteld in Le Mans. Dalarnast dringt de stichting ISC, gelet op het internationale karakter van haar controletaken, bij de minister aan op erkenning als controlerende instantie in het kader van de EG-richtijn inzake alternatieve pluimveeproduktie (2891/93). ISC, Jaanershag 1993, Utrecht, 1994, p.2.

222. In 1993 zijn de eerste aansiuitingen/keuringscertificaten inzake scharrelrundvlees, t. w. 148 aangesloten bedrijven per 31 december 1993, feit. ISC. Jaarverslag 1993, Utrecht, 1994, pp.1/3.

223. Controlereglement scharrelvarkensvlees, in: ISC, Richüjnen, voorschriften en reglementem, Utrecht, jan. 1991 , pp.43-52.

224. ISC, Richtijnen, voorschriften en reglementen, Utrecht, jan, 1991, p.1. 
Met betrekking tot het bereiken van een zo optimaal mogelijk toezicht streeft de stichting ISC belangrijke doelstellingen na als: integrale keten beheersing (d.w.z. het streven naar een produktie van scharrelvarkensvlees, die naast de ISC-eisen tevens voldoet aan de PVV/IKB-normen); accreditatie (d.w.z. het streven naar erkenning door een accrediteringsorganisatie op basis van NEN/ISO-normen); en uniformering van analysemethoden (d.w.z. het onderbrengen wan het onderzoek naar voer- en urinemonsters bij een gecertificeerd laboratorium). ${ }^{225}$

Ter produktkwaliteitsbevordering heeft de stichting ISC, naast haar primair toezichthoudende taakstelling, ook een voorlichtende en informatieve functie.

\subsubsection{RECHTEN EN PLICHTEN ONDER TOEZICHT GESTELDEN}

Onder toezicht gestelde scharrelvarkenshouderijen (vermeerderingsbedrijven of mesterijen) moeten de, volgens het ISC noodzakelijke, controles en inspecties dulden. De reguliere en bijzondere bezoeken, in het kader van ISC-toezicht, richten zich vooral op: de uitwoering van stallen en hokken (inrichting, afmetingen e.d.), de algemene huisvesting en verzorging van de dieren (bezettingsdichtheid, bodemstrooisel, ventilatie e.d.), de aanwezigheid van verboden additieven, preparaten en resten in respectievelijk voer en mest, en natuurlijk de juistheid van de gevoerde administratie. ${ }^{226}$

Met oog op een adequate uitoefening van het ISC-toezicht is bij voorbeeld specifiek het volgende bepaald. De ISC-inspecteur beoordeelt ex art. 7, tweede lid, Rhvv jo. art. 29, lid 2 en lid 3, Rhvv, of de permanent aanwezige (vloer)stro voldoende dik is. De inspecteur beoordeelt, ex art. 11, eerste lid, Rhvv, ook de geschiktheid van afleverfaciliteiten voor varkensvervoer en ex art. 20 Rhvv de mogelijkheid om ongedierte uit bedrijfsruimten te weren. Met oog op inspectie moet elke huisvesting zo nodig kunstlicht beschikbaar kunnen stellen van voldoende sterkte (art. 9, derde lid, Rhvv). Met oog op een inzichtelijke administratie bepaalt art. 12 Rhwv, dat alle varkenshouders een logboek moeten hebben, waarin alle inentingen en veterinaire handelingen worden genoteerd. Dit boek is altijd op het bedrijf aamwezig en ISC-inspecteurs moeten het altijd kunnen inzien.

Scharrelvarkenshouderijen die voor aansluiting bij het ISC in aanmerking willen komen, moeten zich exclusief, dat wil zeggen uitsluitend, richten op de scharrelvleeshouderij (art. 5, lid 7 en lid $8, \mathrm{Cr}$ scharrelvarkensvlees). ${ }^{227}$ Als (potentiële) scharrelvarkenshouders dienen zij zich schriftelijk aan te melden bij het ISC. Bij acceptatie van aansluiting, die pas na een proefperiode plaats vindt, verstrekt de stichting ISC de betrokken scharrelvar" kenshouderij een keuringscertificaat.

225. ISC, Jaarverslag 1993, Utrecht, 1994, p.3.

226. Reglement husuesting, werzorging en woeding, in: ISC, a.w., pp.7-42.

227. Dit geldt, min of meer, ook woor: grossierderijen ex art. 46 Rhvw jo. art. 7 , eerste lid, Cr scharrelvarkenswlees; wleeswarenfabrieken ex art. 60 Rhvw jo: art. 10, eerste lid, Cr scharrelvarkensvlees; uitsnijderjien/voorwe makkingsinrichtingen ex ant. 52 Rhww junctis art. 9, eerste lid, Cr scharrelvarkenswlees en art. 12, eerste lid, Cr scharrelwarkenswlees; versnij-inrichtingen ex art, 68 Rhvv jo. art. 11, eerste lid, $\mathrm{Cr}$ scharrelvarkenswlees; de detailhandel ex art. 78 jo. art. 79 Rhvv jo. art. 13 , eerste lid, $\mathrm{Cr}$ schirrelvarkensvlees; en de horeca ex art. 85 Rhvy jo. art. 14, eerste lid, Cr scharrelvarkensvlees. 
Aansluiting met keuringscertificaat verplicht de betrokken scharrelvarkenshouderij tot thet aanbrengen van ISC-inscriptielabels ${ }^{228}$ met oormerk bij zeugen en met manchet bij biggen, tot het gebruiken van ISC-slachtmerken en tot het melden van elke onder geleidebiljet plaats vindende aan- en afvoer van varkens via de ISC-meldingsbrieven. Daarnaast moeten aangesloten scharrelvarkenshouderijen een overzichtelijke administratie voeren. En ook dienen zij $\mathrm{Vn}$ - even als detaillisten en andere aangeslotenen -, ter dekking van controlekosten, te voldoen aan hun plicht tot het betalen van een financiële bijdrage (t.w. het eenmalig entreegeld, een vaste jaarlijkse bijdrage, plus een heffing per mestbig al dan niet afgeleverd met een slachtvarken) ${ }^{229}$.

Op bedrijven die handelen of bemiddelen in levende scharrelvarkens afkomstig van de bij de ISC aangesloten bedrijven rust, ex art. 41 Reglement huisvesting, verzorging en voeding, een aansluitingsplicht. ${ }^{230}$ Deze handelsbedrijven voorzien hun varkens van identificatiemerken en leveren hun varkens via een geleidebiljet ex art. 42 Rhvv jo. art. 43 Rhvv, waarna ze elke levering binnen bepaalde termijn bij het ISC doorgeven via een meldingsbrief ex art. 6, derde lid, $\mathrm{Cr}$ scharrelvarkensvlees. ${ }^{231}$

Handelsbedrijven verschaffen de stichting ISC vierwekelijkse resultaatoverzichten $\mathrm{ex}$ art. 44 Rhvv jo. art. 6, vierde lid, Cr scharrelvarkensvlees. ${ }^{232}$ Hun in- en verkoopadministratie van scharrelvarkens houden zij gescheiden van hun overige administratieve boekhouding.

Art. 45 Rhwv bepaalt dat hun, soms dus verplicht gescheiden, administratie zodanig is ingericht dat te allen tijde op eenvoudige wijze inzicht verkregen kan worden in de gegevens die benodigd zijn om de naleving van de desbetreffende voorschriften te kunnen controleren. Vergelijkbare administratieverplichtingen rusten op aangesloten veehandelaren, grossierderijen, uitsnijderijen/voorverpakkingsinrichtingen, vleeswarenfabriekenals ook detaillisten ex respectievelijk art. 6, vijfde lid, Cr scharrelvarkenswlees, art. 51 Rhww jo. art. 7, achtste lid, Cr scharrelvarkensvlees, art. 54 Rhvv, art. 66 Rhvv en art. 75 Rhvv.

In het bijzonder inzake de detailhandel bepaalt art. 76 Rhvv jo. art. 14, vijfde lid, $\mathrm{Cr}$ scharrelvarkensvlees, dat de detaillist ten minste drie maanden kassauitdraaien (met -in

228. Vgl. plicht voor detaillist tot het aanbrengen van ISC-sticker op zijn winkelruit ex art. 84 Rlww.

229. Zie voor thet heffingenstelstel het Bijdragenbeshit scharrelvarkenswlees.

230. Vgit. art. 59 Rhvw voor vleeswarenfabrieken en art. $67 \mathbb{R h w}$ woor versnij-unrichtingen.

231. Zie voor grotendeels gelijke verplichtingen inzake meldingsbrieven en geleidebiljetten: art. 7 , darde vijfde, zesde, negende en tiende lid, Cr scharrelvarkenswlees voor grossierderijen; art. 9, tweede lid, $\mathrm{Cr}$ scharrelvarkensvlees voor uitsnijderijen; art. 13, derde lid, $\mathrm{Cr}$ scharrelwarkensvlees voor detailhandelsbedrijwen; en ant. 14, tweede lid en derde lid, $\mathrm{Cr}$ scharrelvarkenswlees voor horecabendrijpem.

232. Vgl. plicht tot opmaak wan maandstaten als neergelegd in: art. 5, vierde lid, Cr scharrelvarkensvlees voor varkenshouderijen, art. 6 , vierde lid, $\mathrm{Cr}$ scharrelvarkensvlees voor veehandelaren; art. 50 Rhww jo. art. 7, zevende lid $\mathrm{Cr}$ scharrelvarkensvlees voor grossierderijen; art. 9, derde lid, $\mathrm{Cr}$ scharrelwarkensvlees voor uitsnijderijen; art. $61 \mathrm{Rhvv}$ jo. art. 10, vierde lid, Cr sctharrellvarkensvlees voor vleeswarenfabrieken; art. 69 Rhvv jo. art. 11, derde lid, Cr scharrelvarkensvlees voom versnij-inrichting; de artt. 76 en $80 \mathrm{Rhvv}$ jo ant. 13, wierde lid, Cr scharrelvarkensvlees woor detaillistem; en art. 88-II Rhwr jo. art. 14, zesde lid, Cr scharrelwarkensvlees voor de horeca. Voor woorwerpakkingsinrichutingen sch rij] art. 12, derde lid, Cr scharrelvarkensvlees dagelijkse opgave van overzichtsstaten voor. 
een zgn. 'price look up' - vermelding van naam en gewicht van ellk in zijn zaak gekocht scharrelvleesartikel) moet bewaren ter verificatie van de stichting ISC.

Speciaal met betrekking tot de, conform artt. 54/55-57 Rhvw aan ISC-eisen inzake aanduidingen voldane, voorverpakking van scharrelvarkensvleesprodukten bepaalt art. 58 Rhwv dat voorwerpakken altijd plaats vindt onder toezicht van RVV-ambtenaren, al dan niet samen met ISC-inspecteurs. Hiervan kan alleen worden afgeweken na toestemming van de ISC-directeur ${ }^{233}$.

Of het nu fokbedrijven, vermeerderingsbedrijven, mesterijen, varkenshandelbedrijven, slachterijen, grossierderijen, voorverpakkingsbedrijven, uitsnijderijen, vleeswarenfabrieken, versnij-inrichtingen, detailhandelbedrijven of horecabedrijven betreft, door hun aansluiting bij de stichting ISC verplichten zij zich tot een aantal algemene verplichtingen. De eerste verplichting, na aanvraag om aansluiting, is dat betrokkene een controlebezoek ex art. 2, tweede lid, Controlereglement scharrelvarkensvlees ${ }^{234}$, en zo nodig een herhaald inspectiebezoek ex art. 2, derde lid, $\mathrm{Cr}$ scharrelvarkensvlees, moet toestaan. Bij, aan betrokkene schriftelijk medegedeeld, positief oordeel van de stichting ISC, is aansluiting - krachtens keuringscertificering ex art. 2, vierde lid, $\mathrm{Cr}$ scharrelvarkensvlees voorlopig feit. Pas na een proefperiode blijkt of de stichting ISC echt accoord gaat met aansluiting (zie art. 2 , vijfde lid, $\mathrm{Cr}$ scharrelvarkensvlees).

Definitieve aansluiting verschaft een aangeslotene, ex art. 3 , derde lid, $\mathrm{Cr}$ scharrelvarkensvlees, het recht om voor de aansluitingsduur wettig gedeponeerde ISC-woordmerken en ISC-beeldmerken te gebruiken. In gevolge art. 2, vierde lid, $\mathrm{Cr}$ scharrelvarkensvlees is dit recht een uitsluitend recht van de stichting ISC en haar aangeslotenen.

Als keerzijde van de médaille moet een aangeslotene zich onderwerpen aan de onder meer in het Controlereglement scharrelvarkensvlees gestelde controle- en uitvoeringsvoorschriften. Deze nalevingsplicht is neergelegd in art. 3, eerste lid jo. art. 3, tweede lid, Cr scharrelvarkensvlees. Art. 3, vijfde lid, Cr scharrelvarkensvlees stelt aanvullend dat een aangeslotene de plicht heeft de, door ISC-inspecteurs in het kader van het Controlereglement scharrelvarkenswlees gegeven, controlebevelen en -aanwijzingen onverwijld op te volgen. ${ }^{235}$ Is een aangeslotene niet trouw aan zijn nalevingsplicht, dan kan de stichting ISC hem daarop aanspreken. Overigens is elke aangeslotene ex art. 4, eerste lid, $\mathrm{Cr}$ scharrelvarkensvlees, mede aansprakelijk voor personen, die in of voor zijn bedrijf werkzaam zijn.

Formele verplichting voor elke aangeslotene is natuurlijk het uitsluitend leveren of afnemen van scharrelvarkensvlees dat voorzien is van een ISC-merkteken en een geleidebiljet ex art. 4, derde lid, $\mathrm{Cr}$ scharrelvarkenvlees. Daarnaast stelt art. 4, vijfde lid, $\mathrm{Cr}$ scharrelvarkensvlees als formele eis, dat een aangeslotene voor uittreding een opzegtermijn van drie maanden in acht moet nemen.

233. Conform art. 89 Ruvw beslist de ISC-directeur overigens in alle gevallen, waarin het Rhvv niet voorziet.

234. Controlereglement scharrelvarkenswles, in: ISC, a.w., pp.43-52.

235. Art. 8, vijfde lid, $\mathrm{Cr}$ scharrelvarkensvlees bepaalt in het bijzonder voor slachtplaatsen, dat slachterijen verplicht zijn zich te houden aan aamwijzingen vam ISC-inspecteurs en, daamaast, dat zij deze aanwijzingen "strikt" op moetten volgen. 
En voor feitelijk toezicht is het noodzakelijk dat een aangeslotene, ex art. 4, vierde lid, Cr scharrelyarkensvlees, een adequate administratie voert.

\subsubsection{TOEZICHTSBEVOEGDHEDEN STICHTING INTERNATIONALE SCHARRELVLEES CONTROLE}

Op elke aangeslotene rust, ex art. 4, tweede lid, $\mathrm{Cr}$ scharrelvarkensvlees, de algemene plicht om ISC-toezicht te dulden. Iedere ISC-inspecteur (conform art. $1 \mathrm{Cr}$ scharrelvarkensvlees is dat een inspecteur in dienst van de stichting ISC, die belast is met de uitvoering van het toezicht op de naleving van de bij of krachtens de reglementen, en de daarbij behorende bijlagen, gegeven voorschriften) ${ }^{236}$ heeft toegang tot inrichtingen, opslagruimten en terreinen van aangeslotenen. Aangeslotenen moeten bij "controle of anderszins" ${ }^{237}$ alle verlangde medewerking verlenen, met inbegrip van het verlenen van inzage van boeken en bescheiden.

ISC-inspecteurs kondigen, ex art. 15, eerste lid, Cr scharrelvarkensvlees, hun controlebezoeken bij bedrijven niet aan. Hun onverwachtse inspectieronden leggen zij af op welliswar regelmatige doch wisselende tijdstippen. Art. 15, tweede lid, Cr scharrelvarkensvlees verplicht elke inspecteur tot periodieke schriftelijke verslaglegging van uitgevoerde controles en bevindingen daarvan.

De inspecteur voert, ex art. 15 , derde lid, $\mathrm{Cr}$ scharrelvarkensvlees, met de ISC-directeur ${ }^{238}$ overleg met betrekking tot geconstateerde overtredingen. Ex art. 15, vierde lid, $\mathrm{Cr}$ scharrelvarkensvlees jo. art. 8 Reglement voor de commissie van beroep van de ISC $^{239}$, treft het stichtingsbestuur ${ }^{240}$ mogelijk passende (tucht)maatregelen tegen betrokken overtreder. Bij herhaalde overtreding kan de aansluiting van de in overtreding zijnde aangeslotene met onmiddellijke ingang worden beëindigd ex art. 15, vijfde lid, $\mathrm{Cr}$ scharrelvarkensvlees. Een dergelijk besluit, waartegen betrokkene ex art. 15, zesde lid, Cr scharrelvarkensvlees, wel in beroep kan gaan, wordt onverwijld medegedeeld en openbaar gemaakt.

In 1993 dringt het ISC-bestuur een maal aan op beëindiging van aansluiting. De commissie van beroep reageert daarop door de maatregel te wijzigen in een boete en de aansluiting te beëindigen op een later tijdstip. ${ }^{241}$ Aan het eind van 1993 zijn twee gevallen te constateren waarin de stichting ISC besluit tot beëindiging van aansluiting. ${ }^{242}$

236. De stichting ISC kent een hoofdinspecteur, een plaatsvervangend hoofdinspecteur en een aantal inspec. teurs.

237. Dit "andersziws" lijkt beperkt te moeten worden opgevat. Ruime interpretatie is onaanwaardbaar. De "controle of andersins' moet altijd ten behoeve/dienste van een behoorlijke uitoefening wan toezicht staan.

238. Conform art. 15, achtste lid, Cr scharrelvarkemsvlees, beslist de directeur in alle gevallen waarin thet Cr scharrelvarkenswlees niet voorziet.

239. Reglement voor de commissie wan beroep wan de ISC, in: ISC, a.w., pp.53-59...

240. In gevolge art. 15, negende lid. $\mathrm{Cr}$ scharrelvarkensvlees is het bestuur bevoegd tot het stellen wan nadere regels.

241. ISC, Jaarverslag 1993, Utrecht, 1994, p.7.

242. ISC, Jaanverslag 1993, Utrecht, 1994, p.15. 
In het kader van het ISC-streven naar accreditie moet het opstellen van een algemeen handboek, een handboek voor produktiecontrole van ISC-scharrelvarkensvlees, en een leidraad voor de kwaliteitscontrole van de overige diersoorten, worden bezien. ${ }^{243} \mathrm{Be}$ geleid door adjunct-directeur en externe adviseurs vervaardigen ISC-medewerkers zelf bedoelde controlehandboeken.

\subsubsection{CUFERMATIGE GEGEVENS STICHTING INTERNATIONALE SCHARRELVLEES CONTROLE}

Het aantal aangeslotenen voor de controle op het produceren, verwerken en verhandelen van scharrelvarkensvlees stijgt aanzienlijk. Vallen in 1986 nog maar 31 aansluiting te registreren, eind 1993 ligt het aantal aansluitingen al op $974 .{ }^{244}$ Wat betreft scharrelkippevlees staan in 1993 maar liefst 1643 producerende, verwerkende en verhandelende bedrijven als aangesloten bij de stichting ISC genoteerd. ${ }^{245} \mathrm{De}$ controlesector scharrelrundvlees is nog jong en telt aan het eind van haar introductiejaar 1993148 aangesloten producerende, verwerkende en verhandelende bedrijven. ${ }^{246} \mathrm{De}$, in het kader van controle op het produceren, verwerken en verhandelen van groepskalfsvlees, aangeslotenen bij de stichting Groepskalfsvlees betreffen 718 bedrijven. ${ }^{247}$

Aan het adres van de verschillende onder toezicht gestelden leggen inspecteurs in 1993 3975 inspectie- en identificatiebezoeken en 61 informatie- en aanmeldingsbezoeken af, waarbij 211 voermonsters worden genomen. ${ }^{248}$ Uit de controlebevindingen met betrekking tot 1993 vallen onder meer problemen op te maken als: afwezigheid van respectievelijk ISC-stempelmerk op vlees en ISC-logo op de winkelruit van de betrokken detailhandel; ontbreken van afleveringsbon, weegbrief of kassauitdraai; ontijdige invulling van maandstaten en niet-openbare, incorrecte bedrijfsadministratie (denk ook aan logboek); en antibiotica of een te hoog gehalte aan ingrediënten in krachtvoer. ${ }^{249}$

243. ISC, Jaarverslag 1993, Utrecht, 1994, p.4.

244. ISC, Jaarversiag 1993, Utrecht, 1994, p.10.

245. ISC, Jaanerslag 1993, Utrecht, 1994, p.12.

246. ISC, Jaanversilag 1993, Utrecht, 1994, p.14.

247. ISC, Joamerslag 1993 , Utrecht, 1994, p.16.

248. ISC, Jaarverslag 1993. Utrecht, 1994, p.18.

249. ISC Jaarwerstag 1993, Utrecht, 1994, p.19. 


\section{$\$ 17.7$ Stichting Nederlandse Algemene Keuringsdienst Groente- en bloemzaden}

Naast organisaties waarvan taken en bevoegdheden voort vloeien uit de Landbouwkwaliteitswetgeving, bestaan er verschillende controle-instellingen die gevolg zijn van bepalingen in de zaaizaad-en plantgoedregelgeving.

Zo kan volgens art. 87, eerste lid, Zaaizaad- en plantgoedwet ${ }^{250}$ ten aanzien van een cultuurgewas bij amvb worden bepaald, dat het bedrijfsmatig voortbrengen, bewaren en bewerken, anders dan voor gebruik in eigen bedrijf, en het bedrijfsmatig in het verkeer brengen, verder verhandelen, invoeren, uitvoeren en ten uitvoer aanbieden van teeltmateriaal (waarmee - in gevolge het tweede lid - bij amvb gelijk gesteld kunnen worden: zaden, welke niet bestemd zijn om door middel van uitzaai voor de teelt van gewassen te dienen) dan wel het bedrijfsmatig doen verrichten van deze handelingen uitsluitend is toegestaan aan hem, die is aangesloten bij een in amvb voor dat cultuurgewas aangewezen keuringsinstelling.

De aangewezen keuringsinstelling moet voldoen aan de in art. $88 \mathrm{Zpw}$ gestelde instellingseisen (als statutaire doelvermelding tot bevordering van betrouwbaar teeltmateriaal, geen winstoogmerk, bestuur met belanghebbenden, ministeriële goedkeuring voor statuten en algemene instellingsvoorschriften, benoeming voorzitter door minister gehoord het bestuur, toepasselijkheid tuchtrecht, regels raad van beroep, aanwezigheid rijkstoezicht). De hieronder ter illustratie gegeven controle-instelling is de aangewezen keuringsinstelling stichting Nederlandse Algemene Keuringsdienst voor Groente- en bloemzaden.

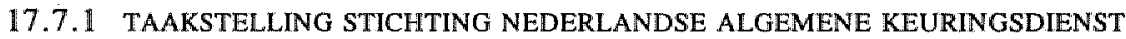 GROENTE-EN BLOEMZADEN}

Ex art. $91 \mathrm{Zpw}$ is de controle-instelling bevoegd voorschriften te geven ten aanzien van: a. gezondheid, zuiverheid en kwaliteit teeltmateriaal; b. sortering, classificatie, verzorging, verpakking, verlading en aanduiding van het teeltmateriaal, voor zover verband houdende met de onder a genoemde onderwerpen; $c$. het gebruik van de op het teeltmateriaal betrekking hebbende bescheiden en kentekenen, welke bij het verrichten van een of meer der in het eerste lid van art. 87 genoemde handelingen moeten worden gebezigd; d. de technische inrichting en administratie van het bedrijf als mede de technische be-

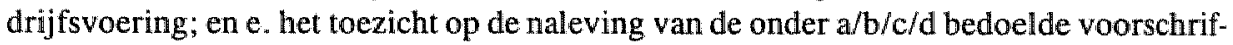
ten en de keuring van het teeltmateriaal.

Voor zover de voorschriften betrekking hebben op de uitvoer, kan de minister conform het tweede lid bepalen, dat het toezicht op de naleving daarvan bij een door hem aan te wijzen instantie berust.

250. Zaaizaad-en plantgoedwet, 6 okt. 1966, Stbl. 1966, 455, gewijz. 8 mei 1969, Stbl. 1969, 191, gewijz. 7 sept. 1972, Stbl. 1972, 461, gewijz. 4 febr. 1981. Stbl. 1981, 35, gewijz. 25 jan. 1984, Stbl. 1984, 19. gewijz. 24 mei 1984, Stbl. 1984, 238, gewijz. 26 juni 1986, Stbl. 1986, 388. 


\subsubsection{AANSLUTTPLICHT IN HET KADER VAN DE EUROPESE EENWORDING}

Tegenwoordig is in gevolge een, naar aanleiding van jurisprudentie van het Europese Hof van Justitie ontstane, wijziging van art. 1 Aansluitingsbesluit NAKG ${ }^{251}$ de aansluitingsplicht voor het bedrijfsmatig verhandelen et cetera van teeltmateriaal geschrapt. Slechts de eerste drie produktiefasen zijn gehandhaafd, voorts is teeltmateriaal toegevoegd. Art. $87 \mathrm{Zpw}$ verklaart betrokken minister bevoegd in door hem te bepalen gevallen of groepen van gevallen van het krachtens het eerste lid bepaalde ontheffing of vrijstelling te verlenen. ${ }^{252}$

\subsubsection{TOEZICHTSBEVOEGDHEDEN STICHTING NEDERLANDSE ALGEMENE KEURINGSDIENST GROENTE- EN BLOEMZADEN}

In gevolge art. 3 Algemeen reglement van de NAKG ${ }^{253}$ richten de controle- en keuringswerkzaamheden van de hier relevante stichting Nederlandse Algemene Keuringsdienst Groente- en bloemzaden zich op het teeltmateriaal van de gewassen vermeld in het Aansluitingsbesluit, dat wordt geteeld, in het verkeer wordt gebracht, bewerkt, verhandeld, uitgevoerd of ingevoerd.

De NAKG oefent conform art. 12, eerste lid, Ar NAKG toezicht en controle uit op alle handelingen welke door een aangeslotene worden of zijn verricht ten aanzien van door hem geteelde, in het verkeer gebrachte of te brengen, verhandelde en te verhandelen partijen zaad. Dit geschiedt vooral aan de hand van de administratieve gegevens en de betreffende keuringsrapporten. De NAKG kan voorschrijven dat bepaalde aan de aangeslotene toegewezen handelingen onder controle van de NAKG moeten geschieden.

De NAKG oefent steeksproefsgewijs controle achteraf uit op de verhandelde partijen zaad. Officieel getrokken monsters (art. 11 Ar NAKG betreft bemonstering) van partijen zaad worden bij uitzaai te velde onderzocht op rasechtheid, raszuiverheid en gezondheid en worden voorts onderworpen aan het onderzoek ten aanzien van de hoedanigheid van het zaad.

\subsubsection{Toezicht ten aanzien van aangeslotenen}

Art. 12, tweede lid, Ar NAKG bepaalt dat, ten einde dit toezicht en deze controle mogelijk te maken aangeslotene verplicht is om: a. de personen, die namens de NAKG het toezicht uitoefenen, vrije toegang te verlenen tot zijn bedrijf, de gebouwen en andere opstallen, voor zover deze door de aangeslotene worden gebruikt voor de uitoefening van zijn bedrijf; b. deze personen desgevraagd inzage te verlenen van administratieve gege-

252. Besluit vrijstelling aansiwiting $N A K G, 18$ mei $1967, J 1423$, Stcrt. 1967, 98, gewijz. 24, juli 1980, J2898, Stcrt. $1980,143$.

253. Algemeen reglewen $N A K G$, bestuursbesluit 676 , ministeriele goedkeuring 13 febr. 1991 . 
vens, welke betrekking hebben op de bedrijfshandelingen, gelegen op het terrein van de NAKG.

Ex art. 4 Keuringsreglement groenteplanten ${ }^{254}$ dient een aangeslotene zorgvuldige administratie te voeren ten aanzien van zijn produktie van en/of handel in teeltmateriaal. Deze administratie, welke ten minste twee jaar dient te worden bewaard, moet in het bijzonder duidelijkheid verschaffen omtrent het gebruikte uitgangsmateriaal (rasnaam., leverancier, partijnummer, hoeveelheid, ontvangstdatum) als mede omtrent het hiervan geproduceerde teeltmateriaal en de bestemming daarvan. Ook art. 8 Keuringsreglement plantuitjes ${ }^{2 s 5}$ bepaalt dat een bewaarplaatshouder een nauwkeurige en overzichtelijke administratie dient bij te houden wan alle in elke afzonderlijke ruimte ingebrachte en afgeleverde (per keuringsnummer afzonderlijk gehouden en geadministreerde) partijen. Art. $2 \mathrm{Kr}$ plantuitjes betreft bij voorbeeld de plicht tot waarachtige en volledige opgave van teeltpercelen voor keuring, mogelijk te voorzien van bewijsstukken. Daamaast bestaat een plicht om de voor een goede uitoefening wan zijn toezicht en controle door de NAKG gevraagde hulp en hulpmiddelen, met mame de te trekken controlemonsters, gratis te verstrekken. En ook is er een plicht alle door de NAKG gevraagde inlichtingen voor zover deze betrekking hebben op aangelegenheden, gelegen op het terrein van de NAKG te verstrekken, eventueel op de wijze en ter plaatse alls door de $\mathrm{NAKG}$ aangegeven.

\subsubsection{Toezicht ten aanzien van niet-aangeslotenen}

Niet-aangeslotenen zijn, als gezegd, tegenwoordig ook gebonden aan bepaalde normen van de NAKG. Relevant artikel, met oog op bekendheid van niet-aangesloten burgers met zaaizaad- en plantgoedregelgeving, is art. 5 Besluit verhandeling teeltmateriaal groenteen bloemgewassen. Daaruit volgt dat de NAKG aan belanghebbenden, weliswaar op aanvraag, elementaire voorschriften (betreffende onder meer keuring) ter beschikking stelt. Hoewel het kenbaarheidsbeginsel nog niet op afdoende wijze is gewaarborgd, legt zo'n bepaling wel een goede basis.

Vrij wel analoog aan de regeling woor aangeslotenen bepaalt art. 4, vijfde lid, Beslluit verhandeling teeltmateriaal groente- en bloemgewassen voor niet-aangeslotenen, dat -ter verkrijging van benodigde gegevens en monsters- degene die teeltmateriaal van de in het Aansluitingsbesluit genoemde gewassen in het verkeer brengt, invoert, witvoert of ter uitvoer aanbiedt of deze handelingen daarmee doet verrichten, verplicht is de door de NAKG met de keuring belaste personen: a. wrije toegang tot het bedrijf en de bedrijfsgebouwen als mede inzage van de in het eerste lid bedoelde administratie te verlenen; $b$. de gevraagde inlichtingen, gegevens en administratieve bescheiden te verstrekken; en $\mathrm{c}$. hulp en hulpmiddelen om niet ter beschikking te stellen en monsternemingen om niet te laten toestaan.

254. Keuringsreglement groenteplanten, bestuursbesiuit 667,26 april 1990, ministeriële goedkeuring 16 aug. 1990.

255. Keuringsreglement plantuitjes, bestuursbesluit 599, ministeriele goedkeuring 8 okt. 1984. 
Ten aanzien van de administratie geldt het volgende. Voor niet-aangeslotenen geldt art. 4 , eerste lid, Besluit verhandeling teeltmateriaal groente- en bloemgewassen ${ }^{256}$. Daaruit volgt dat hij die teeltmateriaal van de in het Aansluitingsbesluit NAGK genoemde gewassen bedrijfsmatig in het verkeer brengt, verder verhandelt, invoert, uitvoert of ten uitvoer aanbiedt of deze handelingen daarmee doet verrichten een volledige administratie ten aanzien van deze handelingen met teeltmateriaal dient bij te houden. Deze administratie dient, volgens het tweede lid, zo danig te zijn ingericht dat op eenvoudige wijze kan worden nagegaan op welke tijdstippen, in welke hoeveelheden en van/aan welke bedrijven teeltmateriaal werd verworven/geleverd.

Ten aanzien van monsterneming bepalen de leden 3 en 4 van art. 4 Besluit verhandeling teeltmateriaal groente- en bloemgewassen het volgende. Hij, die zaden van de in het aansluitingsbesluit NAKG genoemde gewassen bedrijfsmatig invoert, uitvoert en ten uitvoer aanbiedt als mede deze handelingen daarmee doet verrichten, dient van elk van de te verhandelen partij monsters te nemen volgens aanwijzingen gesteld bij door onze minister goedgekeurde voorschriften van de NAKG. Daarnaast dient hij deze monsters ten minste gedurende een periode van twee jaar ordelijk en behoorlijk te bewaren en ter beschikking van de NAKG te houden. Van elk monster moet door een blijvende aanduiding, geplaatst op of aan de verpakking, steeds vaststaan van welke partij het is getrokken. Indien het een mengpartij betreft dan dient even eens te worden aangegeven uit welke partijen en in wellke verhouding de mengpartij is samengesteld.

\subsubsection{KOSTENVERHAAL}

Kosten verbonden aan keuring en dergelijke worden door de controle-instelling verhaald op aangeslotenen en, op de zelfde wijze op, doorberekend aan niet-aangeslotenen. Zie artt. 3/7 Besluit verhandeling teeltmateriaal groente- en bloemgewassen.

\subsubsection{ZELFKEURING}

Verbijzondering van bovenstaande is te vinden in het Keuringsreglement groenteplanten. Dat is toepasselijk op bedrijfsmatige produktie en verhandeling van teeltmateriaal, anders dan zaden, van alle in aansluitingsbesluit genoemde groentegewassen. Art. 2, eerste lid, $\mathrm{Kr}$ groenteplanten bepaalt dat de keuring en controle van het teeltmateriaal plaats heeft door middel van: a. algemeen toezicht op de produktie en verhandeling van teeltmateriaal; b. controle op de herkomst van het gebruikte uitgangsmateriaal; $c$. keuring van het teeltmateriaal; en d. zo nodig nacontrole op rasechtheid, raszuiverheid en de gezondheid wan het gebruikte uitgangsmateriaal en/of daaruit geteelde jonge planten.

De keuring als bedoeld in lid 1, sub c, wordt onder toezicht van de NAKG uitgevoerd door de aangeslotene zelf. Bij deze zelfkeuring dient aangeslotene vooral na te gaan of het teeltmateriaal voldoet aan de eisen gesteld omtrent rasechtheid, raszuiwerheid, ge- 
zondheid en uitwendige kwaliteit. Zie ook art. $7 \mathrm{Kr}$ groenteplanten. Bovendien stelt de NAKG mogelijk eisen aan bedrijfshygiëne (art. $3 \mathrm{Kr}$ groenteplanten), aan verpakking (art. $9 \mathrm{Kr}$ groenteplanten), of aan het medium van de opkweek (art. $6 \mathrm{Kr}$ groenteplanten). In het bijzonder met betrekking tot plantuitjes verricht de NAKG ex art. $4 \mathrm{Kr}$ plantuitjes de wolgende keuringen en controles: a. bemonstering van de zaadpartij waaruit de plantuitjes worden gewonnen [...] met de daarop volgende proeftuinbeoordeling; $b$. een weldkeuring met eventueel daaraan verbonden een gewasbemonstering (hierover art. 5 $\mathrm{Kr}$ plantuitjes; in aansluiting op veldkeuring is gewasbemonstering mogelijk ex art. $6 \mathrm{Kr}$ plantuitjes); c. toezicht op de bewaring in het bijzonder van de plantuitjes, welke als geprepareerd zullen wordlen verhandeld; en d. een partijkeuring.

\subsubsection{AANSPRAKELLUK- EN VERANTWOORDELIJKHEDEN}

De statuten van de stichting NAKG ${ }^{257}$ leggen de stichtingsleden een nalevingsplicht op. Daarnaast verplichten zij degenen die belast zijn met controle tot behoorlijke taakbehartiging.

Art. 17 Statuten NAKG belast de directeur met de algemene dagelijkse leiding van de stichting en bepaalt dat hij er voor verantwoordelijk is dat de besluiten van besturende organen van de stichting prompt worden uitgevoerd. De directeur is binnen het kader wan de statuten en zijn instructie bevoegd alle handelingen te verrichten welke door hem nodig worden geacht voor het goed functioneren van de keuringsdienst. Voorts is de directeur, in gevolge het tweede lid, verantwoordelijk voor de juiste uitvoering van de keuringen, controles en andere (technische) werkzaamheden op het gebied van de stichting. Daartoe geeft hij leiding aan het personeel.

Art. 10 en art. 11 Statuten NAKG regelen het rijkstoezicht op de stichting als mede de samenstelling en benoeming van het (dagelijks) bestuur.

Ten aanzien van al hun bevindingen in het kader van controle- en keuringswerkzaamheden betrachten betrokkenen geheimhouding ex art. 33 Statuten NAKG.

Met art. 26 Statuten NAKG sluit de stichting NAKG alle aansprakelijkheid uit voor de kwaliteit van de door haar gekeurde of onder haar toezicht geteelde of verhandelde groente- en bloemzaden, plantuitjes en -sjalotten.

\subsubsection{TUCHTRECHT}

In gevolge art. 7 Statuten NAGK ${ }^{258}$ zijn NAGK-leden gehouden tot: naleving van deze statuten en van door de stichting of een harer organen vastgesteld op hem betrekking hebbende voorschriften en besluiten; het nalaten van al datgene, waardoor een overtreding van de wettelijke voorschriften, voor zover verband houdende met het werkgebied der stichting, opzettelijk wordt bewerkt of mede bewerkt; het nalaten van iedere handeling, welke indruist tegen het doel en het belang der stichting; voldoening aan de hem krachtens art. 8 geheel of voorwaardelijk opgelegde tuchtmaatregelen. 
Met laatst genoemde bepaling wordt tegemoet gekomen aan art. 88 , tweede lid, sub d, Zpw. Daarin wordt gesteld dat de statuten bepalen dat bij niet-nakoming door een aangeslotene van enige bij de statuten of al gemene geldende voorschriften opgelegde verplichtingen een of meer van de navolgende tuchtmaatregelen kunnen worden opgelegd: berisping, geldboete tot ten hoogste tienduizend gulden, het stellen van de aangeslotene onder verscherpte controle te zijnen laste voor ten hoogste twee jaren en openbaarmaking van de tuchtbeschikking. Indien een aangeslotene in de periode van vijf jaren onmiddellijk wooraf gaande aan het niet nakomen van enige verplichting als bovenbedoeld, hetzij onder werscherpte controle is gesteld te zijnen laste, hetzij aan hem tweemaal een geldboete is opgelegd, kan deze voor ten hoogste drie jaren worden geschorst).

Tuchtrecht krijgt bij voorbeeld toepassing als is geconstateerd dat teeltmateriaal niet op voldoende vakkundige wijze wordt voortgebracht, bewaart of bewerkt, in welk geval de controle-instelling keuring ten hoogste drie jaar kan opschorten. Tijdens opschorting blijft betrokkene aangesloten. Bij misbruik daarvan is tuchtrecht mogelijk (art. $92 \mathrm{Zpw}$ ).

Art. $98 \mathrm{Zpw}$ bepaalt dat ingeval niet-nakoming van een verplichting, als bedoeld in art. 88, tweede lid, sub d, Z $\mathrm{pw}$, tevens een economisch delict oplevert, de officier van justitie - na overleg met de keuringsinstelling - beslist of de overtreding al dan niet tuchtrechtelijk door de keuringsinstelling wordt afgedaan.

Voor zover sprake is van WED-delicten (hetzij misdrijven hetzij overtredingen volgens art. $96 \mathrm{Zpw})$ zijn bij beschikking ${ }^{259}$ AID-functionarissen als opsporingsambtenaren aangewezen.

\section{\$ 17.8 Nederlands Controlebureau Levensmiddelen}

Door de verbrokkeldheid van het bestaande controlesysteem luidt het voorstel het toezicht, door vertegenwoordigers van de ministeries van respectievelijk LNV en WVC ${ }^{260}$ en doorprivaatrechtelijke keuringsinstellingen, te vervangen. Het toezichtsstelsel, waarbij de departementen van LNV en WVC fundamenteel verschillende doeleinden nastreven, t.w. respectievelijk handel/produktkwalititeitsbevorderend en consument/gezondheidsbeschermend, geeft communicatie- en competentieproblemen. Volgens voorstel krijgt een nieuw op te richten nationaal, federatief verband, te weten: het privaatrechtelijk Nederlands Controlebureau Levensmiddelen, voortaan een toezichthoudende functie ${ }^{261}$ ter zake. ${ }^{262}$

259. Beschikking aanwïzing opsporingsambtenaren, 20 okt. 1969. 489/269, Stcrt. 1969, 217

260. Een kamermeerderheid spreekt zich uit voor samenvoeging van keuring sdiensten van deze ministeries. Kamer eens over keuringsdiensten, in: NRC, 15 dec. 1993, p. 21.

26:. Naast de haar opgelegde primaire toexichthoudende taakstelling is het de bedoeling dat het NCL-bestuur, samen te stellen uit de vertegenwoordigers van de besturen wan de afzonderlijke privaatrechtelijke controle-instellingen, en aan te vullen met leden-deskundigen en vertegenwoordigers van consumentenorganisaties zich bezig houdt met adviestaken ten behoeve van onder meer de overheid.

262. I.P.M. Hendriks en A. de Zeeuw, Op weg naar een gezonde kwaliteit" Advies m. b.t. een evenwichrige taakverdeling tussen de departementen van $L N V$ en WVC op het terrein van de levensmiddelenwetgeving ent -controle, september 1992, pp.23-26/32-33. 
Bij dit NCL moeten de bestaande privaatrechtelijke landbouwkwaliteitscontrole-instellingen, en mogelijk nieuw op te richten privaatrechtelijke (voor- en natraject)controleinstanties en de in privaatrechtelijke rechtspersonen om te zetten publiekrechtelijke keuringsdiensten, zich aan sluiten.

Hierbij past de volgende taakverdeling van overheid en bedrijfsleven.

Wat landbouwkwaliteitcontrole betreft doet de overheid er goed aan zich te beperken tot kerntaken als: "a. het stellen van een samenhangend stelsel van normen waaraan consumentenprodukten om redenen van volksgezondheid moeten voldoen; b. hel stellen van randvoorwaarden voor het ontwikkelen van werder gaande kwaliteitseisen en thet "algemeen verbindend verklaren' daarvan, bij voldoende draagvlak binnen het bedrijfsleven; c. het - uitgaande van het IKB - stellen van een samenhangend stelsel van eisen aan de produktie van levensmiddelen, waardoor het bereiken van de voorgeschreven gezondheidsnormen en overige kwaliteitseisen wordt gerealiseerd en kan worden gecontroleerd; d. het (doen) erkennen van privaatrechtelijke keuringsinstellingen en het houden van toezicht op het functioneren er van; en e. het - in aanvulling op het tuchtrecht van de privaatrechtelijke keuringsinstellingen - opsporen van overschrijdingen van de vastgestelde normen en het geven van aanwijzingen ter correctie er van". ${ }^{263}$

Als complement daarvan rusten op het bedrijfsleven de opdrachten als: "a. het bepalen van verder gaande kwaliteitsnormen; b. het instellen van privaatrechtelijke keuringsinstanties die een zo danige controle uitoefenen dat zowel de eisen die de overheid stelt (normen en produktieprocessen) worden gerealiseerd, als de door het bedrijfsleven zell: gewenste overige kwaliteitseisen; c. het zelf regelen van tuchtrecht bij de overtreding van de keuringseisen". 264

\subsubsection{NUTRICIA-KWESTIE}

Dit voornemen tot afstoting van overheidstaken en overlating van controle (en financiering daarvan) aan producenten heeft niet ieders instemming. Ontevredenheid borrelt vooral omhoog naar aanleiding van, het vergelijkbare (en i.c. falende) voedingscontrollestelsel bij, de Nutricia-affaire. De ten laste van het voedingsconcern komende schadeposit van veertig miljoen gulden ${ }^{265}$ toont het belang van de Nutricia-kwestie aan. Medio november 1993 wordt in Nutricia-potjes, varkens-en rundvlees bevattende, babyvoeding verontreiniging met het reinigingsmiddel $p$-tolueensulfonamide ${ }^{266}$ aangetroffen. Niet

263. J.P.M. Hendriks en A. de Zeeuw, a.w. ,pp.29-30.

264. J.P.M. Hendriks en A. de Zeeuw, a.w. p. 30 .

265. Dit bedrag is nodig ter bestrijding van de kosten veroorzaakt door omzetderving, voorraadvernietiging. extra verwoer en woorlichting om het wertrouwen van consument en bedrijfsleven te herwinnen. Oharitaffaire berakkent Nutricia 40 miljoen schade, im: NRC, 31 mei 1995, p.19; Overigens stijgt de netiomwinst van Nutricia in het daarop volgende jaar wel flink mel 35 procent (vam 101 naar 136 miljoen gulden). De: sterke stijging in 1994 houdt natuurlijk ten dele verband met het verlies door de Olwaritaffaire in 1993. Nettowinst van Nutricia wa 'Olwarit" mu sterk gestegen, in: NRC, 31 maart 1995, p. 14.

266. Owerigens acht de rechter deze stof niet schadelijk. Verdachren in Olwarit-zaak vrijgelaten, in: NRC, 17 dec. 1993, p.16; Dit neemt niet weg dat het Hagse openbaar ministerie Nutricia (en eventuele 
het controlelaboratorium van Nutricia, maar de Inspectie Gezondheidsbescherming doet deze ontdekking. Daarom dringt onder meer de Consumentenbond, er bij betrokken ministeries op aan "dat de levensmiddelencontrole een dírecte overheidstaak blijft". ${ }^{267}$ Van uit de politiek redeneren VVD en PvdA in de zelfde richting. Daarentegen ziet D'66 ruimte voor produktcontrole door de levensmiddelenbranche zelf. Daarbij prefereert D'66 wel (externe) verzelfstandiging boven privatisering. ${ }^{268}$

\section{8 .2 VOEDINGSKWALITEITSTOEZICHT VERANTWOORDELUKHEID VAN PRODUCENTEN}

Alle politieke partijen gehoord, wordt de discussie gesloten. Het uiteindelijke kabinetsbesluit omvat het volgende. ${ }^{269}$ De oprichting van een Nederlands Controlebureau Levensmiddelen en -waren lijkt, per 1 januari 1996, inderdaad een feit. Volgens voorstel hebben in het NCL-bestuur nog wel kroonleden zitting. Bovendien krijgen de staatssecretarissen van landbouw en volksgezondheid bepaalde bevoegdheden om het NCL te instrueren. En het staatstoezicht blijft gehandhaafd voor, bij voorbeeld, optreden in geval van calamiteiten.

In het najaar van 1994 blijkt echter dat de beoogde fusie tussen vooral Rijksdienst voor de keuringsdienst en de Keuringsdienst van waren die moet resulteren in het Nederlands Controlebureau Levensmiddelen en waren al weer van de baan is. Hoogstens wordt de rijksdienst voor de keuring van vee en vlees verzelfstandigd, waardoor de dienst kan integreren met de betrokken bedrijfssector. ${ }^{270}$

Begin februari 1995 maakt het kabinet-Kok, wegens het onbreken van onvoldoende steun wan het bedrijfsleven en de consumentenorganisaties, korte metten met het door het kabinet-Lubbers III gedane voorstel betreffende fusie van de Rijksdienst voor Vee en Vlees (die intern wordt verzelfstandigd), delen van de Inspectie Gezondheidsbescherming en de Veterinaire Hoofdinspectie (die allebei worden gehandhafd als onderdelen van staatstoezicht). ${ }^{27}$ Kennelijk is de angst voor, bij zo'n NCL snel voorkomende, ver-

266. $\rightarrow$

leveranciers) vervolgt op verdenking van overtreding wan de Warenwet. Voor het redelijk uitzonderlijke feit dat de Olwarit-kwestie niet tussen Nutricia en de Inspectie Gezondheidsbescherming wordt geschikt windt het $O M$ oorzaak in de "ernst van de zaak en het feit dat al eerder in andere zaken schikkingen zijn aangeboden". Justitite venolgt Nutricia wegens Olvarit-affaire, in: NRC, 27 april 1995, p. 19. Andere bepalende factor voor vervolging is dat Nutricia, die al eerder (juni 1993) is gewaarschuwd voor alanwezigheid van ontsmettingsmiddel in potjes Olvarit, toen niet direct bij de toeleverancier ingreep en pas na circa vijf maanden het publiek waarschuwde. Zie P. Wessels, Rechtszack Olvarit drijf Nutricio in het naww, in: NRC. 28 april 1995 , p.13.

267. Controle op voedsel is taak van de overheid, in: NRC, 18 nov. 1993, p.22.

268. Verlies greep op keuringsdienst stuit op verzet; WD, PvdA tegen plan kabinet, in: NRC 25 nov. 1993, p. 23.

269. Rabinet houdt greep op toezicht eetwaren, in: NRC, 22 jan. 1994, p.2.

270. De na de zomer van 1994 aantredende minister Aartsen merkt wel op dat dit een "lang traject" zal zijn. Keuring woedsel blijft taak overheid, in: NRC, 4 nov. 1994, p.11.

271. Controle levensmiddelen en waren, TK 1994-1995, 23900 XIV en XVI, nrs.39. De voorkeur van het kabinet gaat, gegeven de Europese voorschriften, uit maar een publiekrechtelijke controle-instelling. 
strengeling van publieke en private taken en verantwoordelijkheden te groot. ${ }^{272}$ Volgens het kabinet-Kok blijft de overheid verantwoordelijk voor het toezicht op de naleving van wet- en regelgeving inzake levensmiddelen. Deze eindverantwoordelijkheid laat overigens de mogelijkheid van zelfregulering en -handhaving onverlet.

\section{Ten slotte}

Inderdaad is het toezicht op de naleving van wet-en regelgeving inzake landbouwprodukten een verantwoordelijkheid van de overheid. Op haar rust de, grond- en verdragsrechtelijk geboden, zorgplicht de volksgezondheid te bevorderen. Daarom heeft alleen, algemene belangen dienende, wettelijk geconditioneerde zelfregulering, waarop produkt- en proceskwaliteitscontrole-instellingen toezicht houden, bestaansrecht.

Daarbij spelen private partners wel een eminente rol. Onafwendbaar ondersteuning zoekend in certificering, accreditatie en normalisatie kunnen privaatrechtelijke rechtspersonen of particuliere instellingen uitstekend vrijwillige of verplichte keuringen, inspecties, controlles en dergelijke uitvoeren.

De landbouwsector laat zien dat zij in staat is op snelle en accurate wijze conform Europese maatstaven te werken. Harmonisatie van wetgeving gaat hier hard. Well is het zaak, bij het gelijk trekken van nationale regels, juist in een zware sector als de landbouwsector, te voorkomen dat onwilligen de illegaliteit in duiken en - buiten de strenge eisen van integraal ketenbeheer om - zwarte handel bedrijven.

Ook daarop moeten, de van overheidswege als toezichthoudende entiteiten aangewezen, kwaliteitscontrole-instellingen scherp toezien.

De kwaliteitscontrole-instellingen kleden hun organisatiestructuur de laatste jaren modern aan. Via bij voorbeeld geautomatiseerde verwerking toezichtsgegevens, monitoring, eenduidige handhavingsbeleidsplannen, standaardrapportages en uniforme, voorbedrukte formulieren (voor zelfhandhaving e.d.) kunnen zij steeds efficiënter en effectiever werken. Ook middels bewuste verjonging en voortdurende opleidling van personeel creeren zij een indrukwekkend imago.

272. Normen, Certificaten en Open Grenzen, TK 1994-1995, 21670, nrs.7-8, p.29. In de nota wordt aanbevolen keurings- en certificatiewerkzaamlneden (private functie) duidelijk te scheiden van toezichts-en opsporingsactiviteiten (publieke functie). Natuurlijk is keuring niet altijd putr privaat. Als keuring (meestal uit overwegingen van veiligheid, gezondheid en milieu) wettelijk wordt verplicht (meest: bekende en duidelijke voorbeeld is de APK-keuring), nust op de keuringsinstelling -voor zover deze de keuringstaak uitoefent- openbaar gezag en is deze daarmee bestuursorgaan in de zin van de Awb (pp.5/28); Overigens vindt de Subcommissie Verzelfstandigingen van de Adwiescommilissie varn de Rijksdienst dat, indien keuring wettelij $k$ verplicht word voorgeschreven, de daarmee belaste keuringsinstellingen om de reden dat zij dan openbaar gezag uitoefenen, "bijj voorkeur in de vorm van een publiekrechtelijk (zelfstandig) bestuursorgaan moeten opereren". De minister van economische zaken is, orider erkenning dat voor zover instellingen wettelijk werplichte keuringen uitvoeren zij bestum.rsorgaan in de zin van de Awb zijn, echter niet die mening toegedaan en hecht belang aan de trend particuliere marktpartijen keuringswerk te laten verichtem.. Private instellingen kunnen hier goed dienst doen, omdat de technische keuring shandelingenduideljijk zijn voorgeschreven en hun werkzaamheden zijn geborgd door middel van accreditatie (p.4). 
Kanttekening hierbij is dat een efficiëntere werkmethode niet altijd het belang van onder toezicht gestelden dient. Fnuikend voorbeeld is dat controleurs en inspecteurs niet per definitie van elk afgelegd toezichtsbezoek aan onder toezicht gestelden verslag doen aan laatst genoemden. Dit schaadt mogelijk de rechtsbescherming van onder toezicht gestelden.

Daarnaast dichten sommige statuten (en tuchtreglementen)! van bedoelde rechtspersonen een opvallende bevoegdheid toe aan bestuurders van privaatrechtelijke kwalliteitscontroleinstellingen. De officier van justitie overlegt met de voorzitter of de directeur van een controle-instelling of een geconstateerde overtreding van een onder toezicht gestelde al dan niet strafrechtelijke afdoening krijgt. Dat lijkt een enge weg naar eigenzinnigheid.

Beter is het dat, ten einde te voorkomen dat het strafrecht er bij wordt gehaald of einde loos schikkingen worden aangegaan, kwaliteitscontrole-instellingen de bevoegdheid krijgen om bestuurlijk boeten op te leggen. Deze bevoegdheid dient dan te worden toebedeeld aan speciaal benoemde, deskundige boeteünspecteurs, die werken op basis van een - in overleg met het openbaar ministerie samengestelde - standaardtarieflijst met maximaal (en eventueel minimaal) mogelijke boeten.

Ter taakuitoefening zijn de kwaliteitscontrole-instellingen uitgerust met belangrijke toezichtsbevoegdheden, waaruit de toegenomen verantwoordelijkheid van de controleurs en inspecteurs blijkt. Hierbij moeten controleurs en inspecteurs het toezichtsbelang voortdurend, dat wil zeggen in elk concreet geval, afwegen tegen het individuele belang wan justitiabelen. Voorop staat natuurlijk de zwaarwichtigheid van het handhavingsbelang. Maar, naturulij $\mathrm{k}$ heiligt het controledoel niet alle middelen. Het evenredigheidsbeginsel dient hier als elementair beginsel. Daarnaast kunnen in een belangenafweging verdisconteerd worden beginselen als het gelijkheidsbeginsel (hoe worden andere, al dan niet aangesloten, onder toezicht gestelden in de zelfde of soort gelijke situaties beoordeeld of, anders, bestraft), het vertrouwensbeginsel (in welke mate mogen onder toezicht gestelden op controleplannen afgaan en tot hoe ver mogen zij, mogelijk daarvan afwijkende, opvattingen van een inspecteur voor waar aannemen) of het beginsel van misbruik of ander gebruik (dan het bedoelde gebruik) van toezichtsbevoegdheden.

Voorbeeld van vermelde verbreding van verantwoordelijkheid van inspecteurs is het, onder wakend oog van (assistent-)hoofdinspecteurs, geven van bindende aanwijzingen met betrekking tot onder meer de inrichting van de administratie van of het gebruik van vergunning, certificaat e.d. van onder toezicht gestelden. Dergelijke instructies zijn bestuursrechtelijk afdwingbaar. Hierdoor is het, nog al eens vroegtijdige en oneigenlijke, optreden van het openbaar ministerie niet nodig. Aldus is wellicht waterscheiding aan te brengen tussen de vaak in elkaar overlopende fasen van toezicht en opsporing.

Gegeven de noodzaak van een optimale naleving van wet- en regelgeving inzake het, yeelal grensoverschrijdende, verkeer van landbouwprodukten is het zaak te zorgen voor een witstekende samenwerking tussen binnen- en buitenlandse nagenoeg identieke toezichthoudende entiteiten als mede een voortreffelijke verstandhouding tussen toezichthoudende diensten en opsporende diensten te realiseren. Hiervan geeft de bestaande infrastructuur van de landbouwmarkt behoorlijk blijk. 


\title{
Geraadpleegde literatuur
}

\author{
Appels, B.P.D. \& Visser, C.A.
}

Niemand is tegen Kwaliteit - waar blijven de voorstanders; Adwocauur en ISO-certificatie, in: Advocatenblad, mr.12, 10 juni 1994, pp.50-52.

Centraal Orgaan Zuivelcontrole (incl. Centraal Orgaan voor Kwaliteitsaangelegenheden in de Zuivel)

Jaarverslagen 1989/1990/1991/1993, Leusden.

Flier, P.J. van der \& Oosterkamp, J.S. van den

Voortvarende implementatie van EG-richtlimen, mede in het licht van de Awb en de Aanwijzingen voor de regelgewing, in: SEW, nr.11, 1994, pp.727-752.

Geurts, Th.A.P.M.

Klantvriendelijker werken met de Awb, in: BB, 10 juni 1994, p.27.

Haersolte, J.C. van

Uitvoering EEG-richtlijnen in Nederland '58-'92, "s-Gravenhage, 1993.

Hendriks, J.P.M. \& Zeeuw, A. de

Op weg naar een gezonde kwaliteit: Advies m.b.t. een evenwichtige taakverdeling tussen de departementen van LNV en WVC op het terrein van de levensmiddelenwetgeving en -controle, september 1992.

Pols, B.

Strenge Europese eisen bedreigen produktie diergeneesmiddelen, in: NRC, 13 juli 1994, p.16.

Kwaliteits-Controle-Bureau voor groenten en fruil Jaarverslagem over 199/1992/1993, 's-Gravenhage, 1992/1993/1994.

Ministerie van landbouw, natuurbeheer en visserij

Van meer naar beter: Kwaliteit en kwaliteitsbeleid in de agrarische sector, beleidswoornemem, 's-Gravenhage, mei 1992.

Rood, E.

Overzicht EEG- en Nederlands levensmiddelenbeleid en-recht: inhoud, organisatie, tenuitvoerlegging, handhaving, Apeldoorn/Arnhem, 1993.

Stichting Internationale Scharrelvlees Controle

- Richtlijnen, voorschriften en reglementen, Utrecht, januari 1991;

- Jaarverslag 1993, Utrecht, 1994.

Stichting Keur Alternatief voortgebrachte Landbouwprodukten

- Statuten, reglementen en voorschriften, Zwolle;

- Jaarverslagen 1992/1993, Zwolle, 1993/1994.

Tweede Kamer

- Normen, certificaten en open grenzen, TK 1994-1995, 21670, nrs.7×8;

- Controle levensmiddelen en waren, TK 1994-1995, 23900 XIV en XVI, nr.39.

Valkenburg, $\mathbf{L}$.

De EZ-nota 'Normen, Certificaten en Open Grenzen', in: RegelMaat, nr.3, 1995, pp.100-107.

Wessels, B.

Verzelfstandiging: enkele kanttekeningen uit het vermogensrecht, in: $S \& V, n r .3$, mei/juni 1994, pp.71-77.

Wessels, $\mathbf{P}$.

Rechtszaak Olvarit drijft Nutricia in het natw, in: NRC, 28 april 1995, p.13. 
Hoofdstuk 18

\section{Stichting Verzekeringskamer}

\section{$\$ 18.0$ Vrijheid van uitoefening van het verzekeringsbedrijf}

Uitgangspunt is dat de vrijheid om het assurantiebedrijf uit te oefenen een gemeenschapsrecht is. Op correcte uitoefening wan dit recht in de Europese lidstaat Nederland ziet de stichting Verzekeringskamer toe. ${ }^{1}$

\section{\$ 18.1 Toezichthouder verzekeringsmarkt verzelfstandigd}

De grondslagen voor het toezicht op de uitoefening van het verzekeringsbedrijf zijn te vinden in verschilhende wetten ${ }^{2}$, waaronder: de Wet toezicht verzekeringsbedrijf, de Pensioen- en spaarfondsenwet (Stbl. 1981, 18, laatstelijk gewijzigd d.d. 30 juni 1994, Stbl. 1994, 496 $)^{34}$, de Wet verplichte deelneming in een beroepspensioenregeling

1. De economische activiteit betreft hier het zijn van verzekeraar, niet $z i j n d e$ assurantietussenpersoon. Laatst genoemde bedrijfsactiviteit wordt beheerst door de Wet op het assurantiebeniddelingsbedrif. M. b.t. het toezicht op de naleving van de eisen voor het uitoefenen wan het bedrijf van verzekeraar komt slechts de stichting Verzekeringskamer bevoegdheid toe. Uit Mediawhch bv ws. Sociaal Economische Raad, CBB, 6 juli 1994, nr.93/1408/021/001, in: NJB, nr.40, 11 nov. 1994, rechtsprakkatern nr. 22, p. 532 (bijiage), bijikt dat aan de vaststelling door in casu de SER, dat Med ia vlucht bv verzekeringsovereenkomsten beoogt af te sluiten, geen rechtens rellevante betekenis toe kan komen. Slecints de stichting Verzekeringskamer kan ter zake cen bindend oordeel geven.

2. Art. 3 Statuten stichting Verzekering skamer noemt twalf wetten en lagalt nog ruimte voor andere wetten.

3. O.g.v. deze wet valt het per 11 jan. 1996 geprivatiseerde Aligemeen Burgerlijk Pensioenfonds onder het toezicht wan het zbo belast met het wettelijk toezicht op verzekeringsmaatschappijen en bedrijfspensioenfondsen. Zie wetswoorstel financiele voorzieningen privatisering Abp. TK 1993-1994, 23442, nr. 2 e. $v$. De eigenlijke wet is in werking sinds 1 mei 1994. Zle ook het convenant tussen ministerie van binnenlandse zaken en de wier ambtenarenvakcentrales, dat m.b.t. jaarlijkse premiestijging is bijgesteld. Hierover Noritie Verzekeringskamer: Abp kan niet aan plichten voldoen, in: NRC, 9 febr. 1993, p.1, als mede Verzekeringskamer tevreden met aieuwe tekst ABP-convenam, in: NRC, 17 febr. 1993; Over financielle complicaties van verzelfstandiging $\mathrm{C}$. Petersen, Verzelfstandiging van het Abp: gevolgen woorde overheidsfinancièn, in: OU, nr.3, 1994, pp.114-118; Het ABP valt nog wel onder de competentie wan de nationale ombudsman en niet wan de, vanaf 1 april 1995 klachten wan de pensioenfondsen in het bed rijfs. en beroeps leven behandelende, Ombudsman Pensioenen, van wiens instelling E. Lutjers, Pensioenombudsman naar woorbeeld wan Engeland, in: NRC, 20 aprill 1995, p.21, melding maakt. 
(Stbl. 1972, 400) en de Algemene burgerlijke pensioenwet (Stbl. 1986, 540). Hiervan is de Wiv het meest relevante richtsnoer.

Het voorstel Wet toezicht verzekeringsbedrijf 1993 laat geen twijfell over de ver gaande Europese integratie van het toezicht op assurantiebedrijven. ${ }^{5}$ In de uiteindelijke wet ${ }^{*}$ zijn belangrijke EG-richtlijnen geïmplementeerd. De in gevolge art. $2 \mathrm{Wtv}^{7}$ junctis artt. 2-3 statuten stichting Verzekeringskamer ${ }^{8}$ werkzame toezichthouder, $t$.w. het zelfstan-

4. In de ogen van $\boldsymbol{P}$. Eichholtz en $\mathrm{K}$. Koedijk, Het onzichtbare rendement wan pensioenfondsen, in: NRC. 20 sept. 1994 , p. 31, moet de Verzekeringskamer sterkere toezichtsinstnumenten krijgen. O.g.v. de Psw zijn pensioenfondsen slechts verplichn tor regelmatige vertrouwelijke verslaggeving aan de toezichthouder. Auteurs pleiten voor het opnemen in de Psw van een wettelijke clausule waardoor pensioenfondsen (net als ondernemingen die hun jaarversfag noeten publiceren) resultaten van beleggingsbeleid gestandaardiseerd openbaar moeten maken, zodat externe prestatiemeting mogelijk wordt; A.C.F. Vorsi, Meer openheid bij pensioenfondsen heeft risico's, in: NRC, 4 okt. 1994, p.19, stemt er mee in, dat meer openheid er toe leidt dat de burgers weten waar zij aan toe zijn en dat de pensioenfondsen beter hum best doen., maar betwijfelt dar de pensioenfomdsrendementen stijgen. Z.i. worden pensioenfondsbeheerders door openheid "gedwongen" wan jaar tot jaar goed te presteren. Zo verliezen zij oog voor de lange-termijnrendementen waarin deelnemers in fondsen vooral interesse hebben; En J. Felderhoff en A. Smit, "Mering " van pensioenfondsen is er al, in: NRC, 19 okt. 1994, p.17. merken op dat de wetenschappers Eichholtz en Koedijk weinig oog hebben voor de hoopvolle praktijk: "meer dan 200 Nederlandse pensioenfondsen laten al de beleggingsresultaten op uniforme wijze door een onafhankelijke instelling meten". Hoewel de reswltaten niet per se publiekelijk zichtbaar zijn , bestaat altijd de mogelijkheid om zich daarover te laten informerem. Overigens publiceren fondsen in toenemende mate de extern gemeten rendementen en resultatem in hum jaarverslagen.

5. Naast de meest elementaire Wtv is andere wetgeving relevant voor het verzekeringsbed rijftoezicht Recent voorbeeld is het voorsfel wan de Wertoezicht natura-uitwartverzekeringsbedrijf, TK 1993-1994/1994-1995, 23688, nrs. 1-3 e.w. "Hierover P.J. van den Broek, Toezicht op witwartwerzekeringen, in: VA, nr.2, 1995. pp. $54-62$.

6. Wru 1993, Stbl. 1994, 252.

7. De, indeze wettelijke bepaling geregelde, toezichtstaakopdracht aande stichting Verzekeringskamer betreft geen zuvere attributic. Conform art. 3 Wtv wijst de minister van financien, in samenwerking met de mimister van sociale zaken en werkgelegenheid, namelijk nog een rechtspersoon als Verzekeringskamer aan. Die rechtspersoon moet voldoen aan eisen van: a. bekwatmheid om tak behoorlijk te verwullen; b. onathankelijke takwervulling; en c. statutaire voorziening van (onafhankelijke en deskundige) rabd vam toezicht en pensioenraad. Zie voor aanwijzing wan de Verzekeringskamer besluit in Stcrt. 12 ang. 1992, 159. Het door de minister aanwijzen (of erkennen) van een of meer rechtspersonen komt vaker woor (denk aan de landbouwkwaliteitscontrolle- of zaaizaad-en plantgoedkeuringsinstellingen ex resp. art. 8 Lkw en ant. $87 \mathrm{Zpw}$, of de certificerings. en keuringsorganisaties $0 . \mathrm{g} . \mathrm{v}$. art. $5 \mathrm{Wgw}$, of de rechtsperscionlijkheid bazittende cultuurfondsen als bedoeld in art. 9 W $\mathrm{sc}$ ). Even well is bij de stichting Verzekeringskamer (en ook bij de STE) sprake van cen bijzonderheid: de specifiek aan te wijzen organisatie staat met mam (I) in de wet vermeld. C.A. Schreuder, Privatisering en de geheimhoudingsclain van de Verzekeringskamer, in: $\mathrm{NJB}_{\text {w }}$ nr.43, 2 dec. 1994, pp.1476-1480, i.h.b. p.1478, spreekt correct van "onvolkomen attributie, ondat de in de wet genoemde organisatie nog moet worden aangewezen. Dit is niet hetzelfde als een taaktoedeling bij nader besluit, omdat bij deze taaktoedeling de takkuitwoerende organisatie niet in de wet staat genoemd."

8. Statuten stichring Verzekeringskamer, 5 aug. 1992, De Brauw, Blackstone Westbroek i.s.m. De Bandt, Vart Hecke en Lagae. 
dig bestuursorgaan ${ }^{9}$ stichting Verzekeringskamer bevordert een zo homogeen mogelijk toezicht conform EG-richtlijnen. Ex art. $10 \mathrm{Wtv}$ is zij verplicht tot samenwerking met betrokken toezichthoudende autoriteiten in andere EG-lidstaten.

Om het ultieme doel van werkelijk gelijkwaardige concurrentieposities voor verzekeraars, ongeacht hun vestigingslidstaat, te realiseren zal uiteindelijk zelfs sprake moeten zijn van een, de stichting Verzekeringskamer wellicht verdringende, geìntegreerde supranationale toezichthouder op een kapitaalmarkt. ${ }^{\text {to }}$ Voordat het zo ver komt, is echter nog een lange weg te gaan.

Op 1 september 1992 wordt het toezichthoudend overheidsorgaan Verzekeringskamer, dat vanaf instelling in 1923 een publiekrechtelijk zelfstandig bestuursorgaan is ", verzelfstandigd en omgezet in een privaatrechtelijke stichting. ${ }^{12}$ Deze verzelfstandiging brengt een gewijzigde taakstelling en een nieuwe organisatiestructuur (bestuur, raad van toezicht, afdeling toezicht verzekeringen, afdeling toezicht pensioenen, afdeling onderzoek en advies met een sectie beleidszaken en een sectie juridische zaken, en afdeling algemene zaken met een sector personeel, informatie en organisatie, een sector documentaire informatie en een sector beheer en financiën) ${ }^{13}$ met zich mee. ${ }^{14}$ Met de status van stichting bereikt de Verzekeringskamer mogelijk een "zekere gelijkwaardigheid " ten aanzien van het bedrijfsleven. ${ }^{\text {is }}$

De verzelfstandiging laten de mogelijkheden van de overheid om via regelgeving aard, omvang en inhoud van het toezicht op het verzekeringsbedrijf te bepalen, om het stichtingsbestuur te benoemen of te ontslaan en om statutenwijziging goed te keuren, onverlet. Overigens wordt bij verzelfstandiging uitdrukkelijk afgezien van een instructiebevoegdheid van de minister. Wel kan de betrokken bewindspersoon de aanwijzing van de stichting Verzekeringskamer als toezichthouder op de verzekeringsmarkt intrekken als de stichting niet meer voldoet aan de wettelijke eisen van rechtspersoonlijkheid (raad van

9. "Ook al is zij een zbo", gelet op o.a. respectievelijk verslaglegging aan en bestuorsbenoemuing door de Kroon, blijft de minister -zij het op afstand- "politiek verantwoordelijk voor het doen en laten wan de Verzekeringskamer". Zie P.M. Tulfer, Het wiewwe toezicht op het verzekeringsbedriff, in: VA, deel 63. LXIII, 1986, pp.5-25, i.h.b. p.7.

10. Aldus A. Oosenburg, verwoord door H.L. de Boer, Recht, verzekering en Europa; Een impressie van een theetal studiebijeenkomsten. in: VA, najaar 1994, pp.95-100, i.h.b. p.97.

11. De werzelfstandigingsvariant wan publiekrechtelijk orgaan met eigen rechtspersonnlijkheid valt af, omdat deze vorm "per saldo [...] nadelen van intensieve owerheidsregelgeving blijven kleven zonder cat daarbij voldoende compenserende woondelen wan een grotere beheersvrijheid kunnen worden behaald ". Verzelfstandiging Verzekeringskamer, TK 1988-1989, $21235, \mathrm{nr} .1$, pp. 1-2.

12. Wet houdende regelen m.b.t. de verzelfsuandiging van de Verzekeringskamer, Stbll. 1992, 372.

13. Eind 1993 zijn bestuur, rve en afdelingen naar getal uit te drukken in respectiewelijk $5,5,22,34,20$ en 34.

14. Zie Statuten stichting Verzekeringskamur. Zie ook Zicht op toezicht, publikatie Verzekeringskamer, 1993. Pp. $5-12$.

15. K. Calje, Verzekeringskamer 'geljikwaardig'; Privatisering moet pasitie wan noezichthouder wersterken, in: NRC, 3 jumi 1992, p.19. 
bestuur e.c.) en als de rechtspersoon taken niet meer naar behoren of met de nodige onafhankelijkheid vervult. Hier is de ministeriële invloed niet gering. ${ }^{16}$

De verzelfstandiging betreft slechts de beheersmatige verantwoordelijkheid van thet ministerie van financiën. ${ }^{17} 18$ Het overdragen daarvan aan de Verzekeringskamer moel "een (met oog op snelle maatschappelijke verschuivingen gewenste - JGLvN) flexibelere uitvoering van taken mogelijk maken". ${ }^{19}$ Doelmatigheid en doeltreffendheid van optreden staan centraal.

\section{$\S 18.2$ Taakstelling stichting Verzekeringskamer}

De stichting Verzekeringskamer heeft tot taak om toezicht te houden op verzekeraars en pensioenfondsen. De stichting Verzekeringskamer oefent drieërlei toezicht op verzekeringsinstellingen uit: controlerend, adviserend en bestuurlijk. ${ }^{20} \mathrm{Zij}$ waakt over solvabiliteit, continuilteit en juridische zaken van verzekeringsbedrijven. Ministeries en verzekeraars kunnen haar om raad vragen. ${ }^{21}$ En als toezichthoudend bestuursorgaan reguleert zij de verzekeringsmarkt middels verlening en intrekking van vergunningen voor het uitoefenen van het verzekeringsbedriff en via toestemming voor portefeuille-overdrachten. Dit toezicht heeft geen statisch karakter. Het verandert voortdurend. Daarom moet de stichting Verzekeringskamer innoverend onderzoek verrichten naar passende instrumenten waarmee uitoefening van dynamisch toezicht mogelijk is. De stichting Verzekeringskamer wil dit onderzoek een breed draagvlak geven "door een kruispuntfunctie uit te oefenen tussen toezicht en samenleving". ${ }^{22}$ De vervulling van deze kruispuntfunctie die naast de traditionele toezichtstaak staat, is een belangrijk motief voor de verzelfstandiging van de Verzekeringskamer geweest. ${ }^{23}$ De kruispuntfunctie manifesteert zich evident in bij voorbeeld de, tijdens het WAO-debat in 1993 accuut geworden, zoektocht naar een adequate arbeidsongeschiktheidsdekkingsregeling.

116. In het verlengde hiervan betoogt C.A. Schreuder, Privatisering en de geheimhoudingsclaim van de Verzekeringskakner, in. NIB, nr.43, 2 dec. 1994, pp.1476-1480, overnigend dat door omzetting vande. woegere publiekrechtelijke, Verzekeringskamer in een stichting de verantwoordelijkheid van de minister formeel is vergroot (p. 1477).

17. Verzelfstandiging Verzekeringskamer. TK 1988-1989, 21235, nr.1, p.1.

18. In scherpe bewoordingen wordt hier wel gesproken van een 'sluipweg'. C.A. Schreuder Publiekrechtely. the taken, private rechtsvormen, Deventer, 1994, p.359. Op oneigenlijke wijze is de Verzekeringskarner (die volgens auteur taken uitwoert die het beste passen bij een publiekrechtelijke orgamisatieworm) in een stichting omgezet, alleen om de Vk als stichting buiten de werking van het ARAR en de Comptabiliteitswet te brengen. Auteur ach het meer in overeenstemming met het gelijkheidsbeginsel, dat - als algemene regelgeving voor i.c. de Verzekeringskamer knellend werkt - de Vk daarwan ten dele wordt uitgezonderd/wrijgesteld. Tot het zelfde oondeel komt eerder al de commissie-Scheltena, Steekhoudend münstersichap. TK 1992-1993, 21427, nrs.40-41, p.42.

19. Verzelfstandiging Verzekeringskamer. TK 1988-1989, 21235, nr. 1, p. 1; 0ok Stcrt. 1992, 30.

20. Stichting Verzekeringskamer, Jaamerslag 1992, A peldoom, 1993, p.28.

21. Verzelfstandiging Verzekeringskamer. TK 1988-1989, 21235, nr. 1, p.1, duidt aan dat onder meer "werzwaring van adviserende taken" een flexibele ütwoering van taken door de stichtimg Verzekeringskamer mogelijk moel maken.

22. Stichting Verzekeringskamer, Jaarverslag 1993, Apeldoorn, 1994, p.19.

23. Stichting Verzekeringskamer, Jaarverslag 1993, Apeldoorn, 1994, p.58. 


\section{$\S 18.3$ Normatief toezicht}

Ter taakuitoefening staan de stichting Verzekeringskamer publiekrechtelijke, en daarnaast privaatrechtelijke, bevoegdheden ter beschikking. De uitoefening van deze, aan haar gedelegeerde (regelgevende), bevoegdheden wordt wettelijk begrensd door de reikwijdte van de delegatie.

De stichting Verzekeringskamer stelt bij het, slechts voor zover strikt noodzakelijk, gebruik van regelgevende bevoegdheden het "belang voorop van degenen die als verzekeringsnemers, verzekerden of gerechtigden op uitkeringen betrokken zijn of zullen worden bij verzekeringsovereenkomsten"', ${ }^{4}$

Overigens past haar de terughoudendheid die in een normatief toezichtsstelsel gebruikelijk is. Repressief normatief toezicht wil zeggen dat "er binnen bepaalde wettelijke normen ondernemersvrijheid bestaat met betrekking tot onder meer produktvorm, tariefvaststelling en beleggingsbeleid" . ${ }^{25}$ Zie over normatief toezicht ook paragraaf 18.9 .

Anders dan bij materieel toezicht speelt bij normatief toezicht beperking van prijsconcurrentie geen rol. Op een verzekeringsmarkt met normatief toezicht kunnen in beginsel onbeperkt nieuwe produkten worden geïntroduceerd tegen lage, consument vriendelijke prijzen. Een markt beheerst door normatief toezicht is in principe vrij van verstarring en vrij van overmatige overheidsinterventie of ambtelijke bureaucratie. Normatief toezicht geeft de markt ruimte voor rijkelijke produktvariatie en 'overheidsonafhankelijke' voordelige tariefstelling. De overheid heeft slechts een afgeleide rol. Langs de zijlijn moet de stichting Verzekeringskamer slechts, op grond van de bestaande sifuatie en de beschikbare gegevens die niet anders dan een momentopname opleveren, beoordelen of de onder haar toezicht gestelden ook in de toekomst (financieel) levensvatbaar zijn. Het is de bedoeling van het door haar uitgeoefende toezicht om ontwikkelingen, als onjuiste, onzakelijke, ongewenste of frauduleuze handelingen van een verzekeraar, "zo snel mogelijk te signaleren en in te dammen opdat het bedrijf niet afglijdt naar een op termijn ongezonde situatie". 26 Voor haar anticipatie op mogelijke ondernemersrisico"s is de stichting Verzekeringskamer in het bijzonder aangewezen op een uitvoerige uitwisseling van eerlijke informatie.

\subsubsection{VERGUNNINGVERLENING, -WIJZIGING, EN -INTREKKING}

Belangrijke bevoegdheid van de stichting Verzekeringskamer is dat zij de vergunning, die nodig is om de in art. $3 \mathrm{a}$ Wtv vermelde verschillende branches van het directe levensof schade ${ }^{27}$ verzekeringsbedrijf uit te oefenen, kan verlenen ex art. 24 Wtv. Daarvan

24. Nota n.a.v. eindverslag wet tot wijziging Wh, TK $1989.1990,20884$ nr.9, p.7

25. Stichting Verzekeringskamer, Tweede iussentijdse verslag inzake Vie d'Or. Apeldoorn, $190 \mathrm{kt} .1994$. p. 51 .

26. Stichting Verzekeringskamer, Tweede wussentijdse werslag inzake Vie d'Or, Apeldoom, 19 okt. 1994. p. 52 .

27. Zonder naar woren gebrachte bedenkingen van de stichting Verzekeringskamer zijn combinaties denkbar. Zite art. 64 Wtv (voor werzekeraars met zetel in Nederland) jo. art. 88 Wtv (voor verzekeraars met zetel buiten de $\mathbb{E} G$; ; Vor overdmacht van rechten en verplichting en uit verzekeringsovereenkomsten en omzet- 
doet zij openbaar mededeling in de Staatscourant ex art. 36, derde lid, Wtv, art. 38, vijfde lid, Wiv en art. 48 , tweede lid, Wiv.

Indien nodig (0.a. bij non-usus, te kleine solvabiliteitsmarge, grove nalatigheid, het niet meer voldoen aan vergunningsvoorwaarden of op eigen verzoek van vergunninghouder), zal zij een verleende vergunning weer intrekken ex de artt. 146-152 Wtv. De mogelijkheid van beroep tegen het intrekkingsbesluit schorst de werking van dat besluit. Vergunningintrekking ontslaat de betrokken verzekeraar niet van de plicht zijn bedrijf af te wikkelen (art. 150 Wtv jo. art. $\mathbb{1 4 9}$, tweede lid, Wtv).

Wat levensverzekeraars met zetel in Nederland betreft zijn eind 199171 nv's en 15 onderlinge waarborgmaatschappijen in het bezit van een vergunning. Omdat in de daarop volgende periode bij nv's twee keer sprake is van vergunningverlening en een keer van vergunningintrekking na bedrijfsbeëindiging, betreft het aantal vergunninghouders op 31 december 199272 nv's en 15 ow's. Wat betreft levensverzekeraars met zetell buiten Nederland zijn er op 31 december 1992, even als eind 1991, 6 vergunninghouders in de EG (van wie 1 houder zijn vergunning in 1992 met een branche heeft uitgebreid) en 4 vergunninghouders buiten de EG. ${ }^{28}$ In 1993 doen zich de volgende mutaties voor. Aan levensverzekerings-nv's met zetel in Nederland verleent de stichting Verzekeringskamer 4 nieuwe vergunningen. Bovendien is bij 2 nv's sprake van vergunningverval door bedrijfsbeëindiging en de vergunning van de, nader te bespreken, nv Vie d'Or wordt ingetrokken. Daardoor zijn eind 1993, hier te lande, 73 levensverzekeraars als nv, en nog steeds 15 als ow, vergunninghoudend. Het getal van vergunninghoudende levensverzekeraars buiten Nederland in de EG en buiten de EG komt in 1992 neer op 6 en 4. Omdat maatschappijen met zetel in de EG slechts een keer met vergunningverlening en een keer met vergunningintrekking of -verval worden geconfronteerd, gelden de zelfde cijfers in 1993. ${ }^{29}$

Wat schadeverzekeraars met zetel in Nederland betreft zijn eind 1991129 nv's en 117 ow's in het bezit van een vergunning. In het tijdsbestek daarna verleent de stichting Verzekeringskamer aan nv's en ow's 11 en 6 nieuwe vergunningen en laat zij bij nv's en ow's 3 en 9 vergunningen vervallen (ten gevolge van het ophouden van betrokken rechtspersoon, het voltooien van vereffening van een rechtspersoon, dan wel het aangaan van een juridische fusie) of geheel of gedeeltelijk intrekken (van wege o.a. het niet meer voldoen aan de voorschriften van technische voorzieningen en het niet meer beschikken over de benodigde solvabiliteit warvan sprake is bij onder meer de Trinity Insurance Company Limited te Londen waarvoor een noodregeling wordt getroffen). Het aantal vergunninghouders op 31 december 1992 betreft 137 nv's (waarvan 7 nv's vergunninguitbreiding en $3 \mathrm{nv}$ 's vergunning beperking hebben ondergaan) en $114 \mathrm{ow}$ 's (waarvan $2 \mathrm{ow}^{*} \mathrm{~s}$ vergunninguitbreiding hebben ondergaan). Wat betreft schadeverzekeraars met zetel buiten Nederland zijn er op 31 december 1992105 vergunninghouders in de EG (van wie

27. $\rightarrow$

ting wan de rechtsworm van een verzekeraar is ook mededeling an en toestemming van de stichting Verzekeringskamer, en indien betrokken: een toezichthoudende instamtie ter zake in een ander land, wereist. Zie artt. 119-134 Wrv.

28. Stichting Verzekeringskamer, Jaawershag 1992, Apeldoorn, 1993, pp.57-59.

29. Stichting Verzekeringskamer, Jaarverslag 1993, Apeldoorn, 1994, pp.75-76. 
1. houder zijn vergunning met een of meerdere branches heeft uitgebreid) en 35 vergunninghouders buiten de EG. Het jaar daarvoor liggen de cijfers op respectievelijk 103 en 36. ${ }^{30}$ In 1993 wijzigt de situatie zich als volgt. Aan schadeverzekerings-nv"s met zetel in Nederland verleent de stichting Verzekeringskamer $\mathbb{1 2}$ nieuwe vergunningen. Ook 2 ow"s ontvangen een vergunning. Bovendien is bij een nv sprake van vergunningverval of -intrekking. En 7 ow's hebben te maken met vergunningverval of -intrekking. Vergunninguitbreiding vindt plaats bij $6 \mathrm{nv}$ 's en $1 \mathrm{ow}$. Eén nv krijgt te maken met vergunningbeperking. Zo zijn eind 1993, hier te lande, 148 schadeverzekeraars als nv en 109 als ow, vergunninghoudend. Het getal van vergunninghoudendelevensverzekeraars buiten Nederland in de EG en buiten de EG komt in 1992 neer op 105 en 35. Eind 1993 verhouden deze cijfers zich als 104 tot 32 . Nv's in de EG worden in 19933 keer geconfronteerd met vergunningverlening en 4 keer met vergunningverval of -intrekking. En van ow's met zetel buiten Nederland is de vergunning 3 keer ingetrokken of vervallen. In 1993 komt twee keer vergunninguitbreiding voor bij schadeverzekeringsmaatschappijen in de $\mathbb{E G}^{31}$

\subsubsection{VOORSCHRIFTEN OF VERBOD TOT ACQUISITIE VAN ASSURANTIE- OVEREENKOMSTEN}

Duidelijk gebaar maakt de stichting Verzekeringskamer middels toepassing van art. 113 Wtv of art. $118 \mathrm{Wtv}$. In het belang van degenen die als verzekeringnemers, verzekerden of gerechtigden op uitkeringen worden betrokken bij overeenkomsten of indien de verzekeraar inbreuk maakt op hier te lande vigerende voorschriften, kan de Verzekeringskamer voorschriften of een verbod tot acquisitie van assurantie-overeenkomsten door een verzekeraar opleggen. Alvorens tot sanctie over te gaan, maakt de stichting Verzekeringskamer haar besluit kenbaar aan betrokkene. Blijft een bevredigend antwoord uit of wordt onvoldoende gevolg gegeven aan het verzoek om een einde te maken aan de met voornoemd belang strijdige situatie, dan maakt de Verzekeringskamer het sanctiebesluit te gelde. Na afloop van de, betrokkene gegeven, termijn om tegen het besluit in beroep te gaan, publiceert de stichting Verzekeringskamer haar besluit houdende acquisitievoorschriften of -verbod (dan wel intrekking er van) in de Staatscourant.

\subsubsection{BEPERKING OF VERBOD VOOR VERZEKERAAR OM VRIJ TE BESCHIKKEN OVER ZIJN WAARDEN}

Ook op andere gronden is de stichting Verzekeringskamer geëigend tot het gebruik van het verbod als sanctiemiddel.

Van voorschriften inzake toereikende technische voorzieningen verleent de stichting mogelijk (voorwaardelijke of beperkte) ontheffing dan wel vrijstelling ex art. 65 Wtv of, voor verzekeraars met zetel buiten de EG, ex artt. 92-93 Wtv. Bij het niet voldoen aan deze eisen kan de stichting Verzekeringskamer, volgens art. $135 \mathrm{Wtv}$ jo. art. $140 \mathrm{Wtv}$ en, voor verzekeraars met zetel buiten de EG, ex art. 141 Wtv, de vrije beschikking door 
de verzekeraar over zijn waarden, waar zij zich ook bevinden, beperken of hem verbieden om anders dan met schriftelijke machtiging van de stichting Verzekeringskamer te beschikken over deze waarden.

Deze bevoegdheid gebruikt de stichting Verzekeringskamer in 1993 in twee gevallen ${ }^{32}$.

\subsubsection{BEPERKING OF VERBOD BI NIET-NAKOMING VEREISTE SOLVABILITEITSMARGE, TENZIJ GOEDGEKEURD SANERINGSPLAN AANWEZIG IS}

De zelfde beperkingen of verboden kan de stichting Verzekeringskamer, ex artt. 136-138 Wtw, en ex artt. 142-144 Wtv voor verzekeraars met zetel buiten de EG, ook aanbrengen in het geval verzekeraar de voorschriften inzake de solvabiliteitsmarge niet meer nakomt. Alvorens tot actie over te gaan biedt de stichting Verzekeringskamer betrokken verzekeraar mogelijkheid zijn onhoudbare positie te verhelpen via indiening van een, door de toezichthouder goed te keuren, saneringsplan. De stichting Verzekeringskamer kan wan, door haar toegestane, saneringsplannen wijziging eisen of goedkeuring er van intrekken (respectievelijk art. 136, vierde lid, Wtv en art. 142, vierde lid, Wtv).

De stichting Verzekeringskamer eist in 1992 van 3 verzekeraars ${ }^{33}$ en in 1992 van 1 verzekeraar een saneringsplan ${ }^{34}$

\subsubsection{VERKLARING VAN GEEN BEZWAAR}

Voor het voor de eerste keer verrichten van verzekeringsdiensten - van uit een EG-vestiging naar een andere lidstaat dan Nederland - door een verzekeraar met zetel in Nederland, dan wel - van uit Nederland naar een andere lidstaat - door een verzekeraar met zetel buiten de gemeenschap van Europese lidstaten, is het noodzakelijk dat de Verzekeringskamer verklaart daartegen geen bedenkingen te hebben (respectievelijk art. $76 \mathrm{Wtw}$ en art. $103 \mathrm{Wtv})$.

\subsubsection{TOESTEMMING VOOR OVERDRACHT RECHTEN EN PLICHTEN UIT VERZEKERINGS- OVEREENKOMST EN VOOR OMZETTING RECHTSVORM VAN VERZEKERINGSBEDRUF}

Ex artt. 119-125 Wtw is woor overdracht van rechten en verplichtingen uit overeenkomsten van schadeverzekering en ex artt. $126 \mathrm{Wtv}$ is ook voor omzetting van de rechtsvorm. van een schadeverzekeraar is de schriftelijke toestemming van de stichting Verzekeringskamer vereist. In 1992 verkrijgen 39 nv's en ow's, die het schadeverzekeringsbedrijf uitoefenen, toestemming tot, al dan niet gehele, portefeuille-overdracht. ${ }^{35}$ In 1993 bewilligt de stichting Verzekeringskamer in 15 gehele of gedeeltelijke portefeuille-overdrachten. ${ }^{36}$

32. Stichting Verzekeringskamer, Jaarverslag 1993, Apeldoom, 1994, pp.27/29-30.

33. Stichting Verzekeringskamer, Jaarverslag 1992, Apeldonm, 1993, p.27.

34. Stichting Verzekeringskamer, Jaarverslag 1993, Apeldoom, 1993, p.30.

35. Stichting Verzekeringskamer, Jaarverslag 1992, Apeldoom, 1993, pp.65-66.

36. Stichting Verzekeringskamer, Jaarverslag 1993, Apeldoom, 1994, pp.80-81. 
Dit toestemmingsvereiste geldt tevens voor het levensverzekeringsbedrijf in gevolge respectievelijk de artt. 127-133 Wtv en art. 134 Wtv. In 1992 verkrijgen 2 nv's, die het levensverzekeringsbedrijf uitoefenen, toestemming tot portefeuille-overdracht. ${ }^{37}$ In 1993 bewilligt de stichting Verzekeringskamer in 5, gehele of gedeeltelijke, portefeuilleoverdrachten. ${ }^{38}$

De met portefeuille-overdracht gepaard gaande gegevensverstrekking is in de Wtv met voldoende waarborgen omgeven. Daarom dient deze gegevensverschaffing niet te worden beoordeeld aan de hand van de Wpr. Kortom, de Wtv gaat hier boven de Wpr. ${ }^{39}$

\subsubsection{OVERIGE GOEDKEURINGSEISEN}

Verzekeraars moeten aan de Verzekeringskamer ook goedkeuring vragen voor overboekingen naar hun bijkantoren in andere staten dan wel naar nevenvestigingen buiten Nederland (respectievelijk art. 75 Wtv en art. 102 Wtv). Maakt een verzekeraar aannemelijk dat bij verzekeringsovereenkomsten betrokkenen geen bezwaar hebben tegen overboeking, dan kan de Verzekeringskamer, mogelijk onder beperkingen of voorwaarden, ontheffing verlenen.

Een verklaring van geen bezwaar van de stichting Verzekeringskamer is nodig als een verzekeraar met zetel in Nederland een gekwalificeerde deelneming in een bepaalde geregistreerde kredietinstelling (of een onderneming of instelling die aan het hoofd van een groep waarin een of meer verzekeraars zijn opgenomen) wil houden, verwerven of vergroten. In gevolge art. 172, vierde lid, Wtv verleent de stichting Verzekeringskamer de verklaring van geen bezwaar als verlening hiervan niet meebrengt, dat zij of de betrokken minister moet vrezen woor een ongewenste ontwikkeling van het verzekeringswezen. Bovendien mag vergunningverlening het belang van verzekeringnemers, verzekerden of gerechtigden op verzekeringsovereenkomsten niet schaden. De eis van verklaring van geen bezwaar geldt ook woor een natuurlijk persoon of rechtspersoon die gekwalificeerd wil deelnemen in een verzekeraar met zetel in Nederland (art. 173 Wtv). Ex art. 174, zesde lid, Wtv is wijziging of intrekking van woornoemde verklaring mogelijk, op verzoek van betrokkene of indien voor de verklaring vereiste gegevens ontbreken of onjuist zijn, en anders als binnen een gestelde termijn niet aan verklaringsvoorwaarden is voldaan.

\section{$\$ 18.4$ Toezichtsbevoegdheden stichting Verzekeringskamer}

Voor een behoorlijke uitoefening van haar functie als toezichthouder kan de stichting Verzekeringskamer zich onder meer beroepen op informatieverplichtingen van de verschillende verzekeraars. Een verzoek om informatie moet passen in het kader van het toezicht op de financiële markten. Zij mag geen geheimhoudingsplichten geweld aandoen. $\mathrm{Zij}$ mag geen strijd met de Nederlandse wet of de openbare orde op leveren. Zij moet een

37. Stuchting Verzekeringskamer, Jaarverslag 1992, Apeldoorn, 1993, p.59.

38. Stichting Verzekeringskamer, Jaarverslag 1993, Apeldoom, 1994, pp.76-77.

39. Registratiekamer, Jaarverslag 1989-1991, Rijswijk, 1994, p.51. 
duidelijk omschreven doel dienen. En dat doel mag niet oneigenlijk zijn. Ex respectievelijk art. $55 \mathrm{Wtv}$ junctis art. $71 \mathrm{Wtv}$ en art. $98 \mathrm{Wtv}$, verstrekt een verzekeraar binnen een door de stichting Verzekeringskamer te bepalen termijn de inlichtingen die zij voor de vervalling van de haar taak verlangt. Een uitwerking hiervan is te vinden in de verplichte opgave van de waarden waarmee technische voorzieningen worden gedekt. Zie respectievelijk art. 137 en art. 143 Wtv. In gevolge art. 72 juncto art. 99 Wtv ontvangt de Verzekeringskamer de jaarverslagen van de verschillende verzekeraars. En volgens art. 73 jo. art. $100 \mathrm{Wtv}$ doen verzekeraars aan de Verzekeringskamer opgave van gesloten assurantie-overeenkomsten met betrekking tot nevenvestigingen.

Van wijziging van statuten of technische grondslagen voor tariefberekening doet een levensverzekeraar opgave aan de Verzekeringskamer ex art. 74 Wtv jo. art. 101 Wtv. Dit geldt ook voor een voorgenomen mutatie in karakter van risico bij schadeverzekeringen als mede in aard van levensverzekeringscontracten (respectievelijk art. 77 Wtv jo. art. 80 Wtv en art. 104 jo. art. 111 Wtv). Daarnaast moet de Verzekeringskamer met veranderingen ten aanzien van personen of rechtspersonen die verzekeraars vertegenwoordigen bekend worden gemaakt (artt. 80/84-87/89-91/101/107 Wtv). Sommige voorgestelde wijzigingen kunnen pas werking krijgen na terinzagelegging van wijzigingsbesluiten bij de Verzekeringskamer.

De stichting Verzekeringskamer kan, in gevolge art. 56 Wtv, getuigen, deskundigen, bestuurders en commissarissen van verzekeraars(conglomoraten ${ }^{40}$ ) oproepen. En, als vermeld in art. $57 \mathrm{Wtv}$ jo. art. $81 \mathrm{Wtv}$, kan de stichting ook inzage nemen of door personen, door haar bij uitdrukkelijke en bijzondere volmacht aangewezen, doen nemen van de boeken en zakelijke bescheiden als mede alle andere informatiedragers ${ }^{41}$ van een verzekeraar, een vertegenwoordiger (als bedoeld in respectievelijk artt. 83-87 Wtv en artt. 89-91 Wtv), een derde die de zaken onder zich heeft of een verzekeraar die onder een buitenlandse financiële toezichthouder valt (ex artt. 182-183 Wtv). Mede met oog op de informatieplichten bepalen respectievelijk art. $69 \mathrm{Wtv}$ en art. $96 \mathrm{Wtv}$, dat een verzekeraar zorg draagt voor een goede administratieve organisatie en adequate interne controleprocedures. Deze artikelen ${ }^{42}$ zijn tegenwoordig uitgebreid met een tweede lid luidende: "De Verzekeringskamer kan verzekeraars aanbevelingen en algemene richtlijnen ${ }^{43}$ voor hun bedrijfsvoering geven met betrekking tot de administratieve organisatie - met inbegrip van de financiële administratie - en de interne controle als mede met het oog op het

40. Mvt wijz. Wtw 1993, TK 1993-1994, 23544, nr.3, p.8, beschouwt deze verschijningsplicht als "additioneel, subsidiair en volgtijdelijk"

41. Deze toevoeging brengt het Wetswoorstel inzake informatie-uitwisseling, TK 1993-1994, 23170, nr.268. p.4, zie ook $M v t$, nr.3, pp.2/12-13. Aldus worden art. 33, eerste en tweede lid, art. 48, eerste lid, art. 66, zesde lid, en art. 84, eerste lid, Ww, naar de stand van de technologie gemoderniseerd.

42. Zie respectievelijk art. 70 en art. 98 Wtw, gewijzigd bij Wijziging Wtk 1992 en Wh 1993 i. W.m. het versterken van het toezicht op kredietinstellingen en verzekeraars die deel uitmaken wan een groep. TK 1993-1994, 23544, nrs. 1-2, pp.5-6; Wijziging Wtk, Stbl. 6 april 1994, 278, in werking per 1 juli 1994 volgens Stbl. 1994, 477 .

43. Wat betreft deze mogelijkheden, als eender geregeld voor De Nederlandsche Bank nv, wordt in Whk 1992, TK 1992 19913,22665, nr.6, p. 30, over het karakter daarvan het volgende opgemerkt. Aanbevelingen zijm vrijblijvend. En algemene richtlijnen zijn verplichtend. Algemene richtlijnen "zijn dus algemeen verbindende voorschriften". 
woorkomen van belangenconflicten." Ex art. 180 Wtv jo. art. 14 statuten stichting Verzekeringskamer zijn de stichting Verzekeringskamer en haar werknemers verplicht tot geheimhouding van al hetgeen hun in hun functie bekend wordt en waarvan zij het vertrouwelijke karakter kennen of redelijkerwijs moeten vermoeden, behoudens de uit de wet (bij voorbeeld ex art. 181 Wtv) of taak woort vloeiende noodzaak tot bekendmaking.

Het is de bedoeling dat de verslagstaten van de betrokken verzekeraars globaal inzicht geven. Ex art. 28 , eerste lid, Wtv dienen de staten een duidelijk beeld te geven van de door de verzekeraar gevoerde beheer en van zijn financiële toestand. Art. 28, tweede en derde lid, Wtv gebiedt dat staten vergezeld gaan van een verklaring van een deskundige, accountant of actuaris. Sommige staten moeten worden gepubliceerd. Ten slotte kan de stichting Verzekeringskamer om aanvullende informatie vragen (art. $31 \mathrm{Wtv}$ ) en, indien nodig, adviezen aan de verzekeraar geven in het belang van betrokkenen bij verzekeringsovereenkomsten (art. 34, tweede lid, Wtw). Laatst genoemd artikel kan zeer ruim uitgelegd worden en leiden tot, wellicht overbodige en irrelevante, gedetailleerde informatie door verzekeraars. Van uit deze gedachte is het pleidooi bekend, om de stichting Verzekeringskamer voortaan alleen de jaarrekeningen ${ }^{44}$ van verzekeraars ex art. 368 , titel 8 , boek 2 BW mogelijk met enige aanvullingen, ter bedoelde informatie voor te schotelen. 45.46

44. Zie Wetswoorstel bepalingen ower jaarrekening voor verzekeringsmaatschappijen. TK 1992-1993, 22896. nir. 2 e.v.; J.L. Bouma, Relevante verslagleg ging door verzekeraars omirent het rendement op beleggingen in zakelijke waarden, in: VA, nr. 1, 1995, pp.19-23, bespreekt enkele consequenties van deze bepalingen woor de waardering wan beleggingen gehouden doot verzekeringsbedrijven, i.h.b. m.b.t. de rapportage omitrent de zgn. performance van beleggingen in zakelijke waarden door levensverzekeringsmaatschappijen; Daarnaast is lezenswaardig P.A. Geljon, Jaarverslaggeving van Nederlandse banken, serie bankenen effecteribedrijf nr 35,1994 , over 0 . a. implicaties van het samengaan van verzekeringsmaatschappijen en banken voor de jaarverslaglegging; Zie tevens F. Krens, Internationale imwloeden op de Nederlandse exterme verslagleggingsregels, in: NV, wr.3, 1995, pp.42-47.

45. J.H.W. Goslings, Versiaggeving naar de Verzekeringskamer, in: NV, nr.3, mei/juni 1988, pp.87-89, i.h.b. p. 88 .

46. Is de eigenatr wan een verzekeringsmaatschappij (of andere instantic), niet zijnde een commanditaire vennootschap, niet bereid zijn jmarcijfers vrij te geven, ondat publikatie van vermogensposities zijn privacy/persoonlijke veiligheid bedreigt, dan wijst de rechter dat bezwaar warschijnlijk snel van de hand. Na een jarenlang durend proces wan financier I.J. Kuijten, eigenaar van de tholding Reiss \& Co, conchdeert de Afdel ing Bestuursrechtspraak van de Raad van State, inzake $X$ en $Y$ ws. Minister van economische zaken, d.d. 17 okt. 1994, AB 1995, 89, dat de bescherming van privacy en persoonlijke veiligheid van een grootaandeelhouder, gezien de wetsgeschiedenis, " "geen gewichtige reden" als bedoeld in art. $2: 210$, viende lid ${ }_{n} \mathrm{BW}$ is, evemmin bestaat strijd met ant. 2 of art. 8 EVRM; Ontheffing van de -mede in de Vierde Richtijn van de $\mathbb{R}$ aad van de EG betreffende de jaarrekening van bepaalde vennootschapsvormen d.d. 25 juli 1978, op grondslag van art. 54 , derde lid, sub g, van het EVRM neergelegde-publikatieplicht van de juarrekening is slechts mogelijk wanneer omstandigheden verhinderen dat een behoorlijke jaarrekening wordt opgesteld, denk aan gevallen wan liquidatie. Volgens de ABRS rechtvaardugen het belang van het economisch welzijn van Nederland en de bescherming van de rechten en wrijheden van anderen unmenging ook al betekent publikatie wan jaarcijfers een inbreuk op Kuijtens privelleven; J.N. SchutteVeenstra ${ }_{n}$ Jaarrekeningenrecht, in: TVVS, nr.3, 1995, pp 78-79, annoteert de uitspraak; Zile ook W. van Enk, Financier Kujiten verliest proces om finariecle privacy, in: NRC, 9 now. 1994, p.17. Het gedane rechterlijk oordeell is terecht volgens W. wan Enk, De prïs van privacy, in: NRC, 10 nov. 1994, p. 17, 


\section{\& 18.5 Aanwijzingsrecht als omstreden sanctiemogelijkheid}

Het aanwijzingsrecht ex art. 54 Wtv wordt, na de nodige politieke discussie, in 1993 geintroduceerd. Verzekeraars, uitgezonderd die met zetel buiten Nederland wat betreft het verrichten van diensten naar Nederland (art. $50 \mathrm{Wtv}$ ), kunnen een aanwijzing van de stichting Verzekeringskamer verwachten, indien zij dat noodzakelijk in het belang wan betrokkenen bij verzekeringsovereenkomsten acht. Voldoet verzekeraar daaraan bimen twee weken niet of onvoldoende, dan zijn er twee alternatieven. De eerste mogelijkheid betreft de 'stille curatele' (dat wil zeggen de terechtgewezen verzekeraar mag zijn bevoegdheden uitsluitend uitoefenen na goedkeuring van de stichting Verzekeringskamer). Het niet opvolgen van een aanwijzing of het niet verlenen van medewerking bij stille curatele levert een economisch delict op. De tweede mogelijkheid is publikatie, in de staatscourant en een of meer dagbladen ter keuze van de stichting Verzekeringskamer, van de gegeven aanwijzing inclusief de naar aanleiding van die aanwijzing ontstane correspondentie tussen de regelovertreder en de stichting Verzekeringskamer. Deze maatregel schrikt, door de preventieve werking er van ${ }^{47}$, mogelijk af.

Invoering van 'vooral selectief en slagvaardige instrumenten', als het aanwijzingsrecht en de stille curatele, vindt rechtvaardiging in het bewaken van de soliditeit van verzekeringsmaatschappijen. Die soliditeit is nodig van wege het "groeiend economisch en maatschappelijk belang dat met het verzekeringsbedrijf is gemoeid, de toegenomen concurrentie op de Nederlandse verzekeringsmarkt, die in sommige branche zelfs fel is [...] en de toenemende mate van vertakkingen in concernverband". ${ }^{48}$ De optie van een tijdig en verder gaand ingrijpen met zo nodig onmiddellijke werking, waardoor "het voorzorgskarakter van het toezicht op de verzekeringsbranche aan betekenis wint", is een vereiste voor uitoefening van een anticiperend en meer slagvaardig toezicht. ${ }^{49}$

46., $\rightarrow$

die in rijn cynisch commentaar ter zake op merkt, dat uit de Nederlandse kidnappraktijk blijkt dat "ong geen enkele wijze crimimelen zich baseren op jaarverslagen "; In dit kader is ook relevant dat de ministerraad op 4 nov. 1994 akkoond gat met hat wolgende woorstel van uit het ministerie vam justitie: stichtingen en verenigingen, die een onderneming in stand houden met een omzet van ten minste wijf miljoen gulden, worden jaarlijks verplicht een jaarrekening (conform de eisen neergelegd in het $B$ W) op te stellen en open baar te maken. Daarmee wordt een gelijke behandeling beoogt tussen deze rechtspersonen en anderit rechtspersonen als $n v^{\prime} s_{\text {w }}$ bv's, ow's met oog op eerlijke coneurrentieverhoudingen en bescheming van crediteuren. Zie Jaarrekening stichtingen en werenigingen, in: NJB, nr.41, 18 nov, 1994, p. 1435. Hierover P.M. van der Zanden en F. de Kam, Voorschriften ter zake wan admimistratie en verslaggeving woor verenigingen en stichtingen, in: $\mathrm{Si} \mathrm{V}_{*}$ 1995, pp.42-45. Auteurs wijzen op door de nieuwe regels mogelijk te ontstane problemen met: a. het toerekeningsbeginsel (antvangsten en uitgaven moeten worden toegenkend over de periode waarin prestaties zijn verricht); b. de wijze van omgang mell onderlinge relaties tussen rechtspersonen (in welke mate bestaan kiapitalbanden en moet een geconsolideerde jaarrekening worden opgenaakt); en $c$. het feit dat bepaalde verenigingen niet bij notariele akte zijn opgericht (in wells geval zij mogelijk zijn aan te merken als verenigingen met beperkne rechtsbevoegdheid, waardoor $z_{j}$ zelfstandig financiële verantwoording moeten afleggen).

47. Mvt wet tot wijziging Wh, TK 1988-1989, 20884, nr.3, p.5.

48. Mw wijziging Wtw. T.K 1988-1989, 20884, nr. 3, p.3.

49. Mvt wet tot wijziging Wh. TK 1988-1989, 20884, nr.3, p.5. 
Helaas wordt er, op grond van ervaringen van De Nederlandsche Bank nv, op gewezen dat beide sancties averechts werken. Als zeer waarschijnlijk effect zullen verzekeringnemers, een maal bekend met de aan hun verzekeraar gegeven aanwijzing, "vluchtgedrag" vertonen en hun verzekeringscontract(en) opzeggen. ${ }^{50}$ Daarmee wordt her, eigenlijk met de maatregel beoogde, herstel ${ }^{51}$ van de toch al kritieke bedrijfseconomische positie van betrokken verzekeraar niet gediend. Daarnaast zijn andere zwakke schakels wan de maatregel van stille curatele bekend. Uit een pleidooi voor aanscherping van de wettelijke regeling inzake stille curatele blijken onvolkomenheden als: a. de stille curator kan niet eigenmachtig, d.w.z. niet zonder medewerking van de organen van de betrokken beleggingsinstelling, naleving van zijn instructies afdwingen; en b. de stille curator kan, evenmin als een eigen eis tot schadevergoeding, geen zelfstandige vordering tot ongeldigverklaring van rechtshandelingen (verricht door het bestuur van de betrokken beleggingsinstelling) instellen. ${ }^{52}$

De stichting Verzekeringskamer legt in $19921 \mathrm{keer}^{53}$ en ook in 1993 een bindende aanwijzing (i.c. een produktiestop voor Vie d'Or) ${ }^{54}$ op.

\section{$\S 18.6$ Noodregeling als uiterste sanctiemogelijkheid}

Is sprake wan een verzekeraar die met faillissement wordt bedreigd, dan kan de stichting Verzekeringskamer de rechtbank verzoeken een noodregeling te treffen (art. 154 Wiv). De procedure is geregeld in de artt. 153-171 Wtv. Bij het uitspreken van zo'n noodregeling, verleent de rechter de stichting Verzekeringskamer een machtiging tot vereffening of overdracht van de boedel ex art. 154, tweede lid, Wtv. Nat het uitspreken van zo'n machtiging oefent de stichting Verzekeringskamer bij uitsluiting alle bevoegdheden van de bestuurders, commissarissen of vertegenwoordigers van de betrokken verzekeraar uit (art. 159, eerste lid, Wtv). Daartoe kan zij, in gevolge art. 159 , zevende lid, Wtv, ook personen machtigen. Overdracht van rechten en verplichtingen van verzekeraars mag schuldeisers niet benadelen (art. $164 \mathrm{Wtv}$ ). De kosten van de noodregeling komen ten

50. Ph. H. J. G. van Huizen, Versterking van de toezichtsbevoegdheid van de Verzekeringskamer, in: VA, deel LXVII, 1990, pp.3-18, ill b. pp.9-18.

51. MW wet tot wijziging Wh, TK 1988-1989, 20884, nr.3, p.5.

52. A.L. Leuftink en C.J. Groffen, Enkele kantekeningen bij de 'sirlle curatele' onder de Wib, in: TVVS, nr. 10, 1994, pp. 266-269. Volgens auteurs verdient het aanbeweling (zie p. 269) de stille curator "toe te rusten met een zelfstand ige bevoegdhe to thet instellen wan bepaalde vorderingen, namens de beleggingsinstelling of 'ambtshalve', bij voorbeeld om de nietigheid in te roepen wan benadelingshandelingen uit het verleden en schadevergoeding te vorderen (vgl. de actio pauliarta ex art. 42 e.v. Faillissementswet en de onrechtmatige daadsactie, zo alls deze door de faillissementscurator wordt uitgeoefend). Ook zou hem de bevoegdheid een enquête uit te lokken kunnern worden toegekend." Daamaast willen auteurs de stille: curator een zelfstandige bewoegdheidi tot procederen - gelijk de Trustee in Chapter 11 van de US Bankruptcy Code - toekennen (p.269). Auteurs menen dat uitbreiding vam bevoegdheden van de stille curator te meer van belang is nu de Wtb, i.t.t. de Wtk en de Wtw, niet de mogelijkheid kent van het uitspreken wan een zgn. noodregeling door de rechtbank op verzoek van respectievelijk De Nederlandsche Bank mv en de stichting Verzekering skamer. De omissie van wet- en regelgeving aangaande de bevoegdheden van de stille curator klemt dus minder bij de hier te bespreken Verzekeringskamer.

53. Stichting Verzekeringskamer, Jaarverslag 1992, Apeldoorn, 1993, p.28.

54. Stichting Verzelkeringskamer, Jaarverslag 1993, Apeldoorn, 1994, pp 27/30. 
laste van de betrokken verzekeraar (art. $165 \mathrm{Wtv}$ ). Bij gebleken negatief vermogen van betrokken verzekeraar, waarbij geen gunstige perspectieven voor de toekomst bestaan, verzoekt de stichting Verzekeringskamer om faillietverklaring ex art. 167, eerste lid, Wtv. Na effectuering van de noodmaatregell brengt de stichting Verzekeringskamer ex art. $168 \mathrm{Wtv}$, desgevraagd tijdens de noodregeling, verslag aan de betrokken minister uit.

Op 12 oktober 1992 kondigt de rechter een noodregeling voor de Trinity Insurance Company Limited te Londen af. ${ }^{55}$ Op 12 oktober 1993 en op 15 december 1993 treft de rechter, op verzoek van de stichting Verzekeringskamer, noodregelingen voor Ardenia Insurance Limited te St. Peter Port te Guernsey en Vie d'Or. ${ }^{56}$

\subsubsection{VIE D'OR}

Als vermeld wordt een noodregeling door de rechtbank in "s-Hertogenbosch op 15 december $1993^{57}$ getroffen voor de, met een vermogenstekort van 80 miljoen gulden bedreigde, levensverzekeraar Vie d'Or. ${ }^{58} \mathrm{Al}$ eerder, op 14 december 1993 , wordt de vergunning van Vie d'Or door de stichting Verzekeringskamer ingetrokken na gerezen verdenking van mismanagement en fraude van de directie van het verzekeringsbedrijf: "Vie d'Or voerde produkten die zo veelbelovend waren dat ze te geringe marges hadden, er werden extreem hoge provisies en royalties uitgekeerd, die bovendien vooruit werden betaald. Er was te veel belangenverstrengeling tussen de directie en het bedrijf, er waren dubieuze debiteuren en bovenal was er een slechts administratie. " 59 Ook is er van uit de Vie d"Or-directie herhaaldelijk valse informatie aan aandeelhouders verstrekt. ${ }^{\text {(I) }}$ Bovendien is Vie d'Or niet meer in staat de financiële positie op het wettellijk vereiste peil te brengen.

Door het intreden van de noodregeling, draagt de stichting Verzekeringskamer zorg voor de afwikkeling van zaken van betrokken verzekeraar. Zo vordert de stichting Verzekeringskamer in een gerechtelijke procedure 14 miljoen gulden van het Financieel Begeleidingsinstituut Maes en de directeur daarvan, die tevens topman van Vie d'Or is. Daartoe legt zij beslag op de woning van die directeur en het pand van Vie d'Or. ${ }^{61}$ En de toezichthouder van het Nederlandse verzekeringswezen wenst de ingelegde gelden wan de circa 13.000 polishouders van Vie d'Or bij voorkeur over te dragen aan een andere, financieel draagkrachtige verzekeraar.

55. Stichting Verzekeringskamer, Jaarterslag 1992, Apeldoorn, 1993, p.27.

56. Stichting Verzekeringskamer, Jaarwerslag 1993, Apeldoorn, 1994, pp.27-29.

57. De stichting Verzekering skamer doet uitvoerig chronologisch en inhoudelijk verslag van haar werkzaamheden t.a.v. Vie d'Or van 15 dec. 1993 tot em met 1 aug. 1994, Tweede tussentijdse verslag anzake Me d'Or, 19 okt. 1994. Apeldoom; Van eendere toezichtsactiviteiten wordt mellding gedaan in haar Eerste twassentijdse verslog inzake Vie d'Or, 27 jan. 1994.

58. Einde aan zelfstandig bestaan van Vie d'Or na vermogenstekort, in: NRC bijlage economie, 11 dec.. 1993.

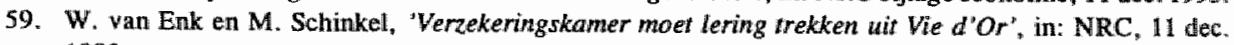
1993.

60. S. Paradijs en M. Princen. Vie d'Or-top lichtte geidschieters fout in, in: De Telegralaf, 15 febr. 1994 , p. 27 .

61. I4 Milioen geclaimd wan oud-topman Vie d'Or, in: NRC, 12 febr. 1994, D. 15. 
Aanvankelijk wil de stichting Verzekeringskamer de boel nog redden. Daartoe richt zij een verzoek aan het Verbond van Verzekeraars om financiële steun met oog op mogelijke sanering van Vie d'Or. ${ }^{62}$ Hoewel dat verzoek niet direct ter zijde wordt geschoven, worden uiteindelijk plannen voor overname van Vie d'Or met potentiële kandidaten, met name Zürich Versicherung, besproken. ${ }^{6.3}$

De wenselijkheid van overname van de noodlijdende verzekeraar wordt nijpender, als een grote Amerikaanse effectenbank, te weten Merrill. Lynch, haar beleggingscontract met Vie d'Or op 20 december 1994 opzegt. ${ }^{64} 65^{65}$ Omdat Merrill Lynch veertig à vijftig procent van de beleggingen van Vie d'Or voor haar rekening neemt, leidt opzegging van de overeenkomst er toe dat het tekort van Vie d'Or de 80 miljoen gulden overschrijdt. Met oog op de contractopzegging wijst een beschuldigende vinger naar de stichting Verzekeringskamer. Als reden van opzegging van het, naar Engels recht opgestelde, contract voert Merrill Lynch namelijk aan, dat sprake is van een 'event of default'. Daardoor worden betrokken beleggingen opeisbaar. Vervolgens kan Merrill Lynch tot liquidatie er van overgaan. De stichting Verzekeringskamer is kennelijk aan deze constructie voorbij gegaan. ${ }^{66}$ De advocaat van de Belangenvereniging Polishouders Vie d'Or te Best ${ }^{67}$ vindt dit merkwaardig. $\mathrm{Hij}$ vergelijkt "de noodregeling toch met een surséance van betaling bij bedrijven, en dan zouden de beleggingen ook opvraagbaar zijn" . ${ }^{68} \mathrm{De}$ belangenvereniging spreekt zich uit voor liquidatie van Vie d'Or, omdat het bij een faillissement nog lang kan duren voordat polishouders een deel van hun wordering terug zien. ${ }^{*}$ Eveneens dringt deze belangenvereniging aan op de aanstelling van een "onafhankelijke toezichthouder op de afwikkeling van Vie d'Or, naast de Verzekeringskamer" ${ }^{70}$ Kennelijk voelt de stichting Verzekeringskamer de noodzaak daarvan. Een afzonderlijke stichting, t.w. de stichting Vie d'Or te Eindhoven, wordt medio april 1994 in thet leven geroepen om aansprakelijkheidsclaims in verband met de slechte afloop van Vie d'Or als mede dubieuze leningen van Vie d'Or te innen, de inboedel van Vie d'Or te veilen en een sociaal plan bij de verzekeraar uit te voeren. ${ }^{71}$ In het bestuur van deze stichting is plaats voor een kandidaat, die wordt voorgedragen coor de belangenvereniging van gedupeerde polishouders. Het uiteindelijke benoemings- en ontslagrecht ten aanzien van bestuurders berust wel bij de stichting Verzekeringskamer. Dit recht tast de

62. Verzekeringskamer vraagt steun bij sanering Vie d'Or, in: NRC, $15 \mathrm{dec}$. 1993, p.23.

63. Zwitsers willen Vie d'Or ovememen, in: NRC, 17 dec. 1993, p.13.

64. Merrill Lynch zegt contract Vie d'Or op, in: NRC, 27 dec. 1993, p.11.

65. Daarnaast ontstat flinke vermogensvermindering tijdens de noodregeling door opzegging van de Schiphol-lening.

66. De stichting Verzekering skamer verweent zich hiertegen door te stellen, dat: a. zij beschikte over onvolledige informatie (slechts uittreksels wan Merrill Lynch-contracten op fimancięle hoofdlijnen); ten b. Merrill Lynch de indruk wekt dat zij de contracten niet opzegt. Verzekeringskamer, Tweede tussentijdse verslag inzake Vie d'Or, 19 oklt. 1994, Apeldoorn, p.33.

67. Daamaast bestaut contact met georganiseerde polishouders via de belangenwereniging Recht voor polishouders van Vie d'Or te Tilburg.

68. B. Bohler, geciteerd in Merrill Lynch zegt contract Vie d'Or op, in: NRC, 27 dec. 1993, p.11.

69. Polishouders Vie d'Or voor liquidatie, in: NRC, 10 febr. 1994, p.20.

70. Polishouders Vie d'Or voor liguidatie, in: NRC, 10 febr. 1994, p.20.

71. Stichting wikkelt ondergang van verzekeraar Vie d'Or af, in: NRC, 27 april. 1994. p.16. 
onafhankelijkheid van de stichting aan en bemoeilijkt het, door de polishouders, aansprakelijk stellen van de Verzekeringskamer. ${ }^{72}$ Voor polishouders schijint pas enig zonlicht door de wolken na de akkoordverklaring van levensverzekeraar Levob - t. w. de dochteronderneming Twenteleven nv - met de overdracht van de portefeuille van Vie d'Or aan Twenteleven $n v^{73}$, welke overdracht van rechten en plichten vanaf 1 augustus 1994 geldingskracht heeft ${ }^{74}$. Hierbij geldt de conditie, dat aandeelhouders en leveranciers van de failliete levensverzekeraar Vie d'Or hun vorderingen niet meer te gelde kunnen maken, maar dat polishouders wel 75 tot 110 procent van hun inleg terug kunnen krijgen. ${ }^{75} \mathrm{Na}$ goedkeuring van de overdracht van levensverzekeringsportefeuille van Vie d'Or aan Levob door de rechtbank te "s-Hertogenbosch schat de voorzitter van de stichting Verzekeringskamer het aandeel, dat polishouders van hun ingelegde gelden mogelijk terug zien, op in elk geval 70 procent. ${ }^{76}$ Anders dan de stichting Verzekeringskamer wil, bepaalt de rechtbank dat niet alleen polishouders, maar ook andere crediteuren aamspraak kunnen maken op gelden die door het faillissement van Vie d'Or wrij komen. Mogelijk komt ook geld los via een aansprakelijksclaim aan het adres van het accountantskantoor dat de jaarverslagen van Vie d'Or altijd heeft gecontroleerd en van goedkeuring heeft voorzien. ${ }^{77}$ Medio december 1994 deelt de stichting polishouders Vie d'Or mee dat zij, op basis van een KPMG-rapport, ex-bestuurders, commissarissen, tussenpersonen en de accountant van Vie d'Or wegens falen aansprakelijk wil stellen voor een bedrag dat mogelijk oploopt tot 185 miljoen gulden. ${ }^{78}$ Belangrijke beschuldiging aan het adres van de directie is dat zij in de periode 1989-1992 via onjuiste waarderingsgrondslagen bewust ondengdelijke jaarrekeningen heeft opgesteld, aan het adres van de commissarissen dat zij zich ten aanzien van die apert niet kloppende jaarrekeningen te weinig kritisch zijn geweest, en aan het adres van de accountant dat deze goedkeuring verschafte aan de kromme jaarrekeningen. Voordat de stichting Vie d'Or een klacht indient bij de Raad van tucht van het Nederlands Instituut van Register Accountants, gunt zij het betrokken accountantskantoor het recht op weerwoord. Al snel laat het accountantskantoor, t.w. Deloitte \& Touche, weten niets te willen hebben van eventuele schikking. Het kantoor, dat vindt dat aansprakelijkstelling "overhaast en ten onrechte" bij Deloitte \& Touche wordt neergelegd, trekt een muur op door vermeende fouten te ont-

72. Aldus B. Böhler, geciteerd door W. van Enk, Aardeelhouders en leveranciers Vie d'Or krijgen geen geld, in: NRC, 14 juni 1994, p.17.

73. De stichting Verzekeringskamer verleent Twenteleven, d.d. 13 april 1994, een vergunning voor uitoefening wan thet directe levensverzekeringsbedrijf. Bekendmaking daarvan geschiedt via Stcrt. 18 april 1994. 73. Zie ook B. Lieuwma, Het leek me een perfecte job; Argelloze Liewwma liet zich in beerput Vie d"Or trekken, ïn: Elan, maart 1994, pp.12-19. Lieuwma geeft een interessante chronologische be schrijving wam de gebeurtenissen bij Vie d'Or.

74. Stichting Verzekeringskamer, Mededeling inzake de noodregeling nv levenswerzekeringsmui. Vie d'Or, in: NRC, 4 aug. 1994, p.18; Conform uitspraak 's-Hertogenbosche rechtbank 15 juli 1994 gepubliceerd in Stcrt. 1-3 aug. 1994, 144-146.

75. W. van Enk, Aande lhouders en leveranciers Vie d'Or krijgen geen geld, in: NRC, 14 jumi 1994, p.17.

76. Polishouders Vie d'Or gaan over nadr Lewab, in: NRC, 16 juli 1994, p.10.

77. Polishouders Ve d'Or gaan aver naar Levab, in: NRC, 16 juli 1994, p. 10.

78. Gedupeerden Vie d"Or eisen schadebedrag tor 185 miljoen, in: NRC, 15 dec. 1994, p.13. 
kennen. ${ }^{79}$ Onder eerlijke erkenning dat het voorbereiden en het realiseren van de verschillende aansprakelijkheidsclaims inderdaad nog veel tijd vragen (het gaat om wel 100 geldvorderingen bij veel tussenpersonen die ten dele voor de rechter moeten worden uitgevochten), laat de stichting Vie d'Or wel weten het serieus te nemen. Uiteindelijk dient de stichting Vie d'Or een klacht tegen Deloitte \& Touche bij de tuchtraad in.

De ernst van de zaak blijkt ook uit het feit dat de procureur-generaal te Amsterdam, op werzoek van de stichting Vie d'Or, bij de ondernemingskamer van het Amsterdamse Gerechtshof een enquêteverzoek inzake de gang van zaken bij Vie d'Or indient.

Daarnaast vraagt de stichting Vie d'Or aan accountant KPMG om een onderzoek in te stellen naar de rol van de stichting Verzekeringskamer bij de teloorgang van Vie d'Or. De stichting Vie d'Or merkt op dat het hierbij interessant is, dat het advocatenkanioor Loeff Claeys Verbeke, vooruit lopend op de in de zomer 1995 te verwachten uitslag van dat KMPG-onderzoek, stelt dat bij negatieve uitkomst er van zowel de Verzekeringskamer als de Staat der Nederlanden verplicht zijn tot schadlevergoeding.

Begin februari 1995 maakt justitie bekend de voormalige top van de failliete levensverzekeringsmaatschappij Vie d'Or te vervolgen. In het strafrechtelijk onderzoek is nog geen plaats voor het staven van mogelijke persoonlijke verrijking van verdachten. ${ }^{82}$ De misdrijven waarvoor verdachte personen moeten terecht staan zijn kennelijk slechts gepleegd om goedkeuring te krijgen voor de jaarrekening over 1992. Verdacht worden: oud-directeur en oprichter F.M. (beschuldigd van verduistering van 2,6 miljoen gulden ${ }^{83}$, vervalsing van geschriften als overeenkomsten, facturen en poliscontracten, het niet overeenkomstig de wensen van beleggers beleggen en het opmaken van valse cliëntenoverzichten); de beide voormalige mededirecteuren; de voormalig controller van Vie d'Or; en een aantal assurantietussenpersonen t.w. Blokland \& Willemsen Nederland, Alexander \& Cook, Wouterse \& Van Arkel ${ }^{84}$ (beschuldigd van belastingfraude, verduistering en valsheid in geschrifte).

De financiële strop ${ }^{85}$, die de polishouders van de ten slotte ter ziele gaande Vie d'Or lijden, maakt de gemoederen weer los over instelling van een garantiefonds. Een dun decennium vóór de teloorgang van voornoemd verzekeraar ligt het besluit, waarin het (ministeriële) 'nee' wordt uitgesproken over invoering van een garantieregeling, op tafel. En dan, in 1994, ziet de stichting Verzekeringskamer, geconfronteerd met polishouders

79. Aldus P. Hoogendoorn, als bestuursvoorzitter wan Deloitte \& Touche, geciteerd in Accountant: ge.en fout bj conrole Vie d'Or, in: NRC, 16 dec. 1994, p.16.

80. Ondernemingskamer verzocht om enquête naar Vie d'Or, in: NRC, 30 maart $1995, \mathrm{p} .19$.

81. Aldus de mening van J. wan Rijn, als voorzitter van de stichting Vie d'Or, verwoord in Gedupeerden Vie d'Or eisen schadebedrag tot 185 miljoen, in: NRC, 15 dec. 1994, pil 13.

82. Dit stelt de polishouders wan Vie d'Or teleur, maar de voorzitter van hun belangenvereniging acht voldoende aanknopingspunten aanwezig voor schadeverhaal via de civiele rechter. Onderzoek parlememt werheugt gedupeerden, in: NRC, 8 febr. 1995, p.17.

83. Dit bedrag betaalt F.M., zonder tegenprestatie, an Vie d"Or. F.M. ontwangt het geld van ext tusserpersoon, dive het bedrag zelf weer wan Wie d'Or krijgt.

84. Dit kantoor koopt via schikking verdere rechtsvervolging af.

85. Nota bene, de noodregeling zelf levert al een strop op van circa 43 miljoen gulden, omdat herverzekeratrs hum contracten hebben kunnen opzeggen. 
die de klappen krijgen en de pijn opvangen van Vie d"Or, aanleiding om de mogelijkheden tot instelling van een garantiefonds opnieuw te onderzoeken en ter discussie te stellen. De stichting Verzekeringskamer, die met haar "liberaal toezicht grote verantwoorde1 lijkheid bij ondernemers ${ }^{\prime \prime}$ legt, meent met oog op de steeds krachtiger concurrentie dat polishouders een betere bescherming verdienen; Op een moordende markt, waar - gebukt onder het Europese juk - zelfregulerende krachten sterk afnemen, is volgens de stichting Verzekeringskamer een garantiefonds alls vangnet geboden. ${ }^{86}$ Het voorstel van de stichting Verzekeringskamer lokt kritiek uit. Krakend luidt het commentaar, dat de toezichthouder op het verzekeringsbedrijf in haar streven naar een maatschappelijk verantwoord verzekeringsbestel de optie van een garantiefonds prefereert boven de keuze voor een strenger toezicht. Als, door déconfitures veroorzaakt, leed wordt verzacht door uitkeringen via een garantiefonds, vraagt de consument niet meer naar de wijze waarop is gecontroleerd door de bevoegde toezichthouder. Het Verbond van Verzekeraars, dat een garantiefonds afwijst omdat een dergelijke regeling mogelijk "premie is voor onverant-

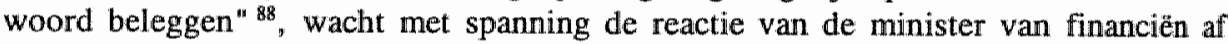
over het - zich op een zo klein mogelijk fonds met naheffingsmogelijkheid gericht onderzoek van de stichting Verzekeringskamer.

\subsubsection{Vie d'Or ter lering van stichting Verzekeringskamer}

Dat de stichting Verzekeringskamer fouten heeft gemaakt bij de controle op het handelen van Vie d"Or en op de afwikkeling van zaken van de in moeilijkheden geraakte Vie d'Or, is evident. Het debâcle Vie d'Or is voor de stichting Verzekeringskamer, die zich op respectievelijk 9 februari 1994 en 16 maart 1994 ter zake moet verantwoorden bij de vaste kamercommissie van financiën ${ }^{39}$, aanleiding bij zich zelf te rade gaan.

Ten eerste kan ze zich afvragen of zij mogelijkheden moet krijgen om "milder' in te grijpen. Vergunningintrekking is immers een "paardemiddel". ${ }^{90}$ De negatieve publiciteit, die intrekking met zich meebrengt, werkt de nodige vertrouwenscrisis in de hand. Ten tweede dient zij te twijfelen aan haar alertheid in de zaak Vie d'Or. Waarom stemt zij bij herhaling in met negatieve verzekeringsresultaten van de verzekeraar, vindt zij extreem hoge provisies verantwoord en geeft zij haar goedkeuring aan 'gaten vullende" herverzekeringen of extra kapitaalinjecties afkomstig van aandeelhouders? ${ }^{9 t}$ De stichting Verzekeringskamer geeft nota bene twee keer aan Vie d'Or het bevel achteraf haar boeken bij te stellen. ${ }^{92}$ Voordat de stichting Verzekeringskamer tot vergunningintrek-

86. Controlew werzekeraars: garantiefonds polishouders", in: NRC, 8 sept. 1994, p. 17; Ook stichting Verzekeringskamer, Tweede inssentijdse werslag inzake Vie d"Or, Apeldoorn, 19 okt. 1994, pp.67-68.

87. W. van Enk, Financiên moet beslissen over garantiefonds verzekeraars, in: NRC. 8 sept. 1994, p.21.

88. Controleur verzekeraars: garantiefonds polishouders, in: NRC, 8 sept. 1994, p.17.

89. Parlement hoort Verzekeringskamer, in: NRC, 3 febr. 1994, p.17.

90. Aldus bewindwoerder C. Boet, geciteerd door W. van Enk en M. Schinkel, 'Verzekeringskamer moet lering trekken wit Vie d'Or', in: NRC, 11 dec. 1993.

91. W. van Enk en M. Schinkel, 'Verzekeringskamer moet lering trekken uit Vie d'Or', in: NRC, 11 dec.
1993 .

92. W. van Enk en M. Schinkel, Geen afgang van Ve d'Or met scherpere controle, in: NRC. 10 dec. 1993 ,
p.9. 
king over gaat, eist zij van Vie d'Or een financieringsplan omdat de solvabiliteitsmarge daalt tot beneden het garantiefonds, geeft zij een bindende aanwijzing (inhoudende een produktiestop), legt zij een verbod op om anders dan met schriftelijke machtiging van de Verzekeringskamer over de waarden ter dekking van de technische voorzieningen te beschikken en eist zij opgave van de in verband met de technische voorzieningen geadministreerde waarden. ${ }^{93}$ Dat de aanwijzingen van de Verzekeringskamer, om de administratie en financiële huishouding op orde te brengen, overigens niet door Vie d'Or worden opgevolgd wordt door betrokken verzekeringsmaatschappij bevestigd. ${ }^{94}$

In dit kader luidt het pleidooi ${ }^{95}$ te komen tot een strenger toezichtsregime van de stichting Verzekeringskamer. De stichting Verzekeringskamer zou namelijk tijdig(er) alarm kunnen slaan, als zij frequenter - liefst maandelijks - zou controleren en daarnaast accountants het hele jaar door steekproeven laat doen. Een dergelijk toezichtsysteem van controle vooraf plus steekproeven functioneert naar tevredenheid bij een andere toezichthouder van de financiële markt, te weten De Nederlandsche Bank nv. Het argument voor het actieve toezicht op de monetaire markt geldt tegenwoordig ook voor de stichting Verzekeringskamer. Immers, liberalisering, deregulering en toenemende verwevenheid tussen verzekeraars en banken leiden er toe, dat verzekeringsmaatschappijen (even als banken) spaar- en beleggingsprodukten aanbieden. Deze (oneigenlijke 'spaar')activiteiten wan verzekeringsbedrijven vallen vaak buiten het terrein van zowel de stichting Verzekeringskamer als De Nederlandsche Bank nw.

Naar aanleiding van de affaire Vie d'Or neemt de Algemene Rekenkamer het toezicht door de stichting Verzekeringskamer onder vuur. De rekenkamer vindt dat de stichting Verzekeringskamer een te grote autonomie ten aanzien van haar toezichtsbeleid heeft. Vandaar doet de rekenkamer de volgende aanbevelingen. Het ministerie van financiën moet bij wet de verplichting krijgen om het beleid van de Verzekeringskamer regellmatig te evallueren. Bovendien moet de Verzekeringskamer worden verplicht regelmatig inlichtingen te verschaffen over verzekeraars. ${ }^{96}$ Hierbij verdient aantekening, dat - tenzij, als bij het onderzoek bij Vie d'Or, de noodzaak aanwezig is - in principe geen afbreuk hoeft te worden gedaan aan geheimhoudingsplichten en onafhankelijkheidseisen van de stichting Verzekeringskamer. De minister van financiën kan in beginsel volstaan met "onder andere beoordeling van de opzet van het gehanteerde toezichtprogramma en de kwaliteit en deskundigheid van het personeel" van de stichting Verzekeringskamer. ${ }^{97}$ Dit systeem van beoordeling van taakvervulling door de toezichthouder op het verzeke-

93. Stichting Verzekeringskamer, Jaarverslag 1993, Apeldoorn, 1994, p.27.

94. Accomntant Vie d'Or wist van misstanden, in: NRC, 9 febr. 1994, p. 16.

915. W. van Enk en M. Schinkel, Geen afgang van Vie d'Or met scherpere comtrole, in: NRC, 10 dec. 1993. p.9.

96. Zie Rekenkamer laakt toezicht verzekeraars, in: NRC, 22 dec. 1993, pp.1/15; Deze aanbeveling nummer 6 , als neer gelegd in het Decemberverslag 1993 van de Algemene Rekenkamer. TK 1993-1994, 23555, nrs. 1-2, p. 29, komt tegemoet aan het regeringsstandpunt inzake functionele decentrallisatie, zie Functioneel bestuur, TK 1990-1991, 21042, nr.4.

97. Decemberverslag 1993 vas de Algemene Rekenkamer, TK 1993-1994, 23555, nr,9, p.8. 
ringsbedrijf voorkomt dat individuele bedrijven ministerieel onderzoek moeten ondergaan.

Deze kritiek wordt weerlegd door de minister van financiẻn. Volgens hem impliceert bet normatieve toezicht op de verzekeringswereld juist actief en anticiperend optreden vam de stichting Verzekeringskamer, vooral sinds de verzelfstandiging van de Verzekeringskamer. ${ }^{9}$ Sinds de toezichthouder van assuradeuren op eigen benen staat, geeft de minister van financiën aan zijn werantwoordingsplicht een enge invulling. Binnen het huidige toezichtsbeleid acht hij een evaluatieplicht ${ }^{99}$ en een inlichtingenrecht "niet wenselijk en niet noodzakelijk". ${ }^{100}$ In het licht van de verdeling van verantwoordelijkheden tussen de minister en de stichting Verzekeringskamer benadrukt betrokken bewindspersoon de onafhankelijkheid van de toezichthouder. Door deze onafhankelijkheid is de toezichthouder niet onderworpen aan bevelen van uit het ministerie. ${ }^{101}$ Zo ook is de geheimhoudingsplicht te verklaren. De stichting Verzekeringskamer neemt "een bijzondere vertrouwenspositie in die van belang is voor een adequate en effectieve uitoefening van het toezicht". ${ }^{102}$ Dit neemt echter niet weg dat de minister en de toezichthouder, wat betreft de beleidsmatige kant van toezichtsuitoefening, "gezamenlijk optrekken en gerregeld met elkaar overleg voeren"; Op basis van deze praktische, nauwe samenwerking is de minister "in staat zich een oordeel te vormen over de kwaliteit van het toezicht in zijn algemeenheid". ${ }^{103}$

De stichting Verzekeringskamer zelf onderschrijft evenmin de kritiek wan de Algemene Rekenkamer. Vervanging van de begin deze eeuw vastgelegde geheimhoudingsplicht door

98. Zie Kok: mandaat wan Verzekeringskamer is woereikend, in: NRC, 24 dec. 1993, p.17.

99. Evaluatie staat als beginsel reeds vermeld in de nota 'Functioneel bestuur'. Evaluatie komt mogelijk ools aan de orde in een toekomstige ramwet voor zbo's. Decemberverslag 19913 van de Algemene Rekenkamer, TK 1993-1994, 23555, nr.4, p.4.

100. Decemberverslag 1993 van de Algemene Rekenkamer, TK 1993-1994, 23555, nrs.1-2, p.30, als medle n. 4, p.6.

101. C.A. Schreuder, Publiekrechtelijke taakverrichting, private rechtspersanen, Deventer, 1994, \$.237. neent wël dat de minister, die -de voor de hier aparte attributievorm noodzakelijke- aanwijzing aan wen rechtspersoon t. w. de stichting Verzekeringskamer geeft om als toezichthouder op het werzekeringsbedrijf op te treden, moet nagaan of er reden is voor intrekking van deze aanwijzing conform (tegenwowdig:) ant. 4, eerste lid, Wtv. Auteur stelt dat, anders dan bij eigenlijke attributie waarbij de minister slechts de takverrichting door de stichting Verzekeringskamer kan controleren, bij deze "onvolkomen attributie" vender gaande mogelijkheden tot ingrijpen heeft. Voorwaarde is wel dat de rechtspersown de gestelde eisen woor alanwijzing als gesteld in art. 3 Wtv niet meer waar maakt. Bedoelde intrekking moet voldoen aan algemene beginselen van behoorlijk bestuur. Blijkt daarvan niet, dan loopt de minister thet risico, dat de aanvankelijk alangewezen instantie schadevergoeding eist; Eind 1994 dringt C.A. Schrettder, Privatisering en de geheimhoudingsiclaim van de Verzekeringskamer, in: NJB, nr.43, 2 dec. 1994 " pp. 1476-1480, nog mals terecht aan op het door de minister onderzoeken van de mogelijkheden di." hij heeft om de aanwijzing van de stichting Verzekeringskamer in te trekken. Omdat de mimister, ter beoordeling of de stichting Verzekeringskamer nog aan de bij de aarwijzing gestelde voorwaanden voldoet, inzicht moet hebben in concrete gevallen (hetgeen niet impliceert dat de minister mag ingrijpen in concrete gevallen) dien de stichting Verzekeringskamer zïch niet langer te verschuillen achter eent geheimhoudlingsplicht: "Zonderadequate informatie vande Verzekeringskamer zijn de bewoegdheid van. de minister een vitwoeringsorganisatie tot Verzekeringskamer aan te wijzen en de bevoegdheid deze aarwijzing in te trekken, een wassen neus" (p. 1479).

102. Decemberverslag 1993 wan de Algemene Rekenkamer, TK 1993-1994, 23555, nr.4, p.6.

103. Decemberverslag 1993 wan de Algemene Rekenkamer, TK 1993-1994, 23555, nr.4, p.7. 
een wettelijke inlichtingenplicht "zou het toezichtsstelsel, gebaseerd op een vertrouwensbasis met de bedrijfstak, in de wortel aantasten. Ook verdragen de voorstellen van de rekenkamer zich niet met de wettelijke adviesfunctie van de Verzekeringskamer. Deze adviesfunctie heeft als uitgangspunt de onafhankelijke positie van de Verzekeringskamer bij het desgevraagd dan wel uit eigen beweging geven van advies aan de overheid in aangelegenheden betreffende het levens- en schadeverzekeringsbedrijf. Tevens druisen de gedane voorstellen in tegen de beoogde afstand tussen de Verzekeringskamer en de overheid. Verder is het merkwaardig dat de Rekenkamer haar mening rechtstreeks koppelt aan het toezichtsbeleid. Dit beleid staat geheel los van de verzelfstandigingsoperatie, terwijl de vormgeving van het toezicht vrij wel identiek is aan dat van collega-toezichthouders als De Nederlandsche Bank en de Stichting Toezicht Effectenverkeer." ${ }^{04}$ De stichting Verzekeringskamer heeft op zich geen moeite met een onderzoek door een externe instantie naar de rechtmatigheid en de doelmatigheid van door de Verzekeringskamer gebruikte financiële middelen. Minder of geen ruimte ziet zij voor een onderzoek waarbij de aandacht vooral ligt op de doelmatigheid, kortom naar de kwaliteit van het uitgeoefende toezicht in concrete gevallen. ${ }^{105}$ Hoewel de stichting Verzekeringskamer, naar eigen zeggen, wel herhaaldelijk overweegt of en, zo ja, in welke mate zij vertrouwelijke gegevens naar buiten moet brengen, houdt zij voet bij stuk. Bewust aanvaardt zij al de, naar haar hoofd geslingerde, "verwijten van onvoldoende openheid, arrogant gedrag, het zich 'verschuillen achter de wet' en het verborgen willen houden van informatie $^{\text {th }}$ "106 Al zou zij misschien anders willen, volgens de stichting Verzekeringskamer laten de nationale wetgeving en de Europese richtlijnen ter zake geen discretionaire bevoegdheid geheime informatie vrij te geven.

Ontevreden ziet de Algemene Rekenkamer zo geen mogelijkheid voor, het -na het onderzoek van de vaste kamercommissie voor financiën door het parlement gewenste, doelmatigheidsonderzoek ex art. 58 Comptabiliteitswet ${ }^{107}$ naar de uitoefening door de stichting Verzekeringskamer van haar toezichtstaak ten aanzien van Vie d'Or en, meer in het algemeen, naar de wijze waarop het toezicht op de verzekeringsbranche is georganiseerd, wooral wat betreft de wijze, de methodiek, de frequentie en de intensiteit van uitoefening

104. Stichting Verzekeringskamer, Jaarverslag 1993, Apeldoorn, 1994, p.59.

105. Stichting Verzekeringskamer, Tweede tussentijdse verslag inzake Vie d"Or, Apeldoorn, 19 okt. 1994 , p. 48 .

106. Stichting Verzekeringskamer, Tweede tussentijdse verslag inzake Vie d'Or, Apeldoom, 19 okt. 1994 , p.61.

107. De woorzitter van de commissie voor de rijksuitgaven Vermeend (PvdA) meent o.tb.v. de Cw dat de AR "ten wolle bewoegd" is onderzoek ter zake te doen. Met referentie aan i.h.b. art. 59, eerste lid, sub d, Cw, acht hij het een "noodzakelijk complement" van de ministeriele verantwoordelijklheid voor rechtspersonen met publiekrechtelijke taken "dat de kamers kunnen worden ingelicht (inzake financieel beheer, doelmatigheid beheer en het functioneren van de rechtspersoon - JGLVN) door een onafhankelijk controleorgaan". Vermeend constateert dat de verzelfstandiging niets afdoet ann "de intentie van de wetgever om de AR zonder woorbehoud de bevoegdheid te geven onderzoek te doen als het gaat om uitoefening varu publiekrechtelijke taken". Zie Handelingen TK-70, 14 april 1994, p.70-5151. 
van controleactiviteiten. ${ }^{108} \mathrm{De}$ - medio 1994 bij het paarse kabinet aantredende - nieuwe minister van financiën mort minder. Ondanks de geheimhoudingsplicht van de stichting Verzekeringskamer, ziet hij - zich daarbij baserend op het advies van de landsadvocaat en het advocatenkantoor Nauta Dutilh - voldoende mogelijkheden voor de Algemene Rekenkamer om in de boeken te snuffelen van de stichting Verzekeringskamer. ${ }^{16}$ De vraag, hoe het spanningsveld tussen het recht op inzage en het beroep op geheimhouding valt op te lossen, gaat ter beantwoording naar de Europese Commissie ${ }^{10}$ en is uiteindelijk aan het oordeel van het Europese Hof van Justitie. De Europese Commissie reageert in elk geval negatief: slechts de minister van financiën en het parlement of inspecteurs daarvan hebben toegang tot onder de toezichthouder rustende informatie, de Europese richtlijnen belemmeren een volledig onafhankelijk onderzoek door de Algemene Rekenkamer in de vertrouwelijke dossiers van de stichting Verzekeringskamer. "II

Ondanks deze afwijzende uitslag zoekt de minister van financiën naar een mogelijkheid om een parlementair onderzoek naar de teloorgang van Vie d'Or te realiseren. Daarom vraagt de bewindspersoon de Europese Commissie nog om een (aanvullend) oordeel over de mogelijkheid van verstrekking van gegevens aan de minister in geval van faillissement van een onder toezicht staande instelling. "

108. Het onderzoek dient er toe de volgende wragen te beantwoorden: a. was het toezichtsbeleid van de Verzekeringskamer in overeenstemming met de ter zake geldende wettelijke regelingen: $b_{n}$ hoe werkte: dit toezichtsbeleid in het bijzonder t.a.w. de sector levensverzekeringsbedrijvem en c. hoe was de uitwoering t.a.v. Vie d'Or gedurende de periode 1985-1993. Zite Toezicht wan de Verzekeringskamer, TK 1993-1994, 23699, nr.1, p.1.

109. Toezicht van de Verzekeringskamer, TK 1993-1994, 23669, mr.2, pp.1-2. In dit stadium denkt de: minister nog niet aan wijziging van de Wiv. Daar dringt de $\mathrm{AR}$, die slechts "ongeclausuleerde toegamg" wenst, wel op aan. Zie Toezicht van de Verzekeringskamer, TK 1993-1994, nr.3, pp.2/5. De AR windt art. 16 Derde schaderichtlijn en art. 15 Derde levensrichdijn (verwerkt in art. 182 gewijzigde Wiv 1993, dat art. 84 Wtv 1993 verwangt) geen absolute belemmering voor een onderzoek. Deze geheimhoudingsbepalingen kennen all uizzonderingen. De AR meent dat het belang van een onderzoek naar dite effectiviteit van toezicht door de Verzekeringskamer "zelfs nog uitstijgt boven de belangem warwoor de richtijnen voomoemde uitzonderingen mogelijk maken'. Bij een onderzoek behandelt de $A R_{\text {, }}$ conform het uit gemeenschapsrecht voort vioeiende proportionaliteitsbeginsel, werkregen informatie vertrouwelijk; Zie ook berichtgeving Zalm: onderzoek Vie d'Or toch zinvol, in: NRC, 2 sept. 1994." p.11.

110. Zie adviesaanw raag als bijlage bij Brieven van de mimister wan financiën en van de Algemene Rekenkamer over her toezicht van de Verzekeringskamer, o.m. op de nv-levensverzekeringsmaatschappij Vie o Or. TK 1993-1994, 23669, nr.3, pp.5-8. Specifieke vragen zijn vooral: a. kan de wetgever, bij mogelijke wijziging wan de WVt, omstandigheden ( 0 , a. noodregeling of faillissement) aangeven waarbij de toezichthouder in zijn bezit zijnde informatie verplicht moet verschaffen aan een extern orgaan, of stagt dat ter beoordeling van de toezichthouder; b. zijn als "centrale overheidsclienst", als bedoald in geheimhoudingsbepalingen van de richtlijnen, de AR en thet parlement (of een inspecteur van het parlement) atan te merken; $c$. is eem bepaling in de Ww op te nemen dat de toezichthouder aan de minister van financièn informatie moet verschaffen, en kan de minister deze gegevens dan doorspelen aan de $A_{\text {, }}$ het parlement of inspecteurs daarvan; , en $\mathrm{d}$. mag de wetgever bepalen dat de AR onbeperkt toegang heeft

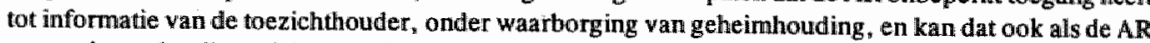
een onderzoek wil verrichten op het verzekeringstoezicht op een verzekeraar in liquidatie.

111. Daarentegen meent de Algemene Rekenkamer dat de geheimhoudingsplichtingen in de Europese richtilijnen alleen gelden woor internationale uitwisseling van gegevens tussent toezichthouders en niet voor ben onafhankelijk nationaal onderzoek naar een faillissement van een werzekeraar.

112. Zalm houdt vast aan onderzoek Vie d'Or, in: NRC, 17 okt. 1994, p.10. 
pese Commissie niet als enige weg ziet, stelt zij wetswijziging als vluchtroute voor. ${ }^{113}$ De voorzitter van de stichting Verzekeringskamer, die heil verwacht van de hoogste Europese instanties, ziet in het ene incident van Vie d'Or geen reden om de generieke wettelijke regeling van de geheimhoudingsplicht te wijzigen: "waarom zou een wettelijke toezichthouder niet op zijn woord geloofd worden?". 114

Voor de Algemene Rekenkamer is dat geloof niet sterk genoeg, zij persisteert bij haar verzoek zelf toegang tot de dossiers van de stichting Verzekeringskamer te hebben. Met het compromisvoorstel van de minister van financiën, dat de stichting Verzekeringskamer bepaalde informatie aan het ministerie geeft dat vervolgens op basis van vertrouwelijkheid de inlichtingen doorspeelt aan de toezichthouder op het assurantiebedrijf, neemt de rekenkamer geen genoegen: haar, in de Grondwet verankerde, onafhankelijke positie is in het geding. " 15

De politiek verantwoordelijke bewindspersoon wijkt echter geen stro breed. De Algemene Rekenkamer wordt gepasseerd. Eind november 1994 stuurt de minister van financiën namelijk aan op wetswijziging ter zake. Volgens deze verandering van regelgeving, die volgens de minister in overeenstemming is met de Europeesrechtelijke geheimhoudingsbepalingen, is een failliete verzekeraar als Vie d'Or verplicht aan de minister vertrouwelijke informatie te verschaffen. ${ }^{116}$ Is de minister een maal in het bezit van particuliere papieren en geheime gegevens, dan kan hij de Algemene Rekenkamer daarin inzage verschaffen. De minister en de Algemene Rekenkamer komen echter niet nader tot elkaar. Tegenover het 'ja' van de minister staat lijnrecht het 'nee' van de Algemene

113. I.th.b. VVD-woordvoender J. van Rey en D'66-woordwoerder G. Ybema, zie Parlement: desnoods wet wjzigen om Verzekeringskamer toch te onderzoeken, in: De Telegraaf, 22 okt. 1994, p. 18; De minister wan financien oordeelt dat het antwoord van de EC inderdaad nuimte laat voor aanpassing van de toezichtswetten. Toezicht wande Verzekeringskamer, TK 1994-1995, 23669, nr.4, p. 1. De wetswijziging. betreft dan wel enkel het aan de minister wan financiën verstrekken wan de toezichthouder van informatie over een onder toezicht staande instelling in geval van failissement. De werschillende fnanciele toezich houders hebben in principe wel begrip voorzo."n wetswijzing, mat hebben communaw tairrechtelijke bezwaren omdat een te grote afwijking met de richtlijnen zou onstaan. Ook de AR kan zich er niet in winden. De AR wenst een wijziging van de CW, in de zin dat ongeclausuleerde toegang tot alle individuele toezichtsdossiers mogelijk wordt. Hoewel de verschillende toezich thouders de volgende, nuimere wetswijziging kunnen aanvaarden, blijft ook hier de $A R$ weigerachtig. De minister van financien owerweegt namelijk een wetswijziging "waarbij de toezichthouders op verzok van de minister van funamciën, met het oog op de vorming wan zijn oordeel over de toereikendheid van de toezich twetgewing en van de uttoefening wan toezicht, hem bepaalde gegevens of inlichtingen te verstrekken die zij hebben verkregen bij de vervulling van hun toezichtstaak. De minister zou de overgelegde gegewens zelf kumnen onderzoeken of daarvoom een derde inschakelen die in zijn opdracht en onder zijn verantwoordelijkheid werkkt. Zowel de minister als de derde zouden gebonden zijn aan de geheimhoudingsplicht, wat echter nilet in de weg behoeft te staan aan het openbaar maken van conclusies in algemene zin." Toezicht wan de Verzekeringskamer, TK 1994-1995, nr.5, 23669, nr.5, p.2.

114. Aldus A.J. Vermaat tijdens de presentatie van bet tweede tussentijdse verslag over de ondergang van de Veldhovense levenswerzekeraar Vie d'Or, gecitee rd in: Toezichthouder: ruimere controle van verzekeraars, in: NRC, 22 okt. 1994, p.17.

115. AR-brief aan minister van financièn (4 nov. 1994). Rekenkamer, Zalm ruziën over Vie d'Or, in: NRC. 4 now. 1994, p. 14.

116. Zalm wil de wet wijzigen woor affaire Vie d'Or, in: NRC, 29 now. 1994, p. 19. 
Rekenkamer. Daarom verzoekt de betrokken bewindspersoon de Raad van State om het onderlinge meningsverschil te beslechten. "17

Dat de zaak Vie d'Or, ook in het parlement, geen sinecure is en hoog wordt opgenomen, blijkt op de valreep van 1994. Met een meerderheid van stemmen spreekt de Tweede Kamer zich in principe uit voor een parlementaire enquête naar het faillissement van de levensverzekeringsmaatschappij. ${ }^{118}$ Of in praktijk ook een parlementaire enquëte plaats vindt, bekijkt een daartoe ingestelde commissie van leden van de Tweede Kamer. Deze commissie rapporteert ter zake eind januari 1995.

Ver uit meest fervent voorstander van een parlementaire enquête benadrukt het belang er van als volgt: "Een onafhankelijke instantie moet haar oordeel daarover (d.w.z. over het mogelijk tekort schieten van de stichting Verzekeringskamer inzake Vie d'Or - JGLwN) uitspreken, wanneer dit wordt gefrustreerd door de Rekenkamer dan moeten we zelf het onderzoek maar gaan uitwoeren.[...] Want in de zaak Vie d"Or moet de onderste steen boven. [...] Waar rook is, is vuur. Het begrip 'geheimhouding" moet. mismanagement verhullen. Tweede Kamerleden hebben een controlerende taak, en die laten we ons niet door een juridisch steekspel ontnemen. " 119

Begin februari geeft voornoemde kamercommissie er inderdaad blijk van een parlementaire enquête naar het faillissement van Vie d'Or in het uiterste geval nodig te vinden. ${ }^{120}$ De enquête krijgt een jnventariserend karakter. Zij is voorlopig vooral gericht op feitenonderzoek. Vraag is hoe de informatie boven tafel te krijgen, indien de stichting Verzekeringskamer besluit zich te beroepen op het verschoningsrecht ex art. 19 Wet op de parlementaire enquête. De voorzitter van de stichting Verzekeringskamer belooft in elk geval al "de lippen stijf op elkaar te houden". 21

117. De minister dient daartioe 17 januari 1995 een adviesaanvraag in. Toezicht wan de Verzekeringskamer " TK 1994-1995, 23669, nr.5, p.2, ook TK 1994-1995, nr.8, p.15.

118. Tweede Kanner voelt woor enquête over Vie d'Or, in: NRC, 21 dec. 1994. pp. 1/15. Positief over een enquête zijn de regeringsfracties VVD, D'66, CDA en GroenLinks. PviA toont zich geen yoorstander en meent dat er, i.p.Y. een zwaar middel als parlementaire enquête, zo snel mogelijk een onafhankelijk onderzoek moet komen; De Algemene Rekenkamer wijst er op dlat een parlementaigen enquetecommissue "zonder neer bevoegd is het onderzoek uit te voeren" en verklaart zich bereid medewerkers woor zo"n commissie ter beschikking te stellen, Toezich van de Verzekeringskamer, TK 1994-1995, 23669, nu.6. p.2.

119. Aldus Tweede Kamerlid J. van Rey (VVD), geciteerd door C. Banning, Parlementaire enquête bepleä maar rol Verzekeringskamer bij Vie d'Or, in: $\mathrm{NRC}, 23 \mathrm{dec} .1994, \mathrm{p} .11$.

120. Parlementair onderzoek naar Ve d'Or; Pleldooi werkgroep Kamer, in: NRC, 7 febr. 1995, p.1.

121. A.I. Vermat, gecited in Parlementair onderzoek naar Vue d"Or, in: NRC, 7 febr. 1995, p.1; Dir is tot groot ongenoegen van minister wan financièn Zalm, die vindt dat de onafhankelijkheid van de sticluting Verzekeringskamer niet zo ver gaat dat haar geheimhoudingsplicht altijd op kan. gaan. Weluswar respecteert Zalm voorlopig de geheimhouding wan de stichting Verzekeringskamer. Maar hij stelt well dat hij daardoor zijn eigen controlefunctie niet naar behoren kan witoefienen. Zalm vindt, anders dan zijn woorganger Kok, zijn wettelijke bevoegdheden t. a.Y. de stichting Verzekeringskamer "niter voldoende om reèel inhoud te kumen geven aan de ministeriële verantwoordelijkheid woor een adfequate uitoefening vam het toezicht", als geciteend door C. Banning, De 'Bende van Vie d'Or" will onderste steent boven, in: NRC, 8 febr. 1995, p.7, die het onderzoek naar de teloorgang van Vie d'Or prachtig typeen als "de processie van Echternach". 
Gestart wordt met een parlementair onderzoek geleid door de zgn. Bende van Vie $\mathrm{d}^{\mathrm{O}} \mathrm{Or}{ }^{1.22}$, dat uit moet monden in hetzij een parlementaire enquête hetzij een onderzoek door de Algemene Rekenkamer. ${ }^{123}$ De keuze hangt af van het advies van de Raad van State.

Het belangrijkste adviescollege van de regering beweert, refererend aan de Grondwet, dat de Algemene Rekenkamer geen taak en bevoegdheid heeft ten aanzien van de private sector, zo lang die geen financiële relatie (als subsidie, deelneming of heffing) met het rijk heeft. Weliswaar acht de Raad van State een onderzoek van de Algemene Rekenkamer mogelijk, maar dat wordt dan door de nationale en Europese geheimhoudingsbepalingen in die mate begrensd "dat zij geen toegang heeft tot de individuele toezichtsdossiers bil de Verzekeringskamer". ${ }^{124}$ Dit advies van de Raad van State vergroot de kans op een parlementaire enquête ter zake.

Vermelde kamercommissie vindt echter een parlementaire enquête nu niet nodig. ${ }^{\text {LSs }}$ Zij verricht voorlopig bij voorkeur zelf onderzoek, maar sluit niet uit dat bij tegenvallend onderzoeksresultaat als nog een parlementaire enquête wordt gehouden. ${ }^{126}$

De stichting Verzekeringskamer zelf, overigens, vindt het toezicht op verzekeraars effectief. Wel gaat zij de controle (jaarlijks achteraf plus eenmaal per vijf, of acht, jaar onderzoek ter plekke) vergroten. En voortaan wil de stichting Verzekeringskamer, met het oog op de ontwikkelingen in de Europese Gemeenschap, "eens per twee jaar periodiek overleg voeren met de verzekeraars, waarbij ook de accountant ${ }^{12 \pi}$, de actuaris en de externe adviseurs worden betrokken". ${ }^{128}$

Weliswaar onder eerlijke erkenning van de schok die de affaire-Vie d'Or in de assurantiewereld te weeg brengt, meent de stichting Verzekeringskamer toch haar toezichtsstelsel

122. D.w.z. de kamercommissievertegenwoordigers: voorzitter G. Ybema (D'66), H. Hoogervorst die J. van Rey vervangt wegens mogelijke belangenverstrengel mg van laatst genoemde (VVD), R. Smits (CDA), T. Witteveen (PvdA) en M. Rabae (Groen Limks).

123. De ex art. 18 RvO TK ingestelde tijdelijke commissie doet de voorbereiding en richt harar onderzoek zo in dat owerdracht van geanalyseerde informatie op een later moment aan de AR of cen parlementaire enquêtecommissie wordit vereenvoudigd. Zie Toezicht wan de Verzekeringskamer. TK 1994-1995, 23669 , nr. 7, pp. 1/12, met overwegingen wan de werkgroep, die kiest voor een tijidelijke commissie, m.b.t. de mogelijke vormen wan onderzoek welke de werkgroep toetst aan de uilgangspunten vam; onaflhankelijkheid. snelle start en korte onderzoeksduur.

124. Raad wan State kiest partij bij Vie d'Or, in: Het Financieele dagblad, 4/6 maart 1995, p.3. De Raad van State ziet trouwens ook niets in beoogde wetswijziging. Daarmee komt volgens de raad de scheiding publieke en priwate sector in het gedrang; Zie ook Dossiers Vie d'or blijen nog gesloten, in: NRC, 4 matart 1995, p.15.

125. Toezicht Vie d'Or. TK 1994-1995, 23699, nr.9. Zie ook Geen enquête naar Vie d"Or, in: NRC, 23 maart 1995, p. 19.

126. Terecht vindt J. Kroon, Verzekeringskamer: papieren tijger?, in: NRC, 24 naart 1995, p.15, het stand punt van de commissie " op zijn minst verbazingweikkend" . De commissie doet immers haar belofte dat zij, na adwies van de Raad van State, zal kiezen yoor hetzij een onderzoek door de Algemene Rekenkamer hetzij een parlementaire enquete niet gestand.

127. Beoogd wordt om accountants, die jaarrekeningen controleren, een meld ingsplicht t.a. w. de Verzekeringskamer op te leggen (zie woorstel Publ. EG C 229, 25 aug. 1993). Stichting Verzekeringskamer, Jaarverslag 1993, Apeldoorn, 1994, p.54.

128. P.J.C. Keizer "geciteerd in Controle op verzkeraars verscherpt, in: NRC, 17 dec. 1993, p.16. 
te mogen verdedigen. Hierbij brengt zij in stelling, dat het bestaande normatief/repressieve toezicht grote voordelen biedt en dat geen enkel systeem van bedrijfseconomisch toezicht een absolute garantie kan geven tegen déconfitures. Vandaar blijft het voor haar zaak "te blijven zoeken naar aanvullingen op en verfijningen van het toezichtsinstrumentarium binnen het bestaande normatieve toezichtstelse] ". 129

Hoewel de stichting Verzekeringskamer toch zo veel mogelijk probeert haar schuld aan de ondergang van Vie d"Or uit de weg te gaan, geeft zij uiteindelijk aan dat haar positie als toezichthouder tijdens de afffaire Vie d'Or als relatief zwak kan worden bestempeld. Om haar positie te verstevigen, hecht zij aan snelle invoering van sterkte/zwakte-analyses, management-audits, frequenter overleg, profit-tests voor nieuwe produkten en protocollen met accountants en actuarissen. Naast dergelijke versterking en uitbreiding van haar toezichtsinstrumentarium, wil de stichting Verzekeringskamer wettelijke mogelijkheden om hogere solvabiliteitseisen op te leggen en meer eisen te stellen bij het geven van een vergunning voor uitoefening van het verzekeringsbedrijf. Bovendien wenst de stichting Verzekeringskamer in de toekomst het recht te krijgen om informatie te vragen bij bestuurders, commissarissen, accountants en actuarissen. ${ }^{130}$

Hier is het zinvol en verhelderend om het toekomstig toezicht op het verzekeringsbedrijt, als de stichting. Verzekeringskamer wenst en zelf schetst in een terugblik op en evaluatie van het haar toezicht op Vie d'Or, min of meer volledig aan te halen.

Hoewel de stichting Verzekeringskamer maar moeilijk haar ongelijk inzake Vie d'Or kan bekennen, ziet zij wel redenen om voortaan tijdiger problemen te onderkennen en kritischer toezicht uit te oefenen. Wat betreft haar optreden bij Vie d'Or wordt zij geconfronteerd met de volgende barrières.

De jonge onderneming Vie d'Or wil snel marktaandeel verwerven. De met dat doel aangestelde tussenpersonen krijgen ongekend hoge provisies uitgekeerd. Het beleggingsbeleid van Vie 'Or is eenzijdig van aard. De financiële herverzekeringscontracten en overige grote beleggingscontracten met o.a. Merrill Lynch en Schiphol kenmerken zich door gevaarlijke eenzijdigheid en bedreigen de continuiteit van Vie d'Or. Financi ële tekorten worden voortdurend opgevuld door extra incidentele vermogensinjecties van aandeellhouders. Het ene gat wordt, als het ware, met het andere gedicht. De jonge organisatie Vie d'Or kampt met vertragingsproblemen aangaande post, administratie en voorlichting naar polishouders. Bovendien dient zij de jaarlijkse verslagstaten te laat in bij de stichting Verzekeringskamer.

Met betrekking tot deze punten maant de stichting Verzekeringskamer, binnen har beperking van normatief toezicht achteraf waarbij onder stille diplomatie zo veel mogelijk het vermijden van elke (per definitie schadelijke en vertrouwenbreuk met de consument opleverende) publiciteit centraal staat, de jong-dynamische verzekeraar tot problemoplossing aan. Op grond van de door haar - in blindelings vertrouwen - betrouwbar geachte beloften van verbetering door financieel deskundigen, directie en bestuurders van Vie d'Or, van wie de stichting Verzekeringskamer echter soms nog niet eens halve 
informatie krïjgt, meent de toezichthouder dat geen gevaar bestaat voor discontinuïteit wan de verzekeraar. Helaas blijkt dat een vergissing.

Achteraf concludeert de stichting Verzekeringskamer dat haar toezichtsbevoegdheden niet toereikend zijn. Haar belangrijkste opmerkingen daarover luiden letterlijk:

"De controlerend accountant dient in het verwolg directer te worden ingeschakeld om zowel gevraagd als ongevraagd de Verzekeringskamer in te lichten over de werking van de administratieve organisatie als zo danig. Hij zou daarbij moeten aangeven waar de zwakke punten liggen en welke initiatieven hij heeft ondernomen om eventuele lacunes met eigen actie te dichten. Daarbij moet het eerder verwoorde economisch principe en - nog meer - de relevantie voor de solvabilliteit in aanmerking te worden genomen. Daartoe is wel een wetswijziging nodig om de accountant te werplichten rechtstreeks en ongevraagd de Verzekeringskamer in te lichten. [....]

Wat betreft het niet tijdig indienen van de verslagstaten kan de conclusie worden getrokken dat het de Verzekeringskamer ontbreekt aan sanctiemiddelen die in overeenstemming zijn met de ernst van de geconstateerde gebreken. [...]

De vraag die kan worden gesteld is of de Verzekeringskamer tevoren inzage moet krijgen of goedkeuring moet geven aan het afsluiten van omvangrijke contracten. Dit is naar de geest strijdig met het repressieve toezichtssysteem. [...]

Het achteraf voorzien in extra vermogen heeft als risico dat de aanwezige solvabiliteitsmarge steeds afhankelijk wordt gesteld van de bereidheid van aandeelhouders om bij te storten. Het biedt de ondermeming meer ruimte als het aanwezige eigen vermogen voor langere tijd de vereiste marge overschrijdt om niet telkens te worden geconfronteerd met tekorten. Het zal duidelijk zijn dat dit éen van de speerpunten is in het toezichtsbeleid van de Verzekeringskamer en dat zij dergelijke verzekeraars daar herhaaldelijk op wijst. Een wettelijk recht om een surplus op de vereiste marge te eisen, waarin groeiverwachtingen tot uitdrukking worden gebracht, heeft de toezichthouder echter niet. [...]

De vraag kan worden gesteld waarom de Verzekeringskamer niet zelf, in een eerder stadium, de verkoop van de verzekeringsportefeuille (van Vie d'Or - JGLvN) aan een mogelijk geïnteresseerde partij in handen heeft genomen. Aan dit scenario is inherent dat de Verzekeringskamer dan ook de verkoopprijs zou kunnen bepallen. Het is aannemellijk dat de door de Verzekeringskamer dan vast te stellen verkoopprijs (aanzienlijk) lager is dan waarvoor aandeelhouders hun bezit zouden willen, en denken te kunnen, verkopen. De Verzekeringskamer heeft, buiten de noodregeling, niet de bevoegdheid bedoeld scenario in gang te zetten zonder daarover overeenstemming met aandeelhouders te hebben. Bedacht moet opnieuw worden dat een (vroegtijdige) bemoeienis wan de Verzekeringskamer met de verkoop tot een verder dalend vertrouwen in de maatschappij leidt, hetgeen de waarde van Vie d'Or drastisch zal doen dalen. Het bedoeld scenario is wel aan de orde geweest in gesprekken met aandeelhouders, maar zelfs een begin van overeenstemming werd niet bereikt. [...]

Het is ongetwijfeld zo dat de kwaliteit van het beleid heeft geleden onder de vele wisselingen in de directie van de onderneming. Bovendien kan achteraf worden geconstateerd dat er van uit de raad van commissarissen als geheel te weinig kritische sturing werd gegeven aan de directie. Deze ervaringen leren dat de huidige vorm van toetsing op 
deskundigheid en betrouwbaarheid van beleidsbepalers en commissarissen te licht is en moet worden verzwaand. [...]

De Verzekeringskamer heeft geen mogelijkheid tot vooraf ingrijpen bij het voortijdig: naar buiten brengen van voor continuiteit bedreigende informatie." "131

De stichting Verzekeringskamer wenst voortaan de obstakels, die zij bij het toezicht op Vie d'Or onder vindt, uit de weg te ruimen.

Daartoe beveelt zij de volgende beleidsvoornemens ten behoeve van de uitvoering varn het toezicht aan:

"Bij startende en in sommige gevallen bij reeds lopende maatschappijen zullen in meerdere mate sterkte/zwakte-analyses moeten worden uitgevoerd, zo nodig door derden;

Voor zover er twijfel bestaat aan de bekwaamheden van het bestuur zal er een management-audit moeten worden geïnitieerd, voor zover dit niet onder het eerste punt is begrepen. Vervolgens zal er een meer adequaat toetsingskader moeten worden ontwikkeld en, waar nodig, moeten worden verfijind voor de toetsing van aantredende bestuurders. Speciale aandacht zal uitgaan naar de potentiële gevaren van belangenverstrengelling. De combinatie in één persoon van grootaandeelhouder met stemrecht en de feitelijke zeggenschap in de verzekeringsonderneming acht de Verzekeringskamer niet gewenst. Ten slotte zal de toetsing tijdens het funktioneren wan daarvoor in aanmerking komende bestuurders moeten worden geïntensiveerd;

Gedurende de eerste jaren van het bestaan van een maatschappij zal frequent overleg met het bestuur onder meer op basis van prognoses en de realisatie daarvan moeten plaats vinden. De frequentie van de rapportage aan de Verzekeringskamer zal in de eerste jaren van het bestaan van de onderneming moeten worden opgevoerd tot meerdere malen per jalar;

Voor nieuwe produkten zal een verplichte profit-test gaan gelden. [...];

Met de accountant en actuaris zullen afspraken moeten worden gemaakt, neergelegd in een protocol. Onderdeel van deze afspraak met de accountant zal moeten zijn dat deze zijn oordeel moet geven over de adequaatheid van de administratieve organisatie met inbegrip van het geautomatiseerde systeem. Ten behoeve daarvan zullen miminumeisen aangaande de administratieve organisatic moeten worden geformuleerd. Vervolgens zullen speciale aandachtsgebieden moeten worden aangegeven waarin de accountant in een bepaald jaar meer gedetailleerde controles moet uitvoeren;

Verzekeraars zullen desgevraagd rapportages van de accountant en actuaris aan bet bestuur en raad van commissarissen onmiddellijk aan de Verzekeringskamer moeten verstrekken." 132

Bovendien raadt de stichting Verzekeringskamer de volgende uitbreiding of verandering van wetgeving inzake toezicht op het verzekeringsbedrijf aan:

"Er dient wettelijk de mogelijkheid te worden geschapen dat de Verzekeringskamer - tijdelijk - een hogere solvabiliteitseis oplegt aan ondememingen waarvoor zij dit nood-

131. Stichting Verzekeringskamer, Tweede tussentijdse verslag inzake Vie d'Or, Apeldoorn, 19 okt. 1994 , pp. 54-62.

132. Stichting Verzekeringskamer, Tweede fussentijdse verslag inzake Vie d'Or, Apeldoorn, 19 okt. 1994 , p.65. 
zakelijk acht. Nog sterkere voorkeur verdient het een nieuwe formule te ontwerpen voor de omvang van de wettelijk vereiste solvabiliteitsmarge van een verzekeraar. Hierin zouden bijzondere factoren mede tot uitdrukking kunnen worden gebracht, als bij voorbeeld de leeftijd van de ondememing, de schaalgrootte, de aard van het verzekerings-en de beleggingsportefeuille en dergelijke;

De in het wettelijk voorgeschreven programma van werkzaamheden te verstrekken kwantitatieve gegevens bij het aanvragen van een vergunning zullen moeten worden uitgebreid. De uitbreiding zal ten minste moeten inhouden het overleggen van een uitvoerig bedrijfsplan en de opzet van de administratieve organisatie. Als vervolg daarop zullen periodiek - ten minste een maal per jaar - gegevens over de realisatie van de plannen moeten worden overlegd aan de Verzekeringskamer. Overigens zij opgemerkt dat ten tijde van de toelating van Vie d'Or de overlegging van een programma van werkzaamheden geen wettelijke eis was;

Het sluiten van contracten die van grote invloed zijn op de toekomstige verplichtingen van de onderneming moeten vooraf aan de Verzekeringskamer worden overlegd, wanneer een bepaalde verzekeraar hiertoe door de Verzekeringskamer is aangewezen. Dat will zeggen dat op dit punt een materieel toezichtselement moet worden geïntroduceerd in de toezichtswetgeving;

$\mathrm{Bij}$ het te laat indienen van verslagstaten moet door de Verzekeringskamer een geldelijke boete kunnen worden opgelegd. Ook in andere situaties waarbij overschrijding van de afgesproken termijn plaats vindt moeten boeten kunnen worden opgelegd;

Het informatierecht dat de Verzekeringskamer al heeft, moet worden uitgebreid met een informatieplicht voor een ieder die in verband met de uitoefening van toezicht door de Verzekeringskamer over relevante informatie beschikt. Te denken valt aan bestuurders, commissarissen, accountants en actuarissen. De zo genaamde 'BCCI-richtlijn' 133 legt

133. Het debatcle met de Bank for Credit and Commerce International geeft aanleiding tot het opstellen van een richtlijn op grond waarwan toezichthoudende autoriteiten sneller informatie inzake fraude en andere onregelmatigheden kumnen krijgen. Vandaar het, woorstel voor een, de bank-, verzekerings-en effectensector owerkoepellende, richtlijin ter zake ter versterking van het bedrijfseconomisch toezicht, die bestaande richtlijnen in genoemde sectoren ten dele wijzigt, Publ. EG, C 229 . 25 aug. 1993. In gevolge art. 5 wan het voorstel voor de richtlijn worden externe accountants werplicht aan autoriteiten belast met toezicht mededeling te doen van vastgesteilde onregelmatigheden waarvan zij tijdens hun werkzammeden keminis hebben gekregen (dit is dus anders dan het vermódem van witwassen van geld op grond warvan banken informatie moeten doorspelen volgens de Wmot en de Wifd). Deze meldingsplicht kan, naast de onderneming waarvan de jaarrekening wordt gecontroleerd, ook betrekking hebben op een andere. ve rbonden onderneming. Voordat accountants meld ing doen, kumen zij thun bevindingen nog verifieren. Owerigens bevat de richt ijn nasist de meldingsplicht: verscherpte woorwaarden woor vergunningwerlening (de structur van een financiele groep moet voldoende transparant zijn); de bepaling dat hoofdkantoor van kredietinstellingen en verzekeringsbedrijven in de lidstaat stat waar de statutaire zetel zich bevind en in welke staat een vergunning is aangewraagd; en uitbreiding van de lijst van instanties waaraan bevoegde wezichthoudende auto riteiten vertrouwelijk informatie mogen verstrekken. Zie beknopt D. II Drijber. Toezicht op financiële instellingen: de 'anti BCCl-richrlijn" "in: TVVS, nr.2, 1995, pp.42-44. 
een dergelijke plicht in bepaalde omstandigheden alleen op aan de controllerend accoun$\operatorname{tant}^{134}$;

De raad van commissarissen zal een grotere rol moeten gaan spelen in de informatievoorziening ten behoeve van de toezichthouder. Zonder een uitspraak te doen over de meest: gewenste vorm, kan worden gedacht aan de volgende alternatieven: a. het verplicht - gevraagd dan wel ongevraagd - melding doen door de raad of haar voorzitter van belangrijke beleidsvoornemens van de onderneming; b. het in bijzondere gevallen aanwijzen van een 'wertrouwenscommissaris' met als speciale taak de bescherming van de belangen van de polishouders; het bij elke beginnende verzekeraar voor een bepaalde -nog vast te stellen- periode verplicht benoemen van een commissaris op voordracht van de Verzekeringskamer. In het geval van een onderneming met de rechtsvorm van een onderlinge waarborgmaatschappij zal een dergelijke taak respectievelijk benoeming moeten toevallen aan de raad van toezicht. In hoe verre in alle gevallen deze aanbeveling moet worden ondersteund door wetswijziging zal nader moeten worden onderzocht;

De Verzekeringskamer moet de wettelijke mogelijkheid krijgen tot inzage in de dossiers van de accountant en actuaris die betrekking hebben op de onder toezicht staande instelling;

Er moet worden onderzocht of en zo ja, hoe de Verzekeringskamer met een snelle toetsing vooraf door de rechter de bevoegdheid zou kunnen worden verleend om, buiten de noodregeling om, een maatschappij te dwingen de verzekeringsportefeuille over te dragen zonder korting van de rechten van de polishouders. Tevens zou in dit verband ook moeten worden nagegaan of de Verzekeringskamer zelf gerechtigd moet worden een portefeuille te onteigenen en over te dragen;

Er moet een wettelijke bepaling worden geïntroduceerd die het mogelijk maakt om in het geval van een gedwongen portefeuille-overdracht, waarbij de rechten van polishouders worden gekort, een bestaand fiscaal compensabel verlies voor de vennootschapsbelasting ten dele ten goede te laten komen aan benadeelde polishouders." 135

Ten slotte, vraag blijft of de stichting Verzekeringskamer, die uit haar verouderde "roll van de sherif met de roestige revolvers" is "wakker geschrokken", wel genoeg doet door haar toezichtsactiviteiten op te voeren. Niet ten onrechte luidt het advies, met oog op de dynamiek van de grensvervagende financiële sector , de communicatie tussen toezichthouder en onder toezicht gestelden te herstellen. Met andere woorden, de toezichthouder moet, "naast zelf te pleiten voor een modern en gecoördineerd toezicht", ook eens gaan "werken aan een hernieuwde gedragscode om het consumentenvertrouwen te herwin. nen". ${ }^{136}$ Met bovenstaande beleidsvoornemens van de stichting Verzekeringskamer probeert de toezichthouder natuurlijk wel het publiek voor de toekomst gerust te stellen.

134. Accountamt H.J. Neeleman van Moret Ermst \& Young stelt dat deze eis "geheel voorbij aan de geheimhoudingsplicht wan de accountant" gaat. Bij wijze van altematief refereert Neeleman aan gedragscodes ter zake die accountants met De Nederlandsche Bank nv aangaan. H.J. van Oostrum, Top-accountomi hekelt beleid Verzekeringskamer, in: NRC, 25 nov. 1994, p. 16.

135. Stichting Verzekeringskamer, Tweede tussentijdse verslag inzake Vie d"Or, Apeldoom, 19 okt. 1994, $\mathrm{pp}_{i}$ 65-67.

136. M. Schinkel, Roestige revalvers, in: NRC, 16 juli $1994, p_{.} 10$. 
Vraag blijft of dit voldoende is voor het geschaad vertrouwen, dat consumenten, met keuzemogelijkheden in een concurrentiekrachtige markt, uiteindelijk wel eens te grof geschaad kunnen vinden.

\section{$\$ 18.7$ Rechtsbescherming en klachtbehandeling}

Is een verzekeraar het niet eens met een besluit van de stichting Verzekeringskamer, dan rest hem als belanghebbende het instellen van beroep bij het College van Beroep voor het Bedrijfsleven. ${ }^{137}$ Dit volgt uit art. 186 Wtv. In geval yan vergunningintrekking moet het beroep, in afwijking van art. 6:7 Awb, binnen acht dagen na bekendmaking van het besluit worden ingesteld. Art. 7:1 Awb vindt ook geen toepassing.

Juist wat betreft haar toezichtstaken is de stichting Verzekeringskamer, even als De Nederlandsche Bank nv en de Stichting Toezicht Effectenverkeer, uitgezonderd van de toepasselijkheid van de Wob en de Wno. ${ }^{138}$ Reden van deze exoneratie is de, door geheimhoudingsplichten gewaarborgde, bijzondere vertrouwenspositie waarin een financieel toezichthouder verkeert.

\section{$\$ 18.8$ Kostenverhaal en (financiële) verslaglegging}

Art. 8 Wtv verplicht de stichting Verzekeringskamer tot jaarlijkse verslaglegging ${ }^{139}$ van haar werkzaamheden, behoudens een aantal expliciet genoemde vertrouwelijke gegevens, aan de minister van financiën. Dit verslag moet openbaar worden gemaakt. Sinds de verzelfstandiging van de Verzekeringskamer geschiedt de financiële verantwoording niet meer volgens de Comptabiliteitswet, maar via de toepasselijke bepalingen van titel 9, boek 2 BW ${ }^{140}$.

De stichting Verzekeringskamer legt ook een lijst van vergunninghoudende verzekeraars ter inzage in gevolge art. 9 Wtv.

De verzekeraars dragen zelf de kosten, verbonden aan de uitvoering van de Wtv, in gevolge art. 184 Wtv. Op grond van een aanslag op kostenbegroting betalen de onder toezicht gestelden vooraf. ${ }^{141}$ De verzelfstandiging van de Verzekeringskamer brengt

137. In gevolge andere wetten, die naast de Wrw voor het toezicht van de stichting Verzekeringskamer relevant zijn, bieden ook de Afdeling bestuursrechtspraak van de Raad wan State en de mimister van sociale zaken (juridische) protectie ter zake.

138. Aanwijzingsbesiluit bestuarsorganen Wob en Who d.d. 16 okt. 1993. Stbl. 1993, 535, pp.4/14-15.

139. Volgens H. Gerritsen, Overpeinzinges bij de taak en de verslagen wan de Verzekeringskamer, in: VA, dl.63, LXII, 1986 , pp. 113-133, i.h.b. p.129, is verslaglegging in vakterminologisch opzicht beperk t toegankelljk. Bovendien vindt hij vermelding van gegevens inzake de positie van de afzonderlijke verzelkeraars (a.a. solwabiliteitsmarges) zinvol.

140. I.h.b. afdeling 15 (artt. 427-446) ingevoerd bij wet van 16 sept. 1993, Stbl. 1993, 515, ter uitvoering van EEG-richtijnen.

141. Besluit houdende wiziging financiering Verzekeringskamer door beroepspensioen-, bedrüfspensioen-, ondertemingspexsioen-en beroepspensioenfondsen, 30 aug. 1993, SZ/SW/O/93/3707, Stcrt. 1993, 165. 
geen structurele financiële of budgettaire consequienties voor de rijksoverheid met zich mee. ${ }^{142}$

De lasten voor de onder toezicht gestelden, voort vloeiend uit informatie-uitwisseling binnen of buiten Nederland, zijn niet onevenredig zwaar. Komen hoge kosten voor in bet kader van een niet regulier of niet routinematig specifiek onderzoek om bepaalde informatie op tafel te krijgen, dan dragen mogelijk betrokkenen de kosten. Dit is meestal voorzien bij afzonderlijke regeling of 'memorandum of understanding'. ${ }^{143}$

\section{$\$ 18.9$ Beperking van de vrijheid van uitoefening van het verzekeringsbedrijf in het licht van harmonisatie van nationale regelgeving ter zake}

De huidige nationale regelgeving, als omschreven, is sterk verweven met Europese coördinatierich"lijnen. De EG-richtlijnen scheppen de voorwaarden voor een interne markt voor verzekeraars met een zetel in Europa.

Ten eerste schept het gemeenschapsrecht de mogelijkheid om op basis van één vergunning overal in de EG het verzekeringsbedrijf uit te oefenen. Deze zgn. "single licence" wordt verstrekt door de toezichthouder waar de (statutaire) zetel van de betreffende verzekeraar zich bevindt. $\mathrm{Om}$ in aanmerking te komen voor vergunningverlening moeten verzekeraars aan bepaalde voorwaarden, die voor Nederland worden gesteld in respectievelijk artt. 25-36 Wtv (voor verzekeraars met zetel in Nederland), artt. 37-38 Wtv (voor verzekeraars met zetel in buitenland die, op grond van hun vergunning daar, een bijkantoor in Nederland willen vestigen) en artt. 39-49 Wtv (voor verzekeraars met zetell buiten de Europese Gemeenschap, die mogelijk vergunningsvoorwaarden kunnen verzachten, waarna de Verzekeringskamer ex art. $49 \mathrm{Wtv}$ een - al dan niet voorwaardelijke of beperkte - verklaring afgeeft en zo nodig weer intrekt), voldoen. Denk aan betrouwbaarheid en deskundigheid, in relatieve/subjectieve zin ${ }^{144}$, van bestuurders van betrokken assurantiebedrijf/branche dan well de bestuurders binnen financiële conglomeraten die (mede)beleidsbepalers zijn voor de betrokken bank of verzekeraar ${ }^{145}$, een minimumbedrag van het zgn. garantiefonds voor levensverzekeringen dan wel een solvabiliteitsmarge voor reeds uitgeoefende branches indien deze hoger is dan bedoeld minimumbedrag (respectievelijk artt. 67-68 Wtv voor verzekeraars met zetel in Nederland en art. $94 \mathrm{Wt}$ voor verzekeraars met zetel buiten Nederland), financiële middelen tot dekking van de te verwachten kosten voor de inrichting van de administratie en van het produktienet.

142. Verzelfstandiging Verzekeringskamer, TK 1988-1989,21235, nr.1, p.2; Decemberverslag 1993 van de Algenene Rekenkamer. TK 1993-1994, 23555, nrs.1-2, p.28.

143. Mvt wetsvoarstel inzake informatie-uitwisseling. TK 1992-1993, 23170, nr.3, p.14.

144. Mvt wijziging Wrv 1993. TK 1993-1994, 23544, nr.3, p.7.

145. De bepaling voor conglomeraten is, als aanvulling van art. 29 W $\mathrm{W}$, geïntroduceerd bij TK 1993.1994, $23544, \mathrm{mr}_{2}, \mathrm{p} .13$. 
De controle op de toelatingseisen betreft, formeel beschouwd, in principe repressief ${ }^{146}$, normatief, prospectief ${ }^{147}$ toezicht. ${ }^{148}$ Normatief toezicht "beperkt zich in beginsel tot een controle op de nalleving van wettelijke normen die uitgaan van de principes van vrijheid van bedrijfsvoering en van openbaarheid van gegevens. Op die wijze komt tot nitdrukking dat de verantwoordelijkheid voor de bedrijfsvoering primair bij de verzekeringsondernemingen zelf ligt. De toezichthouder heeft daarbij hoofdzakelijk een controlerende en soms een corrigerende taak. [...] In een normatief toezichtsstelsel, waarbij de toezichthouder in beginsel een terughoudende positie hoort in te nemen, wordt het vertrouwen in de financiële kracht van het verzekeringsbedrijf in sterke mate bepaald door de kwaliteit en betrouwbaarheid van de bestuurders van verzekeraars. "149

Normatief toezicht biedt de volgende voordelen boven materieel toezicht: a. zij leidt tot een efficiëntere allocatie van middelen, verzekeraars kunnen verantwoordelijkheid niet meer altijd afschuiven op de toezichthouder; en b. in Europees opzicht is harmonisatie van toezicht mogelijk omdat een normatief toezichtsregime tot aanzienlijk minder regelgeving noopt. ${ }^{150}$ Een systeem van normatief toezicht is, gegeven het liberaliseren van de Europese verzekeringsmarkt, niet per se wrij van materiële elementen. Bij verzelfstandiging van de Verzekeringskamer is de opvatting, dat het omslagpunt van normatief naar materieel toezicht hierin ligt dat "a. de verzekeraar voor het uitvoeren van zijn bedrijfsbeleid op onderdelen vooraf toestemming nodig heeft, dan well b. op essentiële onderdelen van dit bedrijfsbeleid zodanig aan voorschriften is gebonden, dat hij geen vrije keuze meer kan maken". "15i Een reden voor verzelfstandiging, tevens belangrijk argument voor de keuze voor de stichtingsvorm aan welke rechtsvorm het voordeel van een grote beheersvrijheid kleeft, is dat de Verzekeringskamer "in sterke mate zal worden betrokken bij de analyse, de advisering, respectievelijk de uitvoering van toezichtselementen, welke een beleidsintensiever gehalte zullen vertonen". ${ }^{152}$ Beter dan ingebed in een ambtelijke structuur, kan een Verzekeringskamer in verzelfstandigde, private vorm inspelen op de aan de Europese eenwording inherente elementen van materieel toezicht. ${ }^{15.3}$

In het huidige normatieve toezichtsstelsel zijn "vooraf gaande goedkeuring en systematische melding van polisvoorwaarden en tarieven" ongeoorloofde condities. ${ }^{154}$ Hiervan uitgezonderd zijn: a. melding van gegevens betreffende verplichte wettelijke aansprake-

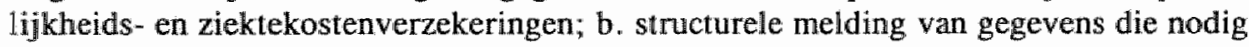

146. Bij aantoonbare noodzaak is preventief toezicht mogelijk. Nota n. a.v. eindverslag wet tor wijziging Wh. TK 1989-1990, 20884, nr.9, p.7.

147. Sichting Verzekering skamer, Jaarverslag 1992, Apeldoorn, 1992, pp.13/28-29.

1.48. Anders A. Kieboom, Op weg naar materieel toezicht?, in: VA, deel 62, LXII, 1985, pp, 181-185. Z.i. is door nieuwe werzekeringstoezichtregels (vervangen WTS -JGLvN) "de deur naar manterieel toezicht wat verder is open gezet".

149. Zie reeds Mut bij wet tor wijziging Wtw. TK 1988-1989, 20884, nr.3, p.2; Mva wet tor wijziging Wiv, TK 1988-1989, 20884, nr.7, p.3.

150. Mwa wet tor wijziging WTw. TK 1988-1989, 20884, nr.7, pp.3-4; Ook over voordeel van normatief boven materieel toezicht E. Lutjens, Pensioenvoorzieningen woar werknemers; Juridische beschowwingen over ouderdomspensioenen, Zwolle, 1989, pp.335-362, i.h.b. pp.356-357.

151. Eindwerslag wet tot wijiging Wtv, TK 1988-1989, 20884, nr.8, p.3.

152. Einduersilag wet tot wijziging Wtv, TK $1988-1989,20884$, nr.8, p.3.

153. Nata n.a. w. het eindverslag wet tot wijziging Wtv, TK 1989-1990, nr.9, pp.546.

154. Mut woorstel Wh 1993, TK 1992-1993, 23199, nr.3, p.7. 
zijn voor het toezicht op de naleving van actuariële beginselen (vooral grondslagem die onmisbaar zijn voor de berekening van tarieven en technische voorzieningen); en $c$. informatieverschaffing over de identiteit en het belang van personen, die een gekwalificeerde deelneming houden bij de verzekeraar die een vergunning aanvraagt.

Ten tweede geldt de regel, dat de vergunningverlener toezicht uitoefent op alle activiteiten van de verzekeraar, aan wie vergunning is verstrekt, in het grensoverschrijdende gebied van de EG. Dat is dus het beginsel van 'home country control' "Hierbij kan een (thuisland)toezichthouder notificatieprocedures, ter verificatie of een verzekeraar bevoegdelijk zijn vak uitoefent, instellen. Een notificatieprocedure is, gegeven de aard er van, lichter dan een vergunningenprocedure.

In het kader van dienstwerrichting naar Nederland zijn in 1991200 en in 1992173 notificatieprocedures afgerond. ${ }^{155}$ In 1993 vinden 16 notificatie-procedures plaats. ${ }^{156}$

Als derde afzonderlijk onderdeel van harmonisatie ter zake, naast het single licence/home country control en het normatief toezicht, wordt wel het financieel toezicht genoemd. Dat betreft vooral: a. nieuwe beleggingsvoorschriften voor de activa die dienen tot dekking van de technische voorzieningen; b. nieuwe regels voor de berekening van technische voorzieningen en de grondslagen die daarbij worden gehanteerd; en c. nieuwe regels ten aanzien van de vermogensbestanddelen die moeten worden meegeteld bij de bepaling van de aanwezige solvabiliteitsmarge ${ }^{157}{ }^{158}$

Deze uniformering van het vergunningstelsel voor uitoefening van het verzekeringsbedrijf steunt merendeels op drie (generaties) algemene EG-richtlijnen. ${ }^{159}$

De eerste generatie richtlijnen schadeverzekering ${ }^{160} /$ levensverzekering $^{161}$ beoogt, via onderlinge afstemming van toelatings- en uitoefeningsvoorwaarden, versoepeling van de uitoefening van het schade- en levensverzekeringsbedrijf. Deze richtlijnen benadrukken de vrijheid van vestiging.

155. Stichting Verzekeringskamer, Jaarverslag 1992, Apeldoom, 1993, p.67.

156. Stichting Verzekeringskamer, Jaarverslag 1993, Apeldoorn, 1994, p.78.

157. Implementatie Nederland per 1 juli 1994 via Regeling/Besluit technische voorzieningen Verzekeringsbe. drijf, Stbl. 1994, 448,

158. Aldus menen A.J.H. Verkerkt en P.J. Pearson, als weer gegeven door H.L. de Boer, Rechr, verzekering en Europa: Een impressie wan een twetal studiebijeenkomsten, in: VA, najaar 1994, pp.95-100, i.h.b. p. 96.

159. Hierover M. R. Mok, Wetswoorstellen informatie-uinwisseling in financiële toezichtwetten en vervanging Wtw, in: TVVS, nr.8, 1993, pp.204-205; Mvt Wt, t.a.p., pp.2-12; Verzekeringskamer, Jaarverslag 1992, pp.35-36.

160. Eerste richtlijn v.d. Raad v.d. EG van 24 juli 1973 tor cä̈rdinatie v.d. wettelijke en bestuursrechrelijke bepalingem betreff. de toegang tot het directe kerzekeringsbedrijf en de uitoefening daanvan, 73/239/EEG, Publ. EG L 228, 16 aug. 1973.

161. Eerste richtlijn v.d. Raad v.d. EG van S. maart 1979 tot coördinatie van de wettelijke en bestuursrechtrelijke bepalingen betreffende het directe levensverzekeringsbedrijf en de uitoefening darvan, 79/267/EEG, Publ. EG L 63, 13 maart 1979. 
De tweede generatie richtlijnen schadeverzekering ${ }^{162163} /$ levensverzekering $^{164}$ heeft coördinatie van de toezichtsregimes in de verschillende lidstaten ten doel. Deze richtlijnen stimuleren de vrijheid van dienstverlening. ${ }^{165}$ Hierdoor is het voor een verzekeraar die in de ene lidstaat is gevestigd mogelijk een verzekering te sluiten met betrekking tot bepaalde risico ${ }^{x}$, of met bepaalde verzekeringnemers, in een andere lidstaat.

De derde richtlijnen schadeverzekering ${ }^{166 / \text { levensverzekering }}{ }^{167}$, gekenmerkt door "thuisland toezicht, wederzijdse erkenning en vrije prijs- en produktconcurrentie" 168 , dienen, via vrijheden van vestiging en dienstverlening, de ultieme totstandkoming van de gemeenschappelijke verzekeringsmarkt. Beperking van de gemeenschappelijke markt ter zake is nog slechts bij uitzondering mogelijk met een beroep op het algemeen belang.

Totale coherentie en eenwording van de verschillende verzekeringsstelsels in de lidstaten is nu namelijk nog niet mogelijk. Vandaar tolereert de Europese rechter bepaalde beperkingen op respectievelijk de vrijheid van dienstverrichting ex artt. 59-60 E(E)G-verdrag, de vrijheid van werknemersverkeer ex art. $48 \mathrm{E}(\mathrm{E}) \mathrm{G}$-verdrag, de vrijheid van betalingsverkeer ex art. $106 \mathrm{E}(\mathrm{E}) \mathrm{G}$-verdrag en de vrijheid van kapitalverkeer ex art. $67 \mathrm{E}(\mathrm{E}) \mathrm{G}$ verdrag met een beroep op het algemeen belang. In oude jurisprudentie wordt de reden van het algemeen belang dwingend geacht gegeven de, met oog op consumentenbescherming, bijzondere gevoeligheid van het verzekeringswezen. ${ }^{169}$ In recentere rechtspraak haakt het Hof van Justitie van de EG, ter rechtvaardiging van inbreuk op alle vier vrijheden, aan bij het algemeen belang van waarborging van de binnen het nationaal belastingstelsel bestaande samenhang tussen aftrekbaarheid van premies en belastbaarheid van

162. Theede richtlin w.d. Raad v.d. EG van 22 juni 1988 tor coördinatie v.d. wettelijke en bestuursrechtelijke bepalingen betreff. het directe verzekeringsbedrijf, tot vaststelling van bepalingen ter bewordering v.d. daadwerkeljke whtoefening w.h. vrif verrichten van diensten, en wijiging v.d. eerste richtijn schadeverzekering, 88/357/EEG, Publ. EG L 172, 4 juli 1988.

163. Over conflictenrecht $\mathrm{K}$. W. Brevet, Tweede richthin schadeverzekering en toepasseljik recht, in: VA, deel 68,1991 , pp. 19-32,

164. Tweede richmin v. d. Raad v.d. EG van 8 now. 1990 tot caördinatie v.d. wettelijke en bestwarshechtelijke bepalingen betreff. het wirecte levensverzekerings bedriff tot vaststelling $v$. d. bepalingen ter bevordering v.d. daadwerkelijke witoefening w.h. wrij verrichten van diensten, en wijziging w.d. eerste richlijn lewensverzekering, 90/619/EEG, Publ. EG L 330, 29 nov. 1990.

165. Hierower uitvoerig Ph.H.J.G. van Huizen, Grote en andere risico "s wan werzekering en het toepass elijk recht volgende de iweede richtlijn dienstwerrichting, in: VA, deel 66, LXVI, 1989, pp.155-169.

166. Derde richrlijn $v . d$. Raad $w_{n} d$. EG van 18 juni 1992 tot coördinatie v.d. wethelijke en bestan rsrechtelijke bepalingen betreff. het directe verzekeringsbedriff. en wijziging w.a. richtijnen schadeverzekering. 92/49/EEG, Publ. EG L 228, 11 aug. 1992.

167. Derde richtlijn v.d. Raad v.d. EG van 10 nov. 1992 to cöiordinatie v.d. whettelijke en bestuursrechtelijke bepalingen betreff. het directe verzekeringsbedrijf. en wijz. v.d. richtijnen schadeverzekerimg, 92/96/EEG, Pubi. EG L 360, 9 dec. 1992.

168. A.M.W. Esser, Nieuwe beleggingsvoorschriften woor Europese verzekeraars, in: VA, deel 70, LXX, 1993, pp. 127-143, i.h.b. p. 129 . Auteur problematiseert wel de, in de richtijnen vemelde, concrete limieten lokaliseringseisen m.b.t. beleggingen.

169. Commistie wg. Duitsland, HvJ EG (205/84) 4 dec. 1986, Jur. 1986. p.3755; Hierover J. Bargesius, Rechterlijk oordeel ower het wrije verkeer wan werzekeringsdiensten in de EEG, in: VA, deel 64, LXIV, 1987. pp. 109-137. 
uitkeringen. ${ }^{170}$ Natuurlijk geldt ook voor deze verenging van de verschillende vrijheden het volgende. Te weten: a. de 'algemeen belang'-voorschriften worden niet-discriminerend toegepast op elke verzekeraar in de betrokken lidstaat; b. zij zijn objectief noodzakelijk; c. zij staan in verhouding tot het nagestreefde doel; en d. de reeds in de lidstat van vestiging van verzekeraar bestaande bepalingen maken de waarborging van het algemeen belang niet mogelijk. ${ }^{171}$

Er bestaat vrees, dat invoering en handhaving van beperkingsbepalingen van algemeen belang in Nederland mogelijk tot materieel toezicht a posteriori (op bij voorbeeld tarieven en poliswoorwaarden!) leidt; "Het begrip 'wettelijke bepalingen van algemeen belang' is zo rekbaar dat het onvermijdelijk leidt tot rechtsonzekerheid en misbruik in de hand werkt door lidstaten die hun eigen verzekeringsmarkt willen afschermen. " inz

Deze angst is rijp voor matiging. Er zijn geen duidelijke aanwijzingen, dat het Hof van Justitie in de toekomst een ruime interpretatie van het "allgemeen belang'-begrip zall aanhangen. Bovenal mag de betekenis van de Cassis-de-Dijon-uitzonderingsregel van in casu het algemeen belang niet eenzijdig worden opgevat. In de wetenschap dat de "rule of reason' een communautair leerstuk met betrekking tot dienstverrichting in verschillende sectoren is, en "waarvan het opnemen in de verzekeringsrichtlijnen een declaratoir karakter" draagt, blijkt de Cassis-de Dijon-rechtspraak niet alleen een "een tweesnijdend zwaard", maar is zij ook "het breekijzer voor dle interne markt". "173 Vrees voor een lichtvaardig gebruik van de exceptie van het algemeen belang is niet nodig, omdat het Hof van Justitie van de EG een zich op het algemeen belang beroepende lidstaat altijd ter verantwoording kan roepen. De toetsing van het hof werloopt volgens het volgende stramien: "a. Beroep op algemeen belang kan alleen bij gebreke van communautaire harmonisatie op het betrokken terrein; $b$. De betrokken bepalingen dienen een algemeen belang in Europeesrechtelijke zin; c. Voldaan moet worden aan door het hof gestelde voorwaarden als: 1 . de beperkende voorschriften moeten zonder onderscheid van toepassing zijin op iedere persoon of onderneming die in de betrokken lidstaat werkzaam is (non-discriminatiebeginsel); 2 . het betrokken belang moet niet reeds gewaarborgd zijn door regelgeving in de lidstaat van herkomst (non-doublure-beginsel); 3 . de beperkende voorschriften moeten objectief noodzakelijk zijn voor de bescherming wan het betrokken algemeen belang (noodzakelijkheidsbeginsel); en 4 . de beperking moet proportioneel zijn in relatie tot het te beschermen belang (proportionaliteitsbeginsel)." 174 Met zo'n toetsing achter de hand bestaat weinig gevaar voor misbruik van het beroep op het algemeen belang.

170. Bachmann, HvJ EG (204/90) 28 jan. 1992; Commissie ws. Belgie, HvJ EG (300/90).

171. W.M.A. Kalkman, R.W.F. Hendriks en P.J.M. Bongaarts, Algemeen belang als blakkode voor de vrijheid van dienstwerrickting door verzekeraars w/d interne markt, in: VA, deel 69, LXLX, 1992, pp. 161-178, i.h.b. pp.175-176.

172. W.M.A. Kalkman, R.W.F. Hendriks en P.J.M. Bongaarts, t.a.p., p.176.

173. P.A.H. Lemaire, De derde generatie EG-verzekeringsrichtlinen; Het algemeen betang als breekizer voor de interne markt, in: het Verzekeringsarchief, deel 69, LXIX, 1992, pp.337-344, i.h.b. pp.339 340 .

174. Aldus schema van P.A.H. Lemaire, verwoord door H.L. de Boer (1994), t.a.p., p.97; Opnieuw geciteerd door H.L. de Boer en H.L. Mulder "Regelgeving 'algemeen belang", in: Bank-en Effectenbedrijf, nr.6, 1995, pp.29-30. 
Desondariks maakt het Verbond van Verzekeraars zich sterk voor concretisering van het beroep op "redenen van algemeen belang". Maar het kabinet onthoudt zich daarvan, omdat de "aard van deze materie zich niet leent voor opneming in de Wtv". ${ }^{175}$ Het regeringsstandpunt ter zake verwijst naar de bekende jurisprudentie van het Hof van Iustitie van de EG, waaraan de regering uitdrukkelijk hecht ${ }^{176}$.

\subsubsection{SAMENWERKING EN INFORMATIE-UITWISSELING MET EUROPESE (EN NIET- EUROPESE) STATEN}

Andere relevante EG-normen versterken nog eens de voorgestane nauwere samenwerking $^{1} 7$, tussen de verschillende toezichthoudende autoriteiten in de afzonderlijke lidstaten, die voort vloeit uit art. $10 \mathrm{Wtv}$.

Goed voorbeeld is de, bij art. 181 Wtv aansluitende, informatie-uitwisselingswet. ${ }^{178}$ Met deze wet krijgen nationale toezichthouders, t.w. stichting Verzekeringskamer, De Nederlandsche Bank nv en Stichting Toezicht Effectenverkeer, en buitenlandse toezichthouders op financieel gebied, zonder doorbreking van (de in toenemende mate aan harmonisatieonderhevige ${ }^{179}$ ) geheimhoudingsplichten ${ }^{130}$, ruimere mogelijkheden ${ }^{131}$ informatie uit te wisselen.

Tot deze verruiming, die beoogt de informatie-uitwisseling uit hoofde van toezichtswetten

175. Adwies wan Verbond voor Verzekeraars, TK 1992-1993, 23199, nr.3, bijlage 6, p.78.

176. O.a. Mwt woarstel Wrv 1993. TK 1992-1993, 23199, nr.3. p.18.

177. Deze krijgt gestalte door o.a. de Pan-Eutopese conferenties en het averleg van de op 21 juni 1993 opgerichte International Association of Insurance Supervisors. Verzekeringskamer, Jaarkerslag 1993 , Apeldoorn, 1994, p.53.

178. Wetswoorstel houdende opneming in de Whk, Ww, Wib en Whe wan bepalingen inz. informatie-uitwisse-

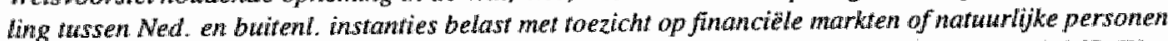
en rechrspersonen die op die markten werkzacm zim, TK 1992-1993/1993-1994, 23170, nrs. 1-268; Wet, Stbl. 17 maant 1994, 235; inw. Stbl. 1994, 299; Vgl. ant. 11 Wtv, dat bij TK 1993-1994, 23170, nr. $268, p .11$, word uitgebreid met een vierde lid inzake verstrekking wan de stichting Verzekeringskamer van informatie (over deskundigheid/betronwbaarheid van beleidsbepalers wan onder toezicht gestelden) aan andere toezichthoudende autoriteiten, die de unlichtingen en gegevens -naar de Verzekeringskamer meent- in het belang yan hun tiakuitoefening modig hebbera. Een nieuw vijfde lid verdutuelijkt dat deze werplichting van de Verzekeringskamer niet geldt indien informatie is verkregen van een buitenlandse instantie als bedoeid in art. 181 , eerste lid, Wtw.

179. Wik 1992, TK 1991-1992, 22665, nr.3, p.65; De Mvt wetsvoorstel inzake informatie-uitwisseling. TK $1992-1993,23170$, nr. 3, p.8, vindt volkomen identieke geheimhoudingsplichten niet nodig, maar acht "toereikende equivalentie" voldoende.

180. Over geheimhoudingsplicht in relatie tot verschoningsrecht en getuigplicht (van i.c. medewerkers van De Nederlandische Bank nv) S.A. Boele, De Wrk 1992, in: TVVS, nr.11, 1993, pp.286-290, 1. h. b. p.290; Volgens Wtk 1992, TK 1991-1992, 22665, nr.3. pp.65-67, betreft het hier afweging van het "voor de rechtsbedeling fundamentele belang vam de waarheidsvind ing en het belang van de handhaving van de vertrouwelijkheid van bepaalde inlichtingen" (p.67). Zie ook over geheimhoudingsplichten van DNB nv, ex art. 64 Wtk 1992, TK 1992-1993, 22665, nr.6, pp.40-42.

181. De VVD-fractie vraagt zich, bij behandeling van de Wtk 1992 af, of in het algemeen niet sprake moet zijn wan verplichting i.p.V. mogelijkheid. Zie Wtk 1992, TK 1992-1993, 22665, nr.8, p.10. Zo'n verplichting van de ene toezichthouder om aan de ande re toezichthouder te allen tijde en ongeclausuleerd 
op financieel gebied een zo uniform mogelijk basis te geven, wordt de wetgever verleid door niet af te wimpelen allures als: de steeds grotere vervlechting van diverse funanciele sectoren, de internationalisering van de financiële markten, de ver gaande tendens tot vorming van financiêle conglomeraten, fusies of overnames en de liberalisering van het structururbeleid voor het bank- en verzekeringswezen. ${ }^{182}$

In het belang van het uitoefenen van adequaat toezicht op de financiële markten, $t$.w. de bank-, effecten- en verzekeringsmarkt, krijgen de betrokken toezichthouders, met oog op zowel sectorale als intersectorale uitwisseling van informatie ${ }^{183}$, overigens niet nieuwe, bevoegdheden waarvan zij gebruik mogen (dus niet dwingend: moeten) maken. Bij het aanwenden van deze bevoegdheden geldt, dat iedere toezichthouder voor zijn toezichtstaak "primair zelf tracht om met gebruikmaking van zijn bevoegdheden de nodige informatie te vergaren bij de onder zijn toezicht gestelden". 185 De bevoegdheden, dienend tot informatie-uitwisseling, zijn slechts secundaire bevoegdheden.

In het verlengde daarvan letten de verschillende toezichthouders er op dat zij, bij het uitwisselen van informatie, hun wettelijke toezichtstaak nimmer te buiten gaan.

Inhoudelijk komen de bevoegdheden op het volgende neer. ${ }^{187}$

Tenzij zij ze zelf weer via een buitenlandse instantie heeft, is de stichting Verzekeringskamer ex art. 9b, vierde en vijfde lid, Wtv verplicht gegegevens en inlichtingen betreffende deskundigheid en betrouwbaarheid van bestuurders van onder toezicht gestelden, welke informatie volgens de stichting Verzekeringskamer van belang is voor de wettelijke overheidstaak van een andere toezichthoudende autoriteit, te verschaffen aan die bevoeg. de andere autoriteit.

Art. 84, eerste lid, Wtw legt in ieder geval de stichting Verzekeringskamer, en eigenlijk alle anderen die een taak vervullen op grond van de $W t v$, een vinger op de mond. Ten aanzien van verkregen informatie geldt een geheimhoudingsplicht. ${ }^{188}$ Verboden is het verder of anders, dan de toezichtstaak vereist, gebruiken en bekend maken daarvan. Pregnant tornt de praktijk aan het principe.

Omdat in de zoektocht naar optimaal toezicht soms wegen naar buiten moeten worden bewandeld, maakt art. 84, tweede lid, Wtv het de stichting Verzekeringskamer toch

181. $\rightarrow$

informatie te verstrekken is "noodzakelijk noch wemselijk" in gevolge Wik 1992, TK 1992-1993, 22665 " nr.9, p.22. Bedoelde plicht bestaat alleen bij een samenwerkingsplicht, conform de, met oog op de informatie-uitwisselingswet, ingevoerde aampassing van art. 2 Wtk 1992.

182. Mvt wetstoorstel inzake informatie-uitwisseling. TK 1992-1993, 23170, nr.3, pp.1/3.

183. Ongeacht of dit informatie betreft "uit eigen dossier' of informatie die juist niet via toezichtsbevoegdheden wordt werkregen.

184. Mvt wetswaorstel inzake informatie-uirwisseling. TK $1992-1993,23170$, nr.3, pp. 2/4, zie ook nr.5, p.4.

185. Mut wetsvoorstel inzake informatie-uitwisseling, TK 1992-1993, $23170, \mathrm{nr}, 3$, p.6.

186. Mw/Mva wetswoorstel inzake informarie-witwisseling, TK 1992-1993, 23170, nr.3/nr.6, pp.6-7/pp.4.5.

187. Deze bevoegdheden zijn vrij wel eender geregeld voor de STE, DNB nv em de stichting Verzekeringskamer.

188. Dit vernieuwde art. 84 Wrv kent eem strengere formulering, als al wondt gebezigd in de toezichtswetten Wik, Wte en Wtb. 
mogelijk om gegevens en inlichtingen uit te wisselen met, al dan niet aangewezen, andere Nederlandse of buitenlandse toezichthouders.

Wel kunnen zich ook hier blokkaden opwerpen. Het doel, waarvoor informatie wordt aangewend, moet voldoende bepaald zijn. Verhindering van informatie-uitwisseling vindt plaats als het gebruik van de informatie niet past binnen het toezicht op de financiële markten. Gegevensverstrekking mag niet strijdig zijn met de openbare orde. De geheimhouding van gegevens moet voldoende worden gew aarborgd. Informatie-uitwisseling mag de belangen, die de wet- en regelgeving inzake het toezicht op de financiële markten beschermt, niet aantasten. En, de inlichtingen en gegevens mogen slechts voor dat doel, waartoe hun verstrekking dient, worden gebruikt. Laatst genoemde beperking $\mathrm{kan}$, in gewolge art. 84, derde lid, Wtv, worden opgeheven door speciale toestemming van de informatieverschaffer.

Ter uitvoering van verdragen tot informatie-uitwisseling of van bindende besluiten van volkenrechtelijke organisaties m.b.t. het toezicht op de financiële markten verschaft art. $84 \mathrm{a}$, eerste lid, Wtv de stichting Verzekeringskamer bevoegdheden tot het (doen) verkrijgen wan inlichtingen en het (doen) instellen van onderzoek bij iedereen waarvan redelijkerwijs kan worden vermoed dat hij over informatie beschikt die in het belang van uitoefening van toezichtstaken is. De stichting Verzekeringskamer wint deze informatie moge-

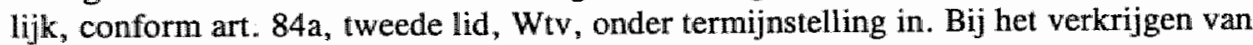
informatie via onderzoek verlenen onder toezicht gestelden, ex art. 84, derde lid, Wtv, alle medewerking die nodig is voor een goede uitvoering van dat onderzoek. Zij dragen echter slechts de verplichting tot het verlenen van inzage van boeken, zakelijke bescheiden en andere informatiedragers. De medewerkingsplicht rust, ex art. 84b, tweede lid, Wtv, ook op een functionaris van een buitenlandse instantie die conform art. 84b, eerste lid, Wtv, wit overwegingen van effectiviteit en doelgerichtheid ${ }^{189}$ mag deel nemen aan de uitvoering van een verzoek om informatieverschaffing. Deze functionaris volgt in gevolge art. $84 \mathrm{~b}$, derde lid, Wtv, de aanwijzingen op van de degene die met de uitvoering van het verzoek is belast.

Bij dit alles geldt, dat bij voorbeeld de stichting Verzekeringskamer door de haar nu opgelegde collegiale informatie-uitwisseling relevante informatie, een maal verkregen van een bevoegde buitenlandse autoriteit, in beginsel moet doorspelen naar andere toezichthouders in Nederland. Soms is dit beginsel bezwaarlijk. Een buitenlandse autoriteit, die de gegevens en inlichtingen ter hand van bij voorbeeld de stichting Verzekeringskamer stelt, kan - gegeven de buitenlandse wetten en regels - aanspraak maken op geheimhouding van de toegespeelde informatie. Natuurlijk staat het de stichting Verzekeringskamer vrij om toestemming van de buitenlandse autoriteit te vragen voor doorgifte van informa tie. Maar verkrijgt de toezichthouder geen toestemming, dan houdt het op. ${ }^{190}$

Wel wordt aangetekend, dat het beroep op een geheimhoudingsplicht het toezicht kan frustreren. Een vervelend gevolg van geheimhouding manifesteert zich in de, medio augustus 1994 in de publiciteit gekomen, zaak van De Nederlandsche Bank nv tegen de 
Franse banktoezichthouder met de naam Commission bancaire.. Tussen beide toexichthouders speelt zich vanaf begin 1990 een kat-en-muis-spelletje af. De Nederlandsche Bank nv vindt het bancair toezicht op de Crédit Lyonnais Bank Nederland (CLBN) een taak voor de Franse toezichthouder, die al belast is met het toezicht op de moederbamk van CLBN in Parijs. Omgekeerd zit de Commission bancaire juist De Nederlandsche Bank nv op de hielen, met de boodschap dat DNB nv zelf aansprakelijk is voor de Nederlands Crédit Lyonnais Bank. Door dit over en weer afschuiven van verantwoordelijkheid raaki het toezicht op de betrokken bank in het gedrang. De nadruk op de competentiestrijd tussen beide toezichthouders ontneemt hen het zicht op de bij de CLBN, vooral door activiteiten van twee Italiaanse zwendelaars veroorzaakte, financiële problemen, die uiteindelijk belangrijk bij dragen aan de miljardenverliezen van de moedermaatschappij wan Crédit Lyonnais Bank in Parijs. De Commission bancaire die, onder druk van DNB nv, vanaf 1990 weliswaar formeel verantwoordelijk ${ }^{191}$ is voor de Nederlandse Crédit Lyonnais Bank, wordt voor zover zij nog toezicht houdt, daarbij in ernstige mate belemmerd door het stilzwijgen van DNB nv. Voor de Franse toezichthouder is het onmogelijk diepgaand inzicht te krijgen in de risico's, die CLBN - door het afsluiten van leningen met dubieuze debiteuren - voor het moederconcern oplevert, omdat DNB nv weigert gedetailleerde schriftelijke informatie daarover te verstrekken. In dit verband schermt De Nederlandsche Bank nv, hoewel het haar wordt toegestaan gegevens over solvabiliteit en liquiditeit van een bank uit te wisselen met een buitenlands toezichthoudend orgaan mits. die toezichthouder geheimhouding betracht, met haar wettelijke geheimhoudingsplich. DNB nv doet daarop ook nog een beroep als de Franse parlementaire enquêtecommissie, die de zaak onderzoekt, vraagt of zij een vertegenwoordiger van DNB nv kan horen met oog op dat onderzoek. ${ }^{192}$

Bedoelde informatie-uitwisseling betreft uitwisseling van administratieve gegevens. In principe wordt informatie, die betrekking heeft op opsporing van strafbare feiten, uitgesloten van bedoelde gegevensuitwisseling. Toch kan het voorkomen dat, in het kader wan toezicht verstrekte, informatie gebruikt wordt in een strafrechtelijke procedure. ${ }^{193}$ Een buitenlandse instantie die gegevens of inlichtingen wil gebruiken voor een strafrechtelijk onderzoek, moet daartoe een verzoek aan de betrokken Nederlandse toezichthouder doen. Deze beslist pas na overleg met de minister van justitie omtrent de consequenties

191. De moederbank van Crédit Lyonnais te Parijs geeft namelijk garanties voor de, door de dochteronderneming in Nederland verstrekte ${ }_{n}$ omstreden leningen. Daarmee staat de aansprakelijkheid van de Franse toezichthoudende autoriteit vast. Parijs blijft veranwoordelijk in affaire CLBN; Controverse tussen centrale banken, in: NRC, 12 aug. 1994, p.11. De Franse overheid, die dus op moet draatien voor de verliezen, zet een rigoureuze reddingsactie voor CLBN in touw. Daarmee is maar liefst 41 miljoen gulden gemoeid. De Europese Commissie lijkt gunstig gestemd ower deze staatssteun. Overigens beshit. de nnoederbank van CL te Parijs tot verkoop van haar meerderheidsbelang van $95 \%$ in CLBN. Doordat (min of meer verdachte) koersstijging optreedt op de dag van melding van mogelijke verkoop rijst de vraag of sprake is wan misbruik van voorkennis. Effectenbeurs bekijkt koers Credit Lyonnais, in: NRC. 20 april 1995, p. 19.

192. B. wan der Velden, "Toezicht op bank CLBN onduidelijk" en Competentiestrijd centrale banken on Crédir Lyortais. in: NRC, 11 aug. 1994, pp.1/11.

193. Mvt welswoorsiel inzake informatie-uitwisseling. TK 1992-1993, 23170, nir.3, pp.6/9. 
ervan voor lopend of toekomstig strafrechtelijk onderzoek als mede omtrent de begrenzingen van wederzijdse hulp- en bijstandmogelijkheden op het terrein van strafrecht. De bewindspersoon stemt toe alls de handhaving van het strafrecht het belang van informatieuitwisseling eist. Hij weigert een verzoek als dat zich niet verdraagt met de openbare orde. Ondanks deze voorzorgsmaatregel wreekt zich mogelijk het diffuse onderscheid tussen toezicht en opsporing.

Ook buiten bedoelde administratieve informatie-uitwisseling valt informatie die om geldige redenen strikt vertrouwelijk is. Uit de in jurisprudentie van het Europese Hof van Justitie, met een beroep op bescherming van rechten van derden, voorkomende weigering van de Europese Commissie om documenten aan een nationale rechter te overleggen, wordt wel een "algemeen communautair beginsel van administratieve zorgvuldigheid" afgeleid. ${ }^{194}$ Een dergelijk beginsel moet uitgangspunt zijn bij onderlinge gegevensuitwisseling tussen lidstaten.

Niet alleen met lidstaten, maar ook met niet-lidstaten kan overeen worden gekomen om informatie wit te wisselen. Bekend voorbeeld is het akkoord dat de Europese Commissie, kennelijk in het kader van het haar toekomende toezicht op het mededingingsrecht ex art. 89 E(E)G-verdrag jo. Kartelverordening 17/62, in 1991 sluit met de Verenigde Staten van Amerika met als doel het concurrentiebeleid van beide kartelautoriteiten meer op elkaar af te stemmen. De overeenkomst, die voorziet in onderlinge uitwisseling van anticoncurrentiële gegevens, vindt basis in het EG-verdrag terug kerende art. 228 EEGverdrag. Dit artikel opent inderdaad de mogelijkheid om dergelijke informatie-uitwisselingsakkoorden te sluiten. Maar de Europese Commissie miskent met name de betekenis van het tweede lid van art. 228 EG-verdrag. De bewoording daarvan luidt ten dele dat "'onder voorbehoud van de aan de Commissie te dezer zake toegekende bevoegdheden" de Raad de mogelijkheid heeft om - na raadpleging van het Europees Parlement - met gekwalificeerde meerderheid van stemmen, op voorstel van de Commissie, dergelijke en andere akkoorden aan te gaan. Volgens de Europese rechter, die het akkoord nietig verkllaart, verschaffen de interne mededingingstoezichtsbevoegdheden van de Kartelverordening de Commissie nog niet de externe bevoegdheid om op eigen houtje overeenkomsten, in casu betreffende informatie-uitwisseling, aan te gaan. ${ }^{195}$ De Raad is de EGvertegenwoordiger ter zake.

Als gezegd wordt de, met de intensievere informatie-uitwisseling gepaard gaande, "formalisering van de geheimhoudingsplicht mede ingegeven door de vervaging van de grenzen tussen de financiële deelmarkten" van banken en verzekeraars. ${ }^{196}$

194. H.A.G. Temmink, Annotatie inz. toelating bestrijdingsmiddel, im: SEW, nr.6, juni 1994, pp.450-456. i.h.b. p. 455 .

195. Framkrijk ws. Commissie, HwJ EG (C-327/91) 9 aug. 1994 in: NJB, nr.30, 2 sept. 1994, p.1057 (rechitspraakbijlage).

196. Mvt woorstel Wh 1993, TK 1992-1993, 23199, nr.3. p.9. 


\subsubsection{PROTOCOL}

In het kader van dat naar elkaar toe groeien van kapitaalmarkten zijn onderlinge afspraken, over de vormgeving van het toezicht op financiële conglomeraten ${ }^{197}$, tussen de stichting Verzekeringskamer en De Nederlandsche Bank nv gemaakt. ${ }^{198}$ Het weliswaar "niet gelijke, maar wel gelijkwaardige" bank- en verzekeringstoezicht, in de zin dat in beide gevallen het toezicht is afgestemd op de kenmerken en risico"s van de betrokken kredietinstellingen en verzekeringsmaatschappijen", maakt intensieve samenwerking mogelijk. ${ }^{199}$ In het overleg tussen financiën, De Nederlandsche Bank nv en de stichting Verzekeringskamer wordt de protocolpraktijk besproken en geëvalueerd. Actief wordt gewerkt aan aanpassingen van het protocol. ${ }^{2(0)}$ Verbetering van het protocolgebruik geschiedt bij voorbeeld met de introductic van art. $175 \mathrm{a}$ Wtv ${ }^{201}$ "Daarmee worden (standaard)protocolvoorschriften niet meer afzonderlijk opgelegd, maar via eenvoudige verwijzing aan de door financiële conglomoraten benodigde verklaring van geen bezwaar verbonden. Voor zover het protocol samenwerkingsafspraken - anders dan aan financièle conglomoraten te stellen voorschriften - bevat, moeten die worden vorm gegeven als regeling in de zin van art. 11 Wtw. Aldus krijgt het protocol een zekere wettelijke basis. ${ }^{202}$

Kort weg berust het protocol op het volgende. De toezichthouder controleert elke vergunninghoudende (dochter)maatschappij en mag ten behoeve van die controle informatie vragen aan elk van bedoelde maatschappijen. Het gehele concern of de topholding staat, tenzij zij vergunninghoudend is, niet onder toezicht. Wel verschaft zij periodiek relevante concerngegevens aan de toezichthouder. Bij de tendens naar een sterk geïntegreerd toezicht op financiële concerns op basis van een volledig geconsolideerde jaarrekening van het concern, zijn vraagtekens te stellen. De kritiek komt op het volgende neer: "a.. het signaleren van potentièle problemen staat nog niet gelijk aan het regelmatig daadwerkelijk voorkomen van zulke probleemgevallen; b. men moet oppassen om regels te ontwerpen op basis van versimpelde modellen, zoals een concern met een bank, een verzekeringsmaatschappij en een neutrale holding; $c$. het streven naar het hanteren van

197. Hierover Verzekeringskamer, Toezicht op conglomeraten; Voor-en nadelen van 'geconsolideerd" toezicht en toezicht 'solo-phws", Apeldoorm, 1992. Uit deze notitie blijkt een voorkeur voor het decentralo toezichtmodel 'solo-plus' (p.10); Ziie natwurlijk ook wettelijke bepalingen neergelegd in artt. 174.178 Wtw 1993, als gebaseerd op Wet I...J i.v.m. het versterken wan het toezich op kredietinstellingen en verzekeraars die diel wit maken van een groep. Stbl. 1994, 278; Vermoedelijk publiceen de Europese Commissie eind 1995 een eerste concept-rüchtijn inzake het toezicht op financièle conglomeraten.

198. Protocol inz. het vanaf 1 januart 1990 te woeren structuurbeleid t. a. v. banken en verzekeraars, 14 sept. 1990. Amsterdan/Apeldoorn als aangepast bij TK 1993-1994, 23400 IXB, nr.21 en geldend per 1 juli 1994.

199. Wik 1992, TK 1992-1993, 22665, n. 9, p.20, en TK 1992-1993, 22665, nr.108b, p.3.

200. Mvt wijz. Wt 1993, TK 1993-1994, 23544, nr.3i, pp.10-11, vgl. TK 1993-1994, 23400 IXB, nr.21.

201. Wijz. Wiv 1993, TK 1993-1994, 23544, nr.2, pp.6-7.

202. O.a. E.D. Drok en C.H.H. Lambers, Het protocol uitgegeven door DNB/Verzekeringskamer, in: N.JB, ur. 14, 8 april 1993, pp.503-504, twijfelen aan de protocol-status. Volgens auteurs bezit het protocol "geen juridisch bindende kracht"; In reactie daarop anders A. Verhoeven, Het Protocol van DNB en de Verzekeringskamer, in: NJB, nr.28, 5 aug. 1993, pp.1022-1023. 
een strikt geconsolideerde jaarrekening voor een concern is technisch geen eenvoudige zaak, want hiervoor wordt ten minste vereist de toepassing van uniforme waarderingsgrondslagen, waarbij in het geval van het levensbedrijf de relatie tussen de waardering van activa met die der passiva een specifiek probleem oplevert; $d$. bovendien is dan vereist een integrale benadering van de in het concern aanwezige risico's; het is een cruciale vraag hoe men het bancaire bedrijf en het verzekeringsbedrijf, welke immers een afwijkend karakter hebben, zal weten te integreren, nog afgezien van de rol van overige niet-financiële dochtermaatschappijen resp. de eventuele eisen te stellen aan de neutrale topholding; e. naast zulke technische en beleidsproblemen moet voorts gewezen worden op denkbare belangenverschillen van groepen van cliënten, zo bestaat het gevaar dat de belangen van de korte termijn claims (bankspaarders) worden begunstigd ten nadele van de lange termijn claims (polïshouders van het levenbedrijf), waarbij extra navrant is dat er wel een (minimum)garantieregeling ${ }^{203}$ voor bankspaarders in Nederland is, maar niet voor polishouders. 204

\subsubsection{MEDEDINGINGSRECHT EN ZELFREGULERING}

Al met al hebben vooral de toename van verzekeringsclaims en het - via de drie Europese richtlijnen - van uit Brussel gedicteerde mededingingsbeleid de strijd om het marktaandeel een prominente plaats gegeven. In de Europese concurrentiële context (en bedrijfseconomisch toezicht) is de traditionele zelfregulering in de verzekeringsbranche vrij wel verloren gegaan. De stichting Verzekeringskamer stelt zich zelf terecht de volgende vraag: "hoe kan zonder een voldoende effectieve zelfregulering van de markt voorkomen worden dat de verzekeringsmarkt periodiek verzeild raakt in een situatie van ongebreidelde concurrentie, met de bijbehorende kans op geforceerde overnames of déconfitures?" 205

Anders dan zij wenst, kan de verzekeringsmarkt, onder meer door het gebrek aan sterke zelfregulering, volledige concurrentie kennelijk nog niet aan kan. Daarom moeten mededingingsbeperkende maatregelen mu nog mogelijk zijn.

De volgende correcte conclusie, voor een goed begrip vooraf gegaan door de letterlijke en enigszins uitgebreide inleiding, is het vermelden waard:

"Zowel in de Europese Gemeenschap als elders vormen de mededingingsregels een fundamenteel element in het streven naar een efficiënte economie. Door toepassing van de direct werkende verbodsbepalingen van het Verdrag m.b.t. de vrijheid van goederenen dienstenverkeer ('negatieve integratie'), door richtlijnen ('positieve integratie') èn door toepassing van het mededingingsrecht vindt de- en reregulering plaats. Zo leiden de liberalisatie en integratie van de verzekeringsmarkten tot meer nationale en grensover-

203. Hierover Notitie garantieregeling verzekeringsbedrijf, TK 1988-1989, 20884, nr.4, pp.1-7. Bij financieel onwermogen van een verzekeraar kan een garantieregeling een gehele of gedeeltelijke overdracht van de portefeuille bevorderen, als mede strekken tot het doen van aanvullende uitkeringen aan gedupeerde verzekeringscrediteuren.

204. A.J. Vermaat, Zicht op toezicht, in: VA, deel 70, LXX, 1993, pp.65-79, i.h.b. p.75.

205. Stichting Verzekeringskamer, Jaanverslag 1993, Apeldoorn, 1994, p.8. 
schrijdende concurrentie èn daaraan gepaard tot meer controle op naleving van de spelregels die willen voorkomen dat het bedrijfsleven die concurrentie vervalst. De financiele sector heeft enige tijd gemeend dat het communautaire mededingingsrecht voor haar niet geldt zolang geen bijzondere regels zijn vastgesteld o.g.v. art. 87, tweede lid, sub c, EGverdrag. Het hof heeft deze stelling verworpen, aangevende dat het "in het kader van haar bevoegdheid om krachtens art. 85 , derde lid, vrijstelling ${ }^{206}$ te verlenen van het verbod van art. 85 , het juist de taak van de Commissie is rekening te houden met de bijzondere aard van bepaalde economische sectoren en de aldaar optredende moeilijkheden. In individuele ontheffingen , die met name betrekking hebben op de verzekering van financiële risico"s, en in de groepsvrijstelling van 1992 is de Commissie inderdaad bereid gebleken acht te slaan op de specifieke aard van het verzekeringsprodukt.. De discussie over de vraag of ter bescherming van de consument een zekere marktordening zo niet door overheidsregulering dan toch in ieder geval door de bedrijfstak zelf noodzakelijk is, is daarmee goeddeels achterhaald. Niet volledig echter. In de toekomst zullen zich ongetwijfeld individuele zaken aandienen waar precedenten geen uitkomst bieden en die buiten de groepsvrijstelling vallen, zodat de vraag rijst of in dat specifieke geval concurrentiebeperkend gedrag gerechtvaardigd is door de bijzondere betreffende verzekeringsactiviteit. [...] Wij zien dat het Europese mededingingsrecht de laatste jaren in toenemende mate knaagt aan de heilige huisjes van de gereglementeerde sectoren en dat van geval tot geval dient te worden vastgesteld of het algemeen belang prevaleert. Zo blijft in de verzekeringssector een rol weggelegd voor de bescherming van de belangen wan de polishouders bij de continuitteit van de verzekeraars waartoe mededingingsbeperkend gedrag in aanulling op controle door toezichthouders noodzakelijk kan zijn; even zeer zullen sociale doelstelling van solidariteit en zekerheid niet ondergraven mogen worden. Waar de grenzen getrokken moeten worden, is echter [...] niet langer aan de nationale overheid maar aan de nationale rechter en aan de Commissie in individuele beschikkingen." 200

206. D.w.z. de groepswrijstelling voor verzekeringsmaatschappijen. Zie Verordening 3932/92/EEG van de Commissie wan 21 dec. 1993 betreffende de toepassing van art. 85 , derde lid van het Verdrag op bepaalde groepen wan overeenkomsten, besluiten en onderling afgestemde feitelijke gedragingen in de: verzekeringssector, Publ. EG, L 398, 31 dec. 1992, 7; In het licht van deze groepsvrijstelling betoogt H.J.W. Eijkelemboom, Mededingingsrecht en collectieve exploitatie wan aureursrecht. wederzids (on)begrip?, in: Informatjerecht/AMI, nr.8, 1994, pp.147-151, i.h.b. p.151, dat deze vrijstellimg er op duidt dat er "-mededingingsrechtelijk gezien-vele aanknopingspunten voor zelfregulering zijn". Z.i. zou zelfregulering, "mede $0 . b . v$. wetenschappelijk verantwoord (economisch) onderzoek en objectieve normen, kunnen leiden tot gedragscodes voor en controlemechanismen" (p.151). Dararnee kunnen marktdeel nemers bedrijfseconomisch gezien doeltreffender werken en voorkomen dat zij "onaangenaam. verrast worden door uitspraken (inzake mededingingsreclht - JGLWN) wan (inter)nationale instanties" (p.147). Auteur dringt er terecht op dat organisaties "de mogelijkheden onderzoeken voor zelfregulering voordat zij zelf worden gereguleerd" (p.147).

207. T.R. Ottervanger, De roepassing van het mededingingsrecht in de verzekeringssector, in: TVVS, Mr.9, 1994, pp.235-239, i.h.b. p.235 en p.238. Zie over mededingingsrecht en regulering ook paragraaf 14.11.1. 


\section{Ten slotte}

De, boven de stichting Verzekeringskamer hangende, luchten rommelen de laatste tijd rumoerig. Bulderend beweegt de kritiek zich over het hoofd van de stichting Verzekeringskamer als het de affaire Vie d'Or betreft. Scherp scheert het mes van twee kanten.

De toezichthouder op het verzekeringsbedrijf intensiveert weliswaar, via samenwerking met andere nationale toezichthouders op verschillende financiële markten en ook mett buitenlandse gelijksoortige toezich thouders, indringend haar toezicht. Toch laat zij lelijke lacunes in de uitvoering van haar toezichtstaken vallen. Daarbij weigert de stichting Verzekeringskamer zich, met een beroep op Europese geheimhoudingsbepalingen, zich in de kaart te laten kijken.

De woor de, op afstand van departementaal Den Haag opererende, Verzekeringskamer beperkt verantwoordelijk minister van financiën moet tussen a. de starre houding van de Algemene Rekenkamer die ongeclausuleerd in de boeken van de Verzekeringskamer wil neuzen en $b$. de weinig toegeeflijke Verzekeringskamer die weigert open boek te doen, manoeuvreren ten einde een middenweg te vinden: wijziging van de Wtv opdat de stichting Verzekeringskamer informatie verstrekt aan de minister, waarna de bewindspersoon bepaalt welke informatie daarvan kan worden door gegeven aan de Algemene Rekenkamer.

Na het nodige heen en weer trekken is het woord aan de commissie die een parlementair onderzoek ter zake verricht en nota bene bij tegenvallend resultaat daarvan een pariementaire enquête niet uitsluit. Overigens blijft het een weinig fraaie constructie om zelfs toepassing van het omslachtige parlementaire enquêtemiddel te overwegen, in die gevallen waarin een onafhankelijk onderzoeksorgaan onheus wordt geweigerd tot het inzien van geheime stukken en de minister te weinig daadkracht vertoont door zijn resterende politieke verantwoordelijkheid niet te gelde te maken.

Al met al kost het enorme energie om taakuitwoering door een toezichthoudend zelfstandig bestuursorgaan te controleren. Terwijl 'toezicht op toezicht' toch duidelijk van algemeen belang is. In gevallen, waarin een toezichthouder heel erg halsstarrig is wat betreft de voor de resterende politieke ministeriële controle noodzakelijke informatieverschaffing, is de vraag meer dan gerechtvaardigd of de minister niet gebruik moet maken van zijn bevoegdheid om de aanwijzing van de stichting Verzekeringskamer (ten dele) in te trekken of te wijzigen. Een toezichthoudend zelfstandig bestuursorgaan, dat het algemeen belang hoog in zijn vaandel moet hebben staan, kan niet ongestraft zijn grove gang gaan. Kortom, juist het overgebleven rijkstoezicht van uit het ministerie moet bij spraakmakende zelfstandige bestuursorganen niet worden verwaarloosd.

In het licht van het aansprakelijk stellen van de stichting Verzekeringskamer, die - als blijkt bij de affaire Vie d'Or - in haar toezicht op de verzekeringssector tekort schiet, lijkt het dan ook zaak niet te vergeten dat dit toezichthoudende zelfstandige bestuursorgaan de Staat der Nederlanden in haar kielzog mee kan trekken. Immers, mede debet aan de teloorgang van Vie d'Or is het gedrag van weliswaar beperkt politiek verantwoordelijke ministers, wat betreft hun toezicht op het reilen en zeilen van de stichting Verzekeringskamer, dat op zijn minst laakbaar kan worden genoemd. Bij taakverwaarlozing van een zelfstandig bestuursorgaan hoort een betrokken bewindspersoon namelijk resoluut in 
te grijpen in plaats van af te wachten. Het is de minister van financiën en de minister van sociale zaken in elk geval kwalijk te nemen dat zij, nu zij het bestuur van de stichting Verzekeringskamer in belangrijke mate bepalen, de kennelijk onbekwaam tot behoorlijke taakvervulling zijnde leden van respectievelijk het bestuur en de raad van toezicht niet tijdig schorsen of ontslaan.

Wrang genoeg ligt, volgens de Verzekeringskamer, een relevante reden van het falen inzake het toezicht op Vie d'Or, in het gebrek aan door de raad van commissarissen (aan de Verzekeringskamer toegespeelde) informatie. Dat is een teken aan de wand voor de invoering van, mogelijk de aansturing van zell fstandige bestuursorganen bevorderende, kwaliteitshandvesten waarin zo'n raad van commissarissen een belangrijke rol wordt aangemeten.

Ook zou meer informatie naar de Verzekeringskamer moeten vrij komen via personen die bij het toezicht zijn betrokken, denk aan accountants en anderen. Hiertoe will de Verzekeringskamer zelfs een informatieplicht opleggen. Hierbij doet het vreemd aan dat de Verzekeringskamer personen, die wettelijke geheimhoudingsplichten hebben, wel wil laten praten, terwijl zij zelf al het mogelijke in het werk stelt om zich (met referentie aan bepaalde geheimhoudingsbepalingen) daarwan te verschonen.

In steviger bodem staat de aanbeveling om een bestuurlijk boetestelsel te introduceren. Een bestuurlijke boete dient dan vooral als sanctie op het niet, niet tijdig of onvolledig inleveren van (financiële) verslagstaten en rapportages door onder toezicht gestelden. Dat is een interessante en goed uitvoerbare optie in het licht van een betere handhaafbaarheid van wet- en regelgeving in de verzekeringswereld.

Hoewel goede aanzetten daartoe worden gegeven via memoranda of understanding, gedragscodes e.d., is het - van uit mededingingsrechtelijk oogpunt - noodzaak de zelfregulerende activiteiten van het betrokken bedrijfsleven te stimuleren. Overigens wordt bij de mogelijkheden van (als overheidstoezicht aanvullende) concurrentiebeperking terecht belangrijk aandacht geschonken aan het algemeen belang van consumenten bij het voortbestaan van een verzekeringsmaatschappij. Als Vie d'Or iets heeft aangetoond, is het wel dat met het belang van polishouders niet mag worden gesold. 


\section{Geraadpleegde literatuur}

Banning, $C$.

- Porlementaire enquête bepleit naar rol Verzekeringskamerbij Vie d'Or, in: $\mathrm{NRC}, 23$ december 1994, p.11;

- De 'Bende vant Vie d'Or" wil onderste steen boven, in: NRC, 8 februari 1995, p.17.

Boele, S.A.

De Wet toezicht kredietwezen 1992, in: TVVS, nr.11, 1993, pp. 286-290.

Boer, H.L. de

- Recht, verzekering en Europa; Een impressie van een tweetal studiebijeenkomsten, in: Het Verzekeringsarchief, oktober/november 1994, pp.95-100.

Boer, H.L. de \& Mulder, H.L.

Regelgeving "algemeen belang", in: Bank-en Effectenbedrijf, nr.6, 1995, pp.29-30.

Borgius, $J$.

Rechterlijk oordeel over het vrije verkeer van wan het verzekeringsdiensten in de EEG, in: het Verzekeringsarchief, deel 64, 1987, pp.109-137.

Brevet, K.W.

De tweede richtlijn schadeverzekering en het toepasselijk recht, in: het Verzekeringsarchief, deel 68, LXIII, 1991, pp.19-32.

Broeke, P.J. van den

Toezicht op uirvaartverzekeringen; Over regulering wan een werzekeringsbranche, in: het Verzekeringsarchief, ar.2, 1995, pp. 54-62.

Caljê, $\mathrm{K}$.

Verzekeringskamer'gelijkwaardig "; Privatisering moet positie van toezichthouder versterken, in: NRC, 3 juni 1992, p.19.

Drok, E.D. \& Lambers, C.H.H.

Het protocol uitgegeven door DNB en de Verzekeringskamer, in: $\mathrm{NJB}_{3}, \mathrm{nr} .14,8$ april 1993, pp.503-504.

Drijber, B.J.

Toezicht op financiële instellingen: de 'anti BCCF-richtlijn', in: TVVS, nr.2, 1995, pp.42-44.

Eichholtz, P. \& Koedijk, K.

Het onzichtbare rendement van pensioenfondsen, in: NRC, 20 september 1994, p. 31.

Enk, W. van

- Aandeethouders en leveranciers Vie d'Or krijgen geen geld, in: NRC, 14 juni 1994, p.17;

- Controleur verzekeraars: garantiefonds polishowders, alsmede Financiën moet bestissen over garantiefonds verzekeraars, in: NRC, 8 september 1994, pp.17/21:

- Financier Kuijten verliest proces om financiële privacy, in: NRC, 9 november 1994, p.17;

- De prijs van privacy, in: NRC, 10 november 1994, p. 17.

Enk, W. van \& Schinkel, M.

- Geen afgang van Vie a'Or met scherpere comtrole, in: NRC, 10 december 1993, p.9;

- 'Verzekeringskamermoet lering trekken wit Vie d'Or', in: NRC economie, 11 december 1993;

- Polishouders Vie d'Or voor liquidatie, in: NRC, 10 februari 1994, p.20;

- Affaire HCS-aandelen woor de rechter: op zoek naar de witte viekken in de wet, in: NRC, 18 maart 1994, p.15.

Esser, A.M.W.

Nieuwe beleggingsvoorschriften voor Europese verzekeraars, in: het Verzekeringsarchief, deel 70, LXX, 1993, pp.129-143.

Eije, J.H. von 
Het overheidstoezicht op het schadeverzekeringsbedrijf in Nedertand en het wetsontwerp WTS (V); Verslag van het wetenschappelijke gedeelte van de vergadering van de vereniging voor werzekeringswetenschap op 19 april 1985 te Utrecht, in: het Verzekeringsarchief, deel 62, LXII, 1985, pp.219-239.

Eijkelenboom, H.J.W.

Mededingingsrecht en collectieve exploitatie van auteursrecht: wederzijds (on)begrip?. in: Informatierecht/AMI, nr.8, 1994, pp.147-151.

Felderhoff, I. \& Smit, A.

"Meting" vant pensioenfondsen is er al, in: NRC, 19 oktober 1994, p. 17.

Gerritsen, $\mathbf{H}$.

Overpeinzingen bij de taak en de verslagen van de Verzekeringskamer, in: het Verzekeringsarchief, deel 63, LXIII, 1986, pp.113-134.

Goslings, J.H.W.

Verslaggeving naar de Verzekeringskamer, in: NV, nr.3, mei/juni 1988, pp.87-89.

Halbertsma, T.M.

Nieuwe toezichtswetgeving voor levenswerzekeraars, in: het Verzekeringsarchief, deel $62, \mathrm{LXI}$, 1985, pp.327-334.

Huizen, Ph.H.J.G. van

- Grote en andere risico's van verzekering en toepasselijk recht volgens de tweede richtijn dienstwerrichting, in: het Verzekeringsarchief, deel 66, LXVI, 1989, pp.155-169;

- Versterking van de toezichtsbevoegdheid van de Verzekeringskamer, in: Het Verzekeringsarchief, dl. LXVII, 1990, pp.3-18.

Kalkman, W.M.A. Hendriks, R.W.F. \& Bongaarts, P.J.M.

Algemeen belang als blokkade voor de vrijheid van dienstverrichting door verzekeraars in de interne markt, in: het Verzekeringsarchief, deel 86, LXIX, 1992, pp.161-178.

Kieboom, A.

Het overheidstoezicht op het schadeverzekeringsbedrijf in Nederland en het wetsontwerp WTS (I); Op weg naar materieel toezicht?, in: het Verzekeringsarchief, deel $62, \mathrm{LXII}, 1985$, pp.181-185.

Krens, F.

Internationale inwloeden op de Nederlandse externe verslaggevingsregels, in: $\mathrm{NV}, \mathrm{nr} .3,1995$, pp.42-47.

Kroon, J.

Verzekeringskamer: papieren tijger?, in: NRC, 24 maart 1995, p.15.

Lemaire, P.A.H.

De derde generatie EG-verzekeringsrichtlijnen: Het algemeen belang als breekijzer woor de interne markt, in: het Verzekeringsarchief, deel 69, LXIX, 1992, pp.337-344.

Leuftink, A.L. \& Groffen, C.J.

Enkele kanttekeningen bij de 'stille curatele 'onder de Wtb, in: TVVS, nr.10, 1994, pp.266-269.

Lieuwma, B.

Het leek me een perfecte job: Argeloze Lieuwma liet zich in beerput Vie d'Or trekken, in: Elan, maart 1994, pp.12-19.

Lutjens, E.

Pensioenvoorzienikgenvoor werknemers; Juridische beschouwingenoverouderdomspensioenen, Zwolle, 1989, pp.335-357.

Mok, R.M.

$\sim$ Het overheidstoezicht op het schadeverzekeringsbedrijfin Nederland en het wetsontwerp WTS (III); De bescherming van de rechten van de verzekerden bij déconfitures van verzekeringsmaatschappijen, in: het Verzekeringsarchief, deel 62, LXII, 1985, pp.201-217; 
$\sim$ Wetsvoorstellen informatie-uitwisseling in financiële toezichtwetten en vervanging Win, in: TVVS, nr.8, 1993, pp.204-205;

-Raad van Europa-verdrag effecterhandel met voorwetenschap, in: TVVS, nr.10, 1994, pp. 272-273

Oostrum, H.J. van

Top-accountant hekelt beleid Verzekeringskamer, in: NRC, 25 nowember 1994, p.16.

Otterwanger, T.R

De toepassing van het mededingingsrecht in de verzekeringssector, in: TVVS, nr.9, 1994, pp.235-239.

Paradijs, S. \& Princen, M.

Vie d"Or-top lichtte geldschieters fout in; Geheime dossiers van verzekeraar leggen misstanden bloot, in: De financiële Tellegraaf, 15 februari 1994 , p. 27.

Rijnvos $_{\text {, C.J. }}$.

Het overineidstoezicht op het schadeverzekeringsbedrijfin Nederland en het wetsontwerp WTS (II); Het toezicht op De Nederlansche Bank resp. Kernpunten uit de Wik, in: het Verzekeringsarchief, deel 62, LXII, 1985, pp.187-199.

Sallomons, R.A.

Het overheidstoezicht op het schadeverzekeringsbedriff in Nederland en het wetsontwerp WTS (VI); Enige kritische opmerkingen, in: het Verzekeringsarchief, deel 62, LXII, 1985, pp. $2411-242$.

Schinkel, W.

Roestige revolvers, in: NRC, 16 juli 1994, p.10.

Schreuder, C..A.

- Publiekrechtelijke taken, private rechtspersonen; Verzelfstandiging en privatisering in de vorm wan vennootschappen en stichtingen, dissertatie RUG, serie bestuursrecht theorie en prakijk nr. 16" Deventer, 1994, pp.236-237/352-367;

- Privatisering en de geheimhoudingsplicht van de Verzekeringskamer, in: NJB, nr. 43, 2 december 1994, pp. 1476-1480.

Schutte-Veenstra, J.N.

Jaarrekeningenrecht, in: TVVS, nr.3, 1995, pp.78-79.

Stichting Verzekeringskamer

- Protocol inzake het vanaf 1 januari 1990 te voeren structuurbeleid ta.v. banken en verzekeraars, 14 september 1990, Apeldoorn/A'dam;

- Jaarverslagen 1992/1993, Apeldoorn;

- Toezicht op conglomeraten. Voor-en nadelen van 'geconsolideerd' toezicht en toezicht 'soloplus", Apeldoorn, 1992;

- Statuten stichting Verzekeringskamer, 5 augustus 1992;

- Zicht op toezicht, Apeldoorn, 1993:

- Tweede tussentijdse verslag van de Verzekeringskamer inzake Vie d'Or, 19 oktober 1994, Apeldoorn.

Tulfer, P.M.

Het nieswe toezicht op het verzekeringsbedrijf, in: het Verzekeringsarchief, deel 63. LXIII, 1986, pp.5-25.

T"weede Kamer

- Wet tot wijziging van de Wtv TK 1989-1990/1990-1991, 20884, nrs. 1-9;

- Verzelfstandiging Verzekeringskamer, TK 1988-1989, 21235, nr.1;

- Wetswoorstel bepalingen over jaarrekening voor verzekeringsmaatschappijen, TK 1992-1993. 22896 , nr.2 e.v.; 
- Wetsvoarstel inzake opneming in de Wtk, Wtw, Wtb en Wte van bepalingen betreffende de informatieuitwisseling tussen Nederlandse en buitenlandse instanties die belast zijn met het toezicht op financiële markten of op natuurlijke personen en rechtspersonen die op die markten werkzaam zijn, TK 1992-1993/1993-1994, 23170, nr.1-11/268;

- Woorstel wan wet tot vervanging Wh door de Wtw 1993, TK 1992-1993, 23199, nrs.1-2;

- Wetsvoorstel financiële voorzieningen privatisering Abp, TK 1993-1994, 23442, nr.2 е.v.;

- Wijziging Wik $1992 \mathrm{en}$ Wrv 1993 i.v.m. het versterken van het toezicht op kredietinstellingen en verzekeraars die deel uitmaken van een groep, TK 1993-1994, 23544, nrs.1-3 e.v.";

- Decemberverslag 1993 van de Algemene Rekenkamer (o. a. over verzelfstandiging stichting Verzekeringskamer), TK 1993-1994, 23555, nrs.1-4;

Wijziging Wet identificatie bijfinanciële dienstverlening 1993, "TK 1993-1994, 23656, nrs. 1-3;"

- Toezicht wan de Verzekeringskamer, onder meer op de nv-levensverzekeringmaatschappij Vie d"Or, TK 1993-1994/1994-1995, 23669, nrs.2-7/8-9;

Voorstel van de Wet toezicht natura-uitvaartverzekeringsbedrijf, TK 1993-1994, 23688, nrs. 1-3.

Velden, B. wan der

'Toezicht op bank CLBN onduidelijk', en Competentiestrijd centrale banken om Crédit Lyonnais, in: NRC, 11 augustus 1994, pp.1/11.

Verhoeven, A.

Het Protocol van De Nederlandsche Bank en de Verzekeringskamer, in: NJB, nr. 28, 5 augustus 1993, pp. $1022-1023$.

Vermaat, A.J.

Zicht op toezicht, in: het Verzekeringsarchief, deel 70, 1993, pp.65-79.

Vorst, A.C.F.

Meer openheid bij pensioenfondsen heeft risico's, in: NRC, 4 oktober 1994, p.19.

Zanden, P.M. van der \& Kam, F. de

Voorschriften ter zake van administratie en verslaggeving voor verenigingen en stichtingen, in: S\&V, 1995, pp.42-45. 


\section{Stichting Toezicht Effectenverkeer}

\section{$\$ 19.0$ Vrijheid van effectenverkeer}

De effectenhandel, als onderdeel van de vrije kapitaalmarkt, heeft een sterk internationaal karakter. Wetten en regels inzake effectenhandel omvatten een belangrijk deel Europese wet- en regelgeving. Daarin vervult de harmonisatie van het financieel (effecten)werkeer een sleutelpositie. Voor vrijmaking van grensoverschrijdend kapitaalverkeer zijn, ex art. 20 Wte jo. art. 25, vierde lid, Wte, eenduidige EG-regelgeving ter zake en, ex art. $24 \mathrm{a}$ Wite, samenwerking van nationale toezichthouders op economisch (effectenhandels)- en monetair verkeer nodig.

\section{$\$ 19.1$ Taakstelling Stichting Toezicht Effectenverkeer}

Het, op zowel de Nederlandse effectenhandel ter beurze' als de buitenbeurshandel, voor als nog enige ${ }^{2}$ toezichthoudende overheidsorgaan ${ }^{3}$ is het zelfstandig bestuursorgaan ${ }^{4}$

1. Dit is een werniming van de Wte ten opzichte van de vroegere Wet effectenhandel. Beide wethelijke regimes winden uitwoerig behandeling bij D.R. Doorenbos, Financieel strafrecht, diss. KUM, Deventer, 1952, pp. $167-251$ e.w.

2. Volgens de Mva woorstel Wte, TK 1988 -1989, 21038, nr.6, p 19, bestaat bij veranderende marktomstan dighteden de mogelijkheid een tweede toezichthouder aan te wijzen. Art. 25 Wte dat van "een of meer rechtspersonen" spreekt, biedt dalartoe basis.

3. Aldus betiteld in de Mva voorstel Wite, TK 1988-1989, 21038, nr.6; De Nota n.a.v. her verslag inzake woorstel Whe 1995, TK 1994-1995, 23874, nr.7, p.28, spreekt echter duidelijk van de STE als zelfstandig bestuursorgan.

4. Gelet op zowel de toezichtstak wan de STE als de ministeriele invloed op het stichtingsbestuur, aldus omschreven door M.R. Mok, Voorstel Whe, in: TVVS, nr.11, 1989 " pp.283-284; Overigens prefereert auteur, in navollging van W.C.L. van der Grinten die uitdnkkelijk ageert tegen het gebruik van privaatrechtelijke rechtspersonen voor de vervulling van overheidstoezicht (Asser-Van der Grinten II; Vertegenwoondiging en rechtspersoon, de rechtspersoon, Zwolle, 1991, p.172), een publiekrechtelijke vorm van zbo's. M.R. Mok, Toezicht effectenverkeer II, in: TVVS, nr.4, 1989, pp. 102-104; Ook W.J. Slagteir, Het fonds CSM wit de betsrnotering?, in: TVVS, nr.12, 1994, pp.326-327, vragt zich af "hoewel hij het theoretisch nog verdedigbaar acht, of het "wel wenselijk is dat de overheid de uitvoering van een publiekrechtelijke taak deleggert aan priwaatrechtelijke rechispersonen". 
Stichting ${ }^{5}$ Toezicht Effectenverkeer ${ }^{6}$ ex art. 25 Wet toezicht effectenverkeer ${ }^{7}$ junctisi artt. 1-5 Delegatiebesluit Wte ${ }^{8} 9$ jo. art. 2, eerste lid, statuten Stichting Toezicht Effectenverkeer ${ }^{160}$. 11

De stichting heeft, conform art. 2 Statuten STE, ten doel: de uitvoering van taken waaronder begrepen toezichtstaken met betrekking tot het effectenverkeer, in gevolge wetgeving op het terrein van het effectenverkeer, ter uitvoering van wet-en regelgeving op voornoemd terrein.

5. De stichtingsvorm is gekozen om de besluitworming binnen de instelling onafhankelijk te doen zijn wan geheel of gedeeltelijke goedkeuring van leden- of aandeelhouderswergadering. Mvt voorstel WTte. TK 1988 1989,21038 , nr. 3 , p. 13 .

6. De, onder werantwoordelijkheid van de minister van financiën door de Vereniging voor de Effectenhandel van de Amsterclamse effectenbeurs en de Vereniging European Options Exchange van de Optiebeurs -bij: ministeriële beschikking d.d. 24 januari 1989, Stcrt. 1989, 23- opgerichte, STE vervangt het vroegere trio toezichthoudende commissies. Over deze Commissie van bijstand voor de uitwoering van de Beurswet. 1914 en de Commissies van toezicht op respectievelijk optiebeurs en financiele terminmmarkt, D.R. Doorenbos, a.w., pp.223-228.

7. Wet inzake het roezicht op het effectenverkeer, 7 maart 1991, Stbl. 1991, 141, gewijz. 23 dec. 1992, Sibl. 1992, 722. Deze wet wordt ingetrokken ex art. 65 Wte 1995 als het (Gewizigd) Voorstel Wte 1995, "TK 1993-1994/1994-1995, 23874, nrs.1-3/9, kracht van wet heeft (conform EG-richtilinen treedt de Wte uiterlijk eind 1995 in werking). Zie paragraaf 19.12 inzake wetsvoorstel.

8. Besluit houdende overdracht van taken en bevoegdheden ing. art. 25 Wte aan de STE, 18 december 1991 , Stbl. 1991, 751, geldend per 15 juni 1992, Stbl. 1992, 258; Dit besluit krijgt uitwerking in de Nadere regeling toezicht effectenverkeer van de STE van 18 april 1992, Stcrt. 1992, 93, gewijzigd Stcrt. $1994,202$.

9. Pelham Trading Company bw vs. minister van financiën, CBB 17 now. 1993, 92/1960/064/201, AB 1994, 365 , m.nt. JHtudV, ook in: SEW, nr.7/8, 1994, pp.544-546, m.nt. K. Sevinga met nodige scepsis t.a.v. ondoorzichtigheid wet, toont het volgende aan. $\mathrm{Er}$ is in art. $36 \mathrm{en}$ art. 37 Wte ten onrechte geen overgangsrecht gecreëerd betreffende, ten eerste, de wijze waarop dient te worden beslist op een bezwaar dat is ingediend onder de vigeur van de voorloper wan de Wte en waarop ten tijde van vermelde inwerkingteding nog niet was beslist, en ten tweede, welk ad ministratief orgaan bevoegd is zo"n bezwaar te behamdelen. Tereclat bepaalt de rechter dat dat niet de minister van financiën, maar de STE is; Inderdaad heeft de wetgever zich hier onachtzaam betoont. Aanwijzing voor de regelgeving. 165 moet voortaan woor dergelijke slordigheden behoeden: "Bij een nieuwe regeling of wijziging van een regeling wordt overwogen of overgangsbepalingen noodzakelijk zijn" . Zie ook de meer specifieke aanwijzingen 166-170. Wat betreft overdracht wan regelgevende bevoegdheden maar de STE is aanwijzing 176 nog wan belang: "De inwerkingtreding van bepalingen betreffende $[.$. . $]$ delegatie van regelgevende bevoegdheden wordt niet geregeld. Deze bepalingen gelden vanaf het tijdstip van totstandkoming van de regeling." $\mathrm{C}$. Bormant Aanwijzingen voor de regelgeving " Zwolle, 1993, pp. 137-144/148; Overigens voorziet het voorstel voor de Wte 1995 er in (zie art. 64 Wte 1995) dat in geval voor het tijdstip van inwerkingtreding van de Wite 1995 beroep wordt ingesteld tegen een 0. g.w. de Wte genomen besluit op het beroep wordt beslist met toepassing wan het voor dat tijdstip geldende recht.

10. Statuten van Stichting Toezicht Effectenverkeer, Amsterdam, 31 januari 1992, verleden bij Lubbers en Dijk notarissen.

11. De Nederlandsche Bank nv oefent het toezicht op beleggingsinstellingen uit. Zie Dellegatiebesluit, Subl. 1990, 458, conform art. 29 Wet toezicht beleggingsinstellingen, Stbl. 1990, 380, juncto het d.d. 13 dec. 1994 gewijzigde en 1 jan. 1995 in werking getreden Besluit toezicht beleggingsinstellingen, Stbil. 1994, 886. DNB nv kan, als bestaand onafhankelijk, deskumdig en gezaghebbend toezichthouder op banken ${ }_{n}$ die nauw verbonden zijn met belegggingsinstellingen, dubbel toezicht vermijden; H.L.M. Rek, De Wtb in de praktijk, in: TVVS, nr.12, 1994, pp.321-325, toont teleturstelling over bepaalde complicaties wan de Wtb. Auteur acht de "verre van perfecte" financiële regelgeving voor reparatie vatbaar. 
Het tweede lid van voornoemd artikel geeft de doelstelling invulling als volgt: a. het toetsen van statuten en reglementen van de onder haar toezicht gestelde organisaties aan de daarvoor geldende wet- en regelgeving; $b$. het toezien op de naleving van de regels op basis van rapportage door de controleorganen van de betreffende organisaties * $\mathrm{c}$. het geven van aanwijzingen en het doen van aanbevelingen aan de onder haar toezicht gestelde organisaties; $\mathrm{d}$. het registreren van meldingen, het stellen van regels aan meldingsplichtigen en het verlenen van ontheffingen aan vennootschappen; $\mathrm{e}$. de inrichting van een secretariaat, ter ondersteuning van het stichtingsbestuur; en $f$. al hetgeen in de ruimste zin daarmee verband heeft.

Voor de uitvoering van haar taken doet de STE een beroep op haar: bestuursleden, bestuursraden en het bureau onderverdeeld in een directeur-secretaris, een sectie juridische en bestuurlijke zaken, een sectie uitwoering toezicht en een chef de bureau/voorlichtingsafdeling. 12

De mogelijkheid van delegatie, waaraan de STE haar status als effectentoezichthouder ontleent, "past in het kabinetsbeleid de uitvoering van bepaalde overheidstaken te verzelfstandigen ${ }^{*}, 1314$

In gevolge art. 25 , tweede lid, Wte vindt overdracht van bevoegdheden (volgens derde lid mogelijk met beperkingen en voorschriften) naar een rechtspersoon, die regelmatig en steekproefsgewijs ${ }^{\text {is }}$ toezicht houdt op de effectenhandel, slechts plaats als:" a. die rechtspersoon in staat is de over te dragen taken en bevoegdheden naar behoren te vervullen ${ }^{\text {t6}} ; \mathrm{b}$. de besluitworming binnen betrokken rechtspersoon zo danig is dat onafhankelijke takkuitoefening wordt gegarandeerd ${ }^{17}$; en $c$. de statuten van die rechtspersoon waarborgen dat de minister van financiën bestuurders van de rechtspersoon benoemt, en indien nodig schorst of ontslaat ${ }^{18}$.

12. Aprill 1995 luiden de bijbehorende getallen van leden en medewerkers tespectievelijk $5,2,1,4,6$ en 3 . Zie STE, Jaanterslag 1994, Amsterdam, 1995, pp.29-30.

13. Mwr voorstel Wre, TK 1988-1989, 21038, nr.3, p.12.

14. M.C.M. wan Dijk en S. Verbeek-Meinhard, Enige kanttekeningen bij het wetsvoorstel houdende regelen inzake het toezicht op het effectenverkeer, in: SEW, nr.1, febt. 1990, pp.58 73, spreken i.c. onjuist van privatisering van overhe idstaken. Bij takowerheveling naar de STE is sprake van werzelfstandiging. Dit meent ook PvdA tijdens behandeling Voorstel Whe, TK 1988-1989, 21038, nr.5, p.9.

15. Mva woorstel We, TK 1988-1989, 21038 , nr.6, p.7.

16. Pas in praktijk worden de eisen voor behoorlijke taakvervulling ter zake duidelijk.

17. Ook deze bepaling vergeet voorwarden te stellen. Wel voert de $M$ wt voorstel Wte, TK 1988-1989, 21038, $n r^{3} 3(6)$, p. 14(6), een statutaire bepaling aan, die de onafinankelijkheid van de STE moet waarborgen: "Alle bestuursleden richten zich zonder last of ruggespraak slechts naar de bellangen van het roezicht; De: beshitvorming binnen het bestun is collegiaal". Zie uiteindelijk het ongeveer overeenkomstige art, 4, tweede lid, Statuten STE; In het Eindverslag woorstel Wte, "TK 1989-1990, 21038, nr. 11, geeft de PvdAfractie wel, h.i. in de Wte onvervulde, randvoorwaarden voor aanvaandbare delegatie maar een onathankelijk orgaan: a. voldoende politiek vastgestelde regels voor taken en bevoegdheden van de toezichthouder." b. de toezichtsorganisatie wordt doon of van wege de overheid tot stand gebracht; en c. de regering is verankwoondelijk woor benoemingen. Van ministeriële zijde luidt de reactie, dat de Whe alleen niet aan de tweede eis woldoet, maar dat is ook niet nodig. Wat betreft de derde eis is, naar statutair woorbeeld, meer politieke invloed (ook op STE-deskundigheid en STE-jaarverslag/begroting) wenselijk. Wte, TK. 1989-1990, 21038, nr. 12, p. 2 .

18. Deze eis stelt de hierna te noemen $\mathrm{W} / \mathrm{mz}$ niet. 
Conform art. 25 , derde lid, Wte zijn voorschriften met betrekking tot de delegatie mogelijk. Het delegatiebesluit kent er drie. T.w.: a. ministeriële goedkeuring van informatieuitwisselingovereenkomsten tussen STE en andere toezichthoudende autoriteiten; $\mathrm{b}$. bij] gebruik van regelgevende bevoegdheden moet de STE overleg met de minister plegen; en c. de STE heeft de plicht de minister, met oog op zijn taakuitoefening, voldoende te informeren over het toezicht op het effectenbedrijf.

De minister van financiën behoudt de, van delegatie aan de STE uitgesloten, volgende bevoegdheden: a. het verlenen dan wel intrekken van erkenningen van effectenbeurzen (ex art. 25, eerste lid, Wte junctis respectievelijk art. 16 en art. 19 Wte); b. het stellen van voorschriften voor effectenorganisaties en houders van effectenbeurzen met oog op uitvoering van Europese regelgeving (ex art. 25 , eerste lid, Wte jo. art. 20 Wte) ${ }^{19}{ }^{20}$; c. het goedkeuren of afkeuren van wijzigingen in de statuten van de toezichthouder(s) op de effectenmarkten (ex art. 25 , eerste lid, Wte jo. art. 26 Wte); d. het vaststellen van regels aangaande de, in verband met de uitoefening van het toezicht op de effectenmarkt mogelijke , retributieheffing (ex art. 25 , eerste lid, Wte jo " art. 28 Wte); e. het stellen van bijzondere bepalingen in verband met uitoefening van het effectenbedrijf in een staat, niet zijnde een Europese lidstaat (ex art. 25 , eerste lid, Wte jo. art. 31 Wte); en f. het verlenen van vrijstellingen van het verbod op het aanbieden van effectenuitgifte buiten besloten kring, van informatieverplichtingen van niet ter beurze genoteerde instellingen, en van het verbod om zonder vergunning als effectenbemiddelaar of vermogensbeheerder op te treden (ex respectievelijk art. 4, art. 5, art. 9 en art. 13 Wte).

Weliswaar zijn deze ministeriële bevoegdheden, en in het bijzonder de aan de bewindspersoon toekomende bevoegdheid om de delegatie aan de STE in het ergste geval in te trekken ${ }^{21}$, niet oninteressant. Maar de STE, die via delegatie zelfs over regelgevende bevoegdheden beschikt, heeft door de flexibele grenzen ${ }^{22}$ waarbinnen zij haar bevoegdheden uitoefent grote beleidswrijheid. Gegeven deze zwaarwichtigheid, luidt de vraag waarom de STE niet bij wet instelling vindt ${ }^{23}$ of waarom zij niet alls nog een wettelijke status krijgt ${ }^{24},{ }^{25}$ De constructie dat de minister bevoegdheden heeft, die hij vrij wel per definitie via algemene maatregel van bestuur over draagt aan een toezichthoudende

19. In feite biedt art. 20 Wte de enige ministeriële instructiemogelijkheid.

20. Ex art. 25, vierde lid, Wte kan de minister ook voorschriften, ter vitvoering van EG-richtijnen imzalke het effectenverkeer, geven aan een rechtspersoon waraan Wte-taken en Wte-bevoegdheden worden gedelegeend.

21. Overigens beschouwt de CDA-fractie dat als "paardemiddel". Einduerslag voorstel Whe, TK 1989-1990, $21038, \mathrm{nr} .11, \mathrm{p} .5$.

22. Mva Wte, TK 1988-1989, 21038, nr.6, pp.27-28, acht het, ter bevordering wan flexibele regelgeving. stellen van uŕvoeringsregels door een gedelegeerd toezichthouder wenselijk wan wege de diversiteit op de effectenmarkten.

23. M.C.M. van Dijk en S. Verbeek-Meinhardt, Enige kanttekeningen bij het wetswoorstel houdende regelen inzake het toezicht op het effectenverkeer, in: SEW, nr. I, februari 1990, pp.58-73, i,h.b. pp.62-63.

24. Aldus CDA-fractie bij behandeling Voorstel Wte, TK 1988-1989, 21038, nr.5, p.8.

25. De Mva woorstel Whe, TK 1988-1989, 21038, nr.6, p.16, verdedigt de instellingsgrondslag van de STE met een beroep op "de noodzakelijk geachte betrokkenheid van de bedrajfstak" , die destijds initiatief nam tot oprichting wan de STE. 
rechtspersoon, mist motivering. ${ }^{26}$ Van uit politieke pretentie luidt het verwijt, dat de constructie "onder de maat is en van minachting voor de medewetgever getuigt" ${ }^{27}$

\subsection{TOEZICHT OP NALEVING VAN EFFECTENWET- EN REGELGEVING}

De Stichting Toezicht Effectenverkeer hecht aan het belang van "normstelling die de grenzen tussen aanvaardbaar en niet-aanvaardbaar marktgedrag aan geeft". $2{ }^{2}$ Door duidelijke normstelling is het vertrouwen van gebruikers in een steeds heviger concurrerende markt te winnen. De dynamiek van de dag drukt het stempel van veranderlijkheid op normstelling. Wel wordt regelgeving steeds meer op schrift gesteld. De toezichthoudende autoriteit acht normen terecht "alleen geloofwaardig als zij adequaat worden nageleefd" ${ }^{29}$

De stichting beschouwt het als haar opdracht deze naleving te waarborgen en, zo nodig, te verbeteren. Hierbij voelt zij zich gesterkt door de Europese belangstelling voor naleving van regels in de effectensector. "De preventieve werking, die van de verhoging (van de effectiviteit bij het toezicht op de wetsnaleving - JGLvN) uitgaat kan onder omstandigheden wellicht juist invoering van nieuwe regelgeving voorkomen." 30

Overigens realiseert de Stichting Toezicht Effectenverkeer zich, bij haar prioriteitsstelling woor wet- en regelnaleving, dat de uitwoering van controle op de naleving steeds " $\mathrm{com}$ plexer en tijdrovender" wordt. " Niet in de laatste plaats omdat betrokkenen zich tegenwoordig al in vroeg stadium van juridische bijstand voorzien.

Het toezicht staat in het teken wan het, zowel efficiënte prijsvorming als optimalle allocatie van middelen in de hand werkende, adequaat functioneren van de effectenmarkten. ${ }^{32}$ Met oog op deze doelstelling wordt het, overigens door de andere doelstelling van de Wet toezicht effectenverkeer - $t$.w. bescherming van beleggers en spaarders tegen malafide aanbiedingen, onvoldoende informatie en ondeskundig optreden - versterkte, vertrouwen en doorzichtigheid in de financiële (effecten)wereld bevorderd. ${ }^{33}$

Het toezicht van de stichting, dat "meer" en "meer rechtstreeks" ${ }^{34}$ dan de controle onder het oude wettelijke regime kan zijn, richt zich op vier toezichtsgebieden. Te weten:

26. M.C.M. van Dijik en S. Verbeek-Meinhardt, t.a.p., p.65, stellen bij bedoelde constructie, datt de minister de politiek verantwoordelijke aanspreekbuis is. De bewindspersoon moet üteindelijk de delegatie aan de STE kunnen verantwoorden. Deze ministeriele verantwoordelijkheid wordt, volgens auteurs, pas echt effectief als de bewindspersoon als uiterste consequentie in noodsituratie overgaat tot intrekking wan dellegatie of wijziging van voorwaarden daarvan. Voor het overige ontneemt de minister, door de wijze watrop hij de oorspronkelijk hem toekomende bewoegdheden hanteent, het parlement vrij wel alle mogelijkhedien tot controle achteraf.

27. Aldus PvdA tijdens behandeling Voorstel Wte, TK 1988-1989, 21038 , nr.5, p.10 en nr. 11, p.5.

28. STE, Marverslag 1993, Amsterdam, april 1994, p.6.

29. STE, Maanerslag 1993, Amsterdam, april 1994, p.6.

30. STE, Jaarverslag 1993, Amsterdam, april 1994, p.7.

31. STE, Jaarverslag 1993, Amsterdam, april 1994, p. 10

32. Mut woorstel Wie. TK $1988-1989,21038$, nr.3, p.2

33. Mwt/Mwa voorstel Whe. TK 1988-1989, 21038 , nr.3, pp.3-4 en nr.6, p.3.

34. E. de Wind, De Wet effectenhandel in praktijk, in: NV, nr.4, april 1991, pp.91-98, i.h.b. pp.92/98. 
a. de verhouding tussen de vragers en de aanbieders van het kapitaal; b. de verhouding tussen de beleggers en tussenpersonen die hen financiële diensten verlenen; $c$. de organisatie van de markt, met name de beurzen; en $d$. de verhouding tussen de beleggers onderling. ${ }^{35}$

Die stichting ziet er op toe dat het "complex van geldende regels" voor leden van erkende effectenbeurzen voor bemiddelingsactiviteiten in of van uit Nederland, en voor degenenen die orders aanbrengen bij de beursleden, "gelijkwaardig" is aan de regels voor niet-vrijgestelde, anders gezegd vergunninghoudende, effecteninstellingen. ${ }^{36}$

\section{$\$ 19.2$ Overheidstoezicht als aanvulling op zelfregulering}

Het effectenverkeer kenmerkt zich van oudsher door een hoge organisatiegraad en, naar tevredenheid functionerende, zelfregulering ${ }^{37} .{ }^{38}$ Het toezicht op hen, die lid zijn wan of aangesloten zijn bij een erkende beurs, wordt uitgeoefend door die erkende beurs zelf. Schiet dit toezicht te kort, dan beschikt de Stichting Toezicht Effectenverkeer over een aantal bewoegdheden om corrigerend op te treden.

Zo laat het toezicht door de Stichting Toezicht Effectenverkeer de eigen verantwoordelijkheid van personen en organisaties die deelnemen aan het effectenverkeer onverlet. $\mathrm{De}$ beurzen dragen zelf zorg voor de naleving van informatievoorschriften die gelden woor ter beurze genoteerde instellingen.

De níet ter beurze geregistreerde effecten(uitgifte/beheer/transactie)instellingen moeten voldoen aan de informatieverplichtingen, die - in het kader van een behoorlijke beleggersbescherming van uit het beginsel van gelijkheid tussen wel en niet ter beurze genoteerde effecteninstellingen ${ }^{39}$ - tegenwoordig in artt. 3-5 Wte junctis artt. 2-8 Beslluit toezicht effectenverkeer ${ }^{40}$ worden gesteld. Deze informatieverplichtingen, voor zover geen jaarrekening- en jaarverslagplichten voort vloeien uit art. 360 , tweede boek, BW, betreffen periodieke verslaggevingen inzake a. de financiële positie van de uitgevende instelling en $b$. de feiten omtrent de uitgevende instelling waarvan een aanzienlijke invloed op de koers van effecten van de uitgevende instelling kan uitgaan.

De Stichting Toezicht Effectenverkeer controleert de naleving van deze informatieverplichtingen. Zij gaat na of regelmatige uitgifte van jaar- en maandelijkse verslagen, kwartaal en weekverslagen plaats vindt. Sedert 15 juni 1993 moeten, al dan niet in Nederland gevestigde ${ }^{4}$, effecteninstellingen met of zonder vergunning wekelijks of per kwartaal opgave doen van eigen vermogen en van eigen middelen waarmee bepaalde risico"s

35. Mwt Wte, TK $1988-1989,21038$, nr.3, p.5.

36. STE, Jaarwerslag 1993, Amsterdam, april 1994, p.15.

37. MW/MRa voorstel We, TK 1988-1989,21038, nr.3, pp.1/10-11 en nr.6, pp. 1-2.

38. Dit beeld is te rooskleurig voor het teleur stellende 1993, het jaar watrin zelfregulering van dle effectenbeurs (met name de $A^{\prime}$ 'damse) sterk erodeent tot een "speeltuin van criminelen en knoeiers". Dit roept de vragg op of de STE niet meer werantwoondelijkheden als onafhankelijke instantie moet krijgen. $K$. Berkhout en $\mathrm{P}$. Wessels, Van Ittersum: affaires schaden imago van beurs, in: NRC, 31 dec. 1993 , p. 19.

39. Mut voorstel Wte, TK $1988-1989,21038$, nr. 3, p. 8.

40. Beskuñt roezicht effectenverkeer, 18 dec. 1991, Stbl, 1991, 750.

41. Bij rapportage aan de buitenlandse toezichthouder hoeft niet meer aan de STE te wonden gerapporteent. 
worden gedekt. ${ }^{42}$ Daarnaast ziet de Stichting Toezicht Effectenverkeer er op toe of actuele effectenberichtgeving de deur uit gaat.

Van de inlichtingenplicht is ontheffing mogelijk op grond van bij voorbeeld strijdigheid daarvan met het algemeen belang of het belang van de vennootschap. In de tweede helft van 1992 is het ene verzoek om ontheffingverlening van de periodieke informatieplicht door de STE afgewezen. ${ }^{43}$ In 1993 verleent de STE twee ontheffingen van de periodieke informatieverplichtingen. ${ }^{44}$ In 1994 komt de STE aan geen enkel verzoek om ontheffing ter zake tegemoet. ${ }^{45}$

Overheidstoezicht als aanvulling op zelfregulering laat zich als volgt illustreren. De Stichting Toezicht Effectenverkeer maakt gebruik van de rapportages van de controlebureaus of afdelingen compliance van de te onderscheiden beurzen of termijnmarkten, waaronder als meest bekende is te noemen het controlebureau van de Vereniging van de Effectenhandel van de Amsterdamse effectenbeurs ${ }^{46} .{ }^{47}$ Om de frustratie van trage ambtelijke molens te voorkomen is het essentieel dat met regelmaat van de klok rapportages worden uitgebracht. ${ }^{48}$ Volgens de stichting worden deze maandelijkse "rapportages, die dienen voor het toezicht op de beurzen, uitgebracht zonder tussenkomst van hun besturen. In geval van een opdracht van de Stichting Toezicht Effectenverkeer tot een onderzoek in een specifiek geval en bij het toezicht op niet-beursleden, vindt het onderzoek onder verantwoordelijkheid van uitsluitend de Stichting Toezicht Effectenverkeer plaats en wordt hierover dan ook alleen gerapporteerd aan de Stichting. Toezicht Effectenverkeer." 49

Door duidelijk niet ondenkbare situatie dat (al dan niet gelaagd) toezicht van verschillende kanten komt, is het noodzaak serieus met onder toezicht gestelden om te gaan. Een te verdeeld toezicht frustreert het, voor toezicht juist zo nodige, vertrouwen van onder

42. STE, Jaarierslag 1993, Amsiendam, april 1994, p.14.

43. STE, Jadrwerslag 1992, Amsterdam, 1993, p.17.

44. STE, Jaarverslag 1993, Amsterdam, april 1994, p.13.

45. STE, Jaarversilag 1994, Amsterdam, 1995, p.14.

46. Vgl. maandelijkse rapportages aan STE van afdeling compliance van de Vereniging Eunopean Options Exchange wan respectievelijk de optiebeurs en de financiële termijnmarkt Amsterdam, als mede de rappontages van de afdeling Compliance wan de agrarische termijnmarkt Amsterdam bw.

47. Over de stormachtige, belangrijke ontwikkeling van interne controle bij Nederlandse financiële instellingen, welke ontwikkeling toezichthouders als DNB nv en de STE steeds meer stimuleren, A. Wielenga, Compliance als integriteitswapen, in: Bank- en effectenbedrijf, maart 1995. pp.20-25.

48. Dit geldit over en weer. Vgl, de situatie tussen De Nederlandsche Bank nw en (effecten)beursbesturen. Het blijkt dat informatie wan de beurs te laat bij DNB arriveert. En het beurslisestuur kllaggt over traagheid in rapportages van DNB. Dat vermindert effectiviteit van optreden. Beurs en Bank met elkaar in de slag om toezich hauderschap, in: $\mathrm{NRC}_{\text {, }} 12$ sept. 1992, p. 18; Het niet goed doorkomen van, woor toezichthouders essentiele (interne controle)rapportages, doet zich extreem voor tussen de failliet gegane effectenbank Barings en de Bank of England, Een belangrijk intern controlerapport (daterend van augustus 1994). waarin reeds een waarschuwing tegen de uiteindelijk verdachte Leeson (een effecttenhandelaatr die een risilcovolle dierivatenhandel aangaat met geld var de Baringsbank waar hij in dienst is) witgaat, zegt de Bank of England nooit onder ogen te hebben gezien. D. Wittenberg; Bank of England: top van Barings overtrad de wet, in: NRC, 6 april 1995, p.18.

49. STE, Jaanverslag 1992, Amsterdam, 1992, p.5. 
toezicht gestelden. Bij voorbeeld bank Labouchere (dochteronderneming van verzekeraar Aegon), die dreigt met juridische stappen tegen de beurs omdat te veel organisaties zich bezig houden met toezicht op de effectenhandel welke organisaties bovendien elkaars bevoegdheid betwisten, toont ongenoegen over de kennelijk bij beurscontrole tot uiting komende "politieke spelletjes". ${ }^{50}$ Daarom dienen de controlebureaus van de verschillende beurzen en de Stichting Toezicht Effectenverkeer zichtbaar hun werkterreinen te scheiden. Zo lang dat niet het geval is, vreten de toezichthouders op het zelfde niveau van zelfregulering elkaar flink aan, maar bijten ook het toezicht door zelfregulerende instanties en het toezicht door een bestuursorgaan elkaar als wilde honden. En in losgeslagen toezichthouders geloven onder toezicht gestelden geen greintje.

\subsubsection{DISFUNCTIONEREN CONTROLEBUREAUS}

In 1993 constateert de STE "ernstige overtredingen" van enkele beursleden. Volgens de STE houden deze overtredingen "enerzijds verband met de verdere verscherping van de regelgeving en treden zij aan het licht door de controle op de naleving daarvan, anderzijds zijn zij het gevolg van een zich ook in de effectenhandel voordoende normvervaging" ${ }^{11}: 52$

Medio 1993 raakt het effectenkantoor Nusse Brink (allthans de directie daarvan) wegens vermeende "witwas"-praktijken in opspraak. ${ }^{53} \mathrm{Het}$ kantoor wordt failliet verklaard. ${ }^{54}$ Bovendien wordt het effectenkantoor verduistering van effecten, bedriegelijke bankbreuk ${ }^{55}$ als mede heling ${ }^{56}$ ten laste gelegd. Het openbaar ministerie onderzoekt, naast verduistering en witwaspraktijken, ook de mogelijkheid van misbruik van voorweten-

50. Aldus Laboucheres bestuursvoorzitter J.B.M. Streppel, geciteerd in: Bank Labouchere ligt in dhe cinch met effectenbeurs, in: NRC, 19 april 1995, p. 20. I.h. b. ondememing Labouchere Clearing, die transacties afwikkelt op de effectenbeurs, heeft last wan het door haar gewraakte gebrek aan eenheid in toezicht. Sitreppel schampert: "De effectenbeurs vind dat ze het primat heeft bij het toezicht op theffecterhandel. Ook de optiebeurs schijnt onder dat toezicht te vallen."

51. STE, Jaarverslag 1993. Amsterdam, 1994, p.8.

52. M.R. Mok. Jaarverslag 1993 STE, in: TVVS, nr.8, 1994, pp.209.210, ziet samenhang tussen beide elementen. $Z$.i. leidt een scherpe controle "tot minder overtredingen dan een slappe maar mogelijk wet tot meer geconstateende overtredingen ${ }^{n}$.

53. Hierover Handelaar geschorst on Nusse Brink-zaak, in. NRC, 21 jan. 1994, pp. 1/11; De STE doet onderzoek naar de persoonlijke banden van een werknemer, in dienst bij optie- en temijnhandelatur Geldeman, met Nusse Brink.

54. Curator R.J. Graf Sohinmelpennick erkent 8,6 miljoen gulden (en betwist daarnaast 4 miljoen gulden) aan vorderingen van crediteuren. Vorderingen van Nusse Brink erkend, in: NRC, 24 febr. 1995 , p. 14.

55. Beurs legt Nusse verduistering ten laste, in: NRC, 26 febr. 1994, pp.17-18. Hoewel de Nusse Brinkactiviteiten (o.a. gebruik van brievenbusmaatschappij, het optreden van een stroman, het opsparen van effectennota's, en contante kasstortingen) een beeld van witwassen oproepen, is het de vraag of dit ook strafrechtelijk walt aan te tonen.

56. K. Berkhout en P. Wessels, Nusse-directewr nu ook verdacht wan witwassen, in: NRC, 18 maart 1994 , p. 13 . 
schap. ${ }^{57}$ In de zaak Nusse Brink worden uiteindelijk maximale geldboeten en gevangenisstraffen geëist. ${ }^{585960}$ In de langdurige rechtszaak worden zowel de beursvoorzitter als enkele medewerkers van het controlebureau van de beurs eind november 1994 door de rechter-commissaris te Amsterdam gehoord. ${ }^{61}$ Hun getuigenverklaringen moeten duidelijkheid verschaffen over de rol die de beurs speelt bij de ondergang van Nusse Brink.

Naar aanleiding van de Nusse Brink-affaire liggen de controlebureaus namelijk flink onder vuur. ${ }^{62}$ De kritiek richt zich op zowel de tekort schietende kwaliteit van de rap-

57. Zie interessante beschrijving, gebaseerd op politieverhoren in de Nusse-zaak, wan de uiteindelijk mislukte poging tot misbruik van voorwetenschap (inzake de ondergang van Medicopharma) door Nusse Brink Commissionains, door K. Berkhout en P. Wessels, Nusse Brink en Medicopharma of de mislukte sprong maar woren, in: NRC, 13 okt.. 1994, p.21: N.a.w. het opsporingsonderzoek naar beursfraude bij Nusse Brink komt het openbaar ministerie op het spoor van thet failliete farmaceutisch concern Medicopharma, warvan waarschijnlijk directeur L.H. misbruik van voorwetenschap heeft gemaakt. Nusse Brink koopt eind 1991 woor eigen rekening en woor cliènten een groot deel aandelen en obligaties Medicophanna. Dit geschiedt tegen goedkoop tarief, omdat Medicopharma bijna failleert. De aankoop wordt gedaan in de verwachting dat, na betaling van alle schuldeisers van Medicopharma, een uitkering zou resteren voor obligatiehouders. Deze werwachting vindt basis in geheime unformatie van de voormalig financieeldirecteur van Medicopharma. Daarom verdenkt justitie L.H. en onderzoekt zij de handel in aandelen en obligaties Medicopharma door Nusse Brink. Aldus K. Berkhout en P. Wessels, Beursfroude vermoed bij Medicopharma "Institie onderzolk misbruik voonwetemschap, in: NRC, 4 febr. 1995, p.17.

58. Celstraf en geldboetes geëist in HCS-zaak en "Rechtsgang belemment financiering Begemann", als mede P. Wessels, Justitie geffi zedensichets beurs, in: NRC, 24 mamrt, pp.1/17.

59. De Commissie van orde legt, als tuchtrechtelijk beursorgaan, de zwaarste straf -t. w. levenslange schorsing-aan betiokken directeuren op. K. Berkhout en P. Wessels, Zeer zware straf beurs voor Nusse Brink. in: NRC, 6 mei 1994, p. 1 ; Na deze primeur wan levenslange uitsluiting van beurslidmaatschap die Nusse Brink ten deel valt, past heit tuchtcollege van de Amsterdamise effectenbeurs de straf van definitieve uiltsluiting trouwens ook toe bij directeur J. Besse van het failliete effectenkantoor Regio Effekt (dat miljowenenverliezen op transacties voor eigen rekenung gedeeltelijk aanzuivert met gelden die cliënten voor beleggingen aan het kantoor hebben toevertrouwd). Tevens wordt cen maximale geldboete van 500.000 gulden opgelegd.

60. Volgens H. de Doelder verdient het tuchtrecht wan de Vereniging voor Effectenhandel aanpassing. De kritiek van Doelder spitst zich toe op de samenstelling van zowel de Commissie van orde (gewormd uit leden wan het beursbestuur, terwijl ook de te behandelen klachten worden aangedragen door het dagelijks bestuur van de beurs) als de Commissie van beroep (benoemd door het zelfde beursbestuur dat ook al deels als aanklager en deels als rechter in eerste instantie fungeert) en op de beslotenheid van de zittingen van de beurscommissies. Over de bijdrage van De Doelder in het boek ondler redactie van. A.B. Hoogenboom, V. Mul en A. Wielenga. Fünanciële integriteit, uitgave Stichting Maatschappij en Politie, Arnhem. 1995. Zie ook J. Alberts., 'Tucktrecht Beurs wergt aanpassing', in: NRC, 23 maart 1995, p.19.

61. X. Berkhout, Bewrswoorzitter getwigt in zank tegen Nusse Brink, in: NRC, 17 sept. 1994, p.13.

62. P. Wessels, Curator Nusse: toezicht faalde, in: $\mathrm{NRC}_{\text {, } 22}$ febr. 1994, p.17; De A'damse effectenbeurs leest het eindrapport wan de curator anders. Zie Beurs ontkent falend roezicht bij Nusse Brink, in: NRC, 24 febr. 1994, p. 19. 
portages ${ }^{63}$ als het constante gevaar van vermenging van belangen van de registeraccountants werkzaam bij de controlebureaus met die van de beursbesturen ${ }^{64}$. ${ }^{65}$

De kritiek weegt zelfs zo zwaar dat het, in de ondergang van Nusse Brink meegesleepte ${ }^{66}$, effectenkantoor Van Meer James Capel begin 1995 voomemens is een miljoenenclaim in te dienen bij de Amsterdamse effectenbeurs wegens falend toezicht op het faillissement van commissionair Nusse Brink. ${ }^{67}$ Mede ten gevolge van een kennelijk niet toereikend beurstoezicht lijdt de dochteronderneming van Van Meer James Capel, te weten Van den Broek, een verlies van 4,6 miljoen gulden. De verbolgen effectenfirma: verwijt de controlebureaus te beperkte controle: hoewel de beurs reeds eind 1991 weet heeft van de risicovolle effectentransacties van Nusse Brink, vindt van af voorjaar 1992 tot april 1993 geen enkele controle meer plaats. Ook na de officiële ontdekking van het frauduleuze handelen van Nusse Brink (voorjaar 1993) duurt het nog enige maanden voordat de beurs een nieuw onderzoek instelt.

De Vereniging voor de Effectenhandel neemt de algemene kritiek op controlebureaus serieus. Haar reactie, na overleg met de STE, omvat maatregelen ter verscherping van de controle op de niet-effectenkredietinstellingen ${ }^{68}$, d.w.z. de kleine beursleden. Sinds 1 januari 1994 moeten beursleden, met grote regelmaat d.w.z. in elk geval maandelijks,

63. Zo zouden werknemers van controlebureaus "well goed kunnen rekenen maar niets afweten wan de handel". Zie Kritiek op beurstoezich laait op; STE buigt zhich over optreden beurs in affaire-Musse Brink, in: NJB, 28 sept. 1993, p.14.

64. K. Berkhout en P. Wessels, Maak misbruik van voonwetenschap openbaar, in: NRC, 18 sept. 1993, p.9. Auteurs willen de controlebureaus financieel onathankelijk van de beurzen maken en, in alle gevallen, rechistreeks onder de STE plaatsen; Deze gedachte leeft meer en meer. Immers, de Amsterdamse effectenbeurs stat op het punt te veranderen van een vereniging van beroepsgenoten in cen bedrijf met aandeelhouders. Daarvan blijft de Vereniging voor de Effectenhandel de eerste drie jaar van het bestalan enig gandeelhouder. Voor de periode na die drie jaar geef de reorganisatie, die het voordeel heeft dar effectenbeurs en optiebeurs dan toch kumnen integreren, onzekerheid over aandeelhouders. Daamaast wordt de positie van thet controlebureau van de effectenbeurs onduidelijk. Behoudt het controlebureau van de effectenbeurs hawr oude plaats dicht bij de markt of is luet beter het bureau onder te brengen bij de STE. J. Alberts, Beurs wordt omgevormid tot bedrijf, in: NRC, 311 mei 1995, pp.1/19; Tijdens een kamerdebat over het voorstel Wte 1995 laat minister Zalm doorschemeren dat de afbalkening van taken en bevoegdheden tussen STE en controlebureau nadere bestudering krijgt en dat daarbij niet wordit uitgesloten dat overheveling van bepaalde taken (bij voorbeeld accountantsdiensten) naar de $\$$ volledige takovermame door de STE. Zolm overweegt meer armilag beurswaakhond, in: NRC, 14 juni $1995, \mathrm{p} .21$

65. Uit een andere -in het buitenland spelende- omvangrijke zaak, t.w. het debâcle van de Britse Baringsbank veroorzaakt door onvoorzichtige en grootschalige derivatenhandel die door tekort schietende interne controle miet tijdig een halt wordt toegeroepen, blijkt ook ondubbelzinnig dat het cruciaal is de functie van toezicht van andere functies te scheiden. Debet aan het faillissement van de Baringsbank is namelijk een effectenhandelaar, die zijn eigen handel mag controlenen en wiens vrouw bovendien werkt bij het interne controlebureau waardoor zijn dubieuze handel wordt gedekt en niet opwalt.

66. Van Meer James Capel sluit met Nusse Brink haussepremie-opties af. Maar, als de koersen stijgen in plaats van dalen waatop Nusse Brink speculeert, kan Nusse Brink de daaraan verbonden verplichtimgen niet meer nakomen. Wegens deze deal met Nusse Brink wordt de directeur van de dochter van Van Meer James Capel ook nog op non-actief gezet.

67. Elfectenhüs wil miljoenen claimen bij beursbestuwr, in: NRC, 6 jan. 1995. p. 14.

68. Effectenkredietinstellingen vallen onder het bancair toezicht wan De Nederlandsche Bank $n v$. 
het controlebureau "een overzicht geven van hun solvabiliteit (het eigen vermogen als percentage van het balanstotaal) en de liquiditeit (de hoeveelheid geld in kas)". Voorheen werden deze zgn. 's \& 1-staten' slechts per kwartaal overlegd. Andere nieuwe richtlijnen inzake financieel toezicht zijn: a. baisse-overeenkomsten moeten voortaan schriftelijk en gedetailleerd worden vastgelegd; b. premieovereenkomsten, walarbij beursleden onderling aandelen op termijn kopen/verkopen, gaan tot het terrein van de EOE-optiebeurs behoren; c. beursleden moeten jaarlijks een accountantsverklaring overleggen ${ }_{*}^{*}$ en d. beurslid, accountant en controlebureau sluiten in de toekomst een tripartiete overeenkomst. ${ }^{69}$ Laatst genoemde maatregel is mogelijk een oplossing woor het bekende probleem, dat controlebureaus niet altijd alle relevante stukken kunnen inzien. ${ }^{70}$ Effecteninstellingen beroepen zich meer dan eens op de Wet persoonsregistraties. Argument daarbij is dat financiële instellingen door cliënten aansprakelijk kunnen worden gesteld als zij al te lichtvaardig privégegevens verstrekken. Dit is helaas vaak een oneigenlijk argument. Het beroep op de Wpr beoogt meestal bewerkstelliging van een 'voordeur-controle'. M.a.w. de beurscontroleurs blijven "buiten" wachten op ontvangst van de rapportages van de interne accountantsdiensten. ${ }^{71} \mathrm{Bij}$ vermoeden, dat een dossier incompleet is, kan het controlebureau well - na een daartoe door de Stichting Toezicht Effectenverkeer gegeven formele onderzoeksopdracht - betrokken bescheiden gaan halen of kopiëren. Maar dat kost tijd.

De teleurstelling van de Stichting Toezicht Effectenverkeer over het optreden van in het bijzonder het controlebureau van de Amsterdamse effectenbeurs zorgt dus voor de nodige maatregelen. De stichting toont dan ook tevredenheid ter zake. De positie van het controlebureau van de effectenbeurs wordt versterkt door personeelsuitbreiding ${ }^{72}$ en de mogelijkheid om, via een opdracht van de STE, bij onderzoeken juridische belemmeringen te doorbreken. Al met al beschouwt de stichting het "als één van haar kerntaken de werkzaamheden van de controlebureaus (waarvan zij immers effectief gebruik kan maken JGLvN) intensief te volgen en zo nodig te coördineren". ${ }^{73}$

Steviger in de schoenen dan voorheen begint het controlebureau van de Amsterdamse effectenbeurs begin februari 1995 dan ook., met oog op eventuele aangifte bij justitie, aan een onderzoek naar mogelijk misbruik van voorkennis bij de handel in aandelen van het beroepskledingfonds Ehco KLM (d.i. Eerste Haaksbergsche Confectie Onderneming Kan

69. Beursbestuur verscherpt toezicht; Op hoeklieden en kleine effectewhuizen. in: NRC, 21 dec. 1993, p.17; STE, Jaarverslag 1993, Amsterdam, april 1994, p.10.

70. Hierower K. Berkhout, Nalotigheid ING bijl aan wortel wan het beurstoezicht, in: NRC, 14 dec. 1993 , p.18.

71. Overigens speelt deze moeilijkheid inzake voordeur-controle vooral bij het beurstoezicht op de gróte banken. Zie Beurs wil controle op 'groorbanken', in: $\mathrm{NRC}, 11 \mathrm{dec} .1993, \mathrm{p} .16$.

72. Met extra menskracht wordt het mogelijk het toezicht te versterken. Het toezicht krijgt impulsen op drie fronten. Ten eerste, de reguliere controle, d.i. het volgen wan handel en wandel van beursleden, vergroot. Ten tweede, de bijzondere controle, vooral op zgn. baisse-posities, wordt meer leven ingeblazen. Ten dende, het toezicht op misbruik van voorwetenschap wordt verhevigd. Aldus Controlebureau beurs intensiveert toezicht op handel, in: NRC, 30 jan. 1995, p.13.

73. STE, Jaarversiag 1993, Amsterdam, april 1994, p.6. 
Langer Mee). ${ }^{74}$ Het controlebureau verricht dit onderzoek in opdracht van de Stichting Toezicht Effectenverkeer. Naar aanleiding van het uit dat onderzoek gerezen en op grond van de door het controlerend orgaan van de EOE optiebeurs aan de STE verschafte informatie ${ }^{75}$ versterkte vermoeden, dat bedrijfsfunctionarissen van de Haagse handelsonderneming Borsumij Wehry met voorkennis hebben gehandeld in aandelen van Ehco KLM, doet de STE aangifte bij justitie. Daarna wordt bekend, dat de ECD ${ }^{76}$ een onderzoek ter zake in stelt. ${ }^{n}$ Het onderzoek richt zich vooral op het vermoeden van handel met voorkennis in aandelen van eigen bedrijf. Met name het pensioenfonds van Borsumij Wehry wordt verdacht van handel in eigen aandelen, waarbij (pensioenfonds)opdrachtuitvoerders waarschijnlijk over geheime interne informatie over het bedrijf hebben beschikt. ${ }^{78}$ Tevens is te bezien of bepaalde functionarissen van het Haagse handelshuis

74. Onderzoek beurshandel in Ehco KLM; Vermoeden beursfraude, in: NRC. 8 febr. 1995, p. 17. De zaalk ligt als volgt. Borsumij Wehry neemt zich voor Ehco Kleding over te nemen. Op gegeven moment llaten de aandelen uit het textielfonds, waarin doorgaans geen of nauwelijks handel wordt gedaan, een ongewoon grote prijsstijging en opmerkelijke hoge omzet zien. N.a.v. de prijsstijging, flimk te weeg gebracht daor een drietal transacties die de koers opdrijven (die vrijdag 3 febr. 1995 plaats vinden, terwijl Borsumij pas op mandag 6 febr. 1995 de overname wan Ehco bekend maakt), schorst de Commissaris voor de Notering tijdelijk de handel in Ehco KLM op. Naderhand blijkt de commissaris de noteringen in het Ehcofonds echter niet door te halen, maar te handhaven. Nadat Borsumij enige dagen na de schorsing een bod doet op alle uitstande Ehco-aandelen, stijgt de koers pijlsnel. De dagomzet is dan ongeẽvenaard groot.

75. Optiebeurs lichte STE ook in over Borsumij, in: NRC, 6 mei 1995, p.14.

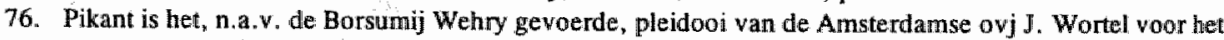
reeds in een vroeg stadium inschakelen wan de ECD in voorkenniszaken ten einde te voorkomen dat bewijsmateriaal bij begin van fraudeonderzoek woortijdig verdwijnt. 'ECD direct inschakelen byj onderzoek beursfraude ${ }^{*}$ in: $\mathrm{NRC}, 18 \mathrm{mei} 1995, \mathrm{p} .25$; Deze, trouwens stevig aan zelf fregulering tornende (ower verbolgenheid van de beursvoorzitter daarover $\mathbf{H . J}$. wan Oastrum, Baron van Ittersum wil baas in eigen beurs blijen, in: NRC, 30 mei 1995, pp.17/21), gedachte is de STE ook toegedaan. Het sneller in actie komen van de ECD levert mogelijk werhoging van onderzoeksefficiency en verkorting van onderzoeksduur op. Aldus STE-directeur E.E. Canneman, geciteerd in: 'Bewrsfraude vergt sneller onderzoek', in: NRC, 24 mei 1995, p.25; Zo lang de ECD geen uitbreiding ondergat, lijkt bovenstaand betoog echter van alle zin ontdaan. Overigens kampt kennelijk niet alleen de $\mathrm{BCD}$, maar ook het $\mathrm{OM}$ met capaciteitsproblemen (en deskundigheidsproblemen). Daarom richten de Tweede Kamerleden Wittogeen-Hevinga (PwdA), Hoogervorst (VVD), Schimmel (D"66) en Smits (CDA) zich in een gezamenlijk schirijuen tot de ministers van financiên, justitie en economische zaken met de vraag om opheldering over mogetjike toename van de georganiseerde fraude op de financiële markten en eventuele opzet vam een ministerieal aktieprogramma ter zake. In het bijzonder informeren de kamerleden naar de in dit kader vereiste hoeveelheid menskracht en deskundigheid en of deze voldoende aanwezig is bij het controlebureau van de effectenbeurs, de STE, de ECD en het OM. Kamer wil meer inzet strijd tegen de beursfraude, in: NRC. 30 mel 1995, $\mathrm{p}_{\mathrm{m}} 17$; I. Alberts en M. Tamminga, Toezich op beurshandel onder scherpe kritiek, in: NRC. 31 mei 1995, p.15, laten er terecht geen twijfel over bestaan dat de overheid personeelsapparaat en expertise wan het $O M$ diringend moet uitbreiden. Juist een reële pakkans en het uitzicht op hoge sancties kunnen een afschrikkende werking op potentièle plegers van beursfraude hebben.

77. ECD onderzoek bij Borsumij, in: NRC, 3 april 1995, p. 10; J. Alberts, Fraude Borsumij is een Klasvieke zaak, in: $\mathrm{NRC}_{\text {, }} 4$ april 1995, p.21, verbaast zich over het feit dat, terwijl met veel grootschaliger zaken niets is gedaan, juist deze zaak wordt opgepakt. Z.i. kan er "niet meer dan een paar duizend gulden aan de gewraakte transacties zijn verdiend. Dat is weinig gell voor het grote risico (ontslag, celstraf, boete) dat de Borsumij-functionarissen hebben gelopen".

78. Onderzoek justitie naar pensioenfonds van Borsumij, in: NRC, 25 aprill 1995, p.13. 
Borsumij Wehry ${ }^{79}$, die met regelmaat de beursregels inzake voorkennis hebben overtreden, zijn vrij te pleiten van handel (via privé-transacties met warrants) met voorwetenschap. Komt het tot een zaak, dan levert die mogelijk broodnodige jurisprudentie inzake handel in eigen aandelen met voorkennis van koersgevoelige informatie op. ${ }^{81}$ Ten dele kan daarbij worden terug gevallen op de rechterlijke uitspraken inzake de eerste voorkenniszaak, t.w. de HCS-affaire (zie paragraaf 19.6.1). ${ }^{82}$

\section{\$19.3 Stichting Toezicht Effectenverkeer als gesubdelegeerde wetgever}

In gevolge art. 18 Wte ${ }^{83}$ kan de stichting "met het oog op een adequate functionering wan de effectenmarkten en de positie van de beleggers op die markten voorschriften geven aan de houder van een effectenbeurs met betrekking tot de voor die effectenbeurs te hanteren regels, hun toepassing of de controle op de naleving van deze regels". \$4 Het karakter van deze bevoegdheid is niet voor iedereen eenduidig. ${ }^{86}$ Bovendien is de betekenis van bedoelde bevoegdheid niet gering. Door de algemene bewoording van art. 18 Wte als mede het strafrechtelijk sluitstuk van art. 18 Wte ex art. 1 , aanhef sub 2 , WED, krijgt de - nota bene op privaatrechtelijke leest geschoeide - regelgevende toe-

79. Hett handelshuis wordt overgenomen door concurrent Hagemeyer. Is die overname een maal feit. dan treden de van woorkennis verdachte bestuumsleden J. Noordam en A. van der Graaf af. J. Alberts, Borsumiji en Hagemayer; samengaan lange droom, in: $\mathrm{NRC}_{\text {, }} 15$ mei 1995, p.11.

80. J. Alberts, Top Borsumij centraal in voorkennis affaire, in: NRC, 27 april 1995, p. 19; J. Alberts, Top Borswhij wijs beschuldigingen af, Onderzoek noar misbrukik voorkenmis, in: NRC, 28 april 1995, p.13.

81. De adwocaten L. Spigt en G. Hoff (Loeff Claeys Verbeke) nemen al snel een voorschot op pleidooien in een eventuele rechtszaak ter zake. Zij maken duidelijk dat de betrokken Borsumij-bestuurders steeds grotere schade oplopen door het te voorbarig en te sterk in de publiciteit gegooide strafrechtelijk onderzoek naar beurshandel met voorkennis. Daarom willen zij het openbaar ministerie, en claarmee de Nederlandse staat, "wolledig aansprakelijk" voor die schade stellen. Daamaast woeren de advocaten an dat het nog twijfelachtig is of sprake is van misbruik van voorwetenschap. Zij spreken slechts van "niet-strafbare voorwillenschap". En ook vechten zaji an dat de, in hei bezit vian de Borsumij-top zijnde, informatic merkbar effect op het verloop van de koers heeft en bestempelen zij de zaak-Borsumij bescheiden als een a-typische zaak. J. Alberts, Borsumij wil schade op het OM verhalen, in: NRC, 19 mei 1995, pp.1/14; Find mei 1995 houden de advocaten ook de STE verantwoordelijk voor de schade die onstaat doon "ernstige tekortkomingen" in het onderzoek van het controlebureau, in welk rapport volgens beiden "geen enkele harde conclusie wondt geformuleend". Aldus geciteerd door J. Alberts, STE eist opheldering over beschuldigingew Borsumij-bestuurder, in: NRC, 3 juni 1995, p. 19.

82. 1. Albers en M. Tamminga, Borsumij in het wotspoor van Begemonn, in: NRC, 2 mei 1995, p. 17.

83. Vgl. regelgevende bevoegctheid van de STE ex art. 8 , derde lid, Wmz.

84. Deze bepaling impliceert voor de minister een algemene instructiebewoegdheid. Indien nod ig zal hij deze, aan de STE gedelegeerde, bevoegdheid intrekken om vervolgens opnieuw zêlf bevoegd te zijn tot het geven varl controlewoorschriften.

85. Art. 18 Wte wordt wel als grondslag gezien voor het opstellen van een zgn. Regeling woor opentoare armbiedingen. Daarower $\mathbf{J}$.W. Winter, Herzlening van de Fusiecade naar Tiburgs model, in: TVVS, nir. 12, 1994, pp. 316-320.

86. D.R. Doorenbos, a.w., p.232, vindt de bevoegdheid ex art. 18 Wte "hybridisch wan aard". Afhankelijk van algennene of individuele strekking van een voorschrift is sprake van hetzij een regelgevende hetzij exen beschilkende bewoegdheid. 
zichthouder Stichting Toezicht Effectenverkeer een "disproportioneel machtsmiddel" in handen "waarvan menig (gemeentelijk of provinciaal) wetgever slechts kan dromen" ". Conform de artt. 3/5/6/7/10/11 Wte treedt de stichting ook anderszins op als gesubdelegeerd wetgever. Voor zover deze gellede normstelling onder art. 1, sub 2, WED valt, zijnin de voorschriften van de stichting strafrechtelijk gesanctioneerd. De gedragsregels van de Nadere regeling toezicht effectenverkeer van de Stichting Toezicht Effectenverkeer ${ }^{2}$, die berusten op art. 7, eerste lid, jo. art. 11, eerste lid, Wte, vallen daarmee tevens onder het strafrechtelijk WED-regime. Aanbevolen is "niet per definitie alle gedragsregels uit de Nadere regeling toezicht effectenverkeer strafrechtelijk te sanctioneren. Bij een weloverwogen 'criminaliseringspolitiek' kan per concrete gedragsregel worden bezien of die voldoende scherpte bezit om te kunnen functioneren in een strafrechtelijke context. De meer deontologische regelgeving ware dan te handhaven met behulp van administratiefrechtelijke en/of civielrechtelijke middelen. Dit voorstel zou kunnen worden gerealiseerd door overtreding van voorschriften, gesteld bij of krachtens artt. 7, eerste lid, en 11 , eerste lid, van de Wte niet (als nu) per definitie alle tot economische delicten bestempelen, maar slechts voor zover aangeduid als strafbaar feit." ${ }^{\circ}$ Daarmee moet een einde komen aan de, tot op heden veelal in voorschriften van de STE, die waarschijnlijk meer met civiel recht dan strafrecht bekend is, voorkomende vage delictsomschrijvingen die niet prakticabel zijn. Aldus worden het lex certa-beginsel en, uiteindelijk, de rechtshandhaving gediend. ${ }^{90}$

De Stichting Toezicht Effectenverkeer oefent de regelgevende bevoegdheden en andere, door de minister aan haar gedelegeerde, taken en bevoegdheden "als eigen taken en bevoegdheden" ${ }^{91}$ uit.

\section{$\S 19.4$ Vergunningverlening, -wijziging en -intrekking}

Een belangrijke taak van de Stichting Toezicht Effectenverkeer is het, onder openbaarmaking er van ${ }^{92}$, verlenen van een (mogelijk voorwaardelijke of beperkte) vergunning om als effectenbemiddelaar of anders vermogensbeheerder op te treden. ${ }^{93}$ Aanvrager komt in aanmerking voor die vergunning, als hij aantoont dat hij voldoet aan de gestelde eisen

87. D.R. Doorenbos, a.w, P. 250 .

88. Nadere regeling toezicht effectenverkeer, ter witvoering van de artt. 2/6/11-15/20-23 Bte, Stcrt. 15 mei $1992,93, \mathrm{pp} .10-12$, ten dele gewijzigd als aangegeven in Stcrt. 20 okt. 1994, 202, p.6.

89. D.R. Doorenbos, Nieuwe strafbepalingen inzake het effectenverkeer, in: TVVS, nr.7, 1993, pp. 169-173, i.h.b. p. 173; Vgl. D.R. Doorenbos, a.W., pp.446-447/510.

90. D.R. Doorenbos, a. w , pp. 250-251. Auteur merkt tereclut op, dat de vereiste ministeriële goedkeuring van STE-voorschriften wan algemene strekking principiële bezwaren tegen dergelijke geprivatiseerde wetgeving grotendeels wegneent.

91. Mva voorstel Wte, TK 1988-1989, 21038, nr.6, p.2.

92. Art. 35 Wte bepaalt: Van de verlening van een vrijstelling, vergunning, erkennimg, ontheffing en de intrekking daarvan wordt mededeling gedaan in de Stalscourant.

93. Sinds mei 1994 moeten ook handelaren in termijncontracten op valuta's, $t$. w . foreign exchange-contracten (forex-contracten) een verguruning aanvragen. Louche termijinhandel dupeent weer particuliere beleggers, in: NRC, 26 mei 1994, p. 20 . 
wan deskundigheid als mede betrouwbaarheid, financiële waarborgen, bedrijfsvoering en aan het publiek te verstrekken informatie (ex respectievelijk artt. 6-9 Wte en artt. 10-13 Whe junctis artt. 9-25 Besluit toezicht effectenverkeer ${ }^{94}$ ).

Effectenbemiddelaars, die zijn aangesloten bij een organisatie waarvan de leden toegang hebben tot een erkende effectenbeurs, krijgen ex art. 8, eerste lid, Wte mogelijk vrijstelling van het in art. 6 Wte vervatte verbod om zonder vergunning als effectenbemiddelaar in of van uit Nederland diensten aan te bieden of te verrichten voor natuurlijke personen of rechtspersonen die niet behoren tot een besloten kring. ${ }^{95}$ Houden degenen, die vrijstelling van vermelde vergunning hebben, zich niet aan de door betrokken beurs gestelde reggels van de organisatie waarvan zij lid zijn, dan kan de Stichting Toezicht Effectenverkeer conform art. 8, derde lid, Wte ${ }^{96}$ aanwijzingen geven aan die organisatie dan wel de houdler van de betreffende effectenbeurs met betrekking tot een door deze jegens de effectenbemiddelaar te volgen gedragslijn.

Indien nodig gaat de Stichting Toezicht Effectenverkeer, ex art. 14 Wte, over tot intrekking wan een verstrekte vergunning. Hierbij stelt zij mogelijk een termijn voor de afwikkeling van bestaande lopende overeenkomsten.

Een effectenbemiddelaar hoeft, na daartoe gedaan verzoek, niet te voldoen aan vermelde wereisten, indien hij aantoont dat hij daaraan redelijkerwijs niet volledig kan voldoen en de doelstellingen van de Wte anderzins voldoende worden bereikt (ex art. 7, tweede lid, Wte). Een wijziging in de situatie van de effectenbemiddelaar kan echter vergen, dat wél aan alle vergunningvereisten moet worden voldaan. De Stichting Toezicht Effectenverkeer gaat dan over tot wijziging of intrekking van haar aanvankelijke toestemming(sbeschikking).

Ter voorkoming van het feit, dat instellingen onder de vlag van verkregen vergunningen effectenwet- en regelgeving ondermijnen, wordt medio 1992 aanvang gemaakt met een jaarlijkse reguliere controle bij vergunninghoudende instellingen. ${ }^{97}$ Deze controle leidt vooral tot bijstellingen betreffende de inrichting van het administratieve systeem en de (bepaling van de) hoogte van het eigen vermogen. ${ }^{98}$

In 1992 heeft de STE 4 aanvragen voor een vergunning gehonoreerd; Bovendien zijn 9 wergunningaanvragen door beleggingsgiro's gedaan. ${ }^{99}$

In gevolge art. 15 Wte houdt de stichting een, bij wet ingesteld openbaar ${ }^{100}$, register, van vergunningverlening en -intrekking bij. Eind 1992 staan 48 effecteninstellingen met vergunning en 674 effecteninstellingen met vrijstelling geregistreerd. ${ }^{101}$ Op 31 december 1993 telt het register 50 vergunninghouders en 850 effecteninstellingen met vrijstel-

94. Beslawit roezicht effectenwerkeer, 18 dec, 1991, Stbl. 1991, 750.

95. Zie ook Vrijstedlingsregeling Wte, Stcrt. 25 maiart 1992, 63.

96. Wat betreft vermogensbeheerders geldt idem dito art. 12 , derde lid, Wie junctis arti. 10-11 Wite.

97. STE, Jaarverstag 1992, Amsterdam, 1993, p.18.

98. STE, Jaarversiag 1993, Amsterdam, april 1994, p.14.

99. STE, Jaarversiag 1992, Amsterdam, 1993 " p.18.

100. Registratielicamer, Jaarverslag 1989-1991, Rijswijk, 1993, p.43. Andere STE-gegevenswerzamelingen vallen onder de Wpr; De Mvt voorstel Wte, TK 1988-1989, 21038, nr.3, p.25, noemt bet register een "openbar naslagwerk"; Dit karakter wordt benadrukt in Nota wan wijziging woorstel Whe 1995. TK 1994-1995, 23874, nr.8, p.3.

101. STE, Jaarverslag 1992, Amsterdam, 1993, p.18. 
ling. ${ }^{102}$ In het zelfde jaar ziet de STE noodzaak éen verleende vergunning in te trekken, omdat de betrokken effecteninstelling niet aannemelijk kan maken dat op afzienbare termijn aan de eigen-vermogenseis kan worden voldaan. ${ }^{103}$ Eind 1994 heeft de STE 1127 effecteninstellingen (52 vergunninghouders en 1075 effecteninstellingen die onder een vrijstelling vallen) in het register opgenomen. ${ }^{104}$ In dat jaar trekt de STE twee vergunningen van effecteninstellingen, maar in geen van beide gevallen is benadeling van beleggers reden van intrekking.

De ECD ${ }^{\text {tos }}$ meldt over 1993 dat zij in het kader van de Wte 21 enquête- en informatieonderzoeken (veelal op verzoek van de STE, betreffende noodzakelijk geachte aanvullende informatie over vergunningaanvragen of bestuurderswisselingen bij vergunninghouders), 7 internationale rechtshulponderzoeken (langdurige onderzoeken voort vloeiende uit o.a. informatie-uitwisselingswet) en 34 opsporingsonderzoeken (waarbij 13 keer sprake is van proces-verbaal, 1 keer van correctie en 20 keer geen sprake is van overtreding) verricht. ${ }^{106}$

Met betrekking tot de zorg wekkende situatie dat effecteninstellingen (vooral op het gebied van opties, valutacontracten, forex-contracten of termijncontracten), die zich net over de Nederlandse grens in met name Duitsland vestigen, zonder de hier te lande vereiste vergunning hun diensten in Nederland aanbieden, onderneemt de ECD ook de nodige actie. De 'zwarte لijst' ${ }^{10 \%}$, die de STE bijhoudt van clandestiene effecteninstellingen die na aanmaning van de STE nog steeds zonder vergunning werken, is voor de ECD indicatief. In elk geval 21 effecteninstellingen, die voorkomen op de zwarte lijst, onderwerpt de ECD aan een onderzoek naar mogelijke strafbare feiten. ${ }^{108}$ Reeds eerder verbaliseert de ECD, naar aanleiding van binnen gekomen klachten van gedupeerden, frauduleuze beleggingsinstellingen.

Medio december 1994 eist een Zwitserse handelaar in valutatermijncontracten t.w. Baratt Brokerage, die op de zwarte lijst van de STE voorkomt, dat de STE de aan zijn adres gedane beschuldigingen 'fraude, oplichting en strafbare feiten' in de landelijke pers rectificeert. ${ }^{109}$ De STE ontkent overigens zich te hebben uitgelaten over fraude bij genoemde effectenhandelaar. Slechts de ECD heeft bekend gemaakt dat zij de opsporing van een aantal op de zwarte lijst staande bedrijven, die flink hebben gefraudeerd, intensiveert. Dit betekent niet dat alle instellingen, die op de lijst voorkomen, de boel per definitie oplichten. Voor de STE betekent platsing op de zwarte lijst in principe alleen,

102. STE, Jaarverslag 1993, Amsterdam, aprill 1994, p.13.

103. STE, Jaarverslag 1993. Amsterdam, aprill 1994, p.14.

104. STE, Jaarverslag 1994, Amsterdam, 1995, p. 14.

105. De Mvt voorstel Wie, TK 1988-1989, 21038, nr.3, p.17, meldt dat -nu de Wte vooral codificeent-de belasting voor opsporingsautoriteiten binnen aanvaardbare grenzen ligt en niet veel zwaarder is dan onder het regime van de oude Wet effectenhandel.

106. ECD. Jaurverslag 1993, "s-Gravenhage, 1994, p.9.

107. In mei 1993 waarschuwt de STE al publiekelijk tegen deze, vooral van uit Duitsland en Belgiè komende. malafide effectenhandelspraktijken. STE, Jaarverslag over 1993, Amsterdam, aprill 1994, p.14.

108. ECD onderzoekt 21 beleggingsinstellingen, in: NRC, 29 now. 1994, p.15.

109. Valutahandelaar Baratt: STE was onzorguldig, in: De Financiele Telegraaf, 17 dec. 1994, p.T51. 
dat sprake is van een effecteninstelling zonder vereiste vergunning. De STE meldt dat de effectenhandelaar Barrat, ondanks aanschrijving waarin de STE wijst op het gebrek aan een vergunning om het effectenbedrijf uit te oefenen, nog steeds geen moeite doet om als nog een vergunning te verkrijgen.

De Amsterdamse rechtbankpresident oordeelt in het kort geding dat de STE niet verplicht is tot rectificatie ter zake. Hoewel de rechter de gewraakte uitspraken, indien zij niet waarheidsgetrouw zijn, als onnodig grievend en daarmee als onrechtmatig kan aanmerken, acht hij de handelswijze van de STE niet onrechtmatig. Dit rechterlijk oordeel vindt vooral basis in het gegeven dat tegen de betrokken effectenhandelaar twee klachten zijn ingediend en deze niet aannemelijk maakt dat de uitspraken aan de STE zijn toe te schrijven. Hierbij refereert de rechtbankpresident aan het feit dat in verschillende persberichten expliciet wordt aangegeven welke uitspraken afkomstig zijn van de STE en welke van de ECD. Bovendien acht de rechter het 'voorshands onaannemelijk', dat de STE verantwoordelijk is voor datgene wat de ECD naar buiten brengt. ${ }^{110}$

Medio mei 1995 blijkt overigens opmerkelijk dat de speculatieve termijntransacties niet alleen van min of meer onbetrouwbare effectenbemiddelaars zonder vergunning uitgaan, maar dat ook officiële banken in Nederland zich bezig houden met de risicovolle forexen termijncontractenhandel. Zo dient een kort geding voor de Amsterdamse rechtbankpresident tussen een belegger (die door een bittere belegging zijn vleeshandel kwijt raakt) en de Nederlandse dochteronderneming van de Belgische Kredietbank (bij welke bank een vermogensbeheerder het geld van bedoelde belegger, die de bank een niet nader gespecificeerde volmacht verstrekt, verspeelt door handel in forex-contracten d.w.z. buiten de beurs om verhandelde opties op wisselkoersen). Deze zaak roept de herinnering op aan een eerdere dergelijke zaak, waarin de raadsman van de in Zwitersland wonende gedupeerde de STE verwijt dat zij "als toezichthouder nalatig is gebleven bij het treffen van adequate maatregelen ter bescherming van beleggers in deze beleggingsprodukten". H?

\section{\$ 19.5 Toezichtsbevoegdheden Stichting Toezicht Effectenverkeer}

In gegeven gevallen van niet-naleving van effectenwet- en regelgeving zijn passende maatregelen nodig. ${ }^{112}$ De Stichting Toezicht Effectenverkeer beschikt, zowel ten aanzien van effectenbemiddelaars, vermogensbeheerders, overige effectenvergunningaanvragers en bij organisaties waarbij zij zijn aangesloten (ex art. 21 , eerste lid, Wte) als ten aanzien van houders van effectenbeurzen en aanvragers van een beurserkenning (ex art.

110. Aldus luidt het oordeel wan rechtbankpresident te Amsterdam R.C. Gisolf, weer gegeven door C. Moerlie, STE hoeft mitspraken niet te recrificeren, in: De Financiële Telegraaf, 23 dec. 1994, p.T23.

111. G. Hoff (advocaat Loef Claeys Verbeke), geciteerd door J. Alberts, Rechtbank buigt zich over speculatieve fermijnhandel; Gedupeerde belegger klaagt Kredietbank aan, in: NRC, 20 mei 1995, p.17.

112. Onder het oude wettelijk regime waren toezichtsbevoegdheden "zeer gebrekkig geregeld", aldus PvdAfractie die dit graag als argument ziet voor de met de Wte gerealiseerde vernieuwing van wettgeving. Zie behardeling Voorstel Whe, TK $1988-1989,21038$, nr. 5, p. 3 . 
21, tweede lid, Wte), over toezichtsbevoegdheden, niet zijnde opsporingsbevoegdheden $^{1 / 3}$. Voldoet het onderzoek bij beide laatst genoemden niet, met andere woorden vordert het belang van het onderzoek meer, dan klopt de STE ex art. 21, derde lid, Wte mogelijk nog aan bij de bij de betreffende beurs aangesloten effectenbemiddelaars en vermogensbeheerdlers. ${ }^{114}$

Naast het vragen van inlichtingen ${ }^{115}$, is het instellen van een onderzoek geoorloofd. Wordt tot het verrichten van onderzoek (of het vragen van, ex art. 21 , vierde lid, Wte binnen een bepaalde termijn te verstrekken, inlichtingen) besloten, dan verleent degene bij wie het onderzoek wordt ingesteld, of een derde die aan onderzoek te onderwerpen voorwerpen onder zich heeft, inzage van alle boeken, bescheiden en andere informatiedragers ${ }^{116}$ die op de uitoefening van zijn beroep of bedrijf betrekking hebben, en overigens alle medewerking die nodig is voor een goede uitvoering wan dat onderzoek (art. 21, vijfde en zesde lid, Wte).

De medewerkingsplicht vindt nog eens versterking in de, in het najaar van 1994 voorgestelde, bevoegdheid van de STE om zich met behulp van de sterke arm toegang te verschaffen tot financiële instellingen, als banken en effectenkantoren, die weigeren te voldoen aan informatieverzoeken. ${ }^{117}$ Voortaan hoeft de ECD dus niet meer eerst in verband met dergelijke weigering te verbaliseren. De STE kan, met de ECD of met de politie, kantoren binnen stappen om daar direct onderzoek ter plekke te verrichten door informatieve stukken in te zien en eventueel te kopiëren. De bevoegdheid om verder dan de deurmat te komen levert meer nog dan voor de STE, die het gemis aan een dergelijke bevoegdheid nooit als hinderlijk heeft ervaren maar wel als zinvol beschouwt in het kader van onderzoeken naar misbruik van voorwetenschap, voordeel op voor justitie wier lasten aanzienlijk worden verlicht.

Ten aanzien van een maal verkregen gegevens of inlichtingen heeft de Stichting Toezicht Effectenverkeer een geheimhoudingsplicht ex art. 22 Wte ${ }^{118}$ jo. art. 11 statuten

113. Zie Mva voorstel Wte "TK 1988-1989, 21038, nr.6, p.30, waar het verzoek van de PwdA om veriening van opsporingsbevoegdheid aan de STE wordt afgewezen, gelet op de tot tevredenheid stemmende samenwerking met ECD en justitie.

114. Deze bepaling is een uitzonderingsbepaling. Zij is toepasselijk als bij voorbeeld de weg van art. 21 , tweede lid, Wte "te tijdrovend" is. Aw" voorstel We, TK 1988-1989, 21038, nr.3, p.26.

115. Overigens blijwen ex art. 21 Wte verkregen inlichtingen, omtrent afzonderlike ondernemingen en instellingen geheim. Zle art. 21, zevende lid, Wte. Het. PwdA-werweer hiertegen luidt, dat deze bepaling te stringent is: "het moet de toezichthouder vrijstaan gemotiveerd publiekelijk te walschuwen of te berispen" "Voorstel Wre, TK 1988-1989, 21038, nr.5, p.10. De Mva woorstel Wte, TK 1988-1989, nr.6. p. 19, belooft hiemaar onderzoek te doen.

116. Deze dende optie wordt aan art. 21, vijfde en zesde lid, Whe toegevoegd bij dle Informatie-winwisselingswet, "TK 1993-1994, 23170 , nr.268, p.8.

117. Aldus de verruiming in het, in paragraal $19.12 \mathrm{e} . \mathrm{w}$. kort weergegeven, Wetswoorstel tor aanpassing wan de Whe (Wte 1995), TK 1993-1994, 23874, mirs.1-3. Zie daarover Meer armslag voor toezichthouder beurs, in: NRC, 10 okt. 1994, p.11.

118. Vgl. art. 14 Wet melding zeggenschap in ter beure genoteerde vernootschappen. 
STE $11 \%$ De informatie mag zij niet verder of anders respectievelijk gebruiken en bekend maken dan voor de uitoefening yan haar toezichtstaak noodzakelijk is. Als uitzondlering op de geheimhoudingsplicht is, met oog op een adequate functionering van de effectenmarkt en de positie van de beleggers op die markten, in gevolge art. 23 Wte openbaarmaking van besluiten en feiten mogelijk. Even zo is bij wege van exceptie ex art. 24 Wte ${ }^{120}$ inlichtingenverstrekking mogelijk aan andere buitenlandse of binnenlandse instanties die (mede) bevoegd zijn tot toezicht op de effectenhandel.

In het licht van deze informatieverstrekking is ook de, mede voor de stichting Verzekeringskamer geldende, genoemde informatie-uitwisselingswet ${ }^{121}$ te bezien. Deze wet vindt nadere uitwerking in de, onderling overeen gekomen, informatieverplichtingen tussen Nederland en de Verenigde Staten van Amerika. ${ }^{122}$ In 1993 ontvangt de STE van de bevoegde Amerikaanse effectentoezichthouder Securities and Exchange Commission twee informatieverzoeken. Middels toepassing van art. 24 Wtv voldoet de STE daaraan naar tevredenheid. ${ }^{123}$ Als doelmatige aanvulling verplichten de STE en de Commodity Futures Trading Commission zich per 1 februari 1994 jegens elkaar tot informatiewerschaffing over, in het bijzonder, opties en termijncontracten. ${ }^{124}$ De Stichting Toezicht Effectenverkeer wenst ook een soort gelijk Memorandum of Understanding met de Ontario Securities Commission en de Commission des Valeurs du Quebec te Canada aan te gaan. Verder voert zij besprekingen over informatie-uitwisseling met de Commission des Opêrations de Bourse uit Frankrijk en de Securities and Futures Commission uit Hong Kong. ${ }^{225}$ Daarnaast ondergaat de internationale samenwerking versterking door een in het kader van de Raad van Europa tot stand gekomen Verdrag inzake handel met

119. Om aan zijin grondwettelijke informatieplicht t.o. . het parlement te kunnen voldoen als mede om anngifte te kunnen doen bij de ECD, moeten de minister wel op verzoek STE-gegevens, ter beoordeling van the functioneren wan de wextchthouder -ook in concrete situaties-, worden verschaft. Aldus PvdA in Eindverslag woorstel Wte, TK 1989-1990, nr.11, p.6, en nr.12, p.10; De STE meldt in het Jaarver. shog 1994, Amsterdam, 1995, p.17, dan ook dat na overleg met DNB nv, STE en de stichting Verzekeringskamer een woorstel van wet in de mak is met een regeling, die voorschrijft dat toezichthoudende autoriteiten de betrokken minister(s) informatie moeten verstrekken over gefailleerde en in liquidatie werkerende instellingen.

120. Bij de informatie-uirwisselingswet, TK 1993-1994, 23170, nr.268, pp.8-10, wordt art. 24 uitgebreid

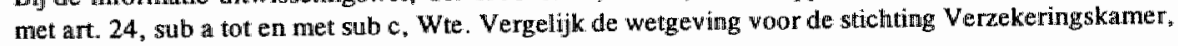
alls weer gegeven in paragraaf 18.9 .1

121. TK 1993-1994, 23170, nr.268, pp.8-10 (inzake arti. 21-22/24-24c Wte). Meer over dit voorstel, dat inmiddels tot wet verheven is, in paragraaf 18.9 .1 .

122. Overeenkonst Nederland - Verenigde Staten wan Amerika inzake wederzÿdse adminisiratieve bijstand" byj de uinwisseling wan informatie op effectengebied. 11 dec. 1992, Trbl. 1990, 11 en 61 , zie ook Trbl. $1992,92$.

123. STE, Jaanversiag 1993, Amsterdam, april 1994, p.25.

124. Overeenkomst tussen Nederland en Verenigde Staten van Amerika inzake wederaijdse administratieve bijstand bij de witwisseling wan informatie op het gebied van opties en termijncontracten, SG 1993-1994, 23495, mrs.1-129, Trbl. 1993, 86 en 183 .

125. STE, Jaanverslag 1993, Amsterdam, april 1994, p.26. 
voorwetenschap. ${ }^{126}$ Teven komen Nederland, Engeland en Ierland overeen om informatie uit te wisselen op het gebied van effecten, termijncontracten en opties. ${ }^{127}$

Art. 21 Wte verschaft de Stichting Toezicht Effectenverkeer dus onmisbare controlebevoegdheden. Hiermee bezit zij het instrumentarium om bij allerlei ondernemingen, bedrijven of instellingen die effecten uitgeven als mede instellingen die in de effectenhandel bemiddelen of effecten van klanten beheren (ex art. 21 , vierde lid, Wte mogelijk onder termijnstelling) inlichtingen te verkrijgen bij vermoeden van ontduiking van effectenwet- en regelgeving, in het bijzonder misbruik van voorwetenschap.

\section{$\S 19.6$ Misbruik van voorwetenschap}

Misbruik van voorwetenschap heeft vooral de volgende effecten. Relevante koersinformatie wordt sneller verwerkt. En niet-ingewijden verlaten de markt. Het eerste effect is positief voor de marktefficiëntie. Het tweede effect heeft als negatieve consequentie, dat de marktliquiditeit vermindert. Om het secundaire gevolg te elimineren en het primaire gevolg te behouden, luidt een voorstel om te komen tot een substituut van handel met voorwetenschap als mechanisme om nieuwe informatie snel te verwerken. Als namelijk een alternatief, denk aan "het instellen van openbare registers waarin de marktposities van ingewijden nauwkeurig worden bijgehouden" mogelijk is, is het van uit economisch perspectief "raadzaam om handel op basis van voorwetenschap te verbieden". ${ }^{128}$

Belangrijke rechtvaardiging van criminalisering van misbruik van voorwetenschap ${ }^{1.29}$ ligt in de - overigens qua zowel kwantiteit als causaliteit moeilijk aantoonbare - schade, die in bepaalde gevallen door de niet ingewijde marktpartij wordt geleden ten gevolge van 'inside-trading'. ${ }^{130}$ Met oog op misbruik van voorwetenschap wordlen de misdrijven van de artt. 335-336a WvSr ${ }^{131}$ uiteindelijk overgebracht naar de artt. 31a-31c Wte. ${ }^{132}$

126. Trbl. 1993, 111, als goedgekeurd door de Staten-Generaal, SG 1994-1995, 24102, nris. 1/219.

127. Verdrag tussen de regering wan het koninkrijk der Nederianden en de regering van het Verenigd Konink rik wan Groot-Briftaniez en Noord-Ierland inzake wederzidse bujstand en de wirwäseling van informatie op het gebied wam effecten, termijncontracten en opties, Landen, 20 juli 1994 , aangeboden bijif brief van de minister van buitenlandse zaken d.d. 24 februari 1995.

128. R. Beetsma en R. Mingels, Handel met woorwetenschap en marktefiticiëntie, in: ESB, 30 maant 1994. pp. 294-296.

129. H. Beckman, $T$. van Wijngarden, $P$. Bavelaar en F. Schneider belichten algemene aspecten van misbruilk van voorwetenschap in: Jurid isch up to Date. Themanummer 'misbruik wan woonwetenschap". nr.15, 18 aug. 1994.

130. D.R. Doorenbos, Misbraik van voonwetenschap: schade en schande?, in: NV, nur.7/8, julliaug. 1989. pp. 164-166; Uitwaeriger D.R. Doorenbos, a.W., pp.465-501; Anders G. Rietkerk, Commenuar op Misbruik won woonwetenschap: schade en schande?, in: NV, nr.10, okt. 1989, pp.210-212.

131 " Deze wetsartikelen hebben, waarschijnlijk vooral van wege de zeer moeilijke bewijslast, nooit toepassing gevonden volgens $\mathrm{K}$. Berkhout en P. Wessels, Maak misbruik wan voorwetenschap openbaar, in: NRC, 18 september 1993, p.9.

132. Bij overbrengingswet van 1 juli 1992, Stbl. 1992, 378. 
Deze wettelijke bepalingen komen op het wolgende neer. Van wege het belang van daarop gebaseerde jonge jurisprudentie is het belangrijk deze artikelen nauwkeurig weer te geven. Conform art. 3la, eerste lid, Wte is het een ieder verboden om, beschikkende over voorwetenschap, in Nederland een transactie te verrichten of te bewerkstelligen in effecten die zijn genoteerd aan een op grond van art. 22 erkende effectenbeurs, indien uit de transactie enig voordeel kan ontstaan. Is sprake van een overtreding van dit verbod, dat als strafbaar feit ex art. 31c Wte een misdrijf oplevert, dan is de rechtbank te Amsterdam in eerste aanleg uitsluitend bevoegd ex art. 31a, vijfde lid, Wte. Art. 31a, tweede lid, Wte kent trouwens nog een dergelijk verbod voor te bewerkstelligen transacties in effecten die zijn genoteerd aan een buiten Nederland gevestigde effectenbeurs. Art. 31a, derde lid, Wte definieert voorwetenschap als bekendheid met een bijzonderheid omtrent de rechtspersoon, vennootschap of instelling, waarop de effecten betrekking hebben of omtrent de handel in effecten: a. waarvan degene die de bijzonderheid kent, weet of redelijkerwijs moet vermoeden dat zij niet openbaar is en dat zij niet zonder schending van een geheim buiten de kring van de geheimhoudingsplichtigen kan komen of is gekomen; en b. waarvan openbaarmaking, naar redelijkerwijs is te verwachten, invloed zal hebben op de koers van de effecten. Art. $31 \mathrm{a}$, vierde lid, Wte bevat een exoneratiebepaling op de in beide eerste leden vermelde verboden: vitgesloten daarvan is de tussenpersoon die, slechts beschikkend over voorwetenschap met betrekking tot de handel, volgens de regels van de goede trouw ter beurze handelt ter bediening van opdrachtgevers. Naast art. $31 \mathrm{a}$ Wte is art. $31 \mathrm{~b}$ relevant. Daarin is het volgende verbod, waarvan overtreding conform art. 31c Wte een misdrijf oplevert, neergelegd. Het is iedereen die effecten uitgeeft of is belast met, of zijn medewerking verleent tot het plaatsen van effecten, verboden te trachten het publiek tot inschrijving of deelneming te bewegen door het opzettelijk verzwijgen of verminken van ware feiten of omstandigheden, of door het voorspiegelen van valse feiten of omstandigheden.

Handelen in strijd met deze Wte-bepalingen, die overigens exact eender terug keren (als artt. 46-48 Wte 1995) in thet voorstel voor een vernieuwde Wte ${ }^{133}$, levert een economisch delict op. ${ }^{134}$ Voordeel hiervan, ten opzichte van de situatie vóór de wetswijziging waarin slechts strafrechtelijk optreden mogelijk was indien een concreet vermoeden van het begaan van een strafbaar feit aanwezig was, is dat de opsporingsambtenaren van de Economische Controledienst tegenwoordig naar de verder gaande opsporingsbevoegdheden uit de WED mogen grijpen, zonder dat een gerechtelijk vooronderzoek nodig is. De in praktijk blijkende vertragende complicatie, dat inschakeling van de Economische

133. De wetgever kiest er niet woor in de Whe 1995 een, aan de eerste jurisprudentie inzake misbruik wan voorkennis aangepaste, regeling voor misbruik wan voorwetenschap op te memen. De Wte 1995 diemt tot implementatie van de richtijn beleggingsdiensten en de richtlijn kapitaaltoereikendhe id. Koersmamipullatie is geen onderwerp van regeling in het wetsvoorstel. Aanwijzing woor de regelgeving 337 verbiedt namelijk in een implementatieregeling andere regels, dan daarwoor benodigd, op te nemen. Nota n.a.w. het verslag inzake het woorstel Wie 1995. TK 1994-1995, 23874, nr.7, p.7.

134." Principieel positief gewaardeerd door D. $\mathbb{R}$. Doorenbos, a.w., pp.345-391. 
Controledienst pas plaats vindt na intern onderzoek van de beurs ${ }^{135}$, wordt via bevredigend overleg tussen de Stichting Toezicht Effectenverkeer, het openbaar ministerie en de beurs verholpen. ${ }^{136}$ Desondanks gaan, vooral na het onderzoek door de beurs en de STE inzake Borsumij Wehry, stenmmen op om de ECD in een zo vroeg mogelijk stadium in te schakelen bij onderzoeken naar misbruik van voorwetenschap (zie paragraaf 19.2.1).

Overigens stelt de ECD in 1992 uitgebreid onderzoek in naar twee gevallen van mogelijk misbruik van voorwetenschap (waaronder de HCS-affaire). ${ }^{137}$ De ECD meldt over 1993 de voltooiing wan 2 onderzoeken ter zake, een met een informatief karakter en de ander wordt afgedaan met een proces-verbaal (de van wege de HCS-zaak bekend geworden Begemann/RDM-affaire); Daarnaast heeft de ECD per eind 1993 nog 3 andere vermeende misbruikgevallen in behandeling, houdt de ECD een vierde zaak nog in portefeuille en begint de ECD in 1994 om redenen van spoed en prioriteit aan een nieuw onderzoek naar een affaire inzake misbruik van voorwetenschap. ${ }^{138}$

Het resultaat van de artt. 31a-31c Wte is redelijk. Maar, het kan nog beter. Een echt effectieve aanpak van misbruik van voorwetenschap is duidelijk meer gegarandeerd als de Stichting Toezicht Effectenverkeer beursfraude (die gemakkelijker, dan het begaan van een strafbaar feit, is aan te tonen) openbaar mag maken. In dit verband luidt een pleidooi ${ }^{139}$ te komen tot het systeem, dat wordt gehanteerd door de beurstoezichthouder Securities and Exchange Commission in de Verenigde Staten. Met de Insider Trading Sanctions Act heeft de SEC een instrument in handen om scherp op te treden tegen ingewijden die profiteren van hun voorkennis inzake de vermogenswaarde van effecten. In tegenstelling tot de Stichting Toezicht Effectenverkeer mag de SEC - onafhankelijk van het openbaar ministerie - een overeenkomst met een verdachte sluiten, bestaande uit een boete die openbaar wordt gemaakt. Hierdoor ontkomt justitie aan cen lastige, lange bewijswergaring. Verdachte blijft bespaard voor een onevenredig zware (negatieve publiciteits)straf door langdurig justitieel onderzoek. De nadelen van zo'n onderzoek dat zich in de tijd voort sleept, komen vooral in de Nederlandse HCS-affaire naar voren. Door een overeenkomst, als voomoemd, kan verdachte - in plaats van betrokken te raken in een, door bewijsmoeilijkheden jarenlang durende, rechtszaak - kiezen voor boetebetaling. Daardoor kan hij zijn schuld, op een voor hem minst belastende wijze, voldoen. In deze aanpak van beursfraude ziet ook de STE zelf heil. ${ }^{140}$ Met het, naar haar zeg-

135. Het beurscontrolebureat onderzoekt $0 . \mathrm{g} . \mathrm{v}$. de Modelcode voorkoming misbruik voorwetenschap of sprake is van een vermoeden van een strafbaar feit. Bij bevestigend antwoord doet zij alangifte bij de dartoe aangewezen OW te Amsterdam. I. Mass, Rechten en plichren van de beursgenoteerde ondermeming, in: Firm, nr. 2, 1994, pp.16-22, i.h.b. p.21.

136. Economische Controledienst, Jaanverslag ECD 1992, Apeldoorn, 1992, p. 16.

137. ECD, Jaamerslag 1992, 's-Gravenhage, 1993, pp.15-16.

138. ECD, Jaarverslag 1993, 's-Gravenhage, 1994, p.11.

139. Zie K. Berkhout en P. Wessels; t.a.p., p.9.

140. Overigens spreekt de STE het verlangen nar meer bevoegdheden, bij voorbeeld om straffen vit te delen, al eerder uit. K. Berkhout en P. Wessels, Controle beurshandel is moeilijk, in: NRC, 16 juni 1993, p.20; En ook STE-directeur-secretaris E.E. Canneman spreekt zich bij de presentatie van het 
gen, 'snelrecht" kan de STE relatief eenvoudig de effectenwet- en regelgeving handhaven. Via toepassing van dit snelrecht ziet de STE in ruil voor een forse boete af van aangifte bij justitie. Deze vorm van schikking levert tijdsbesparing op, is het minst schadelijk voor de overtreder en voorkomt bewijsmoeilijkheden voor het openbaar ministerie ${ }^{141}$. Met een schikking kan de STE het initiatief naar zich toe trekken. Als de STE de mogelijkheid van een afkoopregeling aan haar toezichtsinstrumentarium toe mag voegen ${ }^{142}$, verandert zij van waakhond in "bulldog" 143; Met andere woorden, de STE ondergaat een metamorfose van een "partij in de coulissen in een hoofdrolspeelster op het toneel die zich actief bemoeit met de bestrijding van de beursfraude". ${ }^{1.44}$

Deze kentering vraagt om een kanttekening. De STE, die - voor een in principe beleidsuitvoerende orgaan - al redelijk invloedrijke publiekrechtelijke bevoegdheden heeft, zij het dat de minister de meest indrukwekkende bevoegdheden aan zich houdt, maakt de wens kenbaar een relatief zwaar sanctiemiddel aan zich te willen trekken. De haar al toekomende administratieve sancties, als het geven van aanwijzingen, het intrekken van o.a. vergunningen en thet openbaar kennis geven van het weigeren van vereiste vergunningen e.d., zijn kennelijk nog niet voldoende. Het grijpen naar een zwaarder middel is op zich niet vreemd.

Wel hebben sommigen hier moeite mee, omdat de STE in een privaatrechtelijke rechtsvorm is gegoten. Ondanks de daartoe ingebouwde overheidseisen van onafhankelijkheid (de privalutrechtelijke rechtspersoon is sterk - en voor een taak als controle op zelfregulering wellicht te sterk - publiekrechtelijk ingekleurd, wat op zich al diffurus en oneigenlijk is), loert het gevaar van belangenverstrengeling om de hoek. In dit kader luidt een voor-

140. $\rightarrow$

STE-jaarverslag over 1994 positief uit over invoering van de bevoegdheid tot het opleggen vam bestuurlijke boete of dwangsom. "Beursfraude vergt sneller onderzoek", in: NRC, 24 mei 1995, p.25, zie ook STE, Jaarverslag 1994, Amsterdam, 1995, p. 17.

141. T. a. . het OM merkt de STE op, dat door voortdurende wisseling van frande-officieren gespecialiseerde kennis verloren gaat en de continuïteit gevaar loopt. Zie Toezichthouder op beurs pleit voor snelrech. in: NRC, 26 mei 1994, p. 19.

142. Hoewel het uiteindelijk gepresenteerde woorstel Wte 1995 niets dloet vermoeden, wordt bij de voorbereiding van de herziening van de Wte gesproken over toedeling aan de STE (en de minister) van het opleggen van (administratieve) boeten. Daarvan maakı het Financieele Dagblad, 8/10 oktober 1994, melding; Het Kabinetsstandpunt over het CTW-adwies inzake bestuurlijke boeten, TK 1993-1994, 23400 VI, nr. 48 , p. 19 , maakt well duidelijk dat de regering in samenspraak met de toezichthoudende instanties, als DNB $n w$, stichting, Verzekeringskamer en STE, na gaat "of het mogelijk is bepaalde lichte overtredingen wan daarvoor in aanmerking komende financiële wetgeving bestuursrechtelijk af te doen. Te denken valt bij voorbeeld aan het niet of niet behoorlijk nakomen van bepaalde administratieve verplichtingen"; Uit de Nota m.a.v. het verslag inzake het voorstel Wte 1995, TK 1994-1995, 23874, nr. 7. p. 16 , blijkt dan dat met de betrokken toezichthoudende autoriteiten overeenstemming is bereikt over de uitgangspunten voor de invoering van de bestuurlijke boeten voor nader te bepalen delicten in de wetgeving inzake het toezicht op de financiele markten. Deze wetgeving, die primair de handhaving vam de financiële toezichtsregels beoogt te verbeteren en daarnaast het strafrechtelijk apparaat enigszins kan ontlasten, is in voorbereiding.

143. K. Bierkhout, Beurswaakhond STE kamt uit de coulissen, in: NRC, 26 mei 1994, p.20.

144. Aldus STE-woorzitter Zantman, geciteerd door K. Berkhout, Beurswaakhond STE komt wit coulissers, in: NRC, 26 mei 1994, p. 20. 
stel de STE voortaan alleen en hoogstens te belasten met de controle op de zelfregulering, het eventueel formuleren van nadere regelgeving en het intrekken van vergunningen die zij immers zelf verleent. ${ }^{145}$

Toch gaat het te ver de STE de sanctie van bestuurlijke boete te ontzeggen. Juist voor een toezichthoudende entiteit is het noodzakelijk tijdig over toereikende informatie van onider toezicht gestelden te bezitten. Alleen al daarvoor is invoering van de bevoegdheid om in geval van lichte overtredingen bestuurlijke boeten op te leggen gerechtvaardigd. IJzeren conditie daarbij is dan wel dat de STE niet op eigen houtje werkt. Het openbaar ministerie zal min of meer met dominantie de uiterste waarden van, door de STE op te leggen, boeten bepalen.

\subsubsection{HET STRAFPROCES INZAKE DE HCS-KWESTIE}

Vermelde HCS-zaak wordt door de rechter-commissaris te Amsterdam begin december 1993 afgesloten. Daarmee duurt het justitieel onderzoek naar 'koersorkestratie" ruim drie jaar. Aanvankelijk blijft het antwoord op de vraag of de officier van justitie al dan niet tot vervolging overgaat, op verzoek van verdachten uit. ${ }^{146}$ Uiteindelijk wordt wel owergegaan tot strafvervolging ter zake. Hierdoor is de HCS-kwestie de eerste Nederlandse strafzaak betreffende misbruik van voorkennis over een aan de effectenbeurs genoteerde onderneming. ${ }^{14 \pi}$

De strijd tussen verdediging en openbaar ministerie in het HCS-proces concentreert zich op de vraag of van, de voor misbruik van voorwetenschap vereiste elementen, sprake is: geheime informatie en direct financieel voordeel. ${ }^{148}$ Volgens een van de raadsmannen van verdachten is slechts sprake van, niet strafbare, koersorkestratie en hoogstens van een poging tot handel met voorwetenschap. ${ }^{149}$ Maar het openbaar ministerie acht een voornemen of een plan ook voorwetenschap. ${ }^{150}$ In de motivering van het vonnis, waarin de rechtbank wel tot vrijspraak van onder andere handel met voorkennis in HCSaandelen concludeert ${ }^{151}$, laat de arrondissementsrechtbank - voor misbruik van voorwetenschap essentiële - vragen liggen. In het oordeel gaat de rechter slechts in op de vermeende geheimhoudingsplicht van verdachten en op het begrip koersgevoelige informatie. Uit het vonnis blijkt dat daarmee wordt bedoeld, dat de bezitter van dergelijke informatie "een duidelijke aanwijzing" over de richting van de koers heeft. ${ }^{152}$ Volgens de rechter blijkt in de HCS-zaak aan beide voorwaarden voor voorwetenschap niet te zijn

145. C.A. Schreuder, Publiekrechtelijke taken, privaatrechtelije rechtspersonen, Deventer, 1994, pp. $351-352$.

146. Bestuit over vervolging in HCS-zack uitgesteld" in: NRC, 24 dec. 1993, p. 17.

147. K. Berkhout en P. Wessels, HCS-vervolging doorbraak in bestrijding voonwetenschap, in: NRC, 17

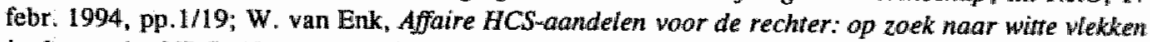
in de wet, in: NRC, 18 mant 1994, p.15.

148. P. Wessels, Twijfels iw HCS-zaak ondermijnen strijd tegen beursfraude, in: NRC, 26 maart 1994, p.17.

149. 'Er horen anderen dan wij hier rerecht te staan", in: NRC, 25 maart 1994, p.l1.

150. P. Wessels, Thijfels in HCS-zaak, ta.p., p.17.

151. Vrijspraak woor alle drie werdachten in HCS-affaire, in: NRC, 7 april 1994, p.1.

152. Begemann 'wrì' naar kapitaalmarkt, in: NRC, 8 aprill 1994, p.11. 
woldaan. Terecht luidt de constatering, dat het openbaar ministerie "in haar poging door een rechterlijke uitspraak tot een ruime interpretatie van de wet te komen door de rechter niet is gevolgd". 153

Van wege de onbevredigende afloop van de eerste strafzaak, in eerste instantie, inzake misbruik van voorwetenschap, stelt de officier van justitie hoger beroep in tegen de wrijspraak van voorlopig twee ${ }^{154}$ van de vier verdachten in de HCS-affaire. De officier vindt dat de rechtbank in haar vonnis ten onrechte "een te enge uitleg geeft aan het begrip geheimhoudingsplicht"; Bovendien meent hij dat het "niet noodzakelijk is dat de insider het toekomstig koersverloop kan voorspellen" ${ }^{m}$. ${ }^{55}$ Ook de ECD toont ongenoegen over de rechterlijke uitspraak. Van uit handhavingsoptiek, in bewijsrechtelijke zin, is de rechterlijke interpretatie van geheimhoudingsplicht onacceptabel, bovendien kan het vereiste verband tussen transactie en verwachte koerswinst bewijsproblemen opleveren. 156

In de HCS-zaak, die in hoger beroep dient voor het Amsterdamse gerechtshof, blijkt uit getuigenverklaringen het volgende. Het in 1991 wankelende automatiseringsbedrijf HCS,

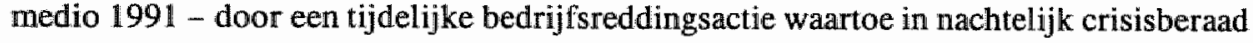
wordt besloten - gedwongen tot een (via een persbericht bekend te maken) kapitaalinjectie in de vorm van een grootschalige verkoop van nieuw uit te geven aandelen ter waarde van circa 4,1 miljoen gulden, waarbij één van de drie beleggers $t$.w. Van den Nieuwenhuyzen de dag na het spoedoverleg aan zijn effectenkantoor Suez Kooijman opdracht geeft om HCS-aandelen af te stoten om de koers te drukken, laat deze verkoop lopen via een tussenrekening. Door tijdgebrek worden de formaliteiten met betrekking tot die rekening bij Suez International Luxembourg nooit vervuld. Wel wordt gehandeld als of die buitenlandse rekening gewoon open staat. Het controlebureau van de beurs vermoedt niets en denkt dat de tussenrekening van een buitenlandse effectenhandelaar is. ${ }^{157}$

Belangrijke bedoeling van de tussenrekening is dat het 'front running' wordt voorkomen dan wel beperkt wordt gehouden. Immers, tijdens de periode $1991 / 1992$ bestaat bij alle Nederlandse financiële instellingen de ongezonde gewoonte om, als medewerkers van die instanties, voor eigen rekening mee te lopen met beursorders van grote klanten ten einde te profiteren van de koersstijging die deze orders veroorzaken. ${ }^{158}$ Door dit zo geheten

153. De HCS-affaire, in: NRC, 9 april 1994, p.9.

154. M. Tamminga, Twee verdachten in HCS-zaak over, in: NRC, 2 sept. 1994, p.11, meldt dat wel J, van den Nieuwenhuyzen van HCS (die, naast de HCS-affaire, ook is verwikkeld in een gerechtelijke procedeure inzake de voorkenniskwestie Begeman/RDM) en J. Gerritse van Suez Koojjman, maar niet $\mathbb{L}_{\text {, }}$ Melchior en E. Albada Jelgersma door het OM worden gedagvaard. Zie ook uitvoerig M. Tamminga, Helff adwocaten in zaak HCS kan toga thuistaten in: NRC, 24 sept. 1994, p.14 en Vart den Mieuwenhicyzen woelde 'morele verplichting" inzake HCS, in: NRC, 27 sept. 1994, p. 21; Tevens Hof hoort baankier Groenink over HCS, in: NRC, 28 sept. 1994, p.17.

155. Officier in beroep tegen uitspraak HCS-affaire, in: NRC, 21 april 1994, p. 19.

156. ECD, Jaarverslag 1993, "Gravenhage, 1994, p.11.

157. Beurshandel negeent verbod op "meelopen"; Handelaar tijdens HCS-proces, in: NRC, 29 sept. 1994, p.17.

158. Beurshundel negeent verbod op 'meelopen'; Handelaar tijdens HCS-proces', in: NRC, 29 sept. 1994, p. 17. 
'front running' wordt het verbod ter zake van de Amsterdamse effectenbeurs massaal en opvallend ontdoken.

Ten aanzien van de reddingsactie in juni 1991 zelf is, afgaande op de geluiden van de getuigenverhoren, kennelijk geen sprake van afspraken over de beurskoers van nieuwe HCS-aandellen. ${ }^{159}$

De advocaat-generaal van het Amsterdams gerechtshof heeft er een zware dobber aan om een van de verdachten, te weten Nieuwenhuyzen ${ }^{160}$ "effectenbeurshandel met misbruik van voorwetenschap in de schoenen te schwiven. Zijn eis luidt: een half jaar gevangenisstraf en twee ton boete. In zijn requisitoir probeert hij het hof te overtuigen. Ter bewijisvoering, dat verdachte ter zake schuldig is, moet hij, bij de verdachte, a. voorwetenschap, b. winstbejag en c. schending geheimhoudingsplicht aan tonen. Hiertoe voert hij het volgende aan. ${ }^{161}$ De indringendheid waarmee betrokken beleggers tijdens het crisisberaad te horen krijgen van de penibele situatie van HCS leidt tot voorwetenschap. De duidelijke aanwijzing van bewuste bepaling door de informatie van de richting van de koers, heeft volgens de advocaat-generaal niets met de werkelijkheid van doen. Deze eis is te stringent en betekent een onredelijke verzwaring van de bewijslast. Volgens hem is een koersstuwende of -drukkende invloed van de informatie voldoende. Over het financieel voordeel wan de transacties is de advocaat-generaal vast beraden. Het doel dik winst te behalen is voor hem duidelijk. En, de geheimhoudingsplicht krijgt ruime uitleg. Tijdens het crisisberaad is sprake van een stilzwijgende overeenkomst dat over een bepaald onderwerp niet met derden wordt gesproken.

Van den Nieuwenhuyzens advocaat wimpelt deze argumenten met verve af. Zijns insziens is wel manipulatie van de koers in het spel, maar niet handel met voorkennis berustend op anticipatie van de te verwachten koersontwikkeling met misbruik als gevolg. Bovendien vindt de raadsman dat eerst het bewust behalen van financieel voordeel moet komen vast te staan, en dat de publikatie van een persbericht met gemaakte afspraken over de HCS-reddingsoperatie een zwijgplicht ondermijnt.

Het Amsterdamse gerechtshof blijkt, op grond van de zelfde feiten, een andere mening dan de Amsterdamse arrondissementsrechtbank te zijn toegedaan. Concludeert de rechtbank tot vrijspraak, het hof verklaart schuldig. De, bij de HCS-affaire betrokken, be-

159. Groenink: geen afspraak over missiekoers HCS, in: NRC, 3 okt. 1994, p. 11.

160. Tegen de andere beklaggde Gerritse luidt de eis van advocaat-generat $A$. van den Perk slechts 75 .000 gulden boete wegens vervalsing van een effectennota. Van den Perk meent dat Gerritse geen misbnaik. van voorwetenschap is te verwijten. Kennelijk zijn de, maar liefst 31 professionele, ECD-opsporings* ambtenaren, die zich bemoeien mett het kosibane HCS-onderzoek, nog niet jager genoeg. M. Tamminga, Speurders grote verliezers HCS affoire, in: NRC, 5 okt. 1994, p.21; Vite indelijk beboet her gerectitshof de man van Suez Kooijman, wegens vervalsing van een effectenmota als gebruikt bij het eerste onder zoek naar de affaire door het Controlebureau van de effectenbeurs, woor 50,000 gulden. Effectenkantoor Stuez Kooijman ook beboet, in: NRC, 18 okt. 1994, p. 15; Swez Kooijman berust daarin en neemt inteme. matregelen om herhaling van valsheid in geschrifte te voorkomen, swez niet in cassatie over HCSaffaire, in: NRC. 27 okt. 1994, p.17.

161. Zie M. Tamminga, Herniewwe eis in HCS-zaak beroent hoofdverdachte niet, in: NRC, 4 okt. 1994, pp. $17 / 23$. 
klaagde ondernemer hangt door de uitspraak in hoger beroep zes maanden celstraf, waarvan drie maanden voorwaardelijk, plus een geldboete van 100.000 gulden boven het hoofd. Onder vernietiging van het vonnis van de rechtbank, spreekt het hof zijn 'schuldig' uit over Van den Nieuwenhuyzen, omdat het hof bij de effectenhandelaar misbruik van voorwetenschap bewezen acht. Voorlopig wordt de door het gerechtshof opgelegde celstraf opgeschort, omdat de veroordeelde ondernemer in cassatie gaat bij de Hoge Raad. ${ }^{162}$ Voor de periode van de behandeling door de hoogste rechter in Nederland trekt Van den Nieuwenhuyzen ${ }^{163}$ zich overigens terug als bestuursvoorzitter van Begemann. ${ }^{164}$

Het arrest van het Amsterdamse gerechtshof, op grond waarvan de advocaat-generaal overweegt of hij de niet gedagvaarde HCS-beleggers (t.w. Jelgersma en Melchior) als nog gaat vervolgen ${ }^{165}$, laat het volgende zien. Anders dan de rechtbank, concludeert het hof dat niet alle relevante feiten via het persbericht openbaar worden gemaakt. De volgende, in de ogen van het hof zelfs meest relevante, feiten hebben geen plaats in het persbericht dat uit de aard der zaak, gegeven de spoed van het chaotisch crisisoverleg met de daarbij gedane belofte om in de komende dagen nadere beslissingen te nemen, kort door de bocht is. Door het persbericht niet expliciet vermelde, mogelijk zelfs 'achtergehouden', informatie betreft de informatie: a. dat HCS het bankroet na bij is; b. dat drie dagen na het crisisberaad een besluit moet vallen over de vorm van aandelenuitgifte (openbare emmissie of in beperkte kring van banken en brede beleggers); $\mathrm{c}_{m}$ dat de beurskoers bepalend is voor die te maken keuze; en d. dat de uitgiftekoers van de nieuwe aandelen wordt bepaald door het koersverloop tijdens de drie bedoelde dagen. ${ }^{166}$ Dergelijke informatie heeft bij openbaarmaking er van invloed op koers. Daarom merkt het hof haar aan als koersgevoelige informatie. Ten aanzien van het begrip 'koersgevoeligheid' is het hof opvallend minder streng dan de rechtbank. Niet vereist is een duidelijke aanwijzing over het verloop van de koers. Voldoende is dat openbaarmaking van relevante informatie slechts invloed heeft op de koers. Gegeven de omvang van de HCSaandelenverkoop met koersdrukkend resultaat, handelt degene, die over belangrijke informatie beschikt, - volgens het hof - met voorkennis. Deze oordeelsnorm van het hof is omstreden. Immers, "voorkennis in informatie veronderstelt ook voorkennis over de koersbeweging. Het een kan niet zonder het ander. Wie voorkennis heeft, maar verliest op zijn handel, straft zich zelf." 167

162. Cassatie Van den Nieuwenhuyzen, in: $\mathbb{N R C}, 21$ okt. 1994, p. 15.

163. Over de 'stormachtige opkomst en de genchtmakende neergang ${ }^{x}$ van deze entrepreneur typerend $M$. Tamminga, Wervelwind Joep werliest vaart na onbeheerste dadendrang, in: NRC, 29 okt. 1994, p.17.

164. W. van Emk, Doemscenario Begemann-groep nabij, in: NRC, 18 okt. 1994, p. 15.

165. Topman Begemann op non-actief ha straf in HCS-zaak, in: NRC, 18 okt. 1994, p. 15.

166. M. Tamminga, Hof kiest nieuwe riching in oordeel voorkentiszaak, in: NRC, 18 okt. 1994, p.15. noemt de aandacht van het hof voor de al dan niet bewust vergeten informanie in het persbericht een " $z$ wakke stee" in het arrest. Z. i. zou publikatie wan deze informatie (over emmissievorm/uitgiftekoers nieuwe aandelen, draaiboek kapitaalinjectie of onderhandelingsposities) de steun vangeldschieters/beleggers hebben gekost en datiardioor de continuiteit van HCS op het spel hebhen gezet.

167. Aldus $\mathrm{M}$. Tamminga, Hof kiest nieuwe richting in oordeel woorkenniszaak, in: NRC, 18 okt. 1994. p. 15, die vindt dat het hof hel uitzicht op winst wel erg in het duister laatt liggen. 
Bovendien meent het hof dat de bij het crisisberaad 'meer of minder ervaren ondernemers en ter zake kundig bankpersoneel' schending van geheimhoudingsplicht kan worden verweten.

In de opvallend grote aandacht voor het arrest van het Amsterdamse hof ${ }^{168}$, terug te voeren op het feil dat het hier de eerste art. 31a Wte-zaak, met soms buitensporige belangstelling voor de persoon van de verdachte en de hoogte van de straf, domineren negatieve tonen. Het hof schept, door zijn ruime uitleg van art. 31a Wte waardoor zelfs in het effectenverkeer als 'gebruikelijk en oirbaar' te beschouwen beurstransacties strafbaar dreigen te worden, geen duidelijkheid en krijgt daardoor mogelijk onbedoelde en te ver strekkende consequenties als volgt. ${ }^{169}$

In de aanklacht tegen de rigoreus nume wetsinterpretatie door het gerechtshof staat de verwijzing naar de parlementaire behandeling van art. $31 \mathrm{a}$ Wte, waaruit blijkt dat slechts 'misbruik van het publiek of schending van vertrouwen in het functioneren van het marktmechanisme' strafrechtelijk - via de wettelijke bepaling - moet worden aangepakt; voorop. Kennelijk is de bedoeling van de wetgever de toepassing van het voorkennisartikel te beperken tot het werkelijk oneerlijke en verwijtbare handelen of nalaten. Het hof gaat in zijn uitspraak "te zeer voorbij aan de misbruik-strekking van de strafbepaling". "170 Deze verwaarlozing van het misbruikaspect speelt het hof parten in bij voorbeeld de uitleg van het begrip koersgevoelige informatie. Als vermeld, vindt het hof het niet nodig dat iemand, die handelt op grond van geheime gegevens, door die informatie inzicht heeft in het verloop van de koers. Dat is vreemd. Het feit dat iemand niet (op grond van vertrowwelijke inlichtingen) kan voorspellen of de koers daalt, stijgt of gelijk blijft, impliceert dat hij er nooit op uit kan zijn daarmee zijn voordeel te doen. Kortom, ook hier moet het karakter van misbruik meer worden benadrukt. Van koersgevoelige informatie is pas sprake als een "insider op grond van deze informatie een redelijke

168. Zowel 's-hof's arrest als de rechtbankuitspraak trekken aandacht. 'Rechter in zaak HCS beinwloed door media", in. NRC. 7 febr. 1995, p. 15. S. Kortmann en IJ. van Hees, in: WPNR, nr.6166, 4 febr. 1995, merken op dat het hof zich in oordeelsworming ontoelaatbaar laat beinwloeden door meningen in de media en opvattingen van deskundigen. Het thof heeft "de schijn gewekt fdoor het eerste arrest te: herschrijven in het tweede arrest, door de tweede versie van het arrest te voorzien van inieuw geformuleerde en aangevulde verwerpingen van verdachte"s verweren, door een afwijkende bewezenverklaring weer te geven, en door kennelijke verschrijvingen in de tenlastelegging te herstellen - JGLvN) dat het $z$ ich zelf de gelegenheid heeft gegeven om de reacties van diverse zijden op zijn eerste uitspraak in due uiteindelijke tekst van het arrest heeft verwerkt". Weliswar niet "s-hofs oordeel zelf, maar wel die daaraan ten grondslag liggende motivering is daardoor beünvloed. Auteurs stellen. "enigszims gechargeerd" dat het hof het "laatste woord in deze zaak heeft gelaten aan het publiek"; De betrokken wicepresident H. Willems ontkent bedoelde beïviloeding: "Rechters kijken naar de zaak zo als die is met alle respect "het kan ons niet schelen wat de pers schrijft", als geciteerd door J. Alberts, Rechter HCS" zaak. geen beinvloeding, in: NRC, 8 febr. 1995, p.21. Nieuwenhuyzen's advocaat L. Spigt acht, met Kortmann en Van Hees, het in de tweede versie van het vonnis weglaten, aanwullen en wegpunten wan tekstdelen in principe onjuist, maar voert dit niet als bezwar aan in het geding voor de Hoge Raad van wege het risico van tenugverwijzing naar het gerechtshof.

169. J.J. van Hees en S.C.J.J. Kortmann, Gerechtshof zit er in HCS-zaak helemaal naast, in: NRC. 19 dec. 1994, p.7.

170. J.J. van Hees en S.C.J.J. Kortmann, Gerechtshof zit er in HCS-zaak helemaal naast, in: NRC, $19 \mathrm{dec}$ 1994, p. 7 . 
prognose kan maken dat de koers aanmerkelijk omhoog of aanmerkelijk omlaag gaat". " 74 hu het hof zo'n ruim bed spreidt, doet de Hoge Raad er verstandig aan om voorzichtig en nauwkeurig te bepalen aan wie de lakens worden uitgedeeld.

Eerder dan verwacht, legt de Hoge Raad zich - medio december 1994 - toe op behandeling van het cassatieberoep inzake de HCS-beurshandel met voorkennis. ${ }^{172}$ Toch loopt ook hier de zaaksbehandeling flinke vertraging op. ${ }^{173}$ Eind maart $1995 \mathrm{krijgt}$ de Hoge Raad het, weliswaar niet-bindende, advies de HCS-zaak terug te sturen naar een ander gerechtshof dan het Amsterdamse hof. Dit advies berust op de twee volgende gronden. ${ }^{174}$ Ten eerste, het Amsterdamse hof makkt wel duidelijk dat Van den Nieuwenhuyzen over koersgevoelige informatie bezil, maar laat achterwege boven water te krijgen of verdachte wetenschap omtrent de richting van de beurskoers heeft. Ten tweede, het Amsterdamse hof heeft zich niet gebogen over de vraag of bij het handelen van Van den Nieuwenhuyzen wellicht sprake is van geaccepteerd gedrag in de effectenwereld.

In zijn oordeel eind juni 1995 conformeert de Hoge Raad zich aan de aanbeveling van de advocaat-generaal. Het hoogste rechtscollege vermietigt het arrest van het Amsterdamse gerechtshof en verwijst de HCS-zaak naar het gerechtshof in Den Haag. ${ }^{175}$ De Hoge Raad kan het Amsterdamse hof niet volgen daar waar het hof het voldoende vindt dat sprake is van een aannemelijke reactie op het nieuws van de HCS-reddingsactie, bovendien verschilt de Hoge Raad met het hof van mening over het behalde voordeel. Cruciale overwegingen van de Hoge Raad ter zake luiden dan dat, ten eerste, "naar objectieve maatstaven redelijkerwijs te verwachten moet zijn dat de bekendmaking van de geheime bijzonderheid - in dit geval het reddingsplan - zal leiden tot een stijging van de koers of een daling daarvan" en, ten tweede, dat (mogelijk) behaald voordeel "rechtstreeks verband" moet hebben met de transactie en daaruit voort vloeit. ${ }^{176}$

Naar aanleiding van de ongeoorloofde handelswijze van de directie van HCS doet de Vereniging Effecten Bezitters het volgende voorstel. Volgens de VEB is het tijd voor een meldingsplicht inzake transacties met aandelen in eigen bedrijf. D.W.z. bestuurders en commissarissen van een beursgenoteerde onderneming moeten 'insider'-transacties

171. J.J. van Hees en S.C.J.J. Kortmann, Gerechtshof zit er in HCS-zaak helemaal naast, in: NRC, 19 dec 1994, p.7.

172. Hoge Raad bwigt zich snel over affaire HCS, in: NRC. 14 dec. 1994, p.17.

173. Adwocaat-generaal J.W. Fokkens krijgt, bij herhaling, witstel i...$m$. de complexiteit van de materie. Cassatie in zaak HCS opgeschort, in. NRC, 20 febr. 1995, p. 10; De zelfde reden wordt aangevoerd woor mieuw uitstel van zes weken, waardoor de uitspraak eind juni 1995 valit te verwachten. Uitstel cassatie zaak Van den Nieuwenhwyzen, in: NRC, mei 1995, p. 17.

174. Aldus advies van advocaat-generaal J. Fokkens. Adviseur Hoge Raad: vernietig HCS-vonnis, in: NRC, 21 maart 1995, p.1.

175. Hoge Raad: arresr over voorkennis HCS-top nietig, in: NRC, 27 jwni 1995, p.1.

176. J. Alberts en M. Tamminga, Lijdensweg bedrijvendokter Joep van den Nieuwenhuyzen wrïwel ren einde. in: NRC, 28 juni 1995, p.15, zie ook Goed voor HCS-zaak, maar slecht voor borsumij, in: NRC, 28 juni 1995, p. 15. 
binnen vijf dagen melden. ${ }^{177}$ Ook de STE acht de tijd rijp woor een wettelijke verplichting van beursfondsen om koersorkestratie te melden. ${ }^{178}$

\section{$\$ 19.7$ Meldingsplichten zeggenschap in vennootschappen}

Naast deze bevoegdheden, die voort vloeien uit de Wte, beschikt de Stichting Toezicht Effectenverkeer over de bevoegdheden neergelegd in de Wet melding zeggenschap in ter beurze genoteerde vennootschappen ${ }^{179}$. Deze wet beoogt primair transparantie van eigendoms- en zeggenschapswerhoudingen op de effectenmarkt. ${ }^{180} \mathrm{Ex}$ art. $15 \mathrm{Wmz}$ junctis artt. 1-5 Delegatiebesluit Wmz ${ }^{\text {18: }}$ zijn, door de minister van financiën, aan de Stichting Toezicht Effectenverkeer beperkt bevoegdheden (met verhaalsmogelijkheid van de daaraan verbonden kosten ex art. $16 \mathrm{Wmz}^{182}$ junctis artt. 1-11 Regeling kostenwerhaal $\left.\mathrm{W} / \mathrm{mz}^{183}\right)^{184}$ gedelegeerd in het kader van het toezicht op betrouwbare, onverwijlde melding ${ }^{185}$ van verkrijging of overdracht van zeggenschap of van een belang in ter beurze van de $\mathrm{EG}$ genoteerde vennootschappen naar Nederlands recht ${ }^{186 .}$.

De onderneming, die wan een aandeelhouder de melding ontvangt dat - naar hij weet of behoort te weten - zijn (potentieel) kapitaalbelang of stemrecht in een Nederlandse beursvennootschap de in artt. 2-3 Wmz voorgeschreven limiet van 5, 10, 25, 50 of $662 / 3$ overschrijdt, moet deze melding ex art. $9 \mathrm{Wmz}$ onverwijld bekend maken via publikatie in een landelijk nieuwsblad, onder verstrekking van afschrift daarvan aan de STE. De STE bepaalt, dat dit moet geschieden in advertentievorm. ${ }^{187}$ Openbaarmaking geschiedt meestal binnen één week na ontvangst van de melding door de betrokken vennoot-

177. "Meldingsplicht voor bestuurders", in: NRC, 24 maart 1994, p.17.

178. Toezichthouder op beurs pleit voor snelrecht, in: NRC, 26 mei 1994, p. 19.

179. Wet melding zeggenschap in ter beurze genoteerde vennowtschappen, 18 dec. 1991, Stbl. 1991, 748, in werking per 1 febr. 1992.

180. Mve voorstel Wmz. TK 1989-1990, 21492, nr.3, p.2.

181. Delegatiebestuit inz. overdracht van taken en bevoegdheden ing. art. 15 Wmzaande STE, 18 dec. 1991, Stbl. 1991,749 .

182. Overigens zijn in gevolge art. 15, eerste lid, Wmz de bevoegdheid tot kostenverhaal en de bevoegdheid. daartoe regels te stellen, als bepaald in art. $16 \mathrm{Wmz}$, witgesloten van delegatie wan taken en bewoegdheden aan de STE.

183. Regeling kostenwerhaal Whe. 16 januari 1992, Stcrt. 1992, 16.

184. Vgl. regresrecht ex art. 28 Wte junctis artt. 1-13 Regeling kostenverhad Whe, 25 maart 1991, Stcrt. $1991,63$.

185. Volgens C.P. Bierhuize, Het voorstel van Wrm, in: NV, nr.5, mei 1990, pp. $145-151$, leidt de wet Wmz. "in een aantal gevallen tot een behoorlijke cumulatie van meldingen" "

186. Daaronder vallen ook de zgn. open-end beleggingsmaatschappijen met veranderlijk kapitaal. Een openend maatschappij geefi aandelen uit op verkoopt ze op aanvraag van het publiek. Hellas biedt de Wmz: beperkte mogelijkheden voor die matschappijen. Oplossing: of de Wmz moet als nog n.v.t. worden verklaard op dergelijke maatschappijen, of deze maatschappijen moeten worden vrijgesteld van melding van kapitaalbelangen. Aldus E.J. van Garderen, Kapitale perikelen rondom de beleggingsmaatschappij wet veranderlijk kapitaal, in: TVVS, nr.6, 1994, pp.151-155, i.h.b. p.155.

187. J. Maas "Rechten en plichren wan de beursgenoteerde onderneming. in: Firm, nr.2, 1994, pp.16-22, i.h.b. p.20. 
schap. ${ }^{188}$ De Stichting Toezicht Effectenverkeer vraagt meldingsplichtigen schriftelijk om opheldering, indien zij vermoedt dat een door hen gedane mededeling niet onverwijld is gedaan. ${ }^{189}$ Ex art. 10, eerste lid, Wmz stelt de STE, mogelijk onder schorsing van de plicht tot openbaarmaking van de melding conform het tweede lid, een onderzoek in of doet zij een onderzoek instellen bij vermoeden ${ }^{150}$ van onjuiste of onvolledige melding ${ }^{191}$, welke melding overigens wel kan worden hersteld ${ }^{192}$ in gevolge het vierde lid. De meldingsplichtige verstrekt ex art. 10, derde lid, Wmz, binnen een daartoe gestelde termijn, de nodige inlichtingen aan de STE. Ten aanzien van deze gegevens betracht de Stichting Toezicht Effectenverkeer geheimhouding ex art. $14 \mathrm{Wmz}$, behoudens voor zover enig wettelijk voorschrift haar tot bekendmaking verplicht of uit haar taak bij de uitvoering van de wet de noodzaak tot bekendmaking voort vloeit.

Tot het er op toezien dat meldingen door vennootschappen ook daadwerkelijk openbaar worden gemaakt en het voorkomen dat onjuiste of onvolledige meldingen worden gedaan blijft de Wmz-taak van de STE ${ }^{193}$ beperkt. Met die taak, die dus niet mag leiden tot meer dan "tot het geven van regels omtrent de wijze van publiceren en de controle op de correcte naleving daarvan" 194 , is een commercieel gebruik van de door de STE verkregen informatie over belangen van beleggers in beursgenoteerde bedrijven onverenig. baar. ${ }^{195}$

Eind 1992 is de STE in het bezit van 1429 meldingen (waarvan 1079 initiële meldingen in 293 nv's en 350 regulliere meldingen); in dat zelfde jaar worden 28 reguliere meldingen ingetrokken (waarvan 13 onjuiste, 12 onverplichte en 3 dubbele meldingen) en één van de drie gedane ontheffingsverzoeken wordt toegewezen. ${ }^{196}$ Eind 1993 constateert de STE 471 meldingen (waarvan 40 meldingen in 297 Wmz-vennootschappen en 431 reguliere meldingen); daarvan betreft $37 \%$ verkrijging of overdracht van aandelen in beleggingsmaatschappijen met veranderlijk kapitaal; de initiële meldingen betreffen vooral correcties van in het vorige jaar onjuist/onvolledig gedane meldingen, als mede meldingen door buitenlandse (moeder)maatschappijen die reeds eerder door Nederlandse ondernemingen zijn gedaan. ${ }^{197}$ In 1994 doen $147 \mathrm{Wmz}$-vennootschappen (waarvan 38

188. STE, Jaanerslag 1993, Amsterdam, april 1994, p.19.

189. STE, Jaanverslag 1993, Amsterdam, april 1994, p.20.

190. D.R. Doorenbos, a.w., p.286, actht dit een opsporingsbevoegdheid. Z.i. wordt deze bevoegdheid, eerder dan die uit het WwSv, uitgeoefend. Z.i. is het vernoeden ex art. 10 Wmz sneller aanwezig dan het redelijk vermoeden ex ant. 27 WvSv.

191. D.R. Doorenbos, a.w. p.286, wijst terecht op de volgende omissie in art. $10 \mathrm{Wmz}$. Er is kennelijk geen onderzoek mogelijk bij vermoeden van thet achterwege laten van een melding.

192. Warbij het tot strafvervolging bevoegde opembaar ministerie, ondanks eventuele toezeggingen van de $S T E$, uiteindelijh bepaalt of dit herstel afdoende is. Art. 10 verbindt immers geen rechtsgevolg aan herstel van een foutmelding. Zie D.R. Doorenbos, a.w., pp.282/285.

193. Owerigens aclit de Amsterdamse beurs zich zelf, meer dan de STE, gekwallificeerd tot uitoefening van Wmz-taken. Zie Beurs wil uitvoering Wmz overnemen, in: NRC, 30 juli 1994, p.13.

194. Mva woorstel Wriz, TK 1989-1990, 21492, nr.6, p. 10

195. Registratiekamer, Wmaz: gegevensverstrekking aan derden, Rijswijk. juli 1994, p.5. Zie paragraaf 19.9 .

196. STE, Jaarverslag 1992, Amsterdam, 1993, pp.20-23.

197. STE, Jaarverslag 1993, Amsterdam, april 1994, p.20. 
belleggingsmaatschappijen met veranderlijk kapitaal een of meer meldingen, afgezien wan onjuiste of onvolledige meldingen ontvangt de STE in 1994392 meldingen. ${ }^{198}$

De handhaving wan de $\mathrm{Wm}$, die sinds 1 februari 1992 in werking is, ligt in handen van de Economische Controle Dienst. In $1992 \mathrm{legt} \mathrm{de} \mathrm{ECD} \mathrm{in} \mathrm{één} \mathrm{van} \mathrm{de} \mathrm{tien} \mathrm{tot} \mathrm{haar} \mathrm{gerich-}$ te verzoeken tot het instellen van een opsporingsonderzoek proces-verbaal op; Vier overige zaken worden begin 1993 afgedaan met proces-verbaal; De andere onderzoeken, betreffende het niet, onvolledig, onjuist of het niet tijdig melden of openbaar maken, lopen nog. ${ }^{199}$ In 1993 geeft de STE alle haar bekende overtredingen door aan de ECD. Bovendien verzoekt zij de ECD specifiek in vijf zaken onderzoek in te stellen naar mogelijke (opzettelijke) overtredingen van de Wmz. ${ }^{200}$ De ECD meldt in 1993 dan als resultaat de afronding van 7 onderzoeken, alle uitmondend in een proces-verbaall op grond van niet, niet volledig of niet tijdig melden, daarnaast deelt de ECD mede dat per 1 januari 1994 nog 8 onderzoeken op dit terrein, welke onderzoeken in het algemeen zeer arbeidsintensief zijn, lopen. ${ }^{201}$

Naast deze strafrechtelijke handhaving van de Wmz, bestaat de mogelijkheid van civielrechtelijke handhaving. T.W.: veroordeling tot melding; schorsing stemrecht voor maximaal drie jaar; schorsing besluit algemene vergadering aandeelhouders, mogelijk met vernietiging van dat ava-besluit; bevel tot onthouding van aandelenverkrijging en stemrecht voor maximaal vijf jaar. Art. 13, vierde lid, Wmz verschaft degenen, die 5\% belang hebben in een Wmz-vennootschap, de mogelijkheild een rechterlijk verbod of gebod te vragen bij handelen in strijd met de Wmz. Deze maatregel vindt in 1993 nog geen toepassing. 202

De Wmz, die nog van redelijke recente datum is, bevindt zich in een groeiproces. Door toenemende bekendheid van justitiabelen met de wet functioneert de $\mathbf{W}$ mz welliswar beter. Maar tegelijkertijd heeft de wet hinderlijke tekortkomingen. Bij voorbeeld, het ontbreken in de Wmz van een meldingsplicht, indien uitsluitend ten gevolge van een wijziging in de noemer een meldingsplichtige drempel wordt gepasseerd, doet af aan de bruikbaarheid en de actualiteit van de overzichten waarin alle bij de STE ontvangen en door vennootschappen openbaar gemaakte meldingen zijn opgenomen. De effectentoezichthouder kan daarom niet komen tot de objectieve overtuiging dat de doelstelling van de wet, t.w. transparantie, is bereikt. Voorzichtig merkt zij op dat bij haar "de indruk bestaat dat de Wmz bijdraagt tot deze doorzichtigheid". "203 Vandaar dringt de STE in een Wmz-evaluatienota aan op de nodige wetswijzigingen. ${ }^{204}$

198. STE, Jaarverslag 1994, Ansterdam, 1995, pp.19-20.

199. ECD, Jaarverstag 1992, 1993, 's-Gravenhage, p.15.

200. STE, Jaamerslag 1993, Amsterdam, april 1994, p.21.

201. ECD, Jaarversiag 1993, "s-Gravenhage, 1994, p.11.

202. STE, Jaarverslag 1993, Amsterdam, april 1994, p.21.

203. STE, Jaarverslag 1993, Anusterdam, 1994, p.21.

204. Zie ook STE, Jaarverslag 1994. Amsterdam, 1995, p.21-22. 
Bij verandering van de Wmz-regels is ook aandacht nodig voor de slordigheid, dat de wetgever eind 1993 (in het kader van afstemming van de Wmz op de Awb) niet het Wmz-artikel inzake de geheimhoudingsplicht maar het Wmz-artikel aangaande de ontheffringsclausule van de publikatieplicht schrapt. Dat de reparatiewetgeving hier lang op zich laat wachten, speelt de STE tijdens uitoefening van haar toezichtstaak parten bij de Wmzzaak aangaande Van den Nieuwenhuyzen. Van Nieuwenhuyzen verkrijgt door een financiele reorganisatie bij Begemann een converteerbare lening van 150 miljoen gulden. Daarin heeft hij al een aandelenbelang heeft van 49,9 procent. Hij acht een Wmz-melding dan ook niet nodig en beroept zich op een ontheffingsmogelijkheid. Zes maanden later zilet hij af van omzetting van zijn lening in aandelen. Formeel gezien daalt zijn belang daardoor weer. Weer ziet hij af van melding en refereert aan zijn eerder gedane ontheffingsverzoek. Zo lang reparatiewetgeving uit blijft, en de Wmz dus nog steeds verstoken is wan een artikel inzake ontheffingsmogelijkheden, kan de STE geen oordeel vormen. Omdat het herstel van de $\mathrm{Wmz}$ wel erg lang op zich laat wachten, dringt de STE eind december 1994 uiteindelijk toch aan op melding door Van den Nieuwenhuyzen. ${ }^{205}$

\section{$\$ 19.8$ Prospectusplicht}

Middels een prospectus kunnen aankomende of bestaande effecteninstellingen hun diensten aankondigen of beschrijven. Het doet denken aan het adverteren met produktaanbieding. Omdat het effectenverkeer een prospectusplícht kent, is echter sprake van oneigenlijke reclame ${ }^{206} .207$

205. Financiële regelgeving vaak doothof; Van den Nieuwerhuyzen zies het licht in de Wmz, in: NRC, $28 \mathrm{dec}$. 1994, p. 17.

206. Illustratief is het arrest $A B N$ AMRO-Bank nw ws. Vereniging tot behartiging van belangen van houders wan obligaties Coopag Finance bv. HR 2 dec. 1994, RvdW 1994, 263, ook in: NJB, nr.1, 6 jan. 1995. rechtspraakkatern nr.263C, pp.4-5 (bijlage). Daarin concludeert de HR tot aansprakelijkheid ex art. 1:194 BW (art. 1461a oud BW) van de lead manager, i.c. de bank, voor misleidende financiële informatie in een emissieprospectus. Deze aansprakelijkheid is trouwens beperkt in die zin dat zij niet bestaat jegens kopers na de emmissie. In het oordeel, waarin de aansprakelijkheid wordt aangenomen, constateert de HR dat de lead manager (met oog op het opstellen van een prospectus - JGLvN) niet zonder meer af mag gaan op door accountants gecontroleerde en goedgekeurde jaarrekeningen van de emitterende vennootschap. Of mag worden vertrouwd op de juistheid en volledigheid van de jaarrekeningen hangt af van omstandigheden. Relevant daarwoor kunnen, naast gegevens van de accountant zelf, zijn: inlichtingen van de obligatie uitgevende instelling of informatie wan de bank of banken die de uitgevende instelling ook tot cliènt hebben (gehad); Positief over deze vitspraak L.R.T. van der Groot, De Beurs wikt, de Hoge Raad beschikt, in: Bank-en Effectenbedrijf, jan./febr. 1995, pp.4-5. Auteur waardeert de aanscherping van de zgn. due diligence-circulaire van 1993: de lead manager, als eerst verantwoordelijke voor een emissieprospectus, wordt terecht belast met de bewijslast. Bovendien kan de lead manager zich niet eenwoudig verschuilen achter verklaringen van deskundigen; Over arrest ook M.J.G.C. Raaijmakers, ABN AMRO/Vereniging Coopag, in: AA, nr.3, 1995, katern nr.44, pp.219-226. Auteur stelt dat de Hoge Raad terecht een posterieure waarschuwingsplicht van de bank jegens het publiek verwerpt. Daarnaast benadnukt auteur het gebundelde karakter van de door de veneniging Coopag ingestelde actie. Ex art. 3:305a BW is dat mogelijk. De rechter acht de vereniging, voor zover het de verklaring voor recht betreft, ontwankelijk nu zij een wolledig bevoegde vereniging is, zij blijkens haar statuten specifieke belangen behartigt wan (Coopag-obligatieverwervende) personen en bedoelde belangen gelijksoortig zijn: Tevens interessante zaaksbespreking door S. A. Bioele, Het arrest van de Hoge Raad in de zaak ABN AMRO/Co op AG, in: TVVS, nr.3, 1995, pp.64-72. 
De STE controleert of een prospectus inderdaad gegevens bevat die redelijkerwijs van belang zijn voor beoordeling van onder meer: aard van een bepaald effect, verwervingsprijs, looptijd en omwisselingskoers, stemgerechtigheid, het bestuur, organisatie, activiteitenscala, financiële positie, actuele stand van zaken en toekomstverwachtingen $^{208} .209$

Als uitvloeisel van EG-regelgeving inzake de wederzijdse erkenning van prospectus$\operatorname{sen}^{210}$ is, ter coördinatie van de eisen gesteld aan de opstelling van, het toezicht op en de verspreiding van het prospectus, uitdrukkelijk de Stichting Toezicht Effectenverkeer als controlerend orgaan aangewezen. ${ }^{211}$

In de tweede helft van 1992 wijst de STE vier van de vijf verzoeken om ontheffing van de prospectusplicht toe. ${ }^{212}$ In 1993 verleent de STE in tien gevallen ontheffing van de prospectusvoorwaarden. ${ }^{213}$ In 1994 verleent de STE vijftien ontheffingen ter zake. ${ }^{214}$

\section{$\S 19.9$ Rechtsbescherming en klachtbehandeling}

Naar aanleiding van het optreden ${ }^{285}$ van de toezichthouder op effectenverkeer, staat beroep door een belanghebbende open bij het College van Beroep voor het Bedrijfsleven ex art. 30, eerste lid, Wte ${ }^{216} 217218$ Van een, binnen zes maanden te geven, beslissing van een houder van een effectenbeurs omtrent de toelating van effecten of het doen vervallen van effecten wit de notering aan die effectenbeurs, kan een belanghebbende in beroep gaan bij de Stichting Toezicht Effectenverkeer zelf (art. $29 \mathrm{Wte}^{219}$ ). ${ }^{220}$

Juist wat betreft haar toezichtstaken is de Stichting Toezicht Effectenverkeer, even als De

207. A.G. Maris en S.A. Boele, Prospectusaansprakelijkheid, in: TVVS, nr.6, 1994, pp. 141-146. Overigens: voeren auteurs pleidooi voor een specifiek "op prospectusaansprakelijkheid toegesneden wettelijke
regeling".

208. Voor potentiele beleggers zijn toelkomstwerwachtingen essentieel. Daarom hecht de STE, wier taak beperkt is tot wastistelling van opname in de prospectus van de mededeling van een accountant, bellang aan het feit dat de accountant ook de toekomstparagraaf beoordeelt. Hierover voert zij owerleg met het NIVRA. STE, Jaarverslag 1994, Amsterdam, 1995, p.13.

209. Uitgebreid paragrafen 1 tot en met 22.7 Bijlage behorendie bij art. 2 Besiluit toezicht effectenverkeer, Stbl. 1991, 750.

210. Richthin v.d. Raad w.d. EG van 23 april 1990 tot wijzighng wan richtlijn 80/390/EEG wat de wederzjdse erkenning wan het aanbiedingsprospectus als prospectus woor de toelating van effecten rot de officiele notering can een effectenbeurs betreft, 90/211/EEG, Publ. EG, L 112, 3 mei 1990.

211. Zie art. I Regeling van de minister van financiën inzake de aanwijzing wan de STE als instantie bedoeld in art: 21, deride lid, wan richrijin 89/298/EEG, 12 juni 1991, Stcrt. $1991,116$.

212. STE, Jaarverslag 1992, Amsterdam, 1993, p.17.

213. STE, Jaarversiag 1993. Amsterdam, april 1994, p.13.

214. SIE, Jaarverslag 1994, Amsterdam, 1995, p.14.

215. Hier rijzen mogelijk problemen. Zie $P$. ws. STE, CBB 7 juli 1994, AB 1995, 79, m.nt. JHwdW. De calsus leert alls volgt. P. werkt voor een effecteninstelling waaraan de STE een vergunning theeft verleend. Voorheen was hij werknemer bij een van uit Duitsland opererende effecteninstelling, die voorkomt in de opsomming van instellingen waartegen de STE eind 1992 een waarschuwing doet uitgaan. Na kennisgeving door de vergunninghoudende effecteninstellimg wan de indiensttreding van de werknemer, vragt de STE om nadere informatie over de nieuwe werknemer. Met deze informatie kan zij zich een owrtleel vormen over de werkervaring, betrouwbaarheid en deskundigheid van bedoelde persoon. 
Nederlandsche Bank nv en de stichting Verzekeringskamer, uitgezonderd van de toepasselijkheid van de Wob en de Wno ${ }^{221}$ Deze uitzondering is nodig door, op grond van Europese richtlijnen gegarandeerde, geheimhoudingsplichten die de aparte vertrouwenspositie van een financieel toezichthouder kenmerken.

Die geheimhoudingsplichten zijn niet zonder betekenis. Naar aanleiding van in het bijzonder de, in art. 14 Wmz neergelegde, geheimhoudingsbepaling ontstaat medio 1994 de nodige commotie. De Registratiekamer krijgt lucht van, door belanghebbenden vermeend, onrechtmatig gebruik van persoonsgegevensregistratie door de STE. De bestreden handelswijze van de STE komt op het volgende neer. De STE heeft de persoonsregistratie, bevattende gegevens alls bedoeld in de Wmz, aangemeld bij de Registratiekamer ex art. $24 \mathrm{Wpr}$. Uit deze persoonsregistratie verstrekt de STE gegevens aan ieder die daarom verzoekt tegen betaling van respectievelijk $f 75,00$ voor een overzicht van alle Wmz-gegevens en $f 7,50$ voor een afschrift van de meldingen van twee beursfondsen naar keuze.

In een, op grond van art. 46, eerste lid, Wpr uitgebracht, openbaar onderzoeksrapport constateert de Registratiekamer strijdigheid van de bepalingen van de $\mathrm{Wpr}$ en de Wmz. ${ }^{222}$ De Registratiekamer interpreteert art. $14 \mathrm{Wmz}$ strikt. Haar reikwijdte moet

215. $\rightarrow$

De STE constateet dat betrokken werknemer in zijn curriculum vitae bedoelde besmette periode uit zijn arbeidsverleden verzwijgt. Dit meldt de STE aan de vergunninghoudende effecteninstelling die hem net heeft aangenomen. Kort daarop wordt betrokkene met onmiddellijke ingang op non-actief gezet. Let wel, voor het magen opdragen van de functie aan die werknemer is een gunstig oordeell over diens geschiktheid van de STE niet vereist. Volgens het CBB betekent de correspondentie van de STE dan ook rechtens geen verhindering voor functieverwulling door de werknemer. M.a.w. het besluit van de STE is geen beschikking omdat zij niet op enig rechtsgevollg is gericht, nu het beoogde gevolg miet door lnet objectiewe recht wordt toegelkend aan het nemen van het besluit zelf. Het ontslag is enkel te zien van uit de priwatrechtelijke arbeidsovereenkomst tussen werknemer en effecteninstelling. Het CBB begeeft zich hier op glad ijs. Want, hoewel de besluitworming van de STE niet binnen haar preventief toezicht walt, kan het bes"uit in het kader van repressief toezicht nog een dominante rol spelen. Van uit het oogpunt van rechtsbescherming tegen de, uiteindelijk invloedrijke, STE ligt het meer voor de hand in casu haar beslitit, min of meer woort vloeiend uit hat toezichtstaak, aan te merken ais een appellabel beshluit.:

216. $\mathrm{Vgl}$. art. $11 \mathrm{Wmz}$.

217. Over een incompleetheid van rechtsbescherming, th wetontbreken van een bijzondere rechtsgang voor beslusten to schorsing, ex art. 65 Wet Arbo (per 1 jan. 1994: Wet bestuurstechtspraak bed rijfsorganisawie), wan een fonds uit de beursnotering, M.C.M. van Dijk, De Wte in vogelwlucht, in: TVVS, nr.8, 1991, pp.204-209, i.h.b. p. 209.

218. C.A. Schreuder, Publiekrechtelijke taken, privare rechtspersonen, Deventer, 1994, p.253, merkt op dat het $\mathrm{CBB}$, ondanks de orisntatie op het economisch bestuursrecht, mogelijk moeite heeft met het boordelen wan priwaatrechtelijke rechtspersonen die bij] verdediging een, op de wet gebaseerd, eigen belang (als inwulling van de abbb) op mogen werpen.

219. Alls gewijzigd bij Alanpassingswer $A w b, 4$ juni 1992, Stbl. 1992, 42.

220. C.A. Schreuder, a.w., p.350, windt de privaatrecthtelijke beroepsmogelijkheid bij de STE en, mogelijk, darma de publiekrechtelijke rechtsbescherming tegen het STE-besluit door het CBB, getuigen van halfslachtigheid. Auteur opteert overtuigend woor twee publiekrechtelijke rechtsgangen ter zake. Alanwizzingsbesiuit bestuursorganen Wob en Who d.d. 16 okt. 1993, Stbl. 1993, 535, pp.4/14-15. 
worden geinterpreteerd "in het licht van het doel, de strekking en de aard van betrokken gegevens en in het bijzonder de wettelijke taak van de STE $^{\text {rf }} .{ }^{223}$ De enige uitzondering op deze geheimhoudingsplicht wordt gemaakt voor internationale informatie-uitwisseling onder de uitdrukkelijke clausule van wederzijdse geheimhouding door de Nederlandse en buitenlandse bevoegde autoriteit. De gevens moeten aanwending krijgen overeenkomstig het doel van de Wmz. De Registratiekamer hecht bovendien belang aan het feit dat de specifieke Wmz-geheimhoudlingsbepaling niet derogeert aan de algemene geheimhoudingsplicht ex art. 2:5 Awb. ${ }^{224}$ Ook als aan art. $14 \mathrm{Wmz}$ minder verstrekkende betekenis moet worden toegekend, stuit het commercieel gebnuik van Wmz-gegevens af op art. 11, eerste lid, Wpr. De, door de STE mogelijk geachte, derdenverstrekking vloeit niet voort uit het doel van de Wmz-persoonsgegevensregistratie. Bij bepaling van dat doel worden aard en betekenis daarvan in het maatschappelijk verkeer in aanmerking genomen. Het tegen vergoeding verstrekken van Wmz-gegevens aan willekeurige derden ligt "op generlei wijze in het verlengde van de toezichthoudende en controletaken van de STE". ${ }^{225}$ Een dergelijke gegevensverstrekking dient geen gerechtvaardigd doel. De transparantie van de beleggingsmarkt wordt er niet door bevorderd. Conclusie moet zijin, dat de STE haar geheimhoudingsplicht ex art. $14 \mathrm{Wmz}$ schendt door, het tegen vaststaande tariewen, werstrekken van Wmz-gegevens aan derden. Als de STE haar houding ter zake niet verandert, wordt de rechter of de minister van financtën ingeschakeld. ${ }^{226} \mathrm{De}$ STE meent echter dat haar handelen niet onrechtmatig is. Daartoe voert zij de volgende redenen aan. ${ }^{227}$ Ten eerste, de omstreden gevensverstrekking aan derden dient het doel van de Wmz, namelijk de doorzichtigheid van de kapitaalmarkt. Ten tweede, de kosten die voor de verstrekking van de - overigens toch al door de beursfondsen openbaar gemaakte - gevens in rekening worden gebracht, betreffen slechts een deel van de werkelijke kosten. ${ }^{228}$ Kortom, volgens de STE is geen sprake van commerciële exploitatie. De STE ziet dus geen reden om te stoppen met de verkoop van gegevens over grote beleggers in Nederlandse beursfondsen. Omdat de STE deze verkoop niet wil opschorten tot de parlementaire behandeling van het wetsontwerp tot wijziging van de $\mathrm{Wmz}_{\text {, raakt } \mathrm{zij}}$ in een juridische procedure betrokken. ${ }^{229}$ In het, voor de president van de Amsterdamse rechtbank aangespannen, kort geding stelt de STE-verdediger dat passieve gegeverns-

223. Registratiekamer, a.w., p.6.

224. Registratiekamer, a. w., p.5.

225. Registratiekamer, a.w. . p.7.

226. Aldus G.T.J. Hoff (allwocaat bij Loeff, Claeys \& Verbeke), geciteerd in Waakhond beurs schendit privacy ", in: NRC. 27 julli 1994, p.13.

227. Adwoccat Hoff sleept STE woor de rechtbauk, in: NRC, 5 aug. 1994, p.10.

228. M. Tamminga, Spel om publicatie wan al publieke informatie, in: NRC, 6 aug . 1994, p.13, windli dat "best becald mag worden" : "heldere informatie over beursbelangen vertegenwoordigt waarde". Te rechtwaardigen is $z$.i. een "premie op de officiële gegevens van de STE", die -in tegenstelling tot de gegevens uit de aan bestandlswervuiling onderhevige Wmz-betronwbaar zijn. Om de kosten te dnukkem adviseert auteur een "licentie voor de publicatie van de officiële meldingsgegevens bij opbod te verkopen.". Auteur vindt dat de regering de Wmz-manco"s (gegevensvervuiling, falende opsporing vam buitenlandse beleggers met grote belangen, en het ontbreken van een openbaar register van meldingen》) weg moet nemen.

229. Advocaat Hoff sleept STE woor de rechtbank, in: NRC, 5 aug. 1994, p. 10. 
werspreiding door de STE door de beugel kan. ${ }^{230}$ De pleiter van de speciaal voor het proces in het leven geroepen Stichting Waakzaamheid Wmz-persoonsregistraties constateert dat de STE aan geheimhouding is gebonden, nu de wetgever niet expliciet een openbaar register ter zake heeft ingesteld. ${ }^{231}$

De president van de Amsterdamse rechtbank stelt, onder verwijzing nalar het ontbreken van een openbaar register, de STE in het ongelijk. ${ }^{232}$ Derdenverstrekking van Wmzgegevens door de STE is niet meer mogelijk, behoudens daarvoor toestemming van betrokkene wordt gegeven, of dat verstrekking nodig is voor het uitwisselen van informatie tussen internationale toezichthouders. De rechter - die constateert dat: a. geen sprake is van doorkruising door de Wob omdat het in casu niet gaat om bestuurlijke informatie; b. openbaarmaking van reeds openbare gegevens (zeker in bewerkte vorm) steeds opnieuw als openbaarmaking geldr; c. de STE zelf ongeoorloofd de bedoeling van de wetgever invult; $d$. het doel van de Wmz uitsluitend ligt in controle; e. betrokken beleggers schade lijden door de gewraakte publikatiemethode van de STE; en $f$. causaal verband aanwezig is - oordeelt het belang van doorzichtigheid van de effectenmarkt ondergeschikt aan dat van de publikatiewijze als voorgeschreven in de Wmz, m.a.w. het belang van privacy en potentiële schade van effectenbeleggers. ${ }^{233}$ De STE mag zich niet meer beleidsruimte toedelen dan haar volgens de Wmz toekomt. In het rechterlijk vonnis klinkt dan ook door "dat de STE niet de eerste toezichthouder of opsporingsinstantie is, die met een beroep op zijn maatschappelijke rol of het algemeen belang meer bevoegdheden opsllorpt dan de wetgever bedoeld had". ${ }^{234}$

Even wel krijgt de toezichthouder op naleving van effectenwet- en regelgeving, in het door de STE aangespannen hoger beroep tegen de uitspraak van de president van de Amsterdamse arrondissementsrechtbank, als nog gelijk. Het Amsterdamse gerechtshof bepaalt begin 1995 dat de STE weer informatie mag verstrekken over grote aandelenbelangen van beleggers in Nederlandse beursgenoteerde bedrijwen. ${ }^{235}$ Het hof acht de STE de centraal fungerende instantie in het kader van de Wmz. Hierbij deelt de wetgever de STE geen beperkte taak toe. ${ }^{236}$ Het hof geeft, anders dan de rechtbankpresident die voorrang geeft aan de letter van de wet, prioriteit aan de strekking van de wet: transparantie van de effectenmarkt. Deze doorzichtigheid is gebaat bij openheid. Het hof meent dat, als de wetgever openbaarheid had willen beperken, hij dat wel expliciet had gedaan (hierbij merkt het hof trouwens als punten van belang aan, dat a. de door de STE verstrekte gegevens reeds tevoren openbaar zijn gemaakt in gevolge de Wmz en b. de gege-

230. STEwertegenwoordiger H.J. Sachse (adwocaat bij Boekel De Nerêt) redeneert, met een Registratiekamerrapportage uitt 1993 waarin het 'nee' wordtuitgesproken tegen actieve verspreiding, a-contrario. Zie Beleggers laken openbaarheid Wmz, in: NRC, 2 sept. 1994, p. 11.

231. Aldus meent G. Hoff, weer gegeven in: Beleggers laken apenbaarheid Wmz, in: NRC, 2 sept. 1994, p. 11 .

232. Beleggers winnen geding over publikatie beursbelangen, in: NRC, 16 sept. 1994, p. 11.

233. Stichting Waakzaamheid Wmz-persoonsregistraties vs. STE, President rechtbank Amsterdam, 15 sept. 1994. KG 1994, 354, ook in: MF, nr.10; okt. 1994, pp. B97-B98 (rechtspraakbijlage).

234. M. Tamminga, Waakhond beurshandel op de vingers getikt, in: NRC, 16 sept. 1994, p.11.

235. Waakhond beurs wint hoger beroep aandelenbelangen, in: NRC, 26 jan. 1995, p.19.

236. STE ws. Stichting waakzaamheid Wmz-persoansregistraties "Hof Amisterdam, 26 jan. 1995, in: MF, nr 3, 1995, pp.B35-B36 (rechtspraakbijlage) en ook in: TVVS, ar.4, 1995, pp.104-105 " 
vens ook reeds publiekelijk zijn gemaakt in het verslag van de STE aan het ministerie van financièn). Volgens het gerechtshof is het voor beleggers belangrijk te weten wie grote aandelenpakketten hebben. Bovendien zijn door de meldingsplicht signalen op te vangen van mogelijke vijandige overnames. Nu zijn juist deze meldingen vatbaar voor fraude: Slechts bedrijwen die aandelen plaatsen, waarbij grote beleggers zijn betrokken die echter niet worden vermeld, moeten daarvan melding doen. Daardoor onstaat grote kans op bestandsvervuiling. Feitelijk hoeft het namelijk niet zo te zijn, dat het bedrijf nog een groot belang bezit. Dat zit vaak bij de niet genoemde (derden-)beleggers. Hoewel cassatie bij de Hoge Raad tegen het arrest van het Amsterdamse gerechtshof er niet in zit, overweegt de verliezende partij wel een brief aan het parlement te sturen om aan te dringen op de reeds lang beloofde verbetering op dit punt van de Wmz. ${ }^{237}$

\section{$\$ 19.10$ Kostenverhaal en (financiële) verslaglegging}

Het optreden van de Stichting Toezicht Effectenverkeer is vooral van publiekrechtelijke aard. Haar taak is een overheidstaak.

In budgettair opzicht valt de Stichting Toezicht Effectenverkeer buiten de rijksbegroting. De kosten, die de haar opgedragen uitwoering wan taken en bevoegdheden met zich mee brengt ${ }^{238}$, worden voornamelijk via retributieheffing op houders van effectenbeurzen en overige personen of organisaties op effectengebied (ex art. 28 Wte) verhaald. Speciaal in het kader wan uitvoering van de W/mz bestaat voor de Stichting Toezicht Effectenverkeer een verhaalsmogelijkheid van de daaraan verbonden kosten open ex art. 16 Wmz junctis artt. 1-11 Regeling kostenverhaal $\left.\mathrm{Wmz}^{239}\right)^{240}$

De Stichting Toezicht Effectenverkeer doet, ex art. 25, vijfde lid, Wte, jaarlijks verslag van haar werkzaamheden aan de minister van financiën, die de rapportage ten dele publiceert. Immers, gegevens met betrekking tot afzonderlijke ondernemingen en instellingen worden alleen met hun toestemming openbaar gemaakt.

\section{$\$ 19.11$ Beperking van de vrijheid van effectenverkeer in het licht van harmonisatie van nationale regelgeving ter zake}

Genoemde regelgeving omtrent prospectussen is gebaseerd op EG-recht. ${ }^{24 !}$ Dit geldt ook voor de wetgeving inzake melding zeggenschap in ter beurze genoteerde vennoot-

237. M. Tammingt, Arrest hof stelt openheid boven privacy van beleggers, in: NRC, 27 jan. 1995, p.11.

238. Met name apparatskosten wan de toezichthouder, waarvan het in rekening brengen in finanicieell-economische wetgeving niet ongebruikelijk is, volgens Mw woorstel Wie, TK 1988 1989, 21038, nr.3, p.28.

239. Regeling kostenverhaal Wmz, 16 jan. 1992, Stcrt. 1992, 16

240. Vigl. regresrecht ex ant. 28 Wte junctis artt. 1-13 Regelling kostenverhaal Wte, 25 maart 1991, Stcrt. 1991,63

241. Richtijn w.d. Raad v.d. EG wan I7april 1989 tot coördïnatie van de eisen gesteld aan de opstelling van, het roezicht op en de verspreiding van het prospectus dat moet worden gepubliceerd bij een openbare aanbieding van effecten, $89 / 298 / \mathrm{EEG}_{3}$ Publ. EG, L 124, 5 mei 1989. 
Hoofdstuk 19

schappen. ${ }^{242}$ En eveneens voor de Nederlandse bepalingen inzake misbruik van voorwetenschap ${ }^{243}$

Daarnaast drukt recente Europese regelgeving haar stempel op de Nederlandse effectenwet- en regelstelling. Denk aan de mimimum-harmonisatie beogende richtlijnen aangaande beleggingsdiensten ${ }^{244}$ (waarin zijn opgenomen een wederzijdse vergunning-erkenning tussen lidstaten, een concentratieverplichting, meldingsverplichtingen, doorzichtigheidsbepalingen, de rechtstreekse toegang van banken tot effectenbeurzen en de toelating van natuurlijke personen tot het verrichten van effectendiensten) en kapitaaltoereikendheid $^{245}: 246$

Tevens relevant zijn de implicaties voor de nationale effectensector van de communautaire regelgeving ${ }^{247}$, die leidt tot respectievelijk de, per 1 februari 1994 in werking zijnde, Wet identiteitsvaststelling bij financiële dienstverlening ${ }^{248}$ en de Wet melding ongebrui-

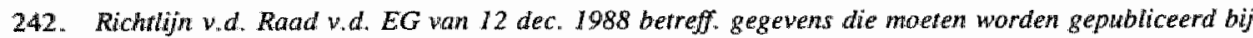
vernening/overdracht w.e. belangrijke deelneming in een ter beurze genoteerde vennootschap. 88/627/EEG, Publ. EG, L 348, 17 dec. 1988.

243. Richalin v.d. Raad v.d. EG van 13 nov. 1989 tot coördinatie van de woorschrifien inzake transacties van ingewidew, 89/592/EEG, Publ. EG, L 334/30, 18 now. 1989. Met instelling van de STE wordt voldaan aan de gemeenschapsverplichting ex art. 8 van bedoelde richtlijn, waarin de eis van een administratief vezichthoudend orgaan ter zake is neergelegd; Ook relevant zijn het Verdrag inzake handel met woorkennis van 20 april 1989 en het Frotocol inzake handel met voometenschap van 11 sept. 1989 (Trbl. 1993, resp. 111 en 112), stilzwijgend goedgekeurd door de minister van buitenlandse zaken, TK 19931994, 23690 (R1501), 345/1. Nederland bekrachtigt d.d. 4 juli 1994 bedoeld verdrag en protocol, en beide treden in werking d.d. 1 nov. 1994. Zie Trbl. 1994, 157-158. Het verdrag met protocol, gericht op informatie-uitwisseling op administratief gebied tussen bevoegde autoriteiten van aangesloten staten als mede wederzijdse rechtshulp in strafzaken, heeft een aanvullende werking op vermelde EG-richulijn en het bilaterale verdrag tassen Nederland en de Verenigde Staten inzake uitwisseling van informatic op effectergebied (Trbl. 1990, 61). Hierover M. R. Mok, Raad van Europa-verdrag effectenhandel met woonwerenschap, in: TVVS, nr.10, 1994, pp.272-273.

244. Richtlin 93/22/EEG wan we Raad van 10 mei 1993 inz. het verrichren van diensterl op het gebled van beleggingen in effecten, Publ. EG, L 141, 1993. Deze richtilijn wordt, samen met de Richtijn 93/6rEEG wan de Raad wan 15 maart 1993' inz. de kapitaaltoereikendheid wan beleggingsondermemilngen en kredietinstelingen, omgezet in het Wetswoorstel houdende het opnieuw waststellen wan de Wte i.w. m. de whoering wan de richliin betreffende het verrichten wan diensten op het gebied van belegging in effecten en van de richtiph betreffende de kapifaaltoereikendheid wan beleggingsondernemingen en kredietinstellingen, TK 1993-1994, 23874, nrs.1-3.

245. Richtlin 93/6/EEG v.d. Racad w.d. EG van 15 maart 1993 tot coördinatie van de regels m, b.t. kapitaal roereikendheld woor beleggingsondernemingen, kredietinstellingen inbegrepen, Publ. EG, 1 141., 1993.

246. Over, overigens niet ingrijpende, gevolgen wan beide richtijnen voor Nederland D.H. Cross, EG richtijnen betreffende bemiddelaars in de effectenhandel, in: TVVS, nt.3. 1994, pp.62-66.

247. Richrligh w.d. Raad v.d EG tot woorkoming w.h. gebruik v.h. financiele stelsel woor het wiswassen van geld, 91/308/EEG, PubI. EG L 166/77, 28 juni 1991; Volgens D.J. Drijber, EEG-richtlijn inzake het wismassen van geld vastgesteld, in: TVVS, nr. 11, 1991, pp.294-295, bied de EG-richtllin weinig hoop voor witwasroutes die (ten delle) buiten EG lopen.

248. Wetswoorstel identificatie bij financiele dienstwerlening., TK 1992-1993, 23008, nrs.1-2; Wet 16 dec. 1993. Stbl 1993,$704 ;$ Stbl. 1994, 48; Conform Wet op de identificatieplicht wan 3 dec. 1993, Stbl. 1993, 660, als woorgesteld in TK 1993-1994, 23656, nrs. 1-3 (gerelateerd aan TK 1991-1992, 22694, nrs. 1-3 en TK 1987-1988, 20612, nurs. 1-3) wordt wet gewijzigd d.d. 19 mei 1994, Stbl. 1994, 358. 
kelijke transacties ${ }^{249}$, 250 Tegen de, in de Wifd en Wmot neergelegde, wettelijke professionele fraudemeldingsplichten ${ }^{251252}$ bestaan bezwaren. De weerstand bij notarissen wordt veroorzaakt door hun geheimhoudingsplicht. ${ }^{253}$ En accountants worstelen met het rijmen van hun 'aversie tegen een wettelijke klikplicht' en het algemeen 'maatschappelijk belang van fraudebestrijding'. 254 Afgezien van problemen met geldende geheimhoudingsplichten, heeft de betrokken financiële banksector problemen met het toenemen van de werklast door de meldingsplichten. Als de Nederlandse overheid aan de Nederlandse banken dan ook nog vraagt om informatie over bankcliëntèle te verschaffen aan de belastingdienst is de maat vol. Volgens de Nederlandse Vereniging van Banken wordt de "grens van deze, kosteloos te verrichten, 'herendiensten' langzamerhand bereikt". ${ }^{255}$ Aan deze klacht komt justitie tegemoet. Per 1 januari 1995 betaalt het openbaar ministerie de banken een standaardvergoeding ${ }^{256}$ voor, een door een vast contactpunt van de bank binnen redelijke termijn te verstrekken, informatie over cliënten die ongebruikelijke ${ }^{257}$ transacties verrichten. ${ }^{258}$ De banken, die bestaan bij de gratie van het vertrouwen van cliënten, zijn tevreden over de voorlopig op proef zijnde betalingsre-

249. Wetsvoorstel melding ongebruikelijke transacties, TK 1992-1993, 23009, nrs.1-2; Wet 16 dec. 1993 . Stbl. 1993, 705; Stbl. 1994, 49.

250. D.R. Doorenbos, Money laundering; De rol van de financiële sector, in: DD, nr.8, 1993, pp.764-779. Auteur mist in beide wetsvoorstellen exacte aanduiding wie als normadressaten gelden. Overigens uif hiij kritiek op de, in de voorstellen aangegeven, beperkingen van strafrechtelijke aansprakelijkheid. Z.i. bezitten de voorstellen "criminaliserende potentie".

251. Melding moet met name als een kiant meer dan 25.000 gulden cash geld will storten of wisselen.

252. Overigems wil de voorzitter van de Nederlandse Vereniging van Makelaars, t.w. B. van Groeningen, dat makelaars bij onroerend goed-transacties, die criminele betrokkenheid vermoeden, worden verplicht tot melding daarwan bij justitie. Op, bij de NVM aangesloten, makelaars rust in gevolge een gedragscode al een interne meldingsplicht, maar daarvan wordt weinig gebruik gemaakt. 'Melding criminele acries door makelaars", in: NRC, 20 febr. 1995, p.10.

253. Aldus K:E.J. Dijk, De notaris en criminaliteitspreventie, in: NJB, nr.42, 25 now. 1994, pp. 1450-1453. Auteur draagt oplossingen aan als vrijwillige meldingsplicht en geclausuleerde opheffing wan het ambtsgebieim.

254. C. Dubbeld en F.A. wan Schaik, Accountants kiezen woor zelfregulering bij fraudemelding, in: NJB, nr. 42, 25 nov. 1994, pp. 1445-1449, vatten de bezwaren samen als; a. de maatschappelijke functie wan accountants komt in de knel; $b$. bij het bedrijfsleven onstaat een lastenverzwaring; ene. ondernemingen en instellingen die geen wettelijke controleplicht hebben, kunnen zich van accountants afwenden (p.1447).

255. Aldus NVB-woorzitter P.J. Kallf, geciteerd in: Banken tegen extra diensten voor overheid, in: NRC, 14 dec. 1994, p. 20.

256. D.w.z. bij het opvragen van meer dan 20 stukken wordt voor elk afzonderlijk, schriftelijk aangevragd stuk $f 5,00$ berekend, en anders wordt er een uurtarief van $f 125,00$ betaald, waarbij het eerste uur niet meetelt.

257. M.S. Groenhuijsen en D. van der Landen, De financiële annpak van de georganiseerde criminaliteit. in: NJB, nr. 17, 28 april 1995, pp.613-621, i.h.b. p.616, wijzen er op dat het -hoewel daartoe een differentiatie-systeem met objectieve en subjectieve indicatoren door de ministers van justitie en financiën is opgesteld-moeilijk is te bepalen wat in het concrete geval als ongebruikelijk moet worden opgevat. Bovendien benadrukken auteurs, die de Wmot terecht bezien van uit het nemo tenetur beginsel en het gegeven dat burgers in het algemeen niet verplicht maar slechts bevoegd zijn tot het doen wan aangifte van gepleegde strafbare feiten, dat hier niet sprake is van verdáchte transacties.

258. J. Alberts, Justifie betaalt banken voor hulp, in: NRC, 15 febr. 1995, p.1. 
geling, maar hebben moeite met de mogelijk makkelijke schending van de privacy van hun klanten. ${ }^{259}$

De STE is sinds 1994 actief betrokken bij de begeleiding van het, onder (financiële) leiding en beheer van de minister van (financiën) justitie staande, onafhankelijke Nederlandse meldpunt ${ }^{260}$ voor ongebruikelijke transacties. ${ }^{261}$ In het najaar van 1994 maken ook de regeringen van de Antillen en Aruba bekend een eigen meldpunt voor ongebruikelijke transacties in voorbereiding te hebben. ${ }^{262}$ Met dit overzeese meldpunt zoekt het Nederlandse meldpunt contact. Bovendien maakt het Nederlandse meldpunt kenbaar met alle bestaande dan wel nog op te richten meldpunten in Europese lidstaten, en mogelijk in Janden buiten Europa, te willen samenwerken.

In 1994 wordt koninklijk konde gedaan van oprichting van een landelijk rechercheteam, dat onder meer onderzoek verricht naar meldingen inzake ongebruikelijke transacties, waarbij financieel-economische opsporingsmethoden centraal staan. ${ }^{263}$ Eind oktober van dat jaar raakt de Amsterdams effectenbeurs al in opspraak doordat justitie over aanwijzingen bezit dat in zeker drie gevallen criminele organisaties relaties hebben in het effectenwezen ${ }^{264}$ Haar vermoeden baseert justitie op het, sinds augustus 1993 lopende en van uit verschillende politiediensten georganiseerde, onderzoek ter zake. Dit onderzoek, naar de mogelijke aanwezigheid en de mate waarin criminele infiltraties en relaties binnen de effectenwereld voorkomen, beslaat ruim 2100 rapporten, 1200 rechtspersonen (bv's/nv's) en 1100 personen werkzaam in de effectenhandel. Het onderzoek berust merendeels op openbare informatie. Denk aan jaarrekeningen, financiële naslagwerken, de registers van de Kamers van Koophandel en prospectussen van beursgenoteerde en -gelieerde bedrijven. De Centrale Recherche Informatiedienst samen met de Fiscale Inlichtingen- en Opsporingsdienst, als mede de Economische Controledienst en een paar politiekorpsen maken zo een sterke start met het boven water brengen van vooral vreemd verdwenen drugsgelden. Vermelde opsporingsinstanties, onder de noemer: Fieccom (d.w.z. fiscaal, economische combinatie), vinden dat de politie haar kennis inzake criminele infiltratie moet verhogen. In dat kader adviseert het Fieccom om bij de verschillende politiekorpsen surveillerende "accountantmanagers, een soort financiële wijkagenten, aan te stellen die goede contacten in de verschillende branches hebben. Die wijkagenten (d.w.z. bij de politie apart aan te stellen gespecialiseerde rechercheurs - JGLvN) kunnen inschatten wat de risico's in bepaalde sectoren, als optiehandel, goederentermijnmarkt, bank- en verze-

259. J. Alberts, Banken als misdacadbestrijders, in: NRC, 16 fiebr. 1995, p.17. Auteur merkt terecht op dat de afgifte van dagrekeningafschriften tegen vergoeding veel eenvoudliger is dan de vroegere weg via het bewel tot huiszoeking bij banken.

260. Dit meldpunt houdt ter taakuitvoering een register aan. Het Reglement politieregister MOT (Stcrt. 1994, 54) regelt de werking daarvan. Zie A.H.J. Kuus, De Wmot en de privacy van klanten van banken, in: CR, nr.4, 1994, pp. 163-167; Over dit meldpunt C.D. Schaap, Meldpunt MOT: spin in het financiele web, in: Banlk-en Effectenbedrijf, mei 1995, pp. 27-30.

261. STE Jaarverslag 1993, Amsterdam, april 1994, p.23.

262. Artillen richt meldpunt op tegen witwassen, in: NRC. 25 okt. 1994, p. 17.

263. Troovirede 1994, in: NRC, 20 sept. 1994, p.23.

264. Jusritie: crimimelen infiltreren op beurs, in: NRC, 24 okt. 1994, p.1. 
keringswezen en de vrije beroepsgroepen, zijn" ${ }^{265}$ Overigens overtuigt het Fieccom kennelijk niet de verantwoordelijke minister van financiën. Eind 1994 geeft de minüster van financiën, mede namens de minister van justitie, te kennen dat hij geen aanleiding heeft te veronderstellen dat toezichthouders op de financiële markten, als de STE en DNB $\mathrm{nv}$, onvoldoende instrumenten hebben om fraude in de de effecten-en bankwereld te voorkomen. ${ }^{266}$

Helaas stemmen de eerste ervaringen met de identificatieplicht, voort vloeiend uit de sinds 1 februari 1994 van kracht zijnde Wifd, niet tot tevredenheid. Bellangrijke oorzaak er van is dat criminelen gemakkelijk via diefstal aan de (vooral in gemeentelijk beheer uitgegeven) identiteitspapieren kunnen komen. De Wmot functioneert evenmin volldoende. Daarvoor zijn de twee volgende redenen aan te geven: a. de meerderheid van de leden van de Nederlandse Vereniging van Banken kan geen meldingen doen, omdat deze leden eenvoudig weg niet in aanraking komen met baliewerk; en b. criminele acties verplaatsen zich naar andere circuits (bij voorbeeld wisselkantoren, casino's, grenscafés en hotellobby's) dan het bankcircuit. ${ }^{267}$ Wat betreft in het bijzonder wisselkantoren moet het aanvullende wetsvoorstel, dat er toe strekt wisselkantoren onder controle van De Nederlandsche Bank nv te brengen, oplossing bieden. ${ }^{268}$ Middels dit toezicht kan De Nederlandsche Bank nv eisen van betrouwbaarheid aan bestuurders van wisselkantoren stellen. De administratie van wisselkantoren moet worden ingericht naar regels die DNB nv daarvoor stelt. Bovendien kan De Nederlandsche Bank nv aan wisselkantoren een registratieplicht opleggen, en indien een wisselkantoor daartoe aanleiding geeft kan DNB nv dat kantoor uit het register schrappen. De Tweede Kamer neemt bedoeld wetsvoorstel, dat per 15 december 1994 status van wet heeft en op 1 januari 1995 in werking

265. Aldus landelijk fraudeofficier H.A.C. Smid, geciteerd in: M. Kerres en P. Wessels, Funatiele wereld rijp voor permanent roezicht, in: NRC, 27 okt. 1994, p. 17. Zie ook Handelingen TK 1994-1995. pp.505-506. De zelfde Smid vindt trouwens dat het Fieccom-onderzoek andere resultaten had kunnen hebben, indien juridische barrières (als de geheimhoudingsplicht en het niet kunner uitwisselen van vertrou welijke gegevens) de samenwerking met de STE. DNB nv en de beurs niet in de weg hadden gestaan; Overigens is de Nederlandse Vereniging van Banken verbolgen over het publieke pleidoai wan Smid, die -door concrete gevallen te noemen, die zeer beperkt zijn in aantall- een kwad daglicht werpt op de hele financięle sector. Zie Banken boos ower uirspraak landelik fraude-officier, in: NRC, 28 okt. 1994, p.11; Deze "toorn van de beurs en banken is typerend voor de verhouding tussen politie en bedrijfsleven als het gaat on een gezamenlijke aanpak van georganiseerde misdaad " "volgens crimino$\operatorname{loog}$ B.M.W.A. Beke, geciteerd door M. Kerres en P. Wessels, "Relatie politie en bedrijuent moef beter", in: NRC, 29 okt. 1994, p. 15. Beke betoogt dat instelling van zgn. accountmanagers mogelijk dit wantrouwen weg neemt.

266. Zalm." toezicht op beurs, bank is woldoende, in: NRC, 10 dec. 1994, p.13. De minister verwijst hierbij! naar, ten eerste, de deskundigheids- en betrowwbaarheidstoetsing bij beleidspalende personen way effecteninstellingen en, ten tweede, de wettelijke verplichting om ongebruikelijke transacties aan te: geven bij een meldpunt van de CRI.

267. 'Identificatieplicht banken werkt niet in praktijk", in:. NRC, 27 mei 1994, pp.11-12.

268. Wetsvoorstel inzake de wisselkantoren, TK 1993-1994, 23777, nrs. 1-3, zie gew ijzigd voorstel TK 19941995, 23777 , nr.50. 
treedt $^{269}$, aan. Enige aarzeling blijft bestaan. Terwijl namelijk banken op grote schaal oneigenlijke transacties boven de 25.000 gulden melden, geven wisselkantoren weinig tot geen gerucht aan dergelijke "transacties met een luchtje", hetgeen leidt tot de veronderstelling "misdaadgeld vooral via wisselkantoren wordt wit gewassen" ${ }^{270}$ Niet alleen de praktijk, ook de wet zelf geeft aanleiding tot problemen.

De Wet inzake de wisselkantoren beoogt vooral een instrument te zijn om witwassen van misdrijfgelden door wisselkantoren tegen te gaan. Daamaast moet de Wiw er voor zorgen dat wisselkantoren aan hur wettelijke verplichtingen voldoen, waardoor de integriteit van het financiële stelsel wordt gewaarborgd. Hoewel de Wiw transparantie beoogt, verliest de wet door onheldere terminologie als 'wisselkantoor' en "wisseltransactie" aan duidelijkheid. Dat komt de handhaafbaarheid van de Wiw niet ten goede. Bovendien zijn de toetsingsnormen voor inschrijving in het register van De Nederiandsche Bank nv (a. DNB nv vreest aantasting of aannemelijke aantasting van de integriteit van het financiële stelsel; b. DNB nv heeft een redelijk vermoeden dat het wisselkantoor zich schuldig maakt of zal maken aan heling van geld; en c. DNB nv is van oordeel dat de bedrijfsvoering of de administratieve organisatie onvoldoende is om aan de op het wisselkantoor rustende wettelijke verplichting te voldoen) "zeer ruim" en "moraliserend", 271

\subsubsection{SAMENWERKING EN INFORMATIE-UITWISSELING MET EUROPESE (EN NIET- EUROPESE) STATEN}

Uit de toelichting op de Nadere regeling toezicht effectenverkeer blijkt terecht de noodzaak, dat de Stichting Toezicht Effectenverkeer "het niveau van haar regels steeds zal bezien maar de stand van de internationale regelgeving (EG)"; Ook zal zij de ontwikkelingen binnen de International Organisation of Securities Commissions nauw volgen ${ }^{\text {"n }} .^{272}$ Het IOSCO kent werkgroepen die zich bezig houden met verschillende onderwerpen, t. W. : a. het ontwikkelen van een door IOSCO-leden te erkennen systeem van (periodieke) rapportage voor uitgevende instellingen, waarvan in meer landen publiekelijk effecten worden verhandeld; $b$. het ontwikkelen van internationale beginselen m.b.t. de doorzichtigheid van de prijsvorming op markten en het bestuderen van 'cross-border proprietary

269. Wet houdende bepalingen inzake wisselkantoren, Stbl. 1994, 903, inwerkingtredingsbesluit 19 dec. 1994. Stbi. 1994, 904. Overigens krijgen wisselkantoren, die conform de Wwk een aanwraag moeten indienen voor hun registratie bij de DNB nv, uitstel daarvan tot de eerste week van maart 1995 . Centrale bank geeft wisselkantoren respijit, in: NRC, 1 maart 1995, p.15.

270. Aldus CDA-woordwoerder Sinits, als geciteerd in Scherpe voorschriften voor wisselkantoren, in: NRC. 7 ok.t. 1994, p.11.

271. J.P. varn Soest, Van wisselaars en wisselkantoren, in: Bank-en Effectenbedrijf, januari/februari 1995. pp. 14-20, i.h.b. pp. 16/20. Auteur acht bovendien de sanctie van uitsluiting va deelname aan bet gehele reguliere financiële verkeer "buiten proportie". Art. 15 Wiw maakt deze sanctie mogelijk. Art. 15 verbiedt elke fimanciële instelling, in de zin wan de Wiw, aan verboden wisselkantoren financiele diensten, als bedoelld in de Wiw, te verlenen, indien de instelling kan vermoeden (auteur vraagt zich hier af of cen onderzoeksplicht ter zake bestaat) dat het om een verboden wisselkantoor gaat. Worden de diensten toch verleend, dan pleegt de dienstverlenende instelling een economisch delict en mogelijk heling. Als de instelling ingeschreven stat als wisselkantoor, riskeen de instelling doorhalling door DNB nv van inschrijving omdat de wettelijk gestelde verplichtingen niet worden nagekomen. Toellichting Nadere regeling toezicht effectenverkeer, Stcrt. 15 mei 1992, 93, p.11. 
trading systems", m.a.w. het ontwikkelen van een adequaat regulerings- en toezichtssysteem voor effectenmarkten; c. het opstellen van regels voor solvabiliteitseisen voor effecteninstellingen die internationaal opereren; en d. het ontwikkelen en stimuleren wan informatie-uitwisseling ${ }^{273}$ en het effectief optreden en bestraffen van fraude door 'boiler-rooms', d.w.z. niet onder toezicht stalande ondernemingen die via agressieve verkoopmethoden de kleine beleggers bewerken tot beleggingen in effecten die niet zijn genoteerd aan een effectenbeurs. ${ }^{274}$

Samenspraak met vertegenwoordigers van bevoegde effectentoezichthoudende autoriteiten in de EG vindt in 1993 nog informeel en incidenteel plaats. ${ }^{275}$

Het overleg wan de Stichting Toezicht Effectenverkeer met eender internationale of Europese organisaties stimuleert de gelijkwaardigheid van effectenwet- en regelgeving.

Uit een, in 1993 ingevoerde, wijziging van die Nadere regeling blijkt het streven naar wederzijdse erkenning van wet- en regelgeving van de verschillende Europese lidstaten. Op grond van de gewijzigde artt. 4-5 Nadere regeling toezicht effectenverkeer kan de STE bepalen "dat effecteninstellingen niet of slechts gedeeltelijk aan voornoemde artikelen behoeven te voldoen, indien zij naar het oordeel in hun lidstaat van herkomst reeds aan gelijkwaardige eisen voor wat betreft hun eigen vermogen en eigen middelen zijn onderworpen " ${ }^{276}$ De STE dient wel tijdig over controle op naleving van de niet-Nederlandse effectenregelgeving door de buitenlandse toezichthouder te worden geïnformeerd.

\subsubsection{MEDEDINGINGSRECHT EN DEREGULERING}

Frappant gegeven is, dat - hoewel de Europese regelgeving nog een streng karakter heeft - de regelgeving in internationaal opzicht wordt verzwakt. Door de toenemende concurrentie tussen financiële centra, die de afgelopen jaren steeds meer door voort schrijdende concentratie in omvang zijn toegenomen, wordt de regelgeving minder en minder. Gevreesd wordt dat de strijd tussen financiële partijen "zal ontaarden in een slag om zo min mogelijk regels" met het "risico van onderregulering om de eigen beurs maar zo aantrekkelijk mogelijk te maken". 277 Zelfs de Stichting Toezicht Effectenverkeer heeft bij voorbeeld de regels voor melding van transacties van grote aandelenpakketten versoepeld. In het vrij wel onvermijdelijk conformeren aan de markt, verliest zij door het afkalven van regelgeving helaas haar sterke positie als toezichthouder op het effectenverkeer. $^{278}$

273. M.b.t. het uitwissellen van informatie ligt een Informatie-uitwisselingsverdrag op effectengebied ter stilzwijgende goedkeuring bij de Staten-General, Trbl. 1994, 182.

274. STE, Jaanerslag 1993, Amsterdam, april 1994, p.28.

275. STE, Jaarversiag 1993, Amsterdam, april 1994, p.29.

276. STE, Jaarverslag 1993, Amsterdam, april 1994, p.17.

277. H. Leland, geciteend door M. Schinkel en M. Tamminga, Deregulering troef in slag om financièle centra; Toezichthouders vragen zich af welke rol zij nog hebben, in: NRC, 28 mei 1994, p.20.

278. Met de nachtmerrie in de financièle wereld wan het plotselinge bankroet van de eeuwenoude Britse bank van de Baring Brothers nog voor ogen, dringt 0.a. Tweede Kamerlid R. de Korte (VVD) in Nederland aan op aanscherping van regulering in de (aanverwante) financiële sector. De Korte vraagt de minister 


\title{
\$19.12 Toezicht op effectenverkeer naar nieuw recht: Wte 1995
}

\author{
Medio 1994 lanceert de wetgever een voorstel voor een nieuwe Wte ${ }^{279}$ (hierna voor het \\ gemak aangeduid als: Wte $1995^{280}$ ). Deze Wte 1995 strekt primair tot uitvoering van \\ de beide Europese richtlijnen inzake respectievelijk beleggingsdiensten en kapitaaltoerei- \\ kendheid. ${ }^{2 B I}$
}

Rode draad in de Wte 1995 is daarom de wederzijdse erkenning van, de in de verschillende lidstaten van de Europese Unie vigerende, vergunningen- en (bedrijfseconomische) toezichtsstelsels. Deze doelstelling van harmonisatie, die tevens de voorschriften voor

278. $\rightarrow$

van financièn om opheldering over de hier te lande vigerende regels m.b.t. het toezicht op het gebruik wan derivaten (vooral door bedrijven). Juist het gebruik (beter gezegd: het frauduleus verbergen van het gevaanijke gebruik) van derivaten -dat wil zeggen opties, termijncontracten en ruilcontracten (swaps) warvan de warde is afgeleid van de onderliggende waarde van effecten, valuta's of grondstoffen waarover contracten zijn gestoten-, die kunnen dienen ter afdekking van financiele risico's maar waarmee even goed grote financiële risico's mogelijk zijn aan te gaan, leiden tot dile ondergang van de Baringsbank. De Engelse toezichthouder op de financielle markt, t. w. de Bank of England, onderneemt nog een reddingspoging, maar die mislukt. Daarom stellt de Bank of England de failliete bank onder controle van een bewindvoerder. Zie o.a. J. Alberts en M. Schinkel, Debâcle bank hier denkbaar" "in NRC, 28 febr. 1995, p. 1, Markten averstukr na bankroet Barings Bank, in: NRC, 27 febr. 1995, p.1, Bankroet van Barings zaait wijfel over bankentaezicht, in: NRC, 27 febr. 1995, p.10, "Ondergang Barings nogelijk door fraude", in : NRC, 28 febr. 1995, p.15; Enige informele aanscherping komt uit de hoek van de stichting Verzekeringskamer, die richtlijnen stelt wan derivaatgebruik door banken en pensioenfondsen. M. Schinkel en M. Tamminga, Derivaremhandel groeit snel bij de banken, in: NRC, 3 mei 1995 , p. 17; Daarnaast vindt verscherping van toezicht op derivaathandel plaats in internationale regels. De Intemationale Organisatie van Effecten Commissies en de commissie voor bankentoezicht wan de Bank woor Internationale Betalingen presenteren medio mei 1995 een ramwerk, waarin toezichthouders op de financiele markten vooral een weg wordt gewezen in het verkrijgen van voldoende informatie (zowel in kwantitatief als kwalitatief opzicht) over financiése risico"s. Toezichthouders: meer grip op derivarenhandel, in: NRC. 16 mei 1995, p.16; Zie overigens A. Nederveen, Derivaten en de Wet toezich effectenverkeer, in: TVVS, nr.6, 1995.

279. Wetsvoorstel houdende het opnieuw waststellen van de Wie i. v.m. de uithoering van de richwim betreffende het verrichten van diensten op het gebied wam beleggingen in effecten en wan de vichtigh betreffende de kapitaaltoereikendhei wan beleggingsondernemingen en kredietinstellingen (Wre 1995), TK 19931994, 23874, nrs. 1-3, zie ook gewujzigd woorstel Wte 1995, TK 1994-1995, 23874, nr.9.

280. Frappant fulmineert M.R. Mok., Wijziging regelgeving toezicht effectenverkeer, in: TVVS, nr. 11, 1994 , Pp2.299-301, i.,1.b. p.299, tegen deze benaming als (feitelijk voorkomend in de) officiële citeertitel wan de herziene Wte. Terecht refereert guteur aan de i.c. kennelijk veronachtzaande formule van art. 185 , wierde lid, Aanwijzingen voor de regelgeving: "met vermelding van het jaartal van het Staatsblad waarin zijjhij zal worden geplaatst". Het jaar waarin de wet verschijnt, wordt automatisch toegewoegd aan de ciltertitel. De citeertitel wan het wets woorstel wan de herziene W/ kan nu tot de onjuiste situatie leiden, dat als de uiterste damum van invoering van de $\mathbb{E G - r i c h u i j n e n ~ i n z a k e ~ b e l e g g i n g s t i e n s t e n ~ e n ~ k a p i t a a l t o e - ~}$ reikendheid niet wordt gehaald, de op inwoering daarvan gebaseerde wet pas in 1996 wordt gereal iseerd, terwijl de citeertitel dan nog merkwaardig genoeg het jaartal 1995 aangeeft. Auteur merkt op dat aanduiding van dat jaartal 1995 een mogelijke overschrijding van de uiterste temijn van invoering van bedoelde EG-richtijimen niet opheft.

281. Dat ook buurland Belgie hard bezig is om wetgeving klaar te stomen voor de, op de richtlijnen gebaseerde, codificatie van effectenwetgeving beschrijven B. Servaes en. F. Hellemans, De hervorming van de financięle markten en financièle transacties in Belgiè, in: SEW, nr.1, 1995, pp.6-28, interessant. 
financiële soliditeit van effecteninstellingen treft ${ }^{282}$, is niet het enige oogmerk van de Wte 1995.

De vernieuwde Wte heeft namelijk ook het liberaliseren van de toegang tot het lidmaatschap van effectenbeurzen en andere, door toezichthoudende autoriteiten als zo danig erkende, gereglementeerde markten op thet oog. ${ }^{283}$

Het, van deze doelstellingen doordrongen, in de Wte 1995 vast gelegde toezicht op het effectenverkeer wijkt qua aard niet af van de huidige Wte. ${ }^{284}$ Ook dit toezicht richt zich op beleggersbescherming en een adequaat functioneren van een eerlijke effectenmarkt.

\subsubsection{TOEZICHTSKARAKTER ONVERANDERD}

De wijzigingen, die de Wte 1995 met zich mee brengt, zijn voornamelijk van technische en redactionele aard. Zo breekt de Wte 1995, bij voorbeeld, met de traditionele tekst door de evidente eliminatie van het onderscheid tussen effectenbemiddelaars en vermogensbeheerders. Beiden worden, naar komend recht, aangeduid als effecteninstelling ex art. 1, aanhef onder d, Wte 1995.

Daar waar sprake is van inhoudelijke wijziging (inzake o.a. de verklaring van geen bezwaar voor houders van gekwalificeerde deelnemingen/effecteninstellingen, het - zelfregulering respecterende - vergunningenstelsel voor effecteninstellingen aangesloten bij erkende effectenbeurzen, en de regels met betrekking tot het geconsolideerd toezicht), vindt zo veel mogelijk aansluiting bij de systematiek van de bestaande Wte plaats. Veelal keren artikelen van de bestaande Wte, zij het opnieuw vernummerd, letterlijk terug in de voorgestelde Wte 1995.

282. Dat zijn regels inzake: a. dle hoogte van het aamwangskapitaal en minimumvereisten t.a.v. de omwang van het risicodragend vermogen dat beschikbaar moet zijn; b. een gemeenschappelijlk kader wour de beheersing en bewaking van de marktrisico's, hergeen omvat positie-, tegenpartij/afwikkellings- ent valutarisico"s (berekenings wijze omvang risico endaartegen dekkend vermogen); c. eengemeenschapphelijk kader voor de niet-marktrisico's (kapitaalwereisten); en d. het toezicht op en de beheersing van grote risico's (limieten en aanwullende kapitaalvereisten). Mw woorste! Wit 1995, TK 1993-1994, 23874, ni. 3, pp. $30-31$.

283. Directeur van zakenbank Kempen \& Co, tevens lid van het Amsterdamse beursbestuur, J. Kram, wreest dat het liberaliseren van de markt (vooral door het, vanaf 1 januari 1996 , verdwijnen van de westigingseis voot buitenlandse effectenmakelatars) het toezicht op de effectenhandel mogelijk in gevar brengt. Per 1996 mogen buitenlandse effectenhuizea, die lid zijn van een erkende Europese effectenbeurs, binnen de Europese Unie rechtstreeks op effectenbeurzen handelen. Spelend mer de gedachte dat "near mate then verder naar het zuiden trekt, de regelgeving en het toezicht afneemt" vraagt Krant zich af hoe de beurs dan "een partij controleent die bij voorbeeld op Siciliè zit? Het gaat toch te ver om te zeggen:

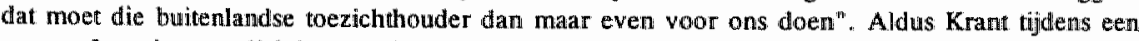
persconferentie ter toelichting van de jaarcijfers van Kempen \& Co, geciteerd door H.J. van Oostrum, Vrees voor actuasting beurstoezich;; Liberalisering effectenhandel, in: NRC, 28 maart 1995, p. 15; $\mathrm{Er}$ lijkt maar ến echte oplossing: "de controlebureaus van de beurzen en de nationale toezichthouders, als in Nederland de STE, zullen in Nederland bilateral voor elkaar toezicht moeten uitoefenem. In praktijk zou dan de Italiaanse beurs de transacties van de Siciliaanse handelaar op de Amsterdamse beurs controleren." Zie H.J " van Oostrum, Beursleden zien vrijmaking toezich als bedreiging, in: $\mathrm{NRC}, 29$ maart 1995, p. 23.

284. Mw woorstel We 1995, TK 1993-1994, 23874, nr.3. p.7. 


\subsubsection{GEDELEGEERD TOEZICHT}

Ook in de herziene Wte ligt delegatie ten grondslag aan taakuïtoefening door de Stichting Toezicht Effectenverkeer. Art. 40, eerste lid, Wte $1995^{285}$ tekent de contouren van het toezicht door de STE. Alle niet aan de minister voorbehouden Wte-taken en Wte-bevoegdheden komen in aanmerking voor, mogelijk ex art. 40, derde lid, Wte 1995 onder beperkingen of voorschriften te realiseren, overdracht naar de STE. Als op onafhankelijke en behoorlijke taakvervulling ingestelde en als rechtspersoon met statutair aangewezen toezichtstaken voor bepaalde organen (denk aan het ministerieel toezicht op de bestuurssamenstelling) tot attributie uitgerust, is de STE daartoe geschikt.

In verband met de algemene afschaffing van de adviesverplichting ${ }^{286}$ wordt art. 40 Wte 1995 uitgebreid als volgt. ${ }^{287}$ Art. 40 , zesde lid, Wte 1995 bepaalt dat een rechtspersoon aan wie het toezicht op de effectenwet-en regelgeving is overgedragen kan worden gehoord alvorens deze: a. een bepaalde amvb wijzigt of intrekt; $b$. een bepaalde vrijstelling verleent, wijzigt of intrekt; $c$. een bepaalde maatregel treft of intrekt; $d$. een bepaalde erkenning verleent of intrekt; e. bepaalde regels stelt; $f$. bepaalde voorschriften geeft; $g$. een bepaalde ontheffing verleent of intrekt; en h. een bepaald besluit neemt of een bepaalde termijn stelt. Vervolgens legt art. 40, zevende lid, Wte 1995, op zo'n rechtspersoon de plicht om bedoeld advies, waarom verzocht, uit te brengen.

\subsubsection{Ministeriele bevoegdheden}

Uitgesloten van deze delegatie zijn, met - naar nieuw recht - enige uitbreiding, de bevoegdheden die de minister nu ook al heeft. ${ }^{288}$ Daarom valt níet onder het werkterrein van de STE:

het verlenen van vrijstelling of, op verzoek, ontheffing van het verbod op het aanbieden van effectenuitgifte buiten besloten kring dan wel zo danige aanbieding via advertenties of documenten in het vooruitzicht te stellen (ex art. 40, eerste lid, Wte $1995^{289}$ junctis art. 4, eerste lid, Wte 1995 en art. 3, eerste lid, Wte 1995); $;^{2 \% 0}$

het verlenen van vrijstelling of, op verzoek, ontheffing van (bedrijfs)informatieverplichtingen van instellingen te wier laste in of van uit Nederland buiten een besloten kring

285. Art. 40, eerste tot en met vijfde lid, Wte 1995 wordt ontleend aan het vrij wel gelijk luidende art. 25 Wte..

286. Voorstel wijziging Awb en andere wetten i.y.m. afschaffing adviesplichten, TK 1994-1995, 23983, mrs. 1. 3.

287. Nota van wijziging woorstel Wte 1995, TK 1994-1995, 23874, nr.8, pp.2-5.

288. Zie paragraaf 19.1 .

289. Art. 40 Wte 1995 wordt, onder enige aanpassing, ondeend aan art. 25 Wte.

290. Anders dan de Raad van State meent, is de wetgever het oordeel toegedaan dat de minister met de hem in artt. 4, 10 en 18 gegeven vrijstellings- en ontheffingsbevoegutheden geen "geheel ongenormeerde bevoegdheden" in handen heeft. Bevoegdheidsbeperking vindt immers plaats door "zowel de doelstelling. van de wet als de reikwijdte van de betrokken bepaling". Dat vermelde vrijstellingsbevoegdheden keuzevrijheid impliceren is noodzakelijk voor het voeren van een adequat beleid: "voor dat beleid en voor de wijze waarop de minister van de bevoegdheden gebruik makkt, is hij verantwoording verschuldigd aan de Staten-Generaal". Aldus Reactie op advies RvSt inzake voorstel Wte 1995, TK 1993-1994. 23874 , nr. A, p.3. 
effecten worden uitgegeven zonder dat daartoe effecten behoren die zijn toegelaten tol de notering aan een erkende effectenbeurs, $m$.a.w. niet ter beurze genoteerde instellingen (ex art. 40, eerste lid, Wte 1995 jo. art. 5 , eerste lid en tweede lid, Wte 1995); het verlenen van vrijstelling of, op verzoek, ontheffing van de vergunningsvoorwaarde voor het als effecteninstelling, hetzij als effectenbemiddelaar hetzij als vermogensbeheerder, in of van uit Nederland aambieden of verrichten van diensten in het effectenverkeer (ex art. 40, eerste lid, Wte 1995 junctis art. 10, eerste lid, Wte 1995 en art. 7, eerste lid, Wte 1995);

het verlenen van vrijstelling ${ }^{291}$ of ontheffing, op verzoek, van de conditie in het bezit the zijn van een erkenning voor het houden van een effectenbeurs (ex art. 40 , eerste lid, Wte 1995 junctis art. 25, eerste lid, Wte 1995 en art. 22, eerste lid, Wte 1995) ${ }^{292,293}$ het verlenen van vrijstelling van de eis van een verklaring van geen bezwaar om een gekwalificeerde deelneming te houden, te verwerven of te vergroten in een vergunninghoudende effecteninstelling dan wel enige zeggenschap verbonden aan een gekwalificeerde deelneming uit te oefenen in zo'n effecteninstelling (ex art. 18, eerste lid, Wte 1995 jo. art. 16, eerste lid, Whe 1995); 294

het uitsluiten van een effecteninstelling - die in Nederland slechts via een bijkantoor of anders aan het effectenverkeer deelneemt - van de afwijking van het vergunningenstelsel indien de andere lidstaat ${ }^{295}$, waar de betrokken effecteninstelling is gevestigd, de richtlijn beleggingsdiensten en de richtlijn kapitaaltoereikendheid niet of onvoldoende zijn uitgevoerd (ex art. 40, eerste lid, Wte 1995 junctis art. 8, eerste lid, Wte 1995 en art. 7, eerste lid en tweede lid sub $\mathrm{i} / \mathrm{j}$, Wte 1995) ${ }^{296}$;

het verlenen van een erkenning voor het houden van een effectenbeurs (ex art. 40, eerste lid, Wte 1995 jo. art. 22, eerste lid, Wte 1995); ${ }^{297}$

29:. Toegevoegd in Nora van wijziging voorstel Wte 1995, TK 1994-1995, 23874, nr.8, p.1.

292. Deze ministeriele bewoegdheidd wordt in de Wte 1995 gelrntroduceerd.

293. Aan woormoemde vrijstellingen (of ontheffingen) worden mogelijk beperkingen gestelld of voorschriften verbonden met oog op een adequate functionering van de effectenmarkten of de positie van beleggers op die markten ex respectievelijk art. 4, tweede lid, Wte 1995, ant. 5, dlerdle lid, Whe 1995, art., 10. tweede lid. Wite 1995 en art. 25, tweede lid, Wte 1995.

294. Aan deze vrijstelling kunnen beperkingen worden gesteld of voorschriften worden vertonden met oog op een gezonde of prudente bedrijfswoering van betrokken effecteninstellingen ex ant. 18, weede lid. Wite 1995.

295. Let wel, art. 1, aamhef onder j, Wte 1995 definieen lidstaat als een "staat die lid is van de Europese Unie als mede een stat, niet zijnde een lidstaat van de Europese Unie, die partij is bij de Overeenkomst betreffende Europese Economische Ruimte". De Mvt voorstel Whe 1995, TK 1993-1994, 23874, nr.3, P.41, omschrijft een EER-staat als een staat die deel uitmmakt wan de Europese Vrijhandels Associatie. De EER is het resultaat van een overeenkomst tussen de EG en de EVA.

296. Deze ministeriele bevoegdheid wordt in de Wte 1995 geüntroduceerd.

297. Erkenning geschiedt eerst madat een, in Nederland gevestigde, effectenbeurshouder wat betreft het houden van de beurs en ook het stellen, controleten en naleven van beursregels (bij) wijziging wan beursregels of -controle stelt de beurshouder de minister vooraf in kennis conform art. 23 Wte 1995) voldoet aan datgene wat nodig is met oog op het adequaat functioneren wan de effectenmarkt of de posities van beleggers op die markt. Zie art. 22, tweede lid, Wte 1995. Van uit dat zelfde oogpunt geschiedt verlening van erkenning mogelijk beperkt of geconditioneerd ex art. 22, derdle lid, Wte 1995 . De Nota van wijziging voorstel Wie 1995, TK 1994-1995, 23874, nr.8, p.1, bepaalt dat cen gereglemen- 
het intrekken van een erkenning (of van de ontheffing van het hebben van een erkenning) als adequate functionering van de effectenmarkt of beleggersprotectie niet voldoende wordt gewaarborgd, en anders als een effectenbeurs opgelegde regels, beperkingen, voorschriften of aanwijzingen niet of niet genoegzaam nakomt/opvolgt (ex art. 40, eerste lid, Wte 1995 jo. art. 26 Wte 1995);

het, ter uitvoering van EG-richtiijnen inzake effectenverkeer, geven van voorschriften aan effectenbemiddelende of vermogensbeherende effecteninstellingen, aangesloten bij een organisatie waarvan de leden toegang hebben tot een erkende effectenbeurs, en aan houders van erkende effectenbeurzen (ex art. 40, eerste lid, Wte 1995 jo. art. 27, tweede lid, Wte 1995) ( $^{298}$;

het, ter vitvoering van besluiten genomen in gevolge de bepalingen betreffende betrekkingen met derde landen in de richtlijn beleggingsdiensten, stellen van bijzondere bepalingen inzake effecteninstellingen met zetel buiten Nederland, denk aan het bepalen tot tijdelijke opschorting of gelimiteerde mogelijkheid tot vergunningaanvragen door dochter- of nevenkantoren met vestigingen in een andere lidstaat dan Nederland of in een staat niet zijnde lidstaat van de Europese Unie (ex art. 40, eerste lid, Wte 1995 jo. art. 45, eerste lid, Wte 1995);

het stellen van regels inzake het omslaan van de kosten van uitvoering van het toezicht op het effectenverkeer op onder toezicht gestelden (ex art. 40, eerste lid, Wte 1995 jo. art. 42 Wte $1995^{299}$;

en, het goedkeuren, en zo nodig weigeren, van statutenwijziging door een aangewezen effectenverkeertoezichthouder als de rechtspersoon STE (ex art. 40, eerste lid, Wte 1995 jo. art. 41, eerste en tweede lid, Wte 1995).

\subsubsection{Bevoegdheden Stichting Toezicht Effectenverkeer}

De Wte 1995 past de bestaande bevoegdheden van de STE aan EG-recht aan. Zo hier en daar introduceert de Wte 1995 nieuwe bevoegdheden in het kader van de rechtshandhavende taak van de STE. Bij het doorlopen van de nieuwe wet komen een en ander aan het licht.

Ook de Wte 1995 stimuleert, conform de traditie in de effectenwereld, zelfregulering. Dit impliceert een terughoudend toezicht ten aanzien van het toezicht op de effectenbeur-

297. $\rightarrow$

teerde markt in de zin van art. 1, sub 13, Richtlijn belieggingsdiensten waarvan de houder is gevestigd in een andere lidstat, is vrijgesteld van de erkenningseis (art. 22, vierde lid, Wte 1995). Wel kan deze vrijstelling worden geconditioneerd in de zin dat de vrijgestelde zich moet houden aan regels die zijin gesteld in thet belang van de adequate functionering van de effectenmarkten en de bescherming wan beleggers op die markten (art. 22, vijfde lid, Wte 1995).

298. Art. 27 , derde lid, Wte 1995 bepaalt dat deze voorschriften binnen een, door de minister bepaalde, termijn gehoor moeten krijgen.. Overigens moet de minister, om te beoordelen of voorschriften nodig zijn, vooraf op de hoogte wonden gesteld van verandering of vernieuwing wan beursnegels waardoor de negels mogelijk niet meer overeen stemmen met EG-recht. Zie art. 27, wierde lid jo. eerste lid, Wte 1995. Ant. 27 Wte 1995 wordt trouwens ontleend ann art. 20 Wte.

295. Art. 42 Wite 1995 wordt, onder enige uitbreiding van verhaalsplichtigen, ontleend aan art. 28 Wte. 
zen. Anders gezegd, "het toezicht op de beurzen heeft, in tegenstelling tot het toezicht daarbuiten, het karakter van een marginale toetsing van zowel de regels als de handhaving daarvan ". ${ }^{300} \mathrm{Nu}$ het belang toeneemt, dat effectenbeurzen hun eigen regels in voldoende mate afstemmen op relevante communautaire regelgeving, is het noodzakelijk dat de bevoegde toezich thoudende autoriteit de mogelijkheid heeft om ter zake te instrueren. Wel mag de toezichthouder "slechts in het uiterste geval" ${ }^{301}$ aanwijzingen geven. Het geven van een aanwijzing is dus als "ultimum remedium" te beschouwen. ${ }^{302}$

Die Wte voorziet nu al in een aantal aanwijzingsbevoegdheden. Daarnaast introduceert de Wte 1995 nieuwe aanwijzingsbevoegdheden. Bij voorbeeld art. 6 Wte 1995 bepaalt dat een effectenuitgevende instelling, waarvan effecten zijn toegelaten tot de notering ter beurze (denk aan de Amsterdamse effectenbeurs), die zich niet houdt of heeft gehouden aan de voor haar geldende beursregels ${ }^{303}$, de volgende aktie van de toezichthouder kan verwachten. De STE vestigt, middels mededeling, de aandacht van de houder van de effectenbeurs op een overtreding. Deze boodschap gaat, zo nodig, gepaard met een - mogelijk nog te wijzigen of uiteindelijk in te trekken - aanwijzing met betrekking tot een door de effectenbeurshouder jegens de instelling te volgen gedragslijn met het oog op een adlequate functionering van de effectenmarkten of de positie van de beleggers op die markten (ex art. 6, eerste lid, Wte 1995). Conform art. 6, tweede lid, Wte 1995 moet een beurshouder zijn goede wil tonen door binnen een door de STE gestelde termijn uitwerking te geven aan de indirect verplichtende aanbeveling. ${ }^{304}$ Deze termijnstelling is nieuw ten opzichte van de oude Wte-regeling ${ }^{305}$. Niet-nakoming ter zake, d.w.z. de aanwijzing vindt geen uitvoering binnen de termijnstelling, levert een economisch delict op. Daarnaast kan de minister van financiën in het uiterste geval de sanctie ex art. 26 Wte 1995 opleggen: intrekken van erkenning voor het houden van een effectenbeurs dan well het intrekken van de ontheffing daarvan. ${ }^{306}$

300. Mut woorstel Wte 1995, TK 1993-1994, 23874, nr.3, p.8.

301. Mur woorstel Whe 1995, TK 1993-1994, 23874, nr.3, p.8.

302. Mwt woorstel We 1995, TK 1993-1994, 23874, mr.3, p.42; Nota n.a.v. versiag voorstel Wte 1995, TK 1994 .1995, 23874 , nr. 7, p. 30

303. Owerigens kan de STE ex art. 24 , tweede lid, Wte 1995, met oog op een adequate functionering wan de effectenmarkten of met oog op beleggersbescherming, aan de houder van een erkende effectenbeurs voorschriften geven m.b.t. de voor die beurs te hanteren regels, hun toepassing of de controle op de nule ving vian die regels. Confornn art. 24, derde lid, Wte 1995 voldoet een houder, bimnen een bepalalde termijn, aan dergelijke voorschriften. Art. 24 Wte 1995 vervangt dus het gewraakte art. 18 Wte (vgl. art. 8, derde lid, Wmz), waaraan de STE regelgevende bevoegdheid onleent.

304. Dit geldt ook voor: een vergunninghoudende effecteninstelling hier te lande ex art. $₫ 1$, vierde en wijfde lid, Whe 1995; cen weliswaar in Nederland gevestigde vergunninghoudende effectenimstelling, mar dan specifiek gelet op de dienstverlening via haar bijkantoor in een andere lidstaat ex art. 13, vierde llid, Wte 1995; een in Nederland zetelende vergunninghoudende effecteninstelling met bijkantoor in een andere lidstamt, nadat een toezichthoudende autoriteit van die andere lidstaat de STE in kennis stelt van niet (voldoende) regelnaleving door de nevenvestiging ex art. 15, tweede lid, Wte 1995. Vgl. het algemene art. 28 Wte 1995. Let wel, de daanuit voort vloeiende aanwijzingsbevoegdheid wordt uitgeoffend bij overtreding van de bij of krachtens de Wte gestelde regels. Zij ziet niet op schending van beursmegels. Daarop spitst specifiek art. 11 Wte 1995 zich toe.

305. Zie respectievelijk art. 8, derde lid, Wte en art. 12, derde lid, Wte, vermeld in paragraaf 19.4.

306. Vgl. art. 19 Wte warin de bijzondere intrekkingsgrond, $t w$, het niet (genoegzaam) opvolgen wan aanwijzingem, nog ontbreekt. 
Belangrijke bevoegdheid om de effectenmarkt te reguleren is natuurlijk die van vergunningverlening. De bewoegdheid tot het verlenen van vergunningen om als effectenbemiddelaar of vermogensbeheerder in of wan uit Nederland diensten aan te bieden of te verrichten, komt toe aan de STE.

In art. 7, eerste lid, Wte 1995 is het verbod om zonder vergunning aan het effectenverkeer deel te nemen vervat. Daarvan zondert art. 7, tweede lid, Wte 1995 een paar categorieën uit. ${ }^{307} \mathrm{Bij}$ voorbeeld, in het kader van de "communautaire draagwijdte" 308 of de wederzijdse erkenning van nationale vergunningen- en toezichtsstelsels zijn nieuw opgenomen in art. 7, tweede lid, Wte 1995 de categorieën sub $i$ en j: een, van het reguliere vergunningsysteem, afwijkend regime geldt voor niet in Nederland gevestigde effecteninstellingen die al dan niet via een bijkantoor het effectenberoep of -bedrijf wel hier te lande willen uitoefenen. Voorwaarde is dan wel dat de toezichthoudende autoriteit in de andere lidstaat vergunning afgeeft of reeds heeft verschaft aan betrokken effecteninstelling.

In gewone situaties verleent de STE - ex art. 7, vierde lid, Wte 1995 -, op verzoek, voomoemde vergunning als wordt voldaan aan de, conform het vijfde lid overigens voor onderscheiden groepen effecteninstellingen verschillende, eisen van: a. deskundigheid en betrouwbaarheid; b. financiële waarborgen, al dan niet op geconsolideerde basis; $c$. bedrijfsvoering en vestiging van het hoofdkantoor; en d. aan het publiek te verstrekken informatie. ${ }^{309}$ Art. 7, zevende lid, Wte 1995 maakt het, met oog op een adequate functionering van de effectenmarkt en beleggersbescherming, mogelijk beperkingen en voorschriften te verbinden aan vergunningverlening.

Daarnaast stelt art. 9 Wte 1995 de STE in staat om, op verzoek, een vergunning te verlenen aan effecteninstellingen, aangesloten bij een organisatie waarvan de leden toegang hebben tot een erkende effectenbeurs, voor zover dienstverlening onderworpen is aan door die organisatie en door de beurshouder gestelde regels. Het gaat hier kennelijk om vergunningverlening voor activiteiten die onder zelfregulering vallen.

Vergumninghoudende effecteninstellingen moeten zich houden aan zowel de algemene eisen alls mogelijke bijzondere voorwaarden voor vergunningbezit ex art. 11 , eerste lid, Wte 1995. Constateert de STE dat dit niet (naar behoren) geschiedt, dan confronteert zij betrokken instelling met een, binnen termijn op te volgen, aanwijzing ex art. 11, vierde en vijfde lid, Wte 1995.

Art. 12, eerste tot en met derde lid, Wte 1995 schrijft een dergelijke vermaningswijze woor wat betreft in het bijzonder effectenondememingen en -instellingen ingeschreven in het register bedoeld in art. 52 Wtk en effecteninstellingen gevestigd in een andere lidstaat met het voornemen om in Nederland het effectenbedrijf uit te oefenen middels een bijkan-

307. Op aambeweling van de Raad van State, die onvrede heeft met de aanduiding vergunning verlening als sprake is van van rechtswege verleende vergunningen (bij kredietinstellingen en ook bij, buiten $\mathbb{N e d e r -}$ Iand toegellaten, effecteninstellingen). worden beide instellingen van wege hun cattegorisch karakter buiten het vergunningsbegrip, als aangeduid in aanwijzing voor de negelgeving 125 , gehouden. Advies RwSt inzake voorstel Wte 1995, TK 1993-1994, 23874, nr. A pp.2-3.

308. Mvi voorstel Wie 1995, TK 1993-1994, 23874, nr.3, p.15.

309. Amaloge regeling, zonder de toevoegingen genoemd onder b en c, wordt gegeven in art. 6, tweede lid, Wte en art. 10 , tweede lid, Wte. 
toor of vrije dienstverrichting. Eerst wijst de STE betrokken bedrijven op het niet naleven van de toepasselijke regels. Zo nodig gaat deze mededeling vergezeld van een meer dwingende aanwijzing, mogelijk met termijnstelling "Gehoorzaamt de nalatige of in overtreding zijnde effecteninstelling daaraan niet, dan maakt de STE haar ongenoegen daarover aan de instelling bekend. Consequentie van die bekendmaking is, dat het de in gebreke blijvende effecteninstelling na ontvangst van die mededeling door de STE verboden is om nog langer als effectenbemiddelaar of vermogensbeheerder op te treden. Daarom wikkelt zij, binnen een door de STE bepaald tijdsbestek, alle lopende overeenkomsten af die door haar zijn aangegaan voordat de bekendmaking door haar is ontvartgen (ex art. 12, vierde lid, Wte 1995). Bij vestiging van een effecteninstelling in een andere lidstaat brengt de STE de toezichthoudende autoriteit van de - van uit de STE gedane - mededeling, aanwijzing en bekendmaking van nalatigheid op de hoogte ex art. 12, vijfdle lid, Wte 1995.

Met art. 12 Wte 1995 vergelijkbare bepalingen zijn te vinden in art. 13 Wte 1995 (voor in Nederland gevestigde effecteninstellingen met plannen voor een bijkantoor in een andere lidstaat) en art. 14 Wte 1995 (voor in Nederland gevestigde effecteninstellingen met plannen voor vrije dienstverlening op effectengebied in een andere lidstaat), beide te relateren aan art. 15, derde lid, Wte 1995. Binnen drie maanden na ontvangst van de, door de reeds in Nederland gevestigde vergunninghoudende effecteninstelling gedane, aanvraag om de vergunning voor het al dan niet via een nevenvestiging deel nemen aan het effectenverkeer in een andere lidstaat, bericht de STE de toezichthoudende autoriteit in de andere lidstaat gegevens als: a. opgave welke andere liclstaat het betreft; b. programmaplan met vermelding van voorgenomen werkzaamheden (en indien sprake is van bijkantoor: organisakiestructuur van het bijkantoor; $c$. adres van het bijkantoor; $d$. "dentiteit van dagelijks bestuur van het bijkantoor; en e. hiernaast kunnen ook gegevens worden verschaft over de toepasselijkheid van een garantieregeling op de verplichtingen wan het bijkantoor).

Met oog op hier te lande zetelende effecteninstellingen die ook aan het effectenverkeer in een andere lidstaat deel nemen, bepaalt art. 15, eerste lid, Wte 1995 dat de toezichthoudende autoriteit van die andere lidstaat, als zij bekend is met het feit dat een effecteninstelling zich niet houdt aan in die andere lidstaat toepasselijke wet- en regelgewing inzake effecten, bij de STE melding maakt van die regelschending. Daardoor is de STE in staat de betrokken effecteninstelling hierop te attenderen en mogelijk, in latere instantie, een aanwijzin te geven

Naast het beslissen ower en het afgeven van vergunningen, berusten bij de STE voortaan ook besluitvorming en verstrekking van verklaringen van geen bezwaar ${ }^{310}$. Deze zijn

310. Het gebruik van de term verkJaring van geen bezwaar in art. $16 \mathrm{e}, \mathrm{w}$. Wte 1995 vindt geen genade in de ogen van de Raad van State. Hierbij refereert de raad aan aanwijzing voor de regelgeving 126. De Raad van State prefereert, wat betreft art. 16 Wte 1995 , het begrip ontheffing als bedoeid in aanwijzing van de regelgewing 125 . De wetgever verontschuldigt zich met een beroep op de, in de Wtk 1992 en de Witw 1993 gebezigde, gelijkluidende vvgb-terminologie: "gelijke terminologie is essentieel voor een goed begrip van de materie". Indendaad is daarnee de consistentie gediend, maar een vreemde verklaring van woordgebruik blijft het. Het doet een beetje denken aan het zetten van de tering naar de nering. Adivies RwSt inzake voorstel Wie 1995, TK 1993-1994, 23874, nr.A. p.5. 
ex art. 16, eerste lid, Wte 1995 nodig om gekwalificeerde deelnemingen in vergunninghoudende effecteninstellingen te houden, te verwerven of te vergroten dan wel daarin enige zeggenschap verbonden aan een gekwalificeerde deeineming uit te oefenen. ${ }^{311}$ Conform art. 16, vierde lid, Wte 1995 verleent de STE, ex art. 16, achtsie lid, Wte 1995 mogelijk onder beperkingen of voorschriften ${ }^{312}$, op verzoek een verklaring van geen bezwaar. Voorwaarde daarbij is dat verlening er van niet leidt tot een negatieve invloed op gezonde of prudente bedrijfswoering van betrokken effecteninstelling. Is de instelling aangesloten bij een erkende effectenbeurs, dan verstrekt de STE eerst een dergelijke verklaring als zij van die beurs positief bericht (ex art. 16, vijfde lid, Wte 1995 inzake de bestuurdersidentiteit van, omvang van en beursregelnaleving door de effecteninstelling) ontvangt. Op aanvragen om verlening van verklaringen van geen bezwaar moet de STE, ex art. 16, zesde lid, Wte 1995, bimen 13 weken beslissen. Bovendien stelt zij betrokken effecteninstelling van een verlening in kennis ex art. 16, zevende lid, Wte 1995.

Handelen degenen, die een gekwalificeerde deelneming houden, verwerven of uitbreiden, zonder bezit van een verklaring van geen bezwaar, dan kan de STE deze overtreders aanmanen. En wel in die zin dat binnen een door haar gestelde termijn ex art. 16, negende lid, Wte 1995 als nog verrichte handelingen ongedaan worden gemaakt of - in geval van een wel afgegeven verklaring van bezwaar - gestelde beperkingen worden nagekomen. Deze verplichting vervalt alls voor het aangevochten handelen als nog een verklaring van geen bezwaar van de grond komt of de, aan wel verleende verklaringen gestelde, beperkingen worden ingetrokken.

Wordt zonder de vereiste verklaring van geen bezwaar zeggenschap verbonden aan een gekwalificeerde deelneming in een effecteninstelling uitgeoefend, dan kan de STE ex art. 16, tiende lid, Wte 1995 aan de rechtbank verzoeken om een mede door de uitgeoefende zeggenschap tot stand gekomen besluit te vernietigen. Dit is ook mogelijk als de, aan een wel afgegeven verklaring gestelde, beperkingen of voorschriften niet in acht worden genomen. Indien vóór de uitspraak als nog een verklaring wan geen bezwaar wordt verleend, dan wel de niet in acht genomen beperking worden ingetrokken, is bedoeld besluit niet vernietigbaar.

Houders van gekwalificeerde deelnemingen in effecteninstellingen melden, ex art. 16, twaalfde lid, Wte 1995 , eventuele daling van de omvang van die deelneming beneden woorgeschreven percentages onverwijld aan de STE. Als de betrokken effecteninstelling hier weet van heeft, rust op haar ook een meldingsplicht tegenover de STE. Ex art. 16, dertiende lid, Wte 1995 zijn de effecteninstellingen zelf verplicht om de STE jaarlijks de identiteit van houders van een gekwalificeerde deelneming mede te delen.

Op houders zijnde moedermaatschappijen, in bezit van een verklaring van geen bezwaar, met gekwalificeerde deelneming in ten minste één van haar - bij een erkende effectenbeurs aangesloten - vergunninghoudende effecten(dochter)instelling, rust in het belang

311. Ex art. 16, tweede en derde lid. Wte 1995 geldt vrijstelling als reeds $0 . g . v$. de Wtk 1992 een verklaring van geen bezwaar is verleend. De onvang van de gekwalificeerde deelneming moet dan wel worden medegedeeld aan de STE.

312. Bij niet-maleving van voorschriften kan de STE ex art. $16^{*}$ eifde lid, Wte 1995 een termijn stellen warbinnen als nog verwulling van voorschriften plaats moet winden. 
van een gezonde bedrijfsvoering, een regelnalevingsplicht ex art. 17, eerste lid, Whe 1995. De in principe ${ }^{313}$ na te leven regels hebben, ex art. 17, tweede lid, Wte 1995, uitsluitend betrekking op financiële waarborgen en te verstrekken gegevens en inlichtingen als mede de verstrekkingsvorm daarvan. Art. 17 ziet op geconsolideerd toezicht.

Berust bij de STE de bewoegheid tot het verlenen van respectievelijk vergunningen en verklaringen van geen bezwaar, zij kan verleende vergunningen of verklaringen van geen bezwaar ook weer intrekken.

Art. 19, eerste lid, Wte 1995 makkt het mogelijk dat de STE een weliswaar door de minister van financiën ex art. 4 en art. 5 Wte 1995 verleende ontheffing dan wel een door haar zelf ex art. 7 Wte 1995 verleende vergunning intrekt. ${ }^{314}$ Intrekking is geconditioneerd. $\mathrm{Zij}$ geschiedt slechts bij voldoening aan een van de volgende voorwaarden: $\mathrm{a}$. de (vergunning)houder verzoekt om intrekking; b. de, voor verlening van vergunning of ontheffing benodigde en verstrekte, gegevens of bescheiden blijken zo danig onjuist of onvolledig, dat op het werzoek om vergunning of ontheffing anders zou zijn beslist als de correcte informatie bekend was geweest bij aanvraag van vergunning of ontheffing; $c$. het zelfde geldt voor, eerst na verlening van vergunning of ontheffing bekend geworden, omstandigheden of feiten die, als de bevoegde autoriteit daarvan op het moment wan verlening had geweten, tot negatiewe beslissing op aanvraag van vergunning of ontheffing zouden hebben geleid; $d$. als de houder gedurende twaalf maanden na verlening geen gebruik maakt van een verleende vergunning, of als hij bekend maakt er geen gebruik van te zullen maken, of als hij gedurende zes maanden zijn werkzaamheden die door verkregen vergunning worden gelegitimeerd stopt, of als hij kennelijk ophoudt effecteninstelling te zijn; en, ten slotte, e. als de houder niet meer voldoet aan de bij of krachtens de Wte 1995 gestelde regels of beperkingen of gegeven voorschriften.

Voor de, in gevolge art. 20 Wte 1995 mogelijke, intrekking van een verklaring van geen bezwaar gelden ongeveer de zelfde condities. ${ }^{315}$ Als specifieke intrekkingsgrond kent art. 20, sub d en sub e, Wte 1995 dan: de houder is niet meer als houder van een gekwalificeerde deelneming aan te merken; en, de houder neemt niet als nog, binnen de in art. 16, negende lid, Wte 1995 gestelde termijn, alle aan de verklaring van geen bezwaar gestelde beperkingen in acht.

In het bijzonder ten aanzien van vergunningintrekking door de STE ex art. 19, eerste lid, Wte 1995 bepaalt art. 19, tweede lid, Wte 1995 het volgende. Binnen een door de STE te stellen termijn wikkelt degene ${ }^{316}$, die met intrekking wordt geconfronteerd, alle lopende d.w.z. vóốr intrekking aangegane overeenkomsten af. Mogelijk verlengt de STE deze termijn.

313. Art. 17, derde lid, Wte 1995 kent een van de STE uitgaande ontheffingsmogelijkheid voor regehnaleving.

314. Art. 19 Wte 1995 is opgesteld overeenkomstig art. 14 Wte.

315. De voonwaarden genoemd in art. 19 Wte 1995 onder a t/m c en e zijn eender neer gelegd in art. 20 Wte 1995.

316. Betrokkene kan ook een ander, die aan hem verantwoording schuldig is, met afwikkeling belasten. 
Van verleende en, na intrekking - ex art. 21, tweede lid, Wte 1995 - doorgehaalde vergumningen (of vrijstellingen van het verbod het effectenbedrijf uit te oefenen zonder vergunning) met daaraan gekoppelde beperkingen of voorschriften houdt de STE conform art. 21 , eerste lid, Wte 1995 een register bij. Aan het begin van elk jaar laat de STE overeenkomstig art. 21, derde 1 id, Wte 1995 de lijst, met de tot het eind van het daaraan vooraf gaande jaar bijgehouden inschrijvingen en doorhalingen, plaatsen in de Staatscourant. Zij houdt, ex art. 21, vierde lid, Wte 1995, een afschrift van het register voor een ieder kosteloos ter inzage.

\subsubsection{2a Toezichtsbevoegdheden Stichting Toezicht Effectenverkeer}

Voor een behoorlijke vervulling van haar rechtshandhavende taak is het belangrijk dat de STE de, ex art. 29 Wte 1995 aan haar toekomende, toezichtsbevoegdheden kan uitoefenen. Ten opzichte van het analoge art. 21 Wte bevat art. 29 Wte 1995 enige uitbreiding en aanpassing. De kring van onder toezicht gestelden ondergaat verbreding. Voortaan kan de STE haar toezichtsbevoegdheden ex art. 29, eerste lid, Wte 1995 ook uitoefenen tegen effecteninstellingen te wier laste buiten besloten kring effectenuitgifte plaats vindt, als mede tegen houders van gekwalificeerde deelnemingen, en tegen betrokkenen die deel uitmaken van een groep waartoe een effecteninstelling behoort ${ }^{317}$. Overigens kan de STE, als van ouds, onderzoek doen bij onder meer houders van erkende/te erkennen beurzen en verschillende aanvragers of houders van vrijstellingen (althans, in de zin van art. 18 Wte 1995)/ontheffingen/vergunningen.

De toezichtsbevoegdheden betreffen nog steeds: het inwinnen of doen inwinnen van, redelijkerwijs voor het toezicht op de naleving van de effectenwet- en regelgeving relevante, inllichtingen (ex art. 29, eerste lid, Wte 1995) als mede het onderzoeken of doen onderzoeken van onder toezicht gestelden, waarvoor inzage van zakelijke gegevens en bescheiden $^{318} \mathrm{kan}$ worden verlangd (ex art. 29, vierde lid, Wte 1995 gerelateerd aan kopieermogelijkheid en tijdelijke afgiftemogelijkheid) en overigens alle medewerking van de onder toezicht gestelden kan worden gevorderd (ex art. 29, vijfde lid, Wte 1995). Gelijk aan de vrij wel zelfde toezichtsregeling voor het algemene bestuursrecht (zie afdeling 5.1 Awb) moet de uitoefening van toezichtsbevoegdheden de redelijkheidstoets kunnen doorstaan. Het feit dat toezichthouders, onder legitimatie ex art. 29, tweede lid,

317. In de oorspronkelijke wersie rept art. 29, eerste lid, Wte 1995 hier van betrokkenen vallend onder het geconsolideerd toezicht op effeeteninstellingen. Bij Nota wan wijziging voorstel Wie 1995, TK 19941995, 23874, nr.8, p.2, wordt dit veranderd in genoemde groepsterminologie. Volgens art. 1 , sub f, We 1995 wordt met een groep dan bedoeid een groep in de zin van art. $24 \mathrm{~b}$ van boek $2 \mathrm{BW}$, met dien verstande dat een natuurlijk persoon die wia formele of feitelijke zeggenschapsstructuur invloed kan uiloefenen op de groep, wordt beschouwd als deel uitmakend van die groep.

318. Conform de Richtlijn beleggingsdienstem en het Bte moet een toezichthouder goed zijn taak kunnen uitoefenen. Dit impliceent wat betreft de administratie van onder toezicht gestelden dat deze goed verzorgd moet zijn. De boekhoudkundige organisatie moet zo zijn ingericht dat de STE inzicht kan kkijgen in: interne controleprocedures, vermogensscheiding, registratie van transactiegegevens, structul rering wan de betrokken effecteninstelling, gedragsregels, een mogelijk geldend garantie(fonds)stelsel, en omstandigheden waaronder transacties op gereglementeerde markten plaats vinden. Zie M' woorstel Whe 1995, TK 1993-1994, 23874, nr.3, pp.20-22. 
Wte 1995, gerechtigd zijn tot plaatsbetreding (inclusief woningbinnentreding) krijgt wel krachtiger vorm door de via art. 29, derde lid, Wte 1995 ingevoerde mogelijkheid om zich toegang te verschaffen met behulp van de sterke arm en zich te laten vergezellen van door hen aangewezen personen. De nieuwe regeling inzake onderzoeks- en controlebevoegdheden ten behoeve van het STE-toezicht sluit aan bij de toezichtsbepalingen van de Awb en de Wet inzake de wisselkantoren.

De informatieverplichting vindt uitwerking in art. 30 Wte 1995 voor een, bij een erkende effectenbeurs aangesloten, effecteninstelling. Zo' $n$ instelling is, ter medewerking aan de controle op de nakoming van beursregels, verplicht gegevens te verstrekken uit een door haar aangehouden Wpr-persoonsregistratie. Hiervoor is dan geen toestemming van geregistreerden vereist.

In verdere verfijning van gegevensverstrekking voorziet art. 31 Wte 1995 . Deze wettelijke bepaling beoogt de bevoegdheden van de toezichthouders op de onderscheiden financiële sectoren te versterken. ${ }^{319}$ In gevolge art. 31, eerste lid, Wte 1995 blijven de, door binnenlandse of buitenlandse wettelijke bevoegde toezichthoudende autoriteiten, bij of krachtens de Wte verkregen gegevens of inlichtingen omtrent afzonderlijke ondernemingen of instellingen geheim. Kortom, publikatie is niet toegestaan. Althans, in principe. Als informatie niet herleid kan worden tot individuele bedrijven is thet een bevoegd toezichthouder op het effectenverkeer toegestaan daarvan mededeling te doen. Aldus art. 31, wijfde lid, Wte 1995 .

Het later toegevoegde zesde lid van art. 31 Wte $1995^{320}$ verstevigt de positie van erkende beurzen als het om informatieverkrijging gaat, die gegeven grensoverschrijdende activiteiten steeds belangrijker wordt. Voorbij gaand aan het eerste, tweede en vijfde lid van art. 31 Wte 1995 kan de STE gegevens of inlichtingen, verkregen bij de vervulling van de haar in gevolge de Wte opgedragen taken (inclusief dus de informatie die de STE krijgt van andere bevoegde toezichthoudende autoriteiten in het buitenland), verstrekken aan de houder van een erkende effectenbeurs met het oog op de controle op de naleving van de voor die beurs te hanteren regels. Ten aanzien van aldus verkregen informatie geldt de in art. 31, eerste en tweede lid, Wte 1995 genoemde geheimhoudingsplicht. Art. 31, tweede lid, Wte 1995 verduidelijkt well dat een ieder de, hem door taakvervulling bekend geworden, bedoelde gegevens en inlichtingen niet verder of anders gebruikt (of openbaar maakt) dan voor de uitoefening van zijn taak of door de Wte wordt geẽist. Uitzondering geldt voor het geval sprake is van optreden als getuige of deskundige in strafzaken. Zie art. 31, derde lid, Wte 1995. Bovendien is, voor zover het gaat om informatie betreffende een effecteninstelling die definitief failliet is verklaard of op grond van rechterlijke uitspraak onherroepelijk is ontbonden, conform art. 31 , vierde lid, Wte 1995 exoneratie mogelijk bij het optreden als getuige of als partij in een compartie van partijen dan wel als deskundige in burgerlijke zaken.

319. Mut woorstel Wite 1995, TK 1993-1994, 23874, nr.3, p.51.

320. Nota n.a.w. het verslag inzake het woorstel Wte 1995, TK 1994-1995, 23874, nr.7, pp. 17-19, Nota wan wijziging woorstel Wte 1995, TK 1994-1995, 23874, nr.8, p.2. 
Bijzondere informatie, die de bevoegde toezichthoudende autoriteit, met het oog op adequate functionering van de effectenmarkten en de positie van beleggers op die markten, ex art. 32 Wte $1995^{321}$ wel naar buiten mag brengen, betreft: a. de onherroepelijke weigering van vergunming of ontheffing; $b$. de uitoefening effectenbedrijf zonder vereiste vergunning of ontheffing; $c$. het niet in acht nemen van de, aan een vrijstelling ex art. 10 Wte 1995 verbonden, voorschriften; d. het houden van een effectenbeurs zonder bezit van benodigde erkenning of ontheffing; of e. het door een effectenbeurshouder niet in acht nemen van de, aan een vrijstelling ex art. 25 Wte 1995 verbonden, voorschrif$\operatorname{ten}^{322}$.

Ten slotte kan informatie niet op exclusieve wijze worden achter gehouden door de, daarvan in het bezit gekomen, toezichthoudende autoriteit in Nederland, als deze oordeelt dat een andere toezichthoudende autoriteit op een financiële markt (o.a. DNB nv en stichting Verzekeringskamer) of een autoriteit belast met de uitvoering van de Wet inzake de wisselkantoren (DNB nv), bij uitoefening van toezichtstaken, belang heeft of zou kunnen hebben bij die inlichtingen en gegevens. Ex art. 34, vierde lid, Wte 1995 moet de informatie dan worden doorgespeeld. Conform art. 34, vijfde lid, Wte 1995 hoeft dit echter weer niet als de gewilde informatie wordt verkregen van een buitenlandse instantie.

\subsubsection{2b Samenwerking en informatie-uitwisseling binnen-en buitenlandse toezichthouders}

Art. 33 Wte $1995^{323}$ bevat ook, van de hoofregel afwijkend, specieke situaties van informatieverstrekking. De Nederlandse toezichthouder op het effectenverkeer kan bevoegdelijk verkregen informatie verstrekken aan Nederlandse of buitenlandse overheidsinstanties dan wel aan Nederlandse of buitenlandse van overheidswege aangewezen instanties die belast zijn met het toezicht op de financiële markten werkzaam zijn. Deze verstrekking kan in gevolge art. 33, eerste lid, Wte 1995 worden belemmerd door een van de volgende blokkaden: a. onvoldoende doelbepaling; b. beoogd gegevensgebruik past niet in het kader van het toezicht op financiële markten; c. informatieverschaffing is strijdig met Nederlandse wetgeving of openbare orde; $d$. onvoldoende waarborging van geheimhouding van informatie; e. redelijkerwijze (mogelijke) strijdigheid van informatieverstrekking met de door de Wte 1995 te beschermen belangen; of f. dreigend gevaar, bij informatieverstrekking, voor détoumement de pouvoir.

Wat dat laatste betreft, mag een buitenlandse bevoegde toezichthoudende autoriteit, na verkregen toestemming van de informatieverschaffer in Nederland, ter harer kennis gekomen gegevens of inlichtingen voor een ander doel, dan het oorspronkelijke doel waarvan bij informatieverlening sprake is, aanwenden, indien voldaan is aan drie min of meer cumulatieve eisen. Ten eerste, beoogd ander gebruik wordt toegestaan voor zover

321. Dit artikel wordt ontleend aan art. 23 Wte."

322. Dit laatste onderdeell wordt ingevaegd bij de Nota van wijziging voorstel Wte 1995, TK 1994-1995, $23874, \mathrm{nr} .8, \mathrm{p} .2$.

323. Art. 33 Wte $1995 \mathrm{v} / \mathrm{m}$ art. 36 Wte 1995 worden ontleend aan de in gevolge de informatie-uitwisselingswet (Stbl. 1994, 235) gewijzigde Wte. 
dat niet in strijd komt met de hiervoor reeds genoemde eisen. Dan wel ten tweede, beoogd gebruik mag voor zover die buitenlandse toezichthouder op andere wijze dan de Wte vermeld van uit Nederland conform daarvoor geldende procedures voor dat andere doel de beschikking over informatie zou kunnen verkrijgen. Als mede ten derde, informatieverstrekking voor een ander dan het oorspronkelijk doel wordt getolereerd, na overleg met de minister van justitie, en als zij ten dienste is van een onderzoek naar strafbare feiten.

Voor zower de uitoefening van het toezicht op het effecteninstellingen (die deel uit maken van een groep) dat vereist, werkt een toezichthoudende autoriteit als de STE - ex art. 34, eerste lid, Wte 1995 - samen, en pleegt zij - ex art. 34, tweede lid, Wte 1995 - overleg, met aangewezen autoriteiten die bevoegdelijk toezicht uitoefenen op kredietinstellingen, verzekeraars en beleggingsinstellingen. Denk aan De Nederlandsche Bank nv of de stichting Verzekeringskamer. Voor deze samenwerking treffen betrokken autoriteiten - ex art. 34, derde lid, Wte 1995 - regelingen. Daarin staan dan in elk geval afspraken over het stellen van gemeenschappelijke regels, het coördineren van werkzaamheden uit hoofde van ieders uitoefening van het toezicht en het uitwisselen van gegegevens en informatie.

Naast samenwerking tussen toezichthouders op verschillende Nederlandse financiële (deel)markten, eist art. 35 Wte 1995 samenwerking van de bevoegde toezichthouder op de effectenmarkt in Nederland met soort gelijke toezichthoudende autoriteiten op het effectenverkeer in andere lidstaten.

Ex art. 36, eerste lid, Wte $1995 \mathrm{kan}$, in het bijzonder ter uitvoering van verdragen tot informatie-uitwisseling dan well ter uitvoering van bindende besluiten van volkenrechtelijke organisaties met betrekking tot het toezicht op financiële markten, ten behoeve van een toezichthouder op het effectenverkeer (werkzaam in een verdragsstaat of onder bedoeld beslluit vallende staat), worden verzocht om het verstrekken van inlichtingen of het (doen) instellen van een onderzoek bij een ieder die in gevolge de Wte 1995 onder zijn toezicht valt of waarvan redelijkerwijs kan worden vermoed dat hij beschikt over gegevens of inlichtingen die mogelijk relevant zijn voor die uitvoering.

Opgevraagde informatie wordt ex art. 36, tweede lid, Wte 1995 binnen een, door de Nederlandse toezichthoudende autoriteit bedongen, termijn gegeven.

En degene bij wie een onderzoek wordt ingesteld, verleent ex art. 36, derde lid, Wte 1995 alle medewerking, voor zover redelijkerwijs nodig is. Maar hij kan slechts worden verplicht inzage te verlenen van zakelijke bescheiden en gegevens die betrekking hebben op zijn beroeps- of bedrijfsuitoefening. Art. 37, eerste lid, Wte 1995 maakt het mogelijk dat een functionaris van een buitenlandse instantie als bedoeld in art. 36, eerste lid, Wte 1995, na toestemming van de Nederlandse toezichthoudende autoriteit, deel neemt aan de uitvoering van een dergelijk onderzoek. Ex art. 37, derde lid, Wte 1995 volgt deze functionaris dan de aanwijzingen op van de persoon die met de uitvoering van het onderzoek is belast. 
Contact van de Nederlandse toezichthouder op het effectenverkeer met soort gelijke toezichthouders in het buitenland bestaat ook als sprake is van effecteninstellingen of ondernemingen die zetelen in een lidstaat buiten Nederland. Ex art. 38, eerste lid, Wte 1995 kan de STE ten behoeve van het toezicht de buitenlandse toezichthouder vragen om ter plaatse de juistheid van de aan de STE verstrekte informatie te verifiëren. Daarnaast gaat de STE zich mogelijk zelf ter plekke van de juistheid van verstrekte inlichtingen en gegevens overtuigen. En anders laat zij zich al daar er van overtuigen. Hiervoor moet zij dan well eerst toestemming van de toezichthoudende autoriteit in de betrokken lidstaat krijgen.

Art. 38, tweede lid, Wte 1995 regelt de situatie voor een door een hier te lande gevestigde effecteninstelling met bijkantoor in een andere lidstaat. In dat geval beschikt de STE, in het belang van het toezicht op het effectenverkeer, over de zelfde mogelijkheden.

Analoge regel, maar dan omgekeerd, is te vinden in art. 39, eerste lid, Wte 1995 voor het natrekken van informatie op verzoek van een niet-Nederlandse toezichthouder aan wie die informatie is verstrekt (als in overeenstemming met de richtlijn kapitaaltoereikendheid in een andere lidstaat door dan wel omtrent een in Nederland gevestigde effecteninstelling of -onderneming inlichtingen aan de toezichthoudende autoriteit van die lidstaat zijn verstrekt). Daarnaast is een vergelijkbare regel opgenomen in art. 39, tweede lid, Wte 1995 voor het, ten behoeve van het toezicht op het effectenverkeer in een betrokken andere lidstaat, verifiëren van gegevens en inlichtingen op verzoek van een toezichthouder in een andere lidstaat die de informatie van een bijkantoor in Nederland heeft betrokken. Ook in deze beide gevallen kan de buitenlandse toezichthouder, die gegevens en inlichtingen ontvangt van een in Nederland zijnde effecteninstelling of -onderneming, de Nederlandse toezichthouder vragen de informatie ter plaatse op betrouwbaarheid te controleren. Zo mogelijk gaat de buitenlandse toezichthouder, na toestemming van de Nederlandse toezichthoudende autoriteit, zelf in Nederland de waarheid achterhalen.

\subsubsection{C Rechtsbescherming}

Tegen door de STE in het kader van haar toezichtstaak genomen besluiten biedt art. 44 Wte $1995^{324}$ aan een belanghebbende rechtsbescherming. Deze is in te roepen bij het College van Beroep voor het bedrijfsleven.

Art. 43 Wte 1995 voorziet voor belanghebbenden in de mogelijkheid om administratief beroep in te stellen tegen een besluit van een houder van een erkende effectenbeurs omtrent de toelating van effecten of het doen vervallen van effecten uit de notering aan die effectenbeurs. Deze beroepsmogelijkheid bestaat niet als dit besluit strekt tot uitvoering van een aanwijzing in de zin van art. 6 Wte $1995 .{ }^{325}$

324. Dit artikell, geredigeerd conform de Awb, wordt, even als art. 43 Wite 1995, ontleend aan art. 29 Wte.

325. Aldus vult de Nota van wijziging woorstel Wre 1995, TK 1994-1995, 23874, nr.8, p.3, art. 43 Wte 1995 aan. $B$ ij het toekemnen van de mogelijkheid tot beroep tegen een aamwijzing zou de STE in beroep "materiaal haar eigen beslluit moeten toetsen. Een dergelijke toets, die neerkomt op heroverweging wan het eigen besluit, is zinvol noch wenselijk. Daar komt bij dat een op grond vam een aanwijzing genomen 
Mede in het licht van de rechtsbescherming is het belangrijk dat van elke verlening of intrekking van vrijstelling, vergunning, erkenning of ontheffing en van het van kracht worden vam het verbod ex art. 12, vierde lid, Wte 1995, publiekelijk kennis wordt gegeven door mededeling er van in de Staatscourant. Aldus bepaalt art. 59 Wte 1995.

\section{Ten slotte}

De effectenwereld is in rep en roer. Tekenend daarvoor is dat de toezichthouder op het effectenbedrijfsverkeer het vuur aan de schenen wordt gelegd. Terecht, want er gaat nog al wat mis in de fraudegevoelige financiële wereld van waardepapieren.

De eerste rechtszaak inzake misbruik van voorwetenschap, t.w. de HCS-zaak, trekt terecht totale aandacht. Nog voordat de hoogste rechter in Nederland uitspraak ter zake doet, ontpopt zich een drama bij Borsumij Wehry waarvan bepaalde bestuurders beschuldigingen van misbruik van voorkennis naar het hoofd krijgen geslingerd.

De rol van de STE bij het aanbrengen van een zaak voor de rechter komt in het algemeen uiteindelijk neer op het doen van aangifte. Daarbij baseert de STE zich op zowel, door haar (op grond van door de STE zelf verzamelde gegevens) opgestelde, eigen rapporten als, all dan niet in haar opdracht opgestelde, rapporten van de controlebureaus van de beurzen. Het blijft navrant dat de STE, vurig voornemens aangifte te doen, zich in gaten en bochten wringt ten einde benodigd bewijsmateriaal te vinden. De mogelijkheid dat de STE in haar wens tot het doen van aangifte, waartoe zij overigens niet verplicht is, grenzen overtreedt is niet ondenkbaar. Toezicht neemt hier snel een vrije loop naar opsporing.

Wrang gegeven is trouwens dat het openbaar ministerie in vermelde zaken, kennelijk in blindelings vertrouwen, bot weg beroep doet op deze rapportages, zonder zelf de juistheid en volledigheid van de weergave daarvan werkelijk te staven. Zo leidt de rit op het opsporingscircuit regelrecht naar de route van het toezichtscircuit. Daarmee ontspoort het openbaar ministerie. Geen valabele reden hiervoor is het, met oog op de behandeling van beursfraude duidelijke, tekort van het $O M$ aan menskracht en deskundigheid waarmee de actieve STE voortdurend hinderlijk wordt geconfronteerd.

De ervaring met het onderzoek door controlebureaus en STE in beide zaken roept de vraag op of de ECD niet eerder dient te worden ingeschakeld. Door snel optreden van de ECD, waarvoor zij wel uitbreiding nodig heeft, kan de duur van het onderzoek worden beperkt, de doelmatigheid van het onderzoek worden verhoogd en is het bewijs minder eenvoudig weg te moffelen. Daardoor komt overigens duidelijk zelfregulering in het gedrang.

Hoewel algemene aanvaarding er van niet aantrekkelijk oogt (het is immers steeds de bedoeling geweest het strafrechtelijk apparat ver te houden en de ECD zo veel mogelijk

325. $\rightarrow$

beursbestuit kan worden aangemerkt als een gebonden beschikking. Aanwijzing voor de regelgeving 15.5 schrijft voor dat administratief beroep slechts kan worden open gesteld tegen een niet in overwegea de mate gebonden beschikking." Aldus TK 1994-1995, 23874, nr.8, pp.5-6; M. R. Mok, Wetswoorstel vezich effectenverkeer 1995, in: TVVS, nr.4, 1995, pp.100 101, acht de nu voorgestelde aanpassing "niet strikt noodzakelijk" van uit de gedachte dat in dergelijke gevallen de bevoegdheid tot behandeling van administratief beroep niet aan de STE hoeft te worden overgedragen, maar bij de minister kan worden grehouden. 
te ontlasten, denk aan de met de Wte 1995 door de STE verkregen mogelijkheid om zélf binnen te treden en eventueel met behulp van de sterke arm toegang te krijgen tot financiële instellingen), kan zekere zin aan dit voorstel niet worden ontzegd. De, weliswaar van verbeteringsdrang bezeten, zelfregulerende krachten tonen zich de laatste jaren niet sterk. De affainre Nusse Brink laat ruimte voor vervelende conclusies als tekortkomingen wan de, tot overmaat van ramp niet altijd op tijd bij de STE aangeleverde, rapportages van de controlebureaus en daamaast belangenverstrengelingen van (in dienst van controlebureaus zijnde) registeraccountants en beursbesturen. Bovendien bakenen de diverse controlebureaus van de verschillende beurzen en termijnmarkten hun werkterreinen niet goed af. Afgezien van deze externe herkenbaarheid, leert de barre Baringsbankaffaire dat elk afzonderlijk controlebureau interne inzichtelijkheid moet bieden door scherpe scheiding aan te brengen tussen de functie van toezicht en andere functies. Daar komt nog bij dat zelfs de taakverdeling tussen controlebureau en STE niet altijd even helder is. Dergelijke ondoorzichtigheid komt een toezichthouder duur te staan. Wil de STE het wertrouwen van onder toezicht gestelden als de bank Labouchere herwinnen, dan moet zij toezicht meer markeren en spoedig muren optrekken.

Juist in het kader van samenwerking moet grenzen helder zijn. Hierbij gaat het niet alleen om de samenwerking met bestuursorganen belast met overheidstoezicht op verschillende financiële deelmarkten in Nederland. Mér nog telt in de toekomst de samenwerking en informatie-uitwisseling met toezich thoudende (overheids)instanties in het buitenland. $\mathrm{Nu}$ effectenbedrijfsvergunningen, door wederzijdse erkenning van (toezicht)regels tussen lidstaten, communautaire draagwijdte krijgen en ondernemende buitenlandse beurzen zich slechts via schermen in Nederlandse beursgebouwen mogen presenteren, staat de STE aan de spannende vooravond van de geboorte van grensoverschrijdend toezicht. Daarmee wordt de noodzaak van snelle, efficiënte en effectieve communicatie tussen (nationale) toezichthouders dringend. In het nauw gedreven sluit de STE zorgzalam memoranda ter zake af en participeert zij in overkoepelende overleggroepen.

De STE is een toezichthouder op een machtige markt. Zij heeft er stimulerend voor te zorgen dat zelfregulering sufficiënt is. En zij heeft er tegelijkertijd tegen te waken dat zelfregulering een eigen leven gaat leiden.

De STE is ook een toezichthouder op een moderne markt. Moderne situaties vragen om moderne regels. Voortdurend onstaan, door het liberaliseren en harmoniseren van markten, nieuwe regels. Effectenwetgeving is daarom wervelende wetgeving. Dat stelt toezichthouder en onder toezicht gestelden soms voor problemen. De kwaliteit van wetgeving laat zo nu en dan te wensen over. Hierbij stelt het teleur dat de signalen die de STE daarover naar de verantwoordelijken uitstraalt, niet altijd even snel worden opgepakt. Des te meer valt dit te betreuren bij de gedachte dat juist een functioneel bestuursorgaan als de STE, dat dicht op zelfregulering zit, als geen ander in staat is om tijdig de complicaties in wet- en regelgeving te zien en overigens de implementatie van Europees recht in nationaal recht te bespoedigen.

Omdat de STE in toenemende mate geconfronteerd wordt met het toezicht op administratieve verplichtingen van onder toezicht gestelden is het verheugend, dat politiek en prak- 
tijk nu enige overeenstemming hebben bereikt over toekenning aan de STE van de bevoegdheid tot het opleggen van bestuurlijke boeten voor lichte overtredingen. 


\section{Geraadpleegde literatuur}

Alberts, $J$.

- Rechter HCS-zaak: geen beïnvloeding, in: NRC, 8 februari 1995, p.21;

- Justitie betaalt banken voor hulp, in: NRC, 15 februari 1995, p.1;

- Banken als misdaadbestrijders, in: NRC, 16 februari 1995, p.17.

- 'Tuchtrecht Beurs vergt aampassing", in: NRC, 23 maart 1995, p.19;

- Banken: justitie faalt bij opsporing criminele gelden, in: NRC, 23 maart 1995, p.1;

- Fraude Borsumij is een klassieke zaak, in: NRC, 4 april 1995, p.21;

- Top Borsumij centraal in voorkennis-affaire, in: NRC, 27 april 1995, p. 19;

- Top Borsumij wijst beschuldigingen af; Onderzoek naar misbruik wan voorkenmis, in: NRC, 28 april 1995, p.13;

- Barsumij en Hagemeyer: samengaan lange draom, in: NRC, 15 mei 1995, p.11;

- Rechtbank buigtzich overspeculatieve termijnhandel; Gedupeerde beleggerklaagt Kredietbank aan, in: NRC, 20 mei 1995, p.17;

- Beurs wordt omgevormd tot bedrijf, in: NRC, 31 mei 1995, pp.1/19;

$\sim$ STE eist opheldering over beschuldigingen Borsumij-bestuurder, in: NRC, 3 juni 1995, p.15.

Alberts, J. \& Tamminga, $M$.

$\sim$ Borsumij in het woetspoor van Begemann, in: NRC, 2 mei 1995, p.17;

- Toezicht op beurshandel onder scherpe kritiek, in: NRC, 31 mei 1995, p.15.

Beetsma, R. \& Mingels, R.

Handel met voorwetenschap en marktefficièntie, in: ESB, 30 maart 1994, pp.294-296.

Berkhout, K.

Nalatigheid ING bijl aan wortel wan het beurstoezicht, in: NRC, 14 december 1993, p.18;

- Beurswakhond STE komt uit de coulissen, in: NRC, 26 mei 1994, p.20;

- Beurswoorzitter getuigt in zaak tegen Nusse Brink, in: NRC. 17 september 1994, p. 13.

Berkhout, K. \& Wessels, P.

- Controle beurshandel is moeilijk: Toezichthouder op effectenverkeer laat 'buitenlandroute. ongemoeid, in: NRC, 16 juni 1993, p.20;

- Maak misbraik wan voorwetenschap openbaar, in: NRC, 18 september 1993, p.9;

- Van Ittersum: affaires schaden imago van beurs, in: NRC, 31 december 1993, p. 19;

- Beurs legt Nusse verduistering ten laste; Kantoor schaadde ook imago Amsterdam. en Nusse Brink strafrechtelijk heel moeilijk aan te pakken, in: NRC, 26 januari 1994, pp.17-18;

- HCS-vervolging doorbraak in bestrijding voorwetenschap, en Ondernemers vervolgd wegens beursfraude, in: NRC, 17 februari 1994, pp. 1/19;

- Nusse-directeur nu ook verdacht van witwassen. in: NRC, 18 maart 1994, p.13;

- Zeer zware siraf beurs voor Nusse Brink, in: NRC, 6 mei 1994, p.1;

- Nusse Brink en Medicopharma of de mislukte sprong naar voren, in: NRC, 13 oktober 1994 , p. 21:

- Beursfraude vermoed bij Medicopharma: Justitie onderzaekt misbruik voonwetenschap, in: $\mathrm{NRC}_{\mathrm{s}} 4$ februari 1995, p. 17.

Bierhuize, C.P.

Het voorstel Wmz, in: NV, nr.5, mei 1990, pp.145-151.

Boele, S.A.

Het arrest van de Hoge Raad in de zaak ABNAMRO/Co op AG, in: TVVS, nr .3, 1995, pp. 64-70. Cross, D.H.

EG-richtijinen betreffende bemiddelaars in de effectenhandel, in: TVVS, nr.3, 1994, pp.62-66. Doorenbos, D.R. 
- Misbruik van voorwetenschap: schade en schande?, in: NV, nr.7/8, juli/aug. 1989,pp.164-166, zie ook Naschrift, in: NV, nr.10, oktober 1989, pp.211-212;

- Financieel strafrecht; Een studie inzake strafrechtelijk gesanctioneerde woorschriften uät de bank-en effectenwetgeving, vennootschapsen rechtspersonenrechtmonografieërleel 40 , dissertatie KUN, Deventer, 1992.

- Nieuwe strafbepalingen inzake het effectenverkeer, in: TVVS, nr.7, 1993, pp.169-173;

- Money laundering; De rol van de financiële sector, in: DD, nr.8, 1993, pp.764-779.

Drijber, D.J.

- EEG-richtlin inzake het witwassen van geld vastgesteld, in: TVVS, nr.11, 1991, pp. 294-295;

- Toezicht op financiële instellingen: de 'anti BCCI-richtlijn', in: TVVS, nr.2, 1995, pp.42-44.

Dubbeld, C. \& Schaik, F.A. van

Accountants kiezen voor zelfregulering bif fraudemelding, in: NJB, nr.42, 25 november 1994. pp.1445-1449.

Dijk, K.E.J.

De notaris en criminaliteitspreventie, in: NJB, nr.42, 25 november 1994, pp. $1450-1453$.

Dijk, M.C.M. van

De Wet toezicht effectenverkeer in vogetvlucht, in: TVVS, nr.8, 1991, pp. 204-209.

Dijk, M.C.M. van \& Verbeek-Meimhardt,S.

Enige kanttekeningen bij het wetsvoorstel houdende regelen inzake het toezicht op het effectenverkeer, in: SEW, nr.1, februari 1990, pp.58-73.

EconomischeControle Dienst

Jaarverslagen 1992/1993, Apeldoorn, 1992/1993.

Eisma, S.E.

Civielrechtelijke gevolgen van handelen in strijd met effectenregelgeving, in: NV, nr.5, 1995, pp. $98-100$.

Enk, W, van

- Affaire HCS-aandelen voor de rechter: op zoek naar witte vlekken in de wet, in: NRC, 18 marart 1994, p. 15;

〜 Doemscenario Begemann-groep nabij, in: NRC, 18 oktober 1994, p.15.

Garderen, E.J. van

Kapitale perikelen rondom de beleggingsmaatschappijmet veranderlijk kapitaal, in: TVVS, nr.6, 1994 , pp. 151-155.

Groenhuighsen, M.S. en Landen, D. van der

De financiële aanpak van de georganiseerde criminaliteit, in: NJB, nr.17,28 april 1995, pp.613621.

Groot, L.R.T. van der

De Beurs wikt, de Hoge Raad beschikt, in: Bank-en Effectenbedrijf, januari/februari 1995 , pp. 4-5.

Hees, J.J.van \& Kortmann, S.C.J.J.

Gerechthof zit er in HCS-zaak helemaal naast, in: NRC, 19 december 1994, p.7.

Hoogerboom, A.B., Mul, V. \& Wielenga, A.

Financiêle integriteit: normafwijkend gedrag en (zelf)regulering binnen het financiële stelsel. Arnhen, 1995.

Huijser, A.P. \& Nieuwkerk, M.

Financièle fragiliteit en toezicht, in: Bank- en effectenbedrijf, januari/februari 1995, pp.38-42.

Kerres, M. \& Wessels, P.

- Justitie wil 'wijkagent' bij bank en beurs, in: NRC, 27 oktober 1994, p. 1, als mede Financiele wereld rijp voor permanent toezicht, in: NRC, 27 oktober 1994, p.17;

- 'Relatie politie en bedrijuen moet beter', in: NRC, 29 oktober 1994, p.15.

Kortmann, S.C.J.J. \& Hees, J.J. van 
Misbruik van voorwetenschap nader beschouwd, in: WPNR, nr.6166, 4 februari 1995. Kuws, A.H.J.

De Whot en de privacy van klanten van banken, in: Computerrecht, nr.4, 1994, pp.163-167. Maas, J.

Rechten en plichten van de beursgenoteerde onderneming, in: Firm, nr.2, 1994, pp.16-22. Maris, A.G. \& Boele, S.A.

Prospectusaansprakelijkheid, in: TVVS, nr.6, 1994, pp.141-146.

Moerlie, C.

STE hoeft witspraken niet te rectificeren, in: De Financiële Telegraaf, 23 december 1994 „p.T23. Mok, R.M.

- Toezicht effectenverkeer II, in: TVVS, nr.4, 1989, pp.102-104;

- Voorstel Wte, in: TVVS, nr.11, 1989, pp.283-284;

- Jaarverslag 1993 STE, in: TVVS, nr.8, 1994, pp.209-210;

- Wijzigingen regelgeving toezicht effectenverkeer, in: TVVS, nr.11, november 1994, pp. 299-301;

- Wetswoorstel toezicht effectenverkeer 1995, in: TVVS, nr.4, 1995, pp.100-101.

Nederween, $A_{\text {. }}$

Derivaten en de Wet toezicht effectenverkeer, in: TVVS, nr.6, 1995.

Oostrum, H.J. van

- Vrees voor aantasting beurstoezicht; Liberalisering effectenhandel, in: NRC, 28 maart 1995,

p.15;

- Beursleden zien vrijmaking toezicht als bedreiging, in: NRC, 29 maart 1995, p.13;

- Baron van Ittersum wil baas in eigen beurs blijven, in: NRC, 30 mei 1995, pp.17/21.

Perrick, S.

Het toezicht op het effectenverkeer in Nederland, oratie EUR d.d. 3 november 1989, Deventer, 1991.

Raaijmakers, M.J.G.C.

ABNAMRO/Vereniging Coopag, in: Ars Aequi, nr.3, 1995, rechtspraakkatermr.44, pp.219-226.

Registratiekamer

- Jaarverslag 1989-199I, Rijswijk, 1993;

- Wmz: gegevensverstrekking aan derden, Rijswijk, juli 1994.

Rek.H.L.M.

De Wtb in de praktijk, in: TVVS, nr.12, 1994, pp.321-325.

Rietkerk, G.

Commentaar op Misbruik van voorwetenschap: schadeen schande?, in: NV, nr. 10, oktober 1989 , pp.210-211.

Schaap, C.D.

Meldpunt MOT: spin in het financielle web, in: Bank-en Effectenbedrijf, mei 1995, pp.27-30,

Schinkel, M. \& Tamminga, M

- Deregulering troef in slag financiële centra: Toezichthouders vragen zich af welke rol zij nog hebben, in: NRC, 28 mei 1994, p.20;

$\sim$ Derivatenhandel groeit snel bij de banken, in: NRC, 3 mei 1995, p.17.

Schreuder, C.A.

Publiekrechtelijke taken, private rechtspersonen; Verzelfstandigingen privatiseringinde vorm van vennootschappen en stichtingen, dissertatie RUG, serie bestuursrecht theorie en prakijk nr.16, Deventer, 1994, pp.342-352/359-367.

Slagter, W.J.

Het fonds CSM wit de beursnotering?, in: TVVS, nr.12, 1994, pp.326-327.

Soest, J.P. van

Van wisselaars en wisselkantoren, in: Bank- en Effectenbedrijf,januari/februari 1995, pp.14-20. 
Stichting Toezicht Effectenverkeer

- Goed beleggen is verstand gebruiken, Amsterdam;

- Jaarverslagen 1992/1993/1994, Amsterdam, 1993/1994/1995.

Tamminga, $M$.

- Spel om publicatie van al publieke informatie, in: NRC , 6 augustus 1994, p.13;

- Twee verdachren in HCS-zaak over; Melchior en Albada Jelgersma worden niet gedagvaard" in: NRC, 2 september 1994, p. 11;

- Waakhond beurshandel op de wingers getikt, in: NRC. 16 september 1994, p.11;

- Helft advocaten in zaak HCS kan toga thuislaten, in: NRC, 24 september 1994, p.14.

$\sim$ Hernieuwde eis in HCS-zaak beroert hoofdverdache nier; 'Stilzwijgende overeenkomst HCS, in: $\mathrm{NRC}_{4} 4$ oktober 1994 , pp. $17 / 23$;

- Speurders grote verliezers HCS affaire, in: NRC, 5 oktober 1994, p.21;

- Hof kiest nieuwe richting in oordeel kenniszaak, in: NRC, 18 oktober 1994, p.15;

- Wervelwind Joep verliest wart na onbeheerste dadendrang, in: NRC, 29 oktober 1994, p.17;

- Arrest hof stelt openheid boven privacy van beleggers, in: NRC, 27 januari 1995, p.11.

Tweede Kamer

- Kamerstukken inzake regelen inzake het toezicht op het effectenverkeer: Wte, TK 1988-1989,

21038, nrs.3/12;

- Wetsvoorstel identificatie bij financiële dienstwerlening. TK 1992-1993, 23008, nrs.1-2;

- Wetsvoorstel melding ongebruikelijke transacties. TK 1992-1993, 23009, nrs.1-2;

- Wetsvoorstel inzake opneming in de Wtk, Wtw, Wtb en Wte van bepalingen betreffende de informatieuitwisseling tussen Nederlandse en buitenlandse instanties die belast zijn met het toezicht op financiële markten of op natuurlijkepersonen en rechtspersonendie op die markten werkzaamzijm. TK 1992-1993,23170;

$\sim$ Ovk tussen Nederland en VS wan Amerika inzake wederzijdse administratieve bijstand bij de uitwisseling van informatie op het gebied van opties en termijncontracten, TK 1993-1994,23495. nrs. 1-129;

- Wijziging Wet identificatie bij financiële dienstwerlening 1993, TK 1993-1994,23656, nrs.1-3;

- Goedkeuring verdrag en protocol inzake handel met voorwetenschap, TK 1993-1994,23690;

- Wetsvoorstel inzake de wisselkantoren, TK 1993-1994,23777, nrs.1-3;

- Wetswoorstelhoudende het opnieuw vaststellen wan de Wte i.v.m. de uitwoering van de richtlijn betreffende het verrichten wan diensten op het gebied van beleggingen in effecten en wan de richtlin betreffende de kapitaaltoereikendheid van beleggingsondernemingen en kredietinstellingen, TK 1993-1994/1994-1995,23874, nrs. 1-6/7-9.

Servaes, B. \& Hellemans, F.

De hervorming van de financiële markten en financiële transacties in België, in: $\mathrm{SEW}, \mathrm{nr}{ } 1,1995$. pp.6-28.

Wessels, $P$.

- Curator Nusse: toezicht faalde; Nog vijf Nusse Brink-klanten verdacht wan 'witwassen', im:

NRC, 22 februari 1994, p. 17;

-Justitie geeft zedenschets beurs, in: NRC, 24 maart 1994, p.17;

- Twijfels in HCS-zaak ondermijnen strijd tegen beursfraude, in: NRC, 26 maart 1994, p.17.

Wielenga, $\mathrm{A}$.

Compliance als integriteitswapen, in: Bank-en effectenbedrijf, maart 1995, pp.21-25.

Wind, E. de

De Wet effectenhandel in de praktijk, in: NV, nr.4, april 1991, pp.91-98.

Winter, J.W.

Herziening van de Fusiecode naar Tilburgs model, in: TVVS, nr. 12, 1994 " pp.316-320. 
Hoofdstuk $20^{1}$

\section{Toezichthoudende zelfstandige bestuursorganen}

\section{$\$ 20.0$ Toenemend aantal toezichthoudende zelfstandige bestuursorganen}

In dit afsluitende hoofdstuk over rechtshandhaving door zelfstandige bestuursorganen hoort een herhaling. Graag wordt wederom gerefereerd aan de, zich uit de marge manoeuvrerende, mening die als volgt weer wordt gegeven. Gegeven de "duidelijke tendens tot verzelfstandiging van de toezichtstaak (los van de respectievelijke departementen) en tot rationalisatie", is het in de toekomst niet uitgesloten dat een toenemend aantal zelfstandige bestuursorganen "belangrijke onderzoekstaken zal uitoefenen in het kader van de bestuurlijke rechtshandhaving". ${ }^{2}$

Ook recente rapportages van externe onderzoekscommissies wijzen in die richting. Uit de onderzoeksvoorstellen blijkt dat de, met oog op de scheiding tussen beleidsbepaling en -uitvoering, vorming van strategisch beleidsbepalende kerndepartementen samen gaat met een toenemend aantal verzelfstandigde uitvoerende diensten. De aanbeveling luidt om in de toekomst nog te verzelfstandigen, of anders: reeds (veelal versnipperd) verzelfstandigde organen belast met gelijksoortige inspectie- of opsporingstaken te koppelen en samen te voegen. ${ }^{3}$ Kennelijk komen in het bijzonder inspectietaken voor externe verzelfstandiging naar zelfstandige bestuursorganen in aanmerking. ${ }^{4}$

Op zich past dit in het departementale denken over de toekomst van de bijzondere handhavingsdiensten. Daarin is weliswaar een verschuiving van strafrechtelijke naar bestuursrechtelijke handhaving waarneembaar. Maar voor de bestaande, op strafrecht georiënteer-

1. Dit hoofdstuk is inclusief deel III: bevindingen en conclusites rechtshandhaving door toezichthoudende zbo"s.

2. J.A.E. Vervaele, Handen en tanden van het (geneenschaps)recht, oratie RUU, 18 febr. 1994, Deventer, 1994 , pp.21-22; Bij herhaling benadrukt door J. Vervaele, Recensie dissertatie Y. Buruma, in: R\&K, nr.4. 1994, pp.392-397, i.th. b. p.397: "Zbo's krijgen steeds meer sanctioneringstaken en de belanghebbenden in thet weld krijgen ook meer handhawingsplichten."

3. Commissie-Wiegel, Naar kerndepartementen, TK 1992-1993, 21427, nr.52, pp.30/49. De commissieWiegel rekent bijzondere opsporingsdiensten en inspecties expliciet niet tot een kerndepartement (p.57).

4. Commissie-Scheltema, Steekhoudend ministerschap. TK 1992-1993, 21427, nrs.40-41, pp.49/52/56. 
de handhavende instanties, rijst dan de - van uit de vakministeries van verschillende antwoorden voorziene - volgende vralag. Wordt het ombouwen of ontstaan naast de bestaande strafrechtelijke handhavingsdiensten nieuwe, op bestuursrecht georiënteerde, diensten. Al met al is op voorhand niet zeker te zeggen of het voornemen om kerndepartementen in te stellen, met uitvoerende en toezichthoudende onderdelen op afstand de inzichtelijkheid en beheersbaarheid van bijzondere handhavingsdiensten er groter op maakt. ${ }^{5} \mathrm{Nu}$ al ontbreekt het de bestaande bijzondere handhavingspraktijk aan eenduidigheid. Soms verrichten verschillende toezichthouders of opsporingsambtenaren hun werk op één zelfde gebied. Met het door elkaar lopen van disciplines wordt de te controleren vis duur betaald. En dit geldt natuurlijk voor respectievelijk elk ander produkt en elke andere dienst onderworpen aan inspectie, keuring of enig ander toezicht. Bovendien is het feit dat, bij privatisering of verzelfstandiging van handhavingstaken, buitengewone opsporingsambtenaren (of andere toezichthouders) hun activiteiten kunnen verrichten voor, veelal commercieel aan de weg timmerende, vennootschappen niet te verwaarlozen.

Zijn zelfstandige bestuursorganen well bij uitstek geschikt om handhavingsbevoegdheden uit te oefenen? Verder gaand, geschiedt het op- of overdragen van toezichts- en opsporingstaken aan deze organen van functioneel bestuur wel voldoende voorzichtig? Kortom, het fenomeen 'toezichthoudend zelfstandig bestuursorgaan' in de vuurlinie.

\section{\$ 20.1 Op zoek naar de verantwoording voor de vermagering van de minister als modetrend}

Voor toezichthoudende zelfstandige bestuursorganen gelden, als voor alle andere willekeurige zelfstandige bestuursorganen, de algemene aspecten van verzelfstandiging van overheidstaken naar min of meer autonome, publiekrechtelijke of privaatrechtelijke, autoriteiten. Ook bij zelfstandige bestuursorganen als toezichthouders moet worden terug gevallen op het uitgangspunt van verzelfstandiging. Waarom is de verzelfstandigde, of: wordt de nog te verzelfstandigen, entiteit op afstand gezet? Wat beweegt bewindspersonen er toe, centimeter na centimeter, de riem strakker aan te trekken: vaniteit of flexibiliteit?

Samenvattend worden nog enige elementen van verzelfstandiging op een rijtje gezet.

Het functioneel decentraliseren van handhavingstaken en daarvoor benodigde publiekrechtelijke bevoegdheden vindt belangrijk basis in het in toenemende mate scheiden van beleidsbepaling en -uitvoering. Het scheiden daarvan, en in een reëlere optie: het onderscheiden daarvan, past in het zoeken naar een zo optimaal mogelijke machtsverdeling, dat is bevoegdheidsverdeling in verticale of horizontale zin. Dit rechtsstatelijk streven naar een evenwichtig stelsel van 'checks and balances" is de moderne, dualistische invulling van de gedateerde trias politica. 
Het verdelen van bevoegdheden impliceert het verdelen van verantwoordelijkheden. ${ }^{6}$ Draagt een minister een deel van zijn macht over aan verzelfstandigde entiteiten, dan werd wijnt een deel verantwoordelijkheid en resteert verantwoordelijkheid voor - duidelijk te maken - hoofdlijnen van beleid. Dit wegvloeien van politieke ministeriële verantwoordelijkheid biedt het voordeel dat de betrokken bewindspersoon wordt ontlast. Daardoor kan departementswerk inzichtelijker zijn. Met als prettige consequentie dat de bij de minister blijvende, persoonlijke en functionele, politieke verantwoordelijkheid voor dat werk mogelijk meer inhoud krijgt. Bestaat er bij het aldus adequater activeren van een meer afgebakende politieke ministeriële verantwoordelijkheid nog ruimte voor een eigen positie van, grof weg gezegd: buiten de onderschikking van de betrokken minister vallende, zelfstandige bestuursorganen, die ministeriële aansturing krijgen via controlevoorzieningen in de vorm van kwaliteitshandvesten? ${ }^{7}$ Tegenwoordig is hiërarchisch ondergeschikt ambtelijk personeel nog niet zelfstandig aanspreekbaar, laat staan verantwoordelijk ${ }^{8}$. Alle pleidooien daartoe ten spijt. Bij, op de beleidskaders na, niet hierrarchisch

6. Overigens waarschuwt J.P.H. Donner, Orde in de ordening van het bestuur, in: B\&M, nr.6. 1994, pp. 294-299, terecht tegen het ongebreideld verdelen wan taken, bevoegdheden en verantwoordelijkheden. Dergelijke veranderingen in het bestuur veroorzaken een "kernprobleem van coördinatie en integratie van het handelen wan uiteenlopende organen en instanties met verschillende taken en verantwoordelijkheden"'.

$\lambda_{n}$ In een kwaliteitshandvest kumnen regelingen worden getroffen inzake adequate informatievoorziening (de verzelfstandigde entiteit moet bij voorbeeld via uitwoeringstoetsen aan haar informatieplicht voldoen), uitwoeringscontracten, periodieke (financiële) verslaglegging, instelling vaneen raad van toezicht, bestuursbenoeming voor beperkte tijd en ministeriële interventiemechanismen (denk aan verwaarlozingsregeling). Helaats constateert de ${ }_{n}$ door schade en schande wijs geworden, stichting Verzekeringskamer, dat de -mooi ogende- ministeriele aansturing van verzelfstandigde entiteiten via dergelijke controlevoonzieningen niet altijo optimaal verloopt. Aan thet fiasco inzake Vie d. Or is onder meer debet de weinig kritische sturing

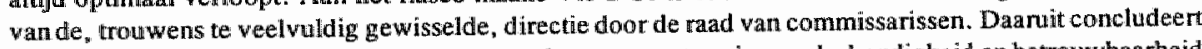
de stichting Verzekeringskamer dat de besta.ande worm van toetsing op deskundigheid en betrouwbarneid wan beleidsbepalers en commissarissen te licht is en moet worden verzwaard. Naast een strengere toetsing wilde stichting Verzekeringskamer een, zowel passieve als actieve, informatie- en melldingsplicht opleggen an miet alleen accountants, actuarissen en bestuurders, maar ook aan commissarissen. Juist de rwc moet ewin shirende rol gaan spelen in de informatievoorziening t.b.v. de toezichthouder.

8. Voor het aannemen van aansprakelijkheid is de ontwikkeling in het ciwell recht interessant. De strekking wan het KEP bv-arrest is wellicht ook van analoge toepassing op extern verzelfstandigde entiteiten met priwarrechtelijke rechtsworm. B. Wessels, Overheidsaansprakelijkheid bij begeleiding paspooriproject, in: juridisch \& fiscaal tijdschrift Priwatisering, nr.1, 25 jan. 1995, pD.4 4 , bespreekt als volgt de krachtige consequenties van dit arrest, 1.w. Staat der Nederlanden vs. Kurvers (inzake KEP bw), HR 14 okt. 1994, NI 1995, 172, ook in: RvdW 1994,204. T.b. . een paspoortproject is X, in de functie van ambtemaar wan buitenlandse zaken als leidinggevende vam het project teisdocumenter, belast met de bewaking van het paspoortproduktie- en verstrekkingensysteem van Nederlandse paspoorten naar Eu ropees model. Dit wordt bepaald in een daartoe geslloten samenwerkingscontract tussen de Staat en Kenmerk En Personificatie bv. Een werkgever van Kodak Nederland bv wordt toegewoegd aan de statutaire directie van KEP bv. Daardoor is hij contractueel werplicht an een drietal overheidsfunctionarissen (onder wie $X$ ) regelmatig de nodige informatie te werstrekken. X 'onklekt" dat de betrokken wenknemer daarmee in gebreke blijft en stelt hem op non-actief. Kodak bv ontslaat hem tot overmaat van ramp. De werknemer dagviardt onder meer de Stat met een wordering uit onrechtmatige daad. Het argument wan de Staat, dat $X$ handelt in naam van de statutaire directie van KEP bv waardoor de Staat geen zeggenschap ter zake heeft, treft geen doel. De Hoge Raad acht het feit dat $X$ namens de bv handel "geenszins onverenigbaar met het aannemen van zeggenschap wan de Stat $m . b . t$. het optreden van de ambtenaar bij de uitoefening van de hem als ambte- 
ondergeschikte ambtenaren van extern verzelfstandigde entiteiten geldt enige afwijking; De minister is verantwoordelijk voor het gebruik van de bevoegdheden die hij zich bij delegatie van bevoegdheden wettelijk voorbehoudt. En de verzelfstandigde entiteit moet eigen gedragingen voor eigen rekening nemen. De betrokken vakminister kan bij zelfstandige bestuursorganen in dienst zijnde ambtenaren niet doen oproepen of verschonen. Evenmin laat de autonome positie van dergelijke ambtenaren toe dat de minister concrete aanwijzingen geeft. Wel is het geoorloofd als de, de op hoofdlijnen verantwoordelijke, minister informatie aan hen vraagt. Maar soms krijgt het parlement, die een medewetgevende en controlerende tak heeft, na bedoelde gegevensverstrekking nog geen helder

8. $\rightarrow$

naar wan het ministerie opgedragen talak in het kader warvan hij de ontechtmatige daad pleegde", in casu dus het optreden vam de ambtenatar $X$ bij het op non-actief stellen van de gedupeende ex-Kodakwerknemer. Wessels vindt het "volkomen terecht' dat de HR de lijn door trekt naar kwalitatieve aansprakelijkstellingen ten laste wan de rijksoverheid.. De kwalitatieve alansprakelijkheid van werkgevers vloeit voort uit art. 6:170, eerste lid, BW. Omdat daarvoor de eis geldt dat de werknemer ondergeschikt is aan de werkgever, levert dit problemen op bij, niet aan politici hiërarchisch ondergeschikt, bestuur op afstand. Mogelijk wél oplossing biedt de risicoaansprakelijkheid ex ant. 6:171 BW. Hier geldt niet de conditie dat degene die voor iemand, al dan niet op unterimbasis, werkt ondergeschikt is alan zijn opdrachtgever. Wessels concludeert dat bij nitbesteding van activiteiten -hij noemt als voorbeeld stichtingen of verenigingen met bedrijfsmattige activiteiten- aansprakelijkheid rust op zowel de niet onderge schik te opdrachtnemer alls de opdrachtgever. Hoe zit het nu met de aansprakelijkheid, voor bij bedrijfsuitoefening gemakte fouten ten nadele van derden door niet-ondergeschikte opdrachtaamemers, als de rijksoverheid overheidstaken en daartoe benodigde bevoegdheden extern werzelfstandigd naar privaatrechtelijke rechtspersonen met, min of meer, bedrijfsmatige activiteiten (verondersteld dat een zeker winststreven wordt getolereerd binnen door de betrokken minister te stellen marges〉? Ook daar lijkt het aannemen van een risico-aansprakelijkheid redlelijk. Soms is het niet alleen sprake van een relatie tussen Staat en, niet-ondergeschikte, extern werzelfstandigde entiteit. In bepaalde gevallen geeft namelijk de verzelfstandigde entiteit op haar beurt weer ble Bedrifsoering uit handen aan een privathechtelijke rechtspersoon. Bij woorbeeld. in geval van thet zbo het toezicht op de naleving wan de fino 1987: stichting, ent sinds begin 1988: rechtspersoon bij wet) wordt aan de private Nationale Investeringsbank. Doorwaten bij door het fonds verstrekte gelden witbesteed verstrekt aan gezonde bedrijwen dingsank. De aandelen wan de NIB, die vooral achtergestelde leningen.

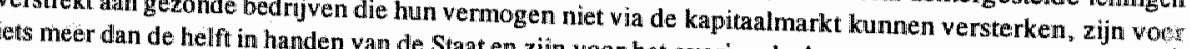
beurs. Maakt een werknemer van de bank als niet-onder het overige deel genoteerd aan de Amsterdamse derde schade lijjd, dan lijken conform ar als net-ondergeschikte van het BvdP een fout waardoor ean afgezien wan persoonlijke aanspralkelijkineid van Even zo lijkt het gerechrvaardigd aransprakelijk de betrokken werkuitvoerder bij verwijitbaar handelen. van de betrokken minister als het Budp maar op afstand staat, eigenhandig de -derden treffende foul al tot de rijksowertheid gerekend mag worden zakkt. Als niet zijnde ondergeschikt voent het zbo de fout tijdens bedrijfsuitoefening makt of veroorbewindspersoon. In de tijd dat het BvdP nog stichtingsvorm bezat uit, als toebedeeld door de betrokken zou een daardoor benadeelde derde logischerwijs zowel het bezal en tijdens bedrijfswoering fouten maalk te, ding kunnen roepen. Dit is dan wel afhankelijk wan de het $B$ dP als de minister daarvoor ter verantwoorgingen van het BwdP-personeel. Hoewel die zeg we de van zeggenschap van de minister over ged ratzeggenschap wel aanwezig kan zijn. Overigenschap bij zbo's mimder is, is het niet uirgesloten dat die dubbele kant heeft. Aantekening werdient wel dat zij niet compleld aardig om te noemen omdat het een werkt namelijk niet bedrijfsmatig. Maar dat neemt niet wegleet overeenstemt met de nealiteit. Het BvdP voor elk ander woorbeeld, waarin sprake is wan een verzelf dat de essentie van bovenstaande wel geld vorm met een zeker winststreven. 
zicht in het door het zelfstandig bestuursorgaan uitgevoerde werk. Zelfstandige ambtenaarlijke aanspreekbaarheid biedt dan mogelijk gunstig perspectief.

Of een zelfstandige ambtenaarlijke verantwoordingsplicht nu groen of rood licht krijgt, de praktijk lijkt aan de theorie een mouw te passen. Immers, een negatief antwoord op zelfstandige ambtenaarlijke aanspreekbaarheid deert niet altijd. Aanvaardbaar alternatief wordt kennelijk gevonden in parlementaire enquêtes, die elkaar de laatste jaren in hoog tempo opvolgen. De parlementaire enquêtes, inzake respectievelijk het toezicht op de uitwoering van de sociale zekerheidswetgeving door bedrijfswerenigingen onder 'wakend' aog van de voormalige Sociale Verzekeringsraad en de politieke ministeriële verantwoordelijkheid woor het optredlen van het IRT liggen nog vers in het geheugen. En een parlementair enquêteonderzoek naar het toezicht op schade- en levensverzekeringsbedrijven (in het bijzonder op Vie d'Or) door de stichting Verzekeringskamer is voorlopig niet uitgesloten en behoort daarom nog altijd tot de mogelijkheden voor de nabije toekomst. In een parlementaire enquête mogen hiërarchisch ondergeschikte ambtenaren buitten insitemming van de betrokken minister worden gehoord. En ook de bij verzelfstandigde entiteiten werkende, in aanzienlijk mindere mate aan een bepaalde minister ondergeschikte, ambtemaren kumen zo publiekelijk worden gehoord.

\subsubsection{NA DE, VOOR VERZELFSTANDIGING VEREISTE, VERKLEEDPARTU NIET TOTAAL ONTBLOOT}

De, uiteindelijk te overwinnen maar aanvankelijk aanvaardbare, angst van moeders met 'kroost op kamers' is dat zij, hoewel matriarchale macht zich mogelijk formeel manifesteert, feitelijk gezien geen greep op hun kinderen meer hebben. Zo ook de frustatie van ministers die op de lange duur weinig tot niets meer te zeggen hebben over diensten die, als verzelfstandigde entiteiten volwaardig volwassen, ver onder de departementale daken weg zijn geschoven. Op zich is deze vrees voor 'het handen af' normaal. Het is, wat heet, een gezonde angst. Er gaat pas iets mis als, daar waar bewindspersonen bij instellingswet van zelfstandige bestuursorganen verantwoordelijkheid op eisen woor gedragingen van die zelfstandige bestuursorganen, ministers zetelen zonder zicht op zelfstandige (uitwoerings)organen. Als verzelfstandigde entiteiten - een maal balorig de ban van bewindspersonen ontvlucht - op drift raken, moet het proces om beleidsuitvoerders op afstand te zetten van beleidsbepalers als mislukt worden beschouwd. Want: "macht is niet erg, maar ongecontroleerde macht wel" ${ }^{*}{ }^{9}$ Als noodzakelijke sturingsinstrumenten en verantwoordelijkheidsmechanismen ontbreken, mag de weg niet vrij zijn voor verzelfstandiging.

Dit neemt niet weg, dat zelfstandige bestuursorganen met, waar nodig, gepaste beleidsruimte binnen een goed uitgevoerd verstandig verzelfstandigingsbeleid bezielend kunnen werken.

9. VWD'er Dijkstal, alls vice-premier van het kabinet-Kok, geciteerd in: Dijkstal vindt privorisering doorgeschoren; "Rol ambrenaren beperken". in: NRC, 11 okt. 1994, p.I. 


\subsubsection{DRANG TOT DEFINIËREN KERNTAKEN OVERHEID ALS VOORDEEL VAN VERZELFSTANDIGING}

Een beleid, waarin verzelfstandiging van overheidsactiviteiten voorrang krijgt, is te waarderen. Zij verdient zelfs stimulans. Bij elke verzelfstandiging stelt de Nederllandse overheid zich namelijk nood gedwongen de vraag of het verrichten van betrokken overheidsdienst nog wel overheidstaak is. Alleen al van wege dit afbakenen van het terrein, waarop de overheid gegeven het algemeen belang en het collectief welzijn actief hoort te zijn, is verzelfstandiging wenselijk. Het volume van verzelfstandiging ligt zo, in eerste instantie, in haar bijdrage aan het debat over doelmatig en markt gericht werken van de overheid.

Bovenstaande betekent dat de overheid niet overijverig moet zijn met het overlaten van activiteiten aan verzelfstandige entiteiten. Niet al te gemakzuchtig mag zij besluiten, dat een overheidstaak voortaan geen overheidstaak meer is. Daar waar nodig moet de overheid de trend achter zich laten en haar oren sluiten voor de aanhoudende lofzang van duur betaalde organisatieadviseurs als mede de ballade van bestuurs- en beleidsmanagers voor het verzelfstandigen of privatiseren van overheidstaken. Simpel weg omdat sommige overheidstaken van oudsher publiek(rechtelijk)e taken zijn, die eigenlijk altijd tot de opdracht van dle overheid moeten blijven horen. Met andere woorden, "er zijn en blijven taken die een overheid legitimeren, omdat er anders geen overheid meer is". " lijk is dat de overheid haar verantwoordelijkheid, die voort vloeit uit haar taakstelling in het licht van op in de Grondwet en verdragsrecht neergelegde grondrechten, in elk geval niet mag ontlopen. Hier heeft de overheid zekere zorgplichten en bepaalde opdrachten om fundamentele rechten en vrijheden te garanderen. Ter bewaking van de Nederlandse rechtsstaat ligt het op haar weg noodzakelijke randvoorwaarden te stellen, zekerheden te scheppen en maatregelen te treffen. De conditionering van een rechtvaardige, gezonde en actieve samenleving en de creatie van een woonrijk en leefbaar milieu behoren bij uitstek tot het gelegitimeerde monopolie van de overheid.

Ontbreekt een publiekrechtelijke positie en is het op afstand van de overheid werken wenselijk, dan is eerder, verder gaand dan en mogelijk in het verlengde van verzelfstandiging, privatisering een prima perspectief. Pure privatisering biedt in elk geval het voordeel van heldere taakafbakening en bevoegdheidsverdeling. Daarnaast geeft zij meer magische momenten van marktwerking krachtige kansen. "

10. 'Op afitiond plaatsen', in: NRC, 19 okt. 1994, p.11.

11. J. van der Bij en J.P. van der Meij, Verzelfstandigen of privatiseren; Concurrentie, produkt of beleidswrijheid zijn bepalend (I), in: OMn, nr. 3, 1995, pp, 74-75 en Verzelfstandigen of priwatiseren, Concurrewtie. produkt of beleidsvrijheid zin bepalend $(I T)$, in: OMn. nr.4, 1995, pp.106-110, verduidelijken onder welke omstandigheden verzelfstandiging of privatisering verannwoord is. 


\subsubsection{VÓÓR VERZELFSTANDIGING KLINKT HET "KRUIS OF MUNT": KOSTILOOS OF NIET}

Eind 1994 weerklinkt dan ook onomwonden een waarschuwing tegen het - sinds zeg maar 1982 - voortvarende verzelfstandigings-en privatiseringsbeleid. Het, meegaand met de 'modetrend", in flinke vaart verzelfstandigen, waarbij uitvoerende diensten onder de ministeriële mantel worden weg geschoven, is in feite vaak een 'vluchtweg voor bezuinigingen" 12

De verzelfstandigingspraktijk is nog in ander opzicht potentieel problematisch. Namelijk, een op afstand gezette beleidsuitvoerder ligt weliswaar niet langer in politieke omarming. Vervelend genoeg vraagt een verzelfstandigde entiteit vaak nog wel om financiële vrijage. Staat de uitvoerder, formeel gesproken, een maal op eigen benen, dan blijkt verzelfstandiging zo, anders dan de bedoeling, zeker niet in alle gevallen tot een kleinere rijksoverheid en ook niet per se tot een goedkoper kostenplaatje bij de uitvoerder te hebben geleid ${ }^{13}$. Met oog op dat laatste, en vooral omdat in het bijzonder zelfstandige bestuursorganen de tucht van de markt missen ${ }^{14}$, hebben verzelfstandigde entiteiten nog vaak te langdurige en daardoor oneigenlijke financiële protectie van de rijksoverheid nodig.

12. Aldus, in navolging vam het rapport van de commissie-Sint, vertrouwelijk advies van de werzamefde secretarissen-general aan het kabinet, weer gegeven door T.J. Meeus, Ambtenaren willen rem op privat;sering: "Afstoten overheidstaken is wak wluchnweg", in: NRC, 19 nov. 1994, p.1.

13. Hierbij moet wel worden gerealiseerd dat 'vers' verzelfstandligde entiteiten met (aanzienlijke) atunloopkosten te maken krijgen. Derk aan uitgaven ter bestrijding van de (aanloop)kosten voor het verwezenlijken van een kwaliteits- en certificatiesysteem of voor het uitdragen van een nieuwe huisstijl. "Voorlichtend" woorbeeld hier is natuurlijk de Informatie Beheer Groep. Daarnaast speelt mee dat een voormalige rijksdienst plotseling "commercieel" moet werken. De Dienst voor het Kadaster en Openbare Registers, die sinds hat omzetting van rijksdienst in zelfstandige dienst (hier valt het versluie rende taalgebruik op van dienst: ten eerste, de verzelfstandigue dienst is nog steeds, een rijksdienst, zij het op afstand; ten tweede, de term dienst suggereert nog een grote afhankelijkheid wan het betrokken departement, terwijh juist de mate wan hierarchie is afgenomen) ook opvallend veel met nieuw logo en veranderde werkwijze in advertenties te koop loopt, is daarvan een fraai voorbeeld. Bij haar start als zbo hanteert de dienst hoge tariewen, die zij als monopolist zelf kan stellen. Immers, woordat bedrijfsmatig werken aan de orde is, moeten oude tekorten wit de vorige situatie worden afgedaan en moet een weerstandsvernogen worden opgebouwd. Dankzij de nodige factoren (kapitaalmarkthausse, afbetaling van "oude koeien" en een op peil gebracht vermogen) kan het kadaster in het najaar wan 1994 de tarieven eindelijk verlagen. Vanaf dat moment zijn die tarieven pas in overeenstemming met het met verzelfstandiging beoogde uitgangspunt van kostendekkendheid. Zie o. a. Stcrt. 13 sept. 1994 en het Besluit kadastrale tarieven, d.d. 12 dec. 1994, Stbl. 1994, 864. De berichtgeving wan uit het ministerie van volkshuiswesting dat de tarieven van het kadaster in januari 1995 gemiddeld 15 procent kelderen (zie Kadaster verlaagt zijn tarieven met 15 procent, in: NRC, 23 dec. 1994 , p.9) en in mei 1995 circa 30 procent zakken (zie Kadaster verlaagt mog eens drastisch farieven, in: NRC, 3 mei 1995, p. 18) volgt kort na het, eind 1994 gepubliceerde en met vernietigend venijn over het Nederlandse verzelfstandigingsbeleid oordelende, Decemberversilag van de Algemene Rekenkamer over 1994, TK 1994-1995, 24045, nrs. 1-2, pp.5-6/62-69. Daarin wordt wermeld dat het kadaster in de periode 1988-1994 ten minste 21 miljoen te veel in rekening brengt aan kopers wan. onroemend goed. Hierover Scherpe kritiek Rekenkamer op privatisering rijksdiensten, in: NRC, 22 dec. 1994, p.17.

14. O.a. T.J. Meeus, Bij privatisering wordt de tucht van de marks te vaak antlopen, in: NRC, 22 dec. 1994 , p.19. 


\subsubsection{DE DRAATTOL VAN HET, MOGELUK DOOR VERZELFSTANDIGING ONTSTANE, "DOLLAR'-DENKEN}

Overigens zorgt de introductie van enige marktwerking bij het zelfstandig functioneren van een voormalige rijksdienst voor het volgende precaire probleem. Het contact tussen bureaucratie en bedrijfsleven veroorzaakt snel dubieuze dubbelrollen. De directie van een zel fstandig bestuursorgaan, die door een beperkte ministeriële politieke verantwoordelijkheid minder boodschap aan de politiek heeft dan vroeger, wil waarschijnlijk de ambtelijke molen sneller doen draaien door de wieken er van zo veel mogelijk te laten beroeren door een van winstvlagen bevangen wind. Het gevaar is duidelijk: "Traditionele vaardigheden - nauwgezet, dienstbaar, onpartijdig, onkreukbaar, betrouwbaar - verliezen aan belang ten opzichte van moderne marktwaarden als snelheid, flexibiliteit en rentabiliteit." is Oneigenlijke concurrentie doet dan snel opgeld. Een zelfstandig bestuursorgaan dient namelijk twee heren: de rijksoverheid en het bedrijfsleven. Het geld dat zo'n bestuursorgaan van overheidswege krijgt toebedeeld voor publiekrechtelijke taakvervulling vraagt er eigenlijk om - onheus genoeg - bedrijfsmatig te worden aangewend op de markt. ${ }^{16}$

Natuurlijk is de overheid geen gewoon bedrijf, en dat mag echt wel extra geld kosten. Maar het blijft vreemd om een verzelfstandigde entiteit, die de markt op moet, te voorzien van financiële steun. Rekening houdend met de bijzondere aard van de overheid is het daarom op passen met "lege noties als flexibiliteit, slagvaardigheid of scheiding van beleid en uitvoering." ${ }^{77}$ In niet alle gevallen reikt die financiële slagvaardigheid van een zelfstandig bestuursorgaan wel zo ver als doet vermoeden. Telkens luidt de vraag hoe ver een verzelfstandigde entiteit werkelijk wordt gedragen door eigen benen.

\subsubsection{Concurrentievervalsing door overheidssteun aan verzelfstandigde entiteiten}

Zelfstandige bestuursorganen dragen mogelijk bij aan concurrentievervalsing. ${ }^{18}$ Het is niet onwaarschijnlijk dat het functioneren van zelfstandige bestuursorganen, die veelal uit publieke middelen worden gefinancierd, private partners die zich op de zelfde markt bewegen en die soms hard moeten knokken om hun zaak te bekostigen, op oneigenlijke wijze dwars zitten. In de ergste gevallen is, naast het werk van zelfstandige bestuursorganen, zelfs geheel geen plaats voor particuliere bedrijfsmatigheid. Zo heeft de Dienst 15. T.J. Meeus, Priwarisering leidde tot bureaucratie der dubbele lowaliteiten, Grafrede over twaalf jaar
ambitieus beleid, in: NRC, 19 nov. $1994_{\text {, p. } 15 \text {. }}$

16. T.J. Meeus, IB Groep of priwatisering als remedie tegen de 'stopwerfstaat", in: NRC, 22 nov. 1994, p. 19. 1994, pp. $20-21$.

18. Het ondermijnen wan concurrentie kan op twee manieren plaats vinden. Ten eerste, juist zbo's kunnen door hun bijzondere positie monopoloijde treks vinden. Ten eerste, juist toezichthoudiende treedt dan mogelijk op als zbo's misbruik van die mache trekken vertonen. Verstoring van de vrije markt. 85-86/90-92 EG-verdrag in het vizier. Ten tweede in het gevagr dat in de ene lidstat cen milder sanctieklimat in het bonder voor toezich thoudende zbo's geldit met tolerant toezicht ebc zo de kracht van concurrentie met zware hand avings lidstaat. Door territoria de toepassing van de art. 101/102 EG-verdrag in beeld. 
wegverkeer niets te vrezen van eventuele concurrentie. Ook de Dienst voor het Kadaster en de Openbare Registers kent nauwelijks, zo niet geen, kapers op de kust. Qua mededingingsrecht is het met veel verzelfstandigingen verdrietig gesteld. Op terreinen, die te bielangrijk zijn om links te laten liggen, is sprake van een afgeschermde markt, waar concurrentie weinig of geen kans heeft. ${ }^{19}$ Daaraan debet is dat de politiek niet principieel stelling durft te nemen tussen verzelfstandiging of privatisering. Uit onwillendheid, onwetendheid of onervarenheid.

Inmiddels wordt het, in elk geval op het ministerie van financiën, toegegeven: geprivatiseerde, maar ook verzelfstandigde entiteiten vallen onder de werking van het EG-verdrag. ${ }^{20}$ Consequentie daarvan is dat zgn. 'exclusief economisch verkeer' niet meer kan. Logischerwijze bij privatisering, maar ook bij verzelfstandiging moet voortaan krachtiger de keus worden gemaakt tussen de vrijheid van de markt of de bescherming door de overheid. Verzelfstandigde entiteiten moeten zich in financieel opzicht los weken van degene die hen heeft leren lopen.

Wellicht oplossing biedt het invoeren van het, reeds in het Verenigd Koninkrijk toegepaste, systeem van 'competetive tendering' voor beleidsuitvoerende eenheden ${ }^{21}$. D.W.Z. "om de zo veel jaren moeten deze diensten zich bloot stellen aan een openbare aanbesteding die private partijen de kans biedt de verzorging van een overheidsdienst over te nemen mits ze de zelfde kwaliteit tegen een lagere prijs kunnen leveren". ${ }^{22}$ Aan het

19. R.J.M. van Wuijtswinkel, Hervorningen in de publieke sector van Nieww-Zeeland, in: OB, nr. 3, 1995, pp. 2-6, i.h.b. p.5, wijt het moeizame verloop wan het verzelfstandigingsproces in Nederland aan: a. het in bepaalde gevallen uitbannen van elke worm wam concurrentie en marktregulering, zo dat verzellistandigde entiteiten monopolistisch blijven; en b. hei onvoldoende rekening houden met het interdependente Karakter van belleidsbepaling en beleidsuitwoering. Volgens auteur moet de verzelfstandigingsdiscussie minder van uit het politiek primaat, en meer wan uit de werkwloer, worden gevoerd. Auteur acht een mic ro-economische benadering van werzelfstandiging " met aandacht voor zowel de bed rijfseconomische performance van verzelfstandigde eenheden als de effectiviteit wan de dienstverlening, dan ook wenselik. Zijn terechte pleidooi voor accountability baseert auteur op de sinatie in Nieuw-Zeelland, waar 'crown entities" succes oogsten.

20. T. I. Meeus, Gedwongen winkelnering diente werdwijnen, in: NRC, 26 nov. 1994, p. 17. Auteur refereert aan een rapport over een 'intern beleidsonderzoek" dat door het departement van financiën eind 1994 wordt uitgebracht onder de nam Concurrentiestelling in de publieke sector.

21. Vooral eenheden op decentrala functioneel/territoriaal niveau. Denk aan werzelfstandigingen bijgemeenten en provincies. Bekend zijn natuurlijk de verzelfstandigingen wan openbare nutsbedrijwen. Illustratief is hier ook het eindadwies 'Markmerking in het openbaar vervoer' van de commissie-Brokx (Utrecht, 1995) om het openbaar wervoer (i.h.b. stads- en streekbuswervoer) meer op de markt te gooien. Hierover Srrippenkaart weg. en meer concurrentie, in: NRC, 8 febr. 1995, pp. 1-3; Onwikkeling én witwoering openbaar vervoer priwatiseren, in: BB, nr, 6, 10 febr. 1995, p. 7 . Gewaar in het plan-Brokx is well dat geen harde output word gevraagd. Dit gebrek aan duidelijke prestatie eisen kan mog wel eens met in het eten gooien," Overigens bestaan, voonit lopend op de plannen van de rijksoverheid on het openbaar vervoer conform de adviezen van de commissie-Brokx gestalte te geven, al pilotprojecten. Een dergelijk project van openbare aanbesteding wordt onder meer uitgevoerd in Zuid-Limburg. Daar rijden vanaf juni 1995 awtobussen van Vancom, dat is na Greyhound de grootste busonderneming in de Verenigde Staten. M.

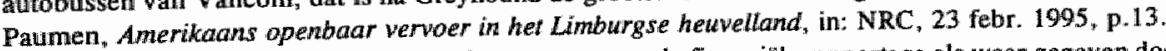

22. Dat is de hopelijk heil brengende essentie van voornoende financiële rapportage als weer gegewen door T.J. Meeus, Gedwongen winkeinering dient te verdwijhen, in: NRC, 26 nov. 1994, P.17. 
transporteren van een dergelijk Brits model naar Nederland kleven bezwaren. Voorzichtigheid spreekt uit de volgende bewoordingen: "Er heerst daar (Verenigd KoninkrijkJGLvN) een extreme anti-overheidsideologie. Het is een misverstand te denken dat een democratie kan functioneren als een bv. Efficiency is niet het enige dat tell. De overheid moet ook rechtszekerheid en gelijke toegang tot publieke diensten bieden." ${ }^{23}$ Bovendien is het bij "tenderen' de vraag "hoe de minister zijn politieke verantwoordelijkheid aanwendt als een verzelfstandigde dienst failliet gaat". ${ }^{24}$

Omdat verzelfstandigde entiteiten slechts een 'kleine kans' hebben om, bloot staande aan open concurrentie, de 'oorlog' met het bedrijfsleven te winnen, bestaat de mogellikheid van een 'nieuwe privatiseringsgolf'. ${ }^{25}$

Toch is het niet verstandig het kind met het badwater weg te gooien. De route van werzelfstandiging via openbare aanbesteding moet zeker niet bij voorbaat worden gebarricadeerd. Daar waar (overheids)diensten worden uitgevoerd in een gesloten klimaat met starre tariefstructuur, is het verstandig zekere flexibilisering, continuilteit, dynamiek, mobiliteit, klantvriendelijkheid en kostenverlaging aan te brengen via introductie van een bepaalde mate van gezonde concurrentie. Daartoe kan een systeem van openbare aanbestedingen de nodige daadkracht geven. ${ }^{26} 27$ Aanbesteding vindt dan plaats in een aantal

23. W.J.M. Kickert, geciteerd door T.J. Meeus, Gedwongen winkelnering dient te verdwijnen, in: NRC, 26 now. 1994, p. 17

24. H. Strietman (directeur onderwijisagentschap, tevens initiator van het, volgens sommigen pretentieuze, platform van managers van ütwoeringsorganisaties), als weer gegeven door T.J. Meeus, Gedwongen winkelnering dient re verdwignen, in: NRC, 26 nov. 1994, p.17.

25. T. I. Meens, Plicn woor priwatisering gevangenissen, in: NRC, 26 nov. 1994, p.17.

26. Over het open stellen van de markt, in het bijzonder de informatie- en telecommunicatiernarkt, door openbare aanbesteding interessant S. Corvers, F. van der Klaauw en W. Wedekind, IT en de Europesie acnbestedingsrichtilinen, in: CR, nr. 1,1995 , pp.16-22. Auteurs, die terecht oproepen tot een actievere opstelling wam de overheid ter zake, wijzen -van wit de beginselen van non discriminatie en objectiviteitop lacunes ter zake. Denk aan: a. aanbestedingsprocedures zijn niet of te summier uitgewerkt; b. de behandelingsduur van offertes is niet geregeld; $c$. de vraag, wie wordt uitgenodigd om zich in te schrijyen bij niet-openbare anabestedingsprocedures, blijf onbeantwoord; en d. de reikwijdte wan de motiveringsplicht, om de ene gegadigde af te wijzen en met de andere gegadligde in zee te gaan, is onduidelijk. Auteurs menen dat de naleving van aanbestedingsregels meer aandacht verdient (de Nederlandse raanwet, Stbl. 1993, 212/213, voorheen woorstel TK 1991-1992,22669, nrs.1 -3, waarinde verschillende anbestedingsrichtlijnen zijn werwerkt, getwigt niet van begrijpelijke en handhaafbare wetgeving ; Zie ook uitwoerig J.P.L. van Marissing. De regelgewing voor overheidsopdrachten, Europese monografieẻn deel 43 , Deventer, 1995; Op grond wan bij 211 wan de 636 Nederlandse gemeenten uitgevoerd onderzoek constateren $\mathbb{L}$. de Boer en J. Telgen, Gemeenten onduiken massaal Europese acanbestedingsregels, in: BBM, 19 mei 1995, pp. 2-5, overigens spijtig dat 70 à 80 procent van die gemeenten de Europese richtijmezi ter
zake aan huin laars lappen.

27. Specifiek de problematiek rondom uitnodiging om zich in te schrijven voor overheidsaanbesteding speelt in de zaak Commissie vs. Itatiaanse republiek, HwJ EG (C-272/91) 26 april 1994, NJ 1995, 167. Het hof neemt het de Italiaanse regering kwalijk dat zij in een overheidsaanbestedingsprocedure, m. $b_{*} t_{\text {. concessie- }}$ verlening voor een systeem ter automatisering van de lotto, vennootschappen uit andere lidstaten de mogelijkheid ontneemt ${ }_{\mathrm{B}}$ om automatiseringssystemen en software te leveren voor het beheer van de dienst waarop de opdracht betrekking heeft, nu de overheid in gebreke blijft met het adequaat aankondigen van en witwoerig uitnodigen van (concessie)gegadigden: "Door eerst [... .] geen mededeling te doen, met oog 
gebieden die een concessie kunnen krijgen voor een van te voren vastgestelde termijn. $\mathrm{Na}$ afloop van die periode, waarvoor de tijdelijke concessie wordt verleend, krijgen (andere) aanbieders dan een kans om een concessie binnen te halen. In dit systeem blijft de overheid verantwoordelijk voor het voortbestaan van de betreffende voorziening. $\mathrm{Zij}$ garandeert een minimumvoorzieningsniveau. Omdat het uitvoering van een overheidstaak betreft, stelt de overheid (kwaliteits)criteria waaraan aanbesteders moeten voldoen willen zij in aanmerking komen voor verlening van concessies. Ook stelt de overheid, in haar voorwaardenschappende rol, in elk geval toelatingsvoorwaarden, contractvormen, procedures, beroepsmogelijkheden vast. Is sprake van tarifering, dan bepaalt de overheid. minimum-en maximumprijzen voor dienstwerlening. Of de hand wordtgehouden aan criteria, tarieven en met name mededingingsrecht (kartelvorming en misbruik van machtsposities) moet een daartoe apart ingesteld onafhankelijke, toezichthoudende instantie controleren ${ }^{28}$. ${ }^{29}$

Het toezicht op het mogelijk ontduiken van mededingingsregels krijgt tegenwoordig terecht meer aandacht. Ten eerste, verzelfstandigde toezichthoudende entiteiten, als in deze studie bedoeld, krijgen in de onomkeerbare Europese beweging te maken met

27. $\rightarrow$

op bekendmaking in het Publ. EG, van de enuntiatieve aankondiging per produktensector wan alle opdrachten waarvan het geraande bedrag ten minste $750.000 \mathrm{ECU}$ bedroeg en die het Italiaanse ministerie van financiēn voornemens was te plaatsen, en door vervolgens [...] geen mededeling te doen van de oproep tot inschrijying voor de concessie voor het systeem ter automatisering van de lotto, en door het meedingen naar die opdracht voor te behouden aan lichamen, vennootschappen, consortiurns of groepen waarin de overheid een meerderheidsbelang heeft, is de Italiaanse regering de werplichtingen niet nagekomen die op haar rusten krachtens art. 52 en art. 59 EG-verdrag en de artt. 9/7-25 van de Richdijin 77/62/EEG (gewijzigd: 88/295/EEG) inzake coördinatie van de procedures voor het plaatsen van overheidsopdrachten voor leweringen." Het hiertegen door de Italiaanse regering aangevoerde argument dat -nu het om een concessie gaat waarbij aan een derde de uitoefening wordt overgedragen van onder het openbaar gezag vallende werkzaamheden, $t$.w. een deel van de organisatorische, toezichthoudiende en attesterende bevoegdheden op het gebied van het lottospel, welke concessie volgens de Italiaanse regering een statsmonopolie is- art. 55 EG-verdrag van toepassing is, doet de commissie af met de opmerking dat invoering van het automatiseringssysteem (waarop de in geding zijnde aanbesteding betrekking heeft) níet inloudt dat de werantwoordelijkheid voor een of meer diverse bij het lottospel noodzakelijke verrichtingen wordt overgedragen aan de concessiehouder. Kartom, het openbaar gezag blifft bij de overheid, die o, a. de prijzen goedkeurt en uitbetaalt en tevens toezicht houdt via trekkings- en zonecommissies zijnde overheidsorganen.

28. De eender vermelle commissie-Brokx stelt een dergelijke landelijke toezichthouder vour het openbaar verwoer. Commissielid $\mathbf{R}$. Pans vindt dat geen politici en ook geen mensen uilt de bedrijfstak zituing mogen nemen in zo'n toezichthoudende instantie. Reizigers zullen niet snel bereid zijn wel zitting daarin te nemen, maar de commissie-Brokx voorziet in een zgn. reizigerspanel waardloor toch enige democratische inbreng aanwezig kan zijin. J. Cüsters, 'Openbaar vervoer laatste jaren te veel gericht op mensen zonder awto', in: BB, nr.6, 10 febr. 1995, p.9.

29. Frappant is ook het -overigens buiten openbare aanbesteding vallende-voorbeeld van het onafhankelijk instinut dat, in plaats van de voorheen met financiële controle belaste gemeenten, toezicht moet houden op de, conform de Wet Balansverkorting Volkshuisvesting of Bruteringswet in geldelijk opzicht van de lokale overheden afgesneden, verzelfstandigde woningcorporaties. Een dergelijke toezichthouder is bevoegd zelfstandig onderzoek te doen naar de solvabiliteit van de corporaties en brengt van zijn bevindingen, al dan niet raadgevend, verslag uit aan de Tweede Kamer. Onafhankelijk instituut moet toezicht houden, in: NRC, 15 maart 1995, p.3. 
mededingingszaken. Neem nu het Commissariaat voor de Media. Het commissariaat komt bij woorbeeld met het volgende aspect van mededingingsrecht in aanraking. Denk aan de, aanvankelijk voorgenomen, afnamegarantie van - uit de de opbrengst van de omroepbijdrage, dus met overheidsgelden, gefinancierde - publieke omroepen met de commerciele omroep Veronica/Endemol. Naar EG-recht is een dergelijke overheidsgarantie in feite een ongeoorloofde steunmaatregel ex art. 92 EG-verdrag. Het commissariaat verklaart zich niet bevoegd daarover een oordeel te geven. Het lijkt wel taak voor het Commissariaat voor de Media zich ter zake een duidelijk beeld te vormen en in dit geval de minister van economische zaken die het oordeel moet geven o.g.v. de Wem (niettegenstaande beroep bij het $C B B$ ) van advies te dienen. Overigens is het de vraag of het commissariaat daartoe wel in staat is. Het commissariaat wordt hierbij hevig belemmerd door de eenzijdig op televisie en radio gerichte Mediawet- en regelgeving. In dit verband is te overwegen een sectoroverkoepelende toezichthouder aan te wijzen die zich in sectieverband ${ }^{30}$ specifiek richt op kartel-en mededingingsrechtelijke aspecten in de totale telecommunicatie-, omroep-en informatiesector. Een dergelijke verzelfstandigde toezichthoudende entiteit ontheft dan niet alleen het Commissarial voor de Media (conform interessant voorstel eventueel, samen met de toezichthoudende en regelgevende Hoofd Directie Telecommunicatie en Post, op te gaan in een Cornmissariaat voor de Elektronische Informatievoorziening met een diensten- en infrastructuurafdeling), maar in elk. geval ook het nog toekomstige Commissariaat woor de Etherfrequenties, de Nederlandse Filmkeuring en de Registratiekamer.

Ten tweede, de machtsmisbruik- en mededingingstoetsing aan artt. 85/86 en art. 90 $\mathbb{E}(\mathbb{E}) \mathrm{Gr}$-verdrag ${ }^{31}$ wordt in toenemende mate niet alleen meer op pure ondernemingen, maar tevens op bedrijfsmatige verzelfstandigde entiteiten, belast met overheidstaken, toegepast.. Hoewel het verschil tussen beide niet naadloos is, is het voor de (nationale) rechter in het concrete geval telkens weer een opgave wat onder een overheidsaanbesteder of andersoortige verzelfstandigde entiteit mei overheidskarakter, moet worden verstaan. ${ }^{32}$

30. Een andere sectie van een dergelijke toezichthouder met integrale inslag kan zich bij voorbeeld, zinvol bezig houden met verboden kartelvorming en mededinging sbeperking in de financiêle wereld waar DNB nv, STE en de stiching Verzekering;kamer werkzan zijn. Overigens betrekt de STE, bellast met het toezicht op de zelfregulering in de effectensector, in haar toetsing van beursregels (met oog op adequate. tunctionering van effectenmarkten en de positie van de beleggers op die markten) wél zelf de aan de beursregels verbonden mededingingsaspecten. Deze toets heeft tot gevolg dat beursregels zijn vrijgesteld van een beoordeling in het kader yan het, op de Wem gebaseerde, Besluit horizontale prijsbinding en het Beshit marktverdelingsregelingen. Nota n.a. v. het werslag inzake het voorstel Wie 1995, TK 1994-1995,
23874 , nt.7, p.6.

31. Exclusiewe rechten kunnen worden aangevochten middels een beroep op: art. 90, eerste lid, E(E)Gverdrag jo, art, $85 \mathrm{E}(\mathrm{E}) \mathrm{G}$-verdrag; art. 90 , tweede lid, $\mathrm{E}(\mathrm{E}) \mathrm{G}$-verdrag; of een Cassis de Dijon-exceptie op de vrijheden ex artt $30,48,59,86 \mathrm{E}(\mathbb{E}) \mathrm{G}$-verdrag (welke beperking niet discriminatoir is, geen doublure met het buitenland - waar het betrokken belang, war de beperking op doelt, al wordt beschermdoplevert, noodzakelijk is en proportioneel is aan het te beschermen belang).

32. Het arrest Gestión Hotelera internacional SA ws. Comunidad Autónomo de Canarias, Aywntamiento de Las Palmas de Grat Canaria Gran Casino de Las Palmas SA, HvJ (C-331/92) 19 april 1994, Jur. 1994, 
Bedoelde toetsing wordt overigens soepel toegepast op verzel fstandigde entiteiten die, als publiekrechtelijke concessiehouders, in het algemeen belang overheidstaken behartigen. ${ }^{33}$ In zijn toetsing neemt de rechter bijzondere omstandigheden en economische condities (bij voorbeeld, moet de concessiehouder bijzondere kosten maken i.v.m. het voldoen aan milieuregelingen e.d.) acht.

\section{$\S 20.2$ Mededingingsrecht}

Van oudsher biedt het in handen van de Staat houden van ondernemingen de mogelijkheid bij uitstek om het marktgedrag van marktdeelnemers van boven af in banen te leiden. Vandaag de dag zijn verzelfstanding en privatisering schering en inslag. Deregulering en liberalisering van wet- en regelgeving geven nationale overheden minder ruimte tot overheidsinterventie ter zake.

Het, in economisch, financieel en sociaal opzicht, in toenemende mate naar elkaar toe groeien van de Europese lidstaten noodzaakt tot harmonisatie van nationale wet- en regelgeving. ${ }^{34}$ Wordt het optimaal harmoniseren wel als einddoel gezien, beter lijkt het voorlopig te volstaan met minimumharmonisatie. ${ }^{35}$ " Minimumharmonisatie is gewenst:

32. $\rightarrow$

p.I-1329, weer gegeven door F. Pouw, in: SEW, nr. I, 1995, pp.48-49, geeft enige richting aan hoe het diffuse begrip overheidsaanbesteding moet worden geïnterpreteerd. In het oordeel van het hof, betreffende het al dan niet vallen van de aanbesteding van respectievelijk inrichting en opening van een casino en exploitatie een hotelbedrijf, onder de werkingssfeer wan richtlijn 71/305/EEG d.d. 26 juli 1971 (aangaande de opheffing van beperkingen van dienstwerrichting op het gebied van overheidsopdrachten voor de uitwoering van werk en van de gunning van owerheidsopdrachten voor de uitvoering van werken door bemiddeling van agentschappen of filialen) komt tot viting dat het al dan niet bijkomstige karakter bepalend is voor de aard wan de aanbestedingsopdracht. Bejde opdrachten, bedioeld in de casus, vallen op zich niet onder de richtlijn. M.b.t. de door de werwijzende rechter aan het hof voorgelegde, meer relevante vraag of een gemengde opdracht, die zowel betrekking heeft op de vitvoering wan werken als op de owerdracht van goederen, onder de richtlijn valt, luidt "s-hofs oordeel als volgt. Als de in het casino en het hotel uit te voeren werken ten opzichte van het primaire woorwerp van de aanbesteding slechts een bijkomstig karakter hebben, kan die aambested ing niet in haar totaliteit aangemerkt worden als overheidsopdracht in de zin van vermelde richtijn. Volgens het hof komt de beoordeling hiervan toe aan de mationale rechter.

33. Waarbij niet exarbitant hoge tarieven mogen worden gesteld en ook geen algehele uitsluiting van potentiele, private concurrenten mag plaats vinden.

34. Bij harmonisatie van nationale handhavingsbepalingen trekken wooral onderwerpen als rechtsinbreuk, aansprakelijkheid, sancties, schikkingen en analoge procedures, extraterritorialiteit, wederzijdse trechtshulp en verjaring de aandacht. A.J.C. de Moor-Van Vugt en E.M. Vermeulen, Europees bestuursrecht. in: NTB $_{n}$ nr.1 1995, pp.10-18, i.h.b. p. 17, melden dat de Europese Commissie overkoepelende regelgewing ter zake voorbereidt op het gebied van met name fraude.

35. Dit laat onverlet het feit dat in bepaalde sectoren hamonisatie al ver is gevorderd. Dit is vooral wat betreft keuring het geval. De landbouwkwaliteitscontrole laat dit goed zien. Deze controle wordt uigevoerd door veelal gelijkwaardige verzelfstandigde keurings- en inspectiediensten in de EG-lidstaten. Ook in de scheepswerfkeuringssector wordt aardig aan de weg getimmerd. De, in toenemende mate gecertificeerde, private ondernemingen geven keuringsverklaringen af die gelden in heel Europa. Harmonisatie is hier in een eindfase. De mogelijkheden van volledige privatisering worden hier zelfs vitdrukkelijk overwogen. 
zowel wat regelgeving als strafmaat betreft. Niet absoluut de zaak gelijktrekken, maar zorgen dat de benadering niet evident anders is. "36" Onwenselijk is het dus de verschillende wetten en regels tot een eenheidsworst te kneden.

Gelukkiger geacht wordt een ontwikkeling waarbij de nationale overheden elkaars 'geboden en verboden' leren respecteren en, zo mogelijk, tot onderlinge coherentie kumnen komen. Daarvan duidelijk voorbeeld is de tegenwoordig terecht toenemende mate van wederzijdse erkenning van de in verschillende lidstaten vigerende controle- en toezichtsstelsels als mede toezichthoudende verzelfstandigde entiteiten. Dit tolerante respect is sterk aanwezig in het kader van het gemeenschappelijk landbouwbeleid (zo doende hebben de landbouwkwaliteitscontrole-instellingen er mee te maken). Tevens manifesteert die wederzijdse waardering van elkaars wet- en regelgeving inzake handhaving zich in de verzekerings- en effectensector (daardoor "voorzien" bij voorbeeld de stichting Verzekeringskamer en de Stichting Toezicht Effectenverkeer door hen te verlenen vergunningen van communautaire draagwijdte). ${ }^{37}{ }^{38}$ Kortom, daar waar de regels niet gelijk zijn te trekken, jagen lidstaten zich niet tegen over elkaar in het harnas, maar kunnen zij (ook al meten zij met twee verschillende maten) ${ }^{39}$ de - tegenwoordig met oog op grens-

36. Ministerie van werkeer en waterstaat, Citaten wit wieniews mer maatschoppelijke sleutelfguren in her kades wan het project Naleving, "s-Gravenhage , augustus 1992, p.23.

37. Inherent aan deze wederzijdse aanvaarding is dan dat bevoegde financiële toezichthoudende autoriterten in elke lidstat een vergumning mogen weigeren of intrekken indien ondubbelzinnig bljikt dat een vergunningaanvrager of een vergunninghouder een andere lidstaat opzoekt om de, in de lidstaat (waarin betrokkene zijn activiteiten vitoefent of wil uitoefenen) geldende, strengere wet- en regelgeving te ontcluiken. Hierover in zijn interessante opstel H.A.G. Temmink, Minimumnormen in EG richulijnen, in: SEW, nr.2, febr. 1995, pp.79-106, i.h.b. pp.84-85/100-101.

38. Overigens is reciprociteit niet altijd leidraad. De Wte 1995 kent bij voorbeeld geen wederkerigheid in die mate dat, als Nederland toetreding van een beurs uit een andere lidstaat toestat, die andere lidstalat daardoor dam ook werplicht is Nederlandse beurzen tot zijn markt toe te laten. Kortom, de regel "toelating. mits" bestaat niet. Een dergelijk criterium past kennelijk niet in het liberaliseren van de effectensector. De toelating wan buitenlandse beurzen stat slechts in het teken van de gedachte wan "level playing field" " die geldt t.a. v. regelgeving en toezicht. Er moet sprake zijn van "equivalentie met de Nederlandlse situatie. ond at beleggers er op moeten kunnen ventrouwen dat de kwaliteit van de betrokken effectembeurs als ook het toezicht op die beurs niet onder dloet voor hetgeen in Nederland geldt". Nofa n.a.v. het versiag inzake het voorstel Wte 1995, TK 1994-1995, 23874, nr. 7. p.9. Het gevaar voor in de vorige noot bedoelde Ubochtconstructies is, volgens de minister van financiën, niet aanmemelijk nu de beslissing woor een vestigingsplaats "niet alleen wordi bepaald door toezichtsregime, mar ook door andere factoren als historische, economische, juridische, fiscale, infrastnacturele en praktische ${ }^{*}$. Nota n.a.v. het werslag inzake het voorstel Whe 1995, TK 1994-1995, 23874, nr.7, p.16.

39. Wel te verstaan, bij wederzijdse erkenning stemt de onderlinge strafmagt nanurlijk in redelijke mate. overeen. Maar ook in het algemeen is het relevant er woor te zorgen dat in de verschillende Exropese staten cle bestraffing van buitemwettelijk gedrag onderling niet opvallend afwijkt. Zijn de sancties per land namelijk ver uit verschillend, dan bestaat het risico dat controle concurrentieverval sendl werkt. Let wel, anders dan de concurmentievervalsing door ondernemershandelen (zie artt. 85/86 EG-verdrag), betreft het hier concurrentievervalsing door verschil in wetgeving en overheidsoptreden in het kader van handhaving en toezicht (zie artt. 101/102 EG-verdrag). In dit verband relevant zijn de uitspraken Grolleman Transport bv, economische pollitierechter Zmtphen, 30 mei 1994, in: SEW, nr.3, 1995, pp.216-219 en Egmond Transportbedriff Nijverdal, economische politierechter Almelo, 10 nov. 1994, in: SEW, nr.3, 1995, pp.219-222. In eerst genoemde zaak, betreffende een chauffeur die de (naar zijn mening in verhouding tot andere lidstatem veel te strenge) Rijtijdenregeling overtreedt, acht de wijze waarop de rijtijdenregelling 
overschrijdende dienstverlening en regelschending noodzakelijke - samenwerking tot stand brengen als zij over en weer hun wettelijke handhawingskaders eerbiedigen. Dergelijke verstandige voorzichtigheid wordt geboden door het subsidiariteitsbeginsel, als neergelegd in art. 3B EG-verdrag. Eigenlijk is dat uitgangspunt "een kwestie van gezond verstand. Je moet niet meer hooi op je vork nemen dan je aankunt. Je kunt sommige zaken beter regelen op een niveau dat dichter bij de burgers staat" . ${ }^{40}$

Harmonisatie laat zich meestal herkennen door het volgende stramien. Eerst worden nationalrechtelijke bepalingen geharmoniseerd. Daarna is communautaire regelgeving aan harmonisatie toe. Zowel nationaal recht als Europees recht voorzien in de mogelijkheid om relatief autonome autoriteiten in te stellen, die toezien op naleving van wet- en regelgeving. Zijn beide fasen van het harmonisatieproces gepasseerd, dan is het tijd om nationaal recht in het kader van communautair recht te zien. Daarvoor zorgen juist de toezichthoudende onafhankelijke autoriteiten. ${ }^{41}$ Bedoeling is dat communautaire toezichthouders nationale toezichthouders op adequate wijze aansturen. Een dergelijke ontwikkeling tekent zich af in de wet- en regelgeving inzake de informationele privacy, die geografisch gezien noodzakelijkerwijs grensoverschrijdend is. De Wpr voorziet in de

39.

in Nederland wordt gehandhaafd in vvereenstemming met de bedoeling van de EEG-verordening $3820 / 85$. De rechter voelt er kennelijk niets voor om een chauffeur toe te staan zelf te bepalen of hij de Nederlandse handhaving (die voldoet aan communautair recht) buiten spel zet met een beroep op de soepele handha ving in de andere lidstaten. In laatst genoemde uitspraak komt de rechter tot de conclusie dat andere lidstaten, anders dan Nederland (dat een voortrekkersrol vervult m. b.t. implementatie, vervolging sintensiteit, controlesystematiek en hoogte van sancties) , nog niet volledig de regels van vermelde verordening hebben geïnplementeerd. Deze constatering werleidt hem er weliswar niet toe de in casu gedlane vorderüg (tot oplegging wan geldboeten aan de chauffeurs die de Rijtijdenwet hebben overtreden) niet-ontvankelijk te verklaren, mar. wel om de op te leggen sancties op de gebleken overtredingen aan te passen (aan het gemiddelde strafmaatniveau in de $\mathrm{EG}$ ), hoewel hij daarbij direct toegeeft dat dit door gebrek aan voldoende gegevens- voor een "aanmerkelijk gedeelte malte-vingerwerk" is. Met referentie aan hell feit dat door lidstaten op te leggen sancties, met de oplegging waarvan zij -bij gebrek aan een kennelijk nog niet haalbare communautaire sanctionering- zijm opgezadeld, passend moeten zijn, d.w.z. evenredig, afschrikwekkend en doeltreffencl, wijst annotator K.J.M. Mortelmans er op dat de Almelose rechter een "gulden middenweg" bewandelt. Deze rechter zit mamelijk tussen: a. ontslag van recthtswervolging met als argument dat andere lidstaten weel minder controleren en straffen (deze sanctie is dus niet doeltreffend en niet afschrikwekkend); en b. een zeer zware geldboete (deze sanctie is onevenredig). Ten slotte merkt Mortelmans terecht op dat een eind moet komen aan het "slapende bestaan" van de artt. 101 en 102 EGverdrag inzake distorsie. Zo lang communautaire handhaving ontbreekt, kunnen Raad of Commissie alls "second best oplossing het natte-vingerwerk wan nationalie rechters stroomlijnen" (p.222).

40. Aldus W. van Gerven, geciteerd door H.J. van Oostnum, Harmoniserev in de marge: Enropess vennootschapsrecht botst met national belang, in: NRC, 7 okt. 1994, p.14. Van Gerven wijst er op dat de Europese richtlijnen na het VvM globaler worden. Dat is kenmelijk een indicatie woor het feit dat harmonisatie miet tot in de puntjes hoeft. Het overhoop halen van tradities en culturen van Europese lidstaten door "een wet" voor te schrijven is verre van verstandig. Doel is slechts te komen tot een "basisniveau wan gelijkwormigheid, zo dat het vrije verkeer van goederen, kapital en diensten binnem de Europese Unie zonder all te veel horten en stoten verloopt".

41. Met de introductie van (een bepaalde mate van) marktwerking grijpt het fenomeen wezichthoudende entiteit flink om zich heen. Her en der worden toezichthoudende entiteiten opgericht. Dat dat niet eindeloos kan, is duidelijk. De mars van toezichthouders moet tijdig een halt toe worden geroepen. Een te grote toemame van toezichthouders werkt mogelijk erosie van rechtshandhaving in de hand. 
oprichting van een Registratiekamer. En de Europese privacyrichtlijn maakt instelling van een communautair controleorgaan mogelijk. Deze, op Europeesrechtelijke leest geschoeide ${ }_{*}$ onafhankelijke Groep voor de privacybescherming, met advies- en aanbevelingsbevoegdheden, coördineert met raad en daad de uitwoering van Europees recht op nationaal niveau.

In het verlengde daarvan ligt de conclusie, dat deregulering op nationaal niveau (waaraan het opstellen wan raam-, kader-en machtigingswetten gerelateerd aan het op grote schaal instellen van toezichthoudende autoriteiten inherent is) in bepaalde gevallen reregulering op Europeesrechtelijk niveau betekent.

Kort weg walt te constateren dat overheidsinterventie in nationaal opzicht \ichtelijk afneemt en in communautair opzicht enigszins toeneemt.

Ook in Nederland werkt de markt meer en meer buiten de overheid om. Deregulering, concurrentie en versterking van de marktwerking zijn ver uit favoriet bij het kabinetKok. ${ }^{42}$

In elk geval bij het afstoten van overheidstaken, en in mindere mate bij het uitbesteden of het op afstand doen uitvoeren van overheidstaken, verovert het mededingingsprincipe zich dan ook een prioritaire positie.

Het toelaten van mededinging of het inbouwen van quasi-concurrentie kan bevorderlijk zijn voor een grijpbaarder, gevarieerder en goedkoper aanbod van produkten of diensten. Het schaduweffect van het werken met, al dan niet kunstmatige ${ }^{43}$, winstprikkels is echter dat elke markt met mededinging kan ontaarden in een markt van machthebbers. Met andere woorden, via verschillende factoren kan concurrentie oneigenlijk worden. Of het nu de markt van omroep, media, film, telecommunicatie, verzekeringen, effecten, persoonsgegevens of landbouw betreft, de gevaren van misbruik van monopolie- of

42. O.a. Troonrede, in: NRC, 20 sept. 1994, p.23; Zie ook Regeerakkoord 1994: Keuzes voor de foekomst, TKK 1993-1994, 23715, nr.11, pp.3-4/23; Dit streven naar marktwerking wordt scherp veroordeeld als "een huis in de pels van paars". Aldus F. van Waarden in gesprek met B. Senstius, "Markregulering Moorkomt wild-west-economie; Utrechtse hoogleraar plet voor "gearganiseerd kapitalisme", in. Intermediair, nr. 14,7 alpril 1995, pp.27-29 (zie ook zijn oratie Breek Nederiand zin dijken door? Ower "flexibele" rigiditeiten). Van Waarden, die vreest dat partijen op een markt met weinig regulering een ongebreidelde strijd aan gaan waandoor alleen de sterkste overleeft die zich vervolgens als monopolist opstelt, pleit voor "coöperatieve concurrentie of georganiseerd kapitalisme [...] gekenmerkt door voorzieningen dlie de concurrentie wel ordenen en matigen, maar niet wegnemen" (p.27). Van Waarden schildert het beleid van kabinet-Kok negatief af: "Onder de naam van marktwerking en decentralisatie gaan we privatiseren, maar in feite creèren we oncontroleerbare monopolies. " (p.27) Daarom will Van Waarden minder ver gaan dan het kabinet. Zi. "kan het zinnig zijn om een beetje markt in te bouwen, zo als ook een beetje staat als correctie op het system kan fungeren. Juist die combinatie wan werschillende systemen -zelfregulering. overheidscontrole en een beetje markwerking-kenmerkt het Nederlandse systeem. [...] Ons sterke punt is nu juist die combinatie." (p.29) De voorzichtigheid van Van Waarden spreelkt ten dele aan voor verzelfstandigingen ${ }_{n}$ matr zij ontneemt het zicht aan privatiseringen die juist meer stimulans verdienen.

43. R.J.M. van Wujjtswinkel, t a.p., p.5, noemt als pseudo-marktprikkels equivalent-belastingen, divididenden, "capital fees" (soort rentevergoeding op het geinvesteende vermogen) die aan de regering worden afgedragen. Indien gecombineend met een 'price tribunal', dat toeziet op de prijszetting van publieke uitwoerende entiteiten, is het mogelijk een marktgevoel te benaderen. 
machtspositie en krachtige kartel(prijs) afspraken vormen reële bedreigingen. Het algemene mededingingsbeleid ${ }^{44}$ dat, naast bijzondere mededingingsregels voor specifieke sectoren, voor de verschillende markten leidraad is, dient daarom te waken tegen onaanvaardbare beperking van de mededinging.

Wat betreft het aparte mediarechtelijke terrein van de informatievoorziening luidt een teleurstellende conclusie, dat het mes van zowel algemeen mededingingstecht (respectievelijk Wem en EG-verdrag in samenhang met bij voorbeeld de EG-Kartelverordening) als bijzonder mededingingsrecht niet scherp genoeg snijdt; Aan mededingingswet - en regelgeving kleven bezwaren van ineffectiviteit (licht regime van Wem-sancties) en ontoepasbaarheid (het in tegenstelling tot de Wem weliswaar ook voor publieke dienstverleners geldende EG-mededingingsrecht dat de communautaire markt betreft, geldt niet voor binnenlandse regionale of lokale situaties ${ }^{45}$ ). ${ }^{46} 47$

Als alternatief voor deze ontoereikende mededingingsregels, prijkt een nieuw mededingingsbeleid op het ideeènbord. Met het doel te komen tot een werkzame mededinging, waardoor als marktresultaat een gevarieerd aanbod tot stand komt dat optimaal toegankelijk is voor de burger, is volgens - het in casu de informatievoorziening betreffend voorstel ${ }^{48}$ een mededingingsbeleid, met ruimte voor een open marktstructuur en innovatief concurrerend marktgedrag, nodig. Tenzij sprake is van een expliciet exclusieve markt, is algemeen mededingingsrecht daarbij uitgangspunt. Dat recht bevat minimale regelgeving met drie verboden om - ten behoeve van aan derden toekomende, voornamelijk uit verdragsrechtelijke grondrechten woort vloeiende, vrijheden ${ }^{49}$ - op effectieve

44. Primair op nationaal niveau neer ggelegd in de Wem. En wat grensowerschrijdend gebied betreft gelden secundair wooral de artt. 85-90 E(E)G-Verdrag.

45. Tenzij de, van een andere orde zijnde, vrijheid van diensten-, goederen-, personen- of kapitaalverkeet iv het geding is.

46. Medinrad, Adwies inzake herstructwreving beleid informatievoarzienimg: Deel M: de mededinging. "sGrawerhage, 8 juni 1994. pp.17-18.

47. In de herziene Wem treden aanzienlijke verbeteringen op. De verniewwde Wem concentreert zich op de noodzaak tot verrwieuwende concurrentie in een dynamische markt. $\mathrm{Zij}$ kent een algemeen werbod op mededingingsafspraken en onderling afgestemde feitelijke gedragingen tussen ondememingem en een verbod op misbruik van machtspositie. Belangrijke vernuiming biedt de introductie van het ondernemersbegrip in de Wem. Daarom vallen voortaan publieke dienstwerleners met bedrijfsmatige activiteiten onder de Wem: "Voor zower zelfstandige, d.w.z. rechtspersoonlijkheid bezittende, onderdelen van de Rijksdienst, met als doel de uitoefening van beroep of bedrijf, deelnemen an het economisch venkeer, vallen zij onder de werkingssfeer varn de wet. Indien een dergelijk onderdeel zelf geen rechtpersoonlijkheid bezit, zal de Stat die in gevolge art. 1, boek 2 BW publiekrechtelijke rechtspersoonijkheid bezit en waar die onderdelen deel van uitmaken. als de ondernemer moeten worden aangemerkt." Mot voorstel wijziging. Wem, TK 1992-1993, 23306, r. 3, p.5.

48. Zie interessant Mediaraad, Advies inzake herstructurening beleid informatievoorziening III, 's-Gravenhage, 1994, pp.21-30; Volgens M. Joosten, Informatiebeleid op maat, in: MF, nr.9, 1994, p.98, mist de mening van de Mediaraad, over publieke functies en verantwoordelijkheden in het informatiebeleid, nog precieze onderbouwing.

49. By voorbeeld de vrijheid tot het uiten en ontwangen wam meningen en beelden, de vrijheid tot behoud vath de informationele priwacy, de wrijheid tot het uitoefenen van het effectenbedrijf of hec verzekeringsbedrijf of het liandbouwbed rijf. 
en flexibele wijze mededingingsbeperkingen tegen te gaan. Ten eerste, een werbod op mededingingsbeperkende concurrentie of misbruik van machtspositie. Ten tweede, een verbod op een mededingingsbeperkende concentratie, gerelateerd aan een stelsel wan aanmelding en preventieve toetsing. ${ }^{\text {so }}$ s1 En ten derde, een verbod op mededingingsbeperkende samenwerking, met mogelijkheid van ontheffing. Het algemene mededingingsrecht met deze drie verboden geldt voor zowel private als publieke dienstverleners. Laatst genoemden even wel onder de restrictie dat de vervulling van hun, bij voorkeur wettelijk vastgelegde, taken van algemeen belang door toepassing van dat recht geen gevaar loopt. Alle verzelfstandigde entiteiten, die een publiekrechtelijke taak uitoefenen en zich op de markt bewegen, vallen dus in beginsel onder het EG-mededingingsrecht. ${ }^{52}$

\subsubsection{MEDEDINGING IN GEDING DOOR BEVOEGDHEIDSUITOEFENING VAN EEN TOEZICHTHOUDEND ZBO}

De terecht, in strengheid toenemende, toetsing van mededinging is te illustreren aan de hand van de omstreden apk-erkenningverlening door de Dienst wegverkeer als toezichthoudend zelfstandig bestuursorgaan met rechtspersoonlijkheid sui generis. Deze bij wet verzelfstandigde dienst is ex art. $3 \mathrm{~b}$, eerste lid, sub j, junctis o.a. art. 28 en art. 32 gewijzigde Wegenverkeerswet $1992^{53}$, bevoegd tot het verlenen van apk-erkenningen. Deze, tegenwoordig bij haar berustende, bevoegdheid komt van oudsher de minister van verkeer en waterstalat toe.

De Dienst wegverkeer kan dus aan natuurlijke of rechtspersonen erkenning verlenen voor het uitvoeren van een algemene periodieke keuring van motorrijtuigen, aanhangers en

50. Voor het geval een algemeen mededingingsbeleid niet van de grond komt, acht de Mediaraad, t.a.p.. p.28, het wenselijk om een stelsel van preventieve concentratiecontrole op te nemen in de door de ratad in eerdere rapporten (respectievelijk Advies inzake herstrucrurering beleid informatievoorziening; Deel 1: hef informatietramsport, "s-Gravenhage, 11 juni 1993, en Advies inzake hersuracturering beleid' informatievoorziening: Deel II: de informatieprodwktie, "s-Gravenhage, 27 januari 1994) woo rgestelde owe rkoepelende Wet op het informatietransport en de Wet op het informatieprodukt.

51. In het algemeen gesproken ontkent A.D. Ham, $O_{p}$ weg naar een nieune Wem, in: $S E W$, nr. 7. pp,492508 , woorlopig de noodzak vant enige vorm van concentratiecontrolle.

52. Zie ook A.T.L.M. van de Ven, Verzelfstandiging en besruurlike decentralisatie, in: S\&V, nr.3, 1994, pp. 61 -65, i.h.b. p.65. Auteur vindt modernisering wan Nederlands mededingingsrecht naar voorbeeld wan EG-mededingingsrecht nodig; Ten dele in het verlengde hitervan acht M.B.W. Biesheuwel, "Rule of reasion", in: NRC, 17 febr. 1995, p.13, het zinval om -nu het Nederlandse mededingingsstelsel (wan oudsher een misbruikstelsel: mededinging wordt getolereerd, tot dat de overheid daartegen protesteert) inderdaad naar Europees mededingingsmodel (vooral een verbodsysteem: elke concurrentiebeperking wordt verboden, tenzij aparte goedkeuring wordt verkregen) neigt- dan ook de 'rule of reason', die in de EU intrede doet, ower te nemen. Deze regel houdt in dat niet iedere concurrentiebeperking ongeoorloofid is: "Aan de hand van een redelijkheidstoets waarbij macro-belangen moeten worden meegewogen dient het kaf van het koren te worden gescheiden."; Over de integratieve communautarisering valn het meded ingingsrecht ook M.H. van der Woude, Nederlands en Europees kartelrecht, in: RM Themis, nr. 5,1995 , pp. 198-204.

53. Wijziging Wegenverkeerswet 1992 houdende verzelfstandiging Rijksdienst voor het wegverkeer. TK 1992. 1993, 22961, nrs. 1-2, p.2. 
opleggers (apk). Die natuurlijke of rechtspersonen exploiteren een onafhankelijk keuringsstation, waar geen onderhoud of reparaties worden verricht, of een garagebedrijf waar zulke werkzaamheden wel worden verricht. Het tarief is bij beide gelijk. Indien de keuring plaats vindt in het kader van een onderhoudsbeurt, die reeds een controle op de keuringseisen inhoudt, hoeft niets te worden bettaald.

De apk-regeling kan, volgens de Hoge Raad, tot gevolg hebben dat geen gebruik wordt gemaakt van misschien wel goedkopere diensten van garagebedrijven in het buitenland en van de mogelijkheid om zich aldaar de nodige onderdelen aan te schaffen, omdat het praktisch is onderhoud en reparatie te laten uitvoeren in een garage waar ook de apk geschiedt.

Even wel constateert het Europese hof van justitie geen strijdigheid met: a. het vrij verkeer van goederen ex art. $30 \mathrm{E}(\mathrm{E}) \mathrm{G}$-verdrag (Immers, het onderhoud gaat gepaard met levering van onderdelen. Daardoor is de levering slechts accessoir aan dienstverrichting); $\mathrm{b}$. het vrij verkeer van dienstverlening ex art. $59 \mathrm{E}(\mathrm{E}) \mathrm{G}$-verdrag (De erkenning van apk-bedrijven is niet mogelijk in buitenlandse lidstaten. Dat feit kan niet worden beoordeeld in het licht van art. $59 \mathrm{E}(\mathrm{E}) \mathrm{G}$-verdrag, immers: zo danige erkeming komt neer op uitbreiding van een overheidsprerogatief buiten het nationale grondgebied) ${ }^{54}$; en $c$. het vrij verkeer van dienstverlening zonder nieuwe beperkingen als, in de vorm van uitwerking van art. $59 \mathrm{E}(\mathrm{E}) \mathrm{G}$-verdrag, verwoord in art. $62 \mathrm{E}(\mathrm{E}) \mathrm{G}$-verdrag (Weliswar berooft de apk-regeling buitenlandse bedrijven van klandizie, maar de regeling vindt rechtvaardiging door eisen van verkeersveiligheid, die als dwingende redenen van algemeen belang zijn te beschouwen. Het hof oordeelt dat de eis van periodieke keuring de verkeersveiligheid dient. De artt. 59 en 62 E(E)G-verdrag verzetten zich zo niet tegen de apk-regeling). Wat betreft de mededinging: betrokken apk-regeling beoogt niet een bestaande overeenkomst of onderling afgestemde feitelijke gedraging toe te staan of te versterken, dan wel een dergelijke overeenkomst of gedraging op te leggen of te vergemakkelijken. In het licht van art. $5 \mathrm{E}(\mathrm{E}) \mathrm{G}$-verdrag junctis artt. 85 en $86 \mathrm{E}(\mathrm{E}) \mathrm{G}$-verdrag constateert het hof in casu geen misbruik van machtspositie ${ }^{55}$ " 56

54. M. R. Mok, Vrijheid wan dienstenverkeer: mededinging, in: TVVS, nr. 12, 1994, pp.336-337, wraagt zich in zijn annotatie bij "s-hofs arrest af warom buitenlandse bedrijven eigenlijk niet erkend kunnen worden. Auteur acht zulke erkenningen wel aamvaardbatr als buitenlandse bedrijven worden "verplicht de extra kosten te dragen die verbonden zijn aan lyet toezicht op het door die bedrijven voldoen aan de eisen" te dragen.

55. Strafraak tegen Van Schaik inzake technische cortrole van motorvoentuigen. HwJ EG (C-55/93) 5 okt. 1994, in: SEW, nr. 11, 1994, pp.28-29 (SEW jurisprudentie EG), ook weer gegeven in: TVVS, nr. 12, $1994^{*}$ pp.336-337. Deze zaak speelt trouwens nog in de periode waarin de Dienst wegverkeer nog niet: is verzedfstandigd.

56. P.J. Slot plaatst terecht de volgende interessante noot bij het arrest, in: SEW, nr. 1, febr. 1995, Pp. 130m 131. Auteur heeft moeite met de weinig gemotiveerde acceptatie door her hof van dwingende eisen van verkeersweiligheid. Bovenal wraggt anteur zich af of het hof, met de stelling dacerkenning van buittenlandse bedrijven neerkomt op uitbreiding van een overheid sprerogatief tot buiten het nationalle grondgebied, niet te snell het pad vam art. $59 \mathrm{EG}$-verdrag verlaat. Auteur meent dat het i.c. niet gaat om bet witoefenen van uitvoerende jurisdictie in andere lidstaten, "maar om de aanvaarding van zulk een jurisdictie uitoefening door andere lidstaten". Dergelijke aanvaarding acht hij modern "gemeengoed": "zij is de kern van de wederzijdse aanvaardingsfilosofie die naast de erkenning van elkaars nomen zeker ook gebaseerd is 
Aan deze zaak geefi de rechter dus nog een relatief gunstige afloop. Evident is echter dat het moeilijk blijft te balanceren op de rand van de afgrond: waar begint en waar eindigt eerlijke mededinging?

\subsubsection{HOE MEER MARKTWERKING, HOE MEER BURGERLUJK RECHT}

Privatisering van overheidstaken stelt aanbieders en afnemers van produkten of diensten bloot aan de machtige marktwerking. Als vermeld kan dit ook bij verzelfstandiging van overheidstaken, zij het op meer gekunstelde wijze, het geval zijn. Winst is hier nog geen war woord. Maar kostendekkendheid staat meestal wel op de kaart als kernthema. ${ }^{\text {s7 }}$ Marktwerking maakt het contractenrecht levendig. In een concurrerende omgeving kunnen partijen met bepaalde wederpartijen (qua prijs, produkt, leveringsvoorwaarden en dergelijke) een en ander overeen komen. Justitiabelen zijn in minder opzichten gebonden aan verplichtingen van de overheid. In een concurrentiële context zijn particulieren in principe vrij om de voor hen meest gunstige situatie te kiezen. Logisch gevolg van, al dan niet gesimuleerde, marktwerking is dat bij voorbeeld afdwingbaarheid van overeenkomsten, actie uit wanprestatie, vernietiging, vernietigbaarheid of ontbinding van contracten, rectificatie, verbod/gebod of declaratoir vonnis via de rechter, essentieel worden. Dergelijke aspecten vinden voornamelijk regeling in het burgerlijk recht. Met andere woorden in een markt, waar macht zich middels mededinging manifesteert, reikt civiel recht aanvaardbare aanknopingspunten aan. Hoe heviger die markt werkt, hoe steviger het burgerlijk recht daarin kerkt.

Het meer dan plausibele pleidlooi om thet "meer uitgekristalliseerde franchisingcontract" als "bruikbare verzelfstandigingsformule of verzelfstandigingsvariant" voor goed herkenbare dienstverlening te zien, en ook belang te hechten aan de werkelijk "wederzijdse betrokkenheid" bij, voor (overheids)taakafstoting of -overheveling naar private partijen relevante, raamovereenkomsten, spreekt dan ook aan. ${ }^{58}$

56. $\rightarrow$

op aanvaarding van elkaars controles", "s-Hofs argument, dat toezicht alleen door Nederlandse instanties op Nedetlands grondgebied kan worden uitgeofend, kan auteur, net alle respect, dan ook "niet meer wan deze tijid" vinden.

57. Za komt bij voorbeeld de, door doelmatigheidsoverwegingen ingegeven, aanpassing van bet beheersregine op het beginsel van bedrijfsecononische kostendekkenheid tot uiting bij de verzelfsitandiging van de monopolist Dienst wan het Kadasteren de Opentbare Registers, TK 1992-1993, 23007, nr.3, pp. 3-4/11/211 22/49, eerder TKK 1991-1992, 22438, nr.1, pp.5-6.

58. Lezenswardig B. Wessels, Vercelfstandiging." enkele kanthekeningen uit het vermogensrech, "in: S\&V, nr. 3, 1994, pp.71-77. Atuteur houdt in zijn betoog publiekrechtelijke organisatievormen buiten beschouwing. Aangezien auteur zbo's slechts als publiekrechtelijk wan aard ziet, vallen die dus buiten zijn verhandeling over de verhouding tussen privatisor en privatisee. Ni deze studie uitgat van de erkemning dat zbo's ook een priwaatrechtelijk karakter kumnen hebben, kan de essentie als auteur aangeeft in zijn artikel ook hier van toepassing zijn. Dat dit waarschijnlijk niet te kort doet aan die essentie van het essay, blijkt wit het feit dat auteur zelf woorbeelden aandraagt die in deze studie aangemerkt worden als, privaratrechtelijk vorm gegeven, zbo"s, met name de STE en Skal. 
Het aspect van mededinging in het midden gelaten, staat natuurlijk het privaatrecht daar als paal boven water, waar justitiabelen met onrechtmatig optreden worden geconfronteerd. Dit kan zelfs betekenen dat belanghebbende burgers niet passief hoeven af te wachten tot bevoegde rechtshandhavende autoriteiten het begane onrecht negatief sanctioneren, maar dat zij zelf - al dan niet in groepsverband - actief optreden tegen wet- of regelschending door de betrokken overtreder om zijn onrechtmatige daad in geding te roepen. Tekenend is de, met name voor het millieurecht geldende, volgende uitspraak: "Het privaatrecht kan ook een deel van de last van de handhaving overnemen. Dat betekent dat je dus mensen, die in hun belang geschaad zijn, laat procederen tegen de overtreder."." 59

\subsubsection{Verhaal van toezichtskosten: burgerlijk recht meer soelaas dan bestuursrecht?}

Niet alleen de rechtshandhaving zelf, ook de daarmee gemoeide kosten zijn ten dele te privatiseren. Kortom, "probeer de handhavingskosten te privatiseren. Voorbeeld: kosten tachograaf verrekenen in prijs van auto's; laat bedrijven jaarlijks een verklaring van een registeraccountant overleggen." 60

Een privaatrechtelijke benadering van in het bijzonder verzelfstandiging van toezichtstaken kan dus een stok achter de deur zijn om ook een visie te ontwikkelen op structurele civiel rechtelijke methoden van financiering van kosten verbonden aan toezichtsuitoefening.

Wellicht biedt dit meer mogelijkheden dan de bestaande publiekrechtelijke opties om toezichtskosten af te wentelen op onder toezicht gestelden. In de bestuursrechtelijke praktijk worden van overheidswege, om overheden in geldelijk opzicht af te dekken, nog al eens financiële voorwaarden en voorschriften aan verlening van vooral vergunningen verbonden. Denk aan: opschortende voorwaarden; vrijwaringsbedingen; waarborgsom; bankgarantie; boetebeding; kostenverhaal; compenserende bijdragen; baatafroming. ${ }^{61}$ Kostenverhaal wordt als volgt geconditioneerd. Financiële voorwaarden, die worden gesteld om de controle te bekostigen, moeten op een wet berusten, nu heffingen wel gedaan mogen worden voor gebruik of diensten, dus als retributie in de echte zin, maar niet ter financiering van het toezicht. ${ }^{62}$

Ter financiering van hun diensten vragen toezichthoudende zelfstandige bestuursorganen veelal vergoedingen voor verleende vergunningen, afgegeven akten of toegekende rechten. Ook voor het verrichten van keuringen en het uitvoeren van inspecties of ander

59. Ministerie van verkeer en waterstaat, Ciraten uit interwiews met maatschappelijke sleutelfiguren in he kader van het project Naleving. "s-Gravenhage, augustus 1992, p.27.

60. Ministerie van verkeer en waterstaat, Citaten uit interviews met maatschappelijke sleurelfiguren in het kader wan het project. Naleving, 's Grawenhage., augustus 1992, p.27.

61. Hierover H.J. Simon, Financièle voorwaarden en woorschriften: een blik van wit de theorie op de prakrijk, in: NTB kingen, -voorwaarden en - voorschriften.

62. ARRS 13 sept. 1984, AB 1985, 351, als aangehaald toor H.J. Simon, Financiele voorwaarden en woarschriften: een bilk van uit de theorie op de praktijk, in: NTB, nr.6, 1994, pp.149-164, i.h.b. p. 160 
onderzoek is het declareren van daaraan verbonden kosten in veel gevallen wettelijk geoorloofd. Via verkoop van produkten en publikaties is tevens geld binnen te halen, al ligt dit al wat moeilijker. Het tegen betaling adviseren van onder toezicht gestelden en het niet (geheel) kosteloos verstrekken van informatie is niet altijd correct. Weliswaar getuigt het van een zakelijke, bedrijfsmatige werkwijze, die meer dan eens de inzet van verzelfstandiging is, maar tegenover de van informatie afhankelijke onder toezicht gestelde belanghebbenden (inbegrepen: derde-belanghebbenden) kan het wel eens een kwade zet zijn. Het feit dat een nog jonge, groeiende organisatie als Stichting Keur Alternatief voortgebrachte Landbouwprodukten enerverend genoeg vijftig gulden vraagt voor een eenvoudig informatiepakket, met controlereglementen die niet uitblinken door compleetheid, is hier indicatief. Ook is te denken aan de nog fris verzelfstandigde stichting Verzekeringskamer die vriendelijk verzoekt een geldelijke tegemoetkoming voor elk jaarverslag op tafel te leggen. Slechts vijftien gulden, maar toch. In gedrang komt hier de specifieke functie van overheidswoorlichting, met name nodig nu het om - weliswaar verzelfstandigde - handhaving gaat, om aan onder toezicht gestelden tijdig toereikende informatie ower hun rechten en plichten (bij voorkeur om niet) beschikbarr te stellen. Inconsequent genoeg stelt zij wel veel andere publikaties gratis ter beschikking. Te denken valt aan de uitvoerige verslaglegging inzake Vie d'Or. Maar misschien heeft dat te maken met het feit dat de stichting Verzekeringskamer daarin zo veel mogelijk eigen schip wil schoon maken. Het geeft in elk geval te denken.

Het vragen van een vergoeding, voor onder meer gedane keuringen en voor afgifte van vergunningen of voor aanbrengen van merktekens, is kennelijk niet te beschouwen als ambtelijke retributie. ${ }^{63} \mathrm{Bij}$ ambtelijke retributie wordt een financiele tegenprestatie gevraagd voor het verrichten van allerlei administratieve handelingen. Het verstrekken van vastgoedinformatie door de Dienst woor het kadaster is een bekend voorbeeld waarbij sprake is van ambtelijke retributie. Zo'n ambtelijke retributie is dus niet aan de orde bij het vragen van een geldelijke tegenprestatie voor uitgevoerde keuringen. Hierbij wordt wel gesproken van het stellen van een overheidsprijs , omdat deze keuringen ook door private sector kunnen worden verricht. Als voorbeeld geldt de stichting Nederlands Instituut voor Lifttechniek, die thet zonder overheidssubsidie moet stellen en daarom een zekere vergoeding voor haar diensten mag vragen. Aantekening verdient dat veel andere toezichthoudende zelfstandige bestuursorganen inderdaad werken met dergelijke overheidsprijzen, die overigens in het gros van de gevallen wel een wettelijke basis hebben.

Belangrijk bij het vragen van financiële wederdiensten is dat de daartoe gestelde tarieven niet de pan uit rijzen. Even als continuitteit en kwaliteit van geleverde diensten door verzelfstandiging niet achter uit mogen gaan, mogen kosten en randvoorwaarden van geleverde diensten daardoor niet omhoog gaan.

Na gebleken onmacht of onkunde om de kosten voor bepaalde overheidsactiviteiten - nota bene met de aanbeveling deze te verzelfstandigen of te privatiseren - inzichtelijk te ma-

63. Versiag van de Algemene Rekenkamer over 1992, TK 1992-1993, 23065, nrs.1 -2, pp.69-71. De Algemene Rekenkamer onderscheidt drie soorten ontvangsten voor de rijksoverheid: a. via amabtelijke retributies; b. via overheidsprijzen met wettalijke basis; en c. via overheidsprijzen zonder wetteljike grondslag. 
ken ${ }^{64}$, worden de handen ineen geslagen ten einde te komen tot een controlelijst die als leidraad kan dienen voor het opstellen en monitoren van bedrijfseconomische tarieven bij onder meer externe verzelfstandigingen. 6566

Dergelijke initiatieven dragen er toe bij, dat de berekening van tarieven helderder wordt. Het betekent niet dat tarifering tevens meer rechtvaardiging krijgt. Ook in de verzelfstandïgde toezichtssfeer blijwen onwerkelijke tarieven bestaan. De financiële vergoeding voor het keuren van een film door de Nederlandse filmkeuring is sinds jaar en dag de zelfde: vanaf 1977 is zij niet veranderd. De geldelijke tegenprestatie, die de (Rijks)dienst wegverkeer vraagt voor het verstrekken van kentekenbewijs deel III, levert meer op dan de kale kostprijs er van. ${ }^{6 ?}$ En dat de Dienst voor het Kadaster en de Openbare Registers moeite heeft met het stellen van de juiste tarieven is reeds vermeld.

In praktijk blijkt dat verzelfstandigde entiteiten een leerproces moeten doormaken wat betreft het werken met de, bij verzelfstandigingen kennelijk zo populaire, kosten-batenanalyse. De zoektocht naar zelfstandig financieel beheer, gekenmerkt door kostendekkendheid, kan lang en pijnlijk zijn. ${ }^{68}$ Inmiddels is duidelijk dat te veel expedities zijn gestart, die beter een paar jaar uitgesteld hadden kunnen worden of wellicht nooit van start hadden mogen gaan. ${ }^{69}$

64. Vierslag van de Algemene Rekenkamer ower 1992, TK 1992-1993, 23065, nrs. 1-2, p.82. Slechts eenderde van de, nog tot de rijksoverheid horende, dienstonderdelen met plannen woor verzelfstandiging is ten tijde van het $\mathrm{AR}$-onderzoek in stat om voor alle onderzochte activiteiten voor derden zowel kosten als bestede uren viast te stellen.

65. Verslag van de Algemene Rekenkamer over 1992, TK 1992-1993, 23065, nrs.1-2, p.74.

66. De Algemene Rekenkamer, Zbo's en ministeriële verantwoordelijkheid. TK 1994-1995, 24130, nr. 3 , pp. 20-21, dringt-ma constatering van het gebrek daaraan (bij 45 organen, waaronder de Registratiekamer, van de 162 door de AR onderzochte zbo's is de wijze van bekostiging niet bij of krachtens een specifieke wet vastgelegd: a.. van die 45 zijn 27 organen uit begrotingsgeld bekostigd, maar niet altijd even duidelijk identifinceerbaar in de begroting terug te vinden terwijl dit van belang is woor het budgetrecht dat een van de voomaamste vormen van controle door de Staten-Generaal op zbo"s is; b. wan die 45 zijn 18 organen, wier bekostigingswijze niet bij of krachtens wet is geregeld, afhankelijk van inkomsten tuit tarieven of heffingen)- aan op het creeten van publiekrechtelijke basis voor door zbo's te hanteren tarieven en heffingen als mede andere methoden van bekostiging.

67. Overigens is, voontit lopend op de werzelfstandiging van de tijksdienst voor het wegverkeer, ook al gewezen op het gevalar, dat de dienst woor het verstrekken van gegevens ower ongeldig op naam gestelde rijbewijzen flinke prijzen gaat vragen. Hier speelt mogelijk het eigen belang van de dienst mee, waardoor de rïksdienst in nog niet verzelfstandigde stat weigert mede te werken aan het Verificatie Informatie Systeem in de zin dat zij vermelde gegevens niet verstrekt t.b. w. van dat systeem. Verzelfstandigingsproblewen, in: OMn, nr.3, 1995, p.80.

68. Dit begint vaak al met het wooraf ontoereikend of onwoldoende defiraieren van reken- en prestatienormen. Anders dan het bedrijfsleven, kost het verzelfstandige entiteiten, die plotseling worden geconfronteerd met (men bepaalde mate van) marktwerking, moeite om de output vast te stellen. Onwennigheid veroorzaakt zo problemen met sturen op afsrand.

69. Als neactie op het vernietigende rappont wan die Algemene Rekenkamer, Zbo s sn ministerięle veraniwoordelikkeld. TK 1994-1995, 24130, nr.3, met de conclusie dat de politieke iministeriele controle op beleidswitwoening en bestedingen wan zbo's ernstig tekort sehiet, wind het CDA-kamerlid Smits het tjd om cen aparte kamercommissie in te stellen die alle verzelfstandigde organen gaat doorlichten op de vraig of ze 


\section{\$20.3 Verzelfstandiging toezichtstaken veroorzaakt door haperende handhaving}

Dat Nederland een ontoereikende handhavingspraktijk kent, blijkt al uit eerdere publikaties. Algemeen wordt het falen in het handhavingsveld aan de volgende factoren toegeschreven. Dat deze problemen, anders dan wellicht beoogd, trouwens niet altijd (direct) door verzelfstandiging worden weggenomen wordt geillustreerd aan de hand van voorbeelden.

Potentiële wet- en regelowertreders laten zich niet weerhouden vam hun buitenwettelijk gedrag door de kleine kans op sanctionering. Overtreders, die regels daadwerkelijk aan hun laars hebben gelapt, laten zich daarvan ook een volgende keer waarschijnlijk niet weerhouden door de meestal lichte (en daardoor inefficiënte) sanctionering van hun eerder handelen of nalaten.

Regelschending ontstaat bewust, maar soms ook onbewust, omdat de betreffende wet-en regelgeving onvoldoende bekend of onvoldoende duidelijk is. Regels zijn niet allijd even helder, doordat zij in hoge mate complex kunnen zijn of mogelijk een griezelige graad wan technische ingewikkeldheid hebben. Twee toonbeelden van technische of moeilijke wetgeving zijn respectievelijk de regelgeving rondom het toezicht door landbouwkwaliteitscontrole-instellingen en de regels die worden gesteld in het kader van het toezicht door de Stichting Toezicht Effectenverkeer ${ }^{70}$.

Wetgevers voorzien regels nog vaak van vage normen. Denk hier aan de praktische problemen waarvoor de Registratiekamer zich ziet geplaatst bij haar toezicht op de gedateerde en de met open termen doorspekte Wpr.

Wezenlijke wetgeving kan verouderd zijn of niet zijn gemoderniseerd in de zin dat zij niet de lijn van Europese of internationale regelgeving oppakt. ${ }^{7}$

Vice versa gelld natuurlijk ook dat zeer jonge wet- of regelgeving nog al eens gebrekkig wordt naleefd. Voordat de reparatiewetgeving wordt gemaakt of voordat de nodige jurisprudentie wordt gevormd, blijft naleving er van achter. Uitgesproken voorbeeld is hier natuurlijk de, door de Stichting Toezicht Effectenverkeer in de gaten te houden, naleving van de $\mathrm{Wmz}$.

Bovendien, te waak is sprake van niet op elkaar afgestemde voorschriften. Onsamenhangende normstelling leidt mogelijk tot angstwekkende administratieve cumulatie. Extra

69. $\rightarrow$

kumen voortbestaan. Naast het CDA vinden ook VVD en PvdA het verstandig de voorwaarden voor verzelfstandiging aan te scherpen. Kamer: scherpere regels voor privatisering rijksdiensten, in: NRC. 1 april 1995, p.1.

70. T.a.v. het voorstel Wte 1995 merkt de PvdA-fractie verongelijkt op dat dit wetswoorstell verre van leesbaar en begrijpelijk is. Zij wijt dit aan het "de lange en ingewikkelde zinnen" als mede aan "het veelvuldig gebruik van het Engelse jargon". De PvdA-fractie betreurt dit in het bijzonder nu zij meent dat "iedere Nederlandse burger (met enige inspanning) in staat moet zijn wetteksten te lezen en te begrijpen". Nota n. $a_{\text {. }} w_{2}$ het verslag inzake Wie 1995. TK 1994-1995, 23784, nr.7, p.3.

71. Overigens levert dit niet altijd een probleem op, omdat Europese regelgeving soms hinderlijk achterloopt op technologische ontwikkelingen. 
problematisch daarbij is dat alle administratieve papieren meestal binnen zeer korte termijn moet worden aangeleverd bij de handhavende instantie.

De handhavingsorganisatie is in bepaalde gevallen niet voldoende op haar handhavingstaken toegerust. Soms ontbreekt het de organisatie aan technische, juridische of inhoudelijke kennis. Daarnaast kan zij ook kampen met een tekort aan personeel of een gebrek aan (financiële) middelen.

Ook al spelen ondercapaciteit en ondeskundigheid een handhavingsorganisatie niet parten. Dan kan een gebrekkige onderlinge communicatie en een verwaarloosde wederzijdse ondersteuning spaken in het wiel veroorzaken. Als, daarnaast, verschillende handhavers overlappende taken of bevoegdheden hebben en handhavingsactiviteiten weinig worden gecoördineerd zit het zadel niet lekker meer. Het is de vraag of de rit nog wordt uitgereden als ook nog pijnlijke hobbels moeten worden gewonnen als: verschillende prioriteiten bij handhavers; lange juridische procedures door o.a. bewijs- of kennisproblemen voor het openbaar ministerie ${ }^{72}$; het te verwachten resultaat na bestraffing is onzeker; of, on verschillende redenen niet of nauwelijks te handhaven voorschriften.

$\mathrm{Na}$ verzelfstandiging treden ter zake wel verbeteringen op. ${ }^{73} \mathrm{Bij}$ voorbeeld, bij verschillende landbouwkwaliteitscontrole-instellingen wordt veel gedaan aan scholing van persomeel. Veel tijd en creativiteit gaat zitten in het geven van onderwijs en het ontwerpen van actuele controlehandboeken. De opleidingen beogen kennisvermeerdering in technisch en juridisch (nationaal-, Europees- en internationaalrechtelijk) opzicht. Zo treedt een nieuwe handhavingselite aan die deskundiger, zelfbewuster (afdeling 5.1 Awb maakt van de toezichthouder een echte autoriteit), sterker (de Awb, zeer waarschijnlijk bepaalde bepalingen in de vierde tranche, geeft toezichthouders een indrukwekkende sanctie in handen via regeling van de bestuurlijke boete) en jonger dan ooit (de vergrijzing wordt duidelijk tegen gegaan) is. Dergelijke verzelfstandigde toezichthoudende autoriteiten geven signalen af dat zij alles doen aan een goed management. Zo veel mogelijk willen, en moeten, zij beschikken over, voor derden op te vragen, periodieke werkplannen met aanduiding van: jaarlijkse prioriteitstelling en werkstrategie, beschrijving toezichtstaken in het licht van bestaande of komende regelgeving, aanwezige personele en materiële middelen, kengetallen als mede input- en outputanalyses inzake toezichtprestaties (kwantiteit en kwaliteit), normontwikkeling ${ }_{n}$ evaluatie en verantwoordingsrapportages. Bovendien, automatiseren en standaardiseren zijn tegenwoordig vast aanwezige agendapunten. Met de terecht toegenomen verslagplichten van toezichthouders is hun werkdruk gestegen. Deze druk is weer te verlichten als het opmaken van inspectierapporten of processen-verbaal via voorgeschreven modellen worden opgemaakt. Daardoor zijn ze, wat administratie betreft, tevens eenvoudig te verwerken. Door zowel toezichtswerkwijzen als toezichtsrapportagemethoden in hoge mate te automatiseren is

72. Wat betreft overtreding van effectenwet- en regelgeving (i.h.b. misbruik van voorwetenschap) wijt de Stichting Toezicht Effectenverkeer bewijsmaeilijkheden aan de veelwuldige wisseling wan fraude-officieren, wiaardoor discontinuitteit en verlies aan gespecialiseerde kennis bij het openbaar ministerie optreden.

73. Vervelend genoeg niet in alle gevallen. Vit de in deze paragraaf eerder vermelde voorbeelden blijkt dat daar waar overheidstoezicht is verzelfstandigd zich nog steeds problemen kunnen voordoen. Denk aan de genoemde voorbelden van vage, complexe of niet tijdig herstelde wetgeving. 
wel (meer) administratief geschoold personeel nodig. Als belangrijk, in de laatste jaren behaald, winstpunt van toezichthoudende verzelfstandigde entiteiten is nog hun verbeterde onderhandelingspositie te noemen. Meer dan vroeger is het nut van samenwerking duidelijk. De toezichthoudende verzelfstandigde autoriteiten proberen zo veel mogelijk, in een vroeg stadium, contact te zoeken en te houden met bijzondere opsporingsinstanties ${ }^{74}$ en in elk geval het openbaar ministerie, de min of meer betrokken vakminister(s) of andere bestuurders, en binnen- en buitenlandse toezichthoudende autoriteiten van vergelijkbare aard ${ }^{75}$.

Het nieuwe gezicht van toezichthouders doet meer recht aan de meest essentiële elementen van hun toezichtstaak: het voorkomen van wetsovertreding en het genereren van signalen van regelschending.

\subsubsection{HIATEN HANDHAVING(SORGANISATIE) BEZIEN VAN UIT HET HOLISTISCH PERSPECTIEF}

Langs verschillende lijnen zijn de moeilijkheden met rechtshandhaving (inclusief toezicht op naleving van wet- en regelgeving) zichtbaar te maken. Twee belangrijke benaderingen luiden als volgt.

Ten eerste bestaat de scherpte van de systeembenadering. Daarin heeft toezicht een plaats binmen een context van politiek (begrotingscyclus, wettelijk kader, controle), bestuur (kerndepartement, openbaar ministerie, andere departementen, internationale organisaties, andlere overhedlen) en werkveld (burgers, instanties, bedrijven).

Ten tweede toont zich de kracht van de ketenbenadering. Deze kent vijf schakels, te weten: beleid, regelgeving, uitvoering, handhaving en organisatie van het toezicht. Alle schakels op zich, en daarnaast de onderlinge aaneenschakeling, laten te wensen over.

Door het "concept van de verzorgbaarheid' onstaat een 'beleidsepidemie". De overheid overschat haar verantwoordelijkheden. Overdaad aan beleid(sintenties) leidt eenwoudig tot een gebrek aan een integrale visie. Het overheidsbeleid is overvloedig, complex, temporeel, ontoegankelijk, onherkenbaar, onsamenhangend, innerlijk tegenstrijdig, en niet afgestemd op het individuele belang van burgers.

Het 'concept van de maakbaarheid' leidt tot 'regelzucht'. Haaks op het dereguleringsdenken, staat het in fors tempo (re)regulleren van de samenleving. Helaas worden regels, die steeds meer modificerend in plaats van codificerend zijn $^{76}{ }^{76}$ steeds sterker gedetailleerd,

74. Denk aan de, in hetteken van juiste takafbakening en samenwerkingsmogelijkheden staamde, werkaf spraken van een landbouwkwaliteitscontrole-instelling als $\$ k a l$ met zowel AID als HIG waardoor zij elkaars controleopdrachten versterken.

75. Wat betreft intensiewe samenwerking tussen verzelfstandigde entiteiten is het, min of meer wettelijke, protocol tussen De Nederlandsche Bank nv en de stichting Verzekeringskamer, waarin zij hurn gelijkwaardige toezicht op respectievelijk bank-en verzekeringsverkeer regelen, interessant.

76. Het economisch ordeningsrecht toont aan dat bij modificerende wetgeving het algemeen belang steeds verder verwijdert raakt van het individuele belang van de burger. Daardoor ontstaan problemen met 
ontcegarkelijk, onduidelijk, inconsistent, ingewikkeld, vaag, multi-interpretabel en inefficient. Het 'concept van de uitvoerbaarheid" veroorzaakt een "uitvoeringsinfarct", Uitwoerirg is politiek niet interessant. Bij beleidsontwikkeling bestaat slechts zijdelings aandach voor uitwoeringsstrategieën. In financieel opzicht wordt ook weinig ruimte gemaakt woor uitwoeringsaspecten. Uitvoerders missen het verband tussen beleidsbepaling en -nitwoew ring. ${ }^{77} \mathrm{Zij}$ stellen beperkt prioriteiten, schenden op grote schaal het gelijkheidsbeginse: en vragen zich te vaak af, met wie, wat en hoe zij moeten uitwoeren.

Het 'concept van de handhaafbaarheid' dwingt tot een 'handhavingsdepressie". De handhavingsdiensten, die overigens steeds minder zichtbaar zijn, werken langs elkar heen. De repressieve kant van handhaving, de opsporing, wordt onevenredig benadrukt. Hoe wel de pakkans groot is, is de burger berekenend. Bovendien komt het effect van opsporing en sanctionering niet echt goed uit de verf.

En het 'concept van de organiseerbaarheid' wakkert 'organisatiewoekering" aan. Whe woert welke (overheids)taken uit? De handhavingsorganisatie is gehavend: bevoegdheden zijn versnipperd verdeeld, onderlinge samenwerking is niet optimaal, middelen om srelle en accurate naleving te bewerkstelligen ontbreken, flexibiliteit is ver te zoeken.

Al deze problemen, met cumulatieve consequentie, worden nog eens versterkt door onvoldoende aandacht voor: eigen verantwoordelijkheden in de samenleving; onderinge samenhang; internationale dimensie; kwantificeren en meten; communicatie; samenwerking; deskundigheid en kennis; eigen verantwoordelijkheden (intern); en onbetreden paden. ${ }^{78}$

Beide modellen geven aan dat de handhavingsorganisatie geen geisoleerd bestaan leef. Vooral de ketenbenadering legt de afhankelijkheidsrelatie met onder meer regelgevers, beleidsmakers en openbaar ministerie bloot.

Juist bij toezichthoudende verzelfstandigde entiteiten is dit afhankelijkheidsbesef belangrijk. Het toezicht maakt deel uit van een integraal geheel.

De fase van handbaving is sterk verweven, zelfs onverbrekelijk verbonden, met de daaraan vooraf gaande en de daarna komende fasen. Toereikend toezicht op nalleving van wet- of regelgeving staat of valt met bij voorbeeld aandacht voor (zowel nationale als Europese en internationale) normstelling. Handhaving levert mogelijk problemen op als wetgeving niet voldoet aan kwaliteitseisen als: a. rechtmatigheid en werwerkelijking van rechtsbeginsellen; b. doeltreffendheid en doelmatigheid; $c$. subsidiariteit en evenredigheid; d. uitwoerbaarheid en handhaafbaarheid; e. onderlinge afstemming; en f. eenvoud, duidelijkheid en toegankelijkheid.

Ook is de fase van handhaving gediend met een goede verstandhouding met de staande magistratuur. Bij voorbeeld, vooroverleg over wenselijke afdoeningsmethodieken en

77. Hier wreekt zich de, door veel voorstanders van verzelfstandiging bejubelde maar praktische onmogelijke strilkte scheiding tussen beleidsbepaling en beleidsuitwoering.

78. Ministerie van verkeer en waterstat, Basisrapport Naleving, "s-Gravemhage, 1992, pp.17-27, in 0verzicht: Het Ketenmodel, "s-Gravenhage, 1992. Over dle bruikbaarheid van het model, waarmee slechts in emst moet worden geexperimenteend, E.C.R. van Rossum, De ketenbenadering: enpraktisch beleidsconcepr, in: RegelMaat, nr.5, 1994, pp.189-195 en eerder E.C. R. van Rossum en P.J. Quartero, Pathologie van de maleving, in: Beleidsanalyse, nr.2, 1993, pp.5*14. 
sepotmogelijkheden van de toezichthoudende autoriteit met het openbaar ministerie kan bepalend zijn voor het uiteindelijke handhavingsresultaat.

Natuurlijk is ook te denken aan het, voor handhavers onontbeerlijke, contact of samenwerking met onder anderen bestuurlijke autoriteiten inclusief Europese instanties, gelijkwaardige toezichthoudende verzelfstandigde entiteiten en niet te vergeten justitiabelen. Verzelfstandiging van handhavingstaken naar specifiek toezichthoudende zelfstandige bestuursorganen is dan ook niet zo maar feit. Stevig gerealiseerd moet worden dat zulke zelfstandige bestuursorganen veel handen moeten schudden. Van vriend. Maar ook van vijand. Immers, zij moeten de tolerantie tonen om, indien nodig, andermans adem in de nek te voelen. Het is, kortom, samenwerking of tegenwerking.

\subsubsection{VERZELFSTANDIGING RECHTSHANDHAVING}

Voorzichtigheid is geboden met het verzelfstandigen van toezichthoudende taken naar zelfstandige bestuursorganen. Dit neemt niet weg dat het uit handen geven van de overheid van handhavingstaken wel goed mogelijk is.

"Voor het concentreren en verzelfstandigen van de handhavingstaak is veel te zeggen. Al eerder werd voorgesteld vergunningverlenende bevoegdheden en handhavingstaken te scheiden. " : In dit verband wordt gepleit "voor zelfstandige bestuursdiensten waarin de handhavingsaktiviteiten van de verschillende bestuurslagen worden ondergebracht. [...] Onderbrenging van de handhavingstaken in een zelfstandig bestuursorgaan zou de nodige afstand kunnen scheppen tussen handhaving en de overige bestuurlijke taken. Een bijkomend voordeel zou zijn dat meer duidelijkheid ontstaat voor de burger. De confrontatie met verschillende handhavers leidt vaak tot verwarring en onbegrip". ${ }^{79}$

Overigens krijgt het voorstel vergunningverlening en toezicht op naleving van vergunningvereisten te separeren ${ }^{80}$ niet bij iedereen voet aan de grond. Het scheiden van " $[. .$. vergunningverlening e.d. en [...] toezicht" wordt, uit het oogpunt van de overlegdimensie van toezicht, wel aangeduid als "disfunctioneel". ${ }^{81}$

79. P.W.A. Gerritzen-Rode, Kronhek wan het milieurecht, un: NJB, nr.35, 7 okt. 1993, pp. 1229-1238, i, h. b. p. 1235. Auteur, die de -volgens baar politiek hoge ogen gooiende- "privatisering ' van het milieuhandhavingsrecht bespreekt, refereert o.a. an de opvatting van J.A. Peters, Soonen handhavers in Een niewwe Weg, in: Opstellen aangeboden aan G.A. Biezeveld, Leidschendam, 1990, p.76.

80. Ook W. Huisman. A. de Lange en E. Niemeyer, Milieucriminaliteit vergt handhoving op maat, in: JV, nr. 9,1994, pp . 27-46, i.h.b. p. 32, noemen deze scheiding als organisatorische maatregel om de bestuurlijke en justitiele handhaving te intensiveren met oog op de bestrijding vam in het bijzonder millieucriminallteit.

81. Y. Bunum, De bijzondere politiediensten in het spanningsveld tussen nationale en unionaire ontwikkelingen, in: DD, nr. 10, 1994, pp. 1031-1055, i.h.b. pp. 1036-1037. Auteur onderscheidt, vooral in bijzondere wetgewing, terecht twee functies van toezicht. Ten eerste is toezicht technisch van aard. Daarop wijzen bevoegdheden tot monsterneming en goederenonderzoeking. Ten tweede heeft toezicht het onmisbare karakter van owerleg. Daar waar samenspraak tussen toezichthouder en onder toezicht gestelde stuk loopt; staan bevoegdheden tot het vragen van inlichtingen en tot het vragen van inzage van boeken, bescheiden en informatiedragers ter beschikking. Auteur wreest dat thet vertrouwen van burgers in bevoegde handha- 
Belangrijke beleidsvoornemens bevestigen dit beeld. Neem het in beweging zijnde beleid inzake etherfrequenties. Verschillende voorstellen voorzien in instelling van een zelfstandig bestuursorgaan voor frequenties, die wordt belast met zowel het toewijzen als het beheren van frequenties. ${ }^{82}$

Volgens voorstel van de Mediaraad ${ }^{83}$ wordt een deskundig Commissariaat voor Frequentiemanagement opgericht, dat geattribueerde bevoegdheden heeft tot bestemming, toewijzing (via vergunningstelsel) en beheer van frequenties. Deze besluitvorming moet overeen stemmen met door de verschillende betrokken ministers gegeven algemene richtlijnen. ${ }^{84} \mathrm{De}$, op hoofdlijnen sturende en verantwoordelijke, bewindspersonen kunnen dergelijke besluiten in voorkomende gevallen schorsen of vernietigen. Om de betrokken departementen inzicht te verschaffen in de werkzaamheden, verschaft het zelfstandig bestuursorgaan jaarlijks een openbaar plan met, ten eerste, overzichten van feitelijke benutting en gebruik en besluiten omtrent bestemming en toewijzing en, ten tweede, indicaties voor ontwikkelingen en beleid op lange termijn.

De Commissie van advies inzake post en telecommunicatie propageert in haar plan ${ }^{85}$, soort gelijk, instelling van de onafhankelijke rechtspersoon sui generis Commissariaat voor de frequenties. Dit zelfstandig bestuursorgaan moet, met een geconditioneerd veilingsprincipe als uitgangspunt ${ }^{86}$, via termijngebonden vergunningen frequenties toewijzen en daarnaast frequenties beheren (inclusief het verkopen van gebruiksrechten van frequenties). Onder het wakend oog van de, op hoofdlijnen toeziende, ministers heeft het commissariaat zo tot taak: het verhandelen van frequenties, het coördineren van frequen-

\section{1. $\rightarrow$}

vende autoriteiten afneemt als uitvoerende taken (waarbij wan uit de handhavende instantie gegeven advies en correctie op positieve wijze centraal staan om justitiabelen zo veel mogelijk te verzekeren van juiste wet-en regelgeving) los worden gemaakt van milde vormen van rechtshandhaving. De milde toezichthouder wordt dan sul suel vereenzelvigd met strengere soorten bestraffers.

82. Hiemaast is te denken aan het tel ecommunicatieterrein. Bekend zijn de pleidooien voor een Commissariaat voor de elektronische informartevoorziening (J.C. Arnbak, J.J. van Cuilenburg en E.J. Dommering. Verbinding en ontvleching in de communicatie. Een studie naar toekomstig overheidsbeleid woor de openbare elektromische informatievoorziening. Amsterdam, 1990) of, andiers gezegd, een Commissariaat voor de telecommunicatie (J.P. Bergfeld, Niewwe hoofdlinen in telecommunicatienegelgewing, in: CR, nr.6, 1993, pp.244-249). Dit, in elk geval het Commissariaat voor de Media en de Hoofd Directie Telecommunicatie en Post vervangende, zbo voert een op algemene ministeriele richtlijmen gebaseerd telecommunicatiebeleid en is belast met integrale uitoefening van taken van vergumningverlening, voorwaardenopstelling, toezicht en mededinging.

83. Mediaraad, Advies inzake frequentiebeleid, nr. $92 / 283-11 \mathrm{I}-\mathrm{G}-1,3$ april 1992 , 's-Gravenhage, pp -3-4/2225/29-30.

84. Juist door deze mimisterielle bevoegdheid kan de bevoegdheid tot machtigingverlening worden getransporteerd naar een zbo. Dergelijke departementale invloed draagt impliciet al bouwstenen voor machtigingen, vergunningen of toestemmingen aan.

85. Commissie van advies inzake post en telecommunicatie, Uitwerking frequentiebeleid, 5 maart 1993, "sGraventhage, pp.3/15.

86. Het bij opbod verkopen, i.p.v, het om niet verstrekken, van fell begeerde vergunningen voor publieke monopolies is een bellangrijke optie voor de toekomst. Terecht achten P. de Graaf en J. Klaver, Veilen van vergurningen mag miet leiden to belastingverhoging, in: $\mathrm{NRC}, 8$ juni $1995, \mathrm{p} .8$, verdeling van vergumingen via veilingsmechamisme alleen aangewezen: "a. in situaties wan echte, technische schaarste en niet van door de overheid geschapen kunstmatige schaarste; $b$. voor zover ook het concurrerende

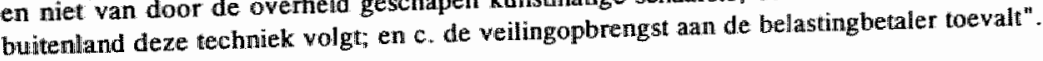


tiegebruik, het maken van afspraken met gebruikers over de termijn van frequentiegebruik, het slechten van geschillen tussen gebruikers, het administreren en plannen van frequentiegebruik en zo voort.

De Nederlandsche Omroep-Zendermaatschappij ontwikkelt ook een dergelijke visie over oprichting van een zelfstandig bestuursorgaan voor de etherfrequenties. Dit zelfstandig. bestuursorgaan stelt, ten eerste, vast welk deel van de ether onder welke voorwaarden wordt bestemd voor en toegewezen aan de verschillende beheerders van de infrastructuur. Ten tweede ziet dit orgaan toe op de wijze waarop de operationele beheerders hun infrastructuur beheren. Concreet verwacht Nozema van zo'n zelfstandig bestuursorgaan, dat het de volgende taken uitvoert: "a. Ontwikkelen van een beleid voor frequentiebeheer dat recht doet aan de verschillende deelbelangen, maar bovenal gericht is op het allgemeen belang. Daarvoor ontvangt het richtlijnen van de overheid; b. O.b.v. het beleid ontwikkelen wan procedures en criteria voor de bestemming en de toewijzing van delen van het frequentiespectrum. Deze procedures zijn openbaar en inzichtelijk voor de betrokken partijen; $c$. Periodiek (doen) uitvoeren van onderzoek naar efficiency van ethergebruik en naar verwachte ontwikkelingen van vraag in de markt; d. Jaarlijks opstellen van een te publiceren plan met overzichten van de feitelijke benutting van frequenties, de besluiten over bestemming en toewijzing, de relevante technische en maatschappelijke ontwikkelingen en de indicaties voor het beleid op langere termijn; e. Opstellen van instructies voor het internationale overleg over bandtoewijzing en verwerken van de resultaten van dit overleg in het nationale beleid van het bestuursorgaan; en f. Jaarlijks met de operationele beheerders evalueren van de feitelijke benutting van frequenties." 87

Kortom, zowel de vergunningwerlenende taak als de handhavende taak kunnen - onveriet het milieurecht waar, als vermeld, een scheiding tussen vergunningverlening en handhaving kennelijk oplossing kan bieden ${ }^{88}$ - dus samen op de schouders van een zelfstandig bestuursorgaan gegooid. Beide zijn extern te verzelfstandigen. Voorwaarde daarbij is wel dat de verschillende functies binnen zo' $n$ extern verzelfstandigd orgaan worden gescheiden. Zo is het aan te bevelen binnen een en het zelfde orgaan bevoegdheden, taken en

87. Nozema, Van beheer naar beleid, Toewijzing en gebruik van etherfrequenties in Nederland, aprill 1993 , Zoetermeer, pp.15-17.

88. Overigens is deze gedachte geen gemeengoed. F. ten Cate, Friese milieuambtenaren worden nog klontwriendeliker; Provincie, gemeente, waterschap in een milieudienst, in: $\mathrm{BB}, \mathrm{nr}, 13,31$ maart 1995 , beschrijft de inferessante situatie in Friesland, dat de grootste provinciale milieudienst heeft, als wolgt. Ir het verlengde van de Wet Milieubeheer die integrale milieuvergunningen voorschrijft, presenteert de provincie Friesland in mei 1995 de Nota Nuthegraal Vergunuingenbeleud. Uit de nota spreekt klantgerichtheid: bedrijwem, die zich coöperatief opstellen bij vergunnimg werlening en zich actief inzetten voor millewbeleid door introductie van een bedrijfsintern millieuzorgsysteem, worden 'volwassen benaderd' en krijgen een 'dunne vergunning". Kortom, als zil hun eigen verantwoordelijkheid serieus nemen, worden ze minder op de huid gezeten. Achterliggende gedachte is dat vergunningverlening niet top-down is (met "stropersgedrag" als gevolg), maar een "wederkerig proces" is. De plannen verwoord in de nota moeten stroken mat de voornemens die sprekem uit de notitie Tuskenspul. Daarin wordt, als uitwloeisel wan bestuurlijke vernieuwing, voorgesteld te komen tot éen, aan kwaliteitsborging onderworpen, zelfstandige milieuadviesdienst waaraan de Friese provincie en gemeenten hun vergunningverlenings-en luandhavingstaken delegeren. Omdat privatisering als te ver gaand wordt beschouwd, krijgt verzelfstandiging voorkeur. 
verantwoordelijkheden te ontvlechten. Separate segmenten moeten zich daarom bezig houden met alleen vergunningverlening, enkel toezicht op de naleving van de vergunning(svoorwaarden), puur boeteoplegging, of een andere taak als formulering van handhavingsbeleid(sregels). Hierbij geldt wel dat, hoewel de verschillende clusters binnen een zelfstandig bestuursorgaan afzonderlijk zijn te herkennen, de te onderscheiden taakeenheden met elkaar noodzakelijkerwijs samenwerkings- en overlegverbanden aangaan en intensief onderhouden.

\subsubsection{Zelfhandhaving}

Door zelfstandige bestuursorganen met handhavingstaken op afstand te zetten van departementaal Den Haag, komen deze verzelfstandigde entiteiten dichter bij de burger. Veel zelfstandige bestuursorganen belast met rechtshandhaving geven burgers, die initiatieven ontplooien om naleving van wet- en regelgeving te stimuleren, redelijke ruimte tot zelfregulering. Daar waar deregulering dood spoor blijkt, staat zelfregulering mogelijk garant voor vitale normstelling (en afdwingbaarheid daarvan).

Dergelijke, in de moderne 'checks and balances' zich een passende plaats aan metende, zelfregulering kan het kader voor convenantworming ${ }^{89}$ zijn. Daarmee krijgt de eigen verantwoordelijkheid van justitiabelen dynamisch gestalte. Het "verantwoord burgerschap' kan ook anders worden ingevuld. Denk onder meer aan het invoeren van interne milieuzorgsystemen of bedrijfssystemen ${ }^{90}$, het stellen van financiële zekerheden, het aanvaarden van risico-aansprakelijkheden (en het daartegen verzekerd zijn ${ }^{\text {s1) }}$ ) of het op zich nemen van zorgplichten. Overigens zijn deze invullingen van burgerlijke verantwoordelijkheid tegenwoordig niet altijd meer vrijwillig en facultatief. Zekere zorgplichten zijn niet uit vrije wil te aanvaarden, maar moeten worden geaccepteerd. Duidelijker voorbeeld dan de milieurechtelijke zorgplicht is er niet.

Hoewel zelfregulering niet de vrije loop mag krijgen, en zij zeker ook negatieve kanten heeft ${ }^{2}$, kan zij zinvol ten dienste zijn bij activiteiten als keuring, inspectie, toezicht, opsporing en sanctionering. Zelfregulering is bij uitstek geschikt voor terreinen van rechtshandhaving. Zij kan in het bijzonder haar waarde bewijzen bij kwaliteitscontrole (als een the onderscheiden vorm van rechtshandhaving).

89. Een convenant draagt mogelijk ook namen als memorandum, intentieverklaring, akkoord, meerjarenafspraak.

90. Hierover met name Notitie bedrijfinterne milieuzorg. TK 1988-1989/1993-1994, 20633, nirs.1-3/5.

91. "Ook het aansprakelijk stellen van de vervuiler is belangrijk, vooral in de preventieve sfeer. Dit kan bij voorbeell door bedrijven een verplichte verzekering tegen milieuschade op te leggen, zondier wellke zij bij voorbeeld door de Kamer wan Koophandel en fabrieken niet worden ingeschreven." Ministerie van verkeer en waterstat, Citaten uit interviews' met sleutelfiguren in het kader van het project Naleving, 'sGrawenhage, augustus 1992, p.27.

Zelfregulering werkt wel eens protectionisme in de hand. Vooral als sprake is van prijsbinding. Hiermee ondermijnt zij v rije concurrentie. Daamaast biedt zij de markt somas oneigenlijke bescherming door interne coöperatie en externe repressie. 
Het particuliere bedrijfsleven stelt zelf, vaak tuchtrechtelijke, regels op. Voorkomen moet natuurlijk wel dat het bedrij fsleven zich met de eigen regels boven de eigenlijke wet stelt. Meer dan eens wordt bij zelfregulering voorzien in vormen van controle door de doelgroep zelf. Met andere woorden, de onder toezicht gestelden controleren bun eigem produkten en doen daarvan melding aan de betrokken toezichthoudende autoriteit. Deze vorm van zelfhandhaving komt frequent voor bij bedrijven onder het regime van verschillende landbouwkwaliteitscontrole-instellingen.

Bij de uitvoering van het landbouwbeleid en de naleving van het toezicht op landbouwkwaliteitscontrolewet-en regelgeving staat zo het Integrale-Keten-Zorg-systeem centraal. Dit bedrijfsinterne zorgstelsell vindt basis in bepaalde ISO-normen. Daarmee worden hier bedoeld de basiswoorwaarden inzake de inrichting en de werking van een bedrijf, die vooral met oog op derden waarborgen dat het bedrijf in staat is de overeen gekomen kwaliteit te leveren. ${ }^{93}$ Voldoet een bedrijf aan dergelijke voorwaarden van onafhankelijkheid, onpartijdigheid, deskundigheid en (betaalbare) kwaliteit van dienstverleming, dan kan aanspraak op (kwaliteits)certificering worden gemaakt. Invoering van kwaliteitssystemen is hoogst actueel, de consument vraagt in de huidige economie om kwaliteit, de tegenwoordig krachtige concurrentie noodzaakt tot een voortdurend kwaliteitsstreven, en de interne bedrijfsorganisatie vraagt om de indringende impulsen van kwaliteitssystemen. ${ }^{94}$ Het breder toepassen van kwaliteits-, produkt- en dienstverleningcertificatie ter rechtshandhaving, met een terug tredende overheid die minder regels stelt ${ }^{95}$ als leidraad, is zinvol en zelfs raadzaam. ${ }^{96} 97$

93. Dit zijn met name de minimumeisen van de ISO-9000-5erie. Deze woorwaarden dienen ter kwaliteitswaar-

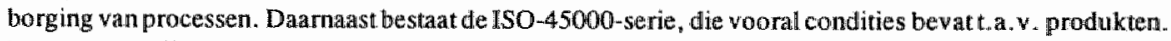
En ten slotte zijn er kempunten van kwaliteitsgarantie m.b.t. te verlenen diensten. In de landbouwkwaliteitssector ligt de nadruk op kwaliteitscertificering van in het bijzonder processen en zijidelings daarvan produkten.

94. P. Noordhoek, Morieven voor kwaliteif (1); De sprong van bedrijfsleven natar overheid, in: $\mathrm{OB}, \mathrm{nI}$. 1 , 1995, pp. 13-16. De auteur ondersche dd de volgende kwaliteitssystemen: a. resultamtgericht (de sy stemen die werder gatan dan de ISO-9000-systemen); b. procesgericht (de ISO-9000-systemen); en $\mathrm{c}$. attitudegericht (de integrale kwaliteitszorg met relationele intentie van werknemers, organisatie en maatschappij); P. Noordhoek, Motieven woor kwalifeit (2): motieven voor de overheid, in: OB, nr.2, 1995, pp. 15i-18, i. h. b. p. 16, stelt onomwonden dat zonder kwaliteitssysteem geen sprake kan $z$ ijn van geslaggde verzelfstandiging: Vervolgens constateert P. Noordhoek, Morieven woor kwaliteit (3); Kwaliteil voorbij wet en: regel, in: OB, ar. 3, 1995, pp. 20-23, dat het voordeel van een kwaliteitssysteem, i.t.t. een wettelijk systeem, ligt in haar preventieve gerichtheid. Mar voor het werkelijk benutten van de dynamiek die kwaliteitshandvesten in eet overheidsorganisatie kunnen brengen, is het noodzakelijk zelfregulering numte te geven mell als logische consequentie dat de formele wetgever een stap terug moet doen.

95. Van uir dit geaichtspunt bespreekt H.A.M. Backx, Normalisatie en certificering als alternatieven voor en in wettelifke regelingen, in: RegelMaat, nr.3, 1995, pp.89-100, woor-en nadelen van zelfregulering en zelfhandhaving.

96. Conmissie-Kortmann, Van keursliff naar kewrmerk, wetgevingsbeleid voor weilig en gezond werk, 1994.

97. Wil certificatie slagen, dan moet zij de concurrentiepositie van Nederlland niet aantasten. Daaraan heeft de overheid bij te dragen. Zij moet aamwaarden dat zij "slechts" een eindverantwoordelijkheid heeft in de $z$ in dat zij voldoende randwoorwaarden aan certificatie stelt en daarop toezicht houdit. Kwaliteitskeuringen. en -inspecties e.d.. moet zij darbij overlatem aan particuliere instellingen, die zij daartoe bij voorkeur aanwijst (walardoor zij, als handhavingswoordeel, de mogelijkheid heeft de aanwijzing in te trekken). 
Bij het enthousiast toepassen van certificatiesystemen met een overheid op afstand, als volwaardig alternatief voor direct overheidstoezicht, worden wel de volgende vraagtekens gezet. ${ }^{98}$ Ten eerste, bij het overlaien van handhavingstaken en -bevoegdheden aan vooral deskundige private partners, loopt de eigenlijke overheid het risico dat zij in hoog tempo aan eigen kennis en expertise verliest. Daardoor wordt het voor de overheid steeds moeilijker de totale certificatieprocedure op effectiviteit, efficiëntie en rechtmatigheid te beoordelen. Ten tweede, bij gebruik van certificatie als toezichtsinstrument bestaat het gevaar dat de overheid feitelijk geen greep heeft op een bepaald terrein. Al met al blijft het belangrijk de, juist bij gedetailleerde, technische en statische wet- en regelgeving mogelijk essentiële, rol van normalisatie, accreditatie en certificatie in nationaal geïniteerd wetgeving- en handhavingsproces af te bakenen. ${ }^{99}$

De landbouwkwaliteitscontrole-instellingen, die in 1995 allemaal erkend worden als kwalliteitsgaranderende certificatie-instellingen ${ }^{100}$, benadrukken standaardisering van inspectie- en controlemethoden. Hiervan getuigen bij voorbeeld de standaardinspectieverslagen. Relevante onderdelen van een transparant toezichtsstelsel, waarin leerzame terugkoppeling van beleidsuitwoering naar beleidsbepaling centraal staat, zijn: interne controles via onder meer monsterneming en andere metingen, evaluaties, rapportages, monitorcontroles en audits (van welk accountantsonderzoek bij voorkeur openbaar ver-

97. $\rightarrow$

Deze aanwijzing mag dan weer niet discriminatoir zijn in de zin dat de overheid slechts aen beperku aantal instellingen aanwijst of dat zij certificatie-instellingen belast met zowel produkt-als kwaliteitssysteembeoordeling. De nota Normen, Certificaten en Open Grenzen, TK 1994-1995, 21670, nis. 7-8, p. 24, noemt dit als een wan de factoren die de concurrentie tussen keuringsinstellingen binnen Europa ondermijnen. Andere probleemfactoren zijn dan: "vrijwillige collectieve contracten (als ansluit-en leveringsvoorwaarden); functievermenging (een nationale instelling is zow el verantwoordelijk voor certificatie alls voor overheidstoexicht); keuze voor het bedrijfsleven voor een nationalle instelling van wege verwachte voordelen; kunstmatig lage tarieven woor keuringen door publieke instellingen; en directe of indirecte subsidiëring (als het gratis ter beschikking stellen van averheidsmedewerkers ana accreditatieof centificatie-instellingen)".

98. R. Vonk en P. Beljaars, Certificatie, een instrument van ees instrument op afstand ", in: $0 \mathrm{~B}, \mathrm{nr} .1,1995$, pp. 28-32, i.h.b. p.31.

Marknwerking, deregulering en wergevingskwaliteit, TK 1994-1995, 24036, nr. I p.12, belooft een, in het licht van uitvoerbaarheid en handhaafbaarheid wan wet- en regelgeving staande, inventarisatie van de nationale en Europese mogelijkheden tot certificatie als alternatief voor of ondersteuning van over heidsregullering .

100. Erkenning (door de Raad voor Certificatie, in wier bestuur de overheid overigens nog wel participeert zo dat de betrokken minister nog enige invloed uitoefent op de feittelijk private certificerende instanties, certificaatvoorwaarden en andere vormen van zelfregulering en -handhaving) als gecertificeerde $d . w . z$. geaccrediteerde instelling en ten gevolge van die erkenning tevens certificatie-ïnstelling, m.a.w. certificerende instelling, zijnde-geschiedt in principe voor een driejarige termijn. Deze beperking in de tijd makt duidelijk dat een dergelijke erkemning geen warborging voor altijd geeft. Het streven marar kwaliteitsverbetering mag niet in het slop raken, maar moet blijven. Dit geldt tevens voor het andiere niveau van certificaatwerlening (de als gecertificeerde zijnde instelling als toezichthouder kan, als gezegd, op eigen beurt weer aan bedrijven als werkuitvoenders allerlei certificaten afgeven), namelijk door de landbouwkwaliteitscontrolle-instelling aan een bij het landbouwprodukt zelf op enigerlei wijze betrokken priwat bedrijf. Ook hier geven $\mathrm{kwaliteitscertificaten,} \mathrm{hoewel} \mathrm{zij} \mathrm{werder} \mathrm{gaan} \mathrm{dan} \mathrm{de} \mathrm{klassieke}$ werguinningen, geen volkomen wribbrief. M.V.C. Aalders, Handhaving en zelfregulering: Milteurech in bedrijiven, in: JV, nr.9, 1994, pp.47-69, i.h.b. p.62, stelt woor op dit niveau te komen tot een "nieuwe vergunningsvorm met flexibele normen en doelschriften" 
slag wordt gedaan). ${ }^{104}$ Het hameren op publikatie van resultaten is mede bedoeld om ondernemingen serieus wérk te laten maken van een bedrijfsintern kwaliteitszorgsysteem. Het mag geen vormloos visitekaarije zijn. Het risico dat dát gebeurt is trouwens niet reẽel aanwezig, omdlat het strafrecht natuurlijk altijd haar schaduw kan werpen op, succes ontberende, zelfregulering en -handhaving. Als aanwulling en, in het ergste geval, als ultimum remedium ${ }^{102}$. $^{103}$

Analoog aan het milieurecht, waar zowel theorie als praktijk zelfregulering en zelfhandhaving gestalte geven, kan voor andere rechtsterreinen worden geredeneerd.. De handhaving van het milieurecht getuigt van aansluiting bij de eigen verantwoordelijkheid van betrokken bedrijven en burgers. De, bij de voorgenomen uitbreiding van de Wet milieubeheer voorgestelde, milieuverslagleggingsplicht is daarvan duidelijk voorbeeld. Zelfregullering en zelfhandhaving staan hier zelfs zo sterk op de voorgrond, dat het de vraag is of "niet een koekoeksei in het nest van de burger wordt gellegd". ${ }^{104}$

De terugtred van de overheid als handhaver van vermelde verplichte verslaglegging in het milieurecht kent kanttekeningen, "die prangerder worden nu de overheid ernst lijkt te maken bij het afstoten of afslanken van haar taken, zeker als dat typische overheidsta-

101. Bij zelfhandlhaving wordt wrijwillig owergegaan tot ananwending van deze middelem. Het gebruik er van komt een bedrijf waarschijnlijk alleen maar ten goede. Vraag is of een bedrijf tot gebruik van dergelijke methoden (kort gezegd: tot het inwoeren van een bedrij(sintern zorgsysteem) ook kan worden verplícht. Mogelijk is dit verdedigbaar van uit de wettelijke zorgplichtbepalingen. Andere vraag is of de witkomsten, van een door een bedrijf zélf uitgevoerd technisch onderzoek (denk aan monsterneming en analyse), een rol moeten spelen in een eventueel strafproces. De terugkoppeling van dergelijke technische gegevens van beleidsuitwoerder naar beleidsbepaler is muttig en toegestaan. Het doorspelen van technische infornatie is ook bruikbaar, maar minder geoorloofd gegeven het nemo tenetur-beginsel. Hie rover wragt M.V.C. A.lders, Handhaving en zelfregulering: Milieurecht in bedrijven, in: JV, nu, 9, 1994, pp.47-69, i.h.b. pp.53-54, alert aandacht. Auteur refereert hierbij anan L. E.M. Hendriks, Techniek en normstelling in het milieustrafrecht, Zwolle, 1994

102. G.A.A.I, wanden Heuwel, Onderhandelen of straffen, Over organisatie-criminaliteit en overheidscontrole. Amhem, 1993, pp.87-89 wijist op de interessante essentie van strafrecht als stok achter de deur. Auteur vindit repressief strafrecht, gegeven het gevaar van collusie, noodzakelijk naast het fraaie, op preventie gerichte, coöperatieve controlemodel. Duidelijker, dan als volgt, kan het bijna niet wonden gesteld (p. 152): "In een sannenleving waarin coôperatieve regelgeving en controlle dominant zijn, is het repressieve model niet alleen een ulcimum remedium tegen onwillige bedrijven of organisaties, het is et ook de belangrijkste objectieve controleur van de controleurs."

103. W. Huisman, A de Lange en E. Niemeyer, Milieucriminaliseit vergt hawdhaving op maat, in: JW, nr. 9 . 1994. pp.26-46, beschrijven, specifiek wat betreft milieurecht, hoe bedrijfsinterne zorgstelsels een zinvolle bijdrage kunnen leveren aan de terecht te prefereren "responsieve handhaving" (dat is de "hand. having op maat", die het midden houdt tussen respectievelijk 'coöperatieve' en 'punitieve' handhaving). Interessant is dat, als uiteindelijk inderdaad het openbaar ministerie wordt ingeschakeld, het mogelijk is te komen tot een schikking met de betrokken regelovertreder onder de voorwaarde dat deze zijn bedrijf op eigen kosten laat doorlichten door een extern bureau op in casu milieuaspecten en dat de pers de resultaten daarvan, na verkregen informatie van in elk geval het auditcomité en het openbaar münisterie, bekend maakt. Auteurs refereren voor deze casus naar de zaak-Kole, als verwoond in: Handhaving, maart/april 1994. p. 18

104. R. van Gestel en J. Verschuuren, Milieuverslaglegging en (zet)handhaving." een ovum nowum in de Wet milieubeheer, in: RegelMat, nr.6. 1994, pp.219-226. 
ken zo als de handhaving van (milieu)wetgeving gaat betreffen". ${ }^{105}$ De eerste kritische noot treft dan ook dat de bescherming van natuur en milieu als algemeen belang naar aard een grondwettelijk gewaarborgde, uitgesproken owerheidstaak is. Slechts de overheid heeft de dwingende middelen en het legitiem gezag om toe te zien op de naleving van milieuwet- en regelgeving. Daardoor geeft de overheid aan haar zorgplicht uitvoering. Alleen als overheidsregulering en -handhaving te wensen over laten, bestaat ruimte voor zelfregulering en -handhaving. De tweede kanttekening heeft een, minder fundamentele, praktische achtergrond. Het overlaten van handhaving aan, al dan niet georganiseerde, private partners is onwenselijk als daardoor geen structureel handhavingsbeleid van de grond komt. Ook moeten de tegenwoordige hoge griffiegelden, de van oudsher verplichte proceswertegenwoordiging in civiel geding en andere procesrisico"s voor particulieren niet worden onderschat. Hierdoor kan adequate handhaving worden belemmerd. Boven" dien bestaat bij doelgroephandhaving het gevaar van incompleetheid doordat de betrokken bedrijfstak geen hoge organisatiegraad kent. Ingrijpen van overheidswege is dan eigenlijk onontbeerlijk. De overheid kan hier faciliterend optreden door bepaalde met de doelgroep overeengekomen afspraken algemeen verbindend te verklaren woor bepaalde bedrijfstakken. ${ }^{106}$ Naast deze faciliterende rol van de overheid als het gaat om toezicht en andere handhaving, manifesteert de kennelijk nog noodzakelijke actieve overheidsparticipatie op het gebied van handhaving zich in het volgende. De overheid moet bereid en in staat zijn in individuele gevallen handhavingsacties te initiëren tegen: a. niet-georganiseerde bedrijven die zich van een algemeen verbindend verklaring niets aantrekken of b. georganiseerde bedrijven die binnen het door het bedrijfsleven opgezette handhavingssysteem niet of onvoldoende aan de invulling van hun zorgplicht worden gehouden. Bij zelfregulering is her, als de overheid toch te hulp wordt geroepen voor het algemeen verbindend verklaren wan doelgroepregelingen, zelfs denkbaar dat niet de bedrijfstak zelf maar de overheid toeziet op convenanten. ${ }^{107}$

Al met al kan zelfregulering het tij keren. Regels, uit te vaardigen door de eigenlijke wetgever, zijn te reduceren, voorlopig ter zijde te leggen of tijdelijk uit te stellen.

106. Een bekende generale avw-bevoegdheid ligt besloten in art. $6: 214 \mathrm{BW}$.

Bij deze door hun gestelde kanttekening refereren R. van Gestel en J. Verschuuren, L.a.p., p.226, aan de noodzakelijke hand having van het milieuverslag. Auteurs vindien deze verslag verplichting, voortikomend uit zelfregulering, niet vatbaar voor zelfhandhaving. Voor het betrokken bestuursorgaan is het milieuverslag een onmisbare steun bij de, op het orgaan rustende, plicht milieuvergunningen te beoordelen op actualiteit en relevante regels te handhaven. Auteurs pleiten er voor om de milieuvergunning en het milieuverslag beter te koppelen. Deze relatie is te realiseren door bij voorbeeld het opstellen "wan een milieuwerslag (op onderdelen) verplicht te stellen in vergunning voorschriften" (p.222). De beoogde samenhang biedt het voordeel dat de gewone handhavingsbepalingen van hoofdstuk 1.8 Wet milieubeheer

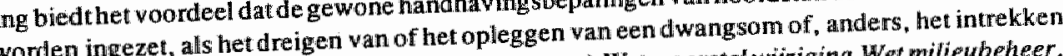
van een verleende vergunning: Zie inzake milieuplan(bureau) Wetsvoorstel wijziging Wet milieubeheer, TK 1994-1995, 24031, nrs. 1-3.

Omgekeerd zijn regels, bij wege van anticipatie, woor een bepaalde periode al wast in te voeren middels convenantvorming. Hier kan het opstellen van convenanten oplossing bieden voor de vaak trage imple mentatie van Europese tichtlijnen. Bij dergelijke zelfregulering, in afwachting op definitieve wetgeving 
Het succes van zelfregulering zit vooral in haar snelheid en flexibiliteit, welke aspecten aantrekkelijk zijn in geval van nog voortdurend in beweging zijnde, dynamische juridische deelterreinen. Zelfregulering scoort door het zicht op het werkveld. Belanghebben den, die zelf vaak de vereiste deskundigheid in huis hebben, werken invloedrijk mee aan het opstellen wan 'eigen' regels. Zeer waarschijnlijk zien zij dan ook de zin in van naleving van regels. Dat is belangrijk. Want zelfregulering gaat heel vaak hand in hand met zelfhandhaving. Het lijkt bijna een probleemloos plaatje.

Niets is minder waar natuurlijk. Bij zelfregulering wordt het probleem van het moeillijk tot onderlinge overeenstemming komen zichtbaar, waardoor haar karakter van snelheid aan waarde inboet. ${ }^{109}$ Is het niet, de grootste schreeuwer zijn zin? Bovendien, de rol van de overheid is niet altijd even duidelijk. Laat staan de positie van derden-belanghebbenden, die meestal niet bij de -toch al niet openbare, dus formeel ondemocratische maar feitelijk vaak wel met parlementaire betrokkenheid vooraf tot stand komende- onderhandelingen worden betrokken. ${ }^{110}$ Het komt voor dat convenanten te vaag zijn, maar ook dat ze te gedetailleerd zijn en daardoor flexibiliteit missen. Soms ontbreken zinvolle sanctiemogelijkheden, soms zijn speciale sanctietoepassers te sterk financieel gebonden aan de zelfregulerende belanghebbende bedrijven ${ }^{11}$. En meer dan eens werkt controle

108. $\rightarrow$

zijn weelal toezichthoudende zelfstandige bestuursorganen, die immers belast zijn met regelhandhaving (en soms zelfs met overgedragen regelstelling), nauw betrokken. Zo doende biedt functioneel bestuur, door de mangel genomen, meer nuimte voor implementatie dan territoriaal bestuur.

109. Dit is een van de vier correcte criteria, die M. Pleijte en B. Wan Geleuken, Het miliewconvenant: Goede woornemens, slechte resultaten, in: JV, nr.9, 1994 , pp.83-94, i.h. b. pp.86-89, noemen om resultaten wan (milieu)convemanten aan af te meten: a. duidelijkheid (probleernfactoren zijn soms abstracte beginselverklaringen en vage, miet te kwantificeren, resultaats- of zorgverplichtingen); b. samenhang (integraal beleid komt snel in de knel als bedrijfstakken, elk voor zich, tot convenantvorming komen); $c$. tijdwinst (voordat een convenant reel gestalte heeft is de klok vaak behoorlijk vender gedraaid, daarnast hebben comvenanten meestal middellange levensduur waardoor de evaluatie er van ongelukkigerwijs even op zich laat wachm; en d. duurzaamheid thet inefficient benaidnuken in convenanten van een produkt of een produktieprocestechniek kan duurzame industrie in de weg staan). Ad $\mathrm{c}$ : het verlies van tijdswinst kan worden geillustreetd aan de hand van het pijnlijk langdurig voorbereiden van bepaalde gedragscodes waarvoor de Registratiekamer een werklaring van genoegzaamheid moet afgeven. Ad d: bij keuringsinstellingen als de landbouw $\mathrm{k}$ waliteitscontrole-instellingen is hier, door de toenemuende aandacht voor compleet kwall itatief ketenbeheer en integrale interne zorgsystemen, een positieve ontwikkeling waar te nemen.

110. G.A.A.J. van den Heuvel, Convenanten in de Nederlandse overlegeconomie, in: JV, nr.9 1994, pp.925, i.h. b. pp. 15-16 tekent hierbij terecht aan, dat parlententaire controle bij convenanten (welke controle futeur, in enen overlegeconomie met de blijende dreiging van collussie, overigens well functioneel acht) niet noodzakelijk is:". een convenant is immers geen daad van wetgeving. Het probleem dat derdenbellanghebbenden zich in toenemende mate niet kunnen beroepen op juridische afdwingbaarheid van waak vage convenanten net slechts inspannings-of resultaatverplichtingen vindt auteur te recht schrijnender; Juist in dit opzicht kunnen toezichthoudende verzelfstandigde entiteiten nut bewijzen. Hierbij: is te refereren aan het toezicht wan de Registratiekamer (in de vorm vam een verklaring van genoegzaamheid), op het opstellen van, weliswaar noodzakelijkerwijs met de Wpr overeenstemmende, zelfregulerende gedragscodes.

111. Denk aan controlebureaus van de effectenbeurs die, al dan niet in opdracht van de STE, wezicht houden op de beurs. Hun geldelijke afhankelijkheid van de beurs kan hen behoorlijk blind maken voor optimalle uitoefening van hun controletaken. 
op basis van convenanten kostenverhogend. Dit is vooral het geval als het convenant verplicht tot certificering.

De voor- en nadelen tegen elkaar afwegende kan de conclusie eigenlijk niet anders zijn dan dat het, bij het verzelfstandigen van handhavingstaken met behulp van een convenant, belangrijk is dat sprake is van wettelijk geconditioneerde zelfregulering.

\section{$\$ 20.4$ Treden van toezicht}

Bij een studie, verhandelend over toezichthoudende zelfstandige bestuursorganen, is het inderdaad relevant zich de inhoud van rechtshandhaving te realiseren. Meer omlijnd nog, duidelijk moet zijn welke gedaanten handhaving, in het bijzonder van het type toezicht, kan aannemen.

Toezicht bevindt zich, globaal genomen, tussen voorlichtingsactie, verbodsuitvaardiging, vergunningintrekking en vrijheidsstraf. Voor deze studie is het onvermijdelijk het toezicht terminologisch te traceren. Kortom, het toezicht toegellicht.

\subsubsection{INSPECTIES INGEDEELD VOLGENS ALGEMENE REKENKAMER}

Ten behoeve van een onderzoek naar - voornamelijk coöperatief ingestelde, preventief toezichthoudende en bestuursrechtelijk sanctionerende - inspecties op het gebied van wetgeving die randvoorwaarden stelt aan het maatschappelijk verkeer maakt de Algemene Rekenkamer onderscheid tussen uitwoering en handhaving van wet- en regelgeving. Uitvoering en handhaving betreffen respectievelijk "de bestuurlijke toepassing van weten regelgeving" en - à la Duk - "het zorg dragen voor de naleving van rechtsregels voor zover die zorg bestaat uit hetzij het uitoefenen van toezicht, hetzij het toepassen van sancties "', ${ }^{112}$

Bij de door haar geselecteerde inspecties splitst de Algemene Rekenkamer het inspectiewerk naar de volgende taken uit. ${ }^{113}$ Ten eerste, toezicht op de naleving van wet- en regelgeving. Dit is het controlewerk dat mogelijk leidt tot: a. voorlichting, advies, overleg, bemiddeling, eis tot naleving en dergelijke; b. het toepassen van bestuursrechtelijke sanctiesalsbestuursdwangtoepassing, inrichtingsluiting, dwangsomoplegging, vergunningintrekking en bestuurlijke boeteoplegging; en c. het opsporen van strafbare feiten. Ten tweede, medewerking aan de uitwoering van beleid. Hiertoe behoren onder meer: vergunningverlening, certificaatafgifte, keurmerkuitreiking en registeractualisering. Ten derde, beleidsrapportage aan het departement. Dat houdt in het, all dan niet met een adviserende of evaluatieve intentie, mondeling of schriftelijk informatie verstrekken aan een betrokken minister of een van zijn ambtenaren. Naast deze drie hoofdtaken, is er een vierde verzamelcategorie taken. Daaronder vallen onder andere: ongevallenanalyse, internationaal overleg, klachtenbehandeling en de medewerking aan beleidsontwikkeling.

112. Algemene Rekenkamer, Verslag van de Algemene Rekenkamer over 1989. TK 1989-1990, 21.481, nrs.12. p. 30 .

113. Algemene Rekenkamer, Verslag wan de Algemene Rekenkamerover 1989, TK 1989-1990, 21481, , 1 rs.1$2 ., 40$. 
Kritiek op deze indeling is afkomstig van ministeriële zijde. De minister van landbouw, natuurbeheer en visserij spreekt van een 'tamelijk gekunsteld' onderscheid. Het commentaar krijgt onderstreping via het voorbeeld van de Rijksdienst voor de Keuring van Vee en Vlees. "De activiteiten van deze dienst betreffen hoofdzakelijk de keuring en controle van bedrijven, dieren en produkten van dierlijke oorsprong. Daarbij is er geen essentieel onderscheid tussen bij voorbeeld intrekking van een erkenning (in de terminologie van het onderzoek "toezicht op naleving') en het onthouden van een certificaat als niet aan de voorwaarden is voldaan (in de terminologie van het onderzoek 'meewerken aan uitvoering')." $114 \mathrm{Na}$ ampele overweging walt te constateren dat deze kritiek tevens opgaat voor bij voorbeeld de privaatrechtelijke landbouwkwaliteitscontrole-instellingen. Ook daar maakt de indeling van de Algemene Rekenkamer kortsluiting.

Zuiver beschouwd, is natuurlijk alleen sprake zijn van toezicht als enkel toezicht wordt uitgeoefend.

Met toezicht wordt formeel dan niet bedoeld opsporing in het licht van strafrechtelijke vervolging en ook niet medewerking aan uitwoering van wet- en regelgeving. Denk aan het - al dan niet tegen betaling, gedeeltelijk, tijdelijk, voorwaardelijk, of het in ander opzicht aan beperkingen blootgestelde dan wel aan voorschriften gebonden - verlenen, wijzigen en intrekken van vergunningen, erkenningen, ontheffingen, vrijstellingen, licenties, concessies, verklaringen van geen bezwaar en dergelijke. Toezicht omvat in deze strikte opvatting evenmin de feitelijke afgifte van keurmerken en dergelijke. Voorop gesteld, deze mening is inderdaad het meest te verantwoorden. In deze studie wordt, ter bevordering van de inzichtelijkheid van de betreffende juridische materie en sector, toezicht op naleving van het gestelde bij of krachtens wet echter in een breder perspectief gezet.

\subsubsection{TOEZICHTHOUDENDE ZELFSTANDIGE BESTUURSORGANEN OP EEN RIJ}

Het onderzoek van de Algemene Rekenkamer inzake inspecties heeft voornamelijk betrekking op gedeconcentreerde diensten. Een aardige analogie met de in deze studie centraal staande zelfstandige bestuursorganen is zeker mogelijk. Maar goed in het oog moet worden gehouden dat hier alleen gedecentraliseerde, en dan wel functioneel gedecentraliseerde, toezichthouders onderwerp van onderzoek zijn.

Om voor te stellen waaruit die wereld van toezichthoudende zell fstandige bestuursorganen bestaat is het nuttig een, overigens niet compleet, maar wel voldoende indicatief, overzicht te geven van bestaande functioneel gedecentraliseerde toezichthouders. Verfrissend daarvoor is een duik in de officiële catalogus van toezichthoudende zelfstandige bestuursorganen. Uit de, tegenwoordig in de staatsalmanak als register vermellde, lelijk lekkende lijst van zelfstandige bestuursorganen kunnen toonaangevende toezichthouders boven water worden gebracht.

114. Algemene Rekenkamer, Verslag wan de Algemene Rekenkaner over 1989, TK 1989-1990, 21481, nrs.12. p. 47 . 
Deze lijst vindt basis in, ten eerste, de formele registratie van zelfstandige bestuursorganen die in de meer recente Staatsalmanakken (onder onderdeel Z) is terug te vinden en in, ten tweede, de optekening van zelfstandige bestuursorganen door de Algemene Rekenkamer ${ }^{115}$. De zbo-aanduiding impliceert trouwens niet dat in alle gevallen sprake is van zuivere zelfstandige bestuursorganen. In het bijzonder (vaak feitelijk taakverrichtende) onafhankelijke inspecties of certificatie-instellingen, die zich bezig houden met het keuren, herkeuren, classificeren e.d. van gevaarlijke werktuigen, is het opplakken van een zbo-etiket niet direct het meest voor de hand liggend. Geconfronteerd met de (anders dan bij voormalige overheidsinstanties die na verzelfstandiging onwennig als semi-overheidsbedrijf op de markt worden gegooid) van uit het verleden reeds bestaande en nu nog toenemende commerciële werkwijze van dergelijke, meestal particuliere, instanties is het zo dat deze zelfstandige keuringsinstanties meer en meer aanspraak maken op aanwijzing als 'notified body". Deze benaming brengt met zich mee dat door de instellingen afgegeven controle- of keuringsverklaringen geldigheid bezitten binmen alle Europese lidstaten.

Alfabetisch worden wel als, meest bekende, toezichthoudende zelfstandige bestuursorganen aangeduid:

het ASB Europe LTD (belast met: classificatie);

het Bedrijfsfonds voor de Pers (belast met: financiële steunverlening en het toezicht op gestelde voorwaarden bij steunverlening);

de (besturen van) bedrijfsverenigingen bij voorbeeld die voor Haven- en aanverwante bedrijven, Binnenscheepvaart en Visserij;

het Bestuur van de stichting Algemeen Bureau voor Ongevallenpreventie en Materiaalzaken;

het bestuur van de Stichting Keur Alternatief voortgebrachte Landbouwprodukten; de stichting Bloembollenkeuringsdienst;

het Bureau Veritas (belast met: het verrichten van keuringen en typekeuringen, en het classificeren van schepen en offshore installaties);

de stichting Centraal Bureau Rijvaardigheidsbewijzen (belast met: het afgeven van theoriecertificaten, van bewijzen van rijvaardigheid en van verklaringen over de lichamelijke en geestelijke geschiktheid);

de stichting Centraal Orgaan voor Kwaliteitsaangelegenheden in de Zuivel;

het College van Toezicht Sociale Verzekeringen (vór 1 januari 1995 was dit de Toezichtkamer van de Sociale Verzekeringsraad);

het College ter beoondeling van geneesmiddelen (belast met: de registratie van farmaceutische specialités/preparaten, de schorsing en de doorhaling van die registratie);

het Commissariaat voor de Media (belast met: het toezicht op Mediawet- en regelgeving, het financieel toezicht, als mede het verlenen vergunningen en concessies);

de commissie voor gebiedsaanwijzing (belast met: de verlening van de vergunning tot. uitoefening van de artsenijbereidkunst, ook aan niet-apotheekhoudende geneeskundigen);

115. Algemene Rekenkamer, Verslag 1994, deel 3: Zbo's en ministeriële werantwoardelijkheid, TK 19941995,24130, nr.3, pp. $65-80$. 
de commissie voor de samenstelling van de rassenlijst voor landbouwgewassen/groentegewassen/fruitgewassen/siergewassen/bosbouwgewassen (belast met: het aanhouden wan aanbevelende rassenlijsten voor landbouwgewassen waarop rassen en andere groepen van planten met rubricering en beschrijwing worden vermeld waarvan de teelt in Nederland van belang wordt geacht, en het beslissen over opneming in bindende lijst van toelating tot handelsverkeer in Nederland);

de stichting Controllebureau voor Pluimvee, Eieren en Eiprodukten;

de coöperatie Coöperatieve Centrale Raiffeisen-Boerenleenbank BA;

de Nederlandsche Bank nv (belast met: het monetair-, solvabiliteit-, liquiditeits-, administratief- en structuurtoezicht op kredietinstellingen);

de Det Norske Veritas (belast met: het verrichten van keuringen en typekeuringen);

de Dienst voor het Kadaster en de Openbare Registers (belast met: de regüstratie van de rechtstoestand en de geldigheid van onroerend goed - hypothecaire en kadastrale boekhouding - en de dienstverlening ter zake aan overheid en maatschappij; het verzamelen en verstrekken van gegevens ten behoeve van ruimtelijk beheer en ruimtelijke ordening, het aanhouden van openbare registers van schepen, luchtvaartuigen en landinrichting, het verzorgen van vastgoedinformatie in de vorm van openbare registers, vastgoedsystemen en topografische kaarten);

de Dienst wegverkeer;

de Germanischer Lloyd (belast met: het verrichten van keuringen, typekeuringen en herhalingskeuringen in de vorm van intermediate and repeatsurveys);

de herkeuringscommissie Arbeidsomstandighedenwet (belast met: de behandeling van verzoeken om herkeuring);

het Instituut voor Milieu- en Agritechniek;

het Instituut voor Onderzoek van het Onderwijs (belast met: de evaluatie van onderwijsvernieuwing);

de stichting Intemationale Scharrelvlees Controle;

de stichting Keboma (belast met: het onderzoeken en het beproeven van mobiele kranen en torenkranen, als mede periodieke keuring);

thet Keuringsinstituut Wet op de gevaarlijke werktuigen;

de Keuringsinstellingen Wet medische hulpmiddelen;

de Koninklijke Nederlandse Toeristenbond (belast met: het afgeven van vaarbewijzen); het Kwaliteits Controle Bureau voor groenten en fruit;

het Kunststoffen en Rubber instituut TNO;

het Lloyd's register of Shipping (belast met: het keuren van scheepcontainers voor ingebruikneming, als mede het verrichten van typekeuringen);

het Nederlands Instituut voor Lifttechniek;

het Neder]ands Meet Instituut Van Swinden Laboratorium bv (belast met o.a.: certificatie);

het Nederlands Meet Instituut IJkwezen bv (belast met o.a.: het toezicht op en het evalueren van $0 . m$. te erkennen bedrijven en interne bedrijfiscontrolesystemen);

het Nederlands Meet Instituut Test- en Adviescentrum bv (belast met o.a.: keuringen, herkeuringen, en evaluaties); 
het Nederlands Meet Instituut Certin bv (belast met o.a.: het keuren, herkeuren, onderzoeken, testen en evalueren van als mede het toezicht op kwaliteitsborgingssystemen van geaccrediteerde leveranciers en onderhoudsfirma's);

de stichting Nederlandse Algemene Keuringsdienst voor Boomkwekerijgewassen (belast met het keuren ter bevordering dat betrouwbaar teeltmateriaal wordt verhandeld, doorverhandeld en uitgevoerd, en ook het ter zake voorschriften stellen);

de stichting Nederlandse Algemene Keuringsdienst voor Groente- en Bloemzaden;

de stichting Nederlandse Algemene Keuringsdienst voor Siergewassen;

de stichting. Nederlandse Algemene Kewringsdienst voor Zaaizaad en Pootgoed van Landbouwgewassen;

de Nederlandse Filmkeuring;

de stichting Nederlandse Vleeswaren Kontrole (belast met: toezicht en keuring, bevorderend de juiste produktie, kwaliteit, verwerking, verpakking, verhandeling of aanduiding van produkten, als mede het uitreiken van merken, tekenen en bewijsstukken);

het Nippon Kaiji Kyokai (belast met: het verrichten van keuringen en typekeuringen); de nv Kema (belast met: het verstrekken wan certificaten, goedkeuringscertificaten, het werrichten van EG-typegoedkeuringen met het daarbij verklaringen verstrekken, intrekken en verlengen, en daarnaast de periodieke en incidentele controle):

de Raad voor de Casinospelen (binnenkort: College van Toezicht op de Kansspelen);

de Registratiekamer;

het Registro Italliano Navale (belast met: het verrichten van keuringen en typekeuringen); de Rijkscommissie voor de Keuring van niet-stamboekhengsten (belast met: de keuring van paarden);

de Stichting Bureau Examens voor het Beroepsvervoer;

de Stichting Examens Personenvervoer;

de stichting Instituut afgifte certificaat Vervoer Gevaarlijke Stoffen*

de Stichting Inschrijving Eigen Vervoer (belast met: het verrichten, het wijzigen, het doorhalen van inschrijvingen, het verlengen van de geldigheidsduur van inschrijvingen, het afgeven van inschrijvingsbewijzen, het afgeven en het intrekken van aanvullende documenten voor grensoverschrijdend vervoer);

de stichting Instituut afgifte diploma"s vervoer binnenvaart;

de stichting Instituut afnemen examens/afgifte radardiploma"s (Kon. Onderwijs Fonds voor de Scheepvaart);

de Stichting keur alternatief woortgebrachte Landbouwprodukten;

de Stichting Opleiding Brood en Banket (belast met: het organiseren van opleidingen en het houden van toezicht daarop, als mede het verlenen van officiële erkenningsverklaringeny;

de stichting Vakopleiding Bouwbedrijf;

de Stichting Register Holland;

de stichting Sterlab/Sterin;

de Stichting toezicht effectenverkeer;

de stichting Verzekeringskamer;

de Waarborg Platina, Goud en Zilver nv (belast met: het onderzoek van edelmetaalgehalte van sieraden, gebruikswoorwerpen en aanverwante voorwerpen, bij goedkeur te voorzien van een gehaltemerk ten einde de consument te beschermen tegen bedrog en ter 
bevordering van een eerlijke handel; Waarborg-werknemers zijn belast met toezicht en opsporing);

de Ziekenfondsraad (binnenkort wellicht de Raad voor de Zorgverzekering).

\subsubsection{IN HET KADER VAN AAN ZBO'S OP- OF OVERGEDRAGEN TOEZICHTSTAKEN UIT TE OEFENEN BEVOEGDHEDEN}

Ter uitvoering van, aan bepaalde zelfstandige bestuursorganen toekomende, toezichtstaken staan dus diverse, veelal routinematige, bevoegdheden ter beschikking. Deze zijn te categoriseren als volgt:

a. het - al dan niet onder beperkingen of voorzien van (financiële) voorschriften verlenen, weigeren, schorsen, wijzigen of intrekken van goedkeuringen, erkenningen, ontheffingen, toelatingen, vergunningen, concessies of licenties;

b. het afgeven, weigeren of ongeldig verklaren van keurmerken, keuringsbewijzen, rijbewijzen, certificaten, en dergelijke;

c. het (doen) verrichten van incidentele of periodieke keuringen, inspecties en dergelijke;

d. het behandelen van bezwaren/klachten inzake verlening of anders, afgifte van vergunningen en dergelijke (en het vandaar uit mogelijk voorlichten van betrokken burgers als medle adviseren van de al dan niet aanspreekbare ministers);

e. het registreren, bewaken, beheren, bewerken en verstrekken van gegevens (zónder mogelijkheid tot commercieel gebruik en mêt mogelijkheid tot privatisering van aan zelfstandige bestuursorganen gekoppelde computers/computercentra ten behoeve van het houden van een registratie) ${ }^{116}$;

f. het voeren van overleg in nationaal of Europees verband dan wel op supra- of internationaal niveau;

g. het, al dan niet ondersteunend, opstellen van norm- en regelgeving (rechtvaardiging vindend in toegestane delegatie of geoorloofde zelfregulering);

h. het vaststellen van tarieven;

i. het opleggen, innen of vorderen van wettelijke heffingen en vergoedingen voor geleverde diensten;

j. het strafvorderlijk opsporen naast, of als sluitstuk van, het houden van bestuurlijk toezicht.

Nog maals, bovenstaande bevoegdheden omvatten veel meer dan zuivere toezichtsbevoegdheden ${ }^{117}$. Werkelijke toezichtsbevoegdheden vinden tegenwoordig regeling in afdeling 5.1 Awb. ${ }^{118}$

116. Ook op Europees niweau is het noodzakelijk adequate (computer)registratiesystemen, waarin nationale registraties mogelijk zijn te integreren, op te bouwen.

117. Bij bij voorbeeld het inspecteren zijn echte toezichtsbevoegdheden natuurlijk wel nodig. Denk aan binnentreding, monsterneming, informatieverstrekking, inzage of andere medewerking.

118. Daarnatast vinden zij regeling in de, de op strafvordering gerichte, WED. Soms levent nietwnakoming van verplichtingen in het kader van uitoefening van toezichtsbevoegheden eem economisch dellict op. 
Boven genoemde bevoegdheden zijn wel hoofdzakelijk aan te merken als publiekrechtelijke bevoegdheden die worden verleend ten einde publiekrechtelijke toezichtstaken te kwmen witoefenen. Het begrip toezicht wordt in deze studie dus in brede, oneigenlijke zin, gebraikt. Het omvat een complex van activiteiten. Immers, de inzichtelijkheid van een beschrijving van toezicht op naleving van wet- en regelgeving (dat betekent in veel gevallen: neemt een vergunninghouder de aan de vergunning gestelde condities in acht) is gebaat bij een duidelijke descriptie van de uitvoering van die wet- en regelgeving (bij) voorbeeld: aan welke eisen moet worden voldaan om met succes een aanvraag tot vergunningverlening in te dienen). Om bij het eigenlijke toezicht uit te komen, moeten eerst de paden die daarnaar toe kunnen leiden worden bewegwijzerd. Hierbij verdient aantekening dat meestal ook toezichthoudende zelfstandige bestuursorganen zelf het hele wettelijke kader in totaal als onderwerp van toezicht beschouwen.

Zo is toezicht op naleving van bepaalde wet- en regelgeving niet los te zien van de er aan vooraf gaande verlening van toestemming. De Dienst wegverkeer controleert of de door de haar verstrekte erkenningen worden nagekomen. De Stichting Toezicht Effectenverkeer houdt toezicht op de naleving van de door haar, mogelijk onder voorschriften of beperkingen, verleende vergunningen. Dit geldt idem dito voor de stichting Verzekeringskamer. De zelfde vlieger ging tot voor kort ook op voor het Commissariaat voor de Media, dat zendtijd voor landelijke publieke omroep verleende en zo nodig wijzigde of introk, maar met de herziene Mediawet is de concessieverlening ten behoeve van publieke omroepen aan het commissariaat ontglipt.

Uit de arbeidsinzet van de toezichthoudende verzelfstandigde entiteiten, die in deze studie behandeling krijgen, blijkt dat toezicht niet altijd zo direct is. Zij kan ook getrapt zijn. Dit gellaagde toezicht (respectievelijk eerstelijns en tweedelijns) doet zich vooral voor bij toezichthoudende verzelfstandigde entiteiten met een inspectiekarakter. Deze vorm van toezicht doet zich voor bij onder meer de landbouwkwaliteitscontrole-instellingen. Daar is meestal sprake van een centrale directie/administratie die als stafeenheid de verschillende (hoofd)toezichtsafdelingen (met geledingen in binnen- en buitenland naar primaire en secundaire produktie), die de operationele eenheden vormen, aanstuurt. Ten behoeve van uitvoering van toezichtstaken van deze verzelfstandigde entiteiten worden vaak zowel opsporingsambtenaren (denk vooral aan ambtenaren van de AID/ECD, de RVV of de HIG) aangewezen als toezichthouders aangenomen. In deze studie staan laatst genoemden, die in dienst zijn bij de betreffende verzelfstandigde entiteit, centraal. Hun werkveld neemt de volgende vormen aan.

Een centrale, directieve eenheid, meestal het bestuur van een toezichthoudende verzelfstandigde entiteit, coördineert het praktische toezicht op de onder toezicht gestelden ${ }^{119}$, 
op wie meestal nalevings-, aransprake lijkheids-, betalings-, (administratie)aantekenings-, meldings- en medewerkingsplichten ${ }^{120}$ rusten, vooral via:

a. het aanstellen en ontslaan van controleurs, inspecteurs, keuringsmeesters of andere toezichthouders;

b. het verschaffen van een lastgewing an de verschillende toezichthouders, houdende een verk]aring dat deze functionarissen zijn belast met het toezicht op naleving van wet- en regelgeving;

c. het opstellen en bekend maken van instructies voor toezichthouders;

d. het belast zijn met het automatiserings- ${ }^{121}$, arbeidswoorwaarden- en personeelsbeleid, inclusief het verzorgen van vakopleidingen om administratieve krachten en toezichthouders adequaat toe te rusten als ook het voorzien in de nodige middelen en infrastructuur;

e. het beoordelen wan meldingen en verantwoordingen van zowel onder toezicht gestelden als inspecteurs en dergelijke, en het aan onder toezicht gestelden in overtreding toezenden van afschriften van inspectieverslagen onder mededeling van afdoeningsen sanctioneringswijze of waarschuwing;

f. het verlenen, intrekken en dergelijke van verschillende soorten certificaten ${ }^{122}$ (of keurmerken) aan onder toezicht gestelden;

g. het opstellen en bekend maken ${ }^{123}$ van een lijst van aangeslotenen bij de toezichthoudende verzelfstandigde entiteit;

h. het opstellen en bekend maken van jaarverslagen, controleresultaten en andere rapportages;

i. het opstellen en bekend maken van standaardcontroleplannen, controle-, keuringsen merkreglementen als mede organisatie-, werkwijze- en (tucht)sanctieregels;

120. Ten eerste, de medewerkingsplicht frustreert mogelijk het rechts beginsel van nemo tenetur. Ten tweede. medewerking splichten rusten ook op derden. Wat betreft Land bouwk waliteitscontrole-instellingen wordt dit in bijna alle gevallen uitalrukkelijkk bepaalt, door het mogelijk te maken om toezichtsbevoegdheden miet alleen wit te oefenen tegen de onder toezicht gestelde, maar mede tegenover degene die voor de onder toezicht gestelde werkt of de derde op wiens terrein en in wiens bedrijf respectievelijk goederen, voeruigen ed. en administratie zijn te vinden. Ook is te denken an het Commissariaat voor de Media dat tegenwoordig, via een derdenbeding de bewoegdheid heeft tot inzage wan de boeken van geinvolveerde externe producenten, die reclamegevoelige programma's maken. welke programma's door een onder toezicht gestelde omroeporganisatie worden vitgezonden.

121. Denk aan de tegenwoordig populaire, efficiëntie bevorderende, monitorcontroles.

122. M.b.t. tot de anvang van de geldigheidsdur wan een certificaat in gevolge EG-Verondening ar. $2196 / 86$ inzake erkenning zetmeelverwerkende industrieèn concludeent de CBB 14 december 1994. inzake Roemond Papier bv ws. Foofdproduktschap voor Akkerbouwprodukten, in: NJB, nr. 13, 31 maart 1995, rechtspraakkatern nr.10, pp.172-173 (bijlage), dat "de afschrijving op een certificaat van een hoeveelheid, verwerkt op een tijdstip waarop dat certificaat nog niet was afgegeven, geen aanspraak schept op restitutie tegen het in dat certificaat vermelde tarief".

123. I.v.m. de toenemende grensoverschrijdende dienstverlening en de hamonisatie wan nationale wet- en regelgeving impliceert deze bekendmaking zowel nationale als Europese publikatie. 
j. het - mogelijk onder ministeriële goedkeuring - verbindend verklaren van, in samenspraak met belanghebbenden opgestelde, privaatrechtelijke normen ${ }^{124}$;

k. het behandelen van klachten en bezwaren ${ }^{125}$ als mede het beslechten van bepaalde geschillen ${ }^{126}$;

1. het samenstellen van mogelijke tuchtgerechten;

m. het belast zi.jn met het financieel beheer, waartoe onder meer het periodiek vaststellen van de financiële bijdragen van onder toezicht gestelden als mede het bepalen van de hoogte van onkostenvergoedingen, contributies, nalatigheidsinteresten en boeten ${ }^{127}$ nodig is;

n. het verschaffen van alle inlichtingen en het verlenen van alle medewerking als mede het afleggen van financiële verantwoording ten behoeve van het, nog resterende, rijkstoezicht (d.w.z. de invulling van de overgebleven, beperkte politieke ministeriële verantwoordelijkheid) ${ }^{128}$;

o. het voeren van overleg en samenwerken met andere, min of meer nauw verwante, controle-instellingen en opsporingsdiensten in (inter)national en Europees verband;

p. het adviseren van de betrokken minister met oog op voorbereiding van wet- en regelgeving in de betrokken sector, met invloed op nationaal maar ook op communautair beleid;

q. het uitvoeren of uitwerken van, op (inter- of intra)departementaal niveau gemaakte, al dan niet grensoverschrijdende overeenkomsten;

$r_{n}$ het toezien op systemen van zelfhandhaving, en zo nodig in het belang van de controle overgaan tot wijziging of intrekking van een stelsel van zelfkeuring of zelfcontrole.

124. Skal, die werkt rnet publiek-en privaatrechtelijke normering, laat zien dat het functionet kan zijn om privaatrechtelijke normen op een gegeven moment te formaliseren en om te zetten in nationale of Eurapese regelgeving. De bij de zelfregulering opgedane ervaring wordt dan nutuig gebruikt bij thet opstelten van officiële wetgewing. Meestal komt het omgekeerde voor: na (overvioed aam) wet- en. regelgewing wordt overgeschakeld op het zelfregulerend vermogen van de matschappij.

125. Mogelijk onder oplegging wan cautieverplichting.

126. Opmerkelijk genoeg komt het woor dat een woorzitter, of een directeur, van cen verzelfstandigde entitei met de ovj kan overleggen of de ovj strafrechtelijke afdoening achter wege wil laten wardoor ruimte wondt gelaten voor tuchtrechtelijke zaaksbehandeling.

127. Bij een ander aspect van boeteoplegging, $t . w$. de bestemming van ingevorderde boetegeldien, bestaat mogelijk gevaar voor aanwending van gelden in eigen belang van de toezichthondende verzelfstandigde entiteit. Dif probleem is wellicht potentieel aanwezig bij toezichthouders in priwate rechtsworm. De in jaarverslagen weer gegeven praktijk, bij bij voorbeeld de privaatrechtelijke landbouwkwaliteitscontroleinstellingen, doet echter vermoeden dat geinde gelden goed terecht komen conform, op grond van regelgeving wan te voren bepaalde, bijzondere bestemming. Anders dan bij stichtingen en verenigingen, geldt genoemd gevaar matuurlijk sterker voor winst gerichte vemnootschappen. Om, in het bijzonder bij bestuurlijke boeteoplegging, het oogmerk van financieel gew in uit te bannen en financiële bijaragen ten goede te doen komen ten behoeve van rechtshandhaving ziet F.C.A.M. Michiels, De boete in opmars? oratie $\mathrm{VU}, \mathrm{Zwolle}, 11 \mathrm{febr}$. 1994, pp.40-41, reden voor oprichting van een landelijk handhaving sfonds. waarin boeteopbrengsten moeten worden gestort.

128. Hierbij dient bedacht te worden dat de besluitvorming van een toezichthoudende werzelfstandigde entite it (inzake 0 .a. het heffen van waste financiële bijdragen of incidentele vergoedingen) ten dele aan ministeriele goedkeuring onderhevig is. Boven regeling van heffingen e.d. in enkel statuten verdiemt het voorkeur om voor het vagen wan geldelijke bijdragen en wergoedingen een publiekrechtelijke regeling op te stellen. 
In het werkveld wordt de administratieve controle, verplicht of op eigen verzoek van onder toezicht gestelden, door inspecteurs, controleurs, keuringsmeesters en andere toezichthouders bij onder toezichi gestelden ${ }^{129}$ feitelijk uitgevoerd middels met name:

a. het, regelmatig ${ }^{130}$ of het aanvullend steeksproefgewijs, visiteren van (waarvoor nodig is: het toegang hebben tot en het binnentreden van ${ }^{131}$ ) percelen, inrichtingen, kantoren, opslagplaatsen, magazijnen, kweek-, produktie-, overslag-, bewaar-, verwerkings-, ondernemings-, verhandel- of verkoopruimten, velden ${ }^{132}$, terreinen en dergellike van onder toezicht gestelden ${ }^{133}$;

b. het onderzoeken van hulpinstrumenten en vervoermiddelen (inclusief lading en bewaarplaatsen), waarbij het stilhouden van, het vrijmaken van en het overbrengen van woertuigen naar een andere plek mogelijk is zodat een zo goed mogelijke inspectie kan plaats vinden;

c. het, al dan niet op kosten van onder toezicht gestelden ${ }^{134}$, nemen van monsters (bij voorkeur met contra-expertise) van grondstoffen, ingrediënten, halffabrikaten of eindprodukten, ter ontleding door een daartoe erkend laboratorium;

d. het inzien van, al dan niet schriftelijke vast gelegde, administratie, voorraadboekhouding, documenten, bescheiden en informatiedragers van onder toezicht gestel-

129. Incilusief derden d.w.z. degenen, die werken in opdracht van onder toezicht gestelden.

130. Regelmatig betekent vaak: op wisselende tijdstippen en onaangekondigd. Tegenwoordig woudt het in bepaalde gevallen juist noodzakelijk geacht om een onder toezicht gestelde op de hoogte te stellen van esn op een bepaalde datam wit te voeren inspectie. Doelmatigheid is hier de achterliggende reden. De onder toezicht kan de nodige voorbereidingen treffen voor de te verwachten controle. En als het een controlebezoek in het buiteinland betreft is thet natuurlijk werstandig er zeker van te zijn niet voor een dichte deur te stalan.

131. Het zich toegang verschaffen is nogelijk met behulp van de sterke arm en, zo nodig, met assistentie van deskundigen of begeleiding van andere personen.

132. Een moderne variant om landbouwgronden en veestapels te controleren is teledetectie.

133. Van oudsher geld te fysieke controle op sortering, inhoudsgewichten, hoeveelheid, verpakking , a anduiding (arnwezigheid, duidelijkheid, volledigheid, betrouwbaarheid), houdbaarheid, produkttechnissche aspecten en, niet te vergeten, (export)bestemming van onder toezicht staande produkten als meest favoriete controlle. Met als motto: 'zelf zien". Ter versteviging van de controle kurnen aanvullend denaturatieof ontaarding sverplichtingen worden opgelegd om industrieel of ambachtelijk hergebruik wan produkten te voorkomen. Langzam en voorzichtig wordt in bepaalde deelsectoren overgestapt op zelfcontrole en zelfkeuring onder toezicht van de betrokken verzelfstandigde kwaliteitscontrole-instelling

134. Het is gebruikelijk de eerste monsters gratis ter beschikking te stellen. Wenst eem onder toezicht gestelde contra-monsterneming, wat-gegeven zijn verdedigingskansen-meer als recht onderkend moet worden, clan is het rechtvaardig om (als de uitslag daarvan in het nadeel wan onder toezicht gestelde uitvalt) de kosten daarvan op them te verhalen. Het zelfde geldr als een onder toezicht gestelde de monsteranalyse niet wil doen plaats vinden bij de, meestal aan de controle-instellingen verbonden, onafhankelijke laboratoria, mar bij cen extern laboratorium. 
den ${ }^{135}$, waarbij de toezichthouder zich zo nodig de werking van apparatuur of programmatuur kan laten tonen;

e. het tijdelijk voor verder onderzoek of kopiëren meenemen van zaken of bescheiden, onder afgifte van een schriftelijk reçu aan onder toezicht gestelden;

f. het vragen van inlichtingen of gegevens aan onder toezicht gestelden;

g. het vragen van andere, voor het toezicht nodige, medewerking van onder toezicht gestelden;

h. het aanbrengen, of zo nodig weer verwijderen, van voorgeschreven erkende keurmerken of zegels;

i. het verwijderen van onjuiste en ontoereikende produktaanduidingen, of een onder toezicht gestelde, al dan niet tijdelijk, het recht tot gebruik van een aanduiding ontnemen;

j. het afkeuren en uit de markt nemen van bepaalde produkten;

k. het opleggen van een produktafleveringsverbod;

1. het, van een onder toezicht gestelde, vorderen een door de centrale entiteit ongeldig verklaarde certificaat of iets dergelijks af te geven;

m. het geven van, min of meer bindende, aanwijzingen aan onder toezicht gestelden betreffende produktie-, afleverings-, aanduidings-, merkaanbrengings-, aankoop-, vervoerswijze e.d. als mede betreffende organisatorische, technische en administratieve voorzieningen van onder toezicht gestelden ${ }^{136}$;

n. het sturend en begeleidend optreden bij zelfhandhaving door onder toezicht gestel$\operatorname{den}^{137}$;

135. Bij de toezichthouders in de financiele sector, die trouwens een meer direct toezicht kennen, worden toenemend strenge eisen aan administratieve boekhouding gesteld. Deze toezichthouders zijn sterk afthankelijk van wat hen wordt medegedeeld in rapportages van met mame accountants die de jaarrekeningen wan onder toezicht gestelden controleren. Zo is de blik van de stichting Verzekeringskamer op Vie d" Or kennelijk in hoge mate ventroebe'ld door de accountantsrapporten die de situatie van de onder toezicht gestelde verzekeringsmaatschappij kemnelijk te rooskleurig voorstellen. De toezichthouder verkeert in de, door het betrokken accountantskantoor Deloitte \& Touche bij herhaling gevoedde, achteraf onjuiste veronderstelling dat Vie d'Or witeindelijk in stat is de balans weer positief te krijgen. Hierdoor wacht de accountant een aansprakelijkheidsstelling, omdat hij de jaarrekeningen niet had mogen goedkeuren. Bovendien acht de stichting Verzekeringskamer het wenselijk dat in elk geval accountants een wettelijke plicht krijgen om gevraagd of ongev raagd aan de toezichthouder inlichtingen te verschaffen over de werking (i.h.b. de zwakke punten) van de administratieve organisatie wan een onder toezicht gestelde. Da.arbij geeft hij aan of en, zo ja, welke actie hij onderneent om zwakheden off fouten in de administratie te (doen) herstellen. Deze wens botst met de geheimhoudingsplichten van accountants. Daarom doet De Nederlandsche Bank nv het juridisch juister. DNB mv gaat ter zake gedragscodes met accountants aan.

136. Wellicht is hier ook te denken aan het geven van aamwijzingen of instructies omtrent het gebruik van

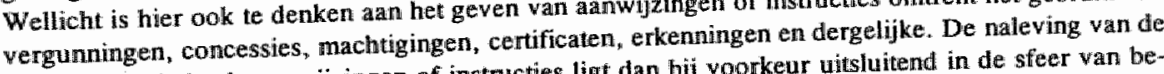
in beginsel bindende aanwijzingen of instructies ligt dan bij voorkeur uitsluitend in de sfeer wan beijke handhaving. Voordeel hiervan is dat het terrein van toezichthouders wordt omlijnd en dat voor de, in het verlengde van opsporing liggende, strafrechtelijke handhaving pas in latere instantie plaats is. Zo wordt sfeenovergang, voor zover mogelijk, vermeden. Bovendien hoeft hett openbaar ministerie niet te pas en te onpas ten tonele te werschijinen. 
o. het opmaken van een, in toenemende mate gestandaardiseerd, inspectieverslag met bewijskracht tot het tegendeel blijkt ${ }^{138}$;

p. het feitelijk innen van, door onder toezicht gestelden af te stane, financiële bijdragen;

q. het uitbrengen van controlerapportages en het afleggen van verantwoording aan de directeur van de toezichthoudende verzelfstandigde entiteit.

\subsubsection{LEGITIMATIE WAN UITOEFENING OVERHEIDSTOEZICHT DOOR ZELFSTANDIGE BESTUURSORGANEN}

De genoemde bevoegdheden hoeven niet per se onder volledige verantwoordelijkheid te vallen. Bij verzelfstandiging van dergelijke, in het kader van toezichtstaken toegekende, bevoegdheden kan de ministeriële verantwoordelijkheid beperkt blijven tot het algemene belleid.

Het feit dat de minister slechts sluimerend toeziet neemt niet weg, dat de aan toezichthoudende zelfstandige bestuursorganen toebedeelde taken en bevoegdheden een exclusief overheidskarakter hebben. Het unieke van toezich thoudende taken ligt vooral in de, grof weg gesproken, grondwettelijke garantie er van. De overheid moet met haar specifieke gezag zorg dragen voor naleving van gegeven grondrechten. Daarnaast heeft zij als plicht verschillende fundamentele vrijheden te waarborgen. De handhaving van primaire grondrechten en fel begeerde vrijheden is niet vatbaar voor privatisering, maar weer wel voor verzelfstandiging.

Het kenmerken van boven genoemde taken als overheidstaken wordt ingegeven door bekende motieven als de volgende ${ }^{139}$. Het feit dat kennelijk wordt gekozen om, via verzelfstandigde entiteiten die handhavende taken uitwoeren, overheidstoezicht uit te oefenen vindt mogelijk basis in paternalisme. Daarnaast onstaat overheidsbemoeienis in geval van natuurlijke monopolies (bij: voorzieningen op zeer grote schaal en tegen grote investeringen, dalende gemiddelde kosten, of voorzieningen die relatief grote investeringen vergen in verhouding tot de vraag). Bij gevaar van aanwezigheid van (positieve of negatieve) externe effecten intervenieert de overheid even eens vaak. Daarnaast doen overwegingen van inkomenspolitiek de overheid nog al eens besluiten tot het overeind houden van overheidsverantwoordelijkheid voor bepaalde toezichtstaken. Ook om belangrijke ontwikkelingen te stimuleren vindt de overheid het soms gerechtvaardigd tijdelijk voor bepaalde taken zorg te dragen. En een rellevante reden voor de overheid om toezichtstaken in huis te houden kan een praktische zijn: bij de overheid is - misschien al van oudsher - de nodige deskundigheid voor takuitoefening aanwezig, of het uitvoeren

138. De laatste jaren wordt na gedane inspectie niet altijd meer een athandelingsvoorstel aan betrokken onder toezicht gestelde verzonden. Uit owerwegingen wan tyjdsbesparing en efficiëntie hanteren sorumige verzelfstandige kwaliteitscontrole-instellingen het sy steem om slechts in die gevallen, waarin een sanctie wordt opgelegd of het xinwol wordt geacht om een bevind ing schriftelijk te bekrachtigen, conclusies van. een uitgevoerd controlebezoek toe te sturen.

139. Algemene Rekenkamer, Verslag van de Algemene Rekenkamer over 1992, TK 1992-1993, 23065, nrs. 12. p.70. 
wan handhavende taken (als neventaken) wordt als onmisbaar sluitstuk en logische aanvulling van andere hoofdtaken beschouwd.

Het feit dat de toezichthouder op afstand staat van de minister betekent niet dat, van oudsher geldend, overheidstoezicht op houdt overheidstoezicht te zijn. In tegendeel, toezichthoudende zelfstandige bestuursorganen voeren hoofdzakelijk taken uit die bij uitsluiting worden voorbehouden aan de overheid. Hun taken zijn publieke taken, maar meer nog publiekrechtelijke taken. Tot de, in deze studie relevante, publiekrechtelijke taakuitoefening krijgen - publiekrechtelijke of privaatrechtelijke ${ }^{140}-$ toezichthoudende zelfstandige bestuursorganen publiekrechtelijke bevoegdheden geattribueerd of gedelegeerd.

Het feit, dat bepaalde verzelfstandigde entiteiten een toezichthoudende taakstelling kennen waaraan uitoefening van openbaar gezag inherent is, wordt gelegitimeerd door rijkelijke rechterlijke controle en beperkte ministeriële politieke controlle.

\subsubsection{Controle door de rechter}

De juridische controle biedt verschillende ingangen. In de meeste gevallen is het oordeel van de burgerlijke rechter, de bestuursrechter, de strafrechter of de tuchtrechter over uitgeoefend toezicht door zelfstandige bestuursorganen af te roepen. Weliswaar gaat dat nilet in alle gevallen probleemloos.

\subsubsection{1a Bestuursrechtspraak}

De bestuursrechtspraak steunt op het besluitbegrip (zie art. 1:3, eerste lid, Awb dat onder besluit verstaat: een schriftelijke beslissing van een bestuursorgaan, inhoudende een publiekrechtelijke rechtshandeling). Nu impliceert het leeuwedeel van het werk van een toezichthoudend zelfstandig bestuursorgaan wel het bekleed zijn met openbaar gezag (zodat art. 1:1, eerste lid, sub b, Awb - inhoudende: een bestuursorgaan is een persoon of college met enig openbaar gezag bekleed - toepasselijk is). Maar daar waar de twijfel inzake toezicht als openbaar gezag overheerst, is met art. 1:1, eerste lid, sub a, Awb - inhoudende: een bestuursorgaan is een orgaan van een rechtspersoon die krachtens publiekrecht is ingesteld - soms slecht uit de voeten te komen. Verzelfstandiging en privatisering leiden dan tot verminderde of zelfs geen toepasselijkheid van de algemene regels van bestuursrecht, doordat min of meer zelfstandig functionerende organen buiten

140 Getuige redelijk recente verzelfstandigingen (denk aan de Dienst wegverkeer) heeft het er alle schijin van dat met oog op transparantie wan publiekrechtelijke bevoegdheidsuitoefening, de zbo-vorm van publiekrechtelijke rechtspersoon sui genteris, die zich kenmerkt door onder meer een zelfstandige begroting tegenwoordig favoriet is. Kennelijk word deze voorkeur ingegeven door de angst dat een zbo met een privaatrechtelijke basis vooral schaduwkanten (o.a. het stellen van vernootschapsbelang boven algemeen belang) heeft. 
de bestuursorganenboot van art. $1: 1$ Awb vallen. ${ }^{14}$ Het bezigen van de term zelfstandig bestuursorgaan vindt dus geen oorzaak in haar feitelijke juistheid, maar in haar herkenbaarheid. Er is weinig op tegen het taalgebruik te substitueren. In deze studie wordt de term dan ook herhaaldelijk vervangen door het begrip verzelfstandigde entiteit. Nadeel van deze term is dat zij voor veel meer staat dan, traditioneel gezegd, zelfstandige bestuursorganen.

Bij de rechtsbescherming, die het algemeen bestuursrecht biedt, zitten nog aardige adders onder het gras. Soms werken toezichthoudende zellfstandige bestuursorganen - bij voorbeeld het Commissariaat voor de Media - met sanctieregelingen die zij uitdrukkelijk aanmerken als beleidsregels. Door twijfel verward, laat de Awb-wetgever aanwankelijk doorschemeren dat belanghebbenden als gedefinieerd in art. $1: 2 \mathrm{Awb}$, ex art. 8:2, aanhef onder a en b, Awb geen beroep op de rechtbank kunnen instellen indien sprake is van (de intrekking of de vaststelling van de inwerkingtreding van) een beleidsregel als gedefinieerd in art. 1:3, vierde lid, Awb. Na verhitte discussie raakt de Awb-wetgever er bij nader inzien van overtuigd dat toch een mogelijkheid moet bestaan om beroep in te stellen bij de administratieve kamer van de rechtbank tegen beleidsregels (en algemeen verbindende voorschriften). Daartoe wordt bepaald dat het bestaande art. 8:2 Awb vijf jaar na haar inwerkingtreding vervalt " ${ }^{142}$ Kortom, vóór 1 januari 1999 is geen beroep bij de rechtbank tegen beleidsregels mogelijk.

Ook een andere uitsluiting van beroep op de rechtbank is voor toezichthoudende zelfstandige bestuursorganen relevant. Art. 8:4, aanhef onder e en f, Awb maakt het voor belanghebbenden onmogelijk beroep bij de rechtbank in te stellen tegen een besluit inhoudende respectievelijk een beoordeling van het kennen of kunnen van een kandidaat of leerling die ter zake is geëxamineerd of op enigerlei andere wijze is getoetst en een technische beoordeling van een voertuig of luchtvaartuig, dan wel een meetmiddel, een onderdeel daarvan of een hulpinrichting daarvoor. Hoewel voor de eerste exoneratie alternatieve tuchtrechtspraak bestaat, is dat niet per se het geval bij de rechtsbescherming tegen besluiten inzake keuringen en meetverrichtingen (al dan niet verplicht uitgevoerd door o.a. particuliere off shore- en scheepskeuringsinstanties als Bureau Veritas, door

141. Zeer terecht voert J.B.J.M. ten Berge, Schakelbepaling in privatiseringswetgeving, in: NTB, nr. 1, 1995, p.9. "gegeven de niet-toepasselijkheid wan de Awb en vooruit lopend op een wenselijke verniming van het orgatabegrip in de Awb" aan om ten aanzien van o.a. stichtingen "in wetgeving m.b.t. de privatiseringsoperatie dan wel in de statuten een schakelbepaling met de Awb" op te nemen. Denkbaar is een bepaling, inhoudende dat op handelingen van organen van een stichting het bepaalde in de afdeling 3.2 tot en met 3.5 als mede titel 4.1 van de Awb van overeenkomstige toepassing is, voor zover de aand wan de handelingen zich daartegen niet verzet (vgl. art. 3:1, tweede lid ${ }^{\prime}$ Awb)." Zo worden, volgens autewr, de "voordelen van privatisering gecombineerd met het behoud van kwaliteitseisen". Overigens denkt auteur naast stichtingen aan allerlei, al dan niet te onstane, bijzondere categorieèn priwaite organisaties. T. W : " 1 . private organisaties die onder overwegende overheidsinvloed staan; 2 . private rechtspersonen, niet behorend onder 1, die een lump sum krijgen van een overheid en deze lump sum in de worm vann subsidie geven aan particulieren (afgezien wan wettelijke constructies - JGLvN); 3. private rechtspersonen die owerheidseigendom exploiteren; 4. private rechtspersonen die in een soort mandaatsverhouding als taakorganisatie wan de overheid publieke taken wervullen".

142. Zie het, 0.g.w. het d.d. 22 juni 1993 aangenomen amendement Biesheuvel/Jurgens (TK 1991-1992, 22495, nr. 19), ingevoerde art. IV A in de overgangsregeling bij de overgangs- en slotbepalingen van de Awb. 
de Dienst wegverkeer erkende apk-keuringsstations en door de besloten vennootschap Nederlands Meet Instituut Test- en adviescentrum).

De wetgeving, op basis warwan de verschillende verzelfstandigde toezichthoudende entiteiten hun toezichtstaken uitoefenen, wil helaas ook nog wel eens lekken. De wettelijke terminologie is niet altijd even sluitend. Dat is jammer, want de aanwijzingen woor de regelgeving ${ }^{143}$ zijn ter zake duidelijk. De meest relevante aanwijzingen worden weergegeven als volgt.

Aanwijzing voor de regelgeving 125, eerste lid, stelt: "Voor een besluit waarbij een uitzondering op een wettelijk verbod of gebod wordt gemaakt voor een categoric van gevallen, wordt de term 'vrijstelling' gebruikt."

Aanwijzing voor de regelgeving 125, tweede lid, stelt: "Voor een beschikking waarbij in een individueel geval cen uitzondering op een wettelijk verbod of gebod wordt gemaakt, wordt de term 'ontheffing' gebruikt."

Aanwijzing voor de regelgeving 125, derde lid, stelt: "Voor een beschikking waarbij een bepaalde handeling wordt toegestaan, wordt de term "vergunning' gebruikt."

Aanwijzing voor de regelgeving 125, vierde lid, stelt: "Voor een beschikking waarbij wordt vastgesteld dat een persoon of instelling aan bepaalde eisen voldoet, wordt de term 'erkenning' gebruikt."

Aanwijzing voor de regelgeving $125 \mathrm{krijgt}$ toelichting als volgt: "Het gebruik van andere termen voor deze figuren als toestemming, instemming of verlof wordt vermeden."

Aanwijzing voor de regelgeving 126, eerste lid, stelt: "Voor de voor de inwerkingtreding van een besluit van een bestuursorgaan vereiste instemming van een ander bestuursorgaan wordt de term 'goedkeuring" gebruikt."

Aanwijzing voor de regelgeving 126, tweede lid, stelt: "Voor de voor het nemen van een besluit door een bestuursorgaan vereiste instemming van een ander bestuursorgaan wordt de term "verklaring van geen bezwaar" gebruikt."

De toelichting bij aanwijzing voor de regelgeving 126 beveelt onder meer aan het begrip 'goedkeuring' te preferen boven 'verklaring van geen bezwaar'.

Aanwijzing voor de regelgeving 127, stelt: "Indien de bevoegdheid wordt toegekend om bij het verlenen van vrijstelling, ontheffing of vergunning een begrenzing naar tijd of plaats dan wel anderszins aan te brengen, wordt de term 'beperking' gebruikt."

De toelichting bij deze aanwijzing verduidelijkt dat, naast begrenzing in tijd en in plaats, ook is te denken aan begrenzingen "t.a.v. het aantal te verrichten handelingen of een begrenzing in de aard van de te verrichten handelingen".

Aanwijzing voor de regelgeving 128 , eerste lid, stelt: "Indien wordt beoogd de verplichtingen van een belanghebbende die hem bij het geven van een beschikking zijn opgelegd, 
door middel van straffen te handhaven, wordt deze strafbaarstelling uitdrukkelijk geregeld."

Aanwijzing voor de regelgeving 128 , tweede lid, stelt: "Voor dergelijke en andere bij het geven van een beschikking op te leggen verplichtingen wordt de term 'voorschriften' gebruikt."

Deze aanwijzing wordt toegelicht als volgt: "'de term 'voorwaarde' wordt niet gebruikt voor verplichtingen als bedoeld in deze aanwijzingen".

Ten aanzien van de term verklaring van geen bezwaar geeft de Wte ${ }^{144}$ aanleiding tot commentaar. Volgens de hernieuwde Wte heeft de Stichting Toezicht Effectenverkeer, ex art. 16, eerste lid, Wte 1995, voortaan ook de bevoegdheid tot het besluiten over en verstrekken van, mogelijk onder beperkingen of voorschriften te verlenen, verklaringen van geen bezwaar (die nodig zijn om gekwalificeerde deelnemingen in vergunninghoudende effecteninstellingen te houden, te verwerven of te vergroten dan wel daarin enige zeggenschap verbonden aan een gekwalificeerde deelneming uit te oefenen). Ten eerste is af te vragen of bedoelde beperkingen of voorschriften niet, conform de aanwijzingen voor de regelgeving, beter passen bij het verlenen van vrijstellingen, ontheffingen en vergunningen. Ten tweede is af te vragen of, in plaats van de term verklaring van geen bezwaar, het ontheffingsbegrip hier niet beter past. Het excuus waarmee de wetgever deze vraag af doet, namelijk dat de vvgb-terminologie aansluit bij de Wtk $1992^{145}$ en de Wtv 1993, klinkt consistent maar raakt verder kant noch wal.

De in de Wpr voorkomende verklaring van genoegzaamheid, waardoor de Registratiekamer ex art. 15 Wpr haar consent over een gedragscode kan uitspreken, is een terminologische rariteit. De keuze voor de terminologie laat zich mogelijk verklaren door het feit dat de verklaring van genoegzaamheid niet bindend is voor de rechter. ${ }^{146}$ Als het toe-

144. Nota bene de meest recente versie: Voorstel whe 1995, TK 1993-1994, 23784, nrs.1-3.

145. Interessant t.a.w. de rechtsbescherming in het kader van een vvgb zijn de, met oog op de slordige samenloop van de Wtk 1992 en de Wet op de telecommunicatievoorzieningen gemakte, opmerkingen van H.J. de Ru, Banken in telecom: verkeerd verbonden; Vergunningstelsel gevactr voor concurrentie?. in: NJB, gr.6, 10 febr. 1995, pp.197-203, i.h.b. pp. 199-201. Bij, tijdens of na verlening, van een GSMvergunning, ontstane wijziging in de samenstelling vam de rechtspersoon-vergumningaanv rager/vergunninghouder wreekt zich mogeligk de geheimhowding van de banktoezichthouder ta. $v$.. vvgb's (althans, voordat ze bekend worden gemalkt in de Statscourant). Zo kan thet gebeuren dat de vergunningverlenende minister van verkeer en waterstaat niet of onvoldoende op de hoogte is met de belangen van de bancaire deelnemingen in niet-financiële ondenemingen. Vice versa kan de minister, als de vergunning een mal wordt verleend, strenge(re) woorwaarden stellen die, als DNB nv deze wö́r verstrekking van een wgb had gekend. DNB nw negatief hadden doen beslissen op de aanwraag om een vvgb. Wat de rechtsbescherming betreft, is de positie van derden belanghebbenden , die bezwaar kunnen aantekenen tegen verlening van een vvgb of een GSM-vergunning, relevant: "Wanmeer er sprake tis van een bezwaarschrift, rijjst er een extra complicatie, immers in de bezwaarschriftemprocedure wordt miet geoordeeld naar het moment van de aanvraag. maar nat het moment van bezwaar."

146. Niet in de laatste plaats omdat de Registratiekamer wel wordt beschouwd als overbodig institunt, verdient het aambeveling een verklaring van genoegzaamheid -hoewel de rechter er al wel het nodige gezag aan verbindt- bindend te doen zijn. Dit vloeit feitelijk al voont uit het feit dat de verklaring valt aan te merken als een bestuit ex ant. 1:3, eerste lid, Awb afkomstig van een bestuursorgaan ex ant. 1:1. 
zicht van de Registratiekamer op de privacyzelfregulering (immers, de verklaring van genoegzaamheid wordt afgegeven voor de, door het bedrijfsleven opgestelde, gedragscodes) serieus wordt genomen moet de besliskracht van de Registratiekamer toch sterker zijn en meer respect kunnen afdwingen.

Ten aanzien van een bijzondere administratieve rechter, te weten het College van Beroep voor het Bedrijfsleven treedt mogelijk de volgende complicatie op. Het CBB, dat als beroepsinstantie voor door de Stichting Toezicht Effectenverkeer en de stichting Verzekeringskamer te nemen besluiten geldt, heeft misschien moeite met oordeelsvorming omtrent het eigen belang (als invulling van de abbb) van dergelijke privaatrechtelijke rechtspersonen, welk belang zij wellicht opwerpen ter verdediging van hun optreden als uitvoerders van publiekrechtelijke taken.

Met betrekking tot dit CBB verdient nog opmerking, dat zij de weg van rechtsbescherming die justitiabelen verongelijkt willen betreden, wel wanordelijk afsluit. Uit het oogpunt van juridische protectie is het immers wrang dat het CBB een, duidelijk in het kader van haar toezichtstaak gegeven, oordeel van de Stichting Toezicht Effectenverkeer niet aanmerkt als een op rechtsgevolg gerichte beschikking. ${ }^{147}$ Daardoor heeft de burger het nakijken. Hoewel het gereserveerde gedrag van het CBB op zich begrijpelijk is, is haar attitude aanmatigend van uit de optiek van rechtsbescherming tegen machtige toezichthouders.

\subsubsection{Ib Civiele rechtspraak}

Wat betreft bescherming tegen het optreden van de Registratiekamer prefereert de wetgever civiel rechtelijke bescherming boven strafrechtelijke protectie. In praktijk doet zich het probleem voor dat de Registratiekamer niet zelf een procedure bij de rechter aanhangig kan maken. Dat is wrang, want het starten van een procesgang is voor belanghebbenden, zelfs voor de vroegere belangenvereniging SWP, kennelijk een (te) kostbare kwestie. Nemen justitiabelen het (financiële) risico op de koop toe en beginnen zij een rechts.gang bij de burgerlijke rechter, dan kan zich de vage terminologie van de Wpr wreken met alle kans op verlies van rechtszekerheid.

146. $\rightarrow$

eerste lid, Awb. Aldus kan de rechterlijke controle dienen als waardig alternatief "voor de bij een extem verzelfstandigde entiteit magenoeg ontbrekende ministeriele controle (welk gebrek de reden is wan de niet-bindende kracht van besluiten van de Registratiekamer).

147. Aldus besluit het CBB aangaande de, weliswaar geen sanctieoordeel inhoudende, correspondentie van de STE aan een vergunninghoudende effecteninstelling, die een werknemer in dienst heeft met een 'besmet' arbeidswerleden waarwan hij bij zijn indiensttreding geen melding heeft gemaakt bij de betrokken effecteninstelling. Als gevolg van de briefw isseling, waarin een oordeel is vervall dat zich presenteert als een in het kader van de Wte relevant rechisoordeel, onslaat de effecteninstelling de bewuste werknemer. 


\subsubsection{1c Tuchtrechtspraak}

De tuchtrechtspraak levert, naast mogelijke moeilijkheden inzake samenloop en eventuele energieke toepasselijkheid op niet-aangeslotenen, geen uitzonderlijke problemen op.

\subsubsection{1d Strafrechtspraak}

Bij de landbouwkwaliteitscontrolewet- en regelgeving is de hoeveelheid door het openbaar ministerie (mogelijk na, het weliswaar omstreden, afdoeningsoverleg met een landbouwkwaliteitscontrole-instelling als Skal) aangeboden schikkingen opvallend hoog. Het aannemen van een aanbod tot transactie is voor de, in overtreding zijnde, onder toezicht gestelde aantrekkelijk vooral door de volgende redenen: het bedrag valt mee; de naam van (het bedrijf van) de onder toezicht gestelde komt niet in de publiciteit; en een mogelijk lastige juridische procedure wordt voorkomen. De hoeveelheid transacties is zelfs zo groot, dat rechterlijke controle op het handelen of nalaten van handhavers (officier van justitie/toezichthoudende verzelfstandigde entiteit) er nog nauwelijks aan te pas komt. Een strafvorderlijk kort geding biedt hier waarschijnlijk niet de beoogde oplossing. De werklast van justitie wordt er niet door verminderd, terwijl dat een belangrijke achtergrond van het invoeren van de transactiemogelijkheid is. Bovendien geldt voor de onder toezicht gestelde, dat zijn naam publiekelijk kenbaar wordt gemaakt. Vandaar is het verstandig te komen hier niet direct te grijpen naar het strafrecht, maar te komen tot invoering in de landbouwkwaliteitscontrole van de bestuurlijke boete (voor frequent voorkomende, lichte en eenvoudige overtredingen). ${ }^{148}$. Weliswaar wordt mogellijk dan toch de werkdruk van de rechterlijke macht vergroot, omdat (beter) beroep tegen het opleggen van bestuurlijke boeten bij een onafhankelijke rechter kan worden ingesteld, maar de identiteit van de betrokken overtreder hoeft niet per se in de publiciteit te komen. Juist de directe toezichthouders en inspecteurs in dienst van landbouwkwaliteitscontrole-instellingen, die precies weten welke overtredingen worden begaan in het werkveld, kunnen - gebonden aan minimumtarief en maximumtarieven - prima een lijst inzake tarifering van boeten opstellen, bij voorkeur in overeenstemming met het openbaar ministerie. ${ }^{149}$

148. Conform analkge opinie inzake levensmiddelentecht van E. Rood, Overzicht EEG-en Nederlands levensmiddelenbeleid en-rech, Apeldoom/Antwerpen, 1993, pp.164-166/180-185, die wat betreft de door hatr uiteindelijk afgeslagen mogelijkheid van thet strafvorderlijk kort geding refereent aan $P$. Osinga; Hoewel de regering, $0 . \mathrm{g} . \mathbf{v}$. het rapport Hendriks/De Zeeuw, kiest woor mchtrechtelijke naast strafrechtelijke handhaving van de Lbkw, beziet zjj of en in welke mate invoiering van een stelsel van bestuurlijke boeten voondelen biedt. Zie Kabinetsstandpunt over CTW-advies inzake bestuurljke boeten, "TK 1993-1994, 23400 VI, nr.48, p.25.

149. Het verdient aanbeveling een antal toezichthouders apart aan te wijzen als bijzondiere boete-inspecteurs. Dit komt een heldere machtsverdeling ten goede. 'Checks and balances' worden meer omlijnd. De onder toezicht gestelde weet met wie hij te maken heeft. waardoor hij de toezichthoudende entiteit als geheel niet direct zijn vertrouwen hoeft te ontzeggen. Bovendien verhoogt het de kwaliteit van toezichyt. Immers, dergelijke inspecteurs zijn typisch deskiundig en hebben affiniteit met het werkweld waardoor boeteoplegging effectiever en efficiënter kan verlopen. Bedoelde bijzondere toezichtfunctie is een $k$ walitatieve functie. Boete-inspecteurs die aan eisen van een bepaald niveau voldoen, kunnen in aanmerking komen voor aanstelling als bij voorbeeld buitengewoon opsporingsambtenaar (vgl. bepaalde private 
Illustratief is ook het toezicht op naleving van effectenwet- en regelgeving door de Stich ting Toezicht Effectenverkeer. De STE is van mening dat de strafrechtelijke aanpak van misbruik van voorwetenschap mogelijk te lang duurt en te diffamerend voor verdachte is. Bovendien kan het in bepaalde rechtszaken moeilijk zijn het begane strafbare feit te bewijzen. Het STE heeft hier voorkeur om, nota bene onafhankelijk van het openbaar ministerie, via een overeenkomst met (verdachte) overtreder te komen tot oplegging van een boete, waardoor aangifte van het strafbare feit bij justitie achterwege blijft. ${ }^{150}$ De boete wordt wel openbaar wordt gemaakt. Maar voor de overtreder is deze publieke kennisgeving waarschijnlijk minder slopend dan het, in een langdurige rechtszaak, bij herhaling besmetten van naam en faam. De voordelen van een dergelijk snelrecht zijn inderdaad duidelijk. Wel is, gegeven het feit dat de STE buiten het openbaar ministerie om, dus op eigen initiatief, met overtreder (boete)afspraken wil maken, doet het voorstel van de STE niet verantwoord aan. De vraag is waarin de STE haar legitimatie zoekt. Zoekt zij wellicht rechtvaardiging bij burgers door publikatie van de boete, opdat de betrokken overtreder middels betaling als het ware de door hem aangebrachte schade herstelt waardoor justitiabelen hun vooroordeel jegens hem laten varen en overtreder van zijn slechte reputatie kumnen ontheffen? Dat lijkt op, zijn zachtst gezegd, naiief.

Wat betreft de Stichting Toezicht Effectenverkeer en strafrecht, kan moeilijk worden volgehouden dat deze goed samen gaan. De STE is, behoorlijk beinvloed door bestuursrecht, vooral civielrechtelijk georiënteerd. Door delegatie van regelstellende bevoegdheden kan zij regels uitvaardigen, waarbij zij overtreding van regels vrij wel altijd als economisch delict bestempelt. Hierbij zorgt haar onwennigheid met strafrechtelijke

149. $\rightarrow$

parkeerwachters). Het aanstellen wan buitengewone opsporingsambtenaren is echter, uit oogpunt wam en begdhedenverstrengeling tussen betrokken rechtspersoon en minister, niet aan te raden bij toez th thoudende verzelfstandigde entiteiten in private rechtsvorm (als wooral vennootschappen); Ook het Kabinetsstandpunt over het CTW-advies inzake bestuurlijke boeten, TK 1993-1994, 23400 VI, nr.48, p.13, onderschrijft het principiële standpunt wan feitelijke distantie tussen respectievelijk het constate ren en het opleggen van een bestuurlijke boete. Wel kan de praktijk, waarin zo veel mogelijk wordi aangeevergdhedenstructuren., anders witwijzen. Het kabinet acht het "derkbaar dat een zbo dll thans reeds met het toezicht op de naleving van de wet is belast, ook het organ wordi dat bevoegd is om boeten op te leggen. De beoogde scheiding tussen de diverse functies zal in dat geval binnen die organisatie gerealiseerd moeten worden." Een dergelijke situatie doet zich trowwens meer woor bij 0 .a. financiele toezichthoudende verzelfstandigde entiteiten dan bij de verzeifstandigde landbouwkwaliteitscontrole-instellingen die duidelijker met direct optredende controleurs en unspecteurs werken Welke constructie in hell concrete geval ook gekozen wordt, de uitoefening van de boetebevoegdheid moet woldoen aan de abbb waaraan de rechter de bevoegdheidsuitoefening kan toetsen; $A$. Mulder, Bockbespreking, in: SEW, nr.3, 1995, pp.222-228, die het wiveau van rechisbescherming in belangrijke mate bepaald ziet door drie factorem waaronder de zelfstand igheid van het net de vaststelling van de sanctie te belasten orgaan, denkt dat aanwijzing van bent van geringe omwang voorgestane functiekan garanderen. Hierbij tekent hij wel aan dat bij ee boeteoplegger zijn bij de uitwoering betrokken scheiding "moeilijk te werwezenlijken valt, terwijh de collega dagelijks zal ontmoeten. Dan onstain noodgrepen, als de aan de boeten zou worden belast; wan meststoffen dat voligens het visserij-ontwerp met het vast"

deskundigheid zullen deze ambon een overtreder. 
sanctionering wrang genoeg vaak voor vage delictsomschrijvingen. Zo brokkelt het rechtszekerheidsbeginsel ongeoorloofd af.

Niet alleen regelstelling door de toezichthouder levert rechtsbeschermingsproblemen op. Ook door de formele wetgever in de Wte bepaalde strafbaarstelling baart soms zorgen. Illustratief zijn de perikelen rondom misbruik van voorkennis, welk handelen strijd met de Wte-bepalingen inzake voorkennis oplevert en daarmee tot economisch delict wordt. Omdat de zittende en de staande magistratuur nog niet bedreven zijn met bedoelde wetsartikelen, wacht de verdachte onder toezicht gestelde een langdurig justitieel onderzoek (wegens bewijsproblemen) met een kennelijk onvermijdelijke, onevenredig negatieve, publiciteitsstraf.

\subsubsection{Controle door de minister}

De ministeriële politieke controle bestaat ook voor de werkzaamheden van toezichthoudende zelfstandige bestuursorganen slechts op hoofdlijnen. De verschillende betrokken ministers zijn in algemene zin verantwoordelijk voor het functioneren van zelfstandige bestuursorganen. Hun generale verantwoordelijkheid neemt niet weg dat zij, zo nodig bij structurele tekortkomingen van zel fstandige bestuursorganen doortaakwerwaarlozing, hun ministeriële plicht om ter zake adequate voorzieningen te treffen moeten uitoefenen.

Globaal gezien hebben de, voor het beleid in grote lijnen, verantwoordelijke ${ }^{151}$ vakministers belangrijke, niet te onderschatten, beinvloedingsinstrumenten.

Hierbij is te denken aan vooral:

a. het, met de nodige terughoudendheid, geven van algemene aanwijzingen of richtlijnen aan een zelfstandig bestuursorgaan;

b. het, bij taakverwaarlozing door een zelfstandig bestuursorgaan, ingrijpen (met daaraan gekoppeld het regelen van een financiële aansprakelijkheidsregeling om schadeclaims, tegen een zelfstandig bestuursorgaan dat zijn opdracht veronachtzaamt, op dat orgaan te kunnen werhalen) ${ }^{\text {is2, }}$

c. het bepalen wan het tarief-, premie- of heffingenbeleid van cen zelfstandig bestuursorgaan;

151. Als uilvloeisel van zijn verantwoordelijkheid mag een minister, na geconstateerd falen van een zbo, niet talen met het intrekken of veranderen van delegatie- of attributievoonwaarden. Dat vereist dat haj altijd de ministeriele bevoegdheid moet hebben om delegatie (of attributie) van bevoegdheden aan een, al dark niet met mam genoemdie, algemeen angewezen of exclusief erkende, verzelfstandigde entiteit in te trekken of, minder ver gaand, de voorwarden er van te wijzigen. Daarom moeten publiekrechtelijke bevoegdheden (toezichthoudende bev oegdheden impliceren in principe uitoefening wan openbaar gezag) bij voorkeur via delegatie of attributie worden over- of opgedragen aan verzelfstandigde entite iten. Atternatiewe wijzen van verkrijging wan openbaar gezag, waarvoor tegenwoondig -kennelijk voorbüj gaand aan het rechtsstarelujke legaliteitsbeginsel- wel wondt geopteerd, verdienen voor toezichthoudende verzelfstandigde entiteiten afkeuring.

152. De STE en de stichting Verzekeringskamer dragen in dit verband een eigen risico bij aansprakelijkheidsstelling tot een bepaald maximumbedrag. Voor zover een aansprakelijkheidsstelling boven dit bedrag untgaat, is de overheid gevrijward. Zie ook Algemene Rekenkamer. Zbo's en ministeriële veranwoor delijkheid, TK 1994 1995, 24130, nr.3. p.32. 
d. het goedkeuren van meerjarenbeleidsplannen en verschillende financièle plannen die een zelfstandig bestuursorgaan vaak verplicht presenteert;

e. het, direct of indirect, goedkeuren van het bestuur en dergelijke van een zelfstandig bestuursorgaan;

f. het benoemen, ontslaan, schorsen van het bestuur van een zelfstandig bestuursorgaan, de raad van toezicht van een zelfstandig bestuursorgaan, en dergelijke;

g. het opleggen van een, zowel actieve als passieve, inlichtingen- en adviesplicht aan de directie van een zelfstandig bestuursorgaan (het verdient aanbeveling de, door een zelfstandig bestuursorgaan respectievelijk verstrekte en afgelegde, informatie, raad en verantwoording mee te nemen in bij voorbeeld een departementaal breed opgezette, geìntegreerde beleids- en begrotingscyclus: dit steit de politiek in staat goedkeuring vooraf of afkeuring achteraf te geven, kortom parlementaire controle vooraf of controle achteraf door het parlement).

Vooral het geven van ministeriele aanwijzingen is een heikel punt. In de discussie daarover geven de meesten een stopteken daar waar bewindspersonen in concreto een zelfstandig bestuursorgaan van aanwijzingen willen voorzien. Overigens zijn wel verschillen in de mate van dit ministerieel toezicht bij toezichthouders te constateren. Voor (individueel) ingrijpen van de betrokken minister hoeft bij voorbeeld de stichting Verzekeringskamer ${ }^{153}$ minder bang te zijn de Ziekenfondsraad.

Het aan de betrokken bewindspersonen blijven voorbehouden van boven genoemde beïnvloedingsinstrumenten, die zich weliswaar mogelijk ontwikkelen tot manipulatieve ministeriële sturingsinstrumenten, impliceert dat de minister inderdaad betrokken blijft bij het functioneren van het betreffende zelfstandig bestuursorgaan. De (gedeeltelijke) ontdemocratisering mag niet gepaard gaan met onverschilligheid. Om de overgebleven draden der democratische legitimatie voor zelfstandige bestuursorganen niet te laten rafelen, moet de minister - om adequaat invulling te kunnen geven aan zijn beïnvloedingsinstrumenten - alert zijn op elke ontwikkeling op het betreffende beleidsterrein waarop het zelfstandig bestuursorgaan zich beweegt. De noodzaak daartoe is gebleken bij de Ziekenfondsraad. Dit toezichthoudende zelfstandig bestuursorgaan heeft in een bepaalde periode wel heel sterke troeven in handen gehad, omdat de betrokken vakminister in gebreke bleef met het formuleren van een visie op het functioneren van de Ziekenfondsraad, waardoor zijn oordeel over de uitoefening van toezicht afhankelijk werd van de opvattingen van de toezichthouder zelf. 15,4

153. Dat overigens de ministeriele mogelijkheden om toezicht te houden op de toezichthouder bij de stichting Verzekeringskamer te kort schieten wordt duidelijk nu de kwestie Vit d'Or. Met het argument haar geheimhouding te verzekeren zwijgr de stichting Verzekering skamer als het graf over de wijze waarop zij toezicht houdt an heeft gehonden.

154. Toezictt door de Ziekenfondsraad, TK 1992-1993, 23211, nrs. 1 2, p.31; Ook Algemene Rekenkamer, Verslag von de Algemene Rekenkamer over 1993. TK 1993-1994, 23670, wrs. 1-2, p. 13. In dic jaarver slag (p. 13) benadrukt de Algemene Rekenkamer het belang "dat de wetgever bij overdracht vam wettellijke taken aan organen buiten de rijksoverheid uitdrukkelijk aandacht besteedt aan een goed geregeld toexicht". 
Toexichthoudende zelfstandige bestuursorganen

\section{$\$ 20.5$ Toezichthoudende verzelfstandigde entiteiten}

In het algemeen kenmerken toezichthoudende verzelfstandigde entiteiten zich als bekleed met een bepaalde dwangmacht. Zij oefenen immers, in eerste instantie, een overheidstaak uit.

\subsubsection{TOEZICHT ALS OVERHEIDSZORG}

Daar waar de overheid toezichtstaken meent te hebben, fundeert zij dit meestal op een of andere zorgplicht. Deze zorgplichten zijn vaak weer te herleiden naar regels van het EVRM, waarin de garantie ligt van zowel de beschermende rechten als de fundamentele vrijheden van de mens.

Het Commissariaat voor de Media draagt Vnb- in het licht van vrijheid van communicatie - de zorg voor een pluriforme, toegankelijke, hoogwaardige en blijvende omroep.

De Nederlandse Film Keuring draagt - in het licht van vrijheid van communicatie - de zorg voor eerlijke en volledige filmvoorlichting aan een vooral jeugdig publiek ter bescherming van schadelijke invloeden via verschillende media.

De Registratiekamer draagt - in het licht van bescherming van privacy - zorg voor bewaking van, al dan niet in persoonsregistraties opgeslagen, persoonsgegevens.

De landbouwkwaliteitscontrole-instellingen dragen -in het licht van vrijheid van landbouwverkeer-zorg voor een extra kwaliteit beogende en produkt autonomie bevorderende landbouwsector.

De Stichting Toezicht Effectenverkeer draagt -in het licht van vrijheid wan effectenverkeer - zorg voor het adequaat functioneren van effectenmarkten (waardoor efficiënte prijsworming en optimale allocatie van middelen stimulans krijgen) als mede het bevorderen van vertrouwen en transparantie van de effectenmarkt (waardoor bescherming van beleggers en spaarders tegen malafide aanbiedingen, onvoldoende informatie en ondeskundig optreden wordt verhoogd).

De stichting Verzekeringskamer draagt -in het licht van vrijheid van assurantieverkeerde zorg voor solvabiliteit, continuïteit en betrouwbaarheid garanderende verzekeringsbedrijven, zo dat eerlijke prijsvorming en verdeling van financièle middelen op de verzekeringsmarkt als mede doorzichtigheid van de assurantiemarkt goede kans van slagen hebben.

\subsubsection{DE TOEZICHTHOUDENDE VERZELFSTANDIGDE ENTITEIT GEKARAKTERISEERD}

Het uitvoeren van toezichtstaken vereist expertise op een bepaald gebied. Het noodzaakt tot het afdwingen van respect bij onder toezicht gestelden. Met andere woorden: toezicht moet indrukwekkend zijn. Dit kan alleen als onder toezicht gestelden geen bemoeienis hebben met het werk van de toezichthouder. Vice versa: de toezichthouder moet onbevoordeeld zijn bevoegdheden kunnen uitoefenen.

Deze elementen van deskundigheid, gezaghebbendheid en onafhankelijkheid spelen bij het op- of overdragen van overheidstoezicht aan verzelfstandigde entiteiten een relevante 
rol. Het attribueren of decentraliseren van publiekrechtelijke toezichtstaken en daaraan gekoppelde bevoegdheden moet dan ook geschieden aan 'op afstand staande' toezichthouders die, bij voorkeur in cumulatieve zin, zijn te kenmerken als:

a. adequaat (accuratat), dat is deskundig:

aldus te typeren zijn het Commissariaat voor de Media, de Nederlandse Film Keuring, de Registratiekamer, de landbouwkwaliteitscontrole-instellingen, de Stichting Toezicht Effectenverkeer en de stichting Verzekeringskamer;

b. autoritair, dat is gezaghebbend:

aldus te typeren zijn het Commissariaat voor de Media (met de kanttekening dat het CvdM op het punt van gezaghebbendheid terrein verliest ten gunste van de betrokken ministers en departementsambtenaren), de Nederlandse Film Keuring (met de kanttekening dat daarvan in praktijk weinig blijkt, ja dat de NFK zich zelfs zo weinig invloedrijk toont, dat stemmen opgaan om de NFK af te schaffen ${ }^{155}$ ), de Registratiekamer (met de kanttekening dat, met oog op het gebrek aan democratische legitimatie in de zin van volledige ministeriële verantwoordelijkheid, bepaalde belangrijke beslissingen van de Registratiekamer niet bindend zijn ${ }^{156}$ ), de landbouwkwaliteitscontrole-instellingen, de Stichting Toezicht Effectenverkeer en de stichting Verzekeringskamer,

c. autonoom, dat is onafhankelijk:

aldus te typeren zijn het Commissariaat voor de Media, de Nederlandse Film Keuring, de Registratiekamer, de landbouwkwaliteitscontrole-instellingen, de Stichting Toezicht Effectenverkeer en de stichting Verzekeringskamer.

Om zich van de noodzakelijke acceptatie en het vereiste kwaliteitsniveau van, het door de toezichthouder uit te oefenen, toezicht te verzekeren is het zinvol zekere democratische inbreng toe te laten. Bij voorkeur geschiedt dit door inbreng van belanghebbenden via, wettelijk geconditioneerde, zelfregulering en zelfhandhaving door het bedrijfsleven. ${ }^{157}$

155. De NFK vind dan ook dat de wetgever haar meer (sanctie)mogelijkheden moet verschaffen. De NFK acht de huidige sanctiebepalingen in de absolutut ontoereikende Wf niet meer woldoende. Daarotn wenst zij invoering wan een vergunningensy steem op filmgebied. Daardoor kam de NFK krachtiger optreden door een maal verleende vergunningen zo nodig in te trekken.

156. Althans formeel gezien. Materjeel beschouwd is aan bedoelde beslissingen zekere rechtskracht te geven door daarop de wettelijke bestuursrechtelijke bepalingen inzake het beshuitbegrip toepasselijk te achten.

157. Gebruikelijk is het ook besturen van werzelfstandigde entiteiten pluriform of paritair samen te stellen. Daardoorkunnen niet alleen overheidsvertegenwoordigers, maarook belanghebbenden in sprak hebben. Overigens is dit bij toezichthoudende verzelfstandigde entiteiten niet allijd even warschijnlijk. Toezichtsuitoefening vergt immers onafhankelijkheid. Hierover, in het licht van "checks and balances', 0. a. de Nata n.a. . het verslag inzake het voorstel Wte 1995, TK 1994-1995, 23874, nr. 7, pp.18/21-22. Om dieze onafhankelijkheid te waarborgen is het aan te raden, los van toexichthoudende verzelfstandigde entiteiten, afzonderlijk "panels' samen te stellen waarin (belanghebbende) justifiabelen zitting nemen en hun mening ventilenen. 


\subsubsection{FUNCTIES VAN TOEZICHT}

De combinatie van vermelde eigenschappen stelt toezichthoudende verzelfstandigde entiteiten in staat om kritisch overheidstoezicht te optimaliseren. Het geeft hen de mogelijkheid om op betrouwbare, daadkrachtige en geloofwaardige wijze toezicht vorm te geven in. Daarmee kunnen zij, als rechtshandhavers, recht doen aan hun:

a. allocatieve functie

d.w.z. de functie om, al dan niet bij gebrek aan genoeg, gelden, middelen of anders te verdelen:

zijnde functie van het Commissariaat voor de Media (tegenwoordig niet alleen meer door technische, maar ook door economische schaarste ingegeven) of van het mogelijk in te stellen Commissariaat voor de Etherfrequenties/de Elektronische Informatievoorziening/het Frequentiemanagement (veroorzaakt door de van wege geavanceerde technologische mogelijkheden ontstane nieuwe vormen van schaarste);

b. regulatieve functie

d.w.z. de functie om een bepaalde markt, of een segment daarvan, doelmatig en rechtvaardig te ordenen:

zijnde functie van het Commissariaat voor de Media (via specifiek zendtijdtoewijzing), de Stichting Toezicht Effectenverkeer (via vooral vergunningverlening) of de stichting Verzekeringskamer (via in het bijzonder vergunningverlening);

c. kwaliteitsbevorderende functie

d.w.z. de functie om produktie- en consumptiehuishouding op algemeen aanvaardbaar intrinsiek niveau en in redelijk acceptabel uiterlijke vorm te krijgen en te stabiliseren ${ }^{158}$ :

zijnde functie van de Stichting Keur Alternatief voortgebrachte Landbouwprodukten (via verlening en afgifte van bedrijfsaansluitings-, procesregistratie-, produktregistratie- en importeursaansluitingscertificaten) of het Kwaliteits-Controle-Bureau voor groenten en fruit (via verschaffing van ontvangst- en controlebewijzen, certificaten van oorsprong, kwaliteitsyerklaringen, controlecertificaten e.d.);

c. voorlichtende functie

d.w.z. de functie ${ }^{159} \mathrm{om}$, al dan niet gevraagd, justitiabelen voldoende te voorzien van objectieve informatie inzake ontwikkelingen in het overheidstoezicht op een bepaald rechtsterrein, opdat zij zo goed mogelijk bereid en in staat zijn wet- en regelgeving m.b.t. dat bepaalde, soms uitermate dynamische en daardoor complexe, terrein na te leven ${ }^{160}$ :

158. De kwaliteitsbevorderende functie brengt in toenemende mate een coördinerende functie ten aamzien wan zelfregulering mee.

159. Hoewel de functie niet primair bet karakter draagt van een defensieve functie, kan het voorkomen dat een toezichthouder het beleid, als in hoofdlijnen door de betrokken minister opgesteld, in verdediging verantwoordt.

160. Uitoefening van de informatieve functie contrasteert mogelijk met een geheimhoudingsplicht wan een toezichthouder. Denk aan de passieve derdenwerstrekking van Wmz-gegevens, tegen lichte vergoeding, door de STE. Hoewel de rechter in hoger beroep -die het belang van doorzichtigheid van de effectenmarkt boven het belang van privacy en potentiële schade van beleggers stelt- anders oordeelt, acht de president van die A "damse rechtbank geheimhouding geschonden. 
zijnde functie van de Registratiekamer (haar informatieve functie wordt geintensiveerd na geconstateerde toename van de mogelijkheid van schriftelijke informatieverzoeken en het gebruik van telefonische spreekuren), de stichting Internationale Scharrelvlees Controle of de Stichting Toezicht Effectenverkeer (in wier voorlichtingsactie, om burgers in te lichten over net over de Nederlandse grens zetelende, malafide effectenbedrijven die hun activiteiten uitoefenen op Nederlands grondgebied zonder in het bezit te zijn van de daarvoor vereiste vergunning, zelfs een warschuwend karakter doorklinkt);

d. stimulerende (en persuasieve) functie

d.W. . de functie om bepaalde doelstellingen te beaccentueren en te doen realiseren: zijnde functie van het Commissariaat voor de Media (vooral van sociaal-culturele aard via het toezicht op de voorschriften inzake het volledig programma) of de stichting Internationale Scharrelvlees Controle (met name van uit ecologische overwegingen voor mens en dier: dat betekent een aansporing voor consumenten om kwalitatief goed en veilig vlees te eten en een aansporing voor scharrelvarkenshouders om hun dieren bewegingsvrijheid, rust, voedsel en dergelijke te geven, kortom dier- en milieuvriendelijk te verzorgen);

e. aspiratieve functie

d.w.z. de functie om iets hogers te bewerkstelligen of een ultieme situatie te bereiken:

zijnde functie van de Stichting Keur Alternatief voortgebrachte Landbouwprodukten (voort vloeiend uit haar streven alle landbouwprodukten te verkrijgen via biologischdynamische teelt);

f. innende functie

d.w.z. de functie van de toezichthouder om verschuldigde gelden, als contributie-, monster(analyse)vergoedings- of boetegelden, te vorderen van onder toezicht gestelden ${ }^{16 t}$ :

zijnde functie van de landbouwkwaliteitscontrole-instellingen, de stichting Verzekeringskamer (sinds verzelfstandiging betallen onder toezicht gestelden o.g. $x^{*}$. een aanslag op de kostenbegroting vooraf), de Stichting Toezicht Effectenverkeer (vooral via retributieheffing voor met name apparaatskosten), de Registratiekamer (via 'voorzichtige' vergoedingen voor het vaststellen privacyreglementen, aanmelden persoonsregistratie en overleg i.v.m. opstellen gedragscodes; de voorzitter van de Registratiekamer wil wel een secuur stelsel wam heffingen invoeren, waarbij hij het daaraan verbinden van administratieve boeten als voordeel ziet) of de Nederlandse Filmkeuring (via vergoedingen voor filmkeuringen);

161. Hieruit is een bijzondere, innende functie af te leiden. Nadat de onder toezhcht van de stichting Verzekeringskamer staande failliete verzekeringsmaatschappij Vie d'Or net een noodregeling wordi geconfronteend, moeten lopende zaken wan Vie d'Or worden afgehandeld. Dat betekent onder meer het innen var dubieuze leningen, het yorderen van aansprakelijkheidsclaims en het veilen van de inboedet van $V i e$ d"Or. Hientoe richt de Verzekeringskamer, mede op aandringen van de belangenorganisatie van polishouders vam. Vie d'Or, een aparte stichting op. Deze stichting is, nasst de Vercekeringskamer zelf, een onafhankelijk toezichthouder op de afwikkeling van Vie d'Or. Omdat de Verzekeringskamer benoe." mings-en ontslagrecht t. a. $v$. het bestuar van deze stichting heeft, is het duidelijk dat de Verzekeringskamer flink wat in de melk varl die "onafhankelijke" stiching te brokkelen heeft. 
g. corrigerende functie

d.w.z. de functie om de onder toezicht gestelden daar, waar naleving op wet- en regelgeving mogelijk in de knell komt, bij te sturen opdat betrokkenen geen maatregelen of straffen te wachten staan:

zijnde functie van de Stichting Keur Alternatief voortgebrachte Landbouwprodukten (in de vorm van een door Skal-controlenrs of Skal-inspecteurs te geven aanwijzing, al dan niet concreet, aan een onder toezicht gestelde betreffende produktie-, afleverings-, aankoop-en verwoerswijze, produktaanduiding en merkaanbrenging of anders m.b.t. zijn organisatorische en administratieve bedrijfswoorzieningen);

h. bestraffende functie ${ }^{162}$

d.w.z. de functie om bij geconstateerde wet- of regelschending ${ }^{163}$ sancties uit civiel-, bestuurs-, straf- of tuchtrecht op te leggen aan betrokkene( $n$ ):

zijnde functie van toezichthoudende verzelfstandigde entiteiten, als geschetst in hoofdstuk 12;

i. beschermende functie

d.w.z. de functie om als ombudsinstantie te bemiddelen in geschillen tussen onder toezicht gestelden in verschillende hoedanigheden, zich uit te spreken over door onder toezicht gestelden ingediende klachten over optreden van de toezichthouder, of (in eerste instantie) te oordelen over door onder toezicht gestelden aangetekende bezwaren tegen sanctionerend optreden van de toezichthouder:

zijnde functie van onder meer de Registratiekamer (denk aan haar, mogelijk conflict oplossende, tussenkomst bij onenigheid tussen houders van registraties en geregistreerde cliënten die uitdraait op het aanhangig maken bij een geschil voor een arrondissementsrechtbank) of van de Stichting Toezicht Effectenverkeer (zo komt aan de STE het oordeel toe over de beslissing van een houder van een effectenbeurs omtrent toelating van effecten of het doen vervallen van effecten uit de notering aan die effectenbeurs);

j. evaluatieve functie

d.w.z. de functie van de toezichthouder om, met oog op de mogelijke behoefte tot bijstelling van belleid en uitvoering, een opbouwend kritisch en objectief oordeel te

162. Let wel, met deze functie is de rechtshandhaving het stadium van het pure toezicht gepasseerd. De functie wordt hier wel genoemd omdat ook, hoofdzakelijk toezichthoudende, werzelfstandigde entiteiten sanctioneren. Denk aan het opleggen van besuurlijke boeten door met name het Commissariaat voor de Media, of an vergurningintrekking door onder meer de stichting Verzekeringskanter of aan het geven van een aanwijzing door byj voorbeeld de Stichting. Toezicht Effectenwerkeer Als vermeld is het zinvol en eigenlijk onvermijdelijk het toezicht in bet hele kader van rechtshandhaving te beschouwen.

163. Het constateren wan begane overtredingen of misdrijven impliceen niet dat aangifte moet worden gedaan. Juist wat betreft toezichthoudende verzelfstandigde entiteiten, die door onder meer geheimhondingsplichten een vertrouwenspositie genieten, bestaat, hoewel hun toezichthoudende taak het doen wan aangifte vaak wel met zich mee brengt, algemene aversie tegen het feit ze aangifteplichtig te verklaren. Word deze weerstand doorbroken, dan raakt het heersende systeem van 'checks and balances" uit zijn bepaalde balans. Desondanks is het te overwegen om zekere zelfstandige entiteiten (m.n. funanciête toezichthouders) bij amvb geclausuleerd aan te wijzen als aangifteplichtig. 
vellen over zijn functioneren in het licht van de voor- en nadelen van verzelfstandigde publiekrechtelijke taakuitwoering ${ }^{164} 165166$ : zijnde functie van bij voorbeeld de stichting Verzekeringskamer (denk aan de rapportages inzake Vie d'Or). ${ }^{167}$

De functies vormen de verschillende gezichten van toezichthouders. Als vriendelijke vraagbaak begrijpend. Als milde moeder belerend. Als boze baas bestraffend. Toezicht, dat algemeen of specifiek en anders integraal of thematisch kan zijn, is dus veelzijdig. Bovendien is toezicht dynamisch. Gegeven maatschappijen in metamorfose en Europa in euforie vraagt toezicht voortdurend om aanpassing. Daarom komt het bij woorbeeld voor dat wordt overwogen de Registratiekamer uit te rusten met een handhavingsinstrument als bestuwrlijke boeteoplegging ${ }^{168}$. Of dat de Stichting Toezicht Effectenverkeer zich het handhavingsmiddel van bestuurlijke boete wil toeèigenen. Of dat de stichting Verzekeringskamer met klem verzoekt het sanctiemiddel wan bestuurlijke boeteoplegging te mogen hanteren ${ }^{169}$. Of dat het Commissariaat voor de Media zijn toezicht terecht wil uitbreiden met wettelijke advisering ${ }^{170}$ en -overigens in lichte overschatting- 'nog liefst per morgen' het management inzake (ether)frequentie aan zich wenst te trekken.

164. Nauw verwant aan of sterker, voort vloeiend uit deze functie is de adviserende functie. D.w.Z. de functie om de, bij het uit te voeren belleid betrokken, bewindspersoon/bewindspersonen raad te geven of en, zo ja, welke beleidswijziging $\mathbf{n}_{\text {. a. }} w$. in het werkveld opgedane ervaringen noodzakelijk is. Deze toezichtsfunctic voorziet in, de juist bij externe verzelfstandiging zo nodige, terugkoppeling van beleid.

165. Ander aspect van de evaluatieve functie ligt in het leerzaam overleg, en in de min of meer verplichte samenwerking, met overige operationale Europese of internationale toezichthouders. De evaluatie functie impliceert dan een coöperatieve functie.

166. Hoewel de praktijk het well laat zien, tijkt het veiliger en juridisch juister een ewaluerende functie in de zin wan interpreterende functie (t.a.W. van wetten afkomstig van de formele wetgever) niet aan toezichthoudende verzelfstandigde entiteiten toe te schrijwen of toe te kenmen.

Vermelde woorbeelden zijn niet uitputtend of limitatief. Per functie is titbreiding mogelijk. Weliswaar zijn boven genoemde voorbeelden niet geheel willekeurig. Aanhaling er wan vindt plaats ondat het woombeelden "bij uitstek" betreft.

168. Zij will dit vooral koppelen aan de invoering van een heffingenstelsel. Hoewel de Registratiekamer nadrukkelijk nadeel ziet in hoge heffingen voor onder meer aanmelding van persoonsmegistraties, vaststelling van reglementen en toetsing wan gedragscodes moeten, ziet zij toch het voordeel van ' woorzichtige* theffingen. Voldoen onder toezicht gestelden niet aan hun wettelijke verplichting om bij voorbeeld gedragscodes aan de Registratiekamer voor te leggen ter genoegzaamverklaring, dan kan de Registratiekamer daar oplegging van een bestwurlijke boete aan verbinder.

69. $Z_{\mathrm{ij}}$ wil dit sanctiemiddel toepassen bij mett name termijnoverschrijding. Denk bij woorbeeld aan het, door onder toezicht gestelden, te laat indienen van verslagstaten.

170. Typerend is het gegeven, dat de minister die de werlening van de eerste serie concessies voor zendtijd 列 zijlijn gezet, wellicht in latere periode concessies mag verlenen) advies omtrent concessieverlening inw int van een speciaal daartoe in het leven geroepen commissie zend tijdconcessieverlening. Logischer lijkt het daarmee direct het CrdM, dat immers al (veel meer) kennis in huils heeft, te belasten. Boven-

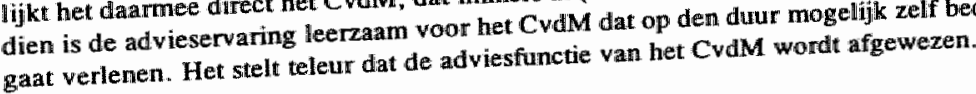




\subsubsection{VERDELING VAN VERANTWOORDELIJKHEDEN MET MANIPXILATIE VAN MACHTEN}

Voornoemde functies beschouwd, valt op dat met de, bij externe verzelfstandiging als uitgangspunt geidende, scheiding tussen beleidsbepaling en beleidsuitvoering de hand wordt gelicht. Soms onbewust. In elke geval onverhuld. Maar miet per se onaanvaardbaar.

Bepaalde beleidsruimte voor een toezichthoudende verzelfstandigde entiteit is meer dan eens niet alleen onvermijdelijk, maar ook wenselijk. Juist in een modeme samenleving, waarin verzelfstandigde toezichthoudende entiteiten een snel aanspreekbare ${ }^{17 !}$, intermediaire bestuurslaag kunnen zijn in grensoverschrijdend opzicht met mogelijkheden tot en vaardigheden voor altematieve, interessante implementatie, is niet zonder meer een resoluut afwijzende attitude tegenover zekere beleidsbepaling van toezichthoudende verzelfstandigde entiteiten nodig. 172173

Bij het overdragen van vooral beleidsuitvoerende en daarnaast beperkt beleidsbepalende publiekrechtelijke bevoegdheden aan een verzelfstandigde entiteit komt misschien het machtsevenwicht in moeilijkheden. Immers, het strikt scheiden van beleidsbepalende taken en beleidsuitvoerende taken past vrij well volmaakt in een zuiver systeem van 'checks and balances'. ${ }^{174}$ Maar daar waar beleidsuitvoering beleidsbepaling impliceert treden complicaties op. Mogelijk manifesteert zich manipulatie van macht.

171. Denk hier aan onder meer bun coördinerend-verzoenende rol in systemen van zelfregulering en ook hun coöpe ratief-innoverende functie ing rensoverschrijdende stelsels van toeztcht. Daardoor houlen nationale verzelfstandigde toezichthoudende entiteiten intenstef contact met zowel onder toezicht gestelden ats collega-toezichthouders in het buitenland. Aldus ontstat een wlotte aanspreekheid.

172. Natuurlijk stant woorzichtigheid voorop. Maar bij de gedachte dat een 'beleidsbepalende' bevoegdheid. van het CvoM bloot statat aan vernietiging of schorsing van de betrokken minister of dac de ged lelegeerde "regelgevende" bevoegdheid wan de STE altijd kan worden ingetrokken door de minister, moet realistisch ruintte worden geboden woor enige beleidsbepaling (inclusief regelstelling) door verzelfstandigde toezichthoudende entiteiten.

173. Het toelaten meer dan alleen beleidsuitvoenende bevoegdheden aan verzelfstandigde toezich thoudende entiteiten impliceert een buitengewoon adequate versiaglegging van werkzaamheden. In jaarverslagen en andere (periodieke) rapportages kat dan nuet meer worden wolstaan met slechts feitelijke informatie. Dat zelfs dit miet altijd lukt, toont de Registratiekamer alan. De Registratiekamer is, nota bene na lange voorbereidingstijd. niet in staat haar eerste jaarverslagen te voorzien van volledige feitelijke informatie. In komende verslaglegging moet de Registratiekamer dan ook beter beslagen ten ijs komen. Niet alleen alle feitelijke, maar ook inhoudelijk beleidsmatige aspecten moet zij de revue laten passeren. "Verkeerd" voorbeeld in dit opzicht is ook een tijd lang de jaarwerslaglegging van het, mede beleidsbepalende, Commissariat voor de Media. Daarin ontbreekt inhoudelijke informatie. Na de nodige kritiek treedt wel verbetering op. In een frequent versehijnend bulletin wan het $C$ wdM wordt per periode biji voorbeeld de besiuitvorming van het CvdM uitgemeten. Bowendien is de berichtgeving niet langer putur formeel, mar ook marerieel. Wat de stichting Verzekeringskamer betreft luidt de kritiek dat haar werslaglegging beleidsmatig beter en vakkundig verfijnder kan. Ten slotte, of het overigens een reële gedachte is om extra verslagleggingsplichten op te leggen is de wraag. Verzelfstandigde entiteiten hebben nu all de grootste moeite om aan al hun informatieplichten (als extra "check' of democratische warborg wegens het gemis aan ministerięle controle, hoewel dit argument betwijfeld kan wonden omdat veel verslaglegging vershiert en verhullend wam opzet isi) te voldoen.

174. Denk an feitelijk uitvoerende zbo"s als Informatie Beheer Groep bv, Dienst Kadaster en Openbare Registraties of Centraal Orgaan Opvang Asielszoekers. 
Daarom dient het op- of overdragen van beleidsuitvoerende taken, die onverbrekelijk verbonden zijn met beperkte beleidsmatige werkzaamheden, omzichtig te geschieden. Bij dergelijke (functionele) decentralisatie moet de rechterlijke controle op gedragingen wan toezichthoudende verzelfstandigde entiteiten, als volwaardig substituut van de democratische controle, extra goed geregeld zijn.

Mogelijk zijn ook aanvullende 'checks' te treffen. Dit is vergelijkbaar bij verzelfstandigde, veelal ook toezichthoudende, entiteiten met een meer dan normaal monopoloide karakter. Door hun uitgesproken alleenrecht zijn zij niet ontvankelijk voor open competentie. Ook hier wordt een, zij het andersoortige, verdeling van machten verstoord. Om de storing in dergelijke gevallen te elimeren, worden wel aanvullende 'checks' ingevoerd. Denkbaar is het, ten einde concurrentie te creëren, (cliënt vervangende) signalerings- en informatiesystemen op te zetten. Helaas kost dit veel geld en moeite. In dergelijke gevallen biedt pure privatisering meer profijt of staat zelfregulering meer échte marktwerking toe.

Ondat aanvullende 'checks' dus niet alles oplossen, komt het aan op kordate controle door de rechter. Een rechter, die zich actief opstelt, kan het evenwicht tussen democratie en rechtsstaat herstellen. Voorwaarde is dat hij er well toe in staat is. Dat wil zeggen, in een duaal stelsel - waarin rechters legislatieve en executieve macht, die steeds vaker de zelfde identiteit hebben, meer dan ooit in de gaten houden en zelfs vervangen ${ }^{175}$ moet er voldoende rechterlijke capaciteit zijn. Immers, even als de wetgever te vaak in gebreke blijft, kan de rechter, zeker met een toenemende verantwoordelijkheid, overbelast raken. De rechterlijke macht verdient, min of meer genoodzaakt, uitbreiding.

175. Schrijnend is het, meestal nood gedwongen, natatig zijn wan de wetgever. De ene keer bliff wardevolle wetgeving gewoon achterwege. De andere keer vardigt de wetgever weliswar wetten wit, maar dan blijken ze niet toereikend (of niet duidetijk) in praktijk. De wetgever words gemaand tot wetswijziging. maar talt daar weel te lang mee. In die gevallen betoont de rechter realiteitszin door jonge of onheldere wetgeving aan of in te vullen. Ewident is de wetgeving op grond warvan de STE haar toezichtstaak moet uitoefenen. In het bijzonder bij de Wmz gaat het mis. De Wmz kent noemenswaardige onvolledig. theden en onduidelijkhedien. Bij herhaling belooft de wetgever de problemen te verhelpen. Maar, zelfis alls de STE werschillende kerem u itdrukkelijk om evaluatienota"s en reparatiewetgeving werzoekt, blijken beloften loze beloften. Het is niet vreemd dat de weg naar de rechter vrij komt. Minder terecht is dat

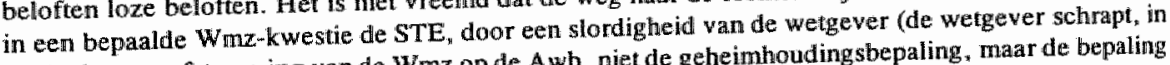
het kader van afstemming van de Wma op de A wb, niet de geheimhoudingsbepaling. maar de bepaling over ontheffing van publikatieplicht uit de $\mathrm{Wmz}$ ) die deze -ondanks adudringen- niet herstelt, zelf het heft in handen neemt. Met de handen in het haar besluit de STE, na lange tijd, dat een onder toezicht gestelde toch maar een gewijzigd aandelenbelang moet melden. Hoewel respect voor het handelen van de STE mogelijk is, is haar optreden tegelijkertijd navrant en fundamenteel onjuist. Hier ligt een taak voor hetzij wetgever hetzij rechter. Op zich is het positief ais een zbo regelstellende taken uitoefent. maar dan moeten daartoe wel de noodzakelijke regelstellende bevoeguhedem bij wet wonden toegekend. Tamelijk willekeurig de wet an- of invullen lijkt niet de meest juiste oplossing. Wel is het goed voorstelbaar beklag te doen over onrechtmatige of onwolledige wetgeving bij de rechterlijke macht. En anders kan een $z \mathrm{bo}$, in afwachting van volledige formele wetgeving, zelf -al dan niet in overleg met zelfregulerende krachten- voorlopig handhawingsbeleid(sregels) stellen, waarbij wellicht komende wetgeving all wordt gekneed. 


\subsubsection{Rechtsstatelijkheid rigoreuzer in regressie}

Op functioneel-decentraal niveau is het mogelijk in ander opzicht rechtsstatelijkheird te forceren. Voorbeelden werken hier verhelderd.

Ten eerste, de Stichting Keur Alternatief voortgebrachte Landbouwprodukten ontkracht de bestawnde machtswerdeling tussen de authentieke rechtsgebieden. Als een onder toezicht gestelde niet aan zijn nalevings- en aansprakelijkheidsplichten voldoet kan hij geconfronteerd worden met een tuchtmaatregel. Oplegging van een tuchtmaatregel is pas mogelijk als de strafrechtelijke weg is afgesneden. De officier van justitie beslist normaliter of een zaak strafrechtelijke afdoening verdient. Bij schending van landbouwkwaliteitscontrolewet- en regelgeving inzake biologische produktiemethode is het opmerkelijk dat de officier van justitie voor zijn besluitvorming, omtrent al dan niet strafrechtelijke vervolging van een overtreding, overleg pleegt met de Skal-voorzitter en anders de Skaldirecteur. De taak van de toezichthoudende verzelfstandigde entiteit verwart zich in een kluwen van toezicht, opsporing en vervolging. Hier raakt de bestuurlijke handhaving aan de strafrechtelijke handhaving. Dat lijkt niet te rijmen met de, rechtsstatelijk correcte, primair keurende, inspecterende en certificerende functie van Skal. Bovendien keert het tij zich zo snel tegen de Skal. In welke mate moeten onder toexicht gestelden de verzelfstandigde entiteit als toezichthoudend, en in welke mate als vervolgend, zien.

Ten tweede, het Commissariaat woor de Media kampt ook met een machtsverdeling in moeilijkheden, waardoor een vertrouwensvacuüm bij onder toezicht gestelden ontstaat. Taakuitoefening door het commissariaat kan onderscheidend vermogen verliezen daar waar het commissariaat zowel toezichthoudend als vervolgend en berechtend optreedt. Zo verleent het commissariaat, als een en de zelfde entiteit, zendtijd en trekt deze even goed weer in. Van uit rechtsstatelijke redenen voert het commissariaat een adviescommissie bezwaarschriften in. Daarin hebben deskundigen zitting. Door het deskundigenoordeel naast het sanctievoornemen van het commissariaat te leggen, wint de besluitvorming van laatst genoemde wellicht aan acceptatie bij onder toezicht gestelden. Overigens is deze opzet (een onpartijdig, deskundig oordeel werpt een helder licht - of een schaduwschijnsel - over de mening van de toezichthoudende verzelfstandigde entiteit) ook op waardevolle wijze in te passen bij andere toezichthoudende verzelfstandigde entiteiten. ${ }^{176}$ Daartoe verplicht de Awb ook min of meer.

\subsubsection{STELSELS TEN GRONDSLAG LIGGEND AAN TOEZICHT}

Toezichthoudende verzelfstandigde entiteiten staan verschillende mogelijkheden ter beschikking om hun toezichtstaak uit te oefenen. De diversiteit aan toezichtsmiddelen doet een beeld ontstaan van overheidstoezicht op basis van stelsels inzake onder meer:

176. Andere optie is om toezichthoudende en sanctionerende taken toe te delen asan separate entiteiten. Voor de $_{\text {, }}$ in deze studie centraal staande, verzelfstandigde entiteiten wordt dit geen juist uitgangspunt geachit. 


\section{a. vergunningen}

d.w.z. de toezichthouder beschikt eenzijdig ${ }^{17 /}$ dat bepaald handelen door een geindividualiseerde onder toezicht gestelde wordt toegestaan:

deel uitmakend van het toezichtsstelsel in het effectenverkeer (Stichting Toezicht Effectenverkeer) en in het verzekeringsverkeer (stichting Verzekeringskamer) ${ }^{178}$;

b. concessies

d.W.z. de toezichthouder komt min of meer tweezijdig ${ }^{179}$ met een onder toezicht gestelde (met voormamelijk privaatrechtelijke karakter) in het algemeen belang overeen dat laatst genoemde een publieke taak uitvoert:

deel uitmakend van het toezichtsstelsel in het mediaverkeer (voor als nog niet het Commissariaat voor de Media, maar de minister van onderwijs, cultuur en wetenschappen ${ }^{180}$;

c. certificaten

d.W.Z. de toezichthouder verschaft een onder toezicht gestelde een bewijs dat laatst genoemde voldoet aan minimumeisen van kwaliteits-, produktie-, proces- of dienstenniveau:

deel uitmakend van het roezichtsstelsel in het landbouwverkeer (o.a. Stichting Keur AlternatiefvoortgebrachteLandbouwpradukten, stichting InternationaleScharrelvlees Controle, Kwaliteits-Controle-Bureau groenten en fruitprodukten), in het vellige werktuigenverkeer (o.a. nv Kema, Nederlands Meet Instituut Van Swinden Laboratorium bv, Nederlands Instituut voor Lifttechniek, Germanischer Lloyd) en het veilig vaar- en rijverkeer (o.a. Koninklijke Nederlanse Toeristenbond en de stichting Centraal Bureau Rijvaardigheidsbewijzen);

d. erkenningen

d.w.z. de toezichthouder beschikt dat een persoon of instelling aan bepaalde voorwaarden voldoet:

deel uitmakend van het toezichtsstelsel in het wegverkeer (Dienst wegverkeer) en in het effectenverkeer (Stichting Toezicht Effectenverkeer);

177. Tenzij vergunmingen hevigg geconditioneerd zijn. De alan vergunningen verbonden voorschrifter en beperkingen moeten door de betrokken onder toezicht gestelde worden anvarard.

178. I $v$ in de zware bewijslast van de artt. 240-240b WvSr, acht de Nederlandse Film Keuring het wenselijk dat een nieuwe Wf wordt ontwerpen waarin de wetgever cok een vergunningensysteem voor het filmverkeer introduceent Inderciaad wint de toezichthouder daardoor waarschijnijk aan kracht. In haar huidige vorm, werkend met de bestande wetgewing. werdient xij in elk geval geen woortzetting. Versterking van het toezichesinstrumentarium van de NFK, of beter nog: aankoppeling bij het Commissariat woor de Media., is noodzakelijk.

179. Aan dit kenmerk wan concessies doet het concessiestelsel in thet mediarecht te kort. Immers, de mediaconcessies vinden fundament in publiek recht. Daamee kunnen zij een nüet eigendijk eenzijdig karakter krijgen.

180. In handen van het CvdM past verlening van concessies aan publieke omroepen (opgelet: concessieverlening aan commerciële omroep heeft het CvdM volgens aanvankelijk voomemen vanaf 1996 wél in handen) het best. Neemt de wetgever de moeite om -mogelijk na radpleging van het CvdM (i.p.. . een aparte adviescommissie concessieverlening)-heldere, eenduidige criteria intrekken. Een dergelijke visie te stellen, dan is het voor het CwdM een koud kunstje concesse voering. 
e. verklaringen van geen bezwaar

d.W.Z. de toezichthouder verklaart zich akkoord met een, door een onder toezicht gestelde, te nemen beslissing, welke beslissing zonder die instemming niet geldig is en vaak zelfs verboden is (met het mogelijke gevolg van ongedaanmaking of aanwijzing onder termijnstelling):

deel uitmakend wan het toezichtsstelsel in het effectenverkeer (Stichting Toezicht Effectenwerkeer) en in het verzekeringsverkeer (stichting Verzekeringskamer).

Inherent aan in het bijzonder verleende vergunningen, concessies of certificaten is dat deze geen eeuwige waarde vertegenwoordigen. Juridische verlening en, in het verlengde, feitelijke afgifte er van geven geen garantie voor altijd. Kwaliteit van produktie(proces) of dienstverrichting moeten voortdurend worden getoetst en daar waar nodig bijgeschaafd. Juist hierom kan het zinvol zijn niet ministers, maar dichter bij het werkveld opererende toezichthoudende verzelfstandigde entiteiten, die toch al belast zijn met sanctiemogelijkheden ten aanzien van afgegeven vergunningen e.d., te belasten met vergunningverlening en de continue bewaking van het synchroon lopen van de formulieren met de feiten. Is de kwaliteit tijdens of enige periode na vergunningverlening nog conform de formele papieren? Correspondeert de actuele vergunninghouder nog met de originaire vergunninggerechtigde? ${ }^{181}$

\subsubsection{TOEZICHT VERPLICHT TOT GEHEIMHOUDING}

De tegenwoordig sterk geformaliseerde geheimhoudingsplichten zijn minder absoluut dan voorheen. Feitelijk zijn ze alleen nog gericht op die gegevens waarvan het vertrouwelijk karakter bekend is of redelijkerwijs vermoed kan worden. Zie, het met Aanwijzing voor de regelgeving 163 overeenstemmende, art. 2:5, eerste lid, Awb: "Een ieder die is

181. Wat betreft vergunningen watrwan de $k$ waliteit van de anwrager (concurrent) bepalend is voor verlening er wan wijst H.J. de Ru, Banken in telecom: verkeerd verbonden, Vergunningstelsel gevaar voor cancurrentie?, in: NRC, ar.6, 10 febr. 1995, pp.197-203, i.th.b. pp.202-203, alert op het gevaar van verhandelbaarheid er wan. In bepaalde gevallen is owerdraagbaarheid wan wergunningen mogelijk, mits daartoe ministerible toestemming wordt gegeven. Denk aan het bepaalde in art. $13 \mathrm{u}$ Wet op de teleconmunica. tievoorzieningen. Auteur vreest dat de eisen die gelden woor dit ministerieel consent "kunnen worden omzeld door owerd racht van aandelen in de vergunninghouder-rechtspersoon" In het verlengde hiervan dreigt voor $\mathrm{i}$.h.b. de telecommunicatiemarktaantasting van concurrentie" "De vergunningverlening blijkt slechts teen momentopname te zijn. De daama ontluikernde markt is ongecontrolleerd, te meer daar mededingingswetgeving hooguit instrumenten biedt om misbnik van machtspositie te verbieden, mat niet om effectieve mededinging daadwerkelijk te beworderen. De levenswatbaarheud staat daarmee op het spel. Hiermee kan de zorgwuldig uitgebalanceende vergunningprocedure in feite waardeloos blijken te zijn." Auteur acht het trouwens terecht een omissie van de wetgever dat -terwijl zo veel andere informatieverplichtingen wel zijn opgenomen- niet is voorzien in een verplichting voor de vergunninglwouder om onwerwijld inlichtingen te verschaffen ower deelnemingen in de vergunninghouder. Wat betreft die deelnemingen voorziet auteur specifiek problemen bij, aan verklaringen van geen bezwaar gebonden, deelnemingen van kredietinstellingen in niet-financiële ondernemingen. Hierbij kan de geheimhouding, die an de belangen van deelneming door de trekikerswervullende banken is verbonden, problematisch zijn voor in casu de minister van verkeer en waterstat als GSM-vergunningverlener: weet hij -bij (voorlopig) gebrek aan publikatie van de wvgb in de Staatscourant- of vvgb's zijin aangewraggd en, zo ja, welke beslissingen daarop zijn genomen? 
betrokken bij de uitvoering van een bestuursorgaan en daarbij de beschikking krijgt over gegevens waarvan hij het vertrouwelijk karakter kent of redelijkerwijs moet vermoeden. en voor wie niet reeds uit hoofde van ambt, beroep of wetelijk voorschrift ter zake van die gegevens een geheimhoudingsplicht geldt, is verplicht tot geheimhouding van die gegevens, behoudens voor zover enig wettelijk voorschrift hem verplicht tot mededeling of uit zijn taak de noodzaak tot mededeling voort vloeit." Het tweede lid van dat artikel maakt deze stelregel mede toepasselijk op instellingen en daartoe behorende of daarvoor werkzame personen die door een bestuursorgaan worden betrokken bij de uitwoering van zijn taak, en op instellingen en daartoe behorende of daarvoor werkende personen die een bij of krachtens de wet toegekende taak uitoefenen.

Deze generale geheimhoudingsplicht, die weliswaar wat toezichthoudende taken van met name Stichting Toezicht Effectenverkeer, De Nederlandsche Bank nv en de stichting Verzekeringskamer betreft de toepasselijkheid van respectievelijk Wob en Wno uitsluit, laat de wettelijke ${ }^{182}$ mogelijkheid onverlet om, in het belang van adequaat overheidstoezicht door een verzelfstandigde entiteit, bepaalde administratieve informatie en gegevens te openbaren of uit te wisselen met bevoegde collega-toezichthouders in het buitenland. Bij het, mogelijk met zowell lidstaten als niet-lidstaten, uitwisselen van al dan niet administratieve informatie is een algemeen communautair beginsel van administratieve zorgvuldigheid leidraad.

Bovendien is het mogelijk geheimhoudingsplichten te passeren met een appèl op de strekking van een wet waarin overheidstoezicht basis vindt. Illustratief is hier het, door het Amsterdamse gerechtshof rechtmatig bevonden, optreden van de Stichting Toezicht Effectenverkeer die, met oog op het bevorderen van de transparantie van de effectenmarkt, aan derden gegevens verstrekt uit het door de toezichthouder aangehouden, overigens niet-openbare, Wmz-register.

Tegenover dit omzeilen van geheimhoudingsplichten staat het buitensporig benadrukken van geheimhoudingsplichten. Daardoor kan, ten eerste, rechtshandhaving door een bevoegde toezichthouder worden gefrustreend. Bovendien is het, ten tweede, mogelijk dat het toezicht op de toezichthouder zelf wordt bemoeilijkt.

Aangaande het eerste element het volgende. Inderdaad houden toezichthoudende verzelfstandigde entiteiten wel eens te streng de hand aan geheimhoudingsplichten. Hoe hardvochtig het beroep van een toezichthouder op een geheimhoudingsplicht kan zijn, toont de halsstarrige houding van De Nederlandsche Bank nv tegen over haar Franse collegabanktoezichthouder aan. DNB nv twist met de Commission Bancaire over wie bevoegd is om toezicht te houden op de Crédit Lyonnais Bank Nederland, waarvan de moederonderneming met zetel in Parijs al onder het wakend oog van de Franse toezichthouder valt.

182. Naast i.h.b. de informatie-uitwisselingswet is te denken aan wetsaanvullende mogelijkheden voort vloeiend uit convenanten. Hiertoe (inclusief $m$.b.t. de met niet reguliere of niet routinematige informatie-uitwisseling gepaand gaande onevenredig hoge kosten) sluiten bij woorbeeld zowel de Stichting Toezicht Effectenverkeer als de stichting Verzekeringskamer bijzondere memoranda of understanding met Europese en internationale toezichthouders af. 
DNB nw houdt haar Franse collega bevoegd formeel toezicht uit te oefenen op CLBN. Tegellikertijd weigert $\mathrm{DNB} n \mathrm{n}$, hoewel uitwisseling wan informatie inzake solvabiliteit en liquiditeit met een buitenlandse toezichthouder (die geheimhouding betracht) haar uitdrukkelijk wordt toegestaan, gedetailleerde informatie over mogelijke risico"s die CLBN door dubieuze leentransacties voor de moederbank oplevert aan de Franse toezichthouder te verstrekken. Aldus belemmert een geheimhoudingsplicht een behoorlijke uitoefening van toezicht.

Betreffende het tweede aspect bestat ook een voorbeeld. De stichting Verzekeringskamer, die inzake Vie d'Or kennelijk niet oplettend genoeg is, verschuilt zich vervelend en oneigenlijk achter haar geheimhoudingsplicht als een Tweede Kamercommissie een onderzoek wil naar het functioneren van het toezicht op de verzekeringsmarkt. Omdat de minister van financiën ${ }^{183}$ en nog minder de Algemene Rekenkamer geen ongeclausuleerde toegang tot boeken en bescheiden van de toezichthouder stelt de volksvertegenwoordiging uiteindelijk een parlementair onderzoek (met daaraan gekoppeld hetzij een parlementaire enquête hetzij een rekenkameronderzoek) in.

Naast belemmering van het ministerieel toezicht op toezichthoudende verzelfstandigde entiteiten, kan het beroep op een geheimhoudingsplicht verhindering van een een sluitende samenwerking van toezichthoudende verzel fstandigdle entiteiten met opsporingsinstanties betekenen. Het door de CRI, FIOD en ECD gedane onderzoek naar criminele infiltratie in het effectenwezen wordt in hoge mate beperkt doordat de Stichting Toezicht Effectenverkeer en De Nederlandsche Bank nv het niet nodig achten om vertrouwelijke informatie ten behoeve van dat onderzoek te verstrekken.

\subsubsection{TOEZICHT, ZONDER ZELFREGULERING, MET MEDEDINGINGSBEPERKING}

Bovengenoemde formalisering van geheimhoudingsplichten wordt ingegeven door het in toenemende mate in elkaar overlopen van werschillende deelmarkten in zekere sectoren. Naast deze functionele grensoverschrijding, bestaat tergende territoriale grensoverschrijding. De Nederlandse gemeenschap wordt een Europese gemeenschap. En de Europese gemeenschap wordt een internationale gemeenschap. Verdwijnen geografische grenzen, dan komen economische einders in zicht. Integratie en liberalisering van markten veroorzaken krachtige concurrentie. En de indringenheid van impulsen om winst te maken doet roepen om een toezichthouder die bereid is geld beluste ondernemers zo nodig in hun commercièle kraag vatten. Daar waar voldoende effectieve zelfregulering ontbreekt, is de behoefte aan toezicht op naleving van wet- en regelgeving bijzonder dringend. Blijft, tot overmat van ramp, het overheidstoezicht ook nog in gebreke, dan is, gegeven de dreigende gevaren van niets ontzienende concurrentie, mededingingsbeperking (als

183. Wel neemt de bewindspersoon zich voor om de Wtw, in overeenstemming met Europese regelgeving inzake geheimhoudingsplichten, te wijzigen in de zin dat failliete verzekeraars als Vie d"Or verplicht zijn aan de betrokken minister vertrouwelijke informatie te verschaffen. De minister is dan weer in staat om aldus verkregen unformatie door te spelen maar een onafhankelijke instamtie als de Algemene Rekenkamer. 
aanwulling op ontoereikend overheidstoezicht) noodzaak. ${ }^{184}$ Bepaling van de grenzen daarvan staat ter beoordeling van, in eerste instantie, de nationale rechter.

Dat zelfregulering nog niet in alle sectoren naar behoren is, stelt teleur. Juist tegenwoordig heeft zij kansen als nooit tevoren. Nu bijna alle wetten verplicht bol staan van dereguleringsparagrafen, hoeft zelf fregulering geen slag in de lucht te zijn. Daar waar regulering van overheidswege ontbreekt, kan zij inspringen op de van uit het bedrij fsleven ontstane behoefte aan perfect passende regels voor eigen kring.

De door deregulering open gelaten ruimte, die anders dan wellicht verwacht niet afdoende door zelfregulering wordt gedicht, verwordt tot vijandig vacuüm. Weliswaar wordt deregulering op nationaal niveau nog gecompenseerd door reregulering op Europees niveau. In internationaal opzicht ligt onderregulering op de loer. Daar waar minder regels worden gesteld en meer marktwerking wordt geîntroduceerd wacht een potentiële, problematische prijzenslag. Dit gevecht is niet zo zeer gevaarlijk in het aan relatief strenge normen gebonden Europa, maar ontlaadt zich juist buiten Europa. In de, aan onderregulering onderhevige, internationale gemeenschap, beginnen -de door toenemende fusies en voortschrijdende concentraties steeds machtiger wordende-concurrenten hun sluwe spel om de knikkers. Dit probleem doet zich vooral voor in de financiële wereld, waaronder de onder toezicht van de Stichting Toezicht Effectenverkeer staande effectenwereld valt.

\section{$\S 20.6$ Aanbevelingen}

In het licht wan het vooraf gaande vormen zich de volgende overwegingen. In deze overdenkingen is plaats voor enige aanbevelingen.

\subsubsection{AANBEVELINGEN M.B.T. RECHTSORDE EN RECHTSSTAAT}

Van uit rechtsordelijk en rechtsstatelijk perspectief gelden aanbevelingen als:

I: Het scheiden van beleidsbepaling (op te dragen aan kerndepartementen) en beleidsuitvoering (op te dragen aan verzelfstandigde entiteiten) ziet op een zuivere machisverdeling. Dit is met name het geval als uitvoeren van beleid de betekenis heeft van toezicht houden op de naleving van het gestelde bij of krachtens wet. In de correcte situatie wordt dit toezicht, zijnde overheidstaak, op-of overgedragen aan een onafhankelijke deskundige verzelfstandigde entiteit.

De, met toedeling of overheveling van publiekrechtelijke taken (in het kader van het legaliteitsbeginsel) doorgaans gepaard gaande, decentralisatie van publiekrechtelijke bevoegdheden geschiedt bij voorkeur via attributie of delegatie. Hierbij is de minister formeel beperkt verantwoordelijk voor het 'op afstand' uitgevoerde rijksbeleid. Maar materieel is de minister, in ultieme gevallen, als reservepost in essentie verantwoordelijk

184. Let wel, zo lang mededingingsbeperking nog mogelijk is. Voorlopig lijken beperkingen op de vrijheid van dienstverlening e.d. nog mogelijk gelet op het daarmee te dienen bescherming wan het algemeen belang en de consumentenbescherming. 
en dient hij zo nodig daadkrachtig delegatie of attributie in te trekken of de voorwaarden er van te wijzigen. Om te weten of er reden bestaat tot intrekking of wijziging van delegatie of atrributie (en ook gegeven de mogelijkheid om de Staat der Nederllanden aansprakelijk te steflen voor het optreden van toezichthoudende zbo's), moet de minister uitdrukkelijk op de hoogte zijn van het reilen en zeilen van toezichthoudende verzelfstandigde entiteiten. Daartoe moeten de kanalen van gevraagde en ongevraagde informatie tussen minister en toezichthouder, als controlevoorzieningen, overdreven open worden gehouden. Anders dan bij onderlinge informatie-uitwisseling tussen binnen- en buitenlandse toezichthouders, mogen geheimhoudingsplichten geenszins in de weg staan aan informatie- en inzagerechten van de minister tegenover de toezichthouder. Elk toezichthoudend zelfstandig bestuursorgaan moet, ter verantwoording, voldoende inzicht geven in de wijze van overheidstaakuitwoering. Aldus hoeven de tegenwoordig snel en oneigenlijk ingestelde, kostbare en tijdrovende parlementaire onderzoeken en parlementaire enquêtes niet als lelijk lapmiddel te dienen.

Redelijk realisme noopt er toe te erkernen dat toezicht vaak meer dan beleidsuitvoering sec inhoudt. Om toezicht, in een complex geheel van marktgerichte maatschappijen, dynamisch te doen zijn is zelfs aan te raden dat toezichthoudende verzelfstandigde entiteiten niet alleen de beleidsuitvoering ter hand nemen. Zinvol is dat zij ook, weliswaar wettelijk geconditioneerde, regelstelling waaronder i.h.b. formulering van technische toezichtsregels of handhavingsbeleid(sregels), wetsvoorbereiding en advisering tot hun takenpakket mogen rekenen. $\mathrm{Zij}$ zijn ter zake kundig, zijn belangeloos, genieten ervaring, zitten 'boven op' de al dan niet zelf gereguleerde werkplek en mogen wat betreft de kwaliteit van toezicht niet onderdoen voor buitenlandse collega's. Gelet op de dure discontinuilteit en het nihile niveau van de vigerende, voor toezichthouders wezenlijke, wetgeving, heeft het er alle schijn van dat zij beter dan de formele wetgever in staat zijn tot adequate en tijdige regelstelling. Even alls de toezichthouder zelf gebaat is bij sufficiënte zelfregulering, kan de wetgever zijn voordeel doen met op de praktijk toegespitste regellstelling en formulering van handhavingsbeleid(sregels) door de toezichthouder. Controleert de toezichthouder zelfregulering, het parlement als wetgever houdt toezicht op regels en beleid van de toezichthouders. Ten eerste, de weel te drukke wetgever wordt zowel kwantitatief als kwalitatief ontlast. Ten tweede, regelstelling via fiexibele, mogellijk van democratische inbreng voorziene, convenanten e.d. door functioneel gedecentraliseerde toezichthouders versnelt, al dan niet voorlopige, implementatie van Europese richtlijnen. Ten derde, de rechterlijke controle, die de gebrekkige ministeriële controle bij verzelfstandigde toezichthouders ook al aanvult, vult reeds nu de lacunes op die de wetgever in vage regels laat. Dit past in een moderne machtsevenwichtsleer. Ook als de rechter minder gaten in warrige wetgeving hoeft te dichten, maar zich meer toe moet leggen op toetsing van door toezichthouders voorbereidde en ontworpen (voorlopige) regels past dit nog steeds in de hedendaagse duasleer inzake machtsverdeling.

II: Gegeven het feit dat toezichthoudende verzelfstandigde entiteiten verschillende functies kunnen uitoefenen, is het noodzakelijk de te onderscheiden soorten uit te oefenen bevoegdheden, voor in elk geval onder toezicht gestelden, helder uit elkaar te houden. 
Een toezichthoudende verzelfstandigde entiteit met een, aan haar toezichtstaak gerelateerde, geschillenbeslechtende functie dient, ten einde het in haar door onder toezicht gestelden gestelde vertrouwen niet te verliezen, woor werkzaamheden t.a.v. klacht- of bezwaarschriftbehandeling een, al dan niet externe, onpartijdige en deskundige adviescommissie in het leven te roepen (vgl. art. 7:13 Awb). Het opdragen van een over ingediende klachten/bezwaren oordelende functie aan een toezichthoudende verzel fstandigdie entiteit dient uitdrukkelijk te worden gemotiveerd. In elk geval daar waar de toezichthoudende verzelfstandigde entiteit een privaatrechtelijke rechtsvorm heeft, dient zij eventuele geschillen niet zelf te beslechten, maar vindt behandeling van bezwaren bij voorkeur plaats door een publiekrechtelijk orgaan.

Een, tot het opleggen van bestuurlijke boeten bevoegde, toezichthoudende verzelfstandigde entiteit, die toezichthouders aanstelt, dient naast inspecteurs en controleurs met reguliere taken afzonderlijke boete-inspecteurs aan te stellen. Deze boete-inspecteurs doen. waarschijnlijk meer, dan primair op preventie gerichte controleurs of inspecteurs, recht doen aan de waarborgen bij behandeling van overtreders. Een dergelijke machtsverdeling voorkomt mogelijk vertrouwenswerlies bij onder toezicht gestelden, die in het algemeen argwanend aankijken tegen een toezichthoudend ambtenaar die tegelijkertijd een sanctionerende functie heeft.

De functiescheiding treft trouwens niet alleen boete-inspecteurs, maar de totale opzet van een toezich thoudende verzelfstandigde entiteit. De hiërarchie binnen een toezichthoudend zelfstandig bestuursorgaan moet helder zijn voor onder toezicht gestelden. In sommige sectoren is het zo, dat een onder toezicht gestelde (indien deze ontevreden is over het optreden van een controleur of een inspecteur die toezicht heeft uitgeoefend op zijn terreinen of in zijn bedrijf) schriftelijk zijn ongenoegen kan uiten bij een hoofdcontroleur of een door laatst genoemde aangewezen assistent-hoofdcontroleur. Op diens uitspraak staat dan weer beroep open bij de directeur van het toezichthoudende bestuursorgaan. Ten einde een optimale rechtsbescherming aan onder toezicht gestelden te bieden is het belangrijk duidelijk te maken wie welke functie bekleedt binnen de toezichthoudende wer zelfstandigde entiteit. Bovendien biedt een heldere functieverdeling -naar rang onderscheiden in onder meer: inspecteurs, inspectiemedewerkers, hoofdcontroleurs met rayon of in afzetmarkten speciale projecten, assistent hoofdcontroleurs in rayons of in afzetmarkten speciale projecten, controleurs, aankomend controleurs en kwaliteitscontroleprocesmanager-mogelijk het voordeel dat gewerkt kan worden met standaardformulieren en gelijksoortige regelingen inzake de organisatiestructuur van toezichthoudende verzel fstandigde entiteiten. Bij voorkeur is daarvoor een standaardformule in afdeling $5.1 \mathrm{Awb}$ te creëren. Deze kunnen toezichthoudende verzelfstandigde entiteiten naar eigen keuze toepassen op hun organisatie. Daardoor wordt hun organisatie doorzichtiger en krijgt een minder complex uiterlijk.

\subsubsection{AANBEVELINGEN M.B.T. RECHTSHANDHAVING EN RECHTSBESCHERMING}

Van uit rechtshandhavings-en rechtsbeschermingsperspectief gelden aanbevelingen als: I: Het verzelfstandigen van publiekrechtelijke toezichtstaken kan huidige handhavingshiaten opvullen en nauwelijks nageleefde regels gelding geven. Zeker als wettelijk gecondi- 
tioneerde zelfregulering daarbij een goede kans krijgt. Een op afstand gezette toezichthoudende entikeit biedt het voordeel van verfijnde verstandhoudingen. $\mathrm{Zij}$ is in staat voldoende contact met de betrokken minister(s) te houden. $\mathrm{Zij} \mathrm{kan,} \mathrm{en} \mathrm{moet} \mathrm{trouwens,}$ een goede samenwerkingsrelatie opbouwen met binnen- en buitenlandse toezichthouders met gelijkwaardig toezicht in soort gelijke sectoren. Zij onderhoudt een behoorlijke band met opsporingsambtenaren. En ze onderhandelt met het vervolgingsapparaat. Kortom, op voorwaarde dat zij adequat, autonoom en autoritair is, is een toezichthoudende verzelfstandigde entiteit een tentakelrijke octopus die een aanzuigende werking heeft op werkbare wet- en regelnalleving.

Il: Toezichthoudende verzelfstandigde entiteiten zijn slechts toezichthoudend. Niet meer en ook niet minder.

Niet meer, omdat toezichthoudend niet opsporingsbevoegd ten aanzien van strafbare feiten betekent. Afdeling 5.1 Awb, waarin ver gaande -nota bene in de praktijk van verzelfstandigde toezichthoudende entiteiten soms overbodige-toezichtsbevoegdheden voor toezichthoudende ambtenaren en particulieren worden gecreëerd, is in dit verband dan ook risicovol. Eenwoudig kan het, in een bestuurlijke hoek te plaatsen, toezicht door bij voorbeeld een bevoegdheid tot binnentreden ontaarden in de, in het kader van bewijsverzameling en strafvordering staande, opsporing. Vice versa tolereert de Hoge Raad dat. tijdens de opsporingsfase toezichtsbevoegdheden mogen worden uitgeoefend. Vooral het heimelijk hellen van toezicht naar opsporing (of omgekeerd) bedreigt het nemo teneturbeginsel. Dit beginsell is weliswaar strafrechtelijk van aard. Maar meer in het algemeen moet strafrechtelijke normering, waaronder de regels inzake strafrechtelijk onrechtmatig. verkregen bewijs, toepasselijk zijn op handelen in de toezichtsfase.

Niet minder, toezicht is wezenlijk en moet niet met éên hand zijn weg te wuiven. Daarom is het verstandig waart te zetten achter de invoering van bestuurlijke boeten voor geringe en norm neutrale, al dan niet eenmalige of voor de eerste keer voorkomende, overtredingen die geen zaaksschade veroorzaken of persoonlijk letsel toebrengen. Juist deskundige toezichthoudende verzelfstandigde entiteiten zijn bij uitstek in staat om een facultatieve bevoegdheid tot het opleggen van, al dan niet voorwaardelijke, bestuurlijke boeten uit te oefenen. In boeteoplegging moet zich het boze gezicht van de toezichthouder tonen. Dat is belangrijk, want daardoor is het niet nodig de nog norsere opsporingsambtenaar er voortijdig en oneigenlijk bij te roepen. Zo stemt tergend, maar transparant toezicht tot tevredenheid bij een onder toezicht gestelde die meer kans op een eerlijke rechtsverdediging maakt. Overigens heeft de rechter, als boeteoplegging wordt aangevochten in bezwaar/beroep dat bij voorkeur geen schorsende werking heeft, naturlijk een niet te onderschatten bevoegdheid opgelegde boeten te toetsen op rechtmatigheid (wat betreft zowel noodzaak als hoogte er van).

Juist in het kader van toezicht houden op naleving van het bij of krachtens de wet gestelde komt de essentie van oplegging van bestuurlijke boeten naar voren. Toereikend toezicht is onmogelijk als onder toezicht gestelden: a. niet tijdig, niet correct of niet volledig aan meld-, verslag-, registratie- of administratieplichten voldoen; b. niet zorgvuldig, niet secuur of niet snel genoeg zelfkeuring en -meting uitvoeren; $c$. niet zichtbaar of niet juist verpakkingen, produktaanduidingen, afleveringsbrieven en dergelijke aanbrengen; en d. 
niet binnen de daarvoor gestelde termijn verschuldigde contributies, heffingen, onkostenvergoedingen en soort gelijke financiële bijdragen betalen. Toezichthoudende verzelfstandigde entiteiten spelen zelfs met de gedachte om bij nog niet onder toezicht gestelden te komen tot oplegging van een bestuurlijke boete. Dit is inderdaad denkbaar als toezichtsstelsels basis vinden in vergunningen, verklaringen van geen bezwaar, concessies, machtigingen en dergelijke. Voorwaarde is dan wel dat op het niet aanmelden ter geboden registratie of het niet aanvragen van verplichte vergunning bij de betrokken toezichthoudende verzelfstandigde entiteit een wettelijk verbod rust.

Toezichthoudende verzelfstandigde entiteiten doen er verstandig aan enkel toezichthouders in dienst te hebben en bij uitvoering van hun toezichtstaken een, voor onder toezicht gestelden duidelijke, afdoende afbakening aan te brengen tussen (interne) ambtelijke of particuliere toezichthouders en (externe) opsporingsambtenaren.

Overigens kan het onvoorzichtig zijn dat toezichthoudende verzelfstandigde entiteiten zelf, via uitdrukkelijke of bijzondere volmacht, particuliere toezichthouders kunnen aanstellen, omdat de minister - terwijl hij al beperkt verantwoordelijk is voor de verzelfstandigde entiteit - dergelijke toezichthouders niet kan instrueren en hun aanwijzing niet kan intrekken. Aanstelling van particulieren moet dan geconditioneerd zijn in de zin dat het bestuur van de verzelfstandigde entiteit deze toezichthouders volmacht verschaft en dat de op hoofdlijnen verantwoordelijke vakminister, als de particuliere toezichthouder disfunctioneert, zo nodig het bestuur kan verplichten betrokken persoon te ontslaan en in het uiterste geval, als het bestuur niet ingrijpt, de samenstelling van het bestuur wijzigt.

Ministeriële intrekking van commissie kan wel bij een buitengewoon opsporingsambtenaar, voor welke ambtenaar bovendien kwaliteit- en betrouwbaarheidseisen gelden. Maar het aanstellen van buitengewone ambtenaren is niet aan te raden bij toezichthoudende verzelfstandigde entiteiten in private rechtsvorm (aangewezen wordt - om redenen van doelmatigheid - meestal een ambtenaar die toch al toezicht houdt, waardoor zich het diffuse onderscheid tussen toezicht en opsporing waarschijnlijk wreekt). Wordt een dergelijke opsporingsambtenaar door ministeriële benoeming te werk gesteld bij een privaatrechtelijke rechtspersoon (wooral commercieel ingestelde vennootschappen), dan botsen mogelijk de verschillende belangen van betrokken bewindspersoon en bestuur van de rechtspersoon en onstaat ongetwijfeld een bevoegdheidsbetwisting.

Een algemene bepaling inzake rechtsbescherming tegen besluiten (niet-zijnde besluiten in de zin van de Awb) van toezichthouders, om alle onzekerheden weg te nemen, ontbreekt helaas nog in afdeling 5.1 van de Awb.

Met oog op de rechtsbescherming is het ook hinderlijk dat de Awb-regeling geen plicht tot schriftelijke verslaglegging van toezichtsactiviteiten kent. Kennelijk wordt voorbij gegaan aan het motiveringsbeginsel. Juist bij een toenemend aantal controleurs en inspecteurs in dienst van toezichthoudende verzelfstandigde entiteiten is de tendens waar te nemen om, uit beleidsoverwegingen van efficiëntie en effectiviteit, over uitgevoerde inspecties niet te rapporteren als geen sanctie wordt opgelegd of geen aanleiding bestaat tot ongerustheid inzake regelnaleving door een betrokken onder toezicht gestelde. Aan 
inspectierapporten mag trouwens geen bewijskracht ten behoeve van strafvordering worden ontleend. Duidelijk is dat doelmatigheid rechtmatigheid zo snel kan schenden.

III: Het, in meest zuivere zin, toezicht houden op naleving van het bij of krachtens wet gestelde is te beschouwen als uittoefening van openbaar gezag. Aldus bezien zijn toezichthoudende verzelfstandigde entiteiten in beginsel bestuursorganen in de zin van de Awb. Aan hun, in het teken van toezicht staande, (rechts)oordelen moet dan ook rechtskracht worden verbonden. Daardoor zijn justitiabelen in staat om bezwaar bij het bevoegde orgaan dan wel beroep bij de bestuursrechter aan te tekenen.

\subsubsection{AANBEVELINGEN M.B.T. GROND- EN GEMEENSCHAPSRECHTEN}

Van uit grond- en gemeenschapsrechtelijk perspectief gelden aanbevelingen als:

I: Toezichthoudende verzelfstandigde entiteiten treffen toereikende voorzieningen om hun zorgplichten te realiseren. Zij dragen zorg voor de beschermende rechten en de fundamentele vrijheden van de mens. Die zorg is een, voorwaardenscheppende, overheidszorg: zij dient het algemeen belang en is gericht op vooral consumenten-, gezondheids- en milieubescherming. In, het in gang gezette economische vernieuwingsproces waarin marktgerichtheid centraal staat, heeft de overheid tot handhavingstaak om behoorlijke randvoorwaarden te scheppen en, niet te vergeten, eerlijke mededinging te bewaken. Deze overheidszorg, die voort vloeit uit de Grondwet en overigens uit verdragsrecht, is onmogelijk zonder handhavingsbevoegdheden binnen een helder handhavingsbeleid.

Zo danige zorgplichten verdienen, onder uitvoerige motivering, nadrukkelijk vermelding in verzelfstandigingswetten. Het, op de zorg toegespitste, handhavingsbeleid moet kenbaar zijn voor in elk geval onder toezicht gestelden. Daarom is het belangrijk dat toezilchthoudende verzelfstandigde entiteiten hun handhavingsbeleid in de vorm van beleidsregels uitdrukkelijk bekend maken. Zijn zij bevoegd tot het stellen van handhavingsregels als nadere regelgeving dan zijn dat algemeen verbindende voorschriften die, zonder uitdrukkelijke bepaling er toe, ook per definitie worden gepubliceerd.

II: Nationale zorgplichten vallen soms samen met die in Europees verband. Vooral in concurrentiële context kan het voor bepaalde, vrij wel per definitie grenzeloze, sectoren als de milieu- en landbouwsector, de telecommunicatiesector of de privacysector, gunstig zijn om grensoverschrijdende verdragsrechtelijke zorg-en handhavingsplichten te bepalen. Hierbij past dan een overkoepellende Europese toezichthoudende entiteit. Deze communautaire toezichthoudende entiteit is in staat om de in de verschillende lidstaten aangeweren toezichthoudende verzelfstandigde entiteiten (die in aantal snel toenemen) te adviseren, te begeleiden, te stimuleren, aan te sturen en, daar waar nationalle verzellfstandigde toezichthoudende entiteiten bevoegdheden ontbreken, aan te vullen. Hierbij vormen de nationale toezichthoudende, functioneel gedecentraliseerde entiteiten als professionele, intermediaire besturen, kennelijk krachtiger dan de wirwar van territoriaal bestuur, adequate aanspreekpunten voor de buitenwacht.

De EG-verdragsrechtelijke samenwerkingsplicht, die voorlidstateneenhandhavingsplicht impliceert waarbij zij bepaalde handhavingsbeginselen als assimilatiebeginsel, proportio- 
naliteits- en effectiviteitsbeginsel in acht moeten nemen, moet er toe leiden dat de takken van toezicht op naleving van het bij of krachtens buiten- of binnenlandse wetgeving bepaalde in essentie gelijkwaardig groejen. Geisoleerd toezicht is, zeker in een statenverband waarop meer en meer marktwerking wordt losgelaten, zinloos.

\subsubsection{AANBEVELINGEN M.B.T. ZELF- EN DEREGULERING}

Van uit zelf-en dereguleringsperspectief gelden aanbevelingen als:

I: Zelfregulering past fraai in een moderne machtsevenwichtsdoctrine. Voor, in principe niet aan ministers hiërarchisch ondergeschikte, toezichthoudende verzelfstandigde entiteiten, die zorg dragen voor een rechtmatig en doelmatig verloop van zelfregulering. (goed te koppelen aan zelfhandhaving), biedt zij het voordeel van democratische inbreng. Zelfregulering versterkt aanvaarding en uitwoering van overheidstoezicht. Als effectieve zelfregulering ontbreekt, moet $\mathrm{zij}$-zeker in een hevig concurrerende markt- worden gestimuleerd. Ten einde te voorkomen dat zelfregulering een eigen leven gaat leiden, is zij slechts geoorloofd indien zij wettelijk geconditioneerd is.

II: Overheidstoezicht door een zelfstandig bestuursorgaan dient prima als sluitstuk van toezicht door zelfregulerende instanties. Voorwaarde daarbij is dan dat, indien verschillende controle-bureaus of controle-instanties op zelfregulerend toezichtsactiviteiten verrichten, zij dit wel gecoördineerd doen. Zo veel mogelijk voorkomen zij taakoverlapping, ten einde het (voor de overlegfunctie van toezicht wezenlijke) vertrouwen bij onder toezicht gestelden niet te schaden. De eis van eenheid in toezicht is essentieel. Zij schept zekerheden en waarborgen voor onder toezicht gestelden en creëert kenbaarheid en duidelijkheid voor het zelfstandig bestuursorgaan dat in eindfase met het overheidstoezicht is belast. Zo lang verdeeldheid toezicht kenmerkt, kan toezicht door zelfregulering niet als basis voor overheidstoezicht door een zelfstandig bestuursorgaan dienen.

III: Zelfregulering heeft alles te maken met (mislukte) deregulering. De dereguleringsoperatie verloopt dramatisch. Wetgevingsjuristen kunnen het niet laten. Terwijl zij aan koersen op detail verliezen zij zicht op samenhang in wetgeving. Terecht gaan geluiden op dat het tij moet keren.

Overigens is het, in het kader van deregulering, zinvol niet meer per deelsector maar per meer omvattende totaalsector (bij voorbeeld de telecommunicatie/informatie/privacysector of de financiële sector) regels te stellen ${ }^{185}$, welke regels in verband met de dynamieke markten niet verstarrend mogen werken en daarom binding moeten hebben met zowel publiekrecht als privaatrecht. Hierdoor is minder complexe regelgeving nodig. Bovendien is, de min of meer noodzakelijke, afstemming op Europees recht eenvoudiger te realiseren.

Rigoreuzer, maar daarom niet minder terecht, is om de van oudsher publiekrechtelijke kaders min of meer te verlaten en sterker te bouwen op de vertrouwde fundamenten van privaatrecht. De aantrekkelijkheid van deze fundamenten zit dan vooral in de flexibiliteit

185. Dergelijke ruime raamwetgeving moet op passend niveau wortlen ingevuld door sterke zelfregulering. 
van de open normen uit het privaatrecht (met als nadeel dat de rechter weer zwaarder belast wordt). In bepaalde sectoren waar concurrentie ongebreideld toeneemt, is het inderdaad zaak te beschouwen of overheidstoezicht op grond van bestuursrecht nog bestaansrecht heeft. In dergelijke markten kunnen priwaatrechtelijke schadevergoedings-, gebod- of verbodsconstructies uitkomst bieden. Daarmee wordt de deregulering gediend. Bovendien biedt een dergelijke benadering het voordeel van het zetten van een noodzakelijke rem op de, te voorziene, tomeloze toename van toezichthoudende verzelfstandigde entiteiten.

In de spaarzame sectoren waar het niet zo droevig is gesteld met deregulering, is het zorg weer niet al te regelloos te worden. Tegenover de deregulering in nationaal opzicht treedt reregulering in Europees verband op. Deze strakke regelgeving verstevigt de positie van onafhankelijke, deskundige communautaire toezichthoudende entiteiten. Alleen een streng verenigd Europa kan de commerciële kracht van niet aan strakke Europese regels gebonden, ja zelfs vaak ondergereguleerde, staten keren. ${ }^{186}$

Nationale deregulering en communautaire reregulering tegen elkaar uitspelend, wordt de noodzaak van nationale toezichthoudende verzelfstandigde entiteiten duidelijk. ${ }^{187} \mathrm{De}$ toenemende Europese regelgeving, met een klemtoon op economische aanbodzijde, kan wel eens de aandacht yoor minder grootschalige problemen verminderen. Daardoor komt de bescherming van afnemers van produkten en diensten, d.w.z. consumenten, in het gedrang. Zeker als de verschillende markten worden gedirigeerd door min of meer geprivatiseerde en verzelfstandigde entiteiten, die over de schouder van Europa heen winstbelust lonken naar internationalle markten die, als vermeld, veel minder door (spel)regels worden beheerst. Ter begeleiding van verschillende verzelfstandigingen, in het bijzonder verzelfstandiging via concessies te verlenen aan openbare aambesteding, dwingt de bescherming van de consument er toe afzonderlijke toezichthoudende entiteiten in te stellen ter bewaking van bepaalde belangen. Dergelijke entiteiten, die overigens in veel voorkomende gevallen (waarin de verzelfstandiging uiteindelijk de weg vrij moet maken voor privatisering) slechts tijdelijk van aard zijn, hebben dus vooral een mededingingsrechtelijke inslag.

186. Overigens antwoordt de minister van financièn in de Nota n.a.v. het verstag inzake het voorstel Whe

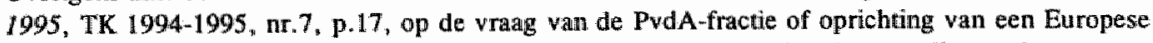
toezichthouder op effectengebied thet maken van goede internationale afspraken kan dienen, dat eventuele opriciting van zo'n communautaire toezichthouder "nog nooit in unternationale fora aan de orde is geweest" ${ }^{\text {th }}$. Bovendien betwijfelt de bewindspersoon of een dergelijk toezichthouder "iets substantieels gan het moken wan goede internationale afspraken zou kunen bijdragen".

187. Keerzijde van een (te) sterke positie van dergelijke mationale entiteiten is dat, terwijl deregulering doelstelling is, hun taak de mededinging in banen te leiden er toe leidt dat nationale herregulering plaats vindt in het kader van a. het beperken van de marktwrijheid en b. het garanderen vam de marktoegang van gelijkwardige partijen. Op deze paradox wijst te recht. J. E.J. Prins, Owertollig recht inzake informarietechnologie, oratie KUB, Deventer, 3 febr. 1995, p.22. Deze dominantie van een toezichthoudiend overheidsorgaan doet zich wooral voor als het accreditatie, certificatie en normallisatie te sterk stuunt en conditioneert door daaraan veel voorschriften te verbinden waardoor helaas herregulering in de hamd wordt gewerkt. 
financiële bescherming zoeken van een verzelfstandigde entiteit, die de tucht van de markt mist, heeft geen bestaansrecht. Bovendien worden, wrang genoeg op grond van. betaling van produkten of diensten met onberedeneerd hoge tariefstelling door de gemeenschap opgebrachte, gelden min of meer commercieel aangewend.

II: Exclusief economisch verkeer is niet eenvoudig meer te realiseren. Met toenemend succes worden exclusieve rechten aangewochten via art. 90, eerste lid, EG-verdrag jo. art. 85 EG-verdrag, via art. 90, tweede lid, EG-verdrag of via een geslaagd beroep op een Cassis-de-Dijon-exceptie (nu een beroep op deze excepties kennelijk nog vrijstaat met oog op in het bijzonder bescherming van het algemeen belang en het consumentenbelang).

Ook verzelfstandigde entiteiten (inbegrepen overheidsaanbesteders) met bedrijfsmatige activiteiten moeten, als zij aanspraak willen maken op uitsluitende rechten, onder de werking van het EG-verdrag vallen. Uitzondering hierop is slechts mogelijk als een verzelfstandigde entiteit evident het algemeen belang nastreeft door uitoefening van een overheidstaak, waarvan de uitvoering wel eens extra duur kan zijn omdat moet worden voldaan aan bij voorbeeld strenge eisen (inzake bij voorbeeld het milieu). Met betrekking tot toezichthoudende verzelfstandigde entiteiten kan de mededingingstoetsing dus wel eens niet, of minder streng, van toepassing zijn.

In tegenstelling tot het Europese mededingingsrecht, dat uitgerust is met zware sancties en toepasselijk is op publieke dienstverleners, is het Nederlandse mededingingsrecht van oudsher relatief licht. Een hele opluchting is het als de herziening van de Wem voorziet in de ombouw van het traditionele misbruikstelsel tot een, van een rekbare 'rule of reason' voorzien, verbodstelsel. Omdat de, vooral verbodswetgeving voor kartels en machtsposities omvattende, Wem er helaas nog niet in voorziet moet worden aangedrongen op invoering in de Wem van enige vorm van controle op fusies. ${ }^{188}$ De noodzaak hiertoe is urgent gegeven de toenemende indringende internationalisering in economisch opzicht.

III: In verband met voortschrijdende fusies en grootschalige concentraties van min of meer commerciële ondernemingen binnen sectoren, waarin toezichthoudende verzelfstandigde entiteiten het vigerende recht moeten handhaven, moeten de grenzen van mededin-

188. In dit opzicht is het, medio 1995 te verwachten, voorstel inzake fusiecontrole toe te juichem. Met dit voorstel krijgt de minister van economische zaken in Nedlerland, welk land als een wan de weinige Europese landen achter blifft met wetgeving op het gebied van fusies, de bevoegdheid om fusies van bedrijven (d.w.z. de fusies die buiten de toetsingsbevoegdheid van de Europese Commissie t.a.v. grensoverschrijdende fusies vallen) wettelijk te toetsen met de mogelijkheid om concurrentievervalsende fusies te verbieden. Hoewel het naar verwachting niet snel tot een verbod zall komen, biedt zo "n toetsing wel de mogelijkheid om voorwaarden te stellen aan fusies. Dit is juist interessant bij de dreiging van monopolieposities van samenwerkende verzelfstandigde entiteiten. Uit dit laatste blijkt al dat het in voorbereiding zijnde wetswoorstel alleen verplichte fusieaanmelding eist van bedrijven die boven een bepalde (fusie)drempel uitkomen. Midden- en kleinbedrijf blijwen buiten beschouwing. Overigens is het de bedoeling een snelle aanmeld ingsprocedure te creèren: via aanmelding bij een ambtelijk kartelbureau kunnem bedrijven vooraf all informeren of bezwaren bestaan tegen de door hun voorgenomen fusie. Wijers will fusies van bedrijven met behulp wan wet kwnnen toetsen, in: NRC. 31 maart 1995, p.11. 
ging scherper worden gesteld. De meeste bestaande toezichthoudende verzelfstandigde entiteiten zijn niet bevoegd, en als zij wel bevoegd zouden zijn: waarschijnlijk - gegeven het soms enge, beperkte kader van bestaande wetgeving op grond waarvan zij hun toezicht moeten uitoefenen- niet in staat, om de activiteiten van onder toezicht gestelden te toetsen op mededingingsrechtelijke aspecten. Betreft het toetsing aan de Wem dan wordt de minister van economische zaken wel als, in eerste instantie, bevoegd aangewezen. Het is zinvol een afzonderlijke toezichthoudende verzelfstandigde entiteit in te stellen, die in de gaten houdt of de markt niet wordt ondermijnd door verboden kartel-en prijsafspraken en oneigenlijke concurrentie. Een dergelijke, mogelijk in de vorm van een onafhankelijk zelfstandig bestuursorgaan te gieten, sectoroverkoepelende entiteit, die toeziet op correcte naleving van mededingingsrecht, wordt bij voorkeur opgesplitst naar sectie (denk aan een financiële sectie, een telecommunicatiesectie, een openbaar vervoersectie e.d.). Daardoor houdt de toezichthoudende entiteit greep op het, weliswaar complexe, geheel van wet- en regelgeving met betrekking tot een zelfde rechtsgebied.

Om praktijkproblemen zo veel mogelijk te voorkomen, dient ten aanzien van wetgeving zelf bij het opstellen er van reeds een concurrentie- en buitenlandtoetsing te geschieden.

\subsubsection{AANBEVELINGEN M.B.T. VERZELFSTANDIGING EN PRIVATISERING}

Van uit verzelfstandigings- en privatiseringsperspectief gelden aanbevelingen als:

I: Meer dan nu moet worden onderkend dat privatisering, boven verzelfstandiging, prioriteit heeft als bij taakuitvoering serieus of onvermijdelijk marktwerking wordt beoogd. Privatisering in eigenlijke zin, waardoor overheidstaken werkelijk worden afgestoten, biedt het voordeel van duidelijke bevoegdheidsverdeling.

Naast pure privatisering bestaat -veelal door toezichthoudende, functioneel gedecentraliseerde, entiteiten versterkte- privatisering in oneigenlijke zin. Dergelijke 'zachte' privatisering beslaat vaak een periode waarin sprake is van een geleidelijke overgang naar echte marktwerking.

Zo lang passende privatiseringswetgeving echter ontbreekt, blijft de winst er van uit. Kortom, om privatisering in banen te leiden, moet de formele wetgever een juridisch kader ter zake creëren. Zo'n rechtsraam geeft in elk geval zicht op de verhouding tussen overheid en bedrijf. Handleidingen daarbij bieden bepalingen inzake:

a. beschermingsconstructies (denk aan exclusieve concessies, enig aandeelhouderschap, bijzondere aandelen);

b. personeel- en arbeidsvoorwaarden;

c. terugkoop van geprivatiseerde ondernemingen;

d. het begeleiden van geprivatiseerde bedrijven met een 'bruidschat';

e. het conditioneren van geldopbrengstbestemming van geprivatiseerde ondernemingen en dergelijke.

Ook wat betreft verzelfstandiging is het tijd voor de formele wetgever essentialia te formuleren. Bij instelling van toezichthoudende verzelfstandigde entiteiten moeten terug kerende agendapunten zijn:

a. de vertrouwensverhouding tussen betrokken minister en verzel fstandigde entiteit (met name de positie van dominante departementsambtenaren moet hierbij niet worden onderschat); 
b. de open ontvlechting van taken, bevoegdhedlen en verantwoordelijkheden binnen een toezichthoudende verzelfstandigde entiteit, weike entiteit overigens ook vaak zelf al uit oogpunt van ontvlechting wan werantwoordelijkheden - bij voorbeeld de verantwoordelijkheid van beheer en zeggenschap en de verantwoordelijkheid regelgeving. te scheppen en toezicht te houden - wordt opgericht (denk aan het scherp scheiden van: a. de functies van certificering en toezicht op certificering: het nationale toezichthoudende zelfstandig bestuursorgaan ziet toe op de private of publieke instellingen die, all dan niet wettelijk verplichte, keuringen uitvoeren en certificaten afgeven, zodat het zbo bij voorkeur zelf geen certificeringsfunctie uitoefent; of b. de functies van vergunningverlening en het toezicht op vergunninguitoefening of de inachtneming van de voorwaarden van de vergunning: beide functies dienen bij te onderscheiden afdelingen, die wel nauw samenwerken, te worden ondergebracht in verband met het milde en minder milde karakter van toezicht als handhavingsvorm);

c. de vaste relatie van toezichthoudende verzelfstandigde entiteiten met meer repressief ingestelde opsporingsdiensten (afstemming van elkaars taken en onderlinge afbakening van bevoegdheden, coöperatieve samenwerking en informatie-uitwisseling tussen binnenlandse en buitenlandse toezichthouders en opspoorders);

d. de klare coördinatie tussen de werkzaamheden van nationale en communautaire toezichthoudende personen;

e. het intensieve en bestendige contact van de toezichthoudende verzelfstandigde entiteit met het openbaar ministerie (evt. uitdrukkelijke regeling van aangifteplichtigheid van toezichthoudende verzelfstandigde entiteit, mogelijk formalisering van continue contactpunten waardoor wisseling van de wacht met daaraan gepaard gaand verlies aan deskundigheid van gespecialiseerde ovj's zo veel mogelijk wordt gecompenseerd of wordt voorkomen);

f. de juridische en feitelijke mogelijkheden tot moderne, grootschalige, tijdsbesparende en doelmatige toezichtsmethoden (teledetectie, monitoring);

g. de brug tussen onafhankelijke toezichthoudende verzelfstanöigõe entiteiten en democratische inbreng (panels bestaande uit bellanghebbenden);

h. voorzieningen ter controle op en aansturing van de toezich thoudende verzelfstandigde entiteit door de betrokken bewindspersoon (hierbij verdient o. a. de sturende rol van de, als controlekracht ingezette, raad van bestuur extra stimulans: de rve moet sterk op deskundigheid en betrouwbaarheid worden gescreend, bovendien is het zinvol de rve zowel een passieve als actieve informatieplicht t.b.v. het bestuur van de betrokken toezichthoudende verzelfstandigde entiteit op te leggen);

i. voorzieningen ter gegevensverstrekking van de toezichthoudende verzelfstandigde entiteit aan de minister (nota bene, meer dan voorheen moeten toezichthoudende verzelfstandigde entiteiten niet alleen feitelijke informatie verschaffen maar ook inhoudelijke inlichtingen geven, uit overwegingen van efficiëntie is het aan te raden ingewikkelde financiële verslaglegging in handen van deskundige derden te geven en overigens bestanden en registers zo mogelijk te integreren en de verwerking er van bij voorkeur uit te besteden aan zelfstandige computercentra);

j. voorzieningen ter gegevensverstrekking van onder toezicht gestelden aan de toezichthoudende verzelfstandigde entiteit en omgekeerd;

k. financiële aspecten. 
In de, voor de toezichthoudende verzelfstandigde entiteit relevante, bijzondere (verzelfstandigings)wetgeving verdient, onder vitvoerige motivering, nadrukkelijk het volgende vermelding:

a. bepaald wordt welke overheidszorg de betrokken toezichthoudende verzelfstandigde entiteit uitvoert, waarbij de noodzaak er van wordt aangegeven;

b. bepaald wordt of de betrokken toezichthoudende verzelfstandigde entiteit, waarbij geen concreet aanwijsbare - al dan niet ambtelijke - toezichthouders werken, zich de toezichtsbevoegdheden van afdeling 5.1 Awb mag aanmeten;

c. bepaald wordt of de betrokken toezichthoudende verzelfstandigde entiteit in private rechtsvorm, niet (geheel) zijnde bestuursorgaan in de zin van de Awb, via een schakelbepaling onder de werking van de Awb valt;

d. bepaald wordt of de betrokken toezichthoudende verzelfstandigde entiteit alle toezichtsbevoegdheden ex afd. 5.1 Awb mag uitoefenen en zo niet, welke toezichtsbevoegdheden de betrokken toezichthoudende verzelfstandigde entiteit dan mag uitoefenen, waarbij de noodzaak er van wordt aangegeven;

e. bepaald wordt of de betrokken toezichthoudende verzelfstandigde entiteit haar rechtshandhavingsinstrumentarium mag uitbreiden met de bevoegdheid tot het opleggen van bestuurlijke boeten, waarbij de noodzaak er yan wordt aangegeven.

II: Het heeft, in bepaalde gevallen, aanzienlijke voordelen de overgang naar private rechtsvorm van een te verzelfstandigen overheidsdienst privatrechtelijk te begeleiden. Via een, door (franchise)raamovereenkomst te realiseren, tweezijdige rechtsbetrekking tussen overheid en verzelfstandigde entiteit kunnen rechten en plichten op gepaste wijze overgaan. Middels een dergelijke privaatrechtelijke constructie zijn goed te regelen: overgang van vermogensbestanddelen, overgang van schulden, overgang van kwalitatieve rechten, overgang van personeels- en arbeidswoorwaardenbeleid, overgang van publiekrechtelijke en privaatrechtelijke bevoegdheden, overgang van kwalitatieve aansprakelijkheden. Art. 6:216 $\mathrm{BW}$ voorkomt dat dergelijke contracten dwingendrechtelijke bepalingen van publiekrechtelijke aard buiten werking kunnen stellen. Ook zorgt de bijzondere aard van de overheid er voor dat zij, indien nodig, de overheersende en beslissende contractspartner is.

III: Voor het op afstand zetten van rechtshandhavende activiteiten in de vorm van toezicht bestaan verschillende mogelijkheden.

Veel gebruikt zijn de volgende varianten:

Ten eerste, de verlening (inclusief de verstrekking) van bij voorbeeld vergunningen wordt samen met het toezicht op naleving van vergunningen (en daarbij gestelde beperkingen of voorschriften) verzelfstandigd.

Ten tweede, de verlening (inclusief de verstrekking) van bij voorbeeld concessies geschiedt door de betrokken bewindspersoon en het toezicht op naleving van concessies (en daarbij gestelde beperkingen of voorschriften) wordt verricht door een daartoe speciaal opgerichte toezichthoudende verzelfstandigde entiteit. 
Hierbij gebeurt het wel dat concessieverlening eerst een bepaald aantal jaren geschiedt door de betrokken bewindspersoon, om vervolgens te worden overgedragen aan de toezichthoudende verzelfstandigde entiteit.

Overigens kent deze tweede variant ook een andere uitwerking. In deze optie gaat het niet om het ontlasten van de minister door een deel van zijn werkzaamheden in handen te geven van een op afstand staande publiekrechtelijke of privaatrechtelijke toezichthoudende entiteit. Deze optie beoogt juist (een geselecteerd aantal) private partners de kans te geven een, van oudsher door de overheid beheerste markt, onder voorwaarden over te nemen. Dergelijke verovering of binnentreding van overheidsdomein via openbare aanbesteding staat in het teken van verhoging van efficiëntie en verruiming van marktwerking. Op het feitelijk uitvoering geven aan de 'overheidstaak' door particuliere ondememers ziet een apart ingestelde toezichthoudende verzelfstandigde entiteit toe.

De eerste variant heeft vooral een praktische achtergrond. De tweede variant (althans de eerste uitwerking er van) berust hoofdzakelijk op politieke overwegingen. Delegatie of attributie van de bevoegdheid tot concessieverlening is daar (nog) niet de aangewezen mogelijkheid, als de uit te woeren taak te politiek bepaald is.

Hoewel het uitgangspunt is dat publiekrechtelijke bevoegdheden, benodigd voor uitvoering van publiekrechtelijke taken, worden opgedragen aan of overgeheveld naar verzelfstandigde entiteiten met publiekrechtelijke rechtsvorm, bestaat ruimte voor uitzondering. Soms kan het functioneel decentraliseren van handhavingsbevoegdheden naar privaatrechtelijke rechtspersonen meer recht doen aan de met verzelfstandiging beoogde flexibiliteit. Min of meer commerciële markten in een dynamische omgeving hebben behoefte aan de buigzaamheid van privaatrecht.

Het, onder wakend oog van een toezichthoudende verzel fstandigde entiteit, werken met concessies is op zich preferabel. Gekunsteld is het echter als concessies worden geschoeid op publiekrechtelijke leest. Daardoor verliezen zij hun veerkrachtigheid. Ook het verankeren van vergunningen in publiekrecht kan een onverhoeds lichten van het schip niet altijd voorkomen. Denk aan onvoorziene, voor de vergunningverlener onbekende, overdraagbaarheid er van door wijziging van belangen in aandelen van een vergunninghouder. Net zo min bieden verleende certificaten genoeg garantie. Op langere termijn vormen zij mogelijk een goedkope aflaat voor certificaathouders, die feitelijk niet meer bieden waarvoor zij formeel - gelet op hun certificaat - staan.

Daarom is het, zeker in een meer open wordende economie, mogelijk oprechter om, in plaats van ouderwetse vormen van publiekrechtelijke regulering, te zoeken naar moderne vormen van regulering. Daartoe is het zinvol het publiekrecht in de tijd aan te passen. Met andere woorden, de formele vergunning moet een jong aangezicht krijgen waardoor zij meer plooibare trekken kan vertonen. Ook is, in voorkomende gevallen, een flexibeler (veilings)verstrekkingsregime aan te raden voor het verlenen van vergunningen. Zo'n vergunning vol dynamiek kan nog wel basis vinden in een, conform de essentie van de Awb, min of meer tweezijdige rechtsbetrekking van publiekrechtelijke aard. Daarnaast is het aan te raden te zoeken naar puur privaatrechtelijke reguleringsvormen. Civielrechtelijk geregelde concessies zijn hier toonbeeld. 


\subsubsection{AANBEVELINGEN M.B.T. HARMONISATIE EN LIBERALISERING}

Van uit harmonisatie- en liberaliseringsperspectief gelden aanbevelingen als:

I: Het liberaliseren van bepaalde markten bevordert in beginsel een gelijkwaardige toegankelijkheid van de markt, een hoogstaande kwaliteit van het produkt(ieproces) of de dienstverlening en een evenredige prijsstelling voor produktvervaardiging of dienstverlening. Het liberaliseren van markten leidt er wel toe dat de overheid minder ruimte heeft tot overheidsinterventie met mogelijk alle kwalijke gevolgen van dien.

Het overblijwende overheidstoezicht in nationaal opzicht wordt weer ingeperkt, bepaald en afgebakend door het hevig harmoniseren van wet- en regelgeving van de verschillende Europese lidstaten. Acht slaand op het subsidiariteitsbeginsel behoudt elke lidstaat terecht identiteit. Met oog op die eigen aard van elke staat is volledige harmonisatie in het algemeen niet aanvaardbaar. Het komt kortom aan op minimumharmonisatie van wet- en regelgeving al dan niet gecombineerd met wederzijdse erkenning van elkaars rechtsstelsels. Bij het over en weer respecteren van in het bijzonder toezichtsstelsels is het, ten einde concurrentievervalsing te voorkomen, nodig dat rechtshandhaving in ruime zin redelijk overeenstemt.

II: Bij liberaliseren, harmoniseren en dereguleren is het zaak er op te letten dat nationale toezichthoudende verzelfstandigde entiteiten niet alle terrein verliezen aan Europese toezichthoudende entiteiten. Dat een verenigd Europa beter, dan elke natie op zich, in staat is een front te vormen tegen een bijna bijtend niet-Europa ligt voor de hand. Niet nodig is dat de lidstaten hun eigen identiteit en hun greep op het geheel verliezen. Voortdurend moeten zij hun nationale handhaving versterken door deze te voorzien van, weliswaar in het licht van zekere harmonisatie met Europees recht concorderende, moderne modules met betrekking tot onder meer toezichts- en sanctioneringsmodaliteiten, samenwerkingsformules of extraterritoriale en wederzijdse rechtshulpverlening.

III: Wat betreft de doelstellingen van liberalisering en deregulering is duidelijk dat zij niet altijd met elkaar stroken. Bij het verder vrij maken van de diverse economische markten is het namelijk vaak zo, dat dit gepaard gaat met het, onder doofheid voor dereguleringsdenken, stellen van nieuwe regels inzake de bewaking van eerlijke mededinging.

\subsubsection{AANBEVELINGEN M.B.T. MONOPOLIEVORMING EN MEDEDINGING}

Van uit monopolievorming - en mededingingsperspectief gelden aanbevelingen als:

I: Het verzelfstandigen van handhavingstaken naar een toezichthoudende entiteit met een monopoloide karakter is niet wenselijk als daardoor oneigenlijke concurrentie op treedt. Er is geen sprake van eerlijke marktwerking.

Dit is enigszins vergelijkbaar met een toezichthoudende verzelfstandigde entiteit die, bij gebrek aan werkelijke winstprikkels, via -mogelijk met overheidsgelden gefinancierdekostbare 'checks and balances' een kunstmatige marktsituatie creëert. Het langdurig 


\section{Geraadpleegde literatuur}

Alders, M. W.C.

Handhaving en zelfregulering, in: JV, nr.9, 1994, pp.47-69.

Backx, H.A.M.

Normalisatie en certificering als alternatieven woor en in wettelijke regelingen, in: RegelMaat, nr. 3, 1995, pp.89-100,

Berge, J.B.J.M. ten

Schakelbepaling in privatiseringswetgeving, in: NTB, nr.1, 1995, p.9.

Buruma, Y.

De bijzondere politiediensten in het spanningsveld tussen nationale en unionaire ontwikkelingen, in: DD, nr.10, 1994, pp.1031-1055.

Bij, J. wan der \& Meij, J.P. van der

$\sim$ Verzelfstandigen of privatiseren; Concurrentie, produkt of beleidsvrijheid zijn bepalend (1), in: Overheidsnanagement, nr.3, 1995, pp.75-76;

- Verzelfstandigen of privatiseren; Concurrentie, produkt of beleidswrijheid zijn bepalend (II), in: Overheidsmanagemen, nr.4, 1995, pp.106-110.

Commissie-Scheltema (eerste externe commissie van de bijzondere commissie vraagpunten)

Steekhoudend ministerschap; Betekenis en toepassing van de mimisterielle verantwoordelijkheid, TK 1992-1993, 21427, nrs.40-41.

Commissie-Wiegel (vierde externe commissie van de bijzondere commissie vraagpunten)

Naarkerndepartementen, kiezen woor een hoogwaardige en flexibele rijksdienst, TK 1992-1993, 21427 , nr. 52.

Corwers, S., Klaauw, F. van der \& Wedekind, W.

IT en de Europese aanbestedingsrichtiinen, in: Computerrecht, nr. $1,1995, \mathrm{pp} .16-22$.

Donner, J.P.H.

Orde in de ordening van het bestuur, in: Beleid \& Maatschappij, nr.6, 1994, pp.294-299.

Fijnaut, C., Huybrechts, L. \& Wijngaert, Ch. van den

EG-fraudebestrijding in de praktijk, uitgave centrum voor de studie van de toepassing van het gemeenschapsrechtin financielleen strafrechtelijkeaangelegenheid, Antwerpen-Apeldoorn/Brusseli, 1994.

Gestel, R. van \& Verschuuren, J.

Milieuverslaglegging en (zelf)handhaving: een ovum novim in de Wet milieubeheer, in: RegelMaat, nr.6, 1994, pp.219-226.

Heuvel, G.A.A.J. van den - Onderhandelen of straffen; Over organisatie-criminaliteit en overheidscontrole, Arnhem, 1993:

- Convenanten in de Nederlandse overlegeconomie, in: JV, nr.9. 1994, pp.9-25.

Huisman, W., Lange, A. de \& Niemeyer, E.

Milieucriminaliteit vergt handhaving op maat, in: JV, nr.9, 1994, pp.26-46.

Joosten, $M$.

Informatiebeleid op maat, in: Mediaforum, nr. 9. 1994, p.98.

Mediaraad

- Advies inzake herstructurering beleid informatiewoorziening "Deel I: Het informatietransport,

"s-Gravenhage, 11 juni 1993;

- Advies inzake herstructurering beleid informatievoarziening; Deel It: de informatieproduktie,

's-Gravenhage, 27 januari 1994;

- Advies inzake herstructurering beleid inzake informatievoorziening; Deel III: de mededinging,

's-Gravenhage, 8 juni 1994. 


\section{Meeus, T.J.}

Ambtenaren willen rem op privatisering: "Afstoten overheidstaken is waak vluchtweg", in: NRC, 19 nowember 1994, p.1;

- Privatisering leidde tot bureaucratie der dubbele Loyaliteiten; Grafrede over twaalf jaar ambitieus beleid, in: NRC, 19 november 1994, p.15;

$\sim$ IB Groep of privatisering als een remedie tegen de 'stopverfstaat', in: $\mathrm{NRC}, 22$ november 1994, p.19;

$\sim$ Gedwongen winkelnering dient te verdwijnen, in: NRC, 26 november 1994, p. 17 ;

- Bij privatisering wordt de tucht wan de markt te vaak ontopen, in: $\mathrm{NRC}, 22$ december 1994 , p.19.

Ministerie wan Verkeer en Waterstaat, structuurschema Verkeer en Vervoer, project Naleving

- Basisrapport Naleving; Waar komen de problemen met handhaving en naleving van beleid vandaan?, "s-Gravenhage, 1992;

$\sim$ Citaten uit interviews met maatschappelijke sleutelfiguren in het kader van het project Nalewing, 's-Gravenhage, augustus 1992;

- Het ketenmodel, "s-Gravenhage, 1992;

- Checklist woor resultaatgericht beleid, "s-Gravenhage, 1992.

Mok, M.R.

Vrijheid van dienstenverkeer: mededinging, in: TVVS, nr.12, 1994, pp.336-337.

Moor-Van Vugt, A.J.C. de \& Vermeulen, E.M.

Kronieken: Europees bestuursrecht, in: NTB, nr.1, 1995, pp.10-18.

Mulder, A.

Boekbespreking, in: SEW, nr.3; 1995, pp.222-227.

Noordegraaf, $M$.

Overheid is geen gewoon bedrijf en dat mag best wat kosten, in: BB, nr.49, 9 dec. 1994, pp. 20-21.

Noordhoek, $\mathrm{P}$.

- Motieven voar kwaliteit (I); De sprong wan bedrijfsleven naar overheid, in: Openbaar Bestuur, nr.1, 1995, pp.13-16;

- Motieven woor kwaliteit (II); Motieven voor de overheid, in: Openbaar Bestuur, nr.2, 1995, pp.15-18;

- Motieven voor kwaliteit (III); Kwaliteit voorbij wet en regel, in: Openbaar Bestuur, nr, 3. 1995, pp. 20-23.

Oostrum, H.J. van

Harmoniseren in de marge; Europees vennootschapsrecht botst met nationaal belang , in: NRC, 7 oktober 1994, p. 14

Pleite, M. \& Geleuken, B. van

Het milieuconvenant; Goede voornemens, slechte resultaten, in: IV, nr.9, 1994, pp.83-94.

Prins, J E.J.

Overtollig recht inzake informatietechologie; Privaatrecht en informatisering in het zicht van een nieuw" millennium, oratie KUB, Deventer, 3 februari 1995.

Rossum, E.R.C.

De ketenbenadering: een praktisch beleidsconcept, in: Regelmaat, $\mathrm{nr} .5,1994, \mathrm{pp} .189-195$.

Rossum, E.R.C. \& Quartero, P.J.

Pathologie van de maleving, in: Beleidsanalyse, nr.2, 1993, pp.5-14.

Ru., H.J. de

Banken in telecom: verkeerd verbonden; Vergunningstelsel gevaar voor concurrentie?, in: NJB, nr.6, 10 rebruari 1995, pp. 197-203.

Senstius, $\mathrm{B}$. 
'Marktregulering woorkomt wild-west-economie'; Utrechts hoogleraar pleit voor 'georganiseerd kapitalisme', in: Intermediair, nr.14, 7 apil 1995, pp.27-29.

Simon, H.J.

Financiele voorwaarden en voorschriften; een blik vamuit de theorie op de praktijk, in: NTB. nr.6, 1994, pp.149-164.

Slot, P.J.

Amnotatie APK-arrest, in: SEW, nr.2, 1995, pp.130-131.

Temmink, H.A.G.

Minimumnormen in EG-richtliinen, in: SEW, nr.2, 1995, pp.79-106.

Tweede Kamer

- Versiag wan de Algemene Rekenkamer over 1989, TK 1989-1990, 21481, nrs.1-2;

Normen, certificaten en open grenzen, TK 1994-1995, 21670, nrs.7-8;

- Verslag van de Algemene Rekenkamer over 1992, TK 1992-1993, 23065, nrs.1-2;

- Verslag van de Algemene Rekenkamer over 1993, TK 1993-1994, 23670, ars. 1-2;

- Regeerakkoord 1994: keuzes voor de toekomst, TK 1993-1994, 23715, nr.11;

- Marktwerking, deregulering en wetgevingskwaliteit, TK 1994-1995, 24036, nr.1;

- Decemberverslag van de Algemene Rekenkamer over 1994, TK 1994-1995, 24045, nrs.1-2;

- Verslag van de Algemene Rekenkamer over 1994, deel 3; Zelfstandige bestuursorganen en ministeriële verantwoordelijkheid, TK 1994-1995, 24130, nr.3.

Valkenburg, $\mathrm{L}$.

De EZ-nota 'Normen, Certificaten en Open Grenzen', in: RegelMaat, nr. 3, 1995, pp.100-107.

Ven, A.T.L.M. van de

Verzelfstandiging en bestuurlijke organisatie, in: S\&V, nr.3, 1994, pp.61-65.

Vervaele, $\mathbf{J}$, A.E.

- Handen en tanden wan het (gemeenschaps)recht, oratie RUU, 18 februari 1994, Deventer, 1994;

- Recensie dissertatie Y. Buruma, in: Recht en Kritiek, nr.4, 1994, pp.392-397.

Vlies, I.C. van der

Handhaving van wetgeving: politiek of technisch begrip, in: RegelMaat, 1989, p.3.

Vonk, R. \& Beljaars, P.

Certificatie, een insirument van een overheid op afstand?, in: Openbaar Bestuur, nr. 1, 1995, pp.28-32.

Wessels, $\mathbb{B}$.

- Verzelfstandiging: enkele kanttekeningen wit het vermogensrech, in: $\mathrm{S} \& \mathrm{~V}, \mathrm{nr} .3,1994$, pp. $71-77$;

- Overheidsaansprakelijkheid bij begeleiding paspoortproject, in: juridisch \& fiscaal tijdschrift Privatisering, n. 1,25 januari 1995 , pp.4-6.

Wuijtswinkel, R.J.M. van

Hervormingen in de publieke sector wan Nieuw-Zeeland, in: Openbaar Bestuur, nr.3, 1995 , pp. 2-6. 



\section{Samenvatting}

Volop worden verzelfstandigingen voltooid. Zie hoofdstuk 1 . Veranderd vaart de, in vlotten geslagen, overheidsorganisatie krachtig koers. Kennelijk alle kritiek voorbij.

Vóór alles wil de rijksoverheid een doelmatiger beheer van overheidseenheden en richt zij zich, in haar streven naar efficiènter en effectiever overheidshandelen, op de markt. Zie hoofdstuk 6 . In haar streven zo veel mogelijk oneigenlijke overheidstaken af te stoten (en daar waar wel sprake is en blijft van echte overheidstaken beleidsbepaling en beleidsuitvoering te scheiden, zie hoofdstuk 9), bezint zij zich op haar kerntaken. Zie hoojdstuk 8 .

Vooral toezichthoudende zelfstandige bestuursorganen, in het bijzonder op te richten ten einde met elkaar verstrengelde taken, bevoegdheden en verantwoordelijkheden te ontvlechten, zijn in zwang. Attributie of delegatie - zie hoofdstuk 5 - van publiekrechtelijke bevoegdheden aan specifiek toezichthoudende zelfstandige bestuursorganen neemt een hoge vlucht. Het decentral iseren van handhavingsbevoegdheden - welk bevoegdhedengebruik er toe leidt dat openbaar gezag wordt uitgeoefend - naar publiekrechtelijk of privaatrechtelijk vorm gegeven functionele bestuursorganen, is het meest aangewezen in situaties waarin de overgang van overheid naar bedrijf zich manifesteert.

$\mathrm{Bij}$ in het verschiet liggende, binnen een bepaalde termijn te realiseren, echte privatisering, warin een door harmonisatie en liberalisering van wet- en regelgeving versterkte vrije markt met volledige concurrentie uitgangspunt is, kunnen zelfstandige bestuursorganen belast met overheidstoezicht zo adequaat dienst doen als voorlopers of begeleiders. Zie hoofdstukken 6, 20.

In het eerste geval acht de rijksoverheid het onverantwoordelijk overheidstoezicht direct te privatiseren. Daarom creëert zij, tussenliggend, een doorgangsmodel. Het overheidstoezicht wordt verzelfstandigd. Uitvoering van toezichthoudende bevoegdheden geschiedt. op afstand van het beleidsbepalende en op hoofdlijnen politiek verantwoordelijke kerndepartement. Maar het weliswaar in principe hiërarchisch niet aan enig minister onderworpen toezichthoudende zelfstandig bestuursorgaan heeft nog wel bepaalde (financiele of politieke) binding met het ministerie. Op grond van de met het zelfstandig bestuursorgaan opgedane ervaring moet het politieke besluit vallen of verdere verzelfstandiging in de rede ligt. Wordt een maal besloten om het publiek toezicht om te zetten in privaat toezicht (nota bene, sommige handhavingstaken blijven door hun grondwettelijk karakter 
onverhoopt overheidstaken en worden, uit overwegingen van doelmatig werken en om redenen van efficiënt beheren, niet tijdelijk maar blijvend extern verzelfstandigd), dan is de tijd rijp voor omschakeling naar een geprivatiseerde instantie. Het zelfstandig bestuursorgaan heeft dan het pad voor pure privatisering geëffend.

In de tweede situatie bewaakt een specifiek daartoe ingesteld toezichthoudend zelfstandig bestuursorgaan een, al dan niet aan openbare aanbesteding gerelateerd, privatiseringsproces. Om te bewerkstelligen dat een organisatie (die langzaam maar zeker wordt losgerukt ait het haar van oudsher passende publieke keurslijf), een maal geconfronteerd met het meer markt georiënteerd werken, bij het verwerven van een positie op een niets ontziende commerciële markt niet wordt gehinderd door haar oude overheidstradities, is tijdelijk toezicht door een flexibel zelfstandig bestuursorgaan nodig. Deze, op een afstand van politiek Den Haag te realiseren, onafhankelijke marktregulering is tevens nodig gegeven het gevaar van belangenverstrengeling, dat zich mogelijk snel bij de Staat als aandeelhouder en regelgever/toezichthouder openbaart.

Toezichthoudende zelfstandige bestuursorganen nemen in de toekomst toe. Voor deze ontwikkeling is het irrealistisch de ogen te sluiten door stoïcijns vast te houden aan argumenten contra externe verzelfstandiging als: het gebrek aan volledige politieke ministeriële verantwoordelijkheid voor het handelen of nalaten van zelfstandige bestuursorganen; de afwezigheid van een wettelijk kader voor zelfstandige bestuursorganen; of de absentie van samenhang in de overheidsorganisatie.

Immers daar, waar door beperkte ministeriële verantwoordelijkheid een vacuüm wordt geforceerd, is ruimte voor aanvullende alternatieven. Zie hoofdstuk 3. Zo bestaat zicht op een zelfstandige ambtenaarlijke spreekplicht. Daarnaast creëren zich bij private zelfstandige besturursorganen kansen van kwalitatieve aansprakelijkheid via toenemende toepassing van civiel recht. De lacune van een legaal kader voor zelfstandige bestuursorganen krijgt binnenkort opvulling. Zie hoofdstuk 4. Een raamwet inzake zelfstandige bestuursorganen is in voorbereiding. En de desintegratie binnen het openbaar bestuur in Nederland verdwijnt vermoedelijk door het aanhangen van functionele bestuursorganen bij oude en nieuwe vormen van territoriale bestuursorganen. Zie hoofdstuk 5.

Zo zijn toezichthoudende zelfstandige bestuursorganen goed bruikbaar voor het ontvlechten van taken, bevoegdheden en verantwoordelijkheden. Voorwaarde daarbij is dan dat ze adequaat worden aangestuurd door het op hoofdlijnen verantwoordelijke departement wia vooral kwaliteitshandvesten - zie hoofdstuk 3 -, waarbij informatievoorziening cruciaal is, en dat ze als ultiem uitvloeisel daarvan geconfronteerd kunnen worden met intrekking of wijziging van delegatie of attributie (dan wel de voorwaarden daarvan) door de betrokken bewindspersoon.

In dit kader is het aanvaardbaar, en van uit het huidige handhavingshiaat zelfs toe te juichen - zie hoofdstuk 20 -, dat de rijksoverheid, op wie verschillende (uit de Grondwet of verdragsrecht voort vloeiende) zorgplichten rusten - zie hoofdstukken $14,15,16,17$, $18,19-$, handhavingsbevoegdheden die nodig zijn om zekere zorgplichten te realiseren opdraagt of overdraagt aan toezichthoudende zelfstandige bestuursorganen. Deze organen, die voor zover ze toezicht uitoefenen openbaar gezag hebben, moeten zich dan kenmerken als autonoom, autoritair en accuraat. Wel is het zaak dat de overheid bij 
vermelde, in het teken wan het algemeen belang staande, functionele decentralisatie van overheidstaken met daaraan gekoppelde publiekrechtelijke bevoegdheden relevante randvoorwaarden stelt. Daarnaast dient de Nederlandse overheid, in haar-slechts summier succes scorende, weinig beterschap belovende en overigens omstreden- streven meer marktwerking te introduceren en dieper in deregulering te duiken, eerlijke mededinging veilig te stellen.

Die randvoorwaarden betreffen in elk geval: a. het rechtsstatelijke legaliteitsprincipe (al dan niet indirecte formeel-wettelijke grondslag voor handhavingsbevoegdheden wit te oefenen door zelfstandige bestuursorganen) - zie hoofdstukken $4,7-; \mathrm{b}$. het rechtsstatelijke machtsverdelingsbeginsel (strikte scheiding tussen, al dan niet personele, functies van toezicht in ruime zin binnen zelfstandige bestuursorganen) - zie hoofdstukken $3,10-; \mathrm{c}$. het democratiebeginsel (dat gestalte krijgt via: a. de, voor zelfstandige bestuursorganen beperkt politiek verantwoordelijke, betrokken ministers die bij voorbeeld eisen kunnen stellen aan tarieven en prijzen gesteld door toezichthoudende zelfstandige bestuursorganen; en b. wettelijk geconditioneerde vormen van zelfregulering, met mogelijk snelle acceptatie van toezicht en snelle implementatie van Europese regelgeving als flinke voordelen) - zie hoofdstuk 20 ; en d. toezichtskwaliteitswarborging (via certificering, accreditatie en normalisatie) - zie hoofdstukken 17,20 .

Eerlijke mededinging eist dan dat de overheid, bij voorkeur via een daartoe specifiek sectoroverkoepelend zelfstandig bestuursorgaan dat toeziet op mededingingsrecht, streng in de gaten houdt of min of meer bedrijfsmatige toezichthoudende zelfstandige besturirsorganen, belast met al dan niet van oudsher bestaande overheidsprerogatieven, misbruik van hun machtspositie maken of anderszins de mededinging vervalsen. Beoordelingskader vormen hier de, in het licht van de (excepties van) vrijheden van vervoer, diensten, goederen en vestiging te beschouwen, artt. 85-92 van het $\mathbb{E} G$-verdrag, die tegenwoordig ook van toepassing zijn op bedrijfsmatige verzelfstandigde entiteiten die overheidstaken uitoefenen. Andere artikelen van vermeld verdrag, t.w. de artt. 101-102, zien op het gevaar van distorsie in afwijkend opzicht. Concurrentievervalsing onstaat namelijk niet alleen doordat gepriviligieerde toezichthoudende zelfstandige bestuursorganen, via o.a. monopoloïde prijsstelling, kunstmatige winstprikkels of andere oneigenlijke checks, de private ondernemingsmarkt ondermijnen. Een beeld van oneerlijke mededinging kan tevens worden opgeroepen door uiteenlopende uitingen van de, door zelfstandige bestuursorganen uit te oefenen, overheidstaak het recht te handhaven. Als verschillen in toezicht- en sanctiemodules tussen gelijksoortige verzelfstandigde entiteiten in verschillende lidstaten bestaan, neigen onder toezicht gestelden er naar zich onder het meest tolerante toezichtssysteem te stellen. Zie hoofdstukken I4, 16, 17, 20.

Enig verschil in toezichtsstelsels is weliswaar geoorloofd. In het kader van het grof weg gelijk trekken van basale beginselen van handhaving is wederzijdse erkenning door Europese lidstaten van elkaars controle- en toezichtsstelsels mogelijk. Dat is doelmatig, want bij voorbeeld dubbele controles worden overbodig. Zie hoofdstukken $13,17,18,19$. Dit over en weer respecteren van onderlinge toezichtsmodules, vergunningen, certificaten en dergelijke is een concrete consequentie van het feit dat de grenzen binnen Europa 
wegvallen, waarbij nationaal erfgoed mogelijk nog wel via het subsidiariteitsbeginsel te sauveren valt, en wordt bovendien vereist in gevolge de in art. 5 EG-verdrag neergelegde samenwerkings(- en handhavings)plicht. Zie hoofdstuk 13. Dit gaat zo ver dat Europese toezichthouders samenwerking zoeken en informatie uitwisselen met nationale toezichthouders. Grens daarbij is dat Europese toezichthouders de autonomie van nationale toezichthouders niet aantasten. Voor de nationale toezichthouders, wat betreft de uitoefening van pure toezichtsbevoegdheden, liggen (overigens onduidelijke) grenzen in afdeling 5.1 Awb. Zie hoofdstuk 11 . Uit oogpunt van de rechtsbescherming voor justitiabelen, die met name zoek raakt daar waar bestuurlijk toezicht zich bemoeit met strafrechtelijke opsporing, is het nog maar de vraag of de Awb-wetgever wijs wet geeft. In elk geval rust op de toezichthouder in elk concreet geval een moeilijke afwegingsplicht. Dit wordt er niet eenvoudiger op als hem ook nog de weliswaar belangrijke bestuurlijke boetebevoegdheid, die in de Awb nog regeling vindt, ten deel valt. Zie hoofdstukken 10, 12 . 


\section{Summary}

More and more government institutions are gaining independence. See chapter 1. Government organization has undergone many changes and, even after having fallen apart, it does not deviate from its course, obviously without provoking any criticism.

Because the central government's prime concern is to manage the government branches in a more efficient and effective way, it is concentrating on the market. See chapter 6. The government is striving to hive off as much as possible those tasks that are outside its range of responsability (as to the tasks for which the central government is and stays responsible, it is striving to distinguish the formulation of policies from the implementation of policies, see chapter 9), and to that end it is reviewing its major tasks. See chap$\operatorname{ter} 8$.

Particularly supervisory ZBO's [independent bodies] are being set up with the aim of straightening out the tangle of duties, powers and responsabilities. More and more authority pertaining to public law - see chapter 5 - is being assigned and delegated to specifically supervisory ZBO's. In situations where the transition from state activity to commercial activity is evident, the best method to follow is to decentralize enforcement tasks - which guarantee the exercise of public authority - and to assign these tasks to ZBO's that have been formed in accordance with public and private law.

When in the future actual privatization is carried through, ZBO's in charge of government control can adequately act as counsellors. This privatization has to be realised within a fixed term and will be based upon the principles of a free market with free competition, a market that will be strengthened by harmonization and liberalization of laws and regulations. See chapters $6,20$.

In the first case, the central government judges an immediate privatization of government control irresponsible and will, consequently, create a temporary, interim model. Govermment control will become independent and autonomous. Supervisory powers will be exercised away from the policy-making and overall politically responsible government department. Yet the supervisory ZBO that basically, in terms of hierarchy, is not subordinate to any minister, will maintain certain (financial or political) relations with the ministry. On the strength of the experiences with $\mathrm{ZBO}$ 's, a political decision should be made on any further decentralization. Once the decision has been made to turn public control into private control (please note: because of their constitutional nature, some enforcement 
tasks will remain government tasks and will, in view of efficiency in functioning and managing, be decentralized, not temporarily, but permanently), the time will be ripe for a changeover to a privatized body. The supervisory $\mathrm{ZBO}$ will then have paved the way for complete priwatization.

In the second case, the process of priwatization, whether or not related to public tendering, will be under control of a ZBO set up specifically for that purpose. A temporary supervision by a flexible $\mathrm{ZBO}$ will be required in order to prevent old government traditions from being an impediment to the acquisition of a position on a relentless market by an organisation (which will slowly but surely be torn loose from its public, of old perfectly fitting straightjacket), once this organisation is confronted with market-orientated operations. This independent orientation towards the market, to be put into practice away from the government in The Hague, will also be required given the risk of a conflict of interest that may soon manifest itself with the State being shareholder as well as controlling and supervising body.

In the future, the number of supervisory ZBO's will grow. It is not realistic to disregard this development by stoically holding on to arguments against decentralization like: full ministerial accountability does not apply to the acts and omissions of ZBO*s; there is no legal framework in which ZBO's fit; government organisation is lacking coherence.

Since limited ministerial accountability forces a vacuum, there is room for supplementary alternatives. See chapter 3. For example, there is some prospect of making civil servants personally answerable. Besides, private ZBO's will create opportunities for qualitative liability by means of an increasing application of civil law. In the near future, the absence of a llegal framework for $\mathrm{ZBO}^{\prime}$ s will be rectified. See chapter 4. Preparations are being made for a legislative framework concerning ZBO's. And the disintegration of public administration in the Netherlands will probably disappear when functional administrative bodies will be integrated into old and new forms of territorial administrative bodies. See chapter 5.

Supervisory ZBO's can help to straighten out the tangle of tasks, powers and responsabillities. This aim can only be achieved on condition that they will be adequately guided by the overall responsible department, in particular by means of quality charters - see chapter 3 -, which guidance will consist principally in the providing of information, and on condition that, as an ultimate consequence, they can be faced with withatrawal or modification of delegation or assignment (or of their terms) by the minister concerned.

In this context it is acceptable, and given the existing enforcement gap even to be welcomed - see chapter 20 - that the central government charged with several obligations (arising out of the Constitution or out of treaty laws) - see chapters 14,15, 16, 17, 18, 19 - can assign or devolve the enforcement powers, required to ensure fulfilment of certain obligations, to supervisory $\mathrm{ZBO}^{\prime}$ 's. These bodies, which will have public authority insofar as they act as supervisors, will have to be autonomous, authoritarian and accurate. However, in the event of an aforementioned functional decentralization of government tasks and of related powers pertaining to public law, the government must lay down relevant limiting conditions, in which public interest will be taken into account. In addition, the Dutch government needs to safeguard fair competition in its, neither very suc- 
cessful, nor really promising and besides controversial, pursuit of deregulation and introduction of market forces.

In any case, these limiting conditions concern: a. the constitutional state principle of legality (an indirect or otherwise procedural basis for enforcement powers to be exercised by ZBO's) - see chapters $4,7-; \mathrm{b}$. the constitutional state principle of power structure (a strict separation of personal or otherwise supervisory duties inside the ZBO's ) - see chapters $3,10-; \mathrm{c}$. the principle of democracy (that takes shape by means of : a. the ministers concerned who, within a certain limit, are politically responsible for the ZBO"s and who can, for example, require the supervisory ZBO's to account for the tariff and prices fixed by them; and b. legally stipulated forms of self-regulation, in which a possibly prompt acceptance of supervision and a prompt implementation of European rules will be big advantages) - see chapter $20 \ldots$ and d. a guarantee for the quality of the supervision (by certifying, accrediting and standardizing) - see chapters 17, 20 .

In order to ensure fair competition, the government must, preferably by means of a specific sector coordinating ZBO that supervises the observance of the rules on competition, keep a close watch on ZBO's having government prerogatives and see to it that they do not abuse their power or otherwise distort competition. Here, assessments will be made on the basis of articles 85-92 of the EEC Treaty, in the light of (exceptions of) freedom of transport, services, goods and establishment, which articles nowadays also apply to independent commercial entities that carry out government tasks. Other articles of this treaty, namely articles 101-102, provide for the danger of distortion. As a matter of fact, distortion of competition is not only brought about by privilleged supervisory ZBO's that undermine the private sector by means of, for instance, monopolistic price fixing, artificial profit incentives or other improper checks. Varying definitions of the government's task of enforcing the law, to be carried out by autonomous agencies, may also create unfair competition. If there are differences in standards to be applied to supervision and to the imposition of sanctions between similar autonomous institutions in various Member States, those who are under supervision will be inclined to subject themselves to the most permissive supervisory system. See chapters $14,16,17,20$.

Some difference in supervisory systems will indeed be permissible. As part of the rough equalization of basic enforcement principles, it is possible for European Member States to recognize each other's controlling and supervising system. This will also be efficient, since for example double checks will no longer be needed. See chapters 13, 17, 18, 19. This agreement to honour mutual standards of supervision, licences, certificates and the like, will be a concrete consequence of the disappearance of the borders inside Europe, taking into account that national heritage may be preserved by means of the principle of subsidiarity, and will even be required because of the obligations laid down in article 5 of the EEC Treaty. See chapter 13. European supervisory institutions are seeking cooperation and exchanging information with national supervisory institutions, the only restriction being that the European supervisors do not harm the autonomy of the national supervisors. The (anyway vague) limits within which the national supervisors will have to keep, have been laid down in section 5.1 Awb [general administrative law]. See chapier 
11. As regards legal protection of justiciable persons, which will notably be jeopardized by the interference from administration in criminal investigation, it remains to be seen whether the Awb-legislation is a wise legislation. Anyhow, it is the difficult duty of the supervisor to determine how to act in each concrete case. And to complicate matters, the supervisor will be empowered to impose fines, a competence still to be provided for by the Awb.

Translation." Mechtild M.A.W. Claessens 


\section{Jurisprudentieregister ${ }^{1}$}

Europese Commissie woor de Rechten var de Mens

S. vs. Zwitserland

ECRM 14 januari 1993

Mediaforum 1994/1, 11

par. 14.11.

NOS vs. Nederland

ECRM 13 oktober 1993

Mediaforum 1994/6, 11

par. 13.1.2.

\section{Europees Hof woor de}

Rechten van de Mers

Engel-Van der Wiel-De Wit-

Dona-Schul

EHRM 23 juni 1976

NJ 1978,223 en 224

par. 12.5 .

Handyside

EHRM 7 december 1976

ECHR, A, 24

par. 14.11 .

Sunday Times

EHRM 26 april 1979

ECHR, A, 30

\author{
par. 14.11. \\ Deweer \\ EHRM 27 februari 1980 \\ ECHR, A, 35 \\ par. 12.5. \\ Ötürk \\ EHRM 21 februari 1984 \\ NJ 1988,937 \\ par. 12.5 . \\ Campbell \\ EHRM 28 juni 1984 \\ ECHR, A, 80 \\ par. 12.5. \\ Lingens \\ EHRM 8 juli 1986 \\ ECHR, A, 103 \\ par. 14.11. \\ Lutz \\ EHRM 25 augustus 1987 \\ NJ 1988, 938 \\ par. 12.5 . \\ Chappell \\ EHRM 30 mart 1989 \\ NJ 1991, 522 \\ par. 16.6. \\ Groppera radio $\mathrm{AG}$ \\ EHRM 28 maart 1990
}

NJ 1991, 739

par. 14.11 .

Weber

EHRM 22 mei 1990

ECHR, A, 177

par. 12.5.

Autronic AG

EHRM 22 mei 1990

NJ 1991,740

par. 14.11.

Huvig vs. Kruslin

EHRM 24 april 1990

N] 1991, 523

par. 11.1.4 en 16.6 .

Demicoli

EHRM 27 augustus 1991

ECHR, A, 210

par. 12.5 .

Spycatchers-mémoires

EHRM 26 november 1991

NJ 1992,457

par. 14.11.

Niemietz vs. Duitsland

EHRM 16 december 1992

NJ 1993,400

par. 11.1.4 en 16.6.

Funke vs. Frankrijk

1. In beginsel wordi de bron aangegeven door vemeld ing van naanusafkorting en verschijningsnummer van een periodiek (inclusief eerste pagina). Soms is sprake wan een extra nummer angeduid met de letter B (na jaartal vermeld tussen haakjes). Bij voorbeeld het NJB kent een bijlage rechtspraak, het extra nummer betreft dan het nummer waaronder de jurisprudentie in het katern wordt vermeld. Bovendien is het, wat betreft o.a. NIB, Mediafomm en SEW, zo dat de aangegewen pagina's de pagina"s betreffen die voorko* men in het jurispndertiebjjlage wam genoende bladen. 
EHRM 25 februari 1993

NJ 1993,485

par. 11.1.4 en 16.6.

Salesi vs. Italië

EHRM 26 februari 1993

NJB 1995/5,63

par. 12.5.

Informationsverein Lentia

vs. Oostenrijk

EHRM 24 november 1993

NJ 1994, 559

par. 14.11.

Bendenoun vs. Frankrijk

EHRM 24 februari 1994

NJ 1994, 496

par. 12.5 .

Hof wan Justitie EG

Sacchi

HvJ EG (155/73) 30 april 1974

Jur. 1974, 409

par. 14.11.1.

Kohlen- und Baustoffgross-

handlung vs. Commissie:

Nold

HvJ EG (4/73) 14 mei 1974

Jur. 1974,508

par. 16.6.

Dassonville

HwJ EG (8/74) 11 juli 1974

Jur. 1974,837

par. 14.11.1.

Wachauf

HvJ EG (5/8:8) 13 juli 1974

Jur. 1974,2609

par. 16.6 .

Binsbergen vs. bestuur van bedrijfsvereniging voor

metaalnijwerheid

HvJ EG $(22 / 74) 3$ december 1974

Jur. 1974, 1299

par. 14.11.1.

Coenen

HvJ EG (39/75) 26 november 1975

Jur. 1975,1547 par. 14.11.1.

Amsterdam Bulb bv ws.

Produktschap voor sier-

gewassen

HvJ EG (50/76) 2 februari 1977

Jur. 1977, 137

par. 13.1 .

Watson

HvI EG (118/75) 7 juli

1976

Jur. 1976, 1185

par. 13.1.1.

Van Tiggele

HvJ EG (82/77) 24 januari 1978

Jur. 1978,901

par. 14.11.1.

Cassis de Dijon

HWJ EG (C-120/78) 20

februari 1979

Jur. 1979, 649

par. 14.11.1.

Haver

HwJ EG (44/79) 13 december 1979

Jur. 1979,3727

par. 16.6.

Debauve

HvJ EG (52/79) 18 maart 1980

Jur. 1980,833

par. 14.11.1.

Panasonic

HwJ EG (136/79) 26 juni 1980

Jur. 1980, 2056

par. 16.6.

Pieck

HvJ EG (157/79) 3 juli 1980

Jur. 1980, 2171

par. 13.1.

Frans-Nederlandse maat-

schappij voor biologische

produkten

HvJ EG $(272 / 80) 17$ đecem-

ber 1981

Jur. 1981,3277 par. 13.1.

Webb

HvJ EG (279/80) 17 december 1981

Jur. 1981, 3305

par. 14.11.1 en 16.6.

Fromme

HvJ EG (54/81) 6 mei 1982

Jur. 1982,1449

par. 13.1.

Coditel II

HvJ EG (262/81) 6 oktober 1982

Jur. 1982, 3381

par. 16.6 .

Von Colson en Kamann

HvJ EG (14/83) 10 april 1984

Jur. 1984, 1891

par. 13.1 en 13.1.4.

Commissie vs. Duitsland

HvJ EG (205/84) 4 decem-

ber 1984

Jur. 1986,3755

par. 18.9 .

Cinéthèque

HvJ EG (61/84) 11 september 1985

Jur. 1985, 2618

par. 14.11.1.

AKZO

HvJ EG (5/85) 23 september 1986

Jur. 1986, 2607

par. 16.6.

Kabelregeling

HvJ EG (352/85) 26 april

1988

NJ 1988,982

par. 14.11.1.

Rush Portuguesa

HvJ EG (113/89) 27 maart

1990

SEW 1991, 194

par. 16.6.

Griekse maīs

HwJ EG (68/88) 21 september 1989

Jur. 1989, 2965 
13 december 1990

SEW 1993, 801

par. 13.1 en 13.1.1.

Hoechst

HVJ EG $(46 / 87,227 / 88) 21$

september 1989

NJCM 1991, 44

par. 16.6.

Dow Benelux

HwJ EG (85/87) 17 oktober 1989

Jur. 1989,2127

par. 16.6.

Dow Chemicall Ibérica

HvJ EG (97-99/87) 170kto-

ber 1989

Jur. 1989,3165

par. 16.6.

Groener

HvI EG (379/87) 28 no-

vember 1989

Jur. 1989,3967

par. 14.11.1.

Drinkwater Verviers

HvJ EG (42/89) 3 juli 1990

M\&R 1991, 31

par. 13.1.3.

Anklagemyndigheden Han-

sen \& Sön

HvJ EG (C-326/88) 10 juli

1990

Jur. 1990, I-2911

par. 13.1 en 13.1.1.

Software

HvJ EG (79/89) 18 april

1991

Jur. 1991,1884

par. 16.6.

Ellinki Radiophonia Tiléo-

rassi $A E$ vs. Dimotiki Etiria

Pliroforissis $\mathrm{c} . \mathrm{s}$.

HvJ EG (C-260/89) 18 juni 1991

Jur. 1991, 2951

par. 14.11.1

Stichting collectieve antennevoorziening Gouda vs.

CrdM
HvJ EG (288/89) 25 juli

1991

Jur. 1991, 2951

par. 14.11.1.

Säger vs. Dennemeyer

HWJ EG (76/90) 25 juli

1991

Jur. 1991,4239

par. 16.6 .

A. Richardt en 'Les accessoires scientifiques' wof

HvJ EG (367/89) 4 oktober

1991

SEW 1994/4, 253

par. 13.1.2.

Conmissie vs. Duitsland

HvJ EG (C-361/88, 59/89)

30 mei 1991

SEW 1994/3

par. 13.1.3.

Emmott.

HvJ EG (C-208/90) 25 juli

1991

Jur. 1991, I-4269

par. 13.3.

Commissie vs. Ned.: Mediawetzaak

HwJ EG (C-353/89) 25 juli

1991

Mediaforum 1991.

par. 14.11.1.

Duitsl. vs. Commissie

HWJ EG (342/89) 17 oktober 1991

Jur. 1991, I-5031

par. 13.3.

Francovich en Bonafaci

HwJ EG (C-6/90, C-9/90)

19 nov. 1991

AB 1994,482

par. 13.3.

Merci convenzionali porto di

Genova SpA vs. Siderurgica

Gabrielli SpA

HIVI EG (C-179/90) 10

december 1991

NJ 1994, 402

par. 14.11.1.
Sociétés Compagnie commercialle de l'Ouest e.a. vs. Receveur principal des douanes de La Pallice-Port HvJ EG (C-78-83/90) 11 maart 1992

SEW 1995/3, 187

par. 14.11.1.

Duitsl. ys. Commissie

HvJ EG (C-240/90) 27

oktober 1992

NJB 1993/2

par. 13.3.

Council of the City of Stokeon-Trent, Norwich City

Council vs. B\&Q plc

HvJ EG (C-169/91) 16

december 1992

SEW 1995/3, 196

par. 14.11.1.

Commissie vs. België:

Vlaams kabeldecreet

HyJ EG (C-211/91) 16

december 1992

Mediaforum 1993/2, 23

par. 14.11.1

VOO vs. CvdM: RTL-

Véronique

HvJ EG (C-148/91) 3 febru-

ari 1993

NJ 1994,29

par. 14.11.1.

Crémieux vs. Frankrijk

HwJ EG 25 februari 1993

NJB 1995/4(B5), 49

par. 11.1.4.

Miailhe vs. Frankrijk

HvJ EG 25 februari 1993

NJB 1995/4(B6), 49

par. 11.1.4.

Openbaar ministerie vs. Paul Corbeau

HvJ EG (C-320/91) 19 mei 1993

SEW 1994/7-8, 515

par. 14.11.1.

Société Labaratoire de prothèse oculaires $t$. Union nationale des syndicals de 
France e.a.

HvJ EG (C-271/92) 25 mei 1993

SEW 1994/6, 437

par. 14.11.1.

Otto vs. Postbank nv

HwJ EG (C-60/92) 10 no-

vember 1993

NJB 1993/44

par. 13.3.

Keck vs. Mithouard

HvJ EG (C-267-268/91) 24

nov. 1993

NI 1994,470

par. 14.11 .1 .

Hünermund e.a. vs. Landesapothekerkammer Bader-

Württemberg

HWJ EG (C-292/92) 15

december 1993

SEW 1995/3, 206

par. 14.11.1.

SAT Fluggesellschaft mbH

vs. Organisation européenne

pour la sécurité de la navigation aérienne (Eurocontrol)

HvJ EG (C-364/92) 19

januari 1994

TVVS 1994/7, 195

par. 14.11.1.

Verband Sozialer Wett-

bewerb eV vs. Clinique

Labaratoires SNC en Estée

Lauder Cosmetics GmbH

HuJ EG (C-315/92) 2 febru-

ari 1994

NJB 1994/8, 93

par. 14.11.1.

Commissie vs. Spanje:

beroepskwalificatie gidsen

HvJ EG (C-375/92) 22

maart 1994

NJB 1994/19, 241

par. 14.11.1.

Schindler vs. Her Majesty"s

Customs and Excise

HvI EG (C-272/92) 24

maart 1994

NJ 1995, 57 par. 14.11.1.

Schmidt vs. Spar- und Leih-

kasse der früheren Amter

Bordesholm, Kiel und.

Cronshagen

HvJ EG (C-392/92) 14 april 1994

NJ 1995,149

par. 6.2.2.

Gestión Hotelera Inter-

nacional SA. vs. Comunidad

Autónoma de Canarias

Ayuntamiento de Las Palmas

de Gran Canaria Gran

Casino de Las Palmas SA

HvJ EG (C-331/92) 19 april 1994

SEW 1995/1, 48

par. 20.1.4.1.

Gemeente Almelo e.a. ws. nv

Energiebedrijf IJsselmij.

HvJ EG (C-393/92) 27 april 1994

NJ 1995, 93

par. 14.11.1.

Corsica Ferries Italia Srl vs.

Corpo dei piloti del porto di

Genova

HvJ EG (C-18/93) 17 mei 1994

NJ 1995,168

par. 14.11.1.

Frankrijk vs. Commissie

HvJ EG (C-41/93) $17 \mathrm{mei}$

1994

NJB 1994/24, 299

par. 16.6.

Samenwerkende Elektrici-

teits-Produktie-bedrijven vs.

Commissie

HvJ EG (C-36/92) 19 mei

1994

TVVS 1994/8, 224

par. 13.3.

Magil TV Guide Ltd

HvJ EG (C-241/91 P en

C-242/91 P)

NJB 1995/22(B7), 283

par. 14.5.2.
Tankstation 't Heuske vof en

Boermans

HvJ EG (C-401/92, 402/92)

2 juni 1994

NJ 1995,181

par. 14.11.1.

Punto Casa SpA vs. Sindaco del Comune di Capena,

Promozioni Polivalenti

Venete Soc. coop. arl en

Sindaco del Comune di Torri

di. Quartesolo

HvJ EG (C-69/93 en

258/93) 2 juni 1994

NJ 1995, 180

par. 14.11.1.

Commissie vs. Verenigd

Koninkrijk van Groot-

Brittanië en Noord-Ierland

HvJ EG (C-382/92, 383/92)

8 juni 1994

NJ 1995,194 en 195

par. 6.2.2.

Fiskano $\mathrm{AB}$ vs. Commissie

HwJ EG (C-135/92) 29 juni

1994

SEW 1994/12, 814

par. 13.3.

Paola Faccini Dori vs.

Recreb Sril

HvJ EG (C-91//92) 14 juli 1994

AA $1994 / 12,845$

par. 13.1.3.

Frankrijk vs. Commissie

HvJ EG (C-327/91) 9

augustus 1994

NJB 1994/30, 1057

par. 18.9.1.

TV 10 SA vs. CvdM

HvJ EG (C-23/93) 5 oktober 1994

NJB $1994 / 40(B 26), 523$

par. 14.11.1.

Van Schaik inzake apk-

erkenning

HvJ EG (C-55/93) 5 oktober 1994

SEW 1994/11,28 
par. 20.2.2.

Lucien Ortscheit GmbH vs.

Eurim Pharm Arzneimittel

GmbH

HvJ EG (C-320/93) 10

november 1994

SEW 1995/3, 211

par. 14.11.1.

Importmaatschappij Édouard

Leclerc-Siplec vs. TF1

Publicité SA en M6 Publicité

SA

Hv』EG $(C-412 / 93) 9$ februari 1995

NJB 1995/21(B5), 267

par. 14.11.1.

\section{Hoge Rarad der Nederlanden}

Jamin

HR 25 januari 1926

NJ 1926, 246

par. 4.4.1.

Geweer

HR 2 december 1935

NJ 1936, 250

par. 11.1.4.

Zeyense nachtbraker

HR 24 oktober 1961

NJ 1962, 86

par. 7.

Bromfietsvalhelm

HR 11 januari 1977

NJ 1977,467

par. 4.4.1.

HR 5 januari 1982

NJ 1982, 308

par. 11.1.4.

Lucky Luijk

HR 21 januari 1983

Gemeentestem 6748, 86

par. 7 .

HR 9 oktober 1984

NJ 1985,176

par. 11.1.4.

Heggeweldse stroper

HR 30 oktober 1984

NJ 1985,275

par. 11.1.4.
Methadonbrief

HR 27 mei 1986

NJ 1987,898

par. 4.1.1.

HR 9 januari 1987

NJ 1987,928

par. 11.1.4.

Schorsende werking

beroep

HR 10 februari 1988

AB 1988, 547

par. 11.2 .

FIOD-optreden in licht

van art. 49 Awr

HR 26 april 1988

NJ 1989,390

par. 11.1.4.

Graasverbod Tsjernobyl

HR 28 februari 1989

NJ 1990,28

par. 11.1.8.

Staat vs. Windmill

HR 26 januari 1990

NJ 1991, 393

par. 10.2.

Bedrijfsverenigingen banken

vs. Boulogne

HR 12 juni 1992

AB 1992, 559

par. 6.4.5e.

Schending zorgwuldigheidsbeginsel door uitoefening toezichthoudende bevoegdheid

HR 4 november 1992

BNB 1993, 90

par. 11.1.

Interpretatie 'belang van de opsporing' ex art. 23 WED

HR 9 maart 1993

NJ 1993, 633

par. 11.1.4.

Staat ws. Magnus

HR 23 oktober 1993

AB 1994, 1

par. 10.2.

Art. 41 Wegenverkeerswet in het licht van het "fair trial'-beginsel
HR 26 oktober 1993

NJB 1994/2

par. 11.1 .4 .

Champignon-conserven

HR 11 januari 1994

NJ 1994,409

par. 17.1 .

Kijkoperaties politie

HR 31 mei 1994

NJB 1994/25, 314

par. 3.2.4.

Vicks pastilles

HR 14 juni 1994

SEW $1995 / 2,140$

par. 14.11.1.

Administratieplichten i.k. .

controle op visserij-

activiteiten

HR 27 september 1994

NJB 1994/44(B225), 592

par. 17.4.3.1.

Staal der Nederlanden vs.

Kurvers (Kenmerk En Personificatie bv inzake paspoort-

project)

HR 14 oktober 1994

NJ 1995,172

par. 20.1.

Nv Gemengd Bedrijf

Haagsche Tramweg Maat-

schapij vs. Eysink Smeets

HR 15 oktober 1994

$\mathrm{AB} 1994,632$

par. 11.1.6.

Scholten vs. gemeente Wierden inzake opsporing via

(film)observatie in overeensternming met het 'in accordance with the law' van art. 8 EVRM

HR 11 november 1994

N.JB 1994/43, 576

par. 11.1.4.

Nemo tenetur: medewerking aan boekenonderzoek staat niet in de weg aan opleggen verhoging

HR 23 november 1994

NJB 1995/4(B5), 57 
par. 11.1.4.

ABN Amrobank nv vs. Vereniging tot behartiging van de belangen van houders van obligaties Coopalg Finance by

HR 2 december 1994 NIB 1995/1(B263c), 4 par. 19.8 .

Vrüstelling winkelsluitingswet t.a.v. benzinestations HR 10 januari 1995 NJB 1995/13(B49), 169 par. 14.11.1.

\section{Gerechishoven}

Ruime uitleg begrip opsporing art. 23 WED: opsporingsbevoegdheden aan te wenden i.k.v. controle Hof 's-Gravenhage, 22 november 1991

M\&R 1993/3, 177

par. 11.1.4.

Waarborg platina, goud en zilver nv

Hof 's-Gravenhage, 17

maart 1992

NJ 1993, 213

par. 6.4.5d.

Vierhand bv vs. NV Databank (Kamers van Koophandel en fabrieken) en KvK Haarlem e.o.

Hof Amsterdam, 21 april 1994

CR 1995/1, 28

par. 14.11.1.

Gemeente Terschelling vs.

Delhez

Hof Leeuwarden, 10 augustus 1994

NJ 1995,202

par. 10.2.

STE ws. Stichting Waakzaamlheid Wmz-persoonsregistratie
Hof Amsterdam, 26 januari 1995

MF 1995/3, B35

par. 19.9.

Arrondissementsrechtbanken

Ministeriële verantwoording aan parlement

Rechtbank Amsterdam, 28 november 1991

KG 1992, 5

par. 3.3.4.1.

Ruime uitleg begrip opsporing art. 23 WED

Rechtbank Amsterdam, 27

december 1991

M\&R 1993/3, 179

par. 11.1.4 en 11.1 .5 .

Persoonsregistratie: sociale dossierverzameling en kaartsystemen van Raad voor de Kinderbescherming

Rechtbank Utrecht, 12 mei 1993

CR 1993/6, 259

par. 16.3.

Hornkamp vs. gemeente

Alkemade inzake art. 3:44

BW en art. 3:3 Awb

Rechtbank "s-Gravenhage, 4 mei 1994

AB 1994, 366

par. 10.2 .

Oujda vs. staats-secretaris

van justitie inzake art. 1:6

Awb

Rechtbank "s-Gravenhage, 11 mei 1994

AB 1994, 598

par. 11.1.4.

\section{President arrondissements- rechtbanken}

Vierhand bv vs. NV Databank

Pres. rechtbank Haarlem, 17 dec. 1993
CR $1995 / 1,26$

par. 14.11.1.

$X$ vs. Bestuur Stichting

KUVO (i.k.v. art. 1:1,

eerste lid, Awb)

Pres. rechtbank Utrecht, 31 maart 1994

AB 1995, 111

par. 6.4.5.

Belangenafweging

APK-erkenning

Pres. rechtbank Rotterdam, 11 meil 1994

KG 1994, 248

par. 13.1 .2 .

Vereniging Bureau voor

Muziekauteursrecht vs.

regeringscommissaris

belast met toezicht

ex art. 30a, vijfde lid,

Auteurswet 1913 (besluit

ex art. $1: 3 \mathrm{Awb}$ )

Pres, rechtbank Amsterdam, 29 aug. 1994

JB 1995/1, 11

par. 6.5.4a en 11.1 .

Stichting waakzaamheid

Wmz-persoonsregistraties

vs. STE

Pres. rechtbank A'dam, 15

sept. 1994

KG 1994, 354

par. 19.9.

\section{Economische politierechter}

Grolleman Transport bv

Economische pol.r. Zut-

phen, 30 mei 1994

SEW 1995/3, 216

par. 20.2 .

Egmond Transportbedrijf

Nijverdal

Economische pol.r. Almelo, 10 nov. 1994

SEW 1995/3, 219

par. 20.2 . 
President rechtbank van koophandel

DC vs. Belgacom

Pres. RvK Brussel, 22 juli 1994

CR 1994/6, 250

par. 14.11.1.

Afdeling Bestuursrechtspraak

Raad van State

Kuijten (Reiss \& Co bv):

privacy geen gewichtige

reden voor ontheffing publi-

katieplicht jaarrekening

ABRS 17 oktober 1994

AB 1995, 89

par. 18.4.

Belangenafweging sanctie-

beleid rijksdienst voor het

wegverkeer

ABRS 3 november 1994

AB 1994, 13

par. 13.1.2.

Afvalstoffen Terminal Moer-

dijk bv vs. minister van

VROM (richtlijn conforme

interpretatie)

ABRS 15 december 1994

NJB 1995/9, B115

par. 13.3.

TV 10 SA vs. CvdM

ABRS I maart 1995

NJB 1995/14, B180

par. 14.11.1.

Afdeling Rechtspraak

Raad van State

Stichting Ontwikkelings- en

Saneringsfonds voor de

Landbouw

ARRS 19 september 1977

tB/S I, 3

par. 6.4.5e en 7 .

Stichting Centraal Orgaan

Ziekenhuis Tarieven

ARRS 3 april 1979
AB 1979,368

par. 6.4.5e.

De Nederlandsche Bank

ARRS 15 januari 1981

AB 1982,39

par. 6.4.5e.

Stichting Nederlandse

organisatie voor Weten-

schappelijk Onderzoek

ARRS 29 september 1983

$\mathrm{AB} 1984,349$

par. 6.4.5.e en 7.

Ontbreken publiekrechtelijke

titel staat niet in de weg aan

beroep tegen uitoefening

publieke taak

ARRS 24 mei 1984

AB 1985, 197

par. 7.

Tros vs. CrdM: Citroën

ARRS 21 mei 1991

Mediaforum 1991/7, 63a

par. 13.1.2.

Lokale sluikreclame

ARRS 21 mei 1991

Mediaforum 1991/7, 61

par. 13.1.2.

Tros vs. CvdM: walkman

ARRS 8 augustus 1991

Mediaforum $1992 / 1,8$

par. 13.1.2.

Tros vs. CwdM: way of life

ARRS \& augustus 1991

Mediaforum 1992/1, 10

par. 13.1.2.

VOO ws. CudM: Q8

ARRS 8 augustus 1991

Mediaforum 1992/1, 3

par. 13.1.2 en 14.2.

Natuurlijk genezen II

ARRS 7 januari 1993

Mediaforum 1993/5, 66

par. 13.1.2.

Osho ws. CvdM

ARRS 8 maart 1993

Mediaforum 1993/6, 71

par. 14.5.1.

NCRV vs. CrdM

ARRS 21 maart 1993
Nil 1994,23

par. 13.1.2.

AVRO vs. CvdM: een

andere wijze

ARRS 22 maart 1993

NJB 1993/20

par. 13.1.2.

VOO vs. CvdM: Vêronique III

ARRS 29 juni 1993

Mediaforum 1993/9, 77

par. 13.1.2 en 14.11.

Directeur Veterinaire Dienst ministerie LNV als bestuursorgaan

ARRS 26 augustus 1993

AB-kort 1994, 49

par. 6.4.5.

Stichting Lokale Omroep

Landsmeer, stichting

Omroeporganisatie Gronin-

gen, stichting Omroep

Monnickendam en organisa-

tie van Lokale omroepen

Nederland vs, CvdM

ARRS 8 november 1993

AB 1995, 98

par. 13.1.2.

Bevoegheid tot opleggen

bestuurlijke boete mist.

wettelijke grondslag

ARRS 4 november 1993

AB 1994, 182

par. 12.2 .

Oriënt Express

ARRS 16 december 1993

Mediaforum 1994/5, 45

par. 13.1.2.

Voorzitter Afdeling

Rechtspraak Raad van Slate

Publiekrechtelijke grondslag overheidstaak

V2 ARRS 21 augustus 1986

AB 1988, 193

par. 7.

Centrale Landintichtings-

commissie 
ARRS 21 juni 1990

Grst. 1991,6920

par. 6.4.5e.

Centraal Fonds voor de

Huisvesting

Vz ARRS 2 oktober 1990

AB 1991, 531

par. 6.4.5e en 7.

Stichting Fonds voor Beel-

dende kunsten, vormgeving

en bouwkunst

$V_{z}$ ARRS 16 jantari 1991

AB 1991,662

par. 6.4.5e en 7 .

Raad w/d Casinospelen

Vz ARRS 9 april 1992

AB 1992, 534

par. 6.4.5e.

Publieke tak geeft

beschikkingsbevoegdheid

VZ ARRS 23 april 1992

AB 1993, 101

par. 7.

A.PK-erkenning

Vz ARRS 27 augustus 1992

AB 1993, 150

par. 13.1.2.

IKON/VARA ws. CvdM

Vz ARRS 2 oktober 1992

AB 1994, 73

par. 14.5.1.

NCRV vs. CvdM

VZ ARRS 25 februari 1993

KG 1993, 166

par. 14.2 .

Standplaatsvergunning via

Pinkpopbureau

Vz ARRS 18 mei 1993

AB 1994, 333

par. 6.2.2.

Schorsüng uitwoeringsbesluit convenant inzake wegbeheer van wege mogelijke strijdigheid van convenant met wet Vz ARRS 1 februari 1994

AB 1994, 282

par. 10.2 .
Afdeling Geschillen van

Besituur Raad van State

Bij wet reeds bestatande toezichtsregeling is als voorschrift bij vergunning ongeoorloofd

AGRS 29 maart 1991

AB-kort 1991, 449

par. 11.2.

Inlichtingenplicht omvat

plicht mede te werken aan

huisbezoek

AGRS 5 februari 1992

Gst. $1993,6974,11$

par. 11.1.4.

Hydro Agri

AGRS 1 september 1992

AB 1993, 400

par. 10.2.

Centrale Raad van Beroep

Stratkorting uitkering door

besturen van bedrijfs-

verenigingen

CRvB 30 mei 1990

AB 1991, 1

par. 13.1.2.

Sancticbelevid bestuar

Nieuwe algemene bedrijfs-

vereniging

CRvB 9 november 1993

AB 1994, 221

par. 13.1.5.

WW-sanctie en art. 6 EVRM

CRVB 21 december 1993

W'W 1992, 252

par. 12.5.

Bestuur van de bedrijfs-

vereniging voor tabak-

verwerkende en argrarische

bedrijven vs. $X$

CRvB 23 maart 1994

AB 1994, 394

par. 13.1.5.

Malusbeslissingen

CRvB 15 februari 1995

JB 1995/3, 64 par. 12.5 .

College wan Beroep woor het Bedrijfsteven

Commissie toelating

bestrijdingsmiddelen

CBB 24 jamuari 1992

$\mathrm{AB} 1992,253$

par. 13.1.2.

Chemische fabriek Brabant

J.W. Voorbraak bv te

Oosterhout vs. staats-

secretaris LNV

CBB 13 november 1992

SEW 1994/6, 450

par. 14.11.1.

Proctor and Gamble Benelux

vs. Produktschap voor

groenten en fruit

CBB 18 juni 1993

SEW 1994/4, 265

par. 17.1 .

Vheeswarenfabriek Th.S. van der Laan bv vs. Produkitschap voor Vee en Vlees CBB 13 augustus 1993

AB 1995, 49

par. 17.2.7.

Pethromi Trading Compans bo vs. minister van financiën CBB 17 november 1993

AB 1994, 365

par. 19.1.

De vrije ether

CBB 5 januari 1994

SEW 1995/1, 65

par. 14.11.1.

Mediavlucht bw vs. SER

CBB 6 julli 1994

NJB 1994/40(B22), 532

par. 18.

P. vs. STE

CBB 7 juli 1994

AB 1995, 79

par. 19.9.

Roermond Papier bv vs.

Hoofdproduktschap Akker-

bouwprodukten 
CBB 14 december 1994 NJB 1995/13(B.10), 172 par. 11.1.8. en 20.4.3. Sky radio Itd vs, minister van V\&W e.a.

CBB 22 maart 1995

NJB 1995/21(B15), 273

par. 11.1.4.

Voorzitter College van Beroep vaor het Bedrijfs leven

Convenant laat bevoegdheid tot vergunningintrekking onverlet

VZ CBB 24 juli 1992

Gemeentestern, 6961

par. 12.2.

Nationale ombudsman

Actieve informatieplicht belastingdienst

No 24 mei 1994

AB 1994, 438

par. 11.1 .1 .

Buitenwettelijke inlichtingenbevoegdheid SVB

No 2 september 1994

AB 1994, 595

par. 11.1.1.

A. vs. minister van V\&W

(inzake verhouding van

convenant tot door de wetgever wastgestelde ruimtelijke ordening procedure)

No 22 december 1994

AB 1995, 154

par. 10.2 .

\section{Commissariaat voor de}

Media

VOO-modespecial

CvdM 18 mei 1989 ,

gewijz. 12 juni 1990 en 30

juli 1990

K\&R 1993, 133

par. 13.1.2.

Tros-nieuwsshow

CvdM 19 september 1990

K\&R 1993, 362

par. 13.1.2.

Zwaluwse Omroep Stichting

CvdM 24 mei 1991

K\&R 1993, 435

par. 13.1.2.

NCRV vs. CVdM:

lunchpakket.

CrdM 24 oktober 1991

K\&R 1993. 447

par. 13.1.2.

VOO-Veronica: sportradio

CvdM 14 juli 1992

K\&R 1993, 514

par. 13.1.2.

\section{Registratiekamer}

Nationale auto pas

Rk 23 februari 1994

CR 1994/6, 257

par. 16.3.

Interdepartementale

gegevensverstrekking

Rk 16 november 1994

CR 1994/5, 216

par. 16.6.1. 



\section{Trefwoordenregister ${ }^{1}$}

\author{
Aangifteplicht 12.1, 20.5.3 \\ Aansluitplicht 17.3.1, 17.4, \\ 17.7.2, 20.4.3 \\ Aanwijzingen yoor de regel- \\ geving 3.3.3,4.3,4.5, \\ $4.5 .1,9.2,10.5,11.1 .1$. \\ $11.1 .3,12.2,13,13.1 .5$. \\ $13.5,19,19.6,19.12$, \\ $19.12 .2 .1,19.12 .2 .2$ \\ $19.12 .2 .2 \mathrm{c}, 20.4 .4 .1 \mathrm{a}$, \\ 20.5 .6 \\ - aanwijzing 6, 7, 810.5 \\ - aanwijzing 1110.5 \\ - aanwijzing 13, 14 10.5 \\ - aanwijzing 164.5 .1 \\ - aanwijzing 174.3 \\ - aanwijxing $20 / 3.3$ \\ - aanwijzing $244,2,4.3$ \\ - aanwijzing 4610.5 \\ -aanwijzing 125, 126 \\ 19.12.2.2 \\ $\sim$ aanwijzing 127,128 \\ $20.4 .4 .1 a$ \\ - aanwijzing 13012.2 \\ - aanwijzing 133 11.1.1. \\ I1.1.5 \\ - aanwijzing $13411 . I .1$ \\ - aamwijzing $1351 / . l_{\text {n }}$ \\ II.I.I \\ - aanwijzing 140, 141, 142, \\ 14312.2 \\ - aanwijzing 14412.0
}

- aanwijzing $146 / 2.2$

- aanwijzing $15519.12 .2 .2 \mathrm{c}$

-aanwijzing 1619.2

- aanwijzing 1644.5

-aanwijzing 165, 166, 167 ,

$168,169,17019.1$

-aanwijzing 17619.1

$\sim$ aanwijzing 18519.12

$\sim$ aanwijzing 186, 187, 188,

$189,190,191,19213.2 .5$

- aanwijzing 25410.5

- aanwijzing 32813.0

- aanwijzing 33719.6

- aanwijzing 33913.0

Aanwijzingsrecht mogelijk met stille curatele of publikatie 18.5

Adviescommissie bezwaar schriften 14.9, 20.5.4.1. 20.6.1

Afschrikwekkendheidsbeginsel 13.1.4

Afstoting overheidstaken $6.2 .2,20.1 .2$

Agentschap 6.3.3

Algemeen belang-exceptie $14.11 .1,18.9 .18 .9 .3$

Algemeen Burgerlijk

Pensioenfonds $6.2 .2,18.1$

Algemene beginselen van behoorlijk bestuur 2.I.3, 3.0, 3.3.4, 4.1.1, 11.1,
13.1.2, 13.1.5

Algemene bestuursdienst 8.1 Algemene Inspectie Dienst $11.1 .5,13.3,17.1 .3,17.2 .3$, $17.2 .9,17.5 .4,17.5 .5$ 17.7 .7

algemeen verbindend verkiaren privaatrechtelijke normen $6.5 \mathrm{c}, 17.2 .2$,

$17.2 .6,20.3 .2 .1$

Algemene Rekenkamer 4.5, $6.4 .5 d, 10.5,18.6 .1 .1$. $20.1 .3,20.2 .2 .1,20.4 .1$. $20.4 .4,20.4 .4 .2$

Alternatieve/aanvullende handhavingsinstrumenten $10.2,20.2 .2 .1$

Ambtenaarlijke aanspreekbaarheid ondergeschikten/nietondergeschikten 3.2 .2

voordelen/nadelen 3.2 .2 American Bureau of Shipping 17.1 .1

Anti-discrimatoire bepalingen 13.2, 14.11.1, 18.9 Assimilatiebeginsel 13.1.1 Attributie 4.4.1, 4.4.3, $20.4 .4 .2,20.6 .1$

Awb

- eerste tranche inzake (bestuurs)orgaanbegrip 4.5 .

1. De cijfers achter de trefwoorden verwijzen naar de paragraafnummering. 
$6.3 .4,6.4 .5,6.4 .5 d, 6.4 .5 f_{\text {. }}$ 7.0.13.1.5, 20.4.4.1a, 20.6 .2

- derde tranche inzake handhaving 10.7, 11.1$11.1 .8,13.1 .2,13.1 .5,13.3$, $13.4,17.2 .9$

- derde tranche inzake delegatie/mandaat 4.4 .3

$\sim$ regeling inzake convenanten 10.2

$\sim$ regeling inzake vergunningsbeperkingen en -voorschriften 20.2.2.1

Awb en Wob 4.5

Baratt Brokerage 19.4

Barings Bank-bankroet

$19.2 .1,19.11 .2$

Bedrijfsfonds voor de Informatieproduktie $1.2,13.2 .1$ Bedrijfsfonds voor de Pers 1.2, 13.2.1, 20.1

Bedrijfsintern zorgsysteem 20.3.2.1

Bedrijfsvereniging 4.5.1, $5.3,6.4 .5 e, 1.2,11.1 .3$, 11.1.7, 12.2, 12.5, 13.1.2, 13.1.5. 16.4

Bedrijfsveremiging voor de Haven- en aanverwante bedrijven, binnenscheepvaart en visserij 13.1.5

Bedrijfsvereniging voor Tabakverwerkende en Agrarische bedrijven 13.1.5 Bekendmaking(svoorschriften) $13.1 .5,20.4 .3$

Beleid

- scheiding beleidsbepalingbeleidsuitwoering $3.3 .3,8.1$, 9.0, 9.1, 20, 20.3.1

samenhang beleidsbepaling-beleidsuitwoering 9.2 - beleidsresistentie zbo's 3.3.3

- beleidsruimte $z$ bo's 9.0 . $19.3,20.1 .1,20.5 .4,20.6 .1$ - beleidsuitwoering en rechtsvorming 3.3.4

- controle-instrumenten bij scheiding tussen beleidsbepaling-beleidsuitwoering 3.3 .3

- emancipatie beleids. uitvoering 9.2

- iworen-toren-effect beleidsbepalers 4.5

Beleidsregels 4.4.1, 4.4.3, $12.2,20.4 .4 .1 \mathrm{a}$

Beleids- en beoordelingsvrijheid 4.4.1, 7.1

Begrotingsrecht 3.2.1, 3.3.3

Beschikkingintrekking en -schorsing 12.2

- bij voorkeur wettelijke grondslag 12.2

- intrekkingsbevoegdheid niet weg door convenant 12.2

Bestuur op afstand $1.3 .5,8.1$ Bestuurlijke boete 10.7 , $11.1 .8,12.2,13.1 .2$ 14.3.1.1, 16.4, 18.6.1.1, 19.6, 20.4.4.Id, 20.5.3, 20.6 .2

Bestuurlijke handhaving 12.2 Bestuurlijke waarborgsom 10.7

Bestuursstrafrecht $12 . I$

Besturen op hoofdlijnen - controlewoorzieningen/" interfaces" 3.3.3 $\sim$ nadelen/woordelen 3.3.3, 3.3 .4

Bestuurs(rechtelijke) bevoegdheid 7.1

Bestuur'srechtelijke rechtsbetrekking $11,1.8$

Bevoegdheid II.I.I

Bewijsgaring/-last 11.1 .4 , 19.6.1

Boetebeleid 13.1.2, 14.2

Boete-inspecteur 12.2, 20.4.4.1d 20.6.I

Buitenland toets $10.5,20.6 .6$

Bureau Veritas 17.1 .1

Bijzonder strafrecht 12.1
Cassis de Dijon-formule 14.11.1, 16.6, 17.1, 18.9, $20.1 .4 .1,20.6 .6$

Cautie storten 17.2.8, 20.4.3 Centraal Besturur voor de Arbeidswoorziening 3.3.4, $4.5,4.5 .1,5.1 .1,5.3,6.4 .5$, 8.1, 9.3,10.2, 12.1

Centraal Bureau voor de Grafische bedrijven 6.4 .5 Centraal Bureau voor de Statistiek 6.4.5, 9.3

Centraal Fonds voor de Volkshuisvesting 3.3.4, $6.4 .5 e, 7,10.2$ Centraal Orgaan Opvang

Asielzoekers 9.1

Centraal Orgaan Tarieven

Gezondheidszorg 6.4.5, $6.4 .5 e, 9.2,9.3,10.2$, $11.1 .5,12.1,12.3$

Centrale Financiën/instellingen O\&W 6.3.3

Centrale Landinrichtingscommissie 6.4.5e, 9.3 Centrale Raad voor Beroep $12.5,13.1 .2$

Centrale Raad voor de Volksgezondheid 6.4.4 Certificatie-instellingen I7.1.1. 20.3.2.1

Certificering 3.0, 10.5 17.1.1. 17.2.7, 17.3.2.1, $17.3 .3,17.4,17.4 .3 .2$ $17.6 .2,20.3 .2 .1,20.5 .5$ - Europese bewijsstukken I7.3.2.1

$\sim$ ongeldigverklaring 17.2 .7 - verlening 17.2 .7 .1 Civielrechtelijke ministeriële verantwoordelijkheid 3.0 Checks and balances 2.2.3. $5.3,14.9,16.1,20.1$, 20.3.2.1, 20.5.4, 20.5.4.1, 20.6.1

Classificatie 15.2

College van Beroep voor het Bedrijfsleven 12.2, 13.1, 
Trefwoordenregister

$13.1 .2,17.1,17.2 .6,18.7$, $19.9 .20 .4 .41 a$

College van toezicht op de Kansspelen 11.1.7

College voor Toelating van

Bestrijdingsmiddelen 13.1.2

Commissariaat voor de

Elektronische Informatie-

voorziening 6.2.2, 20.1.4.1

Commissariaat voor de

Frequenties 6.2.2, 20.1.4.1, 20.3.2, 20.5.3

Commissariaat voor Kartel-

afspraken 6.2 .2

Commissariaat voor de

Media 3.3.4, 4.5, 5.1.1, $5.3,6.2 .2,6.4 .5,9.2,9.3$, 10.7, 11.1.1, 11.1.5, 11.1.7, $12.2,13.1 .2,13.1 .5,14.0$ e.v., 15.2, 20.1.4.1, 20.4.3, $20.4 .4 .1 a, 20.5 .1,20.5 .2$, $20.5 .3,20.5 .4,20.5 .4 .1$. 20.5 .5

Commissie-Brokx 20.1.4.1

Commissie-De Jong 14.3.1.I Commissie-De Koning 3.2.I Commissie-Deetman 3.3, 3.3.1, 8.1, 10.2

Commissie-Dolman 3.3

Commissie-Donner 3.3.4.1

Connmissie-Franssen 5.0,

$5.1,5.2,5.3,8.1$

Commissie-Korthals

Altes 10.7

Commissie-Oele 4.5

Commissie-Scheltema 3.1, $3.2,3.2 .2,3.3 .1,3.3 .4$,

$6.4 .5 a$

Commissie-Sint 6.3 .3

Commissie-Van Traa 3.2.4

Commissie-Vonhoff 6.1

Commissie-Wiegel 3.3.3,

8.1,8.2.1

Commissie-Wierenga 3.2.4

Commissie Binnenvaart-

rampenwet 12.4

Commissies van beroep in

het bijzonder onderwijs 12.4

Commissie van toezicht 15.2
Commissie vergunningen wegvervoer 12.1

Commissie vergunningverlening beroepsvervoer 12.1

Commissies voor samenstel-

ling gewasrassenlijsten $I .2$

Commissie voor toelating

van bestrijdingsmiddelen

12.1

Commissies voor gebieds-

aanwijzing 1.2

Communicatievrijheid

- filmvertoningen 15.0

- omroep 14.0

Communautair toezicht 13.3

Competetive tendering

20.1.4.1

Comptabele ministerièle

verantwoordelijkheid 3.0

Comptabiliteitswet 6.3.3,

$6.4 .5 d$

Concessiesysteem (omroep)

$14.5 .2,20.5 .5,20.6 .7$

Concurrentie vereist

anticiperend toezicht 18.5

Concurrentiebelangen 14.8 ,

14.11.1

Concurrentiecreatie 5.3 ,

$6.2 .2,20.6 .6$

Concurrentietoets 10.5 ,

20.6 .6

Concurrentieversterking

publieke omroep 14.3

Concurrentievervalsing door

tolerant toezicht 17.3 .5 ,

$20.2,20.6 .5$

Concurrentievervalsing door

overheidssteun aan (monopo-

lö̈de) zbo"s 20.1.3, 20.6.6

Conglomorat 18.4

Constitutie 2.2.1

Constitutionele toetsing 2.2 .2

Consumentenbescherming

$6.2 .2,14.11 .3,18.9 .18 .9 .3$,

20.6 .4

Contractmanagement 6.3 .2

Controlebureau Pluimvee,

Eieren en Eiprodukten 12.I,

I2.4
Controlebureaus beurzen

$19.2,19.2 .1,19.6,20.3 .2 .1$

Convenanten $6.2 .2,10.2$,

$10.5,11.1 .6,13,15.2$,

20.3 .2 .1

- convenant als maatregel

voor overgang wan over-

heids- naar bedrijfscultuur

$6.2 .2,15.2$

- convenantgebruik door

(toezichthoudende) zbo's

$10.2,20.5 .6$

- convenant past in modern

machtsevenwicht 20.3.2.I

convenant speelautoma-

ten(controleurs) 10.2

- convenant laat wettelijk

verleende bevoegdheid tot

intrekking van begunstigende

beschikking onverlet 12.2

- convenantworming als

anticipatie op (voorlopig)

uitblijvende implementatie

van EG-regelgeving 20.3.2.1

Convention 14.8

Corporatisme

- publiekrechtelijk $6.5 a$

$\sim$ particulier $6.5 a$

$\sim$ maatschappelijk $6.5 a$

$\sim$ neo $6.5 a$

Criminal charge 12.5, 13.1.1

Criminalisering $19.3,19.6$,

19.11

Cumulatie sancties 10.7,

$12.4,11.1 .8$

De Nederlandsche Bank nw 3.3.4, 6.2.2, 6.4.5e, 10.2. $11.1 .7,12.1,12.2,18.5$. 18.6.1.1, 18.9.1, 18.9.2, $19.2,19.2 .1,19.6,19.9$. $19.11,20.3,20.4 .3,20.5 .6$

Decentralisatie

in enge/ruime zin 5.1

$\sim$ financieel 5.1

$\sim$ functioneel $5.3,6.4 .1$

e.v., 6.4.5, 6.5b-c, 6.5.2,

10.1

$\sim$ maatschappelijk $5.1,6.5 \mathrm{c}$ 
e.v.

$\sim$ politieke afwegingen

decentralisatie 5.0

$\sim$ politieke regie(groep) 5.2

- primaat grondwettelijke

hoofdstructuur organen

van algemeen bestuur 5.0

$\sim$ proces 5.1

$\sim$ recht op decentralisatie

5.1

〜 territorialal $5.2,10.1$

Deconcentratie 3.3.4, 6.3.3, 6.3.4

Delegalisering 3.3 .3

Delegatie $4.4 .2,4.4 .3$,

$20.4 .4 .2,20.6 . t$

Democratische controle

- compensatie gebrekkige

politieke controle $I . I$,

3.3.4.2

Democratische rechtsstaat

cyclisch proces 2.2 .3

- institutionele eisen 2.2

Democratielagen 3.0

Denaturatie- of ontaardings-

verplichtingen als aanvulling

op fysiek toezicht 20.4 .3

Deregulering.

$\sim$ ministeriële commissies

voor deregulering 10.5

- nationale deregulering vs.

Europese reregulering 6.2.2,

$18.9 .3,20.2,20.5 .7,20.6 .4$

- overheid op afstand en

deregulering $14.1,15.2$,

$17.4,18.9$

$\sim$ open normen privaatrecht

alternatief voor dure,

detaillistische wet- en regel-

geving 10.5, 20.2.2, 20.6.4

- paradox 10.5, 20.6.4

$\sim$ regeringscommissaris voor

deregulering 10.5

$\sim$ rekenkamer voor deregu-

lering 10.5

Det Norske Veritas 17.1 .1

Diademode 13.2

Dienst van het Kadaster en

de Openbare Registers 3.2.2,
20.1.3. 20.1.4.1, 20.2.2,

20.2.2.1

Dienst omroep bijdragen

II.1.5, 14.3.1.1

Dienst wegverkeer 3.2 .2 , 3.3.4, 4.3, 5.3, 6.2.2, 9.1,

10.7, 11.1.5, 11.1.7, 12.2,

$13.1 .2,20.1 .4 .1,20.2 .1$,

$20.2 .2 .1,20.4 .3$

Differentiatie territoriaal

bestuur 5.4

Directie justitiële

inrichtingen 6.3 .3

Driestappenbeleid 10.4

Duas 3.2, 3.3.3

Duo-politica 3.2

Duyverman Computer

Centrum 6.3.3

Economische Controle

Dienst 11.1.5, 13.3, 19.4, $19.6,19.6 .1,19.7$

E(E)G-verdrag

art. 3 aanhef onder sub

$\mathrm{g} / \mathrm{o} / \mathrm{p} 14.11 .1$

- art. 3 aanhef onder sub $\mathrm{s}$

6.2 .2

$\sim$ art. 3A 14.11 .1

$\sim \operatorname{art} 3 \mathrm{~B} 13.3,20.2$

$\sim$ art. 513 e.v., 13.3, 13.4

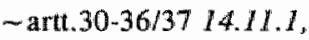

I6.6, 20.2.I

- artt. 38-47 17.1

- art. 4814.1 .1

$\sim$ artt. 59/60/66 14.11.1,

$16.6,20.2 .1$

- artt. 85/87 13.3, 14.11.1.

$20.1 .4 .1,20.2,20.2 .1$,

20.6 .6

$\sim$ art. 90 14.11.1, 20.1.4.1,

$20.2,20.6 .6$

$\sim$ art. $100 \mathrm{~A} 16.6$

artt. 101-102 20.1.4.1

$\sim$ art. $118 \mathrm{~A} 16.6$

$\sim \operatorname{art.} 12814.11 .1$

art. 12914.11 .1

- art. 129A 6.2.2, 16.6

- art. 130 S 16.6

-art. $138 \mathrm{C} 10.3$ $\sim$ art. 14513.3

$\sim$ artt. 155/169-171 13.3

- art. 209A 13.1.1

- art. 228 18.9.1

Eenheid aansturing uitvoeringsorganisatie 9.2

Eerlijk proces $12.5,14.9$

Effectiviteitsbeginsel 13.1 .3

Enquêterecht 3.2.1, 18.6.I, 20.6.1

Erkenning particuliere controle-instelling 17.2.1, 20.2.1, 20.3.2.1

Euro-toezichthouders 13.4

Europese Commissie 13.3, 17.2.4

- afstemming toezicht-

houdende bevoegdheden

voortvloeiend uit EG-verdrag

en WEM 13.3

Europese Gemeenschap 13.3

Europese integratie 13 e.v.

Evenredigheidsbeginsel

13.1.2, 16.6

EVRM

$\sim$ art. $611.1 .4,11.1 .4,12.5$

- art. $811.1 .4,16.6$

$\sim \operatorname{art.} 1013.1 .2,14,14.11$,

16.6

Exceptie vrij verkeer 20.2,

$20.5 .7,20.6 .6$

- omroep 14.11.1

- privacyrecht 16.6

$\sim$ verzekeringsbedrijf 18.9

Exclusieve rechten 14.11 .1 , 20.1.4.1

Federatie woor Bedrijfsverenigingen 13.1 .5

Fieccom 19.11

Financiële dienstverlening

-identiteitsvaststelling

19.11

$\sim$ melding 19.11

- surveillance 19.11

Financiële lastgeving 10.7

Fonds voor de Luchtverontreiniging 6.4 .4

Fonds voor de Podium- 
kunsten 6.4 .5

Franchisingcontract als verzelfstandigingsformule $20.2 .2,20.6 .7$

Functioneel bestuur checks and balances 5.3, $14.9,20.5 .4,20.6 .6$

- concurrentiecreatie 5.3 , $6.2 .2,20.2,20.6 .6$ - concurrentievervalsing $20.1 .4 .1,20.6 .6$

- monopoliepositie 5.3, $6.5 c, 20.1 .4 .1,20.2,20.6 .6$ $\sim$ territoriaal aspect 5.3 , $5.4,6.2 .2$

tussenweg tot gelijke markwoorwaarden 6.2.2, 20.6 .7

$\sim$ toezichthoudende en regelgevende zbo's als intermediair 6.2.2, 14.11.1 Functioneel gedeconcentreerde bestuurszorg $6.5 b$

Garantiefonds 18.6.1 Gedeconcentreerde ambten 3.3.4

Gedragscode 16.3.3

Gelheimhoudingsplicht $11.1 .8,13.3,16.5,16.6 .1$, $17.1 .3,17.2 .2 .2,17.5 .3$. $17.7 .6,18.4,18.6 .1 .1,18.7$, $18.9 .1,19.5,19.6 .1,19.7$, $19.9,20.4 .3,20.4 .4 .2$, $20.5 .3,20.5 .6,20.6 .1$ - frustatie toezicht 18.9 .1 . 20.5 .6

Gelijkheidsbeginsel 9.1

Gemeenschapstrouw 13.1 Gemengde bestuursvorm $6.5 b$

Gentlemen's agreement 15.5.I

Germanischer Lloyd 17.1.1 Goedkeuring, toestemming, vwgb 18.3.5-18.3.7 Grondrechter - beperkingen grond- en gemeenschapsrechten 13.2, $14.0,14.8,14.11,14.11 .1$, $15.5,16.6,17.1,18.9,18.9$, 19.11

- gemeenschapsrechtelijk

$13.2,14.0,15.0,16.0,17.1$, $18.0,19.0$

$\sim$ primair/secundair 2.2 .2

Grondwet 2.2.1

Grote efficiency operatie 8.1

Grote operaties 6.2

Handhaving

- aanwijzing handhavings-

instanties $13.0,13.3,14.0$

- beginselen 13.1

- belang 13.1.2

- beleid 13.1.5,20.6.3

- coöperatief 20.3 .2 .1

- erkenning privaatrechte-

lijke controle-instellingen

$17.2 .1,17.6 .1$

- geintegreerd handhavings-

beleid 13.0

- harmonisatie nationale

handhavingsbepalingen 13.0,

14.0

- ketenbenadering 20.3.l

$\sim$ plan 17.2 .1

- plicht 13.1, 20.6.3

- pro-actief/re-actief 13.0

- problemen 20.3, 20.3.1.

20.6 .2

- publikatieplicht hand-

havingsbeleid 13.1.5

- punitief 20.3.2.1

$\sim$ rechtsstatelijkheid hand-

hawingsvoorschriften 13.3

- responsief 20.3.2.I

$\sim$ systeembenadering 20.3 .1

taak 11.1.5, 11.1.6

- verzelfstandiging hand-

having 20.3 .2 e.v., 20.6 .2

- zorgplicht 13.1 .3

$\sim z$ waarte handhavings-

belang 13.1.2

Harmonisatie functionele/

Wgr-gebiedsindeling 5.3

Harmonisatie $\sim$ mimimum $16.6,19.11$, $20.2,20.6 .5$

- optioneel 14.11.1

- totaal 17.1

Harmonisatie EG-regel-

geving 13.0

$\sim$ effectenverkeer 19.1.

$19.11,19.11 .1$

- filmsector 15.5.I

- landbouwkwaliteitswetgeving 17.1. 17.2.1, 20.2

- omroep $14.0,14.11 .1$

- privacymecht 16.6

verzekeringsbedrijf 18.9

HCS-affaire 19.2.1, 19.6,

19.6.I

Home country control 18.9

Horizontale wetgeving 13.0 , 17.1

Immigratie- en naturalisatiedienst 6.3.3

Imperatieve sanctie 10.7

Implementatie $13.0,13.3$,

17.1, 20.3.2.1, 20.5.4,

20.6.1

Informatie Beheer Groep

$3.2 .2,3.3 .3,3.3 .4,9.1$,

20.1 .3

Informatieplicht publiek- en privaatrechtelijke rechtshandhavers $3.3 .3,13.1 .5$ Informatie-uitw isseling $18.9 .1,20.5 .6$

Informatievoorzieningsbeleid 9.2

Informationeel privacyrecht als vermogensrecht 16.7

Inkijkoperaties 3.2.4

Inlichtingenplicht 3.2 .1

Inningstaak $14.3 .1 .1,14.9$. $17.2 .3,17.6 .2,20.5 .3$

Inspectie voor de Rechtshandhaving 10.0,10.6

Inspectieversiag 11.1.7, 17.2.7.1, 17.2.9, 17.5.5. 17.6 .3

Instructie inspecteurs 17.5 , 17.5 .4 
Integrale Keten Zorgsysteem 17.1.1, 17.6.1. 20.3 .2 .1

Integratie

$\sim$ negatieve 18.9 .3

- positieve 18.9 .3

Intercollegiale toetsing 3.0 Intermediaire bestuurslaag $20.5 .4,20.6 .3$

International Organisation for Standardisation 17.1.1. 20.3.2.1

Interpellatierecht 3.2.1 Interregionaal Recherche Team N-Holland/Utrecht 3.2.4

Jaarrekening 3.3.3, 14.6, $18.4,18.8$

Jachtfonds $6.4 .5,11.1 .5$, 12.4

Kaderwet 5.3

Kansspelverkeer 14.11.I Kamers wan Koophandel en fabrieken 4.5, 5.3, 12.3, 14.11.1

Kenbaarheidsbeginsel 11.1.4, 13.1.5, 16.6, 17.7.3.2

Kerndepartementen 8.1, 9.2 Kettingbeding 14.2

Keurmerk 17.2.6, 17.3.1

Kliklijn

〜 nationaal 10.3

- Europees 10.3

Koersorkestratie 19.6.1

Koninklijk Nedertands

Metereologisch Instituut

$6.3 .3,6.4 .5$

Koninklijke Bibliotheek

6.4 .5

Koninklijke PTT Nederland nv 6.2.2, 14.3.1.1

Kosten toezichthouden 10.5 , 20.2.1

effectenwerkeer 19.7 ,

19.10

$\sim$ filmsector 15.3 $\sim$ landbouwkwaliteitssector 17.2.3, 17.3.3, 17.4. 17.4.5, $17.5 .4,17.6 .2,17.7 .4$

omroep 14.10

- persoonsgegewenswerkeer

16.3.1.16.5

- verzekeringsbedrijf 18.6 ,

18.8

Kosten-batenanalyse 6.3.3,

20.2.2.1

Kwaliteits-Kontrole-Bureau groenten en fruit $12.1,12.4$, $17.3,20.3,20.3 .2 .1,20.5 .3$ Kwalite itsbewaking 17.1.1, 20.3.2.1

Landbou wkwaliteitscontroleinstellingen $20.3,20.3 .2 .1$, $20.4 .1,20.4 .3,20.4 .4 .1 d$, $20.5 .1,20.5 .2$

Landbouwprodukthandelsurij heid 17.1

Landelijke operationele politie-eenheid 3.3.4.I

Legaliteitsbeginsel $2.2 .4,4.3$

- praktische toepassing 4.1

enge interpretatie 4.1.1

- ruime opvatting 4.1.2

Liberalisering 6.2.2,

14.11.1.18.6.1.1, 20.2

Lloyd"s register of Shipping I7.1.1

Maatregelen en aanwijzingen bij niet-naleving (landbouwkwaliteits)controlevoorschriften 17.2.5, 17.2.7.1, $17.4 .2,17.4 .3,17.4 .3 .1$. $17.4 .3 .2,17.5 .4,17.5 .4$, $17.6 .2,17.6 .3,20.4 .3$ Maatregelen, verboden en beperkingen bij niet naleving (verzekeraars)controlevoorschriften 18.3.2-18.3.4

Maatschappelijk middenveld 6.5 .2

Machtsverdeling

- bestaansrecht 2.2.3

- centraal/decentraal 2.2 .3 $\sim$ horizontaal/verticaal 2.2 .3 Management developmentbeleid 8.1

Marktwerking 6.2.2, 14.0, 14.3

- evenwicht mededinging en regulering vrije markt 6.2 .2

- vrije markt en aspecten van regulering,

deregulering, reregulering en zelfregulering $6.2 .2,10.5$, 14.11.1, 14.11.3, 18.6.1.1, $18.9 .3,19.11 .2,20.5 .7$ - toename toezichthoudende entiteiten 20.2

Mededinging

- nationaal en Europees mededing ingsrecht 20.2 , 20.6 .6 - nieuw algemeen mededingingsrecht (met ruimte voor open markstructuur en innovatief concurrerend marktgedrag) als alternatief voor zowel private alls publieke dienstverleners 20.2 - mededingingstoets ook voor bedrijfsmatige verzelfstandigde entiteiten met publiekrechtelijke taakstelling 20.1.4.1, 20.6.6 sectoroverkoepelend orgaan belast met toezicht op kartel- en mededingingsrecht $20.1 .4 .1,20.6 .3,20.6 .6$ - toezichtsbevoegdheden ambtelijke dienst voor de mededinging 13.3 Medeplichtig bestuur 10.1 Medewerkings- (wet- en regelnalevings - , en aansprakelijkheids)plicht $11 . L$, $11.1 .2,11.1 .4,17.2 .2 .1$, $17.5 .2,17.6 .2,17.7 .6,19.5$ Medewetgeven 3.3.3 Mediabestel 14.11 .2 Meta-sturing 3.3.4.1, 9.2 Minimumeisen controle 17.2.2 
Minimumharmonisatie 16.6 ,

19.11

Ministeriële aanwijzingen

- algemeen/concreet 3.3.4

- karakter 3.3 .4

Ministeriële beïnvloedingsmechanismen $3.2 .4,3.3 .4$, $14.10,18.1,19.3,20.4 .4 .2$

Ministeriële commissies voor wetgevingsbeleid 10.0

Misbruik van voorwetenschap 19.2.1, 19.6, 19.6.I

afkoopregeling 19.6

$\sim$ koersorkestratie 19.6 .1

$\sim$ meld ingsplicht 19.6.1

Modelbepalingen

- nationaal 10.5, 11.1.1,

11.1 .3 .12 .2

- Europees 13.1.5

Monitor-en normcontroles

$17.3 .2 .1,17.4,17.6 .1$

Monopoliepositie 5.3, 6.2.2, $6.4 .5 d, 6.5 \mathrm{c}, 14.11$.

$14.11 .1,20.1 .4 .1,20.6 .6$

Ne bis in idem 12.5. 13.1.1

Nederlands Institunt woor

Registeraccountants 12.4

Nederlands Controlebureau

Levensmiddelen 17.8

Nederlands Literair

Produktie- en vertalingen-

fonds 6.4 .5

Nederlands Normalisatie

Instituut 17.1.2

Nederlandsche Marineraad

12.4

Nederlandse Algemene Keu-

ringsdienst voor Groente- en

bloemenzaden 12.1

Nederlandse Federatie voor

Cinematografie 15.2 .1

Nederlandse Filmkeuring

$11.1 .5,15,20.2 .2 .1,20.5 .1$,

$20.5 .2,20.5 .3,20.5 .5$

Nederlandse Omroep

Stichting 14.3.1.2

Nederlandse Organisatie

voor Toegepast Natuur- wetenschappelijk Onderzoek

4.5

Nederlandse Organisatie voor Zuiver Wetenschappe-

lijk Onderzoek 6.4.5e

Nederlandse Video Detaillis-

ten Organisatie 15.2

Nemo tenetur-beginsel

11.1.4, 20.3.2.1, 20.4.3, 20.6 .2

Nippon Kaji Kyokai 6.4.5,

17.1.1

Noodregeling 18.6

Norm Ontwikkelings Com-

missie 17.2 .6

Notified body 17.1.1, 18.9

Nusse Brink-affaire 19.2 .1

Nutricia-affaire 17.8.I

Nw tot Keuring van Elektro-

nische Materialen 17.I.I

Ombudsman 3.3.4.2

Omroepbestel 14.5.2,

14.11.2

Open normen privaatrecht

$10.5,16.4,20.2 .2$

Openbaar lichaam 5.1.1

Openbaar gezag 4.3, 6.4.5,

$6.4 .5 a, 6.4 .5 b_{n}, 7,14.3 .1 .2$,

$20.4 .4 .1 a, 20.6 .2$

Openbaar ministerie

- bestuurlijke pretentie

3.3.4.1

- functioneren 3.3.4.1

- ministeriële verantwoorde-

lijkheid 3.3.4.1

- overleg (over opsporing,

vervolging, berechting) met

overheidsorganen belast met

publieke taak 12.1

- rad van bestuur 3.3.4.1

- verantwoordelijkheid

opsporingsambtenaren/toe-

zichthouders 10.4

Openbaar register 16.3 ,

$17.2 .4,18.8,19.4,19.6$

Opsporingsdiensten

- algemene opsporingsamb-

tenaren 11.1 .5
- buitengewone opsporingsambtenaren 11.1 .5

- bijzondere opsporingsamb-

tenaren 11.1.5

- sturing/samenwerking

politie en OM op arron-

dissementelijk/ressortelijk

niveau $10.4,12.1$

- uitbreiding bijzondere

opsporingsdiensten 10.4 ,

11. 1.5

Optionele harmonisatie

14.11.1

Organisatie voor de Binnen-

visserij 6.4 .5

OV-studentenkaart b $\vee 4.3$,

6.4 .5

Overheidsaanbesteding

$14.11 .1,20.1 .4 .1,20.6 .6$

Overheid op afstand 6.2.2,

14.1, 14.3, 14.3.1.2,

$14.5 .2,14.5 .2,18.1$

Overheidsbedrijven 6.3 .1

Overheidsbevoegdheid 7.1

Overheidsinvloed $6.4 .5 \mathrm{c}$

$\sim$ verkapt/tijdelijk 6.2.2

- tijdelijk bij privaatrechte-

lijk zbo met monopolistische

trekken $6.4 .5 b$

Overheidssturing 2.0

Overheidstaak 20.1.2,

20.3.2.I

$\sim$ exclusieve overheidstaken

20.4 .4

- kerntakenanallyses 8.1

- kerntakendiscussie 8.1 ,

8.2.1, 20.1.2

- primaire/secundaire staats-

taken 8.2.1, 20.3.2.1

- principielle herbezinning

overheidstaken 8.2

- werkzaamheden zelfstan-

dige bestuursorganen 9.3 ,

$14.3 .1 .2,14.4,14.5 .2,15.1$,

$15.6,16.1,17.1 .2,17.2 .2$,

$17.2 .2 .2,17.3 .1,17.3 .3$,

$17.3 .6,17.4,17.5 .1,17.6 .1$,

$17.7 .1,17.8 .1,18.2,19.1$.

19.10 
- taakafstoting onder handhaving vergumuing-en toezichtstelsels 6.2 .2

- tekenend woor al dan niet privaatrechtelijke normtoepassing $6.4 .5 \mathrm{C}$ Owerheidszorg 13.3, 20.5, 20.6 .3

- allocatie 8.1, 9.2, 18.9

$\sim$ herverdeling 8.1

stabilisatie 8.1

Paragouvernementele

instituties 6.4 .2

Parlementaire controle

- functie 3.1

$\sim$ versterking 3.3.3

vooraf/achteraf 3.2, 3.3.3

Parlementair onderzoeksrecht 3.2.1, 18.6.1, 20.6.1

Participatie burgers aan

bestuur 3.3 .3

Particulier initiatief $6.5 b$,

6.5 .3

Particuliere toezichthouders

11.1 .5

〜 belangenverstrengeling

II.1.5

- metl volmacht van zbo's

II.1.7

$\sim$ parkeerwachters 11.1.5

Plantenziektekundige dienst

6.3 .3

Politieke ministeriële

verantwoordelijkheid

- beperkt door instelling

zbo's 3.3.2, 3.3.3

$\sim$ betekenis $3.0,3.1$

- bevoegdheid 3.2 .4

- causaliteit 3.2.4

$\sim$ collectief/individueel 3.2

- complementaire verant-

woordingsmechanismen 1 . if

3.0

- demissionair ministerschap

3.2.4

- effectiviteit 3.3

- fictie 3.3.I

$\sim$ formeel/materieel 3.2 .4
- objectief/subjectief 3.2 .4

- omvang 3.2 .1

- preventieve werking 3.3.1

reikwijdte $3.2 .4,9.2$

- soorten 3.2

- subwerantwoordelijkheid

3.3 .5

- volledig/beperkt 3.3.1,

3.3.5

Politieke rechtspraak 2.2.3

Privaatrechtelijke hand-

having 12.3, 16.4, 17.2.6,

$17.8,18.3 .2-18.3 .4,19.7$,

20.2 .2

Privacyformulier en -regle-

ment 16.3

Privatisering

- beleidskader 6.2

- bescherming rechten

werknemers 6.2 .2

- beschermingsconstructies

6.2 .2

- Dienst privatisering 6.2.2

〜 doeleinden 6.2.1

- proces 6.2 .2

'mallaise' 6.2.2

- oneigenlijk 6.2.2, 20.6.7

- regeringsstandpunt 6.2 .2

$\sim$ verzelfstandigingsvariant

\section{2 .2}

- wet privatisering als

reactie verwaarlozing

privatiseringsbeleid 6.2 .2 ,

20.6.7

Project-ministerschap-

nieuwe-stijl 8.1

Prospectus 19.8

Protocol 18.9.2, 20.3

Profileringseis omroep

14.5.2

Publieke taak 7.0

Publiekrechtelijke taak 7.0,

20.1.2

Publiekrechtelijke bevoegd-

heid

- kenmerken $7.1,11.1 .1$

- grondslag overheidstaak

7.0

soorten 9.4 .1
- toedeling 4.3

- toezichthoudende be-

voegdheid $6.4 .5 a, 7.0$

11.1.I

- uitoefening 6.4 .2

Raad voor Binnenlands

Bestuur 4.4.3, 5.3, 11.1.1-

11.1.3

Raad van State 4.4.3, 4.5.1.

10.5. 11.1.8

Raad van Toezicht van

videovoorlichtung 15.2

Raad voor de Casinospelen

6.4.5e, 10.2, 11.1.5, 11.1.7,

$12.1,12.2$

Raad voor de Certificatie

17.1.2, 20.3.2.1

Raad voor de Luchtvaart

12.4

Raad voor de Ongevallen

12.4

Raad woor de Scheepvaart

12.4

Raad voor de Zorgverzeke-

ring 5.3

Raad voor het Vergunnin-

genbeleid 12.1

Raden van rechtsbijstand in

strafzaken 1.2

Raden voor de Kinder-

bescherming 4.5

Rechtmatigheid van bestuur

4.4

Rechtsbescherming toezichtsuitoefening 10.4

- effectenverkeer 19.9

$\sim$ fillmsector 15.3

$\sim$ landbouwkwaliteits-

controle-instellingen 17.2 .8 ,

$17.4 .2 \times 17.4 .3 .1,17.5 .2$

〜omroep 14.9

$\sim$ privacysector 16.4

verzekeringsbedrijf

18.3.1, 18.7

Rechtsgeldigheid 2.2.4

Rechtspersoon

$\sim$ publiekrechtelijk/privaat-

rechtelijk $6.4,6.4 .5 b$, 
$6.4 .5 c, 20.4 .4$

Rechtshandhawing

communautair 13.0 e. $\mathrm{y}$.

- elementaire overheidstaak

8.2 .1

-(financiële) versterking

$10.0,10.4$

- handhaafbaarheid 10.5,

15.2.I

- rechtsbescherming 10.4

$\sim$ rechtsstatelijke rechtsplicht

10.1

- reservefunctie strafrecht

$10.1,10.3,10.4,10.5,10.7$

Rechtspersoonlijkheid

- privaatrechtelijk/publiekrechtelijk 6.4

Rechtsstaat:

- voorwaarden 2.0

- typen 2.1, 2.1.1, 2.1.2,

2.1.3

Referendum 3.2.1

Regionaal openbaar lichaam

5.2

Registratiekamer 3.3.4, $6.4 .5,10.5,11.1 .5,11.1 .7$, $16,20.2,20.3,20.3 .2 .1$. $20.4 .4 .1 a_{2} 20.4 .4 .1 b_{\text {, }}$ 20.5.1, 20.5.2, 20.5.3, 20.5 .4

Registro Italiano Navale 17.1.1

Reiss \& $\mathrm{Co} 18.5$

Reorganisatie justitie 10.3

Reorganisatie rijksdienst 6.1

Reservepolitie kansspel-

beleid/speelautomaten-

controleurs 11.1 .5

RSV-debat 3.3

rule of reason $14.11 .1,16.6$, $18.9,20.6 .6$

Rijksdienst van Kadaster en Openbare Registers 3.2.2.

5.3. 9.1

Rijksinstituut voor Oorlogs-

documentatie 6.4.3

Rijksoverheid

-in ruime/enge $\operatorname{zin} 1.1$
Rijkstoezicht 17.2.4. 17.4.2, $17.4 .6,17.5 .4,17.7 .6$

Rijksuniversiteiten 6.4 .4

Saneringsplan 18.3 .4

Samenwerking tussen (niet-)

Europese staten 13.0,

$14.11 .2,15.5 .1,16.6 .1$. $17.2 .9,18.9 .1,19.5$,

19.11 .1

Samenwerkingsovereen-

komst tussen publieke en

commerciële omroepen

14.5 .2

Samenwerkingsplan omroep

14.5 .2

Samenwerkingsplicht Euro-

pese staten 13.1

Sanctionering $12 \mathrm{e}, \mathrm{v}$.

- kiesregels 11.1.8

- overleg openbaar ministe-

rie-zbo's over samenloop

sancties 12.4

- voornemensbrief 14.9 ,

18.3 .2

Schaarbeweging 3.3.4

Schaarste 14.0

Schadefonds woor Gewelds-

misdrijven 6.4 .4

Schaduwrecht 10.2

Senter 6.3.3

Single licence 18.9

Sociale Verzekeringsraad,

Toezichtkamer 12.5

Sponsoring 14.2

Spoorwegongevallenraad

12.4

Staatsbelangen 3.2.I

Stamboekverenigingen voor paarden, als erkend 1.2

Standaardcontroleplan

17.2.1, 20.3.2.1

Sterlab-certificaat 17.4

Stichting Bedrijfsfonds voor

Informatieproduktie 14.11 .3

Stichting Bedrijfsfonds voor de Pers 1.2, 11.1.5, 12.2,

14.11.3, 20.1
Stichting Bloembollenkeu-

ringsdienst 12.4

Stichting Bureau Architek-

tenregister 6.4 .5

Stichting Bureau voor

Rechtshulp 6.4 .5

Stichting Centraal Bureau

Rijvaardigheidsbewijzen

6.4 .5

Stichting Centraall Orgaan

$K$ waliteitsaangelegenheden

in de Zuivel 12.1, 12.4,

$17.4,20.3,20.3 .2 .1$

Stichting Controlebureau

Pluimvee en Eieren 17.1.2

Stichting Fonds voor de

Beeldende Kunsten, vorm-

geving en bouwkunst $6.4 .5 e$,

7.0

Stichting Fonds voor bijzondere journalistieke produk-

thes 6.4 .5

Stichting Inschrijwing Eigen

Vervoer 12.1

Stichting Instituut voor

Mechanisatie, Arbeid en

Gebouwen 17.1.1

Stichting Internationale

Scharrelvlees Controle 12.4,

$17.6,20.3,20.3 .2 .1,20.5 .3$

Stichting Keboma 17.1.1

Stichting Keur Alternatief

voortgebrachte Landbouw-

produkten $11.1 .7,12.1$,

$17.2,20.2 .2 .1,20.3$,

$20.3 .2 .1,20.4 .3,20.5 .3$,

20.5 .4

Stichting Mondriaan 6.4.5

Stichting Nederlandse

Algemene Keuringsdienst

Groente- en bloemzaden

$17.7,20.3$

Stichting Nedertandse

Baconcontrole 17.1.2, 17.5,

$20.3,20.3 .2 .1$

Stichting Nederlands Eier-

controle Bureau 17.1.2

Stichting Nederlands

Instituut voor Lifttechniek. 


\subsection{1, 20.2.2.1}

Stichting Nederlands Liftinstituut voor lifttechniek

6.4 .5

Stichting Nederlandse organisatie voor Wetenschappelijk Onderzoek 7.0 Stichting Nederlandse Vleeswaren Kontrole 12.1, 12.4, $17.5,20.3,20.3 .2 .1$

Stichting Ontwikkelings- en saneringsfonds $6.4 .5,6.4 .5 \mathrm{e}$ Stichting Scharreleierencontrole 12.4

Stichting Toezicht Effectenverkeer $6.4 .5 d, 10.7$, $11.1 .1,11.1 .7,12.1,12.2$, 13.1.5, 18.6.1.1, 19, 20.2, $20.3,20.3 .2 .1,20.4 .3$, $20.4 .4 .1 a, 20.4 .4 .1 d$, $20.5 .1,20.5 .2,20.5 .3$, $20.5 .4,20.5 .5,20.5 .6$, 20.5 .7

Stichting Verzekeringskamer 4.5, 5.3, 6.2.2, $6.4 .5 d, 9.2,10.2,11.1 .7$, $12.1,12.2,18.0,19.6,19.9$, $20.1,20.2,20.2 .2 .1,20.3$, $20.4 .3,20.4 .4 .1 a, 20.5 .1$, 20.5 .2 , 20.5.3, 20.5.4, $20.5 .5,20.5 .6$

Stichting Waakzaamheid Persoonsregistratie 16.4 Stimulerende wetgeving/ stimulerend recht 10.5 Stimuleringsfonds voor de architectuur 6.4.5

Strafrechtelijke handhaving $12.1,15.2 .1,16.3 .1,16.4$ 。 $19.3,19.6,20.3 .2 .1$

Strafrechtelijke ministeriële verantwoordelijkheid $\mathbf{3 . 0}$

Technische Commissie

Erkenningen 17.2 .6

Telledetectie: 20.4 .3

Terugtred overheid 6.2.2, 17.1.I
Toetsingscommissie voor wetgeving 13.0

Toezicht op naleving van wet- en regelgeving 11.1 .3 , 11.1 e.v., 14.4. 15.1. 19.1.1, 20.4 e.v. - actief 16.1, 18.6.1.1, 19.6 $\sim$ anticiperend als reactie op concurrentie 18.5

- communautair: observerend/redresserend 13.3 - dynamisch-complex 18.2, 19.1 .1

- functies 20.5.3

$\sim$ geconsolideerd 18.9 .2

$\sim$ kruispuntfunctie toezichtsamenleving 18.2

- liberaal 18.6.1

$\sim$ normatief-prospectief versus materieel 18.3 ,

18.6.1.1, 18.9

normatief-prospectief en

dereguleringsdoel 18.9

$\sim$ rechtstreeks 19.1.1

$\sim$ redelijkheidscriterium

11.1

$\sim$ repressief $14.2,16.3,18.9$

- technische aard en over-

legkarakter 20.3.2

- toezicht en opsporing

$11.1 .4,13.3$

$\sim$ toezichtstelsels 20.5 .5

Toezicht op witwoering wan wettelijke voorschriften II.1.3

Toezichthoudend overheidsorgaan

- communautair 16.0, 20.2,

20.6.3

- kenmerken 20.5.2

$\sim$ nationaal 13.0, 13.3, 14.0, $15.0,16.0,17.2,17.3,17.4$, $17.5,17.6,17.7,17.8,18.1$, $19.1,20.1 .4 .1,20.2$ panel van belanghebbenden of met inbreng van bedrijfsleven naast toezichthoudend zbo 20.1.4.1, 20.5 .2 onafhankelijke toezichthouder naast toezichthoudend zbo 18.6. 20.5.3 $\sim$ supranationaal 18.1 - trans- en internationale samenwerking 13.0, $14.11 .2,15.5 .1,16.6 .1$, $18.9 .1,19.0,19.11 .1$

$\sim$ verwevenheid toezichthoudende zbo's 18.6.1.1, 18.9.2 Toezichthoudende bevoegdheid

- effectenverkeer 19.5, 19.7

$\sim$ Europese Commissie 13.3

$\sim$ film- en videosector $15 . l$ -

15.2

- flora- en fauna 11.1.1

- landbouwkwaliteits-

controleproduktie 17.1 .2 ,

17.1.3, 17.2.2.2, 17.3.2.1, $17.4 .1,17.4 .3 .1,17.4 .5 .1$, $17.5 .3,17.5 .4,17.6 .1$, 17.7.3-17.7.3.2, 17.8 omroep $14.2,14.2 .1$ $\sim$ persoonsregistraties 16.3 , 16.3.2

- publiekrechtelijke aard $6.4 .5 a, 7,11.1 .1,20.6 .2$ $\sim$ rechtsstatelijke eisen van bescherming burgers 11.1 .4 , 11.1.8

$\sim$ rechtvaardiging en noodzaak 11.1.4, 11.1.8 - standaardbevoegdheden Awb en Wem (grenzen) I1.1.I (II.1.2) en 13.3, $20.4 .3,20.6 .2,20.6 .7$

- werzekeringsbedrijf 18.4 $\sim$ wettelijke grondslag 4.3 $\sim$ zaaizaad-/plantgoedkwaliteitscontrole-instellingen 17.7.3

Toezichthoudende taak ～handhavingsbelang 1 11.1.6 $\sim$ monopoliepositie 5.3, $20.1 .4 .1,20.2$ - opdragen aan privaatrechtelijke rechtspersonen met winstoogmerk $6.4 .5 d$, 


\subsection{2}

- toezichthoudende of evaluerende taken, als beleidsuitvoering en -bepaling. opdragen aan zbo"s 9.2 - toezicht en het opleggen van (financiële) lasten $10.5,20.2 .2 .1$

Toezichthouders 10.2, II.1.5

- aangifteplicht $12 . I$

- aanwijzingsrecht 17.2.9,

20.4 .3

- legitimatieplicht $I I . l$,

II.1.5

- legitimatiebewijs 11.1.6, $17.2,17.5$

- nationaal/Europees 13.3,

13.4

- overleg over opsporing en afdoening van economische delicten met openbaar ministerie $12.1,17.2 .6$, $17.5 .2,17.7 .7,20.4 .3$ $\sim$ verantwoordelijkheid minister voor toezichthoudende zbo's 11.1 .7 $\sim$ verantwoordeilijkheid toezichthoudende zbo's naar minister/burgers (goede communicatie over uitvoerings-, handhavings- en controlepraktijk) 8.I, 9.2,

\subsubsection{1}

- verantwoordelijkheid openbaar ministerie 10.4 verhouding controleurs/inspecteurs-directeur toezichthoudend orgaan 17.5 .5 , $17.6 .3,17.7 .6,20.4 .3$. $20.6 .1,20.6 .2$

- verslagleggingsplicht 11.1.7, 20.4.3, 20.6.2 Toezichtkamer van de Sociale Verzekeringsraad $6.4 .5,9.3,11.1 .7,13.1 .5$ Totale harmonisatie 17.1 Transactie 20.4.4.Id Transborder data flow 16.4
Trias politica 2.2.3

Tucht van het budget 5.3

Tucht van de markt 4.5, 5.3

Tuchtrechtelijke handhaving $12.4,15.2 .1,17.2 .6,17.3 .6$, $17.4 .6,17.5 .2,17.5 .5$, $17.6 .3,17.7 .6,19.2 .1$

Tweewegenleer

- privaat-/publiekrechtelijk

10.2

$\sim$ organisatierechtelijk

$6.4 .5 b$

$\mathrm{U}$-bochtconstructie 14.11 .1

Uitbesteding overheids-

taken 6.2 .2

Uitsluiting toegekend voordeel $10.7,13.3$

Uitvoeringsplicht 13.1

Van Meer James Capel-

affaire 19.2 .1

Verantwoording

〜afleggen 3.1

- proces 3.2 .1

- staatsrechtelijke/politieke

sanctionering 3.2.3

Verbond voor Verzekeraars

$18.6 .1,18.9$

Verdrag van Maastricht

$\sim$ art. A 13.0

$\sim \operatorname{art.} \mathrm{G} 13.3$

- art. K2/6.6

Vereniging Belangen Polishouders Vie d"Or 18.6 .1

Vereniging Effectenbezitters 19.6.1

Vereniging Effectenhandel

19.2.1

Vergunningenstelsel 10.2 ,

$14.11,14.11 .3,18.9$,

$20.5,5,20.6 .7$

- vergunningensysteem en

convenanten 12.2

Vergunningverlening, -wijziging, en -intrekking 12.2

$\sim$ effectenbedrijf 19.4

- omroep 14.2
- verzekeringsbedrijf 18.2 ,

18.3.1, 18.6.1.1

Vergunningvoorschriften

$10.2,14.8$

Verificatie $13.3,16.6$

Verklaring van geen bezwaar 20.5.5

Vermaatschappelijking $6.5 \mathrm{C}$

Verslagplichten toezichthoudende zbo"s 20.5.4

- Commissariaat voor de

Media 14.10

- Nederlandse Filmkeuring.

15.4

- Registratiekamer 16.5

- Stichting Keur Alternatief voortgebrachte Landbouwprodukten $17.2 .4,17.2 .7 .1$

- Stichting Nederlandse

Vleeswaren Controle 17.5.5

- Stichting Toezicht Effectenwerkeer 19.10

- Stichting Verzekerings-

kamer 18.6, 18.8

Verslag-, administratie-, meld-, aansluit-, betaal-en medewerkingsplichten onder toezicht gestelden 11.1 .8 , $14.6,17.2 .3,17.3 .2 .1$. $17.4 .2,17.4 .3 .1,17.5 .2$, $17.5 .4,17.5 .4,17.6 .2$, $17.7 .3 .1,17.7 .3 .2,19.2$. $19.6 .1,19.7,20.4 .3$

Verstatelijking $6.5 c_{*} \quad 6.5 .2$

Vertrouwensregel

- bruikbaarheid 3.2

- inwerkingstelling 3.2 .3

- karakter 3.2 .3

〜 ongeschreven rech 2.2 .1

- opzeggen wertrotiwen in relatie tot ministerièle

verantwoordelijkheid 3.2 .3 ,

3.2.4

Verzelfstandiging overheids-

diensten $6.2 .2,20.6 .7$

-intern 6.3

- extern 6.4

- sequentie-/interdepentie-

type 6.2 .2 
Vie d'Or 18.6.1, 18.6.1, $20.1,20.2 .2 .1,20.5 .3$

Vierde macht 2.2 .3

Voorzienbaar 11.1.4,16.6

Vragenrecht 3.2.I

Vrij verkeer

$\sim$ accessoirizelfstandig

karakter 16.6

$\sim$ vrij dienstenverkeer

14.1.1, 16.6, 18.9

vrij goederenwerkeer

14. I.I, 16.6, 18.9

$\sim$ vrij vestigingsverkeer

$16.6,18.9$

- vrij kapitaalverkeer 16.6 , 18.9

Wederkerige rechtsbetrek-

king 11.1.8

Wederzijdse erkenning toezichtsstelsel en -regelgeving $13.1,14.11 .1,18.9$,

$19.11 .1,20.2,20.6 .5$

Wet Economische Delicten

II.1.1, 11.1.4, 11.1.5, 12.I. $18.5,19.3,19.6$

- overleg ovj-zbo over opsporing en afdoening van economische delicten 12.1 , $17.2 .6,17.5 .2,17.6 .7$

Wet economische mededinging 13.3

Wetenschappelijke Raad voor het Regeringsbeleid

1.2, 5.3, 10.1

Wetgeving

- complexe of verouderde

wetgeving 20.3

- proceswerbetering en

kwaliteitseisen $10,5,11.1 .4$

- delegatie van wet- en

regelgevende bevoegdheden aan zbo"s 3.3.4, 10.5,

$13.1 .5,14.1,17.2 .6,17.7 .1$,

18.3, 19.3, 20.6.1

Wetmatigheid van bestuur $4.0,4.4$

Wetsevaluatie $10.2,10.6$
Wettelijk gestructureerde en geconditioneerde zelfregulering $10.5,15.2$, 15.2.1, 16.2, 16.4.20.3.2.I, $20.5 .7,20.6 .2,20.6 .4$ Wirstprikkels $5.3,6.2 .2$, 14.11.1, 20.2, 20.6.6 Wob/Wno: aanwijzingsbesluit bestuursorganen 4.3 , 4.5

$\sim$ t.a.y. Commissariaat yoor de Media 14.9

- t.a.v. de landbouwkwaliteitscontrole-instellingen/ zaaizaad-en plantgoedinstellingen 17.1 .2

- t.a.v. de Nederlandse Filmkeuring 15.3

$\sim$ t.a.v. de Registratiekamer 16.4

-t.a.v. de Stichting Toezicht Effectenverkeer 19.9 $\sim$ t.a.y. de stichting Verzekeringskamer 18.7

\section{Zelfbeheer 6.3 .2}

Zelfregulering of -controle /keuring (en aanvullend overheidstoezicht) 3.3.4, $10.5,13.0,14.3,14.3 .1$, $14.8,15.2,16.2,16.3 .3$, $17.1 .1,17.2 .3,17.3 .3$, 17.3.3.1, 17.5.4.1, 17.6, $17.7 .5,17.8 .2,18.9 .3,19.2$, $20.3 .2 .1,20.5 .7 \times 20.6 .2$, 20.6 .4

Zelfstandige bestuursinstellingen $6.4 .3,6.4 .2$

Zelfstandige bestuurslichamen $6.4 .4,6.4 .2$

Zelfstandige bestuursorganen $6.4 .5,6.4 .2$

$\sim$ aanstellingstermijn 3.3 .3

$\sim$ aansturing 3.3.3

$\sim$ aanwijzingen rijksdienst

inzake zbo's 4.5 .1

$\sim$ aanwijzingsbesluit bestuursorganen Wob/Wno 4.5 $\sim$ aard bevoegdheden $6.4 .5 a$
- adviestaken 9.3, 11.1.7. 14.3.1.1, 16.3, 16.3.2, $17.6 .1,18.2,18.6 .1 .1$, 20.5 .3

- alternatieve checks and balances (i. ..m. ontbreken marktwerking) $14.9,(5.3)$ - argumenten pro/contra instelling zbo's 3.3.3, 3.3.4.2, 4.5, 8.2.1, 10.1, 10.5

$\sim$ bemiddelingsfunctie

16.3.2

- begripsomschrijving

$6.4 .5 f$

- beperking ministeriêle verantwoordelijkheid 3.3 .3 , 3.3.4

- bevoegdheidsuitoefening 9.4 .2

- centrale/decentrale overheid 6.4.5e

- complementaire verantwoordingspatronen $1.1,3.0$ - evaluatieonderzoek 4.5, I4.I

$\sim$ financiële berichtgeving

3.3.3

- financiele protectie

$20.1 .3,20.1 .4$

- formeel-wettelijke basis

4.2

- interfaces 3.3 .3

- informatieplicht 3.3.3,

20.6 .1

- interventiemechanismen

$3.3 .3,14.10$

- inventarisatie/evaluatie

$z b o ' s 1.2,4.5,18.6 .1 .1$

-kaderwet 4.5.1, 20.6.7

$\sim$ kwalitatieve aansprakelijkheid door resterende ministerièle zeggenschap 20.1

- kwaliteitshandvest 3.3 .3 ,

20.1

$\sim$ machtsevenwicht 9.1,

$14.9,20.6 .1$

- modelreglement rechts- 
positie/arbeidswoorwaarden

$6.4 .5 d$

- noodzaak omschrijving en

-regeling 4.5

- omvang 1.2

- openbaar register 4.3 ,

20.4 .2

publiek-/privaatrechtelijke rechtspersoonlijkheid 6.4 ,

$6.4 .5 b-d, 6.5 .1$

$\sim$ raad van toezicht 3.3.3.

20.1

- rechtspositionele status

$6.4 .5 d$

- regelgevers 13.1.5, 14.1,

$16.1,17.2 .6,17.7 .1,18.3$,

19.3

- taakbehartiging 9.3

- tariefstelling al dan niet

i.k.v. kostendekkendheid

20.1 .3

$\sim$ toetsingskader 4.5

- toezicht door Algemene

Rekenkamer 6.4.5d

$\sim$ toezichthouders 11.1 .7

- typologie 9.3

- uitvoeringscontract 3.3 .3

$\sim$ uitvoeringstoets 3.3 .3

- verwaarlozingsregeling

3.3 .3

- vormgeving 4.5

Zendtijdtoewijzing, -vermindering, -wijziging en -intrekking 13.1.2,14.2,14.5.1

Ziekenfondsraad $9.3,11.1 .7$ Zorgplicht $12.3,13.1 .3,14$, $16.3,20.3 .2 .1$ 


\section{Curriculum vitae}

Johanna Gesina Levina van Nus is op 31 oktober 1964 geboren te Hoogland.

Zij behaalt het diploma Voorbereidend Wetenschappelijk Onderwijs in 1983. Van 1983 tot 1986 doorloopt zij succesvol een journalistieke opleiding. En in 1991 studeert zij aan de Rijksuniversiteit Utrecht af in Nederlands recht (zowel civielrechtelijk als bestuursrechtelijk).

In de periode van september 1991 tot september 1995 werkt zij als onderzoekster in opleiding in dienst van de stichting Recht en Openbaar Bestuur (voorheen: Nederlandse Stichting voor Rechtswetenschappelijk Onderzoek). Standplaats voor haar onderzoek is de faculteit der rechtsgeleerdheid van de Rijksuniversiteit Limburg, vakgroep publiekrecht.

Tijdens de periode, waarin haar dissertatieonderzoek inzake uitoefening van overheidstoezicht door zelfstandige bestuursorganen wordt gesubsidieerd, verleent zij medewerking aan juridische publikaties inzake verzelfstandiging en privatisering. 


\section{Ius Commune reeks}

Reeds verschenen:

M. Faure, (red.), Aansprakelijheid voor het nucleaire risico

R. Seerden, Publiekrechtelijke grensoverschrijdende samenwerking tussen decentrale overheden

C. Flinterman, A.W. Heringa, L. Waddington, (red.), The evolving role of parliaments in Europe; L'évolution des parlements en Europe

G. Samuel, The foundations of legal reasoning

G. Smaers, Gedetineerden en mensenrechten

Ch. B. Krol, Als de Koning dit eens wist...!

P. Rambach, Die deliktische Haftung Minderjähriger und ihrer Eltern im französischen, belgischen und deutschen. Deliktsrecht

M. Faure, J. Vervaele, A. Weale, (red.), Environmental Standards in the European Union in an Interdisciplinary Framework

H.J. De Kluiver, W. Van Gerven, (eds.), The European Private Company?

A. Isenbeck, Traditionelles niederländisches Familienrecht und europäische Einflüsse

L. Waddington, Disability, Employment and the European Community

A. Alvarez (red.), De Advocaat-Generaal gehoord, Essays over de totstandkoming van Europees Gemeenschapsrecht

A. van Nus, Toezicht op zelfstandige bestuursorganen 
Binnenkort te verschijnen:

J. Wouters, H. Schmeider, (red.), Current Issues of Cross-border Establishment of Companies in The European Union

F. Stroink, A.W. Heringa (red.), Judicial Control 